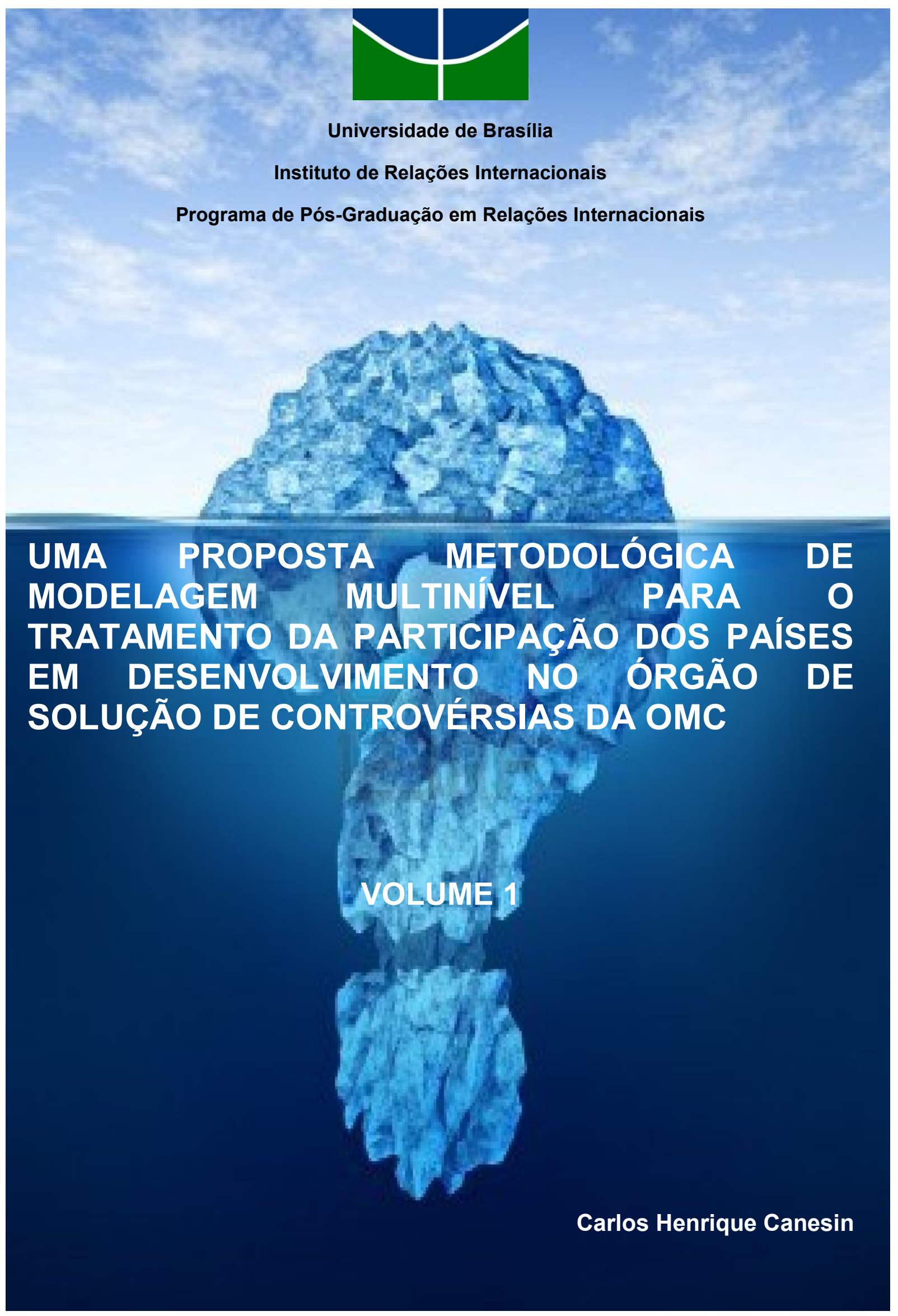




\section{VOLUME 1}

\section{UMA PROPOSTA METODOLÓGICA DE MODELAGEM MULTINÍVEL PARA O TRATAMENTO DA PARTICIPAÇÃO DOS PAÍSES EM DESENVOLVIMENTO NO ÓRGÃO DE SOLUÇÃO DE CONTROVÉRSIAS DA OMC}

Tese apresentada ao Programa de Pós-Graduação em Relações Internacionais da Universidade de Brasília como requisito parcial à obtenção do título de Doutor em Relações Internacionais.

Área de Concentração: Política Internacional e Comparada.

Orientadora: Profa. Dr. Maria Izabel Valladão de Carvalho

Brasília, DF 
Canesin, Carlos Henrique.

CC284p Uma Proposta Metodológica de Modelagem Multinível para o Tratamento da Participação dos Países em Desenvolvimento no Órgão de Solução de Controvérsias da OMC / Carlos Henrique Canesin; orientadora Maria Izabel Valladão de Carvalho. -- Brasília, 2016. Volume 1, p. 194.

Tese 63 (Doutorado - Doutorado em Relações Internacionais) -- Universidade de Brasília, 2016.

1. Organização Mundial do Comércio. 2. Solução de Controvérsias. 3. Países em Desenvolvimento. 4. Modelos Lineares Generalizados. 5. ZINB. I. Valladão de Carvalho, Maria Izabel, orient. II. Título. 


\title{
UMA PROPOSTA METODOLÓGICA DE MODELAGEM MULTINÍVEL PARA O TRATAMENTO DA PARTICIPAÇÃO DOS PAÍSES EM DESENVOLVIMENTO NO ÓRGÃO DE SOLUÇÃO DE CONTROVÉRSIAS DA OMC
}

\author{
Tese apresentada ao Programa de \\ Pós-Graduação em Relações \\ Internacionais da Universidade de \\ Brasília como requisito parcial à \\ obtenção do título de Doutor em \\ Relações Internacionais. \\ Área de Concentração: Política \\ Internacional e Comparada.
}

Aprovada em: 29 de agosto de 2016 - Brasília, DF.

\section{BANCA EXAMINADORA}

Profa. Dra. Maria Izabel Valladão de Carvalho (Orientadora)

Instituto de Relações Internacionais - Universidade de Brasília (UnB)

Prof. Dr. Eduardo Viola

Instituto de Relações Internacionais - Universidade de Brasília (UnB)

Prof. Dr. Roberto Goulart Menezes

Instituto de Relações Internacionais - Universidade de Brasília (UnB)

Prof. Dr. Amâncio Jorge Silva Nunes de Oliveira

Instituto de Relações Internacionais - Universidade de São Paulo (USP)

Prof. Dr. Philipp Ehrl

Programa de Pós-graduação em Economia - Universidade Católica de Brasília (UCB) 


\section{AGRADECIMENTOS}

Inúmeras pessoas foram importantes no decorrer da trajetória de pesquisa e redação do presente trabalho, seja do ponto de vista pessoal, profissional ou acadêmico. Acima de tudo agradeço a Viviani Nikitenko e Carlos Augusto Canesin pelo incansável apoio, dedicação e acima de tudo pela compreensão pelos longos períodos furtados ao convívio familiar. Esta saga não teria sido possível ou faria sentido sem eles. Agradeço aos meus pais, Carlos Alberto Canesin e Regina Célia Canesin, pelo apoio, motivação e acima de tudo pelo exemplo.

Agradeço muito especialmente à Profa. Dra. Maria Izabel Valladão de Carvalho, que mais do que minha orientadora acadêmica, o que por si só não foi tarefa fácil devo honestamente confessar, foi uma amiga compreensiva e pacienciosa ao longo de todos estes anos. Agradeço também em conjunto a todo o corpo de professores de excelência do Instituto de Relações Internacionais da Universidade de Brasília.

Agradeço a Paulo Cesar Nogueira, Antônio Carlos do Prado, Carlos Santana, Alfredo Alves e Mário Seixas, atuais e ex-gestores da Empresa Brasileira de Pesquisa Agropecuária (Embrapa) que de uma forma ou de outra e em distintos momentos, permitiram que o presente trabalho pudesse ser conciliado com minhas atividades profissionais. Agradeço também aos colegas da Embrapa, Adriana Bueno, Alfredo Romminger, Marcos Françozo, Michelline Lins, José Bellini Leite e especialmente Henoque Ribeiro, pelo apoio e motivação no desenvolvimento deste trabalho.

Por fim, porém não menos importante, agradeço enormemente aos Prof. Dr. Eduardo Viola (UnB), Prof. Dr. Roberto Goulart Menezes (UnB), Prof. Dr. Amâncio Jorge Silva Nunes de Oliveira (USP), Prof. Dr. Philipp Ehrl (UCB), Dr. Ivan Oliveira (IPEA) e novamente à incansável Profa. Dra. Maria Izabel Valladão de Carvalho pelos comentários, críticas e sugestões recebidas na Qualificação e Defesa desta Tese, o que contribuiu em grande medida para ressaltar quaisquer méritos existam no presente trabalho. Os defeitos continuam sendo minha falta exclusiva. 


\section{RESUMO}

O objetivo geral deste trabalho é identificar, descrever e modelar os principais determinantes estruturais da atuação dos países em desenvolvimento no sistema de solução de controvérsias da OMC no período de 1995 a 2012. Com isto, pretendemos investigar, através de uma análise empírica, a hipótese de que a diferença observada entre a atuação de países desenvolvidos e em desenvolvimento no OSC pode ser explicada pelos efeitos estruturais intervenientes no sistema (efeitos: iceberg, gravitacional e discriminatório). Ou se existem efeitos externos negativos causados por diferenças relativas de níveis de renda/desenvolvimento que reduzam a participação dos países em desenvolvimento no OSC. Nossas variáveis estruturais potencialmente explicativas deste fenômeno estarão relacionadas a dois efeitos específicos dentro do sistema: gravitacional (econômico) e discriminatório (capacidade legal/institucional e poder relativo). Um modelo útil de determinação e predição do comportamento dos países no OSC não pode se restringir a apontar apenas o comportamento esperado dos atores quanto ao número de reclamações que cada um destes fará no âmbito do sistema de acordo com as variáveis explicativas associadas, o que denominaremos de comportamento ativo. Este é apenas um lado do fenômeno. $\mathrm{O}$ outro lado, igualmente importante, é determinar o comportamento esperado com relação ao número de reclamações recebidas (número de acionamentos) a partir do conjunto de variáveis explicativas pertinentes, ao qual denominaremos de comportamento passivo. No entanto, um modelo robusto para explicar estas dinâmicas observadas no OSC (a parte fora d'água do iceberg de eventos), deve ser capaz de equacionar ao mesmo tempo o volume de eventos observados (com resultado positivo) e o de eventos não observados (os resultados nulos - parte do iceberg submersa). Para equacionar estas questões, desenvolveremos um modelo binomial negativo inflado de zero para controlar tanto o processo binomial negativo de contagem observado diretamente (eventos com resultado positivo) quanto o processo logístico de determinação da categoria dos resultados nulos em eventos (zero condicional) ou não-eventos (zero estrutural). Após o controle deste efeito, ao qual denominaremos efeito iceberg, e dos efeitos das variáveis estruturais (gravitacional e discriminatório) dentro de uma abordagem de Modelos Lineares Generalizados (Mistos), introduziremos em nossos modelos variáveis categóricas representando diferentes subgrupos de renda dos países em desenvolvimento para testar nossa hipótese. Conclui-se que, após o controle de todos os efeitos estruturais, em geral não existem evidências de efeitos externos relevantes ligados a diferenças de níveis de desenvolvimento entre os subgrupos de países em desenvolvimento e os países desenvolvidos. No entanto, no caso especial de países em desenvolvimento que perfazem o subgrupo potencialmente composto por potências intermediárias, ligado ao extrato de renda da metade inferior dos países de renda média-alta, pode-se observar a influência do nível de renda na significativa elevação da média de reclamações-padrão protocoladas pelo grupo no modelo de polo ativo em relação à média dos países desenvolvidos.

Palavras-chave: Países em desenvolvimento. OMC. OSC. MLG. ZINB. 


\begin{abstract}
The aim of this study is to identify, describe and model the main structural determinants of developing countries performance in the WTO dispute settlement system from 1995 to 2012. Through an empirical analysis we intend to evaluate the hypothesis that differences observed between the performance of developed and developing countries in the DSB can be explained by structural effects involved in the system (effects: iceberg, gravitational and discriminatory). Or if there are negative externalities caused by differences in levels of income/development that decrease the participation of developing countries in the DSB. Our potential explanatory structural variables are related to two specific effects within the system: gravitational (economic) and discriminatory (legal/institutional capacity and relative power). An useful model for determining and predicting the behavior of countries in the DSB cannot be restricted to just point the expected behavior of actors regarding the number of complaints that each will post to the system in accordance with the associated explanatory variables, which we will call the active pole. This is just one side of the phenomenon. The other side, equally important, is to determine the expected behavior regarding the number of complaints received from the system, which we will call the passive pole. However, a robust model to explain these dynamics observed in OSC (the part of the iceberg above water) should be able to equate at the same time the volume of observed events (positive results) and the events not observed (null results - the submerged part of the iceberg). To equate these issues, we will develop an inflated negative binomial model for controlling both the observed count of negative binomial process directly (events with a positive result) and the process of logistic determination that separates the category of events with null results (conditional zero) from the category of non-events (structural zero). After controlling this effect, which we shall call iceberg effect, and also the other main structural effects (gravitational and discriminatory) within an approach to Generalized Linear Models (Mixed), we will introduce in our models categorical variables representing different income level subgroups from developing countries in order to test our hypothesis. We conclude that, after controlling for all the structural effects, in general there are no evidences of relevant external effects linked to differences in income levels that differentiate between developing and developed countries participation in the DSB. However, in the special case of developing countries that make up the subgroup potentially composed of middle powers, linked to the bottom half of the upper middle-income statement, one can observe the influence of income level in a significant increase in average standard complaints filed by the group in the active pole model compared to the average of developed countries.
\end{abstract}

Key words: Developing countries. WTO. DSB. GLM. ZINB. 


\section{Lista de Figuras}

Figura 2.1: Fluxo do sistema de solução de controvérsias da OMC ................................................... 40

Figura 2.2: PNB per capita e nível de renda no período 1995-2012 (USD)........................................ 46

Figura 2.3: Classificação dos países-membros da União Europeia (1995-2012).................................... 49

Figura 4.1: Fluxo de eficácia no modelo de polo ativo....................................................................... 105

Figura 4.2: Fluxo de efetividade no modelo de polo passivo.......................................................... 108

Figura 6.1: AA - REC médio ajustado em função do PIB ................................................................ 150

Figura 6.2: AB - REC médio ajustado em função do PIB ............................................................. 151

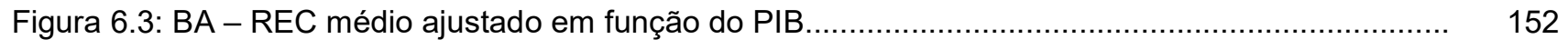

Figura 6.4: BB - REC médio ajustado em função do PIB .............................................................. 152

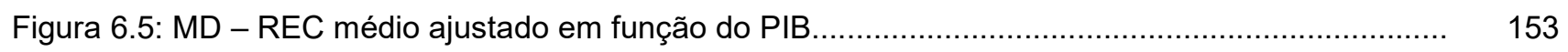

Figura 6.6: $\mathrm{AA}$ - ACI médio ajustado em função do PIB............................................................... 163

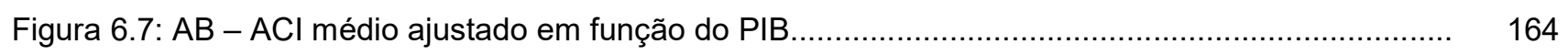

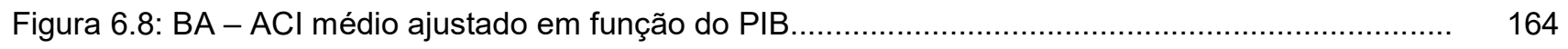

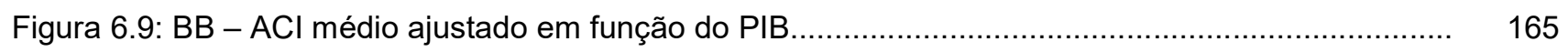

Figura 6.10: MD - ACl médio ajustado em função do PIB.............................................................. 165

Figura 6.11: BB - ACI médio ajustado em função do PIB (sem China e Índia)..................................... 168

Figura 6.12: MD - ACl médio ajustado em função do PIB (sem China e Índia)................................... 168 


\section{Lista de Quadros}

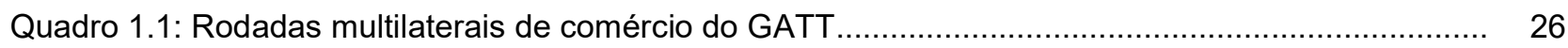

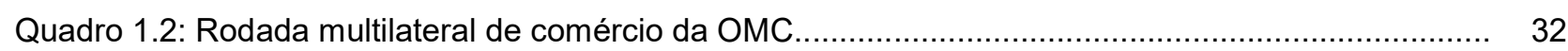

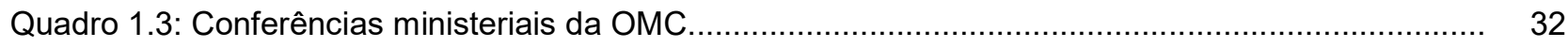

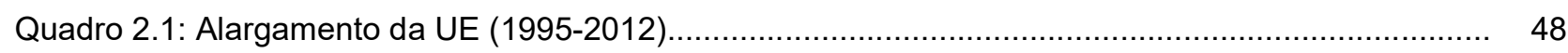

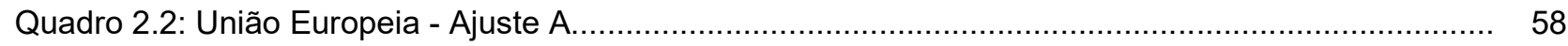

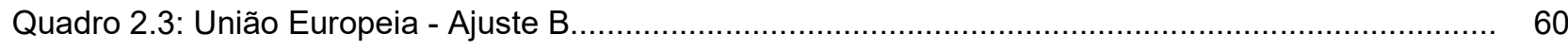

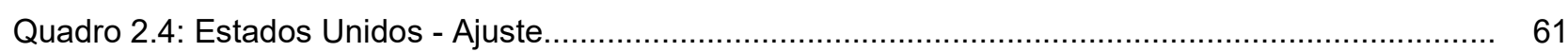

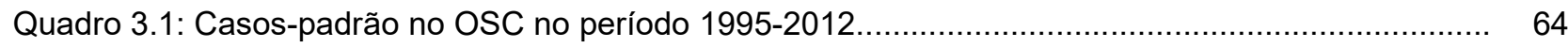

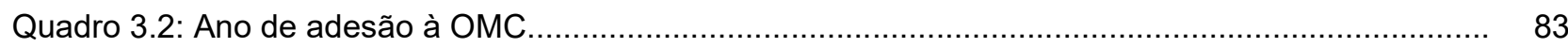

Quadro 5.1: Repositórios institucionais de teses de Doutorado da área de ciência política e relações

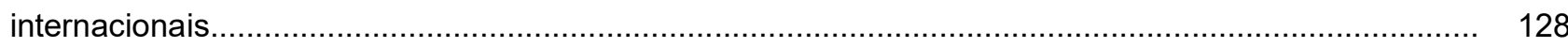

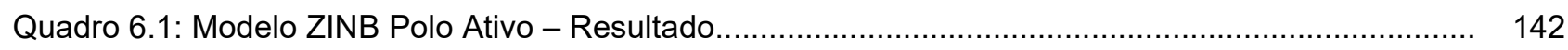

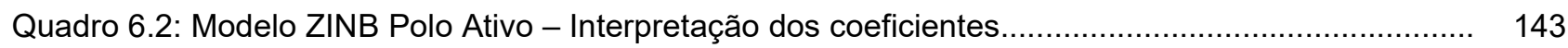

Quadro 6.3: Modelo ZINB Polo Passivo - Resultado......................................................... 156

Quadro 6.4: Modelo ZINB Polo Passivo - Interpretação dos coeficientes............................................. 158

Quadro C.1: Modelos ZINB Polo Ativo e Passivo - Apenas coeficientes significativos.......................... 173 


\section{Lista de Tabelas}

Tabela 3.1: Proporção de reclamações-padrão (do total) e reclamantes-padrão (por grupo). 72

Tabela 3.2: Índice de atividade por grupos de renda. 76

Tabela 3.3: Índice de passividade por grupos de renda. 77

Tabela 3.4: Coeficiente de variação de Pearson por grupo de renda...... 81

Tabela 6.1: Probabilidade média de ocorrência de zero estrutural no polo ativo. 147

Tabela 6.2: REC médio por grupo de renda. 155

Tabela 6.3: Probabilidade média de ocorrência de zero estrutural no polo passivo. 160

Tabela 6.4: ACI médio por grupo de renda. 


\section{Lista de siglas e abreviaturas}

A - Índice de atividade

AA - Subgrupo da metade superior de renda dos países em desenvolvimento de renda média-alta AAE - Áreas Administrativas Especiais da China

$A B$ - Subgrupo da metade inferior de renda dos países em desenvolvimento de renda média-alta

$\mathrm{ACl}$ - Acionamento-padrão

ACP - Acordo de Cotonou

AGOA - African Growth and Opportunity Act

AGRI - Participação relativa da agricultura na pauta comercial

APRE - Aprendizado

BA - Subgrupo da metade superior de renda dos países em desenvolvimento de renda média-baixa

BB - Subgrupo da metade inferior de renda dos países em desenvolvimento de renda média-baixa

BM - Banco Mundial

$\mathrm{BN}$ - Binomial negativo

CAP - Capacidade institucional/legal

$\mathrm{CBI}$ - Caribbean Basin Initiative

CEE - Comunidade Econômica Europeia

CEPAL - Comissão Econômica das Nações Unidas para a América Latina

COMEX - Coeficiente de abertura comercial

CV - Coeficiente de variação de Pearson

DAC - Comitê de Assistência ao Desenvolvimento

DSU - Entendimento sobre Solução de Controvérsias da OMC

EBA - Everything but arms

EC - Índice de eficácia

EUA - Estados Unidos

ET - Índice de inibição de efetividade

FMI - Fundo Monetário Internacional

GATT - Acordo Geral sobre Tarifas e Comércio

Lc - Preditor linear de contagem

Lz - Preditor linear da inflação de zeros

LV - Sistema político livre

MLG - Modelos lineares generalizados

MLGM - Modelos lineares generalizados mistos

$\mathrm{NL}$ - sistema político não livre

OCDE - Organização de Cooperação para o Desenvolvimento Econômico

ODA - Ajuda oficial ao desenvolvimento

ODP - Participação líquida da ODA no PIB

OI - Organização internacional

OIC - Organização Internacional do Comércio 
OMC - Organização Mundial do Comércio

ONU - Organização das Nações Unidas

OSC - Órgão de Solução de Controvérsias

$\mathrm{P}$ - índice de passividade

PD - Países desenvolvidos

PED - Países em desenvolvimento

$\mathrm{PED}_{\mathrm{ma}}$ - Países em desenvolvimento de renda média-alta

$P E D_{m b}$ - Países em desenvolvimento de renda média-baixa

PIB - Produto interno bruto

$\mathrm{PL}$ - sistema político parcialmente livre

PMD (MD) - Países de menor desenvolvimento relativo

PNB - Produto nacional bruto

POL - grau de abertura do sistema político

PREF - Participação líquida da corrente de comércio preferencial na corrente de comércio total

PROC NLMIXED - Processo de otimização não linear misto

p0 - Probabilidade de inflação de zeros

QWIDS - Query Wizard for International Development

REC - Reclamação-padrão

SAS - Statistical Analysis System

SGP - Sistema global de preferências comerciais

$\mathrm{SH}$ - Sistema harmonizado

SITC - Standard International Trade Classification

TRAINS - Trade Analysis Information System

UE - União Europeia

UN Comtrade - United Nations Commodity Trade Statistics Database

UNCTAD - Conferência das Nações Unidas sobre Comércio e Desenvolvimento

UNCTAD/STAT - Divisão de estatística da UNCTAD

WDI - World Development Indicators

WEO - World Economic Outlook

WITS - World Integrated Trade Solution

ZINB - modelo binomial negativo inflado de zero 


\section{SUMÁRIO}

\section{Volume 1}

Introdução.

\section{Capítulo 1 - A Evolução do Sistema Multilateral de Comércio e da Solução de Controvérsias no} GATT/OMC

1.1. Breve introdução sobre comércio internacional, política doméstica e liberalização comercial.

1.2. O sistema multilateral de comércio do GATT à OMC......

1.3. Evolução da solução de controvérsias do GATT à OMC

Capítulo 2 - A Solução de Controvérsias na OMC: Regras, Estratificação de Renda e Casopadrão.

2.1. Regras e procedimentos atuais da solução de controvérsias na OMC...

2.2. Estratificação dos membros da OMC e participação no OSC.

2.3. Participação dos PED no OSC - Uma abordagem preliminar.

2.3.1. Importância da participação dos PED no OSC.

2.3.2. Visão preliminar dos PED no OSC.

2.4. O caso-padrão no OSC.

2.4.1. Padronização.

Capítulo 3 - Participação dos Países em Desenvolvimento no OSC: Evidências Empíricas Preliminares.

3.1. Participação dos PED nos casos-padrão no OSC - Uma visão geral.

3.2. Sistematização preliminar das evidências empíricas

3.2.1. Índice de Atividade (A)....

3.2.2. Índice de Passividade $(P)$.

3.2.3. Coeficiente de variação dos grupos de renda.

3.3. Flexibilização dos pressupostos iniciais

Capítulo 4 - Modelagem Aplicada ao OSC: Polo Ativo e Passivo.

4.1. Estrutura dos dados da variável resposta.

4.2. Discussão do tipo de modelagem aplicável à variável resposta......................................................... 90

4.3. Proposta de índices de avaliação do comportamento dos países em desenvolvimento no OSC....... 100

4.3.1. Índice de eficácia (EC) - Polo ativo.

4.3.2. Índice de inibição de efetividade (ET) - Polo passivo.

5.1. Pesquisa empírica nos estudos da área.

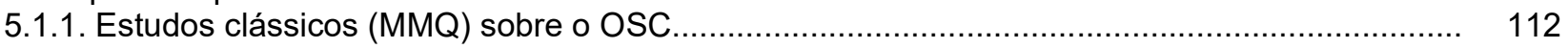

5.1.2. Estudos ZINB (MMV) sobre o OSC.......................................................................................... 122

5.2. Modelagem multinível na academia brasileira de ciência política e relações internacionais............... 126

5.2.1. Considerações finais sobre nossa proposta de modelagem 


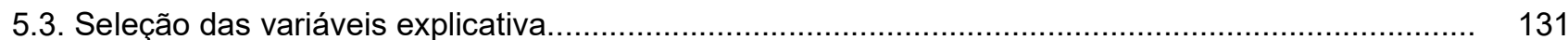

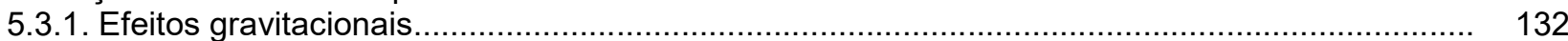

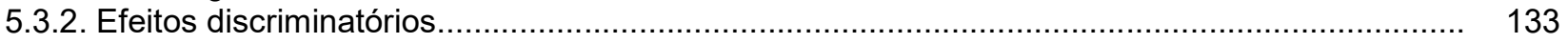

5.3.3. Efeitos de diferenças relativas dos níveis de renda............................................... 139

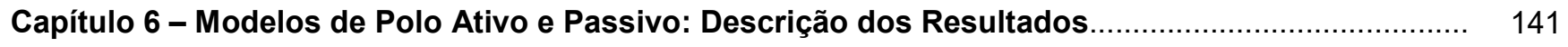

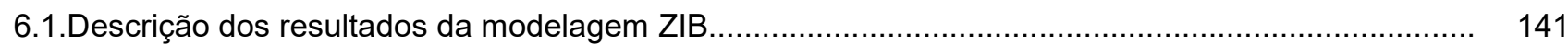

6.1.1. Descrição dos resultados - Modelo ZINB polo ativo (REC) ......................................... 141

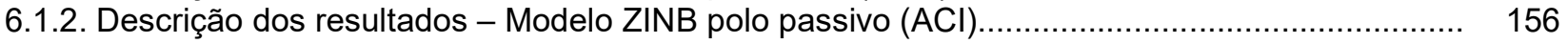

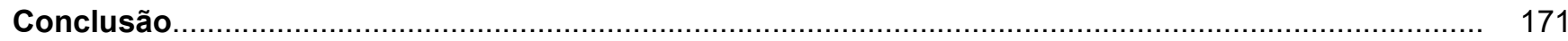

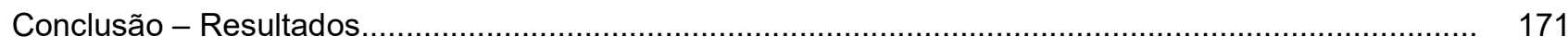

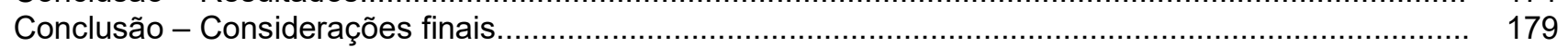

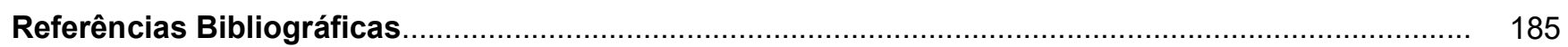




\section{SUMÁRIO}

\section{Volume 2 (Anexo - DVD)}

Anexo 1 - Matriz de casos-padrão

Anexo 2 - Estatística descritiva e CV Pearson para membros individuais

Anexo 3 - Uma breve introdução a MLG/MLGM e formalização do modelo ZINB.

Anexo 4-1 - Efeitos gravitacionais: Variáveis - Dimensão econômica

Anexo 4-2 - Efeitos discriminatórios: Variáveis - Dimensões de poder relativo e capacidade.

Anexo 5 - Modelos: Programação, estimação e testes.

Anexo 5-1 - Modelos Poisson, BN e ZINB: Programação SAS.

Anexo 5-2 - Modelo Poisson - Polo Ativo: Resultado da estimação

Anexo 5-3 - Modelo Poisson - Polo Passivo: Resultado da estimação.

Anexo 5-4 - Modelo Binomial Negativo - Polo Ativo: Resultado da estimação

Anexo 5-5 - Modelo Binomial Negativo - Polo Passivo: Resultado da estimação 585

Anexo 5-6 - Modelo ZINB - Polo Ativo: Resultado da estimação

Anexo 5-7 - Modelo ZINB - Polo Passivo: Resultado da estimação. 593

Anexo 5-8 - Modelo ZINB - Polo Passivo: Resultado da estimação (sem China e Índia). 600

Anexo 6-1 - Valores previstos de CREC e p0 - Modelo ZINB Ativo. 607

Anexo 6-2 - Valores previstos de $\mathrm{CACl}$ e p0 - Modelo ZINB Passivo 


\section{INTRODUÇÃO}

Quem sabe apenas uma parte sobre uma questão, nada sabe sobre ela".

John Stuart Mill (1806-1873), economista britânico

A Organização Mundial do Comércio (OMC), estabelecida no ano de 1995, foi o principal fruto da Rodada Uruguai de negociações multilaterais de comércio e substituiu tanto na prática quanto no imaginário coletivo internacional o perfil anterior de comércio internacional administrado por um comitê de potências comerciais que prevalecia sob o Acordo Geral sobre Tarifas e Comércio (GATT) desde o pós-guerra.

A principal função da OMC é servir como fórum para que seus membros criem e alterem as regras globais de comércio de forma multilateral e, ao mesmo tempo, procurem maximizar os ganhos potenciais do comércio internacional para o conjunto de sociedades representadas pelo sistema. Em conjunto, os membros procurariam criar novas oportunidades econômicas, em um jogo de soma positiva, derrubando progressivamente as barreiras comerciais de forma ainda mais acelerada do que nas décadas anteriores, em futuras rodadas de negociação da entidade.

O Sistema de Solução de Controvérsias da instituição, por sua vez, seria utilizado pelos membros, aliado a sistemas domésticos de defesa comercial alinhados à diretivas multilaterais, para identificar medidas ilegais de acordo com as regras multilaterais e fazer cumprir as obrigações comerciais existentes. Este é, portanto, um mecanismo essencial para garantir a longo prazo a sustentabilidade do sistema através da efetiva execução dos compromissos assumidos pelos membros na organização e, segundo opinião do ex-Diretor Geral da organização, Pascal Lamy, "ensuring a level playing field for all" (OMC, 2013a).

Pesquisa realizada pelo Conselho Consultivo do Diretor-Geral no ano de 2004 (OMC, 2004) mostra que a opinião da comunidade internacional sobre o sistema era bastante positiva à época. Outros estudiosos (BUSCH, REINHARDT, 2000) vão ainda mais longe e chegam a concordar com a afirmação do ex-Diretor Geral Mike Moore (OMC, 2000) de que o mecanismo de solução de controvérsias é o "eixo central" e a "espinha dorsal" do sistema multilateral de comércio.

Com a finalidade de assegurar a participação adequada dos países em desenvolvimento no novo sistema, quando os membros menos desenvolvidos não 
possuíssem recursos ou expertise para aplicar os novos regulamentos ou adotar procedimentos litigiosos, a entidade ofereceria treinamento e assistência, pagas principalmente pelas contribuições dos países desenvolvidos (PD) mais ricos como Estados Unidos (EUA) e União Europeia (UE).

No entanto, o argumento frequente presente na literatura é de que pouco de fato teria sido alcançado no sentido da inclusão desses atores menores no efetivo processo de negociação dos pilares da regulação comercial internacional e na utilização do instrumental criado para garantir um padrão mais justo de comércio, ou seja, na "espinha dorsal" do sistema: o Órgão de Solução de Controvérsias (OSC).

Conforme observam Bown e Hoekam (2005), os países de menor desenvolvimento relativo membros da organização estão quase que completamente ausentes dos procedimentos necessários para garantir o cumprimento dos acordos firmados na OMC e a aplicação correta dos seus direitos de acesso a mercados, representado formalmente pelo sistema de solução de controvérsias. Embora os países em desenvolvimento mais avançados façam uso crescente do Entendimento sobre Solução de Controvérsias da OMC (DSU), os países de menor desenvolvimento relativo (PMD) estariam em sua maioria alijados do processo em qualquer uma das categorias: demandante, acionado ou parte interessada/terceira parte.

Independentemente do juízo de valor que se faça da participação dos países em desenvolvimento no sistema, é ponto pacífico na literatura que o sistema de solução de controvérsias da OMC tem características de um bem público ofertado pela organização e sua eficácia é fundamental tanto do ponto de vista da legitimidade institucional da organização quanto pelas externalidades positivas que pode gerar para o sistema multilateral de comércio e suas partes (BAGWELL et al., 2002).

A participação ativa no sistema de solução de controvérsias da OMC pode ter externalidades positivas se os esforços específicos de um país contribuírem para a remoção de uma barreira comercial que afete negativamente também outros membros da organização.

Ao passo que esta mesma participação, em nível apropriado, reduz a incerteza e dá maiores garantias quanto ao cumprimento dos acordos firmados no âmbito multilateral. Fazendo com que os países estejam mais dispostos a aprofundar o escopo de seus próprios compromissos, dado o reduzido risco de 
deserção, para conseguir vantagens adicionais de outros membros. O que levaria a um efeito em cadeia conduzindo o sistema para níveis maiores de liberalização progressivamente mais rápido.

A garantia do cumprimento dos compromissos acordados é um problema comum na literatura de organizações internacionais, e se materializa no caso da OMC com especial importância para os países em desenvolvimento que ainda não estão totalmente integrados ao sistema (tratamento especial e diferenciado). Assim, uma falha sistêmica que impossibilite aos países em desenvolvimento de exigir o cumprimento de acordos e compromissos existentes pode levar ao colapso não apenas do OSC, mas do próprio motor da OMC que é o processo de liberalização progressiva do comércio internacional.

Este efeito adverso adviria do fato de que os países em desenvolvimento correspondem hoje à maioria dos membros da organização e que, portanto, a continuidade e viabilidade do objetivo principal da OMC requer a incorporação progressiva destes países na normalidade do sistema multilateral.

Caso estes países possuírem suficientes razões para acreditar que não poderão exigir o cumprimento das obrigações dos outros membros por meio do sistema de solução de controvérsias, dentre as quais destacam-se os direitos de acesso a mercado, eles estarão menos propensos a implementar seus próprios compromissos na OMC e a assumir novos compromissos no âmbito do sistema comercial multilateral.

Parte significativa do debate acadêmico sobre a participação dos países em desenvolvimento no sistema multilateral de comércio tem, assim, se concentrado em identificar as possíveis explicações para a baixa participação geral dos países em desenvolvimento no sistema de solução de controvérsias na OMC e analisar quais são os desafios que isto traz para a sustentabilidade e evolução do sistema.

Uma diversa gama de variáveis têm sido sugeridas como potenciais explicações por estas pesquisas, que serão abordadas com maior profundidade no Capítulo 5, das quais se destacam:

- falta de compreensão correta dos direitos e obrigações na OMC;

- problemas de articulação entre o setor público e o setor privado na identificação de demandas;

- restrições de recursos financeiros e humanos para identificar violações e levar 
disputas até o final;

- temor de que as preferências comerciais ou outras formas de assistência sejam retiradas pelos países desenvolvidos em retaliação; dentre outras.

Nós empreenderemos uma discussão pormenorizada das principais variáveis apontadas como potencialmente explicativas do fenômeno da reduzida participação dos países em desenvolvimento no OSC nos próximos capítulos e as submeteremos a testes estatísticos de significância durante a construção de nossos modelos explicativos no Capítulo 6.

Esta pesquisa, no entanto, adotará uma abordagem diferente no tratamento do tema. Nosso ponto de partida retomará as bases empíricas desta discussão, revisando tanto a base teórica quanto metodológica do problema de pequisa. Desta maneira, consideraremos que existem condicionantes estruturais que determinam a participação dos membros da OMC no sistema de solução de controvérsias da entidade. Estes condicionantes podem ser divididos em três dimensões: i) econômica; ii) de poder; e iii) de capacidade.

Nossa pergunta de pesquisa pode, assim, ser subdivida em três componentes:

Embora seja fato indisputável que os PED utilizam menos em nível absoluto o órgão de solução de controvérsias da OMC do que os países desenvolvidos:

(1) A determinação do comportamento dos PED no OSC poderia ser explicada pelos mesmos condicionantes estruturais que determinam a participação dos países desenvolvidos?

(2) Após o correto controle dos principais efeitos estruturais ${ }^{1}$ sobre o sistema, a diferença relativa observada entre a participação prevista no OSC para os $P E D$ e $P D$ (com base nestes condicionantes estruturais) seria estatisticamente significativa em desfavor dos PED?

(3) Ou seja, após uma modelagem que controle os efeitos estruturais, ainda

1 Efeitos estruturais são os efeitos das variáveis estruturais ligadas às dimensões econômica, de poder e de capacidade, bem como o efeito iceberg que será definido adiante. 
existiriam efeitos externos negativos contra a participação dos PED no sistema causados isoladamente por diferenças relativas entre os niveis de desenvolvimento/renda destes e dos $P D$ ?

Dessa forma, o objetivo geral deste trabalho é identificar, descrever e modelar os principais determinantes estruturais da atuação dos países em desenvolvimento no sistema de solução de controvérsias da OMC no período de 1995 a 2012. Com isto, pretendemos investigar, através de uma análise empírica, se a diferença observada entre a atuação de países desenvolvidos e em desenvolvimento pode ser explicado pela diferença observada nos valores de variáveis estruturais explicativas, ou se existem evidências empíricas de que diferenças nos níveis de renda/desenvolvimento são relevantes na determinação de efeitos negativos que reduzam o nível de participação projetada para os PED.

Em termos formais, nossa hipótese de trabalho é:

H1: Não há efeitos negativos externos contra a participação dos PED no OSC advindos de diferenças relativas de nível de desenvolvimento quando comparados aos PD (após o controle dos efeitos estruturais observados no sistema).

Portanto, a hipótese nula adjacente é:

H0: Há efeitos negativos externos contra a atuação dos PED no OSC advindos de diferenças relativas de nível de desenvolvimento quando comparados aos PD.

Conforme discutiremos em maior profundidade nos Capítulos 4 e 5, os efeitos estruturais potencialmente explicativos deste fenômeno estarão relacionados a duas categorias de efeitos específicos sobre o sistema de solução de controvérsias. A primeira categoria será denominada de efeito iceberg, que está ligado à determinação probabilística do processo de habilitação dos membros para participação no sistema. Ou seja, à probabilidade que cada membro individualmente ou grupo de renda, seja efetivamente um participante do sistema de solução de controvérsias. 
A segunda categoria é a das variáveis explicativas estruturais, que podem ser por sua vez de dois tipos: gravitacional (variáveis da dimensão econômica); e discriminatória (dimensões de capacidade e poder). As variáveis explicativas estruturais são definidas a seguir:

\section{a) Efeitos gravitacionais:}

a.i) dimensão econômica - relacionada à estrutura produtiva e do comércio internacional de cada membro. Determinam a maior parte da frequência (número de casos) de participação dos países no OSC de acordo com o tamanho e características macro da economia destes.

O efeito esperado destas variáveis é similar ao conceito da física newtoniana de força gravitacional: "Dois corpos atraem-se com força proporcional às suas massas e inversamente proporcional ao quadrado da distância que separa seus centros de gravidade" (HAZEWINKEL, 2001). Em nosso caso específico, a "massa" (tamanho da economia e suas características) dos países "atrai" (determina) um número de casos específicos no OSC nos quais estes se envolverão. Portanto, a participação dos países no sistema oscilaria em torno desta "órbita" dada por sua "massa".

\section{b) Efeitos discriminatórios:}

b.i) dimensão institucional e legal - relacionada à qualidade e capacidade institucional/legal; e

b.ii) dimensão política ou de poder - que diz respeito às relações de poder e diferenças de poder relativo.

Atuam como moderadoras para ampliar ou reduzir o efeito da "força" gravitacional exercida pelo tamanho econômico do membro, ampliando ou reduzindo a frequência de participação do mesmo.

É importante ressaltar que diferenças no nível absoluto dos efeitos destas variáveis estruturais sobre os membros de diferentes grupos de renda são internos ao sistema e dizem respeito tão somente a diferenças observadas nos valores 
destas variáveis explicativas. Estes efeitos, bem como o efeito iceberg, serão descritos em com maior profundidade ao longo do trabalho e precisarão ser controlados em nossa análise. Estes efeitos em questão são qualitativamente diferentes de potenciais efeitos externos ou ocultos ocasionados pelos diferentes níveis de renda dos membros, cujas evidências empíricas desejamos testar.

Estes últimos não estão relacionados a nenhuma variação específica no valor de variáveis estruturais e sim ao valor do efeito estimado dos coeficientes de variáveis categóricas. Variáveis categóricas são aquelas que não representam quantidades e sim diferentes classes dos indivíduos em uma regressão. Em nosso caso, nossas variáveis categóricas serão definidas no decorrer deste trabalho como variáveis dummy representando cada uma os diferentes subgrupos de renda que serão analisados. Estas variáveis, portanto, estarão ligadas ao próprio processo de desenvolvimento em si.

Um modelo útil de determinação e predição do comportamento dos países no OSC não pode se restringir a apontar apenas o comportamento dos atores quanto ao número de reclamações que cada um destes fará no âmbito do sistema de acordo com as variáveis explicativas associadas, o que denominaremos de polo ou comportamento ativo. Este é apenas um lado do fenômeno.

O outro lado, igualmente importante, é determinar o comportamento esperado com relação ao número de reclamações recebidas (número de acionamentos) a partir do conjunto de variáveis explicativas pertinentes, ao qual denominaremos de polo ou comportamento passivo.

Por fim, deve-se destacar que o fenômeno, que discutiremos em maiores detalhes ao longo do trabalho, resta apenas parcialmente descrito mesmo levandose em consideração seus dois lados - ativo e passivo. Esta parte da história nos descreve apenas "aquilo que é", ou seja, o resultado positivo efetivamente observado de eventos enquanto comportamento dos países e/ou grupos de renda.

O que, por sua vez, não nos conta nada sobre aquilo que "poderia ter sido". Ou seja, não nos coloca em condições inquirir sobre aquele conjunto de comportamentos que poderiam ter se transformado em reclamações ou acionamentos, porém, não o foram. Por não terem sido efetivamente materializados em reclamações/acionamentos, não podemos observar diretamente este conjunto de comportamentos. 
No entanto, estes resultados nulos (não efetivação de uma reclamação/acionamento) são uma parte importante da realidade tanto quanto os resultados positivos (efetivação de um ou mais reclamações/acionamentos). Ambos fazem parte do universo dos eventos, pois, desenvolvem-se no âmbito do mesmo processo decisório (comportamento) de um país, porém, o resultado é diverso em cada um destes casos.

Na medida em que um país decide não protocolar uma reclamação, este comportamento existe, é real e material, tendo envolvido elementos do processo decisório deste país que resultaram nesta decisão. Este evento ou decisão, apesar de existir concretamente, não tem um resultado observável diretamente, pois, este consiste exatamente na ausência da reclamação/acionamento no OSC e, portanto, em um valor nulo do comportamento.

Este valor nulo (ou mais propriamente dito a falta do valor de ao menos uma unidade de reclamação/acionamento) é o único dado observável diretamente no OSC. E neste caso específico, não é possível determinar de antemão se o valor nulo observado é fruto de um evento (que resultou na decisão de não participar e, portanto, em um resultado nulo) ou fruto de um não-evento. O não-evento é a simples ausência de uma decisão, o que significa que o processo decisório não foi ativado pois não havia nenhuma decisão a ser tomada.

Em ambos os casos, seja um evento com resultado nulo (decisão de não participar) ou um não-evento (não decisão), o dado observável diretamente no OSC é o mesmo: resultado nulo - a ausência da reclamação ou do acionamento. Mas apenas o primeiro faz parte do universo dos eventos (decisões).

Para compreender e analisar o comportamento dos países no OSC com profundidade é necessário uma visão compreensiva da realidade (eventos). Portanto, é preciso separar os eventos com resultado nulo, não observáveis diretamente, dos não-eventos, igualmente não observáveis diretamente.

Apenas se pudermos separar estas duas dimensões poderemos ter uma compreensão integral da realidade (eventos), que consiste não apenas de resultados positivos (reclamações/acionamentos efetivados) como também de resultados nulos (reclamações/acionamentos não efetivados). Trata-se de uma posição mais profunda do que apenas uma questão metodológica, esta é antes uma questão ontológica/mereológica (de não tomar a parte pelo todo ou de atribuir ao todo as propriedades da parte). 
Conforme veremos em nossa discussão teórica e metodológica nos Capítulos 4 e 5, concentrar-se apenas na parte (aquilo que vemos - eventos com resultado positivo) nos faz perder de vista o todo (aquilo que não vemos diretamente - eventos com resultado nulo e não-eventos) e acaba por comprometer tanto nossa percepção da realidade quanto nossas conclusões sobre esta. Quando nos concentramos apenas no comportamento dos países que se pode observar (eventos com resultado positivo), falhamos em estimar aquilo que não observamos mas que faz parte do comportamento dos atores (eventos com resultado nulo).

Dessa forma, o enfoque que propomos neste estudo é perguntar (sendo os eventos com resultado positivo, efetivamente observados, as reclamações feitas ou acionamentos recebidos): O que não aconteceu? Por que não aconteceu?

Ou seja, no polo ativo, estamos interessados tanto na quantidade de reclamações que um membro apresentou (eventos com resultado positivo), quanto na quantidade que este deixou de apresentar (eventos com resultado nulo). Já no polo passivo nosso interesse reside, por sua vez, na quantidade de acionamentos que o membro recebeu (eventos com resultado positivo), quanto na quantidade que este deixou de receber (eventos com resultado nulo).

Apenas se pudermos estimar e compreender a diferença entre estes dois universos, o dos eventos - composto por (a) eventos com resultado positivo (reclamações/acionamentos observados) e (b) eventos com resultado nulo (reclamações/acionamentos não efetivados) - e o dos não-eventos - valor nulo decorrente de ausência de decisão - é que poderemos avaliar se existem evidências empíricas de que o comportamento dos PED é estruturalmente diferente do comportamento dos PD no OSC.

Conforme discutiremos em profundidade no Capítulos 4, há uma grande diferença qualitativa entre o universo dos eventos (observados e não observados) e o dos não-eventos. E poder separar os eventos com resultado nulo dos não-eventos é crucial na modelagem do comportamento dos países em desenvolvimento no OSC.

Guiar-se apenas pelo universo dos eventos com resultado positivo (observados) e ignorar os eventos com resultado nulo (não observados) equivale a chocar-se frontalmente contra o volume submerso de um grande iceberg. Enquanto não ser capaz de separar eventos com resultado nulo (não observados) de nãoeventos (também não observados) é não poder distinguir entre o gelo da parte 
submersa deste iceberg e a água salgada circundante.

Por mais adequado ou robusto que um modelo possa parecer ao tentar explicar a dinâmica do comportamento dos países no OSC apenas a partir dos resultados positivos observados na parte acima da linha d'água deste iceberg de eventos, esta será apenas uma explicação parcial que deixará de levar em consideração parte importante da realidade - os eventos não observados com resultado nulo (a parte submersa do iceberg).

Dessa forma, os objetivos específicos desta pesquisa são:

i) Estratificar os membros da OMC em diferentes grupos de renda de acordo com critérios objetivos (e não a auto-designação adotada pela OMC) e padronizar dados com tratamento de casos especiais e distorções (membros compostos como é o caso da União Europeia, dentro outras que serão abordadas nos Capítulos 1 a 3);

ii) Mapear todas as disputas ocorridas no OSC entre 1995 e 2012 e sistematizar uma base de dados que elimine as distorções ocasionadas pelas regras de utilização do sistema de solução de controvérsias (como a data de adesão do membro à $\mathrm{OMC}$, a possibilidade de casos envolvendo mais de um membro em cada um dos polos, dentro outras que serão abordadas nos Capítulos 1 a 3);

iii) Estabelecer critérios, confirmar a identificação de variáveis explicativas e modelar o comportamento observado de acordo com as mesmas (dois modelos: um para o polo ativo - reclamações; e um para o polo passivo - acionamentos);

v) Analisar a consistência dos comportamentos previstos e a representatividade dos resultados; e

vi) A partir dos modelos desenvolvidos, realizar nosso teste de hipótese, confirmando ou não a pertinência do nível de renda como variáveis potencialmente explicativas de diferenças de comportamento observadas no OSC entre subgrupos dos PED e os PD.

Portanto, um fator crítico para a aferição destes resultados é a criação de bases seguras para comparação da atuação dos países em desenvolvimento com a dos países desenvolvidos e com a participação projetada destes grupos pelos 
efeitos estruturais dos modelos (efeito iceberg e efeitos dos coeficientes da variáveis explicativas estruturais - gravitacionais e discriminatórios).

Assim, foi formada uma grande base de dados quantitativos para cada um dos membros da OMC através de um amplo levantamento de dados de fontes primárias e secundárias: revisão bibliográfica junto à bibliografia especializada, dados e documentos produzidos por instituições do Sistema ONU (GATT/OMC, Banco Mundial, FMI, UNCTAD, UN Comtrade, etc), dentre outras.

Esta base de dados foi construída com vistas a desenvolver um modelo tanto descritivo quanto preditivo do comportamento dos países em desenvolvimento no sistema de solução de controvérsias da OMC e tratar nossas variáveis dependentes com uma grande frequência de valores nulos (provenientes tanto de eventos com resultado nulo quanto de não-eventos) em ambos os modelos (ativo e passivo), definidas como: i) modelo ativo - número de casos em que cada membro aparece como reclamante no OSC a cada ano; e ii) modelo passivo - número de casos em que cada membro figura como acionado no OSC a cada ano.

Para isto faremos uma discussão sobre a natureza e características dos nossos dados, das variáveis estruturais explicativas apontadas pela literatura e das variáveis resposta. A partir desta discussão nos aprofundaremos na classe de modelos lineares generalizados para modelagem não-linear de dados de contagem de perfil longitudinal e, conforme se verá ao longo deste trabalho, optaremos pela utilização em ambos os modelos (ativo e passivo) de um modelo multinível binomial negativo inflado de zero (ZINB).

Em um segundo momento, de posse dos resultados das análises quantitativas, os dados serão interpretados qualitativamente de forma a se responder se podem ser considerados como determinantes estruturais válidos da atuação dos países no sistema de solução de controvérsias da OMC.

Em última instância este trabalho procura propiciar contribuição à literatura especializada por meio tanto da consolidação de uma proposta metodológica para estudos na área quanto por oferecer resposta sólida a um conjunto importante e permanente de indagações sobre a participação dos países em desenvolvimento na solução de controvérsias da OMC.

Busca-se assim fornecer aos atores públicos, e aos demais interessados em questões comerciais, bases mais seguras para avaliar o papel do mundo em desenvolvimento no comércio internacional e em que medida os desequilíbrios e 
distorções observados são um problema de desenho de instituições internacionais, e portanto requerem sua reforma, ou fruto de outras desigualdades estruturais de base material, o que requer abordagens diferentes.

Portanto, a direção da resposta às indagações levantadas por esta pesquisa tem alta relevância para a própria sustentabilidade em longo prazo do sistema multilateral de comércio representado pela OMC. Para cumprir nosso intento, este trabalho foi estruturado em dois Volumes, sendo o Volume 1 o trabalho principal composto por seis capítulos e o Volume 2 o Anexo (DVD)².

Os temas abordados no Volume 1 são:

Capítulo 1 - contextualização do surgimento e evolução da OMC e da solução de controvérsias no âmbito da evolução do sistema multilateral de comércio;

Capítulo 2 - descrição das regras e do funcionamento do OSC e definição de critérios objetivos e mensuráveis para a estratificação dos membros da OMC em diferentes grupos de renda;

Capítulo 3 - desenvolvimento de uma metodologia para padronização dos dados levantados nos dois primeiros capítulos de modo a reduzir as distorções observadas nos mesmos e permitir a sumarização das evidências empíricas encontradas até o momento;

Capítulo 4 - compreenderá nossa discussão metodológica e o desenvolvimento de nossa modelagem específica apresentando a construção formal dos modelos que orientarão nossa análise aprofundada do tema ao longo dos capítulos seguintes. Sempre que possível, no decorrer de todo o trabalho, procuraremos apresentar conceitos formais e estatísticos em uma versão textual simples e objetiva. Evitaremos, assim, a excessiva matematização na apresentação de nossos

20 volume de Anexo é comporto por nove anexos que presentam as bases de dados utilizadas na pesquisa, o tratamento dos dados e a uma discussão estatística/econométrica sobre a aplicação do modelo proposto, os testes de modelos concorrentes, os resultados dos modelos discutidos no trabalho principal, bem como demais temas específicos levantados ao longo das discussões no Volume 1. 
argumentos e resultados no Volume 1, embora ela seja crucial na análise e resolução da modelagem proposta. Em consequência, encontra-se no Anexo 3 (Volume 2) a exposição da discussão teórica necessária para a compreensão do arcabouço estatístico utilizado neste trabalho e das diferentes fases de elaboração dos modelos propostos e de nossas escolhas metodológicas;

Capítulo 5 - as evidências iniciais serão discutidas em face da literatura especializada e com a construção de nosso marco teórico para os modelos de análise propostos definiremos as variáveis explicativas estruturais que serão testadas neste estudo. Uma discussão mais profunda sobre o mapeamento, preparação e tratamento destas variáveis pode ser conferida pelos interessados no tema nos Anexos 4-1 e 4-2 (Volume 2);

Capítulo 6 - fará a aplicação da modelagem discutida ao longo do trabalho nos dois polos (ativo e passivo), produzindo os resultados que serão descritos e discutidos em detalhes no próprio capítulo. Uma discussão sobre os modelos "intermediários" construídos na evolução do modelo proposto, teste de modelos e teste de significância de coeficientes poderá ser encontrada no Anexo 5 (Volume 2); e

Conclusão - os resultados descritos no capítulo anterior para cada um dos polos (ativo e passivo) serão agregados para a avaliação final de nossa hipótese de trabalho e discutidos entre si e comparativamente com a literatura. Após a apresentação de nossas conclusões específicas, procuraremos tecer recomendações pontuais para pesquisas futuras, que certamente poderão agregar novos aspectos ao dimensionamento da complexidade do comportamento dos atores, ou apontar a utilidade dos modelos para aplicação em outras situações e períodos, ou mesmo como controle para analisar mudanças qualitativas no tempo e/ou mudanças de regime no sistema de solução de controvérsias.

Os temas abordados no Volume 2 (Anexo - DVD) são:

Anexo 1 - Matriz de casos-padrão;

Anexo 2 - Estatística descritiva e CV Pearson para membros individuais; 
Anexo 3 - Uma breve introdução a MLG/MLGM e formalização do modelo ZINB;

Anexo 4-1 - Efeitos gravitacionais: Variáveis - Dimensão econômica;

Anexo 4-2 - Efeitos discriminatórios: Variáveis - Dimensões de poder relativo e capacidade;

Anexo 5 - Modelos: Programação, estimação e testes;

Anexo 5-1 - Modelos Poisson, BN e ZINB: Programação SAS;

Anexo 5-2 - Modelo Poisson - Polo Ativo: Resultado da estimação;

Anexo 5-3 - Modelo Poisson - Polo Passivo: Resultado da estimação;

Anexo 5-4 - Modelo Binomial Negativo - Polo Ativo: Resultado da estimação;

Anexo 5-5 - Modelo Binomial Negativo - Polo Passivo: Resultado da estimação;

Anexo 5-6 - Modelo ZINB - Polo Ativo: Resultado da estimação;

Anexo 5-7 - Modelo ZINB - Polo Passivo: Resultado da estimação;

Anexo 5-8 - Modelo ZINB - Polo Passivo: Resultado da estimação (sem China e Índia);

Anexo 6-1 - Valores previstos de cREC e p0 - Modelo ZINB Ativo; e

Anexo 6-2 - Valores previstos de cACl e p0 - Modelo ZINB Passivo. 


\title{
Capítulo 1
}

\section{A EVOLUÇÃO DO SISTEMA MULTILATERAL DE COMÉRCIO E DA SOLUÇÃO DE CONTROVÉRSIAS NO GATT/OMC}

Which comes first, the chicken or the egg? The GATT!

\author{
Robert Wolfe, Farm Wars (1998, p. 45)
}

No presente capítulo faremos, na primeira seção, uma breve introdução sobre as relações entre o comércio internacional, a economia política doméstica dos países e o processo de liberalização comercial que transcorreu durante toda a segunda metade do século passado.

Na segunda parte do capítulo, trataremos da evolução do sistema multilateral de comércio de uma pequena parte do mundo ocidental até sua expansão recente pelo globo. O que levou a um grande incremento dos fluxos de comércio, mas também a instabilidades e divergências de interesses.

Por fim, concluiremos o capítulo apresentando uma concisa evolução do tratamento da solução de controvérsias no âmbito do sistema multilateral de comércio, desde os primórdios do GATT até o lançamento da OMC. Aspectos da operação atual deste sistema serão discutidos no próximo capítulo.

\subsection{Breve introdução sobre comércio internacional, política doméstica e liberalização comercial}

Das primeiras civilizações autárquicas remotas ao atual mundo globalizado da tecnologia da informação, uma ampla gama de frentes de contato entre os ambientes externo e interno das diferentes sociedades emergiu. Umas surgiram há muito pouco no tempo histórico, como a mídia eletrônica e a internet; enquanto outras, como o comércio, originalmente na forma de escambo, estão ligadas à gestação mesma das primeiras relações entre as sociedades.

O aumento do volume de comércio internacional aparenta ter forte correlação positiva com o desenvolvimento econômico e social das diferentes comunidades humanas e do próprio sistema internacional, uma vez que as unidades componentes deste sistema tem historicamente no comércio as suas principais bases de contato (BARRAL, 2007). 
O advento das modernas técnicas de produção que permitem a segmentação das cadeias produtivas, de forma a alocar plantas responsáveis por setores específicos em diferentes países de acordo com suas vantagens comparativas, e da tecnologia e logística sofisticada dos fretes internacionais, reduzindo os custos de transporte significativamente, tem contribuído adicionalmente para a ampliação destes fluxos (FRIEDMAN, 2005).

Os dados do comércio internacional para a década de 1990 apontam que o crescimento do intercâmbio comercial, a uma taxa média de $5 \%$ na década, superou consistentemente o crescimento do produto mundial, que cresceu em média em 3\% no período. Tendo apenas o comércio de bens atingido US\$ 6,4 trilhões e o comércio de serviços a marca de US\$ 1,4 trilhão no ano de 2000, representando um crescimento de $12 \%$ e $5 \%$ respectivamente, com ano-base de 1999 (OMC, 2001).

No final da década seguinte, o valor do comércio de bens no ano de 2010 já havia atingido a impressionante cifra de US\$ 15 trilhões, enquanto o valor do comércio de serviços respondia por US\$ 3,7 trilhões (OMC, 2011). A atual fase de crescimento do volume de comércio internacional se iniciou com o fim da Segunda Guerra Mundial, que assistiu tanto a uma reorganização em larga escala dos sistemas produtivos quanto a um reordenamento do sistema internacional em sua vertente bipolar.

A correlação entre o crescimento do comércio internacional e o nível de desenvolvimento econômico alcançado na média pelo mundo cada vez mais globalizado é apontado por estudos empíricos. Ben-David e Loewey (1997) demonstraram que as taxas de crescimento médio robustas e ascendentes alcançadas pela Europa na segunda metade do século passado (no pós Segunda Guerra) estiveram associadas intrinsecamente a um coeficiente de abertura crescente de seus mercados, representado pelo aumento sustentado da corrente de comércio em relação ao Produto Interno Bruto (PIB).

Quando olhamos para o mundo em desenvolvimento, Sachs e Warner (1995) demonstraram em artigo seminal que os países em desenvolvimento com maior abertura ao comércio internacional apresentam taxas médias de crescimento do PIB $3,5 \%$ maior do que os países em desenvolvimento fechados.

Em estudo mais amplo, as evidências empíricas, coletadas de meados da década de 1970 à metade da década de 1990, apontaram que em uma análise entre os países em desenvolvimento considerando grupos de países industrializados e 
países em desenvolvimento abertos e fechados, o grupo de países em desenvolvimento abertos (independentemente da matriz produtiva) cresceu significativamente mais no período do que países fechados e países industriais em conjunto (GREENAWAY et al., 2002).

Mesmo quando levadas em consideração as distorções existentes na comparação entre países com matrizes produtivas, sociedades e desenhos do Estado e institucionais tão diversos, Wacziarg e Welch (2008) demonstraram que em uma análise histórica com referencial apenas no crescimento individual de cada país em desenvolvimento tomado isoladamente, em média a cada $5 \%$ de crescimento da proporção entre a corrente de comércio e o PIB do país ocorre um acréscimo de $1,5 \%$ de crescimento do PIB por ano em média.

Tendo por base estes resultados, a pergunta com qual iniciamos nossa apresentação sobre a histórica recente do sistema multilateral de comércio não é "por que os países decidiram criar mecanismos para promover a liberalização do comércio internacional ?". Mas sim "por que os países restringem o comércio?". Em outras palavras, é preciso desvelar a relação entre o comércio internacional e a política doméstica dos países (GOLDSTEIN, 2012). Partindo de um ponto de vista de economia política doméstica, os países restringem o comércio por cinco razões principais (HOEKMAN, KOSTECKI, 2009):

i) para gerar receita para o governo - historicamente esta é uma das primeiras e principais razões para o surgimento do controle e da tributação do comércio tanto no âmbito internacional quanto, inicialmente, doméstico (para uma visão históricoeconômica deste processo ver: ANDERSON, 1982, 1984);

ii) para alterar os termos de intercâmbio - que significaria promover através de diferentes mecanismos de tributação e controles uma alteração dos preços relativos entre exportações e importações em favor das primeiras. Esta é uma possibilidade teórica que possui diversas premissas e foi muito difundida na América Latina nos anos 1970-1980 pela Comissão Econômica das Nações Unidas para a América Latina (CEPAL).

É importante observar que mesmo que todos os pressupostos necessários sejam satisfeitos este ganho seria apenas transitório, pois, conforme os demais países respondessem a esta política, no longo prazo o efeito seria danoso para todos (para 
uma visão geral dessa corrente ver: BIELSCHOWSKY, 2009; e RODRÍGUEZ, 2009);

iii) visão mercantilista do comércio - que consistiria na visão de que as importações são um mal em si por retirarem divisas da economia doméstica e que as exportações são desejáveis por trazerem mais recursos para o país, devendo este sempre buscar maximizar seu superávit comercial restringindo importações e promovendo as exportações. O conjunto das teorias mercantilistas sempre esteve umbilicalmente associado a questões como nacionalismo e poder estatal.

Embora a inadequação dos pressupostos deste tipo de visão de mundo esteja extensamente demonstrada ao longo dos últimos séculos, tanto teoricamente quanto empiricamente, visto que a Balança de Pagamentos do país sempre irá se equilibrar, a simplicidade e o apelo nacionalista desta visão de mundo ainda fazem muitos estragos em economias nacionais. (para uma visão geral desde a formulação clássica dessa corrente até o fenômeno do neomercantilismo ver: DEYON, 1985; GUIMARÃES, 2005, p. 29-46);

iv) argumento das indústrias nascentes - há uma ampla discussão sobre como mecanismos restritivos ao comércio aplicados em determinadas indústrias por um curto espaço de tempo poderiam em teoria contribuir para a consolidação destes setores sob proteção em benefício da economia nacional. O problema com qualquer restrição provisória é que elas geralmente se tornam permanentes, induzindo o setor produtivo à ineficiência (o que levaria a um consumo da riqueza nacional e não a uma contribuição à mesma), por criarem dependência e interesses consolidados no setor (fenômeno que será discutido a seguir).

Adicionalmente, tanto teoricamente quanto na prática é difícil mensurar todos os efeitos da distorção dos preços relativos provocados pela restrição e os efeitos agregados sobre a economia no longo prazo para afirmar se foram verificados de fato ganhos com a política (para uma visão crítica do tema ver: BALDWIN, 1969; JOHNSON, 1980; e KRUGMAN, OBSTFELD, 2005, p 191-205); e

v) comportamento rentista - o comportamento rentista (rent-seek) é aquele que através da mobilização de um determinado setor econômico que possui interesses concentrados em determinada temática procura transmitir suas preferências ao governo para a adoção de políticas convergentes com seus interesses em 
detrimento do bem-estar da sociedade como um todo. Este fenômeno é muito comum e estudado em profundidade pela economia política nas mais diversas áreas (OLSON, 1965; OLSON, ZECKHAUSER, 1966).

No caso da liberalização do comércio internacional, embora geralmente os ganhos sejam superiores aos custos, as perdas são concentradas em determinados setores organizados que possuem capacidade de mobilização muito superior ao conjunto de todos os consumidores beneficiados pelo processo (para uma visão geral do processo de rent-seeking ver: KRUEGER, 1974; TULLOCK, 2005).

Estas dinâmicas acima descritas ocorrem no nível doméstico dos países e a liberalização comercial depende da quebra ou controle de uma ou mais destas variáveis de forma a permitir a reconfiguração das preferências do ator-Estado em um novo equilíbrio político-econômico (em um ponto mais aberto em relação ao comércio internacional). O sistema multilateral de comércio e suas instituições podem assim ser entendidos como um esforço coletivo dos países de reduzir e/ou controlar o efeito destas variáveis no processo de liberalização comercial (BARTON et al., 2006).

Uma vez escolhido o caminho cooperativo para o controle destas variáveis, surge um problema operacional externo ao jogo que pode afetar seu resultado. Este problema é a factibilidade e credibilidade dos compromissos assumidos. Pois, muito embora os ganhos percebidos conjuntamente na cooperação possam ser suficientes para garantir o compromisso, sempre existe a possibilidade de deserção. Especialmente na área da liberalização comercial, o risco no longo prazo de alterações das preferências dos atores levarem a deserções é elevado (COUTINHO et al., 2007).

Uma solução para este problema cooperativo foi a criação de organismos internacionais capazes de monitorar e garantir em certa medida o cumprimento dos acordos, como o GATT e a OMC, com mandato previamente acordado, de forma a garantir o controle recíproco do comportamento dos atores. Estes mecanismos de controle em áreas onde os ganhos conjuntos percebidos são altos, mas os mecanismos tradicionais de garantir a adesão ao acordo e/ou os mecanismos domésticos de controle são ineficientes, aumenta substancialmente a credibilidade dos compromissos (HERZ, HOFFMANN, 2004). 
Dessa forma, as organizações internacionais de todos os tipos, sejam de caráter técnico como o sistema GATT/OMC e até os arranjos de integração regional, podem ser entendidas como mecanismos de self-enforcement dos acordos internacionais, garantidos por mecanismos de monitoramento da adesão ao mandato pré-estipulado. Assim, a sustentabilidade a longo prazo de qualquer regime internacional capitaneado por uma organização internacional dependerá da eficácia da mesma em garantir o cumprimento dos acordos.

Sob este ponto de vista, o sistema multilateral de comércio pode ser considerado tanto como uma proxy de um mercado quanto como um regime internacional (HOEKMAN, KOSTECKI, Ibid). Pode ser considerado como um mercado, no sentido de sua definição clássica, por ser caracterizado como um fórum onde compradores (demanda) e vendedores (oferta) se encontram para intercambiar bens.

Mas ele é um proxy pois, neste caso, os bens são direitos de acesso aos seus mercados internos nas mais diversas áreas e todos são tanto ofertantes quanto demandantes. Esta dinâmica se assemelharia, portanto, muito mais a um processo de escambo dos mercados de trocas antigos (de onde deriva a própria definição clássica de mercado) do que à moderna dinâmica dos mercados que conhecemos hoje.

No entanto, o resultado produzido é muito semelhante, a troca de concessões desejadas mutuamente dado em um determinado equilíbrio entre a demanda por liberalização e a oferta de liberalização. Ao universalizar e escalar esta dinâmica o sistema multilateral de comércio se tornou também um regime internacional (KRASNER, 1983) composto por: princípios basilares (que abordaremos no próximo tópico); um conjunto de normas e regras estabelecidas pela dinâmica de mercado acima descrita; e um processo decisório estabelecido em torno do qual a expectativa dos atores converge.

É importante, ainda, notar que este é um regime internacional bastante peculiar no qual o sentido do regime é sua própria alteração ao longo do tempo. Embora regimes sustentáveis naturalmente precisem acomodar variações e se adaptar ao longo do tempo em função das mudanças de preferências de seus atores constituintes em uma relação principal-agente, geralmente os regimes não são desenhados para ter uma evolução moto-própria (MILLER, 2005; YOUNG, 1991). 
No caso do comércio internacional, o mote do regime é a liberalização progressiva do comércio e, como consequência, sua própria alteração constante. Ou seja, de suas normas e regras por meio de um processo decisório estabelecido (que também pode variar no tempo) e seguindo determinados princípios, evoluindo ao longo do tempo do imediato pós-guerra até os dias de hoje (ZEILER, 2012; PREEG, 2012).

Sendo assim, o sentido deste regime particular (liberalização progressiva) pode em determinados momentos se dissociar das preferências protecionistas demonstradas em um momento específico do tempo por parcela significativa, ou mesmo todos, os seus atores constituintes. Isso provocaria uma paralisia parcial do sistema em sua dinâmica de mercado, ou seja, na continuidade da troca de concessões de acesso a mercados reciprocamente, bloqueando o avanço do regime no sentido de uma maior liberalização do comércio (ELSIG, DUPONT, 2012; TREBILCOCK et al., 2013)

No entanto, a paralisação da dinâmica de mercado não significa que o sistema deixou de funcionar. Ele pode ainda assim manter suas características do status quo constituído (sem avanços) naquele momento do tempo e seu bom funcionamento seria determinado por sua capacidade de self-enforcement. Ou seja, sua capacidade de garantir o cumprimento das normas e regras existentes a despeito da alteração de preferências dos atores-Estados.

Isto implica em que um conjunto de normas e regras (entendido como um nível específico de liberalização) não pode avançar sem o desejo ativo dos atores constituintes do sistema. Mas que a despeito de mudanças das preferências destes atores ao longo do tempo para níveis de liberalização inferiores ao existente, o regime bloqueia retrocessos. Portanto, a flexibilidade do regime é unidirecional e só permite avanços em seu mote-próprio.

Tal fato faz com que preferências discrepantes de um ator em um determinado período de tempo em direção a formas mais autárquicas de comércio possam ser restringidas pelo regime. Em momentos como estes o regime deve ser capaz de garantir o cumprimento dos compromissos, com a correção de eventuais desvios, de maneira a preservar seu status quo até uma nova convergência das preferências dos atores para a liberalização do comércio e a volta ao funcionamento de sua dimensão de mercado. 


\subsection{O sistema multilateral de comércio do GATT à OMC}

No imediato pós Segunda Guerra mundial, no espectro ocidental do globo, um sistema de cooperação internacional na área econômica de caráter multilateral tripartite é gestado. Em 1944, no famoso hotel Bretton Woods, em New Hampshire nos Estados Unidos (EUA), foi decidido que sob o sistema da Organização das Nações Unidas (ONU) seriam criadas três organizações internacionais com o intuito de coordenar a cooperação em três áreas: financeira; desenvolvimento e reconstrução; e comércio internacional (HERZ, HOFFMANN, Ibid).

A primeira área seria abarcada pelo Fundo Monetário Internacional (FMI), responsável pelos arranjos cambiais e estabilização monetária; a segunda pelo Banco Mundial ou Banco Internacional para a Reconstrução e o Desenvolvimento (BIRD), responsável, em conjunto com a Organização de Cooperação para o Desenvolvimento Econômico (OCDE), por gerir os recursos destinados à reconstrução da Europa devastada pela guerra e mais tarde por programas de financiamento ao desenvolvimento nos países pobres e em desenvolvimento.

No campo do comércio internacional, houve a tentativa de se criar a Organização Internacional do Comércio (OIC), tendo a ONU convocado reunião em Havana, Cuba, em 1946 com esta finalidade específica. Este empreendimento fracassou, pois, um dos principais arquitetos da organização e o responsável pelo maior volume de comércio do globo na época, os Estados Unidos, não pôde ratificar o acordo de criação do organismo devido à forte oposição de seu Congresso (TOYE, 2012).

As negociações em Havana produziram, no entanto, uma solução parcial para este problema. Foi criado um pequeno secretariado para a organização que mesmo a despeito de sua não efetivação em organismo internacional propiciou um fórum (dimensão do mercado) de discussão multilateral na matéria.

Dessa forma, em 1947 foi assinado o Acordo Geral sobre Tarifas e Comércio (GATT), responsável por levar a cabo, mesmo que de forma não institucionalizada, as negociações comerciais multilaterais, que objetivavam há época principalmente a desconstrução das barreiras quantitativas ao comércio internacional, na forma de quotas e outras restrições, além de reduções tarifárias (ZEILER, 2012).

O surgimento do GATT não como uma organização internacional, mas como um mecanismo de um regime incompleto e, portanto, pouco institucionalizado foi paradoxalmente de importância central para o sucesso do próprio regime (BARTON 
et al., 2008). Por se basear muito mais em princípios gerais do que em normas e regras bem definidos, basear seu processo-decisório como regra no consenso entre todas as partes, além de congregar um coletivo de atores com grande convergência temporal de preferências liberalizantes, a dimensão de mercado do sistema pôde avançar rapidamente.

Os dois principais princípios orientadores do sistema alicerçado pelo GATT e ainda hoje prevalecentes são (TREBILCOCK et al., Ibid):

a) Princípio da não-discriminação - este é o principal princípio fundador do sistema multilateral de comércio e implica que no âmbito do sistema os atores não devem discriminar concessões de forma diversa entre os membros e que bens nacionais e estrangeiros devem ter o mesmo tipo de tratamento. Pode-se observar este princípio consolidado em duas importantes regras do sistema:

i) Cláusula da nação mais favorecida (GATT 1947¹/Art. I):. cada parte contratante tem a obrigação dar o mesmo tratamento (mais favorecido) dispensado a uma parte específica a todas as demais partes do sistema. Esta cláusula é fundamental para garantir os efeitos sistêmicos das negociações e especialmente importante para membros com menor poder de barganha, pois, torna automática a extensão dos benefícios negociados por grandes importadores e exportadores. A presente cláusula, portanto, atua de forma a prevenir a ocorrência de discriminação entre as partes contratantes do acordo geral.

ii) Cláusula do tratamento nacional (GATT 1947/Art. II):. as partes contratantes devem dar aos produtos importados o mesmo tratamento dispensado aos produtos nacionais. Após a internalização da mercadoria no mercado doméstico, o produto importado não pode receber tratamento menos favorável do que aquele dispensado ao produto similar nacional.

De forma geral, esta cláusula proíbe a discriminação entre produtos nacionais e importados. O produto estrangeiro deverá receber o mesmo tratamento que o similar nacional no que concerne às leis, regulamentos ou

\footnotetext{
1 The General Agreement on Tariffs and Trade (GATT 1947). Disponível em
} <https://www.wto.org/english/docs_e/legal_e/gatt47_01_e.htm>. Acesso em setembro de 2015. 
requerimentos que afetem sua venda interna, oferta, aquisição, transporte, distribuição e uso.

b) Princípio da reciprocidade - este é um princípio transversal de todo o sistema e basilar nas relações internacionais. De forma geral a reciprocidade é a base sobre a qual os países estabelecem suas relações. Especificamente no sistema multilateral de comércio, a reciprocidade é caracterizada em dois sentidos, um positivo e um negativo.

$\mathrm{Na}$ vertente positiva, o princípio visa reduzir o estímulo ao comportamento carona que poderia ser gerado pela cláusula da nação mais favorecida, limitando o incentivo para que os membros procurem apenas se beneficiar de concessões negociadas por terceiros. É esperado que os membros, assim, sejam proativos e apresentem concessões equivalentes (em termos financeiros).

Do lado negativo, o princípio da reciprocidade autoriza a suspensão de benefícios obtidos por um membro quando este membro deixa de cumprir com seus compromissos. Este aspecto será melhor discutido em nossa abordagem sobre a solução de controvérsias no sistema.

A operação destes princípios alinhada com a inédita convergência de preferências dos principais membros na direção de liberalização do comércio, permitiu que, a despeito das normas e regras frouxas do sistema, o regime se adensasse. Foi esta ambiguidade que permitiu que a apesar de mudanças eventuais nas preferências dos membros e das divergências provocadas nas práticas comerciais destes, os mesmos não se afastassem tanto do normativo do sistema dada sua flexibilidade (Id, Ibid).

Assim, guiando-se muito mais pelos aspectos principiológicos, as partes puderam avançar na dimensão de mercado do sistema, trocando concessões de acesso a seus mercados mesmo com divergências pontuais de práticas comerciais. O acordo estabelecido em 1947, inicialmente modesto, foi sendo gradualmente modificado e ampliado por sucessivas Rodadas de negociação multilaterais (ZEILER, Ibid).

As cinco primeiras Rodadas do GATT trataram prioritariamente de concessões tarifárias entre as partes e se desenvolveram de forma bastante rápida: Genebra (1947), Annecy (1951), Genebra (1956) e Dillon (1960). Estas rodadas 
concentraram-se muito mais na dimensão de mercado do sistema. As três Rodadas seguintes, no entanto, avançaram na institucionalização do sistema e trouxeram novos temas para agenda: Kennedy (1964), Tóquio (1973) e Uruguai (1986).

A Rodada Kennedy, ocorrida entre 1964 e 1967, foi emblemática. No início das negociações da rodada foi instituído o "Tratamento Especial e Diferenciado" para os países em desenvolvimento (GATT/Parte IV) ${ }^{2}$. Esta Rodada marcou o ingresso da Comunidade Econômica Europeia (CEE) como parte do GATT e representante do bloco europeu. A CEE se tornaria um dos principais negociadores do sistema com grande poder de barganha rivalizado apenas pelos Estados Unidos. Adicionalmente, os protocolos ${ }^{3}$ estabelecidos na rodada adensaram a cobertura do regime de comércio multilateral em novas áreas (BARTON et al., Ibid; ZEILER, Ibid; TREBILCOCK et al., Ibid).

A Rodada Tóquio, realizada entre 1973 e 1979, por sua vez avançou fortemente na direção da maior institucionalização do regime, ampliando sensivelmente seu arcabouço normativo. Foram negociados novos acordos, conhecidos como Tokyo Codes ${ }^{4}$, tais como: códigos de regulação de procedimentos alfandegários, barreiras não-tarifárias, valoração aduaneira, licenciamento de importações, barreiras técnicas, compras governamentais, subsídios e direitos compensatórios, e antidumping (BARTON et al., Ibid; ZEILER, Ibid; TREBILCOCK et al., Ibid).

${ }^{2}$ GATT PART IV - $\quad$ Trade and Development. Disponivel em

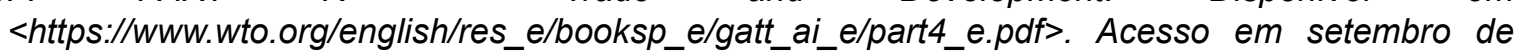
2015.

${ }^{3}$ 1964-1967 Trade Conference Protocols. Disponível em <https://www.wto.org/english/docs_e/legal_e/kennedy_e.pdf>. Acesso em setembro de 2015.

${ }^{4}$ Tokyo Round Codes: Antidumping - Disponível em <https://www.wto.org/english/docs_e/legal_e/tokyo_adp_e.pdf> <https://www.wto.org/english/docs_e/legal_e/tokyo_scm_e.pdf>; Balance-of-Payments Disponível em <https://www.wto.org/english/docs_e/legal_e/tokyo_bop_e.pdf>; Civil Aircraft Disponível em <https://www.wto.org/english/docs_e/legal_e/tokyo_air_e.pdf $>$; Customs Valuation Disponível em <https://www.wto.org/english/docs_e/legal_e/tokyo_val_e.pdf>; Developing Countries - Disponível em <https://www.wto.org/english/docs_e/legal_e/tokyo_safe_e.pdf> e $<$ https://www.wto.org/english/docs_e/legal_e/tokyo_enabling_e.pdf $>$; Differential and more favourable treatment - - Disponível em <https://www.wto.org/english/docs_e/legal_e/tokyo_enabling_e.pdf>; Dispute Settlement Disponivel em <https://www.wto.org/english/docs_e/legal_e/tokyo_notif_e.pdf>; Government Procurement - Disponível em <https://www.wto.org/english/docs_e/legal_e/tokyo_gpr_e.pdf>; Import Licensing - Disponível em <https://www.wto.org/english/docs_e/legal_e/tokyo_lic_e.pdf>; Safeguards - Disponível em <https://www.wto.org/english/docs_e/legal_e/tokyo_safe_e.pdf>; Subsidies - Disponível em <https://www.wto.org/english/docs_e/legal_e/tokyo_scm_e.pdf>; Technical Barriers to Trade - - Disponível ${ }^{-}$em <https://www.wto.org/english/docs_e/legal_e/tokyo_tbt_e.pdf>; Arrangement regarding Bovine Meat - Disponível em <https://www.wto.org/english/docs_e/legal_e/tokyo_abm_e.pdf>; e International Dairy Arrangement <https://www.wto.org/english/docs_e/legal_e/tokyo_dai_e.pdf>. Acesso em setembro de 2015. 
Além de se avançar a liberalização do sistema com uma redução tarifária média de $30 \%$ sobre a tarifa consolidada de produtos industriais. Durante esta Rodada foi também instituída a Cláusula de Habilitação ${ }^{5}$ que permitia a flexibilização da Cláusula da nação mais favorecido na formação de arranjos de comércio preferencial e integração regional entre países em desenvolvimento.

Finalmente, em 1986 é lançada em Punta del Este a Rodada Uruguai, a mais longa e complexa rodada de negociações sob o GATT. Nesta altura o GATT já contava com 123 países-membros (partes contratantes), correspondendo a uma grande diversidade de preferências e visões de mundo (ROLLAND, 2012).

O principal objetivo desta rodada era incorporar ao disciplinamento multilateral do GATT áreas até então ausentes do acordo, os chamados "novos temas", tais como: serviços, comunicações, investimentos e propriedade intelectual. Além de uma agenda latente sobre temas ainda não bem equacionados pelos acordos como padrões técnicos, sanidade, agricultura e barreiras não-tarifárias (PREEG, 2012).

O Quadro 1.1 a seguir nos permite ter uma clara visão do aumento do escopo do sistema tanto no número de países-membros quanto do volume de comércio afetado pelas negociações e da evolução dos temas. A partir da Rodada Kennedy o aspecto meramente tarifário das discussões no GATT começa a ser suplantado, com adensamento do regime:

Quadro 1.1: Rodadas multilaterais de comércio do GATT

\begin{tabular}{|l|l|l|l|l|}
\hline \multicolumn{1}{|c|}{ Ano } & \multicolumn{1}{|c|}{ Rodada } & $\begin{array}{c}\text { Questões temáticas } \\
\text { principais }\end{array}$ & $\begin{array}{c}\text { Comércio } \\
\text { afetado }\end{array}$ & $\begin{array}{c}\text { Número } \\
\text { de países }\end{array}$ \\
\hline 1947 & Genebra I & Tarifas & 10 bilhões & 23 \\
\hline 1949 & Annecy & Tarifas & n. d. & 13 \\
\hline 1951 & Torquay & Tarifas & n. d. & 38 \\
\hline 1956 & Genebra II & Tarifas & $\begin{array}{l}2,5 \\
\text { bilhões }\end{array}$ & 26 \\
\hline $1960-1961$ & Dillon & Tarifas & $\begin{array}{l}4,9 \\
\text { bilhões }\end{array}$ & 26 \\
\hline
\end{tabular}

\footnotetext{
${ }^{5}$ Diferential and more favourable treatment, reciprocity and fuller participation of Developing Countries. Disponível em <https://www.wto.org/english/docs_e/legal_e/tokyo_enabling_e.pdf>. Acesso em setembro de 2015.
} 


\begin{tabular}{|l|l|l|l|l|}
\hline $1964-1967$ & Kennedy & $\begin{array}{l}\text { Tarifas e medidas } \\
\text { antidumping. }\end{array}$ & 40 bilhões & 62 \\
\hline $1973-1979$ & Tóquio & $\begin{array}{l}\text { Tarifas e barreiras } \\
\text { não-tarifárias. }\end{array}$ & $\begin{array}{l}155 \\
\text { bilhões }\end{array}$ & 102 \\
\hline $1986-1994$ & Uruguai & $\begin{array}{l}\text { Tarifas, barreiras não- } \\
\text { tarifárias, produção } \\
\text { agrícola, serviços, } \\
\text { propriedade } \\
\text { intelectual e têxteis. }\end{array}$ & $\begin{array}{l}3,7 \\
\text { trilhões }\end{array}$ & 123 \\
\hline
\end{tabular}

Fonte: Elaboração própria com base em (HERZ, HOFFMANN, Op. Cit., p. 152).

Conforme se pode observar o GATT teve aderência crescente e durante a ordem bipolar abarcava a maioria expressiva dos países do bloco ocidental. Com o fim da bipolaridade, seu escopo se ampliou ainda mais com a membresia de países do antigo bloco soviético.

Apesar da grande aderência ao GATT e relativo sucesso na redução de tarifas ao comércio, sua falta de institucionalização e seu enfoque principalmente tarifário com ênfase sobre o comércio de bens industriais foram gradativamente tornando-o menos eficaz na administração do sistema multilateral em que emergiam novos interesses nas áreas agrícola, de serviços, propriedade intelectual, investimento, além de barreiras não-tarifárias:

\footnotetext{
Por um lado o GATT foi considerado um sucesso, ao reduzir as tarifas comerciais ao longo de várias rodadas de negociações [...] Por outro lado, o GATT se mostrou incapaz de se adaptar às mudanças na economia internacional, principalmente à medida que o processo de globalização se intensificou, no final da década de 1980 (HERZ, HOFFMANN, 2004, p. 153).
}

Com o fortalecimento do regionalismo econômico, a diminuição das barreiras tarifárias e a crescente utilização de barreiras não-tarifárias ao comércio, o aumento da importância do comércio de serviços e propriedade intelectual, além de demandas pela inclusão de uma pauta agrícola nas negociações multilaterais, a falta de institucionalização do GATT tornava-se um problema crescente tanto para o tratamento dos novos temas como para a efetividade dos acordos alcançados (PREEG, Ibid; ROLLAND, Ibid; BARTON et al., Ibid; TREBILCOCK et al., Ibid). Ou seja, o sistema em sua dimensão de regime ainda era deficiente e passava a limitar a evolução da dinâmica de mercado do próprio sistema. 
Assim, em paralelo à Rodada Uruguai do GATT, foi negociada a criação da Organização Mundial do Comércio para dar institucionalidade e maior poder ao organismo responsável pelas negociações comerciais multilaterais. Em 15 de abril de 1994, ao término da Rodada Uruguai, foi assinada a criação da $\mathrm{OMC}^{6}$. Organização que assumiu todos os acordos firmados no âmbito do sistema anteriormente, consolidados no GATT $1994^{7}$ (PREEG, Ibid).

Um dos principais desafios para a continuidade da evolução do sistema multilateral de comércio é a legitimidade. Ou seja, depende da OMC ser vista como uma instituição legítima e razoavelmente neutra para avançar neste processo. Segundo Barton et al. (Ibid), no centro do problema da legitimidade da OMC está o fato de determinadas premissas existentes sobre o papel do sistema multilateral de comércio sob a égide do GATT não são mais compartilhadas pelos componentes do sistema.

O motor principal do sistema sob o GATT era avançar em direção à liberalização gradual do comércio. Quando os atores relevantes no sistema eram apenas os países desenvolvidos e, especialmente sob a ordem mundial bipolar, pertencentes ao mundo ocidental, não havia grandes divergências em suas preferências e em relação à sua visão sobre o objetivo ideacional do sistema - o livre comércio - uma meta considerada mutuamente benéfica a todos.

Mas com o próprio sucesso do sistema e sua expansão tanto do ponto de vista geográfico, passando a abarcar países anteriormente pertencentes ao bloco comunista e ampliando a participação dos países do Sul em desenvolvimento, bem como avançando sobre outras áreas temáticas relacionadas ao comércio, o sistema passou a ser mais institucionalizado, diverso, complexo e rule-oriented (HOEKMAN, KOSTECKI, Ibid; BARTON et al., Ibid; TREBILCOCK et al., Ibid).

Ou seja, o sistema adensou-se enquanto regime internacional. Dessa forma, cada vez mais passou a sofrer com os problemas comuns inerentemente associados ao processo legislativo/constitutivo de qualquer norma ou regulação, especialmente em um contexto onde é negociada por uma grande quantidade de atores com preferências e visões de mundo distintas.

Considerando-se que o processo legislativo consubstanciado no sistema afeta interesses políticos e econômicos diversos e que existem significativos trade

\footnotetext{
${ }^{6}$ Agreement Establishing the World Trade Organization. Disponível em <https://www.wto.org/english/docs_e/legal_e/04-wto.pdf>. Acesso em setembro de 2015.

${ }^{7}$ General Agreement on Tarifs and Trade 1994 (GATT 1994). Disponível em <https://www.wto.org/english/docs_e/legal_e/06-gatt.pdf>. Acesso em setembro de 2015.
} 
offs entre estes interesses que dependem não apenas da forma como as normas são escritas mas também como são interpretadas, não se poderia mais assumir que as regras emergentes deste processo seriam benéficas para todos. Como consequência, a transição do GATT para a OMC significou uma mudança de regime que se desenvolveu não sem considerável turbulência (PREEG, Ibid; ROLLAND, Ibid, HERZ, HOFFMANN, Ibid).

Entre 1995 e 1998 houve a realização de duas conferências ministeriais, órgão máximo da instituição: Cingapura (1996) e Genebra (1998). Estas reuniões foram bastante infrutíferas, de modo que, a despeito da regra que estabelecia uma periodicidade de dois anos entre a realização de cada conferência ministerial, já no ano seguinte em 1999 foi realizada em Seattle a terceira conferência da organização (PREEG, Ibid; ROLLAND, Ibid).

Esta reunião foi marcada pela invasão do local da conferência por manifestantes antiglobalização, que acusavam a OMC de predisposição contra os interesses dos países em desenvolvimento e afirmavam que a abertura de novos mercados efetivamente prejudicaria mais do que ajudaria os trabalhadores destes países (ALTMAN, 2011)

Protestos deste tipo tornaram-se característica recorrente das reuniões da entidade. Rapidamente, os protestos passaram a não se restringirem apenas aos manifestantes que se aglomeravam do lado de fora das convenções, mas passaram às mesas de negociação ecoados pelos próprios representantes dos países em desenvolvimento (Id lbid; ROLLAND, Ibid).

Todo este panorama conturbado observado nos primeiros anos da OMC pode ser considerado como parte do processo de acomodação dos atores ao novo regime de comércio. Este novo regime, representado pela OMC, significou em parte uma continuidade do regime estabelecido no GATT, por manter seus princípios e arcabouço de acordos em geral, além de ter como mote ainda a finalidade última continuar avançando no processo de liberalização comercial.

No entanto, significou também uma ruptura parcial com o regime anterior, com alterações substantivas de regras e procedimentos e ampliando a participação dos países do Sul na organização. Portanto, este processo de acomodação refletiu o reequilíbrio de forças na organização em um novo patamar, ditado pela grande diversidade de preferências apresentadas pelos membros (ALTMAN, Ibid; ROLLAND, Ibid). 
Como resultado, a primeira rodada de negociações multilaterais sob a égide do novo regime só foi lançada sete anos após o surgimento da OMC, no ano de 2001 em Doha (Catar), embalada pela onda de solidariedade internacional que se seguiu aos ataques de 11 de setembro de 2001 nos EUA (PREEG, Ibid). No entanto, isto não significou que tenha havido uma nova convergência de preferências entre os atores do sistema.

Ao contrário, a Rodada Doha tornou-se a primeira rodada de liberalização comercial que não ousa dizer seu nome. Ou seja, pela primeira vez, ao menos no plano do discurso, o objetivo das negociações não teria como foco a meta de liberalização comercial propriamente dita, mas sim o comércio e o desenvolvimento. Ou mais precisamente, o comércio para o desenvolvimento. $O$ que pode ser entendido de diversas maneiras distintas, a depender das preferências domésticas de seus membros, e em muitos casos significar inclusive o oposto ao processo buscado pela organização (ALTMAN, Ibid; ROLLAND, Ibid).

A Rodada Doha foi assim denominada de Rodada do Desenvolvimento, ou Rodada para o Desenvolvimento. Mesmo antes do lançamento da rodada ocorreram intrincadas batalhas diplomáticas em torno das definições de desenvolvimento e do que de fato significava uma rodada para o desenvolvimento (CARVALHO, 2012). Dentre a diversa gama de interesses expostos nestas negociações, é possível identificar seis posições principais de convergência, no que ficou conhecido como Grupo dos Seis: Brasil, Estados Unidos, União Europeia (UE), Japão, Austrália e Índia (NARLIKAR, 2003, 2012).

Em torno de cada país pilar formaram-se coalizões distintas com a consolidação de posições negociadoras semelhantes. $O$ contato entre as posições estratégicas de cada polo era feito por meio de reuniões paralelas entre os líderes de cada bloco, que receberam, inclusive, o título de "mini-ministeriais" pela imprensa internacional.

Grandes exportadores agrícolas, como Estados Unidos, Austrália e, inicialmente, Brasil, em seus principais discursos no lançamento da rodada procuraram enfatizar que sensíveis reduções na proteção tarifária no setor agrícola trariam grandes ganhos para os países pobres através do barateamento dos gêneros alimentícios e pela abertura do mercado mundial para os produtores locais, gerando mais emprego e renda nestes países (NARLIKAR, Ibid; ROLLAND, Ibid).

Já o discurso dos países com baixo nível de desenvolvimento e daqueles com problemas graves de abastecimento e pobreza endêmica, como a Índia, 
desenvolvimento significava poder praticar políticas de proteção e assistência às suas populações, aliadas a uma redução dos subsídios e abertura de mercado dos países ricos (Id Ibid).

A União Europeia, tendo seu próprio e influente lobby de produtores agrícolas para se preocupar, adotou uma posição semelhante à da Índia. Procurou criticar os Estados Unidos por tentarem forçar a rodada rumo a uma liberalização drástica na área, o que seria impossível e mesmo danoso para os países menos desenvolvidos, segundo discurso do Comissário de Comércio Europeu à época, Peter Mandelson (MESSERLIN, 2012).

Estas tensões entre blocos se exacerbaram e se tornaram mais do que evidentes, culminando no fracasso da $\mathrm{V}$ Conferência Ministerial da OMC, realizada em Cancún no ano de 2003. O fracasso se deveu a um recrudescimento na posição dos países em desenvolvimento, que representam hoje cerca de dois terços dos membros da organização, devido ao receio de serem afastados das negociações pelo lançamento conjunto das propostas da União Europeia e dos Estados Unidos para a rodada, em uma reedição mal sucedida do Acordo de Blair House que posto fim às negociações durante a Rodada Uruguai do GATT (PREEG, Ibid; ROLLAND, Ibid).

Em 2004, o grupo Quad, composto por EUA, UE, Canadá e Japão, que antes fechava acordos nos bastidores para acelerar as negociações e em prol de um equilíbrio geral mais próximo dos interesses destes países mais desenvolvidos, foi substituído pelo grupo "Cinco partes interessadas", composto por EUA, UE, Índia, Brasil e Austrália, e que procurava representar um melhor equilíbrio entre os interesses de países desenvolvidos e em desenvolvimento (Id lbid).

Neste novo quadro, Índia e Brasil deveriam representar os interesses do mundo em desenvolvimento, enquanto a Austrália encabeçava os grandes exportadores agrícolas, em especial o grupo de Cairns. Não obstante, a sucessão de fracassos prosseguiu, com a Ministerial de Hong Kong, em 2005, também terminando em impasse, o mesmo resultado repetindo-se novamente em Genebra, em 2006. Mesmo sob a liderança deste novo grupo, não se chegou a um acordo sobre as questões mais fundamentais que travam a rodada: subsídios agrícolas, abertura do setor de serviços e o scheduling (NARLIKAR, Ibid).

Quanto à mesa de negociações, a programação da ministerial de Genebra, que terminou em dezembro de 2009, nem mesmo incluía sessões de negociações oficiais. No presente momento, as negociações da rodada estão em um impasse 
bastante distante de seus auspiciosos discursos de abertura e projeções iniciais, apesar do positivo acordo conhecido como Pacote de Bali alcançado na reunião ministerial no ano de 2013 (OMC, 2014).

Ao contrário do GATT, que teve 8 rodadas de negociação, a OMC está ainda em sua primeira rodada, como detalha a Quadro 1.2. Mas sua arquitetura institucional já propiciou a organização de nove reuniões de Ministros de Comércio e/ou Relações Exteriores denominadas de Reuniões Ministeriais ou apenas de ministeriais, conforme mostra a Quadro 1.3 na próxima página. Inicialmente, estas reuniões foram projetadas para acontecerem a cada dois anos, no entanto, a periodicidade tem variado de acordo com o ritmo das negociações da organização, conforme discutido anteriormente.

Quadro 1.2: Rodada multilateral de comércio da OMC

\begin{tabular}{|c|l|l|l|}
\hline Ano & Rodada & \multicolumn{1}{|c|}{ Questões temáticas principais } & $\begin{array}{l}\text { Número } \\
\text { de países }\end{array}$ \\
\hline $2001-?$ & $\begin{array}{l}\text { Doha } \\
\begin{array}{l}\text { (Rodada do do } \\
\text { Milênio) }\end{array}\end{array}$ & $\begin{array}{l}\text { Tarifas, barreiras não-tarifárias, } \\
\text { agricultura, padrões laborais, meio } \\
\text { ambiente, competição, investimento, } \\
\text { patentes, compras governamentais e } \\
\text { transparência. }\end{array}$ & "Até 31/12/2012 \\
\hline
\end{tabular}

Fonte: Elaboração própria com base em (OMC, 2012).

Quadro 1.3: Conferências ministeriais da OMC

\begin{tabular}{|l|l|l|}
\hline Número & Ano & Local \\
\hline I & 1996 & Cingapura \\
\hline II & 1998 & Genebra (Suíça) \\
\hline III & 1999 & Seattle (EUA) \\
\hline IV & 2001 & Doha (Catar) \\
\hline V & 2003 & Cancún (México) \\
\hline VI & 2005 & Hong Kong (China) \\
\hline VII & 2009 & Genebra \\
\hline VIII & 2011 & Genebra \\
\hline IX & 2013 & Bali (Indonésia) \\
\hline
\end{tabular}

Fonte: Elaboração própria com base em (OMC, 2013b). 
Os desdobramentos descritos pretensamente mostrariam que a OMC fracassou na missão de avançar na abertura de mercados e de ampliar a liberalização do comércio global e poderiam apontar, inclusive, para um fim ou bloqueio da organização (HORN et al., 2010; RUGMAN, 2012; SALLY, 2004; RICHTER, 2014; VALENZUELA, 2011; BAYNE, 2000; BRADFORD, 2007; RAGHAVAN, 2001).

No entanto, em geral, análises mais alarmistas deixam de considerar questões básicas sobre o funcionamento do sistema. A primeira delas é confundir suas duas dimensões. Conforme observamos anteriormente, o sistema possui uma dimensão de mercado/fórum que foi a principal propulsora do GATT com a troca recíproca de acesso a mercados em sucessivas rodadas de liberalização comercial. Ao olhar apenas para esta dimensão e comparar os relativamente rápidos avanços do GATT com a "paralisia" da OMC, talvez nos fosse autorizada uma conclusão pessimista sobre sua evolução.

Mas para isto teríamos que desconsiderar toda a teoria econômica dos retornos marginais decrescentes (NICHOLSON, 2004) que nos diz que conforme maior a quantidade de um fator na função de produção, menores os retornos auferidos por este fator. Ou seja, partindo de uma base onde o comércio internacional era extremamente fechado e controlado, os primeiros ganhos obtidos com a liberalização são muito maiores e mais rápidos, além de visíveis para todos os atores, do que seus sucessores.

Dessa forma, conforme se avança no processo de liberalização, os ganhos, embora existentes, passam a ser menores em termos relativos. Isto torna naturalmente mais complexas e difíceis as negociações. Ao mesmo tempo, o próprio sucesso do sistema o tornou praticamente universal.

Com isso, deste sistema agora é requerido não apenas a convergência de preferências de um pequeno grupo de atores ideologicamente alinhados para avançar a dinâmica de mercado (trocas/liberalização), mas de uma multiplicidade de atores muito diversos entre si (BARTON et al., Ibid; TREBILCOCK et al., Ibid). A coincidência de uma convergência temporal de preferências fortes no sentido da liberalização passou a ter baixa probabilidade de ocorrência, o que nos indica a tendência de que ganhos marginais como o Pacote de Bali deverão ser a nova tônica do sistema e não novos acordos globais amplos.

De outro lado, em sua dimensão de regime internacional, o sistema multilateral de comércio tornou-se mais institucionalizado e robusto do que nunca, 
regulando uma ampla gama de aspectos da vida econômica internacional. Anunciar a "paralisia" e o fim da OMC é ignorar completamente esta importante dimensão do sistema.

Em função do novo contexto, a opinião partilhada por esta pesquisa, é de que a dimensão do regime e não mais a de mercado passou a ter um papel maior no desenvolvimento do sistema. Portanto, é o bom funcionamento da regulação do comércio internacional que deve orientar a análise sobre o sucesso ou insucesso da OMC e não o avanço da dimensão de mercado como no início do sistema multilateral.

\subsection{Evolução da solução de controvérsias do GATT à OMC}

Conforme o regime internacional do sistema multilateral de comércio passou gradativamente de um regime mais principialista e flexível (com menor abrangência) para um regime efetivamente universal (tanto geograficamente quanto em escopo do comércio) e em consequência muito mais normatizado, passou a ser necessário um mecanismo de interpretação oficial e uniforme das regras (BOWN, 2009; GRIMMET, 2011).

Da mesma forma, este mecanismo deveria também procurar garantir o cumprimento destas regras de forma equânime por uma multiplicidade de atores com visões distintas e, não menos importante, ser capaz de punir comportamentos desviantes das normas acordadas.

Conforme pode-se observar no texto original do acordo do GATT $1947^{8}$, foram previstos apenas dois artigos devotados ao tema da solução de controvérsias no sistema. O Artigo XXII estabelecia o mecanismo de consultas, onde cada uma das partes contratantes do GATT poderia solicitar a abertura de consulta a outra parte sobre qualquer assunto que julgasse afetar os compromissos desta no âmbito do acordo. $\mathrm{Na}$ impossibilidade de se chegar a um termo satisfatório entre as partes, o membro poderia solicitar aos demais membros a abertura de consultas contra o terceiro com o auxílio destes.

O Artigo XXIII disciplinava de forma pouco estruturada que caso uma parte considerasse incorrer em prejuízos ou na anulação de vantagens causados por outra parte (por falha desta na implementação de seus compromissos, por outras medidas adotadas fora do acordo quer em conformidade ou não com o mesmo, ou

\footnotetext{
${ }^{8}$ Disponível em <https://www.wto.org/english/docs_e/legal_e/gatt47_e.pdf>.
} 
por qualquer outro motivo a ser especificado) e na ausência de acordo entre ambas as partes para dirimir o conflito, a parte interessada poderia recorrer às partes contratantes em conjunto para dirimir a questão.

Não obstante estas previsões, é importante salientar que a regra básica do processo-decisório era o consenso e que, portanto, a implementação de qualquer decisão dependia também da anuência da parte afetada. Observa-se também que o texto aprovado possuía bastante ambiguidade e poucas previsões práticas sobre a real operação da solução de controvérsias no âmbito do sistema.

Por esta razão, a evolução da solução de controvérsias no âmbito do GATT foi disciplinada em grande medida por sua própria práxis. No entanto, desde o início podem-se observar conceitos fundamentais da operação do sistema de solução de controvérsias: i) as partes devem sempre procurar resolver disputas primeiramente de forma amigável por meio de consultas; e ii) apenas o GATT poderia autorizar a aplicação de penalidades contra seus membros, devendo cada parte abster-se de levar a cabo retaliações unilaterais (HUDEC, 1990).

O primeiro litígio protocolado no âmbito do GATT, Benelux (Bélgica, Holanda e Luxemburgo) contra Cuba, foi protocolado no ano de 1948. Após a falta de acordo entre as partes, o litígio foi resolvido por meio de uma decisão unilateral do presidente do grupo das partes contratantes após solicitação da Holanda (Id, 1998). A partir do segundo caso trazido ao GATT e entre 1949 e 1951 os litígios foram resolvidos, se não de forma plena ao menos em parte, através da instalação de grupos de trabalho específicos para cada caso. Os grupos eram compostos pelas partes em litígio e, em geral, por três outras partes neutras no tema. Cabia a estes grupos de trabalho emitir parecer que seria posteriormente submetido à análise de todas as partes pelo presidente (Id Ibid).

A partir de 1952, o GATT passou a utilizar o modelo de painéis na solução de controvérsias. Primeiramente apenas o presidente do painel era escolhido de forma individual e os demais membros indicados como representantes de países, excluída a participação das partes interessadas (reclamante ou acionado) como membros do painel. Posteriormente, todos os membros dos painéis passaram a ser apontados de forma individual e não como representantes estatais. O procedimento adotado nos painéis incluía ouvir ambas as partes em litígio, mas as excluía do processo decisório do painel. Após a decisão, o presidente do painel deveria submeter o relatório de recomendações à aprovação de todas as partes contratantes do GATT (HUDEC, 1998; JACKSON, 1997; STEWART, 1993). 
O modelo de solução de controvérsias continuou praticamente o mesmo até o final dos anos 1970 com algumas poucas alterações. Em 1958 passou a ser permitida a participação de partes interessadas (terceira parte), não relacionadas às partes em litígio, interessadas em acompanhar o desenvolvimento dos painéis. Em 1966 houve uma alteração de procedimentos para flexibilizar o sistema de solução de controvérsias quando uma das partes em litígio fosse um país em desenvolvimento (STEWART, Ibid.).

Apenas em 1979, com a conclusão da Rodada Tóquio, o sistema de solução de controvérsias do GATT conheceria uma codificação de seus procedimentos com a implementação de sua primeira reforma consolidada no "Entendimento sobre Notificação, Consultas, Solução de Controvérsias e Monitoramento" ${ }^{\text {e }}$ em seu respectivo Anexo, o "Acordo Descritivo de Práticas Costumeiras do GATT no Campo da Solução de Controvérsias (Artigo XXIII:2)".

Estes acordos, no entanto, significaram apenas a codificação e transparência das práticas adotadas na solução de controvérsias e não sua modificação. A primeira reforma mais ampla do sistema de solução de controvérsias ocorreria apenas durante as negociações da Rodada Uruguai (WINHAM, 1986; JACKSON et al., 1984; HUDEC, 1990).

Antes mesmo da conclusão da rodada, um novo conjunto de disposições ${ }^{10}$ sobre a operação do sistema entrou em vigor, dentre as principais mudanças destaca-se: a necessidade de notificação das partes contratantes sobre soluções mutuamente acordadas; cronogramas e prazos para as consultas; a possibilidade de utilização de mecanismos alternativos para a solução de disputas como bons ofícios, conciliação, mediação e arbitragem; regras mais precisas para o funcionamento dos painéis e grupos de trabalho; assistência técnica; adoção de relatórios dos painéis e monitoramento da implementação das decisões (STEWART, Ibid; CROOME, 1999).

No entanto, a adoção dos relatórios dos painéis ainda necessitava do consenso positivo de todas as partes contratantes. Finalmente, durante as negociações de reforma do sistema multilateral de comércio durante a Rodada Uruguai, que culminariam na criação da OMC, o sistema de solução de

\footnotetext{
${ }^{9}$ Understanding regarding notification, consultation, dispute settlement and surveillance. Disponível em <https://www.wto.org/english/docs_e/legal_e/tokyo_notif_e.pdf>. Acesso em setembro de 2015. 10 Uruguai Round ministerial decisions and declarations: Notification procedures - Disponível em <https://www.wto.org/english/docs_e/legal_e/33-dnotf.pdf>; Certain dispute settlement procedures for the GATS - Disponível em <https://www.wto.org/english/docs_e/legal_e/45-dsvds.pdf>; Dispute settlement: application and review of the Dispute Settlement Understanding - Disponivel em <https://www.wto.org/english/docs_e/legal_e/53-ddsu.pdf>. Acesso em setembro de 2015.
} 
controvérsias foi totalmente redesenhado.

O novo sistema foi codificado no "Entendimento sobre Solução de Controvérsias" $^{11}$ (DSU) e foi abolido o modelo de grupos de trabalho ad hoc com a criação de um único Órgão de Solução de Controvérsias (OSC) permanente responsável pela gestão operacional do sistema. No capítulo a seguir discutiremos as principais mudanças observadas no sistema e como o mesmo opera atualmente sob a égide da OMC.

${ }^{11}$ WTO Agreement - Annex 2: Understanding on rules and procedures governing the settlement of disputes. Disponível em <https://www.wto.org/english/tratop_e/dispu_e/dsu_e>. 


\section{Capítulo 2}

\section{A SOLUÇÃO DE CONTROVÉRSIAS NA OMC: REGRAS, ESTRATIFICAÇÃO DE RENDA E CASO-PADRÃO}

Se não podes com eles, junte-se a eles.

(Provérbio popular)

Neste capítulo, inicialmente discorreremos minuciosamente sobre a operação do sistema de soluções de controvérsias da OMC, apresentando suas principais bases, características e rotinas. Na seção seguinte, abordaremos como será conduzida a estratificação dos membros da organização em diferentes grupos de renda para efeito da presente pesquisa.

Por sua vez, na terceira seção introduziremos o tema da participação dos países em desenvolvimento no sistema de solução de controvérsias com base nas premissas apresentadas na seção anterior. Por fim, na última seção discutiremos a criação de um mecanismo de padronização da atuação dos membros da organização no sistema, de modo a permitir o estabelecimento das bases para os ajustes necessários antes de iniciarmos nossa análise empírica.

\subsection{Regras e procedimentos atuais da solução de controvérsias na OMC}

As mudanças observadas entre o sistema de solução de controvérsias do GATT e da OMC foram bastante profundas e significativas. Dentre as principais destaca-se (GRIMMET, Ibid; BOWN, Ibid):

i) consenso negativo - a regra do consenso para a adoção de decisões oriundas do sistema de solução de controvérsias foi invertida e passou a ser necessário o consenso negativo para bloquear a adoção de decisões;

ii) jurisdição exclusiva e obrigatória - os países-membros não podem recorrer a quaisquer outros mecanismos ou foros para resolução de litígios relacionados a seus compromissos na organização; e

iii) criação de um Órgão de Solução de Controvérsias (OSC) permanente e de um Órgão de Apelação independente - responsável pela revisão dos procedimentos do OSC. 
Conforme estabelecido no acordo de constituição do novo sistema de solução de controvérsias (DSU/Art. 2), o Órgão de Soluções de Controvérsias da OMC é um órgão específico, composto por representantes de todos os membros da organização, que se reúne mensalmente. Este é um órgão executivo, cujas principais funções são, entre outras, estabelecer os Painéis, constituir o Órgão de Apelação, decidir sobre os relatórios dos Painéis e do Órgão de Apelação e fiscalizar a implementação das decisões.

Esta é uma instância que une as fases diplomática e jurisdicional do sistema de solução de controvérsias da organização. Como o OSC possui jurisdição obrigatória e exclusiva, nenhum membro pode se negar a reconhecer a competência deste órgão para o tratamento de temas afeitos aos seus compromissos na OMC (BARRAL, 2007). Faremos a seguir uma análise detalhada das disposições do novo acordo de solução de controvérsias estabelecido na Rodada Uruguai.

As fases da solução de controvérsias da OMC estabelecidas pelo DSU são: i) Consultas - negociações diretas (DSU/Art. 4); ii) Implantação de Painel (DSU/Art. 6 a 14); iii) Circulação do relatório final do Painel (DSU/Art. 15); e caso não haja recurso ao Órgão de Apelação, iv-a) Adoção do relatório do Painel pelo Órgão de Solução de Controvérsias (DSU/Art. 16); v) Implementação (DSU/Art. 19 a 21); e caso não haja implementação, vi) Retaliação (DSU/Art. 22 e 23).

Caso haja recurso após o relatório final da fase de Painel, a disputa prossegue para, iv-b) Órgão de Apelação (DSU/Art. 17); v) Relatório do Órgão de Apelação (DSU/Art. 17); vi) Decisão do Órgão de Solução de Controvérsias sobre o relatório do Órgão de Apelação (DSU/Art. 17); vi) Implementação (DSU/Art. 19 a 21); e caso não haja implementação, vii) Retaliação (DSU/Art. 22 e 23).

A participação dos países-membros na solução de controvérsias pode se dar de três formas:

i) reclamante (DSU/Art. 3) - responsável pelo requerimento de abertura de uma disputa, figurando em seu polo ativo; ou

ii) acionado (DSU/Art. 3) - membro citado a responder a abertura de uma disputa, figurando em seu polo passivo; ou

iii) parte interessada (terceira parte) (DSU/Art. 10) - membro não relacionado às partes em disputa que pode requerer sua participação em virtude de interesse especial na matéria em disputa. 
Na Figura 2.1 a seguir pode-se observar esquematicamente o fluxo de uma disputa no OSC:

Figura 2.1: Fluxo do sistema de solução de controvérsias da OMC

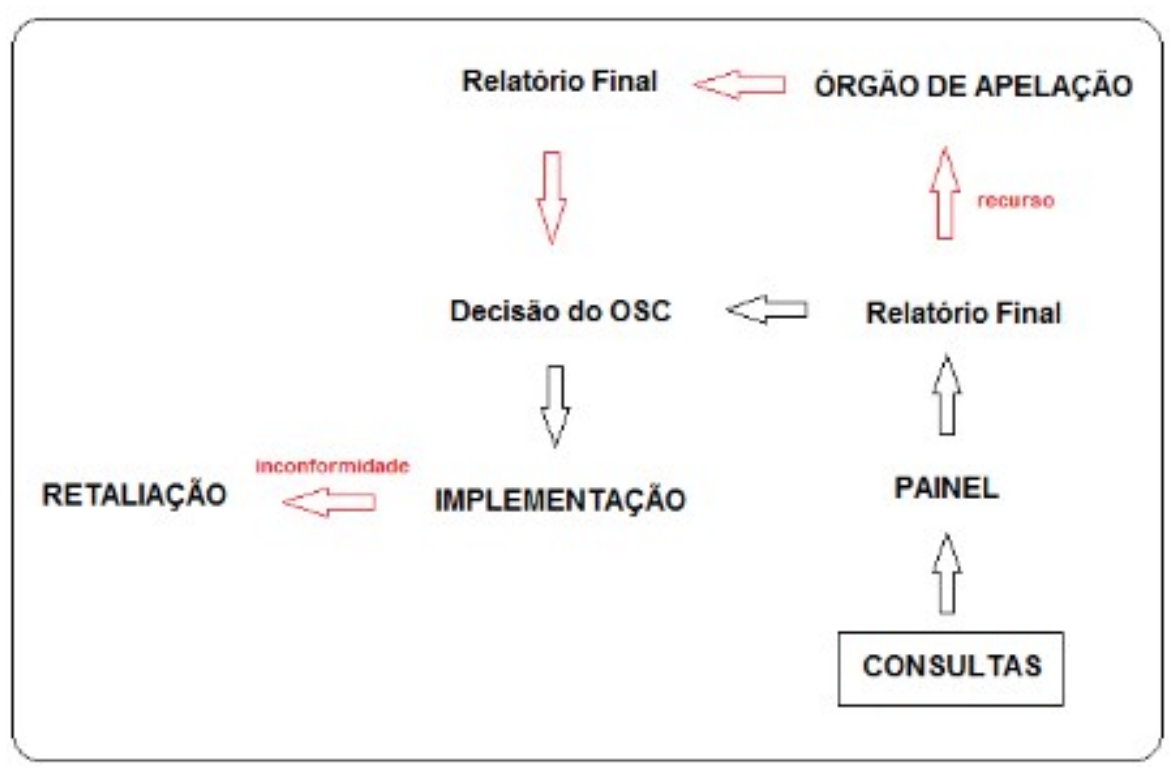

Fonte: Elaboração própria.

Não seria apropriado caracterizar uma parte interessada como um membro neutro na disputa, uma vez que aparecem frequentemente associados aos interesses do reclamante, no entanto este não figura no polo ativo e nem é paciente do processo.

As regras para a formação dos polos das disputas são bastante flexíveis, embora exista a recomendação no âmbito do Art. 9 para, sempre que possível, ao existirem dois ou mais reclamantes contra o mesmo membro em relação a uma mesma matéria seja estabelecido um único painel. Tanto na prática quanto nas disposições legais, porém, a decisão acaba por depender da vontade das partes reclamantes. Não existe nenhuma recomendação, no entanto, acerca do número de membros acionados em um mesmo caso.

Um país-membro pode solicitar a abertura de uma disputa contra um ou mais países-membros no âmbito do mesmo requerimento, disciplinado pelo Art. 7, de modo que estes figurarão todos como acionados no mesmo caso. Ou alternativamente, o membro reclamante pode protocolar requerimentos específicos contra cada um dos países-alvo, de maneira que estes figurarão como acionados em casos individuais. 
De forma homóloga, um ou mais países-membros pode protocolar um requerimento conjuntamente ou isoladamente contra um ou mais países. Se o fizerem isoladamente, serão formados casos individuais. Se o fizerem conjuntamente, será formado um único caso onde estes figurarão conjuntamente como reclamantes. Adicionalmente, após o requerimento de abertura de um procedimento feito por um ou mais países-membros, outros países podem requerer sua inclusão no rol de reclamantes até a instalação do Painel do caso específico (DSU/Art. 9 e 12).

O procedimento é iniciado pela fase de consultas, de acordo com o DSU/Art. 4 , sendo esta preliminar à abertura de qualquer procedimento no OSC. Antes da abertura de procedimento é requerido que as partes em disputa busquem uma solução mutuamente aceitável para o objeto da disputa bilateralmente. A abertura de consulta deve obrigatoriamente ser informada ao OSC e a parte acionada tem 10 dias para responder a consulta.

O procedimento bilateral de negociação inicia-se 30 dias após o pedido de abertura de consultas. Caso na fase de consultas a disputa não seja solucionada, a parte reclamante pode solicitar ao OSC a abertura de um Painel contra o reclamado.

O Painel, também chamado de Grupo de Trabalho, é constituído mediante requerimento da parte reclamante (DSU/Art. 6) e sua abertura somente pode ser recusada por consenso negativo no OSC. O Painel é constituído usualmente na primeira reunião do OSC subsequente ao pedido de abertura.

No entanto, dependendo da natureza do caso a parte reclamante pode solicitar um encontro extraordinário do OSC no prazo de 15 dias após o requerimento, com prazo mínimo de 10 dias para notificação prévia dos membros do órgão. Após a instalação de um Painel, é facultado ao reclamante solicitar a suspensão de seus trabalhos por um período de até 12 meses.

$O$ requerimento de abertura de um Painel deve ser embasado e indicar a falha das consultas na resolução da disputa. $O$ requerimento deve identificar as medidas contestadas, apontar o embasamento legal da disputa e identificar os dispositivos da OMC transgredidos pelo reclamado (DSU/Art. 7).

O Painel será composto por três integrantes encolhidos pelas partes, vedados nacionais de qualquer das partes envolvidas, e excepcionalmente, mediante acordo entre as partes, poderá ser composto por cinco especialistas igualmente neutros (DSU/Art. 8). Após o prazo de 20 dias, se as partes não acordarem a composição do Painel, o Diretor-Geral da OMC pode determinar sua composição. 
Após a formação do Painel, este será responsável tanto pela avaliação fática quanto jurídica da disputa no que concerne ao descumprimento dos dispositivos elencados pela parte reclamante face o acionado (DSU/Art. 11 e 12). No entanto, a apreciação da matéria é restrita aos Termos de Referência acordados para o estabelecimento do Painel (DSU/Art. 7). A decisão do Painel, tanto sobre os aspectos fáticos quanto jurídicos, constará de relatório final que deverá ser submetido ao OSC (DSU/Art. 16).

Uma vez que o Painel não é uma instância decisória do sistema de solução de controvérsias, seu relatório final é considerado apenas uma recomendação. A única instância decisória do sistema, conforme veremos, é o próprio OSC. Portanto, as recomendações do Painel deverão ser aprovadas pelo OSC para produzirem seus efeitos. Se após a publicação do relatório final do Painel nenhuma das partes manifestar sua intenção de recorrer ao Órgão de Apelação no prazo de 60 dias (DSU/Art.15), o relatório é encaminhado para apreciação do OSC.

Ao apreciar o relatório final do Painel, o OSC poderá aplicar sua recomendação por qualquer placar de votação à exceção do consenso negativo (DSU/Art. 16). Tanto o reclamante quanto o acionado podem recorrer do relatório final do Painel durante a fase de revisão interna (DSU/Art. 15). Caso uma das partes recorra ao Órgão de Apelação, a disputa prosseguirá para as próximas fases.

O Órgão de Apelação é uma instância permanente do OSC, ao contrário dos Painéis que são compostos de forma ad hoc (DSU/Art. 17). Ele é composto de sete juízes eleitos pelo OSC por consenso e com mandato de quatro anos renovável por igual período. O critério de distribuição de vagas no Órgão é rotativo e geográfico, no entanto, a renovação deste se dá sempre de forma parcial com a não coincidência dos mandatos.

E embora os juízes do Órgão de Apelação sejam indicados pelos membros, devem atuar de forma independente e autônoma, sem nenhuma vinculação com governos nacionais. O Órgão de Apelação é uma instância de características recursais e como tal, a exemplo da maioria dos sistemas jurídicos, dedica-se apenas às questões relativas ao direito em análise previamente levantadas na instância anterior e não à revisão fática ou de novos dispositivos legais (BARRAL, Ibid).

No entanto, caso haja erro material evidente no relatório do Painel que necessite o exame ou reexame de matéria fática, o Órgão de Apelação pode remeter a disputa novamente para o Painel de modo a evitar a abertura de uma nova disputa no OSC (DSU/Art. 17). 
Por fim, de maneira análoga ao Painel, o Órgão de Apelação não produz decisões e sim apenas recomendações. Em cada caso concreto, serão indicados três juízes do órgão para apreciação da disputa. Estes terão 60 dias, prorrogáveis por mais 30, para a produção de seu relatório final (DSU/Art. 17). O OSC, por sua vez, terá um prazo de 30 dias para deliberar sobre as recomendações feitas pelo relatório final do Órgão de Apelação (DSU/Art. 17).

O sistema de soluções de controvérsias da OMC, apesar de caminhar mais no sentido da judicialização do sistema do que o GATT, possui características bastante distintas dos sistemas jurídicos domésticos ou internacionais regulares. As instâncias do Painel e do Órgão de Apelação não são instâncias jurídicas, pois, não proferem sentenças, mas apenas recomendações. Estas recomendações só adquirem eficácia jurídica após prévia aprovação pelo Órgão de Solução de Controvérsias da organização, que figura como única instância decisória do sistema. Por esta razão o sistema é classificado como "quase-judicial" (TREBILCOCK et al., Ibid).

Após a aprovação pelo OSC do relatório final do Painel ou do Órgão de Apelação inicia-se a fase de implementação. Caso a medida contestada seja considerada incompatível com dispositivos de acordos da OMC, o membro acionado deverá informar ao OSC sobre sua intenção e a forma de correção da distorção apontada ou de compensação ao membro reclamante (DSU/Art. 21).

Se o membro acionado não puder cumprir a decisão do OSC de forma imediata, este deverá propor, em consenso com a parte reclamante, prazo para a efetivação desta correção. Não havendo consenso no estabelecimento deste prazo, o processo entra em fase de arbitragem obrigatória, sendo o árbitro constituído em comum acordo pelas partes (DSU/Art. 21).

Por fim, caso a parte reclamante não verificar a correção da distorção provocada pela parte acionada em prazo razoável e não houver acordo de compensação, esta poderá solicitar autorização para retaliar a parte acionada (DSU/Art. 22). Esta retaliação não têm caráter punitivo, mas sim compensatório pelos danos causados pelo não cumprimento das obrigações da parte acionada sob o acordo da OMC (BARRAL, 2004).

Portanto, a retaliação deverá corresponder à suspensão de direitos ou concessões da parte acionada em montante equivalente ao nível de prejuízo ou redução de benefício incorridos pela parte reclamante conforme determinado pela decisão do OSC. 
O membro reclamante ao requerer o direito de retaliar, deverá informar ao OSC adicionalmente a lista das medidas retaliatórias propostas identificando produtos, setores e acordos envolvidos. Geralmente é requerido que ao menos o setor retaliado pertença ao mesmo Acordo da OMC do setor cuja medida foi considerada incompatível com as normas multilaterais (NETO, 2003).

No entanto, em caráter extraordinário, o reclamante pode solicitar retaliações cruzadas em outros acordos pertencentes ao arcabouço normativo da organização (DSU/Art. 22). Após o requerimento, o OSC terá 30 dias para autorizar a retaliação por qualquer placar de votação ou rejeitá-la por consenso negativo.

O membro acionado pode, ainda, solicitar arbitragem da decisão do OSC caso considere que as medidas retaliatórias aprovadas são impróprias ou desproporcionais ao dano/cessação de benefício incorrido pelo reclamante (DSU/Art. 25). Neste caso, o comitê de arbitragem será composto pelos membros originais do Painel do caso, sempre que possível, e terá prazo de 60 dias para determinar apenas se as medidas retaliatórias aprovadas são proporcionais aos danos ou cessação de benefício causado pelo acionado.

Após a produção do laudo arbitral, sua aprovação no OSC se fará pela regra estabelecida do consenso negativo. Caso o laudo seja aprovado e conclua pela pertinência das medidas propostas, o membro reclamante será autorizado a aplicar as medidas compensatórias solicitadas. É facultada ao reclamante, a despeito da decisão do OSC, a decisão unilateral de não aplicar as medidas autorizadas, aplicálas em montante inferior à autorização ou postergar sua aplicação.

\subsection{Estratificação dos membros da OMC e participação no OSC}

Para entender a dinâmica da atuação dos membros ${ }^{1}$ da OMC no Órgão de Solução de Controvérsias e a atuação dos países em desenvolvimento (PED) neste sistema é necessário primeiramente estabelecer um critério objetivo de classificação dos membros da OMC que represente adequadamente o estágio de desenvolvimento destas diferentes economias no período de análise. E como consequência, suas diferenças de recursos materiais e de acesso a conhecimentos técnicos e jurídicos especializados necessários à atuação no OSC.

\footnotetext{
${ }^{1}$ No âmbito do presente trabalho utilizaremos de forma livre e intercambiável os termos membro, parte ou país para designar os membros da OMC. Embora existam membros que serão considerados membros compostos, conforme posteriormente apresentaremos os casos de União Europeia e China, optamos por manter a simplicidade terminológica e fluidez do texto.
} 
A premissa é a de que os PED, membros com menos recursos materiais e expertise, hesitariam mais em entrar com reclamações no OSC devido aos custos e dificuldades associados a acompanhar o desenrolar dos processos e mesmo de quantificar e provar os prejuízos sofridos por suas economias em virtude das práticas apontadas por estes como desleais (EVANS, SHAFFER, 2011, p. 341-348; CARVALHO, 2012).

A OMC não possui uma lista de países em desenvolvimento e a classificação em diferentes níveis de desenvolvimento na organização depende da autodesignação por cada país (OMC, 2013c), que pode ser alvo de contestação de outros membros. Por não possuir correspondência, portanto, com nenhum critério objetivo que possa ser convencionado e depender mais de uma relação política do que de uma base econômica, a autoclassificação adotada pela OMC não será utilizada.

Dessa forma, no decorrer do restante da presente seção discutiremos os critérios utilizados nesta pesquisa para a classificação dos membros da OMC em diferentes grupos de renda e de forma pormenorizada como se estabeleceram critérios para todos os ajustes para este efeito.

Para efeito da presente pesquisa, optou-se por utilizar como indicador do nível de desenvolvimento das economias dos países-membros da OMC, com alguns ajustes que serão explicitados a seguir, o critério classificatório desenvolvido pelo Banco Mundial: o Produto Nacional Bruto (PNB) per capita calculado pelo método Atlas $^{2}$ (BM, 2013a).

O PNB representa o valor monetário da soma dos bens e serviços finais produzidos por fatores de produção (terra, trabalho e capital) nacionais em um determinado período independentemente do ponto do globo onde se dê a produção física dos mesmos (PAULANI, BRAGA, 2003). Em outros termos, o PNB é equivalente ao Produto Interno Bruto (PIB), que representa o valor da soma dos bens e serviços finais produzidos por uma economia em um período, adicionado da Renda Líquida recebida ou enviada do/ao exterior por esta economia como remuneração aos seus fatores de produção ocupados fora de seu território (Id lbid).

Embora o PIB seja uma medida mais adequada para o tamanho total de uma economia $^{3}$, o PNB é mais adequado enquanto expressão do nível de renda de uma

Disponível em <https://datahelpdesk.worldbank.org/knowledgebase/articles/378832-what-is-theworld-bank-atlas-method>.

3 Mais adiante nesta pesquisa utilizaremos a variável PIB para representar o tamanho da economia dos países propriamente dita e não o nível de desenvolvimento dos mesmos. 
economia por computar as rendas recebidas ou enviadas pelo país. O método Atlas (BM, 2013b) é utilizado pelo Banco Mundial para diminuir o impacto de oscilações da taxa de câmbio dos países e corrigir os dados de acordo com as diferenças entre as taxas de inflação doméstica e internacional no cálculo do PNB.

Dessa forma, utilizaremos no presente estudo uma classificação baseada na metodologia do Banco Mundial para classificação de renda dos países por meio do PNB per capita. O Banco Mundial classifica anualmente os países de acordo com quatro classes de níveis de renda: países desenvolvidos com renda alta; países em desenvolvimento com renda média-alta; países em desenvolvimento com renda média-baixa; e países de menor desenvolvimento relativo com renda baixa.

A Figura 2.2 a seguir apresenta os patamares de PNB per capita anuais, para o período de 1995 a 2012, dentro dos quais os países devem estar para serem classificados a cada ano em um dos quatro estratos de nível de renda estabelecidos pelo Banco Mundial.

Figura 2.2: PNB per capita e nível de renda no período 1995-2012 (USD)

\begin{tabular}{|c|c|c|c|c|}
\hline & \multicolumn{4}{|c|}{ Nível de Renda } \\
\hline Ano & PD & $\mathrm{PED}_{\mathrm{ma}}$ & $\mathrm{PED}_{\mathrm{mb}}$ & PMD \\
\hline 1995 & $>9,385$ & $3,036-9,385$ & $766-3,035$ & $<=765$ \\
\hline 1996 & $>9,645$ & $3,116-9,645$ & $786-3,115$ & $<=785$ \\
\hline 1997 & $>9,655$ & $3,126-9,655$ & $786-3,125$ & $<=785$ \\
\hline 1998 & $>9,360$ & $3,031-9,360$ & $761-3,030$ & $<=760$ \\
\hline 1999 & $>9,265$ & $2,996-9,265$ & $756-2,995$ & $<=755$ \\
\hline 2000 & $>9,265$ & $2,996-9,265$ & $756-2,995$ & $<=755$ \\
\hline 2001 & $>9,205$ & $2,976-9,205$ & $746-2,975$ & $<=745$ \\
\hline 2002 & $>9,075$ & $2,936-9,075$ & $736-2,935$ & $<=735$ \\
\hline 2003 & $>9,385$ & $3,036-9,385$ & $766-3,035$ & $<=765$ \\
\hline 2004 & $>10,065$ & $3,256-10,065$ & $826-3,255$ & $<=825$ \\
\hline 2005 & $>10,725$ & $3,466-10,725$ & $876-3,465$ & $<=875$ \\
\hline 2006 & $>11,115$ & $3,596-11,115$ & $906-3,595$ & $<=905$ \\
\hline 2007 & $>11,455$ & $3,706-11,455$ & $936-3,705$ & $<=935$ \\
\hline 2008 & $>11,905$ & $3,856-11,905$ & $976-3,855$ & $<=975$ \\
\hline 2009 & $>12,195$ & $3,946-12,195$ & $996-3,945$ & $<=995$ \\
\hline 2010 & $>12,275$ & $3,976-12,275$ & $1,006-3,975$ & $<=1,005$ \\
\hline 2011 & $>12,475$ & $4,036-12,475$ & $1,026-4,035$ & $<=1,025$ \\
\hline 2012 & $>12,615$ & $4,086-12,615$ & $1,036-4,085$ & $<=1,035$ \\
\hline
\end{tabular}

Fonte: Elaboração própria com base em BM (2013c).

Nota-se do quadro acima que o nível de renda per capita de um país para ser classificado como país desenvolvido (PD) variou de maior do que USD 9.385 a maior do que USD 12.615 no período de 1995 a 2012. Enquanto o nível de renda 
para ser classificado como país em desenvolvimento de renda média-alta ( $\left.P E D_{m a}\right)$ passou de estar compreendido no intervalo de USD 3.036 a USD 9.385 para o intervalo de USD 4.086 a USD 12.615 no período considerado.

No mesmo período, para ser classificado como país em desenvolvimento de renda média-baixa $\left(\mathrm{PED}_{\mathrm{mb}}\right)$ o nível de renda per capita passou do intervalo de USD 766 a USD 3.035 para o intervalo de USD 1.036 a USD 4.085. Por fim, para ser considerado como país de menor desenvolvimento relativo (PMD) o nível de renda passou de inferior a USD 765 para inferior a USD 1.035.

O foco desta pesquisa é a atuação dos países em desenvolvimento (PED ma, PED $_{m b}$ e PMD) no OSC em um período amplo de 18 anos (1995 a 2012) e a classificação em grupos de renda do Banco Mundial pode variar anualmente com base no cálculo do PNB per capita, visto que o processo de desenvolvimento econômico não é estável e uniforme apesar de seguir geralmente uma tendência regular (JONES, 2009).

Dessa forma, após a construção de nossos modelos explicativos nos próximos capítulos e durante a estimação de nossos modelos no último capítulo, a classificação de nível relativo de renda de cada membro acompanhará o processo de desenvolvimento econômico, podendo a classificação destes variar anualmente de acordo com estes critérios.

Adicionalmente, posteriormente, ao introduzirmos nossa discussão sobre a estimação do efeito de variáveis dummy ligadas aos diferentes níveis de renda per capita dos membros da OMC, promoveremos uma desagregação dos países em desenvolvimento de renda média-alta e média-baixa em quartis.

Uma vez que ambos os subgrupos de países em desenvolvimento são muito heterogêneos e abrigam países nos limites superiores e inferiores de renda em estágios bastante díspares de desenvolvimento econômico, a partir deste expediente espera-se captar melhor as reais diferenças relativas de renda e de outras variáveis associadas.

No entanto, para permitir uma aproximação preliminar sobre o tema, em nossa discussão inicial manteremos a classificação padrão do Banco Mundial com critério constante de classificação de cada membro de acordo com a categoria de renda na qual este apareceu classificado mais frequentemente no período.

A única exceção à aplicação desta regra foi o caso dos países integrantes da União Europeia (UE) devido às peculiaridades do processo de integração regional europeu. A UE enquanto bloco de integração regional é classificada como uma 
União Econômica e Monetária incompleta (UE, 2013a), onde parte de seus integrantes utilizam uma moeda comum e todos os membros participam de um mercado comum com política comercial unificada. A Comissão Europeia, órgão executivo da UE, tem a função de representar seus membros em virtualmente todos os foros da OMC. No entanto, os 27 integrantes do bloco (até o ano de 2012) são também membros individuais da organização.

Em alguns casos especiais, os estados-membros da UE podem decidir atuar de forma separada do restante do bloco como em temas ligados a direitos de propriedade intelectual relacionados ao comércio, ou quando as legislações domésticas diferirem entre os integrantes e não forem disciplinadas por norma comunitária (OMC, 2013d).

Ademais, no caso da participação dos mesmos da UE no OSC eles podem ser reclamantes, acionados ou partes interessadas de forma autônoma, embora esta seja uma ocorrência muito pouco comum. A classificação dos membros da UE enfrenta ainda uma dificuldade adicional, o fato de o bloco ter iniciado o período de análise com composição de 15 integrantes e atravessado dois processos de alargamento para o Leste europeu no período, abarcando 10 novos membros em 2004 e mais dois novos no ano de 2007, conforme o Quadro 2.1 a seguir:

Quadro 2.1: Alargamento da UE (1995-2012)

\begin{tabular}{|c|c|}
\hline União Europeia (Ano) & Membros \\
\hline \multirow{4}{*}{} & Alemanha \\
\cline { 2 - 2 } & Áustria \\
\cline { 2 - 2 } & Bélgica \\
\hline \multirow{4}{*}{ UE15 } & Dinamarca \\
\hline \multirow{4}{*}{ (1995) } & Espanha \\
\hline \multirow{4}{*}{} & Finlândia \\
\hline & França \\
\hline & Grécia \\
\hline & Irlanda \\
\hline & Itália \\
\hline & Luxemburgo \\
\hline & Países Baixos \\
\hline & Portugal \\
\hline & Reino Unido \\
\hline & Suécia \\
\hline
\end{tabular}




\begin{tabular}{|c|c|}
\hline \multirow[b]{5}{*}{ Alargamento UE25 } & Chipre \\
\hline & Eslováquia \\
\hline & Eslovênia \\
\hline & Estônia \\
\hline & Hungria \\
\hline \multirow[t]{5}{*}{$(2004)$} & Letônia \\
\hline & Lituânia \\
\hline & Malta \\
\hline & Polônia \\
\hline & República Checa \\
\hline \multirow{2}{*}{$\begin{array}{c}\text { Alargamento UE27 } \\
(2007)\end{array}$} & Bulgária \\
\hline & Romênia \\
\hline
\end{tabular}

Fonte: Elaboração própria com base em (UE, 2013b).

Conforme se observa na Figura 2.3 abaixo todos os países-membros da UE em 1995 eram considerados desenvolvidos e dentre os novos membros abarcados pelo alargamento de 2004, sete eram considerados $P E D_{m a}$ e outros três eram considerados desenvolvidos. No caso do alargamento de 2007 , os dois novos entrantes eram classificados à época como $P E D_{m a}$.

Figura 2.3: Classificação dos Países-membros da União Europeia (1995-2012)

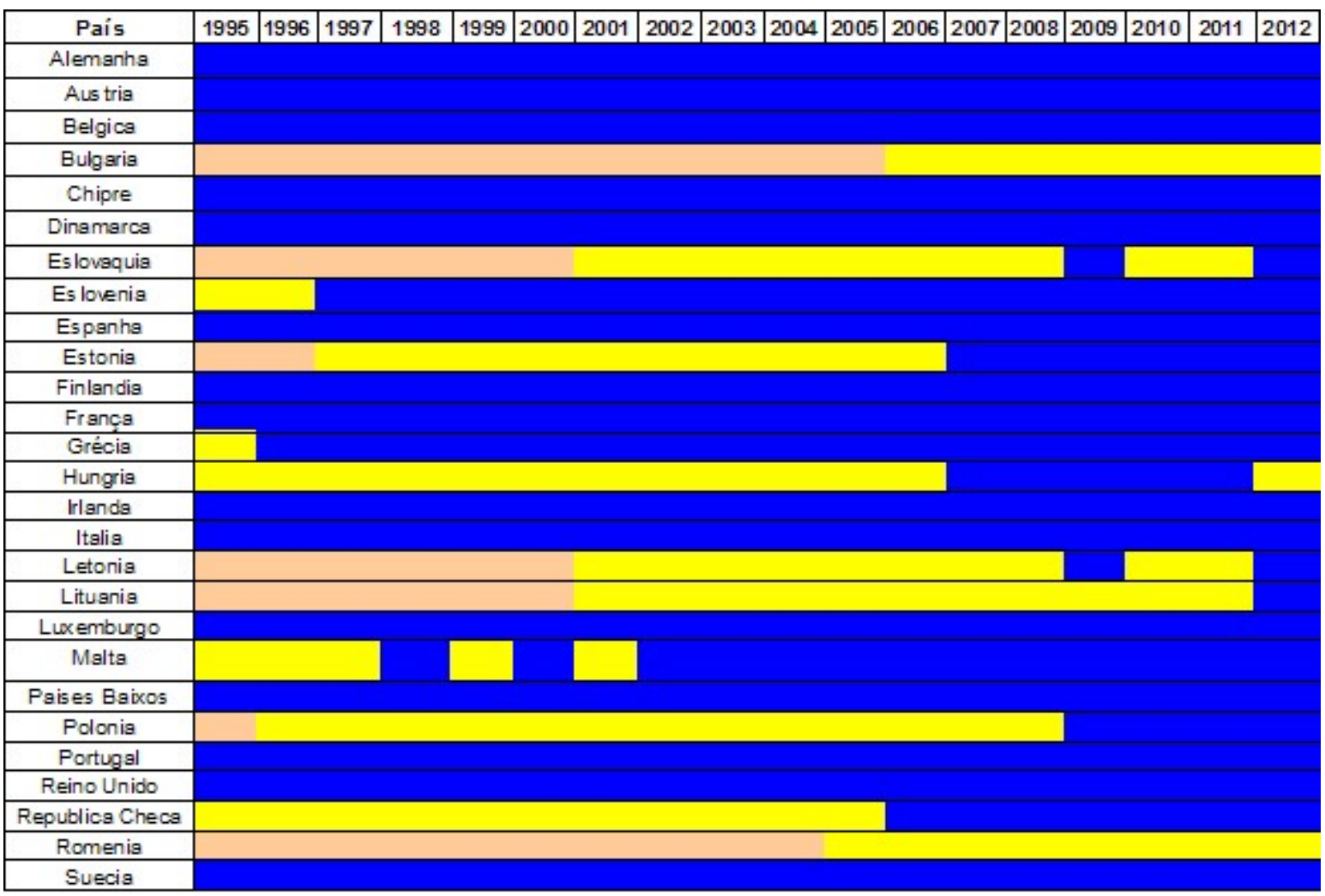

Fonte: Elaboração própria com base em (BM, 2013c). 
Já no ano de 2012, apenas três países integrantes do bloco não eram considerados desenvolvidos: Bulgária, Romênia e Hungria. Todos considerados como $P E D_{m a}$, com destaque para Hungria que foi classificada no período de 2007 a 2011 como PD, perdendo este status em 2012.

Tendo em vistas estas considerações, ressalta-se também o fato de que as adesões ao bloco não se materializam de uma hora para outra, mas envolvem um longo processo, que dura vários anos, de apoio tanto político quanto econômico por parte da UE aos países candidatos (UE, 2013c) e de esforço de assimilação das disciplinas representadas pelo Acervo Comunitário (Acquis Communautaire) ${ }^{4}$ do bloco por parte destes países.

Estes fatores têm implicações óbvias na política econômica e nas práticas comerciais dos países em questão, de modo que todos os países pertencentes ao bloco no ano de 2012 serão considerados para efeitos práticos como se tivessem pertencido formalmente à UE durante todo o período 1995-2012. Dadas ainda as características sui generis do bloco, o conjunto de países-membros da UE serão considerados para efeitos de análise como uma única entidade de renda per capita alta.

Outro caso que deve ser destacado é o de Macau e Hong Kong, Áreas de Administração Especial (AAE) da China, que embora façam parte da China continental desde sua devolução por parte das potências europeias que as mantinham como possessões ultramarinas no território chinês, possuem status de territórios aduaneiros autônomos e são membros individuais da OMC.

Hong Kong foi devolvida pelos britânicos de volta ao controle da China no ano de 1997, enquanto Macau foi devolvida pelos portugueses em 1999. Ambas são consideradas áreas desenvolvidas de alta renda per capita durante todo o período 1995-2012 de acordo com os critérios do Banco Mundial.

Apesar destas AAE gozarem de grande autonomia e terem sistemas de autogestão próprios, elas estiveram durante a maior parte do período de análise sob o controle efetivo do Estado chinês, ao qual estão subordinadas em temas de política externa, defesa e outros temas sensíveis, além de terem seus sistemas políticos parcialmente controlados por Pequim e uma alta simbiose com a economia chinesa.

Portanto, apesar do status especial destas áreas e de serem consideradas como membros desenvolvidos pelos critérios do Banco Mundial, é difícil imaginar

\footnotetext{
${ }^{4}$ Disponível em <http://en.euabc.com/word/12>. Acesso em dezembro de 2015.
} 
que decisões importantes como a abertura de um caso no OSC sejam tomadas de forma realmente autônoma por estas. No entanto, mesmo considerando-se o peso político da China neste processo decisório, neste caso não se optou pela integração destes membros em um único membro composto conjuntamente com a China, como no caso do tratamento dos países-membros da UE.

Neste caso específico, a grande diferença entre os níveis de desenvolvimento $\left(P D \times P E D_{m b}\right)$ e de escala da economia destas áreas face à China ocasionaria sensível distorção dos dados caso as mesmas fossem agregadas em uma única entidade de renda média baixa sob dominância chinesa.

Do total de 157 membros pertencentes à OMC até o final do ano de 2012, nossa análise considerará inicialmente 130 membros após a consolidação do bloco europeu em uma única entidade (UE). Nos capítulos seguintes discutiremos a necessidade de outros ajustes neste quantitativo.

Destes 130 membros, de acordo com nossos critérios fixos preliminares apresentados (que serão posteriormente flexibilizados para a estimação dos modelos): 26 são considerados países desenvolvidos; e 104 são países em desenvolvimento - dos quais 36 são considerados de renda média-alta, 37 são considerados de renda média-baixa e 31 são classificados como países de menor desenvolvimento relativo.

\subsection{Participação dos PED no OSC - Uma abordagem preliminar}

\subsubsection{Importância da participação dos PED no OSC}

Em linha com a argumentação teórica defendida na presente pesquisa, a participação dos países em desenvolvimento no sistema de solução de controvérsias da OMC é importante principalmente por quatro razões:

i) Em um contexto de diminuição da velocidade do avanço da dimensão de mercado do sistema, o OSC passou a ser um dos principais normatizadores deste ao interpretar dispositivos, preencher lacunas legais e criar jurisprudência em um ambiente de case law (commom law) (TREBILCOCK et al, Op. cit; ZIMMERMMAN, 2006). Portanto, participar ativamente do OSC é por consequência participar do desenvolvimento do processo de contínua construção do regime (de suas normas e regras); 
ii) As decisões do OSC afetam diretamente resultados econômicos específicos e funcionam como restrição ao comportamento dos países. A mera capacidade de participar do sistema eleva o poder de barganha do país reclamante. Como consequência, cerca de dois terços das disputas são resolvidas com concessões plenas ou parciais pelos acionados na fase de consultas (BUSCH, REINHARDT, 2000). A participação neste sistema, portanto, é fundamental para a garantia do cumprimento dos compromissos mesmo na ausência do prosseguimento das consultas em casos no OSC;

iii) A incapacidade de participar no sistema de solução de controvérsias pode ter efeitos adversos sobre os termos de troca da economia, afetando negativamente 0 bem-estar do país. A remoção ou redução de uma barreira comercial como consequência da atuação no OSC pode, assim, melhorar os termos de troca e aumentar o bem-estar do país (BAGWELL, STAIGER, 2012); e

iv) A capacidade ou incapacidade de um país em desenvolvimento em garantir o cumprimento de seus direitos de acesso a mercados na OMC através do sistema de solução de controvérsias pode alterar o equilíbrio de forças na barganha política doméstica. O que poderia bloquear ou dar vazão a preferências de grupos mais protecionistas ou mais liberais, a depender deste efeito, podendo afetar no médio longo prazo a formação das preferências do membro na dimensão de mercado do sistema (HOEKMAN, KOSTECKI, Ibid).

Ou seja, a capacidade de garantir o cumprimento dos compromissos acordados é um importante fator para prevalência de preferências liberalizantes nos países em desenvolvimento e, por consequência, fator crítico para a ocorrência de convergência de preferências na dimensão de mercado do sistema, avançando o processo de liberalização.

\subsubsection{Visão preliminar dos PED no OSC}

De um número total de 130 membros pertencentes à OMC entre 1995 e 2012, de acordo com os critérios estabelecidos nesta pesquisa, 84 membros tiveram participação no OSC em ao menos uma das categorias (reclamante ou acionado ou parte interessada) em um total de 454 casos. 
Estes 454 casos contaram com um total de 482 reclamações e 467 acionamentos, onde os membros da OMC estiveram por 949 oportunidades em um dos dois polos destas disputas e atuaram em 1812 outras instâncias como partes interessadas em disputas em que não figuravam em nenhum dos polos - totalizando uma participação dos membros em 3668 diferentes oportunidades no OSC.

Os Estados Unidos apresentou 103 reclamações no período e foi acionado em 119 casos, enquanto a União Europeia, como bloco, apresentou 87 reclamações e foi acionada em 73 casos, ao passo que seus estados-membros foram reclamantes individualmente em 9 oportunidades e acionados em outras 38. No total, EUA e UE respondem por 199 reclamações e foram acionados em 230 casos.

Os 18 outros países desenvolvidos que tiveram participação no OSC no período protocolaram 92 reclamações e foram acionados em 62 oportunidades. No agregado, o conjunto dos países desenvolvidos foi responsável por 291 reclamações e respondeu a 292 acionamentos no OSC.

Já os países em desenvolvimento foram reclamantes coincidentemente por 191 casos e responderam a 175 acionamentos. Dentro deste grupo, os $P E D_{m a}$ foram responsáveis por 103 reclamações e foram acionados em 95 oportunidades; enquanto os $\mathrm{PED}_{\mathrm{mb}}$ protocolaram 85 reclamações e receberam 80; e os PMD foram responsáveis por apenas 3 reclamações, não tendo recebido nenhuma.

Estes dados nos fornecem uma primeira aproximação com o tema de pesquisa e uma visão geral da participação dos PED no sistema de solução de controvérsias da OMC. No entanto, pela própria natureza do funcionamento do OSC e de suas regras, além da situação particular de alguns membros, estes dados possuem distorções consideráveis que precisam ser sanadas para permitir a formação de uma base de dados adequada para as análises estatísticas e qualitativas a serem delineadas neste trabalho.

Do ponto de vista das distorções causadas pelo próprio sistema de soluções de controvérsias, estas derivam da grande flexibilidade das regras existentes para a instauração de um caso no OSC quanto aos seus membros participantes em cada um dos polos - demandante $x$ acionado. Não há uma regra fixa que limite a quantidade de países participantes em cada um dos polos.

Dessa forma, a depender na natureza específica do caso em questão, podese ter como polo ativo da disputa (reclamante) um ou mais países em um mesmo caso, em outros momentos e de acordo com as considerações políticas e estratégicas dos países, estes mesmos membros podem demandar (reclamar) 
ações de forma individual contra um mesmo alvo (acionado) acerca de uma mesma matéria.

No polo passivo (acionado) a mesma situação se repete, ora um país pode ser acionado por um grupo de países em um mesmo caso, ora pode ser acionado individualmente por diferentes países distribuídos em um número maior de casos acerca de uma mesma matéria.

Com isto, observa-se que os 454 casos protocolados no OSC até 31 de dezembro de 2012 produziram um número maior de reclamações (482) e acionamentos (467) do que o próprio número total de casos e que o número de reclamações não pode ser relacionado diretamente ao número de acionamentos, o que ocasiona diversas dificuldades no tratamento dos dados.

Ademais, dadas as especificidades da União Europeia ora os paísesmembros participam como reclamantes/acionados individualmente, ora como bloco. Em alguns casos, ainda, ocorre o acionamento ao mesmo tempo do bloco UE e de estados-membros individuais acerca de uma mesma matéria em um mesmo caso ou em casos separados para cada alvo.

O processo de alargamento europeu traz também algumas distorções que necessitam de correção na participação dos novos membros no OSC, visto que alguns deles antes de sua entrada formal no bloco participavam como reclamantes ou acionados em face de outro estado-membro. O que, de acordo com nossos critérios de classificação, produz o inusitado fenômeno da UE atuar ao mesmo tempo como reclamante e acionada de si mesma em alguns casos.

Com a finalidade de padronizar os dados e eliminar estas distorções criamos a figura do caso-padrão, de forma a criar um novo arranjo de indicadores que reflitam com maior precisão a participação dos países no OSC e permita a realização de análises estatísticas e qualitativas posteriores.

\subsection{O caso-padrão no OSC}

A figura do caso-padrão consiste na atribuição da indissociabilidade entre uma reclamação e um acionamento no OSC, caracterizando-se pela constituição de um binômio permanente demandante-acionado. Este binômio é produto da padronização das reclamações e acionamentos realizados no OSC, de forma a que o polo ativo de cada reclamação acerca de uma determinada matéria se relacione a apenas um caso específico e seja constituída por um único membro reclamante em 
cada caso, correspondendo no polo passivo a apenas um acionado acerca desta mesma matéria em cada caso.

Estas figuras receberão a designação de reclamante-padrão e acionadopadrão, respectivamente. Ou seja, cada caso-padrão unitário corresponderá a apenas um país reclamante-padrão e um país acionado-padrão, conforme abaixo esquematizado:

\section{Caso-padrão $=$ reclamante-padrão $\mathrm{x}$ acionado-padrão}

A partir deste expediente procura-se criar um binômio capaz de tornar os dados mais fidedignos em relação à participação dos países no OSC, corrigindo as distorções provocadas pelas regras de utilização do OSC que fazem com que o número de casos não corresponda ao número de reclamantes e nem este ao número de acionados, padronizando os mesmos para tratamentos posteriores.

Cabe ressaltar, no entanto, que a escolha metodológica aqui empreendida traz o inconveniente de não permitir a análise de um dos fenômenos observados no sistema de solução de controvérsias, o dos caronas que podem se instalar em uma disputa depois que o first mover já incorreu com a maior parte dos custos políticos e econômicos de mover uma disputa (BOWN, Ibid). O que, de qualquer forma, não é o objetivo desta pesquisa.

Assim, uma vez que cada caso-padrão será composto pelo binômio "reclamante-padrão x acionado-padrão", o número total de casos-padrão no OSC será sempre correspondente ao número total de reclamações-padrão, que por sua vez será igual ao número total de acionamentos-padrão.

Para cada país, individualmente, o número total de casos-padrão em que este participa no OSC será sempre igual à soma do número de suas reclamações-padrão e de seus acionamentos-padrão. Este novo arranjo reflete com mais propriedade e de forma direta a real participação dos países no OSC, que estava distorcida pela forma de apresentação dos dados do sistema de solução de controvérsias pela OMC.

Após a definição destes novos conceitos que nortearão o rearranjo dos dados acerca da participação dos países no sistema de solução de controvérsias, foram mapeados os 454 casos protocolados no OSC até o ano de 2012 e desmembrados de forma individual cada um de seus reclamantes e de seus acionados, que foram posteriormente pareados e reagrupados em novos casos-padrão. 
O conceito aqui apresentado de caso-padrão, reclamante-padrão e acionadopadrão guarda, portanto, relação com a metodologia utilizada pela literatura na área que denomina o pareamento direto dos polos de um caso como "casos bilaterais" (HOLMES, 2003; HORN, 2005; FRANCOIS, 2008). No entanto, nós aprofundaremos esta metodologia efetuando correções adicionais e mantendo uma estrita indissociabilidade deste binômio, razão pela qual utilizaremos os termos acima apresentados e não a terminologia regular referida como casos bilaterais.

\subsubsection{Padronização}

Conforme discutimos, antes de adentrarmos a uma apresentação das primeiras evidências empíricas brutas, prévias à nossa modelagem, sobre a participação dos PED no OSC, será necessário padronizar os dados de participação de todos os membros da OMC no sistema. Dessa forma, discutiremos de forma pormenorizada os ajustes feitos na participação de cada membro, quando necessário, nas subseções a seguir:

\section{a) União Europeia - padronização}

Os casos em que a União Europeia ou seus estados-membros figuram nos polos ativo ou passivo receberam atenção especial para a correção da distorção verificada em função das características sui generis do bloco e de seu processo de alargamento ao longo do período. Nestes casos, no polo ativo, quando os estadosmembros participaram como reclamantes individualmente contra outros países, foram eliminados os casos em que os acionados eram outros estados-membros que aderiram ao bloco no período, contabilizando apenas os casos contra países extrabloco e agregando-os aos casos correspondentes ao bloco como reclamante.

No polo passivo, nos casos em que países-membros foram acionados por outros membros da UE, conforme indicado, estes foram eliminados da base de dados para não causar distorção. Já nos casos em que a UE enquanto bloco ou seus estados-membros individuais foram acionados por países extra-bloco adotouse o seguinte expediente:

i) quando foi acionado apenas um país do bloco, estes foram somados aos acionamentos do bloco; 
ii) quando foram acionados mais de um país-membro do bloco ou um (ou mais) país(es)-membro(s) e o próprio bloco no mesmo caso, estes foram contabilizados como apenas um caso e somados aos casos do bloco; e

iii) quando foram acionados mais de um país-membro do bloco ou um (ou mais) país(es)-membro(s) e o próprio bloco acerca de uma mesma demanda dividida em casos diferentes, foi contabilizado apenas um caso à conta do bloco e eliminados os demais casos da base de dados.

A partir do expediente definido acima, os ajustes referentes à participação da UE no OSC foram efetuados em duas etapas. A primeira etapa (Ajuste A), pode ser observada no Quadro 2.2 na página a seguir. O "Ajuste A" é relativo aos casos dos estados-membros que aderiram à UE durante os dois ciclos de alargamento ao longo do período de análise e aos casos em que a UE e um (ou mais) de seu(s) estado(s)-membro(s) foram acionados ao mesmo tempo no mesmo caso ou em casos distintos que versem sobre a mesma controvérsia.

No período 1995-2012 foram protocolados 6 casos no OSC cujos reclamantes viriam a aderir à UE no período e cujos acionados igualmente se tornariam estadosmembros do bloco no mesmo período, o que leva à inusitada situação da UE reclamar contra si e acionar a si mesma. Estes casos estão destacados em verde e são enumerados a seguir: DS143 (Hungria x Eslováquia), DS148 (Hungria $x$ República Checa), S159 (República Checa x Hungria), DS235 (Polônia x Eslováquia) e DS240 (Hungria x Romênia) e DS289 (Polônia x República Checa). Estes casos foram eliminados da base de dados (tanto polo ativo quanto passivo) para evitar distorções.

Restaram, assim, no polo ativo dos países-membros da UE apenas 3 casos contra países extra-bloco, destacados em azul: DS122 (Polônia x Tailândia), DS256 (Hungria x Turquia) e DS297 (Hungria x Croácia). Estes casos foram agregados à conta do bloco, que com as 87 reclamações-padrão protocoladas diretamente pela UE mais as 3 reclamações-padrão protocoladas pelos membros, totalizou 90 reclamações-padrão após o Ajuste $A$.

No polo passivo, a UE como bloco e um (ou mais) de seus estado(s)membro(s) foram acionados simultaneamente no âmbito do mesmo caso em 13 oportunidades diferentes referentes a 6 casos distintos. Estes casos estão destacados em vermelho e são enumerados a seguir: DS316 (EUA x UE, Alemanha, 
Espanha, França e Reino Unido), DS347 (EUA x UE, Alemanha, Espanha, França e Reino Unido), DS408 (Índia x UE e Países Baixos), DS409 (Brasil x UE e Países Baixos), DS443 (Argentina x UE e Espanha) e DS452 (China x UE, Grécia e Itália).

\section{Quadro 2.2: União Europeia - Ajuste A}

\begin{tabular}{|c|c|c|c|c|c|c|c|}
\hline País / Bloco & $\begin{array}{c}\text { Reclamante- } \\
\text { padrão }\end{array}$ & & \begin{tabular}{|c|} 
Acionado- \\
padrão \\
\end{tabular} & & Total 1 & $\begin{array}{l}\text { Terceira } \\
\text { Parte } \\
\end{array}$ & $\begin{array}{l}\text { Total } \\
\text { Geral }\end{array}$ \\
\hline $\begin{array}{l}\text { Uniao Europeia } \\
\text { (Ajuste A) }\end{array}$ & 90 & Casos & 88 & Casos & 178 & 137 & 315 \\
\hline $\begin{array}{l}\text { Uniao Europeia } \\
\text { (Bloco) }\end{array}$ & 87 & & 73 & & 160 & 134 & 294 \\
\hline Alemanha & & & 2 & $\begin{array}{l}\text { DS316 (EUA) e DS347 } \\
\text { (EUA) }\end{array}$ & 2 & & 2 \\
\hline Belgica & & & 3 & 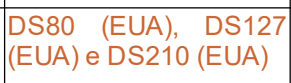 & 3 & & 3 \\
\hline Dinamarca & & & 1 & DS83 (EUA) & 2 & & 2 \\
\hline Espanha & & & 3 & $\begin{array}{|lcc|}\text { DS316 } & \text { (EUA), } & \text { DS347 } \\
\text { (EUA) } & e & \text { DS443 } \\
\text { (Argentina) } & \end{array}$ & 3 & & 3 \\
\hline França & & & 4 & \begin{tabular}{|l} 
DS131 (EUA), DS173 \\
$($ EUA) = DS172, DS316 \\
$($ EUA) e DS347 (EUA)
\end{tabular} & 4 & & 4 \\
\hline Grécia & & & 3 & $\begin{array}{l}\text { DS125 (EUA) = DS124, } \\
\text { DS129 (EUA) e DS452 } \\
\text { (China) }\end{array}$ & 3 & & 3 \\
\hline Hungria & 5 & $\begin{array}{|lc|}\text { DS143 } & \text { (Eslováquia), } \\
\text { DS148 } & \text { (Rep. Checa), } \\
\text { DS240 } & \text { (Romênia), } \\
\text { DS256 } & \text { (Turquia) } \\
\text { DS297 } & \text { (Croácia) }\end{array}$ & 2 & 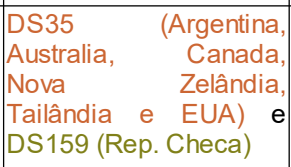 & 7 & 2 & 9 \\
\hline Irlanda & & & 3 & \begin{tabular}{|ll} 
DS68 & (EUA) \\
DS62/67, DS82 (EUA) \\
e DS130 (EUA)
\end{tabular} & 3 & & 3 \\
\hline Italia & & & 1 & DS452 (China) & 1 & & 1 \\
\hline Paises Baixos & & & 3 & \begin{tabular}{|lll} 
DS128 & (EUA), & DS408 \\
(India) e DS409 (Brasil)
\end{tabular} & 3 & & 3 \\
\hline Polonia & 3 & $\mid \begin{array}{lr}\text { DS122 } & \text { (Tailândia), } \\
\text { DS235 } & \text { (Eslováquia) } \\
\text { DS289 } & \text { (Rep. Checa) }\end{array}$ & 1 & DS19 (India) & 4 & 1 & 5 \\
\hline Portugal & & & 1 & DS37 (EUA) & 1 & & 1 \\
\hline Reino Unido & & & 3 & \begin{tabular}{|l} 
DS67 (EUA) \\
DS62/68, DS316 (EUA) \\
e DS347 (EUA)
\end{tabular} & 3 & & 3 \\
\hline Republica Checa & 1 & DS159 (Hungria) & 2 & $\begin{array}{|ll|}\text { DS148 } & \text { (Hungria) } \\
\text { DS289 } & \text { (Polônia) }\end{array}$ & 3 & & 3 \\
\hline Eslovaquia & & & 3 & \begin{tabular}{|lll} 
DS133 (Suiça), & DS143 \\
(Hungria) & e & DS235 \\
(Polônia) & & \\
\end{tabular} & 3 & & 3 \\
\hline Romenia & & & 2 & $\begin{array}{l}\text { DS198 (EUA) e DS240 } \\
\text { (Hungria) }\end{array}$ & 2 & & 2 \\
\hline Suecia & & & 1 & DS86 (EUA) & 1 & & 1 \\
\hline
\end{tabular}

Fonte: Elaboração própria. 
Estes casos referidos já estão contabilizados no número de acionamentos contra o bloco e haveria dupla contagem se fossem somados os acionamentos feitos a seus membros individualmente, de forma que os acionamentos contra os paísesmembros foram eliminados pelo ajuste.

Ainda no que concerne ao polo passivo da UE, em 7 casos a UE e um (ou mais) de seus estado(s)-membro(s) foram acionados separadamente em casos distintos acerca dos mesmos temas. Estes casos estão destacados em rosa e enumerados a seguir: DS173 (EUA x França) = DS172 (EUA x UE); DS125 (EUA x Grécia $)=$ DS124 (EUA x UE); e DS67 (EUA x Reino Unido) = DS68 (EUA x Irlanda $)$ = DS62 (EUA x UE).

Assim, temos 7 casos acerca de na verdade 3 controvérsias, todos tendo sido demandados também à UE enquanto bloco. Como já estão contabilizados nos acionamentos recebidos pela UE, os casos acima em que foram acionados seus estados-membros foram eliminados da base de dados para evitar dupla contagem.

Por fim, finalizando o Ajuste A, os países-membros da UE foram acionados em 15 casos de forma individual sem que o bloco tenha sido acionado no mesmo caso ou em outro caso versando sobre a mesma disputa. Estes casos estão destacados em laranja e foram enumerados a seguir: DS19 (Índia x Polônia), DS35 (Argentina, Austrália, Canadá, Nova Zelândia, Tailândia e EUA x Hungria), DS37 (EUA x Portugal), DS80 (EUA x Bélgica), DS82 (EUA x Irlanda), DS83 (EUA x Dinamarca), DS86 (EUA x Suécia), DS127 (EUA x Bélgica), DS128 (EUA x Países Baixos), DS129 (EUA x Grécia), DS130 (EUA x Irlanda), DS131 (EUA x França), DS133 (Suíça x Eslováquia), DS198 (EUA x Romênia) e DS210 (EUA x Bélgica).

O total de acionamentos-padrão da UE após o Ajuste A consistirá, assim, da soma dos 73 acionamentos recebidos pelo bloco mais os acionamentos em 15 casos recebidos de países extra-bloco por estados-membros individualmente e sem correspondência a acionamentos recebidos pela UE enquanto bloco, totalizando 88 acionamentos-padrão.

Com isto, podemos realizar a segunda etapa de ajustes da EU (Ajuste B), conforme o Quadro 2.3 na página a seguir. O quadro do "Ajuste B" é relativo aos casos em que a UE ou seus estados-membros receberam acionamentos de mais de um país no OSC no âmbito do mesmo caso. Estes casos são: DS16 (EUA, Guatemala, Honduras e México x UE), DS27 (Equador, EUA, Guatemala, Honduras e México x UE), DS35 (Argentina, Austrália, Canadá, Nova Zelândia, Tailândia e EUA x Hungria) e DS158 (EUA, Guatemala, Honduras, México e Panamá x UE). 
Quadro 2.3: União Europeia - Ajuste B

\begin{tabular}{|c|c|c|c|c|c|c|c|}
\hline País / Bloco & $\begin{array}{l}\text { Reclamante- } \\
\text { padrão }\end{array}$ & \multirow{3}{*}{ Casos } & $\begin{array}{l}\text { Acionado- } \\
\text { padrão }\end{array}$ & \multirow{3}{*}{ Casos } & Total 1 & $\begin{array}{c}\text { Terceira } \\
\text { Parte }\end{array}$ & $\begin{array}{l}\text { Total } \\
\text { Gera }\end{array}$ \\
\hline $\begin{array}{c}\text { Uniao Europeia } \\
\text { (Ajuste B) }\end{array}$ & 90 & & 104 & & 194 & 137 & 331 \\
\hline $\begin{array}{c}\text { Uniao Europeia } \\
\text { (Ajuste A) }\end{array}$ & 90 & & 88 & & 178 & 137 & 315 \\
\hline Canada & & & 1 & DS35 & & & \\
\hline Argentina & & & 1 & DS35 & & & \\
\hline Australia & & & 1 & DS35 & & & \\
\hline Equador & & & 1 & DS27 & & & \\
\hline Estados Unidos & & & 4 & DS16, DS27, DS35 e DS158 & & & \\
\hline Guatemala & & & 3 & DS16, DS27 e DS158 & & & \\
\hline Honduras & & & 3 & DS16, DS27 e DS158 & & & \\
\hline Mexico & & & 3 & DS16, DS27 e DS158 & & & \\
\hline Nova Zelândia & & & 1 & DS35 & & & \\
\hline Panama & & & 1 & DS158 & & & \\
\hline Tailândia & & & 1 & DS35 & & & \\
\hline
\end{tabular}

Fonte: Elaboração própria.

Uma vez que cada um destes casos já foi contabilizado uma vez à conta do bloco diretamente ou somado aos acionamentos recebidos pelo bloco em função de um de seus estados-membros, ao se desmembrar estes casos em casos-padrão individuais teremos 20 casos-padrão movidos por reclamantes-padrão individuais contra a UE. Como estes 20 casos-padrão correspondem a 4 casos já contabilizados nos acionamentos contra o bloco, ao final do Ajuste B devemos somar ao total de acionamentos-padrão do Ajuste A mais 16 acionamentos-padrão contra a UE, totalizando 104 acionamentos-padrão.

Tendo em vista que não ocorreu alteração do número de reclamações-padrão após o Ajuste B, no consolidado após o ajuste final a UE foi responsável por 90 reclamações-padrão e recebeu 104 acionamentos-padrão no período 1995-2012. Por fim, na categoria parte interessada foi eliminada uma única ocorrência nesta categoria em que Polônia aparece nesta categoria em caso em que a UE enquanto bloco é a demandante (DS114).

\section{b) Estados Unidos - padronização}

Para realizar os ajustes necessários à padronização dos dados da participação dos EUA no OSC, conforme a Quadro 2.4 na página a seguir, foram realizados ajustes de duas naturezas, um no polo ativo das disputas e outro no polo passivo. No polo ativo, nos casos em que os EUA aparece como reclamante em casos contra a UE e/ou seus estados-membros de forma duplicada (quer no mesmo caso, quer em casos distintos acerca da mesma disputa) e que foram eliminados da 
base de dados na padronização dos casos da UE, estas reclamações duplicadas foram deduzidas do total de reclamações protocoladas pelos EUA no OSC no período.

Assim, de um total de 7 casos que correspondem a estas características há 4 ocorrências de duplicidade que foram deduzidas das 103 reclamações protocoladas pelos EUA no OSC, totalizando 99 reclamações-padrão à conta do país no órgão. Os casos em questão são: DS173 (EUA x França), que versa sobre a mesma controvérsia do DS172 (EUA x UE); DS125 (EUA x Grécia), que trata da mesma disputa refletida no DS124 (EUA x UE); e DS67 (EUA x Reino Unido), que trata da mesma matéria dos casos DS68 (EUA x Irlanda) e DS62 (EUA x UE).

Quadro 2.4: Estados Unidos - Ajuste

\begin{tabular}{|c|c|c|c|c|c|c|c|}
\hline País & $\begin{array}{c}\text { Reclamante- } \\
\text { padrão }\end{array}$ & & $\begin{array}{c}\text { Acionado- } \\
\text { padrão }\end{array}$ & & Total 1 & $\begin{array}{c}\text { Terceira } \\
\text { Parte }\end{array}$ & Total Geral \\
\hline $\begin{array}{c}\text { Estados Unidos } \\
\text { (Ajuste) }\end{array}$ & 99 & Casos & 131 & Casos & 230 & 104 & 334 \\
\hline EUA & 103 & & 119 & & 222 & 104 & 326 \\
\hline França & 1 & DS173 = DS172 & & & & & \\
\hline Grécia & 1 & DS125 = DS124 & & & & & \\
\hline Irlanda & 1 & DS68 = DS62/67 & & & & & \\
\hline Reino Unido & 1 & DS67 = DS62/68 & & & & & \\
\hline India & & & 2 & DS58 e DS217 & & & \\
\hline Malásia & & & 1 & DS58 & & & \\
\hline Paquistão & & & 1 & DS58 & & & \\
\hline Tailândia & & & 2 & DS58 e DS217 & & & \\
\hline Australia & & & 1 & DS217 & & & \\
\hline Brazil & & & 1 & DS217 & & & \\
\hline Chile & & & 1 & DS217 & & & \\
\hline UE & & & 1 & DS217 & & & \\
\hline Indonésia & & & 1 & DS217 & & & \\
\hline Japão & & & 1 & DS217 & & & \\
\hline Coréia do Sul & & & 1 & DS217 & & & \\
\hline Canada & & & 1 & DS234 & & & \\
\hline México & & & 1 & DS234 & & & \\
\hline
\end{tabular}

Fonte: Elaboração própria.

Por sua vez, no polo passivo das disputas foram individualizados em casospadrão distintos todos os casos em que os EUA aparecem como acionados por mais de um país no OSC no âmbito do mesmo caso. Estes casos são: DS58 (Índia, Malásia, Paquistão e Tailândia x EUA), DS217 (Austrália, Brasil, Chile, UE, Índia, Indonésia, Japão, Tailândia e Coreia do Sul x EUA) e DS234 (Canadá e México x EUA).

Assim, após a individualização destes 3 casos, teremos 15 casos-padrão. Tendo em conta que já estão contabilizados como acionamentos contra os EUA estes três casos, temos de somar ao número de acionamentos recebidos pelo país 
mais 12 acionamentos-padrão, totalizando 131 acionamentos-padrão contra o mesmo no período.

Com a criação da figura do caso-padrão e a partir dos ajustes realizados nas duas seções acima (UE e EUA) poderemos agora ter uma visão geral mais consistente dos dados de uso do sistema de solução de controvérsias da OMC - a qual será introduzida no próximo capítulo. A título de esclarecimento, os demais casos no OSC que não foram objeto de ajuste foram convertidos diretamente em casos-padrão por contarem com um único país/bloco reclamante no polo ativo e um único país/bloco acionado no polo passivo da disputa. 


\title{
Capítulo 3
}

\section{PARTICIPAÇÃO DOS PAÍSES EM DESENVOLVIMENTO NO OSC: EVIDÊNCIAS EMPÍRICAS PRELIMINARES}

\author{
"A hora mais escura do dia é a que \\ vem antes do sol nascer".
}

(Provérbio árabe)

No presente capítulo procuraremos abordar o tema da participação dos países em desenvolvimento no sistema de solução de controvérsias da OMC estruturando nossa abordagem inicial sobre as evidências empíricas preliminares encontradas. $O$ estabelecimento das bases empíricas do fenômeno nos auxiliará em nossa discussão da literatura e do modelo de estudo proposto nos próximos capítulos. E a, por fim, trazer à luz nossos resultados no Capítulo 6.

A partir dos dados empíricos da participação no OSC compilados a partir de dados da própria OMC (após a padronização efetuada no capítulo precedente) procuraremos fazer uma sistematização da discussão introduzindo nossa proposta de abordagem do tema e das evidências empíricas iniciais encontradas.

Para tanto, proporemos a criação de dois índices simples para a consolidação preliminar da atividade dos diferentes grupos de renda tanto no polo ativo (índice de atividade), referente à abertura ativa de reclamações no OSC, e no polo passivo (índice de passividade), referente ao recebimento de acionamentos no sistema.

Na penúltima seção, introduziremos a discussão sobre a heterogeneidade dos dados, a ser aprofundada no próximo capítulo, advinda do excesso de valores nulos das variáveis resposta e apresentaremos o coeficiente de variação de Pearson para cada um dos grupos de renda e para os países individualmente ao longo do período.

Por fim, faremos a flexibilização dos pressuposto de trabalho apresentados até o momento de maneira a preparar o terreno para a discussão metodológica a ser realizada no próximo capítulo.

\subsection{Participação dos PED nos casos-padrão no OSC - Uma visão geral}

Tendo por base nossa discussão dos dados e padronização realizada no capítulo anterior, apresentamos no Quadro 3.1 na página a seguir uma visão geral 
do número de casos-padrão protocolados no OSC no período 1995-2012, bem como a distribuições dos reclamantes-padrão e acionados-padrão individualmente e por grupo de renda.

\section{Quadro 3.1: Casos-padrão no OSC no período 1995-2012}

\begin{tabular}{|c|c|c|c|c|c|}
\hline Membro / Grupo & $\begin{array}{l}\text { Reclamante- } \\
\text { padrão }\end{array}$ & $\begin{array}{l}\text { Acionado- } \\
\text { padrão }\end{array}$ & Total 1 & $\begin{array}{c}\text { Parte } \\
\text { Interessada }\end{array}$ & $\begin{array}{l}\text { Total } \\
\text { Geral }\end{array}$ \\
\hline Países Desenvolvidos & 281 & 297 & 578 & 872 & 2027 \\
\hline$E U A / E U$ & 189 & 235 & 424 & 238 & 1086 \\
\hline União Europeia & 90 & 104 & 194 & 133 & 521 \\
\hline Estados Unidos & 99 & 131 & 230 & 105 & 565 \\
\hline Outros PD & 92 & 62 & 154 & 634 & 941 \\
\hline Arábia Saudita & & & 0 & 21 & 21 \\
\hline Austrália & 7 & 13 & 20 & 78 & 118 \\
\hline Barein & & & 0 & 1 & 1 \\
\hline Barbados & & & 0 & 4 & 4 \\
\hline Canadá & 33 & 17 & 50 & 90 & 190 \\
\hline Cingapura & 1 & & 1 & 12 & 14 \\
\hline Coreia do Sul & 15 & 14 & 29 & 77 & 135 \\
\hline Croácia & & 1 & 1 & & 2 \\
\hline Hong Kong (AAE China) & 1 & & 1 & 13 & 14 \\
\hline Islândia & & & 0 & 8 & 8 \\
\hline Israel & & & 0 & 7 & 7 \\
\hline Japão & 17 & 15 & 32 & 136 & 200 \\
\hline Kuwait & & & 0 & 1 & 1 \\
\hline Noruega & 4 & & 4 & 53 & 61 \\
\hline Nova Zelândia & 7 & & 7 & 36 & 50 \\
\hline Oma & & & 0 & 7 & 7 \\
\hline Suíça & 4 & & 4 & 11 & 19 \\
\hline Taiwan & 3 & & 3 & 75 & 81 \\
\hline Trinidade e Tobago & & 2 & 2 & 4 & 8 \\
\hline $\begin{array}{c}\text { Países em } \\
\text { Desenvolvimento }\end{array}$ & 191 & 175 & 366 & 940 & 1627 \\
\hline Renda Média-alta & 103 & 95 & 198 & 447 & 847 \\
\hline África do Sul & & 4 & 4 & 4 & 12 \\
\hline Antígua e Barbuda & 1 & & 1 & & 2 \\
\hline Argentina & 18 & 22 & 40 & 45 & 125 \\
\hline Brasil & 26 & 14 & 40 & 77 & 157 \\
\hline Chile & 10 & 13 & 23 & 36 & 82 \\
\hline Colômbia & 5 & 3 & 8 & 40 & 56 \\
\hline Costa Rica & 5 & & 5 & 15 & 25 \\
\hline
\end{tabular}




\begin{tabular}{|c|c|c|c|c|c|}
\hline Cuba & & & 0 & 17 & 17 \\
\hline Dominica & & & 0 & 3 & 3 \\
\hline Granada & & & 0 & 1 & 1 \\
\hline Jamaica & & & 0 & 8 & 8 \\
\hline Malásia & 1 & 1 & 2 & 5 & 9 \\
\hline Maurício & & & 0 & 6 & 6 \\
\hline México & 23 & 14 & 37 & 69 & 143 \\
\hline Namíbia & & & 0 & 1 & 1 \\
\hline Panamá & 6 & 1 & 7 & 7 & 21 \\
\hline Peru & 3 & 4 & 7 & 16 & 30 \\
\hline República Dominicana & 1 & 7 & 8 & 6 & 22 \\
\hline Rússia & & & 0 & 10 & 10 \\
\hline Santa Lúcia & & & 0 & 3 & 3 \\
\hline São Kitts e Névis & & & 0 & 3 & 3 \\
\hline São Vicente e Granadinas & & & 0 & 1 & 1 \\
\hline Suriname & & & 0 & 1 & 1 \\
\hline Turquia & 2 & 9 & 11 & 52 & 74 \\
\hline Uruguai & 1 & 1 & 2 & 10 & 14 \\
\hline Venezuela & 1 & 2 & 3 & 15 & 21 \\
\hline Renda Média-baixa & 85 & 80 & 165 & 442 & 731 \\
\hline Armênia & & 1 & 1 & & 2 \\
\hline Belize & & & 0 & 4 & 4 \\
\hline Bolívia & & & 0 & 1 & 1 \\
\hline Camarões & & & 0 & 1 & 1 \\
\hline China & 11 & 30 & 41 & 101 & 142 \\
\hline Costa do Marfim & & & 0 & 4 & 4 \\
\hline Egito & & 4 & 4 & 7 & 15 \\
\hline El Salvador & 1 & & 1 & 14 & 16 \\
\hline Equador & 3 & 3 & 6 & 26 & 38 \\
\hline Fiji & & & 0 & 3 & 3 \\
\hline Filipinas & 5 & 6 & 11 & 11 & 33 \\
\hline Guatemala & 8 & 2 & 10 & 30 & 50 \\
\hline Guiana & & & 0 & 3 & 3 \\
\hline Honduras & 8 & & 8 & 21 & 37 \\
\hline Índia & 21 & 21 & 42 & 91 & 175 \\
\hline Indonésia & 6 & 4 & 10 & 10 & 30 \\
\hline Moldávia & 1 & 1 & 2 & 1 & 5 \\
\hline Nicarágua & 1 & 2 & 3 & 15 & 21 \\
\hline Nigéria & & & 0 & 4 & 4 \\
\hline Paquistão & 3 & 2 & 5 & 9 & 19 \\
\hline
\end{tabular}




\begin{tabular}{|c|c|c|c|c|c|}
\hline Paraguai & & & 0 & 15 & 15 \\
\hline Sri Lanka & 1 & & 1 & 3 & 5 \\
\hline Suazilândia & & & 0 & 3 & 3 \\
\hline Tailândia & 13 & 3 & 16 & 63 & 95 \\
\hline Ucrânia & 3 & 1 & 4 & 2 & 10 \\
\hline$P M D$ & 3 & 0 & 3 & 43 & 49 \\
\hline Bangladesh & 1 & & 1 & 1 & 3 \\
\hline Benin & & & 0 & 1 & 1 \\
\hline Chade & & & 0 & 1 & 1 \\
\hline Gana & & & 0 & 1 & 1 \\
\hline Madagascar & & & 0 & 4 & 4 \\
\hline Malaui & & & 0 & 5 & 5 \\
\hline Quênia & & & 0 & 3 & 3 \\
\hline Senegal & & & 0 & 2 & 2 \\
\hline Tanzânia & & & 0 & 3 & 3 \\
\hline Vietnã & 2 & & 2 & 16 & 20 \\
\hline Zâmbia & & & 0 & 2 & 2 \\
\hline Zimbábue & & & 0 & 4 & 4 \\
\hline Total & 472 & 472 & 944 & 1812 & 3654 \\
\hline
\end{tabular}

Fonte: Elaboração própria.

Nota-se que o número de reclamantes-padrão e acionados-padrão foi de 472 no período, sendo este o mesmo número de casos-padrão observados no período após nossos ajustes. Este número de casos-padrão é superior ao de casos protocolados no OSC (454) e representa melhor a real atividade observada no órgão.

Após os ajustes realizados, o número de reclamações-padrão ficou pouco inferior ao de reclamações originais (482) e o número de acionamentos-padrão ficou pouco superior ao de acionamentos originalmente observados (467) devido à eliminação das distorções anteriormente existentes nestes dados.

No Quadro 3.4 pode-se observar a participação geral no OSC de cada um dos membros da OMC que tenha atuado em pelo menos um caso-padrão ao longo do período 1995-2012 em qualquer uma das três categorias possíveis: reclamantepadrão; acionado-padrão; e terceira parte (parte interessada).

É possível observar também a participação agregada de cada grupo de renda no período. Os EUA e a UE foram responsáveis por 189 reclamações-padrão e receberam 235 acionamentos-padrão. Já os países desenvolvidos no agregado 
foram responsáveis por 281 reclamações-padrão e 297 acionamentos-padrão no período.

Os países em desenvolvimento em geral responderam por 191 reclamaçõespadrão e 175 acionamentos-padrão, assim distribuídos: i) PED ma - 103 reclamações-padrão e 95 acionamentos-padrão; ii) $P E D_{m b}-85$ reclamações-padrão e 80 acionamentos-padrão; e iii) PMD - 3 reclamações-padrão e nenhum acionamento-padrão.

Esta litigância foi mapeada em uma Matriz de casos-padrão e disponibilizada no Anexo 1 (v. 02, p. 01) onde é apresentada uma visão compreensiva de toda a litigância recíproca (entre membros individuais e grupos de renda) ocorrida no sistema no período 1995-2012.

Esta matriz foi compilada para apresentar o perfil detalhado de atuação no OSC de todos os países que atuaram nos polos ativo ou passivo de disputas comerciais na OMC durante o período de análise. Assim, de um lado temos este conjunto de países apresentados individualmente e agregados por grupos de renda na categoria de reclamante-padrão (dispostos em linhas) e de outro lado o mesmo conjunto de países na categoria de acionado-padrão (dispostos em colunas).

A partir do cruzamento entre os dois lados desta matriz podemos observar desde o comportamento individual de cada país em questão no período, até o comportamento de cada grupo de renda no agregado. Pode-se saber, assim, quantas reclamações-padrão um determinado país ou grupo de renda apresentou contra qualquer outro país ou grupo de renda, ou como se distribuíram suas reclamações-padrão entre países e grupos de renda.

Ou, alternativamente, quantas vezes um país ou grupo de renda foi acionadopadrão por qualquer outro país ou grupo de renda e como seus acionamentospadrão recebidos estão distribuídos. Ademais é possível verificar se existe litigância recíproca entre os países/grupos e qual é a litigância entre os diferentes grupos de renda.

A seguir apresentaremos os resultados empíricos brutos (sem tratamentos estatísticos) sobre a atuação dos membros da OMC no sistema de solução de controvérsias no período considerado de acordo com os respectivos grupos de renda e com as evidências empíricas apresentadas no Anexo 1 sobre a distribuição da participação destes membros/grupos de renda no OSC: 


\section{a) Países Desenvolvidos}

Os países desenvolvidos foram responsáveis por 59,5\% (281) das reclamações-padrão protocoladas no OSC no período, assim distribuídas:

- 178 são dirigidas aos próprios PD (63,3\% das reclamações-padrão do grupo), sendo:

○ 71 aos EUA (25,3\% das reclamações-padrão do grupo e $40 \%$ das reclamações-padrão contra PD)

○ 56 à UE (20\% das reclamações-padrão do grupo e 31,4\% das reclamações-padrão contra $\mathrm{PD})$

- 127 a ambos em conjunto (45,3\% das reclamações-padrão do grupo e $71,4 \%$ das reclamações-padrão contra PD)

○ 51 aos outros PD (18,2\% das reclamações-padrão do grupo e 28,6\% das reclamações-padrão contra PD)

- 103 são dirigidas a PED (36,6\% das reclamações-padrão do grupo), sendo:

○ 43 aos $P E D_{\text {ma }}$ (15\% das reclamações-padrão do grupo e 41,2\% das reclamações-padrão contra PED)

○ 60 aos $\mathrm{PED}_{\mathrm{mb}}(21,5 \%$ das reclamações-padrão do grupo e 58,8\% das reclamações-padrão contra PED)

○ 0 aos PMD

No polo passivo, os países desenvolvidos receberam 297 acionamentospadrão no período ( $62,9 \%$ do total de acionamentos-padrão no OSC), assim distribuídos:

- 178 acionamentos-padrão recebidos de PD (60\% dos acionamentos-padrão do grupo), sendo:

- 50 recebidos da UE (16,8\% dos acionamentos-padrão do grupo e $28,1 \%$ dos acionamentos-padrão recebidos de PD)

○ 53 recebidos dos EUA (17,9\% dos acionamentos-padrão do grupo e 29,8\% dos acionamentos-padrão recebidos de PD)

- 103 de ambos em conjunto (34,7\% dos acionamentos-padrão do grupo e $57,9 \%$ dos acionamentos-padrão recebidos de PD) 
○ 75 recebidos de outros PD (25,3\% dos acionamentos-padrão do grupo e 42,1\% dos acionamentos-padrão recebidos de PD)

- 119 acionamentos-padrão recebidos de PED (40\% dos acionamentos-padrão do grupo), sendo:

- 61 recebidos de $\operatorname{PED}_{\text {ma }}(20,5 \%$ dos acionamentos-padrão do grupo e $51,3 \%$ dos acionamentos-padrão recebidos de PED)

- 56 recebidos de $\mathrm{PED}_{\mathrm{mb}}(18,8 \%$ dos acionamentos-padrão do grupo e $47 \%$ dos acionamentos-padrão recebidos de PED)

○ 2 recebidos de PMD (0,7\% dos acionamentos-padrão do grupo e

$1,7 \%$ dos acionamentos-padrão recebidos de PED)

\section{b) Países em Desenvolvimento}

No caso dos países em desenvolvimento, os mesmos são responsáveis por 40,5\% (191) das reclamações-padrão protocoladas no OSC no período, assim distribuídas:

- 119 são dirigidas aos PD (62,3\% das reclamações-padrão do grupo), sendo:

○ 60 aos EUA (31,4\% das reclamações-padrão do grupo e 50,4\% das reclamações-padrão contra PD)

○ 48 à UE $(25,1 \%$ das reclamações-padrão do grupo e $40,3 \%$ das reclamações-padrão contra PD)

- 108 a ambos em conjunto (56,3\% das reclamações-padrão do grupo e 90,7\% das reclamações-padrão contra PD)

○ 11 aos outros PD (5,7\% das reclamações-padrão do grupo e 9,3\% das reclamações-padrão contra PD)

- 72 são dirigidas aos próprios PED (37,7\% das reclamações-padrão do grupo), sendo:

○ 52 aos $P E D_{\text {ma }}(27,2 \%$ das reclamações-padrão do grupo e $70,8 \%$ das reclamações-padrão contra PED)

○ 20 aos PED $_{\mathrm{mb}}(10,5 \%$ das reclamações-padrão do grupo e $27,7 \%$ das reclamações-padrão contra PED)

$\circ 0$ aos PMD 
Já no polo passivo das disputas os países em desenvolvimento respondem por $37,1 \%$ (175) dos acionamentos-padrão no período 1995-2012, assim distribuídos:

- 102 acionamentos-padrão recebidos de PD (58,3\% dos acionamentos-padrão do grupo), sendo:

○ 40 recebidos da UE (22,9\% dos acionamentos-padrão do grupo e $39,2 \%$ dos acionamentos-padrão recebidos de PD)

○ 46 recebidos dos EUA (26,3\% dos acionamentos-padrão do grupo e $45,1 \%$ dos acionamentos-padrão recebidos de PD)

- 86 de ambos em conjunto (49,2\% dos acionamentos-padrão do grupo e $84 \%$ dos acionamentos-padrão recebidos de PD)

○ 16 recebidos de outros PD (9,1\% dos acionamentos-padrão do grupo e $15,7 \%$ dos acionamentos-padrão recebidos de PD)

- 73 acionamentos-padrão recebidos de outros PED (41,7\% dos acionamentospadrão do grupo), sendo:

○ 42 recebidos de $P E D_{m a}$ (24\% dos acionamentos-padrão do grupo e $57,5 \%$ dos acionamentos-padrão recebidos de PED)

- 30 recebidos de $\operatorname{PED}_{\mathrm{mb}}(17,1 \%$ dos acionamentos-padrão do grupo e $41,1 \%$ dos acionamentos-padrão recebidos de PED) ○ 1 recebido de PMD (0,6\% dos acionamentos-padrão do grupo e $1,4 \%$ dos acionamentos-padrão recebidos de PED)

Conforme se apreende da Matriz de casos-padrão, há uma litigância mais intensa contra os países desenvolvidos (297 casos-padrão, ou 62,9\% do total) promovida em grande parte pelos próprios PD litigando entre si $(60 \%$ das reclamações-padrão recebidas pelos PD) e em menor medida pelos PED (40\% das reclamações-padrão recebidas pelos $\mathrm{PD}$ ), com equilíbrio entre a participação dos $P E D_{m a}$ e $P E D_{m b}$, observando-se ligeiramente maior participação dos primeiros.

Quando os PED estão no polo ativo, a maior parte de suas reclamaçõespadrão são feitas contra PD (62\%) e uma parte menor se dirige aos outros PED, sendo prioritariamente destinadas aos $\operatorname{PED}_{\text {ma }}(27,6 \%)$.

Um dado, no entanto, parece a princípio discrepante acerca da atuação dos países desenvolvidos face aos países em desenvolvimento: os $P E D_{\text {ma }}$ são 
acionados-padrão no OSC em uma proporção superior aos $P E D_{m b}$ no agregado (95 x 80 casos-padrão, uma diferença de 18,7\%), mas os PED $_{\mathrm{mb}}$ são relativamente mais acionados-padrão pelos países desenvolvidos do que os $P E D_{m a}$. Os $P E D_{m a}$ receberam 42 acionamentos-padrão por parte dos PD no período, enquanto os $\mathrm{PED}_{\mathrm{mb}}$ receberam 60 acionamentos-padrão (42,8\% a mais).

Isto significa que o primeiro alvo prioritário tanto dos PD quanto dos PED no OSC são os próprios PD. Mas que esta coincidência de preferências não existe quando o alvo escolhido é um PED. Os PED (dos três subníveis de renda) quando atuam contra outros PED no OSC dirigem suas reclamações-padrão prioritariamente aos $\mathrm{PED}_{\mathrm{ma}}$, enquanto que os PD têm como alvo prioritário entre os PED o grupo de renda média-baixa $\left(P E D_{m b}\right)$.

Esta diferença de preferência de alvos entre os PD e os PED parece ser a responsável pelo fenômeno observado, fazendo com que $44,2 \%$ dos acionamentospadrão sofridos pelos $\mathrm{PED}_{\text {ma }}$ sejam de $\mathrm{PD}$, ao passo que o expressivo valor de $75 \%$ dos acionamentos-padrão sofridos pelos $P E D_{m b}$ no OSC são feitos por PD.

Uma hipótese a se considerar, é que 45 dos acionamentos-padrão (75\%) sofridos pelos $P E D_{m b}$ por parte de PD se concentrem na China (25 casos-padrão) e Índia (20 casos-padrão) e que, portanto, parece haver indicação de que não apenas o grupo de renda mas também o tamanho dos mercados (além de outras variáveis) são importantes na determinação do alvo de uma ação no OSC.

No entanto, na média a decisão de participar ativamente do OSC como reclamante-padrão parece estar mais correlacionada ao grupo de renda do país do que propriamente ao tamanho de seu mercado interno - os dados apontam elevação no nível de atividade nesta categoria acompanhando a elevação dos níveis de renda per capita dos diferentes grupos, embora haja muita dispersão.

Assim, parece haver a indicação de que a probabilidade de um país atuar ativamente como reclamante-padrão no OSC está ligada ao seu grupo de renda, mas uma vez que tenha optado por atuar sua decisão de qual alvo atacar parece ser mais autônoma em relação a esta variável e levar em conta outras variáveis na sua determinação.

Conforme procuraremos demonstrar ao longo desta pesquisa, uma diferença nestas outras variáveis pode ser capaz de explicar esta diferença de comportamento na escolha de alvos entre PD e PED, ao passo que os grupos de renda podem ser capazes de explicar a participação geral dos países no OSC. Estas observações de 
tendências apontadas pelas evidências empíricas serão cruciais em nossa discussão da literatura e como auxiliares na identificação de variáveis estruturais potencialmente explicativas no desenho dos nossos modelos.

De forma sucinta, os dados disponíveis nos permitem fazer algumas observações preliminares: dos 130 países considerados como membros da OMC nesta pesquisa, 84 tiveram participação no OSC em ao menos uma das categorias (reclamante-padrão ou acionado-padrão ou parte interessada) no período 19952012 , correspondendo a $64,6 \%$ do total de membros; enquanto $32,3 \%$, ou 42 países, participaram como reclamantes-padrão; 34 países, o equivalente a $26,6 \%$ do total, participaram como acionados; e 62,3\% dos membros, ou 81 países, participaram como partes interessadas.

A tabela Tabela 3.1 a seguir apresenta uma visão geral da proporção de reclamações-padrão e de reclamantes-padrão por grupo de renda. Conforme podese observar, dentre aqueles países que atuaram ativamente como reclamantespadrão no OSC no período, os países desenvolvidos foram o grupo de renda que respondeu pela maior proporção de reclamações-padrão protocoladas no órgão (59,5\% do total) e a proporção de membros considerados desenvolvidos que atuaram ativamente no período foi de 46,1\% (12 membros de um total considerado de 26 países no grupo de renda alta na OMC).

Tabela 3.1: Proporção de reclamações-padrão (do total) e reclamantes-padrão (por grupo)

\begin{tabular}{ccc}
$\begin{array}{c}\text { Nível de } \\
\text { Renda }\end{array}$ & $\begin{array}{c}\text { Proporção de } \\
\text { reclamações-padrão do } \\
\text { total (\%) }\end{array}$ & $\begin{array}{c}\text { Proporção de reclamantes- } \\
\text { padrão no grupo (\%) }\end{array}$ \\
PD & 59,5 & 46,1 \\
PED & 40,5 & 28,8 \\
PED $_{\text {ma }}$ & 21,8 & 38,9 \\
PED $_{\text {mb }}$ & 18,0 & 37,8 \\
PMD & 0,6 & 6,4 \\
\hline
\end{tabular}

Fonte: Elaboração própria.

Já os países em desenvolvimento atuaram ativamente em 40,5\% (191) dos casos-padrão protocolados e a atuação ativa dos membros em desenvolvimento enquanto proporção do total de membros em desenvolvimento na organização foi de 28,8\% (30 PED nesta categoria de um total de 104 PED considerados pela 
pesquisa).

Ao se dividir o grupo de PED em seus subgrupos, observa-se que os países em desenvolvimento de renda média-alta responderam por uma participação de $21,8 \%$ (103) do total de reclamações-padrão, enquanto que neste subgrupo a proporção de atuantes nesta categoria foi de 38,9\% (14 de um total de $36 \mathrm{PED}_{\mathrm{ma}}$ ).

No caso dos países em desenvolvimento de renda média-baixa, percebe-se que este subgrupo foi responsável por $18 \%$ das reclamações-padrão protocoladas no OSC no período e que $37,8 \%$ de seus membros aparecem nesta categoria (14 de $37 \mathrm{PED}_{\mathrm{mb}}$ ). Já no caso dos PMD sua participação é negligenciável visto que apenas 0,6\% reclamações-padrão foram protocoladas por integrantes deste grupo no período analisado e que uma pequena proporção de $6,4 \%$ de seus membros atuou nesta categoria (2 de um total de $31 \mathrm{PMD}$ ).

A diferença na atuação de países desenvolvidos e de países em desenvolvimento no OSC conforme se pode observar é sensível. Os países desenvolvidos apesar de perfazerem um grupo com menor número de membros na OMC do que os países em desenvolvimento, são responsáveis por uma maior proporção das reclamações-padrão protocoladas no OSC e uma maior proporção de seus membros atua ativamente no órgão.

Dentro do grupo de países em desenvolvimento, nota-se também uma grande diferença entre a atuação dos países em desenvolvimento de renda média-alta e média-baixa e a dos países de menor desenvolvimento relativo. Enquanto os $\mathrm{PED}_{\mathrm{ma}}$ e $P E D_{m b}$ possuem proporção de reclamações-padrão do total $(21,8 \%$ e $18 \%$ respectivamente) e proporção de reclamantes-padrão no grupo (38,9\% e $37,8 \%$ respectivamente) bastante similares, os PMD possuem apenas $0,6 \%$ e $6,4 \%$, respectivamente, dos dois índices.

\subsection{Sistematização preliminar das evidências empíricas}

Para sistematizar preliminarmente a discussão das evidências empíricas coletadas e permitir uma primeira comparação direta entre os diferentes grupos de renda no OSC nas duas dimensões trabalhadas neste estudo (ativa e passiva), na presente seção proporemos a criação de dois índices de análise: 
i) índice de atividade - que será responsável por consolidar em um único índice a atividade dos diferentes grupos de renda no polo ativo das disputas no sistema de solução de controvérsias da OMC (como reclamantes-padrão); e

ii) índice de passividade - que será responsável por consolidar em um único índice as ocorrências dos países no polo passivo das disputas no sistema de solução de controvérsias da OMC (como acionados-padrão).

\subsection{1. Índice de Atividade (A)}

Por índice de atividade $A$ entenderemos a medida percentual da participação ativa de um grupo de renda em relação à atividade total observada no OSC em proporção à sua própria representatividade como grupo de renda em relação ao número total de membros da OMC.

Ou seja, considerando os diferente grupos de renda $i=\left(P D, P E D, P E D_{\text {ma, }}\right.$ PED $D_{\mathrm{mb}}$ e PMD), o índice em questão será: $A=\left(R A_{i} / R\right) /\left(N_{i} / N\right)$. Sendo $R A_{i}$ o número de reclamações-padrão protocoladas no período pelo grupo de renda; $R$ o número total de reclamações-padrão protocoladas no OSC no período; $N_{i}$ o número de integrantes do grupo de renda; e $N$ o número total de membros da $\mathrm{OMC}$ considerados na pesquisa.

O valor atribuído ao índice de atividade de um grupo específico poderá, assim, assumir valores estritamente positivos no intervalo maior ou igual a 0 até igual ao limite superior $N$. Caso o país possua atividade externa no OSC exatamente proporcional à sua representatividade enquanto grupo de renda na organização, o valor de A deverá ser 1 (100\%).

A ocorrência de valores de A maiores do que 1 indicam superatividade externa no OSC, ou seja, o grupo de renda em questão é mais ativo no sistema do que a sua representatividade enquanto grupo no mesmo. $O$ valor de $A$ será igual ao limite superior de $N(130)$ caso o grupo de renda em questão for composto por um único membro e este tiver uma proporção de reclamações-padrão em relação ao total igual a 1. Ou seja, o país deve ter protocolado todas as reclamações-padrão feitas no OSC no período.

A atuação deste país sozinho seria, então, 130 vezes (13.000\%) maior do que a sua representatividade na $\mathrm{OMC}$, sendo equivalente à atuação de todos os 
membros da organização em agregado. A ocorrência do valor de limite superior de A embora teoricamente plausível é virtualmente impossível na realidade.

Um resultado como este indicaria mais do que um predomínio de um grupo específico de renda no uso do sistema de solução de controvérsias da OMC, isso significaria o controle absoluto deste sistema por parte de um único país - hipótese que parece bastante extrema.

De outro lado, para os casos em que a atividade do grupo de renda for inferior à sua representatividade enquanto grupo na $\mathrm{OMC}, A$ estará compreendido no intervalo maior ou igual a zero até menor do que 1. A ocorrência do limite inferior zero, ponto ao qual denominaremos de inatividade externa, só será possível caso o grupo de renda específico não tenha protocolado nenhuma reclamação-padrão em todo o período.

O intervalo superior de variação possui amplitude maior do que o intervalo inferior, embora obviamente o índice possua espectro de variação infinito dentro dos intervalos, pois, caso a atuação de um membro no OSC seja maior do que sua representatividade na OMC, ela poderá ser desde ligeiramente maior do que $100 \%$ $(A>1)$ até no máximo responder pela atividade de todos os membros da OMC $(A=$ 130).

Já o intervalo inferior de variação é mais curto $(0 \leq A<1)$, pois, caso a atuação no OSC de um grupo de países seja inferior à sua representatividade na OMC, ela poderá ser no mínimo nula, no caso de inatividade, e no máximo marginalmente inferior a $100 \%$.

O valor de referência do índice de atividade é, portanto, 1 (100\%). Ou seja, caso um grupo de renda seja ativo no OSC (protocole reclamações-padrão) em relação à atividade total no órgão de forma proporcional à sua própria representatividade enquanto grupo na $\mathrm{OMC}$, o valor de seu índice de atividade será igual a um - nem superior, nem inferior, e sim neutro em relação à sua própria representatividade.

Dessa forma, variações do índice inferiores ao valor de referência representam uma subatividade do grupo de renda, indicando que o grupo possui atividade no OSC em proporção inferior à sua representatividade enquanto grupo na OMC. Já variações positivas do valor de referência representam uma superatividade do grupo de renda, indicando que o mesmo possui atividade no OSC em proporção superior à 
sua representatividade como grupo na organização.

A Tabela 3.2 a seguir mostra o índice de atividade calculado para cada um dos grupos de renda utilizados em nosso estudo, de acordo com a conformação fixa preliminar definida para os mesmos no período. Conforme se pode observar na tabela, os países desenvolvidos possuem um elevado índice de atividade, sendo caracterizados por uma superatividade no OSC 198\% $\left(A_{P D}-1\right)$ maior do que a sua representatividade enquanto grupo na OMC.

\section{Tabela 3.2: Índice de atividade por grupos de renda}

\begin{tabular}{cc} 
Grupo & Atividade \\
\hline APD & 2,98 \\
A PED & 0,51 \\
A PEDma & 0,79 \\
APEDmb & 0,63 \\
APMD & 0,03 \\
\hline
\end{tabular}

Fonte: Elaboração própria.

Já os países em desenvolvimento em conjunto, com um $A_{P E D}=0,51$, caracterizam-se por uma subatividade no OSC representativa de apenas $51 \%$ de sua proporcionalidade enquanto grupo na OMC. Em termos gerais, portanto, os PED têm uma atividade no OSC igual à metade de sua representatividade na organização.

No caso dos subgrupos de países em desenvolvimento, os $P E D_{m a}$ e $P E D_{m b}$ possuem uma subatividade mais moderada, embora inferior às suas representatividades com, $A_{P E D m a}=0,79$ e $A_{P E D m b}=0,63$, respectivamente, equivalentes a $79 \%$ e $63 \%$ de suas representatividades enquanto grupos na OMC. $O$ caso dos PMD é bastante diferente, este subgrupo é caracterizado por uma aguda subatividade $\left(A_{P M D}=0,03\right)$ que os coloca em uma posição muito baixa de atividade no OSC, apenas $3 \%$ de sua representatividade enquanto grupo no sistema.

Isto demonstra uma diferença aguda entre o desempenho ativo dos PD e dos PED. Além disso a atividade dos grupos de países em desenvolvimento de renda média-alta e média-baixa é relativamente elevada em relação à dos países de menor desenvolvimento relativo, mas bastante inferior à dos PD, como 
intuitivamente seria o esperado.

\subsection{2. Índice de Passividade (P)}

De forma análoga ao índice $A$, entenderemos por índice de passividade $P$ a medida percentual de acionamentos-padrão que um grupo de renda recebe em relação ao total observado no OSC em proporção à sua própria representatividade como grupo de renda em relação ao número total de membros da $\mathrm{OMC}$.

O índice em questão será dado por: $P=\left(R P_{i} / R\right) /\left(N_{i} / N\right)$. Sendo $R P_{i} 0$ número de acionamentos-padrão recebidos no período pelo grupo de renda. $A$ discussão realizada anteriormente para a ocorrência dos intervalos de $A$ é extensível ao índice $P$, bem como a lógica geral de ambos de modo que não nos dedicaremos aqui a repetir esta discussão.

Há, no entanto, uma única ressalva digna de nota sobre a diferença de interpretação entre $A$ e $P$. Enquanto no caso de $A$ índices maiores do que 1 representam superatividade externa (caracterizada por uma proporção superior de reclamações-padrão do grupo em relação à representatividade do mesmo) e menores do que 1 indicam subatividade, no caso de $P$ tem-se o contrário.

Sendo assim, valores de $P$ maiores do que 1 indicam subpassividade do grupo. Ou seja, o mesmo recebe mais acionamentos-padrão do que sua representatividade. Enquanto valores de $P$ inferiores a 1 indicam superpassividade (o grupo recebe menos acionamentos-padrão do que sua representatividade).

A Tabela 3.3 a seguir mostra o índice de passividade calculado para cada um dos grupos de renda utilizados em nosso estudo:

Tabela 3.3: Índice de passividade por grupos de renda

\begin{tabular}{cc} 
Grupo & Passividade \\
\hline P $_{\mathrm{PD}}$ & 3,15 \\
P PED $_{\text {PEDma }}$ & 0,46 \\
P $_{\text {PEDmb }}$ & 0,73 \\
P $_{\text {PMD }}$ & 0,6 \\
\hline
\end{tabular}

Fonte: Elaboração própria. 
Conforme se pode observar na referida tabela, os países desenvolvidos possuem um elevado índice de passividade, ou seja, recebem $215 \%\left(P_{P D}-1\right)$ mais acionamentos-padrão do que sua representatividade como grupo na OMC. Sendo caracterizados, portanto, no período por uma subpassividade $P_{P D}=3,15$.

Os países em desenvolvimento apresentam $P_{P E D}=0,46$, caracterizando-se por uma superpassividade equivalente a $46 \%$ de sua representatividade. No caso de cada subgrupo de países em desenvolvimento, tanto os $P E D_{m a}$ quanto os $P E D_{m b}$ apresentam superpassividade mais moderada, respectivamente com $P_{P E D m a}=0,73 \mathrm{e}$ $P_{\text {PEDmb }}=0,6$. No caso dos PMD, este grupo apresenta passividade inexistente, ou seja, não foi alvo de nenhum acionamento-padrão no OSC em todo o período analisado $\left(P_{P M D}=0\right)$.

Isto indica que em termos proporcionais à representatividade numérica de cada grupo de renda na OMC, os países desenvolvidos são significativamente tanto mais ativos (protocolam mais reclamações) quanto mais passivos (recebem mais acionamentos) dos que os países em desenvolvimento em geral e/ou qualquer de seus subgrupos. Os países desenvolvidos recebem 2,15 vezes mais acionamentos no OSC do que o número de acionamentos esperado em uma distribuição equitativa dada pela proporção do número de membros em seu grupo em relação ao total de membros da OMC.

Por sua vez, os países em desenvolvimento de renda média-alta e médiabaixa, deixam de receber $27 \%$ e $40 \%$, respectivamente, dos acionamentos esperados para os dois grupos em uma distribuição equitativa de acionamentos de acordo com o tamanho proporcional de cada grupo. Os países de menor desenvolvimento relativo não receberam nenhum acionamento no período e, portanto, deixam de receber $100 \%$ dos acionamentos esperados para o grupo.

Os resultados empíricos preliminares encontrados no presente capítulo são apenas uma primeira aproximação sobre o objeto. Na medida em que avançarmos em nossa discussão sobre este objeto, procuraremos demonstrar a necessidade de se desenvolver uma abordagem que permita qualificar melhor os dados encontrados para evitar o risco de se tirar conclusões precipitadas a partir dos dados empíricos brutos ou sem uma correta modelagem do fenômeno.

Em consequência, nosso principal objetivo nos próximos capítulos será desenvolver uma metodologia para controlar os efeitos influentes neste sistema e, dessa maneira, nos auxiliar a captar a integralidade do fenômeno da participação 
dos países em desenvolvimento no sistema de solução de controvérsias da OMC em seus diferentes aspectos.

\subsubsection{Coeficiente de variação dos grupos de renda}

Antes de iniciarmos nossa discussão dos modelos explicativos para o comportamento dos países em desenvolvimento no OSC (polos ativo e passivo) nos próximos capítulos é importante primeiramente nos indagarmos se efetivamente faz sentido a estratificação dos membros da OMC por grupos de renda quando analisamos sua atuação no órgão.

A resposta a esta indagação não é banal e não pode ser tomada como uma premissa deste trabalho, visto que o desafio ao qual nos propomos aqui é exatamente derivar nosso modelo precipuamente das observações empíricas. Assim, pelo contrário, esta será a primeira afirmação que será colocada à prova.

Ao observar-se a grande discrepância no comportamento agregado no OSC entre países desenvolvidos e em desenvolvimento não se pode deduzir diretamente que esta diferença se deva aos diferentes níveis de desenvolvimento representados por cada grupo. Especialmente por que salta aos olhos a atuação bastante heterogênea dos países dentro de cada um dos grupos de renda, o que parece apontar para uma alta dispersão dos dados.

Uma vez que os dados observados da atuação de cada um dos grupos de renda possuem distribuições de valores e frequências diferentes, com médias e desvios padrões distintos, para permitir a comparação direta entre a homogeneidade/heterogeneidade do comportamento observado em cada um dos grupos de renda, sem a distorção provocada por estas grandezas distintas, utilizaremos uma padronização da variabilidade da atuação dos mesmos em termos percentuais para cada grupo de renda.

Para tanto, será calculado para cada grupo o Coeficiente de variação de Pearson (CV) (HOFFMANN, 2001, p. 71) que será expresso como a variação percentual do desvio padrão das reclamações-padrão protocoladas no OSC pelo grupo de renda em relação à média de reclamações-padrão do grupo. Uma vez que CV é expresso em termos percentuais, o coeficiente de variação permitirá a comparação direta da distribuição da atividade de cada grupo. 
Quanto maior for o índice CV maior variação será observada na atuação do grupo. Alternativamente, quanto mais o índice se aproximar do valor zero maior será a homogeneidade de comportamento e, portanto, melhor distribuída será a atuação do grupo. Um valor de referência zero significa que não há variação na distribuição de atividade entre os membros do grupo e que todos participam no OSC com a mesma frequência.

A fórmula do Coeficiente de variação de Pearson aplicado ao nosso objeto específico, tem a forma a seguir: $C V=S / X$; sendo $S$ o desvio-padrão da distribuição de reclamações-padrão no OSC dentro do grupo de renda específico e $X$ a média do número de reclamações-padrão feitas por este grupo de renda.

Uma vez que representa a homogeneidade/heterogeneidade da dispersão da variável, neste caso a atividade no OSC de cada grupo de renda, é necessário adotar alguns parâmetros de referência, elencados a seguir, para classificar a distribuição medida:

$\circ C V=0$ : não há dispersão - atividade completamente homogênea;

$\circ 0<C V \leq 0,25$ : baixa dispersão - atividade homogênea, com variação máxima de $25 \%$ em relação à média do grupo;

$\circ 0,25<C V \leq 0,35$ : dispersão moderada - atividade levemente heterogênea, com variação mínima de $25 \%$ e máxima de $35 \%$ em relação à média do grupo;

$\circ 0,35<C V \leq 0,50$ : alta dispersão - atividade heterogênea, com variação mínima de $35 \%$ e máxima de $50 \%$ em relação à média do grupo; e

○ $0,50<C V$ : altíssima dispersão - atividade com grande heterogeneidade, com variação maior do que $50 \%$ em relação à média do grupo.

A Tabela 3.4 apresentada na página a seguir mostra o índice $C V$ calculado para cada um dos grupos de renda utilizados em nosso estudo. Conforme se observa na tabela abaixo, há uma altíssima dispersão da atividade em todos os grupos de renda estudados, o que significa que o comportamento de seus membros é altamente heterogêneo. 
Tabela 3.4: Coeficiente de variação de Pearson por grupo de renda

\begin{tabular}{cc}
\hline Nível de Renda & CV \\
\hline PD & 2,42 \\
PED & 2,59 \\
PED $_{\text {ma }}$ & 2,21 \\
PED $_{\text {mb }}$ & 1,99 \\
PMD & 4,03 \\
\hline
\end{tabular}

Fonte: Elaboração própria.

Os países desenvolvidos possuem uma variação de $242 \%$ em relação à média do grupo $\left(C V_{P D}=2,42\right)$ no comportamento de seus membros. Apesar do alto índice dos PD, este é superado pelo $C V$ do conjunto dos países em desenvolvimento em termos de irregularidade na atividade de seus membros no OSC, com um valor correspondente a $259 \%$ de variação sobre a média do grupo $\left(C V_{P E D}=2,59\right)$.

Quando analisamos o caso dos $P E D_{m a}$ e $P E D_{m b}$ de forma separada, os países de renda média-alta possuem $221 \%\left(C V_{P E D m a}=2,21\right)$ de variação em seu comportamento sobre a média do grupo, enquanto os membros de renda médiabaixa tem uma variação de $199 \%\left(C V_{P E D m b}=1,99\right)$ na atividade de seus integrantes no OSC em relação à média deste grupo.

O que indica que o grupo $\mathrm{PED}_{\text {ma }}$ possui uma dispersão de atividade similar ao dos países desenvolvidos e que o grupo $P E D_{m b}$ parece possuir uma maior regularidade de comportamento, embora com índices tão altos de dispersão seja muito difícil afirmar a significância destas diferenças sem uma investigação mais profunda.

O caso dos países de menor desenvolvimento relativo é singular. Estes, quando analisados separadamente, apresentam uma altíssima dispersão de comportamento da ordem de 403\% $\left(C V_{P M D}=4,03\right)$ em relação à sua média. Isto indica uma atividade altamente irregular no OSC por parte dos membros deste grupo, o que não chega a ser uma surpresa tendo em vista que a grande maioria dos países neste estrato não possuem atuação ativa (como reclamantes-padrão) no OSC. Por esta razão, os poucos casos de atuação de países neste estrato como reclamantes-padrão representa um grande desvio em relação à média em torno de zero para a atuação deste estrato. 
Estes resultados do Coeficiente de variação de Pearson mostram uma alta dispersão do comportamento dos países independentemente do grupo de renda analisado. A grande frequência de valores nulos para a atividade no OSC, em todos os grupos de renda, é a principal causadora desta distorção. Dessa forma, no decorrer dos próximos capítulos daremos especial ênfase na discussão de técnicas para dirimir estas distorções na construção dos modelos propostos.

O efeito desagregado da distorção provocada pelo excesso de zeros sobre o comportamento individual de cada país pode ser observado no Anexo 2 (v. 02, p. 02), onde são apresentados os valores dos coeficientes de variação (CV) calculados para cada um dos membros individualmente a partir de uma base anualizada de reclamações-padrão considerando as variações anuais em relação à média (de reclamações-padrão no polo ativo e de acionamentos-padrão no polo passivo) no período.

No Anexo 2 são também apresentados os resultados das estatísticas descritivas detalhadas da participação de cada um dos membros da OMC tanto nas reclamações feitas quanto nos acionamentos recebidos (cuja importância será posteriormente discutida). Os dados do número de reclamações-padrão utilizará a variável REC como variável dependente, enquanto $\mathrm{ACl}$ será a denominação da dependente para o número de acionamentos-padrão.

O valor do coeficiente de variação individual de cada membro (onde cada membro será identificado como um número de identidade específico ID) relacionado a REC (polo ativo) ou $\mathrm{ACl}$ (polo passivo) constará das tabelas apresentadas como CV. Os resultados apresentados no referido anexo foram gerados pelo processo univariate do software SAS (vide Capítulo 6 e Anexo 5 para maiores informações sobre o software a programação utilizada nesta pesquisa). A base de dados utilizada para a geração dos resultados no Anexo 2 foi a base final de variáveis consolidada (ver discussão do Capítulo 4 e Anexos 4-1 e 4-2 a serem introduzidos posteriormente). 


\subsection{Flexibilização dos pressupostos iniciais}

Até o presente momento nós tratamos os membros da OMC de forma agregada por grupo de renda considerando um recorte linear de adesão até 31 de dezembro de 2012 e mantendo fixa a classificação de cada membro dentro do mesmo grupo de renda no período. No entanto, a partir deste momento será necessário desagregar os grupos de renda para estimar a curva de regressão de cada um dos membros separadamente. Para isto será necessário flexibilizar nossos pressupostos iniciais e ajustar nossas séries históricas.

Um grande quantitativo de membros da OMC aderiu à organização já no ano de sua instituição, tendo sido igualmente participantes do GATT. No entanto, um número expressivo de países, especialmente em desenvolvimento, não está entre os membros fundadores da organização, tendo aderido mais tarde à mesma em algum período entre 1996 e 2012.

Dessa forma, para evitar distorções, as séries históricas de nossas variáveis resposta e variáveis explicativas serão agregadas aos nossos modelos apenas a partir do ano de adesão de cada membro à organização, conforme pode-se observar no Quadro 3.2 abaixo:

\section{Quadro 3.2: Ano de adesão à OMC}

\begin{tabular}{|c|c|c|c|c|c|c|c|c|c|c|c|c|c|c|c|c|c|}
\hline MEMBRO & 1996 & 1997 & 1998 & 1999 & 2000 & 2001 & 2002 & 2003 & 2004 & 2005 & 2006 & 2007 & 2008 & 2009 & 2010 & 2011 & 2012 \\
\hline \multicolumn{18}{|c|}{ PAÍSES DESENVOLVIDOS } \\
\hline \multicolumn{18}{|l|}{$\begin{array}{l}\text { Arábia } \\
\text { Saudita }\end{array}$} \\
\hline \multicolumn{18}{|l|}{ Croácia } \\
\hline \multicolumn{18}{|l|}{ Omã } \\
\hline \multicolumn{18}{|l|}{ Taiwan } \\
\hline \multicolumn{18}{|l|}{ Catar } \\
\hline \multicolumn{18}{|l|}{$\begin{array}{l}\text { Emirados } \\
\text { Árabes }\end{array}$} \\
\hline \multicolumn{18}{|c|}{ EM DESENVOLVIMENTO } \\
\hline \multicolumn{18}{|c|}{ Renda Média-Alta } \\
\hline \multicolumn{18}{|l|}{ Granada } \\
\hline \multicolumn{18}{|l|}{ Panamá } \\
\hline \multicolumn{18}{|l|}{ Rússia } \\
\hline \multicolumn{18}{|l|}{$\begin{array}{c}\text { St. Kitts e } \\
\text { Nevis }\end{array}$} \\
\hline Albânia & & & & & & & & & & & & & & & & & \\
\hline
\end{tabular}




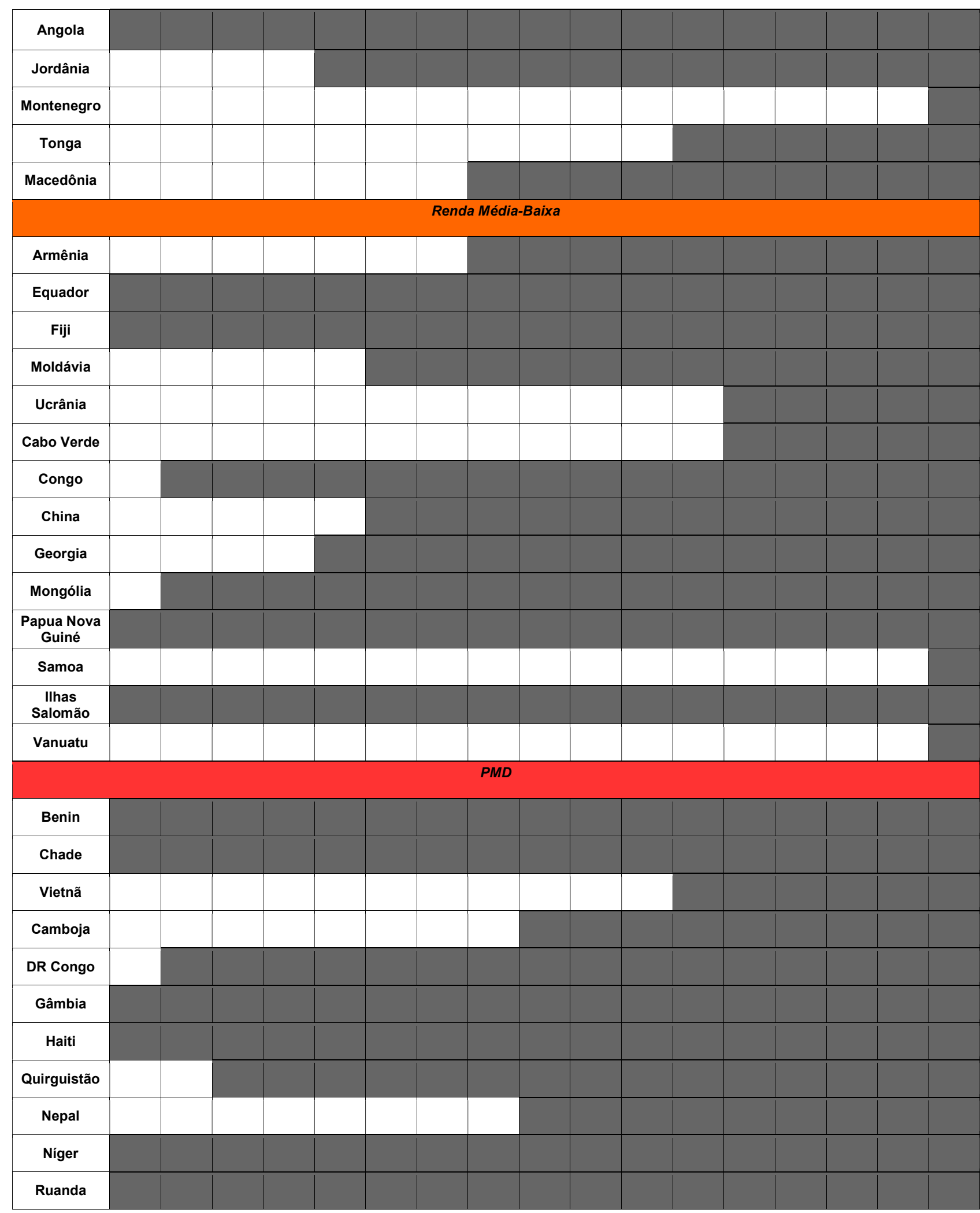

Fonte: elaboração própria.

A única exceção à regra estabelecida acima será a entidade composta União Europeia, de acordo com nossa definição apresentada no Capítulo 2, pois, para efeitos desta pesquisa consideraremos todos os membros do bloco em conjunto e 
assumiremos o início da participação das mesmas como a data de adesão do primeiro membro unitário destas.

É igualmente relevante destacar que a classificação em diferentes grupos de renda dos países aderentes tardios à OMC é apenas uma representação didática de sua classificação mais frequente no período. A partir de agora, flexibilizaremos os agrupamentos fixos e estes membros, bem como os membros fundadores, poderão variar livremente de grupo ao longo do tempo durante nossa modelagem.

Por fim, em função da indisponibilidade de dados para cálculo de variáveis explicativas alguns países tiveram de ser excluídos da presente pesquisa. Discutiremos individualmente as razões específicas para exclusão de cada país durante a apresentação dos ajustes destas variáveis. Neste momento consideramos relevante apenas a enumeração destas exclusões para que tenhamos isto em mente durante as discussões nos próximos capítulos: Angola, República Democrática do Congo (Congo DR), Djibuti, Haiti, Liechtenstein, Miamar e Serra Leoa.

Portanto, a partir deste momento nossos dados estarão desbalanceados e consideraremos um número variável de países na composição de cada grupo de renda dependendo do ano específico ao longo do período de análise. Assim, nos próximos capítulos sempre que nos referirmos a valores médios de variáveis explicativas estruturais estaremos levando em consideração esta composição variável dos grupos de renda em cada ano, o que produzirá resultados distintos de uma média simples de todo o período.

Ou seja, a partir deste momento permitiremos que a composição de cada grupo de renda deixe de ser fixa, passando a variar a cada ano ao longo do período de análise de acordo com o valor anual do PIB per capita de cada país e com a data de adesão de cada membro à organização ao longo deste período.

Em consequência, a média obtida para cada variável explicativa em cada ano específico leva em conta naquele ano apenas os valores correspondentes aos membros do grupo naquele ano, além do número de membros referente a este ano. A média final de cada variável para todo o período será, dessa forma, uma média ponderada das médias anuais com composição variável de membros em cada grupo. 


\section{Capítulo 4}

\section{MODELAGEM APLICADA AO OSC: POLO ATIVO E PASSIVO}

"To be sure of hitting the target, shoot first, and call whatever you hit the target".

Ashleigh Brilliant, humorista britânico

No presente capítulo empreenderemos uma discussão das características particulares da estrutura dos dados de nosso objeto de estudo em suas duas dimensões iniciação de disputas (polo ativo) e recebimento de acionamentos (polo passivo). A partir desta caracterização faremos uma breve discussão sobre a forma mais adequada de tratamento do mesmo tendo em vista nossos objetivos. Esta discussão nos auxiliará na escolha de uma função de distribuição apropriada para nossa modelagem.

Por sua vez, faremos uma sucinta discussão das classes de modelos lineares generalizados. Com base nestas discussões faremos nossa proposição de modelagem ZINB que consideramos adequada ao estudo da participação dos países em desenvolvimento no sistema de solução de controvérsias da OMC. Por fim, abordaremos a criação de dois índices específicos para substituir os índices simples apresentados no capítulo anterior para a avalição do comportamento dos países em desenvolvimento no OSC em comparação aos países desenvolvidos (polo ativo e passivo).

\subsection{Estrutura dos dados da variável resposta}

A primeira etapa em nossa discussão sobre a modelagem do comportamento dos países no OSC é sobre a estrutura dos dados a serem trabalhados pelos dois modelos (polo ativo e polo passivo). Mais especificamente sobre a natureza das variáveis resposta dos modelos. A natureza da variável resposta será crucial na determinação do melhor método de tratamento.

O presente trabalho abrange o período de 1995 a 2012 e procura modelar o comportamento dos países no OSC tanto na iniciação de disputas (polo ativo) quanto na recepção de disputas (polo passivo): i) no polo ativo procura-se modelar a quantidade de reclamações-padrão feitas por cada país a cada ano; e ii) no polo passivo busca-se modelar a quantidade de acionamentos-padrão recebidos por cada país a cada ano. Portanto, temos duas variáveis resposta, uma para o modelo do polo passivo (a qual 
denominaremos $\mathrm{ACl}$ ) e outra para o do polo ativo (a qual denominaremos REC).

Considerando a variação no tempo entre $t=1$ (1995) a $t=18$ (2012) nós teremos 18 conjuntos de observações em cada polo para cada ator considerado no OSC no período. Nós temos tratado até aqui de tecer considerações gerais e efetuar algumas apresentações preliminares dos dados deste período em agregado para basear nossa discussão solidamente no domínio do empírico.

No entanto, para o aprofundamento de nossa análise será necessário desagregar estes dados, conforme abordamos na última seção do capítulo precedente. Isto decorre principalmente do fato de que nossas variáveis dependentes (em ambos os polos) não podem ser caracterizadas como a soma das observações de $t_{1}$ a $t_{18}$, pois, para a sequência de qualquer período de tempo o somatório das observações é sempre aditivo e quando $t$ tende ao infinito, REC/ACI também tenderão ao infinito.

Por sua vez, utilizar uma média das variáveis resposta contra uma média das variáveis explicativas estruturais no período para explicar as variáveis resposta em um estudo transversal (cross section) ao invés do estudo longitudinal (pannel) proposto na presente pesquisa violaria tanto nossos pressupostos teóricos e metodológicos quanto frustraria nossos objetivos.

Ademais, não estamos particularmente interessados neste trabalho na mera determinação da frequência de ocorrências da variável dependente em uma determinada quantidade de tempo (por exemplo: o número de reclamações-padrão feitas em cinco anos). O que buscamos em última medida com a modelagem do comportamento dos países no OSC é avaliar se os países em desenvolvimento estão subrepresentados no uso do sistema de solução de controvérsias da OMC quando levados em conta aspectos objetivos na mensuração de seu comportamento.

Nossas variáveis resposta, portanto, são melhor expressas como dados de contagem, ou seja, como a quantidade de ocorrências do fenômeno analisado a cada observação ao longo do tempo (neste caso a cada ano), portanto, com distribuição discreta e estritamente positiva. O que significa que os valores de REC/ACI podem assumir apenas números inteiros (distribuição não contínua ou discreta) e maiores ou iguais a zero (estritamente positiva) (HILBE, 2014).

Conforme discutido de forma preliminar anteriormente, nossas variáveis resposta apresentam grande número de ocorrências de valores nulos (polo ativo: ausência de reclamações-padrão; e polo passivo: ausência de acionamentos-padrão). Este fenômeno causa uma superdispersão de $\mathrm{REC/ACI}$ apontada pelos altíssimos valores de $\mathrm{CV}$ 
calculados no capítulo anterior e dificulta a análise sem tratamentos estatísticos mais avançados.

Adicionalmente, além da superdispersão, a forma como desenhamos a presente pesquisa faz com que nossas variáveis resposta não possuam um dos requisitos básicos para moldarem-se a tratamentos estatísticos padrão, elas não são de natureza transversal e sim longitudinal. Em outras palavras, não podem ser consideradas como repetições independentes das observações ao longo do tempo e tratadas individualmente em cada observação como em um estudo cross section onde uma das premissas básicas é que não exista dependência entre as observações (PLEWIS, 1997).

Ou seja, nossas variáveis resposta violam o princípio da independência entre as observações, pois, o comportamento dos países no OSC depende não apenas do valor das variáveis explicativas estruturais em um ano específico, mas também do próprio tempo, experiência e do comportamento passado. O que nos faz concluir que existem duas possibilidades para o tratamento de nossas variáveis: estudos de painel (longitudinais) com a utilização de modelos condicionais ou de modelos marginais (BRYK, RAUDENBUSH, 1992; GOLDSTEIN, 1995; HOX, 1994; GELMAN, 2007).

No caso dos modelos marginais, a modelagem da variável resposta é tratada de forma independente da correlação entre os valores de cada observação e da variabilidade interna de cada ator. A modelagem é feita apenas como uma função das variáveis explicativas especificadas pelo modelo. Estes modelos derivam da aplicação estatística em distribuições marginais, onde o interesse está na probabilidade marginal de ocorrência de uma determinada variação da variável resposta em função de uma variação das variáveis explicativas. A resposta média da variável $\mathrm{REC/ACl}$ em cada observação dependeria, ceteris paribus, somente do conjunto de variáveis explicativas, não incorporando nenhuma dependência das observações prévias ou a variabilidade da resposta no tempo (FITZMAURICE et al., 2009).

Ou seja, a interpretação neste caso deve ser de que, tudo o mais constante, os efeitos medidos são efeitos marginais (provocados pela diferença entre valores de duas observações) e não condicionais do tipo "se isto então aquilo", como seria no exemplo "se o valor de $X$ é 10 então o valor de $Y$ é 20". Portanto, o tipo de efeito modelado na abordagem marginal é "ceteris paribus, uma variação em $X$ de tamanho alfa provoca uma variação delta em $Y^{\prime}$. Estamos sempre analisando os efeitos na margem.

No caso dos modelos condicionais, assume-se a existência de uma variabilidade inerente ao comportamento do ator que não seja determinada diretamente pelo conjunto 
de variáveis explicativas que descrevem seu comportamento. Os efeitos desta variabilidade do comportamento dos atores poderia, hipoteticamente, fazer com que valores diferentes de $Y$ fossem gerados pelos mesmos valores de $X$ em momentos diferentes.

Assim, não poderia ser mensurada uma relação direta entre as variáveis explicativas e a variável resposta. Esta relação precisaria ser mediada por meio de uma função de probabilidade com efeito aleatório variando a ligação entre variáveis explicativas e a resposta no tempo, o que permitiria gerar a variabilidade de comportamento em questão em função destas probabilidades. Para isto, este tipo de modelo precisa ser construído em duas ou mais etapas, também conhecidas como níveis, com ao menos um para a função principal e outro para a função de probabilidade. Esta categoria de modelos é também conhecida, portanto, como multinível (HOX, 2010; HOFFMAN, 2015; ROBSON, PEVALIN, 2016).

Considerando nosso objeto específico de pesquisa, que é determinar o comportamento dos países no OSC a partir de variáveis explicativas estruturais e dummies de níveis de renda para analisar se existem efeitos negativos dos diferentes níveis de renda sobre o comportamento dos países em desenvolvimento em comparação aos países desenvolvidos, não há como assumir que cada ocorrência das variáveis resposta varie apenas em função das variáveis explicativas estruturais, que serão apresentadas no próximo capítulo após discussão específica sobre os principais resultados das pesquisas empíricas sobre o OSC.

Assim como no comportamento dos indivíduos, no comportamento dos Estados há muito provavelmente uma influência do comportamento passado no comportamento futuro que perpassa a simples mudança dos valores das variáveis explicativas de qualquer modelo. Além disso, no processo decisório antes da formulação da decisão final existe dependência de outros efeitos no tempo que não podem ser descartados a priori pela pesquisa.

Além disso, intuitivamente extrapolando essa premissa, valores iguais nas variáveis explicativas em momentos $j$ diferentes poderiam hipoteticamente produzir resultados diferentes da variável dependente em cada observação devido à possibilidade de variabilidade interna do comportamento do ator e da relação do comportamento presente com a experiência passada (o comportamento passado). De forma oposta, o mesmo poderia ocorrer no caso de valores diferentes das variáveis explicativas produzirem os mesmos valores da variável resposta em momentos $j$ diferentes. 
A categoria de modelos marginais contrasta-se com a classe de modelos condicionais onde o valor esperado da variável resposta é modelado em função das variáveis explicativas e também condicionado à variação de comportamento dos países em relação ao valor esperado da variável resposta para cada unidade observacional ao longo do tempo. Já nos modelos marginais associa-se a variação do comportamento da variável resposta ao longo do tempo à variação das variáveis explicativas. Os modelos condicionais além de permitirem a modelagem da dependência no tempo permitem também a introdução de hierarquia entre os diferentes níveis do modelo. Razão pela qual são conhecidos também como modelos hierárquicos ou multiníveis (HOX, lbid; HOFFMAN, Ibid; ROBSON, PEVALIN, Ibid).

Tendo em vista a natureza particular de nossos dados e as necessidades específicas de nosso estudo, nas próximas seções empreenderemos uma breve discussão de modelagem e estatística/econometria aplicada. Isto nos permitirá selecionar a classe de modelos melhor candidata para nossos testes e assim avaliar o desempenho de seus estimadores, propiciando a seleção final do melhor modelo para nosso caso concreto.

\subsection{Discussão da modelagem aplicável à variável resposta}

Em um desenho de pesquisa onde o interesse é elucidar a relação entre a mudança nos valores de um conjunto de variáveis explicativas e as mudanças ao longo do tempo de uma variável resposta, pode-se utilizar tanto desenhos de estudos experimentais quanto observacionais. Nas ciências humanas e sociais apenas em condições muito excepcionais desenhos experimentais são factíveis, prevalecendo na área os estudos observacionais.

A coleta de dados pode ser feita prospectivamente ou retrospectivamente, a depender do desenho específico de pesquisa. O período utilizado na coleta dos dados pode ser fixo, quando todas as unidades de tempo entre as coletas são iguais para todos os indivíduos analisados; variável, quando as coletas são feitas conjuntamente para todos os indivíduos mas em intervalos diferentes umas das outras diferentes; ou ainda desbalanceado, quando para cada indivíduo há um tempo distinto entre as coletas.

O tempo neste caso pode ser medido de formas diversas, seja em várias unidades sequenciais ou em qualquer escala ordenada (SINGER, WILLET, 2003). Em nosso caso específico o período é fixo (ex: cada ano em uma sequência de 18 anos de 1995 a 2012), 
mas não se pode assumir a independência entre as observações. Adicionalmente, nossas variáveis resposta são do tipo binomial e de contagem.

Iniciaremos nossa discussão destacando esta última característica distintiva de nossos dados que influirão na seleção do modelo: as observações de REC/ACI são dados de contagem. Dados de contagem são caracterizados por apresentarem somente valores inteiros não negativos e possuírem, portanto, uma distribuição discreta (ou seja, não contínua). Para a modelagem de dados de contagem são utilizados modelos não-lineares (CAMERON, TRIVEDI, 2013).

A distribuição discreta mais comumente utilizada na modelagem de dados de contagem é conhecida como distribuição de Poisson (POISSON, 1838; GELMAN, HILL, 2007). Esta distribuição é do tipo discreta e expressa a probabilidade de um determinado número de eventos ocorrerem em um intervalo fixo (de tempo ou de distância ou de quantidade), de forma independente um dos outros.

Em nosso caso específico, os eventos são protocolar uma reclamação-padrão no OSC (no modelo de polo ativo) ou receber um acionamento-padrão (no modelo de polo passivo). Estes eventos não são parte de uma categoria maior de eventos com outras possibilidades de ocorrência, portanto, são eventos binomiais. Ou seja, existem apenas dois resultados possíveis para estes eventos: ocorrer ou não ocorrer.

Portanto, a distribuição Poisson (contagem e binomial) é a primeira candidata em nossa análise. A distribuição Poisson binomial pode ser enunciada como a distribuição de probabilidade discreta de uma determinada soma de ensaios independentes de Bernoulli, não necessariamente homogeneamente distribuídos, ocorrer em um determinado intervalo. Um ensaio de Bernoulli é um experimento aleatório em que existem apenas dois resultados possíveis (binomial), sucesso (evento ocorrer) ou fracasso (evento não ocorrer), com probabilidade constante (HILBE, 2014).

Sendo $p$ a probabilidade de sucesso, $q=1-p$ a probabilidade de fracasso e $k$ o resultado de cada ensaio (1 para sucesso e 0 para fracasso), a função de probabilidade da distribuição de Bernoulli é dada por:

$f(k ; p)=p^{k}(1-p)^{1-k} ; k\{0,1\}$

Uma das principais propriedades da distribuição Poisson é o fato de que o valor esperado da variável resposta e sua variância são iguais, ou seja, $E(Y)=\operatorname{Var}(Y)$. No entanto, esta característica é também uma de suas limitações. Quando a variância da 
variável resposta é maior do que seu valor esperado (sua média), então estamos em um ambiente de superdispersão dos dados.

Este fenômeno pode ser causado pela alta heterogeneidade entre as unidades de análise e/ou pela dependência entre as observações. Neste ambiente, a distribuição Poisson torna-se inadequada para o tratamento dos dados. Neste caso, pode-se utilizar de uma série de mecanismos para correção desta distribuição Poisson.

No entanto, a distribuição de Poisson binomial geralmente é utilizada em modelagens onde o foco é determinar a probabilidade da ocorrência de uma determinada frequência de sucessos em um intervalo especificado (de tempo ou outros intervalos) (CAMERON, TRIVEDI, Ibid; HILBE, Ibid). Este não é o nosso objetivo no presente trabalho, de forma que continuaremos a investigação na busca por uma distribuição apropriada a este estudo.

Uma candidata para substituir a distribuição Poisson na modelagem de dados de contagem frequentemente referida na literatura é a distribuição Binomial Negativa (BN) (HOX, 1994; HILBE, 2012). A BN, também conhecida como distribuição de Pascal, é uma distribuição discreta de probabilidade do número $k$ de sucessos obtidos em uma sequência de ensaios de Bernoulli antes do número $r$ de fracassos ocorrerem.

Existem algumas possibilidades alternativas de formulação deste enunciado, outra que nos interessa neste estudo é: a distribuição de probabilidade discreta do número $m$ de tentativas necessárias para obter um número $k$ de sucessos (com igual probabilidade $p$ de ocorrência cada) em uma sequência de ensaios de Bernoulli.

Estas duas formulações da distribuição de Pascal trazem aspectos relevantes para o entendimento de nosso objeto de estudo. Quando analisamos o comportamento dos países/grupos no sistema de solução de controvérsias da OMC, ao olhar quer para o polo ativo quer para o passivo, nós conseguimos ver apenas os eventos com resultado positivo que efetivamente ocorreram (reclamações/acionamentos efetivados). Ou seja, vemos apenas os sucessos: a reclamação-padrão protocolada (polo ativo) ou o acionamentopadrão recebido (polo passivo).

Escapa aos nossos olhos toda uma dimensão oculta desta dinâmica - os fracassos: reclamações-padrão não protocoladas ou acionamentos-padrão não recebidos. É como se estivéssemos acima da linha d'água e pudéssemos ver apenas a parte do iceberg que não está submersa. E assim como no caso dos icebergs, o perigo reside exatamente na parte submersa que não podemos ver. 
Quando olhamos para nossas variáveis resposta de forma binomial tendo em mente o processo de Bernoulli, percebemos que elas contam apenas uma parte da história. O cômputo dos sucessos ou eventos com resultado positivo (única dimensão diretamente observável do processo) para permitir a modelagem do comportamento dos países no OSC através de uma distribuição BN em relação ao conjunto de variáveis explicativas, a serem discutidas no próximo capítulo, nos permitirá analisar tanto o comportamento individual dos países quanto estudar a diferença entre o comportamento destes e dos diferentes grupos de renda.

No entanto, esta não é toda a história. Esta parte da história nos descreve apenas "aquilo que é", ", ou seja, o resultado positivo efetivamente observado de eventos enquanto comportamento dos países e/ou grupos de renda. Mas não nos conta nada sobre aquilo que "poderia ter sido", ou em outras palavras, não nos coloca em condições inquirir sobre aquele conjunto de comportamentos que poderiam ter se transformado em reclamações ou acionamentos, porém, não o foram. E por não terem sido efetivamente materializados em reclamações/acionamentos, não podemos observar diretamente este conjunto de comportamentos.

No entanto, estes resultados nulos (não efetivação de uma reclamação/acionamento) são uma parte importante da realidade tanto quanto os resultados positivos (efetivação de um ou mais reclamações/acionamentos). Ambos fazem parte do universo dos eventos, pois, desenvolvem-se no âmbito do mesmo processo decisório (comportamento) de um país. O resultado, porém, é diverso em cada um destes casos.

$\mathrm{Na}$ medida em que um país decide não protocolar uma reclamação, este comportamento existe, é real e material, tendo envolvido elementos do processo decisório deste país que resultaram nesta decisão. Este evento ou decisão, apesar de existir concretamente, não tem um resultado observável diretamente, pois, este consiste exatamente na ausência da reclamação/acionamento no OSC e, portanto, em um valor nulo para o comportamento.

Este valor nulo (ou mais propriamente dito a falta do valor de ao menos uma unidade de reclamação/acionamento) é o único dado observável diretamente no OSC. E neste caso específico, não é possível determinar de antemão se o valor nulo observado é fruto de um evento (que resultou na decisão de não participar e, portanto, em um resultado nulo) ou fruto de um não-evento. O não-evento neste caso seria a simples ausência de uma decisão, o que significa que não houve a conformação de nenhum 
comportamento, visto que o processo decisório do membro não foi ativado, pois, não havia nenhuma decisão a ser tomada.

Em ambos os casos, seja um evento com resultado nulo (decisão de não participar) ou um não-evento (não decisão), o dado observável diretamente no OSC é o mesmo: resultado nulo - a ausência da reclamação ou do acionamento. Mas apenas o primeiro faz parte do universo dos eventos (decisões) e, portanto, é parte do comportamento dos países.

Para compreender e analisar o comportamento dos países no OSC com profundidade é necessário, assim, uma visão compreensiva da realidade (eventos totais = soma dos eventos com resultado positivo e eventos com resultado nulo). Para isto, é preciso separar os eventos com resultado nulo, não observáveis diretamente, dos nãoeventos, igualmente não observáveis diretamente.

Apenas se pudermos separar estas duas dimensões poderemos ter uma compreensão integral da realidade (eventos totais), que consiste não apenas de resultados positivos (reclamações/acionamentos efetivados) como também de resultados nulos (reclamações/acionamentos não efetivados). Trata-se de uma posição mais profunda do que apenas uma questão metodológica, esta é antes uma questão ontológica/mereológica (de não tomar a parte pelo todo ou de atribuir ao todo as propriedades da parte).

Conforme veremos em nossa discussão teórica e metodológica neste e no próximo capítulo, concentrar-se apenas na parte (aquilo que vemos - eventos com resultado positivo) nos faz perder de vista o todo (aquilo que não vemos diretamente - eventos com resultado nulo e não-eventos) e acaba por comprometer tanto nossa percepção da realidade quanto nossas conclusões sobre esta. Quando nos concentramos apenas no comportamento dos países que se pode observar (eventos com resultado positivo), falhamos em estimar aquilo que não observamos mas que faz parte do comportamento dos atores (eventos com resultado nulo).

Dessa forma, o enfoque que propomos neste estudo é perguntar (sendo os eventos com resultado positivo, efetivamente observados, as reclamações feitas ou acionamentos recebidos): O que não aconteceu? Por que não aconteceu?

Ou seja, no polo ativo, estamos interessados tanto na quantidade de reclamações que um membro apresentou (eventos com resultado positivo), quanto na quantidade que este deixou de apresentar (eventos com resultado nulo). Já no polo passivo nosso interesse reside, por sua vez, na quantidade de acionamentos que o membro recebeu 
(eventos com resultado positivo), e na quantidade que este deixou de receber (eventos com resultado nulo).

Apenas se pudermos estimar e compreender a diferença entre estes dois universos, o dos eventos - composto por (a) eventos com resultado positivo (reclamações/acionamentos observados) e (b) eventos com resultado nulo (reclamações/acionamentos não efetivados) - e o dos não-eventos - valor nulo decorrente de ausência de decisão - é que poderemos avaliar se existem evidências empíricas de que o comportamento dos PED é estruturalmente diferente do comportamento dos PD no OSC.

Conforme discutiremos neste capítulo, há uma grande diferença qualitativa entre o universo dos eventos (observados e não observados) e o dos não-eventos. E poder separar os eventos com resultado nulo dos não-eventos é crucial na modelagem do comportamento dos países em desenvolvimento no OSC. Guiar-se apenas pelo universo dos eventos com resultado positivo (observados) e ignorar os eventos com resultado nulo (não observados) equivale a chocar-se frontalmente contra o volume submerso de um grande iceberg.

Enquanto não ser capaz de separar eventos com resultado nulo (não observados) de não-eventos (também não observados) é não poder distinguir entre o gelo da parte submersa deste iceberg e a água salgada circundante. Por mais adequado ou robusto que um modelo possa parecer ao tentar explicar a dinâmica do comportamento dos países no OSC apenas a partir dos resultados positivos observados na parte acima da linha d'água deste iceberg de eventos, esta será apenas uma explicação parcial que deixará de levar em consideração parte importante da realidade - os eventos não observados com resultado nulo (a parte submersa do iceberg).

Nossas variáveis resposta apresentam, portanto, um problema adicional ocasionado pela dimensão dos eventos com resultado nulo (fracassos) e dos nãoeventos, o excesso de valores nulos. Ou seja, uma grande quantidade de países não apresentaram nenhuma reclamação-padrão e/ou não receberam nenhum acionamentopadrão em vários anos ao longo do período considerado de 1995 a 2012.

Este fenômeno, além da relevância teórica apontada pela diferença qualitativa entre a dimensão oculta dos fracassos (eventos com resultado nulo) e dos não-eventos, ocasiona um desafio metodológico adicional (extra-dispersão dos dados) que precisará ser igualmente corrigido no desenho de nossos modelos. 
Para corrigir o excesso de zeros de forma coerente com nosso objeto de estudo e considerações teórico-metodológicas, introduziremos ao modelo BN o processo de correção por inflação de zeros. Discutiremos a seguir brevemente o modelo Binomial Negativo Inflado de Zero (zero inflated negative binomial: ZINB conforme é referido na literatura) (CAMERON, TRIVEDI, 1998; LONG, 1997; HILBE, 2014) com vistas a expandir nossa discussão na busca de uma modelagem tanto descritiva quanto preditiva do comportamento dos países em desenvolvimento no sistema de solução de controvérsias da OMC que possa tratar nossas variáveis dependentes com uma grande frequência de valores zero em uma regressão multivariada.

A regressão binomial negativa, conforme mostramos, é capaz de examinar relações preditivas com variáveis dependentes não-normais e com heterocedasticidade, com variabilidade extra-Poisson. Como o modelo Poisson pressupõe que a variância dos dados seja igual à sua média aritmética, uma violação deste pressuposto torna a aplicação do modelo Poisson contraindicado devido à superdispersão e ao viés provocado nos erros padrões e valores da estatística Z. Diferentemente do caso dos modelos de Poisson, os modelos binomiais negativos podem ser utilizados quando os dados apresentam superdispersão uma vez que incluem componente aleatório que resulta em coeficientes mais precisos do erro padrão.

O modelo binomial negativo, apesar de trabalhar bem com ocorrências de superdispersão como no nosso caso, não admite a ocorrência de muitos valores nulos em dados de uma contagem. Com a finalidade de contornar esta situação, utilizaremos um modelo inflado de zero que, através de métodos de redução de dados, reagrupa os dados estimando dois grupos latentes: i) um composto apenas por ocorrências nulas da variável resposta (denominado zero estrutural); e ii) outro que pode apresentar valores iguais ou maiores a zero (denominado de zero suscetível ou condicional).

Este processo resulta em um componente logístico que analisa a probabilidade dos atores fazerem parte de um agrupamento ou de outro. De acordo com o resultado deste componente logístico, a contagem ou frequência da variável resposta (número de reclamações/acionamentos) dos atores que compõem o agrupamento zero condicional é modelada em paralelo, não sendo afetada pelos valores nulos excedentes (zero estrutural).

Desta forma, um modelo binominal negativo inflado de zero deverá gerar duas saídas simultâneas: i) uma para o componente logístico, ou seja, gerar os agrupamentos em zero estrutural e zero suscetível; e ii) uma modelagem da contagem (frequência de 
$\mathrm{REC} / \mathrm{ACl}$ ) dentre os atores que fazem parte do agrupamento zero suscetível/condicional.

Esta modelagem, além de resolver nosso problema observado no conjunto de dados das variáveis resposta tem a vantagem adicional de modelar o processo de determinação da participação dos países no OSC em dois estágios. No modelo de polo ativo, o primeiro estágio diria respeito à decisão em si de participar ou não participar do sistema como demandante, ou seja, à probabilidade de que um determinado país seja ou não ativo no OSC. O segundo estágio diria respeito, após o controle da probabilidade de atuação (zero estrutural), diretamente à determinação probabilística do valor esperado de disputas (sucessos) em que o participante irá se envolver a cada ano.

Já no modelo de polo passivo, o primeiro estágio determinaria probabilisticamente a suscetibilidade ou não de um determinado país receber acionamentos-padrão no OSC, classificando-o nos agrupamentos zero estrutural ou zero condicional. No segundo estágio, para os países classificados como zero condicional neste modelo, ocorreria a determinação do valor esperado de acionamentos-padrão recebidos a cada ano em função das variáveis explicativas a serem definidas no próximo capítulo.

Em ambos os modelos (ativo e passivo) esta modelagem parece estar de acordo com o fluxo do processo decisório e com nossas premissas de trabalho. Dessa forma, esta modelagem além de resolver o problema da superdispersão dos dados ocasionada pelo excesso de zeros das variáveis dependentes, também unifica em um mesmo tratamento as duas dimensões do processo.

Sendo assim, a partir deste expediente é possível separar os não-eventos (valores nulos ocasionados por não decisão, ou seja, não participação no sistema), que serão a partir de agora definidos como zero estrutural; dos eventos com resultado nulo (valores nulos resultado de decisões de não efetivação de uma reclamação/acionamento), que serão definidos como zero condicional.

O principal mérito desta abordagem é, portanto, separar os eventos dos nãoeventos e permitir que visualizemos de maneira integral tanto a parte acima da linha d'água (sucessos - evento com resultado positivo) quanto a parte abaixo d'água (fracassos - eventos com resultado nulo) do iceberg de eventos de maneira unificada e conectada.

Conforme discutimos anteriormente, um evento em nosso caso específico é uma decisão: protocolar/não protocolar uma reclamação-padrão; ou receber/não receber (decisão do agente na escolha do alvo) um acionamento-padrão. Sob este ponto de vista, o evento pode ter dois resultados: sucesso (protocolar/receber) ou fracasso (não 
protocolar/não receber). Ambos os resultados são fruto de um evento, portanto, de uma decisão.

No entanto, sem o desenvolvimento de ferramentas de análise como as aqui propostas, pode-se observar no OSC apenas uma parte dos resultados destes eventos os sucessos ou eventos com resultado positivo (a parte do iceberg que está fora d'água). O problema reside no fato de que como os fracassos ou eventos com resultado nulo (parte submersa do iceberg) não é observável diretamente. De forma que, sem as ferramentas metodológicas adequadas, não há como saber se a ocorrência de um valor nulo na variável dependente refere-se a um fracasso (fruto de um evento = decisão de não reclamar/acionar) ou simplesmente a um não-evento (e portanto não houve decisão alguma neste caso).

De forma prática, se em um ano $t_{1}$ qualquer observarmos uma quantidade $X>0$ de reclamações-padrão protocoladas pelo membro $A$, temos como afirmar com certeza que o membro $A$ possui $X$ sucessos no ano $t_{1}$. Não temos, ao menos diretamente, no entanto, como afirmar quantos fracassos o membro $A$ teve em $t_{1}$, pois, não podemos observá-los diretamente como no caso dos sucessos. Assim, não é possível saber a quantidade de eventos (decisões) ocorridas em $t_{1}$ em relação a $A$, pois, temos como medir diretamente apenas a quantidade de resultados "positivos" dos eventos mas não a quantidade de eventos em si.

Considerando agora um outro membro aleatório B no mesmo período, caso não seja observada nenhuma reclamação-padrão $(X=0)$ protocolada por este em $t_{1}$ não nos é lícito concluir nada diretamente sobre este fato. Não podemos sequer afirmar que a quantidade de sucessos de $B$ em $t_{1}$ é igual a zero, pois, fundamentalmente não temos como saber antecipadamente se a ausência de reclamação-padrão (o valor nulo em $\mathrm{t}_{1}$ ) é gerada efetivamente por um evento (uma decisão de não protocolar e, portanto, é efetivamente um fracasso) ou trata-se simplesmente de um não-evento (não houve decisão nenhuma no período sobre protocolar ou não qualquer reclamação-padrão). Portanto, apesar do resultado (zero) ser o mesmo em ambos os casos, as razões para estes resultados são radicalmente distintas (evento "com resultado nulo" x não-evento).

Portanto, o método de modelagem proposto aqui tem o mérito de tratar de forma unificada o domínio fático dos eventos em sua integralidade - parte fora d'água do iceberg/sucessos (evento "com resultado positivo") e parte submersa do iceberg/fracassos (evento "com resultado nulo"). E também de separar efetivamente na dimensão submersa do iceberg o domínio dos eventos (gelo - fracassos/eventos com resultado nulo) da água 
salgada (não eventos - não decisão/resultado nulo) ao redor do mesmo.

Nosso modelo inflado de zeros supera estes problemas e resolve também o problema da dimensão hierárquica característica da nossa estrutura de dados. Não levar em conta esta característica no desenho de nosso modelo seria um equívoco. Dessa forma, precisamos fazer uma sucinta discussão da estrutura longitudinal (com dependência no tempo) dos dados desta pesquisa e da estrutura do modelo. Dados longitudinais são aqueles medidos repetidamente em um período determinado de tempo ou em qualquer outra escala ordenatória (DIGGLE et al., 1994; HILBE, 2012, 2014).

O estudo desta dependência no tempo começou a ganhar especial destaque a partir da década de 1980 com o desenvolvimento de uma nova classe de modelos estatísticos capazes de analisar de forma mais precisa mudanças nas unidades de observação ao longo do tempo. Esta classe especial de modelos ficou conhecida na literatura por modelos multiníveis, também chamados de modelos hierárquicos (HOX, 1994; KREFT, DE LEEUW, 1998; BRYK, RAUDENBUSH, 1992; GOLDSTEIN, 1995; LONGFORD, 1993).

Esta classe de modelos é caracterizada por subdividir a modelagem em dois ou mais níveis ou etapas, inserindo o conceito de hierarquia no comportamento das unidades observadas e estabelecendo uma estrutura funcional de correlação entre as medidas da variável dependente observada (até aqui consideradas repetidas e independentes). Portanto, o potencial explicativo desta categoria de modelos reside na interpretação do comportamento individual de cada unidade de forma condicionada.

Os modelos lineares generalizados (MLG) clássicos são expandidos para gerar a modelagem não linear multinível necessária para o tratamento de nosso modelo ZINB. O modelo em questão é uma mistura de duas distribuições, uma logística no primeiro nível do modelo e uma binomial negativa no segundo nível. Nosso objetivo fundamental neste estudo continua a ser a estimação dos efeitos fixos das variáveis explicativas no comportamento dos países (as quais serão discutidas no próximo capítulo), no entanto outros fenômenos que introduzem maior variabilidade no processo precisam ser controlados para permitir a correta estimação dos efeitos das variáveis explicativas.

Portanto, para aumentar a convergência e controle de nosso modelo, técnicas de modelagem não linear e programação de modelos mistos serão aplicadas ao nosso objeto, muito embora não serão inseridos efeitos aleatórios em nosso modelo. Haverá apenas uma estrutura hierárquica em nossa modelagem que trate da estimação das probabilidades de não-eventos $\mathrm{x}$ eventos com resultado nulo (zero estrutural $\mathrm{x}$ zero 
condicional) no primeiro nível para gerar o agrupamento logístico necessário à estimação da frequência de resultados no segundo nível (contagem).

O desenvolvimento de modelos do tipo ZINB parece estar mais concentrado no campo das pesquisas nas áreas de meio ambiente, clima e muito especialmente na área médica. Identificou-se que o artigo regularmente mais citado como proposta de sistematização desta classe de modelos específica foi publicado em 2008 no Journal of Applied Statistics (MOGHIMBEIGI et al, 2008). Este trabalho é considerado seminal ao consolidar uma metodologia padrão para a estatística aplicada em modelos de regressão multinível binomial negativa inflada de zero para a modelagem de dados de contagem longitudinais, superdispersos e com excesso de valores nulos.

Compreendemos, a partir de toda nossa discussão precedente que este é um caminho robusto para o desenho desta pesquisa e de pesquisas quantitativas similares em nosso campo de estudo. Uma vez selecionada a modelagem ZINB como nossa melhor candidata e tendo em mente nossa discussão metodológica no presente capítulo, apresentamos uma visão mais detida do tema no Anexo 3 (v. 02, p. 481), onde trataremos da discussão sobre Modelos Lineares Generalizados (MLG) e Modelos Lineares Generalizados Mistos (MLGM) e da formalização de nossa proposição de modelagem.

A maior parte da discussão teórica e metodológica no presente capítulo e no próximo são feitas descritivamente em linguagem comum e com uso de lógica formal. Procuraremos ao máximo evitar a matematizarão ao longo do texto para manter sempre que possível sua fluidez. Interessados em uma discussão dos pontos abordados aqui são convidados à leitura do referido Anexo. A forma funcional do modelo é apresentado no Anexo 3 e suas equações e programação específica no Capítulo 6 (Anexo 5) após nossa discussão das variáveis explicativas propostas no próximo capítulo.

\subsection{Proposta de índices de avaliação do comportamento dos países em desenvolvimento no OSC}

Ao olharmos para a dinâmica do sistema de solução de controvérsias da $\mathrm{OMC}$, tendo em conta apenas os dados de ocorrência de reclamações/acionamentos (os sucessos), conforme discutimos na seção anterior, temos uma grande distorção no estabelecimento de qualquer referência direta para avaliar o comportamento dos diferentes países/grupos atuantes no mesmo. 
Nesta dimensão é possível descrever o comportamento dos países ou grupos como função das variáveis explicativas (quaisquer que sejam estas) e tecer relações entre as diferenças no comportamento de distintos países/grupos em função dos diferentes valores destas variáveis para estes países/grupos. Não podemos escolher um grupo como padrão e avaliar o comportamento dos demais com base neste grupo, apenas olhando exclusivamente para a dimensão dos sucessos, exatamente por que estamos correlacionando diferenças de valores de propriedades inerentes a estes grupos a diferenças em seu comportamento.

Este seria um equívoco de natureza ontológica/mereológica e metodológica. Portanto, este não é um caminho que se sustente, pois, deixa de captar o todo (eventos totais $=$ sucessos + fracassos) e concentra-se apenas na parte (sucessos), como se esta fosse de fato o todo. Isto decorre do fato de que com este tipo de desenho de pesquisa seria possível prever apenas aquilo que observamos (sucessos), mas não aquilo que não observamos (fracassos).

Dessa forma, poderíamos ver apenas a parte do iceberg fora d'água (sucessos). Com isto, todo o restante do fenômeno ficaria escondido submerso e turvaria nossa visão, pois, além de ignorar os fracassos (parte do iceberg abaixo da linha d'água) não seríamos capazes de distinguir entre o gelo do iceberg (fracassos) e a água salgada circundante (não-eventos). E assim como no caso dos icebergs, o que está sob a linha d'água é mais perigoso do que o que está acima.

Portanto, nossa proposta de tratamento metodológico do presente objeto tem como objetivo fazer com que os fracassos (zero condicional) venham à tona para poder separálos qualitativamente dos não-eventos (zero estrutural). E, mutatis mutandis, assim como no caso dos icebergs, conforme discutimos na seção anterior, com a aplicação de técnicas adequadas podemos estimar o volume de gelo que está debaixo d'água e separá-lo da água salgada a partir do volume de gelo que podemos observar acima da linha d'água.

Com isto (eventos totais) teremos uma visão completa do comportamento dos países/grupos de renda no OSC. A agregação dos sucessos com a estimativa de fracassos nos dará uma visão compreensiva dos eventos. Esta abordagem consiste na proposta de uma solução metodológica unificada para o tratamento de um problema bastante enfatizado nos estudos da área - a tensão constante existente no processo de iniciação de disputas comerciais no OSC, no qual apenas as disputas efetivamente iniciadas são observáveis diretamente. 
A partir deste expediente estaremos em condições de falar não apenas da frequência de sucessos (valor da contagem de REC/ACI), mas também observar diferenças, se existentes, entre a taxa relativa de sucessos ${ }^{1}$ de diferentes grupos de renda. Ao contrário do valor esperado da contagem, a taxa de sucesso é um índice diretamente comparável entre todos os países e grupos de renda para avaliar de forma relacional o comportamento destes no OSC.

O valor esperado da contagem é afetado pelo valor absoluto do conjunto de variáveis explicativas, principalmente os aspectos gravitacionais como o tamanho do PIB conforme veremos no próximo capítulo. Já a taxa de sucesso pode ser constituída como um valor padronizado relativo a cada grupo de renda específico após o controle de todos os demais efeitos/variáveis.

Sendo assim, esta seria imune a diferenças de "tamanho" dos membros/grupos, e, portanto, os valores desta taxa para quaisquer membros/grupos é diretamente comparável. A comparação entre as taxas de sucesso de dois membros/grupos é capaz de indicar (independentemente do valor total da contagem de sucesso de cada um) em termos relativos qual a diferença de uso do sistema existente entre estes membros/grupos advinda de diferenças ligadas aos diferentes níveis de renda.

Uma diferença no índice em favor de um grupo indica que dada uma quantidade de eventos específica probabilística igual para dois ou mais grupos, o mesmo participa mais proporcionalmente no OSC do que o primeiro (quer seja no polo ativo ou passivo). Ou seja, estamos medindo as diferenças de participação no sistema tomando por base de auto-referência cada grupo individualmente.

Avançaremos, a seguir, nesta discussão desmembrando nossas considerações para cada um dos dois polos/modelos (ativo e passivo):

\subsection{1. Índice de eficácia (EC) - Polo ativo}

No polo ativo, a quantidade de eventos totais $m$ em que um grupo de renda teve de tomar uma decisão sobre protocolar ou não uma reclamação-padrão contra outro membro (decisão binomial - sucesso: protocolar; ou fracasso: não protocolar) será estimada indiretamente pelo modelo. Sendo $k$ a quantidade de sucessos e $r$ a de fracassos temos que $m=k+r$.

\footnotetext{
${ }^{1}$ Diferença esperada no número de sucessos dado um mesmo número total de eventos/decisões.
} 
(a) Uma questão que poderia ser discutida aqui é por que existiram $r$ fracassos. Ou seja, por que o país/grupo deixou de protocolar $r$ reclamações-padrão tendo detectado a violação e o dano causado a ele? A resposta a esta pergunta deverá estar relacionada às nossas variáveis explicativas;

(b) No entanto, a dimensão que realmente importa aqui é que se o estabelecimento de um referencial ou baliza adequado para avaliar o comportamento dos grupos deve ser derivado de critérios endógenos aos mesmos, o melhor, se não o único, critério possível para esta finalidade é uma avaliação em torno de $m$;

(c) Assim, partindo das seguintes premissas, que obviamente são uma simplificação instrumental do processo:

- Quando um grupo é confrontado com um momento de decisão sobre protocolar ou não uma determinada reclamação-padrão no OSC é por que o grupo detectou (está ciente) de uma violação aos normativos da $\mathrm{OMC}$, detectou o dano causado a ele por esta violação e já exauriu as fases prévias e possibilidades de negociação bilateral, sendo a decisão de protocolar ou não a reclamação o ato final de levar ou não adiante uma determinada contestação.

- Para qualquer grupo, em um contexto ideal, não deveria haver diferença entre o número de decisões tomadas e o número de sucessos (reclamações-padrão protocoladas), ou seja, $m=k(r=0)$, uma vez que um grupo deveria sempre buscar maximizar seus ganhos e minimizar suas perdas na OMC. Assim, se um grupo deixa de apresentar reclamaçõespadrão $(r>0)$ é por que algum fator o inibiu de fazê-lo, ou seja, reduziu sua participação no sistema.

- No entanto mesmo no caso dos países desenvolvidos não se espera a ocorrência de igualdade entre eventos e sucessos, uma vez que na prática seria bastante difícil de conceber que um grupo sempre decidisse avançar uma disputa comercial independentemente de outras considerações políticas, institucionais e econômicas correlatas (cujo efeito será medido nestas três dimensões por nossas variáveis explicativas a serem especificadas adiante). Ou seja, espera-se que parcela das decisões seja bloqueada resultando em fracasso. 
- Espera-se, em geral, a ocorrência de valores intermediários de sucesso para os grupos. A pergunta adequada aqui é, portanto, se a taxa relativa de sucesso para os países em desenvolvimento é significativamente diferente da dos países desenvolvidos. Apenas diferenças estatisticamente significativas entre os grupos poderão indicar uma super ou subatividade no sistema.

(d) A diferença entre estas taxas, que no polo ativo será definida como índice de eficácia (EC), deverá ser, portanto, nosso critério de avaliação do comportamento de cada grupo em relação ao grupo de referência (países desenvolvidos). Para isto, no polo ativo, o EC será expresso como:

o valor adicional de sucessos $(k)$ (reclamações-padrão protocoladas) obtidos por um determinado grupo de renda em relação ao grupo de referência (países desenvolvidos) dada uma mesma quantidade de decisões/eventos $(m)$ para ambos os grupos.

- Pelas próprias característica e diferenças de valores das variáveis explicativas de cada grupo de renda, cada um deles possuirá uma quantidade absoluta diferente de eventos base $(m)$ para decisão. Dessa forma, utilizaremos variáveis dummy para cada um dos grupos de renda que desejamos medir o índice, que será expresso diretamente pelo efeito estimado dos coeficientes destas variáveis no nível 2 de contagem do modelo (controladas as demais variáveis em seus valores médios para todos os grupos, ou seja, dada uma quantidade igual de eventos $m$ para todos os grupos). A notação utilizada aqui é uma simplificação para permitir uma discussão didática sobre a função e propriedades deste índice.

A ocorrência de um valor de $\mathrm{m}=0$ para um país/grupo significa que não houve nenhum momento de decisão (evento) em que este país/grupo possa ter cogitado apresentar um reclamação-padrão. A depender dos valores das variáveis observadas para o país/grupo em questão (tais como baixo volume de comércio e PIB), este pode não estar apto a detectar violações das normas da OMC, possuir baixa capacidade para avaliar e levar adiante uma disputa, possuir receio extremado de retaliações, dentre outras explicações possíveis. 
Dessa forma, o país/grupo não chega a tomar uma decisão sobre protocolar ou não uma reclamação-padrão, pois, ele está a priori inabilitado para a utilização do sistema no polo ativo. Nestes casos, existe um efeito estrutural que exclui estes países de serem potencialmente reclamantes-padrão no sistema (zero estrutural).

Chamaremos, portanto, ao componente logístico do processo que separa os grupos zero estrutural e zero condicional de processo de habilitação. Ao passo que o país/grupo que reúne condições estruturais para receber protocolar reclamações-padrão (que dependerão de uma decisão para ocorrer ou não) será chamado de "habilitado" (zero condicional).

$\mathrm{Na}$ Figura 4.1 a seguir apresentaremos uma forma esquemática do fluxo de eficácia do processo no modelo de polo ativo:

\section{Figura 4.1 - Fluxo de eficácia no modelo de polo ativo}
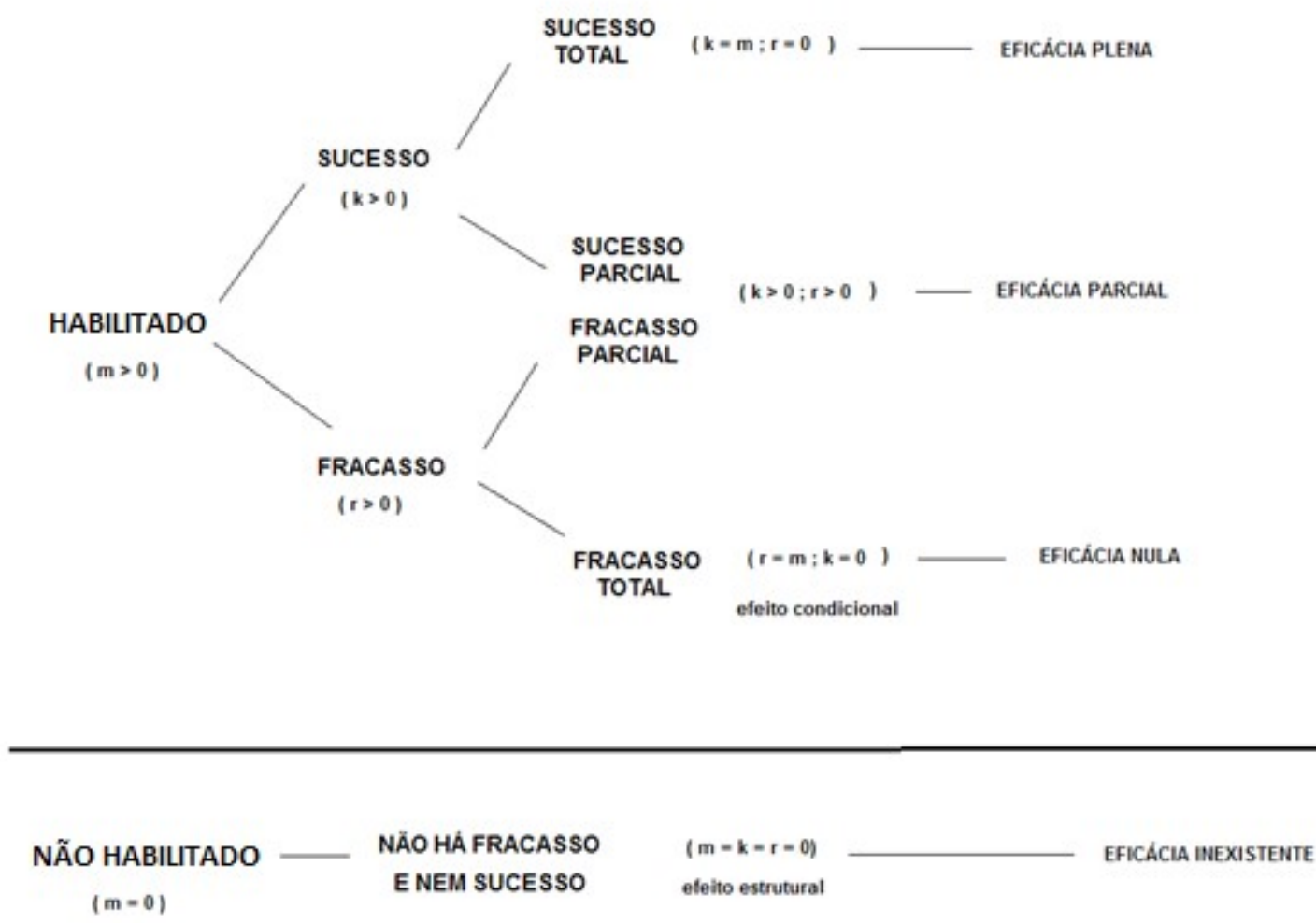

Fonte: Elaboração própria. 


\subsection{2. Índice de inibição de efetividade (ET) - Polo passivo}

No polo passivo, de forma análoga ao polo ativo, utilizaremos as mesmas notações em nossa discussão por uma questão de simplicidade, sendo $m$ a quantidade total de eventos, $k$ a quantidade de sucessos (no sentido do modelo - acionamentos-padrão recebidos) e $r$ a quantidade de fracassos (acionamentos-padrão não recebidos - zero condicional $\mathrm{x}$ diferente do zero estrutural fruto de um não evento), teremos que $m=k+r$.

(a) Similarmente ao polo ativo, a questão que se levanta de uma análise lógica é - por que existiram $r$ fracassos? Por que o grupo deixou de receber $r$ acionamentos-padrão? A resposta a esta pergunta deverá estar igualmente relacionada às nossas variáveis explicativas para este modelo específico;

(b) Partindo das premissas elencadas abaixo, que novamente destacamos são uma simplificação instrumental do processo:

- Quando um grupo é alvo de uma decisão de um outro membro de acioná-lo ou não no OSC é por que o grupo cometeu efetivamente uma violação aos normativos da OMC, esta violação foi detectada por outro membro que dela sofreu danos e já se exauriram as fases prévias e possibilidades de negociação bilateral, sendo a concretização do acionamento (sucesso) ou não concretização (fracasso) o ato final de levar ou não adiante uma determinada contestação contra este país.

- Para qualquer grupo, em um contexto ideal, não deveria haver diferença entre o número de violações cometidas por este, que causem dano a outro membro e tenham sido detectas e não dirimidas antes do outro membro ter efetivamente de decidir por acioná-lo ou não, e o número de sucessos (acionamentos-padrão recebidos).

- O que se traduziria em $m=k(r=0)$, uma vez que todo grupo deveria sempre buscar maximizar seus ganhos e minimizar suas perdas na OMC e, portanto, buscar levar qualquer país/grupo em descumprimento aos normativos da OMC a convergir para a conformidade com o mesmo. Dessa forma, se um grupo deixa de receber acionamentospadrão $(r>0)$ é por que algum fator inibiu a efetivação destas contestações por um segundo grupo contra este. 
- No entanto, assim como no polo ativo, também no polo passivo não se espera a ocorrência de igualdade entre eventos e sucessos, pois, parcela das decisões será bloqueada por diversos fatores ligados a variáveis explicativas que serão apresentadas no próximo capítulo e resultarão, portanto, em fracasso.

- Espera-se, em geral, a ocorrência de valores intermediários de sucesso para os grupos. A pergunta adequada aqui é, de forma similar, o contrário do polo ativo. Se no polo ativo nosso interesse reside na taxa relativa de sucesso, no polo passivo nosso interesse está na taxa relativa de fracasso para os diferentes grupos de renda de países em desenvolvimento em relação aos países desenvolvidos. Igualmente, apenas diferenças estatisticamente significativas entre os grupos poderão indicar uma super ou subpassividade no sistema.

(d) A diferença entre ambas as taxas, que no polo passivo será definida como índice de inibição de efetividade (ET), deverá ser, portanto, nosso critério de avaliação do comportamento de cada grupo em relação ao grupo de referência (países desenvolvidos). Para isto, no polo passivo, o ET será expresso como:

o valor adicional de fracassos ( $r$ ) obtidos por um determinado grupo de renda em seus acionamentos-padrão recebidos em relação ao grupo de referência (países desenvolvidos) dada uma mesma quantidade de decisões/eventos $(m)$ que tenha este grupo como alvo.

- De forma análoga ao polo ativo, a depender dos valores das variáveis explicativas cada grupo de renda será alvo de uma quantidade diferente de eventos base $(m)$ para decisão sobre acionamentos-padrão contra este. Dessa forma, utilizaremos variáveis dummy para cada um dos grupos de renda que desejamos medir o índice, que será expresso diretamente pelo efeito estimado dos coeficientes destas variáveis no nível 2 de contagem do modelo (controladas as demais variáveis em seus valores médios para todos os grupos, ou seja, dada uma quantidade igual de eventos $m$ para todos os grupos). A notação utilizada aqui é uma simplificação para permitir uma discussão didática sobre a função e propriedades deste índice. 
Uma forma esquemática do fluxo de efetividade do processo para o modelo de polo passivo descrito é apresentado na Figura 4.2 a seguir:

Figura 4.2 - Fluxo de efetividade no modelo de polo passivo
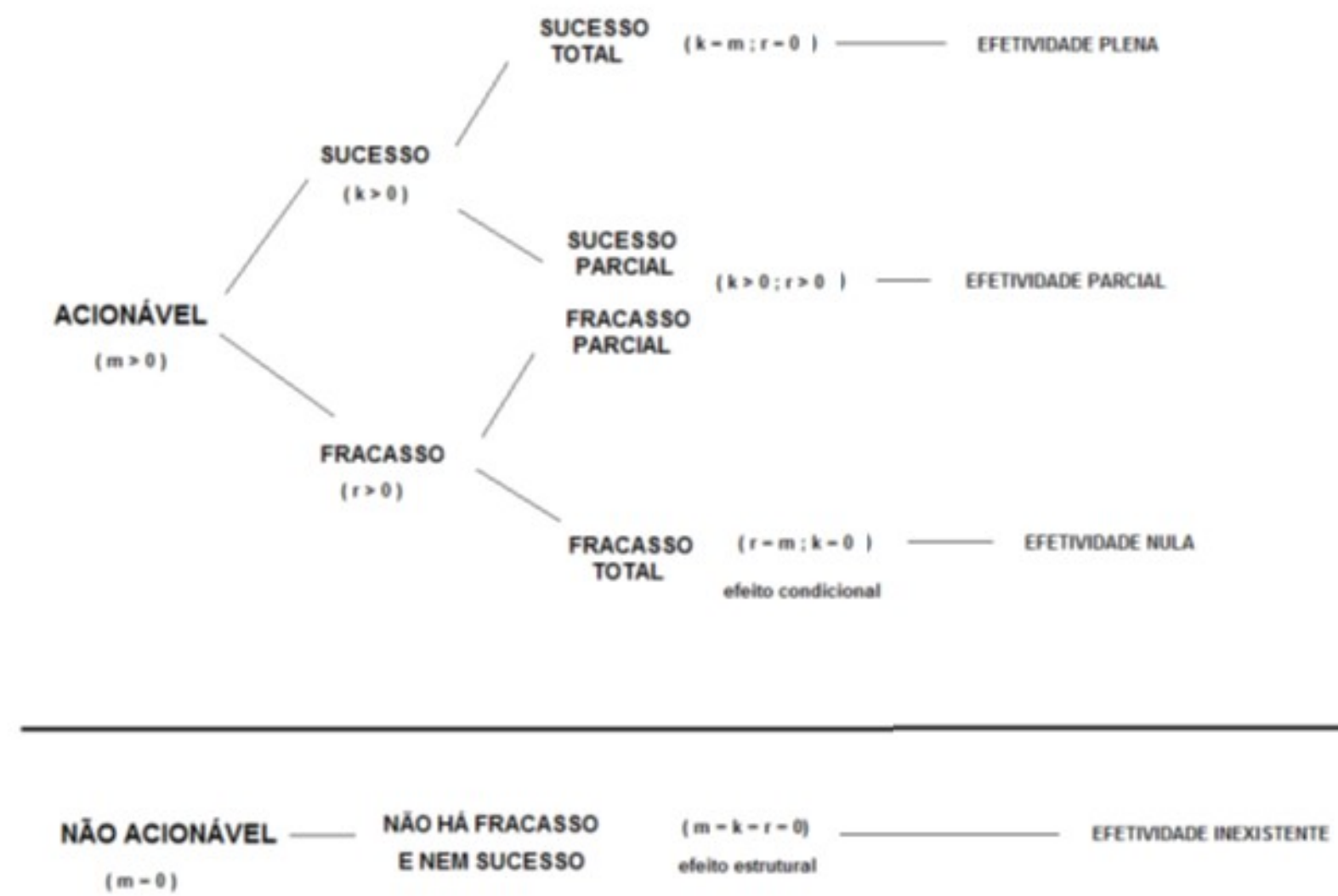

Fonte: Elaboração própria.

A ocorrência de um valor de $\mathrm{m}=0$ para um país/grupo significa que não houve nenhum momento de decisão por qualquer outro membro da OMC que ensejasse a possibilidade de acionar este país/grupo. A depender dos valores das variáveis observadas para o país/grupo em questão (tais como baixos volume de comércio e PIB), as violações das normas da OMC pelo mesmo podem ser inexistentes; poucas (com baixa probabilidade de detecção); e/ou irrelevantes (no sentido do baixo dano relativo causado a outros países potencialmente demandantes).

Dessa forma, os demais membros não chegam a tomar uma decisão sobre o acionamento ou não deste país/grupo, pois, ele está a priori fora do foco. Nestes casos, existe um efeito estrutural que exclui estes países de serem potencialmente acionados no 
sistema (zero estrutural). Chamaremos este tipo de país/grupo de "não acionável". Ao passo que o país/grupo que reúne condições estruturais para receber acionamentos (que dependerão de uma decisão para ocorrer ou não) será chamado de "acionável" (zero condicional).

Ambos os termos conforme empregados neste estudo tem unicamente o sentido estrito acima referido. Portanto, não se confundem com o conceito usado para a factibilidade de ações que causem dano possam ou não ser objeto de demanda no sistema (como nas categorias "subsídios acionáveis" e "subsídios não acionáveis" por exemplo).

A partir desta ótica, o que importa na realidade para a avaliação do comportamento dos diferentes grupos de renda é se, após o controle dos principais efeitos estruturais influentes no sistema (efeito iceberg e efeitos gravitacionais e discriminatórios), existem diferenças estatisticamente significativas dos índices de eficácia (polo ativo) e de inibição de efetividade (polo passivo) entre os diferentes grupos de renda.

Em outras palavras, se após a modelagem com o controle destes efeitos internos ao sistema pode-se observar algum efeito externo atrelado a covariáveis qualitativas ligadas aos diferentes níveis de renda (isto é: dummies para os subgrupos dos países em desenvolvimento) no comportamento dos países em desenvolvimento em comparação com os países desenvolvidos (grupo focal). 


\section{Capítulo 5}

\section{REVISÃO DA LITERATURA E SELEÇÃO DE VARIÁVEIS EXPLICATIVAS}

Apresentaremos no presente capítulo uma revisão da literatura dos principais trabalhos empíricos sobre a determinação do comportamento dos países no sistema de solução de controvérsias da OMC e os resultados encontrados por estes sobre diferenças entre o desempenho de países desenvolvidos e em desenvolvimento. Será dado destaque aos estudos pioneiros na área utilizando metodologias clássicas de regressão para posteriormente adentrarmos na discussão sobre as metodologias mais recentes. Estas últimas são o foco principal deste trabalho e serão discutidas com maior profundidade.

As variáveis explicativas utilizadas nestas pesquisas serão mapeadas de forma a gerar subsídios para nossa discussão específica sobre os requisitos de nosso modelo e a seleção das variáveis estruturais explicativas específicas a serem testadas, que serão apresentadas ao final do capítulo.

\subsection{Pesquisa empírica nos estudos da área}

A OMC e seu sistema de solução de controvérsias são objeto de ampla atenção de pesquisadores de distintas áreas do conhecimento, especialmente direito, economia e ciência política/relações internacionais desde seu nascedouro. Como resultado, nas duas últimas décadas construiu-se um impressionante repositório de conhecimento sobre o tema. Estudos sobre o sistema de solução de controvérsias tem se utilizado extensivamente de diferentes técnicas de análise quantitativa e de modelagem.

Nota-se que as pesquisas quantitativas que buscam entender a dinâmica das disputas e o comportamento dos países no OSC, especialmente dos países em desenvolvimento, ao serem submetidas a um intenso escrutínio podem ser agrupadas basicamente em torno da resposta a duas amplas perguntas de pesquisa.

A primeira pergunta refere-se ao processo de iniciação de disputas. Ou seja, procura responder como se dá a escalada de disputas comerciais no âmbito do sistema e elucidar os determinantes do por que alguns conflitos são resolvidos por meio de consultas bilaterais prévias ou na fase anterior à instalação de um painel enquanto outros 
conflitos são escalados em disputas comerciais na forma de casos no OSC - por que algumas disputas viram casos no sistema e outras não.

A segunda pergunta refere-se fundamentalmente à frequência com que disputas são iniciadas no OSC. Procura, portanto, responder quais são os determinantes do comportamento dos países no OSC em razão de variáveis explicativas diversas como nível de desenvolvimento, tamanho da economia, estrutura do comércio exterior, dentre outras, que possam explicar a diferença observada na frequência de uso do sistema entre os diferentes grupos de países.

Em compreensivo levantamento da literatura sobre a primeira década de operação do Órgão de Solução de Controvérsias da OMC, Horn e Mavroidis (2006) argumentam que a alegação mais frequente reverberada pela literatura no debate sobre tema é que a participação no mecanismo é tendenciosa em detrimento dos países mais pobres e menores.

De acordo com os resultados deste levantamento, estas alegações assumiriam uma forma principal que pode ser enunciada de formas diversas a depender do ponto de partida: os países em desenvolvimento teriam uma subparticipação por não protocolarem reclamações tão frequentemente quanto deveriam; ou os países desenvolvidos teriam uma dominância sobre o sistema protocolando reclamações com mais frequência do que deveriam fazer.

De forma geral, o desenvolvimento da literatura empírica sobre o tema na década seguinte, conforme veremos, evoluiu sensivelmente tanto teorica quanto metodologicamente. Mas estabelecer com progressivamente maior segurança e entender as implicações dos determinantes da participação dos membros da OMC neste sistema e, por conseguinte, poder oferecer respostas mais confiáveis a estas perguntas, continua a ser o principal objetivo dos estudos na área. Estes determinantes, como forma geral, orbitam em três dimensões principais: econômica, de capacidade e de poder. Discutiremos no decorrer do presente capítulo cada uma destas dimensões.

Por sua vez, do ponto de vista metodológico os estudos empíricos na área que utilizam estatística clássica frequentista (baseada na teoria de probalidade da frequência relativa) podem ser divididos igualmente em duas grandes categorias: i) método dos mínimos quadrados (MMQ); e ii) método da máxima verossimilhança (MMV). Não iremos abordar aqui estudos com base em inferência bayesiana e não é nosso foco adentrar na discussão teórica da polêmica entre frequentistas e bayesianos. No caso do presente recorte de pesquisa, não se considerou apropriado o estabelecimento de prioris e a 
utilização de métodos bayesianos.

Portanto, quando nos referirmos aqui do ponto de vista metodológico a estudos clássicos não estamos nos referindo ao conceito como sinônimo de estudos frequentistas em oposição a estudos bayesianos. Por estudos clássicos estaremos nos referindo aos estudos empíricos pioneiros no campo que utilizam métodos tradicionais de regressão linear por minimização da soma do quadrado dos resíduos (MMQ). O método em questão consiste na minimização da soma dos quadrados da diferença entre os valores dos dados e os valores estimados. Ou seja, na minimização do erro ${ }^{1}$.

Especialmente em casos como o do presente estudo, em que há fortes indícios teóricos e metodológicos para considerar que estes pressupostos não sejam válidos para o objeto conforme discutido no capítulo anterior, pode-se supor a hipótese de uma distribuição teórica para a viável resposta (como a distribuição binomial negativa no caso deste estudo) e, por consequinte, para o termo de erro. De forma a que a partir do conjunto de dados observados e do modelo (distribuição) estatístico proposto os estimadores possam calculados a partir da maximização da probabilidade de ocorrência dos dados observados dentro da função de máxima verossimilhança (MMV) (Id Ibid).

Em nossa discussão a seguir, iniciaremos pelos principais estudos clássicos na área (MMQ) que foram responsáveis pelo estabelecimento de referencias básicos para a discussão empírica da determinação do comportamento dos países no OSC, conforme veremos, em três grandes dimensões: econômica, de poder e de capacidade. Estes estudos foram posteriormente amplamente utilizados e debatidos por estudos posteriores (MMQ). No entanto, nosso interesse reside em, após a discussão dos estudos pioneiros (MMQ), na apresentação e discussão de estudos prévios com metodologia MMV que inseriram pioneiramente a modelagem ZINB para abordar diferentes aspectos do sistema de solução de controvérsias da OMC.

\subsubsection{Estudos clássicos (MMQ) sobre o OSC}

\section{a) Dimensão econômica}

\footnotetext{
${ }^{1} \mathrm{O}$ qual se pressupõe seja estritamente exógeno (possua média zero), homocedástico (variância igual para todas as observações), linearmente independente e siga distribuição normal (ROBSON, PEVALIN, 2016).
} 
Em estudo de 1999, Horn et al focam-se em responder a pergunta sobre se a participação dos países mais pobres e menores como reclamantes no OSC é tendenciosa em detrimento destes, no sentido de que se queixariam menos frequentemente do que deveriam, com base nos padrões de comércio e interesses comerciais específicos dos países.

Para resolver este problema, uma definição de referência imparcial precisava ser criada, pois, seria altamente provável que um país que exporta muitos produtos para vários mercados encontrasse mais desvios aos normativos da OMC (a base para a realização de reclamações) do que um país que, principalmente, exportasse um produto para um único mercado, por exemplo.

O primeiro país certamente terá mais oportunidades para decidir sobre protocolar reclamações do que o segundo. Além disso, quanto maior o volume de comércio, em teoria, maior a probabilidade de que a atividade alavanque recursos financeiros suficientes para o país arcar com os custos de um litígio comercial, o que também acabaria por elevar a frequência de litígios.

Horn et al (Ibid) estabeleceram, portanto, a premissa de que o valor de uma referência imparcial deveria permitir aos membros queixar-se de forma proporcional ao número de desvios aos normativos da $\mathrm{OMC}$ (medidas comerciais questionáveis) que estes encontrassem em seu fluxo regular de comércio. Na ausência de uma previsão teórica convincente para o número de ilegalidades cometido por cada país, o estudo assume que os países cometem desvios com a mesma frequência, independentemente de outras características do par de países exportador-importador e do produto.

Utilizando um modelo simples de regressão logística a partir de dados de disputas na OMC para o período 1995-1998 e dados do fluxo comercial para cada par exportadorimportador a 4 dígitos do Sistema Harmonizado (SH), ou seja, dados de comércio agregados no nível de "capítulo"-"posição" na classificação do $\mathrm{SH}$, os autores demonstraram que a distribuição de disputas bilaterais seguia razoavelmente bem a linha de base do fluxo de comércio bilateral definida como referência.

A capacidade preditiva do modelo de Horn et al é elevada após ajustes com a exclusão de pares exportador-importador com valores de comércio bilateral inferiores a sucessivas linhas de corte distintas testadas. Holmes et al (2003), cobrindo o período de 1995 a 2002, e Bown (2005), estudando o período 1995-2001, são os principais responsáveis pelo refinamento desta proposta de tratamento, que foi posteriormente amplamente utilizada em diversos estudos. 
Os países podem optar por prosseguir disputas isoladamente, como coautores ou como partes interessadas. Ou podem decidir não participar diretamente, atuando como caronas. As disputas foram divididas em dois conjuntos distintos, medidas discriminatórias e não discriminatórias (considerando seus impactos generalizados ou restritos ao comércio de outros membros). Para cada uma das disputas envolvendo medidas discriminatórias, exportadores para o mercado alvo foram divididos em dois grupos: prejudicados e beneficiados pela medida. Para cerca de $50 \%$ das disputas envolvendo medidas discriminatórias, foram identificados países prejudicados que não participaram diretamente das disputas.

O resultado foi modelado por meio de um modelo logit multinomial para examinar o impacto sobre a propensão dos países para reclamar, atuar como parte interessada ou simplesmente ser um carona, controlados outros fatores que podem afetar esta participação. Nas disputas envolvendo medidas não discriminatórias (que afetam negativamente muitos parceiros comerciais), demonstrou-se que o volume de exportações está positivamente correlacionado com a propensão a reclamar ou atuar como parte interessada e negativamente com a propensão a atuar como carona.

Guzman e Simmons (2005) basearam-se no conjunto de dados de disputas bilaterais na OMC entre 1995 e abril de 2004, conforme definido pelos pedidos de consultas, para testar diferentes formulações de regressão linear (MMQ). Em diferentes formulações, a variável explicativa principal dos modelos é o PIB do reclamante. O estudo estima uma regressão do PIB contra uma série de variáveis explicativas e controles. Nele a variável PIB é interpretada como uma medida tanto do tamanho do mercado do membro quanto de seu poder político (absoluto) e capacidade total.

Francois et al (2008), em estudo abrangendo o período de 1995 a 2006, partem destes resultados e adotam um modelo de contagem com distribuição binomial negativa para a variável dependente do número de reclamações dos países. Os resultados encontrados apontam que tanto a composição/diversidade quanto o volume de comércio dos países são variáveis explicativas importantes.

Em um pareamento bilateral reclamante-acionado, quanto maior o volume de exportações de um determinado setor econômico de um país para outro, maior é o número de disputas comerciais esperadas. É importante destacar também que de acordo com estes resultados há significativa variação na probabilidade de disputas de acordo com a composição do comércio entre diferentes setores econômicos, sendo a maior probabilidade ligada ao comércio agrícola. 
Ao analisarem quais tipos de disputas são mais propensas a serem escaladas com a instalação de painéis, Guzman e Simmons (2002) demonstram que nos casos em que há restrições a linkages e sidepayments, ou quando a prática comercial contestada não é uma política contínua e sim de aplicação pontual, porém reincidente, o que reduziria a margem de manobra do acionado, existe maior probabilidade de que a disputa em questão seja instalada e que o caso evolua para a fase de painel no OSC.

A partir de um modelo de regressão logística baseado na teoria da barganha com assimetria de informação, Ahn et al (2013) analisaram diversos determinantes econômicos chave para a não-litigância dos países em desenvolvimento no sistema de solução de controvérsias da OMC. Demonstraram, assim, que quanto maior a diferença de PIB entre um par de países (potenciais reclamante $x$ acionado) mais reduzida é a probabilidade de liquidação antecipada da disputa ou ausência de litígio.

Em trabalho recente, Yildrim e De Bièvre (2015) ao analisarem os determinantes da escalada de disputas da OMC opondo ao menos um país em desenvolvimento como reclamante contra a UE como acionada, concluíram que o comportamento da UE na liquidação antecipada ou no escalonamento de uma disputa é dependente da presença de outras partes interessadas, portanto outros potenciais afetados pela disputa, e de sua própria estrutura econômica de comércio exterior.

O comportamento da UE no OSC não dependeria, segundo o estudo, do nível de desenvolvimento do país ou países reclamantes. Estes resultados contrastam frontalmente com os encontrados por Ahn et al. (Ibid) ao analisarem de forma geral a dinâmica países em desenvolvimento versus desenvolvidos no OSC, que apontam a existência de efeitos de poder que serão discutidos adiante.

Conforme fica patente em nossa discussão dos estudos clássicos na área, o PIB e o comércio são, por razões mais do que óbvias, uma dimensão importante da explicação dos determinantes da iniciação de disputas comerciais na OMC. No entanto, esta dimensão não é capaz de explicar inteiramente o fenômeno. Dessa forma, a literatura tem sugerido especialmente duas outras dimensões para avaliação do papel dos países em desenvolvimento neste sistema.

A dimensão de capacidade legal ou institucional e a dimensão de poder. A falta de capacidade dos países mais pobres impediria a participação destes na frequência adequada. Já a segunda, reduziria ainda mais sua participação devido à diferenças de poder relativo em relação aos demais membros no sistema. Discutiremos os principais resultados destas pesquisas sobre estas duas dimensões a seguir. 


\section{b) Dimensão de capacidade legal/institucional}

No modelo proposto por Horn et al (lbid) é utilizado o tamanho das delegações dos países em Genebra e o PIB per capita como proxies para a capacidade legal destes. O estudo, após o controle dos interesses comerciais conforme abordamos anteriormente, encontra fracas evidências de correlação positiva entre capacidade legal e a frequência de reclamações. Os resultados apontam problemas de multicolinearidade destas proxies com outras variáveis no modelo proposto e, portanto, os resultados são pouco significativos.

Por sua vez, os modelos de Bown (lbid) e Holmes et al (lbid), utilizando as mesmas variáveis PIB per capita e tamanho das delegações em Genebra, encontram evidências estatísticas do efeito da correlação positiva entre capacidade e frequência de uso do sistema. No entanto, tamanho do efeito é tão modesto que é negligenciável, de modo que não se pode falar efetivamente em uma influência desta dimensão como determinante do comportamento dos países em desenvolvimento no sistema no caso de ambos os modelos.

De acordo com a modelagem proposta por Guzman e Simmons (Ibid), o PIB também é relevante para medir a capacidade de um país em levar adiante disputas, pois, está correlacionada à capacidade/dispobilidade de recursos financeiros e humanos para usar em caso de contencioso. Caso este seja um efeito importante, esperaríamos ver uma relação negativa entre esta variável e o PIB. A racionale da dinâmica de disputa entre os pares exportador-importador é a mesma dos dois estudos anteriores cidados.

A pesquisa testa também a inclusão de outras proxies de capacidade legal, além da variável comumente empregada do tamanho das delegações dos países em Genebra, que incluem o número de embaixadas do país no mundo, regime político civil ou militar e um índice para a qualidade de burocracias governamentais.

Diversas especificações de modelos lineares são testadas. Uma das especificações que inclui o tamanho do PIB dos reclamantes e acionados encontrou relação negativa e significativa entre ambos. Em outras especificações, o PIB do reclamante foi retirado do modelo em favor do PIB per capita, encontrando-se correlação negativa com o PIB do acionado.

No caso das demais variáveis proxies incluídas nos modelos alternativos, verificouse que todas são estatisticamente significativas e têm o sinal esperado, exceto a variável de qualidade da administração pública. Outro resultado de destaque é a correlação 
positiva e estatisticamente significativa encontrada entre o PIB do reclamante e o valor das importações deste do mercado do exportador acionado.

No geral, Guzman e Simmons (Ibid) destacam que seus resultados tendem a indicar a existência de efeitos da dimensão de capacidade. Apesar de ser muito difícil determinar uma referência não tendenciosa para a participação dos países em desenvolvimento no sistema para esta dimensão, estes parecem constrangidos pela limitação de sua capacidade legal/institucional em comparação com países desenvolvidos. Em virtude destas restrições, os países em desenvolvimento tenderiam a ser mais seletivos quanto aos casos em que participam no OSC.

Por sua vez, Francois et al (Ibid), construindo uma variável proxy utilizando-se do subíndice de qualidade do capital humano governamental, que compõe o índice de eficácia governamental do Banco Mundial, normalizado e multiplicado pelo log do PIB para gerar uma variável "quantidade" de capacidade, encontram efeito positivo da capacidade institucional/legal dos países em coibir acionamentos.

Apesar da direção correta do efeito encontrado, o mesmo torna-se duvidoso devido à forma de especificação da variável que acabou por misturar dimensões diferentes no mesmo índice, que provavelmente foi dominado pelo efeito PIB na variável. Teremos estas considerações em mente quanto discutirmos ao final do presente capítulo a definição de nossas variáveis explicativas.

Os trabalhos de modelagem que têm estudado o problema do deficit de capacidade enfrentado pelos países em desenvolvimento para a iniciação de disputas enumeram ainda duas restrições adicionais à atuação destes. A primeira está relacionada à própria capacidade dos países em desenvolvimento em monitorar e detectar possíveis violações de seus direitos de acesso a mercado na OMC. A capacidade de acesso à informação privada dos atores seria, portanto, crucial.

No caso dos membros mais pobres da OMC, esta seria reduzida, sendo que a maioria dos países de menor desenvolvimento relativo sequer possuem delegação permanente baseada em Genebra para mantê-los atualizados sobre suas obrigações e direitos na OMC (BUSCH, REINHARDT, SCHAFFER, 2009). O acesso desigual à informação faria com que muitos países em desenvolvimento possuíssem uma alta probabilidade de perderem as disputas antes mesmo dos painéis serem estabelecidos (BUSCH, REINHARDT, 2003).

A maioria dos países em desenvolvimento de menor renda, portanto, pode não ser capaz de monitorar violações de seus direitos e reconhecer as oportunidades de litígio. 
Em estudo sobre a correlação entre a interação governo-indústria (expertise privada) e litígios na OMC, Van Kerckhoven e Crombez (2015) demonstram que na ausência de expertise privada e apoio a uma queixa pelo setor privado doméstico de um país, uma quantidade menor de litígios serão levados a efeito pelo país. Os governos dos países em desenvolvimento muitas vezes não possuem informações e pessoal qualificado para identificar violações a seus direitos de acesso a mercado na OMC.

Um segundo aspecto, diz respeito aos custos associados ao escalonamento de um litígio em um caso no OSC à fase de painel, bem como à capacidade dos países em desenvolvimento para levar a disputa adiante. A abertura e a manutenção de um caso no OSC são dispendiosas e demoradas. Os países em desenvolvimento possuem em geral capacidade reduzida para se preparar adequadamente para seguir um caso no OSC (SEVILLA, 1999). Consequentemente, estes dependem em grande medida de capacidade externa.

Concentrando-se sobre os custos crescentes das disputas comerciais no OSC, Busch e Reinhardt (lbid) constataram que a escalada de disputas deveria ser considerada não a norma, mas uma excepcionalidade. Segundo os mesmos, as partes em um litígio de natureza comercial na OMC teriam mais a ganhar com a liquidação antecipada da disputa do que com sua escalada.

A antecipação de uma decisão, ao contrário de sua efetiva realização (que requer uma escalada que leve à decisão de fato), aumentaria as possibilidades de negociação, levando em média a um acordo mútuo mais benéfico para as partes em litígio do que na comparação com uma decisão de painel sobre o caso. Em estudo anterior, utilizando-se um modelo de informação incompleta para a dinâmica de barganha das partes em disputa chegou-se a resultados similares (REINHARDT, 2001).

Ao estudar o impacto dos custos de um litígio, Van Kerckhoven (2015) argumenta que as disputas só são efetivamente iniciadas por um país em desenvolvimento quando este está completamente certo da ocorrência da violação aos normativos da OMC. Além disso, uma vez que a parte acionada pode resolver a disputa de forma bilateral antes da instalação de um painel em condições potencialmente mais favoráveis, mantido o controle sobre os problemas de informação incompleta, a escalada poderia ser explicada por motivações mais políticas do que econômicas.

Neste estudo sobre como as desvantagens de custo empurram os países em desenvolvimento a tomar decisões diferentes das dos países desenvolvidos no OSC, os autores concluem que os países em desenvolvimento apresentam menos queixas no 
sistema e, quando o fazem, são mais propensos a resolver as disputas em consultas bilaterais ou antes da fase de painel. Isto decorreria do fato de possuírem menos recursos financeiros e capacidade legal para se prepararem adequadamente para a disputa no sistema.

Acerca do déficit de capacidade institucional/jurídica dos países em desenvolvimento para levar a cabo e manter litígios no OSC, de acordo com Busch e Reinhardt (2003b) este seria o principal desafio para os países em desenvolvimento em litígios de comércio internacional. De forma semelhante, Bown (2004a, 2004b, 2005) procura demonstrar que a capacidade de absorver os custos diretos esperados de um litígio no OSC, bem como os custos indiretos de economia política devido ao envolvimento em um litígio na OMC, são importantes determinantes na decisão dos países em desenvolvimento em iniciar ou não disputas.

Uma perspectiva diferente sobre a capacidade e propensão de participação no sistema diz respeito ao papel do sistema político doméstico na participação dos países em disputas no sistema multilateral de comércio. Uma vez que a decisão de um país de envolver-se em uma disputa é o resultado de um processo político doméstico, seria esperado que o processo naturalmente dependesse das instituições políticas do país, em particular por que os entes privados não têm legitimidade perante a OMC na iniciação de disputas, cuja prerrogativa é de instituições governamentais ou políticas.

Reinhardt (2000) examinou uma série de aspectos sobre esta questão, com especial interesse em determinar se as democracias são mais ou menos propensas a iniciar disputas. Utilizando uma grande base de dados de disputas "bilaterais" no período de 1948-1998 e modelos estatísticos de regressão probit que agregam índices de democracia e variáveis explicativas que capturam outras características dos membros do GATT/OMC, o estudo concluiu que países mais democráticos são mais propensos a iniciar disputas, mesmo após o controle do tamanho relativo dos países e da dependência comercial recíproca.

A magnitude do efeito encontrado é forte e significativo estatisticamente. Além disso, as democracias seriam não apenas mais propensos a iniciar litígios, mas também a serem alvos de acionamentos. A interpretação do autor para este efeito é de que a pressão para a proteção comercial em sitemas políticos abertos é mais elevada e como resultado países democráticos seriam mais propensos a implementar medidas contrárias aos normativos da OMC. Portanto, os últimos tenderiam por consequência a ser alvo de mais disputas. 


\section{c) Dimensão de poder}

O argumento básico da dimensão de poder sustenta que países mais pobres, com menores recursos de poder, utilizariam menos o sistema de solução de controvérsias da $\mathrm{OMC}$ devido à sua falta de poder. Esta falta de recursos de poder levaria a uma reduzida capacidade de levar o alvo de uma reclamação a implementar as decisões obtidas no âmbito multilateral e/ou ao receio de retaliações ou perda de um tratamento preferencial no comércio ou outra forma de retaliação não-comercial como redução da ajuda externa e outros modos de assistência.

No modelo proposto por Horn et al (Ibid), a influência da dimensão de poder é testada utilizado-se o PIB como proxy do poder absoluto dos países. A diferença entre o número de reclamações previstas pelo modelo e a frequência real de uso foi então estimada entre quatro grupos agregados de países: G4 (EUA, UE, Canadá e Japão), outros países da Organização para a Cooperação e Desenvolvimento Econômico (OCDE), países em desenvolvimento e países de menor desenvolvimento relativo (os dois últimos grupos com base nos critérios das Nações Unidas).

Não foram encontradas evidências de que os países em desenvolvimento estejam subrepresentados em relação aos países desenvolvidos. As conclusões quanto aos PMD não são fortes. A variável empregada sugere que estes estão subrepresentados tanto como reclamantes quanto como acionados em relação aos países desenvolvidos, mas o efeito é muito pequeno e a amostra é reduzida, o que decresce a confiança na significância do resultado.

Por sua vez, o modelo proposto por Bown (Ibid) encontra forte evidência de uma dinâmica de poder na relação bilateral importador-exportador. Uma alta participação das exportações do reclamante em direção ao mercado do acionado aumenta a probabilidade de que o primeiro será um reclamante (e reduz a probabilidade de que o mesmo seja um carona). Uma possível interpretação para este efeito é que o poder é variável relevante na decisão de reclamar, uma vez que um nível alto de poder elevaria a probabilidade de sucesso na disputa e na consecusão do resultado da mesma.

No entanto, a forma como este modelo foi formulado faz com que o efeito do poder exista não apenas entre pares específicos com atributos em níveis distintos, mas também para um conjunto grande de exportadores, inclusive nas relações bilaterais exclusivamente entre países desenvolvidos. Esta é uma indicação de qua a forma de definição desta variável faz com que o modelo capte outros efeitos por meio da mesma, 
introduzindo ruído e tornando as conclusões sobre a validade desta duvidosas.

Guzman e Simmons (Ibid), propõe, por sua vez, uma modelagem onde o poder é definido como a capacidade do membro de exercer poder fora do sistema. Ou seja, pela retirada de conseções ao outro membro ou a imposição de retaliações e não incluem neste conceito o poder exercido dentro do próprio sistema.

Conforme abordamos anteriormente, o PIB é tratado por este modelo como uma medida do poder (absoluto) do reclamante. Portanto, se este for um fator importante para a decisão de reclamar, seria esperada uma relação positiva entre o PIB do reclamante e do acionado. Ou seja, apenas países economicamente grandes teriam condições de desafiar outros países grandes. No entanto, não foram encontradas evidências significativas para este efeito.

Existem também outros resultados importantes de parte dos estudos citados que convergem sobre a operação de outras variáveis de poder na dinâmica das disputas no sistema multilateral (HORN et al, Ibid; BOWN, Ibid). O comércio preferencial parece ser um fator dissuasório importante na determinação da participação dos países no OSC.

Os membros exportadores tenderiam a apresentar menos reclamações contra outros membros do mesmo acordo comercial preferencial a que pertencem ou contra importadores de seus produtos que ofereçam regimes preferenciais. Além disso, mostrase importante a correlação positiva entre o valor da ajuda externa de doadores a potenciais reclamantes conforme se eleva a propensão deste último a abster-se de participar em disputas e negativamente com a propensão a atuar como parte interessada (BOWN, Ibid; FRANCOIS et al, Ibid).

Ahn et al (Ibid) afirmam, porém, que a probabilidade de litigância decai e a de liquidação antecipada aumenta quando o potencial acionado possui um nível de desenvolvimento menor do que o potencial reclamante, tem menos preocupação com sua reputação/imagem e possui menos capacidade de retaliação. Estes resultados são um importante informativo do operação potencial de uma dinâmica de poder que perpassa o ambiente quase-jurisdicional do OSC.

Outra observação importante sugere que a perpectiva de retaliação é um efeito disuarório importante no sistema. Reinhardt (2000) estuda este efeito utilizando variáveis binárias para capturar se no ano anterior ao em análise o acionado iniciou uma disputa contra o reclamante. O efeito encontrado é significativo, indicando que ser alvo de uma disputa no ano anterior aumenta a probabilidade de iniciar uma disputa na direção oposta no ano seguinte por um fator de $55 \%$. 
A probabilidade de violação aos normativos da OMC por um país que enfrente e que não enfrente retaliação (ou mesmo ameaças) é explorada por Bown (2002, 2004a) em uma série de artigos que mostram evidências substanciais de que a ameaça de retaliação por parte de um reclamante aumentar a credibilidade de que o acionado honre seus compromissos na OMC.

Os países em desenvolvimento teriam, ainda, conhecimento da importância de ameaças da dinâmica de retaliação e teriam respondido a esta necessidade mudando seu padrão de iniciação de disputas, de modo a ter melhor controle das instâncias onde estes têm maior alavancagem para ameaçar retaliação e, assim, induzir o cumprimento dos compromissos pelo acionado ou potencial acionado (BOWN, 2004b).

A um nível mais desagregado, Blonigen e Bown (2003) argumentam que a ameaça de uma retaliação contra uma investigação antidumping torna menos provável que um membro da OMC irá incluir o país que provavelmente irá retaliar entre os países que serão reclamados por práticas de dumping. Eles também consideram que a perspectiva de que um determinado membro A possa apresentar uma reclamação (sobre qualquer tema) na OMC contra um membro $B$, faz com que investigações iniciadas dentro do nível doméstico do membro $B$ sobre práticas de dumping do membro $A$ tendam a não ser conclusivas contra o membro A que ameaça retaliação no nível multilateral.

\subsubsection{Estudos ZINB (MMV) sobre o OSC}

Em estudo publicado em 2011, Sattler e Bernauer propuseram de forma pioneira o teste de um modelo binomial negativo inflado de zero com dados em painel (como o do presente estudo) contra um modelo binomial negativo com dados transversais (médias) para examinar a iniciação e frequência de disputa entre pares de membros da OMC (reclamante-acionado) entre 1995 e 2003.

O objetivo deste estudo era comprovar o ajustamento de um modelo explicativo gravitacional contra modelos explicativos alternativos focados na preponderância de relações de poder e na preponderância da diferença de capacidades como fatores centrais na determinação de disputas na OMC.

Segundo resultados do estudo, o principal motor da iniciação de disputas é uma dinâmica gravitacional. Em uma dinâmica de relações bilaterais entre os pares de potencial litígio em análise, economias maiores, mais diversificadas e com maior volume 
de comércio são mais propensas a se envolver em disputas comerciais. O tamanho de seus mercados as tornam alvos mais atraentes de litígios, pois, os ganhos potenciais são maiores, e em contrapartida sua diversidade econômica e volume de comércio bilateral as fazem também mais propensas a terem seus próprios interesses comerciais atingidos. De forma oposta, as variáveis que dizem respeito às dinâmicas de poder relativo e diferenças de capacidade legal e institucional, com potencial para discriminar contra (provocar a exclusão e/ou reduzir o acesso) dos países ao OSC, possuem importância secundária.

Embora o trabalho referido não tenha encontrado evidências fortes de efeitos discriminatórios na iniciação de disputas contra países com pequena capacidade institucional/legal, haveria indicação da presença de um efeito da dinâmica de diferença de poder relativo. Quanto maior a diferença de poder relativo entre o par reclamanteacionado maior (elevação sutil) tende a ser a probabilidade para não iniciação de disputas, sendo o tema tratado fora dos domínios da OMC.

Do ponto de vista metodológico, o modelo binomial negativo inflado de zero proposto pelos autores teve grande êxito em estimar os dados de painel para o modelo completo para todo o período. Neste caso específico, o volume de comércio bilateral foi considerado uma variável significativa no processo de habilitação (inflação de zeros) para não significativa para o processo de contagem (número de disputas) entre os pares de países. Já o PIB é o principal efeito gravitacional e é relevante em ambos os níveis (inflação de zeros e contagem).

Ainda, o resultado do parâmetro de dispersão do modelo ZINB proposto pelos autores não é significativo, de modo que os resultados poderiam potencialmente ser explicados também por um modelo Poisson com correção por inflação de zeros. Esta hipótese é efetivamente testada e comprovada pelos autores.

Por sua vez, Copelovitch e Pevehouse em estudos publicados em 2013 e 2014 demonstram que a política monetária dos países, em especial seus regimes cambiais, são importantes determinantes de disputas comerciais na OMC. Os autores utilizam dados de todos os membros da OMC para o período 1995-2007 em uma modelagem ZINB com apenas um polo (modelo "monadic"). Ou seja, ao contrário do estudo Sattler e Bernauer (2011) e dos estudos clássicos apresentados anteriormente, o modelo proposto por ambos não analisa pares de países reclamante-acionado com a determinação probabilística para ambos os polos pareados (modelos "dyadics").

Isto se deve ao fato de que a proposta teórica deste autores é unidirecional. Os autores desejavam estudar o efeito médio da variação de diferentes variáveis associadas 
a regimes cambiais na variação da probabilidade média de recebimento de acionamentos na OSC por parte dos países (polo passivo). Enquanto os demais estudos apresentados anteriormente, a partir de metodologia consolidada por Horn et al (Ibid) focam-se no estudo da probabilidade de litigância entre pares de países.

De acordo com o referido estudo, países com regimes de taxa de câmbio fixa são tanto mais propensos a iniciar investigações antidumping quanto a ser alvo de acionamentos no OSC. Esse efeito, no entanto, está condicionado ao nível de abertura da conta capital do Balanço de Pagamentos do país, em linha com o modelo de economia aberta de Mundell-Fleming (KRUGMAN, OBSTFELD, 2005).

Estes resultados sugerem que a relação entre taxas de câmbio e política comercial em nível macro proposta pelo modelo Mundell-Fleming estende-se também à atuação dos países na solução de controvérsias no âmbito da OMC. Os governos que sacrificam a autonomia de sua política monetária com a adoção de taxa de câmbio fixa têm fortes incentivos políticos domésticos para adotar políticas comerciais mais protecionistas. Quanto mais protecionista uma determinada política comercial, por sua vez, maior será a probabilidade de que o país seja acionado no âmbito do OSC.

Em artigo de 2015, derivado de Tese de Doutorado defendida na Universidade de Michigan no mesmo ano, Betz desenvolveu a aplicação de uma modelagem bastante similar ao ZINB para o estudo da relação entre sistemas políticos e ciclos eleitorais com relação a disputas na OMC. A modelagem proposta pelo autor consistiu em uma transformação da dependente em uma porcentagem (de disputas) truncada em zero com um modelo de distribuição beta de probabilidade (0 a 1). Ou seja, um modelo de dois níveis com um estimador logístico no primeiro nível para controlar o processo de geração de zeros e, no segundo nível, ao invés de um modelo de contagem (como no caso do binomial negativo) utilizou-se um modelo de proporção.

O autor argumenta que países com instituições eleitorais domésticas que favorecem interesses específicos e/ou restritos (sistemas políticos mais fechados que promovem interesses de grupos de pressão com acesso privilegiado ao processo decisório estatal), ao contrário do esperado, não são mais protecionistas que a média dos países em geral na OMC.

Estes países (com sistemas políticos mais fechados) na verdade possuiriam maior variância de comportamento em relação à média (mas não médias significativamente diferentes do ponto de vista estatístico) e apresentariam, portanto, subgrupos de países consistentemente mais abertos que a média (na hipótese de captura do processo 
decisório estatal por interesses domésticos de grupos exportadores); e ao mesmo tempo subgrupos de países sensivelmente mais fechados do que a média (na hipótese de do processo decisório estatal por grupos domésticos importadores). Ainda, os governos destes países com sistemas político-eleitorais que tendam a promover interesses mais restritos/específicos (quer seja de exportadores, quer de importadores) são mais ativos na iniciação de disputas.

Conforme se pode observar de nossa discussão acima, a literatura empírica na área que tenha avançado na proposição e uso do tipo de modelagem proposta neste trabalho ainda é bastante reduzida. Assim, embora não digam respeito diretamente a uma abordagem do objeto básico da presente pesquisa (disputas no Órgão de Solução de controvérsias da OMC) utilizando-se de alguma proposta específica de modelagem ZINB, é importante mencionar para registro e referência os trabalhos a seguir.

Em estudo recente sobre a influência de variáveis ligadas ao investimento externo direto, comércio intra-firma e desvalorização cambial sobre a propensão de empresas norte-americanas entrarem com pedidos de investigação antidumping junto ao governo norte-americano (defesa comercial no nível doméstico e não multilateral), Jensen et al (2015) propuseram o uso de modelo do tipo ZINB.

Em artigo publicado em outubro de 216, BETZ e KERNER avançam os resultados de Copelovitch e Pevehouse (Ibid) e argumentam que governos de países em desenvolvimento têm maior propensão a levar disputas comerciais ao OSC, quando taxas de câmbio reais supervalorizadas possam colocar seus exportadores em desvantagem competitiva. Os autores reportam testes de modelos utilizando diferentes distribuições, dentre elas uma regressão binomial negativa inflada de zero, onde a equação da inflação inclui o log do comércio, log do PIB per capita, e um indicador de se um país iniciou uma disputa comercial no anterior.

No entanto, resultados para o modelo ZINB testado não são apresentados, pois, de acordo com os autores o teste de Vuong não rejeita o modelo binomial negativo em favor do modelo ZINB e o teste com base no Critério de Informação Bayesiana Schwarz (SBC) refuta o modelo ZINB em favor do modelo binomial negativo. Discutiremos no Capítulo 6 e Anexo 5 as definições e critérios dos testes de Vuong e SBC, que serão igualmente utilizados para validar a modelagem proposta no presente trabalho.

Por fim, em estudo ainda não publicado e que deverá constar como capítulo de livro a ser lançado no próximo ano (KOHL, 2017), registra-se a pesquisa empírica sobre OMC que tenha se utilizado de uma modelagem ZINB. O trabalho em questão foi 
analisado a partir de manuscrito ${ }^{2}$ do autor Tristan Kohl, que é professor da Universidade de Groningen nos Países Baixos.

Utilizando um conjunto de dados cobrindo 181 países para o período 1948-2007 para analisar o impacto da OMC na criação de comércio e seus efeitos para países desenvolvidos e em desenvolvimento, Kohl utiliza um modelo ZINB para medir os ganhos dos membros em diferentes estágios de desenvolvimento. O autor conclui que os membros da OMC ganharam mais (criaram mais comércio) do que os não-membros e o nível de ganho dos membros da OMC é proporcional à extensão da abertura multilateral destes. Pode-se identificar também diferenças de ganhos entre países desenvolvidos e em desenvolvimento, em favor dos primeiros embora não em detrimento dos últimos uma vez que se trata de um jogo de soma positiva.

\subsection{Modelagem multinível na academia brasileira de ciência política e relações internacionais}

Uma revisão da literatura de estatística/econometria aplicada a ciências humanas e sociais mostra que na literatura internacional nas últimas duas décadas tem havido uma adoção crescente do uso de modelagem multinível para o tratamento de dados de contagem, que são variáveis comuns nas observações de fenômenos políticos e sociais. $\mathrm{Na}$ presença de problemas hierárquicos na estrutura dos dados, modelos multiníveis tem sido adaptados à grande área de estudo da ciência política com grande sucesso (por exemplo: MORTON, WILLIAMS, 2010; BECK et al., 1998; BRAMBOR et al., 2006; FLOM, STRAUSS, 2003; GELMAN, 2004; Ibid, 2011; GELMAN, HILL, 2007).

O uso de modelos multiníveis para dados binários nas ciências humanas e sociais tem sido sistematicamente mais adotado em estudos nas áreas de educação, economia/desenvolvimento e psicologia, onde entender aspectos contextuais da estrutura hierárquica dos dados são cruciais. Adicionalmente, com a popularização de ferramentas estatísticas mais robustas e a difusão de softwares de análise, o uso de modelos hierárquicos se espalhou para uma grande diversidade de áreas da pesquisa social (CARRINGTON et al., 2005; STEVENS, 2009).

\footnotetext{
${ }^{2}$ Disponível em <https://goo.gl/pnQnVx>.
} 
$\mathrm{Na}$ academia brasileira é possível observar o uso deste tipo de ferramental especialmente nas áreas de economia (por exemplo: FÁVERO, CONFORTINI, 2010), educação (por exemplo: BARBOSA, FERNANDES, 2000), psicologia (por exemplo: PUENTE-PALACIOS, LAROS, 2009) e com especial destaque ciências da saúde (por exemplo: ZANINI, 2007). A área de saúde, e mais frequentemente as subáreas de epidemiologia e saúde pública, parece ser a principal área de pesquisa a incorporar o uso dos modelos hierárquicos longitudinais para o estudo da relação entre fenômenos biológicos e hábitos, o meio e outras restrições contextuais, na pesquisa acadêmica brasileira.

No âmbito da acadêmica nacional na área de ciência política e relações internacionais, conforme definida pela Coordenação de Aperfeiçoamento de Pessoal de Nível Superior (CAPES), foi possível identificar apenas cinco trabalhos em nível de pósgraduação que tenham utilizado algum tipo de metodologia estatística de regressão multinível/multidimensional/hierárquica em seu desenvolvimento. Esta identificação foi feita a partir do cruzamento de informações entre:

i) os resultados de pesquisa obtidos no banco de dados de teses e dissertações da CAPES (CAPES Banco de Teses $^{3}$ ), utilizando argumentos de pesquisa especificados ${ }^{4}$ (com buscas unitárias para cada argumento) no campo de busca por "Resumo" dos trabalhos nas áreas de ciência política e relações internacionais; e

ii) os dados disponíveis nos repositórios institucionais dos programas de pós-graduação com nível de Doutorado na grande área em questão.

Os repositórios institucionais esquadrinhados foram aqueles cujos programas de pós-graduação pertencentes às áreas de ciência política e/ou relações internacionais possuíssem o nível de Doutorado e estivessem ativos no ano de 2015, conforme dados

3 CAPES Banco de Teses. Disponível em <http://capesdw.capes.gov.br/?login-url-success=/capesdw/>. Acesso em outubro de 2015.

4 Argumentos de busca (busca individual por cada argumento): "condicional" ou "condicionais" ou "longitudinal" ou "longitudinais" ou "nível" ou "níveis" ou "multinível" ou "multiníveis" ou "dimensional" ou "dimensionais" ou "multidimensional" ou "multidimensionais" ou "hierárquico" ou "hierárquica" ou "hierárquicos" ou "hierárquicas" ou "generalizado" ou "generalizados" ou "generalizada" ou "generalizadas" ou "misto" ou "mistos" ou "mista" ou "mistas" ou "estimação" ou "estimações" ou "EEG" ou "GEE" ou "MLG" ou "GLM" ou "MLGM" ou "GLMM" ou "linear" ou "lineares" ou "não-linear" ou "não-lineares" ou "efeito" ou "efeitos" ou "aleatório" ou "aleatórios". 
da Plataforma Sucupira ${ }^{5}$. A escolha por reduzir a pesquisa aos repositórios institucionais com nível de Doutorado foi feita para reduzir o grande número de trabalhos a serem levantados e pelo fato de que o nível de modelagem em questão é de alta complexidade e dificilmente seria objeto de um trabalho em um programa exclusivamente de Mestrado.

Portanto, dos 42 programas de pós-graduação stricto sensu (profissionalizante, mestrado e doutorado) elencados na Plataforma Sucupira na grande área em questão, foram considerados os repositórios institucionais de teses de 18 programas elencados no Quadro 5.1 a seguir:

\section{Quadro 5.1: Repositórios institucionais de teses de Doutorado da área de ciência política e relações internacionais}

\begin{tabular}{|c|c|c|}
\hline PROGRAMA & INSTITUIÇÃO & REPOSITÓRIO \\
\hline $\begin{array}{l}\text { RELAÇÕES } \\
\text { INTERNACIONAIS }\end{array}$ & UNIVERSIDADE DE SÃO PAULO (USP) & $\begin{array}{l}\text { http://www.iri.usp.br/index.php?option=com_k2\&view=item\&l } \\
\text { ayout=item\&id=412\&Itemid=352 }\end{array}$ \\
\hline CIÊNCIA POLÍTICA & UNIVERSIDADE DE SÃO PAULO (USP) & http://www.fflch.usp.br/dcp/html/tesesd.html \\
\hline CIÊNCIA POLÍTICA & \begin{tabular}{llll|} 
UNIVERSIDADE & FEDERAL DE & MINAS \\
GERAIS (UFMG) & & &
\end{tabular} & http://www.bibliotecadigital.ufmg.br/dspace/handle/1843/547 \\
\hline CIÊNCIA POLÍTICA & $\begin{array}{l}\text { UNIVERSIDADE DO ESTADO DO RIO DE } \\
\text { JANEIRO (UERJ) }\end{array}$ & $\begin{array}{l}\text { http://www.bdtd.uerj.br/tde_busca/resultado-tdes- } \\
\text { prog.php?ver=43\&programa=43\&ano_inicio=\&mes_inicio=\& } \\
\text { mes_fim=\&ano_fim=2015\&grau=Todos }\end{array}$ \\
\hline CIÊNCIA POLÍTICA & $\begin{array}{l}\text { UNIVERSIDADE FEDERAL } \quad \text { DE } \\
\text { PERNAMBUCO (UFPE) }\end{array}$ & http://www.repositorio.ufpe.br/handle/123456789/119 \\
\hline CIÊNCIA POLÍTICA & UNIVERSIDADE DE BRASÍLIA (UNB) & http://repositorio.unb.br/handle/10482/574 \\
\hline $\begin{array}{l}\text { RELAÇÕES } \\
\text { INTERNACIONAIS }\end{array}$ & UNIVERSIDADE DE BRASÍLIA (UNB) & http://repositorio.unb.br/handle/10482/577 \\
\hline $\begin{array}{l}\text { RELAÇÕES } \\
\text { INTERNACIONAIS }\end{array}$ & $\begin{array}{l}\text { PONTIFÍCIA UNIVERSIDADE CATÓLICA } \\
\text { DO RIO DE JANEIRO (PUC-RIO) }\end{array}$ & http://www.dbd.puc-rio.br/bibliotecas_puc_rio.php\#BC \\
\hline CIÊNCIA POLÍTICA & $\begin{array}{l}\text { UNIVERSIDADE ESTADUAL } \quad \text { DE } \\
\text { CAMPINAS (UNICAMP) }\end{array}$ & $\begin{array}{l}\text { http://www.ifch.unicamp.br/pos/cienciapolitica/index.php?text } \\
\text { o=producaocientifica\&menu=menupcientifica }\end{array}$ \\
\hline CIENCIA POLITICA & $\begin{array}{l}\text { UNIVERSIDADE FEDERAL DE SÃO } \\
\text { CARLOS (UFSCAR) }\end{array}$ & $\begin{array}{l}\text { http://www.bdtd.ufscar.br/htdocs/tedeSimplificado/tde_busca/ } \\
\text { resultado-tdes-prog.php }\end{array}$ \\
\hline CIÊNCIA POLÍTICA & $\begin{array}{llll}\text { UNIVERSIDADE } & \text { FEDERAL } & \text { DO } & \text { RIO } \\
\text { GRANDE DO SUL (UFRGS) } & & \end{array}$ & http://www.lume.ufrgs.br/handle/10183/1 \\
\hline POLÍTICAS PÚBLICAS & $\begin{array}{lccc}\text { UNIVERSIDADE } & \text { FEDERAL } & \text { DO } & \text { RIO } \\
\text { GRANDE DO SUL (UFRGS) } & & \end{array}$ & http://www.lume.ufrgs.br/handle/10183/1 \\
\hline $\begin{array}{l}\text { RELAÇÕES } \\
\text { INTERNACIONAIS }\end{array}$ & UNESP - UNICAMP - PUC-SP & $\begin{array}{l}\text { http://www.santiagodantassp.locaweb.com.br/novo/dissertac } \\
\text { oes-e-teses.html }\end{array}$ \\
\hline $\begin{array}{l}\text { RELAÇÕES } \\
\text { INTERNACIONAIS: } \\
\text { POLIITICA } \\
\text { INTERNACIONAL }\end{array}$ & $\begin{array}{l}\text { PONTIFÍCIA UNIVERSIDADE CATÓLICA } \\
\text { DE MINAS GERAIS (PUC/MG) }\end{array}$ & $\begin{array}{l}\text { http://www.sistemas.pucminas.br/BDP/SilverStream/Pages/p } \\
\text { g_ConsAreaConhecimentoDet02.html }\end{array}$ \\
\hline CIÊNCIA POLÍTICA & $\begin{array}{l}\text { UNIVERSIDADE FEDERAL FLUMINENSE } \\
\text { (UFF) }\end{array}$ & $\begin{array}{l}\text { http://www.bdtd.ndc.uff.br/tde_busca/resultado-tdes- } \\
\text { prog.php?ver=54\&programa=54\&ano_inicio=\&mes_inicio=\& } \\
\text { mes_fim=\&ano_fim=2015\&grau=Todos }\end{array}$ \\
\hline CIÊNCIA POLÍTICA & $\begin{array}{l}\text { UNIVERSIDADE FEDERAL DO PARANÁ } \\
\text { (UFPR) }\end{array}$ & http://dspace.c3sl.ufpr.br:8080/dspace/handle/1884/39760 \\
\hline
\end{tabular}

5 CAPES - $\quad$ Plataforma $\quad$ Sucupira. $\quad$ Disponível $\quad$ em <https://sucupira.capes.gov.br/sucupira/public/consultas/coleta/programa/listaPrograma.jsf>. Acesso em outubro de 2015. 


\begin{tabular}{|l|llr|l|}
\hline $\begin{array}{l}\text { ECONOMIA POLITICA } \\
\text { INTERNACIONAL }\end{array}$ & $\begin{array}{l}\text { UNIVERSIDADE FEDERAL DO RIO DE } \\
\text { JANEIRO (UFRJ) }\end{array}$ & $\begin{array}{l}\text { http://146.164.2.115/F/63N8MSMMU1LU8X2ETCM3VKABH } \\
\text { RKRT3HPGX3BQTV96FNK2P469N-45164?func=find-b- } \\
\text { 0\&local_base=CCJE }\end{array}$ \\
\hline $\begin{array}{l}\text { ESTUDOS } \\
\begin{array}{l}\text { ESTRATÉGICOS } \\
\text { INTERNACIONAIS }\end{array}\end{array}$ & $\begin{array}{l}\text { UNIVERSIDADE FEDERAL DO RIO } \\
\text { GRANDE DO SUL (UFRGS) }\end{array}$ & http://www.lume.ufrgs.br/handle/10183/1 \\
\hline
\end{tabular}

Fonte: elaboração própria.

A partir deste cruzamento e da leitura dos resumos dos trabalhados que atendessem aos critérios de busca, foram identificados cinco registros de trabalhos que tenham se utilizado de algum tipo de metodologia de regressão multinivel/multidimensional/hierárquica no campo. Todos se tratam de teses apresentadas a programas de pós-graduação em ciência política, sendo duas temáticas de pesquisa, no entanto, afetas às relações internacionais:

NETO, Manoel Galdino Pereira. (2011) Determinantes da Adesão a Tratados de Patentes 1970-2000: Convenção de Paris e Tratados de Cooperação de Patentes. Tese de Doutorado em Ciência Política - Universidade de São Paulo - Faculdade de Filosofia, Letras e Ciências Humanas. São Paulo - SP. Disponível em <http://www.teses.usp.br/teses/disponiveis/8/8131/tde-19062012-132734/pt-br.php>. Acesso em outubro de 2015;

CAVALCANTE, Pedro Luiz Costa. (2012) A Política faz a diferença? Uma análise comparada dos determinantes políticos do desempenho dos governos municipais no Brasil. Tese de Doutorado em Ciência Política - Universidade de Brasília - Instituto de Ciência Política. Brasília - DF. Disponível em <http://repositorio.unb.br/bitstream/10482/10612/1/2012_PedroLuizCostaCavalcante.pdf>. Acesso em outubro de 2015;

RIBEIRO, Pedro Feliu. (2012) Comportamento Legislativo e Política Externa na América Latina. Tese de Doutorado em Ciência Política - Universidade de São Paulo - Faculdade de Filosofia, Letras e Ciências Humanas. São Paulo - SP. Disponível em <http://www.teses.usp.br/teses/disponiveis/8/8131/tde-13032013-110702/pt-br.php>. Acesso em outubro de 2015;

CENEVIVA, Ricardo. (2011) O nível de governo importa para a qualidade da política pública? O caso da educação fundamental no Brasil. Tese de Doutorado em Ciência Política - Universidade de São Paulo - Faculdade de Filosofia, Letras e Ciências Humanas. São Paulo - SP. Disponível em <http://www.teses.usp.br/teses/disponiveis/8/8131/tde-25052012-094817/pt-br.php>. Acesso em outubro de 2015; e

MACHADO, Carlos Augusto Mello. (2012) Condicionantes das coligações para o cargo de prefeito no Brasil. Tese de Doutorado em Ciência Política - Universidade Federal de Minas Gerais - Faculdade de Filosofia e Ciências Humanas. Belo Horizonte - MG. Disponível em < este trabalho não está disponível no repositório da UFMG / razão não 
especificada $>$.

A maioria dos resultados encontrados pelas buscas, não elencados acima, referiam-se a modelagens simples de regressão linear ou de regressão logística. Não foi encontrado, no entanto, nenhum trabalho que tenha se utilizado de combinações das seguintes técnicas: modelagem multinível $\mathrm{x}$ distribuição binomial negativa $\mathrm{x}$ correção por inflação de zeros.

\subsubsection{Considerações finais sobre nossa proposta de modelagem}

Conforme discutimos na seção 5.1.2 o uso de modelos ZINB para estudo do sistema de solução de controvérsias da OMC é um fenômeno recente e que ainda carece de um estudo compreensivo que o sistematize como uma proposta de abordagem padrão para análise do OSC. O presente trabalho procurar contribuir para este objetivo de consolidar na literatura a metodologia aqui apresentada.

Ademais, a modelagem proposta no presente trabalho foi desenvolvida com o foco específico de analisar diferenças no comportamento dos países em desenvolvimento (em diferentes subgrupos de renda) em relação aos países desenvolvidos advindas de diferenças relativas de nível de desenvolvimento de forma isolada dos demais efeitos do modelo, o que ainda não foi feito por estudos prévios.

Dessa forma, o presente trabalho se baseará na proposta de Sattler e Bernauer (Ibid) para a definição de efeitos gravitacionais relacionados ao tamanho da economia e estrutura de comércio como as principais variáveis explicativas de nosso modelo. As demais variáveis em geral serão dadas em proporção destas. No entanto, seguindo a desagregação de polos proposta por Copelovitch e Pevehouse (Ibid), construiremos dois modelos "monadic", um para o polo ativo e outro para o polo passivo.

Assim, poderemos captar o comportamento médio agregado das variáveis de subgrupos de renda cujo efeito desejamos testar, tanto no polo ativo independentemente das características específicas do pareamento do reclamante com o acionado, quanto no polo passivo de forma independente das características do reclamante respectivo. Por fim, é importante ressaltar que o processo binomial negativo (contagem) e a inflação de zeros são duas etapas cruciais da elaboração teórica em nosso modelo de polos separados. 
Estes conceitos necessários não apenas para a estimação do modelo face a propostas alternativas, mas para a própria construção lógica de nosso argumento sobre a interpretação dos índices EC e ET introduzidos no capítulo anterior e, por conseguinte, do comportamento dos países em desenvolvimento nos polos ativo e passivo do OSC em relação aos países desenvolvidos.

Ou seja, ao contrário dos dois estudos em questão, onde a modelagem ZINB é tratada apenas como uma proposta alternativa de modelagem a ser testada contra outras possíveis, a determinação das diferentes categorias de ocorrência em nosso modelo (evento com resultado positivo, evento com resultado nulo e não evento) tem implicações teóricas e analíticas fundamentais. Contrariamente aos resultados reportados por Copelovitch e Pevehouse (Ibid), conforme veremos no próximo capítulo, nossos resultados não suportam teórica ou metodologicamente equivalência com um modelo Poisson com correção por inflação de zeros.

\subsection{Seleção das variáveis explicativas}

A partir da revisão da literatura e da discussão teórica realizada neste capítulo, a presente seção se ocupará da seleção das variáveis a serem utilizadas em nossos modelos ZINB (polo ativo e passivo). A preparação dos dados, os ajustes específicos e uma discussão individualizada da evolução de cada variável no período 1995-2012 são apresentados em duas partes nos Anexos a seguir: i) Anexo 4-1 (v. 02, p. 492) variáveis de efeito gravitacional (dimensão econômica); e ii) Anexo 4-2 (v. 02, p. 527) variáveis de efeito discriminatório (dimensões de poder relativo e de capacidade institucional/legal).

Nosso conjunto de variáveis explicativas será o mesmo para ambos os modelos, uma vez que estamos falando fundamentalmente do mesmo fenômeno apenas, no entanto, olhando por perspectivas opostas de direção (polo ativo x polo passivo). Ao realizarmos o tratamento estatístico dos dados e as regressões no Capítulo 6 discutiremos o impacto mensurado de cada variável explicativa sobre a variável resposta específica de cada modelo. Dessa forma, apresentamos a seguir uma descrição de nossas variáveis explicativas propostas. 


\subsubsection{Efeitos gravitacionais}

i) Dimensão econômica - relacionada à estrutura produtiva e do comércio internacional

\section{Tamanho da economia}

O tamanho da economia de cada país será representado por seu Produto Interno Bruto (PIB). O PIB pode ser entendido como uma medida da relevância do país enquanto mercado potencial para governos e empresas estrangeiras e de seu potencial para ganhos de escala das indústrias domésticas que permitam maior competitividade internacional de seus produtos.

Quanto maior a oferta agregada de bens e serviços circulando na economia, maior a probabilidade de que isto afete interesses de exportadores ou importadores no país ou em outros países. Ademais, o PIB possui correlação positiva com outras variáveis como educação e nível tecnológico (NICHOLSON, 2005). Dessa forma, espera-se uma correlação positiva da variável resposta (tanto no polo ativo quanto passivo) com o tamanho da economia.

\section{Comércio internacional}

O caminho definido para o tratamento da influência dos fluxos de comércio na decisão dos países de participar no OSC é sua mensuração em relação ao peso relativo do comércio na economia. Ou seja, ao quanto os países estão expostos em termos relativos aos fluxos de comércio internacional em relação às suas economias. Esta variável será dada pela relação porcentual entre sua corrente de comércio (exportações mais importações) em relação ao seu PIB, denominada de coeficiente de abertura comercial (COMEX).

De forma similar aos efeitos do tamanho da economia, quanto maior a exposição do país aos fluxos comerciais, maior será a probabilidade de que interesses internos ou externos sejam afetados por políticas comerciais domésticas ou de terceiros. Ou seja, o que importaria realmente no processo da tomada de decisão não seria tanto o efeito médio do comércio na economia, mas a intensidade (entendida como volume) com que o comércio exterior afeta determinados grupos na economia, que teriam maior capacidade $\mathrm{e}$ interesse de mobilização do que o conjunto disperso de atores sociais. 
No entanto, uma vez que o volume de operações comerciais depende diretamente do tamanho do PIB e que a corrente de comércio está contida no mesmo, representando seu efeito agregado na economia, para separar o efeito dos fluxos de comércio internacional dos efeitos do PIB utilizaremos seu valor relativo em relação ao mesmo (o coeficiente de abertura). Assim como no caso do PIB, espera-se uma correlação positiva de $Y$ (tanto no polo ativo quanto passivo) com COMEX.

\section{Estrutura do comércio exterior}

A estrutura de comércio exterior de cada país será tratada de forma a captar os efeitos apontados na literatura da diferença de probabilidade de reclamações e acionamentos derivadas de diferenças na composição intra-indústria (agricultura x setores industriais) da pauta comercial.

Uma vez que a literatura aponta para uma maior probabilidade de litigância ligada ao setor agrícola, nossa variável para captar este efeito será a participação porcentual do comércio agrícola na corrente de comércio total do país, a qual denominaremos de AGRI. Espera-se uma correlação positiva entre a prevalência de uma pauta comercial agrícola e litigância no OSC em ambos os polos do modelo.

No caso desta variável, ao estabelecer a mesma como uma proporção do comércio total do país estamos procurando medir especificamente os efeitos distributivos médios, ou seja, como a proporção da agricultura na corrente de comércio afeta a probabilidade média de litigância.

\subsubsection{Efeitos discriminatórios}

i) Dimensão política ou de poder - diz respeito às relações de poder e diferenças de poder relativo

O conceito de poder, apesar de sua grande importância nas relações internacionais, não é pacífico. Cada escola e teoria procura dar contornos distintos e operacionalização diferente para este elemento central da vida internacional. O poder não pode ser medido diretamente e é por este motivo que a adoção de diferentes variáveis proxy para o mesmo traz implicações diferentes. 
Tendo em mente um conceito meramente operacional de poder definido pela teoria relacional defendida por Bobbio (2000, p. 251), poder é a relação entre dois sujeitos de modo que o primeiro obtém do segundo um comportamento que, em caso contrário, não ocorreria. Dessa forma, a operacionalização do poder nas relações, eminentemente econômicas, entre os países no OSC será determinada também por um conjunto de variáveis econômicas. Esta abordagem possui o inconveniente de não captar a possibilidade de linkages com outras áreas e com outras formas de exercer pressão e poder entre os países.

No entanto, uma vez que o que fundamentalmente está em jogo em uma disputa na OMC é um ganho econômico, a premissa é de que a forma mais eficaz de exercer poder neste caso é pela ameaça de impor uma perda econômica em montante suficiente ao outro a ponto de evitar a abertura de uma disputa específica. Desta forma, a dimensão de poder será tratada em nossos modelos com o uso de duas variáveis para captar seus efeitos: o comércio preferencial e a ajuda oficial ao desenvolvimento.

\section{Comércio preferencial}

A ameaça da retirada de vantagens comerciais preferenciais é uma importante medida da relação de poder de um ator sobre o outro que busca exatamente a elevação de seu ganho líquido com o comércio. Ao contrário do comércio preferencial advindo de acordos de complementação econômica, acordos de livre comércio e processos de integração regional, o comércio preferencial obtido por meio de esquemas autônomos, voluntários e unilaterais de preferências comerciais, como o Sistema Geral de Preferências (SGP), podem se converter em veículos eficientes de condução de relações de poder.

De acordo com a Conferência das Nações Unidas sobre Comércio e Desenvolvimento (UNCTAD), atualmente estão em vigor 13 sistemas nacionais de preferências comerciais do tipo $\mathrm{SGP}^{6}$. Os países que oferecem estes mecanismos são: Austrália, Bielo-Rússia, Bulgária, Canada, Estônia, União Europeia, Japão, Nova Zelândia, Noruega, Rússia, Suíça, Turquia e Estados Unidos. No entanto, apesar de sua importância para a economia de alguns países de menor desenvolvimento relativo, além de sua importância histórica, o sistema SGP não capta todo o espectro do comércio 
preferencial suscetível a relações assimétricas de poder.

Atualmente grande parte dos países, mesmo os em desenvolvimento, oferecem algum grau de preferência comercial aos PMD e os países que possuem esquemas de SGP já tradicionais instituíram outros mecanismos de preferências comerciais específicos que estão ainda mais sujeitos a dinâmicas de poder relativo do que o sistema SGP monitorado pela UNCTAD.

Apenas para citar UE e EUA, o primeiro possui instituídos, além do SGP regular, uma linha de SGP específica para os PMD, o esquema Everything but arms (EBA) ${ }^{7}$ e o Acordo de Cotonou (ACP) $)^{8}$. Enquanto o segundo, em adição ao SGP regular e ao SGP para PMD possui ainda o African Growth and Opportunity Act $(\mathrm{AGOA})^{9}$ e o Caribbean Basin Initiative $(\mathrm{CBI})^{10}$.

Dessa forma, mais do que o esquema SGP, o interesse desta pesquisa está em todo o fluxo de comércio preferencial que possa converter-se em veículo de transmissão de relações de poder devido a diferenças de poder relativo entre o par exportadorimportador. Assim, faremos um mapeamento de todo o fluxo de comércio preferencial entre grupos com destacada assimetria ${ }^{11}$ : i) países desenvolvidos $x$ países em desenvolvimento (todos os subgrupos); ii) países em desenvolvimento de renda médiaalta $\times$ PMD; e iii) países em desenvolvimento de renda média-baixa $\times$ PMD.

Em nossa enunciação relativa a esta variável, a mesma será definida como a participação da balança comercial preferencial (exportações preferenciais menos importações preferenciais) na corrente de comércio total do país, a qual denominaremos PREF. Esta será um indicativo da dependência da capacidade exportadora do país do comércio preferencial sujeito a relações de poder ou de sua capacidade de promover ou bloquear fluxos de exportações preferenciais vindas de outros países para seu mercado e, portanto, exercer influência/poder (a depender do valor positivo ou negativo da relação líquida entre exportações e importações preferenciais). Espera-se uma correlação positiva entre a variável e a frequência de uso do OSC no polo ativo. No polo passivo, espera-se

7 Disponível <http://trade.ec.europa.eu/doclib/docs/2013/april/tradoc_150983.pdf>. Acesso em junho de 2016.

8 Disponível em <http://ec.europa.eu/europeaid/where/acp/overview/cotonou-agreement/index_en.htm_en>. Acesso em junho de 2016.

9 Disponível em <https://ustr.gov/issue-areas/trade-development/preference-programs/african-growth-andopportunity-act-agoa>. Acesso em junho de 2016.

10 Disponível em <https://ustr.gov/issue-areas/trade-development/preference-programs/caribbean-basininitiative-cbi>. Acesso em junho de 2016.

11 Considerando como membros de cada grupo apenas aqueles membros da OMC definidos nesta pesquisa. 
que tenha efeito negativo como inibidor da efetividade de acionamentos.

\section{Ajuda oficial ao desenvolvimento}

Outra variável importante para capturar efeitos da dimensão do poder relativo é a ajuda oficial ao desenvolvimento (official development aid - ODA). Ameaças ou a mera possibilidade de redução do montante de ODA podem ser elementos cruciais no processo decisório de alguns países de menor desenvolvimento relativo.

Esta variável será definida como a participação porcentual do volume líquido (doado menos recebido) de ODA na economia nacional do país (em relação ao PIB), a qual denominaremos de ODP, indicando a suscetibilidade do país (recebedor líquido) ou sua capacidade na alocação (doador líquido) de fluxos de ODA. Espera-se uma correlação positiva (maior frequência de uso) no polo ativo e negativa no polo passivo (inibição da efetividade de acionamentos) quanto maior o valor de ODP.

ii) Dimensão institucional e capacidade legal - relacionada à qualidade e capacidade institucional/legal

\section{Capacidade legal/institucional}

Os efeitos da capacidade legal e institucional dos países sobre a frequência de uso do OSC e sobre a inibição de reclamações são indiretos. Ainda não há na literatura grande consenso sobre a significância deste efeito. Alguns estudos mais recentes, no entanto, tem apontado a importância desta dimensão especialmente para a iniciação de disputas. As principais abordagens na literatura para construção de proxies para a capacidade legal/institucional são o uso do número de membros das delegações dos países na OMC em Genebra e o PNB per capita.

Ambas as abordagens apresentam problemas na presente modelagem: a primeira por que é virtualmente impossível saber a direção do efeito neste caso, ou seja, se o tamanho das delegações são uma consequência da própria suscetibilidade do país a demandar/ser acionado no OSC ou a uma capacidade institucional/legal prévia (de acordo com o ditado popular, não sabemos se "o ovo vem antes ou a galinha"); na segunda o problema consiste na alta correlação da variável com outros efeitos, especialmente o PIB. 
Portanto, nossa abordagem para esta variável será baseada no índice de eficácia governamental (government effectiveness), em termos relativos, calculado pelo Banco Mundial. Como este é um índice qualitativo normalizado, que pode assumir valores positivos ou negativos em torno de uma média, ajustes no mesmo são discutidos no Anexo 4. Espera-se uma correlação positiva entre a capacidade legal/institucional e a frequência de acionamentos no polo ativo e uma correlação negativa no polo passivo.

\section{Aprendizado}

Pretendemos também capturar o efeito aprendizado na participação dos países no OSC apontado pela literatura (HURREL, NARLIKAR, 2006). Assim como nossas variáveis explicativas para determinação da participação dos países em desenvolvimento no sistema multilateral de comércio são exógenas, nossa variável aprendizado também deverá ser exógena.

A variável aprendizado, a qual denominaremos APRE, será composta pelo somatório do número de casos em que o país atuou no OSC como parte interessada até o ano corrente em análise. A premissa é de que a atuação dos países especialmente como parte interessada em procedimentos no OSC não está captada pelas variáveis anteriores e tem o importante efeito de contribuir com a familiarização do país com os procedimentos do órgão.

Assim, além de aprender sobre a operação das diversas instâncias do OSC, os países em desenvolvimento poderiam aprender com a práxis de países mais desenvolvidos dos quais podem assimilar experiência, aumentando sua própria capacidade legal/institucional no tema.

Este processo poderia inclusive contribuir para ampliar a capacidade dos PED de avaliar os custos e benefícios de se iniciar uma determinada demanda no OSC, além das probabilidades de sucesso. Espera-se uma pequena correlação positiva entre esta variável e a dependente no polo ativo para os países em desenvolvimento e uma correlação nula ou insignificante para os países desenvolvidos. Não se espera efeito significativo da variável no polo passivo. 


\section{$\underline{\text { Regime político }}$}

O regime político é o conjunto de instituições pelas quais o Estado se organiza para exercer o poder político (BOBBIO, 2011; SOUZA, 2002). Ou seja, é o conjunto de instituições que media a relação entre os detentores do poder político e a sociedade. Dessa forma, trata-se da característica institucional mais importante do Estado. Independentemente da forma de Estado, sistema de governo e forma de governo, o regime político é a medida da representatividade social no exercício do poder político.

Dessa forma, quanto maior for a permeabilidade e representatividade das instituições do Estado face à sociedade, mais competitivo será o jogo de formação das preferências do ator-Estado. Portanto, quanto mais aberto o regime político mais os detentores do poder político precisarão observar as preferências de amplos e diversos grupos sociais na condução das políticas públicas.

Neste caso, a permeabilidade do processo decisório às preferências de grupos de pressão da sociedade na formação de políticas públicas e a transparência são maiores, porém, a efetividade na transmissão destas preferências é baixa, pois muitas se anulam, e a instabilidade da resultante de preferências é maior.

Quanto mais fechado o regime, mais os detentores do poder político podem ignorar pressões sociais (que podem inclusive ser reprimidas) e desenvolver políticas de seu próprio interesse ou de seu grupo ou outros grupos específicos com acesso privilegiado ao aparato estatal.

Caso em que a permeabilidade do processo decisório às preferências de grupos de pressão da sociedade é baixa, porém, para aqueles grupos com acesso privilegiado ao aparato estatal capazes de transpor estas barreira a efetividade na transmissão de suas próprias preferências para as políticas públicas é alta, bem como a estabilidade destas políticas.

Neste sentido, em nosso caso específico, quanto mais fechado o regime político de um país mais a política comercial deste poderá se distanciar das preferências da sociedade, reduzindo a influência das demais variáveis explicativas. De forma diversa, quanto mais aberto o regime mais próxima deverá estar a política comercial das preferências de sua sociedade, reduzindo eventuais distorções.

Para mensurar o grau de abertura do regime político (ao qual denominaremos $\mathrm{POL}$ ) de cada membro durante o período de análise, utilizaremos a base de dados dos 
relatórios anuais de liberdade política e civil no globo "Freedom in the World"12 produzido pelo think thank internacional sediado em Washington DC Freedom House. Cada membro terá POL classificado anualmente de acordo com seus status no relatório do respectivo ano: Livre (LV); Parcialmente Livre (PL); Não Livre (NL).

A partir da classificação anual de status dos países, introduziremos em nossos dois modelos (polo ativo e polo passivo) dummies para PL e NL de modo testar se há efetivamente efeito restritivo sobre a política comercial em função de graus mais autocráticos de regime político em relação ao grupo-alvo em que os modelos estarão centrados (LV).

\subsubsection{Efeitos de diferenças relativas dos níveis de renda}

Em nossos dois modelos (polo ativo e passivo) inserimos covariáveis qualitativas (dummies) nos níveis um (correção da inflação de zeros - zero estrutural/não-evento $\mathrm{x}$ zero condicional/evento com resultado nulo) e dois (contagem - número de sucessos/evento com resultado positivo), representando os subgrupos de renda dos países em desenvolvimento, com divisão do conjunto dos $P E D_{m a}$ e $P E D_{m b}$ em quartis.

Nosso grupo de variáveis dummy ligadas aos níveis de renda, portanto, são: $A A$ (metade superior de renda dos $P E D_{m a}$ ); $A B$ (metade inferior de renda dos $P E D_{m a}$ ); $B A$ (metade superior dos $P E D_{m b}$ ); BB (metade inferior dos $P E D_{m b}$ ) e MD (PMD). Dessa forma, a estimação dos modelos foi centralizada tomando como grupo focal de referência os países desenvolvidos (PD), sendo papel das covariáveis qualitativas de renda captar eventuais diferenças ocultas entre o comportamento médio de cada grupo de renda em referência à média do grupo de referência PD.

Caso for efetivamente possível observar diferenças estatisticamente significativas ligadas a fatores ocultos (extra sistema) ocasionados por diferenças relativas de nível de desenvolvimento, por uma questão de lógica, estas diferenças deveriam ser observadas ao redor do núcleo $A B, B A$ e $B B$. Este conjunto de subgrupos possui centralidade no processo de desenvolvimento. Os subgrupos BA e BB estão mais próximos dos PMD, que ainda não avançaram no processo de desenvolvimento econômico do que do centro dos PED.

\footnotetext{
${ }^{12}$ Disponível em < https://freedomhouse.org/report-types/freedom-world>.
} 
Por sua vez, os AA estão mais próximos do nível de renda dos países desenvolvidos do que do centro dos PED e, portanto, por dedução lógica estão mais avançados no processo de desenvolvimento econômico, reduzindo potenciais diferenças em seu comportamento, em relação aos PD, ocasionadas por diferenças relativas de nível de renda. 


\section{Capítulo 6}

\section{MODELOS DE POLO ATIVO E PASSIVO: DESCRIÇÃO DOS RESULTADOS}

"Fiat lux"

(Provérbio latino)

No presente capítulo apresentaremos uma descrição pormenorizada dos resultados finais obtidos pelos modelos ZINB de polo ativo e passivo. $A$ análise comparativa da convergência dos resultados consolidados para ambos os polos e em face da literatura disponível será realizada na Conclusão após a descrição pormenorizada de todos os resultados no presente capítulo.

Os aspectos metodológicos e operacionais da construção final de nossos modelos, alinhados às discussões teóricas e metodológicas dos capítulos precedentes, bem com a rotina de programação e os resultados dos testes de Vuong (1989) e Clarke (2007) para comparação com modelos os "intermediários" são apresentados em detalhes no Anexo 5 (v. 02, p. 564).

Para empreender esta tarefa, apresentaremos no referido Anexo testes comparativos em relação aos modelos "intermediários" (Poisson e Binomial Negativo) investigados na construção de nossos modelos ZINB finais. Serão discutidos, ainda, aspectos gerais da programação das estimações dos modelos e os conceitos de teste de modelos e de significância de coeficientes que serão necessários na interpretação dos resultados do presente capítulo.

\subsection{Descrição dos resultados da modelagem ZINB}

\subsubsection{Descrição dos resultados - Modelo ZINB Polo Ativo (REC)}

O resultado final da estimação dos parâmetros do Modelo ZINB Polo Ativo proposto neste estudo pode ser observado no Quadro 6.1 na página a seguir. O resultado completo da estimação do modelo está disponível no Anexo 5-6 (v. 02, p. 587) e o resultado completo da previsão da probabilidade de inflação de zeros (p0) e do valor esperado da contagem de reclamações-padrão (cREC) para cada país/ano 
individualmente está disponível no Anexo 6-1 (v. 02, p. 607).

Uma vez que os resultados apresentados referem-se a um modelo não linear e que a interpretação do nível 1 (inflação de zeros) e do nível 2 (contagem) deve ser distinta, sendo os coeficientes do primeiro interpretados enquanto probabilidades e os dos segundo enquanto unidades de conta, para facilitar a discussão e interpretação do modelo, apresentaremos no Quadro 6.2 os coeficientes estimados já exponenciados, com a direção do efeito e em bases porcentuais ou de contagem em cada caso.

Quadro 6.1: Modelo ZINB Polo Ativo - Resultado

\begin{tabular}{|l|c|c|c|c|c|c|}
\hline \multicolumn{7}{|c|}{ Estimativa dos Parâmetros } \\
\hline Parâmetro & Estimativa & $\begin{array}{c}\text { Erro- } \\
\text { Padrão }\end{array}$ & Valor $\mathbf{t}$ & Prob > It & \multicolumn{2}{|c|}{$\begin{array}{c}\text { Intervalo de } \\
\text { Confiança (95\%) }\end{array}$} \\
\hline z0 & 9,5160 & 2,2435 & 4,24 & $<0,0001$ & 5,1158 & 13,9163 \\
\hline zAA & $-1,4958$ & 1,1625 & $-1,29$ & 0,1983 & $-3,7758$ & 0,7841 \\
\hline zAB & $-1,2543$ & 0,8131 & $-1,54$ & 0,1231 & $-2,8491$ & 0,3404 \\
\hline zBA & $-2,6792$ & 1,0989 & $-2,44$ & 0,0149 & $-4,8344$ & $-0,5240$ \\
\hline zBB & $-3,5097$ & 1,0422 & $-3,37$ & 0,0008 & $-5,5537$ & $-1,4657$ \\
\hline zMD & $-3,0349$ & 1,1733 & $-2,59$ & 0,0098 & $-5,3362$ & $-0,7337$ \\
\hline zPL & $-1,1542$ & 0,6388 & $-1,81$ & 0,0710 & $-2,4070$ & 0,09867 \\
\hline zNL & 1,1384 & 0,7739 & 1,47 & 0,1414 & $-0,3793$ & 2,6562 \\
\hline zPIB & $-0,00773$ & 0,002018 & $-3,83$ & 0,0001 & $-0,01169$ & $-0,00377$ \\
\hline zCOMEX & $-0,00935$ & 0,006123 & $-1,53$ & 0,1269 & $-0,02136$ & 0,002657 \\
\hline zAGRI & $-0,06776$ & 0,02111 & $-3,21$ & 0,0013 & $-0,1092$ & $-0,02637$ \\
\hline zPREF & $-0,00212$ & 0,002572 & $-0,82$ & 0,4097 & $-0,00717$ & 0,002923 \\
\hline zODP & $-0,2738$ & 0,1113 & $-2,46$ & 0,0140 & $-0,4921$ & $-0,05558$ \\
\hline zCAP & $-1,0642$ & 0,4702 & $-2,26$ & 0,0237 & $-1,9864$ & $-0,1420$ \\
\hline zAPRE & $-0,1761$ & 0,05639 & $-3,12$ & 0,0018 & $-0,2867$ & $-0,06548$ \\
\hline cAA & $-0,3037$ & 0,3500 & $-0,87$ & 0,3856 & $-0,9903$ & 0,3828 \\
\hline cAB & 0,5520 & 0,2263 & 2,44 & 0,0148 & 0,1081 & 0,9958 \\
\hline cBA & $-0,06909$ & 0,4006 & $-0,17$ & 0,8631 & $-0,8548$ & 0,7166 \\
\hline cBB & 0,09332 & 0,3448 & 0,27 & 0,7867 & $-0,5830$ & 0,7696 \\
\hline cMD & 0,3801 & 0,3159 & 1,20 & 0,2290 & $-0,2394$ & 0,9997 \\
\hline cPL & $-0,4129$ & 0,2531 & $-1,63$ & 0,1030 & $-0,9093$ & 0,08354 \\
\hline cNL & $-0,09086$ & 0,3932 & $-0,23$ & 0,8173 & $-0,8620$ & 0,6803 \\
\hline cPIB & 0,1697 & 0,01650 & 10,29 & $<0,0001$ & 0,1374 & 0,2021 \\
\hline cCOMEX & $-0,00797$ & 0,002055 & $-3,88$ & 0,0001 & $-0,01201$ & $-0,00394$ \\
\hline cAGRI & $-0,01990$ & 0,009925 & $-2,00$ & 0,0452 & $-0,03936$ & $-0,00043$ \\
\hline
\end{tabular}




\begin{tabular}{|l|c|c|c|c|c|c|}
\hline \multicolumn{7}{|c|}{ Estimativa dos Parâmetros } \\
\hline Parâmetro & Estimativa & $\begin{array}{c}\text { Erro- } \\
\text { Padrão }\end{array}$ & Valor $\mathbf{t}$ & Prob > |t| & \multicolumn{2}{|c|}{$\begin{array}{c}\text { Intervalo de } \\
\text { Confiança (95\%) }\end{array}$} \\
\hline cPREF & 0,002658 & 0,001588 & 1,67 & 0,0942 & $-0,00046$ & 0,005772 \\
\hline cODP & 0,02614 & 0,09401 & 0,28 & 0,7810 & $-0,1583$ & 0,2105 \\
\hline cCAP & 0,1885 & 0,06052 & 3,11 & 0,0019 & 0,06981 & 0,3072 \\
\hline cAPRE & $-0,01272$ & 0,002848 & $-4,47$ & $<0,0001$ & $-0,01831$ & $-0,00713$ \\
\hline alfa & 0,3739 & 0,1115 & 3,35 & 0,0008 & 0,1552 & 0,5927 \\
\hline
\end{tabular}

Fonte: elaboração própria.

Quadro 6.2: Modelo ZINB Polo Ativo - Interpretação dos coeficientes

\begin{tabular}{|l|c|l|c|}
\cline { 3 - 4 } \multicolumn{2}{r|}{$\begin{array}{r}\text { NíVEL 1 } \\
\text { Processo de Inflação de Zeros } \\
\text { (Zero estrutural) }\end{array}$} & \multicolumn{2}{c|}{$\begin{array}{r}\text { NívEL 2 } \\
\text { (Zecesso de Contagem }\end{array}$} \\
\hline Parâmetro & Probabilicional)
\end{tabular}

Fonte: elaboração própria.

No nível 1 do modelo (processo de inflação de zeros), conforme pode-se observar, a maioria das variáveis explicativas incorporadas ao modelo são estatisticamente significativas. Neste nível a probabilidade z0 de pertencer ao grupo de zero estrutural quando o valor das demais variáveis é zero aumenta em 13575\%. Todas as variáveis explicativas quantitativas utilizadas no modelo têm efeitos de seus coeficientes estimados na direção correta teorizada, ou seja, o incremento em uma unidade de qualquer destas 
variáveis reduz a probabilidade de ocorrência de um zero estrutural.

O PIB (em bilhões de USD 2005) é a única variável explicativa no nível $1 \mathrm{com} o$ elevadíssimo grau de significância estatística (probabilidade de rejeitar $\mathrm{H} 0$ de $0.01 \%$ ). Seu impacto é também bastante relevante em função do tamanho absoluto dos valores desta variável que representa o tamanho das economias dos membros. O efeito estimado do coeficiente zPIB é de $-99,23 \%$, ou seja, o incremento do PIB em um bilhão de dólares (ceteris paribus) leva no nível 1 a um decréscimo de 99,23\% da probabilidade de ocorrência de um zero estrutural para o membro.

No caso da participação da agricultura na corrente de comércio (AGRI), o incremento em um porcento na participação desta leva a um decréscimo de 93,45\% na probabilidade de ocorrência de zero estrutural com significância estatística de 0,13\% de não rejeitar $H 0$. Já um aumento de $1 \%$ na participação líquida da ajuda oficial ao desenvolvimento doada em relação ao PIB (ODP) reduz em 76,05\% a probabilidade de ocorrência de zero estrutural ao nível de significância de 1,4\% de não rejeitar H0.

A capacidade legal/institucional mostra-se igualmente influente neste nível, correspondendo a elevação em uma unidade de seu valor a uma redução de $34,5 \%$ da probabilidade de zero estrutural a $2,37 \%$ de significância. No caso do aprendizado, cada incremente em uma unidade da variável leva a uma relevante redução de $83,85 \%$ da probabilidade de zero estrutural com significância de apenas $0,18 \%$ de não rejeitar H0.

Dentre as variáveis quantitativas analisadas, apenas COMEX e PREF foram consideradas não significativas no nível 1. Embora o efeito estimado do incremente em uma unidade porcentual do coeficiente de abertura comercial do país em relação ao PIB (COMEX) reduza a probabilidade de zero estrutural em 99,07\% com aproximadamente $12,69 \%$ de probabilidade não rejeitar H0.

O intervalo de confiança a 95\% varia entre $-0,02136$ e 0,002657 para a presente variável, de forma que não é possível determinar com grande certeza estatística a direção real do efeito de COMEX neste nível. Embora a estimativa de COMEX esteja na direção correta esperada, a mesma deve ser considerada não significativa. Uma potencial explicação para a não significância desta variável neste nível é o fato de que o coeficiente de abertura indica o grau de exposição do PIB aos fluxos de comércio internacional.

Desta forma, o efeito principal é captado pelo PIB e é concebível que no processo decisório de engajamento ou não no sistema (zero estrutural) o tamanho da economia do país seja crucial, ao passo que sua exposição relativa ao comércio pode não ser relevante para a decisão sobre o efetivo engajamento no sistema (zero estrutural) mas ainda sim 
ser importante para, uma vez decidida a participação, a determinação da contagem no nível 2 (número de disputas em que o país irá se envolver).

Menos significativa ainda neste nível, no entanto, é a variável participação líquida relativa do comércio preferencial em relação à corrente de comércio total (PREF). Não obstante uma estimativa de redução em 99,79\% para cada incremento porcentual nesta relação, a probabilidade de não rejeitar $\mathrm{HO}$ é de altíssimos 40,97\%. O comércio preferencial não é uma variável significativa na determinação do processo de inflação de zeros. Este resultado era esperado com base no resultado obtido para a própria variável COMEX.

De forma geral, as variáveis ligadas apenas diretamente ao comércio internacional não foram consideradas significativas no nível 1. Com exceção de AGRI que embora represente a proporção do comércio agrícola na corrente de comércio tem o condão de representar indiretamente também uma característica estrutural do PIB. As vantagens comparativas de um país que impulsionam a composição maior de sua balança comercial com produtos agrícolas deriva da própria estrutura produtiva do país e é portanto um aspecto relevante da conformação do PIB.

Neste sentido, a única variável de poder relativo com influência no processo de determinação do engajamento dos países no sistema (zero estrutural) é exatamente a variável com ligação ao PIB e que pode modificar seu valor, a participação líquida da ajuda oficial ao desenvolvimento no próprio PIB. No geral, no nível 1 do modelo, portanto, além do PIB e de suas variáveis moderadoras (AGRI e ODP) há também influência no processo de controle da inflação de zeros das variáveis da dimensão de capacidade institucional/legal CAP e APRE.

No que tange às variáveis qualitativas analisadas, trataremos primeiramente das variáveis de abertura de sistema político. Existe pouca consistência na indicação do modelo de que algum grau de autarquia, ou seja, redução de abertura do sistema político ou do processo decisório, do status "Livre" para "Parcialmente Livre" leve a uma redução da probabilidade de ocorrência de zero estrutural em 31,53\% com probabilidade de não rejeitar $\mathrm{HO}$ de $7,1 \%$.

A variável pode ser considerada de pequeno grau de significância, no entanto, a direção negativa do efeito está apenas parcialmente definida com variação marginal no espectro positivo (embora praticamente toda a amplitude de variação esteja no campo negativo do efeito). Portanto, pode-se concluir que embora o modelo não comprove este efeito há indicação de alguma influência sutil na transição do nível de abertura do sistema 
político de "Livre" para "Parcialmente Livre" no aumento da probabilidade de engajamento no OSC.

Este mesmo fenômeno não é observado na transição para o status mais autárquico de "Não Livre". O referido status tem efeito positivo estimado de aumento da probabilidade de zero estrutural em 313\%. Ou seja, países fechados tem probabilidade de participação no OSC três vezes menor do que países abertos ("Livres"). No entanto, o efeito da variável precisa ser desconsiderado visto que a significância estatística do resultado é reduzida com alta probabilidade de $14,14 \%$ de não rejeitar $\mathrm{H} 0$.

Por sua vez, quando analisamos os resultados da estimação dos coeficientes de nossas variáveis dummy de renda no nível 1, notamos que à exceção dos subgrupos pertencentes aos $\operatorname{PED}_{\text {ma }}(A A$ e $A B)$, que estão mais próximos do nível de renda dos países desenvolvidos, os efeitos de todos os demais subgrupos têm significância estatística no processo de inflação de zeros.

No entanto, corroborando a hipótese de trabalho da presente pesquisa, a direção do efeito destas variáveis de renda é negativo neste nível e não positivo. Ou seja, pertencer a um dos subgrupos dos países em desenvolvimento (exceto $A A$ e $A B$ ) reduz a probabilidade de ocorrência de um zero estrutural ao invés de aumentar. Isto significa que estes subgrupos de países em desenvolvimento potencialmente possuem uma maior propensão a participar no OSC do que a média dos países desenvolvidos de referência destas dummies.

Mas em contrapartida, quanto menor o nível de renda per capita do subgrupo menor tende a ser o efeito redutor da probabilidade de zero estrutural. Dessa forma, é seguro dizer que muito embora no caso dos países classificados como BA (metade superior dos $P E D_{m b}$ ), BB (metade inferior dos $P E D_{m b}$ ) e MD (PMD) o tamanho do efeito final para cada país possa ser negligenciável, o mesmo é estatisticamente significativo.

No caso destes grupos de menor renda relativa, o efeito varia de $-6,86$ para os BA (probabilidade t de 1,49\%), passando por $-2,99 \%$ para os BB (probabilidade t de 0,08\%) e chegando a $-4,81 \%$ para os PMD (probabilidade t de 0,98\%). Já no caso das subdivisões do extrato $\mathrm{PED}_{\mathrm{ma}}$, embora o valor da probabilidade estimada seja mais alto em relação aos demais grupos, a significância estatística é menor.

Em relação aos países $A B$ (metade inferior dos $P E D_{m a}$ ) a probabilidade de redução de ocorrência de zero estrutural é de 22,41\% com uma probabilidade de não refutar H0 de $19,83 \%$. No caso dos países AA, o efeito estimado é de $-28,53 \%$ com probabilidade $t$ de $12,31 \%$. Em ambos os casos a direção do efeito está estatisticamente indefinida e os 
mesmos devem ser descartados.

Sendo assim, são consideradas variáveis explicativas significativas de renda no nível 1 do modelo os subgrupos dos países de renda média-baixa (BA e BB) e de menor desenvolvimento relativo (MD). Muito embora o modelo indique no nível 1 a redução da probabilidade de ocorrência de zero estrutural para os subgrupos de renda acima identificados, em razão do efeito conjunto das demais variáveis explicativas estes grupos ainda possuem alta probabilidade de pertencerem a um zero estrutural a cada ano.

A Tabela 6.1 a seguir traz a probabilidade média de ocorrência de um zero estrutural para cada um dos grupos de renda como efeito agrupado de todas as variáveis para cada ano no período de 1995-2012. Conforme se observa da tabela e de acordo com o esperado, a probabilidade média de não participação (estrutural) no OSC é decrescente com o nível renda. Sendo a menor probabilidade a dos países desenvolvidos $(47,33 \%)$ e maior probabilidade de não participação a dos países de menor desenvolvimento relativo $(91,97 \%)$.

Tabela 6.1: Probabilidade média de ocorrência de zero estrutural no polo ativo

\begin{tabular}{cc}
\hline Grupo de renda & Probabilidade Média \\
\hline PD & $47,33 \%$ \\
AA & $55,74 \%$ \\
AB & $68,90 \%$ \\
BA & $64,42 \%$ \\
BB & $67,18 \%$ \\
PMD & $91,97 \%$ \\
\hline
\end{tabular}

Fonte: elaboração própria.

É importante notar, ainda, que esta é apenas a probabilidade estrutural de não participação, ou seja, os excessos de zeros (estruturais) nos dados. Neste sentido, a modelagem da efetiva participação no sistema pode resultar ainda em fracasso (zero condicional) que estará incorporado ao valor da contagem no nível 2. Não obstante estas observações, o modelo prediz com elevada significância estatística que os subgrupos BA, BB e MD terão uma participação no OSC marginalmente maior do que os países desenvolvidos para os mesmos níveis das demais variáveis. Ou seja, terão um valor de $m$ (número de eventos/decisões) maior.

Dessa forma, retomando nossa discussão realizada no Capítulo 4 sobre o índice de eficácia EC dado pela razão porcentual entre o número de sucessos $(k)$ e o número de 
eventos $(m)$, para o cálculo da diferença entre o valor de EC entre os diferentes grupos, empreenderemos agora uma discussão sobre o nível 2 (contagem) do modelo.

No nível 2 do modelo, ao contrário do nível 1 de inflação de zeros, não há intercepto conforme os leitores terão notado da especificação do preditor linear $L_{c^{\prime}}$ apresentado no Anexo 5-1. Portanto não há que se falar um quantidade qualquer de reclamações-padrão protocoladas no OSC quando todas as demais variáveis possuem valores nulos, o que seria um contrassenso teórico. Ademais, a inclusão do parâmetro de intercepto no nível 2 do presente modelo leva a uma probabilidade de não rejeição de $\mathrm{H} 0$ do mesmo de $22,66 \%$ tornando-o estatisticamente não diferente de zero e introduzindo ruído no modelo.

Dentre as variáveis quantitativas explicativas no nível 2 do modelo, apenas ODP e PREF foram consideradas não estatisticamente significativas. A primeira com probabilidade t de $78,1 \%$ e efeito estimado de acréscimo de 1,03 reclamações-padrão a cada $1 \%$ de elevação do índice. Já a segunda, com probabilidade t de $9,42 \%$ não possui direção de efeito definido dentro do intervalo de confiança, embora o efeito estimado seja de acréscimo de uma reclamação-padrão para cada elevação de uma unidade percentual líquida do coeficiente.

Dentre as demais variáveis quantitativas, PIB, COMEX e APRE possuem altíssima significância estatística (probabilidade t de $0,01 \%$ ou inferior). Sendo o efeito da primeira positivo de acréscimo de 1,18 reclamações-padrão a cada elevação de uma unidade da variável e das duas últimas negativo com redução de 0,99 (cada) reclamações-padrão a cada acréscimo de $1 \%$ ou uma unidade das variáveis, respectivamente.

O resultado para os efeitos dos coeficientes de COMEX e APRE pode parecer inusitado à primeira vista, mas em ambos os casos há boas razões teóricas para estes resultados. No primeiro caso, a explicação para a direção do efeito pode estar teoricamente em dois processos distintos. O primeiro teria a ver com a saturação do índice, onde níveis crescentes de abertura comercial poderiam levar a uma diminuição progressiva do uso do OSC (não estruturalmente como no nível 1 mas como parte do processo decisório do nível 2) exatamente em função da exposição elevada do próprio PIB aos fluxos de comércio internacional.

O segundo processo tem a ver com o processo de aprendizado e de autoregulação dos mercados. Quanto mais um determinado país participa do comércio internacional em termos relativos à sua economia, mais este tende a incorporar as práticas e padrões regulares do comércio internacional. Com isto o número de suas violações aos normativos 
tenderia a diminuir bem como a de seus parceiros comerciais principais e quando estas ocorrerem outros mecanismos bilaterais de conciliação podem ser utilizados evitando que o tema se transforme em um painel no OSC.

Este segundo processo é também a explicação potencial para o efeito negativo de APRE. Quanto mais os países aumentam seu estoque de conhecimento e aumentam sua interação no sistema, também aprenderão sobre os custos econômicos ocultos (shadow price) de se levar um disputa à frete no OSC, além do elevado dispêndio de recursos humanos, financeiros e de capacidades diretos, e consequentemente poderão procurar evitá-los com a solução bilateral antes de converter o caso em uma disputa comercial no sistema.

Neste sentido, o efeito de APRE seria efetivamente de reduzir o número de disputas em que estes membros irão se envolver dentro do OSC e, portanto, o número de reclamações-padrão protocoladas. Em contrapartida, o estoque de aprendizado poderia em termos potenciais fazer com que os países tenham melhor desempenho naquelas disputas em que acabarem por efetivamente envolverem-se no OSC.

No entanto, no presente modelo não estamos medindo desempenho e não temos como estimar o valor potencial do aprendizado neste processo, apenas sobre a variável dependente do modelo que é o número de reclamações-padrão protocoladas. É interessante notar que, ao contrário de APRE, o efeito da capacidade institucional/legal (CAP) é positivo com elevação de 1,21 reclamações-padrão protocoladas para cada unidade de acréscimo na capacidade (com probabilidade t de 0,19\%).

Considerando que APRE é uma variável estoque (a cada ano corresponde à soma de todo o aprendizado até o ano em análise) e que CAP é uma variável fluxo (seu valor pode ser alterado anualmente e representa a quantidade de capacidade disponível em cada ano específico), faz sentido que a capacidade disponível a cada ano seja mais relevante para a determinação da quantidade de disputas em que o membro irá se envolver em cada ano específico. Enquanto o estoque de aprendizado pode tornar o mesmo membro mais efetivo nestas disputas, inclusive auxiliando-o a evitar o custo de internalizar no sistema parte destas.

Por fim, a variável AGRI possui significância reduzida, pois, embora a probabilidade t seja de $4,52 \%$ a direção do efeito está bem definida dentro do intervalo de confiança. Assim, o modelo indica que para cada elevação de $1 \%$ da participação da agricultura na corrente total de comércio, há redução de 0,98 reclamações-padrão. 0 modelo apesar de não propiciar uma elevada certeza estatística sobre a variável, indica 
que pode ocorrer neste caso um efeito saturação similar ao observado com a variável COMEX.

O presente modelo não confirmou outros resultados apontados pela literatura de aumento da frequência do uso do OSC correlacionado positivamente com a pauta de comércio agrícola. Discutiremos no próximo capítulo este e outros resultados de forma conjunta para os modelos de polo ativo e passivo em face da literatura. Ao contrário, nosso modelo parece conferir grande relevância ao "empuxo" gravitacional da variável PIB, sendo esta a única variável explicativa gravitacional com efeito positivo e significância estatística.

O PIB é responsável pela determinação da maior parte das reclamações-padrão protocoladas anualmente no OSC. Ainda, quanto menor o nível relativo de renda do país maior o impacto do PIB na determinação do número de disputas em que este se envolverá no polo ativo. Para ilustrar este resultado, plotamos gráficos para cada um dos diferentes subgrupos de renda variando o resultado médio de REC (número de reclamações-padrão protocoladas) em função do PIB enquanto mantivemos constante nos níveis médios todas as demais variáveis.

Na Figura 6.1 abaixo pode-se observar a variação do REC médio em função do PIB para o subgrupo AA. A partir da figura é fácil observar que o grupo $A A$ (nível de $A A=1$ - linha pontilhada) segue uma curva inferior crescente e paralela, porém próxima, à linha de regressão ajustada em relação ao $\mathrm{PIB}$ com $\mathrm{AA}=0$.

\section{Figura 6.1: AA - REC médio ajustado em função do PIB}

Fit for REC

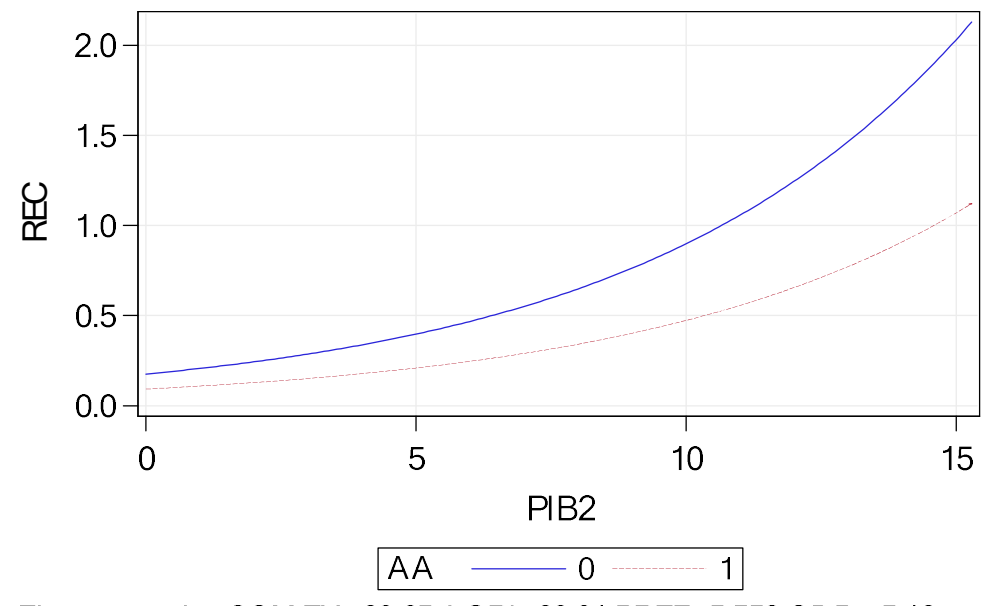

Fit computed at COM EX $=83.65 \mathrm{AGRI}=23.31 \mathrm{PREF}=5.558 \mathrm{ODP}=-5.18$

$\mathrm{CAP}=2.509 \mathrm{APRE}=8.282 \mathrm{AB}=1 \mathrm{BA}=1 \mathrm{BB}=1 \mathrm{M} \mathrm{D}=1 \mathrm{PL}=1 \mathrm{NL}=1$

Fonte: elaboração própria. 
Isto significa que este subgrupo faz em média uma quantidade de reclamaçõespadrão anuais inferior ao determinado exclusivamente por seu PIB e que, portanto, existe efeito geral médio negativo relevante que reduz o número de disputas nas quais seus membros escolhem se envolver.

O que não quer dizer que a resultante deste efeito que reduz o impacto do PIB nesta determinação da contagem provenha de um efeito discriminatório negativo da variável de renda específica do grupo. Neste e nos demais casos que abordaremos a seguir, estamos tratando primeiramente do efeito geral médio de todas as variáveis em relação ao PIB. Investigaremos posteriormente se o efeito de cada uma das variáveis de renda individualmente é estatisticamente significativo ou não.

Por sua vez, a Figura 6.2 a seguir mostra a curva ajustada do grupo $A B(A B=1)$ em relação à regressão ajustada com $A B=0$. Neste caso, a curva de $A B$ é igualmente paralela e mais próxima, porém, superior em relação à linha de regressão geral. $\mathrm{O}$ que mostra que, em termos dos efeitos médios do conjunto de variáveis explicativas, o resultado geral dos efeitos das variáveis sobre o grupo é positivo, fazendo com que este grupo de renda protocole um número maior de reclamações-padrão anualmente do que o determinado por seu PIB.

Figura 6.2: AB - REC médio ajustado em função do PIB

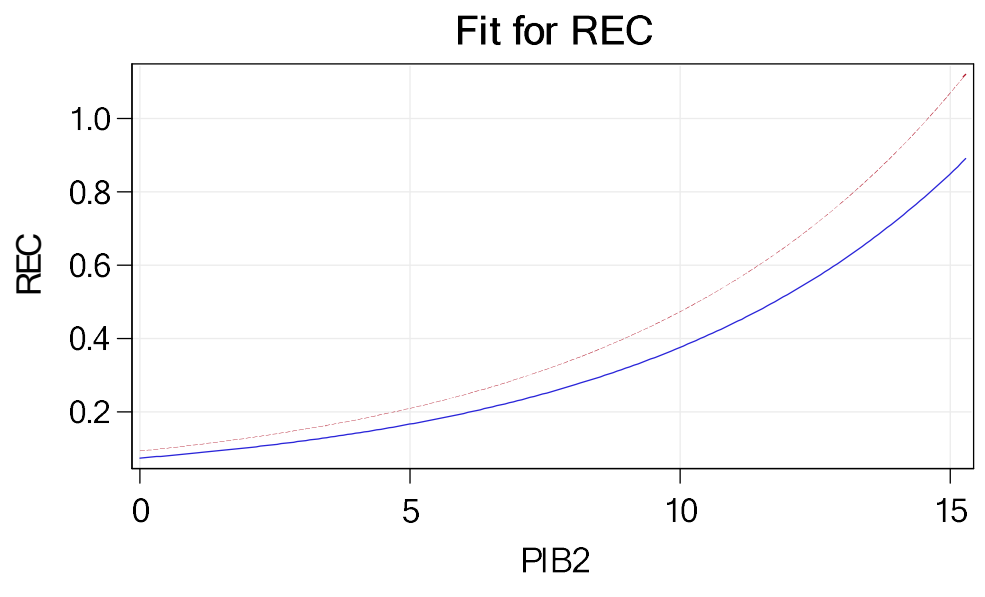

$\mathrm{AB}-0 \quad 1$

Fit computed at $\mathrm{COM} E X=83.65 \mathrm{AGRI}=23.31 \mathrm{PREF}=5.558 \mathrm{ODP}=-5.18$

$\mathrm{CAP}=2.509$ APRE$=8.282 \mathrm{AA}=1 \mathrm{BA}=1 \mathrm{BB}=1 \mathrm{M} \mathrm{D}=1 \mathrm{PL}=1 \mathrm{NL}=1$

Fonte: elaboração própria. 
Já no caso dos grupos BA (Figura 6.3) e BB (Figura 6.4) a seguir, ambos possuem curva ajustadas paralelas, inferiores e bastante próximas de suas curvas ajustadas gerais respectivas, sendo a curva de BB mais próxima do que a de BA. Portanto, o efeito médio final das demais variáveis em relação ao PIB para ambos os grupos é ligeiramente negativo.

Figura 6.3: BA - REC médio ajustado em função do PIB

Fit for REC

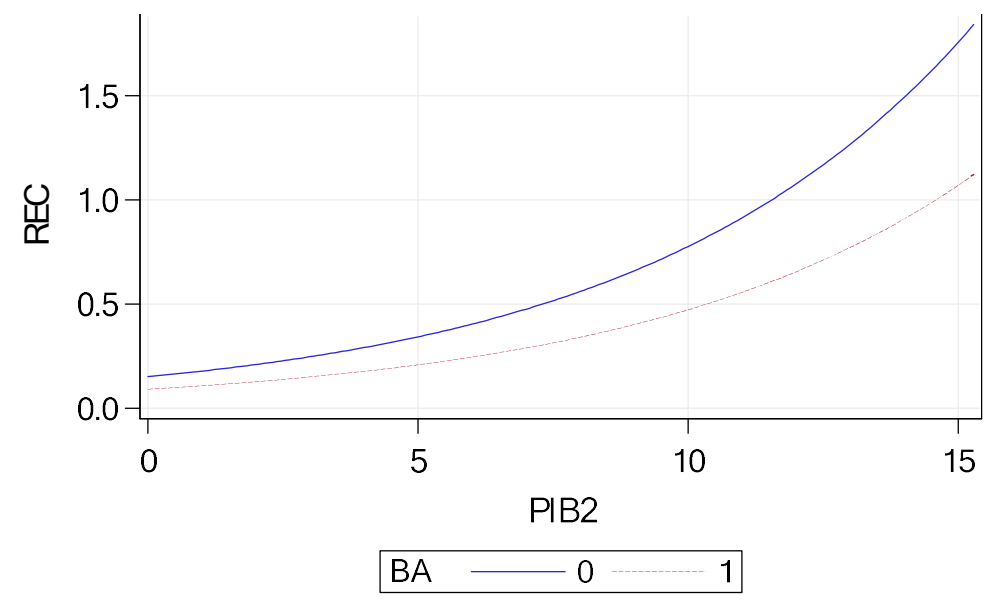

Fit computed at COM EX $=83.65 \mathrm{AGRI}=23.31 \mathrm{PREF}=5.558 \mathrm{ODP}=-5.18$ $\mathrm{CAP}=2.509 \mathrm{APRE}=8.282 \mathrm{AA}=1 \mathrm{AB}=1 \mathrm{BB}=1 \mathrm{MD}=1 \mathrm{PL}=1 \mathrm{NL}=1$

Fonte: elaboração própria.

Figura 6.4: BB - REC médio ajustado em função do PIB

Fit for REC

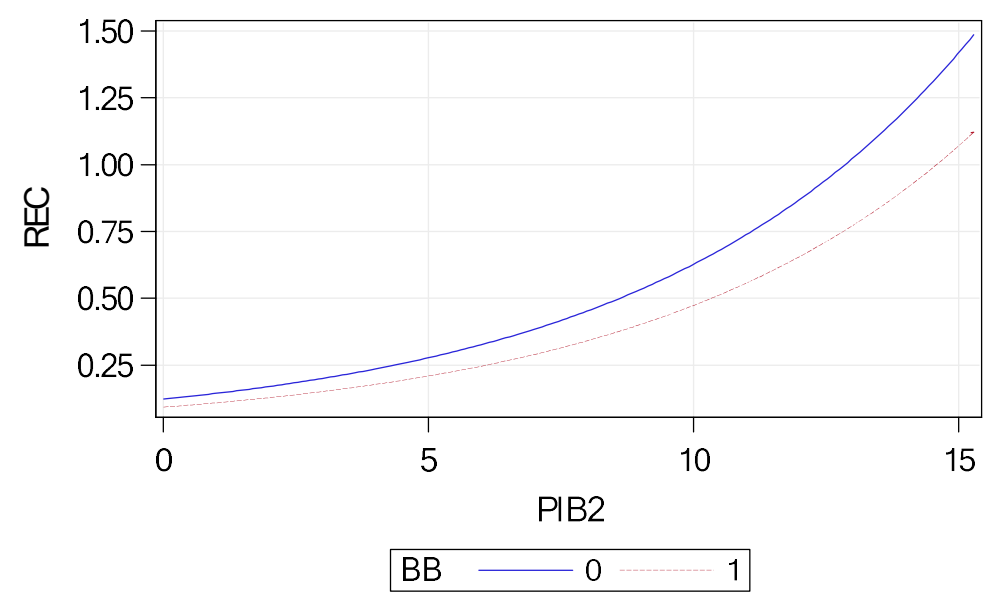

Fit computed at COM EX=83.65 AGRI =23.31 PREF=5.558 ODP=-5.18

$\mathrm{CAP}=2.509$ APRE $=8.282 \mathrm{AA}=1 \mathrm{AB}=1 \mathrm{BA}=1 \mathrm{M} \mathrm{D}=1 \mathrm{PL}=1 \mathrm{NL}=1$

Fonte: elaboração própria. 
Por fim, conforme se observa na Figura 6.5 a seguir e como queríamos demonstrar, a curva ajustada de cada subgrupo de renda vai se aproximando da curva ajustada determinada pelo PIB gradualmente conforme se reduz o nível de renda até que no subgrupo MD ambas as curvas são praticamente idênticas.

Figura 6.5: MD - REC médio ajustado em função do PIB

Fit for REC

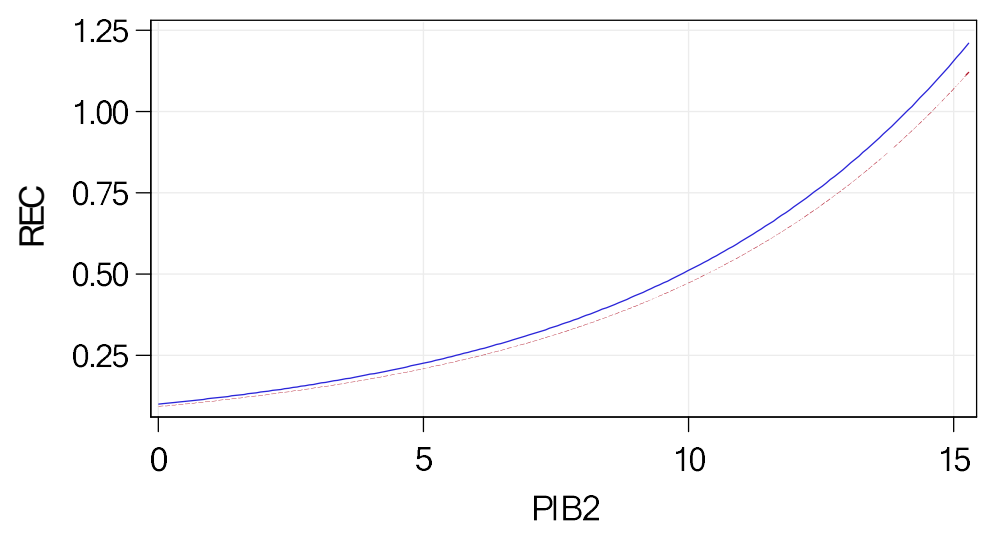

$\mathrm{MD}-0 \quad 1$

Fit computed at COM EX $=83.65 \mathrm{AGRI}=23.31 \mathrm{PREF}=5.558 \mathrm{ODP}=-5.18$

$\mathrm{CAP}=2.509 \mathrm{APRE}=8.282 \mathrm{AA}=1 \mathrm{AB}=1 \mathrm{BA}=1 \mathrm{BB}=1 \mathrm{PL}=1 \mathrm{NL}=1$

Fonte: elaboração própria.

O impacto isolado da variável PIB na determinação do número de reclamaçõespadrão protocoladas é, portanto, bastante relevante e a eficiência deste fator isolado como preditor do valor esperado de reclamações-padrão está negativamente correlacionado ao nível de renda. O que indica que conforme decresce o nível de renda há também tendência de decréscimo do efeito médio de outros fatores que alterem o efeito gravitacional do PIB no efeito final.

Dentre os principais efeitos negativos sobre a participação dos países em desenvolvimento no polo ativo do sistema estão outros dois importantes efeitos gravitacionais que não tem o condão de determinar o valor da contagem como o PIB, mas que atuam como seus moderadores. Trata-se dos efeitos da exposição do PIB aos fluxos de comércio internacional (COMEX) e da proporção do comércio agrícola neste último (AGRI).

Conforme discutimos no Anexo 4-1, todos os subgrupos de países em desenvolvimento possuem valor de AGRI médio sensivelmente superior ao do conjunto dos países desenvolvidos. Ainda, embora o valor de COMEX para os subgrupos dos PED 
seja inferior ao do grupo Outros PD, a participação média da corrente de comércio no PIB destes (exceto PMD) é superior à observada para EUA e UE.

Sendo assim, quanto menor a base do PIB sobre o qual incidirão os efeitos negativos gravitacionais, menor o volume total destes efeitos. Ademais, no caso dos PMD parcela destes efeitos não incidirão sobre o grupo, pois, são em média menos comercialmente abertos do que os demais grupos. $O$ que explica por que as curvas $A A$, $B A, B B$ e MD nas figuras anteriores são paralelas, inferiores e aproximando-se gradativamente da curva ajustada geral conforme se reduz o nível de renda do grupo.

$A$ única exceção a este fenômeno é a curva do grupo $A B$ que foge à tendência e é paralela, porém superior à curva ajustada geral. Conforme veremos a seguir, esta ocorrência particular é explicada pelas características próprias deste subgrupo de renda. Este subgrupo de países intermediários é o único grupo de renda para o qual observamse efeitos discriminatórios causados por diferenças de nível de renda. No entanto, como pode-se observar estes efeitos são positivos e não negativos.

Ou seja, aumentam o número de disputas em que os membros do grupo escolhem se envolver anualmente para além da quantidade determinada pela variação do PIB ao invés de decrescer. No que diz respeito à variáveis dummy analisadas para os demais subgrupos de renda em geral não há evidências de que existam efeitos destas variáveis na determinação do resultado da contagem no nível 2 .

Com exceção de $A B$, todas as demais variáveis não possuem significância estatística devendo ser desconsideradas como efetivas preditoras do valor de REC. Os valores da estatística t para estas é: AA 38,56\%, BA 86,31\%, BB 78,67\% e MD 22,90\%. Já no caso da metade inferior do grupo $P E D_{m a}$, o subgrupo $A B$, há forte evidência no modelo (probabilidade $\mathrm{t}$ de apenas 1,48\%) de que este subgrupo tende a fazer anualmente um maior número de reclamações-padrão (1,74 reclamações a mais) do que os países desenvolvidos quando controladas todas as demais variáveis.

Ou seja, há forte comprovação estatística de que os países intermediários que não estão tão próximos do padrão de renda dos PD como o subgrupo AA e nem em situação de maior vulnerabilidade como os $\mathrm{PED}_{\mathrm{mb}}$ e PMD, possuem um padrão de uso do OSC diferenciado tanto em relação aos países desenvolvidos quanto aos demais subgrupos de renda em desenvolvimento (cujo uso do OSC não se distingue estatisticamente do uso dos PD).

Quanto aos efeitos das variáveis de nível de abertura do sistema político, não foi encontrada significância estatísticas no nível 2 de contagem (PL com probabilidade $t$ de 
$10,30 \%$ e NL de $81,73 \%)$.

Dessa forma, podemos discutir o número médio de reclamações-padrão (REC) protocoladas anualmente por cada grupo de renda previsto pelo modelo, que pode ser observado na Tabela 6.2 a seguir:

Tabela 6.2: REC médio por grupo de renda

\begin{tabular}{cc}
\hline Grupo de renda & REC Médio \\
\hline PD & 0,79 \\
AA & 0,15 \\
AB & 0,24 \\
BA & 0,13 \\
BB & 0,13 \\
PMD & 0,05 \\
\hline
\end{tabular}

Fonte: elaboração própria.

Conforme se observa da tabela acima, o número médio de reclamações-padrão protocoladas pelos países desenvolvidos $(0,79)$ é sensivelmente superior aos dos países em desenvolvimento. Os subgrupos dos $\operatorname{PED} A A(0,15)$, $B A(0,13)$ e $B B(0,13)$ possuem valor esperado de REC bastante próximo. O subgrupo dos $\operatorname{PMD}(0,05)$ possui valor médio inferior, no entanto, isto é explicado pelo PIB médio consideravelmente inferior destes.

Já os $A B(0,24)$, de acordo com o esperado em razão de nossa discussão precedente, são o único subgrupo de renda que foge ao padrão preditivo geral e possuem média superior inclusive que o estrato de renda $A A$. O motivo deste fenômeno não está em diferenças em suas variáveis de efeitos gravitacionais (PIB, COMEX e AGRI) ou de efeitos discriminatórios internos que possuem efeito médio marginal (CAP e APRE), mas sim em sua variável de nível de renda.

Existe a indicação da ocorrência de um fenômeno ligado a este estágio específico de desenvolvimento econômico dos países intermediários que perpassa o processo decisório destes (grupo $A B$ ) e afeta a propensão a se envolverem ativamente em disputas no OSC, o que afeta o valor esperado da contagem para o grupo. O presente trabalho aponta a necessidade do desenvolvimento de estudos de caso e comparados sobre a economia política doméstica do processo decisório destes países que possam contribuir para desvelar este fenômeno.

Por fim, retomando o conceito de nosso índice de eficácia EC relativo, pode-se concluir que não há diferença estatisticamente significativa entre EC para os países 
desenvolvidos em relação à maioria dos subgrupos de renda dos PED (AA, BA, BB e $\mathrm{MD}$ ). Controladas todas as demais variáveis no nível 2 e zeros estruturais no nível 1 , em outras palavras, dado um mesmo número de eventos (número de decisões dada pelo valor médio das demais variáveis no nível 2 após o controle de zeros no nível 1) $m$ para cada um dos grupos, não há evidências estatísticas de que qualquer um destes grupos aufira uma quantidade maior ou menor de sucessos (número de reclamações-padrão) $k$ em relação aos $\mathrm{PD}$.

Ou seja, o coeficiente das variáveis de nível de renda no processo de contagem (nível 2) para estes grupos não tem efeitos estatisticamente significativos quando controlados os zeros estruturais no nível 1 . Já no caso do subgrupo $A B$, há evidências de que o índice de eficácia do subgrupo é mais elevado do que o dos PD. Dados valores médios para todas as variáveis no nível 2 e controlados os não eventos no nível 1 (portanto determinada a mesma quantidade de eventos $m$ no nível de contagem), o número de reclamações-padrão protocoladas (sucessos $k$ ) será 1,74 reclamações-padrão superior para este grupo em relação aos PD.

\subsubsection{Descrição dos resultados - Modelo ZINB Polo Passivo (ACl)}

O resultado final da estimação dos parâmetros do Modelo ZINB Polo Passivo proposto neste estudo pode ser observado no Quadro 6.3 a seguir. $O$ resultado completo da estimação do modelo está disponível no Anexo 5-7 (v. 02, p. 593) e o resultado completo da previsão da probabilidade de inflação de zeros $(\mathrm{p} 0)$ e do valor esperado da contagem de acionamentos-padrão ( $\mathrm{CACl}$ ) para cada país/ano individualmente está disponível no Anexo 6-2 (v. 02, p. 637).

\section{Quadro 6.3: Modelo ZINB Polo Passivo - Resultado}

\begin{tabular}{|l|r|r|r|r|r|r|}
\hline \multicolumn{7}{|c|}{ Estimativa dos Parâmetros } \\
\hline Parâmetro & Estimativa & $\begin{array}{c}\text { Erro- } \\
\text { Padrão }\end{array}$ & Valor $\mathbf{t}$ & Prob > |t| & \multicolumn{2}{c|}{$\begin{array}{c}\text { Intervalo de } \\
\text { Confiança (95\%) }\end{array}$} \\
\hline z0 & 4,5604 & 2,2318 & 2,04 & 0,0412 & 0,1831 & 8,9378 \\
\hline zAA & $-3,7853$ & 1,1814 & $-3,20$ & 0,0014 & $-6,1025$ & $-1,4682$ \\
\hline zAB & $-2,8612$ & 1,1037 & $-2,59$ & 0,0096 & $-5,0259$ & $-0,6966$ \\
\hline zBA & $-4,2393$ & 1,5445 & $-2,74$ & 0,0061 & $-7,2686$ & $-1,2099$ \\
\hline zBB & $-13,7122$ & 6,1329 & $-2,24$ & 0,0255 & $-25,7407$ & $-1,6837$ \\
\hline
\end{tabular}




\begin{tabular}{|c|c|c|c|c|c|c|}
\hline \multicolumn{7}{|c|}{ Estimativa dos Parâmetros } \\
\hline \multirow{2}{*}{$\begin{array}{l}\text { Parâmetro } \\
\text { zMD }\end{array}$} & \multirow{2}{*}{\begin{tabular}{|r|} 
Estimativa \\
$-2,1643$ \\
\end{tabular}} & \multirow{2}{*}{$\begin{array}{r}\begin{array}{c}\text { Erro- } \\
\text { Padrão }\end{array} \\
1,8026 \\
\end{array}$} & \multirow{2}{*}{$\begin{array}{r}\text { Valor } \mathbf{t} \\
-1,20\end{array}$} & \multirow{2}{*}{\begin{tabular}{|r|} 
Prob $>|t|$ \\
0,2301
\end{tabular}} & \multicolumn{2}{|c|}{$\begin{array}{c}\text { Intervalo de } \\
\text { Confiança (95\%) }\end{array}$} \\
\hline & & & & & $-5,6998$ & 1,3713 \\
\hline zPL & $-0,3857$ & 0,7415 & $-0,52$ & 0,6030 & $-1,8400$ & 1,0686 \\
\hline zNL & 10,0396 & 5,7390 & 1,75 & 0,0804 & $-1,2163$ & 21,2956 \\
\hline zPIB & $-0,01081$ & 0,003088 & $-3,50$ & 0,0005 & $-0,01686$ & $-0,00475$ \\
\hline zCOMEX & 0,01622 & 0,008393 & 1,93 & 0,0534 & $-0,00024$ & 0,03268 \\
\hline zAGRI & $-0,00579$ & 0,02505 & $-0,23$ & 0,8172 & $-0,05493$ & 0,04335 \\
\hline zPREF & $-0,00060$ & 0,003626 & $-0,16$ & 0,8693 & $-0,00771$ & 0,006515 \\
\hline zODP & $-0,5890$ & 0,3100 & $-1,90$ & 0,0576 & $-1,1969$ & 0,01891 \\
\hline zCAP & $-0,03069$ & 0,4348 & $-0,07$ & 0,9437 & $-0,8834$ & 0,8220 \\
\hline ZAPRE & 0,008729 & 0,02570 & 0,34 & 0,7341 & $-0,04168$ & 0,05913 \\
\hline cAA & $-0,3973$ & 0,3226 & $-1,23$ & 0,2183 & $-1,0299$ & 0,2354 \\
\hline$C A B$ & 0,05413 & 0,2676 & 0,20 & 0,8397 & $-0,4707$ & 0,5790 \\
\hline cBA & $-0,4951$ & 0,3769 & $-1,31$ & 0,1892 & $-1,2343$ & 0,2442 \\
\hline cBB & $-2,0306$ & 0,4133 & $-4,91$ & $<0,0001$ & $-2,8412$ & $-1,2201$ \\
\hline cMD & 0,5969 & 0,3309 & 1,80 & 0,0715 & $-0,05217$ & 1,2459 \\
\hline cPL & $-0,4455$ & 0,2476 & $-1,80$ & 0,0721 & $-0,9311$ & 0,04000 \\
\hline cNL & 2,2401 & 0,3302 & 6,78 & $<0,0001$ & 1,5924 & 2,8878 \\
\hline cPIB & 0,000197 & 0,000018 & 10,91 & $<0,0001$ & 0,000162 & 0,000232 \\
\hline cCOMEX & $-0,00692$ & 0,002869 & $-2,41$ & 0,0160 & $-0,01254$ & $-0,00129$ \\
\hline cAGRI & 0,01239 & 0,01117 & 1,11 & 0,2676 & $-0,00952$ & 0,03430 \\
\hline cPREF & 0,002019 & 0,002741 & 0,74 & 0,4614 & $-0,00336$ & 0,007395 \\
\hline cODP & 0,1232 & 0,09836 & 1,25 & 0,2106 & $-0,06974$ & 0,3161 \\
\hline cCAP & 0,1556 & 0,06164 & 2,52 & 0,0117 & 0,03474 & 0,2765 \\
\hline CAPRE & $-0,02022$ & 0,002645 & $-7,64$ & $<0,0001$ & $-0,02541$ & $-0,01503$ \\
\hline alfa & 0,2023 & 0,08641 & 2,34 & 0,0194 & 0,03277 & 0,3717 \\
\hline
\end{tabular}

Fonte: elaboração própria.

Assim como no caso do modelo de polo ativo, os resultados apresentados acima referem-se a um modelo não linear. A interpretação do nível 1 (inflação de zeros) e do nível 2 (contagem) deve ser distinta, sendo os coeficientes do primeiro interpretados enquanto probabilidades e os dos segundo enquanto unidades de conta. Para facilitar a discussão e interpretação do modelo, apresentaremos na próxima página os coeficientes estimados já exponenciados, com a direção do efeito e em bases porcentuais ou de contagem em cada caso. 
Quadro 6.4: Modelo ZINB Polo Passivo - Interpretação dos coeficientes

\begin{tabular}{|l|c|l|c|}
\cline { 3 - 4 } \multicolumn{2}{c|}{$\begin{array}{c}\text { Nívec 1 } \\
\text { (Zero estrutural) }\end{array}$} & \multicolumn{2}{c|}{$\begin{array}{c}\text { NíVEL 2 } \\
\text { (Zero condicional) }\end{array}$} \\
\hline Parâmetro & Probabilidade & Parâmetro & Contagem \\
\hline z0 & $9562 \%$ & cAA & $-0,67$ \\
\hline zAA & $-2,27 \%$ & cAB & 1,05 \\
\hline zAB & $-5,72 \%$ & cBA & $-0,61$ \\
\hline zBA & $-1,44 \%$ & cBB & $-0,13$ \\
\hline zBB & $0 \%$ & cMD & 1,82 \\
\hline zMD & $-11,48 \%$ & cPL & $-0,64$ \\
\hline zPL & $-68 \%$ & cNL & 9,34 \\
\hline zNL & $-2291621 \%$ & cPIB & 1,00 \\
\hline zPIB & $-98,92 \%$ & cCOMEX & $-0,99$ \\
\hline zCOMEX & $101,64 \%$ & cAGRI & 1,01 \\
\hline zAGRI & $-99,42 \%$ & cPREF & 1,00 \\
\hline zPREF & $-99,94 \%$ & cODP & 1,13 \\
\hline zODP & $-55,49 \%$ & cCAP & 1,17 \\
\hline zCAP & $-96,98 \%$ & cAPRE & $-0,98$ \\
\hline zAPRE & $100,9 \%$ & & \\
\hline FOn: & &
\end{tabular}

Fonte: elaboração própria.

No nível 1 (processo de inflação de zeros) do modelo de polo passivo, conforme pode-se observar, a maioria das variáveis explicativas não são estatisticamente significativas. Neste nível a probabilidade base z0 de não receber nenhum acionamentopadrão em um determinado ano quando o valor de todas as demais variáveis são nulos aumenta em $9562 \%$. Ou seja, assim como no polo ativo, no modelo de polo passivo as variáveis explicativas que possuem significância no modelo são capazes de captar bem a diferença na formação dos grupos zero estrutural e zero condicional.

O PIB é a única variável explicativa quantitativa com significância estatística no nível 1 (probabilidade $\mathrm{t}$ de rejeitar $\mathrm{HO}$ de $0.05 \%$ ). Seu impacto na redução da probabilidade de zero estrutural é também alto. O efeito estimado do coeficiente zPIB é de $-98,92 \%$. O incremento do PIB em um bilhão de dólares leva no nível 1 a um decréscimo de $98,92 \%$ da probabilidade de um membro não ser alvo potencial de nenhum acionamento-padrão em determinado ano.

Isto não significa que o membro em questão será efetivamente alvo de um ou mais acionamentos-padrão, pois, o processo de contagem se dá no nível 2. A implicação deste 
resultado é de que para cada unidade de elevação do PIB há um decréscimo de 98,92\% da probabilidade de que o país não tenha sido considerado como alvo potencial de um acionamento-padrão por outro membro. Trata-se, portanto, de uma medida da correlação positiva entre o PIB e a habilitação do país a participar do sistema no polo passivo.

No caso das demais variáveis quantitativas, os valores da estatística t para os coeficientes de AGRI (81,72\%), PREF (86,93\%), CAP $(94,37 \%)$ e APRE $(73,41 \%)$ é extremamente alto e as mesmas devem ser definitivamente descartadas como possíveis preditoras da inflação de zeros. No caso das variáveis COMEX e ODP, embora a probabilidade de não rejeição de $\mathrm{H} 0$ destas variáveis oscile pouco acima dos $5 \%$, isto é o suficiente para fazer com que a direção do efeito das mesmas não esteja definido dentro do intervalo de confiança. Como consequência ambas devem também ser descartadas.

O que se observa, portanto, é que nenhuma das demais variáveis quantitativas é relevante no processo de tomada de decisão sobre a habilitação ou não de um determinado país a ser monitorado como alvo potencial de acionamentos-padrão no OSC. A única variável relevante neste processo é o tamanho da economia do país como alvo potencial.

No que tange às variáveis qualitativas analisadas, trataremos primeiramente das variáveis de abertura de sistema político. Não existe indicação no modelo de que haja efeito na redução de abertura do sistema político ou do processo decisório, do status "Livre" para "Parcialmente Livre" ou para "Não Livre". Probabilidade t de PL é de 7,21\% e de NL é de $8,04 \%$ e em ambos os casos a direção do efeito não está definida no intervalo de confiança.

Por sua vez, quando analisamos os resultados da estimação dos coeficientes de nossas variáveis dummy de renda no nível 1 , notamos que à exceção do subgrupo dos PMD, que estão no final do espectro de renda, os efeitos de todos os demais subgrupos têm significância estatística no processo de inflação de zeros.

No entanto, corroborando a hipótese de trabalho da presente pesquisa, a direção do efeito destas variáveis de renda é negativo neste nível e não positivo. Ou seja, pertencer a um dos subgrupos dos países em desenvolvimento (exceto PMD) reduz a probabilidade de não habilitação (zero estrutural) no sistema ao invés d aumentar.

É importante, porém, observar que embora estatisticamente significativo o efeito dos coeficientes de cada um destes subgrupos no processo de inflação de zeros é desprezível. O efeito estimado para os grupos é: $A A=-2,27 \%$ (probabilidade $t$ 0,14\%), $A B=-5,72 \%$ (probabilidade t $0,96 \%$ ); $B A=-1,44 \%$ (probabilidade $t 0,61 \%$ ); e por fim o grupo 
BB (probabilidade t 2,55\%) tem o efeito tão marginal que com duas casas decimais depois da vírgula pode ser considerado nulo.

Sendo assim, são consideradas variáveis explicativas significativas de renda no nível 1 do modelo os subgrupos de renda $A A, A B, B A$ e $B B$. Mas seus efeitos são tão baixos que podem ser negligenciados em favor de uma interpretação mais simples $\mathrm{e}$ parcimoniosa do modelo.

Muito embora o modelo indique no nível 1 a redução da probabilidade de ocorrência de zero estrutural para estes subgrupos de renda acima identificados, em razão do efeito conjunto das demais variáveis explicativas estes grupos ainda possuem alta probabilidade de pertencerem ao grupo zero estrutural a cada ano. De forma geral, o processo de inflação de zero é explicado completamente pelo tamanho da economia de cada membro (variável PIB)

A Tabela 6.3 a seguir traz a probabilidade média de ocorrência de um zero estrutural para cada um dos grupos de renda como efeito agrupado de todas as variáveis para cada ano no período de 1995-2012. Conforme se observa da tabela e de acordo com o esperado, a probabilidade média de não participação (estrutural) no OSC é apresenta tendência levemente decrescente com o nível renda. Sendo a menor probabilidade a dos países desenvolvidos $(69,49 \%)$ e maior probabilidade de não participação a dos países de menor desenvolvimento relativo $(96,92 \%)$.

\section{Tabela 6.3: Probabilidade média de ocorrência de zero estrutural no polo passivo}

\begin{tabular}{cc}
\hline Grupo de renda & Probabilidade Média \\
\hline PD & $69,49 \%$ \\
AA & $61,71 \%$ \\
AB & $80,35 \%$ \\
BA & $77,25 \%$ \\
BB & $28,11 \%$ \\
PMD & $96,92 \%$ \\
\hline
\end{tabular}

Fonte: elaboração própria.

Observa-se, no entanto, a quebra desta tendência para o subgrupo BB (metade inferior dos $P E D_{m b}$ ) que possui baixíssima probabilidade de não habilitação no sistema no polo passivo (apenas $28,11 \%$ de probabilidade de zero estrutural). Ou seja, o grupo em questão possui uma tendência média muito superior à dos demais grupos a ser um alvo potencial no OSC. Uma vez que este grupo é composto na maior parte do período com a 
participação de Índia e China, duas grandes economias com PIB muito superior à média do grupo, o valor do PIB destes membros acaba por deslocar também a probabilidade média auferida ao grupo. Este resultado específico deverá ser investigado posteriormente à luz dos resultados do nível 2 de contagem.

É importante notar, ainda, que esta é apenas a probabilidade estrutural de não participação, ou seja, os excessos de zeros (estruturais) nos dados. Neste sentido, a modelagem da efetiva participação no sistema pode resultar ainda em fracasso (zero condicional) que estará incorporado ao valor da contagem no nível 2.

No nível 2 do modelo de polo passivo, assim como no de polo ativo, não há intercepto. Portanto não há que se falar uma quantidade qualquer de acionamentospadrão recebidos quando todas as demais variáveis possuem valores nulos, o que seria igualmente um contrassenso teórico. Ademais, a inclusão do parâmetro de intercepto no nível 2 do presente modelo leva a uma probabilidade de não rejeição de $\mathrm{H} 0$ do mesmo de 78,65\% tornando-o estatisticamente não diferente de zero e introduzindo ruído no modelo.

Dentre as variáveis quantitativas explicativas no nível 2 do modelo passivo, AGRI, PREF e ODP foram consideradas não estatisticamente significativas. A primeira com probabilidade t de $26,76 \%$, a segunda de $46,14 \%$ e a terceira de $21,06 \%$. As três variáveis devem ser desconsideradas como potenciais preditoras lineares do processo de contagem no nível 2 do polo passivo.

As demais variáveis quantitativas, PIB, COMEX, CAP e APRE possuem alta significância estatística (probabilidade $t$ de $<0,01 \%, 1,6 \%, 1,17 \%$ e $<0,01 \%$, respectivamente). Sendo o efeito da primeira positivo de acréscimo de 1 acionamentopadrão a cada elevação de um bilhão de dólares do PIB, o que faz com que, a exemplo do polo ativo, devido ao valor absoluto desta variável a mesma seja a principal variável preditiva do processo de contagem (número de acionamentos-padrão recebidos).

O resultado para o efeito do coeficiente de COMEX é idêntico ao observado no polo ativo. A cada acréscimo de $1 \%$ do coeficiente de abertura comercial em relação ao PIB decresce em uma reclamação-padrão o valor esperado recebido pelo membro. A explicação potencial para esta ocorrência é a mesma do polo ativo, pois, os efeitos saturação e de regulação atuam em ambos os polos uma vez que toda transação comercial é composta por um par exportador-importador.

Nos casos de CAP e APRE, de maneira similar ao polo ativo, o efeito estimado da primeira no nível de contagem é $+1,17$ e $-0,98$ acionamentos-padrão para cada aumento de uma unidade destas variáveis, respectivamente. Ou seja, a capacidade está 
correlacionada ao aumento da quantidade estimada de acionamentos-padrão recebidos enquanto o aprendizado à redução dos mesmos.

A explicação potencial para a ocorrência do último efeito no polo passivo é similar à do polo ativo. O aprendizado é uma variável estoque e o acúmulo de aprendizado além de dissuadir potencialmente acionamentos-padrão contra o membro tem 0 efeito de familiarizar o membro com os regulamentos e procedimentos da OMC, de forma a potencialmente reduzir a quantidade de violações efetuadas pelo país e ao mesmo tempo torna-lo mais propenso à resolução antecipada de disputas antes que se transformem em um painel no OSC.

Já para a variável CAP, uma vez que esta possui efeito positivo no polo ativo seria esperado, a princípio, que a mesma possuísse efeito oposto (negativo) no polo passivo, atuando como inibidora de acionamentos-padrão. Ocorre, no entanto, que esta é uma variável de fluxo com correlação positiva com o PIB. Ou seja, na média quanto maior o PIB também maior será a capacidade do país.

Não se trata de uma relação de determinação da capacidade pelo PIB, pois se tratam de dimensões distintas do processo, e a variável CAP isolada é considerada significativa. Mas devido a esta correlação entre PIB e CAP, no processo decisório quando se determina a quantidade de acionamentos-padrão recebidos por um membro provenientes de um outro membro com base em níveis crescentes do PIB do primeiro, acaba-se por também estabelecer indiretamente a mesma relação para CAP.

Ademais, a análise de PIB e CAP mostra que a primeira variável varia ao longo do tempo muito mais do que a segunda. A despeito de possíveis variações bruscas no PIB de um ano para outro dificilmente isto trará impactos imediatos sobre a capacidade do país, a não ser em casos muito extremos de colapso econômico.

Assim, a estabilidade da CAP ao longo do tempo é fator de projeção do status/imagem do país no cenário internacional e pode, portanto, levar a uma percepção de "tamanho" ou "renda" adicionais deste país ao seu PIB efetivamente observado em um determinado momento. O que se traduz em nosso modelo como aumento do número de acionamentos-padrão recebidos por este país independentemente da variação anual do PIB.

$\mathrm{Na}$ verdade, conforme discutiremos no próximo capítulo, ao comparar os resultados dos modelos ZINB para os polos ativo e passivo entre si, os valores de todos os coeficientes das variáveis consideradas significativas em comum para ambos os polos é extremamente próximo e possui a mesma direção. Isto significa que ambos os modelos 
convergem fazendo a necessária conexão entre os dois lados reais do processo: ativo $\mathrm{x}$ passivo.

O PIB é, portanto, também no polo passivo o principal responsável pela determinação do número de acionamentos-padrão recebidos anualmente no OSC. No entanto, conforme veremos nas próximas figuras, o PIB isolado é um bom estimador para os países em desenvolvimento nos grupos mais elevados de renda ( $A A, A B$ e $B A$ ), mas tomado isoladamente leva a grandes distorções nos extratos inferiores de renda (BB e $\mathrm{MD})$.

Para ilustrar estes resultados, plotamos gráficos para cada um dos diferentes subgrupos de renda variando o resultado médio de $\mathrm{ACl}$ (número de acionamentos-padrão recebidos) em função do PIB enquanto mantivemos constante nos níveis médios todas as demais variáveis.

Nas Figuras 6.6, 6.7 e 6.8 a seguir e na próxima página pode-se observar a variação do $\mathrm{ACl}$ médio em função do PIB (em trilhões de USD 2005) para os subgrupos $A A, A B$ e $B A$, respectivamente. É fácil verificar que para todos estes grupos a curva ajustada destes pelo PIB é paralela e bastante próxima à curva geral média ajustada pelo PIB. Sendo a curva dos grupos $A A$ e $B A$ inferiores às curvas médias e a do grupo $A B$ superior.

Figura 6.6: AA - ACI médio ajustado em função do PIB

Fit for $\mathrm{ACl}$

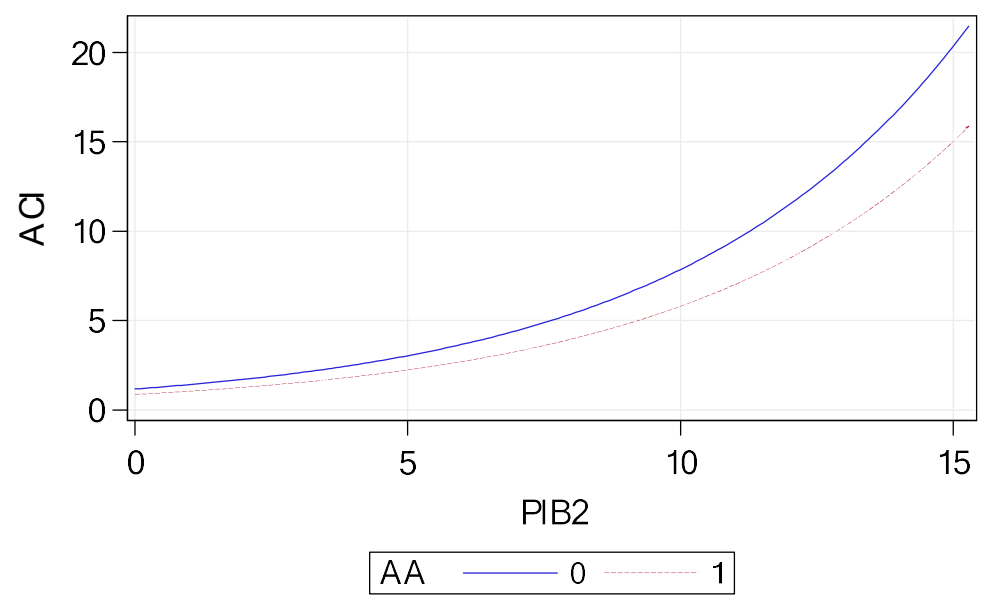

Fit computed at $C O M$ EX $=83.65 \mathrm{AGRI}=23.31 \mathrm{PREF}=5.558 \mathrm{ODP}=-5.18$

$\mathrm{CAP}=2.509 \mathrm{APRE}=8.282 \mathrm{AB}=1 \mathrm{BA}=1 \mathrm{BB}=1 \mathrm{MD}=1 \mathrm{PL}=1 \mathrm{NL}=1$

Fonte: elaboração própria. 
Figura 6.7: $A B$ - $A C I$ médio ajustado em função do PIB

Fit for $\mathrm{ACl}$

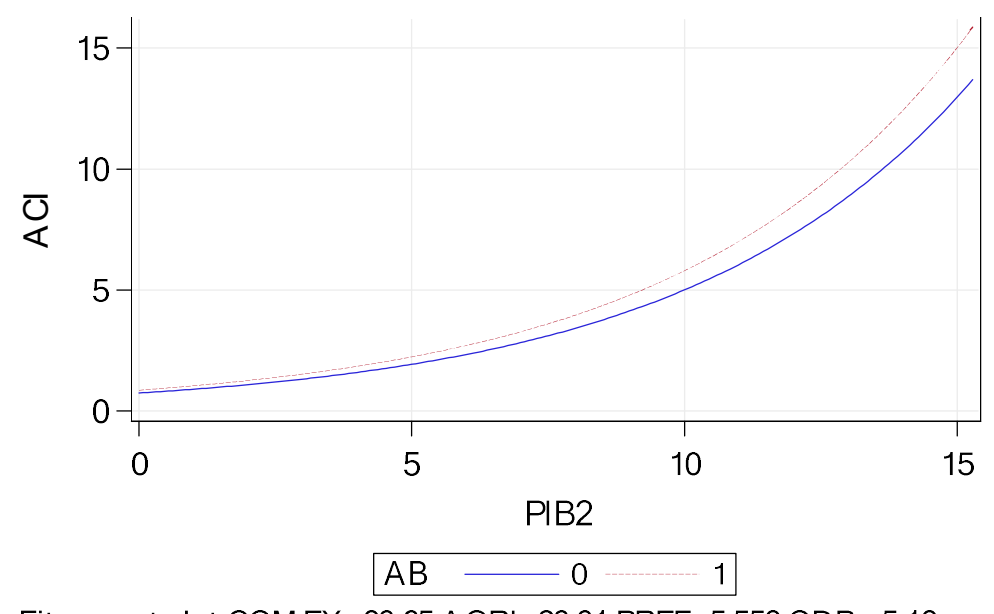

Fit computed at $\mathrm{COM} E X=83.65 \mathrm{AGRI}=23.31 \mathrm{PREF}=5.558 \mathrm{ODP}=-5.18$

$\mathrm{CAP}=2.509 \mathrm{APRE}=8.282 \mathrm{AA}=1 \mathrm{BA}=1 \mathrm{BB}=1 \mathrm{M} \mathrm{D}=1 \mathrm{PL}=1 \mathrm{NL}=1$

Fonte: elaboração própria.

Figura 6.8: BA - ACI médio ajustado em função do PIB

Fit for $\mathrm{ACl}$

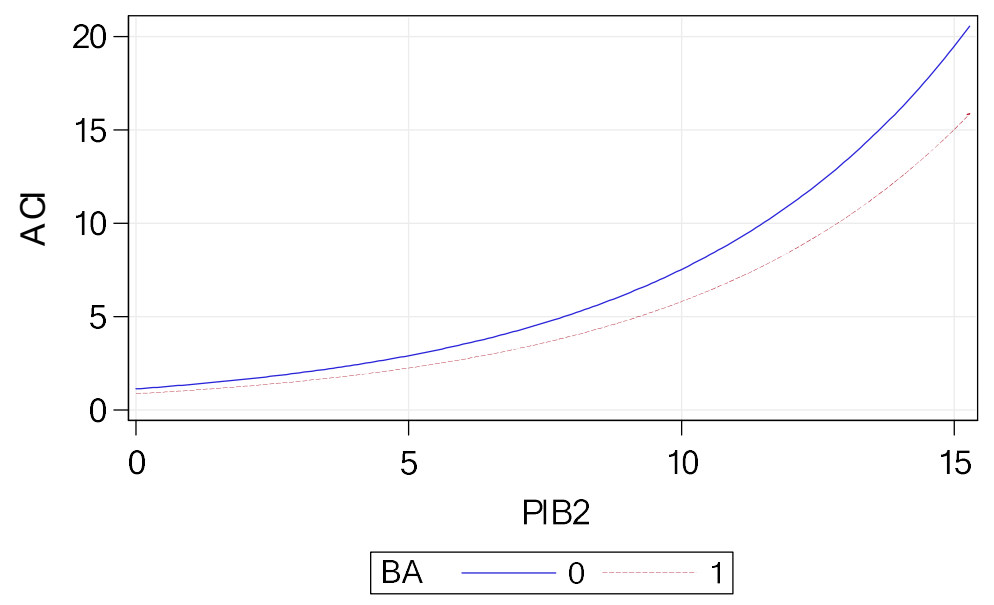

Fit computed at COM EX $=83.65 \mathrm{AGRI}=23.31 \mathrm{PREF}=5.558 \mathrm{ODP}=-5.18$

$\mathrm{CAP}=2.509 \mathrm{APRE}=8.282 \mathrm{AA}=1 \mathrm{AB}=1 \mathrm{BB}=1 \mathrm{MD}=1 \mathrm{PL}=1 \mathrm{NL}=1$

Fonte: elaboração própria.

A interpretação do resultado é extensível do polo ativo, no caso de AA e BA ambos os grupos possuem número médio de acionamentos-padrão recebidos ligeiramente inferior ao estimado isoladamente pelo PIB e no caso de $A B$ o valor esperado é ligeiramente superior ao efeito isolado do PIB. Nos três casos, no entanto, a diferença não é relevante e, portanto, o PIB isoladamente é um bom estimador do valor esperado do número de acionamentos-padrão recebidos por estes grupos. 
Já no caso dos dois subgrupos de renda dos extratos inferiores, a dinâmica muda completamente. Conforme se observa nas Figuras 6.9 e 6.10 a seguir, tanto para BA quanto para MD o PIB isoladamente possui baixo valor preditivo médio. No primeiro caso o grupo recebe um número de acionamentos-padrão expressivamente inferior ao valor esperado isoladamente em função de seu PIB. Já no segundo caso ocorre o inverso, o grupo MD recebe uma quantidade média de acionamentos-padrão consistentemente superior ao valor esperado pelo PIB isoladamente.

Figura 6.9: BB - ACI médio ajustado em função do PIB

Fit for $\mathrm{ACl}$

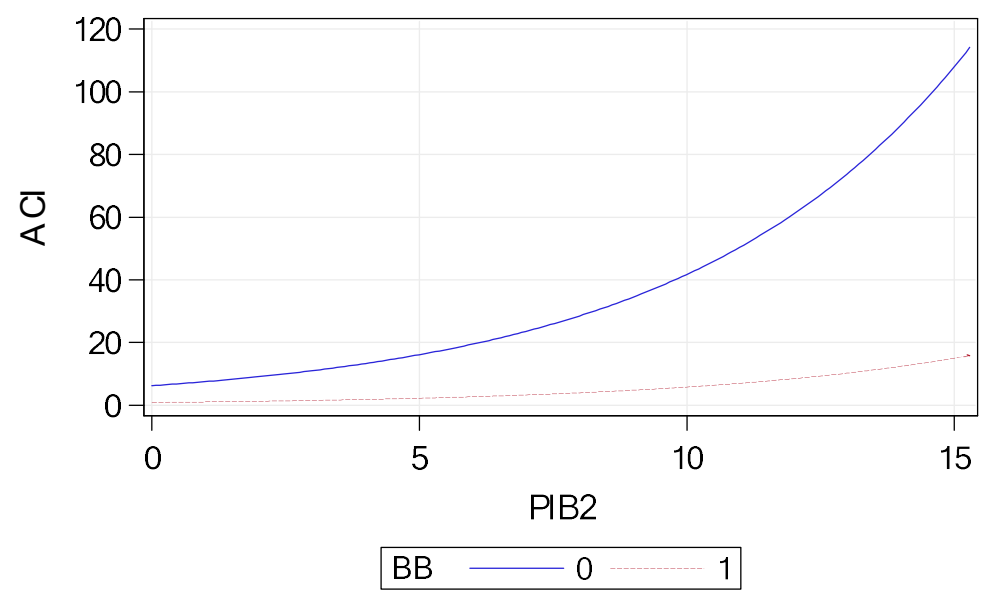

Fit computed at COM EX $=83.65 \mathrm{AGRI}=23.31 \mathrm{PREF}=5.558 \mathrm{ODP}=-5.18$

$\mathrm{CAP}=2.509 \mathrm{APRE}=8.282 \mathrm{AA}=1 \mathrm{AB}=1 \mathrm{BA}=1 \mathrm{MD}=1 \mathrm{PL}=1 \mathrm{NL}=1$

Fonte: elaboração própria.

Figura 6.10: MD - ACI médio ajustado em função do PIB

Fit for $\mathrm{ACl}$

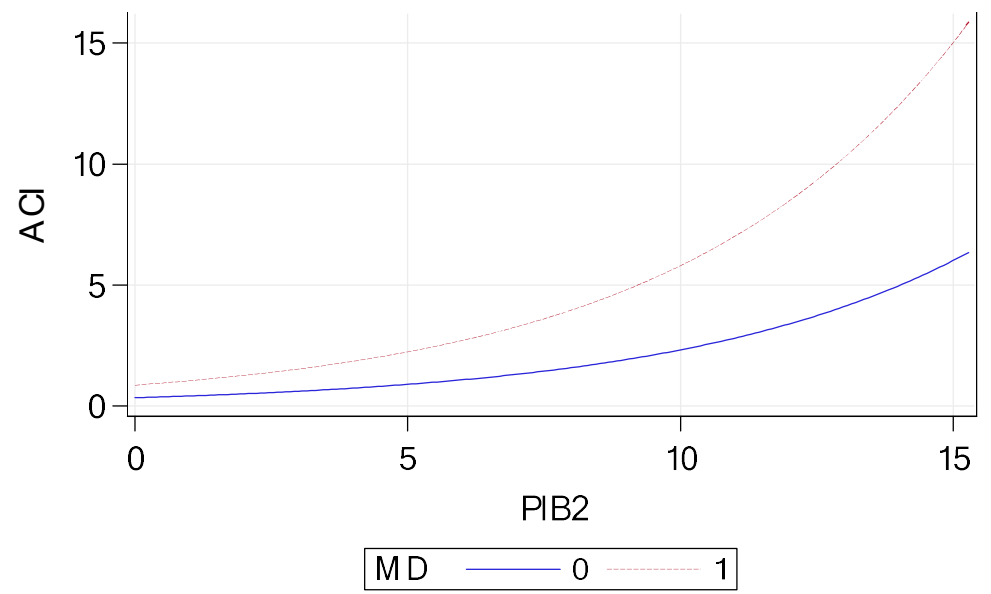

Fit computed at COM EX $=83.65 \mathrm{AGRI}=23.31 \mathrm{PREF}=5.558 \mathrm{ODP}=-5.18$

$\mathrm{CAP}=2.509 \mathrm{APRE}=8.282 \mathrm{AA}=1 \mathrm{AB}=1 \mathrm{BA}=1 \mathrm{BB}=1 \mathrm{PL}=1 \mathrm{NL}=1$

Fonte: elaboração própria. 
O impacto da variável PIB na determinação do número de acionamentos-padrão recebidos é, portanto, bastante relevante e sua eficiência enquanto preditor isolado de $\mathrm{ACl}$ vai na direção contrária à observada para REC no polo ativo. No polo passivo, a capacidade preditiva do PIB cresce com o nível de renda. Este resultado é um indicativo importante de que conforme cresce o nível de renda há tendência de decréscimo do efeito médio de outros fatores que relativizam o efeito gravitacional do PIB no resultado final.

No caso do grupo BB, os resultados em conjunto do nível 1 (inflação de zero) e nível 2 (contagem) nos indicam que em média os membros deste grupo possuem uma probabilidade consistentemente mais elevada de serem monitorados e considerados como alvos potencial pelos demais países (reduzindo a probabilidade de que sejam zeros estruturais).

Porém, durante o processo decisório de determinação do número efetivo de acionamentos-padrão médios recebidos pelo grupo, parcela considerável das decisões resulta em fracasso (não acionamento). Esta interpretação do resultado do gráfico é corroborada pelo efeito estimado do coeficiente de BB no nível 2. Dentre todos os coeficientes ligados aos diferentes níveis de renda este é o único considerado estatisticamente significativo e com o maior grau de certeza estatística possível (probabilidade t de $<0,01 \%$ ).

O efeito esperado do coeficiente é a diminuição média de 0,13 acionamentospadrão recebidos para os membros deste subgrupo de renda. O que indica, novamente retomando os termos introduzidos no Capítulo 4, que há uma inibição de efetividade (ET) contra acionamentos-padrão a este grupo ocasionada por características próprias deste grupo não captadas pelas demais variáveis. Este é um resultado importante, mas ET não é capaz de explicar inteiramente o fenômeno observado. Se a diferença observada entre as curvas adviesse apenas do efeito de ET $=-0,13$, então, ambas deveriam ser paralelas e ET deveria ser a razão de sua diferença em todo o domínio, reduzindo-se a diferença relativa (distância entre as curvas) conforme o crescimento do PIB.

Não é o que se observa, pois, na verdade ocorre o contrário - quanto maior o nível do PIB maior a distância entre as curvas. Assim, chega-se a uma constatação de crucial interesse para este grupo, quanto menor o valor absoluto do PIB de um de seus membros mais eficiente é o próprio PIB deste como preditor isolado do valor esperado de acionamentos-padrão recebidos. Quanto maior o valor absoluto do PIB do membro mais distante (com viés negativo) estará o valor esperado e o estimado pelo preditor isolado do PIB. 
Trata-se de um indicativo da existência de um alto fator de zeros condicionais para este grupo. Ou seja, os países do grupo não estão excluídos a priori (zero estrutural) de serem acionados, no entanto, uma parcela considerável de acionamentos potenciais deixa de ser levada a cabo contra este grupo de renda.

Este é um dos resultados esperados pelo modelo, pois, em termos médios conforme menor o nível de renda do grupo (independendentemente da variação interna do PIB entre seus membros) menores deverão ser os ganhos potenciais médios em uma disputa contra um membro deste grupo e como resultado menor deverá ser a disposição de um terceiro país em acionar um membro do grupo, a despeito da ocorrência de uma violação, resultando não em um zero estrutural mas em um zero condicional (decisão de não-acionamento).

Isto não tem a ver com os efeitos de ET ocasionados pelo coeficiente negativo de $\mathrm{BB}$, pois este efeito já está isolado na modelagem, mas à alta taxa de zeros condicionais que afasta sensivelmente o valor esperado de $\mathrm{ACl}$ para o grupo do valor previstos pelo PIB, tornando esta variável progressivamente menos eficiente na previsão da média do grupo.

A princípio, porém, é necessário interpretar este resultado com cautela visto que a primeira coisa que vêm à mente ao se pensar nas potenciais características de heterogeneidade do grupo BB é a potencial distorção que poderia ser provocada pelo tamanho das economias chinesa e indiana em relação aos demais membros e pela dinâmica própria de acessão da China à OMC.

É importante notar, ainda, que a Índia esteve a maior parte do período em análise (entre 1995 e 2006) classificada como PMD e que a heterogeneidade do mesmo em relação a este grupo é ainda mais aguda do que em relação ao $\mathrm{BB}$. De modo que o resultado da Figura 6.10, que aponta valor esperado de acionamentos-padrão maior para este grupo de renda do que a curva ajustada pelo PIB, deve igualmente ser interpretado com cautela.

A quantidade de acionamentos-padrão recebidos pela Índia neste período tem grande potencial de causar viés de alta sobre a média do grupo MD. Ou seja, esperávamos ver uma curva para MD semelhante à curva para $\mathrm{BB}$, com uma amplitude de diferença da curva média ainda mais aguda inclusive, em razão da dinâmica dos zeros condicionais já relatada. No entanto, a curva observada está acima da curva média. 
Portanto, para testar a hipótese de distorção na tendência média dos grupos BB e MD causada por China e Índia iremos estimar novamente os modelos sem estes dois países. A partir deste resultado, disponível no Anexo 5-8 (v. 02, p. 600), plotamos a seguir novamente os gráficos para cada um dos grupos nas Figuras 6.11 e 6.12, respectivamente.

Figura 6.11: BB - ACI médio ajustado em função do PIB (sem Índia e China)

Fit for $\mathrm{ACl}$

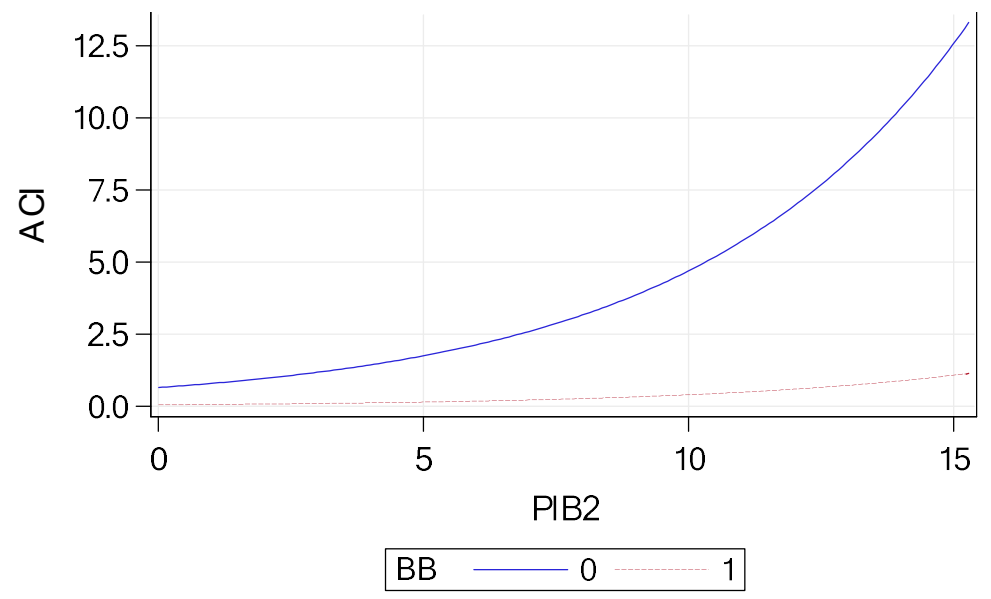

Fit computed at $\mathrm{COM} E X=84.37 \mathrm{AGRI}=23.52 \mathrm{PREF}=5.48 \mathrm{ODP}=-5.26$

$\mathrm{CAP}=2.509 \mathrm{APRE}=7.565 \mathrm{AA}=1 \mathrm{AB}=1 \mathrm{BA}=1 \mathrm{M} \mathrm{D}=1 \mathrm{PL}=1 \mathrm{NL}=1$

Fonte: elaboração própria.

Figura 6.12: MD - ACI médio ajustado em função do PIB (sem Índia e China)

Fit for $\mathrm{ACl}$

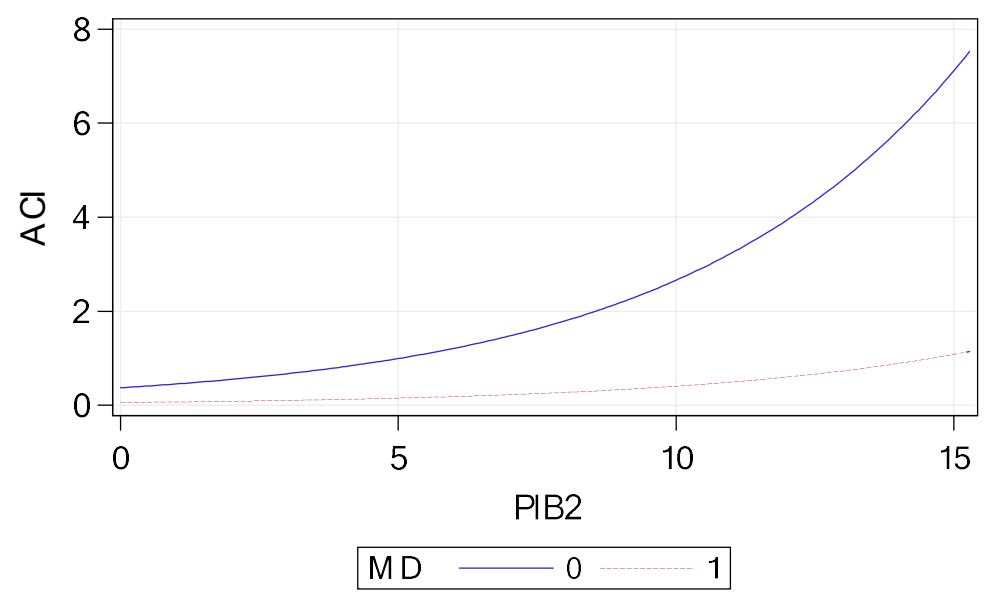

Fit computed at COM EX $=84.37 \mathrm{AGRI}=23.52 \mathrm{PREF}=5.48 \mathrm{ODP}=-5.26$

$\mathrm{CAP}=2.509 \mathrm{APRE}=7.565 \mathrm{AA}=1 \mathrm{AB}=1 \mathrm{BA}=1 \mathrm{BB}=1 \mathrm{PL}=1 \mathrm{NL}=1$

Fonte: elaboração própria. 
Após a retirada de Índia e China notamos que embora os valores de relação do grupo BB tenham sido alterados, não há alteração na tendência anterior. Pode-se concluir, portanto, que estes países não causam grande distorção na forma funcional do ajustamento para o grupo BB. Já no que se refere ao grupo MD observamos uma reversão da tendência anterior. A retirada da Índia do ajustamento deste grupo faz com que a curva do mesmo tenha o mesmo comportamento da curva para BB. A Índia é consequentemente uma fonte de distorção do comportamento esperado para o grupo no polo passivo.

A retirada de ambos os países não altera sensivelmente a estimação dos demais coeficientes do modelo embora leva a alguma pequenas distorções. O valor estimado para ET referente ao grupo BB continua sendo de $-0,13$ acionamentos-padrão. Todas as demais variáveis de renda não possuem significância estatística devendo ser desconsideradas como efetivas preditoras do valor de $\mathrm{ACl}$. Os valores da estatística $\mathrm{t}$ para o modelo completo destas é: AA 21,83\%, AB 83,97\%, BA 18,92\% e MD 7,15\% (com a direção do efeito indefinida).

Quanto aos efeitos das variáveis de nível de abertura do sistema político, não foi encontrada significância estatísticas no nível 2 de contagem para PL (probabilidade $t$ de $7,21 \%$ com direção do efeito indefinido). Ao passo que quanto à dummy NL verificou-se elevada significância estatística (probabilidade de não refutar $\mathrm{HO}<0,01 \%$ ).

A ocorrência desta variável além de estatisticamente significativa leva a um aumento do valor esperado de acionamentos-padrão recebidos em 9,34 unidades pelos países com sistema político fechado/não livre nos níveis médios das demais variáveis controladas. Mesmo no modelo estimado sem os dados de China e Índia o resultado se mantém com viés de baixa marginal a $-9,30$ unidades. Ou seja, a modelagem aqui aplicada é eficiente em separar os diversos efeitos analisados.

Dessa forma, podemos discutir o número médio de acionamentos-padrão ( $\mathrm{ACI})$ recebidos anualmente por cada grupo de renda previsto pelo modelo, que pode ser observado na Tabela 6.4 na página a seguir. Conforme se observa da tabela acima, o número médio de acionamentos-padrão recebidos pelos países desenvolvidos $(0,84)$ é sensivelmente superior aos dos países em desenvolvimento.

Os subgrupos dos $P E D_{\text {ma }}$ possuem médias iguais $(A A=0,22$ e $A B=0,22)$ enquanto o subgrupo $\mathrm{BB}(0,09)$ possui valor médio de $\mathrm{ACl}$ praticamente equidistante de $\mathrm{BA}(0,15) \mathrm{e}$ dos PMD (0,04). A distância acentuada entre BA e BB é causada não apenas pela diferença de valores das variáveis explicativas, mas também por um efeito de inibição de 
efetividade de acionamentos ocorrido em BB.

Tabela 6.4: $\mathrm{ACl}$ médio por grupo de renda

\begin{tabular}{cc} 
Grupo de renda & ACI Médio \\
\hline PD & 0,84 \\
AA & 0,22 \\
AB & 0,22 \\
BA & 0,15 \\
BB & 0,09 \\
PMD & 0,04
\end{tabular}

Fonte: elaboração própria. 


\title{
CONCLUSÃO
}

\author{
"Convicções são inimigos da verdade \\ mais perigosos que as mentiras."
}

Friedrich Nietzsche, Humano, demasiado Humano (2000, p. 150)

As conclusões do presente trabalho dividem-se em duas categorias: resultados e considerações finais. Na primeira, discutimos os resultados de nossa modelagem ZINB descritos no capítulo anterior para cada um dos dois modelos (ativo e passivo) de forma unificada em comparação com os resultados recentes da literatura sobre o tema. $\mathrm{Na}$ segunda, tecemos considerações gerais de cunho qualitativo sobre o tema e suas indicações para o estudo das relações internacionais.

\section{Conclusão - Resultados}

Durante todo o processo de discussão e construção da presente pesquisa, procuramos dialogar em uma via de duas mãos entre o universo teórico e metodológico e o universo empírico, procurando sempre deixar explícitas nossas premissas e abordagem sobre o objeto de pesquisa, de forma que esperamos que este diálogo contínuo tenha podido contribuir para a construção de uma proposta de abordagem metodológica adequada e robusta para o presente estudo.

Do ponto de vista teórico e metodológico, demonstramos a necessidade de avanço da literatura empírica que aborda o fenômeno da litigância no sistema de solução de controvérsias da OMC. A proposta metodológica do presente trabalho pretende contribuir para isto ao auxiliar no equacionamento da separação dos elementos da parte que não podemos observar diretamente deste fenômeno (os fracassos/eventos com resultado nulo e os não-eventos). Apenas se tivermos a capacidade de compreender a completa dinâmica do fenômeno (eventos e não-eventos) poderemos atribuir significado para aquilo que vemos acima da linha d'água (sucessos/eventos com resultado positivo), de acordo com a metáfora do iceberg, em conjunto com o que não podemos ver diretamente abaixo d’água (fracassos/eventos com resultado nulo). 
Dessa forma, tomando por base um reposicionamento teórico e metodológico profundamente arraigado na trama empírica do fenômeno, chegamos à conclusão que um modelo binomial negativo inflado de zeros (ZINB) é a melhor ferramenta para elucidar tanto os eventos (sucessos e fracassos) quanto os não-eventos.

Ao ser construído em dois níveis, um para o processo de inflação de zeros e outro para o processo de contagem, o modelo ZINB é uma ferramenta poderosa para integrar o que está acima e o que está abaixo d'água. Ao olharmos para o primeiro nível do modelo, somos capazes de entender o processo de habilitação dos membros para participação no OSC. Com isto, temos condições de separar os valores nulos dos não-eventos derivados de inação, ou seja, não participação estrutural (zero estrutural), dos valores nulos derivados de ação, ou em outros termos, da decisão de não efetivação de uma reclamação/acionamento (zero condicional).

O valor da variável resposta, resultado observado no OSC, é o mesmo em ambos os casos. Ou mais especificamente, a ausência de observação. No entanto, existe uma diferença qualitativa entre ambos. Enquanto o primeiro diz respeito à incapacidade de participação de um membro no sistema (cuja promoção requer abordagens diferentes), o segundo é parte do resultado da participação deste. Sendo neste caso específico, um fracasso.

E isto precisa ser levado em conta ao analisarmos o comportamento observado dos países no sistema. Portanto, o nível dois do modelo onde ocorre a determinação probabilística da contagem, ou quantidade de sucessos observados, não pode estar dissociado do fenômeno como um todo. Tanto sucessos quanto fracassos compõem o panorama possível de resultados de decisões dos atores no sistema.

A questão relevante é, portanto, se existe diferença no processo que conduz a estes resultados. Em outras palavras, se os determinantes da ação (variáveis explicativas) são os mesmos para os países desenvolvidos e em desenvolvimento. Ou, se existe a operação de efeitos ocultos/externos sobre o fenômeno advindos de diferenças no nível de desenvolvimento relativo dos diferentes grupos. Partimos da hipótese de trabalho de que na não existe diferença neste processo. Nossa hipótese formal será retomada a seguir:

H1: Não há efeitos negativos contra a atuação dos PED no OSC advindos de diferenças relativas de nível de desenvolvimento quando comparados aos PD (após o controle dos 
efeitos estruturais observados no sistema - efeito iceberg e efeitos gravitacionais e discriminatórios).

Na busca por responder a esta questão e testar nossa hipótese, atravessamos a barreira do empírico e colocamos nossas formulações teóricas e metodológicas à prova. Dessa forma, do ponto de vista da análise empírico, após a implementação de todos os ajustes necessários, fomos capazes de refutar HO e comprovar nossa hipótese de trabalho (ausência ou insignificância de efeito negativo de dummies de renda sobre o comportamento dos países em desenvolvimento no OSC) com elevado grau de segurança estatística. Discutiremos a seguir nossos resultados para ambos os polos de forma consolidada e em face de nossa discussão da literatura apresentada no Capítulo 5.

\section{Quadro C.1: Modelos ZINB Polo Ativo e Passivo - Apenas coeficientes} significativos

\begin{tabular}{|c|c|c|c|}
\hline \multicolumn{4}{|c|}{ MODELO DE POLO ATIVO } \\
\hline \multicolumn{2}{|c|}{$\begin{array}{c}\text { NíVEL } 1 \\
\text { Processo de Inflação de Zeros } \\
\text { (Zero estrutural) }\end{array}$} & \multicolumn{2}{|c|}{$\begin{array}{c}\text { NÍVEL } 2 \\
\text { Processo de Contagem } \\
\text { (Zero condicional) }\end{array}$} \\
\hline Parâmetro & $\begin{array}{c}\text { Probabilidade } \\
\text { de zero estrutural }\end{array}$ & Parâmetro & $\begin{array}{l}\text { Contagem } \\
\text { REC }\end{array}$ \\
\hline \multirow[t]{2}{*}{ zo } & $13575 \%$ & & \\
\hline & & CAB & 1,74 \\
\hline zBA & $-6,86 \%$ & & \\
\hline zBB & $-2,99 \%$ & & \\
\hline zMD & $-4,81 \%$ & & \\
\hline zPIB & $-99,23 \%$ & cPIB & 1,18 \\
\hline & & cCOMEX & $-0,99$ \\
\hline zAGRI & $-93,45 \%$ & cAGRI & $-0,98$ \\
\hline ZAPRE & $-83,85 \%$ & CAPRE & $-0,99$ \\
\hline zODP & $-76,05 \%$ & & \\
\hline zCAP & $-34,50 \%$ & cCAP & 1,21 \\
\hline
\end{tabular}

\begin{tabular}{|c|c|c|c|}
\hline \multicolumn{4}{|c|}{ MODELO DE POLO PASSIVO } \\
\hline \multicolumn{2}{|c|}{$\begin{array}{c}\text { NÍVEL } 1 \\
\text { Processo de Inflação de Zeros } \\
\text { (Zero estrutural) }\end{array}$} & \multicolumn{2}{|c|}{$\begin{array}{c}\text { NÍVEL } 2 \\
\text { Processo de Contagem } \\
\text { (Zero condicional) }\end{array}$} \\
\hline Parâmetro & $\begin{array}{c}\text { Probabilidade } \\
\text { de zero estrutural }\end{array}$ & Parâmetro & $\begin{array}{c}\text { Contagem } \\
\mathrm{ACl}\end{array}$ \\
\hline zo & $9562 \%$ & & \\
\hline ZAA & $-2,27 \%$ & & \\
\hline $\mathrm{zAB}$ & $-5,72 \%$ & & \\
\hline \multirow[t]{3}{*}{ zBA } & $-1,44 \%$ & & \\
\hline & & cBB & $-0,13$ \\
\hline & & cNL & 9,34 \\
\hline \multirow[t]{4}{*}{ zPIB } & $-98,92 \%$ & cPIB & 1,00 \\
\hline & & cCOMEX & $-0,99$ \\
\hline & & CAPRE & $-0,98$ \\
\hline & & cCAP & 1,17 \\
\hline
\end{tabular}

Fonte: elaboração própria.

A partir de nossos resultados finais, sumarizados no Quadro acima, concluímos que a principal variável explicativa (quer no polo ativo quer no passivo) tanto do processo de habilitação da participação dos membros no sistema (inflação de zeros) quanto do processo de contagem (determinação do valor esperado de reclamações/acionamentos) é o tamanho da economia de cada membro (PIB). Este resultado corrobora parcialmente o 
fenômeno da dinâmica gravitacional reportado por Sattler e Bernauer (2011).

Ao contrário do resultado do modelo proposto por estes autores, nossos modelos não encontraram significância estatística para o comércio no processo de habilitação, mas considerou-se a variável relevante na determinação da contagem em ambos os polos (número de reclamações protocoladas ou acionamentos recebidos). Este resultado é o inverso do encontrado no estudo referido. Uma parte importante desta diferença neste resultado deve-se à diferença de desenho das pesquisas.

Enquanto o estudo dos autores em questão é estruturado em pares de países (díades) e determina ao mesmo tempo a relação reclamante-acionado e, portanto, a variável comércio diz respeito exclusivamente ao comércio bilateral entre cada par de países específicos, a pesquisa aqui desenvolvida está interessada no efeito médio. A exemplo da proposição de unidirecional de Copelovitch e Pevehouse $(2013 ; 2014)$ nosso foco é a determinação da probabilidade e da contagem de cada polo separadamente.

Ou seja, embora seja uma proposição lógica e bastante razoável que o comércio bilateral seja importante na determinação da probabilidade de que um reclamante específico faça um acionamento contra especificamente outro membro definido no par (reclamante-acionado), quando olhamos em termos médios cada um dos polos separadamente é igualmente razoável conceber que o comércio deixe de ser uma variável relevante face ao efeito maior do tamanho da economia (PIB) na determinação do comportamento médio (e não da escolha do alvo a ser acionado ou na determinação do reclamante específico do qual foi recebida uma reclamação).

Portanto, o resultado reportado pelos autores e o da presente pesquisa são, a princípio, teoricamente conciliáveis. No entanto, a presente pesquisa encontrou resultados bastante interessantes para as variáveis gravitacionais ligadas ao comércio que deverão ser estudados em maior profundidade em pesquisas futuras, preferencialmente, a partir de estudos de caso. As variáveis COMEX e AGRI possuem efeito negativo no nível 2 de contagem do polo ativo e passivo (apenas COMEX é significativo no último).

Uma potencial explicação para este fenômeno é a existência de saturação sobre ambas as variáveis que poderia provocar uma relação quadrática com concavidade negativa ( função com formato $\cap$ ) da variável resposta em função destas variáveis. Para níveis crescentes destas variáveis, até seus respectivos pontos de saturação, o efeito sobre a variável resposta seria positivo, porém, marginalmente decrescente. A partir do nível de saturação o efeito sobre a variável resposta seria negativo e crescente. 
Com isto, para níveis iniciais de abertura comercial e participação da agricultura na corrente de comércio, o efeito sobre o número de reclamações-padrão protocoladas e acionamentos-padrão recebidos tende a ser positivo. Enquanto que a partir do ponto de saturação teórico, progressivamente níveis maiores de abertura e participação da agricultura aumentariam desproporcionalmente a exposição do país aos fluxos comerciais em geral e/ou do setor específico. O que poderia levar a uma retração da participação do país.

Em nenhum dos dois polos foram encontradas evidências da operação de efeitos da dimensão de poder. Encontrou-se, no entanto, evidências da importância da dimensão de capacidade na determinação do número de reclamações-padrão protocoladas a cada ano. O coeficiente desta variável é também positivo no polo passivo, o que nos leva a acreditar que neste polo a mesma variável possa estar captando uma dinâmica do processo decisório dos países em que esta possa ser uma proxy para outros efeitos gravitacionais (ligados ao tamanho da economia) como o status do país alvo.

Uma vez que CAP possui efeito positivo no polo ativo seria esperado que a mesma possuísse efeito oposto (negativo) no polo passivo, atuando como inibidora de acionamentos-padrão. No entanto, esta é uma variável de fluxo com correlação positiva com o PIB, de forma que, em média, quanto maior o PIB maior será a capacidade do país. Devido a esta correlação entre PIB e CAP, no processo decisório quando se determina a quantidade de acionamentos-padrão recebidos por um membro provenientes de um outro membro com base em níveis crescentes do PIB do primeiro, acaba-se por também estabelecer indiretamente a mesma relação para CAP.

Uma vez que o PIB varia ao longo do tempo muito mais do que CAP (como vimos em nossa discussão no Anexo 4-2 sobre a dificuldade de atualização de CAP especialmente para os países em desenvolvimento), a despeito de possíveis variações bruscas no PIB de um ano para outro dificilmente isto trará impactos imediatos sobre a capacidade do país, a não ser em casos muito extremos de colapso econômico.

Assim, a estabilidade da CAP ao longo do tempo é fator de projeção do status/imagem do país no cenário internacional e pode, portanto, estar associada indiretamente a uma percepção gravitacional de "tamanho" adicional deste país ao seu PIB efetivamente observado em um determinado momento. O que se traduz em nosso modelo como aumento do número de acionamentos-padrão recebidos por este país independentemente da variação anual do PIB. 
Estes resultados específicos são sensivelmente diferentes dos reportados pelos autores do modelo ZINB de referência. Nestes encontrou-se evidências da operação de variáveis de poder, mas não de capacidade. Isto pode ser resultado de diferenças de desenho dos modelos e de definição das variáveis explicativas. Os autores em questão utilizaram diferenças no valor logarítmico do PIB e PIB per capita entre pares de países como proxies de poder, bem como o log do PIB per capita e o tamanho das delegações dos países em Genebra como proxies de capacidade.

Novamente, acerca das diferenças de desenho e de objetivo entre ambas as pesquisas, muito embora diferenças de poder relativo possam ser significativas para determinar dentro de um par potencial qual será especificamente o país reclamante e qual o acionado, é igualmente factível que o número médio de reclamações feitas ou acionamentos recebidos de forma isolada tenha pouca, ou nenhuma, influência desta dimensão na formação de sua média.

Ou seja, o poder relativo pode ser uma dimensão relevante para determinação de qual membro será acionado por quem (conforme sugerem os autores). No entanto, o que a presente pesquisa indica é que no valor esperado do número de reclamações/acionamentos, a dimensão gravitacional é crucial e não há influência observável de diferenças de poder relativo. Em termos diversos, a conciliação de ambos os resultados parece indicar que o tamanho da economia e o padrão de comércio determinam a maior parte da contagem média (número de reclamações/acionamentos) e que o poder relativo opera seus efeitos de forma restrita na determinação dos alvos específicos.

No caso da dimensão de capacidade, a comparabilidade das duas proposições é reduzida com nossos modelos, pois, conforme discutimos no Capítulo 5, as proxies escolhidas pela modelagem destes autores em questão trazem problemas adicionais que procuramos evitar no delineamento da presente pesquisa.

De forma geral, as especificações da presente pesquisa leva a modelos de melhor ajustamento e, portanto, com maior potencial explicativo da dinâmica observada no OSC. Enquanto o modelo ZINB proposto por Sattler e Bernauer (Ibid) alcançou índice BIC ("bayesian information criterion") reportado pelos autores de 2266,48, nosso modelo de polo ativo possui BIC 1564,3 (conforme pode ser observado nos resultados do modelo no Anexo 5-6) e o de polo passivo BIC de 1262,5 (conforme pode ser observado nos resultados do modelo no Anexo 5-7). 
O índice BIC é uma medida de ajustamento de modelos onde o modelo estimado é testado contra um modelo hipotético perfeitamente ajustado aos dados baseando-se na função de log-verossimilhança e impondo penalidades para a inserção de parâmetros no modelo. Quanto menor o índice melhor o ajustamento do modelo testado. Para uma discussão sobre programação, estimação e testes de ajustamento de modelos convidamos os leitores à leitura do Anexo 5 (v. 2, p. 564), onde são reportados e discutidos os valores de Log-verossimilhança, Akaike Information Criterion (AIC), Akaike Information Criterion Corrected/Penalized (AICC), Bayesian Information Criterion (BIC) ou Schwarz Bayesian [Information] Criterion (SBC), bem como os testes de Vuong (1989) e Clarke (2007).

Os dois modelos desenvolvidos na presente pesquisa (polo ativo e polo passivo), tratam-se, assim, de modelos ZINB sensivelmente mais ajustados do que o da literatura de referência e, portanto, contribuem para a consolidação da presente proposta metodológica para o tratamento dos determinantes do comportamento dos países no OSC.

Acerca do objetivo da modelagem desenvolvida no presente trabalho, não se verificou influência de fatores externos negativos contra a participação dos países em desenvolvimento no OSC ligados a diferenças no nível de desenvolvimento dos subgrupos de países em desenvolvimento no polo ativo do modelo que reduzam a participação dos países em desenvolvimento no sistema. Na realidade, observa-se como efeito dos subgrupos de renda BA, BB e MD neste polo leve probabilidade negativa no processo de inflação de zeros.

Os três subgrupos, possuem, portanto, probabilidade marginalmente menor de não atuarem como reclamantes-padrão no OSC (zero estrutural) do que os países desenvolvidos (controladas as demais variáveis explicativas). Já no processo de contagem (determinação do número de reclamações-padrão esperadas), o subgrupo $A B$, embora não tenha coeficiente significativo no nível 1, possui efeito positivo estimado de 1,74 unidades de contagem adicionais à média dos países desenvolvidos (para os mesmos níveis das demais variáveis).

Por sua vez, os resultados obtidos na estimação do polo passivo refutam parcialmente a operação de efeitos negativos externos contra a participação dos países em desenvolvidos no OSC ligados a diferenças nos níveis de renda. Em parte, pois, o efeito das variáveis dummy de nível de renda no modelo passivo é misto. No nível 1 (inflação de zeros), os subgrupos $A A, A B$ e $B A$ são alvos mais preferenciais de 
acionamentos do que a média.

Uma explicação potencial para este fato é que isto se deva a seu menor desenvolvimento relativo em relação aos países desenvolvidos, mas conservado ainda assim, mercados domésticos significativos que são alvos potenciais de acionamentos. Do ponto de vista prático, o tamanho do efeito, porém, é estatisticamente negligenciável, variando de $1,44 \%$ a $5,72 \%$ de redução de probabilidade de um zero estrutural em relação aos PD.

O que, no entanto, do ponto de vista teórico é um resultado importante e indica que estes subgrupos de países em desenvolvimento são alvo de um número marginalmente superior de decisões de acionamento do que a média. Por outro lado, este fenômeno não se traduz em um número médio maior de acionamentos efetivamente recebidos por estes grupos de renda no processo de contagem (determinação do valor esperado de acionamentos-padrão recebidos).

Ao contrário, o subgrupo BB, para o qual não foi encontrado efeito significativo no nível 1 de inflação de zeros, possui valor esperado de 0,13 menos acionamentos do que a média. O que indica que este grupo de renda é menos acionado do que a média dos países desenvolvidos, controlados os demais efeitos. O valor absoluto, por sua vez, é bastante baixo e tem impacto reduzido na determinação do comportamento do grupo.

De forma geral, portanto, os países em desenvolvimento embora tenham na média uma tendência maior de participação no sistema de solução de controvérsias tanto no polo ativo quanto passivo do que os países desenvolvidos (menor probabilidade de zero estrutural), na prática este fenômeno se materializa em uma diferença relevante de contagem apenas no polo ativo para os países do extrato de renda média inferior dos $\mathrm{PED}_{\mathrm{ma}}$. Os quais possuem valor esperado de REC maior do que o dos países desenvolvidos.

Os resultados obtidos por nossos modelos quanto ao efeito das variáveis dummies próprias dos subgrupos de níveis de renda não podem ser comparadas diretamente com outros resultados de modelos discutidos na literatura, pois, este efeito não foi mensurado pelos mesmos. Parte do objetivo do presente trabalho consistia exatamente em contribuir com o preenchimento desta lacuna na literatura apresentando uma proposta metodológica para a utilização destas ferramentas específicas para o tratamento da participação dos países em desenvolvimento no OSC. 


\section{Conclusão - Considerações finais}

O uso do sistema de solução de controvérsias pelos membros da OMC, especialmente dos países em desenvolvimento, tem sido o pano de fundo de permanente controvérsia teórica e empírica nas duas últimas décadas. Considerável esforço para elucidar a dinâmica das disputas e a determinação do comportamento dos membros no OSC, com destaque para os países em desenvolvimento, tem sido feito com maior ou menor sucesso por uma grande quantidade de estudos na área. Estes estudos buscam responder basicamente duas perguntas:

i) Como se dá a escalada de disputas comerciais no âmbito do sistema, ou seja, por que alguns conflitos são resolvidos por meio de consultas bilaterais prévias ou na fase anterior à instalação de um painel enquanto outros conflitos são escalados em disputas comerciais na forma de casos no OSC; e

ii) Quais são os determinantes do comportamento dos países no OSC em razão de variáveis explicativas diversas como nível de desenvolvimento, tamanho da economia, estrutura do comércio exterior, dentre outras, que possam explicar a diferença observada na frequência de uso do sistema entre os diferentes grupos de países. Estes determinantes, como forma geral, orbitam em três dimensões principais: econômica (efeitos gravitacionais), de capacidade (efeitos discriminatórios) e de poder (efeitos discriminatórios).

O objetivo principal da presente pesquisa, partindo dos resultados da literatura empírica clássica (MMQ), que apontou e testou os principais determinantes estruturais do comportamento dos países no OSC, e com base nos avanços metodológicos obtidos pela inserção de avançadas metodologias estatísticas/econométricas (MMV) neste campo de estudo, modelagem ZINB, foi a proposição de uma metodologia de tratamento da participação dos países em desenvolvimento no OSC que analise de forma integral este fenômeno em todas as suas dimensões.

Para isto, foram desenvolvidos dois modelos para a determinação do comportamento dos países em desenvolvimento no sistema de solução de controvérsias da OMC. Um para o polo ativo (no qual os países atuam ativamente protocolando reclamações-padrão) e outro para o polo passivo (onde os países atuam passivamente 
recebendo acionamentos-padrão). Os dois polos foram tratados de forma desagregada como dois subsistemas mono-diádicos de um sistema díade maior.

Em outras palavras, o sistema de solução de controvérsias da OMC é um sistema díade (composto necessariamente por dois polos) formado obrigatoriamente por um casopadrão no qual uma reclamação-padrão é igual a um acionamento-padrão, sendo esta díade reciprocamente dependente e autodeterminada. Ou seja, um lado não existe sem o outro, uma reclamação-padrão protocolada no polo ativo não pode existir sem um acionamento-padrão correspondente no polo passivo e vice-versa.

Sendo assim, a maioria dos estudos na área trata este sistema de forma díade diretamente pelo pareamento de um reclamante com um acionado para a formação da díade analítica (também definida como par exportador-importador) que é a base destes estudos. Em geral, estudos tanto clássicos quanto as primeiras proposições ZINB, portanto, tratam a determinação do comportamento dos membros da OMC no sistema de solução de controvérsias de forma díade/pareada.

Assim, como a uma reclamação sempre corresponderá um acionamento específico, estes modelos captam o comportamento dos atores nas relações estabelecidas na formação destes pareamentos. Ou em outros termos, estes modelos estimam o efeito de variáveis explicativas na determinação específica do valor esperado de reclamações de um país $A$ contra os acionamentos recebidos de $A$ por parte de um país $B$. Não se pode falar, por conseguinte, em efeitos médios de forma isolada para quaisquer dos dois países ou polos.

O presente trabalho, no entanto, trata cada um destes polos separadamente, cada um como um lado ou subsistema "mono" do sistema "díade" completo. Com isto, somos capazes de desenvolver um modelo específico para cada um dos polos (ativo e passivo) e estimar os efeitos estruturais médios intervenientes em cada subsistema.

Em consequência, nosso modelo de polo ativo é capaz de estimar o valor esperado (média) de reclamações-padrão feitas por cada membro da OMC (ou grupo de renda) em um determinado ano de forma média independentemente da escolha de alvos específicos. De outro lado, no modelo de polo passivo nosso modelo é capaz de estimar o valor esperado (média) de acionamentos-padrão recebidos por cada membro da OMC (ou grupo de renda) independentemente da fonte destes acionamentos-padrão.

Além disso, ao agregarmos aos nossos modelos (ativo e passivo) a discussão muito recentemente inaugurada na literatura empírica da área sobre o processo de correção da inflação de zeros, qualificamos os modelos propostos a tratarem de forma 
mais compreensiva o fenômeno.

Portanto, com as técnicas incorporadas em nossos modelos binomiais negativos inflados de zero somos capazes não apenas de estimar o valor médio de reclamaçõespadrão (modelo ativo) e acionamentos-padrão (modelo passivo) para cada país/grupo de renda, como estimar a probabilidade de participação ou não de cada país/grupo de renda em cada polo.

Assim, nossa proposta metodológica pode separar probabilistica e qualitativamente a não participação que é parte integrante do comportamento dos países/grupos de renda no sistema e é derivada de uma decisão/evento com resultado nulo (zero condicional) e que, portanto, deve ser incorporada à análise; da não participação derivada de não decisão/não-evento (zero estrutural), que por sua vez deve ser descartada.

Por fim, após o controle dos efeitos estruturais intervenientes na determinação do comportamento dos países no sistema de solução de controvérsias da OMC nos dois polos - (i) efeito iceberg (inflação de zeros); (ii) efeitos gravitacionais; e (iii) efeitos discriminatórios - nossa proposta metodológica foi completada com a inclusão inédita de variáveis categóricas para os diferentes subgrupos de países em desevolvimento.

Com a centralização dos modelos (ativo e passivo) no grupo alvo dos países desenvolvidos e controlados os efeitos acima descritos, nossos modelos são capazes de estimar a existência de diferenças na determinação do comportamento no OSC, em cada um dos polos, entre os países desenvolvidos e os diferentes subgrupos de países em desenvolvimento advindas de diferenças relativas no nível de renda/desenvolvimento de acordo com classificação baseada nos critérios do Banco Mundial.

Dessa forma, podemos concluir que o tamanho do efeito iceberg (nível 1 dos modelos - inflação de zeros) em ambos os polos é apenas marginalmente maior para a maioria dos subgrupos de países em desenvolvimento em relação aos países desenvolvidos.

Ou seja, a maioria dos subgrupos de países em desenvolvimento possui uma probabilidade ligeiramente maior do que os países desenvolvidos a participarem do sistema, quer no polo ativo quer no polo passivo. A diferença entre estas probabilidades, no entanto, é bastante reduzida para esperarmos quaisquer efeitos práticos da mesma na operação regular do sistema.

Quando olhamos para o nível 2 dois dos modelos ativo e passivo (processo de contagem - determinação do valor esperado de reclamações-padrão/acionamentospadrão) é que, porém, notamos as diferenças existentes entre o comportamento ativo e 
passivo dos países em desenvolvimento.

No comportamento passivo, no nível 2 de contagem o valor esperado de acionamentos-padrão recebidos por cada subgrupo de renda dos PED é o mesmo do valor esperado para os $\mathrm{PD}$, com excessão do subgrupo $\mathrm{BB}$ (países em desenvolvimento da metade inferior do extrato de renda média-baixa). No entanto, a diferença observada entre os valores esperados para os PD e o subgrupo BB é muito baixa para permitir que esta constatação opere quaisquer efeitos práticos relevantes no sistema.

Já no comportamento ativo, no nível 2 de contagem o valor esperado de reclamações-padrão protocoladas por cada subgrupo de renda dos PED é o mesmo do valor esperado para os $P D$ à excessão do subgrupo $A B$ (países em desenvolvimento da metade inferior do extrato de renda média-alta). No caso deste subgrupo de renda específico, a diferença de valor esperado é substancialmente maior do que a média de reclamações-padrão protocoladas anualmente no sistema pelos demais membros (que é a mesma para os PD e demais subgrupos de PED nos mesmos níveis das variáveis de controle).

No mesmo nível médio das variáveis de controle, o subgrupo $A B$ possui índice de eficácia EC de 1,74. O que siginifica que os membros deste subgrupo protocolam em média 1,74 mais reclamações-padrão no OSC do que os países desenvolvidos, dado um mesmo número de eventos totais (eventos com resultado positivo e eventos com resultado nulo). Ou seja, este subgrupo de renda específico possui uma taxa de sucesso maior (convertem uma proporção maior de decisões em reclamações-padrão efetivas) do que a dos PD no sistema de solução de controvérsias da OMC.

Diversos países pertencentes, na maior parte do perído em análise, a este subgrupo de renda/desenvolvimento específico, tais como Argentina, Brasil, Chile e México, possuem grandes mercados internos e interesses exportadores bem consolidados. Estes países não estão tão próximos do padrão de desenvolvimento dos países desenvolvidos como o grupo AA nem sofrem das mesmas restrições dos países de menor desenvolvimento classificados como PED $_{\mathrm{mb}}$ e PMD.

O fenômeno observado, assim, pode ser considerado como uma forte evidência empírica em favor das teorias sobre o papel e carcterísticas das potências médias no campo das relações internacionais. Três características fundamentais são comumente utilizadas para o enquadramento dos países no estrato intermediário de potências médias, apesar da falata de consenso na literatura sobre a definição precisa do termo em questão (LIMA, 2007). 
A primeira característica diz respeito às capacidades materiais do país, a segunda à capacidade deste projetar este status ou prestígio a partir destas características no sistema internacional e, por fim, ao reconhecimento deste status pelas grandes potências e demais países no sistema internacional. Para ser enquandrado como uma potência média, portanto, o país precisa não apenas possuir capacidades materiais como buscar que projeção a partir das mesmas no sistema internacional e ter seu status ou prestígio reconhecidos.

Uma visão compreensiva da discussão sobre a conceituação de potências médias e sua inserção na dimensão de mercado (negociações multilaterais e formação de blocos) do sistema multilateral de comércio pode ser encontrada em Leusin Júnior (2015). Há uma extensa literatura abordando o papel das "novas potências"/potências médias e dos BRICS nas negociações multilaterais de comércio da OMC e principalmente na dinâmica de barganha e formação de blocos como o G20 (HURREL, NARLIKAR, 2006; NARLIKLAR, 2004, 2007, 2010; CEPALUNI et al, 2012; EFSTATHOPOULOS, 2012; CARVALHO, 2010).

Considerável atenção tem sido dada também à atuação dos países em desenvolvimento com maiores recursos de poder ou capacidade no sistema de solução de controvérsias da OMC (FRANCOIS et al, 2008; CONTI, 2010; CARVALHO, 2012; RAMANZINI JUNIOR, VIANA, 2012). No entanto, até o presente momento existiam escassas evidências empíricas a corroborar formulações que apontassem especificamente para a existência de diferenças estruturais no comportamento das potências médias neste cenário. Os estudos empíricos na área, conforme discutimos no Capítulo 5, ainda não haviam sido capazes de desagregar os demais efeitos estruturais observados no sistema (efeito iceberg e efeitos gravitacional e discriminatório) dos efeitos externos de diferenças de níveis de renda.

Dessa forma, a proposta de abordagem metodológica desenvolvida no presente trabalho é inédita e, portanto, também nossos resultados empíricos específicos. O que aponta para a necessidade de adensamento das pesquisas empíricas na área de relações internacionais para o estudo deste fenômeno observado no comportamento das potências médias no sistema de solução de controvérsias da OMC.

$\mathrm{Na}$ presente pesquisa, fizemos a opção por um recorte sistêmico buscando compreender de forma integral a determinação do comportamento dos países em desenvolvimento em todas as suas dimensões (eventos com resultado positivo e eventos com resultado nulo) e em ambos os polos (ativo e passivo). Acreditamos que fomos bem 
sucedidos nesta iniciativa.

No entanto, para explicar como diferenças no nível de desenvolvimento relativo afetam o processo decisório das potências médias de forma distinta dos demais países em desenvolvimento e desenvolvidos, será necessário o desenho de pesquisas que desçam ao nível doméstico dos atores e busquem estas respostas na dinâmica da economia política do processo decisório com desenhos de pesquisa de estudos de caso destes países específicos.

Em desenhos de pesquisa desta natureza, os resultados e a metodologia desenvolvidos neste estudo podem ser úteis para controlar os efeitos do nível sistêmico de maneira a isolar o efeito de variáveis do nível doméstico. $O$ desenvolvimento de pesquisas nesta linha será crucial para oferecer uma visão mais compreensiva tanto do processo decisório envolvido na determinação do comportamento das potências médias no polo ativo do OSC, quanto de seus impactos sobre o próprio sistema multilateral de comércio e o sistema internacional em última medida.

A abordagem metodológica aqui desenvolvida pode ser também utilizada para estudos de outras naturezas. O modelo pode ser utilizado para estudar outros períodos ou fazer uma avaliação comparativa entre períodos distintos buscando apontar efeitos de mudanças "no" ou "do" regime em diferentes momentos do tempo. Ou mesmo como uma forma eficiente de controle das demais variáveis e efeitos quando o objetivo é elucidar a dinâmica de efeitos específicos. Dentre uma grande gama de aplicações possíveis. 
Referências Bibliográficas

ABREU, M. P. (1998), BRAZIL, THE GATT, AND THE WTO: HISTORY AND PROSPECTS. Texto para Discussão $n^{\circ}$ 392. Departamento de Economia: PUC-Rio, Rio de Janeiro.

ANDERSON, K.; MARTIN, W.; MENSBRUGGHE, D. (2006), "Doha Policies: Where are the Payoffs?". In: NEWFARMER, R. (org.). Trade, Doha, and Development: A Window into the Issues. World Bank, Washington DC.

ANDERSON, P. (1982), Passagens da antiguidade ao feudalismo. Edições Afrontamentos, Lisboa.

ANDERSON, P. (1984), Linhagens do Estado Absolutista. Brasiliense, São Paulo.

BAGWELL, K.; MAVROIDIS, P.; STAIGER, R. W. (2002), "It's a Question of Market Access", American Journal of International Law, v. 96, n. 1, p. 56-76.

BALDWIN, R. (1969), "The Case Against Infant-Industry Tariff Protection". Journal of Political Economy, p. 132-154.

BANCO MUNDIAL (BM). (2013a), World Bank GNI per capita Operational - Guidelines \& Analytical Classifications. Disponivel em: <http://siteresources.worldbank.org/DATASTATISTICS/Resources/OGHIST.xIs>. Acesso em novembro de 2013.

(2013b), A Short History - GNI per capita. Disponível em: $<$ http://data.worldbank.org/about/country-classifications/a-short-history>. Acesso em novembro de 2013.

BARRAL, W. O. (2007), O Comércio Internacional. Ed. Del Rey, Belo Horizonte.

BARRON, D. N. (1992), "The Analysis of Count Data: Overdispersion and Autocorrelation". American Sociological Association, v. 22 , p. 179-220.

BARTON, J. H.; GOLDSTEIN, J. L.; JOSLING, T. E.; STEINBERG, R. H. (2008), The

Evolution of the Trade Regime: Politics, Law and Economics of the GATT and the WTO. Princeton University Press (ebook).

BAYNE, N. (2000), "Why Did Seattle Fail? Globalization and the Politics of Trade". Government and Opposition, v. 35, n. 2, p. 131-151.

BEN-DAVID, D.; LOEWEY, M. (1997), Free Trade, Growth and Convergence. NBER Working Paper n. 6095.

BETZ, T. (2015), Trading Interests: Domestic Institutions, International Negotiations, 
and the Politics of Trade. Annual Meeting of the American Political Science Association 2015, San Francisco, CA.

BETZ, T.; KERNER, A. (2016), "Real Exchange Rate Overvaluation and WTO Dispute Initiation in Developing Countries". International Organization, October, p. 1-25. BIELSCHOWSKY, R. (2009), "Sesenta años de la CEPAL: estructuralismo y neoestructuralismo". Revista CEPAL, n. 97, p. 173-194.

BOBBIO, N. (2000), Dicionário de Política - Volume 1. Editora UnB, Brasília.

BOWN, C. P.; HOEKAM, B. M. (2005), "WTO Dispute Settlement and the Missing Developing Country Cases: Engaging the Private Sector", Journal of International Economic Law, v. 8, n. 4, p. 861-890.

BOWN, C. P. (2005), "Participation in WTO Dispute Settlement: Complainants, Interested Parties, and Free Riders", World Bank Economic Review, v. 19, n. 2, p. 287-310. . (2009), Self-enforcing Trade: Developing Countries and WTO Dispute

Settlement. The Brookings Institution Press (ebook), Washington DC.

BOX, G.; HUNTER, W.; HUNTER, S. (2005), Statistics for Experimenters: Design, Innovation, and Discovery. Wiley-Interscience (ebook), New York.

BOX, J. F. (1987), "Guinness, Gosset, Fisher, and Small Samples”. Statistical Science, v. 2 , n. 1 , p. $45-52$.

BRADFORD, A. (2007), "International Antitrust Negotiations and the False Hope of the WTO”. Harvard International Law Journal, v. 48, n. 2, p. 102-135.

BRESLOW, N. E; CLAYTON, D. G. (1993), "Aproximate inference in generalized linear mixed models". Journal of the American Statistical Association, v. 88, n. 421, p. 925.

BUSH, M. L.; REINGARDT, E. (2000), "Bargaining in the Shadow of the Law: Early Settlement in GATTMTO Disputes", Fordham International Law Journal, v. 24, n. 1. (2003), "Developing Countries and GATT/WTO Dispute Settlement". Journal of World Trade, v. 37, n. 4, p. 719-735.

BUSH, M. L.; REINGARDT, E.; SHAFFER, G. (2009), "Does Legal Capacity Matter? A survey of WTO members". World Trade Policy, v. 8, n. 4, p. 559-577.

CAMERON, A. C; TRIVEDI, P. K. (1998), Regression Analysis of Count Data. Cambridge University Press, UK. 
CAMERON, A. C.; TRIVEDI, P. K. (2013). Regression Analysis of Count Data. $2^{\text {nd }}$ Edition. Cambridge University Press, New York.

CARVALHO, M. I. V. de. (2010), "Condicionantes Internacionais e Domésticos: O Brasil e o G-20 nas Negociações Agrícolas da Rodada Doha”. Dados, v. 53, p. 405-445.

. (2012), "O Órgão de Solução de Controvérsias da OMC e os países em desenvolvimento: quais são os membros que contam?". Boletim Meridiano 47, v. 13, n. 133, p. 34-41.

CEPAlUNI, G.; PEREIRA NETO, M. G.; OlIVEIRA, A. J. S. N. (2012), “The Bigger, the Better: Coalitions in the GATTMTO”. Brazilian Political Science Review, v. 6, p. 827.

CONTI, J. A. (2010), “Learning to Dispute: repeat participation, expertise, and reputation at the World Trade Organization”. Law \& Social Inquiry, v. 25, n. 3, p. 625-662.

CLARKE, K. A. (2007), "A Simple Distribution-Free Test for Nonnested Hypotheses". Political Analysis, v. 15, n. 3, p. 347-363.

COLLET, D. (1991), Modelling Binary Data. $2^{\text {nd }}$ Editon. Chapman \& Hall, London. COPELOVITCH, M.; PEVEHOUSE, J. C. (2013), "Ties that Bind? Preferential Trade Agreements and Exchange Rate Policy Choice”. International Studies Quarterly, v. 57, n. 2, p. 385-399.

(2014), The Trilemma and Trade policy: Exchange Rates, Financial Openness, and WTO Disputes. Manuscript - University of Wisconsin-Madison, Madison.

COSTA, L. M. (1996), OMC: Manual Prático da Rodada Uruguai. Saraiva, São Paulo.

COUTINHO, M; HOFFMANN, A. R.; KFURI, R. (2007), "Raio X da Integração Regional".

Estudos e Cenários, IUPERJ/UCAM, Rio de Janeiro.

DOBSON, A. J.; BARNETT, A. G. (2008), An introduction to generalized linear models. $3^{\text {rd }}$ Editon. Taylon and Francis, Boca Raton.

EFSTATHOPOULOS, C. (2012), "Leadership in the WTO: Brazil, India and the Doha development agenda". Cambridge Review of International Affairs, v. 25, n. 2, p. 269-293.

ELSIG, M; DUPONT, C. (2012), Persistent Deadlock in Multilateral Trade Negotiations: the Case of Doha. Oxford University Press, p. 587-606 (ebook).

EVANS, D.; SHAFFER, G. C. (2011), "Chapter 10 - Conclusion”, p. 341-348, In: SHAFFER, G. C.; MELÉNDEZ-ORTIZ, R. Dispute Settlement at the WTO: The Developing Country Experience. Cambridge University Press, Cambridge. 
FRANCOIS, J.; HORN, H.; KAUNITZ, N. (2008), Trading Profiles and Developing Country Participation in the WTO Dispute Settlement System. ICTSD Issue Paper $n^{\circ}$ 6, Genebra.

GOLSTEIN, J. (2012), Trade Liberalization and Domestic Politics. Oxford University Press, p. 64-82 (ebook), Oxford.

GREENAWAY, D.; MORGAN, W.; WRIGHT, P. (2002), "Trade Liberalization and Growth in Developing Countries". Journal of Development Economics, n. 67, p. 224-244. GRIMMET, J. J. (2011), Dispute Settlement in the WTO: An Overview. CRS Report (ebook), Washington DC.

GRUPO DE CAIRS. (2012), Website oficial. Disponível em:

<http://www.cairnsgroup.org/index.html>. Acesso em janeiro de 2013.

GUIMARÃES, M. H. (2005), Economia Política do Comércio Internacional. São João do Estoril, Principia (ebook), Cascais.

GUPTA, P. L.; GUPTA, R. C.; TRIPATHI, R. C. (1996), "Analysis of zero adjusted count data". Computational Statisticas \& Data Analysis, n. 23, p. 207-218.

GUZMANM, A. T.; SIMMONS, B. (2002), "To settle or empanel? An empirical analysis of litigation and settlement at the WTO". Journal of Legal Studies, v. 31, p. 205-235.

GUZMANM, A. T.; SIMMONS, B. (2005), "Power plays and capacity constraints: the selection of defendants in WTO disputes". Journal of Legal Studies, v. 34, p. 557-598. HERZ, M.; HOFFMANN, A. R. (2004), Organizações Internacionais: Teoria e Prática. Editora Campus, Rio de Janeiro.

HILBE, J. M. (2011), Negative Binomial Regression. Cambridge University Press (ebook), Cambridge.

. (2014), Modeling Count Data. Cambridge University Press (ebook), Cambridge.

HOEKMAN, B. M.; KOSTECKI, M. M., (2009), The Political Economy of the World Trading System. Oxford University Press (ebook), New York.

HOFFMAN, L. (2015), Longitudinal Analysis: Modeling Withing-person Fluctuation and Change. Taylor and Francis (ebook), New York.

HOFFMANN, R. (2001), Estatística para Economistas. Editora Pioneira, São Paulo. HOLMES, P.; ROLLO, J.; YOUNG, A. R. (2003), Emerging Trends in WTO Dispute

Settlement: Back to the GATT? World Bank Policy Research Working Paper 3133, September 2003. 
HORN, H.; MAVROIDIS, P. C. (2006), "International Trade: Dispute Settlement", Chapter 5. In: GUZMAN, A.; SKYKES, A. (eds) Research Handbook in International Economic Law, Edward Elgar - New York.

HORN, H.; MAVROIDIS, P. C.; SAPIR, A. (2010), Beyond the WTO? An Anatomy of EU and US Preferential Trade Agreements. Bruegel Blue Print Series, New York. HORN, H.; MAVROIDIS, P. C.; NORDSTROM, H. (1999), Is the use of the WTO dispute settlement system biased? CEPR Discussion Paper Series No 2340.

HOX, J. J.; MOERBEEK, M.; SCHOOT, R. V. (2010), Multilevel Analysis: Technics and Applications. Taylor and Francis (ebook), New York.

HURREL, A.; NARLIKAR, A. (2006), "The New Politics of Confrontation: Developing Countries at Cancun and Beyond", Global Society, v. 20, n. 4, p. 415-433.

JENSEN, J. B.; et al. (2015), "The Influence of Foreign Direct Investments, Intrafirm Trading, and Currency Undervaluation on U.S Firm Trade Disputes". International Organization, v. 69, n. 4, p. 913-947.

JOHNSON, H. (1980), "Optimal Trade Intervention in the Presence of Domestic Distortions". In: BALDWIN, R. et al. Trade, Growth and the Balance of payments: Essays in Honor of Gottfried Haberler. Rand McNally, Chicago.

JONES, C. (2000), Introduction to Economic Growth. W. W. Norton \& Company, New York.

KEOHANE, R.; NYE, J. (1989), Power and Interdependence: World Politics in Transition, Little-Brown, Boston.

KOHL, T. (2017), "The WTO's effect on trade: What you give is what you get". Manuscript (forthcoming). In: CHRISTENSEN, B. J.; KOWALCZYK, C. (eds.). Globalization: Strategies and Effects. Springer Verlag, Heidelberg.

KRUEGER, A. (1974), "The Political Economy of the Rent-Seeking Society". American Economic Review, n. 64, v. 3, p. 291-303.

KRUGMAN, P.; OBSTFELD, M. (2005), Economia Internacional: Teoria e Prática. Pearson Addison Wesley, São Paulo.

KURADA, R. R. (2016), Fitting Multilevel Hierarchical Mixed Models Using PROC NLMIXED. Paper SAS4720-2016. SAS Institute - NC.

LEE, Y.; NELDER, J. A.; (2005), "Likelihood for random-effect models". SORT 29, n. 2, July-December, p. 141-164. 
LIMA, P. G. C. (2007), Posicionamento no sistema mundial e semiperiferia: evidências por meio de análise exploratória de dados no perído 1950-2003. Dissertação de Mestrado (Mestrado em Economia) - Universidade Federal Fluminense, Niterói.

LINDSEY, J. (1995). Modelling Frequency and Count Data. Oxford University Press, New York.

LONG, J. S. (1997), Regression Models for Categorical and Limited Dependent Variables. Sage Publications, New York.

MANCO, O. C. U. (2013), Modelos de Regressão Beta com Efeitos Aleatórios Normais e Não-normais para Dados Longitudinais. Tese 123 (Doutorado em Ciências). Instituto de Matemática e Estatística - Universidade de São Paulo, São Paulo.

McCULLOCH, C. E.; SEARLE, S. R.; NEUHAUS, J. M. (2008), Generalized, Linear, and Mixed Models. $2^{\text {nd }}$ Editon. Wiley, New York.

McGILCHRIST, C. A. (1994), "Estimation in generalized mixed models". Journal of the Royal Statistical Socity B, v. 56, n. 1, p 61-69.

MILLER, G. J. (2005), "The Political Evolution of Principal-Agent Models”. Annual Review of Political Science, v. 8, p. 203-225.

MILNER, H. (1997), Interests, Institutions and Information: Domestic Politics and International Relations. Princeton University Press, Princeton.

MOGHIMBEIGI, A.; ESHRAGHIAN, M. R.; MOHAMMAD, K.; MCARDLE, B. (2008),

"Multilevel zero-inflated negative binomial regression modeling for overdispersed count data with extra zeros". Journal of Applied Statistics, v. 35 n. 10, p. 1193-1202.

MORAVCSIK, A. (1993), "Integrating International and Domestic Theories of International Bargaining”. In: EVANS, P.; JACOBSON; H.; PUTNAM, R. Double-Edge Diplomacy. Berkeley, University of California Press, Los Angeles.

. (1997). "Taking Preferences Seriously: A Liberal Theory of International Politics". International Organization, v. 51, n. 4, p. 513-553.

. (1999), The choice for Europe, ULC Press, London.

NARLIKAR, A. (2004), International Trade and Developing Countries: Bargaining Coalitions in the GATT \& WTO. Taylor and Francis (ebook), New York. . (2007), “All's fair in love and trade? Emerging powers". In: WILKINSON, R.; LEE, D. (eds). The WTO after Hong Kong: progress in, and prospects for, the Doha development agenda. Routledge, London. 
. (2010), "New powers in the club: the challenges of global trade governance". International Affairs, v. 86, n. 3, p. 717-728.

NELDER, J. A.; WEDDERBURN, R. W. M. (1972), “Generalized Linear Models”. Journal of the Royal Statistical Society, n. 135, p. 370-384.

NICHOLSON, W. (2005), Microeconomic Theory: Basic Principles and Extensions, Thomson South-Western, New York.

OLSON, M. (1965), The Logic of Collective Action. Harvard University Press, Cambridge.

OLSON, M; ZECKHAUSER, R. (1966), "An Economic Theory of Alliance", Review of Economics and Statistics, v. 48, p. 266-279.

ORGANIZAÇÃO MUNDIAL DO COMÉRCIO (OMC). (2000), WTO's Unique System of Settling Disputes Nears 200 Cases in 2000. PRESS/180, Geneva. Disponível em: <http://www.wto.org/english/news_e/pres00_e/pr180_e.htm>. Acesso em Outubro de 2013.

. (2004), WTO 10th Anniversary - The Future of the WTO: Addressing institutional challenges in the new millennium. Disponível em: <http://www.wto.org/english/thewto_e/10anniv_e/future_wto_e.htm>. Acesso em Outubro de 2013.

(2012), Doha Round: what are they negotiating? Disponível em: <http://www.wto.org/english/tratop_e/dda_e/update_e.htm>. Acesso em junho de 2012.

. (2013a), About the WTO - A statement by former Director-General Pascal Lamy. Disponível em

<http://www.wto.org/english/thewto_e/whatis_e/wto_dg_stat_e.htm>. Acesso em Outubro de 2013.

. (2013b), Who are the developing countries in the WTO? Disponível em: <http://www.wto.org/english/tratop_e/devel_e/d1who_e.htm>. Acesso em julho de 2013.

. (2013c), World Bank GNI per capita Operational - Guidelines \& Analytical Classifications. Disponível em: <http://siteresources.worldbank.org/DATASTATISTICS/Resources/OGHIST.xls>. Acesso em novembro de 2013. 
(2013d), The European Union and the WTO. Disponivel em: $<$ http://www.wto.org/english/thewto_e/countries_e/european_communities_e.htm>. Acesso em junho de 2013.

. (2014), Days 3, 4 and 5: Round-the-clock consultations produce 'Bali Package'. Disponível em:

<http://www.wto.org/english/news_e/news13_e/mc9sum_07dec13_e.htm>. Acesso em janeiro de 2014.

PACKENHAM, R. (1992), The dependency movement. Scholarship and politics in development studies. Harvard University Press, Cambridge.

PEASE, K. (2003), International Organizations: perspectives on governance in the twenty-first century, Pearson Ed, New Jersey.

PREEG, E. H. (2012), The Uruguay Round Negotiations and the Creation of the WTO.

Oxford University Press, p. 122-138 (ebook), New York.

PUTNAM, R. (1988), "Diplomacy and Domestic Politics: The Logic of Two-Level Games", International Organization, v. 42, v. 3, p. 427-460.

RAGHAVAN, C. (2001), "WTO proposals fail to redress implementation grievances of developing countries". Third World Resurgence. NYUP, New York.

RAMANZINI JUNIOR, H.; VIANA, M. T. (2012), "Países em desenvolvimento em uma ordem internacional em transformação: coalizões e soluções de disputas na OMC".

Revista Brasileira de Política Internacional, v. 55, n. 2, p. 48-69.

RICHTER, A. (2014), Doha Development Round: Why did it fail? Ancho Academic Publiching (ebook), Hamburg.

ROBSON, K; PEVALIN, D. (2016), Multilevel Modeling in Plain Language. SAGE (ebook), Washington DC.

RODRÍGUEZ, O. (2009) El estructuralismo latinoamericano. Civilização Brasileira, Rio de Janeiro.

ROLLAND, S. E. (2012), Development at the World Trade Organization. Oxford University Press (ebook), New York.

RUGMAN, A. (2012), The End Of Globalization. Random House, New York.

SACHS, J.; WARNER, A. (1995), "Economic Reform and the Process of Global Economic Integration". Brookings Papers on Economic Activity, n. 1, p. 1-95.

SATTLER, T.; BERNAUER, T. (2011), "Gravitation or discrimination? Determinants of litigation in the World Trade Organisation". European Journal of Political Research, v. 50 , n. 1 , p. 143-167. 
SCHALL, R. (1991), "Estimation in generalized linear models with random effects". Biometrika, v. 78, n. 4, p. 719-727.

SEVILLA, C. R. (1999), Explaining Patterns of GATT/WTO Trade complaints. Warhead Center for International Affairs, Working Paper Series 98-01.

SHAFFER, G. (2003). "How to Make the WTO Dispute Settlement System Work for Developing Countries: Some Proactive Developing Country Strategies". In: Towards A Development-Supportive Dispute Settlement System in the WTO, Resource Paper $n^{\circ}$ 5, ICTSD, Genebra.

SHAFFER, G; MELANDEZ-ORTIZ, R. (2011), Dispute Settlement at the WTO: The Developing Country Experience. Cambridge University Press (ebook), Cambridge.

TOYE, R. (2012), The International Trade Organization. Oxford University Press, p. 85101 (ebook), New York.

TREBILCOCK, M.; HOWSE, R. (2005), The Regulation of International Trade. Routledge (ebook), New York.

TUCÍDIDES. (2001), História da Guerra do Peloponeso. $4^{\text {a }}$ Edição, Coleção IPRI Editora UnB, Brasília.

TULLOCK, G. (2005), The Rent-Seeking Society: The Selected Works of Gordon Tullock. v. 5. Liberty Fund, New York.

UNIÃO EUROPEIA (UE). (2013a), Comissão Européia - União Económica e Monetária. Disponível em:

<http://ec.europa.eu/economy_finance/euro/emu/index_pt.htm>. Acesso em junho de 2013.

(2013b), European Comission - Enlargement. Disponível em> <http://ec.europa.eu/enlargement/countries/check-current-status/index_en.htm>. Acesso em junho de 2013.

(2013c), Ministerial Conferences. Disponível em: <http://www.wto.org/english/thewto_e/minist_e/minist_e.htm>. Acesso em dezembro de 2013.

VAN KERCKHOVEN, S. (2015), Dispute settlement in international trade: an economic analysis of the WTO DSU. MSI Research Report - Department of Managerial Economics, Strategy and Innovation (MSI), Leuven Institute for International Law. 
VAN KERCKHOVEN, S.; CROMBEZ, C. (2015), The WTO DSU: Are all (Un)equal?. MSI Research Report - Department of Managerial Economics, Strategy and Innovation (MSI), Leuven Institute for International Law.

VALENZUELA, M. J. (2011), Why Did the Doha Round Fail? VDM Publishing (ebook), New York.

VORONCA, D. C.; EDEDE, L.; GEBREGZIABHER, M. (2014), Analysis of Zero Inflated Longitudinal Data Using PROC NLMIXED. University of South Carolina, Department of Biostatistics - SESUG 2014, Charleston SC.

VOUNG, Q. H. (1989). "Likelihood Ratio Tests for Model Selection and non-nested Hypotheses". Econometrica, v. 57, n, 2, p. 307-333.

WACZIARG, R.; WELCH, K. H. (2008), "Trade Liberalization and Growth: New Evidence".

World Bank Economic Review, v. 22, n. 2, p. 187-231.

WINKELMANN, R. (2003), Econometric Analysis of Count Data. Springer, New York.

YILDIRIM, A.; DE BIĖVRE, D. (2015), Leader or Laggard? Political Determinants of the EU's Compliance with WTO Dispute Settlement Rulings. GGS Working Paper Series, n. 145.

YOUNG, O. R. (1991), "Political leadership and regime formation: on the development of institutions in international society". International Organization, v. 45, n. 3, p. 281308

ZEILER, T. W. (2012), The Expanding Mandate of the GATT: The first seven rounds. Oxford University Press, p. 102-121 (ebook), New York. 


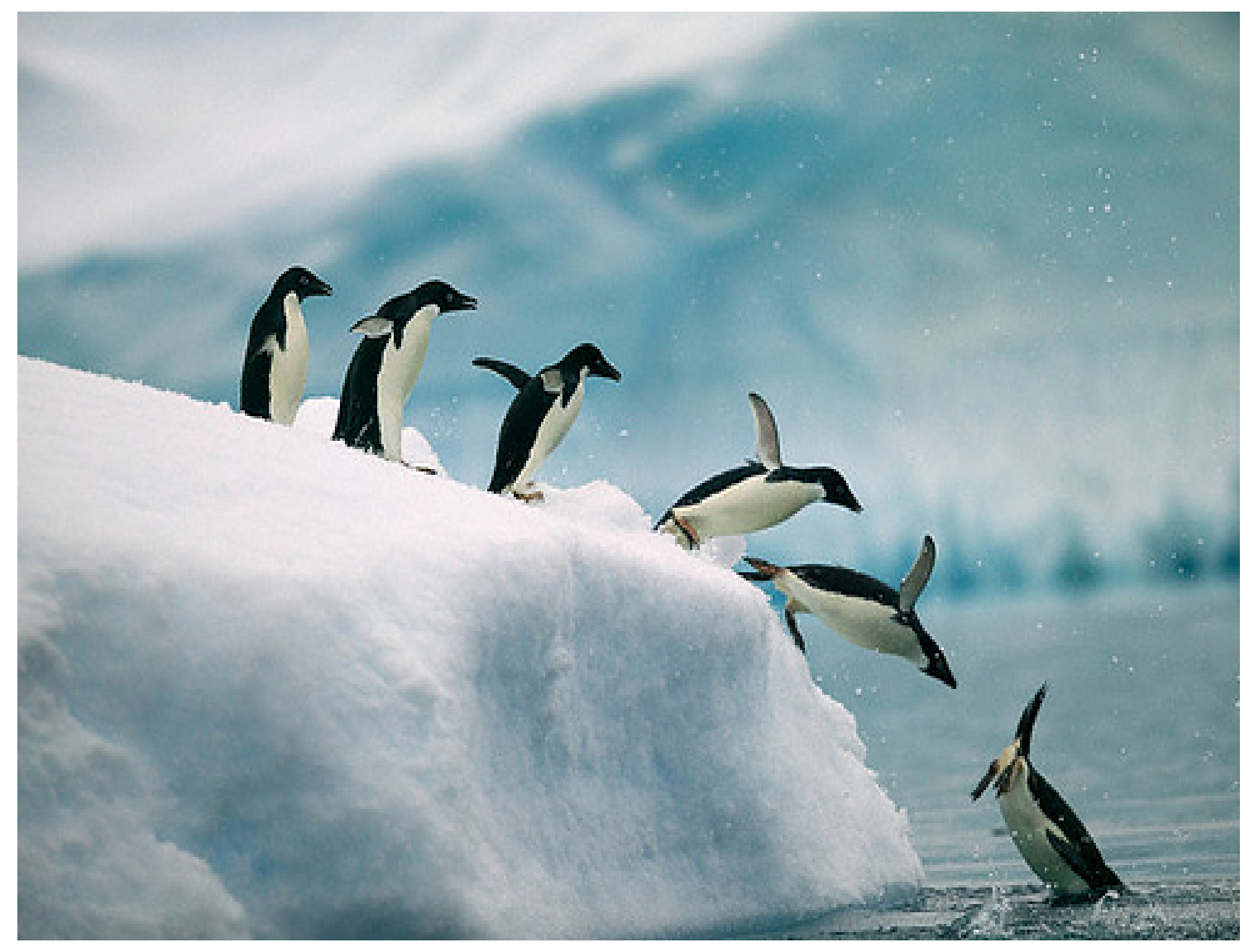




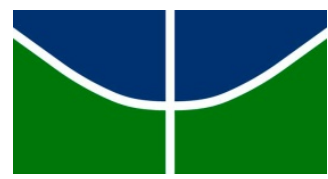

Universidade de Brasília

Instituto de Relações Internacionais

Programa de Pós-Graduação em Relações Internacionais

UMA PROPOSTA METODOLÓGICA DE MODELAGEM MULTINÍVEL PARA O TRATAMENTO DA PARTICIPAÇÃO DOS PAÍSES EM DESENVOLVIMENTO NO ÓRGÃO DE SOLUÇÃO DE CONTROVÉRSIAS DA OMC

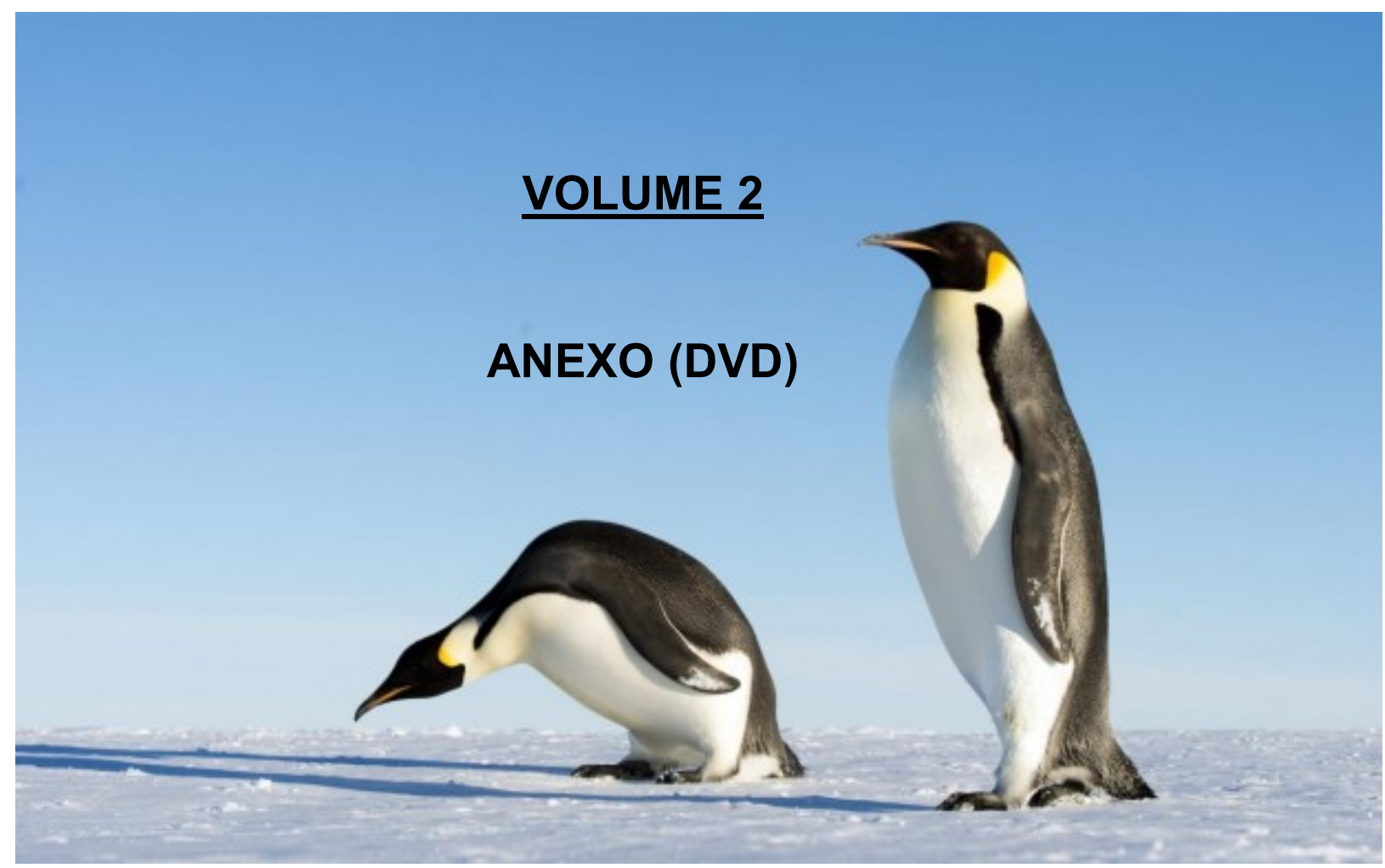

Carlos Henrique Canesin 


\section{VOLUME 2 - ANEXO (DVD)}

UMA PROPOSTA METODOLÓGICA DE MODELAGEM MULTINÍVEL PARA O TRATAMENTO DA PARTICIPAÇÃO DOS PAÍSES EM DESENVOLVIMENTO NO ÓRGÃO DE SOLUÇÃO DE CONTROVÉRSIAS DA OMC

Tese apresentada ao Programa de Pós-Graduação em Relações Internacionais da Universidade de Brasília como requisito parcial à obtenção do título de Doutor em Relações Internacionais.

Área de Concentração: Política Internacional e Comparada.

Orientadora: Profa. Dr. Maria Izabel Valladão de Carvalho

Brasília, DF 
Canesin, Carlos Henrique.

CC284p Uma Proposta Metodológica de Modelagem Multinível para o Tratamento da Participação dos Países em Desenvolvimento no Órgão de Solução de Controvérsias da OMC / Carlos Henrique Canesin; orientadora Maria Izabel Valladão de Carvalho. -- Brasília, 2016. Volume 2 - Anexo (DVD), p. 651.

Tese 63 (Doutorado - Doutorado em Relações Internacionais) -- Universidade de Brasília, 2016.

1. Organização Mundial do Comércio. 2. Solução de Controvérsias. 3. Países em Desenvolvimento. 4. Modelos Lineares Generalizados. 5. ZINB. I. Valladão de Carvalho, Maria Izabel, orient. II. Título. 


\section{Lista de Quadros}

Quadro A1: Matriz de Casos-padrão..

01

Quadro A2: ID - Membros da OMC.

Quadro A4-1.1: PIB em milhões de USD (2005) no período 19952012

COMEX no $\quad$ período $\quad 1995$

Quadro A4-1.2: COMEX no período 1995-

2012

AGRI no $\quad$ período $\quad$ 1995-

Quadro

A4-1.3:

AGR

……………….....

Quadro

A4-2.1:

ODP

no

período

1995-

2012

A4-2.2:

PREF

no

período

1995-

2012

Quadro

A4-2.3:

CAP

no

período

1995-

2012

A4-2.4:

APRE

período

1995-

2012.

Quadro A4-2.5: POL no período 1995-2012.

Quadro A5.1: Critérios de comparação de ajustamento dos modelos (ativo e passivo)......

Quadro A5.2: Resultado dos testes Vuong e Clarke - ZINB x BN 571

Quadro A5-2.1: Variáveis categóricas - Modelo Poisson Ativo 574

Quadro A5-2.2: Ajustamento - Modelo Poisson Ativo 579

Quadro A5-2.3: Estimativa dos Parâmetros - Modelo Poisson Ativo. 579

Quadro A5-2.4: Variáveis categóricas - Modelo Poisson Passivo 580

Quadro A5-2.5: Ajustamento - Modelo Poisson Passivo 581

Quadro A5-2.6: Estimativa dos Parâmetros - Modelo Poisson Passivo 581

Quadro A5-2.7: Variáveis categóricas - Modelo BN Ativo 582

Quadro A5-2.8: Ajustamento - Modelo BN Ativo. 583

Quadro A5-2.8: Estimativa dos Parâmetros - Modelo BN Ativo. 583

Quadro A5-2.9: Variáveis categóricas - Modelo BN Passivo 584

Quadro A5-2.10: Ajustamento - Modelo BN Passivo. 585

Quadro A5-2.11: Estimativa dos Parâmetros - Modelo BN Passivo. 585

Quadro A5-2.12: Histórico de Iterações - Modelo ZINB Ativo 586

Quadro A5-2.13: Ajustamento - Modelo ZINB Ativo. 587

Quadro A5-2.14: Estimativa dos Parâmetros - Modelo ZINB Ativo 591

Quadro A5-2.15: Histórico de Iterações - Modelo ZINB Passivo. 592

Quadro A5-2.16: Ajustamento - Modelo ZINB Passivo. 593

Quadro A5-2.17: Estimativa dos Parâmetros - Modelo ZINB Passivo. 598

Quadro A5-2.18: Histórico de Iterações - Modelo ZINB Passivo (sem China e Índia). 598 600 
Quadro A5-2.19: Ajustamento - Modelo ZINB Passivo (sem China e Índia). 605

Quadro A5-2.20: Estimativa dos Parâmetros - Modelo ZINB Passivo. 605

Quadro A6-1: Valores previstos de cREC e p0 - Modelo ZINB Ativo. 607

Quadro A6-2: Valores previstos de $\mathrm{CACl}$ e p0 - Modelo ZINB Passivo 637 


\section{Lista de Tabelas}

Tabela A4-1.1: PIB médio por grupo de renda em milhões de USD no período 19952012.

Tabela A4-1.2: Comparativo do PIB médio por grupo de renda no período 1995-2012.

Tabela A4-1.3: COMEX médio por grupo de renda no período 19952012.

Tabela A4-1.4: Comparativo do COMEX médio por grupo de renda no período 19952012

Tabela A4-1.5: AGRI média por grupo de renda no período 19952012

Tabela A4-1.6: Comparativo da AGRI média por grupo de renda no período 19952012

Tabela A4-2.1: ODP média por grupo de renda no período 19952012. 528

Tabela A4-2.2: PREF média por grupo de renda no período 19952012

Tabela A4-2.3: Comparativo da PREF por grupo de renda no período 19952012

Tabela A4-2.4: CAP média por grupo de renda no período 19952012

Tabela A4-2.4: Comparativo da CAP média por grupo de renda no período 19952012

Tabela A4-2.5: APRE média por grupo de renda no período 19952012

Tabela A4-2.6: Comparativo da APRE média por grupo de renda no período 19952012 


\section{Lista de siglas e abreviaturas}

A - Índice de atividade

AA - Subgrupo da metade superior de renda dos países em desenvolvimento de renda média-alta AAE - Áreas Administrativas Especiais da China

$A B$ - Subgrupo da metade inferior de renda dos países em desenvolvimento de renda média-alta

$\mathrm{ACl}$ - Acionamento-padrão

ACP - Acordo de Cotonou

AGOA - African Growth and Opportunity Act

AGRI - Participação relativa da agricultura na pauta comercial

APRE - Aprendizado

BA - Subgrupo da metade superior de renda dos países em desenvolvimento de renda média-baixa

BB - Subgrupo da metade inferior de renda dos países em desenvolvimento de renda média-baixa

BM - Banco Mundial

$\mathrm{BN}$ - Binomial negativo

CAP - Capacidade institucional/legal

$\mathrm{CBI}$ - Caribbean Basin Initiative

CEE - Comunidade Econômica Europeia

CEPAL - Comissão Econômica das Nações Unidas para a América Latina

COMEX - Coeficiente de abertura comercial

CV - Coeficiente de variação de Pearson

DAC - Comitê de Assistência ao Desenvolvimento

DSU - Entendimento sobre Solução de Controvérsias da OMC

EBA - Everything but arms

EC - Índice de eficácia

EUA - Estados Unidos

ET - Índice de inibição de efetividade

FMI - Fundo Monetário Internacional

GATT - Acordo Geral sobre Tarifas e Comércio

Lc - Preditor linear de contagem

Lz - Preditor linear da inflação de zeros

LV - Sistema político livre

MLG - Modelos lineares generalizados

MLGM - Modelos lineares generalizados mistos

$\mathrm{NL}$ - sistema político não livre

OCDE - Organização de Cooperação para o Desenvolvimento Econômico

ODA - Ajuda oficial ao desenvolvimento

ODP - Participação líquida da ODA no PIB

OI - Organização internacional

OIC - Organização Internacional do Comércio 
OMC - Organização Mundial do Comércio

ONU - Organização das Nações Unidas

OSC - Órgão de Solução de Controvérsias

$\mathrm{P}$ - índice de passividade

PD - Países desenvolvidos

PED - Países em desenvolvimento

$P E D_{m a}$ - Países em desenvolvimento de renda média-alta

$P E D_{m b}$ - Países em desenvolvimento de renda média-baixa

PIB - Produto interno bruto

$\mathrm{PL}$ - sistema político parcialmente livre

PMD (MD) - Países de menor desenvolvimento relativo

PNB - Produto nacional bruto

POL - grau de abertura do sistema político

PREF - Participação líquida da corrente de comércio preferencial na corrente de comércio total

PROC NLMIXED - Processo de otimização não linear misto

p0 - Probabilidade de inflação de zeros

QWIDS - Query Wizard for International Development

REC - Reclamação-padrão

SAS - Statistical Analysis System

SGP - Sistema global de preferências comerciais

$\mathrm{SH}$ - Sistema harmonizado

SITC - Standard International Trade Classification

TRAINS - Trade Analysis Information System

UE - União Europeia

UN Comtrade - United Nations Commodity Trade Statistics Database

UNCTAD - Conferência das Nações Unidas sobre Comércio e Desenvolvimento

UNCTAD/STAT - Divisão de estatística da UNCTAD

WDI - World Development Indicators

WEO - World Economic Outlook

WITS - World Integrated Trade Solution

ZINB - modelo binomial negativo inflado de zero 


\section{Sumário}

Anexo 1 - Matriz de casos-padrão

Anexo 2 - Estatística descritiva e CV Pearson para membros individuais

Anexo 3 - Uma breve introdução a MLG/MLGM e formalização do modelo ZINB.

Anexo 4-1 - Efeitos gravitacionais: Variáveis - Dimensão econômica

Anexo 4-2 - Efeitos discriminatórios: Variáveis - Dimensões de poder relativo e capacidade...

Anexo 5 - Modelos: Programação, estimação e testes.

Anexo 5-1 - Modelos Poisson, BN e ZINB: Programação SAS.

Anexo 5-2 - Modelo Poisson - Polo Ativo: Resultado da estimação

Anexo 5-3 - Modelo Poisson - Polo Passivo: Resultado da estimação.

Anexo 5-4 - Modelo Binomial Negativo - Polo Ativo: Resultado da estimação

Anexo 5-5 - Modelo Binomial Negativo - Polo Passivo: Resultado da estimação.

Anexo 5-6 - Modelo ZINB - Polo Ativo: Resultado da estimação. 587

Anexo 5-7 - Modelo ZINB - Polo Passivo: Resultado da estimação.

Anexo 5-8 - Modelo ZINB - Polo Passivo: Resultado da estimação (sem China e Índia). 600

Anexo 6-1 - Valores previstos de cREC e p0 - Modelo ZINB Ativo.

Anexo 6-2 - Valores previstos de cACI e p0 - Modelo ZINB Passivo 
Anexo 2

ESTATÍSTICA DESCRITIVA E CV PEARSON PARA MEMBROS INDIVIDUAIS

Quadro A2: ID - Membros da OMC

\begin{tabular}{|c|c|}
\hline ID & MEMBRO \\
\hline 1 & União Europeia \\
\hline 2 & Estados Unidos \\
\hline 3 & Arábia Saudita \\
\hline 4 & Austrália \\
\hline 5 & Barein \\
\hline 6 & Barbados \\
\hline 7 & Canadá \\
\hline 8 & Cingapura \\
\hline 9 & Coréia do Sul \\
\hline 10 & Croácia \\
\hline 11 & Islândia \\
\hline 12 & Israel \\
\hline 13 & Japão \\
\hline 14 & Kuwait \\
\hline 15 & Nova Zelândia \\
\hline 16 & Noruega \\
\hline 17 & Omã \\
\hline 18 & Suíça \\
\hline 19 & Taiwan \\
\hline 20 & Trinidade e Tobago \\
\hline 22 & Catar \\
\hline 24 & África do Sul \\
\hline 25 & Antigua e Barbuda \\
\hline 26 & Argentina \\
\hline 27 & Brasil \\
\hline 28 & Chile \\
\hline 29 & Colômbia \\
\hline 30 & Costa_Rica \\
\hline 31 & Cuba \\
\hline 32 & Dominica \\
\hline 33 & Granada \\
\hline 34 & Jamaica \\
\hline 35 & Malásia \\
\hline 36 & Maurício \\
\hline 37 & México \\
\hline 38 & Namíbia \\
\hline
\end{tabular}




\begin{tabular}{|c|c|}
\hline 39 & Panamá \\
\hline 40 & Peru \\
\hline 41 & República Dominicana \\
\hline 42 & Rússia \\
\hline 43 & São Kitts e Névis \\
\hline 44 & Santa Lúcia \\
\hline 45 & São Vincente e Granadinas \\
\hline 46 & Suriname \\
\hline 47 & Turquia \\
\hline 48 & Uruguai \\
\hline 49 & Venezuela \\
\hline 50 & Albânia \\
\hline 51 & Botsuana \\
\hline 52 & Gabão \\
\hline 53 & Jordânia \\
\hline 54 & Maldivas \\
\hline 55 & Montenegro \\
\hline 56 & Tonga \\
\hline 57 & Tunísia \\
\hline 58 & Macedônia \\
\hline 59 & Armênia \\
\hline 60 & Belize \\
\hline 61 & Bolívia \\
\hline 62 & Camarões \\
\hline 63 & China \\
\hline 64 & Costa do Marfim \\
\hline 65 & Egito \\
\hline 66 & El Salvador \\
\hline 67 & Equador \\
\hline 68 & Fiji \\
\hline 69 & Filipinas \\
\hline 70 & Guatemala \\
\hline 71 & Guiana \\
\hline 72 & Honduras \\
\hline 73 & Índia \\
\hline 74 & Indonésia \\
\hline 75 & Moldávia \\
\hline 76 & Nicarágua \\
\hline 77 & Nigéria \\
\hline 78 & Paquistão \\
\hline 79 & Paraguai \\
\hline 80 & Sri Lanka \\
\hline 81 & Suazilândia \\
\hline 82 & Tailândia \\
\hline
\end{tabular}




\begin{tabular}{|c|c|}
\hline 83 & Ucrânia \\
\hline 84 & Cabo Verde \\
\hline 85 & Congo \\
\hline 86 & Geórgia \\
\hline 87 & Lesoto \\
\hline 88 & Mauritânia \\
\hline 89 & Mongólia \\
\hline 90 & Marrocos \\
\hline 91 & Papua Nova Guine \\
\hline 92 & Samoa \\
\hline 93 & Ilhas Salomão \\
\hline 95 & Bangladesh \\
\hline 96 & Benin \\
\hline 98 & Gana \\
\hline 99 & Madagascar \\
\hline 100 & Malaui \\
\hline 101 & Quênia \\
\hline 102 & Senegal \\
\hline 103 & Tanzânia \\
\hline 104 & Vietnã \\
\hline 105 & Zâmbia \\
\hline 106 & Zimbábue \\
\hline 107 & Burkina Faso \\
\hline 108 & Burundi \\
\hline 109 & Camboja \\
\hline 110 & República Centro Africana \\
\hline 111 & Gâmbia \\
\hline 112 & Guiné \\
\hline 113 & Guiné Bissau \\
\hline 114 & Quirguistão \\
\hline 115 & Mali \\
\hline 116 & Moçambique \\
\hline 117 & Nepal \\
\hline 118 & Niger \\
\hline 119 & Ruanda \\
\hline 120 & Togo \\
\hline 121 & Uganda \\
\hline 122 & Hong Kong \\
\hline 123 & Macau \\
\hline
\end{tabular}

Fonte: Elaboração própria. 
Variável dependente:

REC

ID $=1$

\begin{tabular}{|l|r|l|r|}
\hline \multicolumn{3}{|c|}{ Momento } \\
\hline Média & 18 & Soma dos pesos & 18 \\
\hline Desvio-padrão & 5,7403152 & $\begin{array}{l}\text { Soma das } \\
\text { observações }\end{array}$ & 90 \\
\hline Assimetria & 1,68861791 & Curtose & 22,4705882 \\
\hline $\begin{array}{l}\text { Soma dos } \\
\text { quadrados não } \\
\text { corrigida }\end{array}$ & 832 & $\begin{array}{l}\text { Soma dos } \\
\text { quadrados corrigida }\end{array}$ & 2,52492942 \\
\hline CV Pearson & 94,8063041 & Erro-padrão médio & 1,11730301 \\
\hline
\end{tabular}

\begin{tabular}{|l|r|l|r|}
\hline \multicolumn{4}{|c|}{ Estatística Descritiva Básica } \\
\hline \multicolumn{2}{|c|}{ Posição } & \multicolumn{2}{c|}{ Variabilidade } \\
\hline Média & 5,0 & Desvio-padrão & 4,74032 \\
\hline Mediana & 3,5 & Variância & 22,47059 \\
\hline Moda & 2,0 & Amplitude & 17,00000 \\
\hline & & Amplitude interquartil & 4,00000 \\
\hline
\end{tabular}

\begin{tabular}{|l|l|r|l|l|}
\hline \multicolumn{5}{|c|}{ Testes de Posição: Mu0=0 } \\
\hline Teste & \multicolumn{2}{|c|}{ Estatística } & \multicolumn{2}{c|}{ Valor $\mathbf{p}$} \\
\hline Student t & t & 4,475062 & $\operatorname{Pr}>|\mathbf{t}|$ & 0,0003 \\
\hline Sign & M & 8,5 & $\operatorname{Pr}>=|\mathbf{M}|$ & $<, 0001$ \\
\hline Signed Rank & S & 76,5 & $\operatorname{Pr}>=|\mathbf{S}|$ & $<, 0001$ \\
\hline
\end{tabular}

\begin{tabular}{|l|r|}
\hline \multicolumn{2}{|c|}{ Quantis } \\
\hline Level & Quantil \\
\hline $\mathbf{1 0 0 \%}$ Max & 17,0 \\
\hline $\mathbf{9 9 \%}$ & 17,0 \\
\hline $\mathbf{9 5 \%}$ & 17,0 \\
\hline $\mathbf{9 0 \%}$ & 16,0 \\
\hline $\mathbf{7 5 \%}$ Q3 & 6,0 \\
\hline $\mathbf{5 0 \%}$ Mediana & 3,5 \\
\hline $\mathbf{2 5 \%}$ Q1 & 2,0 \\
\hline $\mathbf{1 0} \%$ & 1,0 \\
\hline $\mathbf{5} \%$ & 0,0 \\
\hline $\mathbf{1} \%$ & 0,0 \\
\hline $\mathbf{0} \%$ Min & 0,0 \\
\hline
\end{tabular}


Variável dependente:

REC

$$
\text { ID }=1
$$

\begin{tabular}{|r|r|r|r|}
\hline \multicolumn{3}{|c|}{ Observações Limite } \\
\hline \multicolumn{2}{|c|}{ Baixa } & \multicolumn{2}{c|}{ Alta } \\
\hline Valor & Obs & Valor & Obs \\
\hline 0 & 13 & 6 & 12 \\
\hline 1 & 16 & 7 & 2 \\
\hline 1 & 7 & 8 & 6 \\
\hline 2 & 18 & 16 & 3 \\
\hline 2 & 15 & 17 & 4 \\
\hline
\end{tabular}


Variável dependente:

ACI

ID $=1$

\begin{tabular}{|l|r|l|r|}
\hline \multicolumn{3}{|c|}{ Momento } \\
\hline Média & 18 & Soma dos pesos & 18 \\
\hline Desvio-padrão & 4,33257912 & Variância \\
\hline Assimetria & 1,18551007 & Curtose & 18,7712418 \\
\hline $\begin{array}{l}\text { Soma dos } \\
\text { quadrados não } \\
\text { corrigida }\end{array}$ & 920 & $\begin{array}{l}\text { Soma dos } \\
\text { quadrados corrigida }\end{array}$ & 0,591638 \\
\hline CV Pearson & 74,9869463 & Erro-padrão médio & 1,021111111 \\
\hline
\end{tabular}

\begin{tabular}{|l|l|l|r|}
\hline \multicolumn{4}{|c|}{ Estatística Descritiva Básica } \\
\hline \multicolumn{2}{|c|}{ Posição } & \multicolumn{2}{c|}{ Variabilidade } \\
\hline Média & 5,777778 & Desvio-padrão & 4,33258 \\
\hline Mediana & 4,000000 & Variância & 18,77124 \\
\hline Moda & 3,000000 & Amplitude & 15,00000 \\
\hline & & Amplitude interquartil & 5,00000 \\
\hline
\end{tabular}

\begin{tabular}{|l|l|r|l|l|}
\hline \multicolumn{5}{|c|}{ Testes de Posição: Mu0=0 } \\
\hline Teste & \multicolumn{2}{|c|}{ Estatística } & \multicolumn{2}{c|}{ Valor $\mathbf{p}$} \\
\hline Student t & t & 5,657839 & $\operatorname{Pr}>|\mathbf{t}|$ & $<, 0001$ \\
\hline Sign & M & 8,5 & $\operatorname{Pr}>=|\mathbf{M}|$ & $<, 0001$ \\
\hline Signed Rank & S & 76,5 & $\operatorname{Pr}>=|\mathbf{S}|$ & $<, 0001$ \\
\hline
\end{tabular}

\begin{tabular}{|l|r|}
\hline \multicolumn{2}{|c|}{ Quantis } \\
\hline Level & Quantil \\
\hline $100 \%$ Max & 15 \\
\hline $99 \%$ & 15 \\
\hline $95 \%$ & 15 \\
\hline $90 \%$ & 15 \\
\hline $75 \%$ Q3 & 8 \\
\hline $50 \%$ Mediana & 4 \\
\hline $25 \%$ Q1 & 3 \\
\hline $10 \%$ & 2 \\
\hline $5 \%$ & 0 \\
\hline $1 \%$ & 0 \\
\hline $0 \%$ Min & 0 \\
\hline
\end{tabular}


Variável dependente:

ACI

$$
\text { ID }=1
$$

\begin{tabular}{|r|r|r|r|}
\hline \multicolumn{3}{|c|}{ Observações Limite } \\
\hline \multicolumn{2}{|c|}{ Baixa } & \multicolumn{2}{c|}{ Alta } \\
\hline Valor & Obs & Valor & Obs \\
\hline 0 & 17 & 8 & 3 \\
\hline 2 & 11 & 8 & 9 \\
\hline 3 & 18 & 12 & 1 \\
\hline 3 & 16 & 15 & 2 \\
\hline 3 & 13 & 15 & 4 \\
\hline
\end{tabular}


Variável dependente:

REC

ID $=2$

\begin{tabular}{|l|r|l|r|}
\hline \multicolumn{4}{|c|}{ Momento } \\
\hline Média & 18 & Soma dos pesos & 18 \\
\hline Desvio-padrão & 4,5 & $\begin{array}{l}\text { Soma das } \\
\text { observações }\end{array}$ \\
\hline Assimetria & 1,4614767 & Curtose & 20,8529412 \\
\hline $\begin{array}{l}\text { Soma dos } \\
\text { quadrados não } \\
\text { corrigida }\end{array}$ & 899 & $\begin{array}{l}\text { Soma dos } \\
\text { quadrados corrigida }\end{array}$ & 1,6870576 \\
\hline CV Pearson & 83,0273104 & Erro-padrão médio & 1,07633486 \\
\hline
\end{tabular}

\begin{tabular}{|l|l|l|r|}
\hline \multicolumn{4}{|c|}{ Estatística Descritiva Básica } \\
\hline \multicolumn{2}{|c|}{ Posição } & \multicolumn{2}{c|}{ Variabilidade } \\
\hline Média & 5,500000 & Desvio-padrão & 4,56650 \\
\hline Mediana & 4,000000 & Variância & 20,85294 \\
\hline Moda & 4,000000 & Amplitude & 16,00000 \\
\hline & & Amplitude interquartil & 5,00000 \\
\hline
\end{tabular}

\begin{tabular}{|l|l|r|l|l|}
\hline \multicolumn{5}{|c|}{ Testes de Posição: Mu0=0 } \\
\hline Teste & \multicolumn{2}{|c|}{ Estatística } & \multicolumn{2}{c|}{ Valor $\mathbf{p}$} \\
\hline Student t & t & 5,109934 & $\operatorname{Pr}>|\mathbf{t}|$ & $<, 0001$ \\
\hline Sign & M & 9 & $\operatorname{Pr}>=|\mathbf{M}|$ & $<, 0001$ \\
\hline Signed Rank & S & 85,5 & $\operatorname{Pr}>=|\mathbf{S}|$ & $<, 0001$ \\
\hline
\end{tabular}

\begin{tabular}{|l|r|}
\hline \multicolumn{2}{|c|}{ Quantis } \\
\hline Level & Quantil \\
\hline $100 \%$ Max & 17 \\
\hline $99 \%$ & 17 \\
\hline $95 \%$ & 17 \\
\hline $90 \%$ & 15 \\
\hline $75 \%$ Q3 & 8 \\
\hline $50 \%$ Mediana & 4 \\
\hline $25 \%$ Q1 & 3 \\
\hline $10 \%$ & 1 \\
\hline $5 \%$ & 1 \\
\hline $1 \%$ & 1 \\
\hline $0 \%$ Min & 1 \\
\hline
\end{tabular}


Variável dependente:

REC

$$
\text { ID }=\mathbf{2}
$$

\begin{tabular}{|r|r|r|r|}
\hline \multicolumn{3}{|c|}{ Observações Limite } \\
\hline \multicolumn{2}{|c|}{ Baixa } & \multicolumn{2}{c|}{ Alta } \\
\hline Valor & Obs & Valor & Obs \\
\hline 1 & 35 & 8 & 24 \\
\hline 1 & 29 & 9 & 22 \\
\hline 1 & 25 & 9 & 23 \\
\hline 2 & 33 & 15 & 21 \\
\hline 3 & 32 & 17 & 20 \\
\hline
\end{tabular}


Variável dependente:

ACI

ID $=$ 2

\begin{tabular}{|c|c|c|c|}
\hline \multicolumn{4}{|c|}{ Momento } \\
\hline $\mathbf{N}$ & 18 & Soma dos pesos & 18 \\
\hline Média & 7,27777778 & $\begin{array}{l}\text { Soma das } \\
\text { observações }\end{array}$ & 131 \\
\hline Desvio-padrão & 5,08522144 & Variância & 25,8594771 \\
\hline Assimetria & 1,39410775 & Curtose & 1,51274684 \\
\hline $\begin{array}{l}\text { Soma dos } \\
\text { quadrados não } \\
\text { corrigida }\end{array}$ & 1393 & $\begin{array}{l}\text { Soma dos } \\
\text { quadrados corrigida }\end{array}$ & 439,611111 \\
\hline CV Pearson & 69,8732717 & Erro-padrão médio & 1,19859819 \\
\hline
\end{tabular}

\begin{tabular}{|l|l|l|r|}
\hline \multicolumn{4}{|c|}{ Estatística Descritiva Básica } \\
\hline \multicolumn{2}{|c|}{ Posição } & \multicolumn{2}{c|}{ Variabilidade } \\
\hline Média & 7,277778 & Desvio-padrão & 5,08522 \\
\hline Mediana & 6,000000 & Variância & 25,85948 \\
\hline Moda & 6,000000 & Amplitude & 17,00000 \\
\hline & & Amplitude interquartil & 7,00000 \\
\hline
\end{tabular}

\begin{tabular}{|l|l|l|l|l|}
\hline \multicolumn{5}{|c|}{ Testes de Posição: Mu0=0 } \\
\hline Teste & \multicolumn{2}{|c|}{ Estatística } & \multicolumn{2}{c|}{ Valor $\mathbf{p}$} \\
\hline Student t & t & 6,071908 & $\operatorname{Pr}>|\mathbf{t}|$ & $<, 0001$ \\
\hline Sign & M & 9 & $\operatorname{Pr}>=|\mathbf{M}|$ & $<, 0001$ \\
\hline Signed Rank & S & 85,5 & $\operatorname{Pr}>=|\mathbf{S}|$ & $<, 0001$ \\
\hline
\end{tabular}

\begin{tabular}{|l|r|}
\hline \multicolumn{2}{|c|}{ Quantis } \\
\hline Level & Quantil \\
\hline $100 \%$ Max & 19 \\
\hline $99 \%$ & 19 \\
\hline $95 \%$ & 19 \\
\hline $90 \%$ & 19 \\
\hline $75 \%$ Q3 & 10 \\
\hline $50 \%$ Mediana & 6 \\
\hline $25 \%$ Q1 & 3 \\
\hline $10 \%$ & 2 \\
\hline $5 \%$ & 2 \\
\hline $1 \%$ & 2 \\
\hline $0 \%$ Min & 2 \\
\hline
\end{tabular}


Variável dependente:

ACI

$$
\mathrm{ID}=\mathbf{2}
$$

\begin{tabular}{|r|r|r|r|}
\hline \multicolumn{3}{|c|}{ Observações Limite } \\
\hline \multicolumn{2}{|c|}{ Baixa } & \multicolumn{2}{c|}{ Alta } \\
\hline Valor & Obs & Valor & Obs \\
\hline 2 & 34 & 10 & 21 \\
\hline 2 & 29 & 11 & 20 \\
\hline 3 & 35 & 11 & 23 \\
\hline 3 & 33 & 19 & 24 \\
\hline 3 & 31 & 19 & 26 \\
\hline
\end{tabular}


Variável dependente:

REC

ID $=\mathbf{3}$

\begin{tabular}{|l|r|l|r|}
\hline \multicolumn{3}{|c|}{ Momento } \\
\hline N & 8 & Soma dos pesos & 8 \\
\hline Média & $\begin{array}{r}0 \\
\text { Soma das } \\
\text { observações }\end{array}$ & 0 \\
\hline Desvio-padrão & 0 & Variância & 0 \\
\hline Assimetria &, Curtose &, \\
\hline $\begin{array}{l}\text { Soma dos } \\
\text { quadrados não } \\
\text { corrigida }\end{array}$ & 0 & $\begin{array}{l}\text { Soma dos } \\
\text { quadrados corrigida }\end{array}$ & 0 \\
\hline CV Pearson &, & Erro-padrão médio & 0 \\
\hline
\end{tabular}

\begin{tabular}{|l|r|l|r|}
\hline \multicolumn{3}{|c|}{ Estatística Descritiva Básica } \\
\hline \multicolumn{2}{|c|}{ Posição } & \multicolumn{2}{c|}{ Variabilidade } \\
\hline Média & 0 & Desvio-padrão & 0 \\
\hline Mediana & 0 & Variância & 0 \\
\hline Moda & 0 & Amplitude & 0 \\
\hline & & Amplitude interquartil & 0 \\
\hline
\end{tabular}

\begin{tabular}{|c|c|c|c|c|}
\hline \multicolumn{5}{|c|}{ Testes de Posição: Mu0=0 } \\
\hline Teste & & & Val & \\
\hline Student $t$ & $\mathbf{t}$ & & $\operatorname{Pr}>|t|$ & \\
\hline Sign & M & & $\operatorname{Pr}>=|M|$ & \\
\hline Signed Rank & $s$ & & $\operatorname{Pr}>=|S|$ & \\
\hline
\end{tabular}

\begin{tabular}{|l|r|}
\hline \multicolumn{2}{|c|}{ Quantis } \\
\hline Level & Quantil \\
\hline $100 \%$ Max & 0 \\
\hline $99 \%$ & 0 \\
\hline $95 \%$ & 0 \\
\hline $90 \%$ & 0 \\
\hline $75 \%$ Q3 & 0 \\
\hline $50 \%$ Mediana & 0 \\
\hline $25 \%$ Q1 & 0 \\
\hline $10 \%$ & 0 \\
\hline $5 \%$ & 0 \\
\hline $1 \%$ & 0 \\
\hline $0 \%$ Min & 0 \\
\hline
\end{tabular}


Variável dependente:

REC

ID $=3$

\begin{tabular}{|r|r|r|r|}
\hline \multicolumn{3}{|c|}{ Observações Limite } \\
\hline \multicolumn{2}{|c|}{ Baixa } & \multicolumn{2}{c|}{ Alta } \\
\hline Valor & Obs & Valor & Obs \\
\hline 0 & 44 & 0 & 40 \\
\hline 0 & 43 & 0 & 41 \\
\hline 0 & 42 & 0 & 42 \\
\hline 0 & 41 & 0 & 43 \\
\hline 0 & 40 & 0 & 44 \\
\hline
\end{tabular}


Variável dependente:

ACI

ID $=3$

\begin{tabular}{|l|r|l|r|}
\hline \multicolumn{3}{|c|}{ Momento } \\
\hline N & 8 & Soma dos pesos & 8 \\
\hline Média & $\begin{array}{l}0 \\
\text { Soma das } \\
\text { observações }\end{array}$ & 0 \\
\hline Desvio-padrão & 0 & Variância & 0 \\
\hline Assimetria &, Curtose &, \\
\hline $\begin{array}{l}\text { Soma dos } \\
\text { quadrados não } \\
\text { corrigida }\end{array}$ & $0 \begin{array}{l}\text { Soma dos } \\
\text { quadrados corrigida }\end{array}$ & 0 \\
\hline CV Pearson &, & Erro-padrão médio & 0 \\
\hline
\end{tabular}

\begin{tabular}{|l|r|l|r|}
\hline \multicolumn{3}{|c|}{ Estatística Descritiva Básica } \\
\hline \multicolumn{2}{|c|}{ Posição } & \multicolumn{2}{c|}{ Variabilidade } \\
\hline Média & 0 & Desvio-padrão & 0 \\
\hline Mediana & 0 & Variância & 0 \\
\hline Moda & 0 & Amplitude & 0 \\
\hline & & Amplitude interquartil & 0 \\
\hline
\end{tabular}

\begin{tabular}{|c|c|c|c|c|}
\hline \multicolumn{5}{|c|}{ Testes de Posição: Mu0=0 } \\
\hline Teste & & & Val & \\
\hline Student $t$ & $\mathbf{t}$ & & $\operatorname{Pr}>|t|$ & \\
\hline Sign & M & & $\operatorname{Pr}>=|M|$ & \\
\hline Signed Rank & $s$ & & $\operatorname{Pr}>=|S|$ & \\
\hline
\end{tabular}

\begin{tabular}{|l|r|}
\hline \multicolumn{2}{|c|}{ Quantis } \\
\hline Level & Quantil \\
\hline $100 \%$ Max & 0 \\
\hline $99 \%$ & 0 \\
\hline $95 \%$ & 0 \\
\hline $90 \%$ & 0 \\
\hline $75 \%$ Q3 & 0 \\
\hline $50 \%$ Mediana & 0 \\
\hline $25 \%$ Q1 & 0 \\
\hline $10 \%$ & 0 \\
\hline $5 \%$ & 0 \\
\hline $1 \%$ & 0 \\
\hline $0 \%$ Min & 0 \\
\hline
\end{tabular}


Variável dependente:

ACI

$$
\text { ID }=\mathbf{3}
$$

\begin{tabular}{|r|r|r|r|}
\hline \multicolumn{3}{|c|}{ Observações Limite } \\
\hline \multicolumn{2}{|c|}{ Baixa } & \multicolumn{2}{c|}{ Alta } \\
\hline Valor & Obs & Valor & Obs \\
\hline 0 & 44 & 0 & 40 \\
\hline 0 & 43 & 0 & 41 \\
\hline 0 & 42 & 0 & 42 \\
\hline 0 & 41 & 0 & 43 \\
\hline 0 & 40 & 0 & 44 \\
\hline
\end{tabular}


Variável dependente:

REC

ID $=4$

\begin{tabular}{|l|r|l|r|}
\hline \multicolumn{4}{|c|}{ Momento } \\
\hline Média & 18 & Soma dos pesos & 18 \\
\hline Desvio-padrão & 0,60768499 & Variância \\
\hline Assimetria & 1,36161604 & Curtose & 0,36928105 \\
\hline $\begin{array}{l}\text { Soma dos } \\
\text { quadrados não } \\
\text { corrigida }\end{array}$ & 9 & $\begin{array}{l}\text { Soma dos } \\
\text { quadrados corrigida }\end{array}$ & 1,12632156 \\
\hline CV Pearson & 156,261854 & Erro-padrão médio & 0,14323277778 \\
\hline
\end{tabular}

\begin{tabular}{|l|l|l|l|}
\hline \multicolumn{4}{|c|}{ Estatística Descritiva Básica } \\
\hline \multicolumn{2}{|c|}{ Posição } & \multicolumn{2}{c|}{ Variabilidade } \\
\hline Média & 0,388889 & Desvio-padrão & 0,60768 \\
\hline Mediana & 0,000000 & Variância & 0,36928 \\
\hline Moda & 0,000000 & Amplitude & 2,00000 \\
\hline & & Amplitude interquartil & 1,00000 \\
\hline
\end{tabular}

\begin{tabular}{|l|l|r|l|l|}
\hline \multicolumn{5}{|c|}{ Testes de Posição: Mu0=0 } \\
\hline Teste & \multicolumn{2}{|c|}{ Estatística } & \multicolumn{2}{c|}{ Valor $\mathbf{~}$} \\
\hline Student t & $\mathbf{t}$ & 2,715084 & $\mathrm{Pr}>|\mathbf{t}|$ & 0,0147 \\
\hline Sign & M & 3 & $\mathrm{Pr}>=|\mathrm{M}|$ & 0,0313 \\
\hline Signed Rank & S & 10,5 & $\mathrm{Pr}>=|\mathbf{S}|$ & 0,0313 \\
\hline
\end{tabular}

\begin{tabular}{|l|r|}
\hline \multicolumn{2}{|c|}{ Quantis } \\
\hline Level & Quantil \\
\hline $100 \%$ Max & 2 \\
\hline $99 \%$ & 2 \\
\hline $95 \%$ & 2 \\
\hline $90 \%$ & 1 \\
\hline $75 \%$ Q3 & 1 \\
\hline $50 \%$ Mediana & 0 \\
\hline $25 \%$ Q1 & 0 \\
\hline $10 \%$ & 0 \\
\hline $5 \%$ & 0 \\
\hline $1 \%$ & 0 \\
\hline $0 \%$ Min & 0 \\
\hline
\end{tabular}


Variável dependente:

REC

$$
\text { ID }=4
$$

\begin{tabular}{|r|r|r|r|}
\hline \multicolumn{3}{|c|}{ Observações Limite } \\
\hline \multicolumn{2}{|c|}{ Baixa } & \multicolumn{2}{c|}{ Alta } \\
\hline Valor & Obs & Valor & Obs \\
\hline 0 & 62 & 1 & 47 \\
\hline 0 & 61 & 1 & 50 \\
\hline 0 & 60 & 1 & 52 \\
\hline 0 & 59 & 1 & 53 \\
\hline 0 & 58 & 2 & 49 \\
\hline
\end{tabular}


Variável dependente:

ACI

ID $=4$

\begin{tabular}{|l|r|l|r|}
\hline \multicolumn{3}{|c|}{ Momento } \\
\hline Média & 18 & Soma dos pesos & 18 \\
\hline Desvio-padrão & 0,95828005 & $\begin{array}{l}\text { Variância } \\
\text { observações }\end{array}$ & 0,91830065 \\
\hline Assimetria & 1,08252963 & Curtose & 0,13098618 \\
\hline $\begin{array}{l}\text { Soma dos } \\
\text { quadrados não } \\
\text { corrigida }\end{array}$ & 25 & $\begin{array}{l}\text { Soma dos } \\
\text { quadrados corrigida }\end{array}$ & 15,6111111 \\
\hline CV Pearson & 132,68493 & Erro-padrão médio & 0,22586877 \\
\hline
\end{tabular}

\begin{tabular}{|l|l|l|c|}
\hline \multicolumn{4}{|c|}{ Estatística Descritiva Básica } \\
\hline \multicolumn{2}{|c|}{ Posição } & \multicolumn{2}{c|}{ Variabilidade } \\
\hline Média & 0,722222 & Desvio-padrão & 0,95828 \\
\hline Mediana & 0,000000 & Variância & 0,91830 \\
\hline Moda & 0,000000 & Amplitude & 3,00000 \\
\hline & & Amplitude interquartil & 1,00000 \\
\hline
\end{tabular}

\begin{tabular}{|l|l|r|l|l|}
\hline \multicolumn{5}{|c|}{ Testes de Posição: Mu0=0 } \\
\hline Teste & \multicolumn{2}{|c|}{ Estatística } & \multicolumn{2}{c|}{ Valor $\mathbf{~}$} \\
\hline Student t & t & 3,19753 & $\operatorname{Pr}>|\mathbf{t}|$ & 0,0053 \\
\hline Sign & M & 4 & $\operatorname{Pr}>=|\mathbf{M}|$ & 0,0078 \\
\hline Signed Rank & S & 18 & $\operatorname{Pr}>=|\mathbf{S}|$ & 0,0078 \\
\hline
\end{tabular}

\begin{tabular}{|l|r|}
\hline \multicolumn{2}{|c|}{ Quantis } \\
\hline Level & 3 \\
\hline $100 \%$ Max & 3 \\
\hline $99 \%$ & 3 \\
\hline $95 \%$ & 2 \\
\hline $90 \%$ & 1 \\
\hline $75 \%$ Q3 & 0 \\
\hline $50 \%$ Mediana & 0 \\
\hline $25 \%$ Q1 & 0 \\
\hline $10 \%$ & 0 \\
\hline $5 \%$ & 0 \\
\hline $1 \%$ & 0 \\
\hline $0 \%$ Min & 0 \\
\hline
\end{tabular}


Variável dependente:

ACI

$$
\text { ID }=4
$$

\begin{tabular}{|r|r|r|r|}
\hline \multicolumn{3}{|c|}{ Observações Limite } \\
\hline \multicolumn{2}{|c|}{ Baixa } & \multicolumn{2}{c|}{ Alta } \\
\hline Valor & Obs & Valor & Obs \\
\hline 0 & 61 & 1 & 57 \\
\hline 0 & 60 & 2 & 45 \\
\hline 0 & 59 & 2 & 48 \\
\hline 0 & 58 & 2 & 52 \\
\hline 0 & 56 & 3 & 62 \\
\hline
\end{tabular}


Variável dependente:

REC

ID $=\mathbf{5}$

\begin{tabular}{|l|r|r|r|}
\hline \multicolumn{3}{|l|}{ Momento } \\
\hline N & 15 Soma dos pesos & 15 \\
\hline Média & $\begin{array}{r}0 \\
\text { Soma das } \\
\text { observações }\end{array}$ & 0 \\
\hline Desvio-padrão & 0 & Variância & 0 \\
\hline Assimetria &, Curtose &, \\
\hline $\begin{array}{l}\text { Soma dos } \\
\text { quadrados não } \\
\text { corrigida }\end{array}$ & 0 & $\begin{array}{l}\text { Soma dos } \\
\text { quadrados corrigida }\end{array}$ & 0 \\
\hline CV Pearson &, & Erro-padrão médio & 0 \\
\hline
\end{tabular}

\begin{tabular}{|l|r|l|r|}
\hline \multicolumn{3}{|c|}{ Estatística Descritiva Básica } \\
\hline \multicolumn{2}{|c|}{ Posição } & \multicolumn{2}{c|}{ Variabilidade } \\
\hline Média & 0 & Desvio-padrão & 0 \\
\hline Mediana & 0 & Variância & 0 \\
\hline Moda & 0 & Amplitude & 0 \\
\hline & & Amplitude interquartil & 0 \\
\hline
\end{tabular}

\begin{tabular}{|c|c|c|c|c|}
\hline \multicolumn{5}{|c|}{ Testes de Posição: Mu0=0 } \\
\hline Teste & & & Val & \\
\hline Student $t$ & $\mathbf{t}$ & & $\operatorname{Pr}>|t|$ & \\
\hline Sign & M & & $\operatorname{Pr}>=|M|$ & \\
\hline Signed Rank & $s$ & & $\operatorname{Pr}>=|S|$ & \\
\hline
\end{tabular}

\begin{tabular}{|l|r|}
\hline \multicolumn{2}{|c|}{ Quantis } \\
\hline Level & Quantil \\
\hline $100 \%$ Max & 0 \\
\hline $99 \%$ & 0 \\
\hline $95 \%$ & 0 \\
\hline $90 \%$ & 0 \\
\hline $75 \%$ Q3 & 0 \\
\hline $50 \%$ Mediana & 0 \\
\hline $25 \%$ Q1 & 0 \\
\hline $10 \%$ & 0 \\
\hline $5 \%$ & 0 \\
\hline $1 \%$ & 0 \\
\hline $0 \%$ Min & 0 \\
\hline
\end{tabular}


Variável dependente:

REC

$$
\text { ID }=\mathbf{5}
$$

\begin{tabular}{|r|r|r|r|}
\hline \multicolumn{3}{|c|}{ Observações Limite } \\
\hline \multicolumn{2}{|c|}{ Baixa } & \multicolumn{2}{c|}{ Alta } \\
\hline Valor & Obs & Valor & Obs \\
\hline 0 & 77 & 0 & 73 \\
\hline 0 & 76 & 0 & 74 \\
\hline 0 & 75 & 0 & 75 \\
\hline 0 & 74 & 0 & 76 \\
\hline 0 & 73 & 0 & 77 \\
\hline
\end{tabular}


Variável dependente:

ACI

ID $=\mathbf{5}$

\begin{tabular}{|l|r|r|r|}
\hline \multicolumn{3}{|l|}{ Momento } \\
\hline N & 15 Soma dos pesos & 15 \\
\hline Média & $\begin{array}{r}0 \\
\text { Soma das } \\
\text { observações }\end{array}$ & 0 \\
\hline Desvio-padrão & 0 & Variância & 0 \\
\hline Assimetria &, Curtose &, \\
\hline $\begin{array}{l}\text { Soma dos } \\
\text { quadrados não } \\
\text { corrigida }\end{array}$ & 0 & $\begin{array}{l}\text { Soma dos } \\
\text { quadrados corrigida }\end{array}$ & 0 \\
\hline CV Pearson &, & Erro-padrão médio & 0 \\
\hline
\end{tabular}

\begin{tabular}{|l|r|l|r|}
\hline \multicolumn{3}{|c|}{ Estatística Descritiva Básica } \\
\hline \multicolumn{2}{|c|}{ Posição } & \multicolumn{2}{c|}{ Variabilidade } \\
\hline Média & 0 & Desvio-padrão & 0 \\
\hline Mediana & 0 & Variância & 0 \\
\hline Moda & 0 & Amplitude & 0 \\
\hline & & Amplitude interquartil & 0 \\
\hline
\end{tabular}

\begin{tabular}{|c|c|c|c|c|}
\hline \multicolumn{5}{|c|}{ Testes de Posição: Mu0=0 } \\
\hline Teste & & & Val & \\
\hline Student $t$ & $\mathbf{t}$ & & $\operatorname{Pr}>|t|$ & \\
\hline Sign & M & & $\operatorname{Pr}>=|M|$ & \\
\hline Signed Rank & $s$ & & $\operatorname{Pr}>=|S|$ & \\
\hline
\end{tabular}

\begin{tabular}{|l|r|}
\hline \multicolumn{2}{|c|}{ Quantis } \\
\hline Level & Quantil \\
\hline $100 \%$ Max & 0 \\
\hline $99 \%$ & 0 \\
\hline $95 \%$ & 0 \\
\hline $90 \%$ & 0 \\
\hline $75 \%$ Q3 & 0 \\
\hline $50 \%$ Mediana & 0 \\
\hline $25 \%$ Q1 & 0 \\
\hline $10 \%$ & 0 \\
\hline $5 \%$ & 0 \\
\hline $1 \%$ & 0 \\
\hline $0 \%$ Min & 0 \\
\hline
\end{tabular}


Variável dependente:

ACI

$$
\text { ID }=\mathbf{5}
$$

\begin{tabular}{|r|r|r|r|}
\hline \multicolumn{3}{|c|}{ Observações Limite } \\
\hline \multicolumn{2}{|c|}{ Baixa } & \multicolumn{2}{c|}{ Alta } \\
\hline Valor & Obs & Valor & Obs \\
\hline 0 & 77 & 0 & 73 \\
\hline 0 & 76 & 0 & 74 \\
\hline 0 & 75 & 0 & 75 \\
\hline 0 & 74 & 0 & 76 \\
\hline 0 & 73 & 0 & 77 \\
\hline
\end{tabular}


Variável dependente:

REC

ID $=6$

\begin{tabular}{|l|r|l|r|}
\hline \multicolumn{3}{|c|}{ Momento } \\
\hline N & 18 & Soma dos pesos & 18 \\
\hline Média & $\begin{array}{l}0 \\
\text { Soma das } \\
\text { observações }\end{array}$ & 0 \\
\hline Desvio-padrão & 0 & Variância & 0 \\
\hline Assimetria &, & Curtose &, \\
\hline $\begin{array}{l}\text { Soma dos } \\
\text { quadrados não } \\
\text { corrigida }\end{array}$ & 0 & $\begin{array}{l}\text { Soma dos } \\
\text { quadrados corrigida }\end{array}$ & 0 \\
\hline CV Pearson &, & Erro-padrão médio & 0 \\
\hline
\end{tabular}

\begin{tabular}{|l|r|l|r|}
\hline \multicolumn{3}{|c|}{ Estatística Descritiva Básica } \\
\hline \multicolumn{2}{|c|}{ Posição } & \multicolumn{2}{c|}{ Variabilidade } \\
\hline Média & 0 & Desvio-padrão & 0 \\
\hline Mediana & 0 & Variância & 0 \\
\hline Moda & 0 & Amplitude & 0 \\
\hline & & Amplitude interquartil & 0 \\
\hline
\end{tabular}

\begin{tabular}{|c|c|c|c|c|}
\hline \multicolumn{5}{|c|}{ Testes de Posição: Mu0=0 } \\
\hline Teste & & & Val & \\
\hline Student $t$ & $\mathbf{t}$ & & $\operatorname{Pr}>|t|$ & \\
\hline Sign & M & & $\operatorname{Pr}>=|M|$ & \\
\hline Signed Rank & $s$ & & $\operatorname{Pr}>=|S|$ & \\
\hline
\end{tabular}

\begin{tabular}{|l|r|}
\hline \multicolumn{2}{|c|}{ Quantis } \\
\hline Level & Quantil \\
\hline $100 \%$ Max & 0 \\
\hline $99 \%$ & 0 \\
\hline $95 \%$ & 0 \\
\hline $90 \%$ & 0 \\
\hline $75 \%$ Q3 & 0 \\
\hline $50 \%$ Mediana & 0 \\
\hline $25 \%$ Q1 & 0 \\
\hline $10 \%$ & 0 \\
\hline $5 \%$ & 0 \\
\hline $1 \%$ & 0 \\
\hline $0 \%$ Min & 0 \\
\hline
\end{tabular}


Variável dependente:

REC

ID $=6$

\begin{tabular}{|r|r|r|r|}
\hline \multicolumn{3}{|c|}{ Observações Limite } \\
\hline \multicolumn{2}{|c|}{ Baixa } & \multicolumn{2}{c|}{ Alta } \\
\hline Valor & Obs & Valor & Obs \\
\hline 0 & 95 & 0 & 91 \\
\hline 0 & 94 & 0 & 92 \\
\hline 0 & 93 & 0 & 93 \\
\hline 0 & 92 & 0 & 94 \\
\hline 0 & 91 & 0 & 95 \\
\hline
\end{tabular}


Variável

dependente:

ACI

ID $=6$

\begin{tabular}{|l|r|l|r|}
\hline \multicolumn{3}{|c|}{ Momento } \\
\hline N & 18 & Soma dos pesos & 18 \\
\hline Média & $\begin{array}{r}0 \\
\text { Soma das } \\
\text { observações }\end{array}$ & 0 \\
\hline Desvio-padrão & 0 & Variância & 0 \\
\hline Assimetria &, Curtose &, \\
\hline $\begin{array}{l}\text { Soma dos } \\
\text { quadrados não } \\
\text { corrigida }\end{array}$ & 0 & $\begin{array}{l}\text { Soma dos } \\
\text { quadrados corrigida }\end{array}$ & 0 \\
\hline CV Pearson &, & Erro-padrão médio & 0 \\
\hline
\end{tabular}

\begin{tabular}{|l|r|l|r|}
\hline \multicolumn{3}{|c|}{ Estatística Descritiva Básica } \\
\hline \multicolumn{2}{|c|}{ Posição } & \multicolumn{2}{c|}{ Variabilidade } \\
\hline Média & 0 & Desvio-padrão & 0 \\
\hline Mediana & 0 & Variância & 0 \\
\hline Moda & 0 & Amplitude & 0 \\
\hline & & Amplitude interquartil & 0 \\
\hline
\end{tabular}

\begin{tabular}{|l|l|l|l|l|}
\hline \multicolumn{4}{|c|}{ Testes de Posição: $\mathrm{Mu0}=0$} \\
\hline Teste & \multicolumn{2}{|c|}{ Estatística } & \multicolumn{2}{c|}{ Valor $\mathbf{p}$} \\
\hline Student t & $\mathbf{t}$ &, & $\mathrm{Pr}>|\mathbf{t}|$ & \\
\hline Sign & $\mathbf{M}$ &, & $\mathrm{Pr}>=|\mathrm{M}|$ & \\
\hline Signed Rank & $\mathbf{S}$ &, & $\mathrm{Pr}>=|\mathrm{S}|$ & \\
\hline
\end{tabular}

\begin{tabular}{|l|r|}
\hline \multicolumn{2}{|c|}{ Quantis } \\
\hline Level & Quantil \\
\hline $100 \%$ Max & 0 \\
\hline $99 \%$ & 0 \\
\hline $95 \%$ & 0 \\
\hline $90 \%$ & 0 \\
\hline $75 \%$ Q3 & 0 \\
\hline $50 \%$ Mediana & 0 \\
\hline $25 \%$ Q1 & 0 \\
\hline $10 \%$ & 0 \\
\hline $5 \%$ & 0 \\
\hline $1 \%$ & 0 \\
\hline $0 \%$ Min & 0 \\
\hline
\end{tabular}




\section{Variável}

dependente:

ACI

ID $=6$

\begin{tabular}{|r|r|r|r|}
\hline \multicolumn{3}{|c|}{ Observações Limite } \\
\hline \multicolumn{2}{|c|}{ Baixa } & \multicolumn{2}{c|}{ Alta } \\
\hline Valor & Obs & Valor & Obs \\
\hline 0 & 95 & 0 & 91 \\
\hline 0 & 94 & 0 & 92 \\
\hline 0 & 93 & 0 & 93 \\
\hline 0 & 92 & 0 & 94 \\
\hline 0 & 91 & 0 & 95 \\
\hline
\end{tabular}


Variável

dependente:

REC

ID $=7$

\begin{tabular}{|l|r|l|r|}
\hline \multicolumn{3}{|c|}{ Momento } \\
\hline N & 18 & Soma dos pesos & 33 \\
\hline Média & 1,83333333 & $\begin{array}{l}\text { Soma das } \\
\text { observações }\end{array}$ \\
\hline $\begin{array}{l}\text { Somaio-padrão } \\
\text { quadrados não } \\
\text { corrigida }\end{array}$ & 1,50489398 & Variância & 2,26470588 \\
\hline CV Pearson & 0,55015309 & Curtose & $-0,4180469$ \\
\hline
\end{tabular}

\begin{tabular}{|l|l|l|l|}
\hline \multicolumn{4}{|c|}{ Estatística Descritiva Básica } \\
\hline \multicolumn{2}{|c|}{ Posição } & \multicolumn{2}{c|}{ Variabilidade } \\
\hline Média & 1,833333 & Desvio-padrão & 1,50489 \\
\hline Mediana & 2,000000 & Variância & 2,26471 \\
\hline Moda & 2,000000 & Amplitude & 5,00000 \\
\hline & & Amplitude interquartil & 2,00000 \\
\hline
\end{tabular}

\begin{tabular}{|l|l|r|l|l|}
\hline \multicolumn{5}{|c|}{ Testes de Posição: Mu0=0 } \\
\hline Teste & \multicolumn{2}{|c|}{ Estatística } & \multicolumn{2}{c|}{ Valor $\mathbf{~}$} \\
\hline Student t & $\mathbf{t}$ & 5,168586 & $\mathrm{Pr}>|\mathbf{t}|$ & $<, 0001$ \\
\hline Sign & $\mathbf{M}$ & 7 & $\mathrm{Pr}>=|\mathrm{M}|$ & 0,0001 \\
\hline Signed Rank & S & 52,5 & Pr $>=|\mathbf{S}|$ & 0,0001 \\
\hline
\end{tabular}

\begin{tabular}{|l|r|}
\hline \multicolumn{2}{|c|}{ Quantis } \\
\hline Level & Quantil \\
\hline $100 \%$ Max & 5 \\
\hline $99 \%$ & 5 \\
\hline $95 \%$ & 4 \\
\hline $90 \%$ & 3 \\
\hline $75 \%$ Q3 & 2 \\
\hline $50 \%$ Mediana & 1 \\
\hline $25 \%$ Q1 & 0 \\
\hline $10 \%$ & 0 \\
\hline $5 \%$ & 0 \\
\hline $1 \%$ & 0 \\
\hline $0 \%$ Min & \\
\hline
\end{tabular}


Variável

dependente:

REC

ID $=7$

\begin{tabular}{|r|r|r|r|}
\hline \multicolumn{3}{|c|}{ Observações Limite } \\
\hline \multicolumn{2}{|c|}{ Baixa } & \multicolumn{2}{c|}{ Alta } \\
\hline Valor & Obs & Valor & Obs \\
\hline 0 & 113 & 3 & 97 \\
\hline 0 & 112 & 3 & 102 \\
\hline 0 & 111 & 4 & 99 \\
\hline 0 & 106 & 4 & 103 \\
\hline 1 & 107 & 5 & 96 \\
\hline
\end{tabular}


Variável

dependente:

ACI

ID $=7$

\begin{tabular}{|l|r|l|r|}
\hline \multicolumn{4}{|c|}{ Momento } \\
\hline Média & 18 & Soma dos pesos & 18 \\
\hline Desvio-padrão & 1,30484266 & $\begin{array}{l}\text { Variância } \\
\text { observações }\end{array}$ \\
\hline Assimetria & 2,07995308 & Curtose & 1,70261438 \\
\hline $\begin{array}{l}\text { Soma dos } \\
\text { quadrados não } \\
\text { corrigida }\end{array}$ & 45 & $\begin{array}{l}\text { Soma dos } \\
\text { quadrados corrigida }\end{array}$ & 4,94598974 \\
\hline CV Pearson & 138,159812 & Erro-padrão médio & 0,30755437 \\
\hline
\end{tabular}

\begin{tabular}{|l|l|l|r|}
\hline \multicolumn{4}{|c|}{ Estatística Descritiva Básica } \\
\hline \multicolumn{2}{|c|}{ Posição } & \multicolumn{2}{c|}{ Variabilidade } \\
\hline Média & 0,944444 & Desvio-padrão & 1,30484 \\
\hline Mediana & 1,000000 & Variância & 1,70261 \\
\hline Moda & 0,000000 & Amplitude & 5,00000 \\
\hline & & Amplitude interquartil & 1,00000 \\
\hline
\end{tabular}

\begin{tabular}{|l|l|r|l|l|}
\hline \multicolumn{5}{|c|}{ Testes de Posição: Mu0=0 } \\
\hline Teste & \multicolumn{2}{|c|}{ Estatística } & \multicolumn{2}{c|}{ Valor $\mathbf{~}$} \\
\hline Student t & t & 3,070821 & $\mathrm{Pr}>|\mathbf{t}|$ & 0,0069 \\
\hline Sign & M & 5 & $\mathrm{Pr}>=|\mathrm{M}|$ & 0,0020 \\
\hline Signed Rank & S & 27,5 & $\mathrm{Pr}>=|\mathrm{S}|$ & 0,0020 \\
\hline
\end{tabular}

\begin{tabular}{|l|r|}
\hline \multicolumn{2}{|c|}{ Quantis } \\
\hline Level & 5 \\
\hline $100 \%$ Max & 5 \\
\hline $99 \%$ & 5 \\
\hline $95 \%$ & 3 \\
\hline $90 \%$ & 1 \\
\hline $75 \%$ Q3 & 1 \\
\hline $50 \%$ Mediana & 0 \\
\hline $25 \%$ Q1 & 0 \\
\hline $10 \%$ & 0 \\
\hline $5 \%$ & 0 \\
\hline $1 \%$ & 0 \\
\hline $0 \%$ Min & \\
\hline
\end{tabular}


Variável

dependente:

ACI

ID $=7$

\begin{tabular}{|r|r|r|r|}
\hline \multicolumn{3}{|c|}{ Observações Limite } \\
\hline \multicolumn{2}{|c|}{ Baixa } & \multicolumn{2}{c|}{ Alta } \\
\hline Valor & Obs & Valor & Obs \\
\hline 0 & 113 & 1 & 111 \\
\hline 0 & 110 & 1 & 112 \\
\hline 0 & 109 & 2 & 107 \\
\hline 0 & 108 & 3 & 99 \\
\hline 0 & 106 & 5 & 98 \\
\hline
\end{tabular}


Variável

dependente:

REC

ID $=8$

\begin{tabular}{|l|r|l|r|}
\hline \multicolumn{3}{|c|}{ Momento } \\
\hline Média & 18 & Soma dos pesos & 18 \\
\hline Desvio-padrão & 0,23570226 & $\begin{array}{l}\text { Variância } \\
\text { observações }\end{array}$ \\
\hline Assimetria & 4,24264069 & Curtose & 0,05555556 \\
\hline $\begin{array}{l}\text { Soma dos } \\
\text { quadrados não } \\
\text { corrigida }\end{array}$ & 1 & $\begin{array}{l}\text { Soma dos } \\
\text { quadrados corrigida }\end{array}$ & 0,94444444 \\
\hline CV Pearson & 424,264069 & Erro-padrão médio & 0,05555556 \\
\hline
\end{tabular}

\begin{tabular}{|l|l|l|r|}
\hline \multicolumn{4}{|c|}{ Estatística Descritiva Básica } \\
\hline \multicolumn{2}{|c|}{ Posição } & \multicolumn{2}{c|}{ Variabilidade } \\
\hline Média & 0,055556 & Desvio-padrão & 0,23570 \\
\hline Mediana & 0,000000 & Variância & 0,05556 \\
\hline Moda & 0,000000 & Amplitude & 1,00000 \\
\hline & & Amplitude interquartil & 0 \\
\hline
\end{tabular}

\begin{tabular}{|l|l|r|l|l|}
\hline \multicolumn{5}{|c|}{ Testes de Posição: Mu0=0 } \\
\hline Teste & \multicolumn{2}{|c|}{ Estatística } & \multicolumn{2}{c|}{ Valor $\mathbf{~}$} \\
\hline Student t & $\mathbf{t}$ & 1 & $\mathrm{Pr}>|\mathbf{t}|$ & 0,3313 \\
\hline Sign & $\mathbf{M}$ & 0,5 & $\mathrm{Pr}>=|\mathbf{M}|$ & 1,0000 \\
\hline Signed Rank & $\mathbf{S}$ & 0,5 & $\mathrm{Pr}>=|\mathbf{S}|$ & 1,0000 \\
\hline
\end{tabular}

\begin{tabular}{|l|r|}
\hline \multicolumn{2}{|c|}{ Quantis } \\
\hline Level & 1 \\
\hline $100 \%$ Max & 1 \\
\hline $99 \%$ & 1 \\
\hline $95 \%$ & 0 \\
\hline $90 \%$ & 0 \\
\hline $75 \%$ Quantil & 0 \\
\hline $50 \%$ Mediana & 0 \\
\hline $25 \%$ Q1 & 0 \\
\hline $10 \%$ & 0 \\
\hline $5 \%$ & 0 \\
\hline $1 \%$ & 0 \\
\hline $0 \%$ Min & \\
\hline
\end{tabular}


Variável

dependente:

REC

ID $=8$

\begin{tabular}{|r|r|r|r|}
\hline \multicolumn{3}{|c|}{ Observações Limite } \\
\hline \multicolumn{2}{|c|}{ Baixa } & \multicolumn{2}{c|}{ Alta } \\
\hline Valor & Obs & Valor & Obs \\
\hline 0 & 131 & 0 & 128 \\
\hline 0 & 130 & 0 & 129 \\
\hline 0 & 129 & 0 & 130 \\
\hline 0 & 128 & 0 & 131 \\
\hline 0 & 127 & 1 & 114 \\
\hline
\end{tabular}


Variável

dependente:

ACI

ID $=8$

\begin{tabular}{|l|r|l|r|}
\hline \multicolumn{3}{|c|}{ Momento } \\
\hline N & 18 & Soma dos pesos & 18 \\
\hline Média & $\begin{array}{r}0 \\
\text { Soma das } \\
\text { observações }\end{array}$ & 0 \\
\hline Desvio-padrão & 0 & Variância & 0 \\
\hline Assimetria &, Curtose &, \\
\hline $\begin{array}{l}\text { Soma dos } \\
\text { quadrados não } \\
\text { corrigida }\end{array}$ & 0 & $\begin{array}{l}\text { Soma dos } \\
\text { quadrados corrigida }\end{array}$ & 0 \\
\hline CV Pearson &, & Erro-padrão médio & 0 \\
\hline
\end{tabular}

\begin{tabular}{|l|r|l|r|}
\hline \multicolumn{3}{|c|}{ Estatística Descritiva Básica } \\
\hline \multicolumn{2}{|c|}{ Posição } & \multicolumn{2}{c|}{ Variabilidade } \\
\hline Média & 0 & Desvio-padrão & 0 \\
\hline Mediana & 0 & Variância & 0 \\
\hline Moda & 0 & Amplitude & 0 \\
\hline & & Amplitude interquartil & 0 \\
\hline
\end{tabular}

\begin{tabular}{|l|l|l|l|l|}
\hline \multicolumn{4}{|c|}{ Testes de Posição: Mu0=0 } \\
\hline Teste & \multicolumn{2}{|c|}{ Estatística } & \multicolumn{2}{c|}{ Valor $\mathbf{p}$} \\
\hline Student t & $\mathbf{t}$ &, & $\mathrm{Pr}>|\mathrm{t}|$ & \\
\hline Sign & $\mathrm{M}$ &, & $\mathrm{Pr}>=|\mathrm{M}|$ & \\
\hline Signed Rank & $\mathrm{S}$ &, & $\mathrm{Pr}>=|\mathrm{S}|$ & \\
\hline
\end{tabular}

\begin{tabular}{|l|r|}
\hline \multicolumn{2}{|c|}{ Quantis } \\
\hline Level & Quantil \\
\hline $100 \%$ Max & 0 \\
\hline $99 \%$ & 0 \\
\hline $95 \%$ & 0 \\
\hline $90 \%$ & 0 \\
\hline $75 \%$ Q3 & 0 \\
\hline $50 \%$ Mediana & 0 \\
\hline $25 \%$ Q1 & 0 \\
\hline $10 \%$ & 0 \\
\hline $5 \%$ & 0 \\
\hline $1 \%$ & 0 \\
\hline $0 \%$ Min & \\
\hline
\end{tabular}


Variável

dependente:

ACI

ID $=8$

\begin{tabular}{|r|r|r|r|}
\hline \multicolumn{3}{|c|}{ Observações Limite } \\
\hline \multicolumn{2}{|c|}{ Baixa } & \multicolumn{2}{c|}{ Alta } \\
\hline Valor & Obs & Valor & Obs \\
\hline 0 & 131 & 0 & 127 \\
\hline 0 & 130 & 0 & 128 \\
\hline 0 & 129 & 0 & 129 \\
\hline 0 & 128 & 0 & 130 \\
\hline 0 & 127 & 0 & 131 \\
\hline
\end{tabular}


Variável

dependente:

REC

ID $=9$

\begin{tabular}{|l|r|l|r|}
\hline \multicolumn{4}{|c|}{ Momento } \\
\hline Média & 18 & Soma dos pesos & 18 \\
\hline Desvio-padrão & 1,04318517 & Variância \\
\hline Assimetria & 1,06871234 & Curtose & 1,08823529 \\
\hline $\begin{array}{l}\text { Soma dos } \\
\text { quadrados não } \\
\text { corrigida }\end{array}$ & 31 & $\begin{array}{l}\text { Soma dos } \\
\text { quadrados corrigida }\end{array}$ & 0,0769905 \\
\hline CV Pearson & 125,18222 & Erro-padrão médio & 18,5 \\
\hline
\end{tabular}

\begin{tabular}{|l|l|l|r|}
\hline \multicolumn{4}{|c|}{ Estatística Descritiva Básica } \\
\hline \multicolumn{2}{|c|}{ Posição } & \multicolumn{2}{c|}{ Variabilidade } \\
\hline Média & 0,833333 & Desvio-padrão & 1,04319 \\
\hline Mediana & 0,500000 & Variância & 1,08824 \\
\hline Moda & 0,000000 & Amplitude & 3,00000 \\
\hline & & Amplitude interquartil & 1,00000 \\
\hline
\end{tabular}

\begin{tabular}{|l|l|r|l|l|}
\hline \multicolumn{5}{|c|}{ Testes de Posição: Mu0=0 } \\
\hline Teste & \multicolumn{2}{|c|}{ Estatística } & \multicolumn{2}{c|}{ Valor $\mathbf{~}$} \\
\hline Student t & t & 3,389172 & $\mathrm{Pr}>|\mathbf{t}|$ & 0,0035 \\
\hline Sign & M & 4,5 & $\mathrm{Pr}>=|\mathrm{M}|$ & 0,0039 \\
\hline Signed Rank & S & 22,5 & $\mathrm{Pr}>=|\mathbf{S}|$ & 0,0039 \\
\hline
\end{tabular}

\begin{tabular}{|l|r|}
\hline \multicolumn{2}{|c|}{ Quantis } \\
\hline Level & Quantil \\
\hline $100 \%$ Max & 3,0 \\
\hline $99 \%$ & 3,0 \\
\hline $95 \%$ & 3,0 \\
\hline $90 \%$ & 3,0 \\
\hline $75 \%$ Q3 & 1,0 \\
\hline $50 \%$ Mediana & 0,5 \\
\hline $25 \%$ Q1 & 0,0 \\
\hline $10 \%$ & 0,0 \\
\hline $5 \%$ & 0,0 \\
\hline $1 \%$ & 0,0 \\
\hline $0 \%$ Min & 0,0 \\
\hline
\end{tabular}


Variável

dependente:

REC

ID $=9$

\begin{tabular}{|r|r|r|r|}
\hline \multicolumn{3}{|c|}{ Observações Limite } \\
\hline \multicolumn{2}{|c|}{ Baixa } & \multicolumn{2}{c|}{ Alta } \\
\hline Valor & Obs & Valor & Obs \\
\hline 0 & 149 & 1 & 148 \\
\hline 0 & 147 & 2 & 134 \\
\hline 0 & 145 & 2 & 141 \\
\hline 0 & 144 & 3 & 137 \\
\hline 0 & 142 & 3 & 140 \\
\hline
\end{tabular}


Variável

dependente:

ACI

ID $=9$

\begin{tabular}{|c|c|c|c|}
\hline \multicolumn{4}{|c|}{ Momento } \\
\hline $\mathbf{N}$ & 18 & Soma dos pesos & 18 \\
\hline Média & 0,77777778 & $\begin{array}{l}\text { Soma das } \\
\text { observações }\end{array}$ & 14 \\
\hline Desvio-padrão & 1,16596618 & Variância & 1,35947712 \\
\hline Assimetria & 1,23597562 & Curtose & $-0,0102556$ \\
\hline $\begin{array}{l}\text { Soma dos } \\
\text { quadrados não } \\
\text { corrigida }\end{array}$ & 34 & $\begin{array}{l}\text { Soma dos } \\
\text { quadrados corrigida }\end{array}$ & 23,1111111 \\
\hline CV Pearson & 149,909937 & Erro-padrão médio & 0,27482086 \\
\hline
\end{tabular}

\begin{tabular}{|l|l|l|c|}
\hline \multicolumn{4}{|c|}{ Estatística Descritiva Básica } \\
\hline \multicolumn{2}{|c|}{ Posição } & \multicolumn{2}{c|}{ Variabilidade } \\
\hline Média & 0,777778 & Desvio-padrão & 1,16597 \\
\hline Mediana & 0,000000 & Variância & 1,35948 \\
\hline Moda & 0,000000 & Amplitude & 3,00000 \\
\hline & & Amplitude interquartil & 1,00000 \\
\hline
\end{tabular}

\begin{tabular}{|l|l|r|l|l|}
\hline \multicolumn{5}{|c|}{ Testes de Posição: Mu0=0 } \\
\hline Teste & \multicolumn{2}{|c|}{ Estatística } & \multicolumn{2}{c|}{ Valor $\mathbf{~}$} \\
\hline Student t & t & 2,830126 & $\mathrm{Pr}>|\mathbf{t}|$ & 0,0115 \\
\hline Sign & M & 3,5 & $\mathrm{Pr}>=|\mathrm{M}|$ & 0,0156 \\
\hline Signed Rank & S & 14 & $\mathrm{Pr}>=|\mathrm{S}|$ & 0,0156 \\
\hline
\end{tabular}

\begin{tabular}{|l|r|}
\hline \multicolumn{2}{|c|}{ Quantis } \\
\hline Level & 3 \\
\hline $100 \%$ Max & 3 \\
\hline $99 \%$ & 3 \\
\hline $95 \%$ & 3 \\
\hline $90 \%$ & 1 \\
\hline $75 \%$ Q3 & 0 \\
\hline $50 \%$ Mediana & 0 \\
\hline $25 \%$ Q1 & 0 \\
\hline $10 \%$ & 0 \\
\hline $5 \%$ & 0 \\
\hline $1 \%$ & 0 \\
\hline $0 \%$ Min & \\
\hline
\end{tabular}


Variável

dependente:

ACI

ID $=9$

\begin{tabular}{|r|r|r|r|}
\hline \multicolumn{3}{|c|}{ Observações Limite } \\
\hline \multicolumn{2}{|c|}{ Baixa } & \multicolumn{2}{c|}{ Alta } \\
\hline Valor & Obs & Valor & Obs \\
\hline 0 & 149 & 1 & 146 \\
\hline 0 & 148 & 2 & 133 \\
\hline 0 & 147 & 3 & 132 \\
\hline 0 & 145 & 3 & 134 \\
\hline 0 & 144 & 3 & 136 \\
\hline
\end{tabular}


Variável

dependente:

REC

ID $=10$

\begin{tabular}{|l|r|r|r|}
\hline \multicolumn{3}{|c|}{ Momento } \\
\hline N & 13 Soma dos pesos & 13 \\
\hline Média & $\begin{array}{r}0 \\
\text { Soma das } \\
\text { observações }\end{array}$ & 0 \\
\hline Desvio-padrão & 0 & Variância & 0 \\
\hline Assimetria &, Curtose &, \\
\hline $\begin{array}{l}\text { Soma dos } \\
\text { quadrados não } \\
\text { corrigida }\end{array}$ & 0 & $\begin{array}{l}\text { Soma dos } \\
\text { quadrados corrigida }\end{array}$ & 0 \\
\hline CV Pearson &, & Erro-padrão médio & 0 \\
\hline
\end{tabular}

\begin{tabular}{|l|r|l|r|}
\hline \multicolumn{3}{|c|}{ Estatística Descritiva Básica } \\
\hline \multicolumn{2}{|c|}{ Posição } & \multicolumn{2}{c|}{ Variabilidade } \\
\hline Média & 0 & Desvio-padrão & 0 \\
\hline Mediana & 0 & Variância & 0 \\
\hline Moda & 0 & Amplitude & 0 \\
\hline & & Amplitude interquartil & 0 \\
\hline
\end{tabular}

\begin{tabular}{|l|l|l|l|l|}
\hline \multicolumn{4}{|c|}{ Testes de Posição: Mu0=0 } \\
\hline Teste & \multicolumn{2}{|c|}{ Estatística } & \multicolumn{2}{c|}{ Valor $\mathbf{p}$} \\
\hline Student $\mathbf{t}$ & $\mathbf{t}$ & \multicolumn{1}{|c|}{, $\operatorname{Pr}>|\mathbf{t}|$} & \\
\hline Sign & $\mathrm{M}$ &, & $\operatorname{Pr}>=|\mathrm{M}|$ & \\
\hline Signed Rank & S &, & $\operatorname{Pr}>=|\mathrm{S}|$ & \\
\hline
\end{tabular}

\begin{tabular}{|l|r|}
\hline \multicolumn{2}{|c|}{ Quantis } \\
\hline Level & 0 \\
\hline $100 \%$ Max & 0 \\
\hline $99 \%$ & 0 \\
\hline $95 \%$ & 0 \\
\hline $90 \%$ & 0 \\
\hline $75 \%$ Q3 & 0 \\
\hline $50 \%$ Mediana & 0 \\
\hline $25 \%$ Q1 & 0 \\
\hline $10 \%$ & 0 \\
\hline $5 \%$ & 0 \\
\hline $1 \%$ & 0 \\
\hline $0 \%$ Min & 0 \\
\hline
\end{tabular}




\section{Variável}

dependente:

REC

ID $=10$

\begin{tabular}{|r|r|r|r|}
\hline \multicolumn{3}{|c|}{ Observações Limite } \\
\hline \multicolumn{2}{|c|}{ Baixa } & \multicolumn{2}{c|}{ Alta } \\
\hline Valor & Obs & Valor & Obs \\
\hline 0 & 162 & 0 & 158 \\
\hline 0 & 161 & 0 & 159 \\
\hline 0 & 160 & 0 & 160 \\
\hline 0 & 159 & 0 & 161 \\
\hline 0 & 158 & 0 & 162 \\
\hline
\end{tabular}


Variável

dependente:

ACI

$I D=10$

\begin{tabular}{|l|r|l|r|}
\hline \multicolumn{3}{|c|}{ Momento } \\
\hline Média & 13 & Soma dos pesos & 13 \\
\hline Desvio-padrão & 0,2773501 & Variância \\
\hline Assimetria & 3,60555128 & Curtose & 0,07692308 \\
\hline $\begin{array}{l}\text { Soma dos } \\
\text { quadrados não } \\
\text { corrigida }\end{array}$ & 1 & $\begin{array}{l}\text { Soma dos } \\
\text { quadrados corrigida }\end{array}$ & 0,92307692 \\
\hline CV Pearson & 360,555128 & Erro-padrão médio & 0,07692308 \\
\hline
\end{tabular}

\begin{tabular}{|l|l|l|r|}
\hline \multicolumn{4}{|c|}{ Estatística Descritiva Básica } \\
\hline \multicolumn{2}{|c|}{ Posição } & \multicolumn{2}{c|}{ Variabilidade } \\
\hline Média & 0,076923 & Desvio-padrão & 0,27735 \\
\hline Mediana & 0,000000 & Variância & 0,07692 \\
\hline Moda & 0,000000 & Amplitude & 1,00000 \\
\hline & & Amplitude interquartil & 0 \\
\hline
\end{tabular}

\begin{tabular}{|l|l|r|l|l|}
\hline \multicolumn{5}{|c|}{ Testes de Posição: Mu0=0 } \\
\hline Teste & \multicolumn{2}{|c|}{ Estatística } & \multicolumn{2}{c|}{ Valor $\mathbf{~}$} \\
\hline Student t & $\mathbf{t}$ & 1 & $\mathrm{Pr}>|\mathbf{t}|$ & 0,3370 \\
\hline Sign & $\mathbf{M}$ & 0,5 & $\mathrm{Pr}>=|\mathbf{M}|$ & 1,0000 \\
\hline Signed Rank & $\mathbf{S}$ & 0,5 & $\mathrm{Pr}>=|\mathbf{S}|$ & 1,0000 \\
\hline
\end{tabular}

\begin{tabular}{|l|r|}
\hline \multicolumn{2}{|c|}{ Quantis } \\
\hline Level & 1 \\
\hline $100 \%$ Max & 1 \\
\hline $99 \%$ & 1 \\
\hline $95 \%$ & 0 \\
\hline $90 \%$ & 0 \\
\hline $75 \%$ Q3 & 0 \\
\hline $50 \%$ Mediana & 0 \\
\hline $25 \%$ Q1 & 0 \\
\hline $10 \%$ & 0 \\
\hline $5 \%$ & 0 \\
\hline $1 \%$ & 0 \\
\hline $0 \%$ Min & \\
\hline
\end{tabular}


Variável

dependente:

ACI

$\mathrm{ID}=10$

\begin{tabular}{|r|r|r|r|}
\hline \multicolumn{3}{|c|}{ Observações Limite } \\
\hline \multicolumn{2}{|c|}{ Baixa } & \multicolumn{2}{c|}{ Alta } \\
\hline Valor & Obs & Valor & Obs \\
\hline 0 & 162 & 0 & 159 \\
\hline 0 & 161 & 0 & 160 \\
\hline 0 & 160 & 0 & 161 \\
\hline 0 & 159 & 0 & 162 \\
\hline 0 & 158 & 1 & 153 \\
\hline
\end{tabular}


Variável

dependente:

REC

$\mathrm{ID}=11$

\begin{tabular}{|l|r|l|r|}
\hline \multicolumn{3}{|c|}{ Momento } \\
\hline N & 18 & Soma dos pesos & 18 \\
\hline Média & $\begin{array}{r}0 \\
\text { Soma das } \\
\text { observações }\end{array}$ & 0 \\
\hline Desvio-padrão & 0 & Variância & 0 \\
\hline Assimetria &, Curtose &, \\
\hline $\begin{array}{l}\text { Soma dos } \\
\text { quadrados não } \\
\text { corrigida }\end{array}$ & 0 & $\begin{array}{l}\text { Soma dos } \\
\text { quadrados corrigida }\end{array}$ & 0 \\
\hline CV Pearson &, & Erro-padrão médio & 0 \\
\hline
\end{tabular}

\begin{tabular}{|l|r|l|r|}
\hline \multicolumn{3}{|c|}{ Estatística Descritiva Básica } \\
\hline \multicolumn{2}{|c|}{ Posição } & \multicolumn{2}{c|}{ Variabilidade } \\
\hline Média & 0 & Desvio-padrão & 0 \\
\hline Mediana & 0 & Variância & 0 \\
\hline Moda & 0 & Amplitude & 0 \\
\hline & & Amplitude interquartil & 0 \\
\hline
\end{tabular}

\begin{tabular}{|l|l|l|l|l|}
\hline \multicolumn{4}{|c|}{ Testes de Posição: Mu0=0 } \\
\hline Teste & \multicolumn{2}{|c|}{ Estatística } & \multicolumn{2}{c|}{ Valor $\mathbf{p}$} \\
\hline Student t & t &, & $\operatorname{Pr}>|\mathbf{t}|$ & \\
\hline Sign & M &, & $\operatorname{Pr}>=|\mathrm{M}|$ & \\
\hline Signed Rank & S &, & $\operatorname{Pr}>=|\mathrm{S}|$ & \\
\hline
\end{tabular}

\begin{tabular}{|l|r|}
\hline \multicolumn{2}{|c|}{ Quantis } \\
\hline Level & 0 \\
\hline $100 \%$ Max & 0 \\
\hline $99 \%$ & 0 \\
\hline $95 \%$ & 0 \\
\hline $90 \%$ & 0 \\
\hline $75 \%$ Q3 & 0 \\
\hline $50 \%$ Mediana & 0 \\
\hline $25 \%$ Q1 & 0 \\
\hline $10 \%$ & 0 \\
\hline $5 \%$ & 0 \\
\hline $1 \%$ & 0 \\
\hline $0 \%$ Min & 0 \\
\hline
\end{tabular}


Variável

dependente:

REC

ID $=11$

\begin{tabular}{|r|r|r|r|}
\hline \multicolumn{3}{|c|}{ Observações Limite } \\
\hline \multicolumn{2}{|c|}{ Baixa } & \multicolumn{2}{c|}{ Alta } \\
\hline Valor & Obs & Valor & Obs \\
\hline 0 & 180 & 0 & 176 \\
\hline 0 & 179 & 0 & 177 \\
\hline 0 & 178 & 0 & 178 \\
\hline 0 & 177 & 0 & 179 \\
\hline 0 & 176 & 0 & 180 \\
\hline
\end{tabular}


Variável

dependente:

ACI

$\mathrm{ID}=11$

\begin{tabular}{|l|r|l|r|}
\hline \multicolumn{3}{|c|}{ Momento } \\
\hline N & 18 & Soma dos pesos & 18 \\
\hline Média & $\begin{array}{r}0 \\
\text { Soma das } \\
\text { observações }\end{array}$ & 0 \\
\hline Desvio-padrão & 0 & Variância & 0 \\
\hline Assimetria &, Curtose &, \\
\hline $\begin{array}{l}\text { Soma dos } \\
\text { quadrados não } \\
\text { corrigida }\end{array}$ & 0 & $\begin{array}{l}\text { Soma dos } \\
\text { quadrados corrigida }\end{array}$ & 0 \\
\hline CV Pearson &, & Erro-padrão médio & 0 \\
\hline
\end{tabular}

\begin{tabular}{|l|r|l|r|}
\hline \multicolumn{3}{|c|}{ Estatística Descritiva Básica } \\
\hline \multicolumn{2}{|c|}{ Posição } & \multicolumn{2}{c|}{ Variabilidade } \\
\hline Média & 0 & Desvio-padrão & 0 \\
\hline Mediana & 0 & Variância & 0 \\
\hline Moda & 0 & Amplitude & 0 \\
\hline & & Amplitude interquartil & 0 \\
\hline
\end{tabular}

\begin{tabular}{|l|l|l|l|l|}
\hline \multicolumn{5}{|c|}{ Testes de Posição: Mu0=0 } \\
\hline Teste & \multicolumn{2}{|c|}{ Estatística } & \multicolumn{2}{c|}{ Valor $\mathbf{p}$} \\
\hline Student t & t &, & $\operatorname{Pr}>|\mathbf{t}|$ & \\
\hline Sign & M &, & $\operatorname{Pr}>=|\mathrm{M}|$ & \\
\hline Signed Rank & S &, & $\operatorname{Pr}>=|\mathrm{S}|$ & \\
\hline
\end{tabular}

\begin{tabular}{|l|r|}
\hline \multicolumn{2}{|c|}{ Quantis } \\
\hline Level & 0 \\
\hline $100 \%$ Max & 0 \\
\hline $99 \%$ & 0 \\
\hline $95 \%$ & 0 \\
\hline $90 \%$ & 0 \\
\hline $75 \%$ Q3 & 0 \\
\hline $50 \%$ Mediana & 0 \\
\hline $25 \%$ Q1 & 0 \\
\hline $10 \%$ & 0 \\
\hline $5 \%$ & 0 \\
\hline $1 \%$ & 0 \\
\hline $0 \%$ Min & 0 \\
\hline
\end{tabular}




\section{Variável}

dependente:

ACI

$\mathrm{ID}=11$

\begin{tabular}{|r|r|r|r|}
\hline \multicolumn{3}{|c|}{ Observações Limite } \\
\hline \multicolumn{2}{|c|}{ Baixa } & \multicolumn{2}{c|}{ Alta } \\
\hline Valor & Obs & Valor & Obs \\
\hline 0 & 180 & 0 & 176 \\
\hline 0 & 179 & 0 & 177 \\
\hline 0 & 178 & 0 & 178 \\
\hline 0 & 177 & 0 & 179 \\
\hline 0 & 176 & 0 & 180 \\
\hline
\end{tabular}


Variável

dependente:

REC

ID $=12$

\begin{tabular}{|l|r|l|r|}
\hline \multicolumn{3}{|c|}{ Momento } \\
\hline N & 18 & Soma dos pesos & 18 \\
\hline Média & $\begin{array}{r}0 \\
\text { Soma das } \\
\text { observações }\end{array}$ & 0 \\
\hline Desvio-padrão & 0 & Variância & 0 \\
\hline Assimetria &, Curtose &, \\
\hline $\begin{array}{l}\text { Soma dos } \\
\text { quadrados não } \\
\text { corrigida }\end{array}$ & 0 & $\begin{array}{l}\text { Soma dos } \\
\text { quadrados corrigida }\end{array}$ & 0 \\
\hline CV Pearson &, & Erro-padrão médio & 0 \\
\hline
\end{tabular}

\begin{tabular}{|l|r|l|r|}
\hline \multicolumn{3}{|c|}{ Estatística Descritiva Básica } \\
\hline \multicolumn{2}{|c|}{ Posição } & \multicolumn{2}{c|}{ Variabilidade } \\
\hline Média & 0 & Desvio-padrão & 0 \\
\hline Mediana & 0 & Variância & 0 \\
\hline Moda & 0 & Amplitude & 0 \\
\hline & & Amplitude interquartil & 0 \\
\hline
\end{tabular}

\begin{tabular}{|l|l|l|l|l|}
\hline \multicolumn{4}{|c|}{ Testes de Posição: Mu0=0 } \\
\hline Teste & \multicolumn{2}{|c|}{ Estatística } & \multicolumn{2}{c|}{ Valor $\mathbf{p}$} \\
\hline Student $\mathbf{t}$ & $\mathbf{t}$ & \multicolumn{1}{|c|}{, $\operatorname{Pr}>|\mathbf{t}|$} & \\
\hline Sign & $\mathrm{M}$ &, & $\operatorname{Pr}>=|\mathrm{M}|$ & \\
\hline Signed Rank & S &, & $\operatorname{Pr}>=|\mathrm{S}|$ & \\
\hline
\end{tabular}

\begin{tabular}{|l|r|}
\hline \multicolumn{2}{|c|}{ Quantis } \\
\hline Level & 0 \\
\hline $100 \%$ Max & 0 \\
\hline $99 \%$ & 0 \\
\hline $95 \%$ & 0 \\
\hline $90 \%$ & 0 \\
\hline $75 \%$ Q3 & 0 \\
\hline $50 \%$ Mediana & 0 \\
\hline $25 \%$ Q1 & 0 \\
\hline $10 \%$ & 0 \\
\hline $5 \%$ & 0 \\
\hline $1 \%$ & 0 \\
\hline $0 \%$ Min & 0 \\
\hline
\end{tabular}


Variável

dependente:

REC

$\mathrm{ID}=12$

\begin{tabular}{|r|r|r|r|}
\hline \multicolumn{3}{|c|}{ Observações Limite } \\
\hline \multicolumn{2}{|c|}{ Baixa } & \multicolumn{2}{c|}{ Alta } \\
\hline Valor & Obs & Valor & Obs \\
\hline 0 & 198 & 0 & 194 \\
\hline 0 & 197 & 0 & 195 \\
\hline 0 & 196 & 0 & 196 \\
\hline 0 & 195 & 0 & 197 \\
\hline 0 & 194 & 0 & 198 \\
\hline
\end{tabular}


Variável

dependente:

ACI

$\mathrm{ID}=12$

\begin{tabular}{|l|r|l|r|}
\hline \multicolumn{3}{|c|}{ Momento } \\
\hline N & 18 & Soma dos pesos & 18 \\
\hline Média & $\begin{array}{r}0 \\
\text { Soma das } \\
\text { observações }\end{array}$ & 0 \\
\hline Desvio-padrão & 0 & Variância & 0 \\
\hline Assimetria &, Curtose &, \\
\hline $\begin{array}{l}\text { Soma dos } \\
\text { quadrados não } \\
\text { corrigida }\end{array}$ & 0 & $\begin{array}{l}\text { Soma dos } \\
\text { quadrados corrigida }\end{array}$ & 0 \\
\hline CV Pearson &, & Erro-padrão médio & 0 \\
\hline
\end{tabular}

\begin{tabular}{|l|r|l|r|}
\hline \multicolumn{3}{|c|}{ Estatística Descritiva Básica } \\
\hline \multicolumn{2}{|c|}{ Posição } & \multicolumn{2}{c|}{ Variabilidade } \\
\hline Média & 0 & Desvio-padrão & 0 \\
\hline Mediana & 0 & Variância & 0 \\
\hline Moda & 0 & Amplitude & 0 \\
\hline & & Amplitude interquartil & 0 \\
\hline
\end{tabular}

\begin{tabular}{|l|l|l|l|l|}
\hline \multicolumn{4}{|c|}{ Testes de Posição: Mu0=0 } \\
\hline Teste & \multicolumn{2}{|c|}{ Estatística } & \multicolumn{2}{c|}{ Valor $\mathbf{p}$} \\
\hline Student $\mathbf{t}$ & $\mathbf{t}$ & \multicolumn{1}{|c|}{, $\operatorname{Pr}>|\mathbf{t}|$} & \\
\hline Sign & $\mathrm{M}$ &, & $\operatorname{Pr}>=|\mathrm{M}|$ & \\
\hline Signed Rank & S &, & $\operatorname{Pr}>=|\mathrm{S}|$ & \\
\hline
\end{tabular}

\begin{tabular}{|l|r|}
\hline \multicolumn{2}{|c|}{ Quantis } \\
\hline Level & 0 \\
\hline $100 \%$ Max & 0 \\
\hline $99 \%$ & 0 \\
\hline $95 \%$ & 0 \\
\hline $90 \%$ & 0 \\
\hline $75 \%$ Q3 & 0 \\
\hline $50 \%$ Mediana & 0 \\
\hline $25 \%$ Q1 & 0 \\
\hline $10 \%$ & 0 \\
\hline $5 \%$ & 0 \\
\hline $1 \%$ & 0 \\
\hline $0 \%$ Min & 0 \\
\hline
\end{tabular}


Variável

dependente:

ACI

$\mathrm{ID}=12$

\begin{tabular}{|r|r|r|r|}
\hline \multicolumn{3}{|c|}{ Observações Limite } \\
\hline \multicolumn{2}{|c|}{ Baixa } & \multicolumn{2}{c|}{ Alta } \\
\hline Valor & Obs & Valor & Obs \\
\hline 0 & 198 & 0 & 194 \\
\hline 0 & 197 & 0 & 195 \\
\hline 0 & 196 & 0 & 196 \\
\hline 0 & 195 & 0 & 197 \\
\hline 0 & 194 & 0 & 198 \\
\hline
\end{tabular}


Variável

dependente:

REC

ID $=13$

\begin{tabular}{|l|r|l|r|}
\hline \multicolumn{4}{|c|}{ Momento } \\
\hline Média & 18 & Soma dos pesos & 18 \\
\hline Desvio-padrão & 0,99836468 & $\begin{array}{l}\text { Variância } \\
\text { observações }\end{array}$ & 0,99673203 \\
\hline Assimetria & 0,91953653 & Curtose & 0,07960441 \\
\hline $\begin{array}{l}\text { Soma dos } \\
\text { quadrados não } \\
\text { corrigida }\end{array}$ & 33 & $\begin{array}{l}\text { Soma dos } \\
\text { quadrados corrigida }\end{array}$ & 16,9444444 \\
\hline CV Pearson & 105,709201 & Erro-padrão médio & 0,23531681 \\
\hline
\end{tabular}

\begin{tabular}{|l|l|l|l|}
\hline \multicolumn{4}{|c|}{ Estatística Descritiva Básica } \\
\hline \multicolumn{2}{|c|}{ Posição } & \multicolumn{2}{c|}{ Variabilidade } \\
\hline Média & 0,944444 & Desvio-padrão & 0,99836 \\
\hline Mediana & 1,000000 & Variância & 0,99673 \\
\hline Moda & 0,000000 & Amplitude & 3,00000 \\
\hline & & Amplitude interquartil & 1,00000 \\
\hline
\end{tabular}

Note: The Moda displayed is the smallest of 2 Modas with a count of 7 ,

\begin{tabular}{|l|l|r|l|l|}
\hline \multicolumn{5}{|c|}{ Testes de Posição: Mu0=0 } \\
\hline Teste & \multicolumn{2}{|c|}{ Estatística } & \multicolumn{2}{c|}{ Valor $\mathbf{~}$} \\
\hline Student t & t & 4,013502 & $\mathrm{Pr}>|\mathbf{t}|$ & 0,0009 \\
\hline Sign & M & 5,5 & $\mathrm{Pr}>=|\mathrm{M}|$ & 0,0010 \\
\hline Signed Rank & S & 33 & $\mathrm{Pr}>=|\mathrm{S}|$ & 0,0010 \\
\hline
\end{tabular}

\begin{tabular}{|l|r|}
\hline \multicolumn{2}{|c|}{ Quantis } \\
\hline Level & Quantil \\
\hline $100 \%$ Max & 3 \\
\hline $99 \%$ & 3 \\
\hline $95 \%$ & 3 \\
\hline $90 \%$ & 1 \\
\hline $75 \%$ Q3 & 1 \\
\hline $50 \%$ Mediana & 0 \\
\hline $25 \%$ Q1 & 0 \\
\hline $10 \%$ & 0 \\
\hline $5 \%$ & 0 \\
\hline $1 \%$ & 0 \\
\hline $0 \%$ Min & \\
\hline
\end{tabular}


Variável

dependente:

REC

$\mathrm{ID}=13$

\begin{tabular}{|r|r|r|r|}
\hline \multicolumn{3}{|c|}{ Observações Limite } \\
\hline \multicolumn{2}{|c|}{ Baixa } & \multicolumn{2}{c|}{ Alta } \\
\hline Valor & Obs & Valor & Obs \\
\hline 0 & 215 & 1 & 214 \\
\hline 0 & 213 & 2 & 203 \\
\hline 0 & 211 & 2 & 206 \\
\hline 0 & 210 & 3 & 200 \\
\hline 0 & 209 & 3 & 216 \\
\hline
\end{tabular}


Variável

dependente:

ACI

$I D=13$

\begin{tabular}{|l|r|l|r|}
\hline \multicolumn{3}{|c|}{ Momento } \\
\hline Média & 18 & Soma dos pesos & 18 \\
\hline Desvio-padrão & 1,3826658 & Variância \\
\hline Assimetria & 1,68570687 & Curtose & 1,91176471 \\
\hline $\begin{array}{l}\text { Soma dos } \\
\text { quadrados não } \\
\text { corrigida }\end{array}$ & 45 & $\begin{array}{l}\text { Soma dos } \\
\text { quadrados corrigida }\end{array}$ & 1,6271716 \\
\hline CV Pearson & 165,919896 & Erro-padrão médio & 0,32589745 \\
\hline
\end{tabular}

\begin{tabular}{|l|l|l|r|}
\hline \multicolumn{4}{|c|}{ Estatística Descritiva Básica } \\
\hline Média & 0,833333 & Desvio-padrão & 1,38267 \\
\hline Mediana & 0,000000 & Variância & 1,91176 \\
\hline Moda & 0,000000 & Amplitude & 4,00000 \\
\hline & & Amplitude interquartil & 1,00000 \\
\hline
\end{tabular}

\begin{tabular}{|l|l|r|l|l|}
\hline \multicolumn{5}{|c|}{ Testes de Posição: Mu0=0 } \\
\hline Teste & \multicolumn{2}{|c|}{ Estatística } & \multicolumn{2}{c|}{ Valor $\mathbf{~}$} \\
\hline Student t & t & 2,557042 & $\mathrm{Pr}>|\mathbf{t}|$ & 0,0204 \\
\hline Sign & M & 3,5 & $\mathrm{Pr}>=|\mathrm{M}|$ & 0,0156 \\
\hline Signed Rank & S & 14 & $\mathrm{Pr}>=|\mathrm{S}|$ & 0,0156 \\
\hline
\end{tabular}

\begin{tabular}{|l|r|}
\hline \multicolumn{2}{|c|}{ Quantis } \\
\hline Level & 4 \\
\hline $100 \%$ Max & 4 \\
\hline $99 \%$ & 4 \\
\hline $95 \%$ & 4 \\
\hline $90 \%$ & 1 \\
\hline $75 \%$ Q3 & 0 \\
\hline $50 \%$ Mediana & 0 \\
\hline $25 \%$ Q1 & 0 \\
\hline $10 \%$ & 0 \\
\hline $5 \%$ & 0 \\
\hline $1 \%$ & 0 \\
\hline $0 \%$ Min & \\
\hline
\end{tabular}


Variável

dependente:

ACI

ID $=13$

\begin{tabular}{|r|r|r|r|}
\hline \multicolumn{3}{|c|}{ Observações Limite } \\
\hline \multicolumn{2}{|c|}{ Baixa } & \multicolumn{2}{c|}{ Alta } \\
\hline Valor & Obs & Valor & Obs \\
\hline 0 & 216 & 1 & 208 \\
\hline 0 & 215 & 1 & 210 \\
\hline 0 & 214 & 3 & 201 \\
\hline 0 & 213 & 4 & 199 \\
\hline 0 & 212 & 4 & 200 \\
\hline
\end{tabular}


Variável

dependente:

REC

$\mathrm{ID}=14$

\begin{tabular}{|l|r|l|r|}
\hline \multicolumn{3}{|c|}{ Momento } \\
\hline N & 13 & Soma dos pesos & 13 \\
\hline Média & $\begin{array}{r}0 \\
\text { Soma das } \\
\text { observações }\end{array}$ & 0 \\
\hline Desvio-padrão & 0 & Variância & 0 \\
\hline Assimetria &, Curtose &, \\
\hline $\begin{array}{l}\text { Soma dos } \\
\text { quadrados não } \\
\text { corrigida }\end{array}$ & 0 & $\begin{array}{l}\text { Soma dos } \\
\text { quadrados corrigida }\end{array}$ & 0 \\
\hline CV Pearson &, & Erro-padrão médio & 0 \\
\hline
\end{tabular}

\begin{tabular}{|l|r|l|r|}
\hline \multicolumn{3}{|c|}{ Estatística Descritiva Básica } \\
\hline \multicolumn{2}{|c|}{ Posição } & \multicolumn{2}{c|}{ Variabilidade } \\
\hline Média & 0 & Desvio-padrão & 0 \\
\hline Mediana & 0 & Variância & 0 \\
\hline Moda & 0 & Amplitude & 0 \\
\hline & & Amplitude interquartil & 0 \\
\hline
\end{tabular}

\begin{tabular}{|l|l|l|l|l|}
\hline \multicolumn{4}{|c|}{ Testes de Posição: Mu0=0 } \\
\hline Teste & \multicolumn{2}{|c|}{ Estatística } & \multicolumn{2}{c|}{ Valor $\mathbf{p}$} \\
\hline Student $\mathbf{t}$ & $\mathbf{t}$ & \multicolumn{1}{|c|}{, $\operatorname{Pr}>|\mathbf{t}|$} & \\
\hline Sign & $\mathrm{M}$ &, & $\operatorname{Pr}>=|\mathrm{M}|$ & \\
\hline Signed Rank & S &, & $\operatorname{Pr}>=|\mathrm{S}|$ & \\
\hline
\end{tabular}

\begin{tabular}{|l|r|}
\hline \multicolumn{2}{|c|}{ Quantis } \\
\hline Level & 0 \\
\hline $100 \%$ Max & 0 \\
\hline $99 \%$ & 0 \\
\hline $95 \%$ & 0 \\
\hline $90 \%$ & 0 \\
\hline $75 \%$ Q3 & 0 \\
\hline $50 \%$ Mediana & 0 \\
\hline $25 \%$ Q1 & 0 \\
\hline $10 \%$ & 0 \\
\hline $5 \%$ & 0 \\
\hline $1 \%$ & 0 \\
\hline $0 \%$ Min & 0 \\
\hline
\end{tabular}


Variável

dependente:

REC

ID $=14$

Observações Limite

Baixa Alta

Valor Obs Valor Obs

\begin{tabular}{|r|r|r|r|}
\hline 0 & 229 & 0 & 225 \\
\hline 0 & 228 & 0 & 226 \\
\hline 0 & 227 & 0 & 227 \\
\hline 0 & 226 & 0 & 228 \\
\hline 0 & 225 & 0 & 229 \\
\hline
\end{tabular}


Variável

dependente:

ACI

ID $=14$

\begin{tabular}{|l|r|l|r|}
\hline \multicolumn{3}{|c|}{ Momento } \\
\hline N & 13 & Soma dos pesos & 13 \\
\hline Média & $\begin{array}{r}0 \\
\text { Soma das } \\
\text { observações }\end{array}$ & 0 \\
\hline Desvio-padrão & 0 & Variância & 0 \\
\hline Assimetria &, Curtose &, \\
\hline $\begin{array}{l}\text { Soma dos } \\
\text { quadrados não } \\
\text { corrigida }\end{array}$ & 0 & $\begin{array}{l}\text { Soma dos } \\
\text { quadrados corrigida }\end{array}$ & 0 \\
\hline CV Pearson &, & Erro-padrão médio & 0 \\
\hline
\end{tabular}

\begin{tabular}{|l|r|l|r|}
\hline \multicolumn{3}{|c|}{ Estatística Descritiva Básica } \\
\hline \multicolumn{2}{|c|}{ Posição } & \multicolumn{2}{c|}{ Variabilidade } \\
\hline Média & 0 & Desvio-padrão & 0 \\
\hline Mediana & 0 & Variância & 0 \\
\hline Moda & 0 & Amplitude & 0 \\
\hline & & Amplitude interquartil & 0 \\
\hline
\end{tabular}

\begin{tabular}{|l|l|l|l|l|}
\hline \multicolumn{4}{|c|}{ Testes de Posição: Mu0=0 } \\
\hline Teste & \multicolumn{2}{|c|}{ Estatística } & \multicolumn{2}{c|}{ Valor $\mathbf{p}$} \\
\hline Student t & t &, & $\operatorname{Pr}>|\mathbf{t}|$ & \\
\hline Sign & M &, & $\operatorname{Pr}>=|\mathrm{M}|$ & \\
\hline Signed Rank & S &, & $\operatorname{Pr}>=|\mathrm{S}|$ & \\
\hline
\end{tabular}

\begin{tabular}{|l|r|}
\hline \multicolumn{2}{|c|}{ Quantis } \\
\hline Level & 0 \\
\hline $100 \%$ Max & 0 \\
\hline $99 \%$ & 0 \\
\hline $95 \%$ & 0 \\
\hline $90 \%$ & 0 \\
\hline $75 \%$ Q3 & 0 \\
\hline $50 \%$ Mediana & 0 \\
\hline $25 \%$ Q1 & 0 \\
\hline $10 \%$ & 0 \\
\hline $5 \%$ & 0 \\
\hline $1 \%$ & 0 \\
\hline $0 \%$ Min & 0 \\
\hline
\end{tabular}


Variável

dependente:

ACI

$\mathrm{ID}=14$

Observações Limite

Baixa Alta

Valor Obs Valor Obs

\begin{tabular}{|r|l|l|l|}
\hline 0 & 229 & 0 & 225 \\
\hline 0 & 228 & 0 & 226 \\
\hline
\end{tabular}

\begin{tabular}{l|l|l|l|}
0 & 227 & 0 & 227 \\
\hline
\end{tabular}

\begin{tabular}{l|l|l|l|l|}
0 & 226 & & 0 & 228 \\
\hline
\end{tabular}

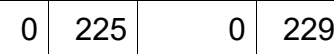


Variável

dependente:

REC

$\mathrm{ID}=15$

\begin{tabular}{|l|r|l|r|}
\hline \multicolumn{4}{|c|}{ Momento } \\
\hline Média & 18 & Soma dos pesos & 18 \\
\hline Desvio-padrão & 0,77754432 & Variância \\
\hline Assimetria & 2,52701335 & Curtose & 0,60457516 \\
\hline $\begin{array}{l}\text { Soma dos } \\
\text { quadrados não } \\
\text { corrigida }\end{array}$ & 13 & $\begin{array}{l}\text { Soma dos } \\
\text { quadrados corrigida }\end{array}$ & 7,24386267 \\
\hline CV Pearson & 199,939967 & Erro-padrão médio & 0,18326897778 \\
\hline
\end{tabular}

\begin{tabular}{|l|l|l|c|}
\hline \multicolumn{4}{|c|}{ Estatística Descritiva Básica } \\
\hline \multicolumn{2}{|c|}{ Posição } & \multicolumn{2}{c|}{ Variabilidade } \\
\hline Média & 0,388889 & Desvio-padrão & 0,77754 \\
\hline Mediana & 0,000000 & Variância & 0,60458 \\
\hline Moda & 0,000000 & Amplitude & 3,00000 \\
\hline & & Amplitude interquartil & 1,00000 \\
\hline
\end{tabular}

\begin{tabular}{|l|l|r|l|l|}
\hline \multicolumn{5}{|c|}{ Testes de Posição: Mu0=0 } \\
\hline Teste & \multicolumn{2}{|c|}{ Estatística } & \multicolumn{2}{c|}{ Valor $\mathbf{~}$} \\
\hline Student t & t & 2,121957 & $\mathrm{Pr}>|\mathbf{t}|$ & 0,0488 \\
\hline Sign & M & 2,5 & $\mathrm{Pr}>=|\mathrm{M}|$ & 0,0625 \\
\hline Signed Rank & S & 7,5 & $\mathrm{Pr}>=|\mathrm{S}|$ & 0,0625 \\
\hline
\end{tabular}

\begin{tabular}{|l|r|}
\hline \multicolumn{2}{|c|}{ Quantis } \\
\hline Level & Quantil \\
\hline $100 \%$ Max & 3 \\
\hline $99 \%$ & 3 \\
\hline $95 \%$ & 1 \\
\hline $90 \%$ & 1 \\
\hline $75 \%$ Q3 & 0 \\
\hline $50 \%$ Mediana & 0 \\
\hline $25 \%$ Q1 & 0 \\
\hline $10 \%$ & 0 \\
\hline $5 \%$ & 0 \\
\hline $1 \%$ & 0 \\
\hline $0 \%$ Min & 3 \\
\hline
\end{tabular}


Variável

dependente:

REC

$\mathrm{ID}=15$

\begin{tabular}{|r|r|r|r|}
\hline \multicolumn{3}{|c|}{ Observações Limite } \\
\hline \multicolumn{2}{|c|}{ Baixa } & \multicolumn{2}{c|}{ Alta } \\
\hline Valor & Obs & Valor & Obs \\
\hline 0 & 247 & 1 & 231 \\
\hline 0 & 246 & 1 & 234 \\
\hline 0 & 245 & 1 & 237 \\
\hline 0 & 244 & 1 & 242 \\
\hline 0 & 243 & 3 & 232 \\
\hline
\end{tabular}


Variável

dependente:

ACI

$\mathrm{ID}=15$

\begin{tabular}{|l|r|l|r|}
\hline \multicolumn{3}{|c|}{ Momento } \\
\hline N & 18 & Soma dos pesos & 18 \\
\hline Média & $\begin{array}{r}0 \\
\text { Soma das } \\
\text { observações }\end{array}$ & 0 \\
\hline Desvio-padrão & 0 & Variância & 0 \\
\hline Assimetria &, Curtose &, \\
\hline $\begin{array}{l}\text { Soma dos } \\
\text { quadrados não } \\
\text { corrigida }\end{array}$ & 0 & $\begin{array}{l}\text { Soma dos } \\
\text { quadrados corrigida }\end{array}$ & 0 \\
\hline CV Pearson &, & Erro-padrão médio & 0 \\
\hline
\end{tabular}

\begin{tabular}{|l|r|l|r|}
\hline \multicolumn{3}{|c|}{ Estatística Descritiva Básica } \\
\hline \multicolumn{2}{|c|}{ Posição } & \multicolumn{2}{c|}{ Variabilidade } \\
\hline Média & 0 & Desvio-padrão & 0 \\
\hline Mediana & 0 & Variância & 0 \\
\hline Moda & 0 & Amplitude & 0 \\
\hline & & Amplitude interquartil & 0 \\
\hline
\end{tabular}

\begin{tabular}{|l|l|l|l|l|}
\hline \multicolumn{4}{|c|}{ Testes de Posição: Mu0=0 } \\
\hline Teste & \multicolumn{2}{|c|}{ Estatística } & \multicolumn{2}{c|}{ Valor $\mathbf{p}$} \\
\hline Student $\mathbf{t}$ & $\mathbf{t}$ & \multicolumn{1}{|c|}{, $\operatorname{Pr}>|\mathbf{t}|$} & \\
\hline Sign & $\mathrm{M}$ &, & $\operatorname{Pr}>=|\mathrm{M}|$ & \\
\hline Signed Rank & S &, & $\operatorname{Pr}>=|\mathrm{S}|$ & \\
\hline
\end{tabular}

\begin{tabular}{|l|r|}
\hline \multicolumn{2}{|c|}{ Quantis } \\
\hline Level & 0 \\
\hline $100 \%$ Max & 0 \\
\hline $99 \%$ & 0 \\
\hline $95 \%$ & 0 \\
\hline $90 \%$ & 0 \\
\hline $75 \%$ Q3 & 0 \\
\hline $50 \%$ Mediana & 0 \\
\hline $25 \%$ Q1 & 0 \\
\hline $10 \%$ & 0 \\
\hline $5 \%$ & 0 \\
\hline $1 \%$ & 0 \\
\hline $0 \%$ Min & 0 \\
\hline
\end{tabular}


Variável

dependente:

ACI

$I D=15$

\begin{tabular}{|r|r|r|r|}
\hline \multicolumn{3}{|c|}{ Observações Limite } \\
\hline \multicolumn{2}{|c|}{ Baixa } & \multicolumn{2}{c|}{ Alta } \\
\hline Valor & Obs & Valor & Obs \\
\hline 0 & 247 & 0 & 243 \\
\hline 0 & 246 & 0 & 244 \\
\hline 0 & 245 & 0 & 245 \\
\hline 0 & 244 & 0 & 246 \\
\hline 0 & 243 & 0 & 247 \\
\hline
\end{tabular}


Variável

dependente:

REC

ID $=16$

\begin{tabular}{|l|r|l|r|}
\hline \multicolumn{4}{|c|}{ Momento } \\
\hline Média & \multicolumn{3}{|c|}{$\begin{array}{l}\text { Soma dos pesos } \\
\text { Soma das } \\
\text { observações }\end{array}$} \\
\hline Desvio-padrão & 0,42779263 & Variância & 0,18300654 \\
\hline Assimetria & 1,46098823 & Curtose & 0,13660714 \\
\hline $\begin{array}{l}\text { Soma dos } \\
\text { quadrados não } \\
\text { corrigida }\end{array}$ & 4 & $\begin{array}{l}\text { Soma dos } \\
\text { quadrados corrigida }\end{array}$ & 3,11111111 \\
\hline CV Pearson & 192,506684 & Erro-padrão médio & 0,10083169 \\
\hline
\end{tabular}

\begin{tabular}{|l|l|l|r|}
\hline \multicolumn{4}{|c|}{ Estatística Descritiva Básica } \\
\hline \multicolumn{2}{|c|}{ Posição } & \multicolumn{2}{c|}{ Variabilidade } \\
\hline Média & 0,222222 & Desvio-padrão & 0,42779 \\
\hline Mediana & 0,000000 & Variância & 0,18301 \\
\hline Moda & 0,000000 & Amplitude & 1,00000 \\
\hline & & Amplitude interquartil & 0 \\
\hline
\end{tabular}

\begin{tabular}{|l|l|r|l|l|}
\hline \multicolumn{5}{|c|}{ Testes de Posição: Mu0=0 } \\
\hline Teste & \multicolumn{2}{|c|}{ Estatística } & \multicolumn{2}{c|}{ Valor $\mathbf{~}$} \\
\hline Student t & t & 2,203893 & $\mathrm{Pr}>|\mathbf{t}|$ & 0,0416 \\
\hline Sign & M & 2 & $\mathrm{Pr}>=|\mathrm{M}|$ & 0,1250 \\
\hline Signed Rank & S & 5 & $\mathrm{Pr}>=|\mathrm{S}|$ & 0,1250 \\
\hline
\end{tabular}

\begin{tabular}{|l|r|}
\hline \multicolumn{2}{|c|}{ Quantis } \\
\hline Level & 1 \\
\hline $100 \%$ Max & 1 \\
\hline $99 \%$ & 1 \\
\hline $95 \%$ & 1 \\
\hline $90 \%$ & 0 \\
\hline $75 \%$ Q3 & 0 \\
\hline $50 \%$ Mediana & 0 \\
\hline $25 \%$ Q1 & 0 \\
\hline $10 \%$ & 0 \\
\hline $5 \%$ & 0 \\
\hline $1 \%$ & 0 \\
\hline $0 \%$ Min & 0 \\
\hline
\end{tabular}


Variável

dependente:

$\boldsymbol{R E C}$

$\mathrm{ID}=16$

Observações Limite

Baixa

Alta

Valor Obs Valor Obs

\begin{tabular}{|r|r|r|r|}
\hline 0 & 265 & 0 & 265 \\
\hline 0 & 264 & 1 & 255 \\
\hline 0 & 263 & 1 & 258 \\
\hline 0 & 261 & 1 & 259 \\
\hline 0 & 260 & 1 & 262 \\
\hline
\end{tabular}


Variável

dependente:

ACI

$\mathrm{ID}=16$

\begin{tabular}{|l|r|l|r|}
\hline \multicolumn{3}{|c|}{ Momento } \\
\hline N & 18 & Soma dos pesos & 18 \\
\hline Média & $\begin{array}{r}0 \\
\text { Soma das } \\
\text { observações }\end{array}$ & 0 \\
\hline Desvio-padrão & 0 & Variância & 0 \\
\hline Assimetria &, Curtose &, \\
\hline $\begin{array}{l}\text { Soma dos } \\
\text { quadrados não } \\
\text { corrigida }\end{array}$ & 0 & $\begin{array}{l}\text { Soma dos } \\
\text { quadrados corrigida }\end{array}$ & 0 \\
\hline CV Pearson &, & Erro-padrão médio & 0 \\
\hline
\end{tabular}

\begin{tabular}{|l|r|l|r|}
\hline \multicolumn{3}{|c|}{ Estatística Descritiva Básica } \\
\hline \multicolumn{2}{|c|}{ Posição } & \multicolumn{2}{c|}{ Variabilidade } \\
\hline Média & 0 & Desvio-padrão & 0 \\
\hline Mediana & 0 & Variância & 0 \\
\hline Moda & 0 & Amplitude & 0 \\
\hline & & Amplitude interquartil & 0 \\
\hline
\end{tabular}

\begin{tabular}{|l|l|l|l|l|}
\hline \multicolumn{4}{|c|}{ Testes de Posição: Mu0=0 } \\
\hline Teste & \multicolumn{2}{|c|}{ Estatística } & \multicolumn{2}{c|}{ Valor $\mathbf{p}$} \\
\hline Student $\mathbf{t}$ & $\mathbf{t}$ & \multicolumn{1}{|c|}{, $\operatorname{Pr}>|\mathbf{t}|$} & \\
\hline Sign & $\mathrm{M}$ &, & $\operatorname{Pr}>=|\mathrm{M}|$ & \\
\hline Signed Rank & S &, & $\operatorname{Pr}>=|\mathrm{S}|$ & \\
\hline
\end{tabular}

\begin{tabular}{|l|r|}
\hline \multicolumn{2}{|c|}{ Quantis } \\
\hline Level & 0 \\
\hline $100 \%$ Max & 0 \\
\hline $99 \%$ & 0 \\
\hline $95 \%$ & 0 \\
\hline $90 \%$ & 0 \\
\hline $75 \%$ Q3 & 0 \\
\hline $50 \%$ Mediana & 0 \\
\hline $25 \%$ Q1 & 0 \\
\hline $10 \%$ & 0 \\
\hline $5 \%$ & 0 \\
\hline $1 \%$ & 0 \\
\hline $0 \%$ Min & 0 \\
\hline
\end{tabular}


Variável

dependente:

ACI

$I D=16$

\begin{tabular}{|r|r|r|r|}
\hline \multicolumn{3}{|c|}{ Observações Limite } \\
\hline \multicolumn{2}{|c|}{ Baixa } & \multicolumn{2}{c|}{ Alta } \\
\hline Valor & Obs & Valor & Obs \\
\hline 0 & 265 & 0 & 261 \\
\hline 0 & 264 & 0 & 262 \\
\hline 0 & 263 & 0 & 263 \\
\hline 0 & 262 & 0 & 264 \\
\hline 0 & 261 & 0 & 265 \\
\hline
\end{tabular}


Variável

dependente:

REC

ID $=17$

\begin{tabular}{|l|r|l|r|}
\hline \multicolumn{3}{|c|}{ Momento } \\
\hline N & 13 & Soma dos pesos & 13 \\
\hline Média & $\begin{array}{r}0 \\
\text { Soma das } \\
\text { observações }\end{array}$ & 0 \\
\hline Desvio-padrão & 0 & Variância & 0 \\
\hline Assimetria &, Curtose &, \\
\hline $\begin{array}{l}\text { Soma dos } \\
\text { quadrados não } \\
\text { corrigida }\end{array}$ & 0 & $\begin{array}{l}\text { Soma dos } \\
\text { quadrados corrigida }\end{array}$ & 0 \\
\hline CV Pearson &, & Erro-padrão médio & 0 \\
\hline
\end{tabular}

\begin{tabular}{|l|r|l|r|}
\hline \multicolumn{3}{|c|}{ Estatística Descritiva Básica } \\
\hline \multicolumn{2}{|c|}{ Posição } & \multicolumn{2}{c|}{ Variabilidade } \\
\hline Média & 0 & Desvio-padrão & 0 \\
\hline Mediana & 0 & Variância & 0 \\
\hline Moda & 0 & Amplitude & 0 \\
\hline & & Amplitude interquartil & 0 \\
\hline
\end{tabular}

\begin{tabular}{|l|l|l|l|l|}
\hline \multicolumn{4}{|c|}{ Testes de Posição: Mu0=0 } \\
\hline Teste & \multicolumn{2}{|c|}{ Estatística } & \multicolumn{2}{c|}{ Valor $\mathbf{p}$} \\
\hline Student $\mathbf{t}$ & $\mathbf{t}$ & \multicolumn{1}{|c|}{, $\operatorname{Pr}>|\mathbf{t}|$} & \\
\hline Sign & $\mathrm{M}$ &, & $\operatorname{Pr}>=|\mathrm{M}|$ & \\
\hline Signed Rank & S &, & $\operatorname{Pr}>=|\mathrm{S}|$ & \\
\hline
\end{tabular}

\begin{tabular}{|l|r|}
\hline \multicolumn{2}{|c|}{ Quantis } \\
\hline Level & 0 \\
\hline $100 \%$ Max & 0 \\
\hline $99 \%$ & 0 \\
\hline $95 \%$ & 0 \\
\hline $90 \%$ & 0 \\
\hline $75 \%$ Q3 & 0 \\
\hline $50 \%$ Mediana & 0 \\
\hline $25 \%$ Q1 & 0 \\
\hline $10 \%$ & 0 \\
\hline $5 \%$ & 0 \\
\hline $1 \%$ & 0 \\
\hline $0 \%$ Min & 0 \\
\hline
\end{tabular}


Variável

dependente:

REC

$\mathrm{ID}=\mathbf{1 7}$

\begin{tabular}{|r|r|r|r|}
\hline \multicolumn{3}{|c|}{ Observações Limite } \\
\hline \multicolumn{2}{|c|}{ Baixa } & \multicolumn{2}{c|}{ Alta } \\
\hline Valor & Obs & Valor & Obs \\
\hline 0 & 278 & 0 & 274 \\
\hline 0 & 277 & 0 & 275 \\
\hline 0 & 276 & 0 & 276 \\
\hline 0 & 275 & 0 & 277 \\
\hline 0 & 274 & 0 & 278 \\
\hline
\end{tabular}


Variável

dependente:

ACI

ID $=17$

\begin{tabular}{|l|r|l|r|}
\hline \multicolumn{3}{|c|}{ Momento } \\
\hline N & 13 & Soma dos pesos & 13 \\
\hline Média & $\begin{array}{r}0 \\
\text { Soma das } \\
\text { observações }\end{array}$ & 0 \\
\hline Desvio-padrão & 0 & Variância & 0 \\
\hline Assimetria &, Curtose &, \\
\hline $\begin{array}{l}\text { Soma dos } \\
\text { quadrados não } \\
\text { corrigida }\end{array}$ & 0 & $\begin{array}{l}\text { Soma dos } \\
\text { quadrados corrigida }\end{array}$ & 0 \\
\hline CV Pearson &, & Erro-padrão médio & 0 \\
\hline
\end{tabular}

\begin{tabular}{|l|r|l|r|}
\hline \multicolumn{3}{|c|}{ Estatística Descritiva Básica } \\
\hline \multicolumn{2}{|c|}{ Posição } & \multicolumn{2}{c|}{ Variabilidade } \\
\hline Média & 0 & Desvio-padrão & 0 \\
\hline Mediana & 0 & Variância & 0 \\
\hline Moda & 0 & Amplitude & 0 \\
\hline & & Amplitude interquartil & 0 \\
\hline
\end{tabular}

\begin{tabular}{|l|l|l|l|l|}
\hline \multicolumn{4}{|c|}{ Testes de Posição: Mu0=0 } \\
\hline Teste & \multicolumn{2}{|c|}{ Estatística } & \multicolumn{2}{c|}{ Valor $\mathbf{p}$} \\
\hline Student t & $\mathbf{t}$ &, & $\mathrm{Pr}>|\mathrm{t}|$ & \\
\hline Sign & $\mathrm{M}$ &, & $\mathrm{Pr}>=|\mathrm{M}|$ & \\
\hline Signed Rank & $\mathrm{S}$ & & $\mathrm{Pr}>=|\mathrm{S}|$ & \\
\hline
\end{tabular}

\begin{tabular}{|l|r|}
\hline \multicolumn{2}{|c|}{ Quantis } \\
\hline Level & Quantil \\
\hline $100 \%$ Max & 0 \\
\hline $99 \%$ & 0 \\
\hline $95 \%$ & 0 \\
\hline $90 \%$ & 0 \\
\hline $75 \%$ Q3 & 0 \\
\hline $50 \%$ Mediana & 0 \\
\hline $25 \%$ Q1 & 0 \\
\hline $10 \%$ & 0 \\
\hline $5 \%$ & 0 \\
\hline $1 \%$ & 0 \\
\hline $0 \%$ Min & \\
\hline
\end{tabular}


Variável

dependente:

ACI

ID $=17$

\begin{tabular}{|r|r|r|r|}
\hline \multicolumn{3}{|c|}{ Observações Limite } \\
\hline \multicolumn{2}{|c|}{ Baixa } & \multicolumn{2}{c|}{ Alta } \\
\hline Valor & Obs & Valor & Obs \\
\hline 0 & 278 & 0 & 274 \\
\hline 0 & 277 & 0 & 275 \\
\hline 0 & 276 & 0 & 276 \\
\hline 0 & 275 & 0 & 277 \\
\hline 0 & 274 & 0 & 278 \\
\hline
\end{tabular}


Variável

dependente:

REC

$\mathrm{ID}=18$

\begin{tabular}{|l|r|l|r|}
\hline \multicolumn{4}{|c|}{ Momento } \\
\hline Média & 18 & Soma dos pesos & 18 \\
\hline Desvio-padrão & 0,54831888 & $\begin{array}{l}\text { Variância } \\
\text { observações }\end{array}$ & 0,30065359 \\
\hline Assimetria & 2,56713519 & Curtose & 6,36294896 \\
\hline $\begin{array}{l}\text { Soma dos } \\
\text { quadrados não } \\
\text { corrigida }\end{array}$ & 6 & $\begin{array}{l}\text { Soma dos } \\
\text { quadrados corrigida }\end{array}$ & 5,11111111 \\
\hline CV Pearson & 246,743496 & Erro-padrão médio & 0,12924 \\
\hline
\end{tabular}

\begin{tabular}{|l|l|l|r|}
\hline \multicolumn{4}{|c|}{ Estatística Descritiva Básica } \\
\hline \multicolumn{2}{|c|}{ Posição } & \multicolumn{2}{c|}{ Variabilidade } \\
\hline Média & 0,222222 & Desvio-padrão & 0,54832 \\
\hline Mediana & 0,000000 & Variância & 0,30065 \\
\hline Moda & 0,000000 & Amplitude & 2,00000 \\
\hline & & Amplitude interquartil & 0 \\
\hline
\end{tabular}

\begin{tabular}{|l|l|r|l|l|}
\hline \multicolumn{5}{|c|}{ Testes de Posição: Mu0=0 } \\
\hline Teste & \multicolumn{2}{|c|}{ Estatística } & \multicolumn{2}{c|}{ Valor $\mathbf{~}$} \\
\hline Student t & t & 1,719454 & $\mathrm{Pr}>|\mathbf{t}|$ & 0,1037 \\
\hline Sign & M & 1,5 & $\mathrm{Pr}>=|\mathrm{M}|$ & 0,2500 \\
\hline Signed Rank & S & 3 & $\mathrm{Pr}>=|\mathrm{S}|$ & 0,2500 \\
\hline
\end{tabular}

\begin{tabular}{|l|r|}
\hline \multicolumn{2}{|c|}{ Quantis } \\
\hline Level & 2 \\
\hline $100 \%$ Max & 2 \\
\hline $99 \%$ & 2 \\
\hline $95 \%$ & 1 \\
\hline $90 \%$ & 0 \\
\hline $75 \%$ Q3 & 0 \\
\hline $50 \%$ Mediana & 0 \\
\hline $25 \%$ Q1 & 0 \\
\hline $10 \%$ & 0 \\
\hline $5 \%$ & 0 \\
\hline $1 \%$ & 0 \\
\hline $0 \%$ Min & 0 \\
\hline
\end{tabular}


Variável

dependente:

REC

$\mathrm{ID}=18$

\begin{tabular}{|r|r|r|r|}
\hline \multicolumn{3}{|c|}{ Observações Limite } \\
\hline \multicolumn{2}{|c|}{ Baixa } & \multicolumn{2}{c|}{ Alta } \\
\hline Valor & Obs & Valor & Obs \\
\hline 0 & 296 & 0 & 295 \\
\hline 0 & 295 & 0 & 296 \\
\hline 0 & 294 & 1 & 281 \\
\hline 0 & 293 & 1 & 286 \\
\hline 0 & 292 & 2 & 282 \\
\hline
\end{tabular}


Variável

dependente:

ACI

ID $=18$

\begin{tabular}{|l|r|l|r|}
\hline \multicolumn{3}{|c|}{ Momento } \\
\hline N & 18 & Soma dos pesos & 18 \\
\hline Média & $\begin{array}{r}0 \\
\text { Soma das } \\
\text { observações }\end{array}$ & 0 \\
\hline Desvio-padrão & 0 & Variância & 0 \\
\hline Assimetria &, Curtose &, \\
\hline $\begin{array}{l}\text { Soma dos } \\
\text { quadrados não } \\
\text { corrigida }\end{array}$ & 0 & $\begin{array}{l}\text { Soma dos } \\
\text { quadrados corrigida }\end{array}$ & 0 \\
\hline CV Pearson &, & Erro-padrão médio & 0 \\
\hline
\end{tabular}

\begin{tabular}{|l|r|l|r|}
\hline \multicolumn{3}{|c|}{ Estatística Descritiva Básica } \\
\hline \multicolumn{2}{|c|}{ Posição } & \multicolumn{2}{c|}{ Variabilidade } \\
\hline Média & 0 & Desvio-padrão & 0 \\
\hline Mediana & 0 & Variância & 0 \\
\hline Moda & 0 & Amplitude & 0 \\
\hline & & Amplitude interquartil & 0 \\
\hline
\end{tabular}

\begin{tabular}{|l|l|l|l|l|}
\hline \multicolumn{4}{|c|}{ Testes de Posição: Mu0=0 } \\
\hline Teste & \multicolumn{2}{|c|}{ Estatística } & \multicolumn{2}{c|}{ Valor $\mathbf{p}$} \\
\hline Student t & t &, & $\operatorname{Pr}>|\mathbf{t}|$ & \\
\hline Sign & M &, & $\operatorname{Pr}>=|\mathrm{M}|$ & \\
\hline Signed Rank & S &, & $\operatorname{Pr}>=|\mathrm{S}|$ & \\
\hline
\end{tabular}

\begin{tabular}{|l|r|}
\hline \multicolumn{2}{|c|}{ Quantis } \\
\hline Level & 0 \\
\hline $100 \%$ Max & 0 \\
\hline $99 \%$ & 0 \\
\hline $95 \%$ & 0 \\
\hline $90 \%$ & 0 \\
\hline $75 \%$ Q3 & 0 \\
\hline $50 \%$ Mediana & 0 \\
\hline $25 \%$ Q1 & 0 \\
\hline $10 \%$ & 0 \\
\hline $5 \%$ & 0 \\
\hline $1 \%$ & 0 \\
\hline $0 \%$ Min & 0 \\
\hline
\end{tabular}


Variável

dependente:

ACI

$\mathrm{ID}=18$

\begin{tabular}{|r|r|r|r|}
\hline \multicolumn{3}{|c|}{ Observações Limite } \\
\hline \multicolumn{2}{|c|}{ Baixa } & \multicolumn{2}{c|}{ Alta } \\
\hline Valor & Obs & Valor & Obs \\
\hline 0 & 296 & 0 & 292 \\
\hline 0 & 295 & 0 & 293 \\
\hline 0 & 294 & 0 & 294 \\
\hline 0 & 293 & 0 & 295 \\
\hline 0 & 292 & 0 & 296 \\
\hline
\end{tabular}


Variável

dependente:

REC

ID $=19$

\begin{tabular}{|l|r|l|r|}
\hline \multicolumn{4}{|c|}{ Momento } \\
\hline Média & 11 & Soma dos pesos & 11 \\
\hline Desvio-padrão & 0,46709937 & Variância & 3 \\
observações & 0,21818182 \\
\hline Assimetria & 1,18937339 & Curtose & $-0,7638889$ \\
\hline $\begin{array}{l}\text { Soma dos } \\
\text { quadrados não } \\
\text { corrigida }\end{array}$ & 3 & $\begin{array}{l}\text { Soma dos } \\
\text { quadrados corrigida }\end{array}$ & 2,18181818 \\
\hline CV Pearson & 171,269768 & Erro-padrão médio & 0,14083576 \\
\hline
\end{tabular}

\begin{tabular}{|l|c|l|c|}
\hline \multicolumn{4}{|c|}{ Estatística Descritiva Básica } \\
\hline \multicolumn{2}{|c|}{ Posição } & \multicolumn{2}{c|}{ Variabilidade } \\
\hline Média & 0,272727 & Desvio-padrão & 0,46710 \\
\hline Mediana & 0,000000 & Variância & 0,21818 \\
\hline Moda & 0,000000 & Amplitude & 1,00000 \\
\hline & & Amplitude interquartil & 1,00000 \\
\hline
\end{tabular}

\begin{tabular}{|l|l|r|l|l|}
\hline \multicolumn{5}{|c|}{ Testes de Posição: Mu0=0 } \\
\hline Teste & \multicolumn{2}{|c|}{ Estatística } & \multicolumn{2}{c|}{ Valor $\mathbf{~}$} \\
\hline Student t & t & 1,936492 & $\mathrm{Pr}>|\mathbf{t}|$ & 0,0816 \\
\hline Sign & M & 1,5 & $\mathrm{Pr}>=|\mathrm{M}|$ & 0,2500 \\
\hline Signed Rank & S & 3 & $\mathrm{Pr}>=|\mathrm{S}|$ & 0,2500 \\
\hline
\end{tabular}

\begin{tabular}{|l|r|}
\hline \multicolumn{2}{|c|}{ Quantis } \\
\hline Level & Quantil \\
\hline $100 \%$ Max & 1 \\
\hline $99 \%$ & 1 \\
\hline $95 \%$ & 1 \\
\hline $90 \%$ & 1 \\
\hline $75 \%$ Q3 & 0 \\
\hline $50 \%$ Mediana & 0 \\
\hline $25 \%$ Q1 & 0 \\
\hline $10 \%$ & 0 \\
\hline $5 \%$ & 0 \\
\hline $1 \%$ & 0 \\
\hline $0 \%$ Min & 1 \\
\hline
\end{tabular}


Variável

dependente:

REC

$I D=19$

\begin{tabular}{|r|r|r|r|}
\hline \multicolumn{3}{|c|}{ Observações Limite } \\
\hline \multicolumn{2}{|c|}{ Baixa } & \multicolumn{2}{c|}{ Alta } \\
\hline Valor & Obs & Valor & Obs \\
\hline 0 & 307 & 0 & 306 \\
\hline 0 & 306 & 0 & 307 \\
\hline 0 & 305 & 1 & 297 \\
\hline 0 & 304 & 1 & 299 \\
\hline 0 & 302 & 1 & 303 \\
\hline
\end{tabular}


Variável

dependente:

ACI

ID $=19$

\begin{tabular}{|l|r|l|r|}
\hline \multicolumn{3}{|c|}{ Momento } \\
\hline N & 11 & Soma dos pesos & 11 \\
\hline Média & $\begin{array}{r}0 \\
\text { Soma das } \\
\text { observações }\end{array}$ & 0 \\
\hline Desvio-padrão & 0 & Variância & 0 \\
\hline Assimetria &, Curtose &, \\
\hline $\begin{array}{l}\text { Soma dos } \\
\text { quadrados não } \\
\text { corrigida }\end{array}$ & 0 & $\begin{array}{l}\text { Soma dos } \\
\text { quadrados corrigida }\end{array}$ & 0 \\
\hline CV Pearson &, & Erro-padrão médio & 0 \\
\hline
\end{tabular}

\begin{tabular}{|l|r|l|r|}
\hline \multicolumn{3}{|c|}{ Estatística Descritiva Básica } \\
\hline \multicolumn{2}{|c|}{ Posição } & \multicolumn{2}{c|}{ Variabilidade } \\
\hline Média & 0 & Desvio-padrão & 0 \\
\hline Mediana & 0 & Variância & 0 \\
\hline Moda & 0 & Amplitude & 0 \\
\hline & & Amplitude interquartil & 0 \\
\hline
\end{tabular}

\begin{tabular}{|l|l|l|l|l|}
\hline \multicolumn{4}{|c|}{ Testes de Posição: Mu0=0 } \\
\hline Teste & \multicolumn{2}{|c|}{ Estatística } & \multicolumn{2}{c|}{ Valor $\mathbf{p}$} \\
\hline Student t & t &, & $\operatorname{Pr}>|\mathbf{t}|$ & \\
\hline Sign & M &, & $\operatorname{Pr}>=|\mathrm{M}|$ & \\
\hline Signed Rank & S &, & $\operatorname{Pr}>=|\mathrm{S}|$ & \\
\hline
\end{tabular}

\begin{tabular}{|l|r|}
\hline \multicolumn{2}{|c|}{ Quantis } \\
\hline Level & 0 \\
\hline $100 \%$ Max & 0 \\
\hline $99 \%$ & 0 \\
\hline $95 \%$ & 0 \\
\hline $90 \%$ & 0 \\
\hline $75 \%$ Q3 & 0 \\
\hline $50 \%$ Mediana & 0 \\
\hline $25 \%$ Q1 & 0 \\
\hline $10 \%$ & 0 \\
\hline $5 \%$ & 0 \\
\hline $1 \%$ & 0 \\
\hline $0 \%$ Min & 0 \\
\hline
\end{tabular}


Variável

dependente:

ACI

$\mathrm{ID}=19$

\begin{tabular}{|r|r|r|r|}
\hline \multicolumn{3}{|c|}{ Observações Limite } \\
\hline \multicolumn{2}{|c|}{ Baixa } & \multicolumn{2}{c|}{ Alta } \\
\hline Valor & Obs & Valor & Obs \\
\hline 0 & 307 & 0 & 303 \\
\hline 0 & 306 & 0 & 304 \\
\hline 0 & 305 & 0 & 305 \\
\hline 0 & 304 & 0 & 306 \\
\hline 0 & 303 & 0 & 307 \\
\hline
\end{tabular}


Variável

dependente:

REC

ID $=\mathbf{2 0}$

\begin{tabular}{|l|r|l|r|}
\hline \multicolumn{3}{|c|}{ Momento } \\
\hline N & 16 & Soma dos pesos & 16 \\
\hline Média & $\begin{array}{r}0 \\
\text { Soma das } \\
\text { observações }\end{array}$ & 0 \\
\hline Desvio-padrão & 0 & Variância & 0 \\
\hline Assimetria &, Curtose &, \\
\hline $\begin{array}{l}\text { Soma dos } \\
\text { quadrados não } \\
\text { corrigida }\end{array}$ & 0 & $\begin{array}{l}\text { Soma dos } \\
\text { quadrados corrigida }\end{array}$ & 0 \\
\hline CV Pearson &, & Erro-padrão médio & 0 \\
\hline
\end{tabular}

\begin{tabular}{|l|r|l|r|}
\hline \multicolumn{3}{|c|}{ Estatística Descritiva Básica } \\
\hline \multicolumn{2}{|c|}{ Posição } & \multicolumn{2}{c|}{ Variabilidade } \\
\hline Média & 0 & Desvio-padrão & 0 \\
\hline Mediana & 0 & Variância & 0 \\
\hline Moda & 0 & Amplitude & 0 \\
\hline & & Amplitude interquartil & 0 \\
\hline
\end{tabular}

\begin{tabular}{|l|l|l|l|l|}
\hline \multicolumn{4}{|c|}{ Testes de Posição: Mu0=0 } \\
\hline Teste & \multicolumn{2}{|c|}{ Estatística } & \multicolumn{2}{c|}{ Valor $\mathbf{p}$} \\
\hline Student $\mathbf{t}$ & $\mathbf{t}$ & \multicolumn{1}{|c|}{, $\operatorname{Pr}>|\mathbf{t}|$} & \\
\hline Sign & $\mathrm{M}$ &, & $\operatorname{Pr}>=|\mathrm{M}|$ & \\
\hline Signed Rank & S &, & $\operatorname{Pr}>=|\mathrm{S}|$ & \\
\hline
\end{tabular}

\begin{tabular}{|l|r|}
\hline \multicolumn{2}{|c|}{ Quantis } \\
\hline Level & 0 \\
\hline $100 \%$ Max & 0 \\
\hline $99 \%$ & 0 \\
\hline $95 \%$ & 0 \\
\hline $90 \%$ & 0 \\
\hline $75 \%$ Q3 & 0 \\
\hline $50 \%$ Mediana & 0 \\
\hline $25 \%$ Q1 & 0 \\
\hline $10 \%$ & 0 \\
\hline $5 \%$ & 0 \\
\hline $1 \%$ & 0 \\
\hline $0 \%$ Min & 0 \\
\hline
\end{tabular}


Variável

dependente:

REC

$\mathrm{ID}=\mathbf{2 0}$

\begin{tabular}{|r|r|r|r|}
\hline \multicolumn{3}{|c|}{ Observações Limite } \\
\hline \multicolumn{2}{|c|}{ Baixa } & \multicolumn{2}{c|}{ Alta } \\
\hline Valor & Obs & Valor & Obs \\
\hline 0 & 323 & 0 & 319 \\
\hline 0 & 322 & 0 & 320 \\
\hline 0 & 321 & 0 & 321 \\
\hline 0 & 320 & 0 & 322 \\
\hline 0 & 319 & 0 & 323 \\
\hline
\end{tabular}


Variável

dependente:

ACI

$I D=20$

\begin{tabular}{|l|r|l|r|}
\hline \multicolumn{4}{|c|}{ Momento } \\
\hline Média & 16 & Soma dos pesos & 16 \\
\hline Desvio-padrão & 0,125 & $\begin{array}{l}\text { Soma das } \\
\text { observações }\end{array}$ \\
\hline Assimetria & 2,50945733 & Curtose & 0,11666667 \\
\hline $\begin{array}{l}\text { Soma dos } \\
\text { quadrados não } \\
\text { corrigida }\end{array}$ & 2 & $\begin{array}{l}\text { Soma dos } \\
\text { quadrados corrigida }\end{array}$ & 4,89795918 \\
\hline CV Pearson & 273,25202 & Erro-padrão médio & 0,08539126 \\
\hline
\end{tabular}

\begin{tabular}{|l|l|l|r|}
\hline \multicolumn{4}{|c|}{ Estatística Descritiva Básica } \\
\hline \multicolumn{2}{|c|}{ Posição } & \multicolumn{2}{c|}{ Variabilidade } \\
\hline Média & 0,125000 & Desvio-padrão & 0,34157 \\
\hline Mediana & 0,000000 & Variância & 0,11667 \\
\hline Moda & 0,000000 & Amplitude & 1,00000 \\
\hline & & Amplitude interquartil & 0 \\
\hline
\end{tabular}

\begin{tabular}{|l|l|r|l|l|}
\hline \multicolumn{5}{|c|}{ Testes de Posição: Mu0=0 } \\
\hline Teste & \multicolumn{2}{|c|}{ Estatística } & \multicolumn{2}{c|}{ Valor $\mathbf{~}$} \\
\hline Student t & t & 1,46385 & $\operatorname{Pr}>|\mathbf{t}|$ & 0,1639 \\
\hline Sign & M & 1 & $\operatorname{Pr}>=|M|$ & 0,5000 \\
\hline Signed Rank & S & 1,5 & $\operatorname{Pr}>=|\mathbf{S}|$ & 0,5000 \\
\hline
\end{tabular}

\begin{tabular}{|l|r|}
\hline \multicolumn{2}{|c|}{ Quantis } \\
\hline Level & 1 \\
\hline $100 \%$ Max & 1 \\
\hline $99 \%$ & 1 \\
\hline $95 \%$ & 1 \\
\hline $90 \%$ & 0 \\
\hline $75 \%$ Quantil & 0 \\
\hline $50 \%$ Mediana & 0 \\
\hline $25 \%$ Q1 & 0 \\
\hline $10 \%$ & 0 \\
\hline $5 \%$ & 0 \\
\hline $1 \%$ & 0 \\
\hline $0 \%$ Min & \\
\hline
\end{tabular}


Variável

dependente:

ACI

$\mathrm{ID}=\mathbf{2 0}$

\begin{tabular}{|r|r|r|r|}
\hline \multicolumn{3}{|c|}{ Observações Limite } \\
\hline \multicolumn{2}{|c|}{ Baixa } & \multicolumn{2}{c|}{ Alta } \\
\hline Valor & Obs & Valor & Obs \\
\hline 0 & 323 & 0 & 321 \\
\hline 0 & 322 & 0 & 322 \\
\hline 0 & 321 & 0 & 323 \\
\hline 0 & 320 & 1 & 312 \\
\hline 0 & 319 & 1 & 313 \\
\hline
\end{tabular}


Variável

dependente:

REC

ID $=22$

\begin{tabular}{|l|r|l|r|}
\hline \multicolumn{3}{|c|}{ Momento } \\
\hline N & 14 & Soma dos pesos & 14 \\
\hline Média & $\begin{array}{r}0 \\
\text { Soma das } \\
\text { observações }\end{array}$ & 0 \\
\hline Desvio-padrão & 0 & Variância & 0 \\
\hline Assimetria &, Curtose &, \\
\hline $\begin{array}{l}\text { Soma dos } \\
\text { quadrados não } \\
\text { corrigida }\end{array}$ & 0 & $\begin{array}{l}\text { Soma dos } \\
\text { quadrados corrigida }\end{array}$ & 0 \\
\hline CV Pearson &, & Erro-padrão médio & 0 \\
\hline
\end{tabular}

\begin{tabular}{|l|r|l|r|}
\hline \multicolumn{3}{|c|}{ Estatística Descritiva Básica } \\
\hline \multicolumn{2}{|c|}{ Posição } & \multicolumn{2}{c|}{ Variabilidade } \\
\hline Média & 0 & Desvio-padrão & 0 \\
\hline Mediana & 0 & Variância & 0 \\
\hline Moda & 0 & Amplitude & 0 \\
\hline & & Amplitude interquartil & 0 \\
\hline
\end{tabular}

\begin{tabular}{|l|l|l|l|l|}
\hline \multicolumn{4}{|c|}{ Testes de Posição: Mu0=0 } \\
\hline Teste & \multicolumn{2}{|c|}{ Estatística } & \multicolumn{2}{c|}{ Valor $\mathbf{p}$} \\
\hline Student $\mathbf{t}$ & $\mathbf{t}$ & \multicolumn{1}{|c|}{, $\operatorname{Pr}>|\mathbf{t}|$} & \\
\hline Sign & $\mathrm{M}$ &, & $\operatorname{Pr}>=|\mathrm{M}|$ & \\
\hline Signed Rank & S &, & $\operatorname{Pr}>=|\mathrm{S}|$ & \\
\hline
\end{tabular}

\begin{tabular}{|l|r|}
\hline \multicolumn{2}{|c|}{ Quantis } \\
\hline Level & 0 \\
\hline $100 \%$ Max & 0 \\
\hline $99 \%$ & 0 \\
\hline $95 \%$ & 0 \\
\hline $90 \%$ & 0 \\
\hline $75 \%$ Q3 & 0 \\
\hline $50 \%$ Mediana & 0 \\
\hline $25 \%$ Q1 & 0 \\
\hline $10 \%$ & 0 \\
\hline $5 \%$ & 0 \\
\hline $1 \%$ & 0 \\
\hline $0 \%$ Min & 0 \\
\hline
\end{tabular}


Variável

dependente:

REC

$\mathrm{ID}=\mathbf{2 2}$

\begin{tabular}{|r|r|r|r|}
\hline \multicolumn{3}{|c|}{ Observações Limite } \\
\hline \multicolumn{2}{|c|}{ Baixa } & \multicolumn{2}{c|}{ Alta } \\
\hline Valor & Obs & Valor & Obs \\
\hline 0 & 337 & 0 & 333 \\
\hline 0 & 336 & 0 & 334 \\
\hline 0 & 335 & 0 & 335 \\
\hline 0 & 334 & 0 & 336 \\
\hline 0 & 333 & 0 & 337 \\
\hline
\end{tabular}


Variável

dependente:

ACI

ID $=22$

\begin{tabular}{|l|r|l|r|}
\hline \multicolumn{3}{|c|}{ Momento } \\
\hline N & 14 & Soma dos pesos & 14 \\
\hline Média & $\begin{array}{r}0 \\
\text { Soma das } \\
\text { observações }\end{array}$ & 0 \\
\hline Desvio-padrão & 0 & Variância & 0 \\
\hline Assimetria &, Curtose &, \\
\hline $\begin{array}{l}\text { Soma dos } \\
\text { quadrados não } \\
\text { corrigida }\end{array}$ & 0 & $\begin{array}{l}\text { Soma dos } \\
\text { quadrados corrigida }\end{array}$ & 0 \\
\hline CV Pearson &, & Erro-padrão médio & 0 \\
\hline
\end{tabular}

\begin{tabular}{|l|r|l|r|}
\hline \multicolumn{3}{|c|}{ Estatística Descritiva Básica } \\
\hline \multicolumn{2}{|c|}{ Posição } & \multicolumn{2}{c|}{ Variabilidade } \\
\hline Média & 0 & Desvio-padrão & 0 \\
\hline Mediana & 0 & Variância & 0 \\
\hline Moda & 0 & Amplitude & 0 \\
\hline & & Amplitude interquartil & 0 \\
\hline
\end{tabular}

\begin{tabular}{|l|l|l|l|l|}
\hline \multicolumn{4}{|c|}{ Testes de Posição: Mu0=0 } \\
\hline Teste & \multicolumn{2}{|c|}{ Estatística } & \multicolumn{2}{c|}{ Valor $\mathbf{p}$} \\
\hline Student $\mathbf{t}$ & $\mathbf{t}$ & \multicolumn{1}{|c|}{, $\operatorname{Pr}>|\mathbf{t}|$} & \\
\hline Sign & $\mathrm{M}$ &, & $\operatorname{Pr}>=|\mathrm{M}|$ & \\
\hline Signed Rank & S &, & $\operatorname{Pr}>=|\mathrm{S}|$ & \\
\hline
\end{tabular}

\begin{tabular}{|l|r|}
\hline \multicolumn{2}{|c|}{ Quantis } \\
\hline Level & 0 \\
\hline $100 \%$ Max & 0 \\
\hline $99 \%$ & 0 \\
\hline $95 \%$ & 0 \\
\hline $90 \%$ & 0 \\
\hline $75 \%$ Q3 & 0 \\
\hline $50 \%$ Mediana & 0 \\
\hline $25 \%$ Q1 & 0 \\
\hline $10 \%$ & 0 \\
\hline $5 \%$ & 0 \\
\hline $1 \%$ & 0 \\
\hline $0 \%$ Min & 0 \\
\hline
\end{tabular}


Variável

dependente:

ACI

$\mathrm{ID}=\mathbf{2 2}$

\begin{tabular}{|r|r|r|r|}
\hline \multicolumn{3}{|c|}{ Observações Limite } \\
\hline \multicolumn{2}{|c|}{ Baixa } & \multicolumn{2}{c|}{ Alta } \\
\hline Valor & Obs & Valor & Obs \\
\hline 0 & 337 & 0 & 333 \\
\hline 0 & 336 & 0 & 334 \\
\hline 0 & 335 & 0 & 335 \\
\hline 0 & 334 & 0 & 336 \\
\hline 0 & 333 & 0 & 337 \\
\hline
\end{tabular}


Variável

dependente:

REC

ID $=24$

\begin{tabular}{|l|r|l|r|}
\hline \multicolumn{3}{|c|}{ Momento } \\
\hline N & 18 & Soma dos pesos & 18 \\
\hline Média & $\begin{array}{r}0 \\
\text { Soma das } \\
\text { observações }\end{array}$ & 0 \\
\hline Desvio-padrão & 0 & Variância & 0 \\
\hline Assimetria &, Curtose &, \\
\hline $\begin{array}{l}\text { Soma dos } \\
\text { quadrados não } \\
\text { corrigida }\end{array}$ & 0 & $\begin{array}{l}\text { Soma dos } \\
\text { quadrados corrigida }\end{array}$ & 0 \\
\hline CV Pearson &, & Erro-padrão médio & 0 \\
\hline
\end{tabular}

\begin{tabular}{|l|r|l|r|}
\hline \multicolumn{3}{|c|}{ Estatística Descritiva Básica } \\
\hline \multicolumn{2}{|c|}{ Posição } & \multicolumn{2}{c|}{ Variabilidade } \\
\hline Média & 0 & Desvio-padrão & 0 \\
\hline Mediana & 0 & Variância & 0 \\
\hline Moda & 0 & Amplitude & 0 \\
\hline & & Amplitude interquartil & 0 \\
\hline
\end{tabular}

\begin{tabular}{|l|l|l|l|l|}
\hline \multicolumn{4}{|c|}{ Testes de Posição: Mu0=0 } \\
\hline Teste & \multicolumn{2}{|c|}{ Estatística } & \multicolumn{2}{c|}{ Valor $\mathbf{p}$} \\
\hline Student $\mathbf{t}$ & $\mathbf{t}$ & \multicolumn{1}{|c|}{, $\operatorname{Pr}>|\mathbf{t}|$} & \\
\hline Sign & $\mathrm{M}$ &, & $\operatorname{Pr}>=|\mathrm{M}|$ & \\
\hline Signed Rank & S &, & $\operatorname{Pr}>=|\mathrm{S}|$ & \\
\hline
\end{tabular}

\begin{tabular}{|l|r|}
\hline \multicolumn{2}{|c|}{ Quantis } \\
\hline Level & 0 \\
\hline $100 \%$ Max & 0 \\
\hline $99 \%$ & 0 \\
\hline $95 \%$ & 0 \\
\hline $90 \%$ & 0 \\
\hline $75 \%$ Q3 & 0 \\
\hline $50 \%$ Mediana & 0 \\
\hline $25 \%$ Q1 & 0 \\
\hline $10 \%$ & 0 \\
\hline $5 \%$ & 0 \\
\hline $1 \%$ & 0 \\
\hline $0 \%$ Min & 0 \\
\hline
\end{tabular}


Variável

dependente:

REC

ID $=\mathbf{2 4}$

\begin{tabular}{|r|r|r|r|}
\hline \multicolumn{3}{|c|}{ Observações Limite } \\
\hline \multicolumn{2}{|c|}{ Baixa } & \multicolumn{2}{c|}{ Alta } \\
\hline Valor & Obs & Valor & Obs \\
\hline 0 & 355 & 0 & 351 \\
\hline 0 & 354 & 0 & 352 \\
\hline 0 & 353 & 0 & 353 \\
\hline 0 & 352 & 0 & 354 \\
\hline 0 & 351 & 0 & 355 \\
\hline
\end{tabular}


Variável

dependente:

ACI

ID $=24$

\begin{tabular}{|l|r|l|r|}
\hline \multicolumn{4}{|c|}{ Momento } \\
\hline Média & 18 & Soma dos pesos & 18 \\
\hline Desvio-padrão & 0,42779263 & Variância \\
observações & 0,18300654 \\
\hline Assimetria & 1,46098823 & Curtose & 0,13660714 \\
\hline $\begin{array}{l}\text { Soma dos } \\
\text { quadrados não } \\
\text { corrigida }\end{array}$ & 4 & $\begin{array}{l}\text { Soma dos } \\
\text { quadrados corrigida }\end{array}$ & 3,11111111 \\
\hline CV Pearson & 192,506684 & Erro-padrão médio & 0,10083169 \\
\hline
\end{tabular}

\begin{tabular}{|l|l|l|r|}
\hline \multicolumn{4}{|c|}{ Estatística Descritiva Básica } \\
\hline \multicolumn{2}{|c|}{ Posição } & \multicolumn{2}{c|}{ Variabilidade } \\
\hline Média & 0,222222 & Desvio-padrão & 0,42779 \\
\hline Mediana & 0,000000 & Variância & 0,18301 \\
\hline Moda & 0,000000 & Amplitude & 1,00000 \\
\hline & & Amplitude interquartil & 0 \\
\hline
\end{tabular}

\begin{tabular}{|l|l|r|l|l|}
\hline \multicolumn{5}{|c|}{ Testes de Posição: Mu0=0 } \\
\hline Teste & \multicolumn{2}{|c|}{ Estatística } & \multicolumn{2}{c|}{ Valor $\mathbf{~}$} \\
\hline Student t & t & 2,203893 & $\operatorname{Pr}>|\mathbf{t}|$ & 0,0416 \\
\hline Sign & M & 2 & $\operatorname{Pr}>=|\mathbf{M}|$ & 0,1250 \\
\hline Signed Rank & S & 5 & $\operatorname{Pr}>=|\mathbf{S}|$ & 0,1250 \\
\hline
\end{tabular}

\begin{tabular}{|l|r|}
\hline \multicolumn{2}{|c|}{ Quantis } \\
\hline Level & 1 \\
\hline $100 \%$ Max & 1 \\
\hline $99 \%$ & 1 \\
\hline $95 \%$ & 1 \\
\hline $90 \%$ & 0 \\
\hline $75 \%$ Q3 & 0 \\
\hline $50 \%$ Mediana & 0 \\
\hline $25 \%$ Q1 & 0 \\
\hline $10 \%$ & 0 \\
\hline $5 \%$ & 0 \\
\hline $1 \%$ & 0 \\
\hline $0 \%$ Min & 0 \\
\hline
\end{tabular}




\section{Variável}

dependente:

ACI

$\mathrm{ID}=\mathbf{2 4}$

\begin{tabular}{|r|r|r|r|}
\hline \multicolumn{3}{|c|}{ Observações Limite } \\
\hline \multicolumn{2}{|c|}{ Baixa } & \multicolumn{2}{c|}{ Alta } \\
\hline Valor & Obs & Valor & Obs \\
\hline 0 & 354 & 0 & 354 \\
\hline 0 & 353 & 1 & 342 \\
\hline 0 & 352 & 1 & 346 \\
\hline 0 & 350 & 1 & 351 \\
\hline 0 & 349 & 1 & 355 \\
\hline
\end{tabular}


Variável

dependente:

REC

ID $=25$

\begin{tabular}{|l|r|l|r|}
\hline \multicolumn{3}{|c|}{ Momento } \\
\hline N & 9 & Soma dos pesos & 9 \\
\hline Média & $\begin{array}{r}0 \\
\text { Soma das } \\
\text { observações }\end{array}$ & 0 \\
\hline Desvio-padrão & 0 & Variância & 0 \\
\hline Assimetria &, Curtose &, \\
\hline $\begin{array}{l}\text { Soma dos } \\
\text { quadrados não } \\
\text { corrigida }\end{array}$ & 0 & $\begin{array}{l}\text { Soma dos } \\
\text { quadrados corrigida }\end{array}$ & 0 \\
\hline CV Pearson &, & Erro-padrão médio & 0 \\
\hline
\end{tabular}

\begin{tabular}{|l|r|l|r|}
\hline \multicolumn{3}{|c|}{ Estatística Descritiva Básica } \\
\hline \multicolumn{2}{|c|}{ Posição } & \multicolumn{2}{c|}{ Variabilidade } \\
\hline Média & 0 & Desvio-padrão & 0 \\
\hline Mediana & 0 & Variância & 0 \\
\hline Moda & 0 & Amplitude & 0 \\
\hline & & Amplitude interquartil & 0 \\
\hline
\end{tabular}

\begin{tabular}{|l|l|l|l|l|}
\hline \multicolumn{4}{|c|}{ Testes de Posição: Mu0=0 } \\
\hline Teste & \multicolumn{2}{|c|}{ Estatística } & \multicolumn{2}{c|}{ Valor $\mathbf{p}$} \\
\hline Student $\mathbf{t}$ & $\mathbf{t}$ & \multicolumn{1}{|c|}{, $\operatorname{Pr}>|\mathbf{t}|$} & \\
\hline Sign & $\mathrm{M}$ &, & $\operatorname{Pr}>=|\mathrm{M}|$ & \\
\hline Signed Rank & S &, & $\operatorname{Pr}>=|\mathrm{S}|$ & \\
\hline
\end{tabular}

\begin{tabular}{|l|r|}
\hline \multicolumn{2}{|c|}{ Quantis } \\
\hline Level & 0 \\
\hline $100 \%$ Max & 0 \\
\hline $99 \%$ & 0 \\
\hline $95 \%$ & 0 \\
\hline $90 \%$ & 0 \\
\hline $75 \%$ Q3 & 0 \\
\hline $50 \%$ Mediana & 0 \\
\hline $25 \%$ Q1 & 0 \\
\hline $10 \%$ & 0 \\
\hline $5 \%$ & 0 \\
\hline $1 \%$ & 0 \\
\hline $0 \%$ Min & 0 \\
\hline
\end{tabular}


Variável

dependente:

REC

$I D=25$

\begin{tabular}{|r|r|r|r|}
\hline \multicolumn{3}{|c|}{ Observações Limite } \\
\hline \multicolumn{2}{|c|}{ Baixa } & \multicolumn{2}{c|}{ Alta } \\
\hline Valor & Obs & Valor & Obs \\
\hline 0 & 364 & 0 & 360 \\
\hline 0 & 363 & 0 & 361 \\
\hline 0 & 362 & 0 & 362 \\
\hline 0 & 361 & 0 & 363 \\
\hline 0 & 360 & 0 & 364 \\
\hline
\end{tabular}


Variável

dependente:

ACI

$\mathrm{ID}=\mathbf{2 5}$

\begin{tabular}{|l|r|l|r|}
\hline \multicolumn{3}{|c|}{ Momento } \\
\hline N & 9 & Soma dos pesos & 9 \\
\hline Média & $\begin{array}{r}0 \\
\text { Soma das } \\
\text { observações }\end{array}$ & 0 \\
\hline Desvio-padrão & 0 & Variância & 0 \\
\hline Assimetria &, Curtose &, \\
\hline $\begin{array}{l}\text { Soma dos } \\
\text { quadrados não } \\
\text { corrigida }\end{array}$ & 0 & $\begin{array}{l}\text { Soma dos } \\
\text { quadrados corrigida }\end{array}$ & 0 \\
\hline CV Pearson &, & Erro-padrão médio & 0 \\
\hline
\end{tabular}

\begin{tabular}{|l|r|l|r|}
\hline \multicolumn{3}{|c|}{ Estatística Descritiva Básica } \\
\hline \multicolumn{2}{|c|}{ Posição } & \multicolumn{2}{c|}{ Variabilidade } \\
\hline Média & 0 & Desvio-padrão & 0 \\
\hline Mediana & 0 & Variância & 0 \\
\hline Moda & 0 & Amplitude & 0 \\
\hline & & Amplitude interquartil & 0 \\
\hline
\end{tabular}

\begin{tabular}{|l|l|l|l|l|}
\hline \multicolumn{4}{|c|}{ Testes de Posição: Mu0=0 } \\
\hline Teste & \multicolumn{2}{|c|}{ Estatística } & \multicolumn{2}{c|}{ Valor $\mathbf{p}$} \\
\hline Student $\mathbf{t}$ & $\mathbf{t}$ & \multicolumn{1}{|c|}{, $\operatorname{Pr}>|\mathbf{t}|$} & \\
\hline Sign & $\mathrm{M}$ &, & $\operatorname{Pr}>=|\mathrm{M}|$ & \\
\hline Signed Rank & S &, & $\operatorname{Pr}>=|\mathrm{S}|$ & \\
\hline
\end{tabular}

\begin{tabular}{|l|r|}
\hline \multicolumn{2}{|c|}{ Quantis } \\
\hline Level & 0 \\
\hline $100 \%$ Max & 0 \\
\hline $99 \%$ & 0 \\
\hline $95 \%$ & 0 \\
\hline $90 \%$ & 0 \\
\hline $75 \%$ Q3 & 0 \\
\hline $50 \%$ Mediana & 0 \\
\hline $25 \%$ Q1 & 0 \\
\hline $10 \%$ & 0 \\
\hline $5 \%$ & 0 \\
\hline $1 \%$ & 0 \\
\hline $0 \%$ Min & \\
\hline
\end{tabular}


Variável

dependente:

ACI

$\mathrm{ID}=\mathbf{2 5}$

\begin{tabular}{|r|r|r|r|}
\hline \multicolumn{3}{|c|}{ Observações Limite } \\
\hline \multicolumn{2}{|c|}{ Baixa } & \multicolumn{2}{c|}{ Alta } \\
\hline Valor & Obs & Valor & Obs \\
\hline 0 & 364 & 0 & 360 \\
\hline 0 & 363 & 0 & 361 \\
\hline 0 & 362 & 0 & 362 \\
\hline 0 & 361 & 0 & 363 \\
\hline 0 & 360 & 0 & 364 \\
\hline
\end{tabular}


Variável

dependente:

REC

$I D=26$

\begin{tabular}{|l|r|l|r|}
\hline \multicolumn{4}{|c|}{ Momento } \\
\hline Média & 18 & Soma dos pesos & 18 \\
\hline Desvio-padrão & 1 & $\begin{array}{l}\text { Soma das } \\
\text { observações }\end{array}$ & 18 \\
\hline Assimetria & 1,78214935 & Cariância & 2,23529412 \\
\hline $\begin{array}{l}\text { Soma dos } \\
\text { quadrados não } \\
\text { corrigida }\end{array}$ & 56 & $\begin{array}{l}\text { Soma dos } \\
\text { quadrados corrigida }\end{array}$ & 2,46052632 \\
\hline CV Pearson & 149,509 & Erro-padrão médio & 0,35239609 \\
\hline
\end{tabular}

\begin{tabular}{|l|l|l|c|}
\hline \multicolumn{4}{|c|}{ Estatística Descritiva Básica } \\
\hline \multicolumn{2}{|c|}{ Posição } & \multicolumn{2}{c|}{ Variabilidade } \\
\hline Média & 1,000000 & Desvio-padrão & 1,49509 \\
\hline Mediana & 0,500000 & Variância & 2,23529 \\
\hline Moda & 0,000000 & Amplitude & 5,00000 \\
\hline & & Amplitude interquartil & 1,00000 \\
\hline
\end{tabular}

\begin{tabular}{|l|l|r|l|l|}
\hline \multicolumn{5}{|c|}{ Testes de Posição: Mu0=0 } \\
\hline Teste & \multicolumn{2}{|c|}{ Estatística } & \multicolumn{2}{c|}{ Valor $\mathbf{~}$} \\
\hline Student t & t & 2,837716 & $\mathrm{Pr}>|\mathbf{t}|$ & 0,0114 \\
\hline Sign & M & 4,5 & $\mathrm{Pr}>=|\mathrm{M}|$ & 0,0039 \\
\hline Signed Rank & S & 22,5 & $\mathrm{Pr}>=|\mathrm{S}|$ & 0,0039 \\
\hline
\end{tabular}

\begin{tabular}{|l|r|}
\hline \multicolumn{2}{|c|}{ Quantis } \\
\hline Level & Quantil \\
\hline $100 \%$ Max & 5,0 \\
\hline $99 \%$ & 5,0 \\
\hline $95 \%$ & 5,0 \\
\hline $90 \%$ & 4,0 \\
\hline $75 \%$ Q3 & 1,0 \\
\hline $50 \%$ Mediana & 0,5 \\
\hline $25 \%$ Q1 & 0,0 \\
\hline $10 \%$ & 0,0 \\
\hline $5 \%$ & 0,0 \\
\hline $1 \%$ & 0,0 \\
\hline $0 \%$ Min & 0,0 \\
\hline
\end{tabular}


Variável

dependente:

REC

$I D=26$

\begin{tabular}{|r|r|r|r|}
\hline \multicolumn{3}{|c|}{ Observações Limite } \\
\hline \multicolumn{2}{|c|}{ Baixa } & \multicolumn{2}{c|}{ Alta } \\
\hline Valor & Obs & Valor & Obs \\
\hline 0 & 381 & 1 & 373 \\
\hline 0 & 380 & 1 & 379 \\
\hline 0 & 378 & 3 & 382 \\
\hline 0 & 377 & 4 & 372 \\
\hline 0 & 375 & 5 & 376 \\
\hline
\end{tabular}


Variável

dependente:

ACI

$I D=26$

\begin{tabular}{|l|r|l|r|}
\hline \multicolumn{4}{|c|}{ Momento } \\
\hline Média & 18 & Soma dos pesos & 18 \\
\hline Desvio-padrão & 1,62898581 & Variância \\
observações & 2,65359477 \\
\hline Assimetria & 1,15933901 & Curtose & 0,11676697 \\
\hline $\begin{array}{l}\text { Soma dos } \\
\text { quadrados não } \\
\text { corrigida }\end{array}$ & 72 & $\begin{array}{l}\text { Soma dos } \\
\text { quadrados corrigida }\end{array}$ & 45,1111111 \\
\hline CV Pearson & 133,280657 & Erro-padrão médio & 0,38395564 \\
\hline
\end{tabular}

\begin{tabular}{|l|l|l|c|}
\hline \multicolumn{4}{|c|}{ Estatística Descritiva Básica } \\
\hline \multicolumn{2}{|c|}{ Posição } & \multicolumn{2}{c|}{ Variabilidade } \\
\hline Média & 1,222222 & Desvio-padrão & 1,62899 \\
\hline Mediana & 0,500000 & Variância & 2,65359 \\
\hline Moda & 0,000000 & Amplitude & 5,00000 \\
\hline & & Amplitude interquartil & 3,00000 \\
\hline
\end{tabular}

\begin{tabular}{|l|l|r|l|l|}
\hline \multicolumn{5}{|c|}{ Testes de Posição: Mu0=0 } \\
\hline Teste & \multicolumn{2}{|c|}{ Estatística } & \multicolumn{2}{c|}{ Valor $\mathbf{~}$} \\
\hline Student t & t & 3,183238 & $\mathrm{Pr}>|\mathbf{t}|$ & 0,0054 \\
\hline Sign & M & 4,5 & $\mathrm{Pr}>=|\mathrm{M}|$ & 0,0039 \\
\hline Signed Rank & S & 22,5 & $\mathrm{Pr}>=|\mathbf{S}|$ & 0,0039 \\
\hline
\end{tabular}

\begin{tabular}{|l|r|}
\hline \multicolumn{2}{|c|}{ Quantis } \\
\hline Level & Quantil \\
\hline $100 \%$ Max & 5,0 \\
\hline $99 \%$ & 5,0 \\
\hline $95 \%$ & 5,0 \\
\hline $90 \%$ & 4,0 \\
\hline $75 \%$ Q3 & 3,0 \\
\hline $50 \%$ Mediana & 0,5 \\
\hline $25 \%$ Q1 & 0,0 \\
\hline $10 \%$ & 0,0 \\
\hline $5 \%$ & 0,0 \\
\hline $1 \%$ & 0,0 \\
\hline $0 \%$ Min & 0,0 \\
\hline
\end{tabular}


Variável

dependente:

ACI

$I D=26$

\begin{tabular}{|r|r|r|r|}
\hline \multicolumn{3}{|c|}{ Observações Limite } \\
\hline \multicolumn{2}{|c|}{ Baixa } & \multicolumn{2}{c|}{ Alta } \\
\hline Valor & Obs & Valor & Obs \\
\hline 0 & 381 & 3 & 369 \\
\hline 0 & 379 & 3 & 370 \\
\hline 0 & 378 & 3 & 371 \\
\hline 0 & 377 & 4 & 368 \\
\hline 0 & 376 & 5 & 382 \\
\hline
\end{tabular}


Variável

dependente:

REC

ID $=\mathbf{2 7}$

\begin{tabular}{|l|r|l|r|}
\hline \multicolumn{4}{|c|}{ Momento } \\
\hline Média & 18 & Soma dos pesos & 18 \\
\hline Desvio-padrão & 2,09262633 & $\begin{array}{l}\text { Variância } \\
\text { observações }\end{array}$ & 4,37908497 \\
\hline Assimetria & 1,62600073 & Curtose & 1,77621787 \\
\hline $\begin{array}{l}\text { Soma dos } \\
\text { quadrados não } \\
\text { corrigida }\end{array}$ & 112 & $\begin{array}{l}\text { Soma dos } \\
\text { quadrados corrigida }\end{array}$ & 74,4444444 \\
\hline CV Pearson & 144,874131 & Erro-padrão médio & 0,49323676 \\
\hline
\end{tabular}

\begin{tabular}{|l|l|l|l|}
\hline \multicolumn{4}{|c|}{ Estatística Descritiva Básica } \\
\hline \multicolumn{2}{|c|}{ Posição } & \multicolumn{2}{c|}{ Variabilidade } \\
\hline Média & 1,444444 & Desvio-padrão & 2,09263 \\
\hline Mediana & 1,000000 & Variância & 4,37908 \\
\hline Moda & 0,000000 & Amplitude & 7,00000 \\
\hline & & Amplitude interquartil & 1,00000 \\
\hline
\end{tabular}

\begin{tabular}{|l|l|r|l|l|}
\hline \multicolumn{5}{|c|}{ Testes de Posição: Mu0=0 } \\
\hline Teste & \multicolumn{2}{|c|}{ Estatística } & \multicolumn{2}{c|}{ Valor $\mathbf{~}$} \\
\hline Student t & t & 2,928501 & $\mathrm{Pr}>|\mathbf{t}|$ & 0,0094 \\
\hline Sign & M & 5 & $\mathrm{Pr}>=|\mathrm{M}|$ & 0,0020 \\
\hline Signed Rank & S & 27,5 & $\mathrm{Pr}>=|\mathrm{S}|$ & 0,0020 \\
\hline
\end{tabular}

\begin{tabular}{|l|r|}
\hline \multicolumn{2}{|c|}{ Quantis } \\
\hline Level & 7 \\
\hline $100 \%$ Max & 7 \\
\hline $99 \%$ & 7 \\
\hline $95 \%$ & 5 \\
\hline $90 \%$ & 1 \\
\hline $75 \%$ Q3 & 1 \\
\hline $50 \%$ Mediana & 0 \\
\hline $25 \%$ Q1 & 0 \\
\hline $10 \%$ & 0 \\
\hline $5 \%$ & 0 \\
\hline $1 \%$ & 0 \\
\hline $0 \%$ Min & \\
\hline
\end{tabular}


Variável

dependente:

REC

ID $=\mathbf{2 7}$

\begin{tabular}{|r|r|r|r|}
\hline \multicolumn{3}{|c|}{ Observações Limite } \\
\hline \multicolumn{2}{|c|}{ Baixa } & \multicolumn{2}{c|}{ Alta } \\
\hline Valor & Obs & Valor & Obs \\
\hline 0 & 399 & 1 & 400 \\
\hline 0 & 397 & 4 & 385 \\
\hline 0 & 394 & 4 & 389 \\
\hline 0 & 393 & 5 & 390 \\
\hline 0 & 392 & 7 & 388 \\
\hline
\end{tabular}


Variável

dependente:

ACI

ID $=\mathbf{2 7}$

\begin{tabular}{|l|r|l|r|}
\hline \multicolumn{4}{|c|}{ Momento } \\
\hline Média & 18 & Soma dos pesos & 18 \\
\hline Desvio-padrão & 1,06027497 & Variância \\
\hline Assimetria & 1,82872703 & Curtose & 1,12418301 \\
\hline $\begin{array}{l}\text { Soma dos } \\
\text { quadrados não } \\
\text { corrigida }\end{array}$ & 30 & $\begin{array}{l}\text { Soma dos } \\
\text { quadrados corrigida }\end{array}$ & 4,05307261 \\
\hline CV Pearson & 136,321067 & Erro-padrão médio & 0,24990921 \\
\hline
\end{tabular}

\begin{tabular}{|l|c|l|c|}
\hline \multicolumn{4}{|c|}{ Estatística Descritiva Básica } \\
\hline \multicolumn{2}{|c|}{ Posição } & \multicolumn{2}{c|}{ Variabilidade } \\
\hline Média & 0,777778 & Desvio-padrão & 1,06027 \\
\hline Mediana & 0,500000 & Variância & 1,12418 \\
\hline Moda & 0,000000 & Amplitude & 4,00000 \\
\hline & & Amplitude interquartil & 1,00000 \\
\hline
\end{tabular}

\begin{tabular}{|l|l|r|l|l|}
\hline \multicolumn{5}{|c|}{ Testes de Posição: Mu0=0 } \\
\hline Teste & \multicolumn{2}{|c|}{ Estatística } & \multicolumn{2}{c|}{ Valor $\mathbf{~}$} \\
\hline Student t & t & 3,112241 & $\mathrm{Pr}>|\mathbf{t}|$ & 0,0063 \\
\hline Sign & M & 4,5 & $\mathrm{Pr}>=|\mathrm{M}|$ & 0,0039 \\
\hline Signed Rank & S & 22,5 & $\mathrm{Pr}>=|\mathrm{S}|$ & 0,0039 \\
\hline
\end{tabular}

\begin{tabular}{|l|r|}
\hline \multicolumn{2}{|c|}{ Quantis } \\
\hline Level & Quantil \\
\hline $100 \%$ Max & 4,0 \\
\hline $99 \%$ & 4,0 \\
\hline $95 \%$ & 4,0 \\
\hline $90 \%$ & 2,0 \\
\hline $75 \%$ Q3 & 1,0 \\
\hline $50 \%$ Mediana & 0,5 \\
\hline $25 \%$ Q1 & 0,0 \\
\hline $10 \%$ & 0,0 \\
\hline $5 \%$ & 0,0 \\
\hline $1 \%$ & 0,0 \\
\hline $0 \%$ Min & 0,0 \\
\hline
\end{tabular}


Variável

dependente:

ACI

ID $=\mathbf{2 7}$

\begin{tabular}{|r|r|r|r|}
\hline \multicolumn{3}{|c|}{ Observações Limite } \\
\hline \multicolumn{2}{|c|}{ Baixa } & \multicolumn{2}{c|}{ Alta } \\
\hline Valor & Obs & Valor & Obs \\
\hline 0 & 400 & 1 & 393 \\
\hline 0 & 399 & 1 & 394 \\
\hline 0 & 398 & 2 & 385 \\
\hline 0 & 397 & 2 & 388 \\
\hline 0 & 396 & 4 & 384 \\
\hline
\end{tabular}


Variável

dependente:

REC

$\mathrm{ID}=\mathbf{2 8}$

\begin{tabular}{|l|r|l|r|}
\hline \multicolumn{4}{|c|}{ Momento } \\
\hline Média & 18 & Soma dos pesos & 18 \\
\hline Desvio-padrão & 0,85558526 & $\begin{array}{l}\text { Variância } \\
\text { observações }\end{array}$ & 0,73202614 \\
\hline Assimetria & 1,70883445 & Curtose & 2,84801499 \\
\hline $\begin{array}{l}\text { Soma dos } \\
\text { quadrados não } \\
\text { corrigida }\end{array}$ & 18 & $\begin{array}{l}\text { Soma dos } \\
\text { quadrados corrigida }\end{array}$ & 12,4444444 \\
\hline CV Pearson & 154,005348 & Erro-padrão médio & 0,20166338 \\
\hline
\end{tabular}

\begin{tabular}{|l|c|l|c|}
\hline \multicolumn{4}{|c|}{ Estatística Descritiva Básica } \\
\hline \multicolumn{2}{|c|}{ Posição } & \multicolumn{2}{c|}{ Variabilidade } \\
\hline Média & 0,555556 & Desvio-padrão & 0,85559 \\
\hline Mediana & 0,000000 & Variância & 0,73203 \\
\hline Moda & 0,000000 & Amplitude & 3,00000 \\
\hline & & Amplitude interquartil & 1,00000 \\
\hline
\end{tabular}

\begin{tabular}{|l|l|r|l|l|}
\hline \multicolumn{5}{|c|}{ Testes de Posição: Mu0=0 } \\
\hline Teste & \multicolumn{2}{|c|}{ Estatística } & \multicolumn{2}{c|}{ Valor $\mathbf{~}$} \\
\hline Student t & t & 2,754866 & $\mathrm{Pr}>|\mathbf{t}|$ & 0,0135 \\
\hline Sign & M & 3,5 & $\mathrm{Pr}>=|\mathrm{M}|$ & 0,0156 \\
\hline Signed Rank & S & 14 & $\mathrm{Pr}>=|\mathrm{S}|$ & 0,0156 \\
\hline
\end{tabular}

\begin{tabular}{|l|r|}
\hline \multicolumn{2}{|c|}{ Quantis } \\
\hline Level & Quantil \\
\hline $100 \%$ Max & 3 \\
\hline $99 \%$ & 3 \\
\hline $95 \%$ & 2 \\
\hline $90 \%$ & 1 \\
\hline $75 \%$ Q3 & 0 \\
\hline $50 \%$ Mediana & 0 \\
\hline $25 \%$ Q1 & 0 \\
\hline $10 \%$ & 0 \\
\hline $5 \%$ & 0 \\
\hline $1 \%$ & 0 \\
\hline $0 \%$ Min & 0 \\
\hline
\end{tabular}


Variável

dependente:

REC

ID $=\mathbf{2 8}$

\begin{tabular}{|r|r|r|r|}
\hline \multicolumn{3}{|c|}{ Observações Limite } \\
\hline \multicolumn{2}{|c|}{ Baixa } & \multicolumn{2}{c|}{ Alta } \\
\hline Valor & Obs & Valor & Obs \\
\hline 0 & 418 & 1 & 406 \\
\hline 0 & 417 & 1 & 409 \\
\hline 0 & 416 & 1 & 411 \\
\hline 0 & 415 & 2 & 408 \\
\hline 0 & 414 & 3 & 407 \\
\hline
\end{tabular}


Variável

dependente:

ACI

$\mathrm{ID}=\mathbf{2 8}$

\begin{tabular}{|l|r|l|r|}
\hline \multicolumn{4}{|c|}{ Momento } \\
\hline Média & 18 & Soma dos pesos & 18 \\
\hline Desvio-padrão & 1,22741026 & $\begin{array}{l}\text { Variância } \\
\text { observações }\end{array}$ \\
\hline Assimetria & 1,67230396 & Curtose & 1,50653595 \\
\hline $\begin{array}{l}\text { Soma dos } \\
\text { quadrados não } \\
\text { corrigida }\end{array}$ & 35 & $\begin{array}{l}\text { Soma dos } \\
\text { quadrados corrigida }\end{array}$ & 1,96267004 \\
\hline CV Pearson & 169,949113 & Erro-padrão médio & 0,28930337 \\
\hline
\end{tabular}

\begin{tabular}{|l|l|l|r|}
\hline \multicolumn{4}{|c|}{ Estatística Descritiva Básica } \\
\hline \multicolumn{2}{|c|}{ Posição } & \multicolumn{2}{c|}{ Variabilidade } \\
\hline Média & 0,722222 & Desvio-padrão & 1,22741 \\
\hline Mediana & 0,000000 & Variância & 1,50654 \\
\hline Moda & 0,000000 & Amplitude & 4,00000 \\
\hline & & Amplitude interquartil & 1,00000 \\
\hline
\end{tabular}

\begin{tabular}{|l|l|r|l|l|}
\hline \multicolumn{5}{|c|}{ Testes de Posição: Mu0=0 } \\
\hline Teste & \multicolumn{2}{|c|}{ Estatística } & \multicolumn{2}{c|}{ Valor $\mathbf{~}$} \\
\hline Student t & t & 2,496418 & $\mathrm{Pr}>|\mathbf{t}|$ & 0,0231 \\
\hline Sign & M & 3 & $\mathrm{Pr}>=|\mathrm{M}|$ & 0,0313 \\
\hline Signed Rank & S & 10,5 & $\mathrm{Pr}>=|\mathrm{S}|$ & 0,0313 \\
\hline
\end{tabular}

\begin{tabular}{|l|r|}
\hline \multicolumn{2}{|c|}{ Quantis } \\
\hline Level & Quantil \\
\hline $100 \%$ Max & 4 \\
\hline $99 \%$ & 4 \\
\hline $95 \%$ & 3 \\
\hline $90 \%$ & 1 \\
\hline $75 \%$ Q3 & 0 \\
\hline $50 \%$ Mediana & 0 \\
\hline $25 \%$ Q1 & 0 \\
\hline $10 \%$ & 0 \\
\hline $5 \%$ & 0 \\
\hline $1 \%$ & 0 \\
\hline $0 \%$ Min & 4 \\
\hline
\end{tabular}


Variável

dependente:

ACI

$I D=28$

\begin{tabular}{|r|r|r|r|}
\hline \multicolumn{3}{|c|}{ Observações Limite } \\
\hline \multicolumn{2}{|c|}{ Baixa } & \multicolumn{2}{c|}{ Alta } \\
\hline Valor & Obs & Valor & Obs \\
\hline 0 & 418 & 1 & 415 \\
\hline 0 & 417 & 2 & 406 \\
\hline 0 & 416 & 2 & 412 \\
\hline 0 & 414 & 3 & 403 \\
\hline 0 & 413 & 4 & 407 \\
\hline
\end{tabular}


Variável

dependente:

REC

$\mathrm{ID}=\mathbf{2 9}$

\begin{tabular}{|l|r|l|r|}
\hline \multicolumn{4}{|c|}{ Momento } \\
\hline Média & 18 & Soma dos pesos & 18 \\
\hline Desvio-padrão & 0,57451315 & Variância \\
\hline Assimetria & 2,07235302 & Curtose & 0,33006536 \\
\hline $\begin{array}{l}\text { Soma dos } \\
\text { quadrados não } \\
\text { corrigida }\end{array}$ & 7 & $\begin{array}{l}\text { Soma dos } \\
\text { quadrados corrigida }\end{array}$ & 3,84862268 \\
\hline CV Pearson & 206,824734 & Erro-padrão médio & 0,13541411111 \\
\hline
\end{tabular}

\begin{tabular}{|l|l|l|r|}
\hline \multicolumn{4}{|c|}{ Estatística Descritiva Básica } \\
\hline \multicolumn{2}{|c|}{ Posição } & \multicolumn{2}{c|}{ Variabilidade } \\
\hline Média & 0,277778 & Desvio-padrão & 0,57451 \\
\hline Mediana & 0,000000 & Variância & 0,33007 \\
\hline Moda & 0,000000 & Amplitude & 2,00000 \\
\hline & & Amplitude interquartil & 0 \\
\hline
\end{tabular}

\begin{tabular}{|l|l|r|l|l|}
\hline \multicolumn{5}{|c|}{ Testes de Posição: Mu0=0 } \\
\hline Teste & \multicolumn{2}{|c|}{ Estatística } & \multicolumn{2}{c|}{ Valor $\mathbf{~}$} \\
\hline Student t & t & 2,051322 & $\mathrm{Pr}>|\mathbf{t}|$ & 0,0560 \\
\hline Sign & $\mathrm{M}$ & 2 & $\mathrm{Pr}>=|\mathrm{M}|$ & 0,1250 \\
\hline Signed Rank & $\mathrm{S}$ & 5 & $\mathrm{Pr}>=|\mathrm{S}|$ & 0,1250 \\
\hline
\end{tabular}

\begin{tabular}{|l|r|}
\hline \multicolumn{2}{|c|}{ Quantis } \\
\hline Level & 2 \\
\hline $100 \%$ Max & 2 \\
\hline $99 \%$ & 2 \\
\hline $95 \%$ & 1 \\
\hline $90 \%$ & 0 \\
\hline $75 \%$ Q3 & 0 \\
\hline $50 \%$ Mediana & 0 \\
\hline $25 \%$ Q1 & 0 \\
\hline $10 \%$ & 0 \\
\hline $5 \%$ & 0 \\
\hline $1 \%$ & 0 \\
\hline $0 \%$ Min & 0 \\
\hline
\end{tabular}


Variável

dependente:

REC

ID $=\mathbf{2 9}$

\begin{tabular}{|r|r|r|r|}
\hline \multicolumn{3}{|c|}{ Observações Limite } \\
\hline \multicolumn{2}{|c|}{ Baixa } & \multicolumn{2}{c|}{ Alta } \\
\hline Valor & Obs & Valor & Obs \\
\hline 0 & 436 & 0 & 436 \\
\hline 0 & 435 & 1 & 421 \\
\hline 0 & 434 & 1 & 424 \\
\hline 0 & 433 & 1 & 431 \\
\hline 0 & 432 & 2 & 425 \\
\hline
\end{tabular}


Variável

dependente:

ACI

$\mathrm{ID}=\mathbf{2 9}$

\begin{tabular}{|l|r|l|r|}
\hline \multicolumn{3}{|c|}{ Momento } \\
\hline Média & 18 & Soma dos pesos & 18 \\
\hline Desvio-padrão & 0,38348249 & $\begin{array}{l}\text { Variância } \\
\text { observações }\end{array}$ & 0,14705882 \\
\hline Assimetria & 1,95576072 & Curtose & 2,04 \\
\hline $\begin{array}{l}\text { Soma dos } \\
\text { quadrados não } \\
\text { corrigida }\end{array}$ & 3 & $\begin{array}{l}\text { Soma dos } \\
\text { quadrados corrigida }\end{array}$ \\
\hline CV Pearson & 230,089497 & Erro-padrão médio & 0,09038769 \\
\hline
\end{tabular}

\begin{tabular}{|l|l|l|r|}
\hline \multicolumn{4}{|c|}{ Estatística Descritiva Básica } \\
\hline \multicolumn{2}{|c|}{ Posição } & \multicolumn{2}{c|}{ Variabilidade } \\
\hline Média & 0,166667 & Desvio-padrão & 0,38348 \\
\hline Mediana & 0,000000 & Variância & 0,14706 \\
\hline Moda & 0,000000 & Amplitude & 1,00000 \\
\hline & & Amplitude interquartil & 0 \\
\hline
\end{tabular}

\begin{tabular}{|l|l|r|l|l|}
\hline \multicolumn{5}{|c|}{ Testes de Posição: Mu0=0 } \\
\hline Teste & \multicolumn{2}{|c|}{ Estatística } & \multicolumn{2}{c|}{ Valor $\mathbf{~}$} \\
\hline Student t & t & 1,843909 & $\mathrm{Pr}>|\mathbf{t}|$ & 0,0827 \\
\hline Sign & M & 1,5 & $\mathrm{Pr}>=|\mathrm{M}|$ & 0,2500 \\
\hline Signed Rank & S & 3 & $\mathrm{Pr}>=|\mathrm{S}|$ & 0,2500 \\
\hline
\end{tabular}

\begin{tabular}{|l|r|}
\hline \multicolumn{2}{|c|}{ Quantis } \\
\hline Level & Quantil \\
\hline $100 \%$ Max & 1 \\
\hline $99 \%$ & 1 \\
\hline $95 \%$ & 1 \\
\hline $90 \%$ & 0 \\
\hline $75 \%$ Q3 & 0 \\
\hline $50 \%$ Mediana & 0 \\
\hline $25 \%$ Q1 & 0 \\
\hline $10 \%$ & 0 \\
\hline $5 \%$ & 0 \\
\hline $1 \%$ & 0 \\
\hline $0 \%$ Min & 1 \\
\hline
\end{tabular}


Variável

dependente:

ACI

ID $=\mathbf{2 9}$

\begin{tabular}{|r|r|r|r|}
\hline \multicolumn{3}{|c|}{ Observações Limite } \\
\hline \multicolumn{2}{|c|}{ Baixa } & \multicolumn{2}{c|}{ Alta } \\
\hline Valor & Obs & Valor & Obs \\
\hline 0 & 436 & 0 & 435 \\
\hline 0 & 435 & 0 & 436 \\
\hline 0 & 434 & 1 & 423 \\
\hline 0 & 433 & 1 & 430 \\
\hline 0 & 432 & 1 & 431 \\
\hline
\end{tabular}


Variável

dependente:

REC

ID $=\mathbf{3 0}$

\begin{tabular}{|l|r|l|r|}
\hline \multicolumn{4}{|c|}{ Momento } \\
\hline Média & 18 & Soma dos pesos & 18 \\
\hline Desvio-padrão & 0,4608886 & Variância \\
observações & 0,2124183 \\
\hline Assimetria & 1,08486086 & Curtose & $-0,9415385$ \\
\hline $\begin{array}{l}\text { Soma dos } \\
\text { quadrados não } \\
\text { corrigida }\end{array}$ & 5 & $\begin{array}{l}\text { Soma dos } \\
\text { quadrados corrigida }\end{array}$ & 3,61111111 \\
\hline CV Pearson & 165,919896 & Erro-padrão médio & 0,10863248 \\
\hline
\end{tabular}

\begin{tabular}{|l|c|l|c|}
\hline \multicolumn{4}{|c|}{ Estatística Descritiva Básica } \\
\hline \multicolumn{2}{|c|}{ Posição } & \multicolumn{2}{c|}{ Variabilidade } \\
\hline Média & 0,277778 & Desvio-padrão & 0,46089 \\
\hline Mediana & 0,000000 & Variância & 0,21242 \\
\hline Moda & 0,000000 & Amplitude & 1,00000 \\
\hline & & Amplitude interquartil & 1,00000 \\
\hline
\end{tabular}

\begin{tabular}{|l|l|r|l|l|}
\hline \multicolumn{5}{|c|}{ Testes de Posição: Mu0=0 } \\
\hline Teste & \multicolumn{2}{|c|}{ Estatística } & \multicolumn{2}{c|}{ Valor $\mathbf{~}$} \\
\hline Student t & t & 2,557042 & $\mathrm{Pr}>|\mathbf{t}|$ & 0,0204 \\
\hline Sign & M & 2,5 & $\mathrm{Pr}>=|\mathrm{M}|$ & 0,0625 \\
\hline Signed Rank & S & 7,5 & $\mathrm{Pr}>=|\mathrm{S}|$ & 0,0625 \\
\hline
\end{tabular}

\begin{tabular}{|l|r|}
\hline \multicolumn{2}{|c|}{ Quantis } \\
\hline Level & 1 \\
\hline $100 \%$ Max & 1 \\
\hline $99 \%$ & 1 \\
\hline $95 \%$ & 1 \\
\hline $90 \%$ & 1 \\
\hline $75 \%$ Q3 & 0 \\
\hline $50 \%$ Mediana & 0 \\
\hline $25 \%$ Q1 & 0 \\
\hline $10 \%$ & 0 \\
\hline $5 \%$ & 0 \\
\hline $1 \%$ & 0 \\
\hline $0 \%$ Min & \\
\hline
\end{tabular}


Variável

dependente:

REC

$\mathrm{ID}=\mathbf{3 0}$

\begin{tabular}{|r|r|r|r|}
\hline \multicolumn{3}{|c|}{ Observações Limite } \\
\hline \multicolumn{2}{|c|}{ Baixa } & \multicolumn{2}{c|}{ Alta } \\
\hline Valor & Obs & Valor & Obs \\
\hline 0 & 454 & 1 & 437 \\
\hline 0 & 453 & 1 & 441 \\
\hline 0 & 451 & 1 & 442 \\
\hline 0 & 450 & 1 & 447 \\
\hline 0 & 449 & 1 & 452 \\
\hline
\end{tabular}


Variável

dependente:

ACI

$\mathrm{ID}=\mathbf{3 0}$

\begin{tabular}{|l|r|l|r|}
\hline \multicolumn{3}{|c|}{ Momento } \\
\hline N & 18 & Soma dos pesos & 18 \\
\hline Média & $\begin{array}{r}0 \\
\text { Soma das } \\
\text { observações }\end{array}$ & 0 \\
\hline Desvio-padrão & 0 & Variância & 0 \\
\hline Assimetria &, Curtose &, \\
\hline $\begin{array}{l}\text { Soma dos } \\
\text { quadrados não } \\
\text { corrigida }\end{array}$ & 0 & $\begin{array}{l}\text { Soma dos } \\
\text { quadrados corrigida }\end{array}$ & 0 \\
\hline CV Pearson &, & Erro-padrão médio & 0 \\
\hline
\end{tabular}

\begin{tabular}{|l|r|l|r|}
\hline \multicolumn{3}{|c|}{ Estatística Descritiva Básica } \\
\hline \multicolumn{2}{|c|}{ Posição } & \multicolumn{2}{c|}{ Variabilidade } \\
\hline Média & 0 & Desvio-padrão & 0 \\
\hline Mediana & 0 & Variância & 0 \\
\hline Moda & 0 & Amplitude & 0 \\
\hline & & Amplitude interquartil & 0 \\
\hline
\end{tabular}

\begin{tabular}{|l|l|l|l|l|}
\hline \multicolumn{5}{|c|}{ Testes de Posição: Mu0=0 } \\
\hline Teste & \multicolumn{2}{|c|}{ Estatística } & \multicolumn{2}{c|}{ Valor $\mathbf{p}$} \\
\hline Student t & t &, & $\operatorname{Pr}>|\mathbf{t}|$ & \\
\hline Sign & M &, & $\operatorname{Pr}>=|\mathrm{M}|$ & \\
\hline Signed Rank & S &, & $\operatorname{Pr}>=|\mathrm{S}|$ & \\
\hline
\end{tabular}

\begin{tabular}{|l|r|}
\hline \multicolumn{2}{|c|}{ Quantis } \\
\hline Level & 0 \\
\hline $100 \%$ Max & 0 \\
\hline $99 \%$ & 0 \\
\hline $95 \%$ & 0 \\
\hline $90 \%$ & 0 \\
\hline $75 \%$ Q3 & 0 \\
\hline $50 \%$ Mediana & 0 \\
\hline $25 \%$ Q1 & 0 \\
\hline $10 \%$ & 0 \\
\hline $5 \%$ & 0 \\
\hline $1 \%$ & 0 \\
\hline $0 \%$ Min & 0 \\
\hline
\end{tabular}


Variável

dependente:

ACI

$\mathrm{ID}=\mathbf{3 0}$

\begin{tabular}{|r|r|r|r|}
\hline \multicolumn{3}{|c|}{ Observações Limite } \\
\hline \multicolumn{2}{|c|}{ Baixa } & \multicolumn{2}{c|}{ Alta } \\
\hline Valor & Obs & Valor & Obs \\
\hline 0 & 454 & 0 & 450 \\
\hline 0 & 453 & 0 & 451 \\
\hline 0 & 452 & 0 & 452 \\
\hline 0 & 451 & 0 & 453 \\
\hline 0 & 450 & 0 & 454 \\
\hline
\end{tabular}


Variável

dependente:

REC

$\mathrm{ID}=31$

\begin{tabular}{|l|r|l|r|}
\hline \multicolumn{3}{|c|}{ Momento } \\
\hline N & 8 & Soma dos pesos & 8 \\
\hline Média & $\begin{array}{r}0 \\
\text { Soma das } \\
\text { observações }\end{array}$ & 0 \\
\hline Desvio-padrão & 0 & Variância & 0 \\
\hline Assimetria &, Curtose &, \\
\hline $\begin{array}{l}\text { Soma dos } \\
\text { quadrados não } \\
\text { corrigida }\end{array}$ & 0 & $\begin{array}{l}\text { Soma dos } \\
\text { quadrados corrigida }\end{array}$ & 0 \\
\hline CV Pearson &, & Erro-padrão médio & 0 \\
\hline
\end{tabular}

\begin{tabular}{|l|r|l|r|}
\hline \multicolumn{3}{|c|}{ Estatística Descritiva Básica } \\
\hline \multicolumn{2}{|c|}{ Posição } & \multicolumn{2}{c|}{ Variabilidade } \\
\hline Média & 0 & Desvio-padrão & 0 \\
\hline Mediana & 0 & Variância & 0 \\
\hline Moda & 0 & Amplitude & 0 \\
\hline & & Amplitude interquartil & 0 \\
\hline
\end{tabular}

\begin{tabular}{|l|l|l|l|l|}
\hline \multicolumn{5}{|c|}{ Testes de Posição: Mu0=0 } \\
\hline Teste & \multicolumn{2}{|c|}{ Estatística } & \multicolumn{2}{c|}{ Valor $\mathbf{p}$} \\
\hline Student t & t &, & $\operatorname{Pr}>|\mathbf{t}|$ & \\
\hline Sign & M &, & $\operatorname{Pr}>=|\mathrm{M}|$ & \\
\hline Signed Rank & S &, & $\operatorname{Pr}>=|\mathrm{S}|$ & \\
\hline
\end{tabular}

\begin{tabular}{|l|r|}
\hline \multicolumn{2}{|c|}{ Quantis } \\
\hline Level & 0 \\
\hline $100 \%$ Max & 0 \\
\hline $99 \%$ & 0 \\
\hline $95 \%$ & 0 \\
\hline $90 \%$ & 0 \\
\hline $75 \%$ Q3 & 0 \\
\hline $50 \%$ Mediana & 0 \\
\hline $25 \%$ Q1 & 0 \\
\hline $10 \%$ & 0 \\
\hline $5 \%$ & 0 \\
\hline $1 \%$ & 0 \\
\hline $0 \%$ Min & 0 \\
\hline
\end{tabular}


Variável

dependente:

REC

ID $=31$

\begin{tabular}{|r|r|r|r|}
\hline \multicolumn{3}{|c|}{ Observações Limite } \\
\hline \multicolumn{2}{|c|}{ Baixa } & \multicolumn{2}{c|}{ Alta } \\
\hline Valor & Obs & Valor & Obs \\
\hline 0 & 462 & 0 & 458 \\
\hline 0 & 461 & 0 & 459 \\
\hline 0 & 460 & 0 & 460 \\
\hline 0 & 459 & 0 & 461 \\
\hline 0 & 458 & 0 & 462 \\
\hline
\end{tabular}


Variável

dependente:

ACI

ID $=31$

\begin{tabular}{|l|r|l|r|}
\hline \multicolumn{3}{|c|}{ Momento } \\
\hline N & 8 & Soma dos pesos & 8 \\
\hline Média & $\begin{array}{r}0 \\
\text { Soma das } \\
\text { observações }\end{array}$ & 0 \\
\hline Desvio-padrão & 0 & Variância & 0 \\
\hline Assimetria &, Curtose &, \\
\hline $\begin{array}{l}\text { Soma dos } \\
\text { quadrados não } \\
\text { corrigida }\end{array}$ & 0 & $\begin{array}{l}\text { Soma dos } \\
\text { quadrados corrigida }\end{array}$ & 0 \\
\hline CV Pearson &, & Erro-padrão médio & 0 \\
\hline
\end{tabular}

\begin{tabular}{|l|r|l|r|}
\hline \multicolumn{3}{|c|}{ Estatística Descritiva Básica } \\
\hline \multicolumn{2}{|c|}{ Posição } & \multicolumn{2}{c|}{ Variabilidade } \\
\hline Média & 0 & Desvio-padrão & 0 \\
\hline Mediana & 0 & Variância & 0 \\
\hline Moda & 0 & Amplitude & 0 \\
\hline & & Amplitude interquartil & 0 \\
\hline
\end{tabular}

\begin{tabular}{|l|l|l|l|l|}
\hline \multicolumn{5}{|c|}{ Testes de Posição: Mu0=0 } \\
\hline Teste & \multicolumn{2}{|c|}{ Estatística } & \multicolumn{2}{c|}{ Valor $\mathbf{p}$} \\
\hline Student t & t &, & $\operatorname{Pr}>|\mathbf{t}|$ & \\
\hline Sign & M &, & $\operatorname{Pr}>=|\mathrm{M}|$ & \\
\hline Signed Rank & S &, & $\operatorname{Pr}>=|\mathrm{S}|$ & \\
\hline
\end{tabular}

\begin{tabular}{|l|r|}
\hline \multicolumn{2}{|c|}{ Quantis } \\
\hline Level & 0 \\
\hline $100 \%$ Max & 0 \\
\hline $99 \%$ & 0 \\
\hline $95 \%$ & 0 \\
\hline $90 \%$ & 0 \\
\hline $75 \%$ Q3 & 0 \\
\hline $50 \%$ Mediana & 0 \\
\hline $25 \%$ Q1 & 0 \\
\hline $10 \%$ & 0 \\
\hline $5 \%$ & 0 \\
\hline $1 \%$ & 0 \\
\hline $0 \%$ Min & 0 \\
\hline
\end{tabular}


Variável

dependente:

ACI

ID $=31$

\begin{tabular}{|r|r|r|r|}
\hline \multicolumn{3}{|c|}{ Observações Limite } \\
\hline \multicolumn{2}{|c|}{ Baixa } & \multicolumn{2}{c|}{ Alta } \\
\hline Valor & Obs & Valor & Obs \\
\hline 0 & 462 & 0 & 458 \\
\hline 0 & 461 & 0 & 459 \\
\hline 0 & 460 & 0 & 460 \\
\hline 0 & 459 & 0 & 461 \\
\hline 0 & 458 & 0 & 462 \\
\hline
\end{tabular}


Variável

dependente:

REC

ID $=32$

\begin{tabular}{|l|r|l|r|}
\hline \multicolumn{3}{|c|}{ Momento } \\
\hline N & 16 & Soma dos pesos & 16 \\
\hline Média & $\begin{array}{r}0 \\
\text { Soma das } \\
\text { observações }\end{array}$ & 0 \\
\hline Desvio-padrão & 0 & Variância & 0 \\
\hline Assimetria &, Curtose &, \\
\hline $\begin{array}{l}\text { Soma dos } \\
\text { quadrados não } \\
\text { corrigida }\end{array}$ & 0 & $\begin{array}{l}\text { Soma dos } \\
\text { quadrados corrigida }\end{array}$ & 0 \\
\hline CV Pearson &, & Erro-padrão médio & 0 \\
\hline
\end{tabular}

\begin{tabular}{|l|r|l|r|}
\hline \multicolumn{3}{|c|}{ Estatística Descritiva Básica } \\
\hline \multicolumn{2}{|c|}{ Posição } & \multicolumn{2}{c|}{ Variabilidade } \\
\hline Média & 0 & Desvio-padrão & 0 \\
\hline Mediana & 0 & Variância & 0 \\
\hline Moda & 0 & Amplitude & 0 \\
\hline & & Amplitude interquartil & 0 \\
\hline
\end{tabular}

\begin{tabular}{|l|l|l|l|l|}
\hline \multicolumn{5}{|c|}{ Testes de Posição: $\mathrm{Mu0}=0$} \\
\hline Teste & \multicolumn{2}{|c|}{ Estatística } & \multicolumn{2}{c|}{ Valor $\mathbf{p}$} \\
\hline Student t & t &, & $\operatorname{Pr}>|t|$ & \\
\hline Sign & M &, & $\operatorname{Pr}>=|\mathrm{M}|$ & \\
\hline Signed Rank & S &, & $\operatorname{Pr}>=|\mathrm{S}|$ & \\
\hline
\end{tabular}

\begin{tabular}{|l|r|}
\hline \multicolumn{2}{|c|}{ Quantis } \\
\hline Level & 0 \\
\hline $100 \%$ Max & 0 \\
\hline $99 \%$ & 0 \\
\hline $95 \%$ & 0 \\
\hline $90 \%$ & 0 \\
\hline $75 \%$ Q3 & 0 \\
\hline $50 \%$ Mediana & 0 \\
\hline $25 \%$ Q1 & 0 \\
\hline $10 \%$ & 0 \\
\hline $5 \%$ & 0 \\
\hline $1 \%$ & 0 \\
\hline $0 \%$ Min & \\
\hline
\end{tabular}


Variável

dependente:

REC

$\mathrm{ID}=32$

\begin{tabular}{|r|r|r|r|}
\hline \multicolumn{3}{|c|}{ Observações Limite } \\
\hline \multicolumn{2}{|c|}{ Baixa } & \multicolumn{2}{c|}{ Alta } \\
\hline Valor & Obs & Valor & Obs \\
\hline 0 & 478 & 0 & 474 \\
\hline 0 & 477 & 0 & 475 \\
\hline 0 & 476 & 0 & 476 \\
\hline 0 & 475 & 0 & 477 \\
\hline 0 & 474 & 0 & 478 \\
\hline
\end{tabular}


Variável

dependente:

ACI

$\mathrm{ID}=32$

\begin{tabular}{|l|r|l|r|}
\hline \multicolumn{3}{|c|}{ Momento } \\
\hline N & 16 & Soma dos pesos & 16 \\
\hline Média & $\begin{array}{r}0 \\
\text { Soma das } \\
\text { observações }\end{array}$ & 0 \\
\hline Desvio-padrão & 0 & Variância & 0 \\
\hline Assimetria &, Curtose &, \\
\hline $\begin{array}{l}\text { Soma dos } \\
\text { quadrados não } \\
\text { corrigida }\end{array}$ & 0 & $\begin{array}{l}\text { Soma dos } \\
\text { quadrados corrigida }\end{array}$ & 0 \\
\hline CV Pearson &, & Erro-padrão médio & 0 \\
\hline
\end{tabular}

\begin{tabular}{|l|r|l|r|}
\hline \multicolumn{3}{|c|}{ Estatística Descritiva Básica } \\
\hline Mosição & \multicolumn{2}{c|}{ Variabilidade } \\
\hline Média & 0 & Desvio-padrão & 0 \\
\hline Moda & 0 & Variância & 0 \\
\hline & & Amplitude & 0 \\
\hline
\end{tabular}

\begin{tabular}{|l|l|l|l|l|}
\hline \multicolumn{4}{|c|}{ Testes de Posição: $\mathrm{Mu0}=0$} \\
\hline Teste & \multicolumn{2}{|c|}{ Estatística } & \multicolumn{2}{c|}{ Valor $\mathbf{p}$} \\
\hline Student t & $\mathbf{t}$ &, & $\mathrm{Pr}>|\mathbf{t}|$ & \\
\hline Sign & $\mathbf{M}$ &, & $\mathrm{Pr}>=|\mathrm{M}|$ & \\
\hline Signed Rank & $\mathbf{S}$ &, & $\mathrm{Pr}>=|\mathrm{S}|$ & \\
\hline
\end{tabular}

\begin{tabular}{|l|r|}
\hline \multicolumn{2}{|c|}{ Quantis } \\
\hline Level & Quantil \\
\hline $100 \%$ Max & 0 \\
\hline $99 \%$ & 0 \\
\hline $95 \%$ & 0 \\
\hline $90 \%$ & 0 \\
\hline $75 \%$ Q3 & 0 \\
\hline $50 \%$ Mediana & 0 \\
\hline $25 \%$ Q1 & 0 \\
\hline $10 \%$ & 0 \\
\hline $5 \%$ & 0 \\
\hline $1 \%$ & 0 \\
\hline $0 \%$ Min & 0 \\
\hline
\end{tabular}


Variável

dependente:

ACI

$\mathrm{ID}=\mathbf{3 2}$

\begin{tabular}{|r|r|r|r|}
\hline \multicolumn{3}{|c|}{ Observações Limite } \\
\hline \multicolumn{2}{|c|}{ Baixa } & \multicolumn{2}{c|}{ Alta } \\
\hline Valor & Obs & Valor & Obs \\
\hline 0 & 478 & 0 & 474 \\
\hline 0 & 477 & 0 & 475 \\
\hline 0 & 476 & 0 & 476 \\
\hline 0 & 475 & 0 & 477 \\
\hline 0 & 474 & 0 & 478 \\
\hline
\end{tabular}


Variável

dependente:

REC

ID $=33$

\begin{tabular}{|l|r|r|r|}
\hline \multicolumn{3}{|l|}{ Momento } \\
\hline N & 14 & Soma dos pesos & 14 \\
\hline Média & $\begin{array}{r}0 \\
\text { Soma das } \\
\text { observações }\end{array}$ & 0 \\
\hline Desvio-padrão & 0 & Variância & 0 \\
\hline Assimetria &, Curtose &, \\
\hline $\begin{array}{l}\text { Soma dos } \\
\text { quadrados não } \\
\text { corrigida }\end{array}$ & 0 & $\begin{array}{l}\text { Soma dos } \\
\text { quadrados corrigida }\end{array}$ & 0 \\
\hline CV Pearson &, & Erro-padrão médio & 0 \\
\hline
\end{tabular}

\begin{tabular}{|l|r|l|r|}
\hline \multicolumn{3}{|c|}{ Estatística Descritiva Básica } \\
\hline \multicolumn{2}{|c|}{ Posição } & \multicolumn{2}{c|}{ Variabilidade } \\
\hline Média & 0 & Desvio-padrão & 0 \\
\hline Mediana & 0 & Variância & 0 \\
\hline Moda & 0 & Amplitude & 0 \\
\hline & & Amplitude interquartil & 0 \\
\hline
\end{tabular}

\begin{tabular}{|l|l|l|l|l|}
\hline \multicolumn{5}{|c|}{ Testes de Posição: Mu0=0 } \\
\hline Teste & \multicolumn{2}{|c|}{ Estatística } & \multicolumn{2}{c|}{ Valor $\mathbf{p}$} \\
\hline Student t & t &, & $\operatorname{Pr}>|\mathbf{t}|$ & \\
\hline Sign & M &, & $\operatorname{Pr}>=|\mathrm{M}|$ & \\
\hline Signed Rank & S &, & $\operatorname{Pr}>=|\mathrm{S}|$ & \\
\hline
\end{tabular}

\begin{tabular}{|l|r|}
\hline \multicolumn{2}{|c|}{ Quantis } \\
\hline Level & 0 \\
\hline $100 \%$ Max & 0 \\
\hline $99 \%$ & 0 \\
\hline $95 \%$ & 0 \\
\hline $90 \%$ & 0 \\
\hline $75 \%$ Q3 & 0 \\
\hline $50 \%$ Mediana & 0 \\
\hline $25 \%$ Q1 & 0 \\
\hline $10 \%$ & 0 \\
\hline $5 \%$ & 0 \\
\hline $1 \%$ & 0 \\
\hline $0 \%$ Min & 0 \\
\hline
\end{tabular}


Variável

dependente:

REC

ID $=33$

\begin{tabular}{|r|r|r|r|}
\hline \multicolumn{3}{|c|}{ Observações Limite } \\
\hline \multicolumn{2}{|c|}{ Baixa } & \multicolumn{2}{c|}{ Alta } \\
\hline Valor & Obs & Valor & Obs \\
\hline 0 & 492 & 0 & 488 \\
\hline 0 & 491 & 0 & 489 \\
\hline 0 & 490 & 0 & 490 \\
\hline 0 & 489 & 0 & 491 \\
\hline 0 & 488 & 0 & 492 \\
\hline
\end{tabular}


Variável

dependente:

ACI

ID $=33$

\begin{tabular}{|l|r|l|r|}
\hline \multicolumn{3}{|c|}{ Momento } \\
\hline N & 14 & Soma dos pesos & 14 \\
\hline Média & $\begin{array}{r}0 \\
\text { Soma das } \\
\text { observações }\end{array}$ & 0 \\
\hline Desvio-padrão & 0 & Variância & 0 \\
\hline Assimetria &, Curtose &, \\
\hline $\begin{array}{l}\text { Soma dos } \\
\text { quadrados não } \\
\text { corrigida }\end{array}$ & 0 & $\begin{array}{l}\text { Soma dos } \\
\text { quadrados corrigida }\end{array}$ & 0 \\
\hline CV Pearson &, & Erro-padrão médio & 0 \\
\hline
\end{tabular}

\begin{tabular}{|l|r|l|r|}
\hline \multicolumn{3}{|c|}{ Estatística Descritiva Básica } \\
\hline \multicolumn{2}{|c|}{ Posição } & \multicolumn{2}{c|}{ Variabilidade } \\
\hline Média & 0 & Desvio-padrão & 0 \\
\hline Mediana & 0 & Variância & 0 \\
\hline Moda & 0 & Amplitude & 0 \\
\hline & & Amplitude interquartil & 0 \\
\hline
\end{tabular}

\begin{tabular}{|l|l|l|l|l|}
\hline \multicolumn{5}{|c|}{ Testes de Posição: Mu0=0 } \\
\hline Teste & \multicolumn{2}{|c|}{ Estatística } & \multicolumn{2}{c|}{ Valor $\mathbf{p}$} \\
\hline Student t & t &, & $\operatorname{Pr}>|\mathbf{t}|$ & \\
\hline Sign & M &, & $\operatorname{Pr}>=|\mathrm{M}|$ & \\
\hline Signed Rank & S &, & $\operatorname{Pr}>=|\mathrm{S}|$ & \\
\hline
\end{tabular}

\begin{tabular}{|l|r|}
\hline \multicolumn{2}{|c|}{ Quantis } \\
\hline Level & 0 \\
\hline $100 \%$ Max & 0 \\
\hline $99 \%$ & 0 \\
\hline $95 \%$ & 0 \\
\hline $90 \%$ & 0 \\
\hline $75 \%$ Q3 & 0 \\
\hline $50 \%$ Mediana & 0 \\
\hline $25 \%$ Q1 & 0 \\
\hline $10 \%$ & 0 \\
\hline $5 \%$ & 0 \\
\hline $1 \%$ & 0 \\
\hline $0 \%$ Min & 0 \\
\hline
\end{tabular}


Variável

dependente:

ACI

ID $=33$

\begin{tabular}{|r|r|r|r|}
\hline \multicolumn{3}{|c|}{ Observações Limite } \\
\hline \multicolumn{2}{|c|}{ Baixa } & \multicolumn{2}{c|}{ Alta } \\
\hline Valor & Obs & Valor & Obs \\
\hline 0 & 492 & 0 & 488 \\
\hline 0 & 491 & 0 & 489 \\
\hline 0 & 490 & 0 & 490 \\
\hline 0 & 489 & 0 & 491 \\
\hline 0 & 488 & 0 & 492 \\
\hline
\end{tabular}


Variável

dependente:

REC

ID $=34$

\begin{tabular}{|l|r|l|r|}
\hline \multicolumn{3}{|c|}{ Momento } \\
\hline N & 14 & Soma dos pesos & 14 \\
\hline Média & $\begin{array}{r}0 \\
\text { Soma das } \\
\text { observações }\end{array}$ & 0 \\
\hline Desvio-padrão & 0 & Variância & 0 \\
\hline Assimetria &, Curtose &, \\
\hline $\begin{array}{l}\text { Soma dos } \\
\text { quadrados não } \\
\text { corrigida }\end{array}$ & 0 & $\begin{array}{l}\text { Soma dos } \\
\text { quadrados corrigida }\end{array}$ & 0 \\
\hline CV Pearson &, & Erro-padrão médio & 0 \\
\hline
\end{tabular}

\begin{tabular}{|l|r|l|r|}
\hline \multicolumn{3}{|c|}{ Estatística Descritiva Básica } \\
\hline \multicolumn{2}{|c|}{ Posição } & \multicolumn{2}{c|}{ Variabilidade } \\
\hline Média & 0 & Desvio-padrão & 0 \\
\hline Mediana & 0 & Variância & 0 \\
\hline Moda & 0 & Amplitude & 0 \\
\hline & & Amplitude interquartil & 0 \\
\hline
\end{tabular}

\begin{tabular}{|l|l|l|l|l|}
\hline \multicolumn{4}{|c|}{ Testes de Posição: Mu0=0 } \\
\hline Teste & \multicolumn{2}{|c|}{ Estatística } & \multicolumn{2}{c|}{ Valor $\mathbf{p}$} \\
\hline Student $\mathbf{t}$ & $\mathbf{t}$ & \multicolumn{1}{|c|}{, $\operatorname{Pr}>|\mathbf{t}|$} & \\
\hline Sign & $\mathrm{M}$ &, & $\operatorname{Pr}>=|\mathrm{M}|$ & \\
\hline Signed Rank & S &, & $\operatorname{Pr}>=|\mathrm{S}|$ & \\
\hline
\end{tabular}

\begin{tabular}{|l|r|}
\hline \multicolumn{2}{|c|}{ Quantis } \\
\hline Level & 0 \\
\hline $100 \%$ Max & 0 \\
\hline $99 \%$ & 0 \\
\hline $95 \%$ & 0 \\
\hline $90 \%$ & 0 \\
\hline $75 \%$ Q3 & 0 \\
\hline $50 \%$ Mediana & 0 \\
\hline $25 \%$ Q1 & 0 \\
\hline $10 \%$ & 0 \\
\hline $5 \%$ & 0 \\
\hline $1 \%$ & 0 \\
\hline $0 \%$ Min & 0 \\
\hline
\end{tabular}


Variável

dependente:

REC

ID $=34$

Observações Limite

Baixa Alta

Valor Obs Valor Obs

\begin{tabular}{|r|r|r|r|}
\hline 0 & 506 & 0 & 502 \\
\hline 0 & 505 & 0 & 503 \\
\hline 0 & 504 & 0 & 504 \\
\hline 0 & 503 & 0 & 505 \\
\hline 0 & 502 & 0 & 506 \\
\hline
\end{tabular}


Variável

dependente:

ACI

ID $=34$

\begin{tabular}{|l|r|l|r|}
\hline \multicolumn{3}{|c|}{ Momento } \\
\hline N & 14 & Soma dos pesos & 14 \\
\hline Média & $\begin{array}{r}0 \\
\text { Soma das } \\
\text { observações }\end{array}$ & 0 \\
\hline Desvio-padrão & 0 & Variância & 0 \\
\hline Assimetria &, Curtose &, \\
\hline $\begin{array}{l}\text { Soma dos } \\
\text { quadrados não } \\
\text { corrigida }\end{array}$ & 0 & $\begin{array}{l}\text { Soma dos } \\
\text { quadrados corrigida }\end{array}$ & 0 \\
\hline CV Pearson &, & Erro-padrão médio & 0 \\
\hline
\end{tabular}

\begin{tabular}{|l|r|l|r|}
\hline \multicolumn{3}{|c|}{ Estatística Descritiva Básica } \\
\hline \multicolumn{2}{|c|}{ Posição } & \multicolumn{2}{c|}{ Variabilidade } \\
\hline Média & 0 & Desvio-padrão & 0 \\
\hline Mediana & 0 & Variância & 0 \\
\hline Moda & 0 & Amplitude & 0 \\
\hline & & Amplitude interquartil & 0 \\
\hline
\end{tabular}

\begin{tabular}{|l|l|l|l|l|}
\hline \multicolumn{4}{|c|}{ Testes de Posição: Mu0=0 } \\
\hline Teste & \multicolumn{2}{|c|}{ Estatística } & \multicolumn{2}{c|}{ Valor $\mathbf{p}$} \\
\hline Student t & $\mathbf{t}$ &, & $\mathrm{Pr}>|\mathrm{t}|$ & \\
\hline Sign & $\mathrm{M}$ &, & $\mathrm{Pr}>=|\mathrm{M}|$ & \\
\hline Signed Rank & $\mathrm{S}$ & & $\mathrm{Pr}>=|\mathrm{S}|$ & \\
\hline
\end{tabular}

\begin{tabular}{|l|r|}
\hline \multicolumn{2}{|c|}{ Quantis } \\
\hline Level & Quantil \\
\hline $100 \%$ Max & 0 \\
\hline $99 \%$ & 0 \\
\hline $95 \%$ & 0 \\
\hline $90 \%$ & 0 \\
\hline $75 \%$ Q3 & 0 \\
\hline $50 \%$ Mediana & 0 \\
\hline $25 \%$ Q1 & 0 \\
\hline $10 \%$ & 0 \\
\hline $5 \%$ & 0 \\
\hline $1 \%$ & 0 \\
\hline $0 \%$ Min & 0 \\
\hline
\end{tabular}


Variável

dependente:

ACI

$\mathrm{ID}=\mathbf{3 4}$

\begin{tabular}{|r|r|r|r|}
\hline \multicolumn{3}{|c|}{ Observações Limite } \\
\hline \multicolumn{2}{|c|}{ Baixa } & \multicolumn{2}{c|}{ Alta } \\
\hline Valor & Obs & Valor & Obs \\
\hline 0 & 506 & 0 & 502 \\
\hline 0 & 505 & 0 & 503 \\
\hline 0 & 504 & 0 & 504 \\
\hline 0 & 503 & 0 & 505 \\
\hline 0 & 502 & 0 & 506 \\
\hline
\end{tabular}


Variável

dependente:

REC

$\mathrm{ID}=35$

\begin{tabular}{|l|r|l|r|}
\hline \multicolumn{3}{|c|}{ Momento } \\
\hline Média & 18 & Soma dos pesos & 18 \\
\hline Desvio-padrão & 0,23570226 & $\begin{array}{l}\text { Variância } \\
\text { observações }\end{array}$ & 0,05555556 \\
\hline Assimetria & 4,24264069 & Curtose & 18 \\
\hline $\begin{array}{l}\text { Soma dos } \\
\text { quadrados não } \\
\text { corrigida }\end{array}$ & 1 & $\begin{array}{l}\text { Soma dos } \\
\text { quadrados corrigida }\end{array}$ & 0,94444444 \\
\hline CV Pearson & 424,264069 & Erro-padrão médio & 0,05555556 \\
\hline
\end{tabular}

\begin{tabular}{|l|l|l|r|}
\hline \multicolumn{4}{|c|}{ Estatística Descritiva Básica } \\
\hline Média & 0,055556 & Desvio-padrão & 0,23570 \\
\hline Mediana & 0,000000 & Variância & 0,05556 \\
\hline Moda & 0,000000 & Amplitude & 1,00000 \\
\hline & & Amplitude interquartil & 0 \\
\hline
\end{tabular}

\begin{tabular}{|l|l|r|l|l|}
\hline \multicolumn{5}{|c|}{ Testes de Posição: Mu0=0 } \\
\hline Teste & \multicolumn{2}{|c|}{ Estatística } & \multicolumn{2}{c|}{ Valor $\mathbf{~}$} \\
\hline Student t & $\mathbf{t}$ & 1 & $\mathrm{Pr}>|\mathbf{t}|$ & 0,3313 \\
\hline Sign & $\mathbf{M}$ & 0,5 & $\mathrm{Pr}>=|\mathrm{M}|$ & 1,0000 \\
\hline Signed Rank & $\mathbf{S}$ & 0,5 & $\mathrm{Pr}>=|\mathbf{S}|$ & 1,0000 \\
\hline
\end{tabular}

\begin{tabular}{|l|r|}
\hline \multicolumn{2}{|c|}{ Quantis } \\
\hline Level & 1 \\
\hline $100 \%$ Max & 1 \\
\hline $99 \%$ & 1 \\
\hline $95 \%$ & 0 \\
\hline $90 \%$ & 0 \\
\hline $75 \%$ Quantil & 0 \\
\hline $50 \%$ Mediana & 0 \\
\hline $25 \%$ Q1 & 0 \\
\hline $10 \%$ & 0 \\
\hline $5 \%$ & 0 \\
\hline $1 \%$ & 0 \\
\hline $0 \%$ Min & \\
\hline
\end{tabular}


Variável

dependente:

REC

$\mathrm{ID}=35$

\begin{tabular}{|r|r|r|r|}
\hline \multicolumn{3}{|c|}{ Observações Limite } \\
\hline \multicolumn{2}{|c|}{ Baixa } & \multicolumn{2}{c|}{ Alta } \\
\hline Valor & Obs & Valor & Obs \\
\hline 0 & 524 & 0 & 521 \\
\hline 0 & 523 & 0 & 522 \\
\hline 0 & 522 & 0 & 523 \\
\hline 0 & 521 & 0 & 524 \\
\hline 0 & 520 & 1 & 508 \\
\hline
\end{tabular}


Variável

dependente:

ACI

$\mathrm{ID}=35$

\begin{tabular}{|l|r|l|r|}
\hline \multicolumn{3}{|c|}{ Momento } \\
\hline Média & 18 & Soma dos pesos & 18 \\
\hline Desvio-padrão & 0,23570226 & $\begin{array}{l}\text { Variância } \\
\text { observações }\end{array}$ & 0,05555556 \\
\hline Assimetria & 4,24264069 & Curtose & 18 \\
\hline $\begin{array}{l}\text { Soma dos } \\
\text { quadrados não } \\
\text { corrigida }\end{array}$ & 1 & $\begin{array}{l}\text { Soma dos } \\
\text { quadrados corrigida }\end{array}$ & 0,94444444 \\
\hline CV Pearson & 424,264069 & Erro-padrão médio & 0,05555556 \\
\hline
\end{tabular}

\begin{tabular}{|l|l|l|r|}
\hline \multicolumn{4}{|c|}{ Estatística Descritiva Básica } \\
\hline Média & 0,055556 & Desvio-padrão & 0,23570 \\
\hline Mediana & 0,000000 & Variância & 0,05556 \\
\hline Moda & 0,000000 & Amplitude & 1,00000 \\
\hline & & Amplitude interquartil & 0 \\
\hline
\end{tabular}

\begin{tabular}{|l|l|r|l|l|}
\hline \multicolumn{5}{|c|}{ Testes de Posição: Mu0=0 } \\
\hline Teste & \multicolumn{2}{|c|}{ Estatística } & \multicolumn{2}{c|}{ Valor $\mathbf{~}$} \\
\hline Student t & $\mathbf{t}$ & 1 & $\operatorname{Pr}>|\mathbf{t}|$ & 0,3313 \\
\hline Sign & M & 0,5 & $\operatorname{Pr}>=|M|$ & 1,0000 \\
\hline Signed Rank & S & 0,5 & $\operatorname{Pr}>=|\mathbf{S}|$ & 1,0000 \\
\hline
\end{tabular}

\begin{tabular}{|l|r|}
\hline \multicolumn{2}{|c|}{ Quantis } \\
\hline Level & 1 \\
\hline $100 \%$ Max & 1 \\
\hline $99 \%$ & 1 \\
\hline $95 \%$ & 0 \\
\hline $90 \%$ & 0 \\
\hline $75 \%$ Quantil & 0 \\
\hline $50 \%$ Mediana & 0 \\
\hline $25 \%$ Q1 & 0 \\
\hline $10 \%$ & 0 \\
\hline $5 \%$ & 0 \\
\hline $1 \%$ & 0 \\
\hline $0 \%$ Min & \\
\hline
\end{tabular}


Variável

dependente:

ACI

$\mathrm{ID}=\mathbf{3 5}$

\begin{tabular}{|r|r|r|r|}
\hline \multicolumn{3}{|c|}{ Observações Limite } \\
\hline \multicolumn{2}{|c|}{ Baixa } & \multicolumn{2}{c|}{ Alta } \\
\hline Valor & Obs & Valor & Obs \\
\hline 0 & 524 & 0 & 521 \\
\hline 0 & 523 & 0 & 522 \\
\hline 0 & 522 & 0 & 523 \\
\hline 0 & 521 & 0 & 524 \\
\hline 0 & 520 & 1 & 507 \\
\hline
\end{tabular}


Variável

dependente:

REC

$I D=36$

\begin{tabular}{|l|r|l|r|}
\hline \multicolumn{3}{|c|}{ Momento } \\
\hline N & 18 & Soma dos pesos & 18 \\
\hline Média & $\begin{array}{r}0 \\
\text { Soma das } \\
\text { observações }\end{array}$ & 0 \\
\hline Desvio-padrão & 0 & Variância & 0 \\
\hline Assimetria &, Curtose &, \\
\hline $\begin{array}{l}\text { Soma dos } \\
\text { quadrados não } \\
\text { corrigida }\end{array}$ & 0 & $\begin{array}{l}\text { Soma dos } \\
\text { quadrados corrigida }\end{array}$ & 0 \\
\hline CV Pearson &, & Erro-padrão médio & 0 \\
\hline
\end{tabular}

\begin{tabular}{|l|r|l|r|}
\hline \multicolumn{3}{|c|}{ Estatística Descritiva Básica } \\
\hline \multicolumn{2}{|c|}{ Posição } & \multicolumn{2}{c|}{ Variabilidade } \\
\hline Média & 0 & Desvio-padrão & 0 \\
\hline Mediana & 0 & Variância & 0 \\
\hline Moda & 0 & Amplitude & 0 \\
\hline & & Amplitude interquartil & 0 \\
\hline
\end{tabular}

\begin{tabular}{|l|l|l|l|l|}
\hline \multicolumn{5}{|c|}{ Testes de Posição: Mu0=0 } \\
\hline Teste & \multicolumn{2}{|c|}{ Estatística } & \multicolumn{2}{c|}{ Valor $\mathbf{p}$} \\
\hline Student t & t &, & $\operatorname{Pr}>|\mathbf{t}|$ & \\
\hline Sign & M &, & $\operatorname{Pr}>=|\mathrm{M}|$ & \\
\hline Signed Rank & S &, & $\operatorname{Pr}>=|\mathrm{S}|$ & \\
\hline
\end{tabular}

\begin{tabular}{|l|r|}
\hline \multicolumn{2}{|c|}{ Quantis } \\
\hline Level & 0 \\
\hline $100 \%$ Max & 0 \\
\hline $99 \%$ & 0 \\
\hline $95 \%$ & 0 \\
\hline $90 \%$ & 0 \\
\hline $75 \%$ Q3 & 0 \\
\hline $50 \%$ Mediana & 0 \\
\hline $25 \%$ Q1 & 0 \\
\hline $10 \%$ & 0 \\
\hline $5 \%$ & 0 \\
\hline $1 \%$ & 0 \\
\hline $0 \%$ Min & 0 \\
\hline
\end{tabular}


Variável

dependente:

REC

$I D=36$

\begin{tabular}{|r|r|r|r|}
\hline \multicolumn{3}{|c|}{ Observações Limite } \\
\hline \multicolumn{2}{|c|}{ Baixa } & \multicolumn{2}{c|}{ Alta } \\
\hline Valor & Obs & Valor & Obs \\
\hline 0 & 542 & 0 & 538 \\
\hline 0 & 541 & 0 & 539 \\
\hline 0 & 540 & 0 & 540 \\
\hline 0 & 539 & 0 & 541 \\
\hline 0 & 538 & 0 & 542 \\
\hline
\end{tabular}


Variável

dependente:

ACI

$\mathrm{ID}=36$

\begin{tabular}{|l|r|l|r|}
\hline \multicolumn{3}{|c|}{ Momento } \\
\hline N & 18 & Soma dos pesos & 18 \\
\hline Média & $\begin{array}{r}0 \\
\text { Soma das } \\
\text { observações }\end{array}$ & 0 \\
\hline Desvio-padrão & 0 & Variância & 0 \\
\hline Assimetria &, Curtose &, \\
\hline $\begin{array}{l}\text { Soma dos } \\
\text { quadrados não } \\
\text { corrigida }\end{array}$ & 0 & $\begin{array}{l}\text { Soma dos } \\
\text { quadrados corrigida }\end{array}$ & 0 \\
\hline CV Pearson &, & Erro-padrão médio & 0 \\
\hline
\end{tabular}

\begin{tabular}{|l|r|l|r|}
\hline \multicolumn{3}{|c|}{ Estatística Descritiva Básica } \\
\hline \multicolumn{2}{|c|}{ Posição } & \multicolumn{2}{c|}{ Variabilidade } \\
\hline Média & 0 & Desvio-padrão & 0 \\
\hline Mediana & 0 & Variância & 0 \\
\hline Moda & 0 & Amplitude & 0 \\
\hline & & Amplitude interquartil & 0 \\
\hline
\end{tabular}

\begin{tabular}{|l|l|l|l|l|}
\hline \multicolumn{4}{|c|}{ Testes de Posição: Mu0=0 } \\
\hline Teste & \multicolumn{2}{|c|}{ Estatística } & \multicolumn{2}{c|}{ Valor $\mathbf{p}$} \\
\hline Student $\mathbf{t}$ & $\mathbf{t}$ & \multicolumn{1}{|c|}{, $\operatorname{Pr}>|\mathbf{t}|$} & \\
\hline Sign & $\mathrm{M}$ &, & $\operatorname{Pr}>=|\mathrm{M}|$ & \\
\hline Signed Rank & S &, & $\operatorname{Pr}>=|\mathrm{S}|$ & \\
\hline
\end{tabular}

\begin{tabular}{|l|r|}
\hline \multicolumn{2}{|c|}{ Quantis } \\
\hline Level & 0 \\
\hline $100 \%$ Max & 0 \\
\hline $99 \%$ & 0 \\
\hline $95 \%$ & 0 \\
\hline $90 \%$ & 0 \\
\hline $75 \%$ Q3 & 0 \\
\hline $50 \%$ Mediana & 0 \\
\hline $25 \%$ Q1 & 0 \\
\hline $10 \%$ & 0 \\
\hline $5 \%$ & 0 \\
\hline $1 \%$ & 0 \\
\hline $0 \%$ Min & 0 \\
\hline
\end{tabular}


Variável

dependente:

ACI

$\mathrm{ID}=\mathbf{3 6}$

\begin{tabular}{|r|r|r|r|}
\hline \multicolumn{3}{|c|}{ Observações Limite } \\
\hline \multicolumn{2}{|c|}{ Baixa } & \multicolumn{2}{c|}{ Alta } \\
\hline Valor & Obs & Valor & Obs \\
\hline 0 & 542 & 0 & 538 \\
\hline 0 & 541 & 0 & 539 \\
\hline 0 & 540 & 0 & 540 \\
\hline 0 & 539 & 0 & 541 \\
\hline 0 & 538 & 0 & 542 \\
\hline
\end{tabular}


Variável

dependente:

REC

ID $=\mathbf{3 7}$

\begin{tabular}{|l|r|l|r|}
\hline \multicolumn{4}{|c|}{ Momento } \\
\hline N & 18 & Soma dos pesos & 18 \\
\hline Desvio-padrão & 1,27777778 & $\begin{array}{l}\text { Soma das } \\
\text { observações }\end{array}$ \\
\hline Assimetria & 0,36137316 & Curtose & 1,38888889 \\
\hline $\begin{array}{l}\text { Soma dos } \\
\text { quadrados não } \\
\text { corrigida }\end{array}$ & 53 & $\begin{array}{l}\text { Soma dos } \\
\text { quadrados corrigida }\end{array}$ & $-1,3515671$ \\
\hline CV Pearson & 92,2313193 & Erro-padrão médio & 0,27777711111 \\
\hline
\end{tabular}

\begin{tabular}{|l|c|l|c|}
\hline \multicolumn{4}{|c|}{ Estatística Descritiva Básica } \\
\hline \multicolumn{2}{|c|}{ Posição } & \multicolumn{2}{c|}{ Variabilidade } \\
\hline Média & 1,277778 & Desvio-padrão & 1,17851 \\
\hline Mediana & 1,000000 & Variância & 1,38889 \\
\hline Moda & 0,000000 & Amplitude & 3,00000 \\
\hline & & Amplitude interquartil & 2,00000 \\
\hline
\end{tabular}

\begin{tabular}{|l|l|r|l|l|}
\hline \multicolumn{5}{|c|}{ Testes de Posição: Mu0=0 } \\
\hline Teste & \multicolumn{2}{|c|}{ Estatística } & \multicolumn{2}{c|}{ Valor $\mathbf{~}$} \\
\hline Student t & $\mathbf{t}$ & 4,6 & $\mathrm{Pr}>|\mathbf{t}|$ & 0,0003 \\
\hline Sign & M & 6 & $\mathrm{Pr}>=|\mathrm{M}|$ & 0,0005 \\
\hline Signed Rank & $\mathbf{S}$ & 39 & $\mathrm{Pr}>=|\mathbf{S}|$ & 0,0005 \\
\hline
\end{tabular}

\begin{tabular}{|l|r|}
\hline \multicolumn{2}{|c|}{ Quantis } \\
\hline Level & Quantil \\
\hline $100 \%$ Max & 3 \\
\hline $99 \%$ & 3 \\
\hline $95 \%$ & 3 \\
\hline $90 \%$ & 2 \\
\hline $75 \%$ Q3 & 1 \\
\hline $50 \%$ Mediana & 0 \\
\hline $25 \%$ Q1 & 0 \\
\hline $10 \%$ & 0 \\
\hline $5 \%$ & 0 \\
\hline $1 \%$ & 0 \\
\hline $0 \%$ Min & 3 \\
\hline
\end{tabular}


Variável

dependente:

REC

ID $=\mathbf{3 7}$

\begin{tabular}{|r|r|r|r|}
\hline \multicolumn{3}{|c|}{ Observações Limite } \\
\hline \multicolumn{2}{|c|}{ Baixa } & \multicolumn{2}{c|}{ Alta } \\
\hline Valor & Obs & Valor & Obs \\
\hline 0 & 559 & 2 & 560 \\
\hline 0 & 558 & 3 & 544 \\
\hline 0 & 552 & 3 & 547 \\
\hline 0 & 550 & 3 & 551 \\
\hline 0 & 546 & 3 & 556 \\
\hline
\end{tabular}


Variável

dependente:

ACI

ID $=\mathbf{3 7}$

\begin{tabular}{|l|r|l|r|}
\hline \multicolumn{4}{|c|}{ Momento } \\
\hline Média & 18 & Soma dos pesos & 18 \\
\hline Desvio-padrão & 1,00326265 & $\begin{array}{l}\text { Variância } \\
\text { observações }\end{array}$ \\
\hline Assimetria & 1,28476928 & Curtose & 1,00653595 \\
\hline $\begin{array}{l}\text { Soma dos } \\
\text { quadrados não } \\
\text { corrigida }\end{array}$ & 28 & $\begin{array}{l}\text { Soma dos } \\
\text { quadrados corrigida }\end{array}$ & 0,88125316 \\
\hline CV Pearson & 128,990912 & Erro-padrão médio & 0,23647111111 \\
\hline
\end{tabular}

\begin{tabular}{|l|l|l|c|}
\hline \multicolumn{4}{|c|}{ Estatística Descritiva Básica } \\
\hline \multicolumn{2}{|c|}{ Posição } & \multicolumn{2}{c|}{ Variabilidade } \\
\hline Média & 0,777778 & Desvio-padrão & 1,00326 \\
\hline Mediana & 0,500000 & Variância & 1,00654 \\
\hline Moda & 0,000000 & Amplitude & 3,00000 \\
\hline & & Amplitude interquartil & 1,00000 \\
\hline
\end{tabular}

\begin{tabular}{|l|l|r|l|l|}
\hline \multicolumn{4}{|c|}{ Testes de Posição: Mu0=0 } \\
\hline Teste & \multicolumn{2}{|c|}{ Estatística } & \multicolumn{2}{c|}{ Valor $\mathbf{~}$} \\
\hline Student t & t & 3,2891 & $\operatorname{Pr}>|\mathbf{t}|$ & 0,0043 \\
\hline Sign & M & 4,5 & $\operatorname{Pr}>=|M|$ & 0,0039 \\
\hline Signed Rank & S & 22,5 & $\operatorname{Pr}>=|\mathbf{S}|$ & 0,0039 \\
\hline
\end{tabular}

\begin{tabular}{|l|r|}
\hline \multicolumn{2}{|c|}{ Quantis } \\
\hline Level & Quantil \\
\hline $100 \%$ Max & 3,0 \\
\hline $99 \%$ & 3,0 \\
\hline $95 \%$ & 3,0 \\
\hline $90 \%$ & 3,0 \\
\hline $75 \%$ Q3 & 1,0 \\
\hline $50 \%$ Mediana & 0,5 \\
\hline $25 \%$ Q1 & 0,0 \\
\hline $10 \%$ & 0,0 \\
\hline $5 \%$ & 0,0 \\
\hline $1 \%$ & 0,0 \\
\hline $0 \%$ Min & 0,0 \\
\hline
\end{tabular}


Variável

dependente:

ACI

ID $=\mathbf{3 7}$

\begin{tabular}{|r|r|r|r|}
\hline \multicolumn{3}{|c|}{ Observações Limite } \\
\hline \multicolumn{2}{|c|}{ Baixa } & \multicolumn{2}{c|}{ Alta } \\
\hline Valor & Obs & Valor & Obs \\
\hline 0 & 560 & 1 & 553 \\
\hline 0 & 559 & 1 & 554 \\
\hline 0 & 558 & 2 & 552 \\
\hline 0 & 557 & 3 & 548 \\
\hline 0 & 556 & 3 & 551 \\
\hline
\end{tabular}


Variável

dependente:

REC

ID $=38$

\begin{tabular}{|l|r|l|r|}
\hline \multicolumn{3}{|c|}{ Momento } \\
\hline N & 13 & Soma dos pesos & 13 \\
\hline Média & $\begin{array}{r}0 \\
\text { Soma das } \\
\text { observações }\end{array}$ & 0 \\
\hline Desvio-padrão & 0 & Variância & 0 \\
\hline Assimetria &, Curtose &, \\
\hline $\begin{array}{l}\text { Soma dos } \\
\text { quadrados não } \\
\text { corrigida }\end{array}$ & 0 & $\begin{array}{l}\text { Soma dos } \\
\text { quadrados corrigida }\end{array}$ & 0 \\
\hline CV Pearson &, & Erro-padrão médio & 0 \\
\hline
\end{tabular}

\begin{tabular}{|l|r|l|r|}
\hline \multicolumn{3}{|c|}{ Estatística Descritiva Básica } \\
\hline \multicolumn{2}{|c|}{ Posição } & \multicolumn{2}{c|}{ Variabilidade } \\
\hline Média & 0 & Desvio-padrão & 0 \\
\hline Mediana & 0 & Variância & 0 \\
\hline Moda & 0 & Amplitude & 0 \\
\hline & & Amplitude interquartil & 0 \\
\hline
\end{tabular}

\begin{tabular}{|l|l|l|l|l|}
\hline \multicolumn{4}{|c|}{ Testes de Posição: Mu0=0 } \\
\hline Teste & \multicolumn{2}{|c|}{ Estatística } & \multicolumn{2}{c|}{ Valor $\mathbf{p}$} \\
\hline Student $\mathbf{t}$ & $\mathbf{t}$ & \multicolumn{1}{|c|}{, $\operatorname{Pr}>|\mathbf{t}|$} & \\
\hline Sign & $\mathrm{M}$ &, & $\operatorname{Pr}>=|\mathrm{M}|$ & \\
\hline Signed Rank & S &, & $\operatorname{Pr}>=|\mathrm{S}|$ & \\
\hline
\end{tabular}

\begin{tabular}{|l|r|}
\hline \multicolumn{2}{|c|}{ Quantis } \\
\hline Level & 0 \\
\hline $100 \%$ Max & 0 \\
\hline $99 \%$ & 0 \\
\hline $95 \%$ & 0 \\
\hline $90 \%$ & 0 \\
\hline $75 \%$ Q3 & 0 \\
\hline $50 \%$ Mediana & 0 \\
\hline $25 \%$ Q1 & 0 \\
\hline $10 \%$ & 0 \\
\hline $5 \%$ & 0 \\
\hline $1 \%$ & 0 \\
\hline $0 \%$ Min & 0 \\
\hline
\end{tabular}


Variável

dependente:

REC

$\mathrm{ID}=\mathbf{3 8}$

\begin{tabular}{|r|r|r|r|}
\hline \multicolumn{3}{|c|}{ Observações Limite } \\
\hline \multicolumn{2}{|c|}{ Baixa } & \multicolumn{2}{c|}{ Alta } \\
\hline Valor & Obs & Valor & Obs \\
\hline 0 & 573 & 0 & 569 \\
\hline 0 & 572 & 0 & 570 \\
\hline 0 & 571 & 0 & 571 \\
\hline 0 & 570 & 0 & 572 \\
\hline 0 & 569 & 0 & 573 \\
\hline
\end{tabular}


Variável

dependente:

ACI

$\mathrm{ID}=38$

\begin{tabular}{|l|r|l|r|}
\hline \multicolumn{3}{|c|}{ Momento } \\
\hline N & 13 & Soma dos pesos & 13 \\
\hline Média & $\begin{array}{r}0 \\
\text { Soma das } \\
\text { observações }\end{array}$ & 0 \\
\hline Desvio-padrão & 0 & Variância & 0 \\
\hline Assimetria &, Curtose &, \\
\hline $\begin{array}{l}\text { Soma dos } \\
\text { quadrados não } \\
\text { corrigida }\end{array}$ & 0 & $\begin{array}{l}\text { Soma dos } \\
\text { quadrados corrigida }\end{array}$ & 0 \\
\hline CV Pearson &, & Erro-padrão médio & 0 \\
\hline
\end{tabular}

\begin{tabular}{|l|r|l|r|}
\hline \multicolumn{3}{|c|}{ Estatística Descritiva Básica } \\
\hline \multicolumn{2}{|c|}{ Posição } & \multicolumn{2}{c|}{ Variabilidade } \\
\hline Média & 0 & Desvio-padrão & 0 \\
\hline Mediana & 0 & Variância & 0 \\
\hline Moda & 0 & Amplitude & 0 \\
\hline & & Amplitude interquartil & 0 \\
\hline
\end{tabular}

\begin{tabular}{|l|l|l|l|l|}
\hline \multicolumn{5}{|c|}{ Testes de Posição: Mu0=0 } \\
\hline Teste & \multicolumn{2}{|c|}{ Estatística } & \multicolumn{2}{c|}{ Valor $\mathbf{p}$} \\
\hline Student t & t &, & $\operatorname{Pr}>|\mathbf{t}|$ & \\
\hline Sign & M &, & $\operatorname{Pr}>=|\mathrm{M}|$ & \\
\hline Signed Rank & S &, & $\operatorname{Pr}>=|\mathrm{S}|$ & \\
\hline
\end{tabular}

\begin{tabular}{|l|r|}
\hline \multicolumn{2}{|c|}{ Quantis } \\
\hline Level & 0 \\
\hline $100 \%$ Max & 0 \\
\hline $99 \%$ & 0 \\
\hline $95 \%$ & 0 \\
\hline $90 \%$ & 0 \\
\hline $75 \%$ Q3 & 0 \\
\hline $50 \%$ Mediana & 0 \\
\hline $25 \%$ Q1 & 0 \\
\hline $10 \%$ & 0 \\
\hline $5 \%$ & 0 \\
\hline $1 \%$ & 0 \\
\hline $0 \%$ Min & 0 \\
\hline
\end{tabular}


Variável

dependente:

ACI

$\mathrm{ID}=\mathbf{3 8}$

\begin{tabular}{|r|r|r|r|}
\hline \multicolumn{3}{|c|}{ Observações Limite } \\
\hline \multicolumn{2}{|c|}{ Baixa } & \multicolumn{2}{c|}{ Alta } \\
\hline Valor & Obs & Valor & Obs \\
\hline 0 & 573 & 0 & 569 \\
\hline 0 & 572 & 0 & 570 \\
\hline 0 & 571 & 0 & 571 \\
\hline 0 & 570 & 0 & 572 \\
\hline 0 & 569 & 0 & 573 \\
\hline
\end{tabular}


Variável

dependente:

REC

ID $=39$

\begin{tabular}{|l|r|l|r|}
\hline \multicolumn{4}{|c|}{ Momento } \\
\hline Média & 16 & Soma dos pesos & 16 \\
\hline Desvio-padrão & 0,375 & $\begin{array}{l}\text { Soma das } \\
\text { observações }\end{array}$ \\
\hline Assimetria & 1,50479414 & Curtose & 0,38333333 \\
\hline $\begin{array}{l}\text { Soma dos } \\
\text { quadrados não } \\
\text { corrigida }\end{array}$ & 8 & $\begin{array}{l}\text { Soma dos } \\
\text { quadrados corrigida }\end{array}$ & 1,58042336 \\
\hline CV Pearson & 165,103783 & Erro-padrão médio & 0,1547848 \\
\hline
\end{tabular}

\begin{tabular}{|l|c|l|c|}
\hline \multicolumn{4}{|c|}{ Estatística Descritiva Básica } \\
\hline \multicolumn{2}{|c|}{ Posição } & \multicolumn{2}{c|}{ Variabilidade } \\
\hline Média & 0,375000 & Desvio-padrão & 0,61914 \\
\hline Mediana & 0,000000 & Variância & 0,38333 \\
\hline Moda & 0,000000 & Amplitude & 2,00000 \\
\hline & & Amplitude interquartil & 1,00000 \\
\hline
\end{tabular}

\begin{tabular}{|l|l|r|l|l|}
\hline \multicolumn{5}{|c|}{ Testes de Posição: Mu0=0 } \\
\hline Teste & \multicolumn{2}{|c|}{ Estatística } & \multicolumn{2}{c|}{ Valor $\mathbf{~}$} \\
\hline Student t & t & 2,422719 & $\mathrm{Pr}>|\mathbf{t}|$ & 0,0285 \\
\hline Sign & M & 2,5 & $\mathrm{Pr}>=|\mathrm{M}|$ & 0,0625 \\
\hline Signed Rank & S & 7,5 & $\mathrm{Pr}>=|\mathbf{S}|$ & 0,0625 \\
\hline
\end{tabular}

\begin{tabular}{|l|r|}
\hline \multicolumn{2}{|c|}{ Quantis } \\
\hline Level & 2 \\
\hline $100 \%$ Max & 2 \\
\hline $99 \%$ & 2 \\
\hline $95 \%$ & 1 \\
\hline $90 \%$ & 1 \\
\hline $75 \%$ Q3 & 0 \\
\hline $50 \%$ Mediana & 0 \\
\hline $25 \%$ Q1 & 0 \\
\hline $10 \%$ & 0 \\
\hline $5 \%$ & 0 \\
\hline $1 \%$ & 0 \\
\hline $0 \%$ Min & 0 \\
\hline
\end{tabular}


Variável

dependente:

REC

ID $=39$

\begin{tabular}{|r|r|r|r|}
\hline \multicolumn{3}{|c|}{ Observações Limite } \\
\hline \multicolumn{2}{|c|}{ Baixa } & \multicolumn{2}{c|}{ Alta } \\
\hline Valor & Obs & Valor & Obs \\
\hline 0 & 588 & 1 & 574 \\
\hline 0 & 587 & 1 & 576 \\
\hline 0 & 586 & 1 & 583 \\
\hline 0 & 585 & 1 & 589 \\
\hline 0 & 582 & 2 & 584 \\
\hline
\end{tabular}


Variável

dependente:

ACI

ID $=39$

\begin{tabular}{|l|r|l|r|}
\hline \multicolumn{3}{|c|}{ Momento } \\
\hline Nédia & 16 & Soma dos pesos & 16 \\
\hline Desvio-padrão & 0,0625 & $\begin{array}{l}\text { Soma das } \\
\text { observações }\end{array}$ & 1 \\
\hline Assimetria & 0,25 & Variância & 0,0625 \\
\hline $\begin{array}{l}\text { Soma dos } \\
\text { quadrados não } \\
\text { corrigida }\end{array}$ & 4 & Curtose & 16 \\
\hline CV Pearson & 1 & $\begin{array}{l}\text { Soma dos } \\
\text { quadrados corrigida }\end{array}$ & 0,9375 \\
\hline
\end{tabular}

\begin{tabular}{|l|l|l|r|}
\hline \multicolumn{4}{|c|}{ Estatística Descritiva Básica } \\
\hline \multicolumn{2}{|c|}{ Posição } & \multicolumn{2}{c|}{ Variabilidade } \\
\hline Média & 0,062500 & Desvio-padrão & 0,25000 \\
\hline Mediana & 0,000000 & Variância & 0,06250 \\
\hline Moda & 0,000000 & Amplitude & 1,00000 \\
\hline & & Amplitude interquartil & 0 \\
\hline
\end{tabular}

\begin{tabular}{|l|l|r|l|l|}
\hline \multicolumn{5}{|c|}{ Testes de Posição: Mu0=0 } \\
\hline Teste & \multicolumn{2}{|c|}{ Estatística } & \multicolumn{2}{c|}{ Valor $\mathbf{p}$} \\
\hline Student t & t & 1 & $\operatorname{Pr}>|\mathbf{t}|$ & 0,3332 \\
\hline Sign & M & 0,5 & $\operatorname{Pr}>=|\mathbf{M}|$ & 1,0000 \\
\hline Signed Rank & S & 0,5 & $\operatorname{Pr}>=|\mathbf{S}|$ & 1,0000 \\
\hline
\end{tabular}

\begin{tabular}{|l|r|}
\hline \multicolumn{2}{|c|}{ Quantis } \\
\hline Level & 1 \\
\hline $100 \%$ Max & 1 \\
\hline $99 \%$ & 1 \\
\hline $95 \%$ & 0 \\
\hline $90 \%$ & 0 \\
\hline $75 \%$ Q3 & 0 \\
\hline $50 \%$ Mediana & 0 \\
\hline $25 \%$ Q1 & 0 \\
\hline $10 \%$ & 0 \\
\hline $5 \%$ & 0 \\
\hline $1 \%$ & 0 \\
\hline $0 \%$ Min & 0 \\
\hline
\end{tabular}


Variável

dependente:

ACI

ID $=39$

\begin{tabular}{|r|r|r|r|}
\hline \multicolumn{3}{|c|}{ Observações Limite } \\
\hline \multicolumn{2}{|c|}{ Baixa } & \multicolumn{2}{c|}{ Alta } \\
\hline Valor & Obs & Valor & Obs \\
\hline 0 & 589 & 0 & 586 \\
\hline 0 & 588 & 0 & 587 \\
\hline 0 & 587 & 0 & 588 \\
\hline 0 & 586 & 0 & 589 \\
\hline 0 & 585 & 1 & 582 \\
\hline
\end{tabular}


Variável

dependente:

REC

$\mathrm{ID}=40$

\begin{tabular}{|l|r|l|r|}
\hline \multicolumn{3}{|c|}{ Momento } \\
\hline Média & 18 & Soma dos pesos & 18 \\
\hline Desvio-padrão & 0,38348249 & $\begin{array}{l}\text { Variância } \\
\text { observações }\end{array}$ & 0,14705882 \\
\hline Assimetria & 1,95576072 & Curtose & 2,04 \\
\hline $\begin{array}{l}\text { Soma dos } \\
\text { quadrados não } \\
\text { corrigida }\end{array}$ & 3 & $\begin{array}{l}\text { Soma dos } \\
\text { quadrados corrigida }\end{array}$ & 2,5 \\
\hline CV Pearson & 230,089497 & Erro-padrão médio & 0,09038769 \\
\hline
\end{tabular}

\begin{tabular}{|l|l|l|r|}
\hline \multicolumn{4}{|c|}{ Estatística Descritiva Básica } \\
\hline \multicolumn{2}{|c|}{ Posição } & \multicolumn{2}{c|}{ Variabilidade } \\
\hline Média & 0,166667 & Desvio-padrão & 0,38348 \\
\hline Mediana & 0,000000 & Variância & 0,14706 \\
\hline Moda & 0,000000 & Amplitude & 1,00000 \\
\hline & & Amplitude interquartil & 0 \\
\hline
\end{tabular}

\begin{tabular}{|l|l|r|l|l|}
\hline \multicolumn{5}{|c|}{ Testes de Posição: Mu0=0 } \\
\hline Teste & \multicolumn{2}{|c|}{ Estatística } & \multicolumn{2}{c|}{ Valor $\mathbf{~}$} \\
\hline Student t & $\mathbf{t}$ & 1,843909 & $\mathrm{Pr}>|\mathbf{t}|$ & 0,0827 \\
\hline Sign & $\mathbf{M}$ & 1,5 & $\mathrm{Pr}>=|\mathrm{M}|$ & 0,2500 \\
\hline Signed Rank & $\mathrm{S}$ & 3 & $\mathrm{Pr}>=|\mathrm{S}|$ & 0,2500 \\
\hline
\end{tabular}

\begin{tabular}{|l|r|}
\hline \multicolumn{2}{|c|}{ Quantis } \\
\hline Level & 1 \\
\hline $100 \%$ Max & 1 \\
\hline $99 \%$ & 1 \\
\hline $95 \%$ & 1 \\
\hline $90 \%$ & 0 \\
\hline $75 \%$ Q3 & 0 \\
\hline $50 \%$ Mediana & 0 \\
\hline $25 \%$ Q1 & 0 \\
\hline $10 \%$ & 0 \\
\hline $5 \%$ & 0 \\
\hline $1 \%$ & 0 \\
\hline $0 \%$ Min & \\
\hline
\end{tabular}


Variável

dependente:

REC

$I D=40$

\begin{tabular}{|r|r|r|r|}
\hline \multicolumn{3}{|c|}{ Observações Limite } \\
\hline \multicolumn{2}{|c|}{ Baixa } & \multicolumn{2}{c|}{ Alta } \\
\hline Valor & Obs & Valor & Obs \\
\hline 0 & 607 & 0 & 606 \\
\hline 0 & 606 & 0 & 607 \\
\hline 0 & 604 & 1 & 590 \\
\hline 0 & 603 & 1 & 596 \\
\hline 0 & 602 & 1 & 605 \\
\hline
\end{tabular}


Variável

dependente:

ACI

$I D=40$

\begin{tabular}{|l|r|l|r|}
\hline \multicolumn{4}{|c|}{ Momento } \\
\hline Nédia & 18 & Soma dos pesos & 18 \\
\hline Desvio-padrão & 0,54831888 & Variância \\
observações & 0,30065359 \\
\hline Assimetria & 2,56713519 & Curtose & 6,36294896 \\
\hline $\begin{array}{l}\text { Soma dos } \\
\text { quadrados não } \\
\text { corrigida }\end{array}$ & 6 & $\begin{array}{l}\text { Soma dos } \\
\text { quadrados corrigida }\end{array}$ & 5,11111111 \\
\hline CV Pearson & 246,743496 & Erro-padrão médio & 0,12924 \\
\hline
\end{tabular}

\begin{tabular}{|l|l|l|r|}
\hline \multicolumn{4}{|c|}{ Estatística Descritiva Básica } \\
\hline \multicolumn{2}{|c|}{ Posição } & \multicolumn{2}{c|}{ Variabilidade } \\
\hline Média & 0,222222 & Desvio-padrão & 0,54832 \\
\hline Mediana & 0,000000 & Variância & 0,30065 \\
\hline Moda & 0,000000 & Amplitude & 2,00000 \\
\hline & & Amplitude interquartil & 0 \\
\hline
\end{tabular}

\begin{tabular}{|l|l|r|l|l|}
\hline \multicolumn{5}{|c|}{ Testes de Posição: Mu0=0 } \\
\hline Teste & \multicolumn{2}{|c|}{ Estatística } & \multicolumn{2}{c|}{ Valor $\mathbf{~}$} \\
\hline Student t & t & 1,719454 & $\mathrm{Pr}>|\mathbf{t}|$ & 0,1037 \\
\hline Sign & M & 1,5 & $\mathrm{Pr}>=|\mathrm{M}|$ & 0,2500 \\
\hline Signed Rank & S & 3 & $\mathrm{Pr}>=|\mathbf{S}|$ & 0,2500 \\
\hline
\end{tabular}

\begin{tabular}{|l|r|}
\hline \multicolumn{2}{|c|}{ Quantis } \\
\hline Level & 2 \\
\hline $100 \%$ Max & 2 \\
\hline $99 \%$ & 2 \\
\hline $95 \%$ & 1 \\
\hline $90 \%$ & 0 \\
\hline $75 \%$ Q3 & 0 \\
\hline $50 \%$ Mediana & 0 \\
\hline $25 \%$ Q1 & 0 \\
\hline $10 \%$ & 0 \\
\hline $5 \%$ & 0 \\
\hline $1 \%$ & 0 \\
\hline $0 \%$ Min & 0 \\
\hline
\end{tabular}


Variável

dependente:

ACI

$\mathrm{ID}=\mathbf{4 0}$

\begin{tabular}{|r|r|r|r|}
\hline \multicolumn{3}{|c|}{ Observações Limite } \\
\hline \multicolumn{2}{|c|}{ Baixa } & \multicolumn{2}{c|}{ Alta } \\
\hline Valor & Obs & Valor & Obs \\
\hline 0 & 607 & 0 & 606 \\
\hline 0 & 606 & 0 & 607 \\
\hline 0 & 605 & 1 & 592 \\
\hline 0 & 604 & 1 & 596 \\
\hline 0 & 603 & 2 & 597 \\
\hline
\end{tabular}


Variável

dependente:

REC

ID $=41$

\begin{tabular}{|l|r|l|r|}
\hline \multicolumn{3}{|c|}{ Momento } \\
\hline Média & 15 & Soma dos pesos & 15 \\
\hline Desvio-padrão & 0,25819889 & $\begin{array}{l}\text { Variância } \\
\text { observações }\end{array}$ & 0,06666667 \\
\hline Assimetria & 3,87298335 & Curtose & 15 \\
\hline $\begin{array}{l}\text { Soma dos } \\
\text { quadrados não } \\
\text { corrigida }\end{array}$ & 1 & $\begin{array}{l}\text { Soma dos } \\
\text { quadrados corrigida }\end{array}$ & 0,93333333 \\
\hline CV Pearson & 387,298335 & Erro-padrão médio & 0,06666667 \\
\hline
\end{tabular}

\begin{tabular}{|l|l|l|r|}
\hline \multicolumn{4}{|c|}{ Estatística Descritiva Básica } \\
\hline \multicolumn{2}{|c|}{ Posição } & \multicolumn{2}{c|}{ Variabilidade } \\
\hline Média & 0,066667 & Desvio-padrão & 0,25820 \\
\hline Mediana & 0,000000 & Variância & 0,06667 \\
\hline Moda & 0,000000 & Amplitude & 1,00000 \\
\hline & & Amplitude interquartil & 0 \\
\hline
\end{tabular}

\begin{tabular}{|l|l|r|l|l|}
\hline \multicolumn{5}{|c|}{ Testes de Posição: Mu0=0 } \\
\hline Teste & \multicolumn{2}{|c|}{ Estatística } & \multicolumn{2}{c|}{ Valor $\mathbf{~}$} \\
\hline Student t & $\mathbf{t}$ & 1 & $\mathrm{Pr}>|\mathbf{t}|$ & 0,3343 \\
\hline Sign & $\mathbf{M}$ & 0,5 & $\mathrm{Pr}>=|\mathrm{M}|$ & 1,0000 \\
\hline Signed Rank & $\mathbf{S}$ & 0,5 & $\mathrm{Pr}>=|\mathbf{S}|$ & 1,0000 \\
\hline
\end{tabular}

\begin{tabular}{|l|r|}
\hline \multicolumn{2}{|c|}{ Quantis } \\
\hline Level & 1 \\
\hline $100 \%$ Max & 1 \\
\hline $99 \%$ & 1 \\
\hline $95 \%$ & 0 \\
\hline $90 \%$ & 0 \\
\hline $75 \%$ Q3 & 0 \\
\hline $50 \%$ Mediana & 0 \\
\hline $25 \%$ Q1 & 0 \\
\hline $10 \%$ & 0 \\
\hline $5 \%$ & 0 \\
\hline $1 \%$ & 0 \\
\hline $0 \%$ Min & 0 \\
\hline
\end{tabular}


Variável

dependente:

REC

ID $=41$

\begin{tabular}{|r|r|r|r|}
\hline \multicolumn{3}{|c|}{ Observações Limite } \\
\hline \multicolumn{2}{|c|}{ Baixa } & \multicolumn{2}{c|}{ Alta } \\
\hline Valor & Obs & Valor & Obs \\
\hline 0 & 621 & 0 & 618 \\
\hline 0 & 620 & 0 & 619 \\
\hline 0 & 619 & 0 & 620 \\
\hline 0 & 618 & 0 & 621 \\
\hline 0 & 617 & 1 & 622 \\
\hline
\end{tabular}


Variável

dependente:

ACI

ID $=41$

\begin{tabular}{|l|r|l|r|}
\hline \multicolumn{4}{|c|}{ Momento } \\
\hline Média & 15 & Soma dos pesos & 15 \\
\hline Desvio-padrão & 1,12546287 & Variância \\
\hline obserimetria & 2,6969175 & Curtose & 1,26666667 \\
\hline $\begin{array}{l}\text { Soma dos } \\
\text { quadrados não } \\
\text { corrigida }\end{array}$ & 21 & $\begin{array}{l}\text { Soma dos } \\
\text { quadrados corrigida }\end{array}$ & 7,32900064 \\
\hline CV Pearson & 241,170615 & Erro-padrão médio & 0,29059326 \\
\hline
\end{tabular}

\begin{tabular}{|l|l|l|r|}
\hline \multicolumn{4}{|c|}{ Estatística Descritiva Básica } \\
\hline \multicolumn{2}{|c|}{ Posição } & \multicolumn{2}{c|}{ Variabilidade } \\
\hline Média & 0,466667 & Desvio-padrão & 1,12546 \\
\hline Mediana & 0,000000 & Variância & 1,26667 \\
\hline Moda & 0,000000 & Amplitude & 4,00000 \\
\hline & & Amplitude interquartil & 0 \\
\hline
\end{tabular}

\begin{tabular}{|l|l|r|l|l|}
\hline \multicolumn{5}{|c|}{ Testes de Posição: Mu0=0 } \\
\hline Teste & \multicolumn{2}{|c|}{ Estatística } & \multicolumn{2}{c|}{ Valor $\mathbf{p}$} \\
\hline Student $\mathbf{t}$ & $\mathbf{t}$ & 1,60591 & $\mathrm{Pr}>|\mathbf{t}|$ & 0,1306 \\
\hline Sign & M & 1,5 & $\operatorname{Pr}>=|\mathbf{M}|$ & 0,2500 \\
\hline Signed Rank & S & 3 & $\operatorname{Pr}>=|\mathbf{S}|$ & 0,2500 \\
\hline
\end{tabular}

\begin{tabular}{|l|r|}
\hline \multicolumn{2}{|c|}{ Quantis } \\
\hline Level & Quantil \\
\hline $100 \%$ Max & 4 \\
\hline $99 \%$ & 4 \\
\hline $95 \%$ & 2 \\
\hline $90 \%$ & 0 \\
\hline $75 \%$ Q3 & 0 \\
\hline $50 \%$ Mediana & 0 \\
\hline $25 \%$ Q1 & 0 \\
\hline $10 \%$ & 0 \\
\hline $5 \%$ & 0 \\
\hline $1 \%$ & 0 \\
\hline $0 \%$ Min & 4 \\
\hline
\end{tabular}


Variável

dependente:

ACI

ID $=41$

\begin{tabular}{|r|r|r|r|}
\hline \multicolumn{3}{|c|}{ Observações Limite } \\
\hline \multicolumn{2}{|c|}{ Baixa } & \multicolumn{2}{c|}{ Alta } \\
\hline Valor & Obs & Valor & Obs \\
\hline 0 & 622 & 0 & 621 \\
\hline 0 & 621 & 0 & 622 \\
\hline 0 & 619 & 1 & 615 \\
\hline 0 & 618 & 2 & 613 \\
\hline 0 & 617 & 4 & 620 \\
\hline
\end{tabular}


Variável

dependente:

REC

$\mathrm{ID}=42$

\begin{tabular}{|l|r|l|r|}
\hline \multicolumn{3}{|c|}{ Momento } \\
\hline N & 1 Soma dos pesos & 1 \\
\hline Média & $\begin{array}{r}0 \\
\text { Soma das } \\
\text { observações }\end{array}$ & 0 \\
\hline Desvio-padrão &, Variância &, \\
\hline Assimetria &, Curtose &, \\
\hline $\begin{array}{l}\text { Soma dos } \\
\text { quadrados não } \\
\text { corrigida }\end{array}$ & 0 & $\begin{array}{l}\text { Soma dos } \\
\text { quadrados corrigida }\end{array}$ & 0 \\
\hline CV Pearson &, & Erro-padrão médio &, \\
\hline
\end{tabular}

\begin{tabular}{|l|r|l|r|}
\hline \multicolumn{3}{|c|}{ Estatística Descritiva Básica } \\
\hline \multicolumn{2}{|c|}{ Posição } & \multicolumn{2}{c|}{ Variabilidade } \\
\hline Média & 0 & Desvio-padrão & 0 \\
\hline Mediana & 0 & Variância & 0 \\
\hline Moda & 0 & Amplitude & Amplitude interquartil \\
\hline & & .
\end{tabular}

\begin{tabular}{|l|l|l|l|l|}
\hline \multicolumn{4}{|c|}{ Testes de Posição: Mu0=0 } \\
\hline Teste & \multicolumn{2}{|c|}{ Estatística } & \multicolumn{2}{c|}{ Valor $\mathbf{p}$} \\
\hline Student $\mathbf{t}$ & $\mathbf{t}$ & \multicolumn{1}{|c|}{, $\operatorname{Pr}>|\mathbf{t}|$} & \\
\hline Sign & $\mathrm{M}$ &, & $\operatorname{Pr}>=|\mathrm{M}|$ & \\
\hline Signed Rank & S &, & $\operatorname{Pr}>=|\mathrm{S}|$ & \\
\hline
\end{tabular}

\begin{tabular}{|l|r|}
\hline \multicolumn{2}{|c|}{ Quantis } \\
\hline Level & 0 \\
\hline $100 \%$ Max & 0 \\
\hline $99 \%$ & 0 \\
\hline $95 \%$ & 0 \\
\hline $90 \%$ & 0 \\
\hline $75 \%$ Q3 & 0 \\
\hline $50 \%$ Mediana & 0 \\
\hline $25 \%$ Q1 & 0 \\
\hline $10 \%$ & 0 \\
\hline $5 \%$ & 0 \\
\hline $1 \%$ & 0 \\
\hline $0 \%$ Min & 0 \\
\hline
\end{tabular}


Variável

dependente:

REC

$\mathrm{ID}=42$

\begin{tabular}{|c|c|c|c|}
\hline \multicolumn{4}{|c|}{ Observações Limite } \\
\hline \multicolumn{2}{|c|}{ Baixa } & \multicolumn{2}{|c|}{ Alta } \\
\hline al & Obs & Valor & Obs \\
\hline 0 & 623 & 0 & 623 \\
\hline
\end{tabular}


Variável

dependente:

ACI

$\mathrm{ID}=42$

\begin{tabular}{|l|r|l|r|}
\hline \multicolumn{3}{|c|}{ Momento } \\
\hline N & 1 Soma dos pesos & 1 \\
\hline Média & $\begin{array}{r}0 \\
\text { Soma das } \\
\text { observações }\end{array}$ & 0 \\
\hline Desvio-padrão &, Variância &, \\
\hline Assimetria &, Curtose &, \\
\hline $\begin{array}{l}\text { Soma dos } \\
\text { quadrados não } \\
\text { corrigida }\end{array}$ & $0 \begin{array}{l}\text { Soma dos } \\
\text { quadrados corrigida }\end{array}$ & 0 \\
\hline CV Pearson &, & Erro-padrão médio &, \\
\hline
\end{tabular}

\begin{tabular}{|l|r|l|r|}
\hline \multicolumn{3}{|c|}{ Estatística Descritiva Básica } \\
\hline \multicolumn{2}{|c|}{ Posição } & \multicolumn{2}{c|}{ Variabilidade } \\
\hline Média & 0 & Desvio-padrão & 0 \\
\hline Mediana & 0 & Variância & 0 \\
\hline Moda & 0 & Amplitude & Amplitude interquartil \\
\hline & &
\end{tabular}

\begin{tabular}{|l|l|l|l|l|}
\hline \multicolumn{5}{|c|}{ Testes de Posição: Mu0=0 } \\
\hline Teste & \multicolumn{2}{|c|}{ Estatística } & \multicolumn{2}{c|}{ Valor $\mathbf{p}$} \\
\hline Student t & t &, & $\operatorname{Pr}>|\mathbf{t}|$ & \\
\hline Sign & M &, & $\operatorname{Pr}>=|\mathrm{M}|$ & \\
\hline Signed Rank & S &, & $\operatorname{Pr}>=|\mathrm{S}|$ & \\
\hline
\end{tabular}

\begin{tabular}{|l|r|}
\hline \multicolumn{2}{|c|}{ Quantis } \\
\hline Level & 0 \\
\hline $100 \%$ Max & 0 \\
\hline $99 \%$ & 0 \\
\hline $95 \%$ & 0 \\
\hline $90 \%$ & 0 \\
\hline $75 \%$ Q3 & 0 \\
\hline $50 \%$ Mediana & 0 \\
\hline $25 \%$ Q1 & 0 \\
\hline $10 \%$ & 0 \\
\hline $5 \%$ & 0 \\
\hline $1 \%$ & 0 \\
\hline $0 \%$ Min & 0 \\
\hline
\end{tabular}


Variável

dependente:

ACI

$\mathrm{ID}=42$

\begin{tabular}{|c|c|c|c|}
\hline \multicolumn{4}{|c|}{ Observações Limite } \\
\hline \multicolumn{2}{|c|}{ Baixa } & \multicolumn{2}{|c|}{ Alta } \\
\hline al & Obs & Valor & Obs \\
\hline 0 & 623 & 0 & 623 \\
\hline
\end{tabular}


Variável

dependente:

REC

ID $=43$

\begin{tabular}{|l|r|r|r|}
\hline \multicolumn{3}{|c|}{ Momento } \\
\hline N & 15 Soma dos pesos & 15 \\
\hline Média & $\begin{array}{r}0 \\
\text { Soma das } \\
\text { observações }\end{array}$ & 0 \\
\hline Desvio-padrão & 0 & Variância & 0 \\
\hline Assimetria &, Curtose &, \\
\hline $\begin{array}{l}\text { Soma dos } \\
\text { quadrados não } \\
\text { corrigida }\end{array}$ & 0 & $\begin{array}{l}\text { Soma dos } \\
\text { quadrados corrigida }\end{array}$ & 0 \\
\hline CV Pearson &, & Erro-padrão médio & 0 \\
\hline
\end{tabular}

\begin{tabular}{|l|r|l|r|}
\hline \multicolumn{3}{|c|}{ Estatística Descritiva Básica } \\
\hline \multicolumn{2}{|c|}{ Posição } & \multicolumn{2}{c|}{ Variabilidade } \\
\hline Média & 0 & Desvio-padrão & 0 \\
\hline Mediana & 0 & Variância & 0 \\
\hline Moda & 0 & Amplitude & 0 \\
\hline & & Amplitude interquartil & 0 \\
\hline
\end{tabular}

\begin{tabular}{|l|l|l|l|l|}
\hline \multicolumn{5}{|c|}{ Testes de Posição: Mu0=0 } \\
\hline Teste & \multicolumn{2}{|c|}{ Estatística } & \multicolumn{2}{c|}{ Valor $\mathbf{p}$} \\
\hline Student t & t &, & $\operatorname{Pr}>|\mathbf{t}|$ & \\
\hline Sign & M &, & $\operatorname{Pr}>=|\mathrm{M}|$ & \\
\hline Signed Rank & S &, & $\operatorname{Pr}>=|\mathrm{S}|$ & \\
\hline
\end{tabular}

\begin{tabular}{|l|r|}
\hline \multicolumn{2}{|c|}{ Quantis } \\
\hline Level & 0 \\
\hline $100 \%$ Max & 0 \\
\hline $99 \%$ & 0 \\
\hline $95 \%$ & 0 \\
\hline $90 \%$ & 0 \\
\hline $75 \%$ Q3 & 0 \\
\hline $50 \%$ Mediana & 0 \\
\hline $25 \%$ Q1 & 0 \\
\hline $10 \%$ & 0 \\
\hline $5 \%$ & 0 \\
\hline $1 \%$ & 0 \\
\hline $0 \%$ Min & 0 \\
\hline
\end{tabular}


Variável

dependente:

REC

$\mathrm{ID}=43$

\begin{tabular}{|r|r|r|r|}
\hline \multicolumn{3}{|c|}{ Observações Limite } \\
\hline \multicolumn{2}{|c|}{ Baixa } & \multicolumn{2}{c|}{ Alta } \\
\hline Valor & Obs & Valor & Obs \\
\hline 0 & 638 & 0 & 634 \\
\hline 0 & 637 & 0 & 635 \\
\hline 0 & 636 & 0 & 636 \\
\hline 0 & 635 & 0 & 637 \\
\hline 0 & 634 & 0 & 638 \\
\hline
\end{tabular}


Variável

dependente:

ACI

$\mathrm{ID}=43$

\begin{tabular}{|l|r|l|r|}
\hline \multicolumn{3}{|c|}{ Momento } \\
\hline N & 15 & Soma dos pesos & 15 \\
\hline Média & $\begin{array}{r}0 \\
\text { Soma das } \\
\text { observações }\end{array}$ & 0 \\
\hline Desvio-padrão & 0 & Variância & 0 \\
\hline Assimetria &, Curtose &, \\
\hline $\begin{array}{l}\text { Soma dos } \\
\text { quadrados não } \\
\text { corrigida }\end{array}$ & 0 & $\begin{array}{l}\text { Soma dos } \\
\text { quadrados corrigida }\end{array}$ & 0 \\
\hline CV Pearson &, & Erro-padrão médio & 0 \\
\hline
\end{tabular}

\begin{tabular}{|l|r|l|r|}
\hline \multicolumn{3}{|c|}{ Estatística Descritiva Básica } \\
\hline \multicolumn{2}{|c|}{ Posição } & \multicolumn{2}{c|}{ Variabilidade } \\
\hline Média & 0 & Desvio-padrão & 0 \\
\hline Mediana & 0 & Variância & 0 \\
\hline Moda & 0 & Amplitude & 0 \\
\hline & & Amplitude interquartil & 0 \\
\hline
\end{tabular}

\begin{tabular}{|l|l|l|l|l|}
\hline \multicolumn{5}{|c|}{ Testes de Posição: Mu0=0 } \\
\hline Teste & \multicolumn{2}{|c|}{ Estatística } & \multicolumn{2}{c|}{ Valor $\mathbf{p}$} \\
\hline Student t & t &, & $\operatorname{Pr}>|\mathbf{t}|$ & \\
\hline Sign & M &, & $\operatorname{Pr}>=|\mathrm{M}|$ & \\
\hline Signed Rank & S &, & $\operatorname{Pr}>=|\mathrm{S}|$ & \\
\hline
\end{tabular}

\begin{tabular}{|l|r|}
\hline \multicolumn{2}{|c|}{ Quantis } \\
\hline Level & 0 \\
\hline $100 \%$ Max & 0 \\
\hline $99 \%$ & 0 \\
\hline $95 \%$ & 0 \\
\hline $90 \%$ & 0 \\
\hline $75 \%$ Q3 & 0 \\
\hline $50 \%$ Mediana & 0 \\
\hline $25 \%$ Q1 & 0 \\
\hline $10 \%$ & 0 \\
\hline $5 \%$ & 0 \\
\hline $1 \%$ & 0 \\
\hline $0 \%$ Min & 0 \\
\hline
\end{tabular}


Variável

dependente:

ACI

ID $=43$

\begin{tabular}{|r|r|r|r|}
\hline \multicolumn{3}{|c|}{ Observações Limite } \\
\hline \multicolumn{2}{|c|}{ Baixa } & \multicolumn{2}{c|}{ Alta } \\
\hline Valor & Obs & Valor & Obs \\
\hline 0 & 638 & 0 & 634 \\
\hline 0 & 637 & 0 & 635 \\
\hline 0 & 636 & 0 & 636 \\
\hline 0 & 635 & 0 & 637 \\
\hline 0 & 634 & 0 & 638 \\
\hline
\end{tabular}


Variável

dependente:

REC

$\mathrm{ID}=44$

\begin{tabular}{|l|r|l|r|}
\hline \multicolumn{3}{|c|}{ Momento } \\
\hline N & 14 & Soma dos pesos & 14 \\
\hline Média & $\begin{array}{r}0 \\
\text { Soma das } \\
\text { observações }\end{array}$ & 0 \\
\hline Desvio-padrão & 0 & Variância & 0 \\
\hline Assimetria &, Curtose &, \\
\hline $\begin{array}{l}\text { Soma dos } \\
\text { quadrados não } \\
\text { corrigida }\end{array}$ & 0 & $\begin{array}{l}\text { Soma dos } \\
\text { quadrados corrigida }\end{array}$ & 0 \\
\hline CV Pearson &, & Erro-padrão médio & 0 \\
\hline
\end{tabular}

\begin{tabular}{|l|r|l|r|}
\hline \multicolumn{3}{|c|}{ Estatística Descritiva Básica } \\
\hline \multicolumn{2}{|c|}{ Posição } & \multicolumn{2}{c|}{ Variabilidade } \\
\hline Média & 0 & Desvio-padrão & 0 \\
\hline Mediana & 0 & Variância & 0 \\
\hline Moda & 0 & Amplitude & 0 \\
\hline & & Amplitude interquartil & 0 \\
\hline
\end{tabular}

\begin{tabular}{|l|l|l|l|l|}
\hline \multicolumn{5}{|c|}{ Testes de Posição: Mu0=0 } \\
\hline Teste & \multicolumn{2}{|c|}{ Estatística } & \multicolumn{2}{c|}{ Valor $\mathbf{p}$} \\
\hline Student t & t &, & $\operatorname{Pr}>|\mathbf{t}|$ & \\
\hline Sign & M &, & $\operatorname{Pr}>=|\mathrm{M}|$ & \\
\hline Signed Rank & S &, & $\operatorname{Pr}>=|\mathrm{S}|$ & \\
\hline
\end{tabular}

\begin{tabular}{|l|r|}
\hline \multicolumn{2}{|c|}{ Quantis } \\
\hline Level & 0 \\
\hline $100 \%$ Max & 0 \\
\hline $99 \%$ & 0 \\
\hline $95 \%$ & 0 \\
\hline $90 \%$ & 0 \\
\hline $75 \%$ Q3 & 0 \\
\hline $50 \%$ Mediana & 0 \\
\hline $25 \%$ Q1 & 0 \\
\hline $10 \%$ & 0 \\
\hline $5 \%$ & 0 \\
\hline $1 \%$ & 0 \\
\hline $0 \%$ Min & 0 \\
\hline
\end{tabular}


Variável

dependente:

REC

ID $=44$

\begin{tabular}{|r|r|r|r|}
\hline \multicolumn{3}{|c|}{ Observações Limite } \\
\hline \multicolumn{2}{|c|}{ Baixa } & \multicolumn{2}{c|}{ Alta } \\
\hline Valor & Obs & Valor & Obs \\
\hline 0 & 652 & 0 & 648 \\
\hline 0 & 651 & 0 & 649 \\
\hline 0 & 650 & 0 & 650 \\
\hline 0 & 649 & 0 & 651 \\
\hline 0 & 648 & 0 & 652 \\
\hline
\end{tabular}


Variável

dependente:

ACI

ID $=44$

\begin{tabular}{|l|r|l|r|}
\hline \multicolumn{3}{|c|}{ Momento } \\
\hline N & 14 & Soma dos pesos & 14 \\
\hline Média & $\begin{array}{r}0 \\
\text { Soma das } \\
\text { observações }\end{array}$ & 0 \\
\hline Desvio-padrão & 0 & Variância & 0 \\
\hline Assimetria &, Curtose &, \\
\hline $\begin{array}{l}\text { Soma dos } \\
\text { quadrados não } \\
\text { corrigida }\end{array}$ & 0 & $\begin{array}{l}\text { Soma dos } \\
\text { quadrados corrigida }\end{array}$ & 0 \\
\hline CV Pearson &, & Erro-padrão médio & 0 \\
\hline
\end{tabular}

\begin{tabular}{|l|r|l|r|}
\hline \multicolumn{3}{|c|}{ Estatística Descritiva Básica } \\
\hline \multicolumn{2}{|c|}{ Posição } & \multicolumn{2}{c|}{ Variabilidade } \\
\hline Média & 0 & Desvio-padrão & 0 \\
\hline Mediana & 0 & Variância & 0 \\
\hline Moda & 0 & Amplitude & 0 \\
\hline & & Amplitude interquartil & 0 \\
\hline
\end{tabular}

\begin{tabular}{|l|l|l|l|l|}
\hline \multicolumn{5}{|c|}{ Testes de Posição: Mu0=0 } \\
\hline Teste & \multicolumn{2}{|c|}{ Estatística } & \multicolumn{2}{c|}{ Valor $\mathbf{p}$} \\
\hline Student t & t &, & $\operatorname{Pr}>|\mathbf{t}|$ & \\
\hline Sign & M &, & $\operatorname{Pr}>=|\mathrm{M}|$ & \\
\hline Signed Rank & S &, & $\operatorname{Pr}>=|\mathrm{S}|$ & \\
\hline
\end{tabular}

\begin{tabular}{|l|r|}
\hline \multicolumn{2}{|c|}{ Quantis } \\
\hline Level & 0 \\
\hline $100 \%$ Max & 0 \\
\hline $99 \%$ & 0 \\
\hline $95 \%$ & 0 \\
\hline $90 \%$ & 0 \\
\hline $75 \%$ Q3 & 0 \\
\hline $50 \%$ Mediana & 0 \\
\hline $25 \%$ Q1 & 0 \\
\hline $10 \%$ & 0 \\
\hline $5 \%$ & 0 \\
\hline $1 \%$ & 0 \\
\hline $0 \%$ Min & 0 \\
\hline
\end{tabular}


Variável

dependente:

ACI

ID $=44$

\begin{tabular}{|r|r|r|r|}
\hline \multicolumn{3}{|c|}{ Observações Limite } \\
\hline \multicolumn{2}{|c|}{ Baixa } & \multicolumn{2}{c|}{ Alta } \\
\hline Valor & Obs & Valor & Obs \\
\hline 0 & 652 & 0 & 648 \\
\hline 0 & 651 & 0 & 649 \\
\hline 0 & 650 & 0 & 650 \\
\hline 0 & 649 & 0 & 651 \\
\hline 0 & 648 & 0 & 652 \\
\hline
\end{tabular}


Variável

dependente:

REC

$\mathrm{ID}=45$

\begin{tabular}{|l|r|l|r|}
\hline \multicolumn{3}{|c|}{ Momento } \\
\hline N & 18 & Soma dos pesos & 18 \\
\hline Média & $\begin{array}{r}0 \\
\text { Soma das } \\
\text { observações }\end{array}$ & 0 \\
\hline Desvio-padrão & 0 & Variância & 0 \\
\hline Assimetria &, Curtose &, \\
\hline $\begin{array}{l}\text { Soma dos } \\
\text { quadrados não } \\
\text { corrigida }\end{array}$ & 0 & $\begin{array}{l}\text { Soma dos } \\
\text { quadrados corrigida }\end{array}$ & 0 \\
\hline CV Pearson &, & Erro-padrão médio & 0 \\
\hline
\end{tabular}

\begin{tabular}{|l|r|l|r|}
\hline \multicolumn{3}{|c|}{ Estatística Descritiva Básica } \\
\hline \multicolumn{2}{|c|}{ Posição } & \multicolumn{2}{c|}{ Variabilidade } \\
\hline Média & 0 & Desvio-padrão & 0 \\
\hline Mediana & 0 & Variância & 0 \\
\hline Moda & 0 & Amplitude & 0 \\
\hline & & Amplitude interquartil & 0 \\
\hline
\end{tabular}

\begin{tabular}{|l|l|l|l|l|}
\hline \multicolumn{5}{|c|}{ Testes de Posição: Mu0=0 } \\
\hline Teste & \multicolumn{2}{|c|}{ Estatística } & \multicolumn{2}{c|}{ Valor $\mathbf{p}$} \\
\hline Student t & t &, & $\operatorname{Pr}>|\mathbf{t}|$ & \\
\hline Sign & M &, & $\operatorname{Pr}>=|\mathrm{M}|$ & \\
\hline Signed Rank & S &, & $\operatorname{Pr}>=|\mathrm{S}|$ & \\
\hline
\end{tabular}

\begin{tabular}{|l|r|}
\hline \multicolumn{2}{|c|}{ Quantis } \\
\hline Level & 0 \\
\hline $100 \%$ Max & 0 \\
\hline $99 \%$ & 0 \\
\hline $95 \%$ & 0 \\
\hline $90 \%$ & 0 \\
\hline $75 \%$ Q3 & 0 \\
\hline $50 \%$ Mediana & 0 \\
\hline $25 \%$ Q1 & 0 \\
\hline $10 \%$ & 0 \\
\hline $5 \%$ & 0 \\
\hline $1 \%$ & 0 \\
\hline $0 \%$ Min & 0 \\
\hline
\end{tabular}


Variável

dependente:

REC

ID $=45$

\begin{tabular}{|r|r|r|r|}
\hline \multicolumn{3}{|c|}{ Observações Limite } \\
\hline \multicolumn{2}{|c|}{ Baixa } & \multicolumn{2}{c|}{ Alta } \\
\hline Valor & Obs & Valor & Obs \\
\hline 0 & 670 & 0 & 666 \\
\hline 0 & 669 & 0 & 667 \\
\hline 0 & 668 & 0 & 668 \\
\hline 0 & 667 & 0 & 669 \\
\hline 0 & 666 & 0 & 670 \\
\hline
\end{tabular}


Variável

dependente:

ACI

$\mathrm{ID}=45$

\begin{tabular}{|l|r|l|r|}
\hline \multicolumn{3}{|c|}{ Momento } \\
\hline N & 18 & Soma dos pesos & 18 \\
\hline Média & $\begin{array}{r}0 \\
\text { Soma das } \\
\text { observações }\end{array}$ & 0 \\
\hline Desvio-padrão & 0 & Variância & 0 \\
\hline Assimetria &, Curtose &, \\
\hline $\begin{array}{l}\text { Soma dos } \\
\text { quadrados não } \\
\text { corrigida }\end{array}$ & 0 & $\begin{array}{l}\text { Soma dos } \\
\text { quadrados corrigida }\end{array}$ & 0 \\
\hline CV Pearson &, & Erro-padrão médio & 0 \\
\hline
\end{tabular}

\begin{tabular}{|l|r|l|r|}
\hline \multicolumn{3}{|c|}{ Estatística Descritiva Básica } \\
\hline \multicolumn{2}{|c|}{ Posição } & \multicolumn{2}{c|}{ Variabilidade } \\
\hline Média & 0 & Desvio-padrão & 0 \\
\hline Mediana & 0 & Variância & 0 \\
\hline Moda & 0 & Amplitude & 0 \\
\hline & & Amplitude interquartil & 0 \\
\hline
\end{tabular}

\begin{tabular}{|l|l|l|l|l|}
\hline \multicolumn{5}{|c|}{ Testes de Posição: Mu0=0 } \\
\hline Teste & \multicolumn{2}{|c|}{ Estatística } & \multicolumn{2}{c|}{ Valor $\mathbf{p}$} \\
\hline Student t & t &, & $\operatorname{Pr}>|\mathbf{t}|$ & \\
\hline Sign & M &, & $\operatorname{Pr}>=|\mathrm{M}|$ & \\
\hline Signed Rank & S &, & $\operatorname{Pr}>=|\mathrm{S}|$ & \\
\hline
\end{tabular}

\begin{tabular}{|l|r|}
\hline \multicolumn{2}{|c|}{ Quantis } \\
\hline Level & 0 \\
\hline $100 \%$ Max & 0 \\
\hline $99 \%$ & 0 \\
\hline $95 \%$ & 0 \\
\hline $90 \%$ & 0 \\
\hline $75 \%$ Q3 & 0 \\
\hline $50 \%$ Mediana & 0 \\
\hline $25 \%$ Q1 & 0 \\
\hline $10 \%$ & 0 \\
\hline $5 \%$ & 0 \\
\hline $1 \%$ & 0 \\
\hline $0 \%$ Min & 0 \\
\hline
\end{tabular}


Variável

dependente:

ACI

$\mathrm{ID}=45$

\begin{tabular}{|r|r|r|r|}
\hline \multicolumn{3}{|c|}{ Observações Limite } \\
\hline \multicolumn{2}{|c|}{ Baixa } & \multicolumn{2}{c|}{ Alta } \\
\hline Valor & Obs & Valor & Obs \\
\hline 0 & 670 & 0 & 666 \\
\hline 0 & 669 & 0 & 667 \\
\hline 0 & 668 & 0 & 668 \\
\hline 0 & 667 & 0 & 669 \\
\hline 0 & 666 & 0 & 670 \\
\hline
\end{tabular}


Variável

dependente:

REC

$I D=46$

\begin{tabular}{|l|r|l|r|}
\hline \multicolumn{3}{|c|}{ Momento } \\
\hline N & 11 & Soma dos pesos & 11 \\
\hline Média & $\begin{array}{r}0 \\
\text { Soma das } \\
\text { observações }\end{array}$ & 0 \\
\hline Desvio-padrão & 0 & Variância & 0 \\
\hline Assimetria &, Curtose &, \\
\hline $\begin{array}{l}\text { Soma dos } \\
\text { quadrados não } \\
\text { corrigida }\end{array}$ & 0 & $\begin{array}{l}\text { Soma dos } \\
\text { quadrados corrigida }\end{array}$ & 0 \\
\hline CV Pearson &, & Erro-padrão médio & 0 \\
\hline
\end{tabular}

\begin{tabular}{|l|r|l|r|}
\hline \multicolumn{3}{|c|}{ Estatística Descritiva Básica } \\
\hline \multicolumn{2}{|c|}{ Posição } & \multicolumn{2}{c|}{ Variabilidade } \\
\hline Média & 0 & Desvio-padrão & 0 \\
\hline Mediana & 0 & Variância & 0 \\
\hline Moda & 0 & Amplitude & 0 \\
\hline & & Amplitude interquartil & 0 \\
\hline
\end{tabular}

\begin{tabular}{|l|l|l|l|l|}
\hline \multicolumn{5}{|c|}{ Testes de Posição: Mu0=0 } \\
\hline Teste & \multicolumn{2}{|c|}{ Estatística } & \multicolumn{2}{c|}{ Valor $\mathbf{p}$} \\
\hline Student t & t &, & $\operatorname{Pr}>|\mathbf{t}|$ & \\
\hline Sign & M &, & $\operatorname{Pr}>=|\mathrm{M}|$ & \\
\hline Signed Rank & S &, & $\operatorname{Pr}>=|\mathrm{S}|$ & \\
\hline
\end{tabular}

\begin{tabular}{|l|r|}
\hline \multicolumn{2}{|c|}{ Quantis } \\
\hline Level & 0 \\
\hline $100 \%$ Max & 0 \\
\hline $99 \%$ & 0 \\
\hline $95 \%$ & 0 \\
\hline $90 \%$ & 0 \\
\hline $75 \%$ Q3 & 0 \\
\hline $50 \%$ Mediana & 0 \\
\hline $25 \%$ Q1 & 0 \\
\hline $10 \%$ & 0 \\
\hline $5 \%$ & 0 \\
\hline $1 \%$ & 0 \\
\hline $0 \%$ Min & 0 \\
\hline
\end{tabular}


Variável

dependente:

REC

$I D=46$

\begin{tabular}{|r|r|r|r|}
\hline \multicolumn{3}{|c|}{ Observações Limite } \\
\hline \multicolumn{2}{|c|}{ Baixa } & \multicolumn{2}{c|}{ Alta } \\
\hline Valor & Obs & Valor & Obs \\
\hline 0 & 681 & 0 & 677 \\
\hline 0 & 680 & 0 & 678 \\
\hline 0 & 679 & 0 & 679 \\
\hline 0 & 678 & 0 & 680 \\
\hline 0 & 677 & 0 & 681 \\
\hline
\end{tabular}


Variável

dependente:

ACI

$I D=46$

\begin{tabular}{|l|r|l|r|}
\hline \multicolumn{3}{|c|}{ Momento } \\
\hline N & 11 & Soma dos pesos & 11 \\
\hline Média & $\begin{array}{r}0 \\
\text { Soma das } \\
\text { observações }\end{array}$ & 0 \\
\hline Desvio-padrão & 0 & Variância & 0 \\
\hline Assimetria &, Curtose &, \\
\hline $\begin{array}{l}\text { Soma dos } \\
\text { quadrados não } \\
\text { corrigida }\end{array}$ & 0 & $\begin{array}{l}\text { Soma dos } \\
\text { quadrados corrigida }\end{array}$ & 0 \\
\hline CV Pearson &, & Erro-padrão médio & 0 \\
\hline
\end{tabular}

\begin{tabular}{|l|r|l|r|}
\hline \multicolumn{3}{|c|}{ Estatística Descritiva Básica } \\
\hline \multicolumn{2}{|c|}{ Posição } & \multicolumn{2}{c|}{ Variabilidade } \\
\hline Média & 0 & Desvio-padrão & 0 \\
\hline Mediana & 0 & Variância & 0 \\
\hline Moda & 0 & Amplitude & 0 \\
\hline & & Amplitude interquartil & 0 \\
\hline
\end{tabular}

\begin{tabular}{|l|l|l|l|l|}
\hline \multicolumn{5}{|c|}{ Testes de Posição: Mu0=0 } \\
\hline Teste & \multicolumn{2}{|c|}{ Estatística } & \multicolumn{2}{c|}{ Valor $\mathbf{p}$} \\
\hline Student t & t &, & $\operatorname{Pr}>|\mathbf{t}|$ & \\
\hline Sign & M &, & $\operatorname{Pr}>=|\mathrm{M}|$ & \\
\hline Signed Rank & S &, & $\operatorname{Pr}>=|\mathrm{S}|$ & \\
\hline
\end{tabular}

\begin{tabular}{|l|r|}
\hline \multicolumn{2}{|c|}{ Quantis } \\
\hline Level & 0 \\
\hline $100 \%$ Max & 0 \\
\hline $99 \%$ & 0 \\
\hline $95 \%$ & 0 \\
\hline $90 \%$ & 0 \\
\hline $75 \%$ Q3 & 0 \\
\hline $50 \%$ Mediana & 0 \\
\hline $25 \%$ Q1 & 0 \\
\hline $10 \%$ & 0 \\
\hline $5 \%$ & 0 \\
\hline $1 \%$ & 0 \\
\hline $0 \%$ Min & 0 \\
\hline
\end{tabular}


Variável

dependente:

ACI

$\mathrm{ID}=46$

\begin{tabular}{|r|r|r|r|}
\hline \multicolumn{3}{|c|}{ Observações Limite } \\
\hline \multicolumn{2}{|c|}{ Baixa } & \multicolumn{2}{c|}{ Alta } \\
\hline Valor & Obs & Valor & Obs \\
\hline 0 & 681 & 0 & 677 \\
\hline 0 & 680 & 0 & 678 \\
\hline 0 & 679 & 0 & 679 \\
\hline 0 & 678 & 0 & 680 \\
\hline 0 & 677 & 0 & 681 \\
\hline
\end{tabular}


Variável

dependente:

REC

ID $=47$

\begin{tabular}{|l|r|l|r|}
\hline \multicolumn{4}{|c|}{ Momento } \\
\hline Média & 18 & Soma dos pesos & 18 \\
\hline Desvio-padrão & 0,32338083 & $\begin{array}{l}\text { Variância } \\
\text { observações }\end{array}$ & 0,10457516 \\
\hline Assimetria & 2,70578807 & Curtose & 5,9765625 \\
\hline $\begin{array}{l}\text { Soma dos } \\
\text { quadrados não } \\
\text { corrigida }\end{array}$ & 2 & $\begin{array}{l}\text { Soma dos } \\
\text { quadrados corrigida }\end{array}$ & 1,77777778 \\
\hline CV Pearson & 291,04275 & Erro-padrão médio & 0,07622159 \\
\hline
\end{tabular}

\begin{tabular}{|l|l|l|r|}
\hline \multicolumn{4}{|c|}{ Estatística Descritiva Básica } \\
\hline \multicolumn{2}{|c|}{ Posição } & \multicolumn{2}{c|}{ Variabilidade } \\
\hline Média & 0,111111 & Desvio-padrão & 0,32338 \\
\hline Mediana & 0,000000 & Variância & 0,10458 \\
\hline Moda & 0,000000 & Amplitude & 1,00000 \\
\hline & & Amplitude interquartil & 0 \\
\hline
\end{tabular}

\begin{tabular}{|l|l|r|l|l|}
\hline \multicolumn{5}{|c|}{ Testes de Posição: Mu0=0 } \\
\hline Teste & \multicolumn{2}{|c|}{ Estatística } & \multicolumn{2}{c|}{ Valor $\mathbf{~}$} \\
\hline Student t & $\mathbf{t}$ & 1,457738 & $\mathrm{Pr}>|\mathbf{t}|$ & 0,1631 \\
\hline Sign & $\mathrm{M}$ & 1 & $\mathrm{Pr}>=|\mathrm{M}|$ & 0,5000 \\
\hline Signed Rank & $\mathrm{S}$ & 1,5 & $\mathrm{Pr}>=|\mathrm{S}|$ & 0,5000 \\
\hline
\end{tabular}

\begin{tabular}{|l|r|}
\hline \multicolumn{2}{|c|}{ Quantis } \\
\hline Level & Quantil \\
\hline $100 \%$ Max & 1 \\
\hline $99 \%$ & 1 \\
\hline $95 \%$ & 1 \\
\hline $90 \%$ & 0 \\
\hline $75 \%$ Q3 & 0 \\
\hline $50 \%$ Mediana & 0 \\
\hline $25 \%$ Q1 & 0 \\
\hline $10 \%$ & 0 \\
\hline $5 \%$ & 0 \\
\hline $1 \%$ & 0 \\
\hline $0 \%$ Min & 1 \\
\hline
\end{tabular}


Variável

dependente:

REC

ID $=47$

\begin{tabular}{|r|r|r|r|}
\hline \multicolumn{3}{|c|}{ Observações Limite } \\
\hline \multicolumn{2}{|c|}{ Baixa } & \multicolumn{2}{c|}{ Alta } \\
\hline Valor & Obs & Valor & Obs \\
\hline 0 & 699 & 0 & 697 \\
\hline 0 & 698 & 0 & 698 \\
\hline 0 & 697 & 0 & 699 \\
\hline 0 & 696 & 1 & 687 \\
\hline 0 & 695 & 1 & 690 \\
\hline
\end{tabular}


Variável

dependente:

ACI

ID $=47$

\begin{tabular}{|l|r|l|r|}
\hline \multicolumn{4}{|c|}{ Momento } \\
\hline Média & 18 & Soma dos pesos & 18 \\
\hline Desvio-padrão & 0,5 & $\begin{array}{l}\text { Soma das } \\
\text { observações }\end{array}$ \\
\hline Assimetria & 2,90670098 & Curtose & 0,97058824 \\
\hline $\begin{array}{l}\text { Soma dos } \\
\text { quadrados não } \\
\text { corrigida }\end{array}$ & 21 & $\begin{array}{l}\text { Soma dos } \\
\text { quadrados corrigida }\end{array}$ & 9,83471074 \\
\hline CV Pearson & 197,036873 & Erro-padrão médio & 0,23221018 \\
\hline
\end{tabular}

\begin{tabular}{|l|c|l|c|}
\hline \multicolumn{4}{|c|}{ Estatística Descritiva Básica } \\
\hline \multicolumn{2}{|c|}{ Posição } & \multicolumn{2}{c|}{ Variabilidade } \\
\hline Média & 0,500000 & Desvio-padrão & 0,98518 \\
\hline Mediana & 0,000000 & Variância & 0,97059 \\
\hline Moda & 0,000000 & Amplitude & 4,00000 \\
\hline & & Amplitude interquartil & 1,00000 \\
\hline
\end{tabular}

\begin{tabular}{|l|l|r|l|l|}
\hline \multicolumn{5}{|c|}{ Testes de Posição: Mu0=0 } \\
\hline Teste & \multicolumn{2}{|c|}{ Estatística } & \multicolumn{2}{c|}{ Valor $\mathbf{~}$} \\
\hline Student t & $\mathbf{t}$ & 2,153222 & $\mathrm{Pr}>|\mathbf{t}|$ & 0,0460 \\
\hline Sign & $\mathrm{M}$ & 3 & $\mathrm{Pr}>=|\mathrm{M}|$ & 0,0313 \\
\hline Signed Rank & $\mathrm{S}$ & 10,5 & $\mathrm{Pr}>=|\mathrm{S}|$ & 0,0313 \\
\hline
\end{tabular}

\begin{tabular}{|l|r|}
\hline \multicolumn{2}{|c|}{ Quantis } \\
\hline Level & Quantil \\
\hline $100 \%$ Max & 4 \\
\hline $99 \%$ & 4 \\
\hline $95 \%$ & 1 \\
\hline $90 \%$ & 1 \\
\hline $75 \%$ Q3 & 0 \\
\hline $50 \%$ Mediana & 0 \\
\hline $25 \%$ Q1 & 0 \\
\hline $10 \%$ & 0 \\
\hline $5 \%$ & 0 \\
\hline $1 \%$ & 0 \\
\hline $0 \%$ Min & 4 \\
\hline
\end{tabular}


Variável

dependente:

ACI

$\mathrm{ID}=\mathbf{4 7}$

\begin{tabular}{|r|r|r|r|}
\hline \multicolumn{3}{|c|}{ Observações Limite } \\
\hline \multicolumn{2}{|c|}{ Baixa } & \multicolumn{2}{c|}{ Alta } \\
\hline Valor & Obs & Valor & Obs \\
\hline 0 & 698 & 1 & 688 \\
\hline 0 & 697 & 1 & 689 \\
\hline 0 & 696 & 1 & 692 \\
\hline 0 & 695 & 1 & 699 \\
\hline 0 & 694 & 4 & 683 \\
\hline
\end{tabular}


Variável

dependente:

REC

$\mathrm{ID}=48$

\begin{tabular}{|l|r|l|r|}
\hline \multicolumn{3}{|c|}{ Momento } \\
\hline Média & 18 & Soma dos pesos & 18 \\
\hline Desvio-padrão & 0,23570226 & $\begin{array}{l}\text { Variância } \\
\text { observações }\end{array}$ & 0,05555556 \\
\hline Assimetria & 4,24264069 & Curtose & 18 \\
\hline $\begin{array}{l}\text { Soma dos } \\
\text { quadrados não } \\
\text { corrigida }\end{array}$ & 1 & $\begin{array}{l}\text { Soma dos } \\
\text { quadrados corrigida }\end{array}$ & 0,94444444 \\
\hline CV Pearson & 424,264069 & Erro-padrão médio & 0,05555556 \\
\hline
\end{tabular}

\begin{tabular}{|l|l|l|r|}
\hline \multicolumn{4}{|c|}{ Estatística Descritiva Básica } \\
\hline Média & 0,055556 & Desvio-padrão & 0,23570 \\
\hline Mediana & 0,000000 & Variância & 0,05556 \\
\hline Moda & 0,000000 & Amplitude & 1,00000 \\
\hline & & Amplitude interquartil & 0 \\
\hline
\end{tabular}

\begin{tabular}{|l|l|r|l|l|}
\hline \multicolumn{5}{|c|}{ Testes de Posição: Mu0=0 } \\
\hline Teste & \multicolumn{2}{|c|}{ Estatística } & \multicolumn{2}{c|}{ Valor $\mathbf{~}$} \\
\hline Student t & $\mathbf{t}$ & 1 & $\mathrm{Pr}>|\mathbf{t}|$ & 0,3313 \\
\hline Sign & $\mathbf{M}$ & 0,5 & $\mathrm{Pr}>=|\mathrm{M}|$ & 1,0000 \\
\hline Signed Rank & $\mathbf{S}$ & 0,5 & $\mathrm{Pr}>=|\mathbf{S}|$ & 1,0000 \\
\hline
\end{tabular}

\begin{tabular}{|l|r|}
\hline \multicolumn{2}{|c|}{ Quantis } \\
\hline Level & 1 \\
\hline $100 \%$ Max & 1 \\
\hline $99 \%$ & 1 \\
\hline $95 \%$ & 0 \\
\hline $90 \%$ & 0 \\
\hline $75 \%$ Quantil & 0 \\
\hline $50 \%$ Mediana & 0 \\
\hline $25 \%$ Q1 & 0 \\
\hline $10 \%$ & 0 \\
\hline $5 \%$ & 0 \\
\hline $1 \%$ & 0 \\
\hline $0 \%$ Min & \\
\hline
\end{tabular}


Variável

dependente:

REC

$\mathrm{ID}=48$

\begin{tabular}{|r|r|r|r|}
\hline \multicolumn{3}{|c|}{ Observações Limite } \\
\hline \multicolumn{2}{|c|}{ Baixa } & \multicolumn{2}{c|}{ Alta } \\
\hline Valor & Obs & Valor & Obs \\
\hline 0 & 717 & 0 & 714 \\
\hline 0 & 716 & 0 & 715 \\
\hline 0 & 715 & 0 & 716 \\
\hline 0 & 714 & 0 & 717 \\
\hline 0 & 713 & 1 & 700 \\
\hline
\end{tabular}


Variável

dependente:

ACI

$\mathrm{ID}=48$

\begin{tabular}{|l|r|l|r|}
\hline \multicolumn{3}{|c|}{ Momento } \\
\hline Média & 18 & Soma dos pesos & 18 \\
\hline Desvio-padrão & 0,23570226 & $\begin{array}{l}\text { Variância } \\
\text { observações }\end{array}$ & 0,05555556 \\
\hline Assimetria & 4,24264069 & Curtose & 18 \\
\hline $\begin{array}{l}\text { Soma dos } \\
\text { quadrados não } \\
\text { corrigida }\end{array}$ & 1 & $\begin{array}{l}\text { Soma dos } \\
\text { quadrados corrigida }\end{array}$ & 0,94444444 \\
\hline CV Pearson & 424,264069 & Erro-padrão médio & 0,05555556 \\
\hline
\end{tabular}

\begin{tabular}{|l|l|l|r|}
\hline \multicolumn{4}{|c|}{ Estatística Descritiva Básica } \\
\hline Média & 0,055556 & Desvio-padrão & 0,23570 \\
\hline Mediana & 0,000000 & Variância & 0,05556 \\
\hline Moda & 0,000000 & Amplitude & 1,00000 \\
\hline & & Amplitude interquartil & 0 \\
\hline
\end{tabular}

\begin{tabular}{|l|l|r|l|l|}
\hline \multicolumn{5}{|c|}{ Testes de Posição: Mu0=0 } \\
\hline Teste & \multicolumn{2}{|c|}{ Estatística } & \multicolumn{2}{c|}{ Valor $\mathbf{~}$} \\
\hline Student t & $\mathbf{t}$ & 1 & $\mathrm{Pr}>|\mathbf{t}|$ & 0,3313 \\
\hline Sign & $\mathbf{M}$ & 0,5 & $\mathrm{Pr}>=|\mathrm{M}|$ & 1,0000 \\
\hline Signed Rank & $\mathbf{S}$ & 0,5 & $\mathrm{Pr}>=|\mathbf{S}|$ & 1,0000 \\
\hline
\end{tabular}

\begin{tabular}{|l|r|}
\hline \multicolumn{2}{|c|}{ Quantis } \\
\hline Level & 1 \\
\hline $100 \%$ Max & 1 \\
\hline $99 \%$ & 1 \\
\hline $95 \%$ & 0 \\
\hline $90 \%$ & 0 \\
\hline $75 \%$ Quantil & 0 \\
\hline $50 \%$ Mediana & 0 \\
\hline $25 \%$ Q1 & 0 \\
\hline $10 \%$ & 0 \\
\hline $5 \%$ & 0 \\
\hline $1 \%$ & 0 \\
\hline $0 \%$ Min & \\
\hline
\end{tabular}


Variável

dependente:

ACI

$\mathrm{ID}=48$

\begin{tabular}{|r|r|r|r|}
\hline \multicolumn{3}{|c|}{ Observações Limite } \\
\hline \multicolumn{2}{|c|}{ Baixa } & \multicolumn{2}{c|}{ Alta } \\
\hline Valor & Obs & Valor & Obs \\
\hline 0 & 717 & 0 & 714 \\
\hline 0 & 716 & 0 & 715 \\
\hline 0 & 715 & 0 & 716 \\
\hline 0 & 714 & 0 & 717 \\
\hline 0 & 713 & 1 & 707 \\
\hline
\end{tabular}


Variável

dependente:

REC

ID $=49$

\begin{tabular}{|l|r|l|r|}
\hline \multicolumn{3}{|c|}{ Momento } \\
\hline Média & 18 & Soma dos pesos & 18 \\
\hline Desvio-padrão & 0,23570226 & $\begin{array}{l}\text { Variância } \\
\text { observações }\end{array}$ & 0,05555556 \\
\hline Assimetria & 4,24264069 & Curtose & 18 \\
\hline $\begin{array}{l}\text { Soma dos } \\
\text { quadrados não } \\
\text { corrigida }\end{array}$ & 1 & $\begin{array}{l}\text { Soma dos } \\
\text { quadrados corrigida }\end{array}$ & 0,94444444 \\
\hline CV Pearson & 424,264069 & Erro-padrão médio & 0,05555556 \\
\hline
\end{tabular}

\begin{tabular}{|l|l|l|r|}
\hline \multicolumn{4}{|c|}{ Estatística Descritiva Básica } \\
\hline Média & 0,055556 & Desvio-padrão & 0,23570 \\
\hline Mediana & 0,000000 & Variância & 0,05556 \\
\hline Moda & 0,000000 & Amplitude & 1,00000 \\
\hline & & Amplitude interquartil & 0 \\
\hline
\end{tabular}

\begin{tabular}{|l|l|r|l|l|}
\hline \multicolumn{5}{|c|}{ Testes de Posição: Mu0=0 } \\
\hline Teste & \multicolumn{2}{|c|}{ Estatística } & \multicolumn{2}{c|}{ Valor $\mathbf{p}$} \\
\hline Student $\mathbf{t}$ & $\mathbf{t}$ & 1 & $\mathrm{Pr}>|\mathbf{t}|$ & 0,3313 \\
\hline Sign & M & 0,5 & $\mathrm{Pr}>=|\mathrm{M}|$ & 1,0000 \\
\hline Signed Rank & $\mathbf{S}$ & 0,5 & $\mathrm{Pr}>=|\mathbf{S}|$ & 1,0000 \\
\hline
\end{tabular}

\begin{tabular}{|l|r|}
\hline \multicolumn{2}{|c|}{ Quantis } \\
\hline Level & 1 \\
\hline $100 \%$ Max & 1 \\
\hline $99 \%$ & 1 \\
\hline $95 \%$ & 0 \\
\hline $90 \%$ & 0 \\
\hline $75 \%$ Q3 & 0 \\
\hline $50 \%$ Mediana & 0 \\
\hline $25 \%$ Q1 & 0 \\
\hline $10 \%$ & 0 \\
\hline $5 \%$ & 0 \\
\hline $1 \%$ & 0 \\
\hline $0 \%$ Min & \\
\hline
\end{tabular}


Variável

dependente:

REC

ID $=49$

\begin{tabular}{|r|r|r|r|}
\hline \multicolumn{3}{|c|}{ Observações Limite } \\
\hline \multicolumn{2}{|c|}{ Baixa } & \multicolumn{2}{c|}{ Alta } \\
\hline Valor & Obs & Valor & Obs \\
\hline 0 & 735 & 0 & 732 \\
\hline 0 & 734 & 0 & 733 \\
\hline 0 & 733 & 0 & 734 \\
\hline 0 & 732 & 0 & 735 \\
\hline 0 & 731 & 1 & 718 \\
\hline
\end{tabular}


Variável

dependente:

ACI

ID $=49$

\begin{tabular}{|l|r|l|r|}
\hline \multicolumn{4}{|c|}{ Momento } \\
\hline Média & 18 & Soma dos pesos & 18 \\
\hline Desvio-padrão & 0,32338083 & $\begin{array}{l}\text { Variância } \\
\text { observações }\end{array}$ & 0,10457516 \\
\hline Assimetria & 2,70578807 & Curtose & 5,9765625 \\
\hline $\begin{array}{l}\text { Soma dos } \\
\text { quadrados não } \\
\text { corrigida }\end{array}$ & 2 & $\begin{array}{l}\text { Soma dos } \\
\text { quadrados corrigida }\end{array}$ & 1,77777778 \\
\hline CV Pearson & 291,04275 & Erro-padrão médio & 0,07622159 \\
\hline
\end{tabular}

\begin{tabular}{|l|l|l|r|}
\hline \multicolumn{4}{|c|}{ Estatística Descritiva Básica } \\
\hline \multicolumn{2}{|c|}{ Posição } & \multicolumn{2}{c|}{ Variabilidade } \\
\hline Média & 0,111111 & Desvio-padrão & 0,32338 \\
\hline Mediana & 0,000000 & Variância & 0,10458 \\
\hline Moda & 0,000000 & Amplitude & 1,00000 \\
\hline & & Amplitude interquartil & 0 \\
\hline
\end{tabular}

\begin{tabular}{|l|l|r|l|l|}
\hline \multicolumn{5}{|c|}{ Testes de Posição: Mu0=0 } \\
\hline Teste & \multicolumn{2}{|c|}{ Estatística } & \multicolumn{2}{c|}{ Valor $\mathbf{~}$} \\
\hline Student t & $\mathbf{t}$ & 1,457738 & $\mathrm{Pr}>|\mathbf{t}|$ & 0,1631 \\
\hline Sign & $\mathrm{M}$ & 1 & $\mathrm{Pr}>=|\mathrm{M}|$ & 0,5000 \\
\hline Signed Rank & $\mathrm{S}$ & 1,5 & $\mathrm{Pr}>=|\mathrm{S}|$ & 0,5000 \\
\hline
\end{tabular}

\begin{tabular}{|l|r|}
\hline \multicolumn{2}{|c|}{ Quantis } \\
\hline Level & 1 \\
\hline $100 \%$ Max & 1 \\
\hline $99 \%$ & 1 \\
\hline $95 \%$ & 1 \\
\hline $90 \%$ & 0 \\
\hline $75 \%$ Quantil & 0 \\
\hline $50 \%$ Mediana & 0 \\
\hline $25 \%$ Q1 & 0 \\
\hline $10 \%$ & 0 \\
\hline $5 \%$ & 0 \\
\hline $1 \%$ & 0 \\
\hline $0 \%$ Min & \\
\hline
\end{tabular}


Variável

dependente:

ACI

$\mathrm{ID}=49$

\begin{tabular}{|r|r|r|r|}
\hline \multicolumn{3}{|c|}{ Observações Limite } \\
\hline \multicolumn{2}{|c|}{ Baixa } & \multicolumn{2}{c|}{ Alta } \\
\hline Valor & Obs & Valor & Obs \\
\hline 0 & 735 & 0 & 733 \\
\hline 0 & 734 & 0 & 734 \\
\hline 0 & 733 & 0 & 735 \\
\hline 0 & 732 & 1 & 718 \\
\hline 0 & 731 & 1 & 725 \\
\hline
\end{tabular}


Variável

dependente:

REC

$\mathrm{ID}=\mathbf{5 0}$

\begin{tabular}{|l|r|r|r|}
\hline \multicolumn{3}{|c|}{ Momento } \\
\hline N & 13 Soma dos pesos & 13 \\
\hline Média & $\begin{array}{r}0 \\
\text { Soma das } \\
\text { observações }\end{array}$ & 0 \\
\hline Desvio-padrão & 0 & Variância & 0 \\
\hline Assimetria &, Curtose &, \\
\hline $\begin{array}{l}\text { Soma dos } \\
\text { quadrados não } \\
\text { corrigida }\end{array}$ & 0 & $\begin{array}{l}\text { Soma dos } \\
\text { quadrados corrigida }\end{array}$ & 0 \\
\hline CV Pearson &, & Erro-padrão médio & 0 \\
\hline
\end{tabular}

\begin{tabular}{|l|r|l|r|}
\hline \multicolumn{3}{|c|}{ Estatística Descritiva Básica } \\
\hline \multicolumn{2}{|c|}{ Posição } & \multicolumn{2}{c|}{ Variabilidade } \\
\hline Média & 0 & Desvio-padrão & 0 \\
\hline Mediana & 0 & Variância & 0 \\
\hline Moda & 0 & Amplitude & 0 \\
\hline & & Amplitude interquartil & 0 \\
\hline
\end{tabular}

\begin{tabular}{|l|l|l|l|l|}
\hline \multicolumn{5}{|c|}{ Testes de Posição: Mu0=0 } \\
\hline Teste & \multicolumn{2}{|c|}{ Estatística } & \multicolumn{2}{c|}{ Valor $\mathbf{p}$} \\
\hline Student t & t &, & $\operatorname{Pr}>|\mathbf{t}|$ & \\
\hline Sign & M &, & $\operatorname{Pr}>=|\mathrm{M}|$ & \\
\hline Signed Rank & S &, & $\operatorname{Pr}>=|\mathrm{S}|$ & \\
\hline
\end{tabular}

\begin{tabular}{|l|r|}
\hline \multicolumn{2}{|c|}{ Quantis } \\
\hline Level & 0 \\
\hline $100 \%$ Max & 0 \\
\hline $99 \%$ & 0 \\
\hline $95 \%$ & 0 \\
\hline $90 \%$ & 0 \\
\hline $75 \%$ Q3 & 0 \\
\hline $50 \%$ Mediana & 0 \\
\hline $25 \%$ Q1 & 0 \\
\hline $10 \%$ & 0 \\
\hline $5 \%$ & 0 \\
\hline $1 \%$ & 0 \\
\hline $0 \%$ Min & 0 \\
\hline
\end{tabular}


Variável

dependente:

REC

$\mathrm{ID}=\mathbf{5 0}$

\begin{tabular}{|r|r|r|r|}
\hline \multicolumn{3}{|c|}{ Observações Limite } \\
\hline \multicolumn{2}{|c|}{ Baixa } & \multicolumn{2}{c|}{ Alta } \\
\hline Valor & Obs & Valor & Obs \\
\hline 0 & 748 & 0 & 744 \\
\hline 0 & 747 & 0 & 745 \\
\hline 0 & 746 & 0 & 746 \\
\hline 0 & 745 & 0 & 747 \\
\hline 0 & 744 & 0 & 748 \\
\hline
\end{tabular}


Variável

dependente:

ACI

$\mathrm{ID}=\mathbf{5 0}$

\begin{tabular}{|l|r|l|r|}
\hline \multicolumn{3}{|c|}{ Momento } \\
\hline N & 13 & Soma dos pesos & 13 \\
\hline Média & $\begin{array}{r}0 \\
\text { Soma das } \\
\text { observações }\end{array}$ & 0 \\
\hline Desvio-padrão & 0 & Variância & 0 \\
\hline Assimetria &, Curtose &, \\
\hline $\begin{array}{l}\text { Soma dos } \\
\text { quadrados não } \\
\text { corrigida }\end{array}$ & 0 & $\begin{array}{l}\text { Soma dos } \\
\text { quadrados corrigida }\end{array}$ & 0 \\
\hline CV Pearson &, & Erro-padrão médio & 0 \\
\hline
\end{tabular}

\begin{tabular}{|l|r|l|r|}
\hline \multicolumn{3}{|c|}{ Estatística Descritiva Básica } \\
\hline \multicolumn{2}{|c|}{ Posição } & \multicolumn{2}{c|}{ Variabilidade } \\
\hline Média & 0 & Desvio-padrão & 0 \\
\hline Mediana & 0 & Variância & 0 \\
\hline Moda & 0 & Amplitude & 0 \\
\hline & & Amplitude interquartil & 0 \\
\hline
\end{tabular}

\begin{tabular}{|l|l|l|l|l|}
\hline \multicolumn{5}{|c|}{ Testes de Posição: Mu0=0 } \\
\hline Teste & \multicolumn{2}{|c|}{ Estatística } & \multicolumn{2}{c|}{ Valor $\mathbf{p}$} \\
\hline Student t & t &, & $\operatorname{Pr}>|\mathbf{t}|$ & \\
\hline Sign & M &, & $\operatorname{Pr}>=|\mathrm{M}|$ & \\
\hline Signed Rank & S &, & $\operatorname{Pr}>=|\mathrm{S}|$ & \\
\hline
\end{tabular}

\begin{tabular}{|l|r|}
\hline \multicolumn{2}{|c|}{ Quantis } \\
\hline Level & 0 \\
\hline $100 \%$ Max & 0 \\
\hline $99 \%$ & 0 \\
\hline $95 \%$ & 0 \\
\hline $90 \%$ & 0 \\
\hline $75 \%$ Q3 & 0 \\
\hline $50 \%$ Mediana & 0 \\
\hline $25 \%$ Q1 & 0 \\
\hline $10 \%$ & 0 \\
\hline $5 \%$ & 0 \\
\hline $1 \%$ & 0 \\
\hline $0 \%$ Min & 0 \\
\hline
\end{tabular}


Variável

dependente:

ACI

$\mathrm{ID}=\mathbf{5 0}$

\begin{tabular}{|r|r|r|r|}
\hline \multicolumn{3}{|c|}{ Observações Limite } \\
\hline \multicolumn{2}{|c|}{ Baixa } & \multicolumn{2}{c|}{ Alta } \\
\hline Valor & Obs & Valor & Obs \\
\hline 0 & 748 & 0 & 744 \\
\hline 0 & 747 & 0 & 745 \\
\hline 0 & 746 & 0 & 746 \\
\hline 0 & 745 & 0 & 747 \\
\hline 0 & 744 & 0 & 748 \\
\hline
\end{tabular}


Variável

dependente:

REC

$\mathrm{ID}=51$

\begin{tabular}{|l|r|r|r|}
\hline \multicolumn{3}{|c|}{ Momento } \\
\hline N & 18 & Soma dos pesos & 18 \\
\hline Média & $\begin{array}{r}0 \\
\text { Soma das } \\
\text { observações }\end{array}$ & 0 \\
\hline Desvio-padrão & 0 & Variância & 0 \\
\hline Assimetria &, Curtose &, \\
\hline $\begin{array}{l}\text { Soma dos } \\
\text { quadrados não } \\
\text { corrigida }\end{array}$ & 0 & $\begin{array}{l}\text { Soma dos } \\
\text { quadrados corrigida }\end{array}$ & 0 \\
\hline CV Pearson &, & Erro-padrão médio & 0 \\
\hline
\end{tabular}

\begin{tabular}{|l|r|l|r|}
\hline \multicolumn{3}{|c|}{ Estatística Descritiva Básica } \\
\hline \multicolumn{2}{|c|}{ Posição } & \multicolumn{2}{c|}{ Variabilidade } \\
\hline Média & 0 & Desvio-padrão & 0 \\
\hline Mediana & 0 & Variância & 0 \\
\hline Moda & 0 & Amplitude & 0 \\
\hline & & Amplitude interquartil & 0 \\
\hline
\end{tabular}

\begin{tabular}{|l|l|l|l|l|}
\hline \multicolumn{5}{|c|}{ Testes de Posição: Mu0=0 } \\
\hline Teste & \multicolumn{2}{|c|}{ Estatística } & \multicolumn{2}{c|}{ Valor $\mathbf{p}$} \\
\hline Student t & t &, & $\operatorname{Pr}>|\mathbf{t}|$ & \\
\hline Sign & M &, & $\operatorname{Pr}>=|\mathrm{M}|$ & \\
\hline Signed Rank & S &, & $\operatorname{Pr}>=|\mathrm{S}|$ & \\
\hline
\end{tabular}

\begin{tabular}{|l|r|}
\hline \multicolumn{2}{|c|}{ Quantis } \\
\hline Level & 0 \\
\hline $100 \%$ Max & 0 \\
\hline $99 \%$ & 0 \\
\hline $95 \%$ & 0 \\
\hline $90 \%$ & 0 \\
\hline $75 \%$ Q3 & 0 \\
\hline $50 \%$ Mediana & 0 \\
\hline $25 \%$ Q1 & 0 \\
\hline $10 \%$ & 0 \\
\hline $5 \%$ & 0 \\
\hline $1 \%$ & 0 \\
\hline $0 \%$ Min & 0 \\
\hline
\end{tabular}


Variável

dependente:

REC

$\mathrm{ID}=\mathbf{5 1}$

\begin{tabular}{|r|r|r|r|}
\hline \multicolumn{3}{|c|}{ Observações Limite } \\
\hline \multicolumn{2}{|c|}{ Baixa } & \multicolumn{2}{c|}{ Alta } \\
\hline Valor & Obs & Valor & Obs \\
\hline 0 & 766 & 0 & 762 \\
\hline 0 & 765 & 0 & 763 \\
\hline 0 & 764 & 0 & 764 \\
\hline 0 & 763 & 0 & 765 \\
\hline 0 & 762 & 0 & 766 \\
\hline
\end{tabular}


Variável

dependente:

ACI

ID $=\mathbf{5 1}$

\begin{tabular}{|l|r|l|r|}
\hline \multicolumn{3}{|c|}{ Momento } \\
\hline N & 18 & Soma dos pesos & 18 \\
\hline Média & $\begin{array}{r}0 \\
\text { Soma das } \\
\text { observações }\end{array}$ & 0 \\
\hline Desvio-padrão & 0 & Variância & 0 \\
\hline Assimetria &, Curtose &, \\
\hline $\begin{array}{l}\text { Soma dos } \\
\text { quadrados não } \\
\text { corrigida }\end{array}$ & 0 & $\begin{array}{l}\text { Soma dos } \\
\text { quadrados corrigida }\end{array}$ & 0 \\
\hline CV Pearson &, & Erro-padrão médio & 0 \\
\hline
\end{tabular}

\begin{tabular}{|l|r|l|r|}
\hline \multicolumn{3}{|c|}{ Estatística Descritiva Básica } \\
\hline \multicolumn{2}{|c|}{ Posição } & \multicolumn{2}{c|}{ Variabilidade } \\
\hline Média & 0 & Desvio-padrão & 0 \\
\hline Mediana & 0 & Variância & 0 \\
\hline Moda & 0 & Amplitude & 0 \\
\hline & & Amplitude interquartil & 0 \\
\hline
\end{tabular}

\begin{tabular}{|l|l|l|l|l|}
\hline \multicolumn{5}{|c|}{ Testes de Posição: Mu0=0 } \\
\hline Teste & \multicolumn{2}{|c|}{ Estatística } & \multicolumn{2}{c|}{ Valor $\mathbf{p}$} \\
\hline Student t & t &, & $\operatorname{Pr}>|\mathbf{t}|$ & \\
\hline Sign & M &, & $\operatorname{Pr}>=|\mathrm{M}|$ & \\
\hline Signed Rank & S &, & $\operatorname{Pr}>=|\mathrm{S}|$ & \\
\hline
\end{tabular}

\begin{tabular}{|l|r|}
\hline \multicolumn{2}{|c|}{ Quantis } \\
\hline Level & 0 \\
\hline $100 \%$ Max & 0 \\
\hline $99 \%$ & 0 \\
\hline $95 \%$ & 0 \\
\hline $90 \%$ & 0 \\
\hline $75 \%$ Q3 & 0 \\
\hline $50 \%$ Mediana & 0 \\
\hline $25 \%$ Q1 & 0 \\
\hline $10 \%$ & 0 \\
\hline $5 \%$ & 0 \\
\hline $1 \%$ & 0 \\
\hline $0 \%$ Min & 0 \\
\hline
\end{tabular}


Variável

dependente:

ACI

ID $=\mathbf{5 1}$

\begin{tabular}{|r|r|r|r|}
\hline \multicolumn{3}{|c|}{ Observações Limite } \\
\hline \multicolumn{2}{|c|}{ Baixa } & \multicolumn{2}{c|}{ Alta } \\
\hline Valor & Obs & Valor & Obs \\
\hline 0 & 766 & 0 & 762 \\
\hline 0 & 765 & 0 & 763 \\
\hline 0 & 764 & 0 & 764 \\
\hline 0 & 763 & 0 & 765 \\
\hline 0 & 762 & 0 & 766 \\
\hline
\end{tabular}


Variável

dependente:

REC

$\mathrm{ID}=52$

\begin{tabular}{|l|r|r|r|}
\hline \multicolumn{3}{|l|}{ Momento } \\
\hline N & 14 & Soma dos pesos & 14 \\
\hline Média & $\begin{array}{r}0 \\
\text { Soma das } \\
\text { observações }\end{array}$ & 0 \\
\hline Desvio-padrão & 0 & Variância & 0 \\
\hline Assimetria &, Curtose &, \\
\hline $\begin{array}{l}\text { Soma dos } \\
\text { quadrados não } \\
\text { corrigida }\end{array}$ & 0 & $\begin{array}{l}\text { Soma dos } \\
\text { quadrados corrigida }\end{array}$ & 0 \\
\hline CV Pearson &, & Erro-padrão médio & 0 \\
\hline
\end{tabular}

\begin{tabular}{|l|r|l|r|}
\hline \multicolumn{3}{|c|}{ Estatística Descritiva Básica } \\
\hline \multicolumn{2}{|c|}{ Posição } & \multicolumn{2}{c|}{ Variabilidade } \\
\hline Média & 0 & Desvio-padrão & 0 \\
\hline Mediana & 0 & Variância & 0 \\
\hline Moda & 0 & Amplitude & 0 \\
\hline & & Amplitude interquartil & 0 \\
\hline
\end{tabular}

\begin{tabular}{|l|l|l|l|l|}
\hline \multicolumn{5}{|c|}{ Testes de Posição: Mu0=0 } \\
\hline Teste & \multicolumn{2}{|c|}{ Estatística } & \multicolumn{2}{c|}{ Valor $\mathbf{p}$} \\
\hline Student t & t &, & $\operatorname{Pr}>|\mathbf{t}|$ & \\
\hline Sign & M &, & $\operatorname{Pr}>=|\mathrm{M}|$ & \\
\hline Signed Rank & S &, & $\operatorname{Pr}>=|\mathrm{S}|$ & \\
\hline
\end{tabular}

\begin{tabular}{|l|r|}
\hline \multicolumn{2}{|c|}{ Quantis } \\
\hline Level & 0 \\
\hline $100 \%$ Max & 0 \\
\hline $99 \%$ & 0 \\
\hline $95 \%$ & 0 \\
\hline $90 \%$ & 0 \\
\hline $75 \%$ Q3 & 0 \\
\hline $50 \%$ Mediana & 0 \\
\hline $25 \%$ Q1 & 0 \\
\hline $10 \%$ & 0 \\
\hline $5 \%$ & 0 \\
\hline $1 \%$ & 0 \\
\hline $0 \%$ Min & 0 \\
\hline
\end{tabular}


Variável

dependente:

REC

$\mathrm{ID}=\mathbf{5 2}$

\begin{tabular}{|r|r|r|r|}
\hline \multicolumn{3}{|c|}{ Observações Limite } \\
\hline \multicolumn{2}{|c|}{ Baixa } & \multicolumn{2}{c|}{ Alta } \\
\hline Valor & Obs & Valor & Obs \\
\hline 0 & 780 & 0 & 776 \\
\hline 0 & 779 & 0 & 777 \\
\hline 0 & 778 & 0 & 778 \\
\hline 0 & 777 & 0 & 779 \\
\hline 0 & 776 & 0 & 780 \\
\hline
\end{tabular}


Variável

dependente:

ACI

$\mathrm{ID}=52$

\begin{tabular}{|l|r|l|r|}
\hline \multicolumn{3}{|c|}{ Momento } \\
\hline N & 14 & Soma dos pesos & 14 \\
\hline Média & $\begin{array}{r}0 \\
\text { Soma das } \\
\text { observações }\end{array}$ & 0 \\
\hline Desvio-padrão & 0 & Variância & 0 \\
\hline Assimetria &, Curtose &, \\
\hline $\begin{array}{l}\text { Soma dos } \\
\text { quadrados não } \\
\text { corrigida }\end{array}$ & 0 & $\begin{array}{l}\text { Soma dos } \\
\text { quadrados corrigida }\end{array}$ & 0 \\
\hline CV Pearson &, & Erro-padrão médio & 0 \\
\hline
\end{tabular}

\begin{tabular}{|l|r|l|r|}
\hline \multicolumn{3}{|c|}{ Estatística Descritiva Básica } \\
\hline \multicolumn{2}{|c|}{ Posição } & \multicolumn{2}{c|}{ Variabilidade } \\
\hline Média & 0 & Desvio-padrão & 0 \\
\hline Mediana & 0 & Variância & 0 \\
\hline Moda & 0 & Amplitude & 0 \\
\hline & & Amplitude interquartil & 0 \\
\hline
\end{tabular}

\begin{tabular}{|l|l|l|l|l|}
\hline \multicolumn{4}{|c|}{ Testes de Posição: Mu0=0 } \\
\hline Teste & \multicolumn{2}{|c|}{ Estatística } & \multicolumn{2}{c|}{ Valor $\mathbf{p}$} \\
\hline Student $\mathbf{t}$ & $\mathbf{t}$ & \multicolumn{1}{|c|}{, $\operatorname{Pr}>|\mathbf{t}|$} & \\
\hline Sign & $\mathrm{M}$ &, & $\operatorname{Pr}>=|\mathrm{M}|$ & \\
\hline Signed Rank & S &, & $\operatorname{Pr}>=|\mathrm{S}|$ & \\
\hline
\end{tabular}

\begin{tabular}{|l|r|}
\hline \multicolumn{2}{|c|}{ Quantis } \\
\hline Level & 0 \\
\hline $100 \%$ Max & 0 \\
\hline $99 \%$ & 0 \\
\hline $95 \%$ & 0 \\
\hline $90 \%$ & 0 \\
\hline $75 \%$ Q3 & 0 \\
\hline $50 \%$ Mediana & 0 \\
\hline $25 \%$ Q1 & 0 \\
\hline $10 \%$ & 0 \\
\hline $5 \%$ & 0 \\
\hline $1 \%$ & 0 \\
\hline $0 \%$ Min & 0 \\
\hline
\end{tabular}


Variável

dependente:

ACI

$\mathrm{ID}=\mathbf{5 2}$

\begin{tabular}{|r|r|r|r|}
\hline \multicolumn{3}{|c|}{ Observações Limite } \\
\hline \multicolumn{2}{|c|}{ Baixa } & \multicolumn{2}{c|}{ Alta } \\
\hline Valor & Obs & Valor & Obs \\
\hline 0 & 780 & 0 & 776 \\
\hline 0 & 779 & 0 & 777 \\
\hline 0 & 778 & 0 & 778 \\
\hline 0 & 777 & 0 & 779 \\
\hline 0 & 776 & 0 & 780 \\
\hline
\end{tabular}


Variável

dependente:

REC

ID $=53$

\begin{tabular}{|l|r|l|r|}
\hline \multicolumn{3}{|c|}{ Momento } \\
\hline N & 13 & Soma dos pesos & 13 \\
\hline Média & $\begin{array}{r}0 \\
\text { Soma das } \\
\text { observações }\end{array}$ & 0 \\
\hline Desvio-padrão & 0 & Variância & 0 \\
\hline Assimetria &, Curtose &, \\
\hline $\begin{array}{l}\text { Soma dos } \\
\text { quadrados não } \\
\text { corrigida }\end{array}$ & 0 & $\begin{array}{l}\text { Soma dos } \\
\text { quadrados corrigida }\end{array}$ & 0 \\
\hline CV Pearson &, & Erro-padrão médio & 0 \\
\hline
\end{tabular}

\begin{tabular}{|l|r|l|r|}
\hline \multicolumn{3}{|c|}{ Estatística Descritiva Básica } \\
\hline \multicolumn{2}{|c|}{ Posição } & \multicolumn{2}{c|}{ Variabilidade } \\
\hline Média & 0 & Desvio-padrão & 0 \\
\hline Mediana & 0 & Variância & 0 \\
\hline Moda & 0 & Amplitude & 0 \\
\hline & & Amplitude interquartil & 0 \\
\hline
\end{tabular}

\begin{tabular}{|l|l|l|l|l|}
\hline \multicolumn{5}{|c|}{ Testes de Posição: Mu0=0 } \\
\hline Teste & \multicolumn{2}{|c|}{ Estatística } & \multicolumn{2}{c|}{ Valor $\mathbf{p}$} \\
\hline Student t & t &, & $\operatorname{Pr}>|\mathbf{t}|$ & \\
\hline Sign & M &, & $\operatorname{Pr}>=|\mathrm{M}|$ & \\
\hline Signed Rank & S &, & $\operatorname{Pr}>=|\mathrm{S}|$ & \\
\hline
\end{tabular}

\begin{tabular}{|l|r|}
\hline \multicolumn{2}{|c|}{ Quantis } \\
\hline Level & 0 \\
\hline $100 \%$ Max & 0 \\
\hline $99 \%$ & 0 \\
\hline $95 \%$ & 0 \\
\hline $90 \%$ & 0 \\
\hline $75 \%$ Q3 & 0 \\
\hline $50 \%$ Mediana & 0 \\
\hline $25 \%$ Q1 & 0 \\
\hline $10 \%$ & 0 \\
\hline $5 \%$ & 0 \\
\hline $1 \%$ & 0 \\
\hline $0 \%$ Min & 0 \\
\hline
\end{tabular}


Variável

dependente:

REC

$\mathrm{ID}=\mathbf{5 3}$

\begin{tabular}{|r|r|r|r|}
\hline \multicolumn{3}{|c|}{ Observações Limite } \\
\hline \multicolumn{2}{|c|}{ Baixa } & \multicolumn{2}{c|}{ Alta } \\
\hline Valor & Obs & Valor & Obs \\
\hline 0 & 793 & 0 & 789 \\
\hline 0 & 792 & 0 & 790 \\
\hline 0 & 791 & 0 & 791 \\
\hline 0 & 790 & 0 & 792 \\
\hline 0 & 789 & 0 & 793 \\
\hline
\end{tabular}


Variável

dependente:

ACI

$\mathrm{ID}=\mathbf{5 3}$

\begin{tabular}{|l|r|l|r|}
\hline \multicolumn{3}{|c|}{ Momento } \\
\hline N & 13 & Soma dos pesos & 13 \\
\hline Média & $\begin{array}{r}0 \\
\text { Soma das } \\
\text { observações }\end{array}$ & 0 \\
\hline Desvio-padrão & 0 & Variância & 0 \\
\hline Assimetria &, Curtose &, \\
\hline $\begin{array}{l}\text { Soma dos } \\
\text { quadrados não } \\
\text { corrigida }\end{array}$ & 0 & $\begin{array}{l}\text { Soma dos } \\
\text { quadrados corrigida }\end{array}$ & 0 \\
\hline CV Pearson &, & Erro-padrão médio & 0 \\
\hline
\end{tabular}

\begin{tabular}{|l|r|l|r|}
\hline \multicolumn{3}{|c|}{ Estatística Descritiva Básica } \\
\hline \multicolumn{2}{|c|}{ Posição } & \multicolumn{2}{c|}{ Variabilidade } \\
\hline Média & 0 & Desvio-padrão & 0 \\
\hline Mediana & 0 & Variância & 0 \\
\hline Moda & 0 & Amplitude & 0 \\
\hline & & Amplitude interquartil & 0 \\
\hline
\end{tabular}

\begin{tabular}{|l|l|l|l|l|}
\hline \multicolumn{4}{|c|}{ Testes de Posição: Mu0=0 } \\
\hline Teste & \multicolumn{2}{|c|}{ Estatística } & \multicolumn{2}{c|}{ Valor $\mathbf{p}$} \\
\hline Student $\mathbf{t}$ & $\mathbf{t}$ & \multicolumn{1}{|c|}{, $\operatorname{Pr}>|\mathbf{t}|$} & \\
\hline Sign & $\mathrm{M}$ &, & $\operatorname{Pr}>=|\mathrm{M}|$ & \\
\hline Signed Rank & S &, & $\operatorname{Pr}>=|\mathrm{S}|$ & \\
\hline
\end{tabular}

\begin{tabular}{|l|r|}
\hline \multicolumn{2}{|c|}{ Quantis } \\
\hline Level & 0 \\
\hline $100 \%$ Max & 0 \\
\hline $99 \%$ & 0 \\
\hline $95 \%$ & 0 \\
\hline $90 \%$ & 0 \\
\hline $75 \%$ Q3 & 0 \\
\hline $50 \%$ Mediana & 0 \\
\hline $25 \%$ Q1 & 0 \\
\hline $10 \%$ & 0 \\
\hline $5 \%$ & 0 \\
\hline $1 \%$ & 0 \\
\hline $0 \%$ Min & 0 \\
\hline
\end{tabular}


Variável

dependente:

ACI

$\mathrm{ID}=\mathbf{5 3}$

\begin{tabular}{|r|r|r|r|}
\hline \multicolumn{3}{|c|}{ Observações Limite } \\
\hline \multicolumn{2}{|c|}{ Baixa } & \multicolumn{2}{c|}{ Alta } \\
\hline Valor & Obs & Valor & Obs \\
\hline 0 & 793 & 0 & 789 \\
\hline 0 & 792 & 0 & 790 \\
\hline 0 & 791 & 0 & 791 \\
\hline 0 & 790 & 0 & 792 \\
\hline 0 & 789 & 0 & 793 \\
\hline
\end{tabular}


Variável

dependente:

REC

$\mathrm{ID}=54$

\begin{tabular}{|l|r|r|r|}
\hline \multicolumn{3}{|c|}{ Momento } \\
\hline N & 12 Soma dos pesos & 12 \\
\hline Média & $\begin{array}{r}0 \\
\text { Soma das } \\
\text { observações }\end{array}$ & 0 \\
\hline Desvio-padrão & 0 & Variância & 0 \\
\hline Assimetria &, Curtose &, \\
\hline $\begin{array}{l}\text { Soma dos } \\
\text { quadrados não } \\
\text { corrigida }\end{array}$ & 0 & $\begin{array}{l}\text { Soma dos } \\
\text { quadrados corrigida }\end{array}$ & 0 \\
\hline CV Pearson &, & Erro-padrão médio & 0 \\
\hline
\end{tabular}

\begin{tabular}{|l|r|l|r|}
\hline \multicolumn{3}{|c|}{ Estatística Descritiva Básica } \\
\hline \multicolumn{2}{|c|}{ Posição } & \multicolumn{2}{c|}{ Variabilidade } \\
\hline Média & 0 & Desvio-padrão & 0 \\
\hline Mediana & 0 & Variância & 0 \\
\hline Moda & 0 & Amplitude & 0 \\
\hline & & Amplitude interquartil & 0 \\
\hline
\end{tabular}

\begin{tabular}{|l|l|l|l|l|}
\hline \multicolumn{5}{|c|}{ Testes de Posição: Mu0=0 } \\
\hline Teste & \multicolumn{2}{|c|}{ Estatística } & \multicolumn{2}{c|}{ Valor $\mathbf{p}$} \\
\hline Student t & t &, & $\operatorname{Pr}>|\mathbf{t}|$ & \\
\hline Sign & M &, & $\operatorname{Pr}>=|\mathrm{M}|$ & \\
\hline Signed Rank & S &, & $\operatorname{Pr}>=|\mathrm{S}|$ & \\
\hline
\end{tabular}

\begin{tabular}{|l|r|}
\hline \multicolumn{2}{|c|}{ Quantis } \\
\hline Level & 0 \\
\hline $100 \%$ Max & 0 \\
\hline $99 \%$ & 0 \\
\hline $95 \%$ & 0 \\
\hline $90 \%$ & 0 \\
\hline $75 \%$ Q3 & 0 \\
\hline $50 \%$ Mediana & 0 \\
\hline $25 \%$ Q1 & 0 \\
\hline $10 \%$ & 0 \\
\hline $5 \%$ & 0 \\
\hline $1 \%$ & 0 \\
\hline $0 \%$ Min & 0 \\
\hline
\end{tabular}


Variável

dependente:

REC

ID $=54$

\begin{tabular}{|r|r|r|r|}
\hline \multicolumn{3}{|c|}{ Observações Limite } \\
\hline \multicolumn{2}{|c|}{ Baixa } & \multicolumn{2}{c|}{ Alta } \\
\hline Valor & Obs & Valor & Obs \\
\hline 0 & 805 & 0 & 801 \\
\hline 0 & 804 & 0 & 802 \\
\hline 0 & 803 & 0 & 803 \\
\hline 0 & 802 & 0 & 804 \\
\hline 0 & 801 & 0 & 805 \\
\hline
\end{tabular}


Variável

dependente:

ACI

ID $=54$

\begin{tabular}{|l|r|l|r|}
\hline \multicolumn{3}{|c|}{ Momento } \\
\hline N & 12 & Soma dos pesos & 12 \\
\hline Média & $\begin{array}{r}0 \\
\text { Soma das } \\
\text { observações }\end{array}$ & 0 \\
\hline Desvio-padrão & 0 & Variância & 0 \\
\hline Assimetria &, Curtose &, \\
\hline $\begin{array}{l}\text { Soma dos } \\
\text { quadrados não } \\
\text { corrigida }\end{array}$ & 0 & $\begin{array}{l}\text { Soma dos } \\
\text { quadrados corrigida }\end{array}$ & 0 \\
\hline CV Pearson &, & Erro-padrão médio & 0 \\
\hline
\end{tabular}

\begin{tabular}{|l|r|l|r|}
\hline \multicolumn{3}{|c|}{ Estatística Descritiva Básica } \\
\hline \multicolumn{2}{|c|}{ Posição } & \multicolumn{2}{c|}{ Variabilidade } \\
\hline Média & 0 & Desvio-padrão & 0 \\
\hline Mediana & 0 & Variância & 0 \\
\hline Moda & 0 & Amplitude & 0 \\
\hline & & Amplitude interquartil & 0 \\
\hline
\end{tabular}

\begin{tabular}{|l|l|l|l|l|}
\hline \multicolumn{5}{|c|}{ Testes de Posição: Mu0=0 } \\
\hline Teste & \multicolumn{2}{|c|}{ Estatística } & \multicolumn{2}{c|}{ Valor $\mathbf{p}$} \\
\hline Student t & t &, & $\operatorname{Pr}>|\mathbf{t}|$ & \\
\hline Sign & M &, & $\operatorname{Pr}>=|\mathrm{M}|$ & \\
\hline Signed Rank & S &, & $\operatorname{Pr}>=|\mathrm{S}|$ & \\
\hline
\end{tabular}

\begin{tabular}{|l|r|}
\hline \multicolumn{2}{|c|}{ Quantis } \\
\hline Level & 0 \\
\hline $100 \%$ Max & 0 \\
\hline $99 \%$ & 0 \\
\hline $95 \%$ & 0 \\
\hline $90 \%$ & 0 \\
\hline $75 \%$ Q3 & 0 \\
\hline $50 \%$ Mediana & 0 \\
\hline $25 \%$ Q1 & 0 \\
\hline $10 \%$ & 0 \\
\hline $5 \%$ & 0 \\
\hline $1 \%$ & 0 \\
\hline $0 \%$ Min & 0 \\
\hline
\end{tabular}


Variável

dependente:

ACI

ID $=54$

\begin{tabular}{|r|r|r|r|}
\hline \multicolumn{3}{|c|}{ Observações Limite } \\
\hline \multicolumn{2}{|c|}{ Baixa } & \multicolumn{2}{c|}{ Alta } \\
\hline Valor & Obs & Valor & Obs \\
\hline 0 & 805 & 0 & 801 \\
\hline 0 & 804 & 0 & 802 \\
\hline 0 & 803 & 0 & 803 \\
\hline 0 & 802 & 0 & 804 \\
\hline 0 & 801 & 0 & 805 \\
\hline
\end{tabular}


Variável

dependente:

REC

$\mathrm{ID}=\mathbf{5 5}$

\begin{tabular}{|l|r|l|r|}
\hline \multicolumn{3}{|c|}{ Momento } \\
\hline N & 1 Soma dos pesos & 1 \\
\hline Média & $\begin{array}{r}0 \\
\text { Soma das } \\
\text { observações }\end{array}$ & 0 \\
\hline Desvio-padrão &, Variância &, \\
\hline Assimetria &, Curtose &, \\
\hline $\begin{array}{l}\text { Soma dos } \\
\text { quadrados não } \\
\text { corrigida }\end{array}$ & $0 \begin{array}{l}\text { Soma dos } \\
\text { quadrados corrigida }\end{array}$ & 0 \\
\hline CV Pearson &, & Erro-padrão médio &, \\
\hline
\end{tabular}

\begin{tabular}{|l|r|l|r|}
\hline \multicolumn{3}{|c|}{ Estatística Descritiva Básica } \\
\hline \multicolumn{2}{|c|}{ Posição } & \multicolumn{2}{c|}{ Variabilidade } \\
\hline Média & 0 & Desvio-padrão & \\
\hline Mediana & 0 & Variância & 0 \\
\hline Moda & 0 & Amplitude & 0 \\
\hline & & Amplitude interquartil & \\
\hline
\end{tabular}

\begin{tabular}{|l|l|l|l|l|}
\hline \multicolumn{4}{|c|}{ Testes de Posição: Mu0=0 } \\
\hline Teste & \multicolumn{2}{|c|}{ Estatística } & \multicolumn{2}{c|}{ Valor $\mathbf{p}$} \\
\hline Student $\mathbf{t}$ & $\mathbf{t}$ & \multicolumn{1}{|c|}{, $\operatorname{Pr}>|\mathbf{t}|$} & \\
\hline Sign & $\mathrm{M}$ &, & $\operatorname{Pr}>=|\mathrm{M}|$ & \\
\hline Signed Rank & S &, & $\operatorname{Pr}>=|\mathrm{S}|$ & \\
\hline
\end{tabular}

\begin{tabular}{|l|r|}
\hline \multicolumn{2}{|c|}{ Quantis } \\
\hline Level & 0 \\
\hline $100 \%$ Max & 0 \\
\hline $99 \%$ & 0 \\
\hline $95 \%$ & 0 \\
\hline $90 \%$ & 0 \\
\hline $75 \%$ Q3 & 0 \\
\hline $50 \%$ Mediana & 0 \\
\hline $25 \%$ Q1 & 0 \\
\hline $10 \%$ & 0 \\
\hline $5 \%$ & 0 \\
\hline $1 \%$ & 0 \\
\hline $0 \%$ Min & 0 \\
\hline
\end{tabular}


Variável

dependente:

REC

$\mathrm{ID}=\mathbf{5 5}$

\begin{tabular}{|c|c|c|c|}
\hline \multicolumn{4}{|c|}{ Observações Limite } \\
\hline \multicolumn{2}{|c|}{ Baixa } & \multicolumn{2}{|c|}{ Alta } \\
\hline al & Obs & Valor & Obs \\
\hline 0 & 806 & 0 & 806 \\
\hline
\end{tabular}


Variável

dependente:

ACI

$\mathrm{ID}=\mathbf{5 5}$

\begin{tabular}{|l|r|l|r|}
\hline \multicolumn{3}{|c|}{ Momento } \\
\hline N & 1 Soma dos pesos & 1 \\
\hline Média & $\begin{array}{r}0 \\
\text { Soma das } \\
\text { observações }\end{array}$ & 0 \\
\hline Desvio-padrão &, Variância &, \\
\hline Assimetria &, Curtose &, \\
\hline $\begin{array}{l}\text { Soma dos } \\
\text { quadrados não } \\
\text { corrigida }\end{array}$ & $0 \begin{array}{l}\text { Soma dos } \\
\text { quadrados corrigida }\end{array}$ & 0 \\
\hline CV Pearson &, & Erro-padrão médio &, \\
\hline
\end{tabular}

\begin{tabular}{|l|r|l|r|}
\hline \multicolumn{3}{|c|}{ Estatística Descritiva Básica } \\
\hline \multicolumn{2}{|c|}{ Posição } & \multicolumn{2}{c|}{ Variabilidade } \\
\hline Média & 0 & Desvio-padrão & \\
\hline Mediana & 0 & Variância & 0 \\
\hline Moda & 0 & Amplitude & 0 \\
\hline & & Amplitude interquartil & 0 \\
\hline
\end{tabular}

\begin{tabular}{|l|l|l|l|l|}
\hline \multicolumn{4}{|c|}{ Testes de Posição: Mu0=0 } \\
\hline Teste & \multicolumn{2}{|c|}{ Estatística } & \multicolumn{2}{c|}{ Valor $\mathbf{p}$} \\
\hline Student $\mathbf{t}$ & $\mathbf{t}$ & \multicolumn{1}{|c|}{, $\operatorname{Pr}>|\mathbf{t}|$} & \\
\hline Sign & $\mathrm{M}$ &, & $\operatorname{Pr}>=|\mathrm{M}|$ & \\
\hline Signed Rank & S &, & $\operatorname{Pr}>=|\mathrm{S}|$ & \\
\hline
\end{tabular}

\begin{tabular}{|l|r|}
\hline \multicolumn{2}{|c|}{ Quantis } \\
\hline Level & 0 \\
\hline $100 \%$ Max & 0 \\
\hline $99 \%$ & 0 \\
\hline $95 \%$ & 0 \\
\hline $90 \%$ & 0 \\
\hline $75 \%$ Q3 & 0 \\
\hline $50 \%$ Mediana & 0 \\
\hline $25 \%$ Q1 & 0 \\
\hline $10 \%$ & 0 \\
\hline $5 \%$ & 0 \\
\hline $1 \%$ & 0 \\
\hline $0 \%$ Min & 0 \\
\hline
\end{tabular}


Variável

dependente:

ACI

$\mathrm{ID}=\mathbf{5 5}$

\begin{tabular}{|c|c|c|c|}
\hline \multicolumn{4}{|c|}{ Observações Limite } \\
\hline \multicolumn{2}{|c|}{ Baixa } & \multicolumn{2}{|c|}{ Alta } \\
\hline Valor & Obs & Valor & Obs \\
\hline 0 & 806 & 0 & 806 \\
\hline
\end{tabular}


Variável

dependente:

REC

$\mathrm{ID}=56$

\begin{tabular}{|l|r|l|r|}
\hline \multicolumn{3}{|c|}{ Momento } \\
\hline N & 6 & Soma dos pesos & 6 \\
\hline Média & $\begin{array}{r}0 \\
\text { Soma das } \\
\text { observações }\end{array}$ & 0 \\
\hline Desvio-padrão & 0 & Variância & 0 \\
\hline Assimetria &, Curtose &, \\
\hline $\begin{array}{l}\text { Soma dos } \\
\text { quadrados não } \\
\text { corrigida }\end{array}$ & 0 & $\begin{array}{l}\text { Soma dos } \\
\text { quadrados corrigida }\end{array}$ & 0 \\
\hline CV Pearson &, & Erro-padrão médio & 0 \\
\hline
\end{tabular}

\begin{tabular}{|l|r|l|r|}
\hline \multicolumn{3}{|c|}{ Estatística Descritiva Básica } \\
\hline \multicolumn{2}{|c|}{ Posição } & \multicolumn{2}{c|}{ Variabilidade } \\
\hline Média & 0 & Desvio-padrão & 0 \\
\hline Mediana & 0 & Variância & 0 \\
\hline Moda & 0 & Amplitude & 0 \\
\hline & & Amplitude interquartil & 0 \\
\hline
\end{tabular}

\begin{tabular}{|l|l|l|l|l|}
\hline \multicolumn{4}{|c|}{ Testes de Posição: Mu0=0 } \\
\hline Teste & \multicolumn{2}{|c|}{ Estatística } & \multicolumn{2}{c|}{ Valor $\mathbf{p}$} \\
\hline Student $\mathbf{t}$ & $\mathbf{t}$ & \multicolumn{1}{|c|}{, $\operatorname{Pr}>|\mathbf{t}|$} & \\
\hline Sign & $\mathrm{M}$ &, & $\operatorname{Pr}>=|\mathrm{M}|$ & \\
\hline Signed Rank & S &, & $\operatorname{Pr}>=|\mathrm{S}|$ & \\
\hline
\end{tabular}

\begin{tabular}{|l|r|}
\hline \multicolumn{2}{|c|}{ Quantis } \\
\hline Level & 0 \\
\hline $100 \%$ Max & 0 \\
\hline $99 \%$ & 0 \\
\hline $95 \%$ & 0 \\
\hline $90 \%$ & 0 \\
\hline $75 \%$ Q3 & 0 \\
\hline $50 \%$ Mediana & 0 \\
\hline $25 \%$ Q1 & 0 \\
\hline $10 \%$ & 0 \\
\hline $5 \%$ & 0 \\
\hline $1 \%$ & 0 \\
\hline $0 \%$ Min & 0 \\
\hline
\end{tabular}


Variável

dependente:

REC

$\mathrm{ID}=56$

\begin{tabular}{|r|r|r|r|}
\hline \multicolumn{3}{|c|}{ Observações Limite } \\
\hline \multicolumn{2}{|c|}{ Baixa } & \multicolumn{2}{c|}{ Alta } \\
\hline Valor & Obs & Valor & Obs \\
\hline 0 & 812 & 0 & 808 \\
\hline 0 & 811 & 0 & 809 \\
\hline 0 & 810 & 0 & 810 \\
\hline 0 & 809 & 0 & 811 \\
\hline 0 & 808 & 0 & 812 \\
\hline
\end{tabular}


Variável

dependente:

ACI

$\mathrm{ID}=56$

\begin{tabular}{|l|r|l|r|}
\hline \multicolumn{3}{|c|}{ Momento } \\
\hline N & 6 & Soma dos pesos & 6 \\
\hline Média & $\begin{array}{r}0 \\
\text { Soma das } \\
\text { observações }\end{array}$ & 0 \\
\hline Desvio-padrão & 0 & Variância & 0 \\
\hline Assimetria &, Curtose &, \\
\hline $\begin{array}{l}\text { Soma dos } \\
\text { quadrados não } \\
\text { corrigida }\end{array}$ & 0 & $\begin{array}{l}\text { Soma dos } \\
\text { quadrados corrigida }\end{array}$ & 0 \\
\hline CV Pearson &, & Erro-padrão médio & 0 \\
\hline
\end{tabular}

\begin{tabular}{|l|r|l|r|}
\hline \multicolumn{3}{|c|}{ Estatística Descritiva Básica } \\
\hline \multicolumn{2}{|c|}{ Posição } & \multicolumn{2}{c|}{ Variabilidade } \\
\hline Média & 0 & Desvio-padrão & 0 \\
\hline Mediana & 0 & Variância & 0 \\
\hline Moda & 0 & Amplitude & 0 \\
\hline & & Amplitude interquartil & 0 \\
\hline
\end{tabular}

\begin{tabular}{|l|l|l|l|l|}
\hline \multicolumn{4}{|c|}{ Testes de Posição: Mu0=0 } \\
\hline Teste & \multicolumn{2}{|c|}{ Estatística } & \multicolumn{2}{c|}{ Valor $\mathbf{p}$} \\
\hline Student $\mathbf{t}$ & $\mathbf{t}$ & \multicolumn{1}{|c|}{, $\operatorname{Pr}>|\mathbf{t}|$} & \\
\hline Sign & $\mathrm{M}$ &, & $\operatorname{Pr}>=|\mathrm{M}|$ & \\
\hline Signed Rank & S &, & $\operatorname{Pr}>=|\mathrm{S}|$ & \\
\hline
\end{tabular}

\begin{tabular}{|l|r|}
\hline \multicolumn{2}{|c|}{ Quantis } \\
\hline Level & 0 \\
\hline $100 \%$ Max & 0 \\
\hline $99 \%$ & 0 \\
\hline $95 \%$ & 0 \\
\hline $90 \%$ & 0 \\
\hline $75 \%$ Q3 & 0 \\
\hline $50 \%$ Mediana & 0 \\
\hline $25 \%$ Q1 & 0 \\
\hline $10 \%$ & 0 \\
\hline $5 \%$ & 0 \\
\hline $1 \%$ & 0 \\
\hline $0 \%$ Min & 0 \\
\hline
\end{tabular}


Variável

dependente:

ACI

$\mathrm{ID}=56$

\begin{tabular}{|r|r|r|r|}
\hline \multicolumn{3}{|c|}{ Observações Limite } \\
\hline \multicolumn{2}{|c|}{ Baixa } & \multicolumn{2}{c|}{ Alta } \\
\hline Valor & Obs & Valor & Obs \\
\hline 0 & 812 & 0 & 808 \\
\hline 0 & 811 & 0 & 809 \\
\hline 0 & 810 & 0 & 810 \\
\hline 0 & 809 & 0 & 811 \\
\hline 0 & 808 & 0 & 812 \\
\hline
\end{tabular}


Variável

dependente:

REC

ID $=\mathbf{5 7}$

\begin{tabular}{|l|r|l|r|}
\hline \multicolumn{3}{|c|}{ Momento } \\
\hline N & 18 & Soma dos pesos & 18 \\
\hline Média & $\begin{array}{r}0 \\
\text { Soma das } \\
\text { observações }\end{array}$ & 0 \\
\hline Desvio-padrão & 0 & Variância & 0 \\
\hline Assimetria &, Curtose &, \\
\hline $\begin{array}{l}\text { Soma dos } \\
\text { quadrados não } \\
\text { corrigida }\end{array}$ & 0 & $\begin{array}{l}\text { Soma dos } \\
\text { quadrados corrigida }\end{array}$ & 0 \\
\hline CV Pearson &, & Erro-padrão médio & 0 \\
\hline
\end{tabular}

\begin{tabular}{|l|r|l|r|}
\hline \multicolumn{3}{|c|}{ Estatística Descritiva Básica } \\
\hline \multicolumn{2}{|c|}{ Posição } & \multicolumn{2}{c|}{ Variabilidade } \\
\hline Média & 0 & Desvio-padrão & 0 \\
\hline Mediana & 0 & Variância & 0 \\
\hline Moda & 0 & Amplitude & 0 \\
\hline & & Amplitude interquartil & 0 \\
\hline
\end{tabular}

\begin{tabular}{|l|l|l|l|l|}
\hline \multicolumn{5}{|c|}{ Testes de Posição: Mu0=0 } \\
\hline Teste & \multicolumn{2}{|c|}{ Estatística } & \multicolumn{2}{c|}{ Valor $\mathbf{p}$} \\
\hline Student t & t &, & $\operatorname{Pr}>|\mathbf{t}|$ & \\
\hline Sign & M &, & $\operatorname{Pr}>=|\mathrm{M}|$ & \\
\hline Signed Rank & S &, & $\operatorname{Pr}>=|\mathrm{S}|$ & \\
\hline
\end{tabular}

\begin{tabular}{|l|r|}
\hline \multicolumn{2}{|c|}{ Quantis } \\
\hline Level & 0 \\
\hline $100 \%$ Max & 0 \\
\hline $99 \%$ & 0 \\
\hline $95 \%$ & 0 \\
\hline $90 \%$ & 0 \\
\hline $75 \%$ Q3 & 0 \\
\hline $50 \%$ Mediana & 0 \\
\hline $25 \%$ Q1 & 0 \\
\hline $10 \%$ & 0 \\
\hline $5 \%$ & 0 \\
\hline $1 \%$ & 0 \\
\hline $0 \%$ Min & 0 \\
\hline
\end{tabular}




\section{Variável}

dependente:

REC

$\mathrm{ID}=\mathbf{5 7}$

\begin{tabular}{|r|r|r|r|}
\hline \multicolumn{3}{|c|}{ Observações Limite } \\
\hline \multicolumn{2}{|c|}{ Baixa } & \multicolumn{2}{c|}{ Alta } \\
\hline Valor & Obs & Valor & Obs \\
\hline 0 & 830 & 0 & 826 \\
\hline 0 & 829 & 0 & 827 \\
\hline 0 & 828 & 0 & 828 \\
\hline 0 & 827 & 0 & 829 \\
\hline 0 & 826 & 0 & 830 \\
\hline
\end{tabular}


Variável

dependente:

ACI

ID $=\mathbf{5 7}$

\begin{tabular}{|l|r|l|r|}
\hline \multicolumn{3}{|c|}{ Momento } \\
\hline N & 18 & Soma dos pesos & 18 \\
\hline Média & $\begin{array}{r}0 \\
\text { Soma das } \\
\text { observações }\end{array}$ & 0 \\
\hline Desvio-padrão & 0 & Variância & 0 \\
\hline Assimetria &, Curtose &, \\
\hline $\begin{array}{l}\text { Soma dos } \\
\text { quadrados não } \\
\text { corrigida }\end{array}$ & 0 & $\begin{array}{l}\text { Soma dos } \\
\text { quadrados corrigida }\end{array}$ & 0 \\
\hline CV Pearson &, & Erro-padrão médio & 0 \\
\hline
\end{tabular}

\begin{tabular}{|l|r|l|r|}
\hline \multicolumn{3}{|c|}{ Estatística Descritiva Básica } \\
\hline \multicolumn{2}{|c|}{ Posição } & \multicolumn{2}{c|}{ Variabilidade } \\
\hline Média & 0 & Desvio-padrão & 0 \\
\hline Mediana & 0 & Variância & 0 \\
\hline Moda & 0 & Amplitude & 0 \\
\hline & & Amplitude interquartil & 0 \\
\hline
\end{tabular}

\begin{tabular}{|l|l|l|l|l|}
\hline \multicolumn{5}{|c|}{ Testes de Posição: Mu0=0 } \\
\hline Teste & \multicolumn{2}{|c|}{ Estatística } & \multicolumn{2}{c|}{ Valor $\mathbf{p}$} \\
\hline Student t & t &, & $\operatorname{Pr}>|\mathbf{t}|$ & \\
\hline Sign & M &, & $\operatorname{Pr}>=|\mathrm{M}|$ & \\
\hline Signed Rank & S &, & $\operatorname{Pr}>=|\mathrm{S}|$ & \\
\hline
\end{tabular}

\begin{tabular}{|l|r|}
\hline \multicolumn{2}{|c|}{ Quantis } \\
\hline Level & 0 \\
\hline $100 \%$ Max & 0 \\
\hline $99 \%$ & 0 \\
\hline $95 \%$ & 0 \\
\hline $90 \%$ & 0 \\
\hline $75 \%$ Q3 & 0 \\
\hline $50 \%$ Mediana & 0 \\
\hline $25 \%$ Q1 & 0 \\
\hline $10 \%$ & 0 \\
\hline $5 \%$ & 0 \\
\hline $1 \%$ & 0 \\
\hline $0 \%$ Min & 0 \\
\hline
\end{tabular}


Variável

dependente:

ACI

$\mathrm{ID}=\mathbf{5 7}$

\begin{tabular}{|r|r|r|r|}
\hline \multicolumn{3}{|c|}{ Observações Limite } \\
\hline \multicolumn{2}{|c|}{ Baixa } & \multicolumn{2}{c|}{ Alta } \\
\hline Valor & Obs & Valor & Obs \\
\hline 0 & 830 & 0 & 826 \\
\hline 0 & 829 & 0 & 827 \\
\hline 0 & 828 & 0 & 828 \\
\hline 0 & 827 & 0 & 829 \\
\hline 0 & 826 & 0 & 830 \\
\hline
\end{tabular}


Variável

dependente:

REC

$\mathrm{ID}=58$

\begin{tabular}{|l|r|l|r|}
\hline \multicolumn{3}{|c|}{ Momento } \\
\hline N & 10 & Soma dos pesos & 10 \\
\hline Média & $\begin{array}{r}0 \\
\text { Soma das } \\
\text { observações }\end{array}$ & 0 \\
\hline Desvio-padrão & 0 & Variância & 0 \\
\hline Assimetria &, Curtose &, \\
\hline $\begin{array}{l}\text { Soma dos } \\
\text { quadrados não } \\
\text { corrigida }\end{array}$ & 0 & $\begin{array}{l}\text { Soma dos } \\
\text { quadrados corrigida }\end{array}$ & 0 \\
\hline CV Pearson &, & Erro-padrão médio & 0 \\
\hline
\end{tabular}

\begin{tabular}{|l|r|l|r|}
\hline \multicolumn{3}{|c|}{ Estatística Descritiva Básica } \\
\hline \multicolumn{2}{|c|}{ Posição } & \multicolumn{2}{c|}{ Variabilidade } \\
\hline Média & 0 & Desvio-padrão & 0 \\
\hline Mediana & 0 & Variância & 0 \\
\hline Moda & 0 & Amplitude & 0 \\
\hline & & Amplitude interquartil & 0 \\
\hline
\end{tabular}

\begin{tabular}{|l|l|l|l|l|}
\hline \multicolumn{4}{|c|}{ Testes de Posição: Mu0=0 } \\
\hline Teste & \multicolumn{2}{|c|}{ Estatística } & \multicolumn{2}{c|}{ Valor $\mathbf{p}$} \\
\hline Student $\mathbf{t}$ & $\mathbf{t}$ & \multicolumn{1}{|c|}{, $\operatorname{Pr}>|\mathbf{t}|$} & \\
\hline Sign & $\mathrm{M}$ &, & $\operatorname{Pr}>=|\mathrm{M}|$ & \\
\hline Signed Rank & S &, & $\operatorname{Pr}>=|\mathrm{S}|$ & \\
\hline
\end{tabular}

\begin{tabular}{|l|r|}
\hline \multicolumn{2}{|c|}{ Quantis } \\
\hline Level & 0 \\
\hline $100 \%$ Max & 0 \\
\hline $99 \%$ & 0 \\
\hline $95 \%$ & 0 \\
\hline $90 \%$ & 0 \\
\hline $75 \%$ Q3 & 0 \\
\hline $50 \%$ Mediana & 0 \\
\hline $25 \%$ Q1 & 0 \\
\hline $10 \%$ & 0 \\
\hline $5 \%$ & 0 \\
\hline $1 \%$ & 0 \\
\hline $0 \%$ Min & 0 \\
\hline
\end{tabular}


Variável

dependente:

REC

$\mathrm{ID}=\mathbf{5 8}$

\begin{tabular}{|r|r|r|r|}
\hline \multicolumn{3}{|c|}{ Observações Limite } \\
\hline \multicolumn{2}{|c|}{ Baixa } & \multicolumn{2}{c|}{ Alta } \\
\hline Valor & Obs & Valor & Obs \\
\hline 0 & 840 & 0 & 836 \\
\hline 0 & 839 & 0 & 837 \\
\hline 0 & 838 & 0 & 838 \\
\hline 0 & 837 & 0 & 839 \\
\hline 0 & 836 & 0 & 840 \\
\hline
\end{tabular}


Variável

dependente:

ACI

$\mathrm{ID}=\mathbf{5 8}$

\begin{tabular}{|l|r|l|r|}
\hline \multicolumn{3}{|c|}{ Momento } \\
\hline N & 10 & Soma dos pesos & 10 \\
\hline Média & $\begin{array}{r}0 \\
\text { Soma das } \\
\text { observações }\end{array}$ & 0 \\
\hline Desvio-padrão & 0 & Variância & 0 \\
\hline Assimetria &, Curtose &, \\
\hline $\begin{array}{l}\text { Soma dos } \\
\text { quadrados não } \\
\text { corrigida }\end{array}$ & 0 & $\begin{array}{l}\text { Soma dos } \\
\text { quadrados corrigida }\end{array}$ & 0 \\
\hline CV Pearson &, & Erro-padrão médio & 0 \\
\hline
\end{tabular}

\begin{tabular}{|l|r|l|r|}
\hline \multicolumn{3}{|c|}{ Estatística Descritiva Básica } \\
\hline \multicolumn{2}{|c|}{ Posição } & \multicolumn{2}{c|}{ Variabilidade } \\
\hline Média & 0 & Desvio-padrão & 0 \\
\hline Mediana & 0 & Variância & 0 \\
\hline Moda & 0 & Amplitude & 0 \\
\hline & & Amplitude interquartil & 0 \\
\hline
\end{tabular}

\begin{tabular}{|l|l|l|l|l|}
\hline \multicolumn{5}{|c|}{ Testes de Posição: Mu0=0 } \\
\hline Teste & \multicolumn{2}{|c|}{ Estatística } & \multicolumn{2}{c|}{ Valor $\mathbf{p}$} \\
\hline Student t & t &, & $\operatorname{Pr}>|\mathbf{t}|$ & \\
\hline Sign & M &, & $\operatorname{Pr}>=|\mathrm{M}|$ & \\
\hline Signed Rank & S &, & $\operatorname{Pr}>=|\mathrm{S}|$ & \\
\hline
\end{tabular}

\begin{tabular}{|l|r|}
\hline \multicolumn{2}{|c|}{ Quantis } \\
\hline Level & 0 \\
\hline $100 \%$ Max & 0 \\
\hline $99 \%$ & 0 \\
\hline $95 \%$ & 0 \\
\hline $90 \%$ & 0 \\
\hline $75 \%$ Q3 & 0 \\
\hline $50 \%$ Mediana & 0 \\
\hline $25 \%$ Q1 & 0 \\
\hline $10 \%$ & 0 \\
\hline $5 \%$ & 0 \\
\hline $1 \%$ & 0 \\
\hline $0 \%$ Min & 0 \\
\hline
\end{tabular}


Variável

dependente:

ACI

$\mathrm{ID}=\mathbf{5 8}$

\begin{tabular}{|r|r|r|r|}
\hline \multicolumn{3}{|c|}{ Observações Limite } \\
\hline \multicolumn{2}{|c|}{ Baixa } & \multicolumn{2}{c|}{ Alta } \\
\hline Valor & Obs & Valor & Obs \\
\hline 0 & 840 & 0 & 836 \\
\hline 0 & 839 & 0 & 837 \\
\hline 0 & 838 & 0 & 838 \\
\hline 0 & 837 & 0 & 839 \\
\hline 0 & 836 & 0 & 840 \\
\hline
\end{tabular}


Variável

dependente:

REC

ID $=\mathbf{5 9}$

\begin{tabular}{|l|r|l|r|}
\hline \multicolumn{3}{|c|}{ Momento } \\
\hline N & 10 & Soma dos pesos & 10 \\
\hline Média & $\begin{array}{r}0 \\
\text { Soma das } \\
\text { observações }\end{array}$ & 0 \\
\hline Desvio-padrão & 0 & Variância & 0 \\
\hline Assimetria &, Curtose &, \\
\hline $\begin{array}{l}\text { Soma dos } \\
\text { quadrados não } \\
\text { corrigida }\end{array}$ & 0 & $\begin{array}{l}\text { Soma dos } \\
\text { quadrados corrigida }\end{array}$ & 0 \\
\hline CV Pearson &, & Erro-padrão médio & 0 \\
\hline
\end{tabular}

\begin{tabular}{|l|r|l|r|}
\hline \multicolumn{3}{|c|}{ Estatística Descritiva Básica } \\
\hline \multicolumn{2}{|c|}{ Posição } & \multicolumn{2}{c|}{ Variabilidade } \\
\hline Média & 0 & Desvio-padrão & 0 \\
\hline Mediana & 0 & Variância & 0 \\
\hline Moda & 0 & Amplitude & 0 \\
\hline & & Amplitude interquartil & 0 \\
\hline
\end{tabular}

\begin{tabular}{|l|l|l|l|l|}
\hline \multicolumn{5}{|c|}{ Testes de Posição: Mu0=0 } \\
\hline Teste & \multicolumn{2}{|c|}{ Estatística } & \multicolumn{2}{c|}{ Valor $\mathbf{p}$} \\
\hline Student t & t &, & $\operatorname{Pr}>|\mathbf{t}|$ & \\
\hline Sign & M &, & $\operatorname{Pr}>=|\mathrm{M}|$ & \\
\hline Signed Rank & S &, & $\operatorname{Pr}>=|\mathrm{S}|$ & \\
\hline
\end{tabular}

\begin{tabular}{|l|r|}
\hline \multicolumn{2}{|c|}{ Quantis } \\
\hline Level & 0 \\
\hline $100 \%$ Max & 0 \\
\hline $99 \%$ & 0 \\
\hline $95 \%$ & 0 \\
\hline $90 \%$ & 0 \\
\hline $75 \%$ Q3 & 0 \\
\hline $50 \%$ Mediana & 0 \\
\hline $25 \%$ Q1 & 0 \\
\hline $10 \%$ & 0 \\
\hline $5 \%$ & 0 \\
\hline $1 \%$ & 0 \\
\hline $0 \%$ Min & 0 \\
\hline
\end{tabular}


Variável

dependente:

REC

ID $=59$

\begin{tabular}{|r|r|r|r|}
\hline \multicolumn{3}{|c|}{ Observações Limite } \\
\hline \multicolumn{2}{|c|}{ Baixa } & \multicolumn{2}{c|}{ Alta } \\
\hline Valor & Obs & Valor & Obs \\
\hline 0 & 850 & 0 & 846 \\
\hline 0 & 849 & 0 & 847 \\
\hline 0 & 848 & 0 & 848 \\
\hline 0 & 847 & 0 & 849 \\
\hline 0 & 846 & 0 & 850 \\
\hline
\end{tabular}


Variável

dependente:

ACI

ID $=59$

\begin{tabular}{|l|r|l|r|}
\hline \multicolumn{4}{|c|}{ Momento } \\
\hline N & 10 & Soma dos pesos & 10 \\
\hline Média & $\begin{array}{l}\text { Soma das } \\
\text { observações }\end{array}$ & 1 \\
\hline Desvio-padrão & 0,31622777 & Variância & 0,1 \\
\hline Assimetria & 3,16227766 & Curtose & 10 \\
\hline $\begin{array}{l}\text { Soma dos } \\
\text { quadrados não } \\
\text { corrigida }\end{array}$ & 1 & $\begin{array}{l}\text { Soma dos } \\
\text { quadrados corrigida }\end{array}$ & 0,9 \\
\hline CV Pearson & 316,227766 & Erro-padrão médio & 0,1 \\
\hline
\end{tabular}

\begin{tabular}{|l|l|l|r|}
\hline \multicolumn{4}{|c|}{ Estatística Descritiva Básica } \\
\hline \multicolumn{2}{|c|}{ Posição } & \multicolumn{2}{c|}{ Variabilidade } \\
\hline Média & 0,100000 & Desvio-padrão & 0,31623 \\
\hline Mediana & 0,000000 & Variância & 0,10000 \\
\hline Moda & 0,000000 & Amplitude & 1,00000 \\
\hline & & Amplitude interquartil & 0 \\
\hline
\end{tabular}

\begin{tabular}{|l|l|r|l|l|}
\hline \multicolumn{5}{|c|}{ Testes de Posição: Mu0=0 } \\
\hline Teste & \multicolumn{2}{|c|}{ Estatística } & \multicolumn{2}{c|}{ Valor $\mathbf{~}$} \\
\hline Student t & $\mathbf{t}$ & 1 & $\operatorname{Pr}>|\mathbf{t}|$ & 0,3434 \\
\hline Sign & M & 0,5 & $\operatorname{Pr}>=|M|$ & 1,0000 \\
\hline Signed Rank & S & 0,5 & $\operatorname{Pr}>=|\mathbf{S}|$ & 1,0000 \\
\hline
\end{tabular}

\begin{tabular}{|l|r|}
\hline \multicolumn{2}{|c|}{ Quantis } \\
\hline Level & Quantil \\
\hline $100 \%$ Max & 1,0 \\
\hline $99 \%$ & 1,0 \\
\hline $95 \%$ & 1,0 \\
\hline $90 \%$ & 0,5 \\
\hline $75 \%$ Q3 & 0,0 \\
\hline $50 \%$ Mediana & 0,0 \\
\hline $25 \%$ Q1 & 0,0 \\
\hline $10 \%$ & 0,0 \\
\hline $5 \%$ & 0,0 \\
\hline $1 \%$ & 0,0 \\
\hline $0 \%$ Min & 0,0 \\
\hline
\end{tabular}


Variável

dependente:

ACI

$\mathrm{ID}=\mathbf{5 9}$

\begin{tabular}{|r|r|r|r|}
\hline \multicolumn{3}{|c|}{ Observações Limite } \\
\hline \multicolumn{2}{|c|}{ Baixa } & \multicolumn{2}{c|}{ Alta } \\
\hline Valor & Obs & Valor & Obs \\
\hline 0 & 850 & 0 & 846 \\
\hline 0 & 849 & 0 & 847 \\
\hline 0 & 847 & 0 & 849 \\
\hline 0 & 846 & 0 & 850 \\
\hline 0 & 845 & 1 & 848 \\
\hline
\end{tabular}


Variável

dependente:

REC

$I D=60$

\begin{tabular}{|l|r|r|r|}
\hline \multicolumn{3}{|c|}{ Momento } \\
\hline N & 18 & Soma dos pesos & 18 \\
\hline Média & $\begin{array}{r}0 \\
\text { Soma das } \\
\text { observações }\end{array}$ & 0 \\
\hline Desvio-padrão & 0 & Variância & 0 \\
\hline Assimetria &, Curtose &, \\
\hline $\begin{array}{l}\text { Soma dos } \\
\text { quadrados não } \\
\text { corrigida }\end{array}$ & 0 & $\begin{array}{l}\text { Soma dos } \\
\text { quadrados corrigida }\end{array}$ & 0 \\
\hline CV Pearson &, & Erro-padrão médio & 0 \\
\hline
\end{tabular}

\begin{tabular}{|l|r|l|r|}
\hline \multicolumn{3}{|c|}{ Estatística Descritiva Básica } \\
\hline \multicolumn{2}{|c|}{ Posição } & \multicolumn{2}{c|}{ Variabilidade } \\
\hline Média & 0 & Desvio-padrão & 0 \\
\hline Mediana & 0 & Variância & 0 \\
\hline Moda & 0 & Amplitude & 0 \\
\hline & & Amplitude interquartil & 0 \\
\hline
\end{tabular}

\begin{tabular}{|l|l|l|l|l|}
\hline \multicolumn{4}{|c|}{ Testes de Posição: Mu0=0 } \\
\hline Teste & \multicolumn{2}{|c|}{ Estatística } & \multicolumn{2}{c|}{ Valor $\mathbf{p}$} \\
\hline Student $\mathbf{t}$ & $\mathbf{t}$ & \multicolumn{1}{|c|}{, $\operatorname{Pr}>|\mathbf{t}|$} & \\
\hline Sign & $\mathrm{M}$ &, & $\operatorname{Pr}>=|\mathrm{M}|$ & \\
\hline Signed Rank & S &, & $\operatorname{Pr}>=|\mathrm{S}|$ & \\
\hline
\end{tabular}

\begin{tabular}{|l|r|}
\hline \multicolumn{2}{|c|}{ Quantis } \\
\hline Level & 0 \\
\hline $100 \%$ Max & 0 \\
\hline $99 \%$ & 0 \\
\hline $95 \%$ & 0 \\
\hline $90 \%$ & 0 \\
\hline $75 \%$ Q3 & 0 \\
\hline $50 \%$ Mediana & 0 \\
\hline $25 \%$ Q1 & 0 \\
\hline $10 \%$ & 0 \\
\hline $5 \%$ & 0 \\
\hline $1 \%$ & 0 \\
\hline $0 \%$ Min & 0 \\
\hline
\end{tabular}


Variável

dependente:

REC

$\mathrm{ID}=60$

\begin{tabular}{|r|r|r|r|}
\hline \multicolumn{3}{|c|}{ Observações Limite } \\
\hline \multicolumn{2}{|c|}{ Baixa } & \multicolumn{2}{c|}{ Alta } \\
\hline Valor & Obs & Valor & Obs \\
\hline 0 & 868 & 0 & 864 \\
\hline 0 & 867 & 0 & 865 \\
\hline 0 & 866 & 0 & 866 \\
\hline 0 & 865 & 0 & 867 \\
\hline 0 & 864 & 0 & 868 \\
\hline
\end{tabular}


Variável

dependente:

ACI

$\mathrm{ID}=60$

\begin{tabular}{|l|r|l|r|}
\hline \multicolumn{3}{|c|}{ Momento } \\
\hline N & 18 & Soma dos pesos & 18 \\
\hline Média & $\begin{array}{r}0 \\
\text { Soma das } \\
\text { observações }\end{array}$ & 0 \\
\hline Desvio-padrão & 0 & Variância & 0 \\
\hline Assimetria &, Curtose &, \\
\hline $\begin{array}{l}\text { Soma dos } \\
\text { quadrados não } \\
\text { corrigida }\end{array}$ & 0 & $\begin{array}{l}\text { Soma dos } \\
\text { quadrados corrigida }\end{array}$ & 0 \\
\hline CV Pearson &, & Erro-padrão médio & 0 \\
\hline
\end{tabular}

\begin{tabular}{|l|r|l|r|}
\hline \multicolumn{3}{|c|}{ Estatística Descritiva Básica } \\
\hline \multicolumn{2}{|c|}{ Posição } & \multicolumn{2}{c|}{ Variabilidade } \\
\hline Média & 0 & Desvio-padrão & 0 \\
\hline Mediana & 0 & Variância & 0 \\
\hline Moda & 0 & Amplitude & 0 \\
\hline & & Amplitude interquartil & 0 \\
\hline
\end{tabular}

\begin{tabular}{|l|l|l|l|l|}
\hline \multicolumn{5}{|c|}{ Testes de Posição: Mu0=0 } \\
\hline Teste & \multicolumn{2}{|c|}{ Estatística } & \multicolumn{2}{c|}{ Valor $\mathbf{p}$} \\
\hline Student t & t &, & $\operatorname{Pr}>|\mathbf{t}|$ & \\
\hline Sign & M &, & $\operatorname{Pr}>=|\mathrm{M}|$ & \\
\hline Signed Rank & S &, & $\operatorname{Pr}>=|\mathrm{S}|$ & \\
\hline
\end{tabular}

\begin{tabular}{|l|r|}
\hline \multicolumn{2}{|c|}{ Quantis } \\
\hline Level & 0 \\
\hline $100 \%$ Max & 0 \\
\hline $99 \%$ & 0 \\
\hline $95 \%$ & 0 \\
\hline $90 \%$ & 0 \\
\hline $75 \%$ Q3 & 0 \\
\hline $50 \%$ Mediana & 0 \\
\hline $25 \%$ Q1 & 0 \\
\hline $10 \%$ & 0 \\
\hline $5 \%$ & 0 \\
\hline $1 \%$ & 0 \\
\hline $0 \%$ Min & 0 \\
\hline
\end{tabular}


Variável

dependente:

ACI

$\mathrm{ID}=60$

\begin{tabular}{|r|r|r|r|}
\hline \multicolumn{3}{|c|}{ Observações Limite } \\
\hline \multicolumn{2}{|c|}{ Baixa } & \multicolumn{2}{c|}{ Alta } \\
\hline Valor & Obs & Valor & Obs \\
\hline 0 & 868 & 0 & 864 \\
\hline 0 & 867 & 0 & 865 \\
\hline 0 & 866 & 0 & 866 \\
\hline 0 & 865 & 0 & 867 \\
\hline 0 & 864 & 0 & 868 \\
\hline
\end{tabular}


Variável

dependente:

REC

$\mathrm{ID}=61$

\begin{tabular}{|l|r|l|r|}
\hline \multicolumn{3}{|c|}{ Momento } \\
\hline N & 18 & Soma dos pesos & 18 \\
\hline Média & $\begin{array}{r}0 \\
\text { Soma das } \\
\text { observações }\end{array}$ & 0 \\
\hline Desvio-padrão & 0 & Variância & 0 \\
\hline Assimetria &, Curtose &, \\
\hline $\begin{array}{l}\text { Soma dos } \\
\text { quadrados não } \\
\text { corrigida }\end{array}$ & 0 & $\begin{array}{l}\text { Soma dos } \\
\text { quadrados corrigida }\end{array}$ & 0 \\
\hline CV Pearson &, & Erro-padrão médio & 0 \\
\hline
\end{tabular}

\begin{tabular}{|l|r|l|r|}
\hline \multicolumn{3}{|c|}{ Estatística Descritiva Básica } \\
\hline \multicolumn{2}{|c|}{ Posição } & \multicolumn{2}{c|}{ Variabilidade } \\
\hline Média & 0 & Desvio-padrão & 0 \\
\hline Mediana & 0 & Variância & 0 \\
\hline Moda & 0 & Amplitude & 0 \\
\hline & & Amplitude interquartil & 0 \\
\hline
\end{tabular}

\begin{tabular}{|l|l|l|l|l|}
\hline \multicolumn{4}{|c|}{ Testes de Posição: Mu0=0 } \\
\hline Teste & \multicolumn{2}{|c|}{ Estatística } & \multicolumn{2}{c|}{ Valor $\mathbf{p}$} \\
\hline Student $\mathbf{t}$ & $\mathbf{t}$ & \multicolumn{1}{|c|}{, $\operatorname{Pr}>|\mathbf{t}|$} & \\
\hline Sign & $\mathrm{M}$ &, & $\operatorname{Pr}>=|\mathrm{M}|$ & \\
\hline Signed Rank & S &, & $\operatorname{Pr}>=|\mathrm{S}|$ & \\
\hline
\end{tabular}

\begin{tabular}{|l|r|}
\hline \multicolumn{2}{|c|}{ Quantis } \\
\hline Level & 0 \\
\hline $100 \%$ Max & 0 \\
\hline $99 \%$ & 0 \\
\hline $95 \%$ & 0 \\
\hline $90 \%$ & 0 \\
\hline $75 \%$ Q3 & 0 \\
\hline $50 \%$ Mediana & 0 \\
\hline $25 \%$ Q1 & 0 \\
\hline $10 \%$ & 0 \\
\hline $5 \%$ & 0 \\
\hline $1 \%$ & 0 \\
\hline $0 \%$ Min & 0 \\
\hline
\end{tabular}


Variável

dependente:

REC

ID $=61$

\begin{tabular}{|r|r|r|r|}
\hline \multicolumn{3}{|c|}{ Observações Limite } \\
\hline \multicolumn{2}{|c|}{ Baixa } & \multicolumn{2}{c|}{ Alta } \\
\hline Valor & Obs & Valor & Obs \\
\hline 0 & 886 & 0 & 882 \\
\hline 0 & 885 & 0 & 883 \\
\hline 0 & 884 & 0 & 884 \\
\hline 0 & 883 & 0 & 885 \\
\hline 0 & 882 & 0 & 886 \\
\hline
\end{tabular}


Variável

dependente:

ACI

$\mathrm{ID}=61$

\begin{tabular}{|l|r|l|r|}
\hline \multicolumn{3}{|c|}{ Momento } \\
\hline N & 18 & Soma dos pesos & 18 \\
\hline Média & $\begin{array}{r}0 \\
\text { Soma das } \\
\text { observações }\end{array}$ & 0 \\
\hline Desvio-padrão & 0 & Variância & 0 \\
\hline Assimetria &, Curtose &, \\
\hline $\begin{array}{l}\text { Soma dos } \\
\text { quadrados não } \\
\text { corrigida }\end{array}$ & 0 & $\begin{array}{l}\text { Soma dos } \\
\text { quadrados corrigida }\end{array}$ & 0 \\
\hline CV Pearson &, & Erro-padrão médio & 0 \\
\hline
\end{tabular}

\begin{tabular}{|l|r|l|r|}
\hline \multicolumn{3}{|c|}{ Estatística Descritiva Básica } \\
\hline \multicolumn{2}{|c|}{ Posição } & \multicolumn{2}{c|}{ Variabilidade } \\
\hline Média & 0 & Desvio-padrão & 0 \\
\hline Mediana & 0 & Variância & 0 \\
\hline Moda & 0 & Amplitude & 0 \\
\hline & & Amplitude interquartil & 0 \\
\hline
\end{tabular}

\begin{tabular}{|l|l|l|l|l|}
\hline \multicolumn{5}{|c|}{ Testes de Posição: Mu0=0 } \\
\hline Teste & \multicolumn{2}{|c|}{ Estatística } & \multicolumn{2}{c|}{ Valor $\mathbf{p}$} \\
\hline Student t & t &, & $\operatorname{Pr}>|\mathbf{t}|$ & \\
\hline Sign & M &, & $\operatorname{Pr}>=|\mathrm{M}|$ & \\
\hline Signed Rank & S &, & $\operatorname{Pr}>=|\mathrm{S}|$ & \\
\hline
\end{tabular}

\begin{tabular}{|l|r|}
\hline \multicolumn{2}{|c|}{ Quantis } \\
\hline Level & 0 \\
\hline $100 \%$ Max & 0 \\
\hline $99 \%$ & 0 \\
\hline $95 \%$ & 0 \\
\hline $90 \%$ & 0 \\
\hline $75 \%$ Q3 & 0 \\
\hline $50 \%$ Mediana & 0 \\
\hline $25 \%$ Q1 & 0 \\
\hline $10 \%$ & 0 \\
\hline $5 \%$ & 0 \\
\hline $1 \%$ & 0 \\
\hline $0 \%$ Min & 0 \\
\hline
\end{tabular}


Variável

dependente:

ACI

$\mathrm{ID}=61$

\begin{tabular}{|r|r|r|r|}
\hline \multicolumn{3}{|c|}{ Observações Limite } \\
\hline \multicolumn{2}{|c|}{ Baixa } & \multicolumn{2}{c|}{ Alta } \\
\hline Valor & Obs & Valor & Obs \\
\hline 0 & 886 & 0 & 882 \\
\hline 0 & 885 & 0 & 883 \\
\hline 0 & 884 & 0 & 884 \\
\hline 0 & 883 & 0 & 885 \\
\hline 0 & 882 & 0 & 886 \\
\hline
\end{tabular}


Variável

dependente:

REC

$\mathrm{ID}=62$

\begin{tabular}{|l|r|l|r|}
\hline \multicolumn{3}{|c|}{ Momento } \\
\hline N & 16 & Soma dos pesos & 16 \\
\hline Média & $\begin{array}{r}0 \\
\text { Soma das } \\
\text { observações }\end{array}$ & 0 \\
\hline Desvio-padrão & 0 & Variância & 0 \\
\hline Assimetria &, Curtose &, \\
\hline $\begin{array}{l}\text { Soma dos } \\
\text { quadrados não } \\
\text { corrigida }\end{array}$ & 0 & $\begin{array}{l}\text { Soma dos } \\
\text { quadrados corrigida }\end{array}$ & 0 \\
\hline CV Pearson &, & Erro-padrão médio & 0 \\
\hline
\end{tabular}

\begin{tabular}{|l|r|l|r|}
\hline \multicolumn{3}{|c|}{ Estatística Descritiva Básica } \\
\hline \multicolumn{2}{|c|}{ Posição } & \multicolumn{2}{c|}{ Variabilidade } \\
\hline Média & 0 & Desvio-padrão & 0 \\
\hline Mediana & 0 & Variância & 0 \\
\hline Moda & 0 & Amplitude & 0 \\
\hline & & Amplitude interquartil & 0 \\
\hline
\end{tabular}

\begin{tabular}{|l|l|l|l|l|}
\hline \multicolumn{5}{|c|}{ Testes de Posição: Mu0=0 } \\
\hline Teste & \multicolumn{2}{|c|}{ Estatística } & \multicolumn{2}{c|}{ Valor $\mathbf{p}$} \\
\hline Student t & t &, & $\operatorname{Pr}>|\mathbf{t}|$ & \\
\hline Sign & M &, & $\operatorname{Pr}>=|\mathrm{M}|$ & \\
\hline Signed Rank & S &, & $\operatorname{Pr}>=|\mathrm{S}|$ & \\
\hline
\end{tabular}

\begin{tabular}{|l|r|}
\hline \multicolumn{2}{|c|}{ Quantis } \\
\hline Level & 0 \\
\hline $100 \%$ Max & 0 \\
\hline $99 \%$ & 0 \\
\hline $95 \%$ & 0 \\
\hline $90 \%$ & 0 \\
\hline $75 \%$ Q3 & 0 \\
\hline $50 \%$ Mediana & 0 \\
\hline $25 \%$ Q1 & 0 \\
\hline $10 \%$ & 0 \\
\hline $5 \%$ & 0 \\
\hline $1 \%$ & 0 \\
\hline $0 \%$ Min & 0 \\
\hline
\end{tabular}


Variável

dependente:

REC

ID $=62$

\begin{tabular}{|r|r|r|r|}
\hline \multicolumn{3}{|c|}{ Observações Limite } \\
\hline \multicolumn{2}{|c|}{ Baixa } & \multicolumn{2}{c|}{ Alta } \\
\hline Valor & Obs & Valor & Obs \\
\hline 0 & 902 & 0 & 898 \\
\hline 0 & 901 & 0 & 899 \\
\hline 0 & 900 & 0 & 900 \\
\hline 0 & 899 & 0 & 901 \\
\hline 0 & 898 & 0 & 902 \\
\hline
\end{tabular}


Variável

dependente:

ACI

$\mathrm{ID}=62$

\begin{tabular}{|l|r|l|r|}
\hline \multicolumn{3}{|c|}{ Momento } \\
\hline N & 16 & Soma dos pesos & 16 \\
\hline Média & $\begin{array}{r}0 \\
\text { Soma das } \\
\text { observações }\end{array}$ & 0 \\
\hline Desvio-padrão & 0 & Variância & 0 \\
\hline Assimetria &, Curtose &, \\
\hline $\begin{array}{l}\text { Soma dos } \\
\text { quadrados não } \\
\text { corrigida }\end{array}$ & 0 & $\begin{array}{l}\text { Soma dos } \\
\text { quadrados corrigida }\end{array}$ & 0 \\
\hline CV Pearson &, & Erro-padrão médio & 0 \\
\hline
\end{tabular}

\begin{tabular}{|l|r|l|r|}
\hline \multicolumn{3}{|c|}{ Estatística Descritiva Básica } \\
\hline \multicolumn{2}{|c|}{ Posição } & \multicolumn{2}{c|}{ Variabilidade } \\
\hline Média & 0 & Desvio-padrão & 0 \\
\hline Mediana & 0 & Variância & 0 \\
\hline Moda & 0 & Amplitude & 0 \\
\hline & & Amplitude interquartil & 0 \\
\hline
\end{tabular}

\begin{tabular}{|l|l|l|l|l|}
\hline \multicolumn{4}{|c|}{ Testes de Posição: Mu0=0 } \\
\hline Teste & \multicolumn{2}{|c|}{ Estatística } & \multicolumn{2}{c|}{ Valor $\mathbf{p}$} \\
\hline Student $\mathbf{t}$ & $\mathbf{t}$ & \multicolumn{1}{|c|}{, $\operatorname{Pr}>|\mathbf{t}|$} & \\
\hline Sign & $\mathrm{M}$ &, & $\operatorname{Pr}>=|\mathrm{M}|$ & \\
\hline Signed Rank & S &, & $\operatorname{Pr}>=|\mathrm{S}|$ & \\
\hline
\end{tabular}

\begin{tabular}{|l|r|}
\hline \multicolumn{2}{|c|}{ Quantis } \\
\hline Level & 0 \\
\hline $100 \%$ Max & 0 \\
\hline $99 \%$ & 0 \\
\hline $95 \%$ & 0 \\
\hline $90 \%$ & 0 \\
\hline $75 \%$ Q3 & 0 \\
\hline $50 \%$ Mediana & 0 \\
\hline $25 \%$ Q1 & 0 \\
\hline $10 \%$ & 0 \\
\hline $5 \%$ & 0 \\
\hline $1 \%$ & 0 \\
\hline $0 \%$ Min & 0 \\
\hline
\end{tabular}


Variável

dependente:

ACI

$\mathrm{ID}=62$

\begin{tabular}{|r|r|r|r|}
\hline \multicolumn{3}{|c|}{ Observações Limite } \\
\hline \multicolumn{2}{|c|}{ Baixa } & \multicolumn{2}{c|}{ Alta } \\
\hline Valor & Obs & Valor & Obs \\
\hline 0 & 902 & 0 & 898 \\
\hline 0 & 901 & 0 & 899 \\
\hline 0 & 900 & 0 & 900 \\
\hline 0 & 899 & 0 & 901 \\
\hline 0 & 898 & 0 & 902 \\
\hline
\end{tabular}


Variável

dependente:

REC

$\mathrm{ID}=63$

\begin{tabular}{|c|c|c|c|}
\hline \multicolumn{4}{|c|}{ Momento } \\
\hline $\mathbf{N}$ & 12 & Soma dos pesos & 12 \\
\hline Média & 0,91666667 & $\begin{array}{l}\text { Soma das } \\
\text { observações }\end{array}$ & 11 \\
\hline Desvio-padrão & 1,08362467 & Variância & 1,17424242 \\
\hline Assimetria & 1,22051544 & Curtose & 0,67579605 \\
\hline $\begin{array}{l}\text { Soma dos } \\
\text { quadrados não } \\
\text { corrigida }\end{array}$ & 23 & $\begin{array}{l}\text { Soma dos } \\
\text { quadrados corrigida }\end{array}$ & 12,9166667 \\
\hline CV Pearson & 118,2136 & Erro-padrão médio & 0,3128155 \\
\hline
\end{tabular}

\begin{tabular}{|l|l|l|c|}
\hline \multicolumn{4}{|c|}{ Estatística Descritiva Básica } \\
\hline \multicolumn{2}{|c|}{ Posição } & \multicolumn{2}{c|}{ Variabilidade } \\
\hline Média & 0,916667 & Desvio-padrão & 1,08362 \\
\hline Mediana & 1,000000 & Variância & 1,17424 \\
\hline Moda & 0,000000 & Amplitude & 3,00000 \\
\hline & & Amplitude interquartil & 1,00000 \\
\hline
\end{tabular}

Note: The Moda displayed is the smallest of 2 Modas with a count of 5 ,

\begin{tabular}{|l|l|r|l|l|}
\hline \multicolumn{5}{|c|}{ Testes de Posição: Mu0=0 } \\
\hline Teste & \multicolumn{2}{|c|}{ Estatística } & \multicolumn{2}{c|}{ Valor $\mathbf{~}$} \\
\hline Student t & t & 2,930375 & $\mathrm{Pr}>|\mathbf{t}|$ & 0,0137 \\
\hline Sign & M & 3,5 & $\mathrm{Pr}>=|\mathrm{M}|$ & 0,0156 \\
\hline Signed Rank & S & 14 & $\mathrm{Pr}>=|\mathbf{S}|$ & 0,0156 \\
\hline
\end{tabular}

\begin{tabular}{|l|r|}
\hline \multicolumn{2}{|c|}{ Quantis } \\
\hline Level & 3 \\
\hline $100 \%$ Max & 3 \\
\hline $99 \%$ & 3 \\
\hline $95 \%$ & 3 \\
\hline $90 \%$ & 1 \\
\hline $75 \%$ Q3 & 1 \\
\hline $50 \%$ Mediana & 0 \\
\hline $25 \%$ Q1 & 0 \\
\hline $10 \%$ & 0 \\
\hline $5 \%$ & 0 \\
\hline $1 \%$ & 0 \\
\hline $0 \%$ Min & \\
\hline
\end{tabular}


Variável

dependente:

REC

$I D=63$

\begin{tabular}{|r|r|r|r|}
\hline \multicolumn{3}{|c|}{ Observações Limite } \\
\hline \multicolumn{2}{|c|}{ Baixa } & \multicolumn{2}{c|}{ Alta } \\
\hline Valor & Obs & Valor & Obs \\
\hline 0 & 908 & 1 & 910 \\
\hline 0 & 907 & 1 & 912 \\
\hline 0 & 906 & 1 & 913 \\
\hline 0 & 905 & 3 & 911 \\
\hline 0 & 903 & 3 & 914 \\
\hline
\end{tabular}


Variável

dependente:

ACI

$\mathrm{ID}=63$

\begin{tabular}{|l|r|l|r|}
\hline \multicolumn{4}{|c|}{ Momento } \\
\hline N & 12 & Soma dos pesos & 12 \\
\hline Desvio-padrão & 2,5 & $\begin{array}{l}\text { Soma das } \\
\text { observações }\end{array}$ \\
\hline Assimetria & 0,42604259 & Curtose & 5,54545455 \\
\hline $\begin{array}{l}\text { Soma dos } \\
\text { quadrados não } \\
\text { corrigida }\end{array}$ & 136 & $\begin{array}{l}\text { Soma dos } \\
\text { quadrados corrigida }\end{array}$ & $-0,8269462$ \\
\hline CV Pearson & 94,1951553 & Erro-padrão médio & 0,67979498 \\
\hline
\end{tabular}

\begin{tabular}{|l|c|l|c|}
\hline \multicolumn{4}{|c|}{ Estatística Descritiva Básica } \\
\hline \multicolumn{2}{|c|}{ Posição } & \multicolumn{2}{c|}{ Variabilidade } \\
\hline Média & 2,500000 & Desvio-padrão & 2,35488 \\
\hline Mediana & 2,500000 & Variância & 5,54545 \\
\hline Moda & 0,000000 & Amplitude & 7,00000 \\
\hline & & Amplitude interquartil & 4,00000 \\
\hline
\end{tabular}

\begin{tabular}{|l|l|r|l|l|}
\hline \multicolumn{5}{|c|}{ Testes de Posição: Mu0=0 } \\
\hline Teste & \multicolumn{2}{|c|}{ Estatística } & \multicolumn{2}{c|}{ Valor $\mathbf{~}$} \\
\hline Student t & t & 3,677579 & $\mathrm{Pr}>|\mathbf{t}|$ & 0,0036 \\
\hline Sign & M & 4 & $\mathrm{Pr}>=|\mathrm{M}|$ & 0,0078 \\
\hline Signed Rank & S & 18 & $\mathrm{Pr}>=|\mathrm{S}|$ & 0,0078 \\
\hline
\end{tabular}

\begin{tabular}{|l|r|}
\hline \multicolumn{2}{|c|}{ Quantis } \\
\hline Level & Quantil \\
\hline $100 \%$ Max & 7,0 \\
\hline $99 \%$ & 7,0 \\
\hline $95 \%$ & 7,0 \\
\hline $90 \%$ & 5,0 \\
\hline $75 \%$ Q3 & 4,0 \\
\hline $50 \%$ Mediana & 2,5 \\
\hline $25 \%$ Q1 & 0,0 \\
\hline $10 \%$ & 0,0 \\
\hline $5 \%$ & 0,0 \\
\hline $1 \%$ & 0,0 \\
\hline $0 \%$ Min & 0,0 \\
\hline
\end{tabular}


Variável

dependente:

ACI

$\mathrm{ID}=63$

\begin{tabular}{|r|r|r|r|}
\hline \multicolumn{3}{|c|}{ Observações Limite } \\
\hline \multicolumn{2}{|c|}{ Baixa } & \multicolumn{2}{c|}{ Alta } \\
\hline Valor & Obs & Valor & Obs \\
\hline 0 & 907 & 4 & 909 \\
\hline 0 & 905 & 4 & 911 \\
\hline 0 & 904 & 4 & 912 \\
\hline 0 & 903 & 5 & 910 \\
\hline 1 & 906 & 7 & 914 \\
\hline
\end{tabular}


Variável

dependente:

REC

$I D=64$

\begin{tabular}{|l|r|l|r|}
\hline \multicolumn{3}{|c|}{ Momento } \\
\hline N & 18 & Soma dos pesos & 18 \\
\hline Média & $\begin{array}{r}0 \\
\text { Soma das } \\
\text { observações }\end{array}$ & 0 \\
\hline Desvio-padrão & 0 & Variância & 0 \\
\hline Assimetria &, Curtose &, \\
\hline $\begin{array}{l}\text { Soma dos } \\
\text { quadrados não } \\
\text { corrigida }\end{array}$ & 0 & $\begin{array}{l}\text { Soma dos } \\
\text { quadrados corrigida }\end{array}$ & 0 \\
\hline CV Pearson &, & Erro-padrão médio & 0 \\
\hline
\end{tabular}

\begin{tabular}{|l|r|l|r|}
\hline \multicolumn{3}{|c|}{ Estatística Descritiva Básica } \\
\hline \multicolumn{2}{|c|}{ Posição } & \multicolumn{2}{c|}{ Variabilidade } \\
\hline Média & 0 & Desvio-padrão & 0 \\
\hline Mediana & 0 & Variância & 0 \\
\hline Moda & 0 & Amplitude & 0 \\
\hline & & Amplitude interquartil & 0 \\
\hline
\end{tabular}

\begin{tabular}{|l|l|l|l|l|}
\hline \multicolumn{4}{|c|}{ Testes de Posição: Mu0=0 } \\
\hline Teste & \multicolumn{2}{|c|}{ Estatística } & \multicolumn{2}{c|}{ Valor $\mathbf{p}$} \\
\hline Student $\mathbf{t}$ & $\mathbf{t}$ & \multicolumn{1}{|c|}{, $\operatorname{Pr}>|\mathbf{t}|$} & \\
\hline Sign & $\mathrm{M}$ &, & $\operatorname{Pr}>=|\mathrm{M}|$ & \\
\hline Signed Rank & S &, & $\operatorname{Pr}>=|\mathrm{S}|$ & \\
\hline
\end{tabular}

\begin{tabular}{|l|r|}
\hline \multicolumn{2}{|c|}{ Quantis } \\
\hline Level & 0 \\
\hline $100 \%$ Max & 0 \\
\hline $99 \%$ & 0 \\
\hline $95 \%$ & 0 \\
\hline $90 \%$ & 0 \\
\hline $75 \%$ Q3 & 0 \\
\hline $50 \%$ Mediana & 0 \\
\hline $25 \%$ Q1 & 0 \\
\hline $10 \%$ & 0 \\
\hline $5 \%$ & 0 \\
\hline $1 \%$ & 0 \\
\hline $0 \%$ Min & 0 \\
\hline
\end{tabular}


Variável

dependente:

REC

ID $=64$

\begin{tabular}{|r|r|r|r|}
\hline \multicolumn{3}{|c|}{ Observações Limite } \\
\hline \multicolumn{2}{|c|}{ Baixa } & \multicolumn{2}{c|}{ Alta } \\
\hline Valor & Obs & Valor & Obs \\
\hline 0 & 932 & 0 & 928 \\
\hline 0 & 931 & 0 & 929 \\
\hline 0 & 930 & 0 & 930 \\
\hline 0 & 929 & 0 & 931 \\
\hline 0 & 928 & 0 & 932 \\
\hline
\end{tabular}


Variável

dependente:

ACI

ID $=64$

\begin{tabular}{|l|r|l|r|}
\hline \multicolumn{3}{|c|}{ Momento } \\
\hline N & 18 & Soma dos pesos & 18 \\
\hline Média & $\begin{array}{r}0 \\
\text { Soma das } \\
\text { observações }\end{array}$ & 0 \\
\hline Desvio-padrão & 0 & Variância & 0 \\
\hline Assimetria &, Curtose &, \\
\hline $\begin{array}{l}\text { Soma dos } \\
\text { quadrados não } \\
\text { corrigida }\end{array}$ & 0 & $\begin{array}{l}\text { Soma dos } \\
\text { quadrados corrigida }\end{array}$ & 0 \\
\hline CV Pearson &, & Erro-padrão médio & 0 \\
\hline
\end{tabular}

\begin{tabular}{|l|r|l|r|}
\hline \multicolumn{3}{|c|}{ Estatística Descritiva Básica } \\
\hline \multicolumn{2}{|c|}{ Posição } & \multicolumn{2}{c|}{ Variabilidade } \\
\hline Média & 0 & Desvio-padrão & 0 \\
\hline Mediana & 0 & Variância & 0 \\
\hline Moda & 0 & Amplitude & 0 \\
\hline & & Amplitude interquartil & 0 \\
\hline
\end{tabular}

\begin{tabular}{|l|l|l|l|l|}
\hline \multicolumn{5}{|c|}{ Testes de Posição: Mu0=0 } \\
\hline Teste & \multicolumn{2}{|c|}{ Estatística } & \multicolumn{2}{c|}{ Valor $\mathbf{p}$} \\
\hline Student t & t &, & $\operatorname{Pr}>|\mathbf{t}|$ & \\
\hline Sign & M &, & $\operatorname{Pr}>=|\mathrm{M}|$ & \\
\hline Signed Rank & S &, & $\operatorname{Pr}>=|\mathrm{S}|$ & \\
\hline
\end{tabular}

\begin{tabular}{|l|r|}
\hline \multicolumn{2}{|c|}{ Quantis } \\
\hline Level & 0 \\
\hline $100 \%$ Max & 0 \\
\hline $99 \%$ & 0 \\
\hline $95 \%$ & 0 \\
\hline $90 \%$ & 0 \\
\hline $75 \%$ Q3 & 0 \\
\hline $50 \%$ Mediana & 0 \\
\hline $25 \%$ Q1 & 0 \\
\hline $10 \%$ & 0 \\
\hline $5 \%$ & 0 \\
\hline $1 \%$ & 0 \\
\hline $0 \%$ Min & 0 \\
\hline
\end{tabular}


Variável

dependente:

ACI

ID $=64$

\begin{tabular}{|r|r|r|r|}
\hline \multicolumn{3}{|c|}{ Observações Limite } \\
\hline \multicolumn{2}{|c|}{ Baixa } & \multicolumn{2}{c|}{ Alta } \\
\hline Valor & Obs & Valor & Obs \\
\hline 0 & 932 & 0 & 928 \\
\hline 0 & 931 & 0 & 929 \\
\hline 0 & 930 & 0 & 930 \\
\hline 0 & 929 & 0 & 931 \\
\hline 0 & 928 & 0 & 932 \\
\hline
\end{tabular}


Variável

dependente:

REC

$I D=65$

\begin{tabular}{|l|r|l|r|}
\hline \multicolumn{3}{|c|}{ Momento } \\
\hline N & 18 & Soma dos pesos & 18 \\
\hline Média & $\begin{array}{r}0 \\
\text { Soma das } \\
\text { observações }\end{array}$ & 0 \\
\hline Desvio-padrão & 0 & Variância & 0 \\
\hline Assimetria &, Curtose &, \\
\hline $\begin{array}{l}\text { Soma dos } \\
\text { quadrados não } \\
\text { corrigida }\end{array}$ & 0 & $\begin{array}{l}\text { Soma dos } \\
\text { quadrados corrigida }\end{array}$ & 0 \\
\hline CV Pearson &, & Erro-padrão médio & 0 \\
\hline
\end{tabular}

\begin{tabular}{|l|r|l|r|}
\hline \multicolumn{3}{|c|}{ Estatística Descritiva Básica } \\
\hline Posição & \multicolumn{2}{c|}{ Variabilidade } \\
\hline Média & 0 & Desvio-padrão & 0 \\
\hline Mediana & 0 & Variância & 0 \\
\hline Moda & 0 & Amplitude & 0 \\
\hline & & Amplitude interquartil & 0 \\
\hline
\end{tabular}

\begin{tabular}{|l|l|l|l|l|}
\hline \multicolumn{4}{|c|}{ Testes de Posição: Mu0=0 } \\
\hline Teste & \multicolumn{2}{|c|}{ Estatística } & \multicolumn{2}{c|}{ Valor $\mathbf{p}$} \\
\hline Student t & $\mathbf{t}$ & & $\operatorname{Pr}>|\mathbf{t}|$ & \\
\hline Sign & $\mathbf{M}$ &, & $\operatorname{Pr}>=|\mathrm{M}|$ & \\
\hline Signed Rank & $\mathbf{S}$ &, & $\operatorname{Pr}>=|\mathrm{S}|$ & \\
\hline
\end{tabular}

\begin{tabular}{|l|r|}
\hline \multicolumn{2}{|c|}{ Quantis } \\
\hline Level & Quantil \\
\hline $100 \%$ Max & 0 \\
\hline $99 \%$ & 0 \\
\hline $95 \%$ & 0 \\
\hline $90 \%$ & 0 \\
\hline $75 \%$ Q3 & 0 \\
\hline $50 \%$ Mediana & 0 \\
\hline $25 \%$ Q1 & 0 \\
\hline $10 \%$ & 0 \\
\hline $5 \%$ & 0 \\
\hline $1 \%$ & 0 \\
\hline $0 \%$ Min & \\
\hline
\end{tabular}


Variável

dependente:

REC

ID $=65$

\begin{tabular}{|r|r|r|r|}
\hline \multicolumn{3}{|c|}{ Observações Limite } \\
\hline \multicolumn{2}{|c|}{ Baixa } & \multicolumn{2}{c|}{ Alta } \\
\hline Valor & Obs & Valor & Obs \\
\hline 0 & 950 & 0 & 946 \\
\hline 0 & 949 & 0 & 947 \\
\hline 0 & 948 & 0 & 948 \\
\hline 0 & 947 & 0 & 949 \\
\hline 0 & 946 & 0 & 950 \\
\hline
\end{tabular}


Variável

dependente:

ACI

$\mathrm{ID}=65$

\begin{tabular}{|l|r|l|r|}
\hline N & \multicolumn{3}{|c|}{ Momento } \\
\hline Média & 0,2222222 & $\begin{array}{l}\text { Soma dos pesos } \\
\text { observações }\end{array}$ & 48 \\
\hline Desvio-padrão & 0,54831888 & Variância & 0,30065359 \\
\hline Assimetria & 2,56713519 & Curtose & 6,36294896 \\
\hline $\begin{array}{l}\text { Soma dos } \\
\text { quadrados não } \\
\text { corrigida }\end{array}$ & 6 & $\begin{array}{l}\text { Soma dos } \\
\text { quadrados corrigida }\end{array}$ & 5,11111111 \\
\hline CV Pearson & 246,743496 & Erro-padrão médio & 0,12924 \\
\hline
\end{tabular}

\begin{tabular}{|l|l|l|r|}
\hline \multicolumn{4}{|c|}{ Estatística Descritiva Básica } \\
\hline \multicolumn{2}{|c|}{ Posição } & \multicolumn{2}{c|}{ Variabilidade } \\
\hline Média & 0,222222 & Desvio-padrão & 0,54832 \\
\hline Mediana & 0,000000 & Variância & 0,30065 \\
\hline Moda & 0,000000 & Amplitude & 2,00000 \\
\hline & & Amplitude interquartil & 0 \\
\hline
\end{tabular}

\begin{tabular}{|l|l|r|l|l|}
\hline \multicolumn{5}{|c|}{ Testes de Posição: Mu0=0 } \\
\hline Teste & \multicolumn{2}{|c|}{ Estatística } & \multicolumn{2}{c|}{ Valor $\mathbf{~}$} \\
\hline Student t & t & 1,719454 & $\mathrm{Pr}>|\mathbf{t}|$ & 0,1037 \\
\hline Sign & M & 1,5 & $\mathrm{Pr}>=|\mathrm{M}|$ & 0,2500 \\
\hline Signed Rank & S & 3 & $\mathrm{Pr}>=|\mathbf{S}|$ & 0,2500 \\
\hline
\end{tabular}

\begin{tabular}{|l|r|}
\hline \multicolumn{2}{|c|}{ Quantis } \\
\hline Level & 2 \\
\hline $100 \%$ Max & 2 \\
\hline $99 \%$ & 2 \\
\hline $95 \%$ & 1 \\
\hline $90 \%$ & 0 \\
\hline $75 \%$ Q3 & 0 \\
\hline $50 \%$ Mediana & 0 \\
\hline $25 \%$ Q1 & 0 \\
\hline $10 \%$ & 0 \\
\hline $5 \%$ & 0 \\
\hline $1 \%$ & 0 \\
\hline $0 \%$ Min & 0 \\
\hline
\end{tabular}


Variável

dependente:

ACI

$\mathrm{ID}=65$

\begin{tabular}{|r|r|r|r|}
\hline \multicolumn{3}{|c|}{ Observações Limite } \\
\hline \multicolumn{2}{|c|}{ Baixa } & \multicolumn{2}{c|}{ Alta } \\
\hline Valor & Obs & Valor & Obs \\
\hline 0 & 950 & 0 & 949 \\
\hline 0 & 949 & 0 & 950 \\
\hline 0 & 948 & 1 & 941 \\
\hline 0 & 947 & 1 & 943 \\
\hline 0 & 946 & 2 & 938 \\
\hline
\end{tabular}


Variável

dependente:

REC

$\mathrm{ID}=66$

\begin{tabular}{|l|r|l|r|}
\hline \multicolumn{3}{|c|}{ Momento } \\
\hline Média & 18 & Soma dos pesos & 18 \\
\hline Desvio-padrão & 0,23570226 & $\begin{array}{l}\text { Variância } \\
\text { observações }\end{array}$ & 0,05555556 \\
\hline Assimetria & 4,24264069 & Curtose & 18 \\
\hline $\begin{array}{l}\text { Soma dos } \\
\text { quadrados não } \\
\text { corrigida }\end{array}$ & 1 & $\begin{array}{l}\text { Soma dos } \\
\text { quadrados corrigida }\end{array}$ & 0,94444444 \\
\hline CV Pearson & 424,264069 & Erro-padrão médio & 0,05555556 \\
\hline
\end{tabular}

\begin{tabular}{|l|l|l|r|}
\hline \multicolumn{4}{|c|}{ Estatística Descritiva Básica } \\
\hline Média & 0,055556 & Desvio-padrão & 0,23570 \\
\hline Mediana & 0,000000 & Variância & 0,05556 \\
\hline Moda & 0,000000 & Amplitude & 1,00000 \\
\hline & & Amplitude interquartil & 0 \\
\hline
\end{tabular}

\begin{tabular}{|l|l|r|l|l|}
\hline \multicolumn{5}{|c|}{ Testes de Posição: Mu0=0 } \\
\hline Teste & \multicolumn{2}{|c|}{ Estatística } & \multicolumn{2}{c|}{ Valor $\mathbf{~}$} \\
\hline Student t & $\mathbf{t}$ & 1 & $\operatorname{Pr}>|\mathbf{t}|$ & 0,3313 \\
\hline Sign & M & 0,5 & $\operatorname{Pr}>=|M|$ & 1,0000 \\
\hline Signed Rank & S & 0,5 & $\operatorname{Pr}>=|\mathbf{S}|$ & 1,0000 \\
\hline
\end{tabular}

\begin{tabular}{|l|r|}
\hline \multicolumn{2}{|c|}{ Quantis } \\
\hline Level & 1 \\
\hline $100 \%$ Max & 1 \\
\hline $99 \%$ & 1 \\
\hline $95 \%$ & 0 \\
\hline $90 \%$ & 0 \\
\hline $75 \%$ Quantil & 0 \\
\hline $50 \%$ Mediana & 0 \\
\hline $25 \%$ Q1 & 0 \\
\hline $10 \%$ & 0 \\
\hline $5 \%$ & 0 \\
\hline $1 \%$ & 0 \\
\hline $0 \%$ Min & \\
\hline
\end{tabular}


Variável

dependente:

REC

ID $=66$

\begin{tabular}{|r|r|r|r|}
\hline \multicolumn{3}{|c|}{ Observações Limite } \\
\hline \multicolumn{2}{|c|}{ Baixa } & \multicolumn{2}{c|}{ Alta } \\
\hline Valor & Obs & Valor & Obs \\
\hline 0 & 968 & 0 & 964 \\
\hline 0 & 967 & 0 & 965 \\
\hline 0 & 965 & 0 & 967 \\
\hline 0 & 964 & 0 & 968 \\
\hline 0 & 963 & 1 & 966 \\
\hline
\end{tabular}


Variável

dependente:

ACI

ID $=66$

\begin{tabular}{|l|r|l|r|}
\hline \multicolumn{3}{|c|}{ Momento } \\
\hline N & 18 & Soma dos pesos & 18 \\
\hline Média & $\begin{array}{r}0 \\
\text { Soma das } \\
\text { observações }\end{array}$ & 0 \\
\hline Desvio-padrão & 0 & Variância & 0 \\
\hline Assimetria &, Curtose &, \\
\hline $\begin{array}{l}\text { Soma dos } \\
\text { quadrados não } \\
\text { corrigida }\end{array}$ & 0 & $\begin{array}{l}\text { Soma dos } \\
\text { quadrados corrigida }\end{array}$ & 0 \\
\hline CV Pearson &, & Erro-padrão médio & 0 \\
\hline
\end{tabular}

\begin{tabular}{|l|r|l|r|}
\hline \multicolumn{3}{|c|}{ Estatística Descritiva Básica } \\
\hline \multicolumn{2}{|c|}{ Posição } & \multicolumn{2}{c|}{ Variabilidade } \\
\hline Média & 0 & Desvio-padrão & 0 \\
\hline Mediana & 0 & Variância & 0 \\
\hline Moda & 0 & Amplitude & 0 \\
\hline & & Amplitude interquartil & 0 \\
\hline
\end{tabular}

\begin{tabular}{|l|l|l|l|l|}
\hline \multicolumn{5}{|c|}{ Testes de Posição: Mu0=0 } \\
\hline Teste & \multicolumn{2}{|c|}{ Estatística } & \multicolumn{2}{c|}{ Valor $\mathbf{p}$} \\
\hline Student t & t &, & $\operatorname{Pr}>|\mathbf{t}|$ & \\
\hline Sign & M &, & $\operatorname{Pr}>=|\mathrm{M}|$ & \\
\hline Signed Rank & S &, & $\operatorname{Pr}>=|\mathrm{S}|$ & \\
\hline
\end{tabular}

\begin{tabular}{|l|r|}
\hline \multicolumn{2}{|c|}{ Quantis } \\
\hline Level & 0 \\
\hline $100 \%$ Max & 0 \\
\hline $99 \%$ & 0 \\
\hline $95 \%$ & 0 \\
\hline $90 \%$ & 0 \\
\hline $75 \%$ Q3 & 0 \\
\hline $50 \%$ Mediana & 0 \\
\hline $25 \%$ Q1 & 0 \\
\hline $10 \%$ & 0 \\
\hline $5 \%$ & 0 \\
\hline $1 \%$ & 0 \\
\hline $0 \%$ Min & 0 \\
\hline
\end{tabular}


Variável

dependente:

ACI

$\mathrm{ID}=66$

\begin{tabular}{|r|r|r|r|}
\hline \multicolumn{3}{|c|}{ Observações Limite } \\
\hline \multicolumn{2}{|c|}{ Baixa } & \multicolumn{2}{c|}{ Alta } \\
\hline Valor & Obs & Valor & Obs \\
\hline 0 & 968 & 0 & 964 \\
\hline 0 & 967 & 0 & 965 \\
\hline 0 & 966 & 0 & 966 \\
\hline 0 & 965 & 0 & 967 \\
\hline 0 & 964 & 0 & 968 \\
\hline
\end{tabular}


Variável

dependente:

REC

ID $=67$

\begin{tabular}{|l|r|l|r|}
\hline \multicolumn{4}{|c|}{ Momento } \\
\hline Média & 17 & Soma dos pesos & 17 \\
\hline Desvio-padrão & 0,39295262 & Variância \\
\hline Assimetria & 1,8662131 & Curtose & 0,15441176 \\
\hline $\begin{array}{l}\text { Soma dos } \\
\text { quadrados não } \\
\text { corrigida }\end{array}$ & 3 & $\begin{array}{l}\text { Soma dos } \\
\text { quadrados corrigida }\end{array}$ & 1,66530612 \\
\hline CV Pearson & 222,673154 & Erro-padrão médio & 0,09530501 \\
\hline
\end{tabular}

\begin{tabular}{|l|l|l|r|}
\hline \multicolumn{4}{|c|}{ Estatística Descritiva Básica } \\
\hline \multicolumn{2}{|c|}{ Posição } & \multicolumn{2}{c|}{ Variabilidade } \\
\hline Média & 0,176471 & Desvio-padrão & 0,39295 \\
\hline Mediana & 0,000000 & Variância & 0,15441 \\
\hline Moda & 0,000000 & Amplitude & 1,00000 \\
\hline & & Amplitude interquartil & 0 \\
\hline
\end{tabular}

\begin{tabular}{|l|l|r|l|l|}
\hline \multicolumn{5}{|c|}{ Testes de Posição: Mu0=0 } \\
\hline Teste & \multicolumn{2}{|c|}{ Estatística } & \multicolumn{2}{c|}{ Valor $\mathbf{p}$} \\
\hline Student t & t & 1,85164 & $\operatorname{Pr}>|\mathbf{t}|$ & 0,0826 \\
\hline Sign & M & 1,5 & $\operatorname{Pr}>=|\mathbf{M}|$ & 0,2500 \\
\hline Signed Rank & S & 3 & $\operatorname{Pr}>=|\mathbf{S}|$ & 0,2500 \\
\hline
\end{tabular}

\begin{tabular}{|l|r|}
\hline \multicolumn{2}{|c|}{ Quantis } \\
\hline Level & Quantil \\
\hline $100 \%$ Max & 1 \\
\hline $99 \%$ & 1 \\
\hline $95 \%$ & 1 \\
\hline $90 \%$ & 0 \\
\hline $75 \%$ Q3 & 0 \\
\hline $50 \%$ Mediana & 0 \\
\hline $25 \%$ Q1 & 0 \\
\hline $10 \%$ & 0 \\
\hline $5 \%$ & 0 \\
\hline $1 \%$ & 0 \\
\hline $0 \%$ Min & 1 \\
\hline
\end{tabular}


Variável

dependente:

REC

ID $=67$

\begin{tabular}{|r|r|r|r|}
\hline \multicolumn{3}{|c|}{ Observações Limite } \\
\hline \multicolumn{2}{|c|}{ Baixa } & \multicolumn{2}{c|}{ Alta } \\
\hline Valor & Obs & Valor & Obs \\
\hline 0 & 985 & 0 & 984 \\
\hline 0 & 984 & 0 & 985 \\
\hline 0 & 983 & 1 & 969 \\
\hline 0 & 982 & 1 & 974 \\
\hline 0 & 981 & 1 & 978 \\
\hline
\end{tabular}


Variável

dependente:

ACI

ID $=67$

\begin{tabular}{|l|r|l|r|}
\hline \multicolumn{4}{|c|}{ Momento } \\
\hline Média & 17 & Soma dos pesos & 17 \\
\hline Desvio-padrão & 0,39295262 & Variância \\
\hline Assimetria & 1,8662131 & Curtose & 0,15441176 \\
\hline $\begin{array}{l}\text { Soma dos } \\
\text { quadrados não } \\
\text { corrigida }\end{array}$ & 3 & $\begin{array}{l}\text { Soma dos } \\
\text { quadrados corrigida }\end{array}$ & 1,66530612 \\
\hline CV Pearson & 222,673154 & Erro-padrão médio & 0,09530501 \\
\hline
\end{tabular}

\begin{tabular}{|l|l|l|r|}
\hline \multicolumn{4}{|c|}{ Estatística Descritiva Básica } \\
\hline \multicolumn{2}{|c|}{ Posição } & \multicolumn{2}{c|}{ Variabilidade } \\
\hline Média & 0,176471 & Desvio-padrão & 0,39295 \\
\hline Mediana & 0,000000 & Variância & 0,15441 \\
\hline Moda & 0,000000 & Amplitude & 1,00000 \\
\hline & & Amplitude interquartil & 0 \\
\hline
\end{tabular}

\begin{tabular}{|l|l|r|l|l|}
\hline \multicolumn{5}{|c|}{ Testes de Posição: Mu0=0 } \\
\hline Teste & \multicolumn{2}{|c|}{ Estatística } & \multicolumn{2}{c|}{ Valor $\mathbf{~}$} \\
\hline Student t & t & 1,85164 & $\operatorname{Pr}>|\mathbf{t}|$ & 0,0826 \\
\hline Sign & M & 1,5 & $\operatorname{Pr}>=|M|$ & 0,2500 \\
\hline Signed Rank & S & 3 & $\operatorname{Pr}>=|\mathbf{S}|$ & 0,2500 \\
\hline
\end{tabular}

\begin{tabular}{|l|r|}
\hline \multicolumn{2}{|c|}{ Quantis } \\
\hline Level & 1 \\
\hline $100 \%$ Max & 1 \\
\hline $99 \%$ & 1 \\
\hline $95 \%$ & 1 \\
\hline $90 \%$ & 0 \\
\hline $75 \%$ Q3 & 0 \\
\hline $50 \%$ Mediana & 0 \\
\hline $25 \%$ Q1 & 0 \\
\hline $10 \%$ & 0 \\
\hline $5 \%$ & 0 \\
\hline $1 \%$ & 0 \\
\hline $0 \%$ Min & 0 \\
\hline
\end{tabular}


Variável

dependente:

ACI

ID $=67$

\begin{tabular}{|r|r|r|r|}
\hline \multicolumn{3}{|c|}{ Observações Limite } \\
\hline \multicolumn{2}{|c|}{ Baixa } & \multicolumn{2}{c|}{ Alta } \\
\hline Valor & Obs & Valor & Obs \\
\hline 0 & 985 & 0 & 984 \\
\hline 0 & 984 & 0 & 985 \\
\hline 0 & 983 & 1 & 972 \\
\hline 0 & 982 & 1 & 973 \\
\hline 0 & 981 & 1 & 976 \\
\hline
\end{tabular}


Variável

dependente:

REC

$\mathrm{ID}=68$

\begin{tabular}{|l|r|l|r|}
\hline \multicolumn{3}{|c|}{ Momento } \\
\hline N & 13 & Soma dos pesos & 13 \\
\hline Média & $\begin{array}{r}0 \\
\text { Soma das } \\
\text { observações }\end{array}$ & 0 \\
\hline Desvio-padrão & 0 & Variância & 0 \\
\hline Assimetria &, Curtose &, \\
\hline $\begin{array}{l}\text { Soma dos } \\
\text { quadrados não } \\
\text { corrigida }\end{array}$ & 0 & $\begin{array}{l}\text { Soma dos } \\
\text { quadrados corrigida }\end{array}$ & 0 \\
\hline CV Pearson &, & Erro-padrão médio & 0 \\
\hline
\end{tabular}

\begin{tabular}{|l|r|l|r|}
\hline \multicolumn{3}{|c|}{ Estatística Descritiva Básica } \\
\hline \multicolumn{2}{|c|}{ Posição } & \multicolumn{2}{c|}{ Variabilidade } \\
\hline Média & 0 & Desvio-padrão & 0 \\
\hline Mediana & 0 & Variância & 0 \\
\hline Moda & 0 & Amplitude & 0 \\
\hline & & Amplitude interquartil & 0 \\
\hline
\end{tabular}

\begin{tabular}{|l|l|l|l|l|}
\hline \multicolumn{5}{|c|}{ Testes de Posição: Mu0=0 } \\
\hline Teste & \multicolumn{2}{|c|}{ Estatística } & \multicolumn{2}{c|}{ Valor $\mathbf{p}$} \\
\hline Student t & t &, & $\operatorname{Pr}>|\mathbf{t}|$ & \\
\hline Sign & M &, & $\operatorname{Pr}>=|\mathrm{M}|$ & \\
\hline Signed Rank & S &, & $\operatorname{Pr}>=|\mathrm{S}|$ & \\
\hline
\end{tabular}

\begin{tabular}{|l|r|}
\hline \multicolumn{2}{|c|}{ Quantis } \\
\hline Level & 0 \\
\hline $100 \%$ Max & 0 \\
\hline $99 \%$ & 0 \\
\hline $95 \%$ & 0 \\
\hline $90 \%$ & 0 \\
\hline $75 \%$ Q3 & 0 \\
\hline $50 \%$ Mediana & 0 \\
\hline $25 \%$ Q1 & 0 \\
\hline $10 \%$ & 0 \\
\hline $5 \%$ & 0 \\
\hline $1 \%$ & 0 \\
\hline $0 \%$ Min & 0 \\
\hline
\end{tabular}


Variável

dependente:

REC

ID $=68$

\begin{tabular}{|r|r|r|r|}
\hline \multicolumn{3}{|c|}{ Observações Limite } \\
\hline \multicolumn{2}{|c|}{ Baixa } & \multicolumn{2}{c|}{ Alta } \\
\hline Valor & Obs & Valor & Obs \\
\hline 0 & 998 & 0 & 994 \\
\hline 0 & 997 & 0 & 995 \\
\hline 0 & 996 & 0 & 996 \\
\hline 0 & 995 & 0 & 997 \\
\hline 0 & 994 & 0 & 998 \\
\hline
\end{tabular}


Variável

dependente:

ACI

$\mathrm{ID}=68$

\begin{tabular}{|l|r|l|r|}
\hline \multicolumn{3}{|c|}{ Momento } \\
\hline N & 13 & Soma dos pesos & 13 \\
\hline Média & $\begin{array}{r}0 \\
\text { Soma das } \\
\text { observações }\end{array}$ & 0 \\
\hline Desvio-padrão & 0 & Variância & 0 \\
\hline Assimetria &, Curtose &, \\
\hline $\begin{array}{l}\text { Soma dos } \\
\text { quadrados não } \\
\text { corrigida }\end{array}$ & 0 & $\begin{array}{l}\text { Soma dos } \\
\text { quadrados corrigida }\end{array}$ & 0 \\
\hline CV Pearson &, & Erro-padrão médio & 0 \\
\hline
\end{tabular}

\begin{tabular}{|l|r|l|r|}
\hline \multicolumn{3}{|c|}{ Estatística Descritiva Básica } \\
\hline \multicolumn{2}{|c|}{ Posição } & \multicolumn{2}{c|}{ Variabilidade } \\
\hline Média & 0 & Desvio-padrão & 0 \\
\hline Mediana & 0 & Variância & 0 \\
\hline Moda & 0 & Amplitude & 0 \\
\hline & & Amplitude interquartil & 0 \\
\hline
\end{tabular}

\begin{tabular}{|l|l|l|l|l|}
\hline \multicolumn{5}{|c|}{ Testes de Posição: Mu0=0 } \\
\hline Teste & \multicolumn{2}{|c|}{ Estatística } & \multicolumn{2}{c|}{ Valor $\mathbf{p}$} \\
\hline Student t & t &, & $\operatorname{Pr}>|\mathbf{t}|$ & \\
\hline Sign & M &, & $\operatorname{Pr}>=|\mathrm{M}|$ & \\
\hline Signed Rank & S &, & $\operatorname{Pr}>=|\mathrm{S}|$ & \\
\hline
\end{tabular}

\begin{tabular}{|l|r|}
\hline \multicolumn{2}{|c|}{ Quantis } \\
\hline Level & 0 \\
\hline $100 \%$ Max & 0 \\
\hline $99 \%$ & 0 \\
\hline $95 \%$ & 0 \\
\hline $90 \%$ & 0 \\
\hline $75 \%$ Q3 & 0 \\
\hline $50 \%$ Mediana & 0 \\
\hline $25 \%$ Q1 & 0 \\
\hline $10 \%$ & 0 \\
\hline $5 \%$ & 0 \\
\hline $1 \%$ & 0 \\
\hline $0 \%$ Min & 0 \\
\hline
\end{tabular}


Variável

dependente:

ACI

$\mathrm{ID}=68$

\begin{tabular}{|r|r|r|r|}
\hline \multicolumn{3}{|c|}{ Observações Limite } \\
\hline \multicolumn{2}{|c|}{ Baixa } & \multicolumn{2}{c|}{ Alta } \\
\hline Valor & Obs & Valor & Obs \\
\hline 0 & 998 & 0 & 994 \\
\hline 0 & 997 & 0 & 995 \\
\hline 0 & 996 & 0 & 996 \\
\hline 0 & 995 & 0 & 997 \\
\hline 0 & 994 & 0 & 998 \\
\hline
\end{tabular}


Variável

dependente:

REC

ID $=69$

\begin{tabular}{|l|r|l|r|}
\hline \multicolumn{4}{|c|}{ Momento } \\
\hline Média & 18 & Soma dos pesos & 18 \\
\hline Desvio-padrão & 0,57451315 & Variância \\
\hline Assimetria & 2,07235302 & Curtose & 0,33006536 \\
\hline $\begin{array}{l}\text { Soma dos } \\
\text { quadrados não } \\
\text { corrigida }\end{array}$ & 7 & $\begin{array}{l}\text { Soma dos } \\
\text { quadrados corrigida }\end{array}$ & 3,84862268 \\
\hline CV Pearson & 206,824734 & Erro-padrão médio & 0,13541411111 \\
\hline
\end{tabular}

\begin{tabular}{|l|l|l|r|}
\hline \multicolumn{4}{|c|}{ Estatística Descritiva Básica } \\
\hline \multicolumn{2}{|c|}{ Posição } & \multicolumn{2}{c|}{ Variabilidade } \\
\hline Média & 0,277778 & Desvio-padrão & 0,57451 \\
\hline Mediana & 0,000000 & Variância & 0,33007 \\
\hline Moda & 0,000000 & Amplitude & 2,00000 \\
\hline & & Amplitude interquartil & 0 \\
\hline
\end{tabular}

\begin{tabular}{|l|l|r|l|l|}
\hline \multicolumn{5}{|c|}{ Testes de Posição: Mu0=0 } \\
\hline Teste & \multicolumn{2}{|c|}{ Estatística } & \multicolumn{2}{c|}{ Valor $\mathbf{~}$} \\
\hline Student t & t & 2,051322 & $\mathrm{Pr}>|\mathbf{t}|$ & 0,0560 \\
\hline Sign & M & 2 & $\mathrm{Pr}>=|\mathrm{M}|$ & 0,1250 \\
\hline Signed Rank & S & 5 & $\mathrm{Pr}>=|\mathrm{S}|$ & 0,1250 \\
\hline
\end{tabular}

\begin{tabular}{|l|r|}
\hline \multicolumn{2}{|c|}{ Quantis } \\
\hline Level & 2 \\
\hline $100 \%$ Max & 2 \\
\hline $99 \%$ & 2 \\
\hline $95 \%$ & 1 \\
\hline $90 \%$ & 0 \\
\hline $75 \%$ Q3 & 0 \\
\hline $50 \%$ Mediana & 0 \\
\hline $25 \%$ Q1 & 0 \\
\hline $10 \%$ & 0 \\
\hline $5 \%$ & 0 \\
\hline $1 \%$ & 0 \\
\hline $0 \%$ Min & 0 \\
\hline
\end{tabular}


Variável

dependente:

REC

ID $=69$

\begin{tabular}{|r|r|r|r|}
\hline \multicolumn{3}{|c|}{ Observações Limite } \\
\hline \multicolumn{2}{|c|}{ Baixa } & \multicolumn{2}{c|}{ Alta } \\
\hline Valor & Obs & Valor & Obs \\
\hline 0 & 1016 & 0 & 1016 \\
\hline 0 & 1015 & 1 & 999 \\
\hline 0 & 1014 & 1 & 1000 \\
\hline 0 & 1013 & 1 & 1012 \\
\hline 0 & 1011 & 2 & 1006 \\
\hline
\end{tabular}


Variável

dependente:

ACI

ID $=69$

\begin{tabular}{|l|r|l|r|}
\hline \multicolumn{3}{|c|}{ Momento } \\
\hline Média & 18 & Soma dos pesos & 18 \\
\hline Desvio-padrão & 0,68599434 & Variância \\
observações & 0,47058824 \\
\hline Assimetria & 1,91328109 & Curtose & 2,44375 \\
\hline $\begin{array}{l}\text { Soma dos } \\
\text { quadrados não } \\
\text { corrigida }\end{array}$ & 10 & $\begin{array}{l}\text { Soma dos } \\
\text { quadrados corrigida }\end{array}$ \\
\hline CV Pearson & 205,798302 & Erro-padrão médio & 0,16169042 \\
\hline
\end{tabular}

\begin{tabular}{|l|l|l|r|}
\hline \multicolumn{4}{|c|}{ Estatística Descritiva Básica } \\
\hline \multicolumn{2}{|c|}{ Posição } & \multicolumn{2}{c|}{ Variabilidade } \\
\hline Média & 0,333333 & Desvio-padrão & 0,68599 \\
\hline Mediana & 0,000000 & Variância & 0,47059 \\
\hline Moda & 0,000000 & Amplitude & 2,00000 \\
\hline & & Amplitude interquartil & 0 \\
\hline
\end{tabular}

\begin{tabular}{|l|l|r|l|l|}
\hline \multicolumn{5}{|c|}{ Testes de Posição: Mu0=0 } \\
\hline Teste & \multicolumn{2}{|c|}{ Estatística } & \multicolumn{2}{c|}{ Valor $\mathbf{~}$} \\
\hline Student t & t & 2,061553 & $\mathrm{Pr}>|\mathbf{t}|$ & 0,0549 \\
\hline Sign & $\mathrm{M}$ & 2 & $\mathrm{Pr}>=|\mathrm{M}|$ & 0,1250 \\
\hline Signed Rank & $\mathrm{S}$ & 5 & $\mathrm{Pr}>=|\mathrm{S}|$ & 0,1250 \\
\hline
\end{tabular}

\begin{tabular}{|l|r|}
\hline \multicolumn{2}{|c|}{ Quantis } \\
\hline Level & 2 \\
\hline $100 \%$ Max & 2 \\
\hline $99 \%$ & 2 \\
\hline $95 \%$ & 2 \\
\hline $90 \%$ & 0 \\
\hline $75 \%$ Q3 & 0 \\
\hline $50 \%$ Mediana & 0 \\
\hline $25 \%$ Q1 & 0 \\
\hline $10 \%$ & 0 \\
\hline $5 \%$ & 0 \\
\hline $1 \%$ & 0 \\
\hline $0 \%$ Min & \\
\hline
\end{tabular}


Variável

dependente:

ACI

$\mathrm{ID}=69$

\begin{tabular}{|r|r|r|r|}
\hline \multicolumn{3}{|c|}{ Observações Limite } \\
\hline \multicolumn{2}{|c|}{ Baixa } & \multicolumn{2}{c|}{ Alta } \\
\hline Valor & Obs & Valor & Obs \\
\hline 0 & 1016 & 0 & 1016 \\
\hline 0 & 1015 & 1 & 1013 \\
\hline 0 & 1012 & 1 & 1014 \\
\hline 0 & 1011 & 2 & 1001 \\
\hline 0 & 1010 & 2 & 1004 \\
\hline
\end{tabular}


Variável

dependente:

REC

$\mathrm{ID}=70$

\begin{tabular}{|l|r|l|r|}
\hline \multicolumn{4}{|c|}{ Momento } \\
\hline Média & 18 & Soma dos pesos & 18 \\
\hline Desvio-padrão & 0,51130999 & $\begin{array}{l}\text { Variância } \\
\text { observações }\end{array}$ & 0,26143791 \\
\hline Assimetria & 0,24447009 & Curtose & $-2,199375$ \\
\hline $\begin{array}{l}\text { Soma dos } \\
\text { quadrados não } \\
\text { corrigida }\end{array}$ & 8 & $\begin{array}{l}\text { Soma dos } \\
\text { quadrados corrigida }\end{array}$ & 4,44444444 \\
\hline CV Pearson & 115,044748 & Erro-padrão médio & 0,12051692 \\
\hline
\end{tabular}

\begin{tabular}{|l|l|l|l|}
\hline \multicolumn{4}{|c|}{ Estatística Descritiva Básica } \\
\hline \multicolumn{2}{|c|}{ Posição } & \multicolumn{2}{c|}{ Variabilidade } \\
\hline Média & 0,444444 & Desvio-padrão & 0,51131 \\
\hline Mediana & 0,000000 & Variância & 0,26144 \\
\hline Moda & 0,000000 & Amplitude & 1,00000 \\
\hline & & Amplitude interquartil & 1,00000 \\
\hline
\end{tabular}

\begin{tabular}{|l|l|r|l|l|}
\hline \multicolumn{5}{|c|}{ Testes de Posição: Mu0=0 } \\
\hline Teste & \multicolumn{2}{|c|}{ Estatística } & \multicolumn{2}{c|}{ Valor $\mathbf{~}$} \\
\hline Student t & t & 3,687818 & $\mathrm{Pr}>|\mathbf{t}|$ & 0,0018 \\
\hline Sign & M & 4 & $\mathrm{Pr}>=|\mathrm{M}|$ & 0,0078 \\
\hline Signed Rank & S & 18 & $\mathrm{Pr}>=|\mathrm{S}|$ & 0,0078 \\
\hline
\end{tabular}

\begin{tabular}{|l|r|}
\hline \multicolumn{2}{|c|}{ Quantis } \\
\hline Level & Quantil \\
\hline $100 \%$ Max & 1 \\
\hline $99 \%$ & 1 \\
\hline $95 \%$ & 1 \\
\hline $90 \%$ & 1 \\
\hline $75 \%$ Q3 & 0 \\
\hline $50 \%$ Mediana & 0 \\
\hline $25 \%$ Q1 & 0 \\
\hline $10 \%$ & 0 \\
\hline $5 \%$ & 0 \\
\hline $1 \%$ & 0 \\
\hline $0 \%$ Min & 1 \\
\hline
\end{tabular}


Variável

dependente:

REC

$I D=70$

\begin{tabular}{|r|r|r|r|}
\hline \multicolumn{3}{|c|}{ Observações Limite } \\
\hline \multicolumn{2}{|c|}{ Baixa } & \multicolumn{2}{c|}{ Alta } \\
\hline Valor & Obs & Valor & Obs \\
\hline 0 & 1034 & 1 & 1023 \\
\hline 0 & 1033 & 1 & 1025 \\
\hline 0 & 1030 & 1 & 1027 \\
\hline 0 & 1029 & 1 & 1031 \\
\hline 0 & 1028 & 1 & 1032 \\
\hline
\end{tabular}


Variável

dependente:

ACI

$I D=70$

\begin{tabular}{|l|r|l|r|}
\hline \multicolumn{4}{|c|}{ Momento } \\
\hline Média & 18 & Soma dos pesos & 18 \\
\hline Desvio-padrão & 0,32338083 & $\begin{array}{l}\text { Variância } \\
\text { observações }\end{array}$ & 0,10457516 \\
\hline Assimetria & 2,70578807 & Curtose & 5,9765625 \\
\hline $\begin{array}{l}\text { Soma dos } \\
\text { quadrados não } \\
\text { corrigida }\end{array}$ & 2 & $\begin{array}{l}\text { Soma dos } \\
\text { quadrados corrigida }\end{array}$ & 1,77777778 \\
\hline CV Pearson & 291,04275 & Erro-padrão médio & 0,07622159 \\
\hline
\end{tabular}

\begin{tabular}{|l|l|l|r|}
\hline \multicolumn{4}{|c|}{ Estatística Descritiva Básica } \\
\hline \multicolumn{2}{|c|}{ Posição } & \multicolumn{2}{c|}{ Variabilidade } \\
\hline Média & 0,111111 & Desvio-padrão & 0,32338 \\
\hline Mediana & 0,000000 & Variância & 0,10458 \\
\hline Moda & 0,000000 & Amplitude & 1,00000 \\
\hline & & Amplitude interquartil & 0 \\
\hline
\end{tabular}

\begin{tabular}{|l|l|r|l|l|}
\hline \multicolumn{5}{|c|}{ Testes de Posição: Mu0=0 } \\
\hline Teste & \multicolumn{2}{|c|}{ Estatística } & \multicolumn{2}{c|}{ Valor $\mathbf{~}$} \\
\hline Student t & t & 1,457738 & $\mathrm{Pr}>|\mathbf{t}|$ & 0,1631 \\
\hline Sign & M & 1 & $\mathrm{Pr}>=|\mathrm{M}|$ & 0,5000 \\
\hline Signed Rank & S & 1,5 & $\mathrm{Pr}>=|\mathrm{S}|$ & 0,5000 \\
\hline
\end{tabular}

\begin{tabular}{|l|r|}
\hline \multicolumn{2}{|c|}{ Quantis } \\
\hline Level & 1 \\
\hline $100 \%$ Max & 1 \\
\hline $99 \%$ & 1 \\
\hline $95 \%$ & 1 \\
\hline $90 \%$ & 0 \\
\hline $75 \%$ Quantil & 0 \\
\hline $50 \%$ Mediana & 0 \\
\hline $25 \%$ Q1 & 0 \\
\hline $10 \%$ & 0 \\
\hline $5 \%$ & 0 \\
\hline $1 \%$ & 0 \\
\hline $0 \%$ Min & \\
\hline
\end{tabular}


Variável

dependente:

ACI

$\mathrm{ID}=\mathbf{7 0}$

\begin{tabular}{|r|r|r|r|}
\hline \multicolumn{3}{|c|}{ Observações Limite } \\
\hline \multicolumn{2}{|c|}{ Baixa } & \multicolumn{2}{c|}{ Alta } \\
\hline Valor & Obs & Valor & Obs \\
\hline 0 & 1034 & 0 & 1032 \\
\hline 0 & 1033 & 0 & 1033 \\
\hline 0 & 1032 & 0 & 1034 \\
\hline 0 & 1031 & 1 & 1018 \\
\hline 0 & 1030 & 1 & 1021 \\
\hline
\end{tabular}


Variável

dependente:

REC

$\mathrm{ID}=71$

\begin{tabular}{|l|r|r|r|}
\hline \multicolumn{3}{|c|}{ Momento } \\
\hline N & 16 Soma dos pesos & 16 \\
\hline Média & $\begin{array}{r}0 \\
\text { Soma das } \\
\text { observações }\end{array}$ & 0 \\
\hline Desvio-padrão & 0 & Variância & 0 \\
\hline Assimetria &, Curtose &, \\
\hline $\begin{array}{l}\text { Soma dos } \\
\text { quadrados não } \\
\text { corrigida }\end{array}$ & 0 & $\begin{array}{l}\text { Soma dos } \\
\text { quadrados corrigida }\end{array}$ & 0 \\
\hline CV Pearson &, & Erro-padrão médio & 0 \\
\hline
\end{tabular}

\begin{tabular}{|l|r|l|r|}
\hline \multicolumn{3}{|c|}{ Estatística Descritiva Básica } \\
\hline \multicolumn{2}{|c|}{ Posição } & \multicolumn{2}{c|}{ Variabilidade } \\
\hline Média & 0 & Desvio-padrão & 0 \\
\hline Mediana & 0 & Variância & 0 \\
\hline Moda & 0 & Amplitude & 0 \\
\hline & & Amplitude interquartil & 0 \\
\hline
\end{tabular}

\begin{tabular}{|l|l|l|l|l|}
\hline \multicolumn{4}{|c|}{ Testes de Posição: Mu0=0 } \\
\hline Teste & \multicolumn{2}{|c|}{ Estatística } & \multicolumn{2}{c|}{ Valor $\mathbf{p}$} \\
\hline Student $\mathbf{t}$ & $\mathbf{t}$ & \multicolumn{1}{|c|}{, $\operatorname{Pr}>|\mathbf{t}|$} & \\
\hline Sign & $\mathrm{M}$ &, & $\operatorname{Pr}>=|\mathrm{M}|$ & \\
\hline Signed Rank & S &, & $\operatorname{Pr}>=|\mathrm{S}|$ & \\
\hline
\end{tabular}

\begin{tabular}{|l|r|}
\hline \multicolumn{2}{|c|}{ Quantis } \\
\hline Level & 0 \\
\hline $100 \%$ Max & 0 \\
\hline $99 \%$ & 0 \\
\hline $95 \%$ & 0 \\
\hline $90 \%$ & 0 \\
\hline $75 \%$ Q3 & 0 \\
\hline $50 \%$ Mediana & 0 \\
\hline $25 \%$ Q1 & 0 \\
\hline $10 \%$ & 0 \\
\hline $5 \%$ & 0 \\
\hline $1 \%$ & 0 \\
\hline $0 \%$ Min & 0 \\
\hline
\end{tabular}


Variável

dependente:

REC

$\mathrm{ID}=71$

\begin{tabular}{|r|c|r|r|}
\hline \multicolumn{3}{|c|}{ Observações Limite } \\
\hline \multicolumn{2}{|c|}{ Baixa } & \multicolumn{2}{c|}{ Alta } \\
\hline Valor & Obs & Valor & Obs \\
\hline 0 & 1050 & 0 & 1046 \\
\hline 0 & 1049 & 0 & 1047 \\
\hline 0 & 1048 & 0 & 1048 \\
\hline 0 & 1047 & 0 & 1049 \\
\hline 0 & 1046 & 0 & 1050 \\
\hline
\end{tabular}


Variável

dependente:

ACI

$\mathrm{ID}=71$

\begin{tabular}{|l|r|l|r|}
\hline \multicolumn{3}{|c|}{ Momento } \\
\hline N & 16 & Soma dos pesos & 16 \\
\hline Média & $\begin{array}{r}0 \\
\text { Soma das } \\
\text { observações }\end{array}$ & 0 \\
\hline Desvio-padrão & 0 & Variância & 0 \\
\hline Assimetria &, Curtose &, \\
\hline $\begin{array}{l}\text { Soma dos } \\
\text { quadrados não } \\
\text { corrigida }\end{array}$ & 0 & $\begin{array}{l}\text { Soma dos } \\
\text { quadrados corrigida }\end{array}$ & 0 \\
\hline CV Pearson &, & Erro-padrão médio & 0 \\
\hline
\end{tabular}

\begin{tabular}{|l|r|l|r|}
\hline \multicolumn{3}{|c|}{ Estatística Descritiva Básica } \\
\hline \multicolumn{2}{|c|}{ Posição } & \multicolumn{2}{c|}{ Variabilidade } \\
\hline Média & 0 & Desvio-padrão & 0 \\
\hline Mediana & 0 & Variância & 0 \\
\hline Moda & 0 & Amplitude & 0 \\
\hline & & Amplitude interquartil & 0 \\
\hline
\end{tabular}

\begin{tabular}{|l|l|l|l|l|}
\hline \multicolumn{5}{|c|}{ Testes de Posição: Mu0=0 } \\
\hline Teste & \multicolumn{2}{|c|}{ Estatística } & \multicolumn{2}{c|}{ Valor $\mathbf{p}$} \\
\hline Student t & t &, & $\operatorname{Pr}>|\mathbf{t}|$ & \\
\hline Sign & M &, & $\operatorname{Pr}>=|\mathrm{M}|$ & \\
\hline Signed Rank & S &, & $\operatorname{Pr}>=|\mathrm{S}|$ & \\
\hline
\end{tabular}

\begin{tabular}{|l|r|}
\hline \multicolumn{2}{|c|}{ Quantis } \\
\hline Level & 0 \\
\hline $100 \%$ Max & 0 \\
\hline $99 \%$ & 0 \\
\hline $95 \%$ & 0 \\
\hline $90 \%$ & 0 \\
\hline $75 \%$ Q3 & 0 \\
\hline $50 \%$ Mediana & 0 \\
\hline $25 \%$ Q1 & 0 \\
\hline $10 \%$ & 0 \\
\hline $5 \%$ & 0 \\
\hline $1 \%$ & 0 \\
\hline $0 \%$ Min & 0 \\
\hline
\end{tabular}


Variável

dependente:

ACI

$\mathrm{ID}=71$

\begin{tabular}{|r|c|r|r|}
\hline \multicolumn{3}{|c|}{ Observações Limite } \\
\hline \multicolumn{2}{|c|}{ Baixa } & \multicolumn{2}{c|}{ Alta } \\
\hline Valor & Obs & Valor & Obs \\
\hline 0 & 1050 & 0 & 1046 \\
\hline 0 & 1049 & 0 & 1047 \\
\hline 0 & 1048 & 0 & 1048 \\
\hline 0 & 1047 & 0 & 1049 \\
\hline 0 & 1046 & 0 & 1050 \\
\hline
\end{tabular}


Variável

dependente:

REC

$I D=72$

\begin{tabular}{|l|r|l|r|}
\hline \multicolumn{4}{|c|}{ Momento } \\
\hline Média & 17 & Soma dos pesos & 17 \\
\hline Desvio-padrão & 0,62426427 & Variância \\
\hline observações & 0,38970588 \\
\hline $\begin{array}{l}\text { Soma dos } \\
\text { quadrados não } \\
\text { corrigida }\end{array}$ & 0,99740052 & Curtose & 0,20057977 \\
\hline CV Pearson & 10 & $\begin{array}{l}\text { Soma dos } \\
\text { quadrados corrigida }\end{array}$ & 6,23529412 \\
\hline
\end{tabular}

\begin{tabular}{|l|c|l|c|}
\hline \multicolumn{4}{|c|}{ Estatística Descritiva Básica } \\
\hline \multicolumn{2}{|c|}{ Posição } & \multicolumn{2}{c|}{ Variabilidade } \\
\hline Média & 0,470588 & Desvio-padrão & 0,62426 \\
\hline Mediana & 0,000000 & Variância & 0,38971 \\
\hline Moda & 0,000000 & Amplitude & 2,00000 \\
\hline & & Amplitude interquartil & 1,00000 \\
\hline
\end{tabular}

\begin{tabular}{|l|l|r|l|l|}
\hline \multicolumn{5}{|c|}{ Testes de Posição: Mu0=0 } \\
\hline Teste & \multicolumn{2}{|c|}{ Estatística } & \multicolumn{2}{c|}{ Valor $\mathbf{~}$} \\
\hline Student t & t & 3,108115 & $\mathrm{Pr}>|\mathbf{t}|$ & 0,0068 \\
\hline Sign & M & 3,5 & $\mathrm{Pr}>=|\mathrm{M}|$ & 0,0156 \\
\hline Signed Rank & S & 14 & $\mathrm{Pr}>=|\mathrm{S}|$ & 0,0156 \\
\hline
\end{tabular}

\begin{tabular}{|l|r|}
\hline \multicolumn{2}{|c|}{ Quantis } \\
\hline Level & 2 \\
\hline $100 \%$ Max & 2 \\
\hline $99 \%$ & 2 \\
\hline $95 \%$ & 1 \\
\hline $90 \%$ & 1 \\
\hline $75 \%$ Q3 & 0 \\
\hline $50 \%$ Mediana & 0 \\
\hline $25 \%$ Q1 & 0 \\
\hline $10 \%$ & 0 \\
\hline $5 \%$ & 0 \\
\hline $1 \%$ & 0 \\
\hline $0 \%$ Min & 0 \\
\hline
\end{tabular}


Variável

dependente:

REC

$\mathrm{ID}=72$

\begin{tabular}{|r|r|r|r|}
\hline \multicolumn{3}{|c|}{ Observações Limite } \\
\hline \multicolumn{2}{|c|}{ Baixa } & \multicolumn{2}{c|}{ Alta } \\
\hline Valor & Obs & Valor & Obs \\
\hline 0 & 1066 & 1 & 1055 \\
\hline 0 & 1064 & 1 & 1056 \\
\hline 0 & 1063 & 1 & 1065 \\
\hline 0 & 1062 & 1 & 1067 \\
\hline 0 & 1061 & 2 & 1059 \\
\hline
\end{tabular}


Variável

dependente:

ACI

$\mathrm{ID}=72$

\begin{tabular}{|l|r|l|r|}
\hline \multicolumn{3}{|c|}{ Momento } \\
\hline N & 17 & Soma dos pesos & 17 \\
\hline Média & $\begin{array}{r}0 \\
\text { Soma das } \\
\text { observações }\end{array}$ & 0 \\
\hline Desvio-padrão & 0 & Variância & 0 \\
\hline Assimetria &, Curtose &, \\
\hline $\begin{array}{l}\text { Soma dos } \\
\text { quadrados não } \\
\text { corrigida }\end{array}$ & 0 & $\begin{array}{l}\text { Soma dos } \\
\text { quadrados corrigida }\end{array}$ & 0 \\
\hline CV Pearson &, & Erro-padrão médio & 0 \\
\hline
\end{tabular}

\begin{tabular}{|l|r|l|r|}
\hline \multicolumn{3}{|c|}{ Estatística Descritiva Básica } \\
\hline \multicolumn{2}{|c|}{ Posição } & \multicolumn{2}{c|}{ Variabilidade } \\
\hline Média & 0 & Desvio-padrão & 0 \\
\hline Mediana & 0 & Variância & 0 \\
\hline Moda & 0 & Amplitude & 0 \\
\hline & & Amplitude interquartil & 0 \\
\hline
\end{tabular}

\begin{tabular}{|l|l|l|l|l|}
\hline \multicolumn{4}{|c|}{ Testes de Posição: Mu0=0 } \\
\hline Teste & \multicolumn{2}{|c|}{ Estatística } & \multicolumn{2}{c|}{ Valor $\mathbf{p}$} \\
\hline Student $\mathbf{t}$ & $\mathbf{t}$ & \multicolumn{1}{|c|}{, $\operatorname{Pr}>|\mathbf{t}|$} & \\
\hline Sign & $\mathrm{M}$ &, & $\operatorname{Pr}>=|\mathrm{M}|$ & \\
\hline Signed Rank & S &, & $\operatorname{Pr}>=|\mathrm{S}|$ & \\
\hline
\end{tabular}

\begin{tabular}{|l|r|}
\hline \multicolumn{2}{|c|}{ Quantis } \\
\hline Level & 0 \\
\hline $100 \%$ Max & 0 \\
\hline $99 \%$ & 0 \\
\hline $95 \%$ & 0 \\
\hline $90 \%$ & 0 \\
\hline $75 \%$ Q3 & 0 \\
\hline $50 \%$ Mediana & 0 \\
\hline $25 \%$ Q1 & 0 \\
\hline $10 \%$ & 0 \\
\hline $5 \%$ & 0 \\
\hline $1 \%$ & 0 \\
\hline $0 \%$ Min & 0 \\
\hline
\end{tabular}


Variável

dependente:

ACI

$\mathrm{ID}=72$

\begin{tabular}{|r|r|r|r|}
\hline \multicolumn{3}{|c|}{ Observações Limite } \\
\hline \multicolumn{2}{|c|}{ Baixa } & \multicolumn{2}{c|}{ Alta } \\
\hline Valor & Obs & Valor & Obs \\
\hline 0 & 1067 & 0 & 1063 \\
\hline 0 & 1066 & 0 & 1064 \\
\hline 0 & 1065 & 0 & 1065 \\
\hline 0 & 1064 & 0 & 1066 \\
\hline 0 & 1063 & 0 & 1067 \\
\hline
\end{tabular}


Variável

dependente:

REC

$\mathrm{ID}=73$

\begin{tabular}{|l|r|l|r|}
\hline \multicolumn{4}{|c|}{ Momento } \\
\hline Média & 18 & Soma dos pesos & 21 \\
\hline Desvio-padrão & 1,15044748 & $\begin{array}{l}\text { Variância } \\
\text { observações }\end{array}$ & 1,32352941 \\
\hline Assimetria & 0,94166257 & Curtose & 0,63634568 \\
\hline $\begin{array}{l}\text { Soma dos } \\
\text { quadrados não } \\
\text { corrigida }\end{array}$ & 47 & $\begin{array}{l}\text { Soma dos } \\
\text { quadrados corrigida }\end{array}$ & 22,5 \\
\hline CV Pearson & 98,6097843 & Erro-padrão médio & 0,27116307 \\
\hline
\end{tabular}

\begin{tabular}{|l|c|l|c|}
\hline \multicolumn{4}{|c|}{ Estatística Descritiva Básica } \\
\hline \multicolumn{2}{|c|}{ Posição } & \multicolumn{2}{c|}{ Variabilidade } \\
\hline Média & 1,166667 & Desvio-padrão & 1,15045 \\
\hline Mediana & 1,000000 & Variância & 1,32353 \\
\hline Moda & 0,000000 & Amplitude & 4,00000 \\
\hline & & Amplitude interquartil & 2,00000 \\
\hline
\end{tabular}

Note: The Moda displayed is the smallest of 2 Modas with a count of 6 ,

\begin{tabular}{|l|l|r|l|l|}
\hline \multicolumn{5}{|c|}{ Testes de Posição: Mu0=0 } \\
\hline Teste & \multicolumn{2}{|c|}{ Estatística } & \multicolumn{2}{c|}{ Valor $\mathbf{~}$} \\
\hline Student t & t & 4,302454 & $\mathrm{Pr}>|\mathbf{t}|$ & 0,0005 \\
\hline Sign & M & 6 & $\mathrm{Pr}>=|\mathrm{M}|$ & 0,0005 \\
\hline Signed Rank & S & 39 & $\mathrm{Pr}>=|\mathbf{S}|$ & 0,0005 \\
\hline
\end{tabular}

\begin{tabular}{|l|r|}
\hline \multicolumn{2}{|c|}{ Quantis } \\
\hline Level & Quantil \\
\hline $100 \%$ Max & 4 \\
\hline $99 \%$ & 4 \\
\hline $95 \%$ & 3 \\
\hline $90 \%$ & 2 \\
\hline $75 \%$ Q3 & 1 \\
\hline $50 \%$ Mediana & 0 \\
\hline $25 \%$ Q1 & 0 \\
\hline $10 \%$ & 0 \\
\hline $5 \%$ & 0 \\
\hline $1 \%$ & 0 \\
\hline $0 \%$ Min & 4 \\
\hline
\end{tabular}


Variável

dependente:

REC

$\mathrm{ID}=73$

\begin{tabular}{|r|r|r|r|}
\hline \multicolumn{3}{|c|}{ Observações Limite } \\
\hline \multicolumn{2}{|c|}{ Baixa } & \multicolumn{2}{c|}{ Alta } \\
\hline Valor & Obs & Valor & Obs \\
\hline 0 & 1084 & 2 & 1074 \\
\hline 0 & 1082 & 2 & 1075 \\
\hline 0 & 1080 & 2 & 1085 \\
\hline 0 & 1078 & 3 & 1071 \\
\hline 0 & 1076 & 4 & 1069 \\
\hline
\end{tabular}


Variável

dependente:

ACI

$\mathrm{ID}=73$

\begin{tabular}{|l|r|l|r|}
\hline \multicolumn{4}{|c|}{ Momento } \\
\hline Média & 18 & Soma dos pesos & 18 \\
\hline Desvio-padrão & 1,82305497 & Variância \\
observações & 3,32352941 \\
\hline Assimetria & 2,34460088 & Curtose & 5,86166497 \\
\hline $\begin{array}{l}\text { Soma dos } \\
\text { quadrados não } \\
\text { corrigida }\end{array}$ & 81 & $\begin{array}{l}\text { Soma dos } \\
\text { quadrados corrigida }\end{array}$ & 56,5 \\
\hline CV Pearson & 156,261854 & Erro-padrão médio & 0,42969818 \\
\hline
\end{tabular}

\begin{tabular}{|l|c|l|r|}
\hline \multicolumn{4}{|c|}{ Estatística Descritiva Básica } \\
\hline \multicolumn{2}{|c|}{ Posição } & \multicolumn{2}{c|}{ Variabilidade } \\
\hline Média & 1,166667 & Desvio-padrão & 1,82305 \\
\hline Mediana & 1,000000 & Variância & 3,32353 \\
\hline Moda & 0,000000 & Amplitude & 7,00000 \\
\hline & & Amplitude interquartil & 1,00000 \\
\hline
\end{tabular}

\begin{tabular}{|l|l|r|l|l|}
\hline \multicolumn{5}{|c|}{ Testes de Posição: Mu0=0 } \\
\hline Teste & \multicolumn{2}{|c|}{ Estatística } & \multicolumn{2}{c|}{ Valor $\mathbf{~}$} \\
\hline Student t & t & 2,715084 & $\mathrm{Pr}>|\mathbf{t}|$ & 0,0147 \\
\hline Sign & M & 5 & $\mathrm{Pr}>=|\mathrm{M}|$ & 0,0020 \\
\hline Signed Rank & S & 27,5 & $\mathrm{Pr}>=|\mathrm{S}|$ & 0,0020 \\
\hline
\end{tabular}

\begin{tabular}{|l|r|}
\hline \multicolumn{2}{|c|}{ Quantis } \\
\hline Level & Quantil \\
\hline $100 \%$ Max & 7 \\
\hline $99 \%$ & 7 \\
\hline $95 \%$ & 4 \\
\hline $90 \%$ & 1 \\
\hline $75 \%$ Q3 & 1 \\
\hline $50 \%$ Mediana & 0 \\
\hline $25 \%$ Q1 & 0 \\
\hline $10 \%$ & 0 \\
\hline $5 \%$ & 0 \\
\hline $1 \%$ & 0 \\
\hline $0 \%$ Min & 7 \\
\hline
\end{tabular}


Variável

dependente:

ACI

$\mathrm{ID}=73$

\begin{tabular}{|r|r|r|r|}
\hline \multicolumn{3}{|c|}{ Observações Limite } \\
\hline \multicolumn{2}{|c|}{ Baixa } & \multicolumn{2}{c|}{ Alta } \\
\hline Valor & Obs & Valor & Obs \\
\hline 0 & 1084 & 1 & 1081 \\
\hline 0 & 1083 & 1 & 1085 \\
\hline 0 & 1082 & 3 & 1077 \\
\hline 0 & 1078 & 4 & 1071 \\
\hline 0 & 1076 & 7 & 1070 \\
\hline
\end{tabular}


Variável

dependente:

REC

ID $=74$

\begin{tabular}{|l|r|l|r|}
\hline \multicolumn{3}{|c|}{ Momento } \\
\hline Média & 18 & Soma dos pesos & 18 \\
\hline Desvio-padrão & 0,48507125 & Variância \\
\hline Assimetria & 0,7730823 & Curtose & 0,23529412 \\
\hline $\begin{array}{l}\text { Soma dos } \\
\text { quadrados não } \\
\text { corrigida }\end{array}$ & 6 & $\begin{array}{l}\text { Soma dos } \\
\text { quadrados corrigida }\end{array}$ & $-1,59375$ \\
\hline CV Pearson & 145,521375 & Erro-padrão médio & 0,11433239 \\
\hline
\end{tabular}

\begin{tabular}{|l|l|l|c|}
\hline \multicolumn{4}{|c|}{ Estatística Descritiva Básica } \\
\hline Média & 0,333333 & Desvio-padrão & 0,48507 \\
\hline Mediana & 0,000000 & Variância & 0,23529 \\
\hline Moda & 0,000000 & Amplitude & 1,00000 \\
\hline & & Amplitude interquartil & 1,00000 \\
\hline
\end{tabular}

\begin{tabular}{|l|l|r|l|l|}
\hline \multicolumn{5}{|c|}{ Testes de Posição: Mu0=0 } \\
\hline Teste & \multicolumn{2}{|c|}{ Estatística } & \multicolumn{2}{c|}{ Valor $\mathbf{~}$} \\
\hline Student t & t & 2,915476 & $\mathrm{Pr}>|\mathbf{t}|$ & 0,0096 \\
\hline Sign & M & 3 & $\mathrm{Pr}>=|\mathrm{M}|$ & 0,0313 \\
\hline Signed Rank & S & 10,5 & $\mathrm{Pr}>=|\mathbf{S}|$ & 0,0313 \\
\hline
\end{tabular}

\begin{tabular}{|l|r|}
\hline \multicolumn{2}{|c|}{ Quantis } \\
\hline Level & 1 \\
\hline $100 \%$ Max & 1 \\
\hline $99 \%$ & 1 \\
\hline $95 \%$ & 1 \\
\hline $90 \%$ & 1 \\
\hline $75 \%$ Q3 & 0 \\
\hline $50 \%$ Mediana & 0 \\
\hline $25 \%$ Q1 & 0 \\
\hline $10 \%$ & 0 \\
\hline $5 \%$ & 0 \\
\hline $1 \%$ & 0 \\
\hline $0 \%$ Min & \\
\hline
\end{tabular}


Variável

dependente:

REC

$\mathrm{ID}=74$

\begin{tabular}{|r|r|r|r|}
\hline \multicolumn{3}{|c|}{ Observações Limite } \\
\hline \multicolumn{2}{|c|}{ Baixa } & \multicolumn{2}{c|}{ Alta } \\
\hline Valor & Obs & Valor & Obs \\
\hline 0 & 1102 & 1 & 1091 \\
\hline 0 & 1100 & 1 & 1095 \\
\hline 0 & 1098 & 1 & 1099 \\
\hline 0 & 1097 & 1 & 1101 \\
\hline 0 & 1096 & 1 & 1103 \\
\hline
\end{tabular}


Variável

dependente:

ACI

ID $=74$

\begin{tabular}{|l|r|l|r|}
\hline \multicolumn{3}{|c|}{ Momento } \\
\hline Média & 18 & Soma dos pesos & 18 \\
\hline Desvio-padrão & 0,94280904 & $\begin{array}{l}\text { Variância } \\
\text { observações }\end{array}$ & 0,88888889 \\
\hline Assimetria & 4,24264069 & Curtose & 18 \\
\hline $\begin{array}{l}\text { Soma dos } \\
\text { quadrados não } \\
\text { corrigida }\end{array}$ & 16 & $\begin{array}{l}\text { Soma dos } \\
\text { quadrados corrigida }\end{array}$ & 15,1111111 \\
\hline CV Pearson & 424,264069 & Erro-padrão médio & 0,22222222 \\
\hline
\end{tabular}

\begin{tabular}{|l|l|l|r|}
\hline \multicolumn{4}{|c|}{ Estatística Descritiva Básica } \\
\hline Média & 0,222222 & Desvio-padrão & 0,94281 \\
\hline Mediana & 0,000000 & Variância & 0,88889 \\
\hline Moda & 0,000000 & Amplitude & 4,00000 \\
\hline & & Amplitude interquartil & 0 \\
\hline
\end{tabular}

\begin{tabular}{|l|l|r|l|l|}
\hline \multicolumn{5}{|c|}{ Testes de Posição: Mu0=0 } \\
\hline Teste & \multicolumn{2}{|c|}{ Estatística } & \multicolumn{2}{c|}{ Valor $\mathbf{~}$} \\
\hline Student t & $\mathbf{t}$ & 1 & $\mathrm{Pr}>|\mathbf{t}|$ & 0,3313 \\
\hline Sign & $\mathbf{M}$ & 0,5 & $\mathrm{Pr}>=|\mathrm{M}|$ & 1,0000 \\
\hline Signed Rank & $\mathbf{S}$ & 0,5 & $\mathrm{Pr}>=|\mathbf{S}|$ & 1,0000 \\
\hline
\end{tabular}

\begin{tabular}{|l|r|}
\hline \multicolumn{2}{|c|}{ Quantis } \\
\hline Level & Quantil \\
\hline $100 \%$ Max & 4 \\
\hline $99 \%$ & 4 \\
\hline $95 \%$ & 0 \\
\hline $90 \%$ & 0 \\
\hline $75 \%$ Q3 & 0 \\
\hline $50 \%$ Mediana & 0 \\
\hline $25 \%$ Q1 & 0 \\
\hline $10 \%$ & 0 \\
\hline $5 \%$ & 0 \\
\hline $1 \%$ & 0 \\
\hline $0 \%$ Min & 4 \\
\hline
\end{tabular}


Variável

dependente:

ACI

$\mathrm{ID}=74$

\begin{tabular}{|r|c|r|r|}
\hline \multicolumn{3}{|c|}{ Observações Limite } \\
\hline \multicolumn{2}{|c|}{ Baixa } & \multicolumn{2}{c|}{ Alta } \\
\hline Valor & Obs & Valor & Obs \\
\hline 0 & 1103 & 0 & 1100 \\
\hline 0 & 1102 & 0 & 1101 \\
\hline 0 & 1101 & 0 & 1102 \\
\hline 0 & 1100 & 0 & 1103 \\
\hline 0 & 1099 & 4 & 1087 \\
\hline
\end{tabular}


Variável

dependente:

REC

$\mathrm{ID}=75$

\begin{tabular}{|l|r|l|r|}
\hline \multicolumn{3}{|c|}{ Momento } \\
\hline Média & 12 & Soma dos pesos & 12 \\
\hline Desvio-padrão & 0,28867513 & Variância \\
observações & 0,08333333 \\
\hline Assimetria & 3,46410162 & Curtose & 12 \\
\hline $\begin{array}{l}\text { Soma dos } \\
\text { quadrados não } \\
\text { corrigida }\end{array}$ & 1 & $\begin{array}{l}\text { Soma dos } \\
\text { quadrados corrigida }\end{array}$ & 0,91666667 \\
\hline CV Pearson & 346,410162 & Erro-padrão médio & 0,08333333 \\
\hline
\end{tabular}

\begin{tabular}{|l|l|l|r|}
\hline \multicolumn{4}{|c|}{ Estatística Descritiva Básica } \\
\hline Média & 0,083333 & Desvio-padrão & 0,28868 \\
\hline Mediana & 0,000000 & Variância & 0,08333 \\
\hline Moda & 0,000000 & Amplitude & 1,00000 \\
\hline & & Amplitude interquartil & 0 \\
\hline
\end{tabular}

\begin{tabular}{|l|l|r|l|l|}
\hline \multicolumn{5}{|c|}{ Testes de Posição: Mu0=0 } \\
\hline Teste & \multicolumn{2}{|c|}{ Estatística } & \multicolumn{2}{c|}{ Valor $\mathbf{~}$} \\
\hline Student t & $\mathbf{t}$ & 1 & $\operatorname{Pr}>|\mathbf{t}|$ & 0,3388 \\
\hline Sign & M & 0,5 & $\operatorname{Pr}>=|M|$ & 1,0000 \\
\hline Signed Rank & S & 0,5 & $\operatorname{Pr}>=|\mathbf{S}|$ & 1,0000 \\
\hline
\end{tabular}

\begin{tabular}{|l|r|}
\hline \multicolumn{2}{|c|}{ Quantis } \\
\hline Level & 1 \\
\hline $100 \%$ Max & 1 \\
\hline $99 \%$ & 1 \\
\hline $95 \%$ & 0 \\
\hline $90 \%$ & 0 \\
\hline $75 \%$ Quantil & 0 \\
\hline $50 \%$ Mediana & 0 \\
\hline $25 \%$ Q1 & 0 \\
\hline $10 \%$ & 0 \\
\hline $5 \%$ & 0 \\
\hline $1 \%$ & 0 \\
\hline $0 \%$ Min & \\
\hline
\end{tabular}


Variável

dependente:

REC

$\mathrm{ID}=75$

\begin{tabular}{|r|r|r|r|}
\hline \multicolumn{3}{|c|}{ Observações Limite } \\
\hline \multicolumn{2}{|c|}{ Baixa } & \multicolumn{2}{c|}{ Alta } \\
\hline Valor & Obs & Valor & Obs \\
\hline 0 & 1115 & 0 & 1111 \\
\hline 0 & 1113 & 0 & 1112 \\
\hline 0 & 1112 & 0 & 1113 \\
\hline 0 & 1111 & 0 & 1115 \\
\hline 0 & 1110 & 1 & 1114 \\
\hline
\end{tabular}


Variável

dependente:

ACI

$I D=75$

\begin{tabular}{|l|r|l|r|}
\hline \multicolumn{3}{|c|}{ Momento } \\
\hline Média & 12 & Soma dos pesos & 12 \\
\hline Desvio-padrão & 0,28867513 & Variância \\
observações & 0,08333333 \\
\hline Assimetria & 3,46410162 & Curtose & 12 \\
\hline $\begin{array}{l}\text { Soma dos } \\
\text { quadrados não } \\
\text { corrigida }\end{array}$ & 1 & $\begin{array}{l}\text { Soma dos } \\
\text { quadrados corrigida }\end{array}$ & 0,91666667 \\
\hline CV Pearson & 346,410162 & Erro-padrão médio & 0,08333333 \\
\hline
\end{tabular}

\begin{tabular}{|l|l|l|r|}
\hline \multicolumn{4}{|c|}{ Estatística Descritiva Básica } \\
\hline Média & 0,083333 & Desvio-padrão & 0,28868 \\
\hline Mediana & 0,000000 & Variância & 0,08333 \\
\hline Moda & 0,000000 & Amplitude & 1,00000 \\
\hline & & Amplitude interquartil & 0 \\
\hline
\end{tabular}

\begin{tabular}{|l|l|r|l|l|}
\hline \multicolumn{5}{|c|}{ Testes de Posição: Mu0=0 } \\
\hline Teste & \multicolumn{2}{|c|}{ Estatística } & \multicolumn{2}{c|}{ Valor $\mathbf{~}$} \\
\hline Student t & $\mathbf{t}$ & 1 & $\operatorname{Pr}>|\mathbf{t}|$ & 0,3388 \\
\hline Sign & M & 0,5 & $\operatorname{Pr}>=|M|$ & 1,0000 \\
\hline Signed Rank & S & 0,5 & $\operatorname{Pr}>=|\mathbf{S}|$ & 1,0000 \\
\hline
\end{tabular}

\begin{tabular}{|l|r|}
\hline \multicolumn{2}{|c|}{ Quantis } \\
\hline Level & 1 \\
\hline $100 \%$ Max & 1 \\
\hline $99 \%$ & 1 \\
\hline $95 \%$ & 0 \\
\hline $90 \%$ & 0 \\
\hline $75 \%$ Quantil & 0 \\
\hline $50 \%$ Mediana & 0 \\
\hline $25 \%$ Q1 & 0 \\
\hline $10 \%$ & 0 \\
\hline $5 \%$ & 0 \\
\hline $1 \%$ & 0 \\
\hline $0 \%$ Min & \\
\hline
\end{tabular}


Variável

dependente:

ACI

$\mathrm{ID}=75$

\begin{tabular}{|r|r|r|r|}
\hline \multicolumn{3}{|c|}{ Observações Limite } \\
\hline \multicolumn{2}{|c|}{ Baixa } & \multicolumn{2}{c|}{ Alta } \\
\hline Valor & Obs & Valor & Obs \\
\hline 0 & 1115 & 0 & 1111 \\
\hline 0 & 1113 & 0 & 1112 \\
\hline 0 & 1112 & 0 & 1113 \\
\hline 0 & 1111 & 0 & 1115 \\
\hline 0 & 1110 & 1 & 1114 \\
\hline
\end{tabular}


Variável

dependente:

REC

$\mathrm{ID}=76$

\begin{tabular}{|l|r|l|r|}
\hline \multicolumn{3}{|c|}{ Momento } \\
\hline Média & 18 & Soma dos pesos & 18 \\
\hline Desvio-padrão & 0,23570226 & $\begin{array}{l}\text { Variância } \\
\text { observações }\end{array}$ & 0,05555556 \\
\hline Assimetria & 4,24264069 & Curtose & 18 \\
\hline $\begin{array}{l}\text { Soma dos } \\
\text { quadrados não } \\
\text { corrigida }\end{array}$ & 1 & $\begin{array}{l}\text { Soma dos } \\
\text { quadrados corrigida }\end{array}$ & 0,94444444 \\
\hline CV Pearson & 424,264069 & Erro-padrão médio & 0,05555556 \\
\hline
\end{tabular}

\begin{tabular}{|l|l|l|r|}
\hline \multicolumn{4}{|c|}{ Estatística Descritiva Básica } \\
\hline Média & 0,055556 & Desvio-padrão & 0,23570 \\
\hline Mediana & 0,000000 & Variância & 0,05556 \\
\hline Moda & 0,000000 & Amplitude & 1,00000 \\
\hline & & Amplitude interquartil & 0 \\
\hline
\end{tabular}

\begin{tabular}{|l|l|r|l|l|}
\hline \multicolumn{5}{|c|}{ Testes de Posição: Mu0=0 } \\
\hline Teste & \multicolumn{2}{|c|}{ Estatística } & \multicolumn{2}{c|}{ Valor $\mathbf{~}$} \\
\hline Student t & $\mathbf{t}$ & 1 & $\operatorname{Pr}>|\mathbf{t}|$ & 0,3313 \\
\hline Sign & M & 0,5 & $\operatorname{Pr}>=|M|$ & 1,0000 \\
\hline Signed Rank & S & 0,5 & $\operatorname{Pr}>=|\mathbf{S}|$ & 1,0000 \\
\hline
\end{tabular}

\begin{tabular}{|l|r|}
\hline \multicolumn{2}{|c|}{ Quantis } \\
\hline Level & 1 \\
\hline $100 \%$ Max & 1 \\
\hline $99 \%$ & 1 \\
\hline $95 \%$ & 0 \\
\hline $90 \%$ & 0 \\
\hline $75 \%$ Quantil & 0 \\
\hline $50 \%$ Mediana & 0 \\
\hline $25 \%$ Q1 & 0 \\
\hline $10 \%$ & 0 \\
\hline $5 \%$ & 0 \\
\hline $1 \%$ & 0 \\
\hline $0 \%$ Min & \\
\hline
\end{tabular}


Variável

dependente:

REC

$\mathrm{ID}=76$

\begin{tabular}{|r|r|r|r|}
\hline \multicolumn{3}{|c|}{ Observações Limite } \\
\hline \multicolumn{2}{|c|}{ Baixa } & \multicolumn{2}{c|}{ Alta } \\
\hline Valor & Obs & Valor & Obs \\
\hline 0 & 1133 & 0 & 1130 \\
\hline 0 & 1132 & 0 & 1131 \\
\hline 0 & 1131 & 0 & 1132 \\
\hline 0 & 1130 & 0 & 1133 \\
\hline 0 & 1129 & 1 & 1124 \\
\hline
\end{tabular}


Variável

dependente:

ACI

$\mathrm{ID}=76$

\begin{tabular}{|l|r|l|r|}
\hline \multicolumn{4}{|c|}{ Momento } \\
\hline Média & 18 & Soma dos pesos & 18 \\
\hline Desvio-padrão & 0,47140452 & Variância \\
observações & 18 \\
\hline Assimetria & 4,24264069 & Curtose & 0,22222222 \\
\hline $\begin{array}{l}\text { Soma dos } \\
\text { quadrados não } \\
\text { corrigida }\end{array}$ & 4 & $\begin{array}{l}\text { Soma dos } \\
\text { quadrados corrigida }\end{array}$ & 3,77777778 \\
\hline CV Pearson & 424,264069 & Erro-padrão médio & 0,11111111 \\
\hline
\end{tabular}

\begin{tabular}{|l|l|l|r|}
\hline \multicolumn{4}{|c|}{ Estatística Descritiva Básica } \\
\hline \multicolumn{2}{|c|}{ Posição } & \multicolumn{2}{c|}{ Variabilidade } \\
\hline Média & 0,111111 & Desvio-padrão & 0,47140 \\
\hline Mediana & 0,000000 & Variância & 0,22222 \\
\hline Moda & 0,000000 & Amplitude & 2,00000 \\
\hline & & Amplitude interquartil & 0 \\
\hline
\end{tabular}

\begin{tabular}{|l|l|r|l|l|}
\hline \multicolumn{5}{|c|}{ Testes de Posição: Mu0=0 } \\
\hline Teste & \multicolumn{2}{|c|}{ Estatística } & \multicolumn{2}{c|}{ Valor $\mathbf{~}$} \\
\hline Student t & $\mathbf{t}$ & 1 & $\mathrm{Pr}>|\mathbf{t}|$ & 0,3313 \\
\hline Sign & $\mathbf{M}$ & 0,5 & $\mathrm{Pr}>=|\mathbf{M}|$ & 1,0000 \\
\hline Signed Rank & $\mathbf{S}$ & 0,5 & $\mathrm{Pr}>=|\mathbf{S}|$ & 1,0000 \\
\hline
\end{tabular}

\begin{tabular}{|l|r|}
\hline \multicolumn{2}{|c|}{ Quantis } \\
\hline Level & 2 \\
\hline $100 \%$ Max & 2 \\
\hline $99 \%$ & 2 \\
\hline $95 \%$ & 0 \\
\hline $90 \%$ & 0 \\
\hline $75 \%$ Q3 & 0 \\
\hline $50 \%$ Mediana & 0 \\
\hline $25 \%$ Q1 & 0 \\
\hline $10 \%$ & 0 \\
\hline $5 \%$ & 0 \\
\hline $1 \%$ & 0 \\
\hline $0 \%$ Min & \\
\hline
\end{tabular}


Variável

dependente:

ACI

$I D=76$

\begin{tabular}{|r|r|r|r|}
\hline \multicolumn{3}{|c|}{ Observações Limite } \\
\hline \multicolumn{2}{|c|}{ Baixa } & \multicolumn{2}{c|}{ Alta } \\
\hline Valor & Obs & Valor & Obs \\
\hline 0 & 1133 & 0 & 1130 \\
\hline 0 & 1132 & 0 & 1131 \\
\hline 0 & 1131 & 0 & 1132 \\
\hline 0 & 1130 & 0 & 1133 \\
\hline 0 & 1129 & 2 & 1121 \\
\hline
\end{tabular}


Variável

dependente:

REC

ID $=77$

\begin{tabular}{|l|r|l|r|}
\hline \multicolumn{3}{|c|}{ Momento } \\
\hline N & 15 & Soma dos pesos & 15 \\
\hline Média & $\begin{array}{r}0 \\
\text { Soma das } \\
\text { observações }\end{array}$ & 0 \\
\hline Desvio-padrão & 0 & Variância & 0 \\
\hline Assimetria &, Curtose &, \\
\hline $\begin{array}{l}\text { Soma dos } \\
\text { quadrados não } \\
\text { corrigida }\end{array}$ & 0 & $\begin{array}{l}\text { Soma dos } \\
\text { quadrados corrigida }\end{array}$ & 0 \\
\hline CV Pearson &, & Erro-padrão médio & 0 \\
\hline
\end{tabular}

\begin{tabular}{|l|r|l|r|}
\hline \multicolumn{3}{|c|}{ Estatística Descritiva Básica } \\
\hline \multicolumn{2}{|c|}{ Posição } & \multicolumn{2}{c|}{ Variabilidade } \\
\hline Média & 0 & Desvio-padrão & 0 \\
\hline Mediana & 0 & Variância & 0 \\
\hline Moda & 0 & Amplitude & 0 \\
\hline & & Amplitude interquartil & 0 \\
\hline
\end{tabular}

\begin{tabular}{|l|l|l|l|l|}
\hline \multicolumn{4}{|c|}{ Testes de Posição: Mu0=0 } \\
\hline Teste & \multicolumn{2}{|c|}{ Estatística } & \multicolumn{2}{c|}{ Valor $\mathbf{p}$} \\
\hline Student $\mathbf{t}$ & $\mathbf{t}$ & \multicolumn{1}{|c|}{, $\operatorname{Pr}>|\mathbf{t}|$} & \\
\hline Sign & $\mathrm{M}$ &, & $\operatorname{Pr}>=|\mathrm{M}|$ & \\
\hline Signed Rank & S &, & $\operatorname{Pr}>=|\mathrm{S}|$ & \\
\hline
\end{tabular}

\begin{tabular}{|l|r|}
\hline \multicolumn{2}{|c|}{ Quantis } \\
\hline Level & 0 \\
\hline $100 \%$ Max & 0 \\
\hline $99 \%$ & 0 \\
\hline $95 \%$ & 0 \\
\hline $90 \%$ & 0 \\
\hline $75 \%$ Q3 & 0 \\
\hline $50 \%$ Mediana & 0 \\
\hline $25 \%$ Q1 & 0 \\
\hline $10 \%$ & 0 \\
\hline $5 \%$ & 0 \\
\hline $1 \%$ & 0 \\
\hline $0 \%$ Min & 0 \\
\hline
\end{tabular}


Variável

dependente:

REC

ID $=77$

\begin{tabular}{|r|r|r|r|}
\hline \multicolumn{3}{|c|}{ Observações Limite } \\
\hline \multicolumn{2}{|c|}{ Baixa } & \multicolumn{2}{c|}{ Alta } \\
\hline Valor & Obs & Valor & Obs \\
\hline 0 & 1148 & 0 & 1144 \\
\hline 0 & 1147 & 0 & 1145 \\
\hline 0 & 1146 & 0 & 1146 \\
\hline 0 & 1145 & 0 & 1147 \\
\hline 0 & 1144 & 0 & 1148 \\
\hline
\end{tabular}


Variável

dependente:

ACI

ID $=77$

\begin{tabular}{|l|r|l|r|}
\hline \multicolumn{3}{|c|}{ Momento } \\
\hline N & 15 & Soma dos pesos & 15 \\
\hline Média & $\begin{array}{r}0 \\
\text { Soma das } \\
\text { observações }\end{array}$ & 0 \\
\hline Desvio-padrão & 0 & Variância & 0 \\
\hline Assimetria &, Curtose &, \\
\hline $\begin{array}{l}\text { Soma dos } \\
\text { quadrados não } \\
\text { corrigida }\end{array}$ & 0 & $\begin{array}{l}\text { Soma dos } \\
\text { quadrados corrigida }\end{array}$ & 0 \\
\hline CV Pearson &, & Erro-padrão médio & 0 \\
\hline
\end{tabular}

\begin{tabular}{|l|r|l|r|}
\hline \multicolumn{3}{|c|}{ Estatística Descritiva Básica } \\
\hline \multicolumn{2}{|c|}{ Posição } & \multicolumn{2}{c|}{ Variabilidade } \\
\hline Média & 0 & Desvio-padrão & 0 \\
\hline Mediana & 0 & Variância & 0 \\
\hline Moda & 0 & Amplitude & 0 \\
\hline & & Amplitude interquartil & 0 \\
\hline
\end{tabular}

\begin{tabular}{|l|l|l|l|l|}
\hline \multicolumn{4}{|c|}{ Testes de Posição: Mu0=0 } \\
\hline Teste & \multicolumn{2}{|c|}{ Estatística } & \multicolumn{2}{c|}{ Valor $\mathbf{p}$} \\
\hline Student $\mathbf{t}$ & $\mathbf{t}$ & \multicolumn{1}{|c|}{, $\operatorname{Pr}>|\mathbf{t}|$} & \\
\hline Sign & $\mathrm{M}$ &, & $\operatorname{Pr}>=|\mathrm{M}|$ & \\
\hline Signed Rank & S &, & $\operatorname{Pr}>=|\mathrm{S}|$ & \\
\hline
\end{tabular}

\begin{tabular}{|l|r|}
\hline \multicolumn{2}{|c|}{ Quantis } \\
\hline Level & 0 \\
\hline $100 \%$ Max & 0 \\
\hline $99 \%$ & 0 \\
\hline $95 \%$ & 0 \\
\hline $90 \%$ & 0 \\
\hline $75 \%$ Q3 & 0 \\
\hline $50 \%$ Mediana & 0 \\
\hline $25 \%$ Q1 & 0 \\
\hline $10 \%$ & 0 \\
\hline $5 \%$ & 0 \\
\hline $1 \%$ & 0 \\
\hline $0 \%$ Min & 0 \\
\hline
\end{tabular}


Variável

dependente:

ACI

ID $=77$

\begin{tabular}{|r|r|r|r|}
\hline \multicolumn{3}{|c|}{ Observações Limite } \\
\hline \multicolumn{2}{|c|}{ Baixa } & \multicolumn{2}{c|}{ Alta } \\
\hline Valor & Obs & Valor & Obs \\
\hline 0 & 1148 & 0 & 1144 \\
\hline 0 & 1147 & 0 & 1145 \\
\hline 0 & 1146 & 0 & 1146 \\
\hline 0 & 1145 & 0 & 1147 \\
\hline 0 & 1144 & 0 & 1148 \\
\hline
\end{tabular}


Variável

dependente:

REC

$\mathrm{ID}=78$

\begin{tabular}{|l|r|l|r|}
\hline \multicolumn{3}{|c|}{ Momento } \\
\hline Média & 18 & Soma dos pesos & 18 \\
\hline Desvio-padrão & 0,38348249 & $\begin{array}{l}\text { Variância } \\
\text { observações }\end{array}$ & 0,14705882 \\
\hline Assimetria & 1,95576072 & Curtose & 2,04 \\
\hline $\begin{array}{l}\text { Soma dos } \\
\text { quadrados não } \\
\text { corrigida }\end{array}$ & 3 & $\begin{array}{l}\text { Soma dos } \\
\text { quadrados corrigida }\end{array}$ \\
\hline CV Pearson & 230,089497 & Erro-padrão médio & 0,09038769 \\
\hline
\end{tabular}

\begin{tabular}{|l|l|l|r|}
\hline \multicolumn{4}{|c|}{ Estatística Descritiva Básica } \\
\hline \multicolumn{2}{|c|}{ Posição } & \multicolumn{2}{c|}{ Variabilidade } \\
\hline Média & 0,166667 & Desvio-padrão & 0,38348 \\
\hline Mediana & 0,000000 & Variância & 0,14706 \\
\hline Moda & 0,000000 & Amplitude & 1,00000 \\
\hline & & Amplitude interquartil & 0 \\
\hline
\end{tabular}

\begin{tabular}{|l|l|r|l|l|}
\hline \multicolumn{5}{|c|}{ Testes de Posição: Mu0=0 } \\
\hline Teste & \multicolumn{2}{|c|}{ Estatística } & \multicolumn{2}{c|}{ Valor $\mathbf{~}$} \\
\hline Student t & t & 1,843909 & $\mathrm{Pr}>|\mathbf{t}|$ & 0,0827 \\
\hline Sign & M & 1,5 & $\mathrm{Pr}>=|\mathrm{M}|$ & 0,2500 \\
\hline Signed Rank & S & 3 & $\mathrm{Pr}>=|\mathrm{S}|$ & 0,2500 \\
\hline
\end{tabular}

\begin{tabular}{|l|r|}
\hline \multicolumn{2}{|c|}{ Quantis } \\
\hline Level & Quantil \\
\hline $100 \%$ Max & 1 \\
\hline $99 \%$ & 1 \\
\hline $95 \%$ & 1 \\
\hline $90 \%$ & 0 \\
\hline $75 \%$ Q3 & 0 \\
\hline $50 \%$ Mediana & 0 \\
\hline $25 \%$ Q1 & 0 \\
\hline $10 \%$ & 0 \\
\hline $5 \%$ & 0 \\
\hline $1 \%$ & 0 \\
\hline $0 \%$ Min & 1 \\
\hline
\end{tabular}


Variável

dependente:

REC

$I D=78$

\begin{tabular}{|r|r|r|r|}
\hline \multicolumn{3}{|c|}{ Observações Limite } \\
\hline \multicolumn{2}{|c|}{ Baixa } & \multicolumn{2}{c|}{ Alta } \\
\hline Valor & Obs & Valor & Obs \\
\hline 0 & 1166 & 0 & 1165 \\
\hline 0 & 1165 & 0 & 1166 \\
\hline 0 & 1164 & 1 & 1150 \\
\hline 0 & 1163 & 1 & 1154 \\
\hline 0 & 1162 & 1 & 1159 \\
\hline
\end{tabular}


Variável

dependente:

ACI

$\mathrm{ID}=78$

\begin{tabular}{|l|r|l|r|}
\hline \multicolumn{4}{|c|}{ Momento } \\
\hline Média & 18 & Soma dos pesos & 18 \\
\hline Desvio-padrão & 0,32338083 & $\begin{array}{l}\text { Variância } \\
\text { observações }\end{array}$ & 0,10457516 \\
\hline Assimetria & 2,70578807 & Curtose & 5,9765625 \\
\hline $\begin{array}{l}\text { Soma dos } \\
\text { quadrados não } \\
\text { corrigida }\end{array}$ & 2 & $\begin{array}{l}\text { Soma dos } \\
\text { quadrados corrigida }\end{array}$ & 1,77777778 \\
\hline CV Pearson & 291,04275 & Erro-padrão médio & 0,07622159 \\
\hline
\end{tabular}

\begin{tabular}{|l|l|l|r|}
\hline \multicolumn{4}{|c|}{ Estatística Descritiva Básica } \\
\hline \multicolumn{2}{|c|}{ Posição } & \multicolumn{2}{c|}{ Variabilidade } \\
\hline Média & 0,111111 & Desvio-padrão & 0,32338 \\
\hline Mediana & 0,000000 & Variância & 0,10458 \\
\hline Moda & 0,000000 & Amplitude & 1,00000 \\
\hline & & Amplitude interquartil & 0 \\
\hline
\end{tabular}

\begin{tabular}{|l|l|r|l|l|}
\hline \multicolumn{5}{|c|}{ Testes de Posição: Mu0=0 } \\
\hline Teste & \multicolumn{2}{|c|}{ Estatística } & \multicolumn{2}{c|}{ Valor $\mathbf{~}$} \\
\hline Student t & t & 1,457738 & $\mathrm{Pr}>|\mathbf{t}|$ & 0,1631 \\
\hline Sign & M & 1 & $\mathrm{Pr}>=|\mathrm{M}|$ & 0,5000 \\
\hline Signed Rank & S & 1,5 & $\mathrm{Pr}>=|\mathrm{S}|$ & 0,5000 \\
\hline
\end{tabular}

\begin{tabular}{|l|r|}
\hline \multicolumn{2}{|c|}{ Quantis } \\
\hline Level & 1 \\
\hline $100 \%$ Max & 1 \\
\hline $99 \%$ & 1 \\
\hline $95 \%$ & 1 \\
\hline $90 \%$ & 0 \\
\hline $75 \%$ Quantil & 0 \\
\hline $50 \%$ Mediana & 0 \\
\hline $25 \%$ Q1 & 0 \\
\hline $10 \%$ & 0 \\
\hline $5 \%$ & 0 \\
\hline $1 \%$ & 0 \\
\hline $0 \%$ Min & \\
\hline
\end{tabular}


Variável

dependente:

ACI

$\mathrm{ID}=78$

\begin{tabular}{|r|r|r|r|}
\hline \multicolumn{3}{|c|}{ Observações Limite } \\
\hline \multicolumn{2}{|c|}{ Baixa } & \multicolumn{2}{c|}{ Alta } \\
\hline Valor & Obs & Valor & Obs \\
\hline 0 & 1166 & 0 & 1164 \\
\hline 0 & 1165 & 0 & 1165 \\
\hline 0 & 1164 & 0 & 1166 \\
\hline 0 & 1163 & 1 & 1150 \\
\hline 0 & 1162 & 1 & 1151 \\
\hline
\end{tabular}


Variável

dependente:

REC

$I D=79$

\begin{tabular}{|l|r|r|r|}
\hline \multicolumn{3}{|l|}{ Momento } \\
\hline N & 18 Soma dos pesos & 18 \\
\hline Média & $\begin{array}{r}0 \\
\text { Soma das } \\
\text { observações }\end{array}$ & 0 \\
\hline Desvio-padrão & 0 & Variância & 0 \\
\hline Assimetria &, Curtose &, \\
\hline $\begin{array}{l}\text { Soma dos } \\
\text { quadrados não } \\
\text { corrigida }\end{array}$ & 0 & $\begin{array}{l}\text { Soma dos } \\
\text { quadrados corrigida }\end{array}$ & 0 \\
\hline CV Pearson &, & Erro-padrão médio & 0 \\
\hline
\end{tabular}

\begin{tabular}{|l|r|l|r|}
\hline \multicolumn{3}{|c|}{ Estatística Descritiva Básica } \\
\hline \multicolumn{2}{|c|}{ Posição } & \multicolumn{2}{c|}{ Variabilidade } \\
\hline Média & 0 & Desvio-padrão & 0 \\
\hline Mediana & 0 & Variância & 0 \\
\hline Moda & 0 & Amplitude & 0 \\
\hline & & Amplitude interquartil & 0 \\
\hline
\end{tabular}

\begin{tabular}{|l|l|l|l|l|}
\hline \multicolumn{4}{|c|}{ Testes de Posição: Mu0=0 } \\
\hline Teste & \multicolumn{2}{|c|}{ Estatística } & \multicolumn{2}{c|}{ Valor $\mathbf{p}$} \\
\hline Student $\mathbf{t}$ & $\mathbf{t}$ & \multicolumn{1}{|c|}{, $\operatorname{Pr}>|\mathbf{t}|$} & \\
\hline Sign & $\mathrm{M}$ &, & $\operatorname{Pr}>=|\mathrm{M}|$ & \\
\hline Signed Rank & S &, & $\operatorname{Pr}>=|\mathrm{S}|$ & \\
\hline
\end{tabular}

\begin{tabular}{|l|r|}
\hline \multicolumn{2}{|c|}{ Quantis } \\
\hline Level & 0 \\
\hline $100 \%$ Max & 0 \\
\hline $99 \%$ & 0 \\
\hline $95 \%$ & 0 \\
\hline $90 \%$ & 0 \\
\hline $75 \%$ Q3 & 0 \\
\hline $50 \%$ Mediana & 0 \\
\hline $25 \%$ Q1 & 0 \\
\hline $10 \%$ & 0 \\
\hline $5 \%$ & 0 \\
\hline $1 \%$ & 0 \\
\hline $0 \%$ Min & 0 \\
\hline
\end{tabular}


Variável

dependente:

REC

$I D=79$

\begin{tabular}{|r|c|r|r|}
\hline \multicolumn{3}{|c|}{ Observações Limite } \\
\hline \multicolumn{2}{|c|}{ Baixa } & \multicolumn{2}{c|}{ Alta } \\
\hline Valor & Obs & Valor & Obs \\
\hline 0 & 1184 & 0 & 1180 \\
\hline 0 & 1183 & 0 & 1181 \\
\hline 0 & 1182 & 0 & 1182 \\
\hline 0 & 1181 & 0 & 1183 \\
\hline 0 & 1180 & 0 & 1184 \\
\hline
\end{tabular}


Variável

dependente:

ACI

$\mathrm{ID}=79$

\begin{tabular}{|l|r|r|r|}
\hline \multicolumn{3}{|l|}{ Momento } \\
\hline N & 18 Soma dos pesos & 18 \\
\hline Média & $\begin{array}{r}0 \\
\text { Soma das } \\
\text { observações }\end{array}$ & 0 \\
\hline Desvio-padrão & 0 & Variância & 0 \\
\hline Assimetria &, Curtose &, \\
\hline $\begin{array}{l}\text { Soma dos } \\
\text { quadrados não } \\
\text { corrigida }\end{array}$ & 0 & $\begin{array}{l}\text { Soma dos } \\
\text { quadrados corrigida }\end{array}$ & 0 \\
\hline CV Pearson &, & Erro-padrão médio & 0 \\
\hline
\end{tabular}

\begin{tabular}{|l|r|l|r|}
\hline \multicolumn{3}{|c|}{ Estatística Descritiva Básica } \\
\hline \multicolumn{2}{|c|}{ Posição } & \multicolumn{2}{c|}{ Variabilidade } \\
\hline Média & 0 & Desvio-padrão & 0 \\
\hline Mediana & 0 & Variância & 0 \\
\hline Moda & 0 & Amplitude & 0 \\
\hline & & Amplitude interquartil & 0 \\
\hline
\end{tabular}

\begin{tabular}{|l|l|l|l|l|}
\hline \multicolumn{4}{|c|}{ Testes de Posição: Mu0=0 } \\
\hline Teste & \multicolumn{2}{|c|}{ Estatística } & \multicolumn{2}{c|}{ Valor $\mathbf{p}$} \\
\hline Student $\mathbf{t}$ & $\mathbf{t}$ & \multicolumn{1}{|c|}{, $\operatorname{Pr}>|\mathbf{t}|$} & \\
\hline Sign & $\mathrm{M}$ &, & $\operatorname{Pr}>=|\mathrm{M}|$ & \\
\hline Signed Rank & S &, & $\operatorname{Pr}>=|\mathrm{S}|$ & \\
\hline
\end{tabular}

\begin{tabular}{|l|r|}
\hline \multicolumn{2}{|c|}{ Quantis } \\
\hline Level & 0 \\
\hline $100 \%$ Max & 0 \\
\hline $99 \%$ & 0 \\
\hline $95 \%$ & 0 \\
\hline $90 \%$ & 0 \\
\hline $75 \%$ Q3 & 0 \\
\hline $50 \%$ Mediana & 0 \\
\hline $25 \%$ Q1 & 0 \\
\hline $10 \%$ & 0 \\
\hline $5 \%$ & 0 \\
\hline $1 \%$ & 0 \\
\hline $0 \%$ Min & 0 \\
\hline
\end{tabular}


Variável

dependente:

ACI

$\mathrm{ID}=79$

\begin{tabular}{|r|c|r|r|}
\hline \multicolumn{3}{|c|}{ Observações Limite } \\
\hline \multicolumn{2}{|c|}{ Baixa } & \multicolumn{2}{c|}{ Alta } \\
\hline Valor & Obs & Valor & Obs \\
\hline 0 & 1184 & 0 & 1180 \\
\hline 0 & 1183 & 0 & 1181 \\
\hline 0 & 1182 & 0 & 1182 \\
\hline 0 & 1181 & 0 & 1183 \\
\hline 0 & 1180 & 0 & 1184 \\
\hline
\end{tabular}


Variável

dependente:

REC

$\mathrm{ID}=\mathbf{8 0}$

\begin{tabular}{|l|r|l|r|}
\hline \multicolumn{3}{|c|}{ Momento } \\
\hline N & 14 & Soma dos pesos & 14 \\
\hline Média & $\begin{array}{r}0 \\
\text { Soma das } \\
\text { observações }\end{array}$ & 0 \\
\hline Desvio-padrão & 0 & Variância & 0 \\
\hline Assimetria &, Curtose &, \\
\hline $\begin{array}{l}\text { Soma dos } \\
\text { quadrados não } \\
\text { corrigida }\end{array}$ & 0 & $\begin{array}{l}\text { Soma dos } \\
\text { quadrados corrigida }\end{array}$ & 0 \\
\hline CV Pearson &, & Erro-padrão médio & 0 \\
\hline
\end{tabular}

\begin{tabular}{|l|r|l|r|}
\hline \multicolumn{3}{|c|}{ Estatística Descritiva Básica } \\
\hline \multicolumn{2}{|c|}{ Posição } & \multicolumn{2}{c|}{ Variabilidade } \\
\hline Média & 0 & Desvio-padrão & 0 \\
\hline Mediana & 0 & Variância & 0 \\
\hline Moda & 0 & Amplitude & 0 \\
\hline & & Amplitude interquartil & 0 \\
\hline
\end{tabular}

\begin{tabular}{|l|l|l|l|l|}
\hline \multicolumn{5}{|c|}{ Testes de Posição: Mu0=0 } \\
\hline Teste & \multicolumn{2}{|c|}{ Estatística } & \multicolumn{2}{c|}{ Valor $\mathbf{p}$} \\
\hline Student t & t &, & $\operatorname{Pr}>|\mathbf{t}|$ & \\
\hline Sign & M &, & $\operatorname{Pr}>=|\mathrm{M}|$ & \\
\hline Signed Rank & S &, & $\operatorname{Pr}>=|\mathrm{S}|$ & \\
\hline
\end{tabular}

\begin{tabular}{|l|r|}
\hline \multicolumn{2}{|c|}{ Quantis } \\
\hline Level & 0 \\
\hline $100 \%$ Max & 0 \\
\hline $99 \%$ & 0 \\
\hline $95 \%$ & 0 \\
\hline $90 \%$ & 0 \\
\hline $75 \%$ Q3 & 0 \\
\hline $50 \%$ Mediana & 0 \\
\hline $25 \%$ Q1 & 0 \\
\hline $10 \%$ & 0 \\
\hline $5 \%$ & 0 \\
\hline $1 \%$ & 0 \\
\hline $0 \%$ Min & 0 \\
\hline
\end{tabular}


Variável

dependente:

REC

$\mathrm{ID}=\mathbf{8 0}$

\begin{tabular}{|r|r|r|r|}
\hline \multicolumn{3}{|c|}{ Observações Limite } \\
\hline \multicolumn{2}{|c|}{ Baixa } & \multicolumn{2}{c|}{ Alta } \\
\hline Valor & Obs & Valor & Obs \\
\hline 0 & 1198 & 0 & 1194 \\
\hline 0 & 1197 & 0 & 1195 \\
\hline 0 & 1196 & 0 & 1196 \\
\hline 0 & 1195 & 0 & 1197 \\
\hline 0 & 1194 & 0 & 1198 \\
\hline
\end{tabular}


Variável

dependente:

ACI

$\mathrm{ID}=\mathbf{8 0}$

\begin{tabular}{|l|r|l|r|}
\hline \multicolumn{3}{|c|}{ Momento } \\
\hline N & 14 & Soma dos pesos & 14 \\
\hline Média & $\begin{array}{r}0 \\
\text { Soma das } \\
\text { observações }\end{array}$ & 0 \\
\hline Desvio-padrão & 0 & Variância & 0 \\
\hline Assimetria &, Curtose &, \\
\hline $\begin{array}{l}\text { Soma dos } \\
\text { quadrados não } \\
\text { corrigida }\end{array}$ & 0 & $\begin{array}{l}\text { Soma dos } \\
\text { quadrados corrigida }\end{array}$ & 0 \\
\hline CV Pearson &, & Erro-padrão médio & 0 \\
\hline
\end{tabular}

\begin{tabular}{|l|r|l|r|}
\hline \multicolumn{3}{|c|}{ Estatística Descritiva Básica } \\
\hline \multicolumn{2}{|c|}{ Posição } & \multicolumn{2}{c|}{ Variabilidade } \\
\hline Média & 0 & Desvio-padrão & 0 \\
\hline Mediana & 0 & Variância & 0 \\
\hline Moda & 0 & Amplitude & 0 \\
\hline & & Amplitude interquartil & 0 \\
\hline
\end{tabular}

\begin{tabular}{|l|l|l|l|l|}
\hline \multicolumn{5}{|c|}{ Testes de Posição: Mu0=0 } \\
\hline Teste & \multicolumn{2}{|c|}{ Estatística } & \multicolumn{2}{c|}{ Valor $\mathbf{p}$} \\
\hline Student t & t &, & $\operatorname{Pr}>|\mathbf{t}|$ & \\
\hline Sign & M &, & $\operatorname{Pr}>=|\mathrm{M}|$ & \\
\hline Signed Rank & S &, & $\operatorname{Pr}>=|\mathrm{S}|$ & \\
\hline
\end{tabular}

\begin{tabular}{|l|r|}
\hline \multicolumn{2}{|c|}{ Quantis } \\
\hline Level & 0 \\
\hline $100 \%$ Max & 0 \\
\hline $99 \%$ & 0 \\
\hline $95 \%$ & 0 \\
\hline $90 \%$ & 0 \\
\hline $75 \%$ Q3 & 0 \\
\hline $50 \%$ Mediana & 0 \\
\hline $25 \%$ Q1 & 0 \\
\hline $10 \%$ & 0 \\
\hline $5 \%$ & 0 \\
\hline $1 \%$ & 0 \\
\hline $0 \%$ Min & 0 \\
\hline
\end{tabular}


Variável

dependente:

ACI

$\mathrm{ID}=\mathbf{8 0}$

\begin{tabular}{|r|r|r|r|}
\hline \multicolumn{3}{|c|}{ Observações Limite } \\
\hline \multicolumn{2}{|c|}{ Baixa } & \multicolumn{2}{c|}{ Alta } \\
\hline Valor & Obs & Valor & Obs \\
\hline 0 & 1198 & 0 & 1194 \\
\hline 0 & 1197 & 0 & 1195 \\
\hline 0 & 1196 & 0 & 1196 \\
\hline 0 & 1195 & 0 & 1197 \\
\hline 0 & 1194 & 0 & 1198 \\
\hline
\end{tabular}


Variável

dependente:

REC

$\mathrm{ID}=\mathbf{8 1}$

\begin{tabular}{|l|r|l|r|}
\hline \multicolumn{3}{|c|}{ Momento } \\
\hline N & 8 & Soma dos pesos & 8 \\
\hline Média & $\begin{array}{r}0 \\
\text { Soma das } \\
\text { observações }\end{array}$ & 0 \\
\hline Desvio-padrão & 0 & Variância & 0 \\
\hline Assimetria &, Curtose &, \\
\hline $\begin{array}{l}\text { Soma dos } \\
\text { quadrados não } \\
\text { corrigida }\end{array}$ & 0 & $\begin{array}{l}\text { Soma dos } \\
\text { quadrados corrigida }\end{array}$ & 0 \\
\hline CV Pearson &, & Erro-padrão médio & 0 \\
\hline
\end{tabular}

\begin{tabular}{|l|r|l|r|}
\hline \multicolumn{3}{|c|}{ Estatística Descritiva Básica } \\
\hline \multicolumn{2}{|c|}{ Posição } & \multicolumn{2}{c|}{ Variabilidade } \\
\hline Média & 0 & Desvio-padrão & 0 \\
\hline Mediana & 0 & Variância & 0 \\
\hline Moda & 0 & Amplitude & 0 \\
\hline & & Amplitude interquartil & 0 \\
\hline
\end{tabular}

\begin{tabular}{|l|l|l|l|l|}
\hline \multicolumn{5}{|c|}{ Testes de Posição: Mu0=0 } \\
\hline Teste & \multicolumn{2}{|c|}{ Estatística } & \multicolumn{2}{c|}{ Valor $\mathbf{p}$} \\
\hline Student t & t &, & $\operatorname{Pr}>|\mathbf{t}|$ & \\
\hline Sign & M &, & $\operatorname{Pr}>=|\mathrm{M}|$ & \\
\hline Signed Rank & S &, & $\operatorname{Pr}>=|\mathrm{S}|$ & \\
\hline
\end{tabular}

\begin{tabular}{|l|r|}
\hline \multicolumn{2}{|c|}{ Quantis } \\
\hline Level & 0 \\
\hline $100 \%$ Max & 0 \\
\hline $99 \%$ & 0 \\
\hline $95 \%$ & 0 \\
\hline $90 \%$ & 0 \\
\hline $75 \%$ Q3 & 0 \\
\hline $50 \%$ Mediana & 0 \\
\hline $25 \%$ Q1 & 0 \\
\hline $10 \%$ & 0 \\
\hline $5 \%$ & 0 \\
\hline $1 \%$ & 0 \\
\hline $0 \%$ Min & 0 \\
\hline
\end{tabular}


Variável

dependente:

REC

ID $=\mathbf{8 1}$

\begin{tabular}{|r|r|r|r|}
\hline \multicolumn{3}{|c|}{ Observações Limite } \\
\hline \multicolumn{2}{|c|}{ Baixa } & \multicolumn{2}{c|}{ Alta } \\
\hline Valor & Obs & Valor & Obs \\
\hline 0 & 1206 & 0 & 1202 \\
\hline 0 & 1205 & 0 & 1203 \\
\hline 0 & 1204 & 0 & 1204 \\
\hline 0 & 1203 & 0 & 1205 \\
\hline 0 & 1202 & 0 & 1206 \\
\hline
\end{tabular}


Variável

dependente:

ACI

ID $=81$

\begin{tabular}{|l|r|l|r|}
\hline \multicolumn{3}{|c|}{ Momento } \\
\hline N & 8 & Soma dos pesos & 8 \\
\hline Média & $\begin{array}{r}0 \\
\text { Soma das } \\
\text { observações }\end{array}$ & 0 \\
\hline Desvio-padrão & 0 & Variância & 0 \\
\hline Assimetria &, Curtose &, \\
\hline $\begin{array}{l}\text { Soma dos } \\
\text { quadrados não } \\
\text { corrigida }\end{array}$ & 0 & $\begin{array}{l}\text { Soma dos } \\
\text { quadrados corrigida }\end{array}$ & 0 \\
\hline CV Pearson &, & Erro-padrão médio & 0 \\
\hline
\end{tabular}

\begin{tabular}{|l|r|l|r|}
\hline \multicolumn{3}{|c|}{ Estatística Descritiva Básica } \\
\hline \multicolumn{2}{|c|}{ Posição } & \multicolumn{2}{c|}{ Variabilidade } \\
\hline Média & 0 & Desvio-padrão & 0 \\
\hline Mediana & 0 & Variância & 0 \\
\hline Moda & 0 & Amplitude & 0 \\
\hline & & Amplitude interquartil & 0 \\
\hline
\end{tabular}

\begin{tabular}{|l|l|l|l|l|}
\hline \multicolumn{5}{|c|}{ Testes de Posição: Mu0=0 } \\
\hline Teste & \multicolumn{2}{|c|}{ Estatística } & \multicolumn{2}{c|}{ Valor $\mathbf{p}$} \\
\hline Student t & t &, & $\operatorname{Pr}>|\mathbf{t}|$ & \\
\hline Sign & M &, & $\operatorname{Pr}>=|\mathrm{M}|$ & \\
\hline Signed Rank & S &, & $\operatorname{Pr}>=|\mathrm{S}|$ & \\
\hline
\end{tabular}

\begin{tabular}{|l|r|}
\hline \multicolumn{2}{|c|}{ Quantis } \\
\hline Level & 0 \\
\hline $100 \%$ Max & 0 \\
\hline $99 \%$ & 0 \\
\hline $95 \%$ & 0 \\
\hline $90 \%$ & 0 \\
\hline $75 \%$ Q3 & 0 \\
\hline $50 \%$ Mediana & 0 \\
\hline $25 \%$ Q1 & 0 \\
\hline $10 \%$ & 0 \\
\hline $5 \%$ & 0 \\
\hline $1 \%$ & 0 \\
\hline $0 \%$ Min & 0 \\
\hline
\end{tabular}


Variável

dependente:

ACI

ID $=\mathbf{8 1}$

\begin{tabular}{|r|r|r|r|}
\hline \multicolumn{3}{|c|}{ Observações Limite } \\
\hline \multicolumn{2}{|c|}{ Baixa } & \multicolumn{2}{c|}{ Alta } \\
\hline Valor & Obs & Valor & Obs \\
\hline 0 & 1206 & 0 & 1202 \\
\hline 0 & 1205 & 0 & 1203 \\
\hline 0 & 1204 & 0 & 1204 \\
\hline 0 & 1203 & 0 & 1205 \\
\hline 0 & 1202 & 0 & 1206 \\
\hline
\end{tabular}


Variável

dependente:

REC

$\mathrm{ID}=82$

\begin{tabular}{|c|c|c|c|}
\hline \multicolumn{4}{|c|}{ Momento } \\
\hline $\mathbf{N}$ & 18 & Soma dos pesos & 18 \\
\hline Média & 0,72222222 & $\begin{array}{l}\text { Soma das } \\
\text { observações }\end{array}$ & 13 \\
\hline Desvio-padrão & 0,89479249 & Variância & 0,80065359 \\
\hline Assimetria & 1,1757372 & Curtose & 0,92934277 \\
\hline $\begin{array}{l}\text { Soma dos } \\
\text { quadrados não } \\
\text { corrigida }\end{array}$ & 23 & $\begin{array}{l}\text { Soma dos } \\
\text { quadrados corrigida }\end{array}$ & 13,6111111 \\
\hline CV Pearson & 123,894344 & Erro-padrão médio & 0,21090461 \\
\hline
\end{tabular}

\begin{tabular}{|l|c|l|c|}
\hline \multicolumn{4}{|c|}{ Estatística Descritiva Básica } \\
\hline \multicolumn{2}{|c|}{ Posição } & \multicolumn{2}{c|}{ Variabilidade } \\
\hline Média & 0,722222 & Desvio-padrão & 0,89479 \\
\hline Mediana & 0,500000 & Variância & 0,80065 \\
\hline Moda & 0,000000 & Amplitude & 3,00000 \\
\hline & & Amplitude interquartil & 1,00000 \\
\hline
\end{tabular}

\begin{tabular}{|l|l|r|l|l|}
\hline \multicolumn{5}{|c|}{ Testes de Posição: Mu0=0 } \\
\hline Teste & \multicolumn{2}{|c|}{ Estatística } & \multicolumn{2}{c|}{ Valor $\mathbf{~}$} \\
\hline Student t & t & 3,424402 & $\mathrm{Pr}>|\mathbf{t}|$ & 0,0032 \\
\hline Sign & M & 4,5 & $\mathrm{Pr}>=|\mathrm{M}|$ & 0,0039 \\
\hline Signed Rank & S & 22,5 & $\mathrm{Pr}>=|\mathrm{S}|$ & 0,0039 \\
\hline
\end{tabular}

\begin{tabular}{|l|r|}
\hline \multicolumn{2}{|c|}{ Quantis } \\
\hline Level & Quantil \\
\hline $100 \%$ Max & 3,0 \\
\hline $99 \%$ & 3,0 \\
\hline $95 \%$ & 3,0 \\
\hline $\mathbf{9 0} \%$ & 2,0 \\
\hline $75 \%$ Q3 & 1,0 \\
\hline $50 \%$ Mediana & 0,5 \\
\hline $25 \%$ Q1 & 0,0 \\
\hline $10 \%$ & 0,0 \\
\hline $5 \%$ & 0,0 \\
\hline $1 \%$ & 0,0 \\
\hline $0 \%$ Min & 0,0 \\
\hline
\end{tabular}


Variável

dependente:

REC

$\mathrm{ID}=\mathbf{8 2}$

\begin{tabular}{|r|r|r|r|}
\hline \multicolumn{4}{|c|}{ Observações Limite } \\
\hline \multicolumn{2}{|c|}{ Baixa } & \multicolumn{2}{c|}{ Alta } \\
\hline Valor & Obs & Valor & Obs \\
\hline 0 & 1224 & 1 & 1218 \\
\hline 0 & 1223 & 1 & 1220 \\
\hline 0 & 1222 & 2 & 1212 \\
\hline 0 & 1221 & 2 & 1215 \\
\hline 0 & 1219 & 3 & 1208 \\
\hline
\end{tabular}


Variável

dependente:

ACI

$\mathrm{ID}=82$

\begin{tabular}{|l|r|r|r|}
\hline \multicolumn{4}{|c|}{ Momento } \\
\hline Média & 18 & Soma dos pesos & 18 \\
\hline Desvio-padrão & 0,51449576 & $\begin{array}{l}\text { Variância } \\
\text { observações }\end{array}$ & 0,26470588 \\
\hline Assimetria & 3,23941772 & Curtose & 10,4938272 \\
\hline $\begin{array}{l}\text { Soma dos } \\
\text { quadrados não } \\
\text { corrigida }\end{array}$ & 5 & $\begin{array}{l}\text { Soma dos } \\
\text { quadrados corrigida }\end{array}$ \\
\hline CV Pearson & 308,697453 & Erro-padrão médio & 0,12126781 \\
\hline
\end{tabular}

\begin{tabular}{|l|l|l|r|}
\hline \multicolumn{4}{|c|}{ Estatística Descritiva Básica } \\
\hline \multicolumn{2}{|c|}{ Posição } & \multicolumn{2}{c|}{ Variabilidade } \\
\hline Média & 0,166667 & Desvio-padrão & 0,51450 \\
\hline Mediana & 0,000000 & Variância & 0,26471 \\
\hline Moda & 0,000000 & Amplitude & 2,00000 \\
\hline & & Amplitude interquartil & 0 \\
\hline
\end{tabular}

\begin{tabular}{|l|l|r|l|l|}
\hline \multicolumn{5}{|c|}{ Testes de Posição: Mu0=0 } \\
\hline Teste & \multicolumn{2}{|c|}{ Estatística } & \multicolumn{2}{c|}{ Valor $\mathbf{~}$} \\
\hline Student t & $\mathbf{t}$ & 1,374369 & $\mathrm{Pr}>|\mathbf{t}|$ & 0,1872 \\
\hline Sign & $\mathrm{M}$ & 1 & $\mathrm{Pr}>=|\mathrm{M}|$ & 0,5000 \\
\hline Signed Rank & $\mathrm{S}$ & 1,5 & $\mathrm{Pr}>=|\mathrm{S}|$ & 0,5000 \\
\hline
\end{tabular}

\begin{tabular}{|l|r|}
\hline \multicolumn{2}{|c|}{ Quantis } \\
\hline Level & 2 \\
\hline $100 \%$ Max & 2 \\
\hline $99 \%$ & 2 \\
\hline $95 \%$ & 1 \\
\hline $90 \%$ & 0 \\
\hline $75 \%$ Qu & 0 \\
\hline $50 \%$ Mediana & 0 \\
\hline $25 \%$ Q1 & 0 \\
\hline $10 \%$ & 0 \\
\hline $5 \%$ & 0 \\
\hline $1 \%$ & 0 \\
\hline $0 \%$ Min & \\
\hline
\end{tabular}


Variável

dependente:

ACI

$\mathrm{ID}=\mathbf{8 2}$

\begin{tabular}{|r|r|r|r|}
\hline \multicolumn{4}{|c|}{ Observações Limite } \\
\hline \multicolumn{2}{|c|}{ Baixa } & \multicolumn{2}{c|}{ Alta } \\
\hline Valor & Obs & Valor & Obs \\
\hline 0 & 1224 & 0 & 1222 \\
\hline 0 & 1223 & 0 & 1223 \\
\hline 0 & 1222 & 0 & 1224 \\
\hline 0 & 1221 & 1 & 1210 \\
\hline 0 & 1219 & 2 & 1220 \\
\hline
\end{tabular}


Variável

dependente:

REC

ID $=83$

\begin{tabular}{|l|r|l|r|}
\hline \multicolumn{3}{|c|}{ Momento } \\
\hline Média & 5 & Soma dos pesos & 5 \\
\hline Desvio-padrão & 0,6 & $\begin{array}{l}\text { Soma das } \\
\text { observações }\end{array}$ & 3 \\
\hline Assimetria & $-0,6085806$ & Curtose & 0,3 \\
\hline $\begin{array}{l}\text { Soma dos } \\
\text { quadrados não } \\
\text { corrigida }\end{array}$ & 3 & $\begin{array}{l}\text { Soma dos } \\
\text { quadrados corrigida }\end{array}$ & $-3,3333333$ \\
\hline CV Pearson & 91,2870929 & Erro-padrão médio & 0,24494897 \\
\hline
\end{tabular}

\begin{tabular}{|l|l|l|c|}
\hline \multicolumn{4}{|c|}{ Estatística Descritiva Básica } \\
\hline \multicolumn{2}{|c|}{ Posição } & \multicolumn{2}{c|}{ Variabilidade } \\
\hline Média & 0,600000 & Desvio-padrão & 0,54772 \\
\hline Mediana & 1,000000 & Variância & 0,30000 \\
\hline Moda & 1,000000 & Amplitude & 1,00000 \\
\hline & & Amplitude interquartil & 1,00000 \\
\hline
\end{tabular}

\begin{tabular}{|l|l|r|l|l|}
\hline \multicolumn{5}{|c|}{ Testes de Posição: Mu0=0 } \\
\hline Teste & \multicolumn{2}{|c|}{ Estatística } & \multicolumn{2}{c|}{ Valor $\mathbf{p}$} \\
\hline Student t & t & 2,44949 & $\operatorname{Pr}>|\mathbf{t}|$ & 0,0705 \\
\hline Sign & M & 1,5 & $\operatorname{Pr}>=|\mathbf{M}|$ & 0,2500 \\
\hline Signed Rank & S & 3 & $\operatorname{Pr}>=|\mathbf{S}|$ & 0,2500 \\
\hline
\end{tabular}

\begin{tabular}{|l|r|}
\hline \multicolumn{2}{|c|}{ Quantis } \\
\hline Level & 1 \\
\hline $100 \%$ Max & 1 \\
\hline $99 \%$ & 1 \\
\hline $95 \%$ & 1 \\
\hline $90 \%$ & 1 \\
\hline $75 \%$ Q3 & 1 \\
\hline $50 \%$ Mediana & 0 \\
\hline $25 \%$ Q1 & 0 \\
\hline $10 \%$ & 0 \\
\hline $5 \%$ & 0 \\
\hline $1 \%$ & 0 \\
\hline $0 \%$ Min & \\
\hline
\end{tabular}


Variável

dependente:

REC

ID $=83$

\begin{tabular}{|r|r|r|r|}
\hline \multicolumn{3}{|c|}{ Observações Limite } \\
\hline \multicolumn{2}{|c|}{ Baixa } & \multicolumn{2}{c|}{ Alta } \\
\hline Valor & Obs & Valor & Obs \\
\hline 0 & 1226 & 0 & 1225 \\
\hline 0 & 1225 & 0 & 1226 \\
\hline 1 & 1229 & 1 & 1227 \\
\hline 1 & 1228 & 1 & 1228 \\
\hline 1 & 1227 & 1 & 1229 \\
\hline
\end{tabular}


Variável

dependente:

ACI

ID $=83$

\begin{tabular}{|l|r|l|r|}
\hline \multicolumn{4}{|c|}{ Momento } \\
\hline Média & 5 & Soma dos pesos & 5 \\
\hline Desvio-padrão & 0,4472136 & $\begin{array}{l}\text { Soma das } \\
\text { observações }\end{array}$ & 1 \\
\hline Assimetria & 2,23606798 & Curtose & 0,2 \\
\hline $\begin{array}{l}\text { Soma dos } \\
\text { quadrados não } \\
\text { corrigida }\end{array}$ & 1 & $\begin{array}{l}\text { Soma dos } \\
\text { quadrados corrigida }\end{array}$ & 0,8 \\
\hline CV Pearson & 223,606798 & Erro-padrão médio & 0,2 \\
\hline
\end{tabular}

\begin{tabular}{|l|l|l|r|}
\hline \multicolumn{4}{|c|}{ Estatística Descritiva Básica } \\
\hline \multicolumn{2}{|c|}{ Posição } & \multicolumn{2}{c|}{ Variabilidade } \\
\hline Média & 0,200000 & Desvio-padrão & 0,44721 \\
\hline Mediana & 0,000000 & Variância & 0,20000 \\
\hline Moda & 0,000000 & Amplitude & 1,00000 \\
\hline & & Amplitude interquartil & 0 \\
\hline
\end{tabular}

\begin{tabular}{|l|l|r|l|l|}
\hline \multicolumn{5}{|c|}{ Testes de Posição: Mu0=0 } \\
\hline Teste & \multicolumn{2}{|c|}{ Estatística } & \multicolumn{2}{c|}{ Valor $\mathbf{~}$} \\
\hline Student t & $\mathbf{t}$ & 1 & $\operatorname{Pr}>|\mathbf{t}|$ & 0,3739 \\
\hline Sign & M & 0,5 & $\operatorname{Pr}>=|M|$ & 1,0000 \\
\hline Signed Rank & S & 0,5 & $\operatorname{Pr}>=|\mathbf{S}|$ & 1,0000 \\
\hline
\end{tabular}

\begin{tabular}{|l|r|}
\hline \multicolumn{2}{|c|}{ Quantis } \\
\hline Level & 1 \\
\hline $100 \%$ Max & 1 \\
\hline $99 \%$ & 1 \\
\hline $95 \%$ & 1 \\
\hline $90 \%$ & 0 \\
\hline $75 \%$ Q3 & 0 \\
\hline $50 \%$ Mediana & 0 \\
\hline $25 \%$ Q1 & 0 \\
\hline $10 \%$ & 0 \\
\hline $5 \%$ & 0 \\
\hline $1 \%$ & 0 \\
\hline $0 \%$ Min & \\
\hline
\end{tabular}


Variável

dependente:

ACI

$\mathrm{ID}=\mathbf{8 3}$

\begin{tabular}{|r|r|r|r|}
\hline \multicolumn{3}{|c|}{ Observações Limite } \\
\hline \multicolumn{2}{|c|}{ Baixa } & \multicolumn{2}{c|}{ Alta } \\
\hline Valor & Obs & Valor & Obs \\
\hline 0 & 1229 & 0 & 1225 \\
\hline 0 & 1227 & 0 & 1226 \\
\hline 0 & 1226 & 0 & 1227 \\
\hline 0 & 1225 & 0 & 1229 \\
\hline 1 & 1228 & 1 & 1228 \\
\hline
\end{tabular}


Variável

dependente:

REC

ID $=84$

\begin{tabular}{|l|r|l|r|}
\hline \multicolumn{3}{|c|}{ Momento } \\
\hline N & 4 & Soma dos pesos & 4 \\
\hline Média & $\begin{array}{r}0 \\
\text { Soma das } \\
\text { observações }\end{array}$ & 0 \\
\hline Desvio-padrão & 0 & Variância & 0 \\
\hline Assimetria &, Curtose &, \\
\hline $\begin{array}{l}\text { Soma dos } \\
\text { quadrados não } \\
\text { corrigida }\end{array}$ & 0 & $\begin{array}{l}\text { Soma dos } \\
\text { quadrados corrigida }\end{array}$ & 0 \\
\hline CV Pearson &, & Erro-padrão médio & 0 \\
\hline
\end{tabular}

\begin{tabular}{|l|r|l|r|}
\hline \multicolumn{3}{|c|}{ Estatística Descritiva Básica } \\
\hline \multicolumn{2}{|c|}{ Posição } & \multicolumn{2}{c|}{ Variabilidade } \\
\hline Média & 0 & Desvio-padrão & 0 \\
\hline Mediana & 0 & Variância & 0 \\
\hline Moda & 0 & Amplitude & 0 \\
\hline & & Amplitude interquartil & 0 \\
\hline
\end{tabular}

\begin{tabular}{|l|l|l|l|l|}
\hline \multicolumn{5}{|c|}{ Testes de Posição: Mu0=0 } \\
\hline Teste & \multicolumn{2}{|c|}{ Estatística } & \multicolumn{2}{c|}{ Valor $\mathbf{p}$} \\
\hline Student t & t &, & $\operatorname{Pr}>|\mathbf{t}|$ & \\
\hline Sign & M &, & $\operatorname{Pr}>=|\mathrm{M}|$ & \\
\hline Signed Rank & S &, & $\operatorname{Pr}>=|\mathrm{S}|$ & \\
\hline
\end{tabular}

\begin{tabular}{|l|r|}
\hline \multicolumn{2}{|c|}{ Quantis } \\
\hline Level & 0 \\
\hline $100 \%$ Max & 0 \\
\hline $99 \%$ & 0 \\
\hline $95 \%$ & 0 \\
\hline $90 \%$ & 0 \\
\hline $75 \%$ Q3 & 0 \\
\hline $50 \%$ Mediana & 0 \\
\hline $25 \%$ Q1 & 0 \\
\hline $10 \%$ & 0 \\
\hline $5 \%$ & 0 \\
\hline $1 \%$ & 0 \\
\hline $0 \%$ Min & 0 \\
\hline
\end{tabular}


Variável

dependente:

REC

ID $=84$

\begin{tabular}{|r|r|r|r|}
\hline \multicolumn{4}{|c|}{ Observações Limite } \\
\hline \multicolumn{2}{|c|}{ Baixa } & \multicolumn{2}{|c|}{ Alta } \\
\hline Valor & Obs & Valor & Obs \\
\hline 0 & 1233 & 0 & 1230 \\
\hline 0 & 1232 & 0 & 1231 \\
\hline 0 & 1231 & 0 & 1232 \\
\hline 0 & 1230 & 0 & 1233 \\
\hline
\end{tabular}


Variável

dependente:

ACI

ID $=84$

\begin{tabular}{|l|r|l|r|}
\hline \multicolumn{3}{|c|}{ Momento } \\
\hline N & 4 & Soma dos pesos & 4 \\
\hline Média & $\begin{array}{r}0 \\
\text { Soma das } \\
\text { observações }\end{array}$ & 0 \\
\hline Desvio-padrão & 0 & Variância & 0 \\
\hline Assimetria &, Curtose &, \\
\hline $\begin{array}{l}\text { Soma dos } \\
\text { quadrados não } \\
\text { corrigida }\end{array}$ & 0 & $\begin{array}{l}\text { Soma dos } \\
\text { quadrados corrigida }\end{array}$ & 0 \\
\hline CV Pearson &, & Erro-padrão médio & 0 \\
\hline
\end{tabular}

\begin{tabular}{|l|r|l|r|}
\hline \multicolumn{3}{|c|}{ Estatística Descritiva Básica } \\
\hline \multicolumn{2}{|c|}{ Posição } & \multicolumn{2}{c|}{ Variabilidade } \\
\hline Média & 0 & Desvio-padrão & 0 \\
\hline Mediana & 0 & Variância & 0 \\
\hline Moda & 0 & Amplitude & 0 \\
\hline & & Amplitude interquartil & 0 \\
\hline
\end{tabular}

\begin{tabular}{|l|l|l|l|l|}
\hline \multicolumn{4}{|c|}{ Testes de Posição: Mu0=0 } \\
\hline Teste & \multicolumn{2}{|c|}{ Estatística } & \multicolumn{2}{c|}{ Valor $\mathbf{p}$} \\
\hline Student $\mathbf{t}$ & $\mathbf{t}$ & \multicolumn{1}{|c|}{, $\operatorname{Pr}>|\mathbf{t}|$} & \\
\hline Sign & $\mathrm{M}$ &, & $\operatorname{Pr}>=|\mathrm{M}|$ & \\
\hline Signed Rank & S &, & $\operatorname{Pr}>=|\mathrm{S}|$ & \\
\hline
\end{tabular}

\begin{tabular}{|l|r|}
\hline \multicolumn{2}{|c|}{ Quantis } \\
\hline Level & 0 \\
\hline $100 \%$ Max & 0 \\
\hline $99 \%$ & 0 \\
\hline $95 \%$ & 0 \\
\hline $90 \%$ & 0 \\
\hline $75 \%$ Q3 & 0 \\
\hline $50 \%$ Mediana & 0 \\
\hline $25 \%$ Q1 & 0 \\
\hline $10 \%$ & 0 \\
\hline $5 \%$ & 0 \\
\hline $1 \%$ & 0 \\
\hline $0 \%$ Min & 0 \\
\hline
\end{tabular}


Variável

dependente:

ACI

ID $=84$

\begin{tabular}{|r|r|r|r|}
\hline \multicolumn{3}{|c|}{ Observações Limite } \\
\hline \multicolumn{2}{|c|}{ Baixa } & \multicolumn{2}{c|}{ Alta } \\
\hline Valor & Obs & Valor & Obs \\
\hline 0 & 1233 & 0 & 1230 \\
\hline 0 & 1232 & 0 & 1231 \\
\hline 0 & 1231 & 0 & 1232 \\
\hline 0 & 1230 & 0 & 1233 \\
\hline
\end{tabular}


Variável

dependente:

REC

ID $=85$

\begin{tabular}{|l|r|l|r|}
\hline \multicolumn{3}{|c|}{ Momento } \\
\hline N & 6 & Soma dos pesos & 6 \\
\hline Média & $\begin{array}{r}0 \\
\text { Soma das } \\
\text { observações }\end{array}$ & 0 \\
\hline Desvio-padrão & 0 & Variância & 0 \\
\hline Assimetria &, Curtose &, \\
\hline $\begin{array}{l}\text { Soma dos } \\
\text { quadrados não } \\
\text { corrigida }\end{array}$ & 0 & $\begin{array}{l}\text { Soma dos } \\
\text { quadrados corrigida }\end{array}$ & 0 \\
\hline CV Pearson &, & Erro-padrão médio & 0 \\
\hline
\end{tabular}

\begin{tabular}{|l|r|l|r|}
\hline \multicolumn{3}{|c|}{ Estatística Descritiva Básica } \\
\hline \multicolumn{2}{|c|}{ Posição } & \multicolumn{2}{c|}{ Variabilidade } \\
\hline Média & 0 & Desvio-padrão & 0 \\
\hline Mediana & 0 & Variância & 0 \\
\hline Moda & 0 & Amplitude & 0 \\
\hline & & Amplitude interquartil & 0 \\
\hline
\end{tabular}

\begin{tabular}{|l|l|l|l|l|}
\hline \multicolumn{5}{|c|}{ Testes de Posição: Mu0=0 } \\
\hline Teste & \multicolumn{2}{|c|}{ Estatística } & \multicolumn{2}{c|}{ Valor $\mathbf{p}$} \\
\hline Student t & t &, & $\operatorname{Pr}>|\mathbf{t}|$ & \\
\hline Sign & M &, & $\operatorname{Pr}>=|\mathrm{M}|$ & \\
\hline Signed Rank & S &, & $\operatorname{Pr}>=|\mathrm{S}|$ & \\
\hline
\end{tabular}

\begin{tabular}{|l|r|}
\hline \multicolumn{2}{|c|}{ Quantis } \\
\hline Level & 0 \\
\hline $100 \%$ Max & 0 \\
\hline $99 \%$ & 0 \\
\hline $95 \%$ & 0 \\
\hline $90 \%$ & 0 \\
\hline $75 \%$ Q3 & 0 \\
\hline $50 \%$ Mediana & 0 \\
\hline $25 \%$ Q1 & 0 \\
\hline $10 \%$ & 0 \\
\hline $5 \%$ & 0 \\
\hline $1 \%$ & 0 \\
\hline $0 \%$ Min & 0 \\
\hline
\end{tabular}


Variável

dependente:

REC

ID $=85$

\begin{tabular}{|r|r|r|r|}
\hline \multicolumn{3}{|c|}{ Observações Limite } \\
\hline \multicolumn{2}{|c|}{ Baixa } & \multicolumn{2}{c|}{ Alta } \\
\hline Valor & Obs & Valor & Obs \\
\hline 0 & 1239 & 0 & 1235 \\
\hline 0 & 1238 & 0 & 1236 \\
\hline 0 & 1237 & 0 & 1237 \\
\hline 0 & 1236 & 0 & 1238 \\
\hline 0 & 1235 & 0 & 1239 \\
\hline
\end{tabular}


Variável

dependente:

ACI

ID $=85$

\begin{tabular}{|l|r|l|r|}
\hline \multicolumn{3}{|c|}{ Momento } \\
\hline N & 6 & Soma dos pesos & 6 \\
\hline Média & $\begin{array}{r}0 \\
\text { Soma das } \\
\text { observações }\end{array}$ & 0 \\
\hline Desvio-padrão & 0 & Variância & 0 \\
\hline Assimetria &, Curtose &, \\
\hline $\begin{array}{l}\text { Soma dos } \\
\text { quadrados não } \\
\text { corrigida }\end{array}$ & 0 & $\begin{array}{l}\text { Soma dos } \\
\text { quadrados corrigida }\end{array}$ & 0 \\
\hline CV Pearson &, & Erro-padrão médio & 0 \\
\hline
\end{tabular}

\begin{tabular}{|l|r|l|r|}
\hline \multicolumn{3}{|c|}{ Estatística Descritiva Básica } \\
\hline \multicolumn{2}{|c|}{ Posição } & \multicolumn{2}{c|}{ Variabilidade } \\
\hline Média & 0 & Desvio-padrão & 0 \\
\hline Mediana & 0 & Variância & 0 \\
\hline Moda & 0 & Amplitude & 0 \\
\hline & & Amplitude interquartil & 0 \\
\hline
\end{tabular}

\begin{tabular}{|l|l|l|l|l|}
\hline \multicolumn{4}{|c|}{ Testes de Posição: Mu0=0 } \\
\hline Teste & \multicolumn{2}{|c|}{ Estatística } & \multicolumn{2}{c|}{ Valor $\mathbf{p}$} \\
\hline Student $\mathbf{t}$ & $\mathbf{t}$ & \multicolumn{1}{|c|}{, $\operatorname{Pr}>|\mathbf{t}|$} & \\
\hline Sign & $\mathrm{M}$ &, & $\operatorname{Pr}>=|\mathrm{M}|$ & \\
\hline Signed Rank & S &, & $\operatorname{Pr}>=|\mathrm{S}|$ & \\
\hline
\end{tabular}

\begin{tabular}{|l|r|}
\hline \multicolumn{2}{|c|}{ Quantis } \\
\hline Level & 0 \\
\hline $100 \%$ Max & 0 \\
\hline $99 \%$ & 0 \\
\hline $95 \%$ & 0 \\
\hline $90 \%$ & 0 \\
\hline $75 \%$ Q3 & 0 \\
\hline $50 \%$ Mediana & 0 \\
\hline $25 \%$ Q1 & 0 \\
\hline $10 \%$ & 0 \\
\hline $5 \%$ & 0 \\
\hline $1 \%$ & 0 \\
\hline $0 \%$ Min & 0 \\
\hline
\end{tabular}


Variável

dependente:

ACI

$\mathrm{ID}=\mathbf{8 5}$

\begin{tabular}{|r|c|r|r|}
\hline \multicolumn{3}{|c|}{ Observações Limite } \\
\hline \multicolumn{2}{|c|}{ Baixa } & \multicolumn{2}{c|}{ Alta } \\
\hline Valor & Obs & Valor & Obs \\
\hline 0 & 1239 & 0 & 1235 \\
\hline 0 & 1238 & 0 & 1236 \\
\hline 0 & 1237 & 0 & 1237 \\
\hline 0 & 1236 & 0 & 1238 \\
\hline 0 & 1235 & 0 & 1239 \\
\hline
\end{tabular}


Variável

dependente:

REC

$\mathrm{ID}=\mathbf{8 6}$

\begin{tabular}{|l|r|l|r|}
\hline \multicolumn{3}{|c|}{ Momento } \\
\hline N & 13 & Soma dos pesos & 13 \\
\hline Média & $\begin{array}{r}0 \\
\text { Soma das } \\
\text { observações }\end{array}$ & 0 \\
\hline Desvio-padrão & 0 & Variância & 0 \\
\hline Assimetria &, Curtose &, \\
\hline $\begin{array}{l}\text { Soma dos } \\
\text { quadrados não } \\
\text { corrigida }\end{array}$ & 0 & $\begin{array}{l}\text { Soma dos } \\
\text { quadrados corrigida }\end{array}$ & 0 \\
\hline CV Pearson &, & Erro-padrão médio & 0 \\
\hline
\end{tabular}

\begin{tabular}{|l|r|l|r|}
\hline \multicolumn{3}{|c|}{ Estatística Descritiva Básica } \\
\hline \multicolumn{2}{|c|}{ Posição } & \multicolumn{2}{c|}{ Variabilidade } \\
\hline Média & 0 & Desvio-padrão & 0 \\
\hline Mediana & 0 & Variância & 0 \\
\hline Moda & 0 & Amplitude & 0 \\
\hline & & Amplitude interquartil & 0 \\
\hline
\end{tabular}

\begin{tabular}{|l|l|l|l|l|}
\hline \multicolumn{5}{|c|}{ Testes de Posição: Mu0=0 } \\
\hline Teste & \multicolumn{2}{|c|}{ Estatística } & \multicolumn{2}{c|}{ Valor $\mathbf{p}$} \\
\hline Student t & t &, & $\operatorname{Pr}>|\mathbf{t}|$ & \\
\hline Sign & M &, & $\operatorname{Pr}>=|\mathrm{M}|$ & \\
\hline Signed Rank & S &, & $\operatorname{Pr}>=|\mathrm{S}|$ & \\
\hline
\end{tabular}

\begin{tabular}{|l|r|}
\hline \multicolumn{2}{|c|}{ Quantis } \\
\hline Level & 0 \\
\hline $100 \%$ Max & 0 \\
\hline $99 \%$ & 0 \\
\hline $95 \%$ & 0 \\
\hline $90 \%$ & 0 \\
\hline $75 \%$ Q3 & 0 \\
\hline $50 \%$ Mediana & 0 \\
\hline $25 \%$ Q1 & 0 \\
\hline $10 \%$ & 0 \\
\hline $5 \%$ & 0 \\
\hline $1 \%$ & 0 \\
\hline $0 \%$ Min & 0 \\
\hline
\end{tabular}


Variável

dependente:

REC

ID $=86$

\begin{tabular}{|r|r|r|r|}
\hline \multicolumn{3}{|c|}{ Observações Limite } \\
\hline \multicolumn{2}{|c|}{ Baixa } & \multicolumn{2}{c|}{ Alta } \\
\hline Valor & Obs & Valor & Obs \\
\hline 0 & 1252 & 0 & 1248 \\
\hline 0 & 1251 & 0 & 1249 \\
\hline 0 & 1250 & 0 & 1250 \\
\hline 0 & 1249 & 0 & 1251 \\
\hline 0 & 1248 & 0 & 1252 \\
\hline
\end{tabular}


Variável

dependente:

ACI

ID $=86$

\begin{tabular}{|l|r|l|r|}
\hline \multicolumn{3}{|c|}{ Momento } \\
\hline N & 13 & Soma dos pesos & 13 \\
\hline Média & $\begin{array}{r}0 \\
\text { Soma das } \\
\text { observações }\end{array}$ & 0 \\
\hline Desvio-padrão & 0 & Variância & 0 \\
\hline Assimetria &, Curtose &, \\
\hline $\begin{array}{l}\text { Soma dos } \\
\text { quadrados não } \\
\text { corrigida }\end{array}$ & 0 & $\begin{array}{l}\text { Soma dos } \\
\text { quadrados corrigida }\end{array}$ & 0 \\
\hline CV Pearson &, & Erro-padrão médio & 0 \\
\hline
\end{tabular}

\begin{tabular}{|l|r|l|r|}
\hline \multicolumn{3}{|c|}{ Estatística Descritiva Básica } \\
\hline \multicolumn{2}{|c|}{ Posição } & \multicolumn{2}{c|}{ Variabilidade } \\
\hline Média & 0 & Desvio-padrão & 0 \\
\hline Mediana & 0 & Variância & 0 \\
\hline Moda & 0 & Amplitude & 0 \\
\hline & & Amplitude interquartil & 0 \\
\hline
\end{tabular}

\begin{tabular}{|l|l|l|l|l|}
\hline \multicolumn{5}{|c|}{ Testes de Posição: Mu0=0 } \\
\hline Teste & \multicolumn{2}{|c|}{ Estatística } & \multicolumn{2}{c|}{ Valor $\mathbf{p}$} \\
\hline Student t & t &, & $\operatorname{Pr}>|\mathbf{t}|$ & \\
\hline Sign & M &, & $\operatorname{Pr}>=|\mathrm{M}|$ & \\
\hline Signed Rank & S &, & $\operatorname{Pr}>=|\mathrm{S}|$ & \\
\hline
\end{tabular}

\begin{tabular}{|l|r|}
\hline \multicolumn{2}{|c|}{ Quantis } \\
\hline Level & 0 \\
\hline $100 \%$ Max & 0 \\
\hline $99 \%$ & 0 \\
\hline $95 \%$ & 0 \\
\hline $90 \%$ & 0 \\
\hline $75 \%$ Q3 & 0 \\
\hline $50 \%$ Mediana & 0 \\
\hline $25 \%$ Q1 & 0 \\
\hline $10 \%$ & 0 \\
\hline $5 \%$ & 0 \\
\hline $1 \%$ & 0 \\
\hline $0 \%$ Min & 0 \\
\hline
\end{tabular}


Variável

dependente:

ACI

$\mathrm{ID}=\mathbf{8 6}$

\begin{tabular}{|r|r|r|r|}
\hline \multicolumn{3}{|c|}{ Observações Limite } \\
\hline \multicolumn{2}{|c|}{ Baixa } & \multicolumn{2}{c|}{ Alta } \\
\hline Valor & Obs & Valor & Obs \\
\hline 0 & 1252 & 0 & 1248 \\
\hline 0 & 1251 & 0 & 1249 \\
\hline 0 & 1250 & 0 & 1250 \\
\hline 0 & 1249 & 0 & 1251 \\
\hline 0 & 1248 & 0 & 1252 \\
\hline
\end{tabular}


Variável

dependente:

REC

ID $=\mathbf{8 7}$

\begin{tabular}{|l|r|l|r|}
\hline \multicolumn{3}{|c|}{ Momento } \\
\hline N & 10 & Soma dos pesos & 10 \\
\hline Média & $\begin{array}{r}0 \\
\text { Soma das } \\
\text { observações }\end{array}$ & 0 \\
\hline Desvio-padrão & 0 & Variância & 0 \\
\hline Assimetria &, Curtose &, \\
\hline $\begin{array}{l}\text { Soma dos } \\
\text { quadrados não } \\
\text { corrigida }\end{array}$ & 0 & $\begin{array}{l}\text { Soma dos } \\
\text { quadrados corrigida }\end{array}$ & 0 \\
\hline CV Pearson &, & Erro-padrão médio & 0 \\
\hline
\end{tabular}

\begin{tabular}{|l|r|l|r|}
\hline \multicolumn{3}{|c|}{ Estatística Descritiva Básica } \\
\hline \multicolumn{2}{|c|}{ Posição } & \multicolumn{2}{c|}{ Variabilidade } \\
\hline Média & 0 & Desvio-padrão & 0 \\
\hline Mediana & 0 & Variância & 0 \\
\hline Moda & 0 & Amplitude & 0 \\
\hline & & Amplitude interquartil & 0 \\
\hline
\end{tabular}

\begin{tabular}{|l|l|l|l|l|}
\hline \multicolumn{5}{|c|}{ Testes de Posição: Mu0=0 } \\
\hline Teste & \multicolumn{2}{|c|}{ Estatística } & \multicolumn{2}{c|}{ Valor $\mathbf{p}$} \\
\hline Student t & t &, & $\operatorname{Pr}>|\mathbf{t}|$ & \\
\hline Sign & M &, & $\operatorname{Pr}>=|\mathrm{M}|$ & \\
\hline Signed Rank & S &, & $\operatorname{Pr}>=|\mathrm{S}|$ & \\
\hline
\end{tabular}

\begin{tabular}{|l|r|}
\hline \multicolumn{2}{|c|}{ Quantis } \\
\hline Level & 0 \\
\hline $100 \%$ Max & 0 \\
\hline $99 \%$ & 0 \\
\hline $95 \%$ & 0 \\
\hline $90 \%$ & 0 \\
\hline $75 \%$ Q3 & 0 \\
\hline $50 \%$ Mediana & 0 \\
\hline $25 \%$ Q1 & 0 \\
\hline $10 \%$ & 0 \\
\hline $5 \%$ & 0 \\
\hline $1 \%$ & 0 \\
\hline $0 \%$ Min & 0 \\
\hline
\end{tabular}


Variável

dependente:

REC

ID $=87$

\begin{tabular}{|r|r|r|r|}
\hline \multicolumn{3}{|c|}{ Observações Limite } \\
\hline \multicolumn{2}{|c|}{ Baixa } & \multicolumn{2}{c|}{ Alta } \\
\hline Valor & Obs & Valor & Obs \\
\hline 0 & 1262 & 0 & 1258 \\
\hline 0 & 1261 & 0 & 1259 \\
\hline 0 & 1260 & 0 & 1260 \\
\hline 0 & 1259 & 0 & 1261 \\
\hline 0 & 1258 & 0 & 1262 \\
\hline
\end{tabular}


Variável

dependente:

ACI

ID $=87$

\begin{tabular}{|l|r|l|r|}
\hline \multicolumn{3}{|c|}{ Momento } \\
\hline N & 10 & Soma dos pesos & 10 \\
\hline Média & $\begin{array}{r}0 \\
\text { Soma das } \\
\text { observações }\end{array}$ & 0 \\
\hline Desvio-padrão & 0 & Variância & 0 \\
\hline Assimetria &, Curtose &, \\
\hline $\begin{array}{l}\text { Soma dos } \\
\text { quadrados não } \\
\text { corrigida }\end{array}$ & 0 & $\begin{array}{l}\text { Soma dos } \\
\text { quadrados corrigida }\end{array}$ & 0 \\
\hline CV Pearson &, & Erro-padrão médio & 0 \\
\hline
\end{tabular}

\begin{tabular}{|l|r|l|r|}
\hline \multicolumn{3}{|c|}{ Estatística Descritiva Básica } \\
\hline \multicolumn{2}{|c|}{ Posição } & \multicolumn{2}{c|}{ Variabilidade } \\
\hline Média & 0 & Desvio-padrão & 0 \\
\hline Mediana & 0 & Variância & 0 \\
\hline Moda & 0 & Amplitude & 0 \\
\hline & & Amplitude interquartil & 0 \\
\hline
\end{tabular}

\begin{tabular}{|l|l|l|l|l|}
\hline \multicolumn{5}{|c|}{ Testes de Posição: Mu0=0 } \\
\hline Teste & \multicolumn{2}{|c|}{ Estatística } & \multicolumn{2}{c|}{ Valor $\mathbf{p}$} \\
\hline Student t & t &, & $\operatorname{Pr}>|\mathbf{t}|$ & \\
\hline Sign & M &, & $\operatorname{Pr}>=|\mathrm{M}|$ & \\
\hline Signed Rank & S &, & $\operatorname{Pr}>=|\mathrm{S}|$ & \\
\hline
\end{tabular}

\begin{tabular}{|l|r|}
\hline \multicolumn{2}{|c|}{ Quantis } \\
\hline Level & 0 \\
\hline $100 \%$ Max & 0 \\
\hline $99 \%$ & 0 \\
\hline $95 \%$ & 0 \\
\hline $90 \%$ & 0 \\
\hline $75 \%$ Q3 & 0 \\
\hline $50 \%$ Mediana & 0 \\
\hline $25 \%$ Q1 & 0 \\
\hline $10 \%$ & 0 \\
\hline $5 \%$ & 0 \\
\hline $1 \%$ & 0 \\
\hline $0 \%$ Min & 0 \\
\hline
\end{tabular}


Variável

dependente:

ACI

ID $=\mathbf{8 7}$

\begin{tabular}{|r|r|r|r|}
\hline \multicolumn{3}{|c|}{ Observações Limite } \\
\hline \multicolumn{2}{|c|}{ Baixa } & \multicolumn{2}{c|}{ Alta } \\
\hline Valor & Obs & Valor & Obs \\
\hline 0 & 1262 & 0 & 1258 \\
\hline 0 & 1261 & 0 & 1259 \\
\hline 0 & 1260 & 0 & 1260 \\
\hline 0 & 1259 & 0 & 1261 \\
\hline 0 & 1258 & 0 & 1262 \\
\hline
\end{tabular}


Variável

dependente:

REC

$\mathrm{ID}=\mathbf{8 8}$

\begin{tabular}{|l|r|l|r|}
\hline \multicolumn{3}{|c|}{ Momento } \\
\hline N & 15 & Soma dos pesos & 15 \\
\hline Média & $\begin{array}{r}0 \\
\text { Soma das } \\
\text { observações }\end{array}$ & 0 \\
\hline Desvio-padrão & 0 & Variância & 0 \\
\hline Assimetria &, Curtose &, \\
\hline $\begin{array}{l}\text { Soma dos } \\
\text { quadrados não } \\
\text { corrigida }\end{array}$ & 0 & $\begin{array}{l}\text { Soma dos } \\
\text { quadrados corrigida }\end{array}$ & 0 \\
\hline CV Pearson &, & Erro-padrão médio & 0 \\
\hline
\end{tabular}

\begin{tabular}{|l|r|l|r|}
\hline \multicolumn{3}{|c|}{ Estatística Descritiva Básica } \\
\hline \multicolumn{2}{|c|}{ Posição } & \multicolumn{2}{c|}{ Variabilidade } \\
\hline Média & 0 & Desvio-padrão & 0 \\
\hline Mediana & 0 & Variância & 0 \\
\hline Moda & 0 & Amplitude & 0 \\
\hline & & Amplitude interquartil & 0 \\
\hline
\end{tabular}

\begin{tabular}{|l|l|l|l|l|}
\hline \multicolumn{4}{|c|}{ Testes de Posição: Mu0=0 } \\
\hline Teste & \multicolumn{2}{|c|}{ Estatística } & \multicolumn{2}{c|}{ Valor $\mathbf{p}$} \\
\hline Student $\mathbf{t}$ & $\mathbf{t}$ & \multicolumn{1}{|c|}{, $\operatorname{Pr}>|\mathbf{t}|$} & \\
\hline Sign & $\mathrm{M}$ &, & $\operatorname{Pr}>=|\mathrm{M}|$ & \\
\hline Signed Rank & S &, & $\operatorname{Pr}>=|\mathrm{S}|$ & \\
\hline
\end{tabular}

\begin{tabular}{|l|r|}
\hline \multicolumn{2}{|c|}{ Quantis } \\
\hline Level & 0 \\
\hline $100 \%$ Max & 0 \\
\hline $99 \%$ & 0 \\
\hline $95 \%$ & 0 \\
\hline $90 \%$ & 0 \\
\hline $75 \%$ Q3 & 0 \\
\hline $50 \%$ Mediana & 0 \\
\hline $25 \%$ Q1 & 0 \\
\hline $10 \%$ & 0 \\
\hline $5 \%$ & 0 \\
\hline $1 \%$ & 0 \\
\hline $0 \%$ Min & 0 \\
\hline
\end{tabular}


Variável

dependente:

REC

ID $=\mathbf{8 8}$

\begin{tabular}{|r|r|r|r|}
\hline \multicolumn{4}{|c|}{ Observações Limite } \\
\hline \multicolumn{2}{|c|}{ Baixa } & \multicolumn{2}{c|}{ Alta } \\
\hline Valor & Obs & Valor & Obs \\
\hline 0 & 1277 & 0 & 1273 \\
\hline 0 & 1276 & 0 & 1274 \\
\hline 0 & 1275 & 0 & 1275 \\
\hline 0 & 1274 & 0 & 1276 \\
\hline 0 & 1273 & 0 & 1277 \\
\hline
\end{tabular}


Variável

dependente:

ACI

ID $=\mathbf{8 8}$

\begin{tabular}{|l|r|l|r|}
\hline \multicolumn{3}{|c|}{ Momento } \\
\hline N & 15 & Soma dos pesos & 15 \\
\hline Média & $\begin{array}{r}0 \\
\text { Soma das } \\
\text { observações }\end{array}$ & 0 \\
\hline Desvio-padrão & 0 & Variância & 0 \\
\hline Assimetria &, Curtose &, \\
\hline $\begin{array}{l}\text { Soma dos } \\
\text { quadrados não } \\
\text { corrigida }\end{array}$ & 0 & $\begin{array}{l}\text { Soma dos } \\
\text { quadrados corrigida }\end{array}$ & 0 \\
\hline CV Pearson &, & Erro-padrão médio & 0 \\
\hline
\end{tabular}

\begin{tabular}{|l|r|l|r|}
\hline \multicolumn{3}{|c|}{ Estatística Descritiva Básica } \\
\hline \multicolumn{2}{|c|}{ Posição } & \multicolumn{2}{c|}{ Variabilidade } \\
\hline Média & 0 & Desvio-padrão & 0 \\
\hline Mediana & 0 & Variância & 0 \\
\hline Moda & 0 & Amplitude & 0 \\
\hline & & Amplitude interquartil & 0 \\
\hline
\end{tabular}

\begin{tabular}{|l|l|l|l|l|}
\hline \multicolumn{5}{|c|}{ Testes de Posição: Mu0=0 } \\
\hline Teste & \multicolumn{2}{|c|}{ Estatística } & \multicolumn{2}{c|}{ Valor $\mathbf{p}$} \\
\hline Student t & t &, & $\operatorname{Pr}>|\mathbf{t}|$ & \\
\hline Sign & M &, & $\operatorname{Pr}>=|\mathrm{M}|$ & \\
\hline Signed Rank & S &, & $\operatorname{Pr}>=|\mathrm{S}|$ & \\
\hline
\end{tabular}

\begin{tabular}{|l|r|}
\hline \multicolumn{2}{|c|}{ Quantis } \\
\hline Level & 0 \\
\hline $100 \%$ Max & 0 \\
\hline $99 \%$ & 0 \\
\hline $95 \%$ & 0 \\
\hline $90 \%$ & 0 \\
\hline $75 \%$ Q3 & 0 \\
\hline $50 \%$ Mediana & 0 \\
\hline $25 \%$ Q1 & 0 \\
\hline $10 \%$ & 0 \\
\hline $5 \%$ & 0 \\
\hline $1 \%$ & 0 \\
\hline $0 \%$ Min & 0 \\
\hline
\end{tabular}


Variável

dependente:

ACI

ID $=\mathbf{8 8}$

\begin{tabular}{|r|r|r|r|}
\hline \multicolumn{4}{|c|}{ Observações Limite } \\
\hline \multicolumn{2}{|c|}{ Baixa } & \multicolumn{2}{c|}{ Alta } \\
\hline Valor & Obs & Valor & Obs \\
\hline 0 & 1277 & 0 & 1273 \\
\hline 0 & 1276 & 0 & 1274 \\
\hline 0 & 1275 & 0 & 1275 \\
\hline 0 & 1274 & 0 & 1276 \\
\hline 0 & 1273 & 0 & 1277 \\
\hline
\end{tabular}


Variável

dependente:

REC

ID $=89$

\begin{tabular}{|l|r|l|r|}
\hline \multicolumn{3}{|c|}{ Momento } \\
\hline N & 10 & Soma dos pesos & 10 \\
\hline Média & $\begin{array}{r}0 \\
\text { Soma das } \\
\text { observações }\end{array}$ & 0 \\
\hline Desvio-padrão & 0 & Variância & 0 \\
\hline Assimetria &, Curtose &, \\
\hline $\begin{array}{l}\text { Soma dos } \\
\text { quadrados não } \\
\text { corrigida }\end{array}$ & 0 & $\begin{array}{l}\text { Soma dos } \\
\text { quadrados corrigida }\end{array}$ & 0 \\
\hline CV Pearson &, & Erro-padrão médio & 0 \\
\hline
\end{tabular}

\begin{tabular}{|l|r|l|r|}
\hline \multicolumn{3}{|c|}{ Estatística Descritiva Básica } \\
\hline \multicolumn{2}{|c|}{ Posição } & \multicolumn{2}{c|}{ Variabilidade } \\
\hline Média & 0 & Desvio-padrão & 0 \\
\hline Mediana & 0 & Variância & 0 \\
\hline Moda & 0 & Amplitude & 0 \\
\hline & & Amplitude interquartil & 0 \\
\hline
\end{tabular}

\begin{tabular}{|l|l|l|l|l|}
\hline \multicolumn{4}{|c|}{ Testes de Posição: Mu0=0 } \\
\hline Teste & \multicolumn{2}{|c|}{ Estatística } & \multicolumn{2}{c|}{ Valor $\mathbf{p}$} \\
\hline Student $\mathbf{t}$ & $\mathbf{t}$ & \multicolumn{1}{|c|}{, $\operatorname{Pr}>|\mathbf{t}|$} & \\
\hline Sign & $\mathrm{M}$ &, & $\operatorname{Pr}>=|\mathrm{M}|$ & \\
\hline Signed Rank & S &, & $\operatorname{Pr}>=|\mathrm{S}|$ & \\
\hline
\end{tabular}

\begin{tabular}{|l|r|}
\hline \multicolumn{2}{|c|}{ Quantis } \\
\hline Level & 0 \\
\hline $100 \%$ Max & 0 \\
\hline $99 \%$ & 0 \\
\hline $95 \%$ & 0 \\
\hline $90 \%$ & 0 \\
\hline $75 \%$ Q3 & 0 \\
\hline $50 \%$ Mediana & 0 \\
\hline $25 \%$ Q1 & 0 \\
\hline $10 \%$ & 0 \\
\hline $5 \%$ & 0 \\
\hline $1 \%$ & 0 \\
\hline $0 \%$ Min & 0 \\
\hline
\end{tabular}


Variável

dependente:

REC

ID $=89$

\begin{tabular}{|r|c|r|r|}
\hline \multicolumn{3}{|c|}{ Observações Limite } \\
\hline \multicolumn{2}{|c|}{ Baixa } & \multicolumn{2}{c|}{ Alta } \\
\hline Valor & Obs & Valor & Obs \\
\hline 0 & 1287 & 0 & 1283 \\
\hline 0 & 1286 & 0 & 1284 \\
\hline 0 & 1285 & 0 & 1285 \\
\hline 0 & 1284 & 0 & 1286 \\
\hline 0 & 1283 & 0 & 1287 \\
\hline
\end{tabular}


Variável

dependente:

ACI

ID $=89$

\begin{tabular}{|l|r|l|r|}
\hline \multicolumn{3}{|c|}{ Momento } \\
\hline N & 10 & Soma dos pesos & 10 \\
\hline Média & $\begin{array}{r}0 \\
\text { Soma das } \\
\text { observações }\end{array}$ & 0 \\
\hline Desvio-padrão & 0 & Variância & 0 \\
\hline Assimetria &, Curtose &, \\
\hline $\begin{array}{l}\text { Soma dos } \\
\text { quadrados não } \\
\text { corrigida }\end{array}$ & 0 & $\begin{array}{l}\text { Soma dos } \\
\text { quadrados corrigida }\end{array}$ & 0 \\
\hline CV Pearson &, & Erro-padrão médio & 0 \\
\hline
\end{tabular}

\begin{tabular}{|l|r|l|r|}
\hline \multicolumn{3}{|c|}{ Estatística Descritiva Básica } \\
\hline \multicolumn{2}{|c|}{ Posição } & \multicolumn{2}{c|}{ Variabilidade } \\
\hline Média & 0 & Desvio-padrão & 0 \\
\hline Mediana & 0 & Variância & 0 \\
\hline Moda & 0 & Amplitude & 0 \\
\hline & & Amplitude interquartil & 0 \\
\hline
\end{tabular}

\begin{tabular}{|l|l|l|l|l|}
\hline \multicolumn{5}{|c|}{ Testes de Posição: Mu0=0 } \\
\hline Teste & \multicolumn{2}{|c|}{ Estatística } & \multicolumn{2}{c|}{ Valor $\mathbf{p}$} \\
\hline Student t & t &, & $\operatorname{Pr}>|\mathbf{t}|$ & \\
\hline Sign & M &, & $\operatorname{Pr}>=|\mathrm{M}|$ & \\
\hline Signed Rank & S &, & $\operatorname{Pr}>=|\mathrm{S}|$ & \\
\hline
\end{tabular}

\begin{tabular}{|l|r|}
\hline \multicolumn{2}{|c|}{ Quantis } \\
\hline Level & 0 \\
\hline $100 \%$ Max & 0 \\
\hline $99 \%$ & 0 \\
\hline $95 \%$ & 0 \\
\hline $90 \%$ & 0 \\
\hline $75 \%$ Q3 & 0 \\
\hline $50 \%$ Mediana & 0 \\
\hline $25 \%$ Q1 & 0 \\
\hline $10 \%$ & 0 \\
\hline $5 \%$ & 0 \\
\hline $1 \%$ & 0 \\
\hline $0 \%$ Min & 0 \\
\hline
\end{tabular}


Variável

dependente:

ACI

ID $=89$

\begin{tabular}{|r|c|r|r|}
\hline \multicolumn{3}{|c|}{ Observações Limite } \\
\hline \multicolumn{2}{|c|}{ Baixa } & \multicolumn{2}{c|}{ Alta } \\
\hline Valor & Obs & Valor & Obs \\
\hline 0 & 1287 & 0 & 1283 \\
\hline 0 & 1286 & 0 & 1284 \\
\hline 0 & 1285 & 0 & 1285 \\
\hline 0 & 1284 & 0 & 1286 \\
\hline 0 & 1283 & 0 & 1287 \\
\hline
\end{tabular}


Variável

dependente:

REC

ID $=90$

\begin{tabular}{|l|r|r|r|}
\hline \multicolumn{3}{|l|}{ Momento } \\
\hline N & 18 Soma dos pesos & 18 \\
\hline Média & $\begin{array}{r}0 \\
\text { Soma das } \\
\text { observações }\end{array}$ & 0 \\
\hline Desvio-padrão & 0 & Variância & 0 \\
\hline Assimetria &, Curtose &, \\
\hline $\begin{array}{l}\text { Soma dos } \\
\text { quadrados não } \\
\text { corrigida }\end{array}$ & 0 & $\begin{array}{l}\text { Soma dos } \\
\text { quadrados corrigida }\end{array}$ & 0 \\
\hline CV Pearson &, & Erro-padrão médio & 0 \\
\hline
\end{tabular}

\begin{tabular}{|l|r|l|r|}
\hline \multicolumn{3}{|c|}{ Estatística Descritiva Básica } \\
\hline \multicolumn{2}{|c|}{ Posição } & \multicolumn{2}{c|}{ Variabilidade } \\
\hline Média & 0 & Desvio-padrão & 0 \\
\hline Mediana & 0 & Variância & 0 \\
\hline Moda & 0 & Amplitude & 0 \\
\hline & & Amplitude interquartil & 0 \\
\hline
\end{tabular}

\begin{tabular}{|l|l|l|l|l|}
\hline \multicolumn{4}{|c|}{ Testes de Posição: Mu0=0 } \\
\hline Teste & \multicolumn{2}{|c|}{ Estatística } & \multicolumn{2}{c|}{ Valor $\mathbf{p}$} \\
\hline Student $\mathbf{t}$ & $\mathbf{t}$ & \multicolumn{1}{|c|}{, $\operatorname{Pr}>|\mathbf{t}|$} & \\
\hline Sign & $\mathrm{M}$ &, & $\operatorname{Pr}>=|\mathrm{M}|$ & \\
\hline Signed Rank & S &, & $\operatorname{Pr}>=|\mathrm{S}|$ & \\
\hline
\end{tabular}

\begin{tabular}{|l|r|}
\hline \multicolumn{2}{|c|}{ Quantis } \\
\hline Level & 0 \\
\hline $100 \%$ Max & 0 \\
\hline $99 \%$ & 0 \\
\hline $95 \%$ & 0 \\
\hline $90 \%$ & 0 \\
\hline $75 \%$ Q3 & 0 \\
\hline $50 \%$ Mediana & 0 \\
\hline $25 \%$ Q1 & 0 \\
\hline $10 \%$ & 0 \\
\hline $5 \%$ & 0 \\
\hline $1 \%$ & 0 \\
\hline $0 \%$ Min & 0 \\
\hline
\end{tabular}


Variável

dependente:

REC

$\mathrm{ID}=\mathbf{9 0}$

\begin{tabular}{|r|r|r|r|}
\hline \multicolumn{3}{|c|}{ Observações Limite } \\
\hline \multicolumn{2}{|c|}{ Baixa } & \multicolumn{2}{c|}{ Alta } \\
\hline Valor & Obs & Valor & Obs \\
\hline 0 & 1305 & 0 & 1301 \\
\hline 0 & 1304 & 0 & 1302 \\
\hline 0 & 1303 & 0 & 1303 \\
\hline 0 & 1302 & 0 & 1304 \\
\hline 0 & 1301 & 0 & 1305 \\
\hline
\end{tabular}


Variável

dependente:

ACI

ID $=90$

\begin{tabular}{|l|r|l|r|}
\hline \multicolumn{3}{|c|}{ Momento } \\
\hline N & 18 & Soma dos pesos & 18 \\
\hline Média & $\begin{array}{r}0 \\
\text { Soma das } \\
\text { observações }\end{array}$ & 0 \\
\hline Desvio-padrão & 0 & Variância & 0 \\
\hline Assimetria &, Curtose &, \\
\hline $\begin{array}{l}\text { Soma dos } \\
\text { quadrados não } \\
\text { corrigida }\end{array}$ & 0 & $\begin{array}{l}\text { Soma dos } \\
\text { quadrados corrigida }\end{array}$ & 0 \\
\hline CV Pearson &, & Erro-padrão médio & 0 \\
\hline
\end{tabular}

\begin{tabular}{|l|r|l|r|}
\hline \multicolumn{3}{|c|}{ Estatística Descritiva Básica } \\
\hline \multicolumn{2}{|c|}{ Posição } & \multicolumn{2}{c|}{ Variabilidade } \\
\hline Média & 0 & Desvio-padrão & 0 \\
\hline Mediana & 0 & Variância & 0 \\
\hline Moda & 0 & Amplitude & 0 \\
\hline & & Amplitude interquartil & 0 \\
\hline
\end{tabular}

\begin{tabular}{|l|l|l|l|l|}
\hline \multicolumn{4}{|c|}{ Testes de Posição: Mu0=0 } \\
\hline Teste & \multicolumn{2}{|c|}{ Estatística } & \multicolumn{2}{c|}{ Valor $\mathbf{p}$} \\
\hline Student $\mathbf{t}$ & $\mathbf{t}$ & \multicolumn{1}{|c|}{, $\operatorname{Pr}>|\mathbf{t}|$} & \\
\hline Sign & $\mathrm{M}$ &, & $\operatorname{Pr}>=|\mathrm{M}|$ & \\
\hline Signed Rank & S &, & $\operatorname{Pr}>=|\mathrm{S}|$ & \\
\hline
\end{tabular}

\begin{tabular}{|l|r|}
\hline \multicolumn{2}{|c|}{ Quantis } \\
\hline Level & 0 \\
\hline $100 \%$ Max & 0 \\
\hline $99 \%$ & 0 \\
\hline $95 \%$ & 0 \\
\hline $90 \%$ & 0 \\
\hline $75 \%$ Q3 & 0 \\
\hline $50 \%$ Mediana & 0 \\
\hline $25 \%$ Q1 & 0 \\
\hline $10 \%$ & 0 \\
\hline $5 \%$ & 0 \\
\hline $1 \%$ & 0 \\
\hline $0 \%$ Min & 0 \\
\hline
\end{tabular}


Variável

dependente:

ACI

ID $=90$

\begin{tabular}{|r|c|r|r|}
\hline \multicolumn{3}{|c|}{ Observações Limite } \\
\hline \multicolumn{2}{|c|}{ Baixa } & \multicolumn{2}{c|}{ Alta } \\
\hline Valor & Obs & Valor & Obs \\
\hline 0 & 1305 & 0 & 1301 \\
\hline 0 & 1304 & 0 & 1302 \\
\hline 0 & 1303 & 0 & 1303 \\
\hline 0 & 1302 & 0 & 1304 \\
\hline 0 & 1301 & 0 & 1305 \\
\hline
\end{tabular}


Variável

dependente:

REC

ID $=91$

\begin{tabular}{|l|r|l|r|}
\hline \multicolumn{3}{|c|}{ Momento } \\
\hline N & 6 & Soma dos pesos & 6 \\
\hline Média & $\begin{array}{r}0 \\
\text { Soma das } \\
\text { observações }\end{array}$ & 0 \\
\hline Desvio-padrão & 0 & Variância & 0 \\
\hline Assimetria &, Curtose &, \\
\hline $\begin{array}{l}\text { Soma dos } \\
\text { quadrados não } \\
\text { corrigida }\end{array}$ & 0 & $\begin{array}{l}\text { Soma dos } \\
\text { quadrados corrigida }\end{array}$ & 0 \\
\hline CV Pearson &, & Erro-padrão médio & 0 \\
\hline
\end{tabular}

\begin{tabular}{|l|r|l|r|}
\hline \multicolumn{3}{|c|}{ Estatística Descritiva Básica } \\
\hline \multicolumn{2}{|c|}{ Posição } & \multicolumn{2}{c|}{ Variabilidade } \\
\hline Média & 0 & Desvio-padrão & 0 \\
\hline Mediana & 0 & Variância & 0 \\
\hline Moda & 0 & Amplitude & 0 \\
\hline & & Amplitude interquartil & 0 \\
\hline
\end{tabular}

\begin{tabular}{|l|l|l|l|l|}
\hline \multicolumn{4}{|c|}{ Testes de Posição: Mu0=0 } \\
\hline Teste & \multicolumn{2}{|c|}{ Estatística } & \multicolumn{2}{c|}{ Valor $\mathbf{p}$} \\
\hline Student $\mathbf{t}$ & $\mathbf{t}$ & \multicolumn{1}{|c|}{, $\operatorname{Pr}>|\mathbf{t}|$} & \\
\hline Sign & $\mathrm{M}$ &, & $\operatorname{Pr}>=|\mathrm{M}|$ & \\
\hline Signed Rank & S &, & $\operatorname{Pr}>=|\mathrm{S}|$ & \\
\hline
\end{tabular}

\begin{tabular}{|l|r|}
\hline \multicolumn{2}{|c|}{ Quantis } \\
\hline Level & 0 \\
\hline $100 \%$ Max & 0 \\
\hline $99 \%$ & 0 \\
\hline $95 \%$ & 0 \\
\hline $90 \%$ & 0 \\
\hline $75 \%$ Q3 & 0 \\
\hline $50 \%$ Mediana & 0 \\
\hline $25 \%$ Q1 & 0 \\
\hline $10 \%$ & 0 \\
\hline $5 \%$ & 0 \\
\hline $1 \%$ & 0 \\
\hline $0 \%$ Min & 0 \\
\hline
\end{tabular}


Variável

dependente:

REC

ID $=91$

\begin{tabular}{|r|c|r|r|}
\hline \multicolumn{3}{|c|}{ Observações Limite } \\
\hline \multicolumn{2}{|c|}{ Baixa } & \multicolumn{2}{c|}{ Alta } \\
\hline Valor & Obs & Valor & Obs \\
\hline 0 & 1311 & 0 & 1307 \\
\hline 0 & 1310 & 0 & 1308 \\
\hline 0 & 1309 & 0 & 1309 \\
\hline 0 & 1308 & 0 & 1310 \\
\hline 0 & 1307 & 0 & 1311 \\
\hline
\end{tabular}


Variável

dependente:

ACI

ID $=91$

\begin{tabular}{|l|r|l|r|}
\hline \multicolumn{3}{|c|}{ Momento } \\
\hline N & 6 & Soma dos pesos & 6 \\
\hline Média & $\begin{array}{r}0 \\
\text { Soma das } \\
\text { observações }\end{array}$ & 0 \\
\hline Desvio-padrão & 0 & Variância & 0 \\
\hline Assimetria &, Curtose &, \\
\hline $\begin{array}{l}\text { Soma dos } \\
\text { quadrados não } \\
\text { corrigida }\end{array}$ & 0 & $\begin{array}{l}\text { Soma dos } \\
\text { quadrados corrigida }\end{array}$ & 0 \\
\hline CV Pearson &, & Erro-padrão médio & 0 \\
\hline
\end{tabular}

\begin{tabular}{|l|r|l|r|}
\hline \multicolumn{3}{|c|}{ Estatística Descritiva Básica } \\
\hline \multicolumn{2}{|c|}{ Posição } & \multicolumn{2}{c|}{ Variabilidade } \\
\hline Média & 0 & Desvio-padrão & 0 \\
\hline Mediana & 0 & Variância & 0 \\
\hline Moda & 0 & Amplitude & 0 \\
\hline & & Amplitude interquartil & 0 \\
\hline
\end{tabular}

\begin{tabular}{|l|l|l|l|l|}
\hline \multicolumn{5}{|c|}{ Testes de Posição: Mu0=0 } \\
\hline Teste & \multicolumn{2}{|c|}{ Estatística } & \multicolumn{2}{c|}{ Valor $\mathbf{p}$} \\
\hline Student t & t &, & $\operatorname{Pr}>|\mathbf{t}|$ & \\
\hline Sign & M &, & $\operatorname{Pr}>=|\mathrm{M}|$ & \\
\hline Signed Rank & S &, & $\operatorname{Pr}>=|\mathrm{S}|$ & \\
\hline
\end{tabular}

\begin{tabular}{|l|r|}
\hline \multicolumn{2}{|c|}{ Quantis } \\
\hline Level & 0 \\
\hline $100 \%$ Max & 0 \\
\hline $99 \%$ & 0 \\
\hline $95 \%$ & 0 \\
\hline $90 \%$ & 0 \\
\hline $75 \%$ Q3 & 0 \\
\hline $50 \%$ Mediana & 0 \\
\hline $25 \%$ Q1 & 0 \\
\hline $10 \%$ & 0 \\
\hline $5 \%$ & 0 \\
\hline $1 \%$ & 0 \\
\hline $0 \%$ Min & 0 \\
\hline
\end{tabular}


Variável

dependente:

ACI

ID $=91$

\begin{tabular}{|r|c|r|r|}
\hline \multicolumn{3}{|c|}{ Observações Limite } \\
\hline \multicolumn{2}{|c|}{ Baixa } & \multicolumn{2}{c|}{ Alta } \\
\hline Valor & Obs & Valor & Obs \\
\hline 0 & 1311 & 0 & 1307 \\
\hline 0 & 1310 & 0 & 1308 \\
\hline 0 & 1309 & 0 & 1309 \\
\hline 0 & 1308 & 0 & 1310 \\
\hline 0 & 1307 & 0 & 1311 \\
\hline
\end{tabular}


Variável

dependente:

REC

$\mathrm{ID}=92$

\begin{tabular}{|l|r|l|r|}
\hline \multicolumn{3}{|c|}{ Momento } \\
\hline N & 1 Soma dos pesos & 1 \\
\hline Média & $\begin{array}{r}0 \\
\text { Soma das } \\
\text { observações }\end{array}$ & 0 \\
\hline Desvio-padrão &, Variância &, \\
\hline Assimetria &, Curtose &, \\
\hline $\begin{array}{l}\text { Soma dos } \\
\text { quadrados não } \\
\text { corrigida }\end{array}$ & 0 & $\begin{array}{l}\text { Soma dos } \\
\text { quadrados corrigida }\end{array}$ & 0 \\
\hline CV Pearson &, & Erro-padrão médio &, \\
\hline
\end{tabular}

\begin{tabular}{|l|r|l|r|}
\hline \multicolumn{3}{|c|}{ Estatística Descritiva Básica } \\
\hline \multicolumn{2}{|c|}{ Posição } & \multicolumn{2}{c|}{ Variabilidade } \\
\hline Média & 0 & Desvio-padrão & 0 \\
\hline Mediana & 0 & Variância & 0 \\
\hline Moda & 0 & Amplitude & Amplitude interquartil \\
\hline & & Am & 0
\end{tabular}

\begin{tabular}{|l|l|l|l|l|}
\hline \multicolumn{4}{|c|}{ Testes de Posição: Mu0=0 } \\
\hline Teste & \multicolumn{2}{|c|}{ Estatística } & \multicolumn{2}{c|}{ Valor $\mathbf{p}$} \\
\hline Student $\mathbf{t}$ & $\mathbf{t}$ & \multicolumn{1}{|c|}{, $\operatorname{Pr}>|\mathbf{t}|$} & \\
\hline Sign & $\mathrm{M}$ &, & $\operatorname{Pr}>=|\mathrm{M}|$ & \\
\hline Signed Rank & S &, & $\operatorname{Pr}>=|\mathrm{S}|$ & \\
\hline
\end{tabular}

\begin{tabular}{|l|r|}
\hline \multicolumn{2}{|c|}{ Quantis } \\
\hline Level & 0 \\
\hline $100 \%$ Max & 0 \\
\hline $99 \%$ & 0 \\
\hline $95 \%$ & 0 \\
\hline $90 \%$ & 0 \\
\hline $75 \%$ Q3 & 0 \\
\hline $50 \%$ Mediana & 0 \\
\hline $25 \%$ Q1 & 0 \\
\hline $10 \%$ & 0 \\
\hline $5 \%$ & 0 \\
\hline $1 \%$ & 0 \\
\hline $0 \%$ Min & 0 \\
\hline
\end{tabular}


Variável

dependente:

REC

ID $=92$

Observações Limite

Baixa

Alta

Valor Obs Valor Obs

\begin{tabular}{l|l|l|l|}
0 & 1312 & & 1312 \\
\hline
\end{tabular} 
Variável

dependente:

ACI

$\mathrm{ID}=92$

\begin{tabular}{|l|r|l|r|}
\hline \multicolumn{3}{|c|}{ Momento } \\
\hline N & 1 Soma dos pesos & 1 \\
\hline Média & $\begin{array}{r}0 \\
\text { Soma das } \\
\text { observações }\end{array}$ & 0 \\
\hline Desvio-padrão &, Variância &, \\
\hline Assimetria &, Curtose &, \\
\hline $\begin{array}{l}\text { Soma dos } \\
\text { quadrados não } \\
\text { corrigida }\end{array}$ & 0 & $\begin{array}{l}\text { Soma dos } \\
\text { quadrados corrigida }\end{array}$ & 0 \\
\hline CV Pearson &, & Erro-padrão médio &, \\
\hline
\end{tabular}

\begin{tabular}{|l|r|l|r|}
\hline \multicolumn{3}{|c|}{ Estatística Descritiva Básica } \\
\hline \multicolumn{2}{|c|}{ Posição } & \multicolumn{2}{c|}{ Variabilidade } \\
\hline Média & 0 & Desvio-padrão & 0 \\
\hline Mediana & 0 & Variância & 0 \\
\hline Moda & 0 & Amplitude & Amplitude interquartil \\
\hline & & Am & 0
\end{tabular}

\begin{tabular}{|l|l|l|l|l|}
\hline \multicolumn{4}{|c|}{ Testes de Posição: Mu0=0 } \\
\hline Teste & \multicolumn{2}{|c|}{ Estatística } & \multicolumn{2}{c|}{ Valor $\mathbf{p}$} \\
\hline Student $\mathbf{t}$ & $\mathbf{t}$ & \multicolumn{1}{|c|}{, $\operatorname{Pr}>|\mathbf{t}|$} & \\
\hline Sign & $\mathrm{M}$ &, & $\operatorname{Pr}>=|\mathrm{M}|$ & \\
\hline Signed Rank & S &, & $\operatorname{Pr}>=|\mathrm{S}|$ & \\
\hline
\end{tabular}

\begin{tabular}{|l|r|}
\hline \multicolumn{2}{|c|}{ Quantis } \\
\hline Level & 0 \\
\hline $100 \%$ Max & 0 \\
\hline $99 \%$ & 0 \\
\hline $95 \%$ & 0 \\
\hline $90 \%$ & 0 \\
\hline $75 \%$ Q3 & 0 \\
\hline $50 \%$ Mediana & 0 \\
\hline $25 \%$ Q1 & 0 \\
\hline $10 \%$ & 0 \\
\hline $5 \%$ & 0 \\
\hline $1 \%$ & 0 \\
\hline $0 \%$ Min & 0 \\
\hline
\end{tabular}


Variável

dependente:

ACI

ID $=92$

Observações Limite

Baixa Alta

Valor Obs Valor Obs

\begin{tabular}{l|l|l|l|}
0 & 1312 & & 1312 \\
\hline
\end{tabular} 
Variável

dependente:

REC

$\mathrm{ID}=93$

\begin{tabular}{|l|r|r|r|}
\hline \multicolumn{3}{|l|}{ Momento } \\
\hline N & 11 Soma dos pesos & 11 \\
\hline Média & $\begin{array}{l}0 \\
\text { Soma das } \\
\text { observações }\end{array}$ & 0 \\
\hline Desvio-padrão & 0 & Variância & 0 \\
\hline Assimetria &, Curtose &, \\
\hline $\begin{array}{l}\text { Soma dos } \\
\text { quadrados não } \\
\text { corrigida }\end{array}$ & 0 & $\begin{array}{l}\text { Soma dos } \\
\text { quadrados corrigida }\end{array}$ & 0 \\
\hline CV Pearson &, & Erro-padrão médio & 0 \\
\hline
\end{tabular}

\begin{tabular}{|l|r|l|r|}
\hline \multicolumn{3}{|c|}{ Estatística Descritiva Básica } \\
\hline \multicolumn{2}{|c|}{ Posição } & \multicolumn{2}{c|}{ Variabilidade } \\
\hline Média & 0 & Desvio-padrão & 0 \\
\hline Mediana & 0 & Variância & 0 \\
\hline Moda & 0 & Amplitude & 0 \\
\hline & & Amplitude interquartil & 0 \\
\hline
\end{tabular}

\begin{tabular}{|l|l|l|l|l|}
\hline \multicolumn{5}{|c|}{ Testes de Posição: $M u 0=0$} \\
\hline Teste & \multicolumn{2}{|c|}{ Estatística } & \multicolumn{2}{c|}{ Valor $p$} \\
\hline Student t & t &, & $\operatorname{Pr}>|t|$ & \\
\hline Sign & M &, & $\operatorname{Pr}>=|M|$ & \\
\hline Signed Rank & S &, & $\operatorname{Pr}>=|S|$ & \\
\hline
\end{tabular}

\begin{tabular}{|l|r|}
\hline \multicolumn{2}{|c|}{ Quantis } \\
\hline Level & 0 \\
\hline $100 \%$ Max & 0 \\
\hline $99 \%$ & 0 \\
\hline $95 \%$ & 0 \\
\hline $90 \%$ & 0 \\
\hline $75 \%$ Q3 & 0 \\
\hline $50 \%$ Mediana & 0 \\
\hline $25 \%$ Q1 & 0 \\
\hline $10 \%$ & 0 \\
\hline $5 \%$ & 0 \\
\hline $1 \%$ & 0 \\
\hline $0 \%$ Min & 0 \\
\hline
\end{tabular}


Variável

dependente:

REC

ID $=93$

\begin{tabular}{|r|r|r|r|}
\hline \multicolumn{3}{|c|}{ Observações Limite } \\
\hline \multicolumn{2}{|c|}{ Baixa } & \multicolumn{2}{c|}{ Alta } \\
\hline Valor & Obs & Valor & Obs \\
\hline 0 & 1323 & 0 & 1319 \\
\hline 0 & 1322 & 0 & 1320 \\
\hline 0 & 1321 & 0 & 1321 \\
\hline 0 & 1320 & 0 & 1322 \\
\hline 0 & 1319 & 0 & 1323 \\
\hline
\end{tabular}


Variável

dependente:

ACI

ID $=93$

\begin{tabular}{|l|r|r|r|}
\hline \multicolumn{3}{|l|}{ Momento } \\
\hline N & 11 Soma dos pesos & 11 \\
\hline Média & $\begin{array}{l}0 \\
\text { Soma das } \\
\text { observações }\end{array}$ & 0 \\
\hline Desvio-padrão & 0 & Variância & 0 \\
\hline Assimetria &, Curtose &, \\
\hline $\begin{array}{l}\text { Soma dos } \\
\text { quadrados não } \\
\text { corrigida }\end{array}$ & 0 & $\begin{array}{l}\text { Soma dos } \\
\text { quadrados corrigida }\end{array}$ & 0 \\
\hline CV Pearson &, & Erro-padrão médio & 0 \\
\hline
\end{tabular}

\begin{tabular}{|l|r|l|r|}
\hline \multicolumn{3}{|c|}{ Estatística Descritiva Básica } \\
\hline \multicolumn{2}{|c|}{ Posição } & \multicolumn{2}{c|}{ Variabilidade } \\
\hline Média & 0 & Desvio-padrão & 0 \\
\hline Mediana & 0 & Variância & 0 \\
\hline Moda & 0 & Amplitude & 0 \\
\hline & & Amplitude interquartil & 0 \\
\hline
\end{tabular}

\begin{tabular}{|l|l|l|l|l|}
\hline \multicolumn{5}{|c|}{ Testes de Posição: Mu0=0 } \\
\hline Teste & \multicolumn{2}{|c|}{ Estatística } & \multicolumn{2}{c|}{ Valor $\mathbf{p}$} \\
\hline Student t & t &, & $\operatorname{Pr}>|\mathbf{t}|$ & \\
\hline Sign & M &, & $\operatorname{Pr}>=|\mathrm{M}|$ & \\
\hline Signed Rank & S &, & $\operatorname{Pr}>=|\mathrm{S}|$ & \\
\hline
\end{tabular}

\begin{tabular}{|l|r|}
\hline \multicolumn{2}{|c|}{ Quantis } \\
\hline Level & 0 \\
\hline $100 \%$ Max & 0 \\
\hline $99 \%$ & 0 \\
\hline $95 \%$ & 0 \\
\hline $90 \%$ & 0 \\
\hline $75 \%$ Q3 & 0 \\
\hline $50 \%$ Mediana & 0 \\
\hline $25 \%$ Q1 & 0 \\
\hline $10 \%$ & 0 \\
\hline $5 \%$ & 0 \\
\hline $1 \%$ & 0 \\
\hline $0 \%$ Min & 0 \\
\hline
\end{tabular}


Variável

dependente:

ACI

ID $=93$

\begin{tabular}{|r|r|r|r|}
\hline \multicolumn{3}{|c|}{ Observações Limite } \\
\hline \multicolumn{2}{|c|}{ Baixa } & \multicolumn{2}{c|}{ Alta } \\
\hline Valor & Obs & Valor & Obs \\
\hline 0 & 1323 & 0 & 1319 \\
\hline 0 & 1322 & 0 & 1320 \\
\hline 0 & 1321 & 0 & 1321 \\
\hline 0 & 1320 & 0 & 1322 \\
\hline 0 & 1319 & 0 & 1323 \\
\hline
\end{tabular}


Variável

dependente:

REC

ID $=95$

\begin{tabular}{|l|r|l|r|}
\hline \multicolumn{3}{|c|}{ Momento } \\
\hline Nédia & 16 & Soma dos pesos & 16 \\
\hline Desvio-padrão & 0,0625 & $\begin{array}{l}\text { Soma das } \\
\text { observações }\end{array}$ & 1 \\
\hline Assimetria & 0,25 & Variância & 0,0625 \\
\hline $\begin{array}{l}\text { Soma dos } \\
\text { quadrados não } \\
\text { corrigida }\end{array}$ & 4 & Curtose & 16 \\
\hline CV Pearson & 1 & $\begin{array}{l}\text { Soma dos } \\
\text { quadrados corrigida }\end{array}$ & 0,9375 \\
\hline
\end{tabular}

\begin{tabular}{|l|l|l|r|}
\hline \multicolumn{4}{|c|}{ Estatística Descritiva Básica } \\
\hline \multicolumn{2}{|c|}{ Posição } & \multicolumn{2}{c|}{ Variabilidade } \\
\hline Média & 0,062500 & Desvio-padrão & 0,25000 \\
\hline Mediana & 0,000000 & Variância & 0,06250 \\
\hline Moda & 0,000000 & Amplitude & 1,00000 \\
\hline & & Amplitude interquartil & 0 \\
\hline
\end{tabular}

\begin{tabular}{|l|l|r|l|l|}
\hline \multicolumn{5}{|c|}{ Testes de Posição: Mu0=0 } \\
\hline Teste & \multicolumn{2}{|c|}{ Estatística } & \multicolumn{2}{c|}{ Valor $\mathbf{~}$} \\
\hline Student t & $\mathbf{t}$ & 1 & $\mathrm{Pr}>|\mathbf{t}|$ & 0,3332 \\
\hline Sign & $\mathbf{M}$ & 0,5 & $\mathrm{Pr}>=|\mathrm{M}|$ & 1,0000 \\
\hline Signed Rank & $\mathbf{S}$ & 0,5 & $\mathrm{Pr}>=|\mathrm{S}|$ & 1,0000 \\
\hline
\end{tabular}

\begin{tabular}{|l|r|}
\hline \multicolumn{2}{|c|}{ Quantis } \\
\hline Level & 1 \\
\hline $100 \%$ Max & 1 \\
\hline $99 \%$ & 1 \\
\hline $95 \%$ & 0 \\
\hline $90 \%$ & 0 \\
\hline $75 \%$ Quantil & 0 \\
\hline $50 \%$ Mediana & 0 \\
\hline $25 \%$ Q1 & 0 \\
\hline $10 \%$ & 0 \\
\hline $5 \%$ & 0 \\
\hline $1 \%$ & 0 \\
\hline $0 \%$ Min & \\
\hline
\end{tabular}


Variável

dependente:

REC

ID $=95$

\begin{tabular}{|r|r|r|r|}
\hline \multicolumn{3}{|c|}{ Observações Limite } \\
\hline \multicolumn{2}{|c|}{ Baixa } & \multicolumn{2}{c|}{ Alta } \\
\hline Valor & Obs & Valor & Obs \\
\hline 0 & 1339 & 0 & 1336 \\
\hline 0 & 1338 & 0 & 1337 \\
\hline 0 & 1337 & 0 & 1338 \\
\hline 0 & 1336 & 0 & 1339 \\
\hline 0 & 1335 & 1 & 1332 \\
\hline
\end{tabular}


Variável

dependente:

ACI

ID $=95$

\begin{tabular}{|l|r|l|r|}
\hline \multicolumn{3}{|c|}{ Momento } \\
\hline N & 16 & Soma dos pesos & 16 \\
\hline Média & $\begin{array}{r}0 \\
\text { Soma das } \\
\text { observações }\end{array}$ & 0 \\
\hline Desvio-padrão & 0 & Variância & 0 \\
\hline Assimetria &, Curtose &, \\
\hline $\begin{array}{l}\text { Soma dos } \\
\text { quadrados não } \\
\text { corrigida }\end{array}$ & 0 & $\begin{array}{l}\text { Soma dos } \\
\text { quadrados corrigida }\end{array}$ & 0 \\
\hline CV Pearson &, & Erro-padrão médio & 0 \\
\hline
\end{tabular}

\begin{tabular}{|l|r|l|r|}
\hline \multicolumn{3}{|c|}{ Estatística Descritiva Básica } \\
\hline \multicolumn{2}{|c|}{ Posição } & \multicolumn{2}{c|}{ Variabilidade } \\
\hline Média & 0 & Desvio-padrão & 0 \\
\hline Mediana & 0 & Variância & 0 \\
\hline Moda & 0 & Amplitude & 0 \\
\hline & & Amplitude interquartil & 0 \\
\hline
\end{tabular}

\begin{tabular}{|l|l|l|l|l|}
\hline \multicolumn{5}{|c|}{ Testes de Posição: Mu0=0 } \\
\hline Teste & \multicolumn{2}{|c|}{ Estatística } & \multicolumn{2}{c|}{ Valor $\mathbf{p}$} \\
\hline Student t & t &, & $\operatorname{Pr}>|\mathbf{t}|$ & \\
\hline Sign & M &, & $\operatorname{Pr}>=|\mathrm{M}|$ & \\
\hline Signed Rank & S &, & $\operatorname{Pr}>=|\mathrm{S}|$ & \\
\hline
\end{tabular}

\begin{tabular}{|l|r|}
\hline \multicolumn{2}{|c|}{ Quantis } \\
\hline Level & 0 \\
\hline $100 \%$ Max & 0 \\
\hline $99 \%$ & 0 \\
\hline $95 \%$ & 0 \\
\hline $90 \%$ & 0 \\
\hline $75 \%$ Q3 & 0 \\
\hline $50 \%$ Mediana & 0 \\
\hline $25 \%$ Q1 & 0 \\
\hline $10 \%$ & 0 \\
\hline $5 \%$ & 0 \\
\hline $1 \%$ & 0 \\
\hline $0 \%$ Min & 0 \\
\hline
\end{tabular}


Variável

dependente:

ACI

ID $=95$

\begin{tabular}{|r|r|r|r|}
\hline \multicolumn{3}{|c|}{ Observações Limite } \\
\hline \multicolumn{2}{|c|}{ Baixa } & \multicolumn{2}{c|}{ Alta } \\
\hline Valor & Obs & Valor & Obs \\
\hline 0 & 1339 & 0 & 1335 \\
\hline 0 & 1338 & 0 & 1336 \\
\hline 0 & 1337 & 0 & 1337 \\
\hline 0 & 1336 & 0 & 1338 \\
\hline 0 & 1335 & 0 & 1339 \\
\hline
\end{tabular}


Variável

dependente:

REC

$I D=96$

\begin{tabular}{|l|r|r|r|}
\hline \multicolumn{3}{|l|}{ Momento } \\
\hline N & 17 Soma dos pesos & 17 \\
\hline Média & $\begin{array}{l}0 \\
\text { Soma das } \\
\text { observações }\end{array}$ & 0 \\
\hline Desvio-padrão & 0 & Variância & 0 \\
\hline Assimetria &, Curtose &, \\
\hline $\begin{array}{l}\text { Soma dos } \\
\text { quadrados não } \\
\text { corrigida }\end{array}$ & 0 & $\begin{array}{l}\text { Soma dos } \\
\text { quadrados corrigida }\end{array}$ & 0 \\
\hline CV Pearson &, & Erro-padrão médio & 0 \\
\hline
\end{tabular}

\begin{tabular}{|l|r|l|r|}
\hline \multicolumn{3}{|c|}{ Estatística Descritiva Básica } \\
\hline \multicolumn{2}{|c|}{ Posição } & \multicolumn{2}{c|}{ Variabilidade } \\
\hline Média & 0 & Desvio-padrão & 0 \\
\hline Mediana & 0 & Variância & 0 \\
\hline Moda & 0 & Amplitude & 0 \\
\hline & & Amplitude interquartil & 0 \\
\hline
\end{tabular}

\begin{tabular}{|l|l|l|l|l|}
\hline \multicolumn{4}{|c|}{ Testes de Posição: Mu0=0 } \\
\hline Teste & \multicolumn{2}{|c|}{ Estatística } & \multicolumn{2}{c|}{ Valor $\mathbf{p}$} \\
\hline Student $\mathbf{t}$ & $\mathbf{t}$ & \multicolumn{1}{|c|}{, $\operatorname{Pr}>|\mathbf{t}|$} & \\
\hline Sign & $\mathrm{M}$ &, & $\operatorname{Pr}>=|\mathrm{M}|$ & \\
\hline Signed Rank & S &, & $\operatorname{Pr}>=|\mathrm{S}|$ & \\
\hline
\end{tabular}

\begin{tabular}{|l|r|}
\hline \multicolumn{2}{|c|}{ Quantis } \\
\hline Level & 0 \\
\hline $100 \%$ Max & 0 \\
\hline $99 \%$ & 0 \\
\hline $95 \%$ & 0 \\
\hline $90 \%$ & 0 \\
\hline $75 \%$ Q3 & 0 \\
\hline $50 \%$ Mediana & 0 \\
\hline $25 \%$ Q1 & 0 \\
\hline $10 \%$ & 0 \\
\hline $5 \%$ & 0 \\
\hline $1 \%$ & 0 \\
\hline $0 \%$ Min & 0 \\
\hline
\end{tabular}


Variável

dependente:

REC

ID $=96$

\begin{tabular}{|r|c|r|r|}
\hline \multicolumn{3}{|c|}{ Observações Limite } \\
\hline \multicolumn{2}{|c|}{ Baixa } & \multicolumn{2}{c|}{ Alta } \\
\hline Valor & Obs & Valor & Obs \\
\hline 0 & 1356 & 0 & 1352 \\
\hline 0 & 1355 & 0 & 1353 \\
\hline 0 & 1354 & 0 & 1354 \\
\hline 0 & 1353 & 0 & 1355 \\
\hline 0 & 1352 & 0 & 1356 \\
\hline
\end{tabular}


Variável

dependente:

ACI

ID $=96$

\begin{tabular}{|l|r|l|r|}
\hline \multicolumn{3}{|c|}{ Momento } \\
\hline N & 17 & Soma dos pesos & 17 \\
\hline Média & $\begin{array}{r}0 \\
\text { Soma das } \\
\text { observações }\end{array}$ & 0 \\
\hline Desvio-padrão & 0 & Variância & 0 \\
\hline Assimetria &, Curtose &, \\
\hline $\begin{array}{l}\text { Soma dos } \\
\text { quadrados não } \\
\text { corrigida }\end{array}$ & 0 & $\begin{array}{l}\text { Soma dos } \\
\text { quadrados corrigida }\end{array}$ & 0 \\
\hline CV Pearson &, & Erro-padrão médio & 0 \\
\hline
\end{tabular}

\begin{tabular}{|l|r|l|r|}
\hline \multicolumn{3}{|c|}{ Estatística Descritiva Básica } \\
\hline \multicolumn{2}{|c|}{ Posição } & \multicolumn{2}{c|}{ Variabilidade } \\
\hline Média & 0 & Desvio-padrão & 0 \\
\hline Mediana & 0 & Variância & 0 \\
\hline Moda & 0 & Amplitude & 0 \\
\hline & & Amplitude interquartil & 0 \\
\hline
\end{tabular}

\begin{tabular}{|l|l|l|l|l|}
\hline \multicolumn{4}{|c|}{ Testes de Posição: Mu0=0 } \\
\hline Teste & \multicolumn{2}{|c|}{ Estatística } & \multicolumn{2}{c|}{ Valor $\mathbf{p}$} \\
\hline Student $\mathbf{t}$ & $\mathbf{t}$ & \multicolumn{1}{|c|}{, $\operatorname{Pr}>|\mathbf{t}|$} & \\
\hline Sign & $\mathrm{M}$ &, & $\operatorname{Pr}>=|\mathrm{M}|$ & \\
\hline Signed Rank & S &, & $\operatorname{Pr}>=|\mathrm{S}|$ & \\
\hline
\end{tabular}

\begin{tabular}{|l|r|}
\hline \multicolumn{2}{|c|}{ Quantis } \\
\hline Level & 0 \\
\hline $100 \%$ Max & 0 \\
\hline $99 \%$ & 0 \\
\hline $95 \%$ & 0 \\
\hline $90 \%$ & 0 \\
\hline $75 \%$ Q3 & 0 \\
\hline $50 \%$ Mediana & 0 \\
\hline $25 \%$ Q1 & 0 \\
\hline $10 \%$ & 0 \\
\hline $5 \%$ & 0 \\
\hline $1 \%$ & 0 \\
\hline $0 \%$ Min & 0 \\
\hline
\end{tabular}


Variável

dependente:

ACI

ID $=96$

\begin{tabular}{|r|r|r|r|}
\hline \multicolumn{3}{|c|}{ Observações Limite } \\
\hline \multicolumn{2}{|c|}{ Baixa } & \multicolumn{2}{c|}{ Alta } \\
\hline Valor & Obs & Valor & Obs \\
\hline 0 & 1356 & 0 & 1352 \\
\hline 0 & 1355 & 0 & 1353 \\
\hline 0 & 1354 & 0 & 1354 \\
\hline 0 & 1353 & 0 & 1355 \\
\hline 0 & 1352 & 0 & 1356 \\
\hline
\end{tabular}


Variável

dependente:

REC

ID $=98$

\begin{tabular}{|l|r|l|r|}
\hline \multicolumn{3}{|c|}{ Momento } \\
\hline N & 18 & Soma dos pesos & 18 \\
\hline Média & $\begin{array}{r}0 \\
\text { Soma das } \\
\text { observações }\end{array}$ & 0 \\
\hline Desvio-padrão & 0 & Variância & 0 \\
\hline Assimetria &, Curtose &, \\
\hline $\begin{array}{l}\text { Soma dos } \\
\text { quadrados não } \\
\text { corrigida }\end{array}$ & 0 & $\begin{array}{l}\text { Soma dos } \\
\text { quadrados corrigida }\end{array}$ & 0 \\
\hline CV Pearson &, & Erro-padrão médio & 0 \\
\hline
\end{tabular}

\begin{tabular}{|l|r|l|r|}
\hline \multicolumn{3}{|c|}{ Estatística Descritiva Básica } \\
\hline \multicolumn{2}{|c|}{ Posição } & \multicolumn{2}{c|}{ Variabilidade } \\
\hline Média & 0 & Desvio-padrão & 0 \\
\hline Mediana & 0 & Variância & 0 \\
\hline Moda & 0 & Amplitude & 0 \\
\hline & & Amplitude interquartil & 0 \\
\hline
\end{tabular}

\begin{tabular}{|l|l|l|l|l|}
\hline \multicolumn{4}{|c|}{ Testes de Posição: Mu0=0 } \\
\hline Teste & \multicolumn{2}{|c|}{ Estatística } & \multicolumn{2}{c|}{ Valor $\mathbf{p}$} \\
\hline Student $\mathbf{t}$ & $\mathbf{t}$ & \multicolumn{1}{|c|}{, $\operatorname{Pr}>|\mathbf{t}|$} & \\
\hline Sign & $\mathrm{M}$ &, & $\operatorname{Pr}>=|\mathrm{M}|$ & \\
\hline Signed Rank & S &, & $\operatorname{Pr}>=|\mathrm{S}|$ & \\
\hline
\end{tabular}

\begin{tabular}{|l|r|}
\hline \multicolumn{2}{|c|}{ Quantis } \\
\hline Level & 0 \\
\hline $100 \%$ Max & 0 \\
\hline $99 \%$ & 0 \\
\hline $95 \%$ & 0 \\
\hline $90 \%$ & 0 \\
\hline $75 \%$ Q3 & 0 \\
\hline $50 \%$ Mediana & 0 \\
\hline $25 \%$ Q1 & 0 \\
\hline $10 \%$ & 0 \\
\hline $5 \%$ & 0 \\
\hline $1 \%$ & 0 \\
\hline $0 \%$ Min & 0 \\
\hline
\end{tabular}


Variável

dependente:

REC

ID $=98$

\begin{tabular}{|r|r|r|r|}
\hline \multicolumn{3}{|c|}{ Observações Limite } \\
\hline \multicolumn{2}{|c|}{ Baixa } & \multicolumn{2}{c|}{ Alta } \\
\hline Valor & Obs & Valor & Obs \\
\hline 0 & 1374 & 0 & 1370 \\
\hline 0 & 1373 & 0 & 1371 \\
\hline 0 & 1372 & 0 & 1372 \\
\hline 0 & 1371 & 0 & 1373 \\
\hline 0 & 1370 & 0 & 1374 \\
\hline
\end{tabular}


Variável

dependente:

ACI

ID $=98$

\begin{tabular}{|l|r|l|r|}
\hline \multicolumn{3}{|c|}{ Momento } \\
\hline N & 18 & Soma dos pesos & 18 \\
\hline Média & $\begin{array}{r}0 \\
\text { Soma das } \\
\text { observações }\end{array}$ & 0 \\
\hline Desvio-padrão & 0 & Variância & 0 \\
\hline Assimetria &, Curtose &, \\
\hline $\begin{array}{l}\text { Soma dos } \\
\text { quadrados não } \\
\text { corrigida }\end{array}$ & 0 & $\begin{array}{l}\text { Soma dos } \\
\text { quadrados corrigida }\end{array}$ & 0 \\
\hline CV Pearson &, & Erro-padrão médio & 0 \\
\hline
\end{tabular}

\begin{tabular}{|l|r|l|r|}
\hline \multicolumn{3}{|c|}{ Estatística Descritiva Básica } \\
\hline \multicolumn{2}{|c|}{ Posição } & \multicolumn{2}{c|}{ Variabilidade } \\
\hline Média & 0 & Desvio-padrão & 0 \\
\hline Mediana & 0 & Variância & 0 \\
\hline Moda & 0 & Amplitude & 0 \\
\hline & & Amplitude interquartil & 0 \\
\hline
\end{tabular}

\begin{tabular}{|l|l|l|l|l|}
\hline \multicolumn{4}{|c|}{ Testes de Posição: Mu0=0 } \\
\hline Teste & \multicolumn{2}{|c|}{ Estatística } & \multicolumn{2}{c|}{ Valor $\mathbf{p}$} \\
\hline Student $\mathbf{t}$ & $\mathbf{t}$ & \multicolumn{1}{|c|}{, $\operatorname{Pr}>|\mathbf{t}|$} & \\
\hline Sign & $\mathrm{M}$ &, & $\operatorname{Pr}>=|\mathrm{M}|$ & \\
\hline Signed Rank & S &, & $\operatorname{Pr}>=|\mathrm{S}|$ & \\
\hline
\end{tabular}

\begin{tabular}{|l|r|}
\hline \multicolumn{2}{|c|}{ Quantis } \\
\hline Level & 0 \\
\hline $100 \%$ Max & 0 \\
\hline $99 \%$ & 0 \\
\hline $95 \%$ & 0 \\
\hline $90 \%$ & 0 \\
\hline $75 \%$ Q3 & 0 \\
\hline $50 \%$ Mediana & 0 \\
\hline $25 \%$ Q1 & 0 \\
\hline $10 \%$ & 0 \\
\hline $5 \%$ & 0 \\
\hline $1 \%$ & 0 \\
\hline $0 \%$ Min & 0 \\
\hline
\end{tabular}


Variável

dependente:

ACI

ID $=98$

\begin{tabular}{|r|r|r|r|}
\hline \multicolumn{4}{|c|}{ Observações Limite } \\
\hline \multicolumn{2}{|c|}{ Baixa } & \multicolumn{2}{c|}{ Alta } \\
\hline Valor & Obs & Valor & Obs \\
\hline 0 & 1374 & 0 & 1370 \\
\hline 0 & 1373 & 0 & 1371 \\
\hline 0 & 1372 & 0 & 1372 \\
\hline 0 & 1371 & 0 & 1373 \\
\hline 0 & 1370 & 0 & 1374 \\
\hline
\end{tabular}


Variável

dependente:

REC

ID $=99$

\begin{tabular}{|l|r|r|r|}
\hline \multicolumn{3}{|l|}{ Momento } \\
\hline N & 18 Soma dos pesos & 18 \\
\hline Média & $\begin{array}{r}0 \\
\text { Soma das } \\
\text { observações }\end{array}$ & 0 \\
\hline Desvio-padrão & 0 & Variância & 0 \\
\hline Assimetria &, Curtose &, \\
\hline $\begin{array}{l}\text { Soma dos } \\
\text { quadrados não } \\
\text { corrigida }\end{array}$ & 0 & $\begin{array}{l}\text { Soma dos } \\
\text { quadrados corrigida }\end{array}$ & 0 \\
\hline CV Pearson &, & Erro-padrão médio & 0 \\
\hline
\end{tabular}

\begin{tabular}{|l|r|l|r|}
\hline \multicolumn{3}{|c|}{ Estatística Descritiva Básica } \\
\hline \multicolumn{2}{|c|}{ Posição } & \multicolumn{2}{c|}{ Variabilidade } \\
\hline Média & 0 & Desvio-padrão & 0 \\
\hline Mediana & 0 & Variância & 0 \\
\hline Moda & 0 & Amplitude & 0 \\
\hline & & Amplitude interquartil & 0 \\
\hline
\end{tabular}

\begin{tabular}{|l|l|l|l|l|}
\hline \multicolumn{5}{|c|}{ Testes de Posição: $M u 0=0$} \\
\hline Teste & \multicolumn{2}{|c|}{ Estatística } & \multicolumn{2}{c|}{ Valor $p$} \\
\hline Student t & t &, & $\operatorname{Pr}>|t|$ & \\
\hline Sign & M &, & $\operatorname{Pr}>=|M|$ & \\
\hline Signed Rank & S &, & $\operatorname{Pr}>=|S|$ & \\
\hline
\end{tabular}

\begin{tabular}{|l|r|}
\hline \multicolumn{2}{|c|}{ Quantis } \\
\hline Level & 0 \\
\hline $100 \%$ Max & 0 \\
\hline $99 \%$ & 0 \\
\hline $95 \%$ & 0 \\
\hline $90 \%$ & 0 \\
\hline $75 \%$ Q3 & 0 \\
\hline $50 \%$ Mediana & 0 \\
\hline $25 \%$ Q1 & 0 \\
\hline $10 \%$ & 0 \\
\hline $5 \%$ & 0 \\
\hline $1 \%$ & 0 \\
\hline $0 \%$ Min & 0 \\
\hline
\end{tabular}


Variável

dependente:

REC

ID $=99$

\begin{tabular}{|r|c|r|r|}
\hline \multicolumn{3}{|c|}{ Observações Limite } \\
\hline \multicolumn{2}{|c|}{ Baixa } & \multicolumn{2}{c|}{ Alta } \\
\hline Valor & Obs & Valor & Obs \\
\hline 0 & 1392 & 0 & 1388 \\
\hline 0 & 1391 & 0 & 1389 \\
\hline 0 & 1390 & 0 & 1390 \\
\hline 0 & 1389 & 0 & 1391 \\
\hline 0 & 1388 & 0 & 1392 \\
\hline
\end{tabular}


Variável

dependente:

ACI

ID=99

\begin{tabular}{|l|r|l|r|}
\hline \multicolumn{3}{|c|}{ Momento } \\
\hline N & 18 & Soma dos pesos & 18 \\
\hline Média & $\begin{array}{r}0 \\
\text { Soma das } \\
\text { observações }\end{array}$ & 0 \\
\hline Desvio-padrão & 0 & Variância & 0 \\
\hline Assimetria &, Curtose &, \\
\hline $\begin{array}{l}\text { Soma dos } \\
\text { quadrados não } \\
\text { corrigida }\end{array}$ & 0 & $\begin{array}{l}\text { Soma dos } \\
\text { quadrados corrigida }\end{array}$ & 0 \\
\hline CV Pearson &, & Erro-padrão médio & 0 \\
\hline
\end{tabular}

\begin{tabular}{|l|r|l|r|}
\hline \multicolumn{3}{|c|}{ Estatística Descritiva Básica } \\
\hline \multicolumn{2}{|c|}{ Posição } & \multicolumn{2}{c|}{ Variabilidade } \\
\hline Média & 0 & Desvio-padrão & 0 \\
\hline Mediana & 0 & Variância & 0 \\
\hline Moda & 0 & Amplitude & 0 \\
\hline & & Amplitude interquartil & 0 \\
\hline
\end{tabular}

\begin{tabular}{|l|l|l|l|l|}
\hline \multicolumn{4}{|c|}{ Testes de Posição: Mu0=0 } \\
\hline Teste & \multicolumn{2}{|c|}{ Estatística } & \multicolumn{2}{c|}{ Valor $\mathbf{p}$} \\
\hline Student $\mathbf{t}$ & $\mathbf{t}$ & \multicolumn{1}{|c|}{, $\operatorname{Pr}>|\mathbf{t}|$} & \\
\hline Sign & $\mathrm{M}$ &, & $\operatorname{Pr}>=|\mathrm{M}|$ & \\
\hline Signed Rank & S &, & $\operatorname{Pr}>=|\mathrm{S}|$ & \\
\hline
\end{tabular}

\begin{tabular}{|l|r|}
\hline \multicolumn{2}{|c|}{ Quantis } \\
\hline Level & 0 \\
\hline $100 \%$ Max & 0 \\
\hline $99 \%$ & 0 \\
\hline $95 \%$ & 0 \\
\hline $90 \%$ & 0 \\
\hline $75 \%$ Q3 & 0 \\
\hline $50 \%$ Mediana & 0 \\
\hline $25 \%$ Q1 & 0 \\
\hline $10 \%$ & 0 \\
\hline $5 \%$ & 0 \\
\hline $1 \%$ & 0 \\
\hline $0 \%$ Min & 0 \\
\hline
\end{tabular}


Variável

dependente:

ACI

ID $=99$

\begin{tabular}{|r|c|r|r|}
\hline \multicolumn{3}{|c|}{ Observações Limite } \\
\hline \multicolumn{2}{|c|}{ Baixa } & \multicolumn{2}{c|}{ Alta } \\
\hline Valor & Obs & Valor & Obs \\
\hline 0 & 1392 & 0 & 1388 \\
\hline 0 & 1391 & 0 & 1389 \\
\hline 0 & 1390 & 0 & 1390 \\
\hline 0 & 1389 & 0 & 1391 \\
\hline 0 & 1388 & 0 & 1392 \\
\hline
\end{tabular}


Variável

dependente:

REC

ID $=100$

\begin{tabular}{|l|r|l|r|}
\hline \multicolumn{3}{|c|}{ Momento } \\
\hline N & 18 & Soma dos pesos & 18 \\
\hline Média & $\begin{array}{r}0 \\
\text { Soma das } \\
\text { observações }\end{array}$ & 0 \\
\hline Desvio-padrão & 0 & Variância & 0 \\
\hline Assimetria &, Curtose &, \\
\hline $\begin{array}{l}\text { Soma dos } \\
\text { quadrados não } \\
\text { corrigida }\end{array}$ & 0 & $\begin{array}{l}\text { Soma dos } \\
\text { quadrados corrigida }\end{array}$ & 0 \\
\hline CV Pearson &, & Erro-padrão médio & 0 \\
\hline
\end{tabular}

\begin{tabular}{|l|r|l|r|}
\hline \multicolumn{3}{|c|}{ Estatística Descritiva Básica } \\
\hline \multicolumn{2}{|c|}{ Posição } & \multicolumn{2}{c|}{ Variabilidade } \\
\hline Média & 0 & Desvio-padrão & 0 \\
\hline Mediana & 0 & Variância & 0 \\
\hline Moda & 0 & Amplitude & 0 \\
\hline & & Amplitude interquartil & 0 \\
\hline
\end{tabular}

\begin{tabular}{|l|l|l|l|l|}
\hline \multicolumn{4}{|c|}{ Testes de Posição: Mu0=0 } \\
\hline Teste & \multicolumn{2}{|c|}{ Estatística } & \multicolumn{2}{c|}{ Valor $\mathbf{p}$} \\
\hline Student $\mathbf{t}$ & $\mathbf{t}$ & \multicolumn{1}{|c|}{, $\operatorname{Pr}>|\mathbf{t}|$} & \\
\hline Sign & $\mathrm{M}$ &, & $\operatorname{Pr}>=|\mathrm{M}|$ & \\
\hline Signed Rank & S &, & $\operatorname{Pr}>=|\mathrm{S}|$ & \\
\hline
\end{tabular}

\begin{tabular}{|l|r|}
\hline \multicolumn{2}{|c|}{ Quantis } \\
\hline Level & 0 \\
\hline $100 \%$ Max & 0 \\
\hline $99 \%$ & 0 \\
\hline $95 \%$ & 0 \\
\hline $90 \%$ & 0 \\
\hline $75 \%$ Q3 & 0 \\
\hline $50 \%$ Mediana & 0 \\
\hline $25 \%$ Q1 & 0 \\
\hline $10 \%$ & 0 \\
\hline $5 \%$ & 0 \\
\hline $1 \%$ & 0 \\
\hline $0 \%$ Min & 0 \\
\hline
\end{tabular}


Variável

dependente:

REC

ID $=100$

\begin{tabular}{|r|c|r|r|}
\hline \multicolumn{3}{|c|}{ Observações Limite } \\
\hline \multicolumn{2}{|c|}{ Baixa } & \multicolumn{2}{c|}{ Alta } \\
\hline Valor & Obs & Valor & Obs \\
\hline 0 & 1410 & 0 & 1406 \\
\hline 0 & 1409 & 0 & 1407 \\
\hline 0 & 1408 & 0 & 1408 \\
\hline 0 & 1407 & 0 & 1409 \\
\hline 0 & 1406 & 0 & 1410 \\
\hline
\end{tabular}


Variável

dependente:

ACI

ID $=100$

\begin{tabular}{|l|r|l|r|}
\hline \multicolumn{3}{|c|}{ Momento } \\
\hline N & 18 & Soma dos pesos & 18 \\
\hline Média & $\begin{array}{r}0 \\
\text { Soma das } \\
\text { observações }\end{array}$ & 0 \\
\hline Desvio-padrão & 0 & Variância & 0 \\
\hline Assimetria &, Curtose &, \\
\hline $\begin{array}{l}\text { Soma dos } \\
\text { quadrados não } \\
\text { corrigida }\end{array}$ & 0 & $\begin{array}{l}\text { Soma dos } \\
\text { quadrados corrigida }\end{array}$ & 0 \\
\hline CV Pearson &, & Erro-padrão médio & 0 \\
\hline
\end{tabular}

\begin{tabular}{|l|r|l|r|}
\hline \multicolumn{3}{|c|}{ Estatística Descritiva Básica } \\
\hline \multicolumn{2}{|c|}{ Posição } & \multicolumn{2}{c|}{ Variabilidade } \\
\hline Média & 0 & Desvio-padrão & 0 \\
\hline Mediana & 0 & Variância & 0 \\
\hline Moda & 0 & Amplitude & 0 \\
\hline & & Amplitude interquartil & 0 \\
\hline
\end{tabular}

\begin{tabular}{|l|l|l|l|l|}
\hline \multicolumn{4}{|c|}{ Testes de Posição: Mu0=0 } \\
\hline Teste & \multicolumn{2}{|c|}{ Estatística } & \multicolumn{2}{c|}{ Valor $\mathbf{p}$} \\
\hline Student t & t & \multicolumn{1}{|c|}{, $\operatorname{Pr}>|\mathbf{t}|$} & \\
\hline Sign & M &, & $\operatorname{Pr}>=|\mathrm{M}|$ & \\
\hline Signed Rank & S &, & $\operatorname{Pr}>=|\mathrm{S}|$ & \\
\hline
\end{tabular}

\begin{tabular}{|l|r|}
\hline \multicolumn{2}{|c|}{ Quantis } \\
\hline Level & 0 \\
\hline $100 \%$ Max & 0 \\
\hline $99 \%$ & 0 \\
\hline $95 \%$ & 0 \\
\hline $90 \%$ & 0 \\
\hline $75 \%$ Q3 & 0 \\
\hline $50 \%$ Mediana & 0 \\
\hline $25 \%$ Q1 & 0 \\
\hline $10 \%$ & 0 \\
\hline $5 \%$ & 0 \\
\hline $1 \%$ & 0 \\
\hline $0 \%$ Min & 0 \\
\hline
\end{tabular}


Variável

dependente:

ACI

ID $=100$

\begin{tabular}{|r|c|r|r|}
\hline \multicolumn{3}{|c|}{ Observações Limite } \\
\hline \multicolumn{2}{|c|}{ Baixa } & \multicolumn{2}{c|}{ Alta } \\
\hline Valor & Obs & Valor & Obs \\
\hline 0 & 1410 & 0 & 1406 \\
\hline 0 & 1409 & 0 & 1407 \\
\hline 0 & 1408 & 0 & 1408 \\
\hline 0 & 1407 & 0 & 1409 \\
\hline 0 & 1406 & 0 & 1410 \\
\hline
\end{tabular}


Variável

dependente:

REC

ID $=101$

\begin{tabular}{|l|r|l|r|}
\hline \multicolumn{3}{|c|}{ Momento } \\
\hline N & 16 & Soma dos pesos & 16 \\
\hline Média & $\begin{array}{r}0 \\
\text { Soma das } \\
\text { observações }\end{array}$ & 0 \\
\hline Desvio-padrão & 0 & Variância & 0 \\
\hline Assimetria &, Curtose &, \\
\hline $\begin{array}{l}\text { Soma dos } \\
\text { quadrados não } \\
\text { corrigida }\end{array}$ & 0 & $\begin{array}{l}\text { Soma dos } \\
\text { quadrados corrigida }\end{array}$ & 0 \\
\hline CV Pearson &, & Erro-padrão médio & 0 \\
\hline
\end{tabular}

\begin{tabular}{|l|r|l|r|}
\hline \multicolumn{3}{|c|}{ Estatística Descritiva Básica } \\
\hline \multicolumn{2}{|c|}{ Posição } & \multicolumn{2}{c|}{ Variabilidade } \\
\hline Média & 0 & Desvio-padrão & 0 \\
\hline Mediana & 0 & Variância & 0 \\
\hline Moda & 0 & Amplitude & 0 \\
\hline & & Amplitude interquartil & 0 \\
\hline
\end{tabular}

\begin{tabular}{|l|l|l|l|l|}
\hline \multicolumn{4}{|c|}{ Testes de Posição: Mu0=0 } \\
\hline Teste & \multicolumn{2}{|c|}{ Estatística } & \multicolumn{2}{c|}{ Valor $\mathbf{p}$} \\
\hline Student t & t & \multicolumn{1}{|c|}{, $\operatorname{Pr}>|\mathbf{t}|$} & \\
\hline Sign & M &, & $\operatorname{Pr}>=|\mathrm{M}|$ & \\
\hline Signed Rank & S &, & $\operatorname{Pr}>=|\mathrm{S}|$ & \\
\hline
\end{tabular}

\begin{tabular}{|l|r|}
\hline \multicolumn{2}{|c|}{ Quantis } \\
\hline Level & 0 \\
\hline $100 \%$ Max & 0 \\
\hline $99 \%$ & 0 \\
\hline $95 \%$ & 0 \\
\hline $90 \%$ & 0 \\
\hline $75 \%$ Q3 & 0 \\
\hline $50 \%$ Mediana & 0 \\
\hline $25 \%$ Q1 & 0 \\
\hline $10 \%$ & 0 \\
\hline $5 \%$ & 0 \\
\hline $1 \%$ & 0 \\
\hline $0 \%$ Min & 0 \\
\hline
\end{tabular}


Variável

dependente:

REC

ID $=101$

\begin{tabular}{|r|c|r|r|}
\hline \multicolumn{3}{|c|}{ Observações Limite } \\
\hline \multicolumn{2}{|c|}{ Baixa } & \multicolumn{2}{c|}{ Alta } \\
\hline Valor & Obs & Valor & Obs \\
\hline 0 & 1426 & 0 & 1422 \\
\hline 0 & 1425 & 0 & 1423 \\
\hline 0 & 1424 & 0 & 1424 \\
\hline 0 & 1423 & 0 & 1425 \\
\hline 0 & 1422 & 0 & 1426 \\
\hline
\end{tabular}


Variável

dependente:

ACI

ID $=101$

\begin{tabular}{|l|r|l|r|}
\hline \multicolumn{3}{|c|}{ Momento } \\
\hline N & 16 & Soma dos pesos & 16 \\
\hline Média & $\begin{array}{r}0 \\
\text { Soma das } \\
\text { observações }\end{array}$ & 0 \\
\hline Desvio-padrão & 0 & Variância & 0 \\
\hline Assimetria &, Curtose &, \\
\hline $\begin{array}{l}\text { Soma dos } \\
\text { quadrados não } \\
\text { corrigida }\end{array}$ & 0 & $\begin{array}{l}\text { Soma dos } \\
\text { quadrados corrigida }\end{array}$ & 0 \\
\hline CV Pearson &, & Erro-padrão médio & 0 \\
\hline
\end{tabular}

\begin{tabular}{|l|r|l|r|}
\hline \multicolumn{3}{|c|}{ Estatística Descritiva Básica } \\
\hline \multicolumn{2}{|c|}{ Posição } & \multicolumn{2}{c|}{ Variabilidade } \\
\hline Média & 0 & Desvio-padrão & 0 \\
\hline Mediana & 0 & Variância & 0 \\
\hline Moda & 0 & Amplitude & 0 \\
\hline & & Amplitude interquartil & 0 \\
\hline
\end{tabular}

\begin{tabular}{|l|l|l|l|l|}
\hline \multicolumn{4}{|c|}{ Testes de Posição: Mu0=0 } \\
\hline Teste & \multicolumn{2}{|c|}{ Estatística } & \multicolumn{2}{c|}{ Valor $\mathbf{p}$} \\
\hline Student t & t & \multicolumn{1}{|c|}{, $\operatorname{Pr}>|\mathbf{t}|$} & \\
\hline Sign & M &, & $\operatorname{Pr}>=|\mathrm{M}|$ & \\
\hline Signed Rank & S &, & $\operatorname{Pr}>=|\mathrm{S}|$ & \\
\hline
\end{tabular}

\begin{tabular}{|l|r|}
\hline \multicolumn{2}{|c|}{ Quantis } \\
\hline Level & 0 \\
\hline $100 \%$ Max & 0 \\
\hline $99 \%$ & 0 \\
\hline $95 \%$ & 0 \\
\hline $90 \%$ & 0 \\
\hline $75 \%$ Q3 & 0 \\
\hline $50 \%$ Mediana & 0 \\
\hline $25 \%$ Q1 & 0 \\
\hline $10 \%$ & 0 \\
\hline $5 \%$ & 0 \\
\hline $1 \%$ & 0 \\
\hline $0 \%$ Min & 0 \\
\hline
\end{tabular}


Variável

dependente:

ACI

ID $=101$

\begin{tabular}{|r|c|r|r|}
\hline \multicolumn{3}{|c|}{ Observações Limite } \\
\hline \multicolumn{2}{|c|}{ Baixa } & \multicolumn{2}{c|}{ Alta } \\
\hline Valor & Obs & Valor & Obs \\
\hline 0 & 1426 & 0 & 1422 \\
\hline 0 & 1425 & 0 & 1423 \\
\hline 0 & 1424 & 0 & 1424 \\
\hline 0 & 1423 & 0 & 1425 \\
\hline 0 & 1422 & 0 & 1426 \\
\hline
\end{tabular}


Variável

dependente:

REC

ID $=102$

\begin{tabular}{|l|r|l|r|}
\hline \multicolumn{3}{|c|}{ Momento } \\
\hline N & 17 & Soma dos pesos & 17 \\
\hline Média & $\begin{array}{r}0 \\
\text { Soma das } \\
\text { observações }\end{array}$ & 0 \\
\hline Desvio-padrão & 0 & Variância & 0 \\
\hline Assimetria &, Curtose &, \\
\hline $\begin{array}{l}\text { Soma dos } \\
\text { quadrados não } \\
\text { corrigida }\end{array}$ & 0 & $\begin{array}{l}\text { Soma dos } \\
\text { quadrados corrigida }\end{array}$ & 0 \\
\hline CV Pearson &, & Erro-padrão médio & 0 \\
\hline
\end{tabular}

\begin{tabular}{|l|r|l|r|}
\hline \multicolumn{3}{|c|}{ Estatística Descritiva Básica } \\
\hline \multicolumn{2}{|c|}{ Posição } & \multicolumn{2}{c|}{ Variabilidade } \\
\hline Média & 0 & Desvio-padrão & 0 \\
\hline Mediana & 0 & Variância & 0 \\
\hline Moda & 0 & Amplitude & 0 \\
\hline & & Amplitude interquartil & 0 \\
\hline
\end{tabular}

\begin{tabular}{|l|l|l|l|l|}
\hline \multicolumn{4}{|c|}{ Testes de Posição: Mu0=0 } \\
\hline Teste & \multicolumn{2}{|c|}{ Estatística } & \multicolumn{2}{c|}{ Valor $\mathbf{p}$} \\
\hline Student $\mathbf{t}$ & $\mathbf{t}$ & \multicolumn{1}{|c|}{, $\operatorname{Pr}>|\mathbf{t}|$} & \\
\hline Sign & $\mathrm{M}$ &, & $\operatorname{Pr}>=|\mathrm{M}|$ & \\
\hline Signed Rank & S &, & $\operatorname{Pr}>=|\mathrm{S}|$ & \\
\hline
\end{tabular}

\begin{tabular}{|l|r|}
\hline \multicolumn{2}{|c|}{ Quantis } \\
\hline Level & 0 \\
\hline $100 \%$ Max & 0 \\
\hline $99 \%$ & 0 \\
\hline $95 \%$ & 0 \\
\hline $90 \%$ & 0 \\
\hline $75 \%$ Q3 & 0 \\
\hline $50 \%$ Mediana & 0 \\
\hline $25 \%$ Q1 & 0 \\
\hline $10 \%$ & 0 \\
\hline $5 \%$ & 0 \\
\hline $1 \%$ & 0 \\
\hline $0 \%$ Min & 0 \\
\hline
\end{tabular}


Variável

dependente:

REC

ID $=102$

\begin{tabular}{|r|r|r|r|}
\hline \multicolumn{3}{|c|}{ Observações Limite } \\
\hline \multicolumn{2}{|c|}{ Baixa } & \multicolumn{2}{c|}{ Alta } \\
\hline Valor & Obs & Valor & Obs \\
\hline 0 & 1443 & 0 & 1439 \\
\hline 0 & 1442 & 0 & 1440 \\
\hline 0 & 1441 & 0 & 1441 \\
\hline 0 & 1440 & 0 & 1442 \\
\hline 0 & 1439 & 0 & 1443 \\
\hline
\end{tabular}


Variável

dependente:

ACI

ID $=102$

\begin{tabular}{|l|r|l|r|}
\hline \multicolumn{3}{|c|}{ Momento } \\
\hline N & 17 & Soma dos pesos & 17 \\
\hline Média & $\begin{array}{r}0 \\
\text { Soma das } \\
\text { observações }\end{array}$ & 0 \\
\hline Desvio-padrão & 0 & Variância & 0 \\
\hline Assimetria &, Curtose &, \\
\hline $\begin{array}{l}\text { Soma dos } \\
\text { quadrados não } \\
\text { corrigida }\end{array}$ & 0 & $\begin{array}{l}\text { Soma dos } \\
\text { quadrados corrigida }\end{array}$ & 0 \\
\hline CV Pearson &, & Erro-padrão médio & 0 \\
\hline
\end{tabular}

\begin{tabular}{|l|r|l|r|}
\hline \multicolumn{3}{|c|}{ Estatística Descritiva Básica } \\
\hline \multicolumn{2}{|c|}{ Posição } & \multicolumn{2}{c|}{ Variabilidade } \\
\hline Média & 0 & Desvio-padrão & 0 \\
\hline Mediana & 0 & Variância & 0 \\
\hline Moda & 0 & Amplitude & 0 \\
\hline & & Amplitude interquartil & 0 \\
\hline
\end{tabular}

\begin{tabular}{|l|l|l|l|l|}
\hline \multicolumn{4}{|c|}{ Testes de Posição: Mu0=0 } \\
\hline Teste & \multicolumn{2}{|c|}{ Estatística } & \multicolumn{2}{c|}{ Valor $\mathbf{p}$} \\
\hline Student $\mathbf{t}$ & $\mathbf{t}$ & \multicolumn{1}{|c|}{, $\operatorname{Pr}>|\mathbf{t}|$} & \\
\hline Sign & $\mathrm{M}$ &, & $\operatorname{Pr}>=|\mathrm{M}|$ & \\
\hline Signed Rank & S &, & $\operatorname{Pr}>=|\mathrm{S}|$ & \\
\hline
\end{tabular}

\begin{tabular}{|l|r|}
\hline \multicolumn{2}{|c|}{ Quantis } \\
\hline Level & 0 \\
\hline $100 \%$ Max & 0 \\
\hline $99 \%$ & 0 \\
\hline $95 \%$ & 0 \\
\hline $90 \%$ & 0 \\
\hline $75 \%$ Q3 & 0 \\
\hline $50 \%$ Mediana & 0 \\
\hline $25 \%$ Q1 & 0 \\
\hline $10 \%$ & 0 \\
\hline $5 \%$ & 0 \\
\hline $1 \%$ & 0 \\
\hline $0 \%$ Min & 0 \\
\hline
\end{tabular}


Variável

dependente:

ACI

ID $=102$

\begin{tabular}{|r|r|r|r|}
\hline \multicolumn{3}{|c|}{ Observações Limite } \\
\hline \multicolumn{2}{|c|}{ Baixa } & \multicolumn{2}{c|}{ Alta } \\
\hline Valor & Obs & Valor & Obs \\
\hline 0 & 1443 & 0 & 1439 \\
\hline 0 & 1442 & 0 & 1440 \\
\hline 0 & 1441 & 0 & 1441 \\
\hline 0 & 1440 & 0 & 1442 \\
\hline 0 & 1439 & 0 & 1443 \\
\hline
\end{tabular}


Variável

dependente:

REC

ID $=103$

\begin{tabular}{|l|r|l|r|}
\hline \multicolumn{3}{|c|}{ Momento } \\
\hline N & 18 & Soma dos pesos & 18 \\
\hline Média & $\begin{array}{r}0 \\
\text { Soma das } \\
\text { observações }\end{array}$ & 0 \\
\hline Desvio-padrão & 0 & Variância & 0 \\
\hline Assimetria &, Curtose &, \\
\hline $\begin{array}{l}\text { Soma dos } \\
\text { quadrados não } \\
\text { corrigida }\end{array}$ & 0 & $\begin{array}{l}\text { Soma dos } \\
\text { quadrados corrigida }\end{array}$ & 0 \\
\hline CV Pearson &, & Erro-padrão médio & 0 \\
\hline
\end{tabular}

\begin{tabular}{|l|r|l|r|}
\hline \multicolumn{3}{|c|}{ Estatística Descritiva Básica } \\
\hline \multicolumn{2}{|c|}{ Posição } & \multicolumn{2}{c|}{ Variabilidade } \\
\hline Média & 0 & Desvio-padrão & 0 \\
\hline Mediana & 0 & Variância & 0 \\
\hline Moda & 0 & Amplitude & 0 \\
\hline & & Amplitude interquartil & 0 \\
\hline
\end{tabular}

\begin{tabular}{|l|l|l|l|l|}
\hline \multicolumn{4}{|c|}{ Testes de Posição: Mu0=0 } \\
\hline Teste & \multicolumn{2}{|c|}{ Estatística } & \multicolumn{2}{c|}{ Valor $\mathbf{p}$} \\
\hline Student $\mathbf{t}$ & $\mathbf{t}$ & \multicolumn{1}{|c|}{, $\operatorname{Pr}>|\mathbf{t}|$} & \\
\hline Sign & $\mathrm{M}$ &, & $\operatorname{Pr}>=|\mathrm{M}|$ & \\
\hline Signed Rank & S &, & $\operatorname{Pr}>=|\mathrm{S}|$ & \\
\hline
\end{tabular}

\begin{tabular}{|l|r|}
\hline \multicolumn{2}{|c|}{ Quantis } \\
\hline Level & 0 \\
\hline $100 \%$ Max & 0 \\
\hline $99 \%$ & 0 \\
\hline $95 \%$ & 0 \\
\hline $90 \%$ & 0 \\
\hline $75 \%$ Q3 & 0 \\
\hline $50 \%$ Mediana & 0 \\
\hline $25 \%$ Q1 & 0 \\
\hline $10 \%$ & 0 \\
\hline $5 \%$ & 0 \\
\hline $1 \%$ & 0 \\
\hline $0 \%$ Min & 0 \\
\hline
\end{tabular}


Variável

dependente:

REC

ID $=103$

\begin{tabular}{|r|c|r|r|}
\hline \multicolumn{3}{|c|}{ Observações Limite } \\
\hline \multicolumn{2}{|c|}{ Baixa } & \multicolumn{2}{c|}{ Alta } \\
\hline Valor & Obs & Valor & Obs \\
\hline 0 & 1461 & 0 & 1457 \\
\hline 0 & 1460 & 0 & 1458 \\
\hline 0 & 1459 & 0 & 1459 \\
\hline 0 & 1458 & 0 & 1460 \\
\hline 0 & 1457 & 0 & 1461 \\
\hline
\end{tabular}


Variável

dependente:

ACI

ID $=103$

\begin{tabular}{|l|r|l|r|}
\hline \multicolumn{3}{|c|}{ Momento } \\
\hline N & 18 & Soma dos pesos & 18 \\
\hline Média & $\begin{array}{r}0 \\
\text { Soma das } \\
\text { observações }\end{array}$ & 0 \\
\hline Desvio-padrão & 0 & Variância & 0 \\
\hline Assimetria &, Curtose &, \\
\hline $\begin{array}{l}\text { Soma dos } \\
\text { quadrados não } \\
\text { corrigida }\end{array}$ & 0 & $\begin{array}{l}\text { Soma dos } \\
\text { quadrados corrigida }\end{array}$ & 0 \\
\hline CV Pearson &, & Erro-padrão médio & 0 \\
\hline
\end{tabular}

\begin{tabular}{|l|r|l|r|}
\hline \multicolumn{3}{|c|}{ Estatística Descritiva Básica } \\
\hline \multicolumn{2}{|c|}{ Posição } & \multicolumn{2}{c|}{ Variabilidade } \\
\hline Média & 0 & Desvio-padrão & 0 \\
\hline Mediana & 0 & Variância & 0 \\
\hline Moda & 0 & Amplitude & 0 \\
\hline & & Amplitude interquartil & 0 \\
\hline
\end{tabular}

\begin{tabular}{|l|l|l|l|l|}
\hline \multicolumn{5}{|c|}{ Testes de Posição: $\mathrm{Mu0}=0$} \\
\hline Teste & \multicolumn{2}{|c|}{ Estatística } & \multicolumn{2}{c|}{ Valor $\mathbf{p}$} \\
\hline Student t & t &, & $\operatorname{Pr}>|t|$ & \\
\hline Sign & M &, & $\operatorname{Pr}>=|\mathrm{M}|$ & \\
\hline Signed Rank & S &, & $\operatorname{Pr}>=|\mathrm{S}|$ & \\
\hline
\end{tabular}

\begin{tabular}{|l|r|}
\hline \multicolumn{2}{|c|}{ Quantis } \\
\hline Level & 0 \\
\hline $100 \%$ Max & 0 \\
\hline $99 \%$ & 0 \\
\hline $95 \%$ & 0 \\
\hline $90 \%$ & 0 \\
\hline $75 \%$ Q3 & 0 \\
\hline $50 \%$ Mediana & 0 \\
\hline $25 \%$ Q1 & 0 \\
\hline $10 \%$ & 0 \\
\hline $5 \%$ & 0 \\
\hline $1 \%$ & 0 \\
\hline $0 \%$ Min & 0 \\
\hline
\end{tabular}


Variável

dependente:

ACI

ID $=103$

\begin{tabular}{|r|c|r|r|}
\hline \multicolumn{3}{|c|}{ Observações Limite } \\
\hline \multicolumn{2}{|c|}{ Baixa } & \multicolumn{2}{c|}{ Alta } \\
\hline Valor & Obs & Valor & Obs \\
\hline 0 & 1461 & 0 & 1457 \\
\hline 0 & 1460 & 0 & 1458 \\
\hline 0 & 1459 & 0 & 1459 \\
\hline 0 & 1458 & 0 & 1460 \\
\hline 0 & 1457 & 0 & 1461 \\
\hline
\end{tabular}


Variável

dependente:

REC

ID $=104$

\begin{tabular}{|l|r|l|r|}
\hline \multicolumn{4}{|c|}{ Momento } \\
\hline Média & 6 & Soma dos pesos & 6 \\
\hline Desvio-padrão & 0,51639778 & Variância \\
observações & 0,26666667 \\
\hline Assimetria & 0,96824584 & Curtose & $-1,875$ \\
\hline $\begin{array}{l}\text { Soma dos } \\
\text { quadrados não } \\
\text { corrigida }\end{array}$ & 2 & $\begin{array}{l}\text { Soma dos } \\
\text { quadrados corrigida }\end{array}$ & 1,33333333 \\
\hline CV Pearson & 154,919334 & Erro-padrão médio & 0,21081851 \\
\hline
\end{tabular}

\begin{tabular}{|l|l|l|c|}
\hline \multicolumn{4}{|c|}{ Estatística Descritiva Básica } \\
\hline \multicolumn{2}{|c|}{ Posição } & \multicolumn{2}{c|}{ Variabilidade } \\
\hline Média & 0,333333 & Desvio-padrão & 0,51640 \\
\hline Mediana & 0,000000 & Variância & 0,26667 \\
\hline Moda & 0,000000 & Amplitude & 1,00000 \\
\hline & & Amplitude interquartil & 1,00000 \\
\hline
\end{tabular}

\begin{tabular}{|l|l|r|l|l|}
\hline \multicolumn{5}{|c|}{ Testes de Posição: Mu0=0 } \\
\hline Teste & \multicolumn{2}{|c|}{ Estatística } & \multicolumn{2}{c|}{ Valor $\mathbf{~}$} \\
\hline Student t & t & 1,581139 & $\mathrm{Pr}>|\mathbf{t}|$ & 0,1747 \\
\hline Sign & M & 1 & $\mathrm{Pr}>=|\mathrm{M}|$ & 0,5000 \\
\hline Signed Rank & S & 1,5 & $\mathrm{Pr}>=|\mathrm{S}|$ & 0,5000 \\
\hline
\end{tabular}

\begin{tabular}{|l|r|}
\hline \multicolumn{2}{|c|}{ Quantis } \\
\hline Level & 1 \\
\hline $100 \%$ Max & 1 \\
\hline $99 \%$ & 1 \\
\hline $95 \%$ & 1 \\
\hline $90 \%$ & 1 \\
\hline $75 \%$ Q3 & 0 \\
\hline $50 \%$ Mediana & 0 \\
\hline $25 \%$ Q1 & 0 \\
\hline $10 \%$ & 0 \\
\hline $5 \%$ & 0 \\
\hline $1 \%$ & 0 \\
\hline $0 \%$ Min & \\
\hline
\end{tabular}


Variável

dependente:

REC

ID $=104$

\begin{tabular}{|r|c|r|r|}
\hline \multicolumn{3}{|c|}{ Observações Limite } \\
\hline \multicolumn{2}{|c|}{ Baixa } & \multicolumn{2}{c|}{ Alta } \\
\hline Valor & Obs & Valor & Obs \\
\hline 0 & 1466 & 0 & 1463 \\
\hline 0 & 1464 & 0 & 1464 \\
\hline 0 & 1463 & 0 & 1466 \\
\hline 0 & 1462 & 1 & 1465 \\
\hline 1 & 1467 & 1 & 1467 \\
\hline
\end{tabular}


Variável

dependente:

ACI

ID $=104$

\begin{tabular}{|l|r|l|r|}
\hline \multicolumn{3}{|c|}{ Momento } \\
\hline N & 6 & Soma dos pesos & 6 \\
\hline Média & 0 & $\begin{array}{l}\text { Soma das } \\
\text { observações }\end{array}$ & 0 \\
\hline Desvio-padrão & 0 & Variância & 0 \\
\hline Assimetria &, & Curtose &, \\
\hline $\begin{array}{l}\text { Soma dos } \\
\text { quadrados não } \\
\text { corrigida }\end{array}$ & 0 & $\begin{array}{l}\text { Soma dos } \\
\text { quadrados corrigida }\end{array}$ & 0 \\
\hline CV Pearson &, & Erro-padrão médio & 0 \\
\hline
\end{tabular}

\begin{tabular}{|l|r|l|r|}
\hline \multicolumn{3}{|c|}{ Estatística Descritiva Básica } \\
\hline \multicolumn{2}{|c|}{ Posição } & \multicolumn{2}{c|}{ Variabilidade } \\
\hline Média & 0 & Desvio-padrão & 0 \\
\hline Mediana & 0 & Variância & 0 \\
\hline Moda & 0 & Amplitude & 0 \\
\hline & & Amplitude interquartil & 0 \\
\hline
\end{tabular}

\begin{tabular}{|l|l|l|l|l|}
\hline \multicolumn{4}{|c|}{ Testes de Posição: Mu0=0 } \\
\hline Teste & \multicolumn{2}{|c|}{ Estatística } & \multicolumn{2}{c|}{ Valor $\mathbf{p}$} \\
\hline Student t & $\mathbf{t}$ &, & $\mathrm{Pr}>|\mathrm{t}|$ & \\
\hline Sign & $\mathrm{M}$ &, & $\mathrm{Pr}>=|\mathrm{M}|$ & \\
\hline Signed Rank & $\mathrm{S}$ & & $\mathrm{Pr}>=|\mathrm{S}|$ & \\
\hline
\end{tabular}

\begin{tabular}{|l|r|}
\hline \multicolumn{2}{|c|}{ Quantis } \\
\hline Level & Quantil \\
\hline $100 \%$ Max & 0 \\
\hline $99 \%$ & 0 \\
\hline $95 \%$ & 0 \\
\hline $90 \%$ & 0 \\
\hline $75 \%$ Q3 & 0 \\
\hline $50 \%$ Mediana & 0 \\
\hline $25 \%$ Q1 & 0 \\
\hline $10 \%$ & 0 \\
\hline $5 \%$ & 0 \\
\hline $1 \%$ & 0 \\
\hline $0 \%$ Min & 0 \\
\hline
\end{tabular}


Variável

dependente:

ACI

\section{ID $=104$}

\begin{tabular}{|r|r|r|r|}
\hline \multicolumn{3}{|c|}{ Observações Limite } \\
\hline \multicolumn{2}{|c|}{ Baixa } & \multicolumn{2}{c|}{ Alta } \\
\hline Valor & Obs & Valor & Obs \\
\hline 0 & 1467 & 0 & 1463 \\
\hline 0 & 1466 & 0 & 1464 \\
\hline 0 & 1465 & 0 & 1465 \\
\hline 0 & 1464 & 0 & 1466 \\
\hline 0 & 1463 & 0 & 1467 \\
\hline
\end{tabular}


Variável

dependente:

REC

ID $=105$

\begin{tabular}{|l|r|l|r|}
\hline \multicolumn{3}{|c|}{ Momento } \\
\hline N & 18 & Soma dos pesos & 18 \\
\hline Média & $\begin{array}{r}0 \\
\text { Soma das } \\
\text { observações }\end{array}$ & 0 \\
\hline Desvio-padrão & 0 & Variância & 0 \\
\hline Assimetria &, Curtose &, \\
\hline $\begin{array}{l}\text { Soma dos } \\
\text { quadrados não } \\
\text { corrigida }\end{array}$ & 0 & $\begin{array}{l}\text { Soma dos } \\
\text { quadrados corrigida }\end{array}$ & 0 \\
\hline CV Pearson &, & Erro-padrão médio & 0 \\
\hline
\end{tabular}

\begin{tabular}{|l|r|l|r|}
\hline \multicolumn{3}{|c|}{ Estatística Descritiva Básica } \\
\hline \multicolumn{2}{|c|}{ Posição } & \multicolumn{2}{c|}{ Variabilidade } \\
\hline Média & 0 & Desvio-padrão & 0 \\
\hline Mediana & 0 & Variância & 0 \\
\hline Moda & 0 & Amplitude & 0 \\
\hline & & Amplitude interquartil & 0 \\
\hline
\end{tabular}

\begin{tabular}{|l|l|l|l|l|}
\hline \multicolumn{4}{|c|}{ Testes de Posição: Mu0=0 } \\
\hline Teste & \multicolumn{2}{|c|}{ Estatística } & \multicolumn{2}{c|}{ Valor $\mathbf{p}$} \\
\hline Student $\mathbf{t}$ & $\mathbf{t}$ & \multicolumn{1}{|c|}{, $\operatorname{Pr}>|\mathbf{t}|$} & \\
\hline Sign & $\mathrm{M}$ &, & $\operatorname{Pr}>=|\mathrm{M}|$ & \\
\hline Signed Rank & S &, & $\operatorname{Pr}>=|\mathrm{S}|$ & \\
\hline
\end{tabular}

\begin{tabular}{|l|r|}
\hline \multicolumn{2}{|c|}{ Quantis } \\
\hline Level & 0 \\
\hline $100 \%$ Max & 0 \\
\hline $99 \%$ & 0 \\
\hline $95 \%$ & 0 \\
\hline $90 \%$ & 0 \\
\hline $75 \%$ Q3 & 0 \\
\hline $50 \%$ Mediana & 0 \\
\hline $25 \%$ Q1 & 0 \\
\hline $10 \%$ & 0 \\
\hline $5 \%$ & 0 \\
\hline $1 \%$ & 0 \\
\hline $0 \%$ Min & 0 \\
\hline
\end{tabular}


Variável

dependente:

REC

ID $=105$

\begin{tabular}{|r|c|r|r|}
\hline \multicolumn{3}{|c|}{ Observações Limite } \\
\hline \multicolumn{2}{|c|}{ Baixa } & \multicolumn{2}{c|}{ Alta } \\
\hline Valor & Obs & Valor & Obs \\
\hline 0 & 1485 & 0 & 1481 \\
\hline 0 & 1484 & 0 & 1482 \\
\hline 0 & 1483 & 0 & 1483 \\
\hline 0 & 1482 & 0 & 1484 \\
\hline 0 & 1481 & 0 & 1485 \\
\hline
\end{tabular}


Variável

dependente:

ACI

ID $=105$

\begin{tabular}{|l|r|r|r|}
\hline \multicolumn{3}{|l|}{ Momento } \\
\hline N & 18 Soma dos pesos & 18 \\
\hline Média & $\begin{array}{r}0 \\
\text { Soma das } \\
\text { observações }\end{array}$ & 0 \\
\hline Desvio-padrão & 0 & Variância & 0 \\
\hline Assimetria &, Curtose &, \\
\hline $\begin{array}{l}\text { Soma dos } \\
\text { quadrados não } \\
\text { corrigida }\end{array}$ & 0 & $\begin{array}{l}\text { Soma dos } \\
\text { quadrados corrigida }\end{array}$ & 0 \\
\hline CV Pearson &, & Erro-padrão médio & 0 \\
\hline
\end{tabular}

\begin{tabular}{|l|r|l|r|}
\hline \multicolumn{3}{|c|}{ Estatística Descritiva Básica } \\
\hline \multicolumn{2}{|c|}{ Posição } & \multicolumn{2}{c|}{ Variabilidade } \\
\hline Média & 0 & Desvio-padrão & 0 \\
\hline Mediana & 0 & Variância & 0 \\
\hline Moda & 0 & Amplitude & 0 \\
\hline & & Amplitude interquartil & 0 \\
\hline
\end{tabular}

\begin{tabular}{|l|l|l|l|l|}
\hline \multicolumn{4}{|c|}{ Testes de Posição: Mu0=0 } \\
\hline Teste & \multicolumn{2}{|c|}{ Estatística } & \multicolumn{2}{c|}{ Valor $\mathbf{p}$} \\
\hline Student t & $\mathbf{t}$ &, & $\mathrm{Pr}>|\mathrm{t}|$ & \\
\hline Sign & $\mathrm{M}$ &, & $\mathrm{Pr}>=|\mathrm{M}|$ & \\
\hline Signed Rank & $\mathrm{S}$ & & $\mathrm{Pr}>=|\mathrm{S}|$ & \\
\hline
\end{tabular}

\begin{tabular}{|l|r|}
\hline \multicolumn{2}{|c|}{ Quantis } \\
\hline Level & 0 \\
\hline $100 \%$ Max & 0 \\
\hline $99 \%$ & 0 \\
\hline $95 \%$ & 0 \\
\hline $90 \%$ & 0 \\
\hline $75 \%$ Q3 & 0 \\
\hline $50 \%$ Mediana & 0 \\
\hline $25 \%$ Q1 & 0 \\
\hline $10 \%$ & 0 \\
\hline $5 \%$ & 0 \\
\hline $1 \%$ & 0 \\
\hline $0 \%$ Min & 0 \\
\hline
\end{tabular}


Variável

dependente:

ACI

ID $=105$

\begin{tabular}{|r|c|r|r|}
\hline \multicolumn{3}{|c|}{ Observações Limite } \\
\hline \multicolumn{2}{|c|}{ Baixa } & \multicolumn{2}{c|}{ Alta } \\
\hline Valor & Obs & Valor & Obs \\
\hline 0 & 1485 & 0 & 1481 \\
\hline 0 & 1484 & 0 & 1482 \\
\hline 0 & 1483 & 0 & 1483 \\
\hline 0 & 1482 & 0 & 1484 \\
\hline 0 & 1481 & 0 & 1485 \\
\hline
\end{tabular}


Variável

dependente:

REC

ID $=106$

\begin{tabular}{|l|r|l|r|}
\hline \multicolumn{3}{|c|}{ Momento } \\
\hline N & 16 & Soma dos pesos & 16 \\
\hline Média & $\begin{array}{r}0 \\
\text { Soma das } \\
\text { observações }\end{array}$ & 0 \\
\hline Desvio-padrão & 0 & Variância & 0 \\
\hline Assimetria &, Curtose &, \\
\hline $\begin{array}{l}\text { Soma dos } \\
\text { quadrados não } \\
\text { corrigida }\end{array}$ & 0 & $\begin{array}{l}\text { Soma dos } \\
\text { quadrados corrigida }\end{array}$ & 0 \\
\hline CV Pearson &, & Erro-padrão médio & 0 \\
\hline
\end{tabular}

\begin{tabular}{|l|r|l|r|}
\hline \multicolumn{3}{|c|}{ Estatística Descritiva Básica } \\
\hline \multicolumn{2}{|c|}{ Posição } & \multicolumn{2}{c|}{ Variabilidade } \\
\hline Média & 0 & Desvio-padrão & 0 \\
\hline Mediana & 0 & Variância & 0 \\
\hline Moda & 0 & Amplitude & 0 \\
\hline & & Amplitude interquartil & 0 \\
\hline
\end{tabular}

\begin{tabular}{|l|l|l|l|l|}
\hline \multicolumn{4}{|c|}{ Testes de Posição: Mu0=0 } \\
\hline Teste & \multicolumn{2}{|c|}{ Estatística } & \multicolumn{2}{c|}{ Valor $\mathbf{p}$} \\
\hline Student $\mathbf{t}$ & $\mathbf{t}$ & \multicolumn{1}{|c|}{, $\operatorname{Pr}>|\mathbf{t}|$} & \\
\hline Sign & $\mathrm{M}$ &, & $\operatorname{Pr}>=|\mathrm{M}|$ & \\
\hline Signed Rank & S &, & $\operatorname{Pr}>=|\mathrm{S}|$ & \\
\hline
\end{tabular}

\begin{tabular}{|l|r|}
\hline \multicolumn{2}{|c|}{ Quantis } \\
\hline Level & 0 \\
\hline $100 \%$ Max & 0 \\
\hline $99 \%$ & 0 \\
\hline $95 \%$ & 0 \\
\hline $90 \%$ & 0 \\
\hline $75 \%$ Q3 & 0 \\
\hline $50 \%$ Mediana & 0 \\
\hline $25 \%$ Q1 & 0 \\
\hline $10 \%$ & 0 \\
\hline $5 \%$ & 0 \\
\hline $1 \%$ & 0 \\
\hline $0 \%$ Min & 0 \\
\hline
\end{tabular}


Variável

dependente:

REC

ID $=106$

\begin{tabular}{|r|c|r|r|}
\hline \multicolumn{3}{|c|}{ Observações Limite } \\
\hline \multicolumn{2}{|c|}{ Baixa } & \multicolumn{2}{c|}{ Alta } \\
\hline Valor & Obs & Valor & Obs \\
\hline 0 & 1501 & 0 & 1497 \\
\hline 0 & 1500 & 0 & 1498 \\
\hline 0 & 1499 & 0 & 1499 \\
\hline 0 & 1498 & 0 & 1500 \\
\hline 0 & 1497 & 0 & 1501 \\
\hline
\end{tabular}


Variável

dependente:

ACI

ID $=106$

\begin{tabular}{|l|r|l|r|}
\hline \multicolumn{3}{|c|}{ Momento } \\
\hline N & 16 & Soma dos pesos & 16 \\
\hline Média & $\begin{array}{r}0 \\
\text { Soma das } \\
\text { observações }\end{array}$ & 0 \\
\hline Desvio-padrão & 0 & Variância & 0 \\
\hline Assimetria &, Curtose &, \\
\hline $\begin{array}{l}\text { Soma dos } \\
\text { quadrados não } \\
\text { corrigida }\end{array}$ & 0 & $\begin{array}{l}\text { Soma dos } \\
\text { quadrados corrigida }\end{array}$ & 0 \\
\hline CV Pearson &, & Erro-padrão médio & 0 \\
\hline
\end{tabular}

\begin{tabular}{|l|r|l|r|}
\hline \multicolumn{3}{|c|}{ Estatística Descritiva Básica } \\
\hline \multicolumn{2}{|c|}{ Posição } & \multicolumn{2}{c|}{ Variabilidade } \\
\hline Média & 0 & Desvio-padrão & 0 \\
\hline Mediana & 0 & Variância & 0 \\
\hline Moda & 0 & Amplitude & 0 \\
\hline & & Amplitude interquartil & 0 \\
\hline
\end{tabular}

\begin{tabular}{|l|l|l|l|l|}
\hline \multicolumn{4}{|c|}{ Testes de Posição: Mu0=0 } \\
\hline Teste & \multicolumn{2}{|c|}{ Estatística } & \multicolumn{2}{c|}{ Valor $\mathbf{p}$} \\
\hline Student t & $\mathbf{t}$ &, & $\mathrm{Pr}>|\mathrm{t}|$ & \\
\hline Sign & $\mathrm{M}$ &, & $\mathrm{Pr}>=|\mathrm{M}|$ & \\
\hline Signed Rank & $\mathrm{S}$ &, & $\mathrm{Pr}>=|\mathrm{S}|$ & \\
\hline
\end{tabular}

\begin{tabular}{|l|r|}
\hline \multicolumn{2}{|c|}{ Quantis } \\
\hline Level & 0 \\
\hline $100 \%$ Max & 0 \\
\hline $99 \%$ & 0 \\
\hline $95 \%$ & 0 \\
\hline $90 \%$ & 0 \\
\hline $75 \%$ Q3 & 0 \\
\hline $50 \%$ Mediana & 0 \\
\hline $25 \%$ Q1 & 0 \\
\hline $10 \%$ & 0 \\
\hline $5 \%$ & 0 \\
\hline $1 \%$ & 0 \\
\hline $0 \%$ Min & \\
\hline
\end{tabular}


Variável

dependente:

ACI

ID $=106$

\begin{tabular}{|r|c|r|r|}
\hline \multicolumn{3}{|c|}{ Observações Limite } \\
\hline \multicolumn{2}{|c|}{ Baixa } & \multicolumn{2}{c|}{ Alta } \\
\hline Valor & Obs & Valor & Obs \\
\hline 0 & 1501 & 0 & 1497 \\
\hline 0 & 1500 & 0 & 1498 \\
\hline 0 & 1499 & 0 & 1499 \\
\hline 0 & 1498 & 0 & 1500 \\
\hline 0 & 1497 & 0 & 1501 \\
\hline
\end{tabular}


Variável

dependente:

REC

ID $=\mathbf{1 0 7}$

\begin{tabular}{|l|r|l|r|}
\hline \multicolumn{3}{|c|}{ Momento } \\
\hline N & 16 & Soma dos pesos & 16 \\
\hline Média & $\begin{array}{r}0 \\
\text { Soma das } \\
\text { observações }\end{array}$ & 0 \\
\hline Desvio-padrão & 0 & Variância & 0 \\
\hline Assimetria &, Curtose &, \\
\hline $\begin{array}{l}\text { Soma dos } \\
\text { quadrados não } \\
\text { corrigida }\end{array}$ & 0 & $\begin{array}{l}\text { Soma dos } \\
\text { quadrados corrigida }\end{array}$ & 0 \\
\hline CV Pearson &, & Erro-padrão médio & 0 \\
\hline
\end{tabular}

\begin{tabular}{|l|r|l|r|}
\hline \multicolumn{3}{|c|}{ Estatística Descritiva Básica } \\
\hline \multicolumn{2}{|c|}{ Posição } & \multicolumn{2}{c|}{ Variabilidade } \\
\hline Média & 0 & Desvio-padrão & 0 \\
\hline Mediana & 0 & Variância & 0 \\
\hline Moda & 0 & Amplitude & 0 \\
\hline & & Amplitude interquartil & 0 \\
\hline
\end{tabular}

\begin{tabular}{|l|l|l|l|l|}
\hline \multicolumn{4}{|c|}{ Testes de Posição: Mu0=0 } \\
\hline Teste & \multicolumn{2}{|c|}{ Estatística } & \multicolumn{2}{c|}{ Valor $\mathbf{p}$} \\
\hline Student $\mathbf{t}$ & $\mathbf{t}$ & \multicolumn{1}{|c|}{, $\operatorname{Pr}>|\mathbf{t}|$} & \\
\hline Sign & $\mathrm{M}$ &, & $\operatorname{Pr}>=|\mathrm{M}|$ & \\
\hline Signed Rank & S &, & $\operatorname{Pr}>=|\mathrm{S}|$ & \\
\hline
\end{tabular}

\begin{tabular}{|l|r|}
\hline \multicolumn{2}{|c|}{ Quantis } \\
\hline Level & 0 \\
\hline $100 \%$ Max & 0 \\
\hline $99 \%$ & 0 \\
\hline $95 \%$ & 0 \\
\hline $90 \%$ & 0 \\
\hline $75 \%$ Q3 & 0 \\
\hline $50 \%$ Mediana & 0 \\
\hline $25 \%$ Q1 & 0 \\
\hline $10 \%$ & 0 \\
\hline $5 \%$ & 0 \\
\hline $1 \%$ & 0 \\
\hline $0 \%$ Min & 0 \\
\hline
\end{tabular}


Variável

dependente:

REC

ID $=107$

\begin{tabular}{|r|c|r|r|}
\hline \multicolumn{3}{|c|}{ Observações Limite } \\
\hline \multicolumn{2}{|c|}{ Baixa } & \multicolumn{2}{c|}{ Alta } \\
\hline Valor & Obs & Valor & Obs \\
\hline 0 & 1517 & 0 & 1513 \\
\hline 0 & 1516 & 0 & 1514 \\
\hline 0 & 1515 & 0 & 1515 \\
\hline 0 & 1514 & 0 & 1516 \\
\hline 0 & 1513 & 0 & 1517 \\
\hline
\end{tabular}


Variável

dependente:

ACI

ID $=\mathbf{1 0 7}$

\begin{tabular}{|l|r|l|r|}
\hline \multicolumn{3}{|c|}{ Momento } \\
\hline N & 16 & Soma dos pesos & 16 \\
\hline Média & $\begin{array}{r}0 \\
\text { Soma das } \\
\text { observações }\end{array}$ & 0 \\
\hline Desvio-padrão & 0 & Variância & 0 \\
\hline Assimetria &, Curtose &, \\
\hline $\begin{array}{l}\text { Soma dos } \\
\text { quadrados não } \\
\text { corrigida }\end{array}$ & 0 & $\begin{array}{l}\text { Soma dos } \\
\text { quadrados corrigida }\end{array}$ & 0 \\
\hline CV Pearson &, & Erro-padrão médio & 0 \\
\hline
\end{tabular}

\begin{tabular}{|l|r|l|r|}
\hline \multicolumn{3}{|c|}{ Estatística Descritiva Básica } \\
\hline \multicolumn{2}{|c|}{ Posição } & \multicolumn{2}{c|}{ Variabilidade } \\
\hline Média & 0 & Desvio-padrão & 0 \\
\hline Mediana & 0 & Variância & 0 \\
\hline Moda & 0 & Amplitude & 0 \\
\hline & & Amplitude interquartil & 0 \\
\hline
\end{tabular}

\begin{tabular}{|l|l|l|l|l|}
\hline \multicolumn{4}{|c|}{ Testes de Posição: Mu0=0 } \\
\hline Teste & \multicolumn{2}{|c|}{ Estatística } & \multicolumn{2}{c|}{ Valor $\mathbf{p}$} \\
\hline Student t & t & \multicolumn{1}{|c|}{, $\operatorname{Pr}>|\mathbf{t}|$} & \\
\hline Sign & M &, & $\operatorname{Pr}>=|\mathrm{M}|$ & \\
\hline Signed Rank & S &, & $\operatorname{Pr}>=|\mathrm{S}|$ & \\
\hline
\end{tabular}

\begin{tabular}{|l|r|}
\hline \multicolumn{2}{|c|}{ Quantis } \\
\hline Level & 0 \\
\hline $100 \%$ Max & 0 \\
\hline $99 \%$ & 0 \\
\hline $95 \%$ & 0 \\
\hline $90 \%$ & 0 \\
\hline $75 \%$ Q3 & 0 \\
\hline $50 \%$ Mediana & 0 \\
\hline $25 \%$ Q1 & 0 \\
\hline $10 \%$ & 0 \\
\hline $5 \%$ & 0 \\
\hline $1 \%$ & 0 \\
\hline $0 \%$ Min & 0 \\
\hline
\end{tabular}


Variável

dependente:

ACI

ID $=107$

\begin{tabular}{|r|c|r|r|}
\hline \multicolumn{3}{|c|}{ Observações Limite } \\
\hline \multicolumn{2}{|c|}{ Baixa } & \multicolumn{2}{c|}{ Alta } \\
\hline Valor & Obs & Valor & Obs \\
\hline 0 & 1517 & 0 & 1513 \\
\hline 0 & 1516 & 0 & 1514 \\
\hline 0 & 1515 & 0 & 1515 \\
\hline 0 & 1514 & 0 & 1516 \\
\hline 0 & 1513 & 0 & 1517 \\
\hline
\end{tabular}


Variável

dependente:

REC

ID $=108$

\begin{tabular}{|l|r|l|r|}
\hline \multicolumn{3}{|c|}{ Momento } \\
\hline N & 18 & Soma dos pesos & 18 \\
\hline Média & $\begin{array}{r}0 \\
\text { Soma das } \\
\text { observações }\end{array}$ & 0 \\
\hline Desvio-padrão & 0 & Variância & 0 \\
\hline Assimetria &, Curtose &, \\
\hline $\begin{array}{l}\text { Soma dos } \\
\text { quadrados não } \\
\text { corrigida }\end{array}$ & 0 & $\begin{array}{l}\text { Soma dos } \\
\text { quadrados corrigida }\end{array}$ & 0 \\
\hline CV Pearson &, & Erro-padrão médio & 0 \\
\hline
\end{tabular}

\begin{tabular}{|l|r|l|r|}
\hline \multicolumn{3}{|c|}{ Estatística Descritiva Básica } \\
\hline \multicolumn{2}{|c|}{ Posição } & \multicolumn{2}{c|}{ Variabilidade } \\
\hline Média & 0 & Desvio-padrão & 0 \\
\hline Mediana & 0 & Variância & 0 \\
\hline Moda & 0 & Amplitude & 0 \\
\hline & & Amplitude interquartil & 0 \\
\hline
\end{tabular}

\begin{tabular}{|l|l|l|l|l|}
\hline \multicolumn{4}{|c|}{ Testes de Posição: Mu0=0 } \\
\hline Teste & \multicolumn{2}{|c|}{ Estatística } & \multicolumn{2}{c|}{ Valor $\mathbf{p}$} \\
\hline Student $\mathbf{t}$ & $\mathbf{t}$ & \multicolumn{1}{|c|}{, $\operatorname{Pr}>|\mathbf{t}|$} & \\
\hline Sign & $\mathrm{M}$ &, & $\operatorname{Pr}>=|\mathrm{M}|$ & \\
\hline Signed Rank & S &, & $\operatorname{Pr}>=|\mathrm{S}|$ & \\
\hline
\end{tabular}

\begin{tabular}{|l|r|}
\hline \multicolumn{2}{|c|}{ Quantis } \\
\hline Level & 0 \\
\hline $100 \%$ Max & 0 \\
\hline $99 \%$ & 0 \\
\hline $95 \%$ & 0 \\
\hline $90 \%$ & 0 \\
\hline $75 \%$ Q3 & 0 \\
\hline $50 \%$ Mediana & 0 \\
\hline $25 \%$ Q1 & 0 \\
\hline $10 \%$ & 0 \\
\hline $5 \%$ & 0 \\
\hline $1 \%$ & 0 \\
\hline $0 \%$ Min & 0 \\
\hline
\end{tabular}


Variável

dependente:

REC

ID $=108$

\begin{tabular}{|r|c|r|r|}
\hline \multicolumn{3}{|c|}{ Observações Limite } \\
\hline \multicolumn{2}{|c|}{ Baixa } & \multicolumn{2}{c|}{ Alta } \\
\hline Valor & Obs & Valor & Obs \\
\hline 0 & 1535 & 0 & 1531 \\
\hline 0 & 1534 & 0 & 1532 \\
\hline 0 & 1533 & 0 & 1533 \\
\hline 0 & 1532 & 0 & 1534 \\
\hline 0 & 1531 & 0 & 1535 \\
\hline
\end{tabular}


Variável

dependente:

ACI

ID $=108$

\begin{tabular}{|l|r|l|r|}
\hline \multicolumn{3}{|c|}{ Momento } \\
\hline N & 18 & Soma dos pesos & 18 \\
\hline Média & $\begin{array}{r}0 \\
\text { Soma das } \\
\text { observações }\end{array}$ & 0 \\
\hline Desvio-padrão & 0 & Variância & 0 \\
\hline Assimetria &, Curtose &, \\
\hline $\begin{array}{l}\text { Soma dos } \\
\text { quadrados não } \\
\text { corrigida }\end{array}$ & 0 & $\begin{array}{l}\text { Soma dos } \\
\text { quadrados corrigida }\end{array}$ & 0 \\
\hline CV Pearson &, & Erro-padrão médio & 0 \\
\hline
\end{tabular}

\begin{tabular}{|l|r|l|r|}
\hline \multicolumn{3}{|c|}{ Estatística Descritiva Básica } \\
\hline \multicolumn{2}{|c|}{ Posição } & \multicolumn{2}{c|}{ Variabilidade } \\
\hline Média & 0 & Desvio-padrão & 0 \\
\hline Mediana & 0 & Variância & 0 \\
\hline Moda & 0 & Amplitude & 0 \\
\hline & & Amplitude interquartil & 0 \\
\hline
\end{tabular}

\begin{tabular}{|l|l|l|l|l|}
\hline \multicolumn{4}{|c|}{ Testes de Posição: $\mathrm{Mu0}=0$} \\
\hline Teste & \multicolumn{2}{|c|}{ Estatística } & \multicolumn{2}{c|}{ Valor $\mathbf{p}$} \\
\hline Student t & t &, & $\operatorname{Pr}>|t|$ & \\
\hline Sign & M &, & $\operatorname{Pr}>=|\mathrm{M}|$ & \\
\hline Signed Rank & S &, & $\operatorname{Pr}>=|\mathrm{S}|$ & \\
\hline
\end{tabular}

\begin{tabular}{|l|r|}
\hline \multicolumn{2}{|c|}{ Quantis } \\
\hline Level & 0 \\
\hline $100 \%$ Max & 0 \\
\hline $99 \%$ & 0 \\
\hline $95 \%$ & 0 \\
\hline $90 \%$ & 0 \\
\hline $75 \%$ Q3 & 0 \\
\hline $50 \%$ Mediana & 0 \\
\hline $25 \%$ Q1 & 0 \\
\hline $10 \%$ & 0 \\
\hline $5 \%$ & 0 \\
\hline $1 \%$ & 0 \\
\hline $0 \%$ Min & 0 \\
\hline
\end{tabular}


Variável

dependente:

ACI

ID $=108$

\begin{tabular}{|r|c|r|r|}
\hline \multicolumn{3}{|c|}{ Observações Limite } \\
\hline \multicolumn{2}{|c|}{ Baixa } & \multicolumn{2}{c|}{ Alta } \\
\hline Valor & Obs & Valor & Obs \\
\hline 0 & 1535 & 0 & 1531 \\
\hline 0 & 1534 & 0 & 1532 \\
\hline 0 & 1533 & 0 & 1533 \\
\hline 0 & 1532 & 0 & 1534 \\
\hline 0 & 1531 & 0 & 1535 \\
\hline
\end{tabular}


Variável

dependente:

REC

ID $=109$

\begin{tabular}{|l|r|l|r|}
\hline \multicolumn{3}{|c|}{ Momento } \\
\hline N & 9 & Soma dos pesos & 9 \\
\hline Média & $\begin{array}{r}0 \\
\text { Soma das } \\
\text { observações }\end{array}$ & 0 \\
\hline Desvio-padrão & 0 & Variância & 0 \\
\hline Assimetria &, Curtose &, \\
\hline $\begin{array}{l}\text { Soma dos } \\
\text { quadrados não } \\
\text { corrigida }\end{array}$ & 0 & $\begin{array}{l}\text { Soma dos } \\
\text { quadrados corrigida }\end{array}$ & 0 \\
\hline CV Pearson &, & Erro-padrão médio & 0 \\
\hline
\end{tabular}

\begin{tabular}{|l|r|l|r|}
\hline \multicolumn{3}{|c|}{ Estatística Descritiva Básica } \\
\hline \multicolumn{2}{|c|}{ Posição } & \multicolumn{2}{c|}{ Variabilidade } \\
\hline Média & 0 & Desvio-padrão & 0 \\
\hline Mediana & 0 & Variância & 0 \\
\hline Moda & 0 & Amplitude & 0 \\
\hline & & Amplitude interquartil & 0 \\
\hline
\end{tabular}

\begin{tabular}{|l|l|l|l|l|}
\hline \multicolumn{4}{|c|}{ Testes de Posição: Mu0=0 } \\
\hline Teste & \multicolumn{2}{|c|}{ Estatística } & \multicolumn{2}{c|}{ Valor $\mathbf{p}$} \\
\hline Student $\mathbf{t}$ & $\mathbf{t}$ & \multicolumn{1}{|c|}{, $\operatorname{Pr}>|\mathbf{t}|$} & \\
\hline Sign & $\mathrm{M}$ &, & $\operatorname{Pr}>=|\mathrm{M}|$ & \\
\hline Signed Rank & S &, & $\operatorname{Pr}>=|\mathrm{S}|$ & \\
\hline
\end{tabular}

\begin{tabular}{|l|r|}
\hline \multicolumn{2}{|c|}{ Quantis } \\
\hline Level & 0 \\
\hline $100 \%$ Max & 0 \\
\hline $99 \%$ & 0 \\
\hline $95 \%$ & 0 \\
\hline $90 \%$ & 0 \\
\hline $75 \%$ Q3 & 0 \\
\hline $50 \%$ Mediana & 0 \\
\hline $25 \%$ Q1 & 0 \\
\hline $10 \%$ & 0 \\
\hline $5 \%$ & 0 \\
\hline $1 \%$ & 0 \\
\hline $0 \%$ Min & 0 \\
\hline
\end{tabular}


Variável

dependente:

REC

ID $=109$

\begin{tabular}{|r|r|r|r|}
\hline \multicolumn{3}{|c|}{ Observações Limite } \\
\hline \multicolumn{2}{|c|}{ Baixa } & \multicolumn{2}{c|}{ Alta } \\
\hline Valor & Obs & Valor & Obs \\
\hline 0 & 1544 & 0 & 1540 \\
\hline 0 & 1543 & 0 & 1541 \\
\hline 0 & 1542 & 0 & 1542 \\
\hline 0 & 1541 & 0 & 1543 \\
\hline 0 & 1540 & 0 & 1544 \\
\hline
\end{tabular}


Variável

dependente:

ACI

ID $=109$

\begin{tabular}{|l|r|l|r|}
\hline \multicolumn{3}{|c|}{ Momento } \\
\hline N & 9 & Soma dos pesos & 9 \\
\hline Média & $\begin{array}{r}0 \\
\text { Soma das } \\
\text { observações }\end{array}$ & 0 \\
\hline Desvio-padrão & 0 & Variância & 0 \\
\hline Assimetria &, Curtose &, \\
\hline $\begin{array}{l}\text { Soma dos } \\
\text { quadrados não } \\
\text { corrigida }\end{array}$ & 0 & $\begin{array}{l}\text { Soma dos } \\
\text { quadrados corrigida }\end{array}$ & 0 \\
\hline CV Pearson &, & Erro-padrão médio & 0 \\
\hline
\end{tabular}

\begin{tabular}{|l|r|l|r|}
\hline \multicolumn{3}{|c|}{ Estatística Descritiva Básica } \\
\hline \multicolumn{2}{|c|}{ Posição } & \multicolumn{2}{c|}{ Variabilidade } \\
\hline Média & 0 & Desvio-padrão & 0 \\
\hline Mediana & 0 & Variância & 0 \\
\hline Moda & 0 & Amplitude & 0 \\
\hline & & Amplitude interquartil & 0 \\
\hline
\end{tabular}

\begin{tabular}{|l|l|l|l|l|}
\hline \multicolumn{4}{|c|}{ Testes de Posição: Mu0=0 } \\
\hline Teste & \multicolumn{2}{|c|}{ Estatística } & \multicolumn{2}{c|}{ Valor $\mathbf{p}$} \\
\hline Student $\mathbf{t}$ & $\mathbf{t}$ & \multicolumn{1}{|c|}{, $\operatorname{Pr}>|\mathbf{t}|$} & \\
\hline Sign & $\mathrm{M}$ &, & $\operatorname{Pr}>=|\mathrm{M}|$ & \\
\hline Signed Rank & S &, & $\operatorname{Pr}>=|\mathrm{S}|$ & \\
\hline
\end{tabular}

\begin{tabular}{|l|r|}
\hline \multicolumn{2}{|c|}{ Quantis } \\
\hline Level & 0 \\
\hline $100 \%$ Max & 0 \\
\hline $99 \%$ & 0 \\
\hline $95 \%$ & 0 \\
\hline $90 \%$ & 0 \\
\hline $75 \%$ Q3 & 0 \\
\hline $50 \%$ Mediana & 0 \\
\hline $25 \%$ Q1 & 0 \\
\hline $10 \%$ & 0 \\
\hline $5 \%$ & 0 \\
\hline $1 \%$ & 0 \\
\hline $0 \%$ Min & 0 \\
\hline
\end{tabular}


Variável

dependente:

ACI

ID $=109$

\begin{tabular}{|r|r|r|r|}
\hline \multicolumn{3}{|c|}{ Observações Limite } \\
\hline \multicolumn{2}{|c|}{ Baixa } & \multicolumn{2}{c|}{ Alta } \\
\hline Valor & Obs & Valor & Obs \\
\hline 0 & 1544 & 0 & 1540 \\
\hline 0 & 1543 & 0 & 1541 \\
\hline 0 & 1542 & 0 & 1542 \\
\hline 0 & 1541 & 0 & 1543 \\
\hline 0 & 1540 & 0 & 1544 \\
\hline
\end{tabular}


Variável

dependente:

REC

ID $=110$

\begin{tabular}{|l|r|l|r|}
\hline \multicolumn{3}{|c|}{ Momento } \\
\hline N & 18 & Soma dos pesos & 18 \\
\hline Média & $\begin{array}{r}0 \\
\text { Soma das } \\
\text { observações }\end{array}$ & 0 \\
\hline Desvio-padrão & 0 & Variância & 0 \\
\hline Assimetria &, Curtose &, \\
\hline $\begin{array}{l}\text { Soma dos } \\
\text { quadrados não } \\
\text { corrigida }\end{array}$ & 0 & $\begin{array}{l}\text { Soma dos } \\
\text { quadrados corrigida }\end{array}$ & 0 \\
\hline CV Pearson &, & Erro-padrão médio & 0 \\
\hline
\end{tabular}

\begin{tabular}{|l|r|l|r|}
\hline \multicolumn{3}{|c|}{ Estatística Descritiva Básica } \\
\hline \multicolumn{2}{|c|}{ Posição } & \multicolumn{2}{c|}{ Variabilidade } \\
\hline Média & 0 & Desvio-padrão & 0 \\
\hline Mediana & 0 & Variância & 0 \\
\hline Moda & 0 & Amplitude & 0 \\
\hline & & Amplitude interquartil & 0 \\
\hline
\end{tabular}

\begin{tabular}{|l|l|l|l|l|}
\hline \multicolumn{4}{|c|}{ Testes de Posição: Mu0=0 } \\
\hline Teste & \multicolumn{2}{|c|}{ Estatística } & \multicolumn{2}{c|}{ Valor $\mathbf{p}$} \\
\hline Student $\mathbf{t}$ & $\mathbf{t}$ & \multicolumn{1}{|c|}{, $\operatorname{Pr}>|\mathbf{t}|$} & \\
\hline Sign & $\mathrm{M}$ &, & $\operatorname{Pr}>=|\mathrm{M}|$ & \\
\hline Signed Rank & S &, & $\operatorname{Pr}>=|\mathrm{S}|$ & \\
\hline
\end{tabular}

\begin{tabular}{|l|r|}
\hline \multicolumn{2}{|c|}{ Quantis } \\
\hline Level & 0 \\
\hline $100 \%$ Max & 0 \\
\hline $99 \%$ & 0 \\
\hline $95 \%$ & 0 \\
\hline $90 \%$ & 0 \\
\hline $75 \%$ Q3 & 0 \\
\hline $50 \%$ Mediana & 0 \\
\hline $25 \%$ Q1 & 0 \\
\hline $10 \%$ & 0 \\
\hline $5 \%$ & 0 \\
\hline $1 \%$ & 0 \\
\hline $0 \%$ Min & 0 \\
\hline
\end{tabular}


Variável

dependente:

REC

ID $=110$

\begin{tabular}{|r|r|r|r|}
\hline \multicolumn{3}{|c|}{ Observações Limite } \\
\hline \multicolumn{2}{|c|}{ Baixa } & \multicolumn{2}{c|}{ Alta } \\
\hline Valor & Obs & Valor & Obs \\
\hline 0 & 1562 & 0 & 1558 \\
\hline 0 & 1561 & 0 & 1559 \\
\hline 0 & 1560 & 0 & 1560 \\
\hline 0 & 1559 & 0 & 1561 \\
\hline 0 & 1558 & 0 & 1562 \\
\hline
\end{tabular}


Variável

dependente:

ACI

ID $=110$

\begin{tabular}{|l|r|l|r|}
\hline \multicolumn{3}{|c|}{ Momento } \\
\hline N & 18 & Soma dos pesos & 18 \\
\hline Média & $\begin{array}{r}0 \\
\text { Soma das } \\
\text { observações }\end{array}$ & 0 \\
\hline Desvio-padrão & 0 & Variância & 0 \\
\hline Assimetria &, Curtose &, \\
\hline $\begin{array}{l}\text { Soma dos } \\
\text { quadrados não } \\
\text { corrigida }\end{array}$ & 0 & $\begin{array}{l}\text { Soma dos } \\
\text { quadrados corrigida }\end{array}$ & 0 \\
\hline CV Pearson &, & Erro-padrão médio & 0 \\
\hline
\end{tabular}

\begin{tabular}{|l|r|l|r|}
\hline \multicolumn{3}{|c|}{ Estatística Descritiva Básica } \\
\hline \multicolumn{2}{|c|}{ Posição } & \multicolumn{2}{c|}{ Variabilidade } \\
\hline Média & 0 & Desvio-padrão & 0 \\
\hline Mediana & 0 & Variância & 0 \\
\hline Moda & 0 & Amplitude & 0 \\
\hline & & Amplitude interquartil & 0 \\
\hline
\end{tabular}

\begin{tabular}{|l|l|l|l|l|}
\hline \multicolumn{4}{|c|}{ Testes de Posição: Mu0=0 } \\
\hline Teste & \multicolumn{2}{|c|}{ Estatística } & \multicolumn{2}{c|}{ Valor $\mathbf{p}$} \\
\hline Student $\mathbf{t}$ & $\mathbf{t}$ &, & $\operatorname{Pr}>|\mathbf{t}|$ \\
\hline Sign & M &, & $\operatorname{Pr}>=|\mathrm{M}|$ & \\
\hline Signed Rank & S &, & $\operatorname{Pr}>=|\mathrm{S}|$ & \\
\hline
\end{tabular}

\begin{tabular}{|l|r|}
\hline \multicolumn{2}{|c|}{ Quantis } \\
\hline Level & 0 \\
\hline $100 \%$ Max & 0 \\
\hline $99 \%$ & 0 \\
\hline $95 \%$ & 0 \\
\hline $90 \%$ & 0 \\
\hline $75 \%$ Q3 & 0 \\
\hline $50 \%$ Mediana & 0 \\
\hline $25 \%$ Q1 & 0 \\
\hline $10 \%$ & 0 \\
\hline $5 \%$ & 0 \\
\hline $1 \%$ & 0 \\
\hline $0 \%$ Min & \\
\hline
\end{tabular}


Variável

dependente:

ACI

ID $=110$

\begin{tabular}{|r|c|r|r|}
\hline \multicolumn{3}{|c|}{ Observações Limite } \\
\hline \multicolumn{2}{|c|}{ Baixa } & \multicolumn{2}{c|}{ Alta } \\
\hline Valor & Obs & Valor & Obs \\
\hline 0 & 1562 & 0 & 1558 \\
\hline 0 & 1561 & 0 & 1559 \\
\hline 0 & 1560 & 0 & 1560 \\
\hline 0 & 1559 & 0 & 1561 \\
\hline 0 & 1558 & 0 & 1562 \\
\hline
\end{tabular}


Variável

dependente:

REC

ID $=111$

\begin{tabular}{|l|r|l|r|}
\hline \multicolumn{3}{|c|}{ Momento } \\
\hline N & 17 & Soma dos pesos & 17 \\
\hline Média & $\begin{array}{r}0 \\
\text { Soma das } \\
\text { observações }\end{array}$ & 0 \\
\hline Desvio-padrão & 0 & Variância & 0 \\
\hline Assimetria &, Curtose &, \\
\hline $\begin{array}{l}\text { Soma dos } \\
\text { quadrados não } \\
\text { corrigida }\end{array}$ & 0 & $\begin{array}{l}\text { Soma dos } \\
\text { quadrados corrigida }\end{array}$ & 0 \\
\hline CV Pearson &, & Erro-padrão médio & 0 \\
\hline
\end{tabular}

\begin{tabular}{|l|r|l|r|}
\hline \multicolumn{3}{|c|}{ Estatística Descritiva Básica } \\
\hline \multicolumn{2}{|c|}{ Posição } & \multicolumn{2}{c|}{ Variabilidade } \\
\hline Média & 0 & Desvio-padrão & 0 \\
\hline Mediana & 0 & Variância & 0 \\
\hline Moda & 0 & Amplitude & 0 \\
\hline & & Amplitude interquartil & 0 \\
\hline
\end{tabular}

\begin{tabular}{|l|l|l|l|l|}
\hline \multicolumn{4}{|c|}{ Testes de Posição: Mu0=0 } \\
\hline Teste & \multicolumn{2}{|c|}{ Estatística } & \multicolumn{2}{c|}{ Valor $\mathbf{p}$} \\
\hline Student t & t & \multicolumn{1}{|c|}{, $\operatorname{Pr}>|\mathbf{t}|$} & \\
\hline Sign & M &, & $\operatorname{Pr}>=|\mathrm{M}|$ & \\
\hline Signed Rank & S &, & $\operatorname{Pr}>=|\mathrm{S}|$ & \\
\hline
\end{tabular}

\begin{tabular}{|l|r|}
\hline \multicolumn{2}{|c|}{ Quantis } \\
\hline Level & 0 \\
\hline $100 \%$ Max & 0 \\
\hline $99 \%$ & 0 \\
\hline $95 \%$ & 0 \\
\hline $90 \%$ & 0 \\
\hline $75 \%$ Q3 & 0 \\
\hline $50 \%$ Mediana & 0 \\
\hline $25 \%$ Q1 & 0 \\
\hline $10 \%$ & 0 \\
\hline $5 \%$ & 0 \\
\hline $1 \%$ & 0 \\
\hline $0 \%$ Min & 0 \\
\hline
\end{tabular}


Variável

dependente:

REC

\section{ID $=111$}

\begin{tabular}{|r|c|r|r|}
\hline \multicolumn{3}{|c|}{ Observações Limite } \\
\hline \multicolumn{2}{|c|}{ Baixa } & \multicolumn{2}{c|}{ Alta } \\
\hline Valor & Obs & Valor & Obs \\
\hline 0 & 1579 & 0 & 1575 \\
\hline 0 & 1578 & 0 & 1576 \\
\hline 0 & 1577 & 0 & 1577 \\
\hline 0 & 1576 & 0 & 1578 \\
\hline 0 & 1575 & 0 & 1579 \\
\hline
\end{tabular}


Variável

dependente:

ACI

ID $=111$

\begin{tabular}{|l|r|l|r|}
\hline \multicolumn{3}{|c|}{ Momento } \\
\hline N & 17 & Soma dos pesos & 17 \\
\hline Média & $\begin{array}{r}0 \\
\text { Soma das } \\
\text { observações }\end{array}$ & 0 \\
\hline Desvio-padrão & 0 & Variância & 0 \\
\hline Assimetria &, Curtose &, \\
\hline $\begin{array}{l}\text { Soma dos } \\
\text { quadrados não } \\
\text { corrigida }\end{array}$ & 0 & $\begin{array}{l}\text { Soma dos } \\
\text { quadrados corrigida }\end{array}$ & 0 \\
\hline CV Pearson &, & Erro-padrão médio & 0 \\
\hline
\end{tabular}

\begin{tabular}{|l|r|l|r|}
\hline \multicolumn{3}{|c|}{ Estatística Descritiva Básica } \\
\hline \multicolumn{2}{|c|}{ Posição } & \multicolumn{2}{c|}{ Variabilidade } \\
\hline Média & 0 & Desvio-padrão & 0 \\
\hline Mediana & 0 & Variância & 0 \\
\hline Moda & 0 & Amplitude & 0 \\
\hline & & Amplitude interquartil & 0 \\
\hline
\end{tabular}

\begin{tabular}{|l|l|l|l|l|}
\hline \multicolumn{5}{|c|}{ Testes de Posição: $\mathrm{Mu0}=0$} \\
\hline Teste & \multicolumn{2}{|c|}{ Estatística } & \multicolumn{2}{c|}{ Valor $\mathbf{p}$} \\
\hline Student t & t &, & $\operatorname{Pr}>|t|$ & \\
\hline Sign & M &, & $\operatorname{Pr}>=|\mathrm{M}|$ & \\
\hline Signed Rank & S &, & $\operatorname{Pr}>=|\mathrm{S}|$ & \\
\hline
\end{tabular}

\begin{tabular}{|l|r|}
\hline \multicolumn{2}{|c|}{ Quantis } \\
\hline Level & 0 \\
\hline $100 \%$ Max & 0 \\
\hline $99 \%$ & 0 \\
\hline $95 \%$ & 0 \\
\hline $90 \%$ & 0 \\
\hline $75 \%$ Q3 & 0 \\
\hline $50 \%$ Mediana & 0 \\
\hline $25 \%$ Q1 & 0 \\
\hline $10 \%$ & 0 \\
\hline $5 \%$ & 0 \\
\hline $1 \%$ & 0 \\
\hline $0 \%$ Min & 0 \\
\hline
\end{tabular}


Variável

dependente:

ACI

ID $=111$

\begin{tabular}{|r|c|r|r|}
\hline \multicolumn{3}{|c|}{ Observações Limite } \\
\hline \multicolumn{2}{|c|}{ Baixa } & \multicolumn{2}{c|}{ Alta } \\
\hline Valor & Obs & Valor & Obs \\
\hline 0 & 1579 & 0 & 1575 \\
\hline 0 & 1578 & 0 & 1576 \\
\hline 0 & 1577 & 0 & 1577 \\
\hline 0 & 1576 & 0 & 1578 \\
\hline 0 & 1575 & 0 & 1579 \\
\hline
\end{tabular}


Variável

dependente:

REC

ID $=112$

\begin{tabular}{|l|r|l|r|}
\hline \multicolumn{3}{|c|}{ Momento } \\
\hline N & 18 & Soma dos pesos & 18 \\
\hline Média & $\begin{array}{r}0 \\
\text { Soma das } \\
\text { observações }\end{array}$ & 0 \\
\hline Desvio-padrão & 0 & Variância & 0 \\
\hline Assimetria &, Curtose &, \\
\hline $\begin{array}{l}\text { Soma dos } \\
\text { quadrados não } \\
\text { corrigida }\end{array}$ & 0 & $\begin{array}{l}\text { Soma dos } \\
\text { quadrados corrigida }\end{array}$ & 0 \\
\hline CV Pearson &, & Erro-padrão médio & 0 \\
\hline
\end{tabular}

\begin{tabular}{|l|r|l|r|}
\hline \multicolumn{3}{|c|}{ Estatística Descritiva Básica } \\
\hline \multicolumn{2}{|c|}{ Posição } & \multicolumn{2}{c|}{ Variabilidade } \\
\hline Média & 0 & Desvio-padrão & 0 \\
\hline Mediana & 0 & Variância & 0 \\
\hline Moda & 0 & Amplitude & 0 \\
\hline & & Amplitude interquartil & 0 \\
\hline
\end{tabular}

\begin{tabular}{|l|l|l|l|l|}
\hline \multicolumn{4}{|c|}{ Testes de Posição: Mu0=0 } \\
\hline Teste & \multicolumn{2}{|c|}{ Estatística } & \multicolumn{2}{c|}{ Valor $\mathbf{p}$} \\
\hline Student $\mathbf{t}$ & $\mathbf{t}$ & \multicolumn{1}{|c|}{, $\operatorname{Pr}>|\mathbf{t}|$} & \\
\hline Sign & $\mathrm{M}$ &, & $\operatorname{Pr}>=|\mathrm{M}|$ & \\
\hline Signed Rank & S &, & $\operatorname{Pr}>=|\mathrm{S}|$ & \\
\hline
\end{tabular}

\begin{tabular}{|l|r|}
\hline \multicolumn{2}{|c|}{ Quantis } \\
\hline Level & 0 \\
\hline $100 \%$ Max & 0 \\
\hline $99 \%$ & 0 \\
\hline $95 \%$ & 0 \\
\hline $90 \%$ & 0 \\
\hline $75 \%$ Q3 & 0 \\
\hline $50 \%$ Mediana & 0 \\
\hline $25 \%$ Q1 & 0 \\
\hline $10 \%$ & 0 \\
\hline $5 \%$ & 0 \\
\hline $1 \%$ & 0 \\
\hline $0 \%$ Min & 0 \\
\hline
\end{tabular}


Variável

dependente:

REC

ID $=112$

\begin{tabular}{|r|c|r|r|}
\hline \multicolumn{3}{|c|}{ Observações Limite } \\
\hline \multicolumn{2}{|c|}{ Baixa } & \multicolumn{2}{c|}{ Alta } \\
\hline Valor & Obs & Valor & Obs \\
\hline 0 & 1597 & 0 & 1593 \\
\hline 0 & 1596 & 0 & 1594 \\
\hline 0 & 1595 & 0 & 1595 \\
\hline 0 & 1594 & 0 & 1596 \\
\hline 0 & 1593 & 0 & 1597 \\
\hline
\end{tabular}


Variável

dependente:

ACI

ID $=112$

\begin{tabular}{|l|r|l|r|}
\hline \multicolumn{3}{|c|}{ Momento } \\
\hline N & 18 & Soma dos pesos & 18 \\
\hline Média & $\begin{array}{r}0 \\
\text { Soma das } \\
\text { observações }\end{array}$ & 0 \\
\hline Desvio-padrão & 0 & Variância & 0 \\
\hline Assimetria &, Curtose &, \\
\hline $\begin{array}{l}\text { Soma dos } \\
\text { quadrados não } \\
\text { corrigida }\end{array}$ & 0 & $\begin{array}{l}\text { Soma dos } \\
\text { quadrados corrigida }\end{array}$ & 0 \\
\hline CV Pearson &, & Erro-padrão médio & 0 \\
\hline
\end{tabular}

\begin{tabular}{|l|r|l|r|}
\hline \multicolumn{3}{|c|}{ Estatística Descritiva Básica } \\
\hline \multicolumn{2}{|c|}{ Posição } & \multicolumn{2}{c|}{ Variabilidade } \\
\hline Média & 0 & Desvio-padrão & 0 \\
\hline Mediana & 0 & Variância & 0 \\
\hline Moda & 0 & Amplitude & 0 \\
\hline & & Amplitude interquartil & 0 \\
\hline
\end{tabular}

\begin{tabular}{|l|l|l|l|l|}
\hline \multicolumn{4}{|c|}{ Testes de Posição: Mu0=0 } \\
\hline Teste & \multicolumn{2}{|c|}{ Estatística } & \multicolumn{2}{c|}{ Valor $\mathbf{p}$} \\
\hline Student $\mathbf{t}$ & $\mathbf{t}$ & \multicolumn{1}{|c|}{, $\operatorname{Pr}>|\mathbf{t}|$} & \\
\hline Sign & $\mathrm{M}$ &, & $\operatorname{Pr}>=|\mathrm{M}|$ & \\
\hline Signed Rank & S &, & $\operatorname{Pr}>=|\mathrm{S}|$ & \\
\hline
\end{tabular}

\begin{tabular}{|l|r|}
\hline \multicolumn{2}{|c|}{ Quantis } \\
\hline Level & 0 \\
\hline $100 \%$ Max & 0 \\
\hline $99 \%$ & 0 \\
\hline $95 \%$ & 0 \\
\hline $90 \%$ & 0 \\
\hline $75 \%$ Q3 & 0 \\
\hline $50 \%$ Mediana & 0 \\
\hline $25 \%$ Q1 & 0 \\
\hline $10 \%$ & 0 \\
\hline $5 \%$ & 0 \\
\hline $1 \%$ & 0 \\
\hline $0 \%$ Min & 0 \\
\hline
\end{tabular}


Variável

dependente:

ACI

ID $=112$

\begin{tabular}{|r|c|r|r|}
\hline \multicolumn{3}{|c|}{ Observações Limite } \\
\hline \multicolumn{2}{|c|}{ Baixa } & \multicolumn{2}{c|}{ Alta } \\
\hline Valor & Obs & Valor & Obs \\
\hline 0 & 1597 & 0 & 1593 \\
\hline 0 & 1596 & 0 & 1594 \\
\hline 0 & 1595 & 0 & 1595 \\
\hline 0 & 1594 & 0 & 1596 \\
\hline 0 & 1593 & 0 & 1597 \\
\hline
\end{tabular}


Variável

dependente:

REC

ID $=113$

\begin{tabular}{|l|r|l|r|}
\hline \multicolumn{3}{|c|}{ Momento } \\
\hline N & 4 & Soma dos pesos & 4 \\
\hline Média & $\begin{array}{r}0 \\
\text { Soma das } \\
\text { observações }\end{array}$ & 0 \\
\hline Desvio-padrão & 0 & Variância & 0 \\
\hline Assimetria &, Curtose &, \\
\hline $\begin{array}{l}\text { Soma dos } \\
\text { quadrados não } \\
\text { corrigida }\end{array}$ & 0 & $\begin{array}{l}\text { Soma dos } \\
\text { quadrados corrigida }\end{array}$ & 0 \\
\hline CV Pearson &, & Erro-padrão médio & 0 \\
\hline
\end{tabular}

\begin{tabular}{|l|r|l|r|}
\hline \multicolumn{3}{|c|}{ Estatística Descritiva Básica } \\
\hline \multicolumn{2}{|c|}{ Posição } & \multicolumn{2}{c|}{ Variabilidade } \\
\hline Média & 0 & Desvio-padrão & 0 \\
\hline Mediana & 0 & Variância & 0 \\
\hline Moda & 0 & Amplitude & 0 \\
\hline & & Amplitude interquartil & 0 \\
\hline
\end{tabular}

\begin{tabular}{|l|l|l|l|l|}
\hline \multicolumn{4}{|c|}{ Testes de Posição: Mu0=0 } \\
\hline Teste & \multicolumn{2}{|c|}{ Estatística } & \multicolumn{2}{c|}{ Valor $\mathbf{p}$} \\
\hline Student $\mathbf{t}$ & $\mathbf{t}$ & \multicolumn{1}{|c|}{, $\operatorname{Pr}>|\mathbf{t}|$} & \\
\hline Sign & $\mathrm{M}$ &, & $\operatorname{Pr}>=|\mathrm{M}|$ & \\
\hline Signed Rank & S &, & $\operatorname{Pr}>=|\mathrm{S}|$ & \\
\hline
\end{tabular}

\begin{tabular}{|l|r|}
\hline \multicolumn{2}{|c|}{ Quantis } \\
\hline Level & 0 \\
\hline $100 \%$ Max & 0 \\
\hline $99 \%$ & 0 \\
\hline $95 \%$ & 0 \\
\hline $90 \%$ & 0 \\
\hline $75 \%$ Q3 & 0 \\
\hline $50 \%$ Mediana & 0 \\
\hline $25 \%$ Q1 & 0 \\
\hline $10 \%$ & 0 \\
\hline $5 \%$ & 0 \\
\hline $1 \%$ & 0 \\
\hline $0 \%$ Min & 0 \\
\hline
\end{tabular}


Variável

dependente:

REC

ID $=113$

\begin{tabular}{|r|r|r|r|}
\hline \multicolumn{3}{|c|}{ Observações Limite } \\
\hline \multicolumn{2}{|c|}{ Baixa } & \multicolumn{2}{c|}{ Alta } \\
\hline Valor & Obs & Valor & Obs \\
\hline 0 & 1601 & 0 & 1598 \\
\hline 0 & 1600 & 0 & 1599 \\
\hline 0 & 1599 & 0 & 1600 \\
\hline 0 & 1598 & 0 & 1601 \\
\hline
\end{tabular}


Variável

dependente:

ACI

ID $=113$

\begin{tabular}{|l|r|l|r|}
\hline \multicolumn{3}{|c|}{ Momento } \\
\hline N & 4 & Soma dos pesos & 4 \\
\hline Média & $\begin{array}{r}0 \\
\text { Soma das } \\
\text { observações }\end{array}$ & 0 \\
\hline Desvio-padrão & 0 & Variância & 0 \\
\hline Assimetria &, Curtose &, \\
\hline $\begin{array}{l}\text { Soma dos } \\
\text { quadrados não } \\
\text { corrigida }\end{array}$ & 0 & $\begin{array}{l}\text { Soma dos } \\
\text { quadrados corrigida }\end{array}$ & 0 \\
\hline CV Pearson &, & Erro-padrão médio & 0 \\
\hline
\end{tabular}

\begin{tabular}{|l|r|l|r|}
\hline \multicolumn{3}{|c|}{ Estatística Descritiva Básica } \\
\hline \multicolumn{2}{|c|}{ Posição } & \multicolumn{2}{c|}{ Variabilidade } \\
\hline Média & 0 & Desvio-padrão & 0 \\
\hline Mediana & 0 & Variância & 0 \\
\hline Moda & 0 & Amplitude & 0 \\
\hline & & Amplitude interquartil & 0 \\
\hline
\end{tabular}

\begin{tabular}{|l|l|l|l|l|}
\hline \multicolumn{4}{|c|}{ Testes de Posição: Mu0=0 } \\
\hline Teste & \multicolumn{2}{|c|}{ Estatística } & \multicolumn{2}{c|}{ Valor $\mathbf{p}$} \\
\hline Student t & t & \multicolumn{1}{|c|}{, $\operatorname{Pr}>|\mathbf{t}|$} & \\
\hline Sign & M &, & $\operatorname{Pr}>=|\mathrm{M}|$ & \\
\hline Signed Rank & S &, & $\operatorname{Pr}>=|\mathrm{S}|$ & \\
\hline
\end{tabular}

\begin{tabular}{|l|r|}
\hline \multicolumn{2}{|c|}{ Quantis } \\
\hline Level & 0 \\
\hline $100 \%$ Max & 0 \\
\hline $99 \%$ & 0 \\
\hline $95 \%$ & 0 \\
\hline $90 \%$ & 0 \\
\hline $75 \%$ Q3 & 0 \\
\hline $50 \%$ Mediana & 0 \\
\hline $25 \%$ Q1 & 0 \\
\hline $10 \%$ & 0 \\
\hline $5 \%$ & 0 \\
\hline $1 \%$ & 0 \\
\hline $0 \%$ Min & 0 \\
\hline
\end{tabular}


Variável

dependente:

ACI

ID $=113$

\begin{tabular}{|r|r|r|r|}
\hline \multicolumn{3}{|c|}{ Observações Limite } \\
\hline \multicolumn{2}{|c|}{ Baixa } & \multicolumn{2}{c|}{ Alta } \\
\hline Valor & Obs & Valor & Obs \\
\hline 0 & 1601 & 0 & 1598 \\
\hline 0 & 1600 & 0 & 1599 \\
\hline 0 & 1599 & 0 & 1600 \\
\hline 0 & 1598 & 0 & 1601 \\
\hline
\end{tabular}


Variável

dependente:

REC

ID $=114$

\begin{tabular}{|l|r|l|r|}
\hline \multicolumn{3}{|c|}{ Momento } \\
\hline N & 15 & Soma dos pesos & 15 \\
\hline Média & $\begin{array}{r}0 \\
\text { Soma das } \\
\text { observações }\end{array}$ & 0 \\
\hline Desvio-padrão & 0 & Variância & 0 \\
\hline Assimetria &, Curtose &, \\
\hline $\begin{array}{l}\text { Soma dos } \\
\text { quadrados não } \\
\text { corrigida }\end{array}$ & 0 & $\begin{array}{l}\text { Soma dos } \\
\text { quadrados corrigida }\end{array}$ & 0 \\
\hline CV Pearson &, & Erro-padrão médio & 0 \\
\hline
\end{tabular}

\begin{tabular}{|l|r|l|r|}
\hline \multicolumn{3}{|c|}{ Estatística Descritiva Básica } \\
\hline \multicolumn{2}{|c|}{ Posição } & \multicolumn{2}{c|}{ Variabilidade } \\
\hline Média & 0 & Desvio-padrão & 0 \\
\hline Mediana & 0 & Variância & 0 \\
\hline Moda & 0 & Amplitude & 0 \\
\hline & & Amplitude interquartil & 0 \\
\hline
\end{tabular}

\begin{tabular}{|l|l|l|l|l|}
\hline \multicolumn{4}{|c|}{ Testes de Posição: Mu0=0 } \\
\hline Teste & \multicolumn{2}{|c|}{ Estatística } & \multicolumn{2}{c|}{ Valor $\mathbf{p}$} \\
\hline Student $\mathbf{t}$ & $\mathbf{t}$ & \multicolumn{1}{|c|}{, $\operatorname{Pr}>|\mathbf{t}|$} & \\
\hline Sign & $\mathrm{M}$ &, & $\operatorname{Pr}>=|\mathrm{M}|$ & \\
\hline Signed Rank & S &, & $\operatorname{Pr}>=|\mathrm{S}|$ & \\
\hline
\end{tabular}

\begin{tabular}{|l|r|}
\hline \multicolumn{2}{|c|}{ Quantis } \\
\hline Level & 0 \\
\hline $100 \%$ Max & 0 \\
\hline $99 \%$ & 0 \\
\hline $95 \%$ & 0 \\
\hline $90 \%$ & 0 \\
\hline $75 \%$ Q3 & 0 \\
\hline $50 \%$ Mediana & 0 \\
\hline $25 \%$ Q1 & 0 \\
\hline $10 \%$ & 0 \\
\hline $5 \%$ & 0 \\
\hline $1 \%$ & 0 \\
\hline $0 \%$ Min & 0 \\
\hline
\end{tabular}


Variável

dependente:

REC

\section{ID $=114$}

\begin{tabular}{|r|c|r|r|}
\hline \multicolumn{3}{|c|}{ Observações Limite } \\
\hline \multicolumn{2}{|c|}{ Baixa } & \multicolumn{2}{c|}{ Alta } \\
\hline Valor & Obs & Valor & Obs \\
\hline 0 & 1616 & 0 & 1612 \\
\hline 0 & 1615 & 0 & 1613 \\
\hline 0 & 1614 & 0 & 1614 \\
\hline 0 & 1613 & 0 & 1615 \\
\hline 0 & 1612 & 0 & 1616 \\
\hline
\end{tabular}


Variável

dependente:

ACI

ID $=114$

\begin{tabular}{|l|r|l|r|}
\hline \multicolumn{3}{|c|}{ Momento } \\
\hline N & 15 & Soma dos pesos & 15 \\
\hline Média & $\begin{array}{r}0 \\
\text { Soma das } \\
\text { observações }\end{array}$ & 0 \\
\hline Desvio-padrão & 0 & Variância & 0 \\
\hline Assimetria &, Curtose &, \\
\hline $\begin{array}{l}\text { Soma dos } \\
\text { quadrados não } \\
\text { corrigida }\end{array}$ & 0 & $\begin{array}{l}\text { Soma dos } \\
\text { quadrados corrigida }\end{array}$ & 0 \\
\hline CV Pearson &, & Erro-padrão médio & 0 \\
\hline
\end{tabular}

\begin{tabular}{|l|r|l|r|}
\hline \multicolumn{3}{|c|}{ Estatística Descritiva Básica } \\
\hline \multicolumn{2}{|c|}{ Posição } & \multicolumn{2}{c|}{ Variabilidade } \\
\hline Média & 0 & Desvio-padrão & 0 \\
\hline Mediana & 0 & Variância & 0 \\
\hline Moda & 0 & Amplitude & 0 \\
\hline & & Amplitude interquartil & 0 \\
\hline
\end{tabular}

\begin{tabular}{|l|l|l|l|l|}
\hline \multicolumn{4}{|c|}{ Testes de Posição: Mu0=0 } \\
\hline Teste & \multicolumn{2}{|c|}{ Estatística } & \multicolumn{2}{c|}{ Valor $\mathbf{p}$} \\
\hline Student t & t & \multicolumn{1}{|c|}{, $\operatorname{Pr}>|\mathbf{t}|$} & \\
\hline Sign & M &, & $\operatorname{Pr}>=|\mathrm{M}|$ & \\
\hline Signed Rank & S &, & $\operatorname{Pr}>=|\mathrm{S}|$ & \\
\hline
\end{tabular}

\begin{tabular}{|l|r|}
\hline \multicolumn{2}{|c|}{ Quantis } \\
\hline Level & 0 \\
\hline $100 \%$ Max & 0 \\
\hline $99 \%$ & 0 \\
\hline $95 \%$ & 0 \\
\hline $90 \%$ & 0 \\
\hline $75 \%$ Q3 & 0 \\
\hline $50 \%$ Mediana & 0 \\
\hline $25 \%$ Q1 & 0 \\
\hline $10 \%$ & 0 \\
\hline $5 \%$ & 0 \\
\hline $1 \%$ & 0 \\
\hline $0 \%$ Min & 0 \\
\hline
\end{tabular}


Variável

dependente:

ACI

ID $=114$

\begin{tabular}{|r|c|r|r|}
\hline \multicolumn{3}{|c|}{ Observações Limite } \\
\hline \multicolumn{2}{|c|}{ Baixa } & \multicolumn{2}{c|}{ Alta } \\
\hline Valor & Obs & Valor & Obs \\
\hline 0 & 1616 & 0 & 1612 \\
\hline 0 & 1615 & 0 & 1613 \\
\hline 0 & 1614 & 0 & 1614 \\
\hline 0 & 1613 & 0 & 1615 \\
\hline 0 & 1612 & 0 & 1616 \\
\hline
\end{tabular}


Variável

dependente:

REC

ID $=115$

\begin{tabular}{|l|r|l|r|}
\hline \multicolumn{3}{|c|}{ Momento } \\
\hline N & 16 & Soma dos pesos & 16 \\
\hline Média & $\begin{array}{r}0 \\
\text { Soma das } \\
\text { observações }\end{array}$ & 0 \\
\hline Desvio-padrão & 0 & Variância & 0 \\
\hline Assimetria &, Curtose &, \\
\hline $\begin{array}{l}\text { Soma dos } \\
\text { quadrados não } \\
\text { corrigida }\end{array}$ & 0 & $\begin{array}{l}\text { Soma dos } \\
\text { quadrados corrigida }\end{array}$ & 0 \\
\hline CV Pearson &, & Erro-padrão médio & 0 \\
\hline
\end{tabular}

\begin{tabular}{|l|r|l|r|}
\hline \multicolumn{3}{|c|}{ Estatística Descritiva Básica } \\
\hline \multicolumn{2}{|c|}{ Posição } & \multicolumn{2}{c|}{ Variabilidade } \\
\hline Média & 0 & Desvio-padrão & 0 \\
\hline Mediana & 0 & Variância & 0 \\
\hline Moda & 0 & Amplitude & 0 \\
\hline & & Amplitude interquartil & 0 \\
\hline
\end{tabular}

\begin{tabular}{|l|l|l|l|l|}
\hline \multicolumn{5}{|c|}{ Testes de Posição: Mu0=0 } \\
\hline Teste & \multicolumn{2}{|c|}{ Estatística } & \multicolumn{2}{c|}{ Valor $\mathbf{p}$} \\
\hline Student t & t &, & $\operatorname{Pr}>|\mathbf{t}|$ & \\
\hline Sign & M &, & $\operatorname{Pr}>=|\mathrm{M}|$ & \\
\hline Signed Rank & S &, & $\operatorname{Pr}>=|\mathrm{S}|$ & \\
\hline
\end{tabular}

\begin{tabular}{|l|r|}
\hline \multicolumn{2}{|c|}{ Quantis } \\
\hline Level & 0 \\
\hline $100 \%$ Max & 0 \\
\hline $99 \%$ & 0 \\
\hline $95 \%$ & 0 \\
\hline $90 \%$ & 0 \\
\hline $75 \%$ Q3 & 0 \\
\hline $50 \%$ Mediana & 0 \\
\hline $25 \%$ Q1 & 0 \\
\hline $10 \%$ & 0 \\
\hline $5 \%$ & 0 \\
\hline $1 \%$ & 0 \\
\hline $0 \%$ Min & 0 \\
\hline
\end{tabular}


Variável

dependente:

REC

\section{ID $=115$}

\begin{tabular}{|r|c|r|r|}
\hline \multicolumn{3}{|c|}{ Observações Limite } \\
\hline \multicolumn{2}{|c|}{ Baixa } & \multicolumn{2}{c|}{ Alta } \\
\hline Valor & Obs & Valor & Obs \\
\hline 0 & 1632 & 0 & 1628 \\
\hline 0 & 1631 & 0 & 1629 \\
\hline 0 & 1630 & 0 & 1630 \\
\hline 0 & 1629 & 0 & 1631 \\
\hline 0 & 1628 & 0 & 1632 \\
\hline
\end{tabular}


Variável

dependente:

ACI

ID $=115$

\begin{tabular}{|l|r|l|r|}
\hline \multicolumn{3}{|c|}{ Momento } \\
\hline N & 16 & Soma dos pesos & 16 \\
\hline Média & $\begin{array}{r}0 \\
\text { Soma das } \\
\text { observações }\end{array}$ & 0 \\
\hline Desvio-padrão & 0 & Variância & 0 \\
\hline Assimetria &, Curtose &, \\
\hline $\begin{array}{l}\text { Soma dos } \\
\text { quadrados não } \\
\text { corrigida }\end{array}$ & 0 & $\begin{array}{l}\text { Soma dos } \\
\text { quadrados corrigida }\end{array}$ & 0 \\
\hline CV Pearson &, & Erro-padrão médio & 0 \\
\hline
\end{tabular}

\begin{tabular}{|l|r|l|r|}
\hline \multicolumn{3}{|c|}{ Estatística Descritiva Básica } \\
\hline \multicolumn{2}{|c|}{ Posição } & \multicolumn{2}{c|}{ Variabilidade } \\
\hline Média & 0 & Desvio-padrão & 0 \\
\hline Mediana & 0 & Variância & 0 \\
\hline Moda & 0 & Amplitude & 0 \\
\hline & & Amplitude interquartil & 0 \\
\hline
\end{tabular}

\begin{tabular}{|l|l|l|l|l|}
\hline \multicolumn{4}{|c|}{ Testes de Posição: Mu0=0 } \\
\hline Teste & \multicolumn{2}{|c|}{ Estatística } & \multicolumn{2}{c|}{ Valor $\mathbf{p}$} \\
\hline Student t & $\mathbf{t}$ &, & $\mathrm{Pr}>|\mathrm{t}|$ & \\
\hline Sign & $\mathrm{M}$ &, & $\mathrm{Pr}>=|\mathrm{M}|$ & \\
\hline Signed Rank & $\mathrm{S}$ &, & $\mathrm{Pr}>=|\mathrm{S}|$ & \\
\hline
\end{tabular}

\begin{tabular}{|l|r|}
\hline \multicolumn{2}{|c|}{ Quantis } \\
\hline Level & 0 \\
\hline $100 \%$ Max & 0 \\
\hline $99 \%$ & 0 \\
\hline $95 \%$ & 0 \\
\hline $90 \%$ & 0 \\
\hline $75 \%$ Q3 & 0 \\
\hline $50 \%$ Mediana & 0 \\
\hline $25 \%$ Q1 & 0 \\
\hline $10 \%$ & 0 \\
\hline $5 \%$ & 0 \\
\hline $1 \%$ & 0 \\
\hline $0 \%$ Min & 0 \\
\hline
\end{tabular}


Variável

dependente:

ACI

ID $=115$

\begin{tabular}{|r|c|r|r|}
\hline \multicolumn{3}{|c|}{ Observações Limite } \\
\hline \multicolumn{2}{|c|}{ Baixa } & \multicolumn{2}{c|}{ Alta } \\
\hline Valor & Obs & Valor & Obs \\
\hline 0 & 1632 & 0 & 1628 \\
\hline 0 & 1631 & 0 & 1629 \\
\hline 0 & 1630 & 0 & 1630 \\
\hline 0 & 1629 & 0 & 1631 \\
\hline 0 & 1628 & 0 & 1632 \\
\hline
\end{tabular}


Variável

dependente:

REC

ID $=116$

\begin{tabular}{|l|r|l|r|}
\hline \multicolumn{3}{|c|}{ Momento } \\
\hline N & 17 & Soma dos pesos & 17 \\
\hline Média & $\begin{array}{r}0 \\
\text { Soma das } \\
\text { observações }\end{array}$ & 0 \\
\hline Desvio-padrão & 0 & Variância & 0 \\
\hline Assimetria &, Curtose &, \\
\hline $\begin{array}{l}\text { Soma dos } \\
\text { quadrados não } \\
\text { corrigida }\end{array}$ & 0 & $\begin{array}{l}\text { Soma dos } \\
\text { quadrados corrigida }\end{array}$ & 0 \\
\hline CV Pearson &, & Erro-padrão médio & 0 \\
\hline
\end{tabular}

\begin{tabular}{|l|r|l|r|}
\hline \multicolumn{3}{|c|}{ Estatística Descritiva Básica } \\
\hline \multicolumn{2}{|c|}{ Posição } & \multicolumn{2}{c|}{ Variabilidade } \\
\hline Média & 0 & Desvio-padrão & 0 \\
\hline Mediana & 0 & Variância & 0 \\
\hline Moda & 0 & Amplitude & 0 \\
\hline & & Amplitude interquartil & 0 \\
\hline
\end{tabular}

\begin{tabular}{|l|l|l|l|l|}
\hline \multicolumn{4}{|c|}{ Testes de Posição: Mu0=0 } \\
\hline Teste & \multicolumn{2}{|c|}{ Estatística } & \multicolumn{2}{c|}{ Valor $\mathbf{p}$} \\
\hline Student $\mathbf{t}$ & $\mathbf{t}$ & \multicolumn{1}{|c|}{, $\operatorname{Pr}>|\mathbf{t}|$} & \\
\hline Sign & $\mathrm{M}$ &, & $\operatorname{Pr}>=|\mathrm{M}|$ & \\
\hline Signed Rank & S &, & $\operatorname{Pr}>=|\mathrm{S}|$ & \\
\hline
\end{tabular}

\begin{tabular}{|l|r|}
\hline \multicolumn{2}{|c|}{ Quantis } \\
\hline Level & 0 \\
\hline $100 \%$ Max & 0 \\
\hline $99 \%$ & 0 \\
\hline $95 \%$ & 0 \\
\hline $90 \%$ & 0 \\
\hline $75 \%$ Q3 & 0 \\
\hline $50 \%$ Mediana & 0 \\
\hline $25 \%$ Q1 & 0 \\
\hline $10 \%$ & 0 \\
\hline $5 \%$ & 0 \\
\hline $1 \%$ & 0 \\
\hline $0 \%$ Min & 0 \\
\hline
\end{tabular}


Variável

dependente:

REC

ID $=116$

\begin{tabular}{|r|r|r|r|}
\hline \multicolumn{3}{|c|}{ Observações Limite } \\
\hline \multicolumn{2}{|c|}{ Baixa } & \multicolumn{2}{c|}{ Alta } \\
\hline Valor & Obs & Valor & Obs \\
\hline 0 & 1649 & 0 & 1645 \\
\hline 0 & 1648 & 0 & 1646 \\
\hline 0 & 1647 & 0 & 1647 \\
\hline 0 & 1646 & 0 & 1648 \\
\hline 0 & 1645 & 0 & 1649 \\
\hline
\end{tabular}


Variável

dependente:

ACI

ID $=116$

\begin{tabular}{|l|r|l|r|}
\hline \multicolumn{3}{|c|}{ Momento } \\
\hline N & 17 & Soma dos pesos & 17 \\
\hline Média & 0 & $\begin{array}{l}\text { Soma das } \\
\text { observações }\end{array}$ & 0 \\
\hline Desvio-padrão & 0 & Variância & 0 \\
\hline $\begin{array}{l}\text { Assimetria } \\
\text { quadrados não } \\
\text { corrigida }\end{array}$ & 0 & $\begin{array}{l}\text { Soma dos } \\
\text { quadrados corrigida }\end{array}$ & 0 \\
\hline CV Pearson &, & Erro-padrão médio & 0 \\
\hline
\end{tabular}

\begin{tabular}{|l|r|l|r|}
\hline \multicolumn{3}{|c|}{ Estatística Descritiva Básica } \\
\hline Posição & \multicolumn{2}{c|}{ Variabilidade } \\
\hline Média & 0 & Desvio-padrão & 0 \\
\hline Mediana & 0 & Variância & 0 \\
\hline Moda & 0 & Amplitude & 0 \\
\hline & & Amplitude interquartil & 0 \\
\hline
\end{tabular}

\begin{tabular}{|l|l|l|l|l|}
\hline \multicolumn{4}{|c|}{ Testes de Posição: Mu0=0 } \\
\hline Teste & \multicolumn{2}{|c|}{ Estatística } & \multicolumn{2}{c|}{ Valor $\mathbf{p}$} \\
\hline Student t & $\mathbf{t}$ & & $\operatorname{Pr}>|\mathbf{t}|$ & \\
\hline Sign & $\mathbf{M}$ &, & $\operatorname{Pr}>=|\mathrm{M}|$ & \\
\hline Signed Rank & $\mathbf{S}$ &, & $\operatorname{Pr}>=|\mathrm{S}|$ & \\
\hline
\end{tabular}

\begin{tabular}{|l|r|}
\hline \multicolumn{2}{|c|}{ Quantis } \\
\hline Level & Quantil \\
\hline $100 \%$ Max & 0 \\
\hline $99 \%$ & 0 \\
\hline $95 \%$ & 0 \\
\hline $90 \%$ & 0 \\
\hline $75 \%$ Q3 & 0 \\
\hline $50 \%$ Mediana & 0 \\
\hline $25 \%$ Q1 & 0 \\
\hline $10 \%$ & 0 \\
\hline $5 \%$ & 0 \\
\hline $1 \%$ & 0 \\
\hline $0 \%$ Min & \\
\hline
\end{tabular}


Variável

dependente:

ACI

ID $=116$

\begin{tabular}{|r|c|r|r|}
\hline \multicolumn{3}{|c|}{ Observações Limite } \\
\hline \multicolumn{2}{|c|}{ Baixa } & \multicolumn{2}{c|}{ Alta } \\
\hline Valor & Obs & Valor & Obs \\
\hline 0 & 1649 & 0 & 1645 \\
\hline 0 & 1648 & 0 & 1646 \\
\hline 0 & 1647 & 0 & 1647 \\
\hline 0 & 1646 & 0 & 1648 \\
\hline 0 & 1645 & 0 & 1649 \\
\hline
\end{tabular}


Variável

dependente:

REC

ID $=\mathbf{1 1 7}$

\begin{tabular}{|l|r|l|r|}
\hline \multicolumn{3}{|c|}{ Momento } \\
\hline N & 4 & Soma dos pesos & 4 \\
\hline Média & $\begin{array}{r}0 \\
\text { Soma das } \\
\text { observações }\end{array}$ & 0 \\
\hline Desvio-padrão & 0 & Variância & 0 \\
\hline Assimetria &, Curtose &, \\
\hline $\begin{array}{l}\text { Soma dos } \\
\text { quadrados não } \\
\text { corrigida }\end{array}$ & 0 & $\begin{array}{l}\text { Soma dos } \\
\text { quadrados corrigida }\end{array}$ & 0 \\
\hline CV Pearson &, & Erro-padrão médio & 0 \\
\hline
\end{tabular}

\begin{tabular}{|l|r|l|r|}
\hline \multicolumn{3}{|c|}{ Estatística Descritiva Básica } \\
\hline \multicolumn{2}{|c|}{ Posição } & \multicolumn{2}{c|}{ Variabilidade } \\
\hline Média & 0 & Desvio-padrão & 0 \\
\hline Mediana & 0 & Variância & 0 \\
\hline Moda & 0 & Amplitude & 0 \\
\hline & & Amplitude interquartil & 0 \\
\hline
\end{tabular}

\begin{tabular}{|l|l|l|l|l|}
\hline \multicolumn{5}{|c|}{ Testes de Posição: $\mathrm{Mu0}=0$} \\
\hline Teste & \multicolumn{2}{|c|}{ Estatística } & \multicolumn{2}{c|}{ Valor $\mathbf{p}$} \\
\hline Student t & t &, & $\operatorname{Pr}>|t|$ & \\
\hline Sign & M &, & $\operatorname{Pr}>=|\mathrm{M}|$ & \\
\hline Signed Rank & S &, & $\operatorname{Pr}>=|\mathrm{S}|$ & \\
\hline
\end{tabular}

\begin{tabular}{|l|r|}
\hline \multicolumn{2}{|c|}{ Quantis } \\
\hline Level & 0 \\
\hline $100 \%$ Max & 0 \\
\hline $99 \%$ & 0 \\
\hline $95 \%$ & 0 \\
\hline $90 \%$ & 0 \\
\hline $75 \%$ Q3 & 0 \\
\hline $50 \%$ Mediana & 0 \\
\hline $25 \%$ Q1 & 0 \\
\hline $10 \%$ & 0 \\
\hline $5 \%$ & 0 \\
\hline $1 \%$ & 0 \\
\hline $0 \%$ Min & 0 \\
\hline
\end{tabular}


Variável

dependente:

REC

ID $=117$

\begin{tabular}{|r|r|r|r|}
\hline \multicolumn{3}{|c|}{ Observações Limite } \\
\hline \multicolumn{2}{|c|}{ Baixa } & \multicolumn{2}{c|}{ Alta } \\
\hline Valor & Obs & Valor & Obs \\
\hline 0 & 1653 & 0 & 1650 \\
\hline 0 & 1652 & 0 & 1651 \\
\hline 0 & 1651 & 0 & 1652 \\
\hline 0 & 1650 & 0 & 1653 \\
\hline
\end{tabular}


Variável

dependente:

ACI

ID $=\mathbf{1 1 7}$

\begin{tabular}{|l|r|l|r|}
\hline \multicolumn{3}{|c|}{ Momento } \\
\hline N & 4 & Soma dos pesos & 4 \\
\hline Média & 0 & $\begin{array}{l}\text { Soma das } \\
\text { observações }\end{array}$ & 0 \\
\hline Desvio-padrão & 0 & Variância & 0 \\
\hline Assimetria &, & Curtose &, \\
\hline $\begin{array}{l}\text { Soma dos } \\
\text { quadrados não } \\
\text { corrigida }\end{array}$ & 0 & $\begin{array}{l}\text { Soma dos } \\
\text { quadrados corrigida }\end{array}$ & 0 \\
\hline CV Pearson &, & Erro-padrão médio & 0 \\
\hline
\end{tabular}

\begin{tabular}{|l|r|l|r|}
\hline \multicolumn{3}{|c|}{ Estatística Descritiva Básica } \\
\hline \multicolumn{2}{|c|}{ Posição } & \multicolumn{2}{c|}{ Variabilidade } \\
\hline Média & 0 & Desvio-padrão & 0 \\
\hline Mediana & 0 & Variância & 0 \\
\hline Moda & 0 & Amplitude & 0 \\
\hline & & Amplitude interquartil & 0 \\
\hline
\end{tabular}

\begin{tabular}{|l|l|l|l|l|}
\hline \multicolumn{4}{|c|}{ Testes de Posição: $\mathrm{Mu0}=0$} \\
\hline Teste & \multicolumn{2}{|c|}{ Estatística } & \multicolumn{2}{c|}{ Valor $\mathbf{p}$} \\
\hline Student t & t &, & $\operatorname{Pr}>|t|$ & \\
\hline Sign & M &, & $\operatorname{Pr}>=|\mathrm{M}|$ & \\
\hline Signed Rank & S &, & $\operatorname{Pr}>=|\mathrm{S}|$ & \\
\hline
\end{tabular}

\begin{tabular}{|l|r|}
\hline \multicolumn{2}{|c|}{ Quantis } \\
\hline Level & 0 \\
\hline $100 \%$ Max & 0 \\
\hline $99 \%$ & 0 \\
\hline $95 \%$ & 0 \\
\hline $90 \%$ & 0 \\
\hline $75 \%$ Q3 & 0 \\
\hline $50 \%$ Mediana & 0 \\
\hline $25 \%$ Q1 & 0 \\
\hline $10 \%$ & 0 \\
\hline $5 \%$ & 0 \\
\hline $1 \%$ & 0 \\
\hline $0 \%$ Min & \\
\hline
\end{tabular}


Variável

dependente:

ACI

ID $=117$

\begin{tabular}{|r|r|r|r|}
\hline \multicolumn{3}{|c|}{ Observações Limite } \\
\hline \multicolumn{2}{|c|}{ Baixa } & \multicolumn{2}{c|}{ Alta } \\
\hline Valor & Obs & Valor & Obs \\
\hline 0 & 1653 & 0 & 1650 \\
\hline 0 & 1652 & 0 & 1651 \\
\hline 0 & 1651 & 0 & 1652 \\
\hline 0 & 1650 & 0 & 1653 \\
\hline
\end{tabular}


Variável

dependente:

REC

ID $=118$

\begin{tabular}{|l|r|l|r|}
\hline \multicolumn{3}{|c|}{ Momento } \\
\hline N & 17 & Soma dos pesos & 17 \\
\hline Média & $\begin{array}{r}0 \\
\text { Soma das } \\
\text { observações }\end{array}$ & 0 \\
\hline Desvio-padrão & 0 & Variância & 0 \\
\hline Assimetria &, Curtose &, \\
\hline $\begin{array}{l}\text { Soma dos } \\
\text { quadrados não } \\
\text { corrigida }\end{array}$ & 0 & $\begin{array}{l}\text { Soma dos } \\
\text { quadrados corrigida }\end{array}$ & 0 \\
\hline CV Pearson &, & Erro-padrão médio & 0 \\
\hline
\end{tabular}

\begin{tabular}{|l|r|l|r|}
\hline \multicolumn{3}{|c|}{ Estatística Descritiva Básica } \\
\hline \multicolumn{2}{|c|}{ Posição } & \multicolumn{2}{c|}{ Variabilidade } \\
\hline Média & 0 & Desvio-padrão & 0 \\
\hline Mediana & 0 & Variância & 0 \\
\hline Moda & 0 & Amplitude & 0 \\
\hline & & Amplitude interquartil & 0 \\
\hline
\end{tabular}

\begin{tabular}{|l|l|l|l|l|}
\hline \multicolumn{4}{|c|}{ Testes de Posição: Mu0=0 } \\
\hline Teste & \multicolumn{2}{|c|}{ Estatística } & \multicolumn{2}{c|}{ Valor $\mathbf{p}$} \\
\hline Student t & t & \multicolumn{1}{|c|}{, $\operatorname{Pr}>|\mathbf{t}|$} & \\
\hline Sign & M &, & $\operatorname{Pr}>=|\mathrm{M}|$ & \\
\hline Signed Rank & S &, & $\operatorname{Pr}>=|\mathrm{S}|$ & \\
\hline
\end{tabular}

\begin{tabular}{|l|r|}
\hline \multicolumn{2}{|c|}{ Quantis } \\
\hline Level & 0 \\
\hline $100 \%$ Max & 0 \\
\hline $99 \%$ & 0 \\
\hline $95 \%$ & 0 \\
\hline $90 \%$ & 0 \\
\hline $75 \%$ Q3 & 0 \\
\hline $50 \%$ Mediana & 0 \\
\hline $25 \%$ Q1 & 0 \\
\hline $10 \%$ & 0 \\
\hline $5 \%$ & 0 \\
\hline $1 \%$ & 0 \\
\hline $0 \%$ Min & 0 \\
\hline
\end{tabular}


Variável

dependente:

REC

ID $=118$

\begin{tabular}{|r|c|r|r|}
\hline \multicolumn{3}{|c|}{ Observações Limite } \\
\hline \multicolumn{2}{|c|}{ Baixa } & \multicolumn{2}{c|}{ Alta } \\
\hline Valor & Obs & Valor & Obs \\
\hline 0 & 1670 & 0 & 1666 \\
\hline 0 & 1669 & 0 & 1667 \\
\hline 0 & 1668 & 0 & 1668 \\
\hline 0 & 1667 & 0 & 1669 \\
\hline 0 & 1666 & 0 & 1670 \\
\hline
\end{tabular}


Variável

dependente:

ACI

ID $=118$

\begin{tabular}{|l|r|l|r|}
\hline \multicolumn{3}{|c|}{ Momento } \\
\hline N & 17 & Soma dos pesos & 17 \\
\hline Média & $\begin{array}{r}0 \\
\text { Soma das } \\
\text { observações }\end{array}$ & 0 \\
\hline Desvio-padrão & 0 & Variância & 0 \\
\hline Assimetria &, Curtose &, \\
\hline $\begin{array}{l}\text { Soma dos } \\
\text { quadrados não } \\
\text { corrigida }\end{array}$ & 0 & $\begin{array}{l}\text { Soma dos } \\
\text { quadrados corrigida }\end{array}$ & 0 \\
\hline CV Pearson &, & Erro-padrão médio & 0 \\
\hline
\end{tabular}

\begin{tabular}{|l|r|l|r|}
\hline \multicolumn{3}{|c|}{ Estatística Descritiva Básica } \\
\hline \multicolumn{2}{|c|}{ Posição } & \multicolumn{2}{c|}{ Variabilidade } \\
\hline Média & 0 & Desvio-padrão & 0 \\
\hline Mediana & 0 & Variância & 0 \\
\hline Moda & 0 & Amplitude & 0 \\
\hline & & Amplitude interquartil & 0 \\
\hline
\end{tabular}

\begin{tabular}{|l|l|l|l|l|}
\hline \multicolumn{4}{|c|}{ Testes de Posição: $\mathbf{M u 0}=0$} \\
\hline Teste & \multicolumn{2}{|c|}{ Estatística } & \multicolumn{2}{|c|}{ Valor $\mathbf{p}$} \\
\hline Student $\mathbf{t}$ & $\mathbf{t}$ &, $\operatorname{Pr}>|\mathbf{t}|$ & \\
\hline Sign & $\mathbf{M}$ &, $\operatorname{Pr}>=|\mathrm{M}|$ & \\
\hline Signed Rank & $\mathbf{S}$ &, & $\operatorname{Pr}>=|\mathrm{S}|$ & \\
\hline
\end{tabular}

\begin{tabular}{|l|r|}
\hline \multicolumn{2}{|c|}{ Quantis } \\
\hline Level & 0 \\
\hline $100 \%$ Max & 0 \\
\hline $99 \%$ & 0 \\
\hline $95 \%$ & 0 \\
\hline $90 \%$ & 0 \\
\hline $75 \%$ Q3 & 0 \\
\hline $50 \%$ Mediana & 0 \\
\hline $25 \%$ Q1 & 0 \\
\hline $10 \%$ & 0 \\
\hline $5 \%$ & 0 \\
\hline $1 \%$ & 0 \\
\hline $0 \%$ Min & \\
\hline
\end{tabular}


Variável

dependente:

ACI

ID $=118$

\begin{tabular}{|r|c|r|r|}
\hline \multicolumn{3}{|c|}{ Observações Limite } \\
\hline \multicolumn{2}{|c|}{ Baixa } & \multicolumn{2}{c|}{ Alta } \\
\hline Valor & Obs & Valor & Obs \\
\hline 0 & 1670 & 0 & 1666 \\
\hline 0 & 1669 & 0 & 1667 \\
\hline 0 & 1668 & 0 & 1668 \\
\hline 0 & 1667 & 0 & 1669 \\
\hline 0 & 1666 & 0 & 1670 \\
\hline
\end{tabular}


Variável

dependente:

REC

ID $=119$

\begin{tabular}{|l|r|l|r|}
\hline \multicolumn{3}{|c|}{ Momento } \\
\hline N & 16 & Soma dos pesos & 16 \\
\hline Média & $\begin{array}{r}0 \\
\text { Soma das } \\
\text { observações }\end{array}$ & 0 \\
\hline Desvio-padrão & 0 & Variância & 0 \\
\hline Assimetria &, Curtose &, \\
\hline $\begin{array}{l}\text { Soma dos } \\
\text { quadrados não } \\
\text { corrigida }\end{array}$ & 0 & $\begin{array}{l}\text { Soma dos } \\
\text { quadrados corrigida }\end{array}$ & 0 \\
\hline CV Pearson &, & Erro-padrão médio & 0 \\
\hline
\end{tabular}

\begin{tabular}{|l|r|l|r|}
\hline \multicolumn{3}{|c|}{ Estatística Descritiva Básica } \\
\hline \multicolumn{2}{|c|}{ Posição } & \multicolumn{2}{c|}{ Variabilidade } \\
\hline Média & 0 & Desvio-padrão & 0 \\
\hline Mediana & 0 & Variância & 0 \\
\hline Moda & 0 & Amplitude & 0 \\
\hline & & Amplitude interquartil & 0 \\
\hline
\end{tabular}

\begin{tabular}{|l|l|l|l|l|}
\hline \multicolumn{4}{|c|}{ Testes de Posição: Mu0=0 } \\
\hline Teste & \multicolumn{2}{|c|}{ Estatística } & \multicolumn{2}{c|}{ Valor $\mathbf{p}$} \\
\hline Student $\mathbf{t}$ & $\mathbf{t}$ & \multicolumn{1}{|c|}{, $\operatorname{Pr}>|\mathbf{t}|$} & \\
\hline Sign & $\mathrm{M}$ &, & $\operatorname{Pr}>=|\mathrm{M}|$ & \\
\hline Signed Rank & S &, & $\operatorname{Pr}>=|\mathrm{S}|$ & \\
\hline
\end{tabular}

\begin{tabular}{|l|r|}
\hline \multicolumn{2}{|c|}{ Quantis } \\
\hline Level & 0 \\
\hline $100 \%$ Max & 0 \\
\hline $99 \%$ & 0 \\
\hline $95 \%$ & 0 \\
\hline $90 \%$ & 0 \\
\hline $75 \%$ Q3 & 0 \\
\hline $50 \%$ Mediana & 0 \\
\hline $25 \%$ Q1 & 0 \\
\hline $10 \%$ & 0 \\
\hline $5 \%$ & 0 \\
\hline $1 \%$ & 0 \\
\hline $0 \%$ Min & 0 \\
\hline
\end{tabular}


Variável

dependente:

REC

ID $=119$

\begin{tabular}{|r|c|r|r|}
\hline \multicolumn{3}{|c|}{ Observações Limite } \\
\hline \multicolumn{2}{|c|}{ Baixa } & \multicolumn{2}{c|}{ Alta } \\
\hline Valor & Obs & Valor & Obs \\
\hline 0 & 1686 & 0 & 1682 \\
\hline 0 & 1685 & 0 & 1683 \\
\hline 0 & 1684 & 0 & 1684 \\
\hline 0 & 1683 & 0 & 1685 \\
\hline 0 & 1682 & 0 & 1686 \\
\hline
\end{tabular}


Variável

dependente:

ACI

ID $=119$

\begin{tabular}{|l|r|l|r|}
\hline \multicolumn{3}{|c|}{ Momento } \\
\hline N & 16 & Soma dos pesos & 16 \\
\hline Média & $\begin{array}{r}0 \\
\text { Soma das } \\
\text { observações }\end{array}$ & 0 \\
\hline Desvio-padrão & 0 & Variância & 0 \\
\hline Assimetria &, Curtose &, \\
\hline $\begin{array}{l}\text { Soma dos } \\
\text { quadrados não } \\
\text { corrigida }\end{array}$ & 0 & $\begin{array}{l}\text { Soma dos } \\
\text { quadrados corrigida }\end{array}$ & 0 \\
\hline CV Pearson &, & Erro-padrão médio & 0 \\
\hline
\end{tabular}

\begin{tabular}{|l|r|l|r|}
\hline \multicolumn{3}{|c|}{ Estatística Descritiva Básica } \\
\hline \multicolumn{2}{|c|}{ Posição } & \multicolumn{2}{c|}{ Variabilidade } \\
\hline Média & 0 & Desvio-padrão & 0 \\
\hline Mediana & 0 & Variância & 0 \\
\hline Moda & 0 & Amplitude & 0 \\
\hline & & Amplitude interquartil & 0 \\
\hline
\end{tabular}

\begin{tabular}{|l|l|l|l|l|}
\hline \multicolumn{4}{|c|}{ Testes de Posição: Mu0=0 } \\
\hline Teste & \multicolumn{2}{|c|}{ Estatística } & \multicolumn{2}{c|}{ Valor $\mathbf{p}$} \\
\hline Student $\mathbf{t}$ & $\mathbf{t}$ & \multicolumn{1}{|c|}{, $\operatorname{Pr}>|\mathbf{t}|$} & \\
\hline Sign & $\mathrm{M}$ &, & $\operatorname{Pr}>=|\mathrm{M}|$ & \\
\hline Signed Rank & S &, & $\operatorname{Pr}>=|\mathrm{S}|$ & \\
\hline
\end{tabular}

\begin{tabular}{|l|r|}
\hline \multicolumn{2}{|c|}{ Quantis } \\
\hline Level & 0 \\
\hline $100 \%$ Max & 0 \\
\hline $99 \%$ & 0 \\
\hline $95 \%$ & 0 \\
\hline $90 \%$ & 0 \\
\hline $75 \%$ Q3 & 0 \\
\hline $50 \%$ Mediana & 0 \\
\hline $25 \%$ Q1 & 0 \\
\hline $10 \%$ & 0 \\
\hline $5 \%$ & 0 \\
\hline $1 \%$ & 0 \\
\hline $0 \%$ Min & 0 \\
\hline
\end{tabular}


Variável

dependente:

ACI

ID $=119$

\begin{tabular}{|r|c|r|r|}
\hline \multicolumn{3}{|c|}{ Observações Limite } \\
\hline \multicolumn{2}{|c|}{ Baixa } & \multicolumn{2}{c|}{ Alta } \\
\hline Valor & Obs & Valor & Obs \\
\hline 0 & 1686 & 0 & 1682 \\
\hline 0 & 1685 & 0 & 1683 \\
\hline 0 & 1684 & 0 & 1684 \\
\hline 0 & 1683 & 0 & 1685 \\
\hline 0 & 1682 & 0 & 1686 \\
\hline
\end{tabular}


Variável

dependente:

REC

ID $=120$

\begin{tabular}{|l|r|l|r|}
\hline \multicolumn{3}{|c|}{ Momento } \\
\hline N & 17 & Soma dos pesos & 17 \\
\hline Média & $\begin{array}{r}0 \\
\text { Soma das } \\
\text { observações }\end{array}$ & 0 \\
\hline Desvio-padrão & 0 & Variância & 0 \\
\hline Assimetria &, Curtose &, \\
\hline $\begin{array}{l}\text { Soma dos } \\
\text { quadrados não } \\
\text { corrigida }\end{array}$ & 0 & $\begin{array}{l}\text { Soma dos } \\
\text { quadrados corrigida }\end{array}$ & 0 \\
\hline CV Pearson &, & Erro-padrão médio & 0 \\
\hline
\end{tabular}

\begin{tabular}{|l|r|l|r|}
\hline \multicolumn{3}{|c|}{ Estatística Descritiva Básica } \\
\hline \multicolumn{2}{|c|}{ Posição } & \multicolumn{2}{c|}{ Variabilidade } \\
\hline Média & 0 & Desvio-padrão & 0 \\
\hline Mediana & 0 & Variância & 0 \\
\hline Moda & 0 & Amplitude & 0 \\
\hline & & Amplitude interquartil & 0 \\
\hline
\end{tabular}

\begin{tabular}{|l|l|l|l|l|}
\hline \multicolumn{4}{|c|}{ Testes de Posição: Mu0=0 } \\
\hline Teste & \multicolumn{2}{|c|}{ Estatística } & \multicolumn{2}{c|}{ Valor $\mathbf{p}$} \\
\hline Student $\mathbf{t}$ & $\mathbf{t}$ & \multicolumn{1}{|c|}{, $\operatorname{Pr}>|\mathbf{t}|$} & \\
\hline Sign & $\mathrm{M}$ &, & $\operatorname{Pr}>=|\mathrm{M}|$ & \\
\hline Signed Rank & S &, & $\operatorname{Pr}>=|\mathrm{S}|$ & \\
\hline
\end{tabular}

\begin{tabular}{|l|r|}
\hline \multicolumn{2}{|c|}{ Quantis } \\
\hline Level & 0 \\
\hline $100 \%$ Max & 0 \\
\hline $99 \%$ & 0 \\
\hline $95 \%$ & 0 \\
\hline $90 \%$ & 0 \\
\hline $75 \%$ Q3 & 0 \\
\hline $50 \%$ Mediana & 0 \\
\hline $25 \%$ Q1 & 0 \\
\hline $10 \%$ & 0 \\
\hline $5 \%$ & 0 \\
\hline $1 \%$ & 0 \\
\hline $0 \%$ Min & 0 \\
\hline
\end{tabular}


Variável

dependente:

REC

ID $=120$

\begin{tabular}{|r|r|r|r|}
\hline \multicolumn{3}{|c|}{ Observações Limite } \\
\hline \multicolumn{2}{|c|}{ Baixa } & \multicolumn{2}{c|}{ Alta } \\
\hline Valor & Obs & Valor & Obs \\
\hline 0 & 1703 & 0 & 1699 \\
\hline 0 & 1702 & 0 & 1700 \\
\hline 0 & 1701 & 0 & 1701 \\
\hline 0 & 1700 & 0 & 1702 \\
\hline 0 & 1699 & 0 & 1703 \\
\hline
\end{tabular}


Variável

dependente:

ACI

ID $=120$

\begin{tabular}{|l|r|l|r|}
\hline \multicolumn{3}{|c|}{ Momento } \\
\hline N & 17 & Soma dos pesos & 17 \\
\hline Média & $\begin{array}{r}0 \\
\text { Soma das } \\
\text { observações }\end{array}$ & 0 \\
\hline Desvio-padrão & 0 & Variância & 0 \\
\hline Assimetria &, Curtose &, \\
\hline $\begin{array}{l}\text { Soma dos } \\
\text { quadrados não } \\
\text { corrigida }\end{array}$ & 0 & $\begin{array}{l}\text { Soma dos } \\
\text { quadrados corrigida }\end{array}$ & 0 \\
\hline CV Pearson &, & Erro-padrão médio & 0 \\
\hline
\end{tabular}

\begin{tabular}{|l|r|l|r|}
\hline \multicolumn{3}{|c|}{ Estatística Descritiva Básica } \\
\hline \multicolumn{2}{|c|}{ Posição } & \multicolumn{2}{c|}{ Variabilidade } \\
\hline Média & 0 & Desvio-padrão & 0 \\
\hline Mediana & 0 & Variância & 0 \\
\hline Moda & 0 & Amplitude & 0 \\
\hline & & Amplitude interquartil & 0 \\
\hline
\end{tabular}

\begin{tabular}{|l|l|l|l|l|}
\hline \multicolumn{5}{|c|}{ Testes de Posição: $\mathrm{Mu0}=0$} \\
\hline Teste & \multicolumn{2}{|c|}{ Estatística } & \multicolumn{2}{c|}{ Valor $\mathbf{p}$} \\
\hline Student t & t &, & $\operatorname{Pr}>|t|$ & \\
\hline Sign & M &, & $\operatorname{Pr}>=|\mathrm{M}|$ & \\
\hline Signed Rank & S &, & $\operatorname{Pr}>=|\mathrm{S}|$ & \\
\hline
\end{tabular}

\begin{tabular}{|l|r|}
\hline \multicolumn{2}{|c|}{ Quantis } \\
\hline Level & 0 \\
\hline $100 \%$ Max & 0 \\
\hline $99 \%$ & 0 \\
\hline $95 \%$ & 0 \\
\hline $90 \%$ & 0 \\
\hline $75 \%$ Q3 & 0 \\
\hline $50 \%$ Mediana & 0 \\
\hline $25 \%$ Q1 & 0 \\
\hline $10 \%$ & 0 \\
\hline $5 \%$ & 0 \\
\hline $1 \%$ & 0 \\
\hline $0 \%$ Min & 0 \\
\hline
\end{tabular}


Variável

dependente:

ACI

ID $=120$

\begin{tabular}{|r|r|r|r|}
\hline \multicolumn{3}{|c|}{ Observações Limite } \\
\hline \multicolumn{2}{|c|}{ Baixa } & \multicolumn{2}{c|}{ Alta } \\
\hline Valor & Obs & Valor & Obs \\
\hline 0 & 1703 & 0 & 1699 \\
\hline 0 & 1702 & 0 & 1700 \\
\hline 0 & 1701 & 0 & 1701 \\
\hline 0 & 1700 & 0 & 1702 \\
\hline 0 & 1699 & 0 & 1703 \\
\hline
\end{tabular}


Variável

dependente:

REC

ID $=121$

\begin{tabular}{|l|r|l|r|}
\hline \multicolumn{3}{|c|}{ Momento } \\
\hline N & 18 & Soma dos pesos & 18 \\
\hline Média & $\begin{array}{r}0 \\
\text { Soma das } \\
\text { observações }\end{array}$ & 0 \\
\hline Desvio-padrão & 0 & Variância & 0 \\
\hline Assimetria &, Curtose &, \\
\hline $\begin{array}{l}\text { Soma dos } \\
\text { quadrados não } \\
\text { corrigida }\end{array}$ & 0 & $\begin{array}{l}\text { Soma dos } \\
\text { quadrados corrigida }\end{array}$ & 0 \\
\hline CV Pearson &, & Erro-padrão médio & 0 \\
\hline
\end{tabular}

\begin{tabular}{|l|r|l|r|}
\hline \multicolumn{3}{|c|}{ Estatística Descritiva Básica } \\
\hline \multicolumn{2}{|c|}{ Posição } & \multicolumn{2}{c|}{ Variabilidade } \\
\hline Média & 0 & Desvio-padrão & 0 \\
\hline Mediana & 0 & Variância & 0 \\
\hline Moda & 0 & Amplitude & 0 \\
\hline & & Amplitude interquartil & 0 \\
\hline
\end{tabular}

\begin{tabular}{|l|l|l|l|l|}
\hline \multicolumn{4}{|c|}{ Testes de Posição: Mu0=0 } \\
\hline Teste & \multicolumn{2}{|c|}{ Estatística } & \multicolumn{2}{c|}{ Valor $\mathbf{p}$} \\
\hline Student $\mathbf{t}$ & $\mathbf{t}$ & \multicolumn{1}{|c|}{, $\operatorname{Pr}>|\mathbf{t}|$} & \\
\hline Sign & $\mathrm{M}$ &, & $\operatorname{Pr}>=|\mathrm{M}|$ & \\
\hline Signed Rank & S &, & $\operatorname{Pr}>=|\mathrm{S}|$ & \\
\hline
\end{tabular}

\begin{tabular}{|l|r|}
\hline \multicolumn{2}{|c|}{ Quantis } \\
\hline Level & 0 \\
\hline $100 \%$ Max & 0 \\
\hline $99 \%$ & 0 \\
\hline $95 \%$ & 0 \\
\hline $90 \%$ & 0 \\
\hline $75 \%$ Q3 & 0 \\
\hline $50 \%$ Mediana & 0 \\
\hline $25 \%$ Q1 & 0 \\
\hline $10 \%$ & 0 \\
\hline $5 \%$ & 0 \\
\hline $1 \%$ & 0 \\
\hline $0 \%$ Min & 0 \\
\hline
\end{tabular}


Variável

dependente:

REC

ID $=121$

\begin{tabular}{|r|c|r|r|}
\hline \multicolumn{3}{|c|}{ Observações Limite } \\
\hline \multicolumn{2}{|c|}{ Baixa } & \multicolumn{2}{c|}{ Alta } \\
\hline Valor & Obs & Valor & Obs \\
\hline 0 & 1721 & 0 & 1717 \\
\hline 0 & 1720 & 0 & 1718 \\
\hline 0 & 1719 & 0 & 1719 \\
\hline 0 & 1718 & 0 & 1720 \\
\hline 0 & 1717 & 0 & 1721 \\
\hline
\end{tabular}


Variável

dependente:

ACI

ID $=121$

\begin{tabular}{|l|r|l|r|}
\hline \multicolumn{3}{|c|}{ Momento } \\
\hline N & 18 & Soma dos pesos & 18 \\
\hline Média & $\begin{array}{r}0 \\
\text { Soma das } \\
\text { observações }\end{array}$ & 0 \\
\hline Desvio-padrão & 0 & Variância & 0 \\
\hline Assimetria &, Curtose &, \\
\hline $\begin{array}{l}\text { Soma dos } \\
\text { quadrados não } \\
\text { corrigida }\end{array}$ & 0 & $\begin{array}{l}\text { Soma dos } \\
\text { quadrados corrigida }\end{array}$ & 0 \\
\hline CV Pearson &, & Erro-padrão médio & 0 \\
\hline
\end{tabular}

\begin{tabular}{|l|r|l|r|}
\hline \multicolumn{3}{|c|}{ Estatística Descritiva Básica } \\
\hline \multicolumn{2}{|c|}{ Posição } & \multicolumn{2}{c|}{ Variabilidade } \\
\hline Média & 0 & Desvio-padrão & 0 \\
\hline Mediana & 0 & Variância & 0 \\
\hline Moda & 0 & Amplitude & 0 \\
\hline & & Amplitude interquartil & 0 \\
\hline
\end{tabular}

\begin{tabular}{|l|l|l|l|l|}
\hline \multicolumn{5}{|c|}{ Testes de Posição: $\mathrm{Mu0}=0$} \\
\hline Teste & \multicolumn{2}{|c|}{ Estatística } & \multicolumn{2}{c|}{ Valor $\mathbf{p}$} \\
\hline Student t & t &, & $\operatorname{Pr}>|t|$ & \\
\hline Sign & M &, & $\operatorname{Pr}>=|\mathrm{M}|$ & \\
\hline Signed Rank & S &, & $\operatorname{Pr}>=|\mathrm{S}|$ & \\
\hline
\end{tabular}

\begin{tabular}{|l|r|}
\hline \multicolumn{2}{|c|}{ Quantis } \\
\hline Level & 0 \\
\hline $100 \%$ Max & 0 \\
\hline $99 \%$ & 0 \\
\hline $95 \%$ & 0 \\
\hline $90 \%$ & 0 \\
\hline $75 \%$ Q3 & 0 \\
\hline $50 \%$ Mediana & 0 \\
\hline $25 \%$ Q1 & 0 \\
\hline $10 \%$ & 0 \\
\hline $5 \%$ & 0 \\
\hline $1 \%$ & 0 \\
\hline $0 \%$ Min & 0 \\
\hline
\end{tabular}


Variável

dependente:

ACI

ID $=121$

\begin{tabular}{|r|c|r|r|}
\hline \multicolumn{3}{|c|}{ Observações Limite } \\
\hline \multicolumn{2}{|c|}{ Baixa } & \multicolumn{2}{c|}{ Alta } \\
\hline Valor & Obs & Valor & Obs \\
\hline 0 & 1721 & 0 & 1717 \\
\hline 0 & 1720 & 0 & 1718 \\
\hline 0 & 1719 & 0 & 1719 \\
\hline 0 & 1718 & 0 & 1720 \\
\hline 0 & 1717 & 0 & 1721 \\
\hline
\end{tabular}


Variável

dependente:

REC

ID $=122$

\begin{tabular}{|l|r|l|r|}
\hline \multicolumn{3}{|c|}{ Momento } \\
\hline Média & 18 & Soma dos pesos & 18 \\
\hline Desvio-padrão & 0,23570226 & $\begin{array}{l}\text { Variância } \\
\text { observações }\end{array}$ \\
\hline Assimetria & 4,24264069 & Curtose & 0,05555556 \\
\hline $\begin{array}{l}\text { Soma dos } \\
\text { quadrados não } \\
\text { corrigida }\end{array}$ & 1 & $\begin{array}{l}\text { Soma dos } \\
\text { quadrados corrigida }\end{array}$ & 0,94444444 \\
\hline CV Pearson & 424,264069 & Erro-padrão médio & 0,05555556 \\
\hline
\end{tabular}

\begin{tabular}{|l|l|l|r|}
\hline \multicolumn{4}{|c|}{ Estatística Descritiva Básica } \\
\hline \multicolumn{2}{|c|}{ Posição } & \multicolumn{2}{c|}{ Variabilidade } \\
\hline Média & 0,055556 & Desvio-padrão & 0,23570 \\
\hline Mediana & 0,000000 & Variância & 0,05556 \\
\hline Moda & 0,000000 & Amplitude & 1,00000 \\
\hline & & Amplitude interquartil & 0 \\
\hline
\end{tabular}

\begin{tabular}{|l|l|r|l|l|}
\hline \multicolumn{5}{|c|}{ Testes de Posição: Mu0=0 } \\
\hline Teste & \multicolumn{2}{|c|}{ Estatística } & \multicolumn{2}{c|}{ Valor $\mathbf{~}$} \\
\hline Student t & $\mathbf{t}$ & 1 & $\mathrm{Pr}>|\mathbf{t}|$ & 0,3313 \\
\hline Sign & $\mathbf{M}$ & 0,5 & $\mathrm{Pr}>=|\mathbf{M}|$ & 1,0000 \\
\hline Signed Rank & $\mathbf{S}$ & 0,5 & $\mathrm{Pr}>=|\mathbf{S}|$ & 1,0000 \\
\hline
\end{tabular}

\begin{tabular}{|l|r|}
\hline \multicolumn{2}{|c|}{ Quantis } \\
\hline Level & 1 \\
\hline $100 \%$ Max & 1 \\
\hline $99 \%$ & 1 \\
\hline $95 \%$ & 0 \\
\hline $90 \%$ & 0 \\
\hline $75 \%$ Quantil & 0 \\
\hline $50 \%$ Mediana & 0 \\
\hline $25 \%$ Q1 & 0 \\
\hline $10 \%$ & 0 \\
\hline $5 \%$ & 0 \\
\hline $1 \%$ & 0 \\
\hline $0 \%$ Min & \\
\hline
\end{tabular}


Variável

dependente:

REC

ID $=122$

\begin{tabular}{|r|c|r|r|}
\hline \multicolumn{3}{|c|}{ Observações Limite } \\
\hline \multicolumn{2}{|c|}{ Baixa } & \multicolumn{2}{c|}{ Alta } \\
\hline Valor & Obs & Valor & Obs \\
\hline 0 & 1739 & 0 & 1736 \\
\hline 0 & 1738 & 0 & 1737 \\
\hline 0 & 1737 & 0 & 1738 \\
\hline 0 & 1736 & 0 & 1739 \\
\hline 0 & 1735 & 1 & 1723 \\
\hline
\end{tabular}


Variável

dependente:

ACI

ID $=122$

\begin{tabular}{|l|r|l|r|}
\hline \multicolumn{3}{|c|}{ Momento } \\
\hline N & 18 & Soma dos pesos & 18 \\
\hline Média & $\begin{array}{r}0 \\
\text { Soma das } \\
\text { observações }\end{array}$ & 0 \\
\hline Desvio-padrão & 0 & Variância & 0 \\
\hline Assimetria &, Curtose &, \\
\hline $\begin{array}{l}\text { Soma dos } \\
\text { quadrados não } \\
\text { corrigida }\end{array}$ & 0 & $\begin{array}{l}\text { Soma dos } \\
\text { quadrados corrigida }\end{array}$ & 0 \\
\hline CV Pearson &, & Erro-padrão médio & 0 \\
\hline
\end{tabular}

\begin{tabular}{|l|r|l|r|}
\hline \multicolumn{3}{|c|}{ Estatística Descritiva Básica } \\
\hline \multicolumn{2}{|c|}{ Posição } & \multicolumn{2}{c|}{ Variabilidade } \\
\hline Média & 0 & Desvio-padrão & 0 \\
\hline Mediana & 0 & Variância & 0 \\
\hline Moda & 0 & Amplitude & 0 \\
\hline & & Amplitude interquartil & 0 \\
\hline
\end{tabular}

\begin{tabular}{|l|l|l|l|l|}
\hline \multicolumn{5}{|c|}{ Testes de Posição: $\mathrm{Mu0}=0$} \\
\hline Teste & \multicolumn{2}{|c|}{ Estatística } & \multicolumn{2}{c|}{ Valor $\mathbf{p}$} \\
\hline Student t & t &, & $\operatorname{Pr}>|t|$ & \\
\hline Sign & M &, & $\operatorname{Pr}>=|\mathrm{M}|$ & \\
\hline Signed Rank & S &, & $\operatorname{Pr}>=|\mathrm{S}|$ & \\
\hline
\end{tabular}

\begin{tabular}{|l|r|}
\hline \multicolumn{2}{|c|}{ Quantis } \\
\hline Level & 0 \\
\hline $100 \%$ Max & 0 \\
\hline $99 \%$ & 0 \\
\hline $95 \%$ & 0 \\
\hline $90 \%$ & 0 \\
\hline $75 \%$ Q3 & 0 \\
\hline $50 \%$ Mediana & 0 \\
\hline $25 \%$ Q1 & 0 \\
\hline $10 \%$ & 0 \\
\hline $5 \%$ & 0 \\
\hline $1 \%$ & 0 \\
\hline $0 \%$ Min & 0 \\
\hline
\end{tabular}


Variável

dependente:

ACI

ID $=122$

\begin{tabular}{|r|r|r|r|}
\hline \multicolumn{3}{|c|}{ Observações Limite } \\
\hline \multicolumn{2}{|c|}{ Baixa } & \multicolumn{2}{c|}{ Alta } \\
\hline Valor & Obs & Valor & Obs \\
\hline 0 & 1739 & 0 & 1735 \\
\hline 0 & 1738 & 0 & 1736 \\
\hline 0 & 1737 & 0 & 1737 \\
\hline 0 & 1736 & 0 & 1738 \\
\hline 0 & 1735 & 0 & 1739 \\
\hline
\end{tabular}


Variável dependente:

REC

ID $=123$

\begin{tabular}{|l|r|l|r|}
\hline \multicolumn{3}{|c|}{ Momento } \\
\hline N & 18 & Soma dos pesos & 18 \\
\hline Média & $\begin{array}{l}0 \\
\text { Soma das } \\
\text { observações }\end{array}$ & 0 \\
\hline Desvio-padrão & 0 & Variância & 0 \\
\hline Assimetria &, Curtose &, \\
\hline $\begin{array}{l}\text { Soma dos } \\
\text { quadrados não } \\
\text { corrigida }\end{array}$ & $0 \begin{array}{l}\text { Soma dos } \\
\text { quadrados corrigida }\end{array}$ & 0 \\
\hline CV Pearson &, & Erro-padrão médio & 0 \\
\hline
\end{tabular}

\begin{tabular}{|l|r|l|r|}
\hline \multicolumn{3}{|c|}{ Estatística Descritiva Básica } \\
\hline \multicolumn{2}{|c|}{ Posição } & \multicolumn{2}{c|}{ Variabilidade } \\
\hline Média & 0 & Desvio-padrão & 0 \\
\hline Mediana & 0 & Variância & 0 \\
\hline Moda & 0 & Amplitude & 0 \\
\hline & & Amplitude interquartil & 0 \\
\hline
\end{tabular}

\begin{tabular}{|l|l|l|l|l|}
\hline \multicolumn{4}{|c|}{ Testes de Posição: Mu0=0 } \\
\hline Teste & \multicolumn{2}{|c|}{ Estatística } & \multicolumn{2}{c|}{ Valor $\mathbf{p}$} \\
\hline Student t & $\mathbf{t}$ &, & $\operatorname{Pr}>|\mathbf{t}|$ & \\
\hline Sign & M &, & $\operatorname{Pr}>=|\mathrm{M}|$ & \\
\hline Signed Rank & S &, & $\operatorname{Pr}>=|\mathrm{S}|$ & \\
\hline
\end{tabular}

\begin{tabular}{|l|r|}
\hline \multicolumn{2}{|c|}{ Quantis } \\
\hline Level & 0 \\
\hline $100 \%$ Max & 0 \\
\hline $99 \%$ & 0 \\
\hline $95 \%$ & 0 \\
\hline $90 \%$ & 0 \\
\hline $75 \%$ Q3 & 0 \\
\hline $50 \%$ Mediana & 0 \\
\hline $25 \%$ Q1 & 0 \\
\hline $10 \%$ & 0 \\
\hline $5 \%$ & 0 \\
\hline $1 \%$ & 0 \\
\hline $0 \%$ Min & 0 \\
\hline
\end{tabular}


Variável dependente:

REC

ID $=123$

\begin{tabular}{|r|r|r|r|}
\hline \multicolumn{3}{|c|}{ Observações Limite } \\
\hline \multicolumn{2}{|c|}{ Baixa } & \multicolumn{2}{c|}{ Alta } \\
\hline Valor & Obs & Valor & Obs \\
\hline 0 & 1757 & 0 & 1753 \\
\hline 0 & 1756 & 0 & 1754 \\
\hline 0 & 1755 & 0 & 1755 \\
\hline 0 & 1754 & 0 & 1756 \\
\hline 0 & 1753 & 0 & 1757 \\
\hline
\end{tabular}


Variável dependente:

ACI

ID $=123$

\begin{tabular}{|l|r|l|r|}
\hline \multicolumn{3}{|c|}{ Momento } \\
\hline N & 18 & Soma dos pesos & 18 \\
\hline Média & 0 & $\begin{array}{l}\text { Soma das } \\
\text { observações }\end{array}$ & 0 \\
\hline Desvio-padrão & 0 & Variância & 0 \\
\hline Assimetria &, & Curtose &, \\
\hline $\begin{array}{l}\text { Soma dos } \\
\text { quadrados não } \\
\text { corrigida }\end{array}$ & 0 & $\begin{array}{l}\text { Soma dos } \\
\text { quadrados corrigida }\end{array}$ & 0 \\
\hline CV Pearson &, & Erro-padrão médio & 0 \\
\hline
\end{tabular}

\begin{tabular}{|l|r|l|r|}
\hline \multicolumn{3}{|c|}{ Estatística Descritiva Básica } \\
\hline Posição & \multicolumn{2}{c|}{ Variabilidade } \\
\hline Média & 0 & Desvio-padrão & 0 \\
\hline Mediana & 0 & Variância & 0 \\
\hline Moda & 0 & Amplitude & 0 \\
\hline & & Amplitude interquartil & 0 \\
\hline
\end{tabular}

\begin{tabular}{|l|l|l|l|l|}
\hline \multicolumn{4}{|c|}{ Testes de Posição: Mu0=0 } \\
\hline Teste & \multicolumn{2}{|c|}{ Estatística } & \multicolumn{2}{c|}{ Valor $\mathbf{p}$} \\
\hline Student t & $\mathbf{t}$ &, & $\operatorname{Pr}>|\mathbf{t}|$ & \\
\hline Sign & $\mathrm{M}$ &, & $\mathrm{Pr}>=|\mathrm{M}|$ & \\
\hline Signed Rank & $\mathrm{S}$ &, & $\operatorname{Pr}>=|\mathrm{S}|$ & \\
\hline
\end{tabular}

\begin{tabular}{|l|r|}
\hline \multicolumn{2}{|c|}{ Quantis } \\
\hline Level & Quantil \\
\hline $100 \%$ Max & 0 \\
\hline $99 \%$ & 0 \\
\hline $95 \%$ & 0 \\
\hline $90 \%$ & 0 \\
\hline $75 \%$ Q3 & 0 \\
\hline $50 \%$ Mediana & 0 \\
\hline $25 \%$ Q1 & 0 \\
\hline $10 \%$ & 0 \\
\hline $5 \%$ & 0 \\
\hline $1 \%$ & 0 \\
\hline $0 \%$ Min & 0 \\
\hline
\end{tabular}


Variável dependente:

ACI

$$
\text { ID }=123
$$

\begin{tabular}{|r|r|r|r|}
\hline \multicolumn{3}{|c|}{ Observações Limite } \\
\hline \multicolumn{2}{|c|}{ Baixa } & \multicolumn{2}{c|}{ Alta } \\
\hline Valor & Obs & Valor & Obs \\
\hline 0 & 1757 & 0 & 1753 \\
\hline 0 & 1756 & 0 & 1754 \\
\hline 0 & 1755 & 0 & 1755 \\
\hline 0 & 1754 & 0 & 1756 \\
\hline 0 & 1753 & 0 & 1757 \\
\hline
\end{tabular}




\section{Anexo 3}

\section{UMA BREVE INTRODUÇÃO A MLG/MLGM E FORMALIZAÇÃO DO MODELO ZINB}

\section{A3.1. Uma breve introdução aos Modelos Lineares Generalizados (MLG)}

Uma vez selecionada a distribuição BN como a mais adequada para os nossos propósitos neste estudo, retomaremos a discussão da literatura de modelos para avançar na especificação das correções necessárias para esta pesquisa. Há uma extensa discussão na literatura sobre a utilização de distribuições Poisson e BN no tratamento de modelos de regressão para dados de contagem e correção para excessos de zeros (BARRON, 1992; LINDSEY, 1995; GUPTA et al., 1996; LONG, 1997; WINKELMANN, 2003; DOBSON, BARNETT, 2008; CAMERON, TRIVEDI, 2013).

A literatura mostra que a abordagem dos Modelos Lineares Generalizados (MLG) é a mais promissora. Modelos aplicados não lineares de análise para dados não-normais começaram a ser utilizados na década de 1930 na pesquisa biomédica, posteriormente sendo difundidos para diferentes áreas de pesquisa (McCULLOCH et al, 2008).

No entanto, apenas na década de 1970 estes modelos foram sistematizados e homogeneizados como uma nova classe de modelos para o tratamento de regressão não linear, por meio do trabalho seminal de Nelder e Wedderburn (1972). A partir de então, esta classe de modelos passou a ser conhecida como Modelos Lineares Generalizados.

As principais características dos MLG são:

i) Possuir um componente aleatório que especifica a distribuição condicional da variável resposta $Y$. Ou seja, a variável $Y$ é tratada como um vetor $Y_{i}=\left(Y_{1} \ldots Y_{n}\right)$ de variáveis aleatórias independentes que seguem uma distribuição de densidade linear da família de distribuições exponenciais $Y_{i} \sim f Y_{i}\left(y_{i} ; \theta_{i}, \Phi\right)=\exp \left\{\Phi^{-1}\left[y_{i} \theta_{i}-b\left(\theta_{i}\right)\right]+c\left(y_{i}, \Phi\right)\right\}$. Sendo $\Phi^{-1} \mathrm{o}$ parâmetro de dispersão da distribuição; $\theta_{i}$ seu parâmetro de posição; $b\left(\theta_{i}\right)$ uma função de variação exclusivamente da posição; e $c\left(y_{i}, \Phi\right)$ uma função não constante dependente apenas de $y_{i}$ (o valor de uma observação específica de $y$ ) e/ou $\Phi$ (o inverso do parâmetro de dispersão). Alguns dos principais exemplos de distribuições da família exponencial são Normal, Gama, Binomial, Poisson, Binomial Negativa, dentre outras; 
ii) Possuir um preditor linear como função dos regressores $\eta_{i}=\beta_{1} X_{i 1}+\ldots+\beta_{p} X_{i p}$, sendo composto por um vetor $p$ de variáveis explicativas formado por $X_{i}^{T}=\left(X_{i 1}, \ldots, X_{i p}\right)$ para cada unidade observacional $i$ (cada país em nosso caso) e por um vetor de $p$ parâmetros $\left.\beta=\beta_{1}, \ldots, \beta_{p}\right)^{T}$; e

iii) Por fim, deve possuir uma função de ligação dada por $h($.) entre seu componente aleatório e seu preditor linear, de forma a relacionar o parâmetro de posição com o vetor de variáveis resposta. Esta função de ligação deve ser duplamente diferenciável, ou seja, sua derivada de segunda ordem deve existir de modo a dar a direção do efeito. Alternativamente, $h($.) pode ser modelada por uma transformação da média (valor esperado) pois esta é função de $\theta_{i}$, como função linear dos parâmetros, ou seja, com $h\left(E\left(Y_{i}\right)\right)=h\left(\mu_{i}\right)=X_{i}^{T} \beta$.

No desenho de um modelo MLG é fundamental a correta escolha de qual modelo de distribuição da família exponencial será utilizada. Em nosso caso nós já selecionamos a distribuição binomial negativa como a mais adequada em nossa modelagem. Vamos, portanto, apresentar a seguir a BN dentro desta abordagem.

Observando-se uma sequência de ensaios de Bernoulli independentes, cada um com resultado dicotômico de sucesso ou fracasso dados pelas probabilidades $p$ e $(1-p)$, respectivamente, até que um número $r$ previamente definido de fracassos ocorra, teremos uma variável aleatória independente $Y$ com distribuição binomial negativa dada pela função $Y \sim B N(r, p)$. A função de probabilidade da $B N$ definida por $(r, p)$ é dada por:

$\left.f Y(y ; r, p)=P(y=Y)=\frac{(y+r-1) !}{y !(r-1) !}\right] p^{y}(1-p)^{r}, y=0,1,2,3, \ldots$ (dados de contagem).

O valor esperado e a variância de $Y$ são dessa forma dados respectivamente por:

$E(Y)=\frac{p r}{1-p} ; e \operatorname{Var}(Y)=\frac{p r}{(1-p)^{2}}$

Em casos de superdispersão da variável $Y$, como neste trabalho, é possível admitir que a variável resposta $Y$ siga uma distribuição Poisson condicionada aos parâmetros da função de probabilidade da BN. Dessa forma, neste caso particular da distribuição Poisson os parâmetros da distribuição podem ser dados por variáveis aleatórias com 
distribuições previamente conhecidas.

Como consequência, uma distribuição marginal de $Y$ será do tipo $B N$ caso a distribuição a priori dos parâmetros for do tipo Gama. Assim, considerando duas variáveis aleatórias $Y$ e $Z$, na qual $Y \mid Z$ siga uma distribuição Poisson e a distribuição a priori de $Z$ seja Gama com parâmetros $\Phi \mu$ e $\Phi$, teremos:

$Y \mid Z \sim P o(Z) ;$ sendo $f Y \mid Z(y \mid z)=e^{-z} y ! Z^{y} 1\{0,1, \ldots\}$ (y); e

$Z \sim G(\Phi \mu, \Phi) ;$ sendo $g Z(z)=\frac{\left(\Phi^{\varphi \mu}\right)}{\Gamma(\Phi \mu)} z^{\Phi \mu-1} e^{-\Phi_{z}} 1(0, \infty)(z)$

A integração da distribuição conjunta de $Y$ e $Z$ em relação a $Z$ determinará a distribuição marginal de $Y$, sendo $Y \sim B N(\Phi \mu, \Phi /(\Phi+1))$ onde:

$f Y(y)=\frac{(y+\Phi \mu-1) !}{y !(\Phi \mu-1) !}\left[\frac{(\Phi)}{(\Phi+1)}\right]^{\Phi_{\mu}}\left[\frac{(1)}{(\Phi+1)}\right]^{\nu} 1_{\{0,1, \ldots\}}(y)$

Com isto é possível demonstrar que $E(Y)=\mu$ e que $\operatorname{Var}(Y)=\mu(\Phi+1) / \Phi$.

Alternativamente, pode-se considerar $Y \mid Z \sim P o(Z)$ onde a distribuição de $Z$ é a priori do tipo Gama e seus parâmetros são $v$ e $\mu / v$ onde:

$Y \mid Z \sim P o(Z)$, sendo $f Y \mid Z(y \mid z)=e^{-z} y ! \quad Z^{y} 1\{0,1, \ldots\}$

$Z \sim G(v, \mu / v)$, sendo $g Z(z)=\frac{(\mu / v)^{v} Z^{v-1}}{\Gamma(v)} e^{-z(v / \mu)} 1(0, \infty)(z)$

Dessa forma, teremos a função de distribuição de $Y$ dada por uma distribuição binomial com função de variância quadrática determinada por:

$$
f Y(y)=\frac{(y+v-1) !}{y !(v-1) !}\left[\frac{(v / \mu)}{(v / \mu+1)}\right]^{v}\left[\frac{(1)}{(v / \mu+1)}\right]^{y} 1_{\{0,1, \ldots\}}(y)
$$

Assim, de forma análoga, teremos que $E(Y)=\mu$ e $\operatorname{Var}(Y)=\mu+\mu^{2} / V$. Ou seja, a variância de $Y$ será sempre maior do que o valor esperado de $Y$ (a média $\mu$ ). Esta é uma 
propriedade extremamente importante deste modelo no tratamento de dados com superdispersão como no caso deste estudo.

\section{A3.2. Uma breve discussão dos Modelos Lineares Generalizados Mistos (MLGM)}

Os MLG podem ser estendidos de modo a comportarem efeitos aleatórios em seus preditores lineares. A literatura denomina a extensão dos MLG (efeitos fixos) com efeitos aleatórios em mais de um nível do modelo como Modelos Lineares Generalizados Mistos (MLGM) (MCCULOCH, SEARLE, Ibid; HOX et al, 2010; MANCO, 2013; HOFFMAN, 2015; ROBSON, PEVALIN, 2016). Por esta razão, esta classe de modelos é também chamada de modelos condicionais, multiníveis ou hierárquicos.

Os efeitos aleatórios introduzidos pelo modelo misto são dessa forma um componente probabilístico condicional que visa capturar a variabilidade da variável resposta em relação às diferentes unidades de observação. Esta variabilidade é gerada pela possibilidade do modelo de introduzir efeitos aleatórios no intercepto e nos coeficientes (parâmetros) associados ao conjunto de variáveis explicativas.

Dada a distribuição condicional da variável resposta $Y$ para um determinado vetor $u$, sendo $Y \circ$ vetor de respostas compostas por elementos condicionalmente independentes (mas não necessariamente) com densidade no arcabouço da família exponencial, temos:

$$
\begin{aligned}
& Y_{i} \mid u \sim \text { indep. } f Y_{i} \mid u\left(y_{i} \mid u\right) \\
& f Y_{i} \mid u\left(y_{i} \mid u\right)=\exp \left\{\frac{w_{i}}{\Phi}\left[y_{i} \theta_{i}-b\left(\theta_{i}\right)\right]+c\left(y_{i} ; \Phi\right)\right\} \\
& \mu_{i}=\frac{\partial b\left(\theta_{i}\right)}{\partial \theta_{i}}
\end{aligned}
$$

De forma que:

$E\left(Y_{i} \mid u\right)=\mu_{i} ;$ e $g\left(\mu_{i}\right)=x_{i}^{\prime} \beta+z_{i}^{\prime} u$

Sendo $g\left(\mu_{i}\right)$ a função de ligação padrão MLG $x_{i}^{\prime} \beta$, onde $x_{i}^{\prime}$ é a i-ésima linha de uma matriz de efeitos fixos e $\beta$ o seu vetor de parâmetros de efeitos fixos, acrescida de um componente aleatório $z_{i}^{\prime} u$, onde $z_{i}^{\prime}$ é a i-ésima linha de uma matriz de efeitos aleatórios e $u$ é seu vetor de efeitos aleatórios. Dessa forma, a média condicional de $y_{i}$ 
para um determinado vetor $u$ será $\mu_{i}$.

Por sua vez, o vetor $u$ deverá seguir uma distribuição conhecida para seus efeitos aleatórios. O mais comum é assumir que os efeitos aleatórios possuam uma distribuição do tipo normal, ou seja, $u \sim N(0, G)$. O que dadas nossas observações teóricas e empíricas é uma premissa bastante razoável para a construção do nosso modelo. Em outros casos específicos pode ser justificável levantar suspeição sobre a não-normalidade dos efeitos aleatórios, situação onde outras técnicas deverão ser empregadas (LEE, NELDER, 1996).

Considerando a forma funcional do modelo condicional apresentado acima e sendo $a_{i}(\Phi)=w_{i} / \Phi$, temos que:

$E\left(Y_{i}\right)=E\left[E\left(Y_{i} \mid u\right)\right]=E\left[\mu_{i}\right]=E\left[g^{-1}\left(x_{i}^{\prime} \beta+z_{i}^{\prime} u\right)\right]$; sendo a variância marginal de $y$ dada por $\operatorname{Var}\left(Y_{i}\right)=\operatorname{Var}\left[E\left(Y_{i} \mid u\right)\right]+E\left[\operatorname{Var}\left(Y_{i} \mid u\right)\right]=\operatorname{Var}\left[\mu_{i}\right]+E\left[a(\Phi) \operatorname{Var}\left(\mu_{i}\right)\right]$ $\operatorname{Var}\left(Y_{i}\right)=\operatorname{Var}\left[g^{-1}\left(x_{i}^{\prime} \beta+z_{i}^{\prime} u\right)\right]+E\left\{a_{i}(\Phi) \operatorname{Var}\left[g^{-1}\left(x_{i}^{\prime} \beta+z_{i}^{\prime} u\right)\right]\right\}$

A equação acima não pode ser simplificada a não ser que sejam estipuladas expressamente premissas a priori para a forma funcional de $g($ (.) ou para a distribuição condicional do vetor $Y$. Adicionalmente, a introdução de efeitos aleatórios no modelo acarretará no estabelecimento de correlação entre observações que possuam um ou mais efeitos comuns. Tomando-se a independência condicional das observações de $y$ teremos que:

$\operatorname{Cov}\left(Y_{i}, Y_{j}\right)=\operatorname{Cov}\left[E\left(Y_{i} \mid u\right), E\left(Y_{j} \mid u\right)\right]+E\left[\operatorname{Cov}\left(Y_{i}, Y_{j} \mid u\right)\right]=\operatorname{Cov}\left(\mu_{i}, \mu_{j}\right)+E(0)$

$\operatorname{Cov}\left(Y_{i}, Y_{j}\right)=\operatorname{Cov}\left[g^{-1}\left(x_{i}^{\prime} \beta+z_{i}^{\prime} u\right), g^{-1}\left(x_{j}^{\prime} \beta+z_{j}^{\prime} u\right)\right]$

Os estimadores específicos resultantes dependerão da distribuição da função da variável aleatória. Existem na literatura diferentes técnicas descritas para a estimação dos parâmetros deste modelo genérico, em uma abordagem de estimação por máxima verossimilhança podem ser utilizados estimadores por máxima verossimilhança adaptados dos modelos mistos gerais (SCHALL, 1991), estimador de máxima verossimilhança marginal (BRESLOW, CLAYTON, 1993), melhor preditor linear nãoviesado (McGILCHRIST, 1994), estimador de máxima verossimilhança hierárquico (LEE, NELDER, 2005), dentro outros. 
O próximo passo, portanto, no desenho de nosso modelo será agregar as propriedades dos modelos hierárquicos, ou multiníveis, para o tratamento de dados com estrutura longitudinal às qualidades de um modelo binomial negativo (com posterior correção por inflação de zeros) para modelagem de dados de contagem com superdispersão dentro da abordagem MLGM. Para isto faremos uma breve discussão do processo de integração de ambas as técnicas na construção de um modelo multinível de análise de dados longitudinais de contagem superdispersos.

O modelo BN multinível (MLGM) é similar ao modelo BN tradicional (MLG), porém, incorpora um conjunto de componentes aleatórios que introduzem a variabilidade necessária na hierarquização do modelo. Este tipo de modelo pode ser desenhado a partir de uma extensão do modelo linear generalizado. Para a estimação de seus parâmetros de máxima verossimilhança podemos utilizar técnicas de integração numérica como a quadratura de Gauss-Hermite (MANCO, Ibid). Nos casos em que dimensões de grande ordem estejam envolvidas, outras técnicas como Markov chain Monte Carlo (MCMC) podem ser utilizadas.

A quadratura de Gauss-Hermite consiste, em sua aplicação unidimensional, no processo de aproximação de integrais de forma funcional a seguir:

$\int_{-\infty}^{\infty} e^{-x^{2}} f(x) d x$; por meio de um polinômio de soma ponderada do tipapo $\underset{q}{Q} \sum w_{q} f\left(x_{q}\right)$.

Onde $f(x)$ (com $x \in R$ ) representa uma função regular e $x_{q}$ é o nó que representa a q-ésima raiz do polinômio de Hermite de ordem $Q$ :

$H_{Q}(x)=(-1)^{Q} e^{x^{2} / 2^{Q}\left(d^{-x} e / 2\right) / d x}$

Sendo os pesos de ponderação $w_{q}$ dependentes de $x_{q}$ e do número de nós $Q$, dados pela equação:

$w_{q}\left(x_{q}\right)=\left(2^{Q-1} Q ! \sqrt{ }\right) /\left(Q^{2}\left[H_{Q-1}\left(x_{q}\right)\right]^{2}\right)$.

A extensão da técnica de Gauss-Hermite para o nível multidimensional pode ser feita pela equação $g(x)=w(x) f(x)$; sendo $g(x)$ uma função regular em $R^{k} \rightarrow R$ com vetor de $k$ dimensões onde $x=\left(x_{1}, \ldots, x_{k}\right)$ e $w(x)$ uma função de pesos em $R^{k} \rightarrow R_{+}$. A técnica pode ser utilizada, por meio da equação de pesos dada por: 
$w(x)=\exp \left(-x^{T} x\right)=\exp \left(-x_{1}^{2}\right) \ldots \exp \left(-x_{k}^{2}\right) ;$ para aproximar uma integral de $k$ dimensões $(k$ níveis), conforme a seguir:

$\int R k g(x) d x \approx \int R \ldots \int R w\left(x_{1}, \ldots, x_{k}\right) f\left(x_{1}, \ldots, x_{k}\right) d x_{1} \ldots d z_{k}$

Assim para $Q_{r}$ em uma dimensão, ou nível, de número $r$ qualquer $(r=1, \ldots, k) \mathrm{e}$ sendo $x_{k r}^{r}$ a $k_{r}$-ésima raiz do polinômio de Hermite de ordem $Q_{r}$ e peso $W^{r}{ }_{k r}$ teremos uma aproximação do tipo:

$\int R k g(x) d x \approx \sum_{q=1}^{Q 1} w_{q 1}^{(1)} w_{q k=1}^{Q k} \sum_{k q}^{(k)} \stackrel{(1)}{w_{k q}} f\left(x_{q 1}, \ldots, x_{q k}\right)$

O desenho de um modelo BN multinível (e posteriormente a aplicação ZINB multinível) pode ser feito de quatro formas distintas em cada nível, a depender do tipo de efeitos que se busca estudar. Pode-se não introduzir efeitos aleatórios além do próprio algoritmo do $\mathrm{BN}$, pode-se introduzir aleatoriedade no intercepto, nos coeficientes, ou em ambos.

Conforme debatido no Capítulo 4, nossos modelos não incluirão efeitos aleatórios, apenas modelagem multinível hierárquica com uma mistura de distribuições com um componente logístico e um binomial negativo para dar conta da variabilidade do fenômeno estudado em ambas as dimensões. Em nossa programação iremos construir e estimar nossos próprios parâmetros em uma função de log-verossimilhança dentro de uma linguagem de programação de modelos não lineares mistos.

Portanto, supondo que o parâmetro $v_{i j}$ seja conhecido e que $y_{i j}$ seja para o iésimo país $(i=1, \ldots, n)$ a j-ésima observação $\left(j=1, \ldots, J_{i} ; t=1, \ldots, 18\right)$; seguindo o vetor resposta $Y_{i}=\left(y_{i 1}, \ldots, y_{i j i}\right)^{T}$ com parâmetros $v \in e[(v / u) / 1+(v / u)]$ uma distribuição Binomial Negativa; a função de densidade condicional da observação individual $J_{i}$ do iésimo país será dada por:

$$
\begin{aligned}
f\left(Y_{i} \mid \mu_{i}, v_{i}\right)= & \prod_{J=1}^{J i} f\left(y_{i j} ; v_{i j}, \frac{v_{i j} / \mu_{i j}}{1+v_{i j} / \mu_{i j}}\right) \\
& \prod_{J=1}^{J i} \frac{\left(y_{i j}+v_{i j}-1\right) !}{y_{i j} !\left(v_{i j}-1\right) !}\left(\frac{v_{i j} / \mu_{i j}}{v_{i j} / \mu_{i j}+1}\right)^{v i j}\left(\frac{1}{v_{i j} / \mu_{i j}+1}\right)^{y i j}
\end{aligned}
$$




$$
\prod_{j=1}^{J i} c_{1}\left(\frac{v_{i j} / \mu_{i j-}}{v_{i j} / \mu_{i j}+1}\right)^{v i j}\left(\frac{1}{v_{i j} / \mu_{i j}+1}\right)^{v i j} ; \text { onde } c_{1}=\frac{\left(y_{i j}+v_{i j}-1\right) !}{y_{i j} !\left(v_{i j}-1\right) !}
$$

O valor esperado e a variância serão, respectivamente, $E\left(Y_{i}\right)=\mu_{i}$ e $\operatorname{Var}\left(Y_{i}\right)=\mu_{i}+\left(\mu_{i}{ }^{2} / V_{i}\right)$.

E o logaritmo da função de máxima verossimilhança correspondente será dado por:

$\ell\left(Y_{i} \mid \mu_{i}, V_{i}\right)=$

$\sum_{j=1}^{J i}\left\{\log \left[\left(y_{i j}+v_{i j}+1\right) !-\log \left[\left(y_{i j} !\left(v_{i j}-1\right) !\right]+y_{i j}\left[-\log \left(v_{i j} / \mu_{i j}+1\right)\right]+v_{i j}\left[\log \left(v_{i j} / \mu_{i j}\right)-\log \left(v_{i j} / \mu_{i j}+1\right)\right]\right\}\right.\right.$

$\sum_{j=1}^{J i}\left\{\log \left[\left(y_{i j}+v_{i j}+1\right) !-\log \left(y_{i j} !\right)-\log \left[\left(v_{i j}-1\right) !\right]-v_{i j} \log \left(v_{i j} / \mu_{i j}+1\right)+v_{i j} \log \left(v_{i j}\right)-v_{i j} \log \left(\mu_{i j}\right)-y_{i j}\left[\log \left(v_{i j} / \mu_{i j}+1\right)\right]\right\}\right.$

$\sum_{j=1}^{J i}\left\{c_{2}-v_{i j} \log \left(\mu_{i j}\right)-v_{i j} \log \left(v_{i j} / \mu_{i j}+1\right)-y_{i j}\left[\log \left(v_{i j} / \mu_{i j}+1\right)\right]\right\} ;$ onde

$c_{2}=\log \left[\left(y_{i j}+v_{i j}+1\right) !-\log \left(y_{i j} !\right)-\log \left[\left(v_{i j}-1\right) !\right]+v_{i j} \log \left(v_{i j}\right)\right.$

A densidade marginal pode ser calculada com auxílio da quadratura de GaussHermite introduzida previamente. Os parâmetros deste modelo podem ser estimados utilizando-se métodos de escore de Fisher, Newton, Quase-Newton, dentro outros (MANCO, Ibid; HOFFMAN, Ibid; ROBSON, PEVALIN, Ibid). Conforme abordaremos no Capítulo 6 (Anexo 5) nossa programação usará o método quase-newton e quadratura gaussiana.

Em nosso caso específico, utilizaremos uma modelagem do tipo ZINB multinível e embora a técnica empregada seja a mesma no desenho de nossos dois modelos explicativos (modelo de polo ativo e modelo de polo passivo), discutiremos o ajuste de cada um destes dois modelos específicos separadamente no Capítulo 6 a partir de seus resultados respectivos.

A construção de nossos modelos será feita em dois níveis hierárquicos, sendo o primeiro nível responsável pelo processo de predição probabilístico da inflação de zeros (zero estrutural), ao qual denominaremos de processo de habilitação. E o segundo nível será responsável pela predição probabilística do processo de contagem (número de sucessos) auferidos por cada membro a cada ano. 
O nível 1 (habilitação) deve controlar a probabilidade de cada membro de participar ou não no sistema (zero estrutural). O nível 2 (contagem) determinará o valor espero de sucessos para cada país/grupo a cada ano.

Por fim, em nosso modelo ZINB partiremos dos desenvolvimentos de Moghimbeigi et al "Multilevel zero-inflated negative binomial regression modeling for overdispersed count data with extra zeros" (2008) que consolida a estatística padrão para uso deste tipo de modelo na área de pesquisa médica para propor as seguintes considerações no equacionamento de nossa modelagem específica:

(a) O processo de geração das contagens do ajustamento do modelo será independente do processo de geração de zeros estruturais. Ou seja, no modelo do polo ativo o resultado probabilístico da modelagem da participação ou não de um país $i$ no OSC de acordo com características estruturais dadas pelas variáveis explicativas (zero estrutural e zero suscetível) deverá ser independente do resultado da decisão da frequência de sua participação (a contagem de sucessos).

- No modelo do polo passivo isso significará que a modelagem da probabilidade do país $i$ ser acionável no OSC de acordo com as variáveis explicativas (zero estrutural e zero suscetível) deverá ser independente da determinação do quantitativo de acionamentos recebidos (número de sucessos);

(b) Partindo da premissa de trabalho de que a conformidade com as regras da OMC seja o padrão, a ocorrência de violações aos normativos da OMC por parte dos países que possam ensejar seu acionamento no OSC será considerada aleatória e seguirá uma distribuição do tipo normal.

(c) A detecção pelos países da ocorrência de violações aos normativos da OMC que os afetem negativamente não será considerada aleatória e sim tão somente o evento base (violação). A detecção (evento) e a decisão (sucesso ou fracasso) dependerão das variáveis explicativas que serão definidas pelos modelos. Este fenômeno será considerado como um evento aleatório (tentativa) em um ensaio de Bernoulli que gera uma decisão (resultado) que pode ser um sucesso ou um fracasso. 
- Esta premissa é uma simplificação intuitiva e bastante funcional do processo e obviamente não compreende todas as suas dimensões como a participação de expertise privada, apoio de instituições internacionais, cooperação técnica, etc. No entanto, para a finalidade do presente estudo mantém um alto poder explicativo na análise do fenômeno.

Dessa forma, considerando que ambos os modelos (polo ativo e polo passivo) terão a mesma forma funcional, omitiremos aqui suas designações específicas para permitir um entendimento genérico da modelagem proposta. Nosso modelo genérico será, portanto, definido como:

Sendo a variável resposta do país $i$ na observação de número $j$ definida por $Y_{i j}$ $\left(i=1,2, \ldots, n ; j=1,2, \ldots J_{i}\right)$;

Sendo o número total de observações dado por $\sum_{i=1}^{n} J_{i}=J$;

Sendo o vetor de variáveis explicativas para o componente binomial negativo $X_{i j}$;

Sendo o vetor de coeficientes de regressão do componente binomial negativo $\beta$;

Sendo o vetor de variáveis explicativas para o componente logístico $Z_{i j}$;

Sendo o vetor de coeficientes de regressão do componente logístico $\gamma$;

O modelo será definido como:

$\log \left(\lambda_{i j}\right)=X_{i j}^{\prime} \beta$

$\operatorname{logit}\left(\pi_{i j}\right)=Z_{i j}{ }^{\prime} \gamma$ 


\title{
Anexo 4-1 \\ EFEITOS GRAVITACIONAIS: VARIÁVEIS - DIMENSÃO ECONÔMICA
}

\author{
"Gravity is a contributing factor in nearly 73 percent \\ of all accidents involving falling objects." \\ Dave Barry, humorista norte-americano
}

No presente Anexo apresentaremos as fontes, fórmula de cálculo e ajustes realizados em nossas variáveis explicativas da dimensão econômica (efeitos gravitacionais) introduzidas no Capítulo 5. A nossa base de dados das variáveis será a mesma para ambos os modelos (polos ativo e passivo). A primeira seção traz o ajuste para o tamanho da economia, a segunda para os fluxos de comércio e a terceira para a estrutura do comércio exterior.

\section{A4-1.1 Tamanho da economia (PIB)}

Os valores para o PIB dos membros da OMC foram retirados da base do World Development Indicators ${ }^{1}$ (WDI) do Banco Mundial (BM). Os valores são apresentados em milhões de dólares a preços constantes de 2005. No caso da União Europeia, os valores apurados referem-se à soma dos membros que compõe esta entidade, conforme definido no Capítulo 2. Demais ajustes necessários e/ou estimativas serão explicitados individualmente a seguir:

Angola - estão disponíveis dados do PIB a preços constantes apenas em 2005, enquanto há disponibilidade de dados de inflação/deflator do PIB até 2002. Para estimar o valor do PIB real dos demais anos foi utilizado o PIB nominal e os dados de inflação quando disponíveis. No entanto, como se verá adiante na discussão das demais variáveis, o país foi excluído da pesquisa e não serão apresentados dados para o mesmo nem comporá a média de seu grupo de renda;

Catar - dados do PIB a preços constantes não estão disponíveis antes de 1999 e dados de inflação/deflator do PIB antes de 2000, não sendo possível estimar o valor do PIB real

1 Disponível em <http://databank.worldbank.org/data/reports.aspx?source=world-development-indicators>. 
para este período. O período 1996(ano de adesão à OMC)-1998 para o país foi excluído da base de dados;

Haiti - apenas a partir de 1998 estão disponíveis dados do PIB real e a partir de 1999 de inflação, tendo o período anterior sido excluído da base de dados. No entanto, como se verá adiante na discussão das demais variáveis, o país foi excluído da pesquisa e não serão apresentados dados para o mesmo nem comporá a média de seu grupo de renda;

Liechtenstein - não estão disponíveis dados do PIB a preços constantes USD 2005 para o país e nem dados de inflação/deflator do PIB a partir de 2010. Devido a problemas adicionais com a base de dados de outras variáveis, conforme veremos à frente, o país foi excluído da pesquisa e não serão apresentados dados para o mesmo nem comporá a média de seu grupo de renda;

Maldivas - estão disponíveis dados do PIB a preços constantes a partir de 2001 e de inflação a partir de 2002. O período 1995-2000 foi excluído da base de dados do país;

Taiwan - o BM não possui dados para o país, de modo que os valores foram calculados indiretamente a partir de dados do PIB corrente e do deflator do PIB (base 2006) disponíveis na base World Economic Outlook ${ }^{2}$ (WEO) do Fundo Monetário Internacional (FMI). O deflator foi recalculado com base no ano de 2006 e os valores do PIB real (USD 2005) com base no PIB nominal anual; e

Miamar - dados sobre o país não estão disponíveis na base WDI/BM de forma que se utilizou neste caso também o WEO/FMI. Nesta base estão disponíveis dados a partir de 1998 do PIB nominal em dólares e do deflator do PIB com base no ano de 2000. O PIB de 2005 foi mantido constante e os demais valores ajustados por seus deflatores após recálculo com base no ano de 2005. Os valores 1995-1997 estão indisponíveis. No entanto, como se verá adiante na discussão das demais variáveis, o país foi excluído da pesquisa e não serão apresentados dados para o mesmo nem comporá a média de seu grupo de renda.

2 Disponível em <http://www.imf.org/external/pubs/ft/weo/2012/02/weodata/index.aspx>. Acesso em janeiro de 2016. 
Os valores do PIB a preços constantes (USD 2005) individuais para cada país são apresentados no Quadro A4-1.1 (p. 509) ao final do presente Anexo. Considerando-se a média móvel de cada grupo de renda, sumarizamos na Tabela A4-1.1 a seguir os valores observados ao longo do período:

Tabela A4-1.1: PIB médio por grupo de renda em milhões de USD no período 19952012

\begin{tabular}{|c|c|c|c|c|c|c|c|c|c|c|}
\hline MEMBRO & 1995 & 1996 & 1997 & 1998 & 1999 & 2000 & 2001 & 2002 & 2003 & (cont...) \\
\hline \multicolumn{11}{|l|}{ UE / EUA Média } \\
\hline PD Médio & 9359504 & 9714779 & 10150684 & 10602380 & 11099123 & 11553319 & 11666077 & 11874448 & 12207737 & \\
\hline \multicolumn{11}{|c|}{ Outros PD Médio 103029601059347510971628113766501180933912279869124814161267465112930169} \\
\hline PED $_{\text {ma }}$ Médio & 103831 & 100577 & 102802 & 104774 & 105065 & 103002 & 99623 & 100979 & 100477 & \\
\hline PED $_{\text {mb }}$ Médio & 54998 & 51178 & 49228 & 49325 & 51710 & 52079 & 100445 & 106942 & 112206 & \\
\hline PED Médio & 60366 & 55711 & 56340 & 56462 & 57491 & 58015 & 74904 & 77824 & 80258 & \\
\hline PMD Médio & 6557 & 6006 & 6257 & 6337 & 6610 & 6819 & 7162 & 7370 & 7677 & \\
\hline MEMBRO & 2004 & 2005 & 2006 & 2007 & 2008 & 2009 & 2010 & 2011 & 2012 & MÉDIA \\
\hline \multicolumn{11}{|c|}{ UE / EUA Média 13996937142894461476674815221041152887421461889214926815151947011512929313669160} \\
\hline PD Médio & 12669891 & 13093726 & 13442887 & 13681978 & 13642078 & 13263438 & 13599258 & 13817044 & 141377491 & 12198672 \\
\hline \multicolumn{11}{|c|}{ Outros PD Médio 13333414136915861410481714451509144654101394116514263036145058721463352112933916} \\
\hline PED $_{\text {ma }}$ Médio & 106851 & 112325 & 118759 & 121536 & 125513 & 123094 & 130762 & 137399 & 161640 & 114389 \\
\hline PED $_{\text {mb }}$ Médio & 122278 & 133421 & 146972 & 163296 & 167900 & 179841 & 196664 & 211810 & 219416 & 120539 \\
\hline PED Médio & 84618 & 90723 & 98051 & 104832 & 109360 & 113028 & 122121 & 130260 & 143096 & 87414 \\
\hline PMD Médio & 7956 & 8421 & 8925 & 11674 & 12306 & 12880 & 13673 & 14555 & 15395 & 9254 \\
\hline
\end{tabular}

Fonte: elaboração própria com base em BM e FMI.

Ao passo que comparativo das médias móveis de cada grupo de renda pode ser analisado na Tabela A4-1.2 abaixo:

Tabela A4-1.2: Comparativo do PIB médio por grupo de renda no período 1995-2012

\begin{tabular}{|c|c|c|c|c|c|c|c|}
\hline MEMBRO & $\begin{array}{c}\text { UE / EUA } \\
\text { Média }\end{array}$ & $\begin{array}{c}\text { PD } \\
\text { Médio }\end{array}$ & $\begin{array}{c}\begin{array}{c}\text { Outros PD } \\
\text { Médio }\end{array} \\
\end{array}$ & $\begin{array}{l}\text { PED }_{\text {ma }} \\
\text { Médio }\end{array}$ & $\begin{array}{l}\text { PED }_{\text {mb }} \\
\text { Médio } \\
\end{array}$ & $\begin{array}{l}\text { PED } \\
\text { Médio }\end{array}$ & $\begin{array}{c}\text { PMD } \\
\text { Médio }\end{array}$ \\
\hline UE / EUA Média & $\ldots$ & $12 \%$ & $6 \%$ & $11850 \%$ & $11240 \%$ & $15537 \%$ & $147604 \%$ \\
\hline PD Médio & $\ldots$ & $\ldots$ & $-6 \%$ & $10564 \%$ & $10020 \%$ & $13855 \%$ & $131714 \%$ \\
\hline Outros PD Médio & $\ldots$ & $\ldots$ & $\ldots$ & $11207 \%$ & $10630 \%$ & $14696 \%$ & $139659 \%$ \\
\hline PED $_{\mathrm{ma}}$ Médio & $\ldots$ & $\ldots$ & $\ldots$ & $\ldots$ & $-5 \%$ & $31 \%$ & $1136 \%$ \\
\hline PED $_{\mathrm{mb}}$ Médio & $\ldots$ & $\ldots$ & $\ldots$ & $\ldots$ & $\ldots$ & $38 \%$ & $1203 \%$ \\
\hline PED Médio & $\ldots$ & $\ldots$ & $\ldots$ & $\ldots$ & $\ldots$ & $\ldots$ & $845 \%$ \\
\hline
\end{tabular}

Fonte: elaboração própria. 
A partir da apresentação dos dados em questão pode-se concluir que no período a média de EUA e UE foi consistentemente mais elava do que todos os outros grupos de renda, incluindo a média dos outros PD e todos os PD em conjunto. O efeito agregado de UE/EUA fez também com que a média de todos os PD seja maior que a média dos demais PD (excluindo os dois atores). Como esperado, tanto a média de todos os PD quanto apenas de Outros PD é maior do que os demais grupos. Igualmente esperado, a média dos $P E D_{m a}$ e $P E D_{m b}$ é maior do que a do conjunto dos PED, enquanto esta última é maior do que a do grupo PMD isoladamente.

A surpresa fica por conta da média dos $\mathrm{PED}_{\mathrm{ma}}$ que é $5 \%$ menor do que a dos $P E D_{m b}$, isto se deve ao efeito de China e Índia que apresentaram sustentado crescimento do produto em todo o período. Caso o efeito China e Índia fosse excluído dos dados dos $\mathrm{PED}_{\mathrm{mb}}$, o grupo dos $\mathrm{PED}_{\mathrm{ma}}$ teria média de produto $193 \%$ maior que este grupo.

\section{A4-1.2. Coeficiente de Abertura (COMEX)}

O coeficiente de abertura comercial dos países, definido como a corrente de comércio em relação ao PIB foi calculado com base nos valores de exportações e importações em relação ao PIB retirados da base de dados WDI do Banco Mundial.

No caso na União Europeia, apesar do BM apresentar os valores de importações e exportações relativas da entidade para todos os anos do período analisado, uma vez que consideramos uma composição fixa para a organização com 27 membros (UE27) em todo o período, calculamos nosso próprio índice para a entidade multiplicando o coeficiente de cada estado-membro (do comércio extra-bloco) por seu PIB relativo ao PIB total da UE para todos os membros. Não estão disponíveis dados para Malta no ano de 2012, de forma que os dados do país não são considerados no coeficiente da entidade neste ano.

Os demais ajustes realizados nos dados são descritos a seguir:

Taiwan - por razões políticas a Organização das Nações Unidas e suas agências não coletam ou divulgam dados de comércio diretamente identificados com o país. No entanto, estes dados podem ser obtidos indiretamente, uma vez que no sistema da United Nations Commodity Trade Statistics Database ${ }^{3}$ (UN Comtrade) existe a classificação "Other Asia, nes" (not elsewhere specified) sob o código de classificação 490. Na prática, 
esta classificação é compreendida majoritariamente pelo fluxo comercial de Taiwan que não pode ser reportado diretamente e por um pequeno ruído de outros fluxos eventualmente não reportados na região.

Dessa forma, calcularemos o valor do COMEX para Taiwan a partir do agrupamento anual do volume de exportações e importações sob todos os códigos do sistema harmonizado para todos os parceiros provenientes do código 490 e posteriormente dividindo pelo PIB nominal do país em cada ano de acordo com os dados do FMI apresentados anteriormente;

Cabo Verde - dados para o ano de 2012 não estão disponíveis, tendo sido excluído o ano;

Djibuti - não estão disponíveis dados de importação e exportação relativos a partir de 2008, tendo o período subsequente sido excluído de nossa base. No entanto, o país foi posteriormente excluído da pesquisa;

Emirados Árabes - não estão disponíveis os valores relativos de exportação de bens e serviços antes de 2001, de modo que o período foi excluído;

Jamaica - não estão disponíveis dados no período de 1998 a 2001, de modo que o período foi igualmente excluído;

Liechtenstein - no caso desde micro-país não estão disponíveis quaisquer dados sobre sua estrutura de comércio internacional na base de dados do Banco Mundial, do FMI, do UN Comtrade ou da UNCTAD (STAT) ${ }^{4}$. Uma vez que o país não teve nenhuma participação no OSC em qualquer categoria no período em análise e dada a impossibilidade de obter dados sobre o comércio exterior do país o mesmo foi excluído de nossa modelagem;

Miamar - a partir de 2005 não estão disponíveis os dados em questão para o país. Ainda, devido à indisponibilidade adicional de dados de outras variáveis o país foi posteriormente excluído da pesquisa;

Papua Nova Guiné - a partir de 2005 não estão disponíveis os dados em questão para o país, tendo sido excluídos do modelo;

4 Disponível em <http://unctadstat.unctad.org/EN/>. 
Serra Leoa - nos anos de 2011 e 2012 não estão disponíveis dados. O país foi posteriormente excluído da base de dados devido a outras inconsistências;

Sri Lanka - não há disponibilidade de dados para 2011 e 2012, de forma que estes anos foram excluídos;

Suriname - não estão disponíveis dados a partir de 2006, de modo que o período foi igualmente excluído; e

Suazilândia - em relação à ausência de dados para 2012, este ano foi retirado da base.

Os valores de COMEX individuais para cada país em todo o período são apresentados no Quadro A4-1.2 (p. 515) ao final do presente Anexo. Considerando-se a média de cada grupo de renda, além dos valores individuais de UE e EUA, sumarizaremos na Tabela A4-1.3 a seguir os valores observados ao longo do período:

Tabela A4-1.3: COMEX médio por grupo de renda no período 1995-2012

\begin{tabular}{|c|c|c|c|c|c|c|c|c|c|c|}
\hline MEMBRO & 1995 & 1996 & 1997 & 1998 & 1999 & 2000 & 2001 & 2002 & 2003 & (cont...) \\
\hline União Europeia & 61,55 & 63,29 & 66,40 & 66,75 & 67,68 & 74,59 & 73,56 & 71,01 & 69,19 & \\
\hline Estados Unidos & 22,38 & 22,61 & 23,34 & 22,76 & 23,19 & 24,98 & 22,80 & 22,15 & 22,45 & \\
\hline UE / EUA Média & 41,97 & 42,95 & 44,87 & 44,75 & 45,44 & 49,78 & 48,18 & 46,58 & 45,82 & \\
\hline PD Médio & 97,56 & 97,07 & 97,78 & 95,59 & 96,34 & 100,15 & 97,94 & 95,82 & 99,44 & \\
\hline Outros PD Médio & 104,98 & 104,29 & 104,84 & 102,37 & 102,70 & 105,75 & 103,47 & 101,01 & 105,08 & \\
\hline PED $_{\text {ma }}$ Médio & 77,79 & 79,87 & 83,99 & 84,32 & 82,42 & 79,34 & 78,09 & 77,58 & 78,77 & \\
\hline PED $_{m b}$ Médio & 79,09 & 80,71 & 85,55 & 87,72 & 84,40 & 89,08 & 89,12 & 89,87 & 91,90 & \\
\hline PED Médio & 72,48 & 71,40 & 75,34 & 76,27 & 74,49 & 76,00 & 75,65 & 75,50 & 77,50 & \\
\hline PMD Médio & 57,03 & 50,01 & 51,35 & 52,88 & 53,13 & 55,29 & 54,32 & 53,34 & 55,69 & \\
\hline MEMBRO & 2004 & 2005 & 2006 & 2007 & 2008 & 2009 & 2010 & 2011 & 2012 & MÉDIA \\
\hline União Europeia & 71,52 & 74,16 & 77,93 & 78,87 & 80,53 & 71,51 & 78,14 & 83,02 & 83,35 & 72,95 \\
\hline Estados Unidos & 24,29 & 25,50 & 26,87 & 27,96 & 29,94 & 24,77 & 28,18 & 30,89 & 30,70 & 25,32 \\
\hline UE / EUA Média & 47,91 & 49,83 & 52,40 & 53,41 & 55,24 & 48,14 & 53,16 & 56,95 & 57,03 & 49,13 \\
\hline PD Médio & 105,81 & 108,37 & 112,07 & 111,03 & 116,18 & 101,97 & 109,56 & 115,68 & 115,10 & 104,08 \\
\hline Outros PD Médio & 111,90 & 114,22 & 118,03 & 116,79 & 122,27 & 107,35 & 115,20 & 121,56 & 120,90 & 110,15 \\
\hline PED $_{\text {ma }}$ Médio & 82,10 & 84,26 & 85,83 & 88,83 & 91,15 & 79,00 & 81,24 & 85,83 & 84,55 & 82,50 \\
\hline PED $_{m b}$ Médio & 93,02 & 96,23 & 92,69 & 92,37 & 94,15 & 81,99 & 88,16 & 92,19 & 90,79 & 88,84 \\
\hline PED Médio & 80,13 & 82,56 & 81,89 & 83,96 & 86,14 & 75,82 & 80,27 & 84,49 & 84,07 & 78,55 \\
\hline PMD Médio & 61,13 & 62,89 & 63,62 & 67,94 & 69,79 & 64,07 & 69,07 & 73,08 & 75,16 & 60,54 \\
\hline
\end{tabular}

Fonte: elaboração própria. 
Tendo em mente a evolução da variável, apresentamos uma relação comparativa para a média dos grupos no período na Tabela A4-1.4 abaixo:

Tabela A4-1.4: Comparativo do COMEX médio por grupo de renda no período 19952012

\begin{tabular}{|c|c|c|c|c|c|c|c|c|}
\hline MEMBRO & $\begin{array}{c}\text { União } \\
\text { Europeia }\end{array}$ & Estados Unidos & $\begin{array}{c}\text { PD } \\
\text { Médio }\end{array}$ & $\begin{array}{c}\text { Outros PD } \\
\text { Médio }\end{array}$ & $\begin{array}{l}\text { PED }_{\text {ma }} \\
\text { Médio }\end{array}$ & $\begin{array}{l}\text { PED }_{m b} \\
\text { Médio }\end{array}$ & $\begin{array}{c}\text { PED } \\
\text { Médio }\end{array}$ & $\begin{array}{c}\text { PMD } \\
\text { Médio }\end{array}$ \\
\hline União Europeia & $\ldots$ & $188,09 \%$ & $-29,91 \%$ & $-33,77 \%$ & $-11,58 \%$ & $-17,89 \%$ & $-7,14 \%$ & $20,49 \%$ \\
\hline Estados Unidos & $\ldots$ & $\ldots$ & $-75,67 \%$ & $-77,01 \%$ & $-69,31 \%$ & $-71,50 \%$ & $-67,77 \%$ & $-58,18 \%$ \\
\hline UE / EUA Média & $\ldots$ & $\ldots$ & $-52,79 \%$ & $-55,39 \%$ & $-40,44 \%$ & $-44,69 \%$ & $-37,45 \%$ & $-18,85 \%$ \\
\hline PD Médio & $\ldots$ & $\ldots$ & $\ldots$ & $-5,51 \%$ & $26,16 \%$ & $17,16 \%$ & $32,49 \%$ & $71,91 \%$ \\
\hline Outros PD Médio & $\ldots$ & $\ldots$ & $\ldots$ & $\ldots$ & $33,52 \%$ & $23,99 \%$ & $40,22 \%$ & $81,93 \%$ \\
\hline PED $_{\text {ma }}$ Médio & $\ldots$ & $\ldots$ & $\ldots$ & $\ldots$ & $\ldots$ & $-7,13 \%$ & $5,02 \%$ & $36,26 \%$ \\
\hline PED $_{\mathrm{mb}}$ Médio & $\ldots$ & $\ldots$ & $\ldots$ & $\ldots$ & $\ldots$ & $\ldots$ & $13,09 \%$ & $46,73 \%$ \\
\hline PED Médio & $\ldots$ & $\ldots$ & $\ldots$ & $\ldots$ & $\ldots$ & $\ldots$ & $\ldots$ & $29,75 \%$ \\
\hline
\end{tabular}

Fonte: Elaboração própria.

A tabela acima traz valores da variável não apenas para os diferentes grupos de renda, mas também de forma separada para UE e EUA. Isto se deve ao fato de que no diz respeito à presente variável não faz sentido o agrupamento de ambos os atores em uma única entidade média para efeitos comparativos.

O comportamento de ambos no período é bastante distinto. O coeficiente de abertura na União Europeia varia de 61,55 no ano de 1995, com tendência de crescimento sustentado, até uma alta de 83,35 no ano de 2012 , revelando uma grande abertura comercial média da entidade com tendência ascendente.

Por sua vez, o coeficiente de abertura norte-americano, apesar de apresentar tendência ascendente sutil, varia de apenas 22,38 no ano de 1995 a uma máxima de 30,89 no ano de 2011 , mantendo estabilidade no ano seguinte $(30,70)$. O que revela um grau de abertura relativa da economia muito menor do que o bloco europeu.

Não obstante o elevado grau de abertura europeu em relação ao norte-americano, o bloco mostrou-se em média menos aberto no período do que a média dos demais grupos de renda exceto os PMD, sendo, no entanto, apenas 20,49\% mais aberta comercialmente que estes em termos relativos às suas economias.

O grau relativo de abertura média da economia norte-americana no período é inferior à média de todos os grupos de renda, inclusive ao dos PMD em $-58,18 \%$. Já os demais países desenvolvidos são mais abertos em média tanto em relação à UE e EUA 
quanto a qualquer agrupamento de países em desenvolvimento.

Por sua vez, os $P E D_{\text {ma }}$ são mais abertos do que os PMD, porém, são $7,13 \%$ menos abertos em média do que os $P E D_{m b}$. No caso dos $P E D_{m b}$, estes são tanto mais abertos em média em relação à média dos PED quanto em relação aos PMD. Os PMD são em média o grupo mais fechado, com exceção dos EUA, que se mostra consistentemente mais fechado em média em termos relativos do que mesmo os países de menor desenvolvimento relativo. Em relação à presente variável não foram observadas distorções provocadas por China e Índia nos dados.

\section{A4-1.3. Participação da agricultura no comércio (AGRI)}

A participação da agricultura no comércio exterior será definida como a participação porcentual da soma do valor corrente de exportações e importações de bens agrícolas básicos, matérias-primas agrícolas e gêneros alimentícios em relação ao valor total da corrente de comércio (exportação e importação) em cada ano. Para isto utilizaremos a base de dados da UN Comtrade e o sistema de classificação da ONU Standard International Trade Classification (SITC), em sua revisão 3, para filtrar o volume de comércio.

Definiremos a exportação e importação de produtos agrícolas básicos e matériasprimas como aqueles classificados no SITC na Seção 2, exceto as divisões 22, 27 e 28 (combustíveis, minerais, metais, pedras preciosas, fertilizantes e sucatas). Por sua vez a exportação e importação de gêneros alimentícios serão compreendidas nas classificações do SITC na Seção 0 (alimentos e animais vivos), Seção 1 (bebidas e tabaco), Seção 4 (gorduras e óleos animais e vegetais), além da divisão 22 (óleo de sementes, nozes e bruto). Da mesma forma que nossas demais variáveis, o caso da UE receberá tratamento especial para que todos os seus componentes sejam agregados de forma ponderada. Demais ajustes nos dados são descritos abaixo:

Angola - não estão disponíveis nas bases do BM, FMI, UN Comtrade e UNCTAD-STAT dados sobre a estrutura de comércio exterior do país, apenas dados parciais de 2005, portanto, o país foi excluído de nossa análise;

Antígua e Barbuda - entre os anos 1995-1998 e 2001-2004 e no ano de 2008 não há disponibilidade de dados para importação e exportação de produtos agrícolas básicos ou alimentares, tendo sido estes períodos excluídos de nossa base. Nos anos de 2006, 2009 
e 2010 não há dados para exportações de produtos agrícolas básicos ou alimentares, foi usada a média de 2005 e 2007 para as exportações no primeiro caso e de 2007 e 2011 nos dois últimos;

Arábia Saudita - No ano de 2008 não há dados sobre exportação de produtos agrícolas básicos, o valor para este ano é uma média de 2007 e 2009;

Barein - não há dados para exportação e importação de produtos agrícolas básicos e nem de gêneros alimentícios no período 1997 a 1999, os dados para este período foram excluídos;

Bangladesh - não há dados de importação e exportação de produtos agrícolas básicos ou alimentares para 1999 e 2012, tendo sido estes anos excluídos da base do país;

Botsuana - dados de importação e exportação de produtos agrícolas básicos e alimentos estão disponíveis apenas a partir de 2000 , tendo sido o período precedente excluído da base de dados do país;

Brunei - dados para exportação e importação de produtos agrícolas básicos e alimentícios não estão disponíveis nos períodos de 1995-1996, 1999-2000, 2005 e 20072011. O país foi excluído da base de dados;

Burkina Faso - dados de exportações e importações de produtos agrícolas básicos e alimentos não estão disponíveis nos anos de 2006 e 2012, tendo sido estes excluídos da base do país;

Cabo Verde - dados de exportações de produtos agrícolas básicos não estão disponíveis para 2008 e 2010. No primeiro caso foi utilizada média do primeiro ano anterior disponível e de 2009, já no último foi usada média de 2009 e 2011. Quanto aos dados de exportação de alimentos, não há disponibilidade para o ano de 2008, considerou-se média de 2007 e 2009 neste caso. Adicionalmente, não há dados de importações e exportações totais em 2012, tendo sido geradas estimativas para estes dados a partir de nossas estimativas de COMEX discutidas nos ajustes da variável anterior;

Camarões - no período 1998-1999 não existem dados para exportações de produtos agrícolas básicos ou alimentares, tendo o mesmo sido excluído; 
Catar - dados de exportações de produtos agrícolas básicos não estão disponíveis para 1997 e 2012, no primeiro caso foi utilizada média de 1996 e 1998 e no segundo repetido o valor de 2011. Por sua vez, dados de importações de produtos básicos e de gêneros alimentícios não estão disponíveis nos anos de 1997, 2009, 2011 e 2012. Nos dois primeiros casos foi utilizada média simples dos anos imediatamente anterior e posterior e para os últimos média de 2008-2010;

Chade - não estão disponíveis dados sobre o comércio internacional do país, com exceção de informação parcial do ano de 1995, no BM ou no UN Comtrade. O país foi excluído da pesquisa;

Macau - a partir de 2010 não há dados disponíveis sobre exportação de produtos agrícolas básicos, de modo que foi utilizada média dos três últimos anos com dados disponíveis;

Congo - não estão disponíveis dados completos no período 1997-2006 para exportações e importações de produtos agrícolas básicos e alimentos, tendo sido o período retirado da base do país;

Cuba - não estão disponíveis dados para importação e exportação de produtos agrícolas básicos ou alimentares nos períodos de 1995-1998 e de 2007-2012, tendo sido estes excluídos;

Democrática República do Congo (Congo DR) - não estão disponíveis nas bases do BM, FMI, UN Comtrade e UNCTAD-STAT dados sobre a estrutura de comércio exterior do país, tendo o mesmo sido excluído de nossa análise;

Djibuti - não estão disponíveis nas bases do BM, FMI, UN Comtrade e UNCTAD-STAT dados sobre a estrutura de comércio exterior do país à exceção de dados parciais do ano de 2009, razão pela qual o país foi excluído de nossa análise;

Dominica - nos anos de 1998 e 2011 não existem dados de importação e exportação de produtos agrícolas básicos ou alimentares, os mesmos foram excluídos;

Emirados Árabes - não estão disponíveis dados de importação e exportação de produtos agrícolas básicos e alimentos nos períodos de 1996-1998, 2001-2004, 2006 e a partir de 2009. O país foi excluído de nossa base de dados; 
Fiji - entre 1996-1999 não há disponibilidade de dados para importação e exportação de produtos agrícolas básicos ou alimentares, tendo sido o período excluído;

Gabão - no ano de 1995 e a partir de 2010 não há disponibilidade de dados de importação e exportação de produtos agrícolas básicos e alimentos, sendo portanto estes períodos excluídos;

Gana - dados de exportação de produtos agrícolas básicos ou alimentares não estão disponíveis para os anos de 1995, 2002 e 2004, tendo sido utilizado no primeiro caso dados de 1996 e nos demais a média dos anos imediatamente anteriores e posteriores, respectivamente. No caso da importação de produtos agrícolas básicos ou alimentares não estão disponíveis dados também para os anos de 1995 e 2004, utilizou-se do mesmo expediente para cálculo das exportações nestes anos;

Granada - dados para exportações de bens agrícolas de base e de alimentos não estão disponíveis a partir de 2009, tendo sido utilizada a média dos três anos imediatamente anteriores para o ano de 2009. Por sua vez, no caso das importações de bens agrícolas de base e de alimentos não estão disponíveis dados a partir de 2010, tendo sido excluído o período 2010-2012 da base de dados do país;

Guiana - entre 1995-1996 não há disponibilidade de dados para importação e exportação de produtos agrícolas básicos ou alimentares, tendo sido este período excluído;

Guiné - dados para exportações e importações de produtos agrícolas básicos e alimentos não estão disponíveis em 2003 e a partir de 2009, sendo considerada média de 2002 e 2004 no primeiro caso e de 2006-2008 no segundo;

Guiné-Bissau - estão disponíveis dados obre exportações e importações de produtos agrícolas básicos e alimentos apenas nos períodos de 1995 e 2001-2003, tendo sido os demais períodos retirados da base do país;

Haiti - nas bases de dados BM, FMI, UN Comtrade e UNCTAD-STAT estão disponíveis apenas dados parciais do comércio exterior do país nos anos de 1995 a 1997 o que provocou a exclusão do país de nosso modelo;

Honduras - no ano de 2008 não há dados para importação e exportação de produtos agrícolas básicos ou alimentares, o ano foi retirado da base; 
Ilhas Salomão - dados sobre exportações e importações de produtos agrícolas básicos e alimentos do país estão disponíveis a partir de 2002, tendo sido desconsiderado o período precedente;

Jamaica - no período de 1998-2001 não estão disponíveis dados sobre o volume total de exportações e importações a preços correntes, tendo sido utilizados média dos anos imediatamente anterior e posterior;

Kuwait - não estão disponíveis dados no ano de 2005 para importações e exportações de produtos agrícolas básicos nem de alimentos, tendo sido este excluído. Dados sobre a exportação de produtos agrícolas básicos não estão disponíveis a partir de 2010. Dados sobre a importação de produtos agrícolas básicos não estão disponíveis a partir de 2009. Quanto ao comércio de alimentos, não há dados disponíveis para importação a partir de 2009 e de exportação a partir de 2010. O período 2009-2012 foi, portanto, desconsiderado;

Lesoto - entre 1995-1999 e 2005-2007 não há disponibilidade de dados completos para exportações e importações de produtos agrícolas básicos e alimentos, tendo sido ambos os período excluídos;

Macedônia - no ano de 2008 não há disponibilidade de dados para exportação de produtos básicos e alimentos, foi utilizada média de 2007 e 2009 para o ano;

Malaui - entre os anos de 1996 e 1998 não estão disponíveis dados para importação de produtos agrícolas básicos ou alimentares, tendo sido utilizada média dos anos $1995 \mathrm{e}$ 1999 para o período;

Maldivas - no ano de 2010 não está disponível o valor das exportações de produtos agrícolas básicos, foi utilizada média dos anos 2009 e 2011;

Mali - nos anos de 1995 e 2009 não há dados para exportações e importações de produtos agrícolas básicos e alimentos, estes foram retirados da base de dados;

Mauritânia - não estão disponíveis dados para exportações e importações de produtos agrícolas básicos e alimentos no período 1997-1999, o período foi excluído. No ano de 2006 não estão disponíveis dados de exportação de produtos agrícolas básicos e alimentos, utilizando-se média de 2005 e 2007; 
Moçambique - no ano de 1998 não há disponibilidade de dados para exportações e importações de produtos agrícolas básicos e alimentos, o ano foi excluído. Já no caso das importações não há dados também para 1999, foi utilizada média de 1997 e 2000 neste caso;

Mongólia - dados completos de exportações e importações de produtos agrícolas básicos e alimentos não estão disponíveis a partir de 2008. Adicionalmente, os dados de importação de alimentos e produtos básicos também não está disponível no ano de 2002. Estes períodos foram excluídos;

Miamar - estão disponíveis nas bases de dados BM, FMI, UN Comtrade e UNCTADSTAT apenas dados parciais do comércio exterior do país nos anos de 2001 e 2010, o que nos obrigou a excluir o país de nossa análise;

Namíbia - no período de 1995-1999 não há disponibilidade de dados para importação e exportação de produtos agrícolas básicos ou alimentares, o período foi retirado da base;

Nepal - não estão disponíveis dados de exportações e importações de produtos agrícolas básicos e alimentos no período 2004-2008, sendo este eliminado da análise;

Nigéria - nos anos de 1995 e 2004-2005 não há dados para importação e exportação de produtos agrícolas básicos ou alimentares, foram excluídos ambos os períodos;

Panamá - no ano de 2004 não estão disponíveis dados para importação agrícola de base e nem de alimentos, utilizou-se média de 2003 e 2005 neste caso;

Papua Nova Guiné - não estão disponíveis dados de exportações e importações de produtos agrícolas básicos e alimentos nos períodos de 1996-1997, 1999 e 2005-2010. Os períodos em questão foram excluídos da base do membro;

Quênia - não há disponibilidade de dados de importação e exportação de produtos agrícolas básicos ou alimentares para 2011 e 2012, fora eliminados estes anos;

República Dominicana - entre 1998-2000 não há disponibilidade de dados sobre exportações e importações de bens agrícolas de base e de alimentos, tendo sido este período eliminado. No caso das importações de bens agrícolas de base e de alimentos não há dados adicionalmente para o período 1995-1997, tendo sido utilizada a média dos três primeiros anos com dados disponíveis; 
Ruanda - no ano de 2000 não há disponibilidade para dados de exportações e importações de produtos agrícolas básicos e alimentos, tendo sido o mesmo eliminado;

São Vicente e Granadinas - no ano de 1996 não há dados para importação de produtos agrícolas básicos ou alimentares, foi utilizada média de 1995 e 1997;

Senegal - não há disponibilidade de dados de importação e exportação de produtos agrícolas básicos ou alimentares para 1995, sendo o ano excluído;

Serra Leoa - há disponibilidade apenas de dados parciais de 2000 e 2002 nas bases de BM, FMI, UN Comtrade e UNCTAD-STAT de modo que o país foi excluído da análise;

Sri Lanka - no período 1995-1998 não há dados para importação e exportação de produtos agrícolas básicos ou alimentares, o período foi eliminado. No caso da exportação de bens e serviços, não há dados a partir de 2011, tendo sido utilizada média dos três anos precedentes;

St. Kitts e Névis - nos anos de 1998 e 2012 não há dados para exportação e importação de produtos agrícolas básicos ou alimentares, tendo sido estes eliminados;

St. Lúcia - a partir do ano de 2009 não existem dados para exportação e importação de produtos agrícolas básicos ou alimentares, tendo sido retirado da base este período;

Suriname - a partir de 2006 não estão disponíveis dados sobre o volume total de importação e exportação a preços correntes, tendo sido utilizada média dos três anos precedentes para o período;

Suazilândia - não há dados para importação e exportação de produtos agrícolas básicos ou alimentares para os períodos 1995-1999 e 2008-2012, sendo estes eliminados da base;

Tanzânia - nos anos de 1995 e 1996 não há disponibilidade de dados de exportação de produtos agrícolas básicos ou alimentares, foi utilizada média dos três primeiros anos de dados disponíveis;

Togo - no ano de 2006 não há disponibilidade para dados de exportações e importações de produtos agrícolas básicos e alimentos, sendo este elimindo;

Trinidade e Tobago - não há disponibilidade nos anos de 2011 e 2012 de dados para 
importação e exportação de produtos agrícolas básicos ou alimentares, sendo estes excluídos;

União Europeia - no caso da Bélgica, não há dados para importação e exportação de produtos agrícolas básicos e de gêneros alimentícios no período 1995-1998, foi utilizada média dos três primeiros anos com dados disponíveis. Estão ausentes os mesmos dados para Luxemburgo no mesmo período, tendo sido utilizado igual expediente.

No caso da Bulgária, estes dados não estão disponíveis apenas para o ano de 1995, tendo sido utilizados os dados de 1996. Por fim, em relação a Malta, para o ano de 1995 utilizou-se do mesmo expediente anterior com a Bulgária para a falta destes valores e no caso do ano de 2012, na ausência de dados do volume total para exportação e importação, utilizou-se os dados de 2011;

Vanuatu - dados sobre exportações e importações de produtos agrícolas básicos e alimentos não estão disponíveis para 2012. O país foi excluído da pesquisa devido à falta de dados desta variável para o ano, o primeiro de sua adesão à OMC;

Venezuela - não há disponibilidade de dados para exportação de produtos agrícolas básicos ou alimentares para os anos de 2007 e 2012, tendo sido utilizada média de 2006 e 2008 no primeiro caso e repetido os valores de 2011 no segundo; e

Zimbábue - não há dados de exportação de produtos agrícolas básicos ou alimentares disponíveis nos anos de 1998 e 2003, bem como de importação de produtos agrícolas básicos ou alimentares em 1998, 2000 e 2003. Os anos de 1998 e 2003 foram eliminados e o valor das importações em 2000 foi estimado utilizando média dos anos imediatamente anterior e posterior.

Os valores relativos da participação da agricultura na corrente de comércio individuais para cada país são apresentados no Quadro A4-1.3 (p. 521) ao final deste Anexo. A Tabela A4-1.5 a seguir traz média de cada grupo de renda ao longo do período:

Tabela A4-1.5: AGRI média por grupo de renda no período 1995-2012

\begin{tabular}{ccccccccccc}
\hline MEMBRO & $\mathbf{1 9 9 5}$ & $\mathbf{1 9 9 6}$ & $\mathbf{1 9 9 7}$ & $\mathbf{1 9 9 8}$ & $\mathbf{1 9 9 9}$ & $\mathbf{2 0 0 0}$ & $\mathbf{2 0 0 1}$ & $\mathbf{2 0 0 2}$ & $\mathbf{2 0 0 3}$ & (cont...) \\
\hline União Europeia & 12,81 & 12,25 & 11,58 & 11,24 & 10,85 & 9,54 & 9,74 & 10,04 & 10,10 & \\
Estados Unidos & 10,49 & 10,23 & 9,20 & 8,52 & 7,91 & 7,31 & 7,69 & 7,87 & 8,11 & \\
UE / EUA Média & 11,65 & 11,24 & 10,39 & 9,88 & 9,38 & 8,42 & 8,71 & 8,95 & 9,11 &
\end{tabular}




\begin{tabular}{|c|c|c|c|c|c|c|c|c|c|c|}
\hline PD Médio & 14,88 & 14,12 & 13,39 & 13,21 & 12,63 & 11,08 & 11,82 & 11,64 & 10,32 & \\
\hline Outros PD Médio & 15,31 & 14,46 & 13,74 & 13,60 & 13,01 & 11,36 & 12,15 & 11,90 & 10,44 & \\
\hline PED $_{\text {ma }}$ Médio & 24,59 & 26,56 & 26,08 & 24,98 & 24,93 & 23,41 & 23,80 & 24,51 & 25,09 & \\
\hline PED $_{\mathrm{mb}}$ Médio & 29,65 & 28,24 & 27,65 & 27,86 & 25,69 & 23,60 & 24,39 & 24,22 & 24,09 & \\
\hline PED Médio & 29,07 & 30,10 & 29,75 & 29,59 & 28,39 & 26,98 & 27,32 & 27,17 & 27,70 & \\
\hline PMD Médio & 34,80 & 36,58 & 37,02 & 37,26 & 35,83 & 35,80 & 35,66 & 34,43 & 35,98 & \\
\hline MEMBRO & 2004 & 2005 & 2006 & 2007 & 2008 & 2009 & 2010 & 2011 & 2012 & MÉDIA \\
\hline União Europeia & 9,57 & 9,41 & 9,00 & 9,24 & 9,54 & 10,78 & 10,28 & 10,59 & 10,72 & 10,40 \\
\hline Estados Unidos & 7,69 & 7,27 & 7,11 & 7,56 & 8,04 & 9,08 & 8,80 & 9,03 & 8,84 & 8,38 \\
\hline UE / EUA Média & 8,63 & 8,34 & 8,06 & 8,40 & 8,79 & 9,93 & 9,54 & 9,81 & 9,78 & 9,39 \\
\hline PD Médio & 10,40 & 9,33 & 8,78 & 8,91 & 9,06 & 10,42 & 10,13 & 9,83 & 9,96 & 11,11 \\
\hline Outros PD Médio & 10,58 & 9,43 & 8,84 & 8,96 & 9,08 & 10,46 & 10,18 & 9,83 & 9,97 & 11,30 \\
\hline PED $_{\text {ma }}$ Médio & 23,65 & 22,03 & 21,05 & 20,94 & 21,62 & 23,93 & 23,17 & 22,03 & 23,65 & 23,67 \\
\hline PED $_{\mathrm{mb}}$ Médio & 22,82 & 22,05 & 21,21 & 20,74 & 21,46 & 24,58 & 22,79 & 24,05 & 23,77 & 24,38 \\
\hline PED Médio & 26,18 & 24,78 & 24,08 & 23,29 & 23,44 & 25,54 & 24,59 & 24,58 & 25,14 & 26,54 \\
\hline PMD Médio & 33,43 & 31,50 & 31,36 & 29,17 & 28,17 & 28,70 & 28,60 & 28,35 & 28,91 & 32,86 \\
\hline
\end{tabular}

Fonte: Elaboração própria.

De forma agregada para todo o período, a Tabela A4-1.6 abaixo apresenta a relação comparativa da média da AGRI para todos os grupos de renda:

Tabela A4-1.6: Comparativo da AGRI média por grupo de renda no período 19952012

\begin{tabular}{|c|c|c|c|c|c|c|c|c|}
\hline MEMBRO & União Europeia & Estados Unidos & $\begin{array}{c}\text { PD } \\
\text { Médio }\end{array}$ & $\begin{array}{c}\text { Outros PD } \\
\text { Médio }\end{array}$ & $\begin{array}{l}\text { PED }_{\text {ma }} \\
\text { Médio }\end{array}$ & $\begin{array}{l}\text { PED }_{m b} \\
\text { Médio }\end{array}$ & $\begin{array}{c}\text { PED } \\
\text { Médio }\end{array}$ & $\begin{array}{l}\text { PMD } \\
\text { Médio }\end{array}$ \\
\hline União Europeia & $\ldots$ & $24,23 \%$ & $-6,31 \%$ & $-7,89 \%$ & $-56,04 \%$ & $-57,32 \%$ & $-60,79 \%$ & $-68,34 \%$ \\
\hline Estados Unidos & $\ldots$ & $\ldots$ & $-24,58 \%$ & $-25,85 \%$ & $-64,61 \%$ & $-65,65 \%$ & $-68,44 \%$ & $-74,51 \%$ \\
\hline UE / EUA Média & $\ldots$ & $\ldots$ & $-15,44 \%$ & $-16,87 \%$ & $-60,33 \%$ & $-61,49 \%$ & $-64,62 \%$ & $-71,43 \%$ \\
\hline PD Médio & $\ldots$ & $\ldots$ & $\ldots$ & $-1,69 \%$ & $-53,08 \%$ & $-54,45 \%$ & $-58,15 \%$ & $-66,21 \%$ \\
\hline Outros PD Médio & $\ldots$ & $\ldots$ & $\ldots$ & $\ldots$ & $-52,27 \%$ & $-53,67 \%$ & $-57,43 \%$ & $-65,63 \%$ \\
\hline PED $_{\text {ma }}$ Médio & $\ldots$ & $\ldots$ & $\ldots$ & $\ldots$ & $\ldots$ & $-2,92 \%$ & $-10,81 \%$ & $-27,98 \%$ \\
\hline PED $_{m b}$ Médio & $\ldots$ & $\ldots$ & $\ldots$ & $\ldots$ & $\ldots$ & $\ldots$ & $-8,13 \%$ & $-25,81 \%$ \\
\hline PED Médio & $\ldots$ & $\ldots$ & $\ldots$ & $\ldots$ & $\ldots$ & $\ldots$ & $\ldots$ & $-19,25 \%$ \\
\hline
\end{tabular}

Fonte: Elaboração própria.

A partir da apresentação dos dados em questão pode-se concluir que no período a média da participação da agricultura no comércio exterior da UE foi superior apenas a dos EUA, sendo ligeiramente inferior à média dos demais países desenvolvidos $(-7,89 \%)$ e significativamente inferior à dos países em desenvolvimento qualquer que seja o grupo de 
renda. Por sua vez, a participação da pauta agrícola no comércio exterior norte-americano é inferior à de qualquer grupo de países.

Os outros países desenvolvidos possuem participação da agricultura no comércio cerca de $50 \%$ inferior à de qualquer grupo de países em desenvolvimento. Por sua vez, a média dos países em desenvolvimento de renda média-alta é inferior à dos demais subgrupos em desenvolvimento, enquanto a dos de renda média-baixa é inferior aos PMD e à média dos PED. 
Quadro A4-1.1: PIB em milhões de USD (2005) no período 1995-2012

\begin{tabular}{|c|c|c|c|c|c|c|c|c|c|c|c|c|c|c|c|c|c|c|}
\hline MEMBRO & 1995 & 1996 & 1997 & 1998 & 1999 & 2000 & 2001 & 2002 & 2003 & 2004 & 2005 & 2006 & 2007 & 2008 & 2009 & 2010 & 2011 & 2012 \\
\hline \multicolumn{19}{|c|}{ PAIISES DESENVOLVIDOS } \\
\hline PD Médio & 1606797 & $\mid 1653602$ & 1709470 & 1753793 & 1714038 & 1606990 & 1631688 & 1593848 & 1626613 & 1679340 & 1660742 & 1710555 & 1756176 & 1760989 & $\mid 1699981$ & $\mid 1750162$ & 1781215 & 1803305 \\
\hline \multicolumn{19}{|c|}{ UE/EUA } \\
\hline União Europeia & 11246416 & $\mid 11472170$ & 11792573 & 12150920 & 12519556 & 13006419 & 13296756 & $\mid 13474854$ & $\mid 13652601$ & |13996937|| & |14289446 & $\mid 14766748$ & 15221041 & 15288742 & 14618892 & 14926815 & |15194701 & 15129293 \\
\hline Estados Unidos & 9359504 & || 9714779 & $\mid 10150684$ & 10602380 & |11099123 & 11553319 & $\mid 11666077$ & $\mid 11874448 \|$ & $|12207737| \mid$ & $\mid 12669891 \|$ & $|13093726|$ & $\mid$ |13442887 & 13681978 & 13642078 & $\mid 13263438$ & $\mid 13599258$ & $\mid$ |13817044 & 14137749 \\
\hline UE / EUA Média & 10302960 & $\mid 10593475$ & 10971628 & 11376650 & 11809339 & 12279869 & 12481416 & 12674651 & $\mid 12930169$ & $\mid 13333414$ & |13691586 || & $\mid 14104817$ & 14451509 & 14465410 & |13941165 & |14263036 & |14505872 & 14633521 \\
\hline \multicolumn{19}{|c|}{ OUTROS DESENVOLVIDOS } \\
\hline Arábia Saudita & & & & & & & & & & & 328460 & $\mid$\begin{tabular}{||l}
346777 \\
\end{tabular} & 367557 & 398532 & 405821 & 425146 & 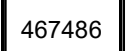 & 492658 \\
\hline Austrália & 480120 & 499080 & 518781 & 541806 & 568934 & 590945 & $\mid 602346$ & 625577 & $\mid$\begin{tabular}{||c|c}
64487 \\
-1
\end{tabular} & 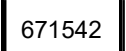 & 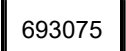 & 713749 & 740569 & 768020 & 781995 & 797778 & $\mid 816761$ & 846432 \\
\hline Bahrein & 10052 & 10465 & 10789 & 11306 & 11792 & 12417 & 12726 & 13186 & 13980 & 14956 & 15969 & 17002 & 18412 & 19561 & 20058 & 20928 & 21367 & 22134 \\
\hline Barbados & 3105 & 3230 & 3381 & 3507 & 3518 & 3676 & 3588 & 3617 & 3695 & 3746 & 3898 & 4119 & 4189 & 4207 & 4038 & 4049 & 4078 & 4089 \\
\hline Canada & 842744 & 856899 & 893346 & 930314 & 976804 & 1026847 & $\mid 1044184$ & $\mid 1073441$ & $\mid 094108$ & $\mid 1128450$ & || 1164144 & $\mid 1194666$ & 1218658 & || 232983 & $\mid 1199551$ & $\mid 1240027$ & || 276733 & 1301282 \\
\hline Cingapura & 76309 & 82057 & 88860 & 86883 & 92178 & 100380 & 99424 & 103612 & 108207 & 118540 & 127418 & 138707 & 151345 & 154051 & 153121 & 176458 & 187411 & 193810 \\
\hline Coréia do Sul & 553331 & 593093 & 627295 & 591452 & 654918 & 712756 & 745010 & 800383 & 823860 & $\mid$\begin{tabular}{||l} 
\\
864228
\end{tabular} & 898137 & $\mid 944626$ & 996235 & 1024420 & $\mid 1031668$ & 1098694 & 1139144 & 1165258 \\
\hline Croácia & & & & & & 36454 & 37706 & 39685 & 41890 & 43601 & 45416 & 47589 & 50040 & 51068 & 47297 & 46492 & 46362 & 45347 \\
\hline Hong Kong & 129723 & 135247 & 142144 & 133782 & 137136 & 147645 & $\mid 148473$ & 150933 & $\mid 155546$ & 169078 & 181570 & 194339 & 206903 & 211305 & 206109 & 220058 & 230653 & 234575 \\
\hline Islândia & 10678 & 11188 & 11738 & 12504 & 13024 & 13639 & 14152 & 14217 & 14606 & 15807 & 16749 & 17454 & 19111 & 19393 & 18485 & 17822 & 18176 & 18391 \\
\hline Israel & 98662 & 104737 & 109012 & 113647 & 117895 & 128437 & $\mid$\begin{tabular}{|l|l|}
$\mid 28747$ \\
\end{tabular} & $\mid$\begin{tabular}{||l}
128659 \\
\end{tabular} & $\mid$\begin{tabular}{||l}
130174 \\
\end{tabular} & 136831 & 142838 & 151125 & 160396 & 165303 & 167401 & 176636 & 185521 & 190864 \\
\hline Japão & 4132182 & || 4240034 & $\mid 4307689$ & 4221400 & || 4212985 & 4308093 & 4323406 & $\mid 4335925$ & $\mid 4408990$ & $\mid 4513074$ & $\mid 4571867$ & $\mid 4649265$ & 4751185 & || 4701695 & || 4441834 & || 6648469 & $\mid 4627424$ & 4708575 \\
\hline Kuwait & 49547 & 49847 & 51080 & 52950 & 52003 & 54444 & 54841 & 56486 & 66270 & 73402 & 80798 & 86874 & 92079 & 94363 & 87686 & 85610 & 93853 & 100072 \\
\hline Nova Zelândia & 81915 & 84881 & 86559 & 87081 & 91884 & 94423 & 97661 & $\mid$\begin{tabular}{||l}
$\mid 02432$ \\
\end{tabular} & 107176 & 111266 & 115061 & 118241 & 121740 & 119774 & 119473 & 121195 & 123884 & 126581 \\
\hline Noruega & 231758 & 243411 & 256274 & 263000 & 268295 & 276894 & $\mid 282669$ & 286732 & 289370 & $\mid 300826$ & 308722 & 316116 & 325378 & 326628 & 321329 & 323263 & 326394 & 335366 \\
\hline Omã & & & & & & 29769 & 31103 & 30761 & 29940 & 30327 & 31082 & 32752 & 34210 & 37015 & 39278 & 41164 & 40715 & 43598 \\
\hline
\end{tabular}




\begin{tabular}{|c|c|c|c|c|c|c|c|c|c|c|c|c|c|c|c|c|c|c|}
\hline Suíça & 2023 & 2101 & 2166 & 2222 & 2288 & 2328 & 2355 & 2397 & 2451 & 2522 & 2584 & 2669 & 2763 & 2829 & 2864 & 2912 & 2951 & 3040 \\
\hline Taiwan & & & & & & & & 307781 & 314794 & 344635 & 364849 & 372225 & 386846 & 382192 & 363175 & 407637 & 428955 & 430449 \\
\hline Trinidad e Tobago & 7481 & 8008 & 8624 & 9324 & 10072 & 10833 & 11285 & 12181 & 13940 & 15048 & 15982 & 18093 & 18953 & 19596 & 18736 & 18718 & 18719 & 18975 \\
\hline Catar & & & & & 20271 & 30084 & 31257 & 33502 & 34748 & 41427 & 44530 & 56184 & 66289 & 77998 & 87324 & $\mid 104433$ & 118401 & 124179 \\
\hline Macau & 6943 & 6916 & 6895 & 6578 & 6420 & 6786 & 6983 & 7604 & 8561 & 10863 & 11793 & 13493 & 15427 & 15950 & 16223 & 20684 & 25088 & 27387 \\
\hline Outros PD Médio & 447309 & 461619 & 474516 & 470745 & 452125 & 421115 & 426163 & 427448 & 436765 & 452595 & 457658 & 471129 & 486643 & 490547 & 475862 & 498874 & 508749 & 520284 \\
\hline \multicolumn{19}{|c|}{ EM DESENVOLVIMENTO } \\
\hline PED Médio & 60366 & 55711 & 56340 & 56462 & 57491 & 58015 & 74904 & 77824 & 80258 & 84618 & 90723 & 98051 & 104832 & 109360 & 113028 & 122121 & 130260 & 143096 \\
\hline \multicolumn{19}{|c|}{ Renda Média-Alta } \\
\hline África do Sul & 186132 & 194136 & 199184 & 200179 & 204984 & 213593 & 219360 & 227477 & 234186 & 244852 & 257773 & 272169 & 286759 & 295910 & 291358 & 300215 & 309859 & 316737 \\
\hline Antígua e Barbuda & 662 & 707 & 741 & 774 & 806 & 846 & 819 & 843 & 893 & 940 & 997 & 1131 & 1238 & 1239 & 1090 & 1012 & 994 & 1034 \\
\hline Argentina & 176167 & 185903 & 200982 & 208720 & 201654 & 200063 & 191242 & 170407 & 185466 & 202213 & 220814 & 239368 & 258436 & 266382 & 266516 & 291705 & 316169 & 318704 \\
\hline Brasil & 695120 & 710465 & 734586 & 737071 & 740528 & 770983 & 783765 & 807694 & 816904 & 863965 & 891630 & 926943 & 983230 & 1033313 & 1032010 & 1109707 & 1153100 & 1175187 \\
\hline Chile & 82598 & 88721 & 94582 & 97637 & 96894 & 101251 & 104641 & 106908 & 111138 & 117852 & 124404 & 129884 & 136587 & 141084 & 139622 & 147655 & $\mid$\begin{tabular}{|l}
$\mid 156278$ \\
\end{tabular} & 164806 \\
\hline Colômbia & 115545 & 117921 & 121966 & 122661 & 117504 & 122698 & 124756 & 127880 & 132891 & 139978 & 146566 & 156383 & 167174 & 173103 & 175962 & 182951 & $\mid$\begin{tabular}{|l}
$\mid 195007$ \\
\end{tabular} & 202893 \\
\hline Costa Rica & 12846 & 12960 & 13683 & 14832 & 16052 & 16341 & 16517 & 16996 & 18085 & 18855 & 19965 & 21718 & 23441 & 24081 & 23837 & 25018 & 26148 & 27499 \\
\hline Cuba & 26732 & 28827 & 29630 & 29676 & 31513 & 33378 & 34440 & 34932 & 36256 & 38349 & 42644 & 47790 & 51260 & 53370 & 54144 & 55437 & 56991 & 58709 \\
\hline Dominica & 306 & 314 & 318 & 334 & 336 & 338 & 339 & 333 & 359 & 371 & 370 & 381 & 405 & 434 & 429 & 432 & 432 & 426 \\
\hline Granada & & 446 & 466 & 497 & 547 & 557 & 546 & 564 & 618 & 614 & 695 & 667 & 708 & 715 & 668 & 664 & 670 & 662 \\
\hline Jamaica & 10404 & 10392 & 10274 & 10034 & 10139 & 10228 & 10365 & 10572 & 10960 & 11105 & 11204 & 11529 & 11694 & 11610 & 11096 & 10931 & 11119 & 11052 \\
\hline Malásia & 90111 & 99124 & 106383 & 98554 & 104603 & 113869 & 114459 & 120629 & 127612 & 136268 & 143534 & 151550 & 161096 & 168880 & $\mid 166324$ & 178675 & $\mid$\begin{tabular}{|l}
$\mid 188133$ \\
\end{tabular} & 198431 \\
\hline Maurício & 4083 & 4311 & 4556 & 4832 & 4959 & 5406 & 5545 & 5662 & 5869 & 6207 & 6284 & 6532 & 6917 & 7298 & 7520 & 7829 & 8133 & 8393 \\
\hline México & 623097 & 659703 & 705637 & 738815 & 758520 & 798694 & 793858 & 794906 & 806215 & 840847 & 866346 & 909183 & 938503 & 951454 & 906320 & 953440 & 990811 & 1030829 \\
\hline Namíbia & 4803 & 4956 & 5165 & 5335 & 5515 & 5708 & 5775 & 6052 & 6308 & 7082 & 7261 & 7775 & 8289 & 8509 & 8534 & 9050 & 9510 & 9992 \\
\hline
\end{tabular}


511

\begin{tabular}{|c|c|c|c|c|c|c|c|c|c|c|c|c|c|c|c|c|c|c|}
\hline Panamá & & & 10931 & 11733 & 12193 & 12524 & 12596 & 12876 & 13418 & 14427 & 15465 & 16783 & 18816 & 20538 & 21354 & 22603 & 25038 & 27603 \\
\hline Peru & 53491 & 54988 & 58550 & 58321 & 59192 & 60787 & 61163 & 64498 & 67185 & 70516 & 74948 & 80591 & 87456 & 95452 & 96453 & 104604 & 111354 & 117980 \\
\hline R. Dominicana & 20482 & 21942 & 23699 & 25360 & 27063 & 28594 & 29111 & 30796 & 30718 & 31121 & 34004 & 37633 & 40822 & 42105 & 42499 & 46028 & 47326 & 48570 \\
\hline Rússia & & & & & & & & & & & & & & & & & & 980326 \\
\hline St. Kitts e Nevis & & 396 & 423 & 420 & 434 & 456 & 479 & 488 & 475 & 497 & 543 & 575 & 591 & 616 & 581 & 563 & 572 & 565 \\
\hline St. Lúcia & 722 & 762 & 765 & 813 & 832 & 869 & 841 & 841 & 882 & 954 & 947 & 1025 & 1031 & 1060 & 1055 & 1037 & 1044 & 1033 \\
\hline $\begin{array}{l}\text { St. Vincente e } \\
\text { Granadinas }\end{array}$ & 389 & 394 & 408 & 424 & 436 & 443 & 451 & 479 & 516 & 537 & 551 & 593 & 583 & 623 & 610 & 589 & 587 & 595 \\
\hline Suriname & 1261 & 1277 & 1350 & 1371 & 1359 & 1358 & 1420 & 1481 & 1570 & 1715 & 1794 & 1863 & 1958 & 2039 & 2100 & 2209 & 2325 & 2397 \\
\hline Turquia & 317018 & 340413 & 366208 & 374661 & 362052 & 386579 & 364554 & 387025 & 407402 & 445547 & 482980 & 516274 & 540377 & 543937 & 517687 & 565092 & 614666 & 627742 \\
\hline Uruguai & 14936 & 15769 & 17117 & 17891 & 17544 & 17205 & 16544 & 15265 & 15387 & 16157 & 17363 & 18074 & 19257 & 20639 & 21515 & 23193 & 24391 & 25201 \\
\hline Venezuela & 123574 & 123330 & 131187 & 131573 & 123717 & 128279 & 132633 & 120887 & 111512 & 131904 & 145513 & 159879 & 173874 & 183051 & 177189 & 174551 & 181841 & 192071 \\
\hline Albânia & & & & & & 6134 & 6622 & 6902 & 7300 & 7717 & 8159 & 8602 & 9109 & 9795 & 10123 & 10499 & 10766 & 10919 \\
\hline Botswana & 6454 & 6831 & 7379 & 7432 & 8151 & 8313 & 8333 & 8839 & 9248 & 9498 & 9931 & 10762 & 11653 & 12380 & 11433 & 12412 & 13163 & 13799 \\
\hline Gabão & 8567 & 8878 & 9387 & 9714 & 8846 & 8679 & 8865 & 8843 & 9041 & 9104 & 9459 & 9115 & 9706 & 9412 & 9300 & 10149 & 10869 & 11440 \\
\hline Jordânia & & & & & & 9241 & 9729 & 10292 & 10721 & 11639 & 12589 & 13608 & 14720 & 15785 & 16649 & 17038 & 17474 & 17938 \\
\hline Maldivas & & & & & & & 889 & 940 & 1074 & 1225 & 1120 & 1351 & 1497 & 1684 & 1591 & 1686 & 1833 & 1878 \\
\hline Montenegro & & & & & & & & & & & & & & & & & & 2814 \\
\hline Tonga & & & & & & & & & & & & & 244 & 250 & 253 & 264 & 269 & 270 \\
\hline Tunísia & 20279 & 21728 & 22910 & 24006 & 25460 & 26659 & 27671 & 28037 & 29355 & 31186 & 32273 & 33965 & 36244 & 37780 & 38930 & 40297 & 39524 & 41142 \\
\hline Macedônia & & & & & & & & & 5709 & 5976 & 6259 & 6580 & 7006 & 7389 & 7363 & 7610 & 7788 & 7753 \\
\hline PEDma Médio & 103831 & 100577 & 102802 & 104774 & 105065 & 103002 & 99623 & 100979 & 100477 & 106851 & 112325 & 118759 & 121536 & 125513 & 123094 & 130762 & 137399 & 161640 \\
\hline \multicolumn{19}{|c|}{ Renda Média-Baixa } \\
\hline Armênia & & & & & & & & & 3896 & 4304 & 4900 & 5547 & 6310 & 6745 & 5791 & 5918 & 6196 & 6643 \\
\hline Belize & 642 & 651 & 674 & 699 & 761 & 860 & 903 & 949 & 1038 & 1086 & 1114 & 1165 & 1178 & 1216 & 1225 & 1266 & 1292 & 1342 \\
\hline
\end{tabular}




\begin{tabular}{|c|c|c|c|c|c|c|c|c|c|c|c|c|c|c|c|c|c|c|}
\hline Bolívia & 6925 & 7227 & 7585 & 7967 & 8001 & 8201 & 8339 & 8547 & 8778 & 9145 & 9549 & 10007 & 10464 & 11107 & 11480 & 11954 & 12576 & 13220 \\
\hline Camarões & 11006 & 11546 & 12160 & 12755 & 13273 & 13827 & 14451 & 15031 & 15637 & 16215 & 16588 & 17123 & 17680 & 18190 & 18541 & 19147 & 19940 & 20855 \\
\hline China & & & & & & & $\mid$\begin{tabular}{||l}
$\mid 1542080$ \\
\end{tabular} & $\mid$\begin{tabular}{||l}
1682269 \\
\end{tabular} & $\mid$\begin{tabular}{||l|l}
1850832 \\
\end{tabular} & $\mid 2037315$ & $\mid 2268599$ & $\mid$\begin{tabular}{||l}
2556444 \\
\end{tabular} & 2919330 & || 3200268 & || 3495767 & $\mid$\begin{tabular}{||l}
$\mid 3867426$ \\
\end{tabular} & 4234233 & 4562398 \\
\hline Costa do Marfim & 14639 & 15771 & 16361 & 17168 & 17446 & 17085 & 17105 & 16820 & 16591 & 16796 & 17085 & 17344 & 17650 & 18099 & 18687 & 19064 & 18228 & 20180 \\
\hline Egito & 58533 & 61453 & 64828 & 67445 & 71562 & 75404 & 78070 & 79920 & 82472 & 85847 & 89686 & 95823 & 102615 & 109954 & $\mid 115106$ & 121021 & 123220 & 125923 \\
\hline El Salvador & 13093 & 13316 & 13881 & 14402 & 14898 & 15219 & 15479 & 15841 & 16206 & 16506 & 17094 & 17763 & 18445 & 18680 & 18094 & 18341 & 18748 & 19101 \\
\hline Equador & & 31569 & 32936 & 34012 & 32400 & 32753 & 34069 & 35464 & 36430 & 39421 & 41507 & 43335 & 44284 & 47099 & 47366 & 49036 & 52894 & 55878 \\
\hline $\mathrm{Fiji}$ & & 2517 & 2462 & 2494 & 2713 & 2667 & 2720 & 2807 & 2836 & 2986 & 3007 & 3062 & 3036 & 3068 & 3025 & 3115 & 3020 & 3069 \\
\hline Filipinas & 69129 & 73170 & 76964 & 76520 & 78879 & 82358 & 84742 & 87831 & 92197 & 98372 & $\mid 103072$ & $\mid$\begin{tabular}{||l}
$\mid$ \\
108476
\end{tabular} & 115653 & 120456 & 121839 & 131138 & 135937 & 145023 \\
\hline Guatemala & 19312 & 19883 & 20751 & 21787 & 22626 & 23442 & 23989 & 24916 & 25547 & 26352 & 27211 & 28675 & 30483 & 31483 & 31649 & 32557 & 33912 & 34919 \\
\hline Guiana & 696 & 751 & 798 & 784 & 807 & 796 & 814 & 823 & 815 & 841 & 825 & 867 & 928 & 946 & 978 & 1021 & 1076 & 1128 \\
\hline Honduras & 6635 & 6874 & 7217 & 7426 & 7286 & 7705 & 7915 & 8212 & 8585 & 9120 & 9672 & 10307 & 10945 & 11408 & 11131 & 11546 & 11989 & 12484 \\
\hline Índia & 448721 & 482598 & 502142 & 533197 & 580362 & 602653 & $\mid 631725$ & 655756 & $\mid$\begin{tabular}{||l|}
707301 \\
\end{tabular} & || 763340 & 834215 & $\mid 911496$ & 1000835 & || 039777 & 1127948 & $\mid$\begin{tabular}{||l}
1243675 \\
\end{tabular} & 1326235 & 1393626 \\
\hline Indonésia & 219165 & 235915 & 247003 & 214579 & 216277 & 226918 & 235186 & 245768 & 257516 & $\mid$\begin{tabular}{||l}
270472 \\
\end{tabular} & 285869 & $\mid$\begin{tabular}{||l}
301594 \\
\end{tabular} & 320730 & 340018 & $\mid$\begin{tabular}{||l}
355757 \\
\end{tabular} & 377899 & 401214 & 425408 \\
\hline Moldávia & & & & & & & 2252 & 2428 & 2588 & 2780 & 2988 & 3132 & 3228 & 3478 & 3270 & 3502 & 3727 & 3701 \\
\hline Nicarágua & 4236 & 4505 & 4683 & 4857 & 5199 & 5412 & 5572 & 5614 & 5756 & 6062 & 6321 & 6584 & 6932 & 7130 & 6933 & 7154 & 7600 & 7990 \\
\hline Nigéria & 57836 & 60724 & 62425 & 64121 & 64425 & 67851 & 70844 & 73525 & 81138 & $\mid$\begin{tabular}{||l}
$\mid$ \\
108510
\end{tabular} & $\mid$\begin{tabular}{||l|}
112248 \\
\end{tabular} & $\mid$\begin{tabular}{||l}
121465 \\
\end{tabular} & 129759 & 137895 & $\mid$\begin{tabular}{||l}
$\mid 147458$ \\
\end{tabular} & 159018 & $\mid$\begin{tabular}{|l}
$\mid 166790$ \\
\end{tabular} & $\mid \begin{array}{l}173927 \\
\end{array}$ \\
\hline Paquistão & 73113 & 76657 & 77434 & 79409 & 82316 & 85822 & 87524 & 90346 & 94724 & $\mid$\begin{tabular}{||l}
$\mid$ \\
101704
\end{tabular} & $\mid$\begin{tabular}{||l|}
$\mid 109502$ \\
\end{tabular} & $\mid$\begin{tabular}{||l}
116267 \\
\end{tabular} & 121886 & $\mid$\begin{tabular}{||l}
$\mid$ \\
123959
\end{tabular} & 127469 & 129518 & $\mid$\begin{tabular}{|l|}
$\mid 133077$ \\
\end{tabular} & \begin{tabular}{|l}
137744 \\
\end{tabular} \\
\hline Paraguai & 7784 & 7906 & 8242 & 8247 & 8135 & 7946 & 7880 & 7878 & 8219 & 8552 & 8735 & 9155 & 9651 & 10265 & 9858 & 11148 & 11632 & 11488 \\
\hline Sri Lanka & 15715 & 16312 & 17357 & 18172 & 18954 & 20091 & 19780 & 20565 & 21786 & 22972 & 24406 & 26278 & 28064 & 29734 & 30786 & 33254 & 36049 & 39345 \\
\hline Swazilândia & 2023 & 2101 & 2166 & 2222 & 2288 & 2328 & 2355 & 2397 & 2451 & 2522 & 2584 & 2669 & 2763 & 2829 & 2864 & 2912 & 2951 & 3040 \\
\hline Tailândia & 140119 & 148039 & 143963 & 132973 & 139053 & 145249 & 150252 & 159491 & $\mid$\begin{tabular}{||l|}
170957 \\
\end{tabular} & $\mid$\begin{tabular}{||l}
$\mid$ \\
181709
\end{tabular} & $\mid$\begin{tabular}{||l|}
189318 \\
\end{tabular} & $\mid$\begin{tabular}{||l}
$\mid$ \\
198724
\end{tabular} & 209525 & $\mid$\begin{tabular}{||l}
$\mid$ \\
$\mid$
\end{tabular} 13140 & $\mid$\begin{tabular}{||l}
$\mid 211567$ \\
\end{tabular} & 227448 & 229345 & 246139 \\
\hline Ucrânia & & & & & & & & & & & & & & 102026 & 86926 & 90577 & 95287 & 95478 \\
\hline Cabo Verde & & & & & & & & & & & & & & 1289 & 1273 & 1291 & 1343 & 1357 \\
\hline
\end{tabular}




\begin{tabular}{|c|c|c|c|c|c|c|c|c|c|c|c|c|c|c|c|c|c|c|}
\hline Congo & & & 4588 & 4760 & 4637 & 4988 & 5178 & 5415 & 5459 & 5649 & 6087 & 6467 & 6364 & 6719 & 7221 & 7853 & 8121 & 8430 \\
\hline Georgia & & & & & & 4501 & 4717 & 4976 & 5526 & 5849 & 6411 & 7012 & 7878 & 8060 & 7756 & 8241 & 8834 & 9381 \\
\hline Lesoto & 1009 & 1062 & 1105 & 1125 & 1129 & 1187 & 1238 & 1244 & 1302 & 1332 & 1368 & 1427 & 1495 & 1581 & 1634 & 1763 & 1834 & 1925 \\
\hline Mauritânia & 1556 & 1647 & 1580 & 1624 & 1749 & 1742 & 1777 & 1789 & 1896 & 2005 & 2184 & 2597 & 2670 & 2699 & 2671 & 2798 & 2921 & 3095 \\
\hline Mongólia & & & 1711 & 1768 & 1822 & 1843 & 1898 & 1988 & 2127 & 2353 & 2523 & 2739 & 3020 & 3289 & 3247 & 3454 & 4051 & 4550 \\
\hline Marrocos & 38078 & 43203 & 42334 & 45712 & 45954 & 46686 & 50212 & 51877 & 55154 & 57802 & 59524 & 64143 & 65878 & 69781 & 72742 & 75517 & 79479 & 81871 \\
\hline Papua Nova Guiné & & 4761 & 4575 & 4403 & 4484 & 4372 & 4367 & 4360 & 4454 & 4576 & 4866 & 4978 & 5334 & 5686 & 6035 & 6499 & 7192 & 7774 \\
\hline Samoa & & & & & & & & & & & & & & & & & & 518 \\
\hline Ilhas Salomão & & 459 & 452 & 461 & 458 & 393 & 362 & 351 & 374 & 393 & 414 & 443 & 475 & 509 & 485 & 518 & 585 & 612 \\
\hline PEDmb Médio & 54998 & 51178 & 49228 & 49325 & 51710 & 52079 & 100445 & 106942 & 112206 & 122278 & 133421 & 146972 & 163296 & 167900 & 179841 & 196664 & 211810 & 219416 \\
\hline \multicolumn{19}{|c|}{ PMD } \\
\hline Bangladesh & 42812 & 44749 & 46758 & 49178 & 51475 & 54200 & 56952 & 59135 & 61937 & 65183 & 69443 & 74076 & 79305 & 84074 & 88316 & 93236 & 99264 & 105737 \\
\hline Benin & & 3236 & 3421 & 3557 & 3747 & 3966 & 4178 & 4372 & 4523 & 4723 & 4804 & 4993 & 5292 & 5551 & 5680 & 5800 & 5972 & 6249 \\
\hline Gana & 6794 & 7107 & 7405 & 7753 & 8094 & 8393 & 8729 & 9122 & 9596 & 10134 & 10732 & 11418 & 11915 & 13005 & 13635 & 14712 & 16779 & 18338 \\
\hline Madagascar & 3731 & 3811 & 3952 & 4107 & 4298 & 4503 & 4774 & 4169 & 4577 & 4818 & 5039 & 5292 & 5623 & 6023 & 5782 & 5797 & 5881 & 6059 \\
\hline Malawi & 2069 & 2220 & 2304 & 2394 & 2467 & 2506 & 2381 & 2422 & 2555 & 2679 & 2755 & 2812 & 3079 & 3335 & 3637 & 3874 & 4043 & 4119 \\
\hline Quênia & 14089 & 14673 & 14743 & 15228 & 15579 & 15673 & 16265 & 16354 & 16834 & 17693 & 18738 & 19951 & 21317 & 21367 & 22074 & 23928 & 25391 & 26547 \\
\hline Senegal & 5671 & 5785 & 5966 & 6318 & 6719 & 6934 & 7251 & 7299 & 7786 & 8244 & 8707 & 8921 & 9362 & 9707 & 9942 & 10357 & 10540 & 11000 \\
\hline Tanzânia & 9681 & 10121 & 10478 & 10867 & 11393 & 11955 & 12672 & 13579 & 14515 & 15651 & 16930 & 17719 & 19219 & 20289 & 21381 & 22740 & 24538 & 25799 \\
\hline Vietnã & & & & & & & & & & & & & 66051 & 69790 & 73557 & 78282 & 83167 & 87531 \\
\hline Zâmbia & 5164 & 5485 & 5694 & 5672 & 5936 & 6167 & 6495 & 6788 & 7259 & 7770 & 8332 & 8990 & 9741 & 10499 & 11467 & 12647 & 13449 & 14354 \\
\hline Zimbábue & 7536 & 8317 & 8540 & 8786 & 8714 & 8447 & 8569 & 7807 & 6480 & 6104 & 5755 & 5556 & 5353 & 4407 & 4671 & 5202 & 5822 & 6437 \\
\hline Burkina Faso & 2897 & 3216 & 3419 & 3669 & 3940 & 4012 & 4277 & 4464 & 4812 & 5027 & 5463 & 5804 & 6133 & 6580 & 6775 & 7347 & 7826 & 8331 \\
\hline Burundi & 1078 & 992 & 976 & 1022 & 1012 & 1003 & 1024 & 1069 & 1056 & 1107 & 1117 & 1177 & 1234 & 1296 & 1341 & 1392 & 1450 & 1508 \\
\hline
\end{tabular}




\begin{tabular}{|c|c|c|c|c|c|c|c|c|c|c|c|c|c|c|c|c|c|c|}
\hline Camboja & & & & & & & & & & 5557 & 6293 & 6971 & 7683 & 8197 & 8204 & 8693 & 9308 & 9984 \\
\hline R. Centro-Africana & 1153 & 1107 & 1166 & 1220 & 1264 & 1233 & 1288 & 1334 & 1262 & 1338 & 1350 & 1399 & 1464 & 1494 & 1520 & 1566 & 1618 & 1684 \\
\hline Gâmbia & & 441 & 463 & 479 & 510 & 538 & 569 & 551 & 589 & 630 & 624 & 631 & 654 & 692 & 736 & 784 & 750 & 794 \\
\hline Guiné & 2083 & 2176 & 2289 & 2372 & 2463 & 2525 & 2617 & 2752 & 2786 & 2852 & 2937 & 3010 & 3063 & 3215 & 3206 & 3268 & 3395 & 3529 \\
\hline Guiné-Bissau & 591 & 660 & 703 & 505 & 511 & 538 & 550 & 545 & 548 & 563 & 587 & 600 & 620 & 639 & 661 & 690 & 752 & 735 \\
\hline Quirguistão & & & & 1870 & 1938 & 2043 & 2152 & 2152 & 2303 & 2465 & 2460 & 2537 & 2753 & 2985 & 3071 & 3056 & 3238 & 3235 \\
\hline Mali & 3262 & 3492 & 3661 & 3938 & 4162 & 4026 & 4503 & 4698 & 5055 & 5169 & 5486 & 5774 & 6023 & 6322 & 6605 & 6989 & 7179 & 7181 \\
\hline Moçambique & 2926 & 3712 & 4114 & 4602 & 4962 & 5045 & 5687 & 6187 & 6590 & 7104 & 7724 & 8485 & 9115 & 9742 & 10360 & 11053 & 11840 & 12692 \\
\hline Nepal & & & & & & & & & & 7857 & 8130 & 8404 & 8691 & 9221 & 9639 & 10103 & 10449 & 10949 \\
\hline Niger & & 2519 & 2589 & 2859 & 2842 & 2802 & 3001 & 3091 & 3255 & 3259 & 3405 & 3603 & 3716 & 4072 & 4043 & 4382 & 4483 & 5013 \\
\hline Ruanda & & 1249 & 1422 & 1548 & 1666 & 1804 & 1961 & 2225 & 2258 & 2415 & 2581 & 2820 & 3035 & 3373 & 3585 & 3847 & 4149 & 4514 \\
\hline Togo & 1618 & 1761 & 2014 & 1968 & 2017 & 2001 & 1969 & 1950 & 2047 & 2090 & 2115 & 2201 & 2251 & 2301 & 2382 & 2477 & 2598 & 2752 \\
\hline Uganda & 4863 & 5304 & 5575 & 5848 & 6319 & 6518 & 6856 & 7454 & 7937 & 8477 & 9014 & 9986 & 10826 & 11769 & 12622 & 13275 & 14559 & 15201 \\
\hline PMD Médio & 6557 & 6006 & 6257 & 6337 & 6610 & 6819 & 7162 & 7370 & 7677 & 7956 & 8421 & 8925 & 11674 & 12306 & 12880 & 13673 & 14555 & 15395 \\
\hline
\end{tabular}

Fonte: elaboração própria. 
Quadro A4-1.2: COMEX no período 1995-2012

\begin{tabular}{|c|c|c|c|c|c|c|c|c|c|c|c|c|c|c|c|c|c|c|}
\hline MEMBRO & $\mid 1995$ & $\mid 1996$ & $\mid 1997$ & 1998 & $\mid 1999$ & 2000 & $\mid 2001$ & $\mid 2002$ & 2003 & 2004 & $\mid 2005$ & 2006 & 2007 & $\mid 2008$ & 2009 & 2010 & $\mid 2011$ & $\mid 2012$ \\
\hline \multicolumn{19}{|c|}{ PAISES DESENVOLVIDOS } \\
\hline PD Médio & 97,56 & 97,07 & 97,78 & 95,59 & 96,34 & 100,15 & 97,94 & 95,82 & 99,44 & 105,81 & 108,37 & 112,07 & 1,03 & 116,18 & 01,97 & 109,56 & 115,68 & 15,10 \\
\hline & & & & & & & & & & & & & & & & & & \\
\hline Striad & 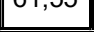 & 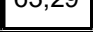 & 00,40 & 00,10 & 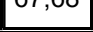 & $\mid$ & 更 & & 00,10 & 1 & ${ }^{14,10}$ & ri,90 & ${ }^{10,01}$ & 0,00 & (1,01 & 10,14 & 00,02 & 83,35 \\
\hline Estados Unidos & 22,38 & 22,61 & 23,34 & 22,76 & 23,19 & 24,98 & 22,80 & 22,15 & 22,45 & 24,29 & 25,50 & 26,87 & 27,96 & 29,94 & 24,77 & 28,18 & 30,89 & 30,70 \\
\hline UE / EUA Média & $\mid 41,97$ & 42,95 & |44,87 & 44,75 & 45,44 & 49,78 & 48,18 & 46,58 & 45,82 & $47,91 \mid$ & $\mid 49,83$ & 52,40 & $\mid 53,41$ & 55,24 & 48,14 & 53,16 & 56,95 & 57,03 \\
\hline \multicolumn{19}{|c|}{ OUTROS DESENVOLVIDOS } \\
\hline Arábia Saudita & & & & & & & & & & & $\mid 81,95$ & 89,94 & 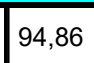 & 96,10 & 84,86 & 82,77 & 85,76 & 83,74 \\
\hline Austrália & 37,73 & 38,22 & 37,95 & 39,97 & 39,01 & 40,90 & 44,12 & 41,33 & 39,97 & 36,73 & 38,87 & 41,02 & 41,40 & 42,12 & 44,95 & 39,86 & 41,24 & 42,70 \\
\hline Bahrein & 152,46 & 164,12 & 148,58 & 128,49 & 141,83 & 135,81 & 127,03 & 130,61 & 128,09 & 140,74 & 148,31 & 147,10 & 137,79 & 145,88 & 117,96 & 120,47 & 126,81 & 122,16 \\
\hline Barbados & $\mid 90,07$ & 91,57 & |93,88 & 86,30 & 86,43 & 88,79 & 84,65 & 81,81 & 88,31 & 90,21 & |95,66 & 94,59 & $\mid$ |93,71 & 98,45 & 85,84 & 96,60 & 91,46 & \begin{tabular}{|c|c|}
89,91 & -1
\end{tabular} \\
\hline Canada & |69,33 & 70,48 & |74,59 & 78,21 & 80,40 & 83,18 & 78,80 & 76,28 & 70,21 & $70,51 \mid$ & $\mid 70,02$ & 68,22 & $\mid 66,51$ & 67,21 & 58,35 & 60,02 & 62,33 & 62,26 \\
\hline Cingapura & 345,74 & 335,93 & 325,39 & 313,88 & 337,54 & 366,07 & 352,75 & 354,28 & 382,79 & 406,29 & 422,33 & 430,36 & 398,66 & 439,66 & 360,23 & 372,10 & 376,15 & 368,23 \\
\hline Coréia do Sul & 54,32 & 54,71 & 60,23 & 72,91 & 65,43 & 67,95 & |63,91 & 60,15 & 63,39 & |72,76 | & 71,18 & 73,55 & $\mid$\begin{tabular}{||l}
$\mid 77,24$ \\
\end{tabular} & 99,93 & 90,41 & 95,65 & 110,00 & 109,89 \\
\hline Croácia & & & & & & 76,06 & 80,84 & 83,22 & 85,22 & 84,92 & $\mid 84,73$ & 86,07 & $\mid 85,27$ & 84,99 & 72,76 & 75,90 & 81,27 & 82,68 \\
\hline Hong Kong & 290,35 & 274,21 & 262,02 & 248,00 & 248,88 & 279,12 & 269,55 & 286,57 & 327,17 & $364,59 \mid$ & 377,09 & |392,44 & $\mid 396,77$ & 407,38 & 374,58 & 432,95 & 447,06 & 449,99 \\
\hline Islândia & 65,96 & 70,38 & 70,36 & 72,19 & 69,85 & 71,95 & 75,72 & |70,55 & 68,99 & 70,75|| & $\mid 72,87$ & 79,44 & $\mid$\begin{tabular}{||l|l|} 
& 75,90
\end{tabular} & 85,20 & 90,60 & 97,27 & 105,24 & 107,91 \\
\hline Israel & 62,96 & 61,36 & 60,53 & 59,80 & 67,76 & 71,19 & 64,93 & 68,62 & 70,09 & 78,16 & 81,48 & 81,11 & 81,49 & 77,29 & 63,79 & 67,81 & 71,47 & 72,45 \\
\hline Japão & $\mid 16,75$ & $\mid 18,94$ & |20,39 & 19,69 & 18,76 & 20,31 & 20,26 & 21,16 & 22,09 & 24,46 & $\mid$\begin{tabular}{|l|}
$\mid 27,22$ \\
\end{tabular} & 31,09 & $\mid$\begin{tabular}{||l|l|} 
& 33,80
\end{tabular} & 35,23 & 25,02 & 29,15 & 31,16 & 31,34 \\
\hline Kuwait & |94,32 & 91,47 & |92,45 & 94,95 & 85,37 & 86,62 & 86,84 & 81,23 & 86,56 & $89,30 \mid$ & $\mid 92,24$ & 89,71 & $\mid$\begin{tabular}{||l|l|} 
&
\end{tabular} & 92,68 & 88,86 & 97,03 & 99,12 & 101,01 \\
\hline Nova Zelândia & |56,91 & 55,12 & 55,25 & 57,90 & 61,40 & 68,52 & 67,23 & 62,58 & 57,84 & 58,71 & $\mid 57,85$ & 59,66 & $\mid$\begin{tabular}{||l|l|}
58,60 \\
\end{tabular} & 64,99 & 55,56 & 58,75 & 60,01 & 57,69 \\
\hline Noruega & |68,33 & 71,12 & |73,06 & 72,02 & 70,01 & 74,62 & |73,27 & 67,65 & 66,58 & 69,05 & 70,85 & \begin{tabular}{|l|}
72,39 \\
\end{tabular} & 73,19 & 74,94 & 67,13 & 68,41 & 69,83 & 68,31 \\
\hline Omã & & & & & & 79,59 & 81,04 & |77,02 & 82,55 & 90,25 & $\mid 89,34$ & 87,84 & $\mid 96,47$ & 95,66 & 85,28 & 89,82 & 115,94 & 116,87 \\
\hline
\end{tabular}




\begin{tabular}{|c|c|c|c|c|c|c|c|c|c|c|c|c|c|c|c|c|c|c|}
\hline Suíça & $\mid 77,30$ & 79,82 & $\mid 89,35$ & 88,89 & 90,10 & 98,25 & $\mid 96,17$ & |91,24 & 89,76 & 94,14 & 100,62 & 104,94 & 111,89 & 115,37 & 107,32 & 117,77 & 123,08 & 124,18 \\
\hline Taiwan & & & & & & & & $\mid 80,75$ & 86,75 & 99,98 & $\mid 101,68$ & 113,38 & 121,77 & 127,07 & 102,84 & 125,23 & 129,83 & 126,45 \\
\hline Trinidad e Tobago & 92,12 & 86,89 & $|108,50|$ & 102,33 & 94,68 & 104,9 & $\mid 100,45$ & 95,60 & 90,00 & 94,27 & $\mid 105,33$ & 119,28 & $\mid 102,59$ & 105,80 & \begin{tabular}{|c|}
90,48 \\
-1
\end{tabular} & 90,33 & 105,83 & 96,50 \\
\hline Catar & & & & & 85,73 & 89,61 & $\mid 94,97$ & $\mid 88,47$ & 90,16 & 90,37 & $\mid$ |94,75 & |98,57 & || 96,11 & 89,43 & \begin{tabular}{|l|l}
80,14 \\
$\quad r$
\end{tabular} & 86,07 & 97,54 & 103,83 \\
\hline Macau & $7,91 \|$ & 135,83 & $|137,54|$ & 140,45 & $\mid 148,73$ & 165,0 & 168,31 & $\mid 174,45$ & 176,20 & 173,72 & 156,89 & 151,31 & $\mid 159,36$ & 160,30 & $|143,73|$ & 155,78 & 3165,28 & 159,76 \\
\hline Outros PD Médio & 104, & 104,29 & ||104,84 & 102,37 & 102,70 & 05,7 & 03,47 & 101,01 & 105,08 & 111,90 & $\mid 114,22$ & 118,03 & $\left.\right|^{116,79}$ & 122,27 & 107,35 & 115,20 & 121,56 & 120,90 \\
\hline \multicolumn{19}{|c|}{ EM DESENVOLVIMENTO } \\
\hline PED Médio & 72,48 & 71,40 & 75,34 & 76,27 & 74,49 & 76,00 & 75,65 & 75,50 & 77,50 & 80,13 & | 82,56 & 81,89 & || 83,96 & 86,14 & 75,82 & 80,27 & 84,49 & 84,07 \\
\hline \multicolumn{19}{|c|}{ Renda Média-Alta } \\
\hline África do Sul & 43,61 & 46,67 & 46,85 & 48,90 & 46,86 & 51,44 & 54,80 & 59,76 & 51,40 & 51,08 & 53,15 & 60,28 & 63,68 & 72,87 & 55,42 & 55,99 & 60,02 & 60,74 \\
\hline Antígua e Barbuda & 180,90 & 174,23 & $\mid 158,93$ & 154,16 & 153,74 & 123,1 & 120,44 & 112,43 & 118,74 & 125,37 & 123,12 & 120,39 & 117,41 & 117,09 & 105,11 & 105,92 & 104,35 & 103,69 \\
\hline Argentina & 19,77 & 21,51 & 23,34 & 23,35 & 21,38 & 22,62 & 21,85 & 41,75 & 40,64 & 36,97 & 36,80 & 35,89 & 35,86 & 36,27 & 30,18 & 32,21 & 33,57 & 29,20 \\
\hline Brasil & 16,63 & 15,64 & 16,58 & $\mid 16,44$ & 20,98 & 22,64 & 26,94 & 27,62 & 28,14 & 29,68 & $\mid 27,09$ & 26,04 & 25,29 & 27,26 & 22,11 & 22,52 & 23,72 & 24,81 \\
\hline Chile & 56,41 & 56,24 & 56,29 & 55,87 & 56,92 & 57,87 & 61,41 & 61,94 & 65,12 & 68,26 & 69,97 & 71,94 & 75,79 & 81,04 & 66,77 & 69,73 & 72,95 & 68,81 \\
\hline Colômbia & 35,50 & 36,04 & 35,60 & 35,91 & 36,15 & 32,67 & 33,90 & 32,98 & 36,52 & 35,86 & |35,63 & 38,17 & | 36,33 & 38,05 & 34,28 & 33,70 & 38,67 & 38,30 \\
\hline Costa Rica & 77,92 & 82,10 & 85,34 & |97,53 & 97,67 & 94,39 & 86,01 & 90,02 & 95,20 & 95,74 & $\mid 102,47$ & 104,41 & 102,23 & 100,63 & 83,98 & 79,10 & 79,40 & 78,94 \\
\hline Cuba & 29,31 & 32,63 & 32,75 & $\mid 32,50$ & 31,87 & 31,08 & |29,36 & 24,73 & 26,59 & 31,31 & $\mid$\begin{tabular}{||l|}
$\mid 39,36$ \\
\end{tabular} & 37,19 & 37,97 & 44,92 & 32,91 & 40,29 & 46,96 & 45,87 \\
\hline Dominica & $\mid 114,22$ & 112,71 & $\mid 126,13$ & 125,29 & 126,02 & 97,54 & | 83,64 & $\mid 82,74$ & 78,76 & 81,27 & $\mid 87,90$ & 87,95 & $\mid 91,12$ & 96,93 & 84,25 & 88,82 & 90,92 & 84,56 \\
\hline Granada & & 110,23 & 113,68 & 120,47 & 127,58 & 104,9 & 91,72 & 82,31 & 83,08 & 86,27 & 78,38 & 80,84 & 85,16 & 79,85 & 71,08 & 73,06 & 75,99 & 75,28 \\
\hline Jamaica & 111,30 & 99,07 & 90,99 & & & & & 81,85 & 88,15 & 89,32 & 90,49 & 100,75 & 101,24 & 113,58 & 86,89 & 80,93 & 83,92 & 82,16 \\
\hline Malásia & 192,11 & 181,77 & 185,66 & 209,49 & 217,57 & 220,4 & 203,36 & 199,36 & 194,19 & 210,37 & 3,85 & 202,58 & 192,47 & 176,67 & 162,56 & 157,94 & 154,94 & 147,84 \\
\hline Maurício & 119,74 & 127,86 & 127,81 & 132,20 & 131,35 & 123,3 & 130,99 & 120,60 & 112,07 & 110,41 & $\mid 125,71$ & 131,38 & 125,04 & 119,03 & 107,28 & 116,26 & 119,78 & 121,27 \\
\hline México & 46,11 & 50,72 & 49,32 & 51,78 & 51,27 & 53,13 & 48,53 & 48,37 & 51,24 & 54,23 & 54,58 & 56,46 & | 57,08 & 58,07 & 56,13 & 61,02 & 63,88 & 66,53 \\
\hline Namíbia & |94,42 & 97,62 & $\mid$ ||94,02 & $\mid 93,25$ & 92,28 & 85,43 & $\mid 88,85$ & |94,08 & 95,86 & 81,89 & | 80,76 & 87,03 & $\mid 106,30$ & 121,21 & $|125,48|$ & 108,41 & 103,00 & 103,57 \\
\hline
\end{tabular}




\begin{tabular}{|c|c|c|c|c|c|c|c|c|c|c|c|c|c|c|c|c|c|c|}
\hline Panamá & & & 175,81 & 160,28 & 134,28 & 142,39 & 138,64 & 129,74 & 1122,14 & 131,52 & 144,55 & 146,19 & 145,38 & \begin{tabular}{|l|l|}
8 & 149,00 \\
\end{tabular} & 138,73 & 139,69 & 158,35 & 154,75 \\
\hline Peru & 31,64 & 32,25 & 34,01 & 33,23 & 33,40 & 35,58 & 34,80 & 34,83 & 36,67 & 41,03 & 46,87 & 50,83 & 53,88 & 56,47 & 46,42 & 50,01 & 55,24 & 52,27 \\
\hline R. Dominicana & |75,09 & 73,35 & $\mid 76,42$ & $\mid 79,38$ & 79,89 & 82,91 & |74,72 & |72,81 & 86,49 & $\mid 83,88$ & |65,53 & 67,97 & $\mid 61,94$ & 61,44 & 50,60 & 54,83 & 57,50 & 57,50 \\
\hline Rússia & & & & & & & & & & & & & & & & & & $\mid 51,82$ \\
\hline St. Kitts e Nevis & & 100,68 & 94,26 & 92,70 & 90,16 & 95,01 & 85,80 & 85,27 & 90,93 & || 86,92 & 93,30 & 87,47 & $\mid 84,68$ & 91,53 & 76,73 & 83,69 & 85,40 & 84,20 \\
\hline St. Lúcia & 136,86 & 130,85 & 127,89 & 122,96 & 119,44 & 105,37 & 98,40 & 96,53 & 109,84 & 108,28 & 118,28 & 106,72 & $\mid 102,66$ & 6113,55 & 100,43 & 3111,75 & 107,68 & 103,37 \\
\hline St. Vincente e Granadinas & $\mid 98,36$ & 101,22 & 108,49 & 108,78 & 106,77 & 95,87 & $\mid 89,62$ & 85,11 & 85,98 & || $87,50$ & |89,29 & 88,06 & $\mid 94,30$ & 92,17 & 85,99 & 84,02 & 82,74 & 85,44 \\
\hline Suriname & $\mid 50,06$ & 54,11 & | 59,99 & $\mid$\begin{tabular}{||c}
$\mid 83,60$ \\
\end{tabular} & |60,87 & 52,93 & |78,00 & $\mid 58,38$ & 65,30 & |74,22 & |75,58 & & & & & & & \\
\hline Turquia & $\mid 44,24$ & $\mid 49,37$ & $\mid 54,97$ & $\mid 41,52$ & 38,73 & 43,19 & $\mid 50,76$ & $\mid 48,80$ & 47,03 & || 49,74 & $\mid 47,21$ & 50,25 & $\mid$\begin{tabular}{||c|c|}
49,81 &
\end{tabular} & 52,25 & 47,74 & 47,97 & 56,62 & 57,75 \\
\hline Uruguai & 38,10 & 39,53 & $\mid$\begin{tabular}{||l}
$\mid 37,71$ \\
\end{tabular} & $\mid$\begin{tabular}{||l}
$\mid$ \\
35,64
\end{tabular} & 33,39 & 36,71 & $\mid 36,31$ & |40,03 & 51,76 & $\mid 61,48$ & |58,88 & |61,97 & $\mid 59,21$ & 65,21 & 53,41 & 51,69 & 53,28 & |54,94 \\
\hline Venezuela & $\mid 48,92$ & |57,84 & 51,25 & $\mid 43,60$ & $\mid 42,07$ & 47,86 & $\mid 42,14$ & $\mid 48,58$ & 50,58 & || $55,37$ & |60,13 & $\mid 58,67$ & $\mid$\begin{tabular}{||c|}
$\mid 56,20$ \\
\end{tabular} & 51,83 & 38,52 & 46,14 & 49,64 & 50,40 \\
\hline Albânia & & & & & & $\mid 55,92$ & $\mid 57,43$ & 63,93 & 65,44 & 66,36 & $\mid 70,30$ & 73,46 & $\mid 82,87$ & 86,03 & 83,36 & 85,46 & 90,76 & 85,34 \\
\hline Botswana & |94,60 & 90,96 & $\mid 108,60$ & 101,84 & 98,93 & 91,92 & 87,53 & |91,84 & 85,83 & $\mid 91,00$ & | 88,51 & 86,33 & $\mid 95,10$ & 96,72 & 86,69 & 88,14 & 95,62 & 100,77 \\
\hline Gabão & $\mid$\begin{tabular}{||c|}
95,13 \\
\end{tabular} & |95,67 & $\mid$\begin{tabular}{||l}
$\mid 98,54$ \\
\end{tabular} & 95,97 & 97,73 & 101,70 & |83,64 & 84,76 & 80,30 & 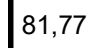 & 84,75 & \begin{tabular}{|l|l|}
89,77 \\
\end{tabular} & $\mid 85,13$ & 88,17 & 81,69 & 89,16 & 90,50 & 92,34 \\
\hline Jordânia & & & & & & 110,49 & 109,44 & 114,19 & 115,86 & 134,82 & 146,91 & 141,75 & $\mid 145,99$ & 9144,02 & 114,96 & 117,26 & 121,51 & 120,51 \\
\hline Maldivas & & & & & & & $\mid 104,08$ & 104,43 & 107,19 & 117,35 & 120,83 & 123,66 & $\mid 197,53$ & $3 \mid 191,44$ & $4 \mid 147,89$ & 9159,39 & 204,76 & 184,50 \\
\hline Montenegro & & & & & & & & & & & & & & & & & & \begin{tabular}{|l|l|}
111,77 \\
\end{tabular} \\
\hline Tonga & & & & & & & & & & & & & $\mid 64,79$ & 66,50 & 68,98 & 61,03 & 66,04 & 75,61 \\
\hline Tunisia & $\mid 93,71$ & $\mid 85,72$ & $\mid 80,50$ & $\mid$\begin{tabular}{||l}
$\mid$ \\
$\mid 79,98$
\end{tabular} & 77,91 & 82,46 & $\mid 89,55$ & $\mid 85,34$ & 82,39 & $\mid$\begin{tabular}{||l}
$\mid 86,95$ \\
\end{tabular} & 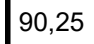 & |93,94 & $\mid 104,08$ & $8 \mid 115,40$ & 94,37 & 105,76 & 105,74 & 107,80 \\
\hline Macedônia & & & & & & & & & $\mid 71,07$ & $\mid 80,87$ & $\mid$\begin{tabular}{||l}
$\mid 85,84$ \\
\end{tabular} & 92,55 & $\mid 106,09$ & $9 \mid 111,57$ & 87,18 & 97,88 & 113,19 & 112,22 \\
\hline PEDma Médio & |77,79 & |79,87 & $\mid 83,99$ & $\mid$\begin{tabular}{||l}
$\mid 84,32$ \\
\end{tabular} & 82,42 & 79,34 & 78,09 & |77,58 & 78,77 & 82,10 & | 84,26 & 85,83 & $\mid 88,83$ & 91,15 & 79,00 & 81,24 & 85,83 & 84,55 \\
\hline & & & & & & & nda $M$ & Média-B: & 3aixa & & & & & & & & & \\
\hline Armênia & & & & & & & & & 82,19 & $\mid 75,04$ & $\mid$\begin{tabular}{||l}
$\mid 72,04$ \\
\end{tabular} & 62,61 & $\mid$\begin{tabular}{||l|l|} 
& 58,34
\end{tabular} & 55,70 & 58,48 & 66,15 & 71,11 & $\mid 75,97$ \\
\hline Belize & $\mid 97,07$ & 100,27 & 108,49 & 109,51 & 122,41 & 126,64 & 119,97 & 118,69 & 119,12 & 109,08 & 117,36 & 122,79 & || $122,31$ & 132,02 & 2107,85 & $5 \mid 115,68$ & 123,20 & 125,37 \\
\hline
\end{tabular}




\begin{tabular}{|c|c||c||c|c||c|c|c|c|c|c|c|c||c|c|c|c|c|c|}
\hline Bolivia & 49,74 & 49,86 & 50,47 & 52,28 & 44,17 & 45,60 & 45,23 & 49,35 & 51,97 & 57,46 & 67,64 & 74,54 & 76,06 & 82,87 & 68,63 & 75,51 & 82,48 & 84,95 \\
\hline Camarões & 41,37 & 41,77 & 39,79 & 39,14 & 38,67 & 42,91 & 45,13 & 40,65 & 40,15 & 39,23 & 41,93 & 43,96 & 48,54 & 52,34 & 37,07 & 40,36 & 44,86 & 45,40 \\
\hline China & & & & & & & & & & & & \\
\hline
\end{tabular}




\begin{tabular}{|c|c|c|c|c|c|c|c|c|c|c|c|c|c|c|c|c|c|c|}
\hline Congo & & & 135,76 & 148,90 & 131,39 & 123,91 & 130,73 & 135,46 & 156,86 & 131,37 & $7 \longdiv { 1 3 8 , 6 6 }$ & 149,78 & 132,05 & 122,15 & 120,62 & 139,82 & 145,12 & 144,10 \\
\hline Georgia & & & & & & 62,66 & 63,33 & 71,63 & 78,26 & 79,74 & 85,32 & 89,88 & 89,16 & 87,02 & 78,67 & 87,72 & 91,02 & 95,95 \\
\hline Lesoto & 3,70 & 159,03 & $\mid 154,11$ & $|182,67|$ & 166,84 & 169,57 & 190,40 & 209,89 & 199,44 & 186,15 & $5 \mid 169,75$ & 172,65 & 170,10 & 176,55 & 158,46 & 1155,76 & $\mid 151,86$ & 147,09 \\
\hline Mauritânia & 98,57 & 94,71 & 84,63 & 69,85 & 63,86 & 75,26 & 76,03 & 70,61 & 68,26 & 92,26 & 113,20 & 98,44 & 103,01 & 112,99 & 97,70 & 111,92 & 121,52 & 144,39 \\
\hline Mongólia & & & 99,99 & 107,35 & 112,24 & 121,89 & 115,82 & 118,52 & 120,30 & 131,33 & 122,38 & 112,93 & 117,88 & 121,20 & 107,81 & 103,35 & 127,00 & 109,59 \\
\hline Marrocos & 53,82 & 48,66 & 53,27 & 52,52 & 55,96 & 61,33 & 61,35 & 62,41 & 60,16 & 63,69 & 70,23 & 73,88 & 78,49 & 85,67 & 67,92 & 75,25 & 83,43 & 85,12 \\
\hline Papua Nova Guin & & $\mid 107,80$ & $\mid 99,21$ & 102,86 & 116,01 & 115,42 & 117,58 & $\mid 118,92$ & 123,45 & $|131,08|$ & 124,48 & & & & & & & \\
\hline Samoa & & & & & & & & & & & & & & & & & & $\mid 79,39$ \\
\hline Ilhas Salomão & & 90,23 & 104,25 & 88,86 & 77,79 & 62,72 & 52,40 & 50,55 & 58,08 & 73,30 & 88,68 & 93,37 & 105,67 & 111,50 & 96,90 & 132,35 & 134,43 & 125,45 \\
\hline PEDmb Médio & 79,09 & 80,71 & 85,55 & 87,72 & 84,40 & 89,08 & 89,12 & 89,87 & 91,90 & 93,02 & 96,23 & 92,69 & 92,37 & 94,15 & 81,99 & 88,16 & 92,19 & 90,79 \\
\hline Bangladesh & 28,21 & 26,08 & 26,33 & 27,88 & 28,39 & 29,32 & 32,10 & 28,97 & 27,66 & 26,86 & 34,40 & 38,11 & 39,94 & 42,62 & 40,09 & 37,80 & 47,42 & 48,11 \\
\hline Benin & & 56,52 & 58,71 & 59,59 & 64,67 & 55,99 & 57,28 & 51,48 & 48,72 & 46,37 & $\mid 45,82$ & 46,85 & 57,80 & 56,50 & 52,70 & 60,99 & 55,58 & 60,37 \\
\hline Gana & 57,42 & 72,20 & 85,40 & 80,60 & 81,71 & 116,05 & 110,05 & 97,49 & 97,29 & 99,67 & 98,17 & 65,92 & 65,35 & 69,51 & 71,59 & 75,38 & 86,30 & 93,17 \\
\hline Madagascar & 55,85 & 46,50 & 51,83 & 50,80 & 56,68 & 68,68 & 61,37 & 38,58 & 55,16 & 80,12 & 73,77 & 75,50 & 82,39 & 83,45 & 74,00 & 68,02 & 69,08 & 72,98 \\
\hline Malawi & 78,46 & 54,70 & 54,94 & 70,88 & 71,32 & 60,94 & 67,12 & 54,96 & 67,29 & 68,15 & 76,23 & 69,73 & 68,59 & 77,10 & 63,61 & 74,32 & 69,39 & 89,22 \\
\hline Quênia &, 75 & 57,31 & 54,06 & 48,90 & 48,19 & 53,31 & 55,95 & 55,17 & 54,13 & 59,48 & 64,48 & 55,24 & 53,89 & 57,58 & 50,86 & 54,23 & 60,45 & 55,22 \\
\hline Senegal & 68,19 & 59,75 & 60,87 & 61,96 & 63,11 & 65,14 & 66,49 & 67,51 & 65,36 & 66,91 & 69,44 & 68,72 & 73,29 & 78,56 & 65,49 & 65,11 & 66,85 & 66,62 \\
\hline Tanzânia & 65,58 & 51,88 & 41,91 & 37,42 & 35,38 & 33,49 & 38,29 & 37,42 & 41,37 & 45,72 & 39,08 & 42,11 & 50,60 & 49,44 & 43,65 & 47,88 & 56,80 & 54,40 \\
\hline Vietnã & & & & & & & & & & & & & 154,61 & 154,32 & 136,31 & 152,22 & 162,91 & 156,55 \\
\hline Zâmbia & 69,23 & 63,82 & 58,27 & 56,25 & 59,77 & 60,39 & 64,67 & 64,92 & 62,31 & 70,81 & 62,20 & 57,86 & |65,77 & 59,45 & 56,12 & 67,90 & 69,89 & 79,27 \\
\hline Zimbábue & 79,16 & 72,07 & 82,21 & 88,51 & 70,92 & 74,07 & 67,90 & 66,81 & 70,45 & 76,04 & 76,04 & 82,82 & 84,17 & 109,52 & 68,48 & 100,37 & 122,31 & 96,11 \\
\hline Burkina Faso & 40,75 & 38,18 & 37,42 & 40,94 & 33,69 & 34,51 & 32,37 & 30,87 & 30,73 & 37,13 & 35,54 & 36,78 & 35,42 & 36,31 & 40,42 & 48,87 & 58,15 & 62,68 \\
\hline Burundi & 40,20 & 21,57 & 24,28 & 27,44 & 23,54 & 22,55 & 20,96 & $\mid 21,67$ & 27,38 & 31,58 & $\mid 41,65$ & 54,15 & $\mid 41,48$ & 47,42 & 49,93 & 48,10 & 47,02 & 46,42 \\
\hline
\end{tabular}




\begin{tabular}{|c|c|c|c|c|c|c|c|c|c|c|c|c|c|c|c|c|c|c|}
\hline Camboja & & & & & & & & & & 134,51 & 136,83 & 144,61 & 138,27 & 133,32 & 105,14 & 113,60 & 113,58 & 120,74 \\
\hline R. Centro-Africana & 50,48 & 47,08 & 55,82 & 51,05 & $\mid$\begin{tabular}{||l}
$\mid 43,21$ \\
-1
\end{tabular} & 45,66 & $\mid$\begin{tabular}{||l}
39,73 \\
-
\end{tabular} & |36,11 & 36,23 & $\mid 33,24$ & $\mid$\begin{tabular}{||l}
34,73 \\
\end{tabular} & 36,40 & $\mid 37,57$ & 34,44 & 33,92 & 38,32 & 37,88 & 36,41 \\
\hline Gâmbia & & $\mid 50,95$ & 48,32 & 53,87 & $\mid$\begin{tabular}{||l}
52,41 \\
-
\end{tabular} & 56,36 & $\mid 46,93$ & \begin{tabular}{||l}
$\mid 59,64$ \\
\end{tabular} & 68,86 & 69,09 & |70,31 & 61,95 & $\mid$\begin{tabular}{||c|}
56,80 \\
\end{tabular} & 56,05 & 64,61 & 66,46 & 67,08 & 74,92 \\
\hline Guiné & 45,64 & 43,54 & 42,42 & $\mid 48,21$ & $\mid$\begin{tabular}{||l}
$\mid 47,67$ \\
-
\end{tabular} & 53,48 & $\mid 58,60$ & |55,45 & 51,14 & | 50,44 & |69,90 & 83,21 & $\mid 65,18$ & 75,01 & 57,33 & 64,88 & 78,38 & 91,69 \\
\hline Guiné-Bissau & 46,81 & 42,36 & 60,90 & 50,29 & | 67,68 & 54,87 & $\mid 48,02$ & $\mid 41,18$ & 43,27 & $\mid 44,85$ & $\mid$\begin{tabular}{||l|l}
$\mid 48,43$ \\
\end{tabular} & $\mid 49,54$ & $\mid$\begin{tabular}{||l|}
$\mid$ \\
54,12
\end{tabular} & 52,77 & 53,76 & 55,33 & 57,64 & 39,61 \\
\hline Quirguistão & & & & 94,51 & $\mid 99,20$ & 89,43 & $\mid 73,75$ & $\mid 82,92$ & 83,93 & $\mid 93,82$ & |95,08 & 120,75 & $\mid 137,06$ & 146,11 & $1 \mid 133,38$ & 133,23 & 136,18 & 139,68 \\
\hline Mali & 56,24 & 52,49 & |57,04 & 50,18 & 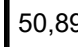 & 55,52 & |60,37 & |60,32 & 62,13 & | 57,05 & $\mid$\begin{tabular}{||l}
$\mid 57,94$ \\
\end{tabular} & 62,81 & $\mid 61,83$ & 47,36 & 43,97 & 46,17 & 51,72 & 55,04 \\
\hline Moçambique & 70,13 & |53,72 & $\mid 46,08$ & 41,13 & $\mid 49,60$ & 52,40 & $\mid 55,42$ & $\mid 80,42$ & 76,51 & 77,21 & $\mid$\begin{tabular}{||l} 
\\
76,37
\end{tabular} & 71,20 & $\mid$\begin{tabular}{||l|} 
\\
70,75
\end{tabular} & 64,10 & 68,73 & 76,16 & 82,36 & 104,23 \\
\hline Nepal & & & & & & & & & & 46,15 & |44,06 & 44,76 & $\mid 44,58$ & 46,04 & 47,08 & 45,98 & 41,83 & 43,66 \\
\hline Níger & & $\mid 44,40$ & $\mid 41,47$ & 44,10 & $\mid$\begin{tabular}{||l}
39,13 \\
\end{tabular} & 43,49 & $\mid 41,53$ & $\mid 42,39$ & 39,98 & 45,27 & $\mid 47,40$ & $\mid 45,92$ & $\mid 47,35$ & 53,42 & 67,18 & 71,29 & 68,69 & 61,22 \\
\hline Ruanda & & $\mid 32,23$ & 33,47 & 28,79 & $\mid$\begin{tabular}{||l}
30,75 \\
\end{tabular} & 31,20 & $\mid$\begin{tabular}{||l}
32,75 \\
\end{tabular} & $\mid$\begin{tabular}{||l}
$\mid 30,75$ \\
\end{tabular} & 32,00 & $\mid 35,88$ & $\mid$\begin{tabular}{||l}
$\mid 36,67$ \\
\end{tabular} & 37,59 & $\mid$\begin{tabular}{||l|}
$\mid 40,34$ \\
\end{tabular} & 40,56 & 38,71 & 40,05 & 44,05 & 46,09 \\
\hline Togo & 69,85 & 77,42 & 73,78 & 72,99 & $\mid$\begin{tabular}{||c|}
67,89 \\
\end{tabular} & 81,99 & $\mid$\begin{tabular}{||l} 
\\
82,29
\end{tabular} & $\mid 85,59$ & 102,48 & $\mid 96,43$ & |98,70 & |94,32 & $\mid 92,41$ & 87,43 & 89,09 & 97,47 & 95,76 & 106,60 \\
\hline Uganda & 32,62 & 35,39 & 34,16 & 30,04 & $\mid$\begin{tabular}{||l}
$\mid$ \\
$\mid$
\end{tabular} 6,02 & 32,75 & $\mid$\begin{tabular}{||l}
35,33 \\
\end{tabular} & $\mid$\begin{tabular}{||l}
$\mid 36,28$ \\
\end{tabular} & 36,59 & 35,46 & $\mid$\begin{tabular}{||l}
38,99 \\
\end{tabular} & 43,63 & 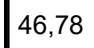 & 56,26 & 49,70 & 45,73 & 52,71 & 53,10 \\
\hline PMD Médio & 57,03 & $\mid$\begin{tabular}{|l}
$\mid 50,01$ \\
\end{tabular} & 51,35 & 52,88 & $\mid 53,13$ & 55,29 & ||54,32 & | 53,34 & 55,69 & $\mid 61,13$ & |62,89 & |63,62 & $\mid$ |67,94 & 69,79 & 64,07 & 69,07 & 73,08 & $\mid 75,16$ \\
\hline
\end{tabular}

Fonte: elaboração própria. 
Quadro A4-1.3: AGRI no período 1995-2012

\begin{tabular}{|c|c|c|c|c|c|c|c|c|c|c|c|c|c|c|c|c|c|c|}
\hline MEMBRO & $\mid 1995$ & |1996| & $1997 \mid$ & 1998 & |1999 | & 2000 & |2001 & 2002 & 2003 & |2004 | & 2005 & 2006 & 2007 & 2008 & 2009 & 2010 & 2011 & 2012 \\
\hline \multicolumn{19}{|c|}{ PAISES DESENVOLVIDOS } \\
\hline PD Médio & 15,17 & 15,37 & 15,00 & 14,64 & 13,43 & 11,48 & 12,28 & 12,15 & 10,72 & 10,80 & 9,92 & 9,09 & 9,28 & 9,49 & 11,35 & 11,05 & 11,16 & 11,40 \\
\hline \multicolumn{19}{|c|}{ UE / EUA } \\
\hline União Europeia & 12,81 & 12,25 & 11,58 & 11,24 & 10,85 & 9,54 & 9,74 & 10,04 & 10,10 & 9,57 & 9,41 & 9,00 & | 9,24 & 9,54 & 10,78 & 10,28 & 10,59 & 10,72 \\
\hline Estados Unidos & 10,49 & 10,23 & 9,20 & 8,52 & 7,91 & 7,31 & 7,69 & 7,87 & 8,11 & 7,69 & 7,27 & 7,11 & 7,56 & 8,04 & 9,08 & 8,80 & 9,03 & 8,84 \\
\hline UE / EUA Média & 11,65 & $\mid 11,24$ & 10,39 & 9,88 & 9,38 & 8,42 & 8,71 & 8,95 & 9,11 & 8,63 & 8,34 & 8,06 & 8,40 & 8,79 & 9,93 & | 9,54 & 9,81 & |9,78 \\
\hline \multicolumn{19}{|c|}{ OUTROS DESENVOLVIDOS } \\
\hline Arábia Saudita & & & & & & & & & & & $\mid$\begin{tabular}{||l}
$\mid 5,21$ \\
\end{tabular} & |5,21 & $\mid 5,66$ & $\mid 4,11$ & $|5,46|$ & $\mid$\begin{tabular}{|ll}
$\mid$ & 7,38
\end{tabular} & $\mid$\begin{tabular}{||c|}
6,14 \\
\end{tabular} & $\mid$\begin{tabular}{|l}
5,72 \\
\end{tabular} \\
\hline Austrália & $|17,97|$ & $\mid 19,16$ & 19,48 & 17,47 & 17,79 & 15,66 & 16,81 & 16,63 & 14,66 & $|15,26|$ & 12,52 & $\mid 11,84$ & 11,11 & 9,84 & 11,33 & 9,77 & $\mid 10,28$ & 10,70 \\
\hline Bahrein & 7,45 & 12,54 & & & & 4,78 & | 5,71 & 5,65 & 4,99 & |4,22|| & 3,43 & 2,84 & 2,60 & 4,10 & 5,55 & $\mid$\begin{tabular}{||l}
$\mid 4,49$ \\
\end{tabular} & $\mid 4,45$ & 6,21 \\
\hline Barbados & 30,72 & 34,46 & 32,47 & 28,93 & 27,73 & 27,08 & 30,14 & 31,57 & 28,23 & $31,34 \mid$ & 27,01 & 24,03 & 26,66 & 29,04 & $|30,45|$ & 29,86 & 24,93 & 25,27 \\
\hline Canada & $\mid 12,41$ & 11,99 & $11,60 \mid$ & 10,90 & 10,32 & 10,15 & $\mid 10,19$ & 10,36 & 10,16 & |10,56 | & 9,69 & $\mid 9,66$ & $\mid 9,95$ & $\mid 10,16$ & $\mid 11,97$ & $\mid 11,44$ & $\mid 11,43$ & 11,25 \\
\hline Cingapura & 12,12 & 10,00 & 9,89 & 12,13 & 12,80 & 9,95 & 12,22 & 11,84 & 2,78 & 7,78 & 5,94 & 5,26 & $\mid 5,47$ & |5,97 & |6,50|| & | 6,23 & $\mid$\begin{tabular}{||l|l} 
& 5,69 \\
\end{tabular} & 5,47 \\
\hline Coréia do Sul & $\mid 7,40$ & 7,36 & 6,79 & 6,23 | & 5,92 & 5,19 & |5,68 & 5,60 & 5,10 & |4,45 | & $\mid 4,05$ & 3,80 & 3,90 & 3,92 & 4,13 & $\mid$\begin{tabular}{||l}
$\mid 4,06$ \\
\end{tabular} & $\mid 4,42$ & $\mid 4,28$ \\
\hline Croácia & & & & & & 11,56 & $\mid 12,02$ & $\mid 12,72$ & 12,87 & $11,11 \mid$ & 11,58 & 11,82 & $\mid 11,32$ & 10,94 & 13,66 & 13,19 & $\mid 13,71$ & $\mid 14,84$ \\
\hline Hong Kong & $\mid 10,08$ & 10,19 & 10,11 & $8,91 \mid$ & 8,17 & 7,44 & $\mid$\begin{tabular}{|l|l} 
& 7,52 \\
\end{tabular} & 7,70 & 7,51 & |7,32|| & $\mid 6,76$ & |6,88 & | 8,33 & 10,28 & 13,80 & $\mid 14,25$ & 16,90 & 18,70 \\
\hline Islândia & 46,36 & 44,74 & 43,47 & 41,92 & 38,93 & 35,73 & 37,81 & $|39,77|$ & 37,50 & $|35,31| \mid$ & |30,14 & 25,91 & $\mid 24,22$ & 24,04 & 29,82 & 28,63 & 28,61 & 29,26 \\
\hline Israel & 7,69 & 7,62 & 7,29 & \begin{tabular}{|l||}
6,98 \\
\end{tabular} & $6,6,13$ & 4,72 & 5,07 & 5,05 & 5,21 & 3,55 & 4,79 & 4,86 & 5,19 & 5,54 & \begin{tabular}{|l|}
6,33 \\
\end{tabular} & 6,11 & 5,91 & 5,87 \\
\hline Japão & 10,56 & 10,49 & 9,68 & 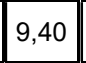 & 9,09 & 7,86 & $\mid 8,32$ & |7,99 & 7,39 & |6,94|| & $\mid 6,41$ & 5,78 & | 5,62 & 5,59 & 6,56 & 5,87 & 6,26 & $\mid 6,10$ \\
\hline Kuwait & 7,58 & 7,47 & 7,26 & $8, \mid$ & 8,58 & 5,11 & 5,47 & 5,71 & 5,01 & 4,20 & & 4,24 & 4,35 & 4,43 & & & & \\
\hline Nova Zelândia & $\mid 36,78$ & 36,94 & 36,32 & $|35,52|$ & 34,01 & 35,53 & $\mid 37,10$ & 37,09 & 36,24 & |35,63|| & 34,99 & 35,67 & 35,89 & 35,65 & |39,63 & $\mid 39,87$ & 39,86 & 39,74 \\
\hline Noruega & $\mid 9,67$ & 8,98 & 8,77 & 9,92 & 9,61 & 7,65 & | 7,75 & 8,17 & 7,80 & 7,34 & |6,83 & 6,44 & 6,66 & 6,21 & 8,19 & | 8,38 & $\mid$\begin{tabular}{||l} 
\\
7,97
\end{tabular} & 8,05 \\
\hline Omã & & & & & & 9,95 & $\mid 12,22$ & 11,84 & 2,78 & 7,78 & $\mid$\begin{tabular}{||l|l|} 
& 5,94 \\
\end{tabular} & $\mid 5,26$ & $\mid 5,47$ & 5,97 & 6,50 & 6,23 & 5,69 & 5,47 \\
\hline
\end{tabular}




\begin{tabular}{|c|c|c|c|c|c|c|c|c|c|c|c|c|c|c|c|c|c|c|}
\hline Suiça & $\mid 5,95$ & 5,79 & 5,49 & $\mid 5,38$ & 5,27 & 4,93 & $\mid$\begin{tabular}{||l}
$\mid$ \\
4,77
\end{tabular} & $\mid$\begin{tabular}{||c|}
4,78 \\
\end{tabular} & 4,93 & $\mid 4,72$ & $\mid 4,64$ & $\mid$\begin{tabular}{|l}
$\mid 4,58$ \\
\end{tabular} & $\mid$\begin{tabular}{||l}
4,78 \\
\end{tabular} & $\mid 5,10$ & $\mid$\begin{tabular}{||c||}
$\mid 5,64$ \\
\end{tabular} & 5,32 & $\mid 5,23$ & $\mid$\begin{tabular}{||l}
5,12 \\
\end{tabular} \\
\hline Taiwan & & & & & & & & $\mid 4,38$ & 4,34 & || 3,93 & $\mid$\begin{tabular}{||l}
$\mid 3,76$ \\
-1
\end{tabular} & $\mid$\begin{tabular}{||l}
3,29 \\
-
\end{tabular} & $\mid$\begin{tabular}{||l|l} 
& 3,23
\end{tabular} & $\mid$\begin{tabular}{||l|l|} 
& 3,49
\end{tabular} & $\mid 3,80$ & |3,51|| & $\mid 3,69$ & $\mid$\begin{tabular}{||l|l}
$\mid$ & 3,76
\end{tabular} \\
\hline Trinidad e Tobago & $\mid 11,92$ & 11,06 & 10,63 & $\mid 11,79$ & 10,31 & 7,29 & |7,15 & 8,01 & 6,71 & $\mid$\begin{tabular}{||l}
$\mid 5,95$ \\
\end{tabular} & $\mid 5,56$ & 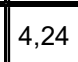 & $\mid$\begin{tabular}{||l|l|} 
& 4,79
\end{tabular} & $\mid 4,26$ & $\mid 6,39$ & |5,92|| & & \\
\hline Catar & & & & & 4,83 & 2,23 & $\mid$\begin{tabular}{||l}
$\mid 2,31$ \\
\end{tabular} & 2,34 & 2,80 & $\mid 2,03$ & $\mid 2,32$ & |2,21 & $\mid 2,15$ & $\mid 2,49$ & $\mid 2,71$ & |2,54 | & $\mid 2,47$ & $\mid 2,63$ \\
\hline Macau & 20,72 & 20,30 & 16,98 & 14,03 & 12,97 & 13,69 & $\mid 15,53$ & 15,59 & 15,36 & 13,84 & 14,49 & $\mid 13,43$ & $\mid 13,84$ & $\mid 15,92$ & $\mid 26,76$ & $|17,64|$ & $\mid 16,52$ & $\mid 17,63$ \\
\hline Outros PD Médio & 15,64 & 15,92 & 15,66 & 15,32 & 13,97 & 11,82 & 12,68 & 12,48 & 10,90 & 11,02 & 10,08 & 9,19 & 9,37 & 9,56 & 11,50 & 11,21 & 11,31 & 11,58 \\
\hline \multicolumn{19}{|c|}{ EM DESENVOLVIMENTO } \\
\hline PED Médio & 30,09 & 30,63 & $\overline{30,}$ & 29,84 & $\overline{28}$ & 26,88 & 27,82 & 27,63 & 28,02 & 26,36 & 24,82 & 23,95 & 23,22 & 23,29 & 25,39 & 24,51 & 24,16 & 24,02 \\
\hline \multicolumn{19}{|c|}{ Renda Média-Alta } \\
\hline África do Sul & 10,49 & 11,69 & 11,08 & 11,41 & 10,32 & 9,16 & 8,88 & 10,26 & 9,65 & 8,60 & 8,01 & 7,06 & 7,18 & 7,58 & 9,75 & 9,70 & 9,53 & 9,72 \\
\hline Antígua e Barbuda & & & & & 20,75 & 26,23 & & & & & 19,07 & 21,78 & 29,23 & & 32,94 & 35,85 & 41,53 & 46,93 \\
\hline Argentina & 30,32 & 30,55 & 27,04 & 27,10 & 27,13 & 25,44 & 27,78 & 34,50 & 34,78 & 30,97 & 29,13 & 28,06 & 30,95 & 31,98 & 31,61 & 29,93 & 30,59 & 30,72 \\
\hline Brasil & 22,53 & 22,46 & 21,41 & 21,08 & 20,64 & 17,36 & 18,38 & 20,38 & 21,91 & 20,74 & 19,24 & 18,56 & 18,73 & 18,26 & 21,91 & 19,82 & 19,56 & 20,09 \\
\hline Chile & 23,06 & 22,31 & 20,59 & 22,11 & 24,24 & 21,91 & $\mid 22,70$ & 23,55 & 23,23 & 19,81 & $\mid 16,99$ & 14,87 & 15,14 & 16,48 & $\mid 17,81$ & $\mid 15,46$ & 15,82 & 15,98 \\
\hline Colômbia & 22,13 & 22,28 & 23,26 & 23,49 & 22,24 & 19,13 & 18,27 & 19,07 & 18,46 & 17,02 & 16,12 & 15,32 & 14,87 & 14,64 & 15,06 & 13,11 & 11,92 & 11,43 \\
\hline Costa Rica & 38,91 & 42,01 & 31,93 & 26,78 & 20,26 & 21,03 & 21,63 & 21,00 & 20,69 & 22,22 & 19,39 & 19,34 & 20,14 & 20,85 & 17,35 & 23,26 & 22,92 & 23,35 \\
\hline \multicolumn{19}{|l|}{ Cuba } \\
\hline Dominica & 38,55 & 38,49 & 38,15 & & 34,04 & 30,39 & 30,37 & 33,07 & 29,79 & 29,97 & 26,78 & 28,05 & |27,67 & 29,63 & 33,37 & 25,93 & & 21,78 \\
\hline Granada & & 52,54 & 46,41 & 35,20 & 50,77 & 27,00 & 33,15 & 44,00 & 42,80 & 47,35 & 38,36 & 36,82 & 27,77 & 34,31 & 37,00 & & & \\
\hline Jamaica & 18,98 & 19,78 & 20,77 & & & & & 19,24 & 19,23 & 19,23 & 16,63 & 16,27 & 14,45 & 13,66 & 22,28 & 21,09 & 19,27 & 19,19 \\
\hline Malásia & 10,82 & 10,38 & 9,93 & 10,43 & 9,15 & 7,05 & |7,49 & 8,21 & 8,88 & 8,77 & 8,09 & 8,30 & 9,78 & 11,71 & 11,91 & $\mid 12,44$ & 14,58 & 13,14 \\
\hline Maurício & 24,48 & 25,46 & 22,68 & 22,61 & 20,03 & 17,47 & 21,73 & 23,89 & 22,38 & 23,05 & 24,48 & 22,51 & 24,46 & 25,19 & 28,40 & 29,79 & 28,49 & 29,34 \\
\hline México & 8,88 & 8,52 & 7,55 & 7,32 & 6,37 & 5,77 & $\mid$\begin{tabular}{||c}
6,42 \\
-1
\end{tabular} & 6,53 & 7,08 & 6,90 & || 6,66 & |6,53 & |6,78 & |7,20 & 7,98 & |7,11 & 7,49 & 6,78 \\
\hline Namíbia & & & & & & |23,54 & 24,61 & 25,88 & 30,98 & 24,67 & 25,28 & 21,92 & 19,95 & $\mid 18,37$ & $\mid 19,12$ & 20,12 & $|19,47|$ & 19,87 \\
\hline
\end{tabular}




\begin{tabular}{|c|c|c|c|c|c|c|c|c|c|c|c|c|c|c|c|c|c|c|}
\hline Panamá & & & 44,73 & 44,21 & 42,05 & 44,29 & 47,01 & 148,46 & \begin{tabular}{|l|l|}
62,05 \\
\end{tabular} & 550,76 & 651,21 & 48,64 & 48,20 & 49,28 & 50,40 & 41,99 & 6,71 & 42,78 \\
\hline Peru & 23,07 & 24,83 & 25,17 & 22,50 & 24,42 & 22,85 & 23,73 & \begin{tabular}{|l|l|}
3 & 23,38 \\
\end{tabular} & 821,79 & 920,82 & 18,49 & $9 \mid 16,18$ & 15,15 & 15,96 & 18,81 & 16,83 & 17,22 & 216,35 \\
\hline R. Dominicana & 18,62 & 14,52 & 14,66 & & & & 26,90 & \begin{tabular}{l|l}
0 & 16,95
\end{tabular} & \begin{tabular}{l|l|}
5 & 17,29 \\
\end{tabular} & $\begin{array}{l}9 \\
9\end{array}$ & $1 \mid 14,68$ & B 16,22 & 15,90 & 17,71 & $\mid 19,28$ & $|20,21|$ & 19,5 & 4 \\
\hline Rússia & & & & & & & & & & & & & & & & & & 8,54 \\
\hline St. Kitts e Nevis & & 41,79 & 39,89 & & 24,32 & 23,55 & 22,19 & 922,71 & 120,64 & 425,62 & 22,98 & 14,87 & 16,11 & 15,98 & 18,80 & 17,92 & 20,08 & \\
\hline St. Lúcia & 48,42 & 50,08 & 47,88 & 51,04 & 51,33 & 50,61 & 51,67 & 747,48 & 845,67 & 748,41 & 47,21 & $\sqrt[39,03]{ }$ & 38,64 & 37,39 & & & & \\
\hline St. Vincente e Granadinas & 51,79 & 52,57 & 51,33 & 51,98 & 52,65 & 56,45 & 54,87 & 756,36 & 641,64 & 450,66 & 649,95 & 47,93 & 45,65 & 44,55 & 44,79 & 42,70 & $44,0 \varepsilon$ & 44,70 \\
\hline Suriname & $\mid 16,35$ & 18,56 & 15,51 & 13,82 & 15,59 & 9,76 & $\mid$\begin{tabular}{||l|}
$\mid 10,94$ \\
\end{tabular} & \begin{tabular}{l|l}
411,39
\end{tabular} & \begin{tabular}{l|l}
9 & 10,05
\end{tabular} & \begin{tabular}{|l|l|}
5 & 7,89 \\
\end{tabular} & 6,24 & & & & & & & \\
\hline Turquia & 16,37 & 15,68 & 14,92 & 14,19 & 12,54 & 10,56 & 10,85 & 59,5 & 9,30 & 8,09 & 8,15 & 7,35 & 7,23 & 7,53 & 8,96 & 8,74 & |9,00 & 8,93 \\
\hline Uruguai & 36,75 & 37,94 & 35,68 & 34,85 & 34,85 & 33,18 & 33,55 & 541,01 & 141,98 & 839,04 & 47,81 & 36,84 & 36,81 & 36,47 & 42,87 & 41,86 & 41,80 & 40,63 \\
\hline Venezuela & 10,01 & 8,59 & 7,31 & 9,10 & 8,07 & 6,16 & 6,95 & 56,40 & 7,19 & 6,34 & 4,10 & | 3,32 & 3,62 & 7,22 & 9,17 & |6,49 & $\mid 6,84$ & 8,06 \\
\hline Albânia & & & & & & $\mid 8,38$ & 8,58 & \begin{tabular}{l|l}
8 & 9,26
\end{tabular} & \begin{tabular}{|l|l|} 
& 7,76
\end{tabular} & 8,40 & 7,55 & 7,44 & 7,71 & | 7,76 & $\mid 10,18$ & 9,57 & | 7,02 & 6,53 \\
\hline Botswana & 14,79 & 14,79 & 14,99 & 11,99 & 15,35 & 14,20 & 13,79 & \begin{tabular}{l|l}
9 & 11,90
\end{tabular} & $\begin{array}{lll}0 & 40,84\end{array}$ & \begin{tabular}{|l|l|}
4 & 14,83 \\
\end{tabular} & 11,66 & 10,59 & 912,15 & 510,17 & 12,49 & $\mid 12,16$ & 12,3 & | 12,61 \\
\hline Gabão & & 25,78 & 27,18 & 322,18 & 321,18 & 31,05 & 18,03 & \begin{tabular}{l|l}
3 & 17,14
\end{tabular} & \begin{tabular}{l|l}
4 & 17,59
\end{tabular} & \begin{tabular}{l|l}
9 & 17,50
\end{tabular} & \begin{tabular}{l|l}
0 & 15,10
\end{tabular} & \begin{tabular}{|l|l}
14,76 \\
\end{tabular} & 16,09 & 16,78 & 17,81 & & & \\
\hline Jordânia & & & & & & 41,12 & 41,48 & 843,88 & 846,42 & 246,71 & 47,49 & 53,09 & 61,09 & 57,69 & 63,58 & 63,4 & 60,9 & $\begin{array}{ll}163,53 \\
\end{array}$ \\
\hline Maldivas & & & & & & & 30,08 & 15 & \begin{tabular}{|l|l|}
5 & 35,65
\end{tabular} & 525,85 & 522,88 & 15,30 & 14,72 & 15,99 & 23,49 & 24,37 & 23,18 & 24,36 \\
\hline Montenegro & & & & & & & & & & & & & & & & & & 43,53 \\
\hline Tonga & & & & & & & & & & & & & $\mid 11,03$ & 10,77 & 10,17 & 9,93 & $\mid 12,02$ & $2|10,47|$ \\
\hline Tunísia & 7 & 21,74 & 23,99 & 18,57 & 18,97 & 15,07 & 16,44 & $\begin{array}{l}417,40 \\
\end{array}$ & $\begin{array}{ll}0 & 16,61 \\
\end{array}$ & 115,67 & 715,30 & 14,51 & 13,33 & 13,66 & 16,06 & 14,83 & 13,57 & 74,52 \\
\hline Macedônia & & & & & & & & & 26,61 & 126,17 & 737,68 & 43,80 & 32,76 & 40,12 & 44,90 & 46,54 & 46,08 & 48,95 \\
\hline PEDma Médio & 24,16 & 26,39 & 25,76 & 23,90 & 25,02 & 22,89 & 24,00 & 024,57 & 725,17 & 723,68 & 822,03 & 21,51 & 21,40 & 21,83 & 23,94 & 22,90 & 21,54 & 23,51 \\
\hline & & & & & & Renc & da Méc & édia-Bai & aixa & & & & & & & & & \\
\hline Armênia & & & & & & & & & 17,55 & $5 \mid 19,46$ & 617,46 & 16,01 & 16,29 & 20,29 & 20,51 & 18,54 & 20,35 & 22,36 \\
\hline Belize & 53,2 & 50,42 & 52,68 & 51,37 & 18,4 & 45,57 & 23,38 & \begin{tabular}{l|l}
8 & 16,58
\end{tabular} & \begin{tabular}{l|l|}
8 & 47,38
\end{tabular} & $\begin{array}{ll}8 & 47,79 \\
\end{array}$ & 950,03 & 43,34 & 39,96 & 34,43 & 41,94 & 40,00 & 33,91 & 42,53 \\
\hline
\end{tabular}




\begin{tabular}{|c|c|c|c|c|c|c|c|c|c|c|c|c|c|c|c|c|c|c|}
\hline Bolivia & 20,31 & 23,94 & 23,31 & 19,12 & 18,16 & 22,46 & 24,24 & 22,93 & 23,79 & 21,98 & 17,44 & 13,82 & 14,49 & 13,00 & 15,61 & 12,73 & 11,34 & 11,85 \\
\hline Camarões & 9,67 & $|34,82|$ & 36,62 & & & 22,06 & 27,02 & 24,81 & 24,35 & 25,32 & 24,82 & 24,16 & 20,99 & 42,95 & 48,66 & $\mid 27,85$ & $|45,31|$ & 25,80 \\
\hline China & & & & & & & $\mid 14,75$ & 13,52 & $|12,87|$ & 12,11 & $\mid 11,19$ & 10,51 & 10,65 & 11,25 & 11,67 & 11,59 & 12,23 & 12,47 \\
\hline Costa do Marfin & 5,43 & 51,60 & 47,47 & 48,84 & 45,17 & 43,37 & 45,68 & 49,53 & 45,90 & 37,83 & 31,83 & 31,80 & 34,09 & 35,94 & 40,69 & 41,15 & 48,49 & 40,29 \\
\hline Egito & 6,68 & 26,36 & 23,33 & 23,01 & 23,13 & 22,89 & 23,72 & 25,27 & 22,902 & 22,39 & 17,84 & 15,68 & 17,29 & 16,74 & 20,11 & 21,35 & 22,63 & 21,86 \\
\hline El Salvador & $|31,83|$ & 32,80 & $|34,52|=$ & 30,76 & 29,60 & 16,07 & $\mid 14,80$ & 14,59 & $|14,60| 1$ & $|14,92|$ & 16,01 & $|16,09|$ & $\mid 17,17$ & 17,86 & $\mid 19,62$ & $\mid 17,97$ & $\mid 19,59$ & 20,26 \\
\hline Equador & & 33,90 & 35,72 & 36,44 & 37,68 & 27,51 & 27,43 & 27,15 & 27,802 & 23,13 & 20,82 & 19,79 & 20,42 & 19,48 & 25,01 & 20,87 & 21,31 & 20,31 \\
\hline Fiji & & & & & & $26,61 \mid$ & $|34,66| 3$ & 37,42 & $35,\left.34\right|_{3} ^{3}$ & 33,56 & 38,77 & $|38,57|$ & $|39,43|$ & 41,22 & 44,85 & 42,02 & 43,76 & 45,57 \\
\hline Filipinas & 12,29 & 10,72 & 9,27 & 8,95 & 7,59 & 6,89 & 7,56 & 6,97 & 7,03 & 7,09 & 7,25 & 6,79 & 7,26 & 9,90 & 10,31 & 9,95 & 11,22 & 10,51 \\
\hline Guatemala & 37,48 & 37,67 & 36,69 & 34,32 & 33,59 & 32,81 & 31,60 & 32,40 & 28,392 & 27,56 & 21,57 & 27,53 & 23,28 & 24,59 & 28,66 & 27,78 & 27,62 & 28,52 \\
\hline Guiana & & & $|37,90|=$ & 39,63 & 34,30 & 37,11 & $|36,66|$ & 40,73 & $40,92 \mid 3$ & 37,72 & 39,21 & $\mid 35,43$ & 33,72 & 34,52 & 38,33 & 36,85 & 34,83 & 33,78 \\
\hline Honduras & 50,21 & 43,60 & 42,51 & 44,24 & 38,60 & 47,93 & 45,23 & 40,58 & 39,13 & 38,53 & 38,83 & 34,42 & 31,44 & & 36,23 & 34,67 & 39,50 & 34,57 \\
\hline Índia & 13,85 & 14,14 & 14,20 & 15,30 & 13,09 & 11,00 & 12,05 & 11,43 & 10,64 & 9,48 & 7,88 & 7,37 & 7,97 & 7,50 & 7,30 & 7,79 & 7,84 & 8,79 \\
\hline Indonésia & 16,49 & 16,63 & 14,80 & 16,50 & 18,74 & 14,53 & 14,69 & 16,33 & 16,54 & 15,88 & 14,30 & 15,46 & 17,77 & 17,33 & 17,08 & 17,44 & 18,51 & 17,31 \\
\hline Moldávia & & & & & & & $|36,37|$ & 36,35 & $35,34]$ & 32,56 & 35,76 & 29,79 & 28,55 & 27,75 & 36,06 & 35,10 & 33,75 & 30,13 \\
\hline Nicarágua & 10,3 & 35,23 & 34,59 & 42,89 & 40,30 & 40,62 & 39,31 & 35,58 & 38,54 & 38,98 & 38,68 & 38,76 & 41,012 & 27,15 & 45,92 & 45,92 & 47,09 & 31,69 \\
\hline Nigéria & & 10,07 & 8,96 & 11,53 & 11,47 & 5,84 & 10,82 & 9,43 & 7,60 & & & 6,47 & 11,23 & 5,60 & 9,24 & 7,44 & 18,84 & 15,77 \\
\hline Paquistão & 19,74 & 17,23 & 18,73 & 20,65 & 19,00 & 15,51 & 14,80 & 14,53 & 14,43 & 14,16 & 14,29 & 13,70 & 13,74 & 17,70 & 16,69 & 18,25 & 18,98 & 16,69 \\
\hline Paraguai & 50,92 & 52,24 & 52,48 & 56,37 & 54,27 & 51,975 & 53,25 & 55,64 & 55,075 & 53,94 & 51,64 & 48,55 & $50,57=$ & 50,34 & 51,58 & 35,66 & 35,61 & 34,09 \\
\hline Sri Lanka & & & & & 19,49 & 17,75 & 18,96 & 18,71 & $|18,60|$ & 17,62 & 18,34 & 18,54 & 18,80 & 20,26 & 22,42 & 22,72 & 21,26 & 20,07 \\
\hline Swazilândia & & & & & & 31,663 & 33,90 & 21,06 & 20,76 & 18,92 & 22,43 & 25,46 & 24,86 & & & & & \\
\hline Tailândia & 15,67 & 15,83 & 15,37 & 16,23 & 14,75 & 12,89 & 13,50 & 13,36 & 13,56 & 12,51 & 11,07 & 11,33 & 11,52 & 12,64 & 13,58 & 12,95 & 14,29 & 12,94 \\
\hline Ucrânia & & & & & & & & & & & & & & 12,24 & 18,16 & 15,18 & 13,71 & 17,46 \\
\hline Cabo Verde & & & & & & & & & & & & & & 40,12 & 44,90 & 46,54 & 46,08 & \\
\hline
\end{tabular}




\begin{tabular}{|c|c|c|c|c|c|c|c|c|c|c|c|c|c|c|c|c|c|c|}
\hline Congo & & & & & & & & & & & & & 4,62 & 5,44 & 5,32 & |4,46 & $\mid 3,27$ & 3,47 \\
\hline Georgia & & & & & & $\mid 26,58$ & 24,16 & $|26,88| z$ & $27,\left.15\right|^{2}$ & 26,50 & 26,01 & 121,17 & $20,33 \mid$ & $|17,09|_{2}^{2}$ & 924,38 & 20,53 & 16,93 & 21,82 \\
\hline Lesoto & & & & & & $\|15,97\|$ & 25,54 & 20,69 & $|16,73| 1$ & $\mid 13,09$ & & & & $|22,24|_{2}^{2}$ & 424,71 & $|22,49|$ & 23,93 & 22,48 \\
\hline Mauritânia & 44,79 & 44,18 & & & & $\mid 19,89$ & $\mid 21,17$ & $|22,66|_{2}^{2}$ & $26,82 \mid 1$ & 18,04 & $\mid 14,34$ & 422,80 & $20,\left.99\right|_{2} ^{2}$ & $|22,86|_{2}^{2}$ & 627,33 & 33,14 & $\mid 16,96$ & 19,07 \\
\hline Mongólia & & & 23,23 & 25,85 & 23,42 & 23,77 & $\mid 21,26$ & & $|15,35| 1$ & 14,70 & 14,30 & 13,89 & $\mid 12,98$ & & & & & \\
\hline Marrocos & |29,67 & 29,25 & 27,22 & 20,10 & $\mid 19,37$ & 19,83 & $\mid 19,90$ & $20,07 \mid$ & $|18,46| 1$ & 16,99 & $\mid 17,81$ & $1 \mid 16,29$ & $|17,40|$ & $\mid 15,75$ & $5 \mid 17,92$ & 16,66 & 16,28 & 15,99 \\
\hline Papua Nova Guin & & & & $\mid 28,13$ & & 18,14 & 17,96 & $24,28 \mid z$ & $20,\left.53\right|_{2} ^{2}$ & 25,67 & & & & & & & & \\
\hline Samoa & & & & & & & & & & & & & & & & & & $\mid 29,09$ \\
\hline Ilhas Salomão & & & & & & & & 34,16 & 27,472 & 25,23 & 17,47 & 73,00 & 11,28 & 12,15 & 13,96 & 14,06 & 17,05 & 9,60 \\
\hline PEDmb Médio & 32,86 & 30,56 & 29,48 & 29,51 & 26,01 & 25,08 & 25,32 & $|25,30| z$ & $24,89 \mid 2$ & 24,12 & 23,48 & 21,95 & $|21,34| z$ & $|21,88| z$ & 25,77 & 23,86 & 24,60 & 22,49 \\
\hline & & & & & & & $P M D$ & & & & & & & & & & & \\
\hline Bangladesh & 17,76 & 17,93 & 17,71 & 15,72 & & 16,86 & 16,84 & 14,93 & $|18,42|$ & 17,17 & 15,68 & 16,78 & 21,50 & $\mid 17,67$ & 16,74 & 17,24 & 17,90 & \\
\hline Benin & & 61,90 & 60,51 & 59,58 & 53,03 & 51,88 & $45,81=$ & $53,81=5$ & 53,35 & 53,60 & $|57,33|$ & 54,86 & $54,70=5$ & $51,34 \mid 5$ & 52,43 & 61,97 & 52,40 & 60,46 \\
\hline Gana & 36,37 & 37,54 & 30,12 & 38,61 & 34,79 & 33,45 & 34,84 & 42,39 & $44,42 \mid 3$ & 37,62 & $|31,32|$ & 33,92 & 36,85 & 36,19 & 37,74 & 36,44 & 23,27 & 22,88 \\
\hline Madagascar & 42,75 & 35,37 & 35,11 & 29,54 & 26,25 & 25,92 & 32,47 & 36,53 & $34,70 \mid 2$ & 25,55 & $\mid 24,57$ & 24,77 & 22,73 & $|15,25|$ & 18,17 & 20,20 & 25,19 & 24,66 \\
\hline Malawi & 44,68 & 46,08 & 43,73 & 50,51 & 43,92 & 45,31 & 45,05 & 48,53 & $|46,28| 4$ & 42,43 & $|39,46|$ & 38,88 & 43,72 & $41,04 \mid 4$ & 43,72 & 40,44 & 42,65 & 39,35 \\
\hline Quênia & 35,36 & 35,87 & 37,05 & 36,87 & 36,84 & 37,26 & $|39,03|$ & $|27,27|$ & 31,74 & 37,31 & $|27,37|$ & 29,23 & 30,19 & 30,73 & 32,66 & 30,84 & & \\
\hline Senegal & & 21,95 & 22,11 & 27,07 & 24,35 & 37,72 & 37,25 & 24,87 & 35,123 & 33,29 & 30,20 & 33,95 & 31,21 & 25,55 & 27,54 & 26,25 & 28,65 & 28,41 \\
\hline Tanzânia & 37,46 & 43,46 & 45,83 & 40,10 & 41,38 & 42,03 & 42,69 & 42,66 & 41,693 & 39,30 & 37,94 & 33,59 & 29,59 & 22,95 & 23,92 & 21,97 & 20,59 & 24,24 \\
\hline Vietnã & & & & & & & & & & & & & 15,67 & 15,98 & 16,66 & 17,17 & 17,29 & 15,78 \\
\hline Zâmbia & 7,92 & 10,92 & 9,77 & 14,47 & 15,26 & 12,04 & 12,30 & $\mid 14,80$ & $\mid 14,69$ & 16,04 & $\mid 13,05$ & 8,59 & 7,20 & 6,35 & 8,08 & |6,15 & | 7,34 & 9,85 \\
\hline Zimbábue & 28,24 & 35,68 & 30,83 & & 36,85 & 34,62 & 36,87 & 25,00 & & 32,38 & $|23,60|$ & 23,47 & $|19,61| z$ & $25,15 \mid z$ & 29,12 & 21,69 & 22,81 & 26,54 \\
\hline Burkina Faso & 46,96 & 43,19 & 35,32 & 40,85 & 38,77 & 33,09 & 40,76 & $39,74=$ & 39,784 & 40,19 & 38,95 & & $40,98=$ & 39,153 & 38,98 & 43,67 & 45,78 & \\
\hline Burundi & 46,20 & 39,08 & 56,20 & 47,45 & 44,65 & 49,05 & 40,35 & $|37,51| 4$ & $|41,08|_{3}^{3} \quad$ & $31,21 \mid$ & $|24,22|$ & 34,34 & $|21,62| z$ & $|26,51|_{2}^{2}$ & $|23,52| 2$ & 26,36 & 35,18 & 38,87 \\
\hline
\end{tabular}


Camboja

\begin{tabular}{|l||l|l|l||l|l||l|l|l|l|}
\hline 6,80 & 6,31 & 5,70 & 5,27 & 5,26 & 6,30 & 6,52 & 7,18 & 6,92 \\
\hline
\end{tabular}

\begin{tabular}{l|l|l|l|l|l|l|l|l|l|l|l|l|l|l|l|l|l|l|l|} 
R. Centro-Africana & 24,88 & 25,70 & 25,67 & 31,92 & 30,98 & 29,22 & 30,88 & 27,38 & 27,83 & 47,92 & 44,37 & 35,93 & 34,15 & 38,67 & 39,33 & 32,84 & 33,11 & 32,09 \\
\hline
\end{tabular}

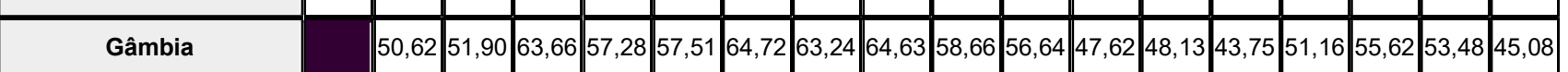

\begin{tabular}{|l|l|l|l|l|l|l|l|l|l|l|l|l|l|l|l|l|l|l|l|}
\hline Guiné & 21,26 & 15,19 & 17,21 & 17,09 & 19,49 & 16,51 & 13,91 & 14,06 & 12,80 & 12,49 & 14,51 & 20,43 & 12,13 & 10,72 & 14,44 & 14,70 & 15,20 & 15,80 \\
\hline
\end{tabular}

Guiné-Bissau

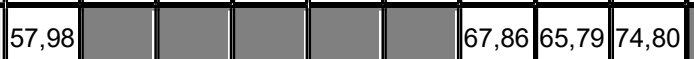

Quirguistão

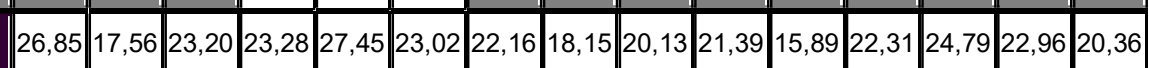

Mali

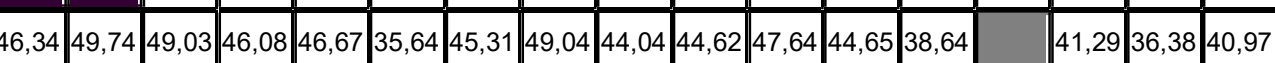

Moçambique

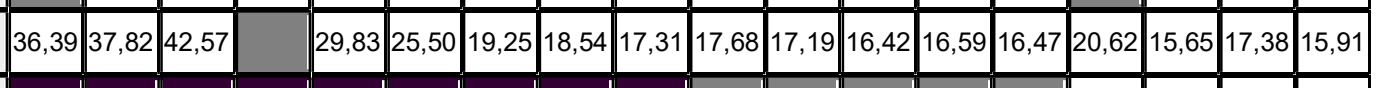

Nepal

\begin{tabular}{|c|c|c|c|c|c|c|c|c|c|c|c|c|c|c|c|c|c|c|}
\hline Nepal & & & & & & & & & & & & & & & 20,26 & 17,73 & 18,17 & 20,84 \\
\hline Níger & & 39,95 & 35,67 & 37,03 & 37,40 & 44,16 & 48,65 & 40,96 & $\mid 37,98$ & $\mid 39,62$ & $\mid 38,58$ & $\mid 35,41$ & $\mid 30,04$ & 35,07 & 23,00 & 19,30 & 17,26 & 26,91 \\
\hline Ruanda & & 31,17 & 30,29 & 36,63 & 36,87 & & 32,26 & 16,54 & 30,97 & |32,24 & 30,41 & 40,87 & 28,83 & 29,32 & 22,59 & 25,74 & 26,56 & 28,53 \\
\hline Togo & 37,37 & 34,65 & 32,94 & 25,49 & 31,67 & 28,27 & 25,86 & 29,07 & 22,99 & 26,39 & 22,00 & & $\mid 19,77$ & 19,69 & 15,72 & 17,82 & 19,51 & 19,68 \\
\hline Uganda & 37,36 & 36,07 & 42,75 & 39,58 & 41,11 & 34,22 & $\mid 36,29$ & 38,19 & 39,13 & 42,57 & 41,66 & 34,09 & 33,64 & 37,99 & 36,48 & 35,39 & 30,63 & 26,55 \\
\hline PMD Médio & 34,93 & 35,55 & 35,86 & 36,40 & 35,44 & 34,50 & $\mid 35,78$ & 34,55 & 36,44 & 32,90 & 30,35 & 30,32 & |27,92 & 26,89 & 26,73 & 27,11 & $\mid 26,54$ & 26,85 \\
\hline
\end{tabular}

Fonte: elaboração própria. 


\title{
Anexo 4-2 \\ EFEITOS DISCRIMINATÓRIOS: \\ VARIÁVEIS - DIMENSÕES DE PODER RELATIVO E CAPACIDADE
}

\begin{abstract}
"De espírito forte devem ser considerados, e com razão, os que, mesmo conhecendo claramente as dificuldades da situação e apreciando os prazeres da vida, justamente por isso não se retiram diante dos perigos."
\end{abstract}

Tucídides, História da Guerra do Peloponeso (2001, p. 257)

No presente Anexo, a exemplo do anterior, continuaremos a apresentação das fontes, fórmulas de cálculo e ajustes realizados em nossas variáveis explicativas, neste caso, das dimensões de poder relativo e capacidade legal/institucional (efeitos discriminatórios).

Na primeira seção apresentaremos as variáveis da dimensão política ou de poder relativo, discorrendo brevemente sobre os ajustes efetuados. $\mathrm{Na}$ segunda seção abordaremos a dimensão de capacidade legal/institucional.

\section{A4-2.1. Dimensão política ou de poder relativo}

\section{A4-2.1.1. Participação da ODA líquida no PIB (ODP)}

A participação líquida dos fluxos de ODA em relação ao PIB será calculada a partir dos dados de ODA líquida anual dividida pelo valor do PIB respectivo a cada ano. Os valores anuais do fluxo líquido de ajuda oficial ao desenvolvimento (ODA) em milhões de dólares, onde valores positivos indicam maior envio do que recebimento de ODA e negativos recebimento líquido, serão obtidos da base disponível no WDI/BM, com exceção dos países doadores para os quais estas informações não estão disponíveis nesta base.

Para estes, países doadores desenvolvidos pertencentes ao Comitê de Assistência ao Desenvolvimento $(\mathrm{DAC})^{1}$ da Organização para a Cooperação e o Desenvolvimento

1 Austrália, Áustria, Bélgica, Canadá, República Checa, Dinamarca, Finlândia, França, Alemanha, Grécia, Islândia, Irlanda, Itália, Japão, Coréia do Sul, Luxemburgo, Países Baixos, Nova Zelândia, Noruega, Polônia, Portugal, Eslováquia, Eslovênia, Espanha, Suécia, Suíça, Reino Unido e Estados Unidos. 
Econômico (OCDE), os dados foram obtidos da própria base da QWIDS/OCDE ${ }^{2}$. O caso da UE seguirá o mesmo tratamento adotado anteriormente. Outros ajustes são descritos a seguir:

Hong Kong - estão disponíveis dados de ODA apenas para os anos de 1995 e 1996, no entanto, como o valor é desprezível foi considerado valor nulo para todo o período posterior;

Macau - estão disponíveis dados de ODA apenas entre 1995 e 1999, tratando-se porém de valores negligenciáveis, o período posterior foi considerado como de valores nulos;

Taiwan (Chinese Taipei conforme classificação nesta base) - será utilizada diretamente a base QWIDS/OCDE; e

St. Kitts e Névis - não há dados para o ano de 2004, de modo que os valores para este ano são a média de 2003 e 2005.

O comportamento da ODA líquida para os diferentes grupos de renda não traz nenhuma surpresa para o período, prevalecendo a gradação lógica na hierarquia de doadores líquidos ( $1^{\circ}$ União Europeia, $2^{\circ}$ EUA e $3^{\circ}$ Outros PD) e recebedores líquidos $\left(1^{\circ}\right.$ PMD, $2^{\circ} \mathrm{PED}_{\mathrm{mb}}$ e $3^{\circ} \mathrm{PED}_{\mathrm{ma}}$ ).

No Quadro A4-2.1 (p. 537) ao final do Anexo pode-se observar os valores anuais individuais de ODP para cada um dos países. Assim como no caso da ODA líquida, não há surpresas nos valores médios auferidos para ODP para os diferentes grupos de renda ao longo do período conforme pode-se observar na Tabela A4-2.1 abaixo:

Tabela A4-2.1: ODP média por grupo de renda no período 1995-2012

\begin{tabular}{ccccccccccc}
\hline MEMBRO & $\mathbf{1 9 9 5}$ & $\mathbf{1 9 9 6}$ & $\mathbf{1 9 9 7}$ & $\mathbf{1 9 9 8}$ & $\mathbf{1 9 9 9}$ & $\mathbf{2 0 0 0}$ & $\mathbf{2 0 0 1}$ & $\mathbf{2 0 0 2}$ & $\mathbf{2 0 0 3}$ & (cont...) \\
\hline União Europeia & 0,37 & 0,37 & 0,33 & 0,33 & 0,32 & 0,32 & 0,33 & 0,35 & 0,36 & \\
Estados Unidos & 0,10 & 0,12 & 0,09 & 0,10 & 0,10 & 0,10 & 0,11 & 0,13 & 0,15 & \\
UE / EUA Média & 0,24 & 0,24 & 0,21 & 0,22 & 0,21 & 0,21 & 0,22 & 0,24 & 0,25 & \\
PD Médio & 0,28 & 0,20 & 0,16 & 0,17 & 0,14 & 0,17 & 0,19 & 0,19 & 0,24 & \\
Outros PD Médio & 0,29 & 0,20 & 0,15 & 0,16 & 0,13 & 0,17 & 0,19 & 0,18 & 0,24 &
\end{tabular}

2 Disponivel em <https://stats.oecd.org/qwids/>. 


\begin{tabular}{|c|c|c|c|c|c|c|c|c|c|c|}
\hline PED $_{\text {ma }}$ Médio & $-2,68$ & $-2,57$ & $-1,39$ & $-1,05$ & $-1,18$ & $-1,55$ & $-1,58$ & $-1,84$ & $-1,59$ & \\
\hline PED $_{\text {mb }}$ Médio & $-5,49$ & $-5,18$ & $-5,50$ & $-4,94$ & $-4,63$ & $-4,69$ & $-5,55$ & $-5,56$ & $-5,93$ & \\
\hline PED Médio & $-9,44$ & $-7,82$ & $-6,77$ & $-6,52$ & $-6,14$ & $-5,64$ & $-6,49$ & $-6,70$ & $-6,57$ & \\
\hline PMD Médio & $-22,53$ & $-16,19$ & $-14,38$ & $-13,84$ & $-13,49$ & $-12,34$ & $-13,84$ & $-14,47$ & $-14,51$ & \\
\hline MEMBRO & 2004 & 2005 & 2006 & 2007 & 2008 & 2009 & 2010 & 2011 & 2012 & MÉDIA \\
\hline União Europeia & 0,35 & 0,47 & 0,47 & 0,43 & 0,46 & 0,48 & 0,50 & 0,48 & 0,45 & 0,40 \\
\hline Estados Unidos & 0,17 & 0,23 & 0,18 & 0,16 & 0,18 & 0,21 & 0,20 & 0,20 & 0,19 & 0,15 \\
\hline UE / EUA Média & 0,26 & 0,35 & 0,32 & 0,29 & 0,32 & 0,35 & 0,35 & 0,34 & 0,32 & 0,27 \\
\hline PD Médio & 0,23 & 0,19 & 0,19 & 0,21 & 0,20 & 0,23 & 0,21 & 0,18 & 0,18 & 0,20 \\
\hline Outros PD Médio & 0,22 & 0,17 & 0,17 & 0,21 & 0,19 & 0,21 & 0,19 & 0,16 & 0,16 & 0,19 \\
\hline PED $_{\text {ma }}$ Médio & $-1,35$ & $-1,63$ & $-1,20$ & $-1,90$ & $-2,10$ & $-2,20$ & $-2,43$ & $-2,35$ & $-2,08$ & $-1,81$ \\
\hline PED $_{m b}$ Médio & $-6,55$ & $-6,25$ & $-6,01$ & $-5,37$ & $-5,51$ & $-5,68$ & $-6,63$ & $-5,12$ & $-4,97$ & $-5,53$ \\
\hline PED Médio & $-6,97$ & $-6,46$ & $-6,21$ & $-6,25$ & $-6,51$ & $-6,50$ & $-7,07$ & $-6,31$ & $-5,87$ & $-6,68$ \\
\hline PMD Médio & $-15,10$ & $-13,45$ & $-13,91$ & $-12,96$ & $-13,28$ & $-12,92$ & $-12,80$ & $-12,31$ & $-12,14$ & $-14,14$ \\
\hline
\end{tabular}

Fonte: Elaboração própria.

O comportamento da variável para os diferentes grupos de renda não traz igualmente nenhuma surpresa para o período, prevalecendo níveis bastante baixos de participação da ajuda oficial ao desenvolvimento líquida (enviada) para os doadores que variam de $0,15 \%$ de participação média no PIB no caso norte-americano, passando por uma participação média de $0,20 \%$ nos casos dos Outros países desenvolvidos, chegando a uma média de $0,40 \%$ de participação no caso na UE.

Por sua vez, quanto aos recebedores líquidos, a participação no PIB é consideravelmente mais elevada, chegando a ser bastante relevante no caso dos PMD $(14,14 \%)$ e $P E D_{m b}(5,53 \%)$, porém situando-se num patamar sensivelmente mais baixo no caso dos $\operatorname{PED}_{\mathrm{ma}}(1,81 \%)$.

\section{A4-2.1.2. Balança comercial preferencial relativa (PREF)}

Nossa variável de comércio preferencial será definida como a participação da balança comercial preferencial (exportações preferencias menos as importações preferenciais) em relação à corrente de comércio total do país. Para o cálculo, o valor anual das exportações-importações preferenciais bilaterais entre cada membro da OMC foi obtida a partir da base de dados Trade Analysis Information System (TRAINS) $)^{3}$ da 
UNCTAD e da ferramenta World Integrated Trade Solution (WITS) ${ }^{4}$ do Banco Mundial.

Cada entrada dos pares importador-exportador foi filtrada eliminando-se dos dados os períodos em que um dos dois não era membro da OMC. Posteriormente foram eliminados todos os pares de dados pertencentes a mecanismos de integração e os que correspondiam aos seguintes critérios: (importador-exportador) PD-PD e $P E D_{m a}-P E D_{m b}$. Dessa forma, obtivemos uma nova base de dados do comércio preferencial bilateral que pudesse comportar dinâmicas de poder devido à assimetria dos parceiros.

Os valores bilaterais de cada par foram somados respectivamente aos importadores e exportadores a cada ano para obter os valores totais para cada membro. Os dados consolidados de importações e exportações preferenciais obtidos dos pareamentos foi então utilizado para cálculo da balança comercial preferencial, que posteriormente foi dividida pelo valor da corrente de comércio de cada membro a cada ano.

Os valores da PREF para cada país são apresentados no Quadro A4-2.2 (p. 543) ao final do Anexo. Os valores médios observados ao longo do período para os grupos de renda podem ser observados na Tabela A4-2.2 abaixo:

Tabela A4-2.2: PREF média por grupo de renda no período 1995-2012

\begin{tabular}{|c|c|c|c|c|c|c|c|c|c|c|}
\hline MEMBRO & 1995 & 1996 & 1997 & 1998 & 1999 & 2000 & 2001 & 2002 & 2003 & (cont...) \\
\hline União Europeia & $-0,08$ & $-0,11$ & $-0,12$ & $-0,12$ & $-0,12$ & $-0,10$ & $-0,11$ & $-0,14$ & $-0,19$ & \\
\hline Estados Unidos & $-11,15$ & $-11,63$ & $-12,39$ & $-12,88$ & $-13,61$ & $-14,92$ & $-15,42$ & $-16,69$ & $-17,82$ & \\
\hline UE / EUA Média & $-2,65$ & $-2,79$ & $-2,97$ & $-3,05$ & $-3,26$ & $-3,50$ & $-3,38$ & $-3,71$ & $-4,15$ & \\
\hline PD Médio & $-3,53$ & $-3,73$ & $-3,56$ & $-3,48$ & $-3,93$ & $-4,02$ & $-4,16$ & $-4,93$ & $-5,29$ & \\
\hline Outros PD Médio & $-6,84$ & $-6,54$ & $-5,07$ & $-4,45$ & $-5,72$ & $-5,30$ & $-6,38$ & $-7,73$ & $-7,62$ & \\
\hline PED $_{\text {ma }}$ Médio & 8,79 & 10,41 & 9,20 & 9,87 & 11,50 & 10,05 & 12,91 & 9,40 & 12,47 & \\
\hline PED $_{\text {mb }}$ Médio & 8,05 & 9,08 & 9,35 & 8,92 & 10,93 & 8,66 & 8,86 & 9,74 & 8,35 & \\
\hline PED Médio & 10,67 & 15,99 & 15,85 & 12,92 & 14,92 & 10,68 & 12,25 & 10,92 & 10,69 & \\
\hline PMD Médio & 16,54 & 33,35 & 35,52 & 23,19 & 25,71 & 15,79 & 17,51 & 16,28 & 14,84 & \\
\hline MEMBRO & 2004 & 2005 & 2006 & 2007 & 2008 & 2009 & 2010 & 2011 & 2012 & MÉDIA \\
\hline União Europeia & $-0,15$ & $-0,15$ & $-0,15$ & $-6,30$ & $-7,15$ & $-6,52$ & $-7,22$ & $-7,67$ & $-9,16$ & $-2,53$ \\
\hline Estados Unidos & $-19,34$ & $-21,07$ & $-22,25$ & $-22,35$ & $-22,39$ & $-21,96$ & $-23,74$ & $-24,30$ & $-25,26$ & $-18,29$ \\
\hline UE / EUA Média & $-4,66$ & $-5,16$ & $-5,43$ & $-10,18$ & $-10,95$ & $-10,21$ & $-11,31$ & $-11,88$ & $-13,25$ & $-6,25$ \\
\hline PD Médio & $-5,89$ & $-6,66$ & $-7,40$ & $-11,59$ & $-11,86$ & $-11,83$ & $-12,65$ & $-11,97$ & $-13,88$ & $-7,24$ \\
\hline Outros PD Médio & $-8,24$ & $-9,55$ & $-11,50$ & $-12,87$ & $-11,64$ & $-13,62$ & $-13,44$ & $-9,42$ & $-12,42$ & $-8,80$ \\
\hline
\end{tabular}

4 Disponível em <http://wits. worldbank.org/>. 


\begin{tabular}{ccccccccccc} 
PED mádio & 7,36 & 7,22 & 6,85 & 16,33 & 13,89 & 15,47 & 15,16 & 13,79 & 13,50 & 11,34 \\
PED $_{\text {mb Médio }}$ & 7,40 & 6,68 & 6,72 & 9,89 & 34,28 & 27,43 & 24,51 & 33,53 & 29,61 & 14,56 \\
PED Médio & 8,88 & 8,54 & 7,49 & 12,07 & 20,85 & 18,63 & 16,54 & 19,42 & 17,66 & 13,61 \\
PMD Médio & 15,36 & 15,44 & 11,82 & 10,57 & 9,71 & 9,74 & 7,27 & 6,67 & 4,98 & 16,13 \\
\hline
\end{tabular}

Fonte: Elaboração própria.

Por sua vez, é apresentada de forma resumida um comparativo das diferenças de valor médio da variável para os grupos de renda no período na Tabela A4-2.3 a seguir:

Tabela A4-2.3: Comparativo da PREF média por grupo de renda no período 19952012

\begin{tabular}{|c|c|c|c|c|c|c|c|c|}
\hline MEMBRO & União Europeia & Estados Unidos & $\begin{array}{l}\text { PD } \\
\text { Médio }\end{array}$ & $\begin{array}{c}\text { Outros PD } \\
\text { Médio }\end{array}$ & $\begin{array}{l}\text { PED }_{\text {ma }} \\
\text { Médio }\end{array}$ & $\begin{array}{l}\text { PED }_{m b} \\
\text { Médio }\end{array}$ & $\begin{array}{l}\text { PED } \\
\text { Médio }\end{array}$ & $\begin{array}{l}\text { PMD } \\
\text { Médio }\end{array}$ \\
\hline União Europeia & $\ldots$ & $-86,16 \%$ & $-65,05 \%$ & $-71,22 \%$ & $-122,32 \%$ & $-117,39 \%$ & $-118,60 \%$ & $-115,70 \%$ \\
\hline Estados Unidos & $\ldots$ & $\ldots$ & $152,51 \%$ & $107,88 \%$ & $-261,22 \%$ & $-225,64 \%$ & $-234,37 \%$ & $-213,38 \%$ \\
\hline UE / EUA Média & $\ldots$ & $\ldots$ & $-13,71 \%$ & $-28,96 \%$ & $-155,09 \%$ & $-142,93 \%$ & $-145,92 \%$ & $-138,75 \%$ \\
\hline PD Médio & $\ldots$ & $\ldots$ & $\ldots$ & $-17,67 \%$ & $-163,85 \%$ & $-149,76 \%$ & $-153,21 \%$ & $-144,90 \%$ \\
\hline Outros PD Médio & $\cdots$ & $\cdots$ & $\ldots$ & $\cdots$ & $-177,55 \%$ & $-160,44 \%$ & $-164,64 \%$ & $-154,54 \%$ \\
\hline PED $_{\text {ma }}$ Médio & $\cdots$ & $\cdots$ & $\ldots$ & $\ldots$ & $\ldots$ & $-22,07 \%$ & $-16,65 \%$ & $-29,67 \%$ \\
\hline PED $_{\text {mb }}$ Médio & $\ldots$ & $\ldots$ & $\ldots$ & $\ldots$ & $\ldots$ & $\ldots$ & $6,95 \%$ & $-9,75 \%$ \\
\hline PED Médio & $\cdots$ & $\ldots$ & $\ldots$ & $\ldots$ & $\ldots$ & $\ldots$ & $\ldots$ & $-15,62 \%$ \\
\hline
\end{tabular}

Fonte: Elaboração própria.

Conforme pode-se observar, os EUA são de longe os maiores alocadores de fluxos comerciais preferenciais líquidos no sistema, sendo 107,88\% maior que a dos demais PD e a capacidade da UE 86,16\% menor. Os demais resultados estão dentro do esperado, com gradação na participação nos fluxos de comércio preferencial crescente: i) PED ma; ii) PED $D_{\mathrm{mb}}$; e iii) PMD.

\section{A4-2.2. Dimensão institucional/legal}

\section{A4-2.2.1. Capacidade legal/institucional relativa (CAP)}

A capacidade legal e institucional relativa dos países (CAP) será medida pelo índice (normalizado) de eficácia governamental calculado pelo Banco Mundial na série World Bank Worldwide Governance Research Indicators Dataset ${ }^{5}$. O índice de eficácia governamental capta a percepção da qualidade dos serviços públicos, da qualidade dos

5 Disponível em <http://www.govindicators.org $>$. 
recursos humanos na esfera pública, do grau de independência das pressões políticas, da qualidade da formulação e implementação de políticas públicas e da credibilidade dos compromissos do governo, de acordo com metodologia desenvolvida por Kaufmann, Kraay e Mastruzzi (2010).

A estimativa para o índice de cada país é o valor agregado destes itens, em unidades de uma distribuição normal padrão, variando de $-2,5$ a $+2,5$. Portanto, países próximos a zero tem eficácia média, quanto maior o índice mais eficaz é o setor público do país em relação aos demais e quanto menor menos eficaz relativamente aos outros. Para normalizar nossos dados e evitar valores negativos, será somado o valor de $+2,5$ ao índice para normalização.

A disponibilidade de dados para a série histórica do índice começa em 1996 e não está disponível para os anos de 1997, 1999 e 2001. Como regras geral, no primeiro caso foram repetidos os dados de 1996 e nos demais foi utilizada uma média simples dos anos imediatamente anterior e posterior, respectivamente. Os demais ajustes efetuados nos dados são descritos a seguir:

Cabo Verde, Ilhas Salomão e Tonga - estão disponíveis dados apenas a partir de 1998, tendo sido considerada uma média dos anos de 1998, 2000 e 2001 para o período precedente, respectivamente, para cada país;

Catar - não há dados para o ano de 2012, tendo sido repetido o valor de 2011; e

Montenegro - estão disponíveis dados apenas a partir de 2005, de modo que os valores para o período anterior referem-se a uma média dos três primeiros anos disponíveis.

O resultado para os valores individuais da CAP para cada um dos países podem ser observados no Quadro A4-2.3 (p. 548) ao final do presente Anexo. Por sua vez, a Tabela A4-2.4 na página a seguir traz a média de cada grupo de renda ao longo do período. 
Tabela A4-2.4: CAP média por grupo de renda no período 1995-2012

\begin{tabular}{|c|c|c|c|c|c|c|c|c|c|c|}
\hline MEMBRO & 1995 & 1996 & 1997 & 1998 & 1999 & 2000 & 2001 & 2002 & 2003 & (cont...) \\
\hline União Europeia & 3,60 & 3,60 & 3,61 & 3,61 & 3,62 & 3,63 & 3,66 & 3,70 & 3,72 & \\
\hline Estados Unidos & 4,21 & 4,21 & 4,25 & 4,30 & 4,32 & 4,34 & 4,27 & 4,20 & 4,11 & \\
\hline UE / EUA Média & 3,90 & 3,90 & 3,93 & 3,95 & 3,97 & 3,98 & 3,97 & 3,95 & 3,91 & \\
\hline PD Médio & 3,08 & 3,02 & 3,03 & 3,03 & 3,05 & 3,00 & 3,00 & 3,01 & 3,03 & \\
\hline Outros PD Médio & 3,19 & 3,14 & 3,14 & 3,15 & 3,18 & 3,14 & 3,14 & 3,15 & 3,18 & \\
\hline PED $_{\text {ma }}$ Médio & 2,24 & 2,20 & 2,19 & 2,19 & 2,20 & 2,19 & 2,17 & 2,15 & 2,18 & \\
\hline PED $_{m b}$ Médio & 1,79 & 1,75 & 1,73 & 1,74 & 1,72 & 1,67 & 1,66 & 1,65 & 1,65 & \\
\hline PED Médio & 1,87 & 1,81 & 1,81 & 1,83 & 1,82 & 1,80 & 1,79 & 1,77 & 1,79 & \\
\hline PMD Médio & 1,64 & 1,62 & 1,67 & 1,73 & 1,73 & 1,72 & 1,69 & 1,66 & 1,67 & \\
\hline MEMBRO & 2004 & 2005 & 2006 & 2007 & 2008 & 2009 & 2010 & 2011 & 2012 & MÉDIA \\
\hline União Europeia & 3,71 & 3,65 & 3,62 & 3,57 & 3,59 & 3,60 & 3,61 & 3,59 & 3,58 & 3,63 \\
\hline Estados Unidos & 4,30 & 4,07 & 4,10 & 4,15 & 4,10 & 4,00 & 4,05 & 4,01 & 4,01 & 4,17 \\
\hline UE / EUA Média & 4,01 & 3,86 & 3,86 & 3,86 & 3,84 & 3,80 & 3,83 & 3,80 & 3,80 & 3,90 \\
\hline PD Médio & 3,09 & 2,98 & 3,05 & 3,06 & 3,06 & 3,09 & 3,09 & 3,07 & 3,07 & 3,05 \\
\hline Outros PD Médio & 3,24 & 3,12 & 3,20 & 3,21 & 3,22 & 3,25 & 3,26 & 3,22 & 3,23 & 3,19 \\
\hline PED $_{\text {ma }}$ Médio & 2,15 & 2,19 & 2,19 & 2,18 & 2,19 & 2,19 & 2,19 & 2,19 & 2,16 & 2,19 \\
\hline PED $_{m b}$ Médio & 1,62 & 1,61 & 1,61 & 1,62 & 1,60 & 1,59 & 1,59 & 1,60 & 1,58 & 1,65 \\
\hline PED Médio & 1,76 & 1,74 & 1,75 & 1,77 & 1,76 & 1,75 & 1,75 & 1,76 & 1,74 & 1,78 \\
\hline PMD Médio & 1,66 & 1,58 & 1,61 & 1,65 & 1,65 & 1,61 & 1,62 & 1,65 & 1,60 & 1,65 \\
\hline
\end{tabular}

Fonte: Elaboração própria.

Enquanto a Tabela A4-2.5 abaixo mostra de forma sumarizada a relação porcentual das diferenças médias de capacidade entre os grupos no período:

Tabela A4-2.5: Comparativo da CAP média por grupo de renda no período 1995-2012

\begin{tabular}{|c|c|c|c|c|c|c|c|c|}
\hline MEMBRO & União Europeia & Estados Unidos & $\begin{array}{c}\text { PD } \\
\text { Médio } \\
\end{array}$ & $\begin{array}{c}\text { Outros PD } \\
\text { Médio }\end{array}$ & $\begin{array}{l}\text { PED }_{\text {ma }} \\
\text { Médio }\end{array}$ & $\begin{array}{l}\text { PED }_{m b} \\
\text { Médio }\end{array}$ & $\begin{array}{l}\text { PED } \\
\text { Médio }\end{array}$ & $\begin{array}{l}\text { PMD } \\
\text { Médio }\end{array}$ \\
\hline União Europeia & $\ldots$ & $-12,98 \%$ & $19,10 \%$ & $13,80 \%$ & $65,88 \%$ & $119,13 \%$ & $103,49 \%$ & $119,32 \%$ \\
\hline Estados Unidos & $\ldots$ & $\ldots$ & $36,86 \%$ & $30,77 \%$ & $90,62 \%$ & $151,82 \%$ & $133,84 \%$ & $152,04 \%$ \\
\hline UE / EUA Média & $\ldots$ & $\ldots$ & $27,93 \%$ & $22,24 \%$ & $78,19 \%$ & $135,39 \%$ & $118,59 \%$ & $135,59 \%$ \\
\hline PD Médio & $\ldots$ & $\ldots$ & $\ldots$ & $-4,45 \%$ & $39,28 \%$ & $84,00 \%$ & $70,86 \%$ & $84,16 \%$ \\
\hline Outros PD Médio & $\ldots$ & $\ldots$ & $\ldots$ & $\ldots$ & $45,77 \%$ & $92,56 \%$ & $78,82 \%$ & $92,73 \%$ \\
\hline PED $_{\text {ma }}$ Médio & $\ldots$ & $\cdots$ & .. & $\ldots$ & $\ldots$ & $32,10 \%$ & $22,67 \%$ & $32,22 \%$ \\
\hline PED $_{\text {mb }}$ Médio & $\ldots$ & $\ldots$ & $\cdots$ & $\ldots$ & $\ldots$ & $\ldots$ & $-7,14 \%$ & $0,09 \%$ \\
\hline PED Médio & $\ldots$ & $\ldots$ & $\ldots$ & $\ldots$ & $\ldots$ & $\ldots$ & $\ldots$ & $7,78 \%$ \\
\hline
\end{tabular}

Fonte: Elaboração própria. 
A partir da apresentação dos dados em questão pode-se concluir que na média a capacidade legal/institucional relativa de todos os grupos de renda manteve-se regular ao longo do período. No que tange aos países desenvolvidos, a capacidade relativa da UE é inferior apenas à dos EUA em 12,98\%, sendo 13,80\% maior do que a dos outros países desenvolvidos e consistentemente maior do que a dos em desenvolvimento, variando aproximadamente de 2,6 a 3,2 vezes a capacidade dos diferentes grupos de renda dos PED.

Os EUA, por sua vez, detém capacidade $30,77 \%$ maior que a média dos outros PD e entre 2,9 e 3,5 vezes maior que os demais grupos de países em desenvolvimento. Os outros países desenvolvidos possuem capacidade relativa entre 2,4 e 2,9 vezes a média dos diferentes grupos em desenvolvimento. No âmbito dos subgrupos em desenvolvimento, os $\mathrm{PED}_{\mathrm{ma}}$ possuem capacidade cerca de $32 \%$ maior do que os $\mathrm{PED}_{\mathrm{mb}} \mathrm{e}$ $\mathrm{PMD}$. Enquanto, ao seu turno, os $\mathrm{PED}_{\mathrm{mb}}$ tem capacidade média similar aos PMD.

\section{A4-2.2.1.2. Aprendizado (APRE)}

A variável aprendizado (APRE) será dada pela soma do quantitativo total de casos em que um membro teve participação como parte interessada até o ano corrente em análise. Para esta variável faremos nossa própria compilação, utilizando a metodologia definida nesta pesquisa, a partir dos dados de casos unitários disponíveis no OSC/OMC. Os valores de APRE são apresentados no Quadro A4-2.4 (p. 554) ao final do Anexo.

Considerando-se a média da APRE anual de cada grupo de renda, sumarizamos na Tabela A4-2.6 a seguir os valores observados ao longo do período:

Tabela A4-2.6: APRE média por grupo de renda no período 1995-2012

\begin{tabular}{ccccccccccc}
\hline MEMBRO & $\mathbf{1 9 9 5}$ & $\mathbf{1 9 9 6}$ & $\mathbf{1 9 9 7}$ & $\mathbf{1 9 9 8}$ & $\mathbf{1 9 9 9}$ & $\mathbf{2 0 0 0}$ & $\mathbf{2 0 0 1}$ & $\mathbf{2 0 0 2}$ & $\mathbf{2 0 0 3}$ & (cont...) \\
\hline União Europeia & 4,00 & 11,00 & 15,00 & 18,00 & 26,00 & 34,00 & 41,00 & 59,00 & 66,00 & \\
Estados Unidos & 5,00 & 12,00 & 22,00 & 29,00 & 31,00 & 37,00 & 42,00 & 49,00 & 58,00 & \\
UE / EUA Média & 4,50 & 11,50 & 18,50 & 23,50 & 28,50 & 35,50 & 41,50 & 54,00 & 62,00 & \\
$\quad$ PD Médio & 1,53 & 3,90 & 5,85 & 7,00 & 9,10 & 10,18 & 11,32 & 15,39 & 18,00 & \\
Outros PD Médio & 1,25 & 3,24 & 4,71 & 5,47 & 7,35 & 8,05 & 8,74 & 12,30 & 14,50 & \\
PED $_{\text {ma Médio }}$ & 0,12 & 0,89 & 1,41 & 2,00 & 2,38 & 2,94 & 3,23 & 5,45 & 6,56 & \\
PED & Médio & 0,23 & 1,27 & 1,39 & 1,71 & 2,07 & 2,72 & 2,90 & 5,10 & 6,44 \\
PED Médio & 0,12 & 0,82 & 1,06 & 1,39 & 1,65 & 2,11 & 2,29 & 4,02 & 5,00 & \\
PMD Médio & 0,00 & 0,18 & 0,18 & 0,22 & 0,22 & 0,22 & 0,22 & 0,65 & 0,83 & \\
\hline
\end{tabular}




\begin{tabular}{|c|c|c|c|c|c|c|c|c|c|c|}
\hline MEMBRO & 2004 & 2005 & 2006 & 2007 & 2008 & 2009 & 2010 & 2011 & 2012 & MÉDIA \\
\hline União Europeia & 70,00 & 74,00 & 79,00 & 88,00 & 95,00 & 101,00 & 111,00 & 116,00 & 133,00 & 63,39 \\
\hline Estados Unidos & 61,00 & 64,00 & 71,00 & 74,00 & 77,00 & 84,00 & 90,00 & 94,00 & 105,00 & 55,83 \\
\hline UE / EUA Média & 65,50 & 69,00 & 75,00 & 81,00 & 86,00 & 92,50 & 100,50 & 105,00 & 119,00 & 59,61 \\
\hline PD Médio & 19,70 & 20,43 & 22,61 & 24,52 & 27,04 & 29,30 & 30,70 & 31,70 & 36,96 & 18,07 \\
\hline Outros PD Médio & 16,10 & 15,81 & 17,62 & 19,14 & 21,48 & 23,48 & 24,33 & 25,14 & 30,14 & 14,38 \\
\hline PED $_{\text {ma }}$ Médio & 6,91 & 7,13 & 7,75 & 8,36 & 9,15 & 10,21 & 11,09 & 11,39 & 12,77 & 6,10 \\
\hline PED $_{\text {mb }}$ Médio & 6,94 & 7,38 & 7,97 & 8,53 & 8,79 & 9,44 & 10,41 & 10,76 & 12,60 & 5,93 \\
\hline PED Médio & 5,19 & 5,43 & 5,87 & 6,26 & 6,72 & 7,35 & 8,04 & 8,29 & 9,69 & 4,52 \\
\hline PMD Médio & 0,76 & 0,76 & 0,76 & 0,81 & 0,92 & 1,00 & 1,08 & 1,12 & 1,62 & 0,64 \\
\hline
\end{tabular}

Fonte: Elaboração própria.

Por fim, a Tabela A4-2.7 abaixo faz um resumo comparativo do comportamento médio da variável em relação a cada grupo de renda:

Tabela A4-2.7: Comparativo da APRE média por grupo de renda no período 19952012

\begin{tabular}{ccccccccc}
\hline MEMBRO & União Europeia & Estados Unidos & $\begin{array}{c}\text { PD } \\
\text { Médio }\end{array}$ & $\begin{array}{c}\text { Outros PD } \\
\text { Médio }\end{array}$ & $\begin{array}{c}\text { PED }_{\text {ma }} \\
\text { Médio }\end{array}$ & $\begin{array}{c}\text { PED } \\
\text { Médio }\end{array}$ & $\begin{array}{c}\text { PED } \\
\text { Médio }\end{array}$ & $\begin{array}{c}\text { PMD } \\
\text { Médio }\end{array}$ \\
\hline União Europeia & $\ldots$ & $13,53 \%$ & $250,83 \%$ & $340,80 \%$ & $939,72 \%$ & $969,74 \%$ & $1303,33 \%$ & $9795,99 \%$ \\
Estados Unidos & $\ldots$ & $\ldots$ & $209,02 \%$ & $288,26 \%$ & $815,79 \%$ & $842,24 \%$ & $1136,06 \%$ & $8616,45 \%$ \\
UE / EUA Média & $\ldots$ & $\ldots$ & $229,93 \%$ & $314,53 \%$ & $877,75 \%$ & $905,99 \%$ & $1219,69 \%$ & $9206,22 \%$ \\
PD Médio & $\ldots$ & $\ldots$ & $\ldots$ & $25,64 \%$ & $196,35 \%$ & $204,91 \%$ & $300,00 \%$ & $2720,70 \%$ \\
Outros PD Médio & $\ldots$ & $\ldots$ & $\ldots$ & $\ldots$ & $135,87 \%$ & $142,68 \%$ & $218,36 \%$ & $2145,00 \%$ \\
PED & $\ldots$ & $\ldots$ & $\ldots$ & $\ldots$ & $\ldots$ & $2,89 \%$ & $34,97 \%$ & $851,80 \%$ \\
PED & $\ldots$ & $\ldots$ & $\ldots$ & $\ldots$ & $\ldots$ & $\ldots$ & $31,18 \%$ & $825,08 \%$ \\
PED Médio & $\ldots$ & $\ldots$ & $\ldots$ & $\ldots$ & $\ldots$ & $\ldots$ & $\ldots$ & $605,18 \%$ \\
\hline
\end{tabular}

Fonte: Elaboração própria.

Conforme pode-se visualizar, a União Europeia participou em um somatório anual médio maior de casos como parte interessada do que todos os demais membros, inclusive EUA (cerca de $13 \%$ mais casos). Por sua vez, os EUA tem participação média substancialmente maior do que todos os demais grupos, enquanto os outros PD maior do que os subgrupos de PED.

Já no caso dos países em desenvolvimento de renda média-alta e média-baixa, houve convergência no desempenho de ambos os grupos, praticamente não existindo diferença na média. Dessa forma, os dois grupos tem desempenho médio cerca de 8 vezes maior do que os PMD. 


\section{A4-2.2.1.3. Abertura do regime político (POL)}

A variável $\mathrm{POL}$ será dividida em duas variáveis dummy para representar as diferenças de abertura dos regimes políticos dos membros da OMC no período. Utilizaremos a definição do relatório anual "Freedom in the World" do think thank internacional Freedom House, que classifica países e territórios anualmente de acordo com os status de: Livre (LV); Parcialmente Livre (PL); Não Livre (NL). Nossas variáveis dummy representarão em nossos modelos os estágios de supressão de liberdade política caracterizados por PL e NL.

De acordo a metodologia do estudo de referência ${ }^{7}$, anualmente a cada país é atribuído entre 0 e 4 pontos em uma série de 25 indicadores, com uma pontuação agregada de até 100. Esta pontuação é usada para determinar duas classificações numéricas, para os direitos políticos e para as liberdades civis destes países, que são ponderadas e padronizadas entre 1 a 7 , em uma classificação onde 1 representa o regime político mais livre e 7 o menos livre.

Os valores de POL são apresentados no Quadro A4-2.5 (p. 559) ao final do presente Anexo. Uma vez que se trata de uma variável qualitativa, não apresentaremos uma discussão sobre a evolução dos valores ou comparação dos mesmos em relação aos diferentes grupos de renda no período. Os únicos ajustes necessários dizem respeito à UE, classificada com uma única entidade aberta (LV) no período, e as AEE da China:

Hong Kong e Macau - apesar de não haver classificação disponível para ambas as AAE da China na base em questão, uma vez que ambos os territórios estiveram sob controle estrangeiro ou de Pequim durante o período, estas foram classificadas como NL.

\footnotetext{
${ }^{6}$ Disponível em < https://freedomhouse.org/report-types/freedom-world>. Acesso em setembro de 2016.

7 Disponível em <https://freedomhouse.org/report/freedom-world-2016/methodology>. Acesso em setembro de 2016.
} 
Quadro A4-2.1: ODP no período 1995-2012

\begin{tabular}{|c|c|c|c|c|c|c|c|c|c|c|c|c|c|c|c|c|c|c|}
\hline MEMBRO & 1995 & 1996 & 1997 & 1998 & 1999 & 2000 & $\mid 2001$ & 2002 & 2003 & 2004 & 2005 & 2006 & 2007 & 2008 & 2009 & $|2010|$ & 2011 & $\mid 2012$ \\
\hline \multicolumn{19}{|c|}{ PAISES DESENVOLVIDOS } \\
\hline PD Médio & 0,28 & 0,20 & 0,16 & 0,17 & 0,14 & 0,17 & 0,19 & 0,19 & 0,24 & 0,23 & 0,19 & 0,19 & 0,21 & 0,20 & 0,23 & 0,21 & 0,18 & 0,18 \\
\hline União Europeia & 0,37 & 0,37 & 0,33 & 0,33 & 0,32 & 0,32 & 0,33 & 0,35 & 0,36 & 0,35 & 0,47 & 0,47 & 0,43 & 0,46 & 0,48 & 0,50 & \begin{tabular}{|l|}
0,48 \\
\end{tabular} & 0,45 \\
\hline Estados Unidos & 0,10 & 0,12 & 0,09 & 0,10 & 0,10 & $\mid$\begin{tabular}{||l}
0,10 \\
\end{tabular} & $\mid$\begin{tabular}{||l}
0,11 \\
\end{tabular} & 0,13 & 0,15 & 0,17 & 0,23 & 0,18 & 0,16 & 0,18 & 0,21 & $\mid 0,20$ & 0,20 & 0,19 \\
\hline UE / EUA Média & 0,24 & 0,24 & 0,21 & 0,22 & 0,21 & $\mid$\begin{tabular}{||l}
0,21 \\
-1
\end{tabular} & $\mid$\begin{tabular}{||l}
0,22 \\
\end{tabular} & | 0,24 & 0,25 & 0,26 & 0,35 & 0,32 & 0,29 & 0,32 & 0,35 & 0,35 & $\mid 0,34$ & 0,32 \\
\hline \multicolumn{19}{|c|}{ OUTROS DESENVOLVIDOS } \\
\hline Arábia Saudita & & & & & & & & & & & 0,01 & 0,01 & $-0,03$ & 0,00 & 0,00 & $\mid 0,00$ & 0,00 & 0,00 \\
\hline Austrália & 0,34 & 0,27 & 0,27 & 0,27 & 0,26 & $\mid$\begin{tabular}{|ll}
$\mid 0,27$ \\
\end{tabular} & $\mid$\begin{tabular}{||l}
$\mid$ \\
0,25
\end{tabular} & 0,26 & $\mid 0,25$ & 0,25 & 0,25 & 0,30 & 0,32 & 0,32 & 0,29 & $\mid 0,32$ & $\mid 0,34$ & 0,36 \\
\hline Bahrein & 1,72 & 2,18 & & & & 0,68 & $\mid 0,82$ & 0,68 & $\mid 1,25$ & 0,46 & 0,00 & 0,00 & 0,00 & 0,00 & 0,00 & 0,00 & 0,00 & 0,00 \\
\hline Barbados & $-0,05$ & 0,18 & \begin{tabular}{|l|l|} 
& 0,17 \\
\end{tabular} & 0,56 & $\mid-0,07$ & $\mid$\begin{tabular}{||l}
$\mid 0,01$ \\
\end{tabular} & $\mid-0,04$ & 0,11 & $\mid 0,63$ & 0,85 & $-0,05$ & $-0,05$ & 0,40 & 0,16 & $\mid 0,27$ & $\mid 0,37$ & $\mid 0,00$ & 0,00 \\
\hline Canada & 0,38 & 0,32 & 0,34 & 0,30 & 0,28 & 0,25 & 0,22 & 0,28 & $\mid 0,24$ & 0,27 & 0,34 & 0,29 & 0,29 & 0,33 & 0,30 & 0,34 & 0,32 & 0,32 \\
\hline Cingapura & \begin{tabular}{|c|}
$-0,02$ \\
\end{tabular} & $-0,02$ & 0,00 & 0,00 & 0,00 & 0,00 & 0,00 & $-0,01$ & $-0,01$ & $-0,01$ & 0,00 & 0,00 & 0,00 & 0,00 & 0,00 & 0,00 & 0,00 & 0,00 \\
\hline Coréia do Sul & 0,02 & 0,03 & 0,04 & 0,05 & $\mid$\begin{tabular}{|ll}
$\mid 0,07$ \\
\end{tabular} & $\mid$\begin{tabular}{||l}
$\mid 0,04$ \\
\end{tabular} & $\mid$\begin{tabular}{||l}
0,06 \\
\end{tabular} & 0,05 & $\mid 0,06$ & 0,06 & 0,10 & 0,05 & 0,07 & 0,09 & 0,10 & 0,12 & 0,12 & 0,14 \\
\hline Croácia & & & & & & $\mid 0,31$ & $\mid$\begin{tabular}{||l}
0,54 \\
\end{tabular} & 0,54 & 0,36 & 0,29 & 0,28 & 0,41 & 0,28 & 0,35 & 0,28 & 0,23 & 0,00 & 0,00 \\
\hline Hong Kong & 0,01 & 0,01 & 0,00 & 0,00 & 0,00 & 0,00 & 0,00 & 0,00 & 0,00 & 0,00 & 0,00 & 0,00 & 0,00 & 0,00 & 0,00 & 0,00 & 0,00 & 0,00 \\
\hline Islândia & 0,00 & 0,00 & 0,00 & 0,00 & $\mid 0,09$ & $\mid$\begin{tabular}{||l}
$\mid 0,10$ \\
\end{tabular} & $\mid$\begin{tabular}{|ll}
$\mid$ & 0,13
\end{tabular} & 0,15 & $\mid 0,17$ & 0,18 & 0,18 & 0,27 & 0,27 & 0,47 & 0,35 & 0,29 & 0,21 & 0,22 \\
\hline Israel & \begin{tabular}{|l|}
$-0,28$ \\
\end{tabular} & $-1,82$ & $-0,96$ & $-0,85$ & $-0,70$ & $\mid-0,60$ & $\mid-0,13$ & $-0,55$ & $\mid-0,31$ & $-0,32$ & 0,00 & 0,00 & 0,00 & 0,00 & 0,00 & 0,00 & 0,00 & 0,00 \\
\hline Japão & \begin{tabular}{|l|}
0,27 \\
\end{tabular} & 0,20 & 0,21 & 0,27 & 0,27 & \begin{tabular}{|l|l|}
0,28 \\
\end{tabular} & 0,23 & 0,23 & 0,20 & 0,19 & 0,28 & 0,25 & 0,17 & \begin{tabular}{|l|}
0,19 \\
\end{tabular} & \begin{tabular}{|l|}
0,18 \\
\end{tabular} & 0,20 & 0,18 & 0,17 \\
\hline Kuwait & $-0,01$ & $-0,07$ & 0,00 & $-0,02$ & $-0,02$ & $\mid-0,01$ & $\mid-0,01$ & $-0,02$ & $\mid-0,01$ & $-0,01$ & & $\mid 0,00$ & $0,0,00$ & 0,00 & & & & \\
\hline Nova Zelândia & 0,23 & 0,21 & 0,26 & 0,27 & 0,27 & 0,25 & 0,25 & 0,22 & 0,23 & 0,23 & 0,27 & 0,27 & 0,27 & 0,30 & 0,28 & 0,26 & 0,28 & 0,28 \\
\hline Noruega & 0,86 & 0,83 & 0,84 & 0,89 & 0,88 & 0,76 & 0,80 & 0,89 & 0,92 & 0,87 & 0,94 & 0,89 & 0,95 & 0,89 & 1,06 & 1,05 & 0,96 & 0,93 \\
\hline Omã & & & & & & $\mid$\begin{tabular}{||c|}
0,42 \\
|
\end{tabular} & $\mid$\begin{tabular}{||c}
$\mid$ \\
0,04
\end{tabular} & 0,41 & $\mid 0,31$ & 0,42 & 0,06 & 0,16 & 0,52 & 0,13 & 0,32 & $-0,04$ & 0,00 & 0,00 \\
\hline
\end{tabular}




\begin{tabular}{|c|c|c|c|c|c|c|c|c|c|c|c|c|c|c|c|c|c|c|}
\hline Suiça & 0,33 & 0,32 & 0,32 & 0,31 & 0,34 & 0,32 & 0,33 & 0,32 & 0,36 & 0,39 & 0,42 & 0,38 & 0,37 & $\mid$\begin{tabular}{||c}
0,42 \\
-1
\end{tabular} & 0,44 & 0,39 & 0,46 & 0,47 \\
\hline Taiwan & & & & & & & & 0,00 & 0,00 & 0,15 & 0,14 & 0,14 & 0,13 & $\mid$\begin{tabular}{||l}
0,11 \\
-11
\end{tabular} & 0,13 & 0,10 & $\mid 0,09$ & 0,06 \\
\hline Trinidad e Tobago & 0,51 & 0,31 & 0,62 & 0,24 & 0,41 & $-0,02$ & $-0,02$ & $-0,10$ & $-0,03$ & $-0,01$ & $-0,01$ & 0,08 & 0,10 & $\mid$\begin{tabular}{||c}
0,03 \\
-1
\end{tabular} & 0,04 & $\mid$\begin{tabular}{|l}
0,02 \\
-1
\end{tabular} & & \\
\hline Catar & & & & & $-0,05$ & $-0,01$ & $-0,02$ & $-0,02$ & $-0,02$ & $-0,01$ & 0,00 & 0,00 & 0,00 & $\mid 0,00$ & 0,00 & 0,00 & 0,00 & 0,00 \\
\hline Macau & $-0,06$ & 0,00 & 0,01 & 0,01 & 0,01 & 0,00 & 0,00 & 0,00 & 0,00 & 0,00 & 0,00 & 0,00 & 0,00 & 0,00 & 0,00 & 0,00 & 0,00 & 0,00 \\
\hline Outros PD Médio & 0,29 & 0,20 & 0,15 & 0,16 & 0,13 & 0,17 & 0,19 & 0,18 & 0,24 & 0,22 & 0,17 & 0,17 & 0,21 & $\mid 0,19$ & 0,21 & $\mid 0,19$ & 0,16 & 0,16 \\
\hline \multicolumn{19}{|c|}{ EM DESENVOLVIMENTO } \\
\hline PED Médio & $-9,44$ & $-7,82$ & $-6,77$ & $-6,52$ & $-6,14$ & $-5,64$ & $-6,49$ & $-6,70$ & $-6,57$ & $-6,97$ & $-6,46$ & $-6,21$ & $-6,25$ & $-6,51$ & $-6,50$ & $-7,07$ & $-6,31$ & $-5,87$ \\
\hline \multicolumn{19}{|c|}{ Renda Média-Alta } \\
\hline África do Sul & $-0,25$ & $-0,25$ & $-0,33$ & $-0,38$ & $-0,41$ & $-0,37$ & $-0,36$ & $-0,45$ & $-0,38$ & $-0,28$ & $-0,27$ & $-0,27$ & $-0,28$ & $-0,40$ & $-0,37$ & $-0,28$ & $-0,34$ & $-0,28$ \\
\hline Antígua e Barbuda & & & & & $-1,71$ & $-1,32$ & & & & & $-0,82$ & $-0,30$ & $-0,60$ & & $-0,49$ & $-1,73$ & $-1,41$ & $-0,20$ \\
\hline Argentina & $-0,06$ & $-0,05$ & $-0,04$ & $-0,03$ & $-0,03$ & $-0,02$ & $-0,06$ & $-0,09$ & $-0,09$ & $-0,05$ & $-0,05$ & $-0,04$ & $-0,03$ & $\mid-0,03$ & $-0,03$ & $-0,03$ & $\mid-0,02$ & $-0,03$ \\
\hline Brasil & $-0,04$ & $-0,03$ & $-0,03$ & $-0,03$ & $-0,02$ & $-0,04$ & $-0,04$ & $-0,04$ & $-0,04$ & $-0,02$ & $-0,03$ & $-0,01$ & $-0,02$ & $\mid-0,03$ & $-0,02$ & $\mid-0,02$ & $-0,03$ & $-0,05$ \\
\hline Chile & $-0,23$ & $-0,27$ & $-0,16$ & $-0,14$ & $-0,10$ & $-0,06$ & $-0,11$ & 0,01 & $-0,12$ & $-0,06$ & $-0,15$ & $-0,07$ & $-0,07$ & $\mid-0,06$ & $-0,05$ & $-0,10$ & $\mid-0,07$ & $-0,05$ \\
\hline Colômbia & $-0,19$ & $-0,20$ & $-0,19$ & $-0,17$ & $-0,36$ & $-0,19$ & $-0,40$ & $-0,46$ & $-0,88$ & $-0,46$ & $-0,44$ & $-0,64$ & $-0,36$ & $\mid-0,41$ & $-0,47$ & $\mid-0,24$ & $-0,32$ & $-0,22$ \\
\hline Costa Rica & $-0,26$ & 0,11 & 0,06 & $-0,13$ & 0,07 & $-0,07$ & 0,00 & 0,00 & $-0,17$ & $-0,07$ & $-0,13$ & $-0,14$ & $-0,23$ & $-0,22$ & $-0,38$ & $-0,26$ & $-0,09$ & $-0,06$ \\
\hline Cuba & & & & & $-0,21$ & $-0,15$ & $-0,17$ & $-0,19$ & $-0,21$ & $-0,28$ & $-0,21$ & $-0,18$ & & & & & & \\
\hline Dominica & $\mid-11,87$ & $-19,81$ & $-6,36$ & & $-4,06$ & $-5,12$ & $-6,19$ & $-9,56$ & $-3,46$ & $-8,62$ & $-6,18$ & $-5,20$ & $-4,83$ & $\mid-5,05$ & $-7,56$ & $\mid-6,70$ & & $\mid-5,41$ \\
\hline Granada & & $-4,24$ & $-3,08$ & $-1,96$ & $-2,91$ & $-3,39$ & $-2,29$ & $-2,05$ & $-1,99$ & $-2,93$ & $-7,87$ & $-3,99$ & $-3,21$ & $\mid-4,23$ & $-6,75$ & & & \\
\hline Jamaica & $-1,95$ & $-0,91$ & $-0,97$ & & & & & $-0,26$ & $-0,07$ & $-0,86$ & $-0,38$ & $-0,33$ & $-0,23$ & $\mid-0,65$ & $-1,31$ & $\mid-1,11$ & $\mid-0,28$ & $-0,18$ \\
\hline Malásia & $-0,13$ & 0,47 & 0,25 & $-0,30$ & $-0,20$ & $-0,05$ & $-0,04$ & $-0,09$ & $-0,10$ & $-0,26$ & $-0,02$ & $-0,15$ & $-0,11$ & $-0,07$ & $-0,07$ & 0,00 & $-0,01$ & $-0,01$ \\
\hline Maurício & $-0,57$ & $-0,44$ & $-1,00$ & $-0,97$ & $\mid-0,97$ & $-0,44$ & $-0,46$ & $-0,49$ & 0,25 & $-0,52$ & $-0,55$ & $-0,28$ & $-0,86$ & $\mid-1,13$ & $-1,76$ & $\mid-1,27$ & $\mid-1,66$ & $-1,55$ \\
\hline México & $-0,12$ & $-0,07$ & $-0,02$ & 0,00 & $-0,01$ & 0,01 & $-0,02$ & $-0,02$ & $-0,02$ & $-0,01$ & $-0,02$ & $-0,03$ & $-0,01$ & $\mid-0,01$ & $-0,02$ & $-0,05$ & $-0,08$ & $-0,04$ \\
\hline Namíbia & & & & & & $\mid-3,86$ & $-3,16$ & $-4,19$ & $-2,83$ & $-2,59$ & $-1,75$ & $-1,91$ & $-2,53$ & $\mid-2,52$ & $-3,74$ & $\mid-2,36$ & $\mid-2,35$ & $-2,04$ \\
\hline
\end{tabular}




\begin{tabular}{|c|c|c|c|c|c|c|c|c|c|c|c|c|c|c|c|c|c|c|}
\hline Panamá & & & $-0,48$ & $-0,21$ & $-0,12$ & $-0,14$ & $-0,23$ & $-0,17$ & $-0,22$ & $-0,17$ & $-0,19$ & $-0,17$ & 0,60 & $-0,11$ & $-0,24$ & $-0,42$ & $-0,35$ & $-0,14$ \\
\hline Peru & $-0,75$ & $-0,63$ & $-0,71$ & $-0,93$ & $-0,92$ & $-0,80$ & $-0,89$ & $-0,92$ & $-0,91$ & $-0,74$ & $-0,64$ & $\mid-0,58$ & $-0,33$ & $\mid-0,41$ & $\mid-0,39$ & | 0,22 & $-0,38$ & $-0,21$ \\
\hline R. Dominicana & $\mid-0,77$ & $-0,57$ & $-0,38$ & & & & $\mid-0,45$ & $-0,57$ & $-0,35$ & $-0,42$ & $-0,25$ & $\mid-0,16$ & $-0,29$ & $\mid-0,34$ & $\mid-0,26$ & $-0,34$ & $-0,40$ & $-0,45$ \\
\hline Rússia & & & & & & & & & & & & & & & & & & 0,00 \\
\hline St. Kitts e Nevis & & $-2,25$ & $-2,14$ & & $-1,29$ & $-1,00$ & $-2,38$ & $-6,35$ & $-0,04$ & $-0,01$ & $-0,49$ & $\mid-0,85$ & $-0,53$ & $\mid-6,68$ & $\mid-0,76$ & $\mid-1,72$ & $-2,30$ & \\
\hline St. Lúcia & $\mid-9,25$ & $-7,27$ & $-4,48$ & $-0,99$ & $-3,94$ & $-1,48$ & $-2,38$ & $-4,69$ & $-2,03$ & 2,59 & $-1,20$ & $\mid-1,81$ & $-1,76$ & $\mid-1,70$ & & & & \\
\hline St. Vincente e Granadinas & $-15,64$ & $-8,16$ & $-1,76$ & $-5,70$ & $-4,40$ & $-1,64$ & $-1,96$ & $-1,03$ & $-1,41$ & $-2,16$ & $-1,48$ & $-0,81$ & $-10,46$ & $-3,99$ & $-4,65$ & $-2,52$ & $-2,69$ & $-1,24$ \\
\hline Suriname & $\mid-11,10$ & $-12,64$ & $-8,27$ & $-6,29$ & $-4,26$ & $-3,85$ & $\mid-3,39$ & $-1,12$ & $-0,89$ & $-1,68$ & $-2,52$ & & & & & & & \\
\hline Turquia & $\mid-0,19$ & $-0,14$ & 0,00 & $-0,01$ & 0,00 & $-0,12$ & $\mid-0,07$ & $-0,12$ & $-0,06$ & $-0,07$ & $-0,08$ & $\mid-0,11$ & $-0,12$ & $\mid-0,15$ & $\mid-0,22$ & $-0,14$ & $-0,43$ & $-0,40$ \\
\hline Uruguai & $-0,35$ & $-0,17$ & $-0,14$ & $-0,10$ & $-0,09$ & $-0,08$ & $\mid-0,07$ & $-0,10$ & $-0,20$ & $-0,22$ & $-0,09$ & $\mid-0,11$ & $-0,16$ & $\mid-0,11$ & $\mid-0,16$ & $-0,12$ & $-0,05$ & $-0,04$ \\
\hline Venezuela & $\mid-0,06$ & $-0,06$ & $-0,01$ & $-0,05$ & $-0,05$ & $-0,07$ & $\mid-0,04$ & $-0,06$ & $-0,10$ & $-0,04$ & $-0,04$ & $\mid-0,03$ & $-0,03$ & $\mid-0,02$ & $\mid-0,02$ & $\mid-0,01$ & $-0,02$ & $-0,01$ \\
\hline Albânia & & & & & & $-8,45$ & $\mid-6,77$ & $-6,91$ & $\mid-6,61$ & $-4,80$ & $-4,70$ & $\mid-4,37$ & $-3,59$ & $\mid-3,69$ & $-3,59$ & $\mid-3,61$ & $-3,46$ & $-3,31$ \\
\hline Botswana & $\mid-1,98$ & $\mid-1,46$ & $-2,50$ & $-2,01$ & $\mid-1,07$ & $-0,58$ & $\mid-0,57$ & $-0,61$ & $-0,40$ & $-0,66$ & $-0,59$ & $\mid-0,74$ & $-0,99$ & $\mid-5,92$ & $-2,59$ & $\mid-1,28$ & $\mid-0,91$ & $-0,53$ \\
\hline Gabão & & $\mid-1,91$ & $-0,63$ & $-0,69$ & $-0,84$ & $-0,24$ & $\mid-0,14$ & $-1,31$ & 0,17 & $-0,53$ & $-0,76$ & $\mid-0,37$ & $-0,55$ & $\mid-0,64$ & $\mid-0,84$ & & & \\
\hline Jordânia & & & & & & $-8,45$ & $-6,86$ & $-7,79$ & $-15,54$ & $-6,32$ & $-6,64$ & $\mid-4,86$ & $-4,75$ & $\mid-4,91$ & $-4,74$ & $\mid-5,92$ & $-5,71$ & $-6,58$ \\
\hline Maldivas & & & & & & & $-4,16$ & $-4,34$ & $-2,83$ & $-2,81$ & $-7,90$ & $\mid-3,35$ & $-2,72$ & $\mid-3,31$ & $-2,08$ & $-6,50$ & $-2,36$ & $-2,96$ \\
\hline Montenegro & & & & & & & & & & & & & & & & & & $\mid-1,98$ \\
\hline Tonga & & & & & & & & & & & & & $\mid-15,84$ & $-12,44$ & $\mid-18,49$ & $-27,47$ & $-32,96$ & $-27,71$ \\
\hline Tunisia & $\mid-0,52$ & $-0,82$ & $-1,28$ & $-0,92$ & $-1,52$ & $-1,29$ & $-2,19$ & $-1,23$ & $-1,32$ & $-1,34$ & $-1,31$ & $\mid-1,47$ & $-0,92$ & $\mid-0,97$ & $\mid-1,28$ & $\mid-1,39$ & $-2,27$ & $-2,59$ \\
\hline Macedônia & & & & & & & & & $-6,28$ & $-5,52$ & $-4,41$ & $\mid-3,70$ & $-3,11$ & $\mid-2,80$ & $-2,69$ & $-2,59$ & $-2,46$ & $-1,99$ \\
\hline PEDma Médio & $-2,68$ & $-2,57$ & $-1,39$ & $-1,05$ & $-1,18$ & $-1,55$ & $-1,58$ & $-1,84$ & $-1,59$ & $-1,35$ & $-1,63$ & $-1,20$ & $-1,90$ & $-2,10$ & $-2,20$ & $-2,43$ & $-2,35$ & $-2,08$ \\
\hline & & & & & & & & & & & & \multicolumn{7}{|c|}{ Renda Média-Baixa } \\
\hline Armênia & & & & & & & & & $-8,75$ & $-6,88$ & $-3,34$ & $\mid-3,22$ & $\mid-3,61$ & $\mid-2,45$ & $\mid-5,84$ & $\mid-3,52$ & $-3,78$ & $-2,46$ \\
\hline Belize & $\mid-3,05$ & $-3,34$ & $-2,23$ & $-2,30$ & $-6,67$ & $-1,88$ & $-2,75$ & $-2,59$ & $\mid-1,31$ & $-0,81$ & $-1,22$ & $\mid-0,79$ & $\mid-1,92$ & $\mid-1,98$ & $-2,21$ & $\mid-1,95$ & $-1,59$ & $-1,73$ \\
\hline
\end{tabular}




\begin{tabular}{|c|c|c|c|c|c|c|c|c|c|c|c|c|c|c|c|c|c|c|}
\hline Bolivia & $-10,96$ & $\mid-11,44$ & $-9,03$ & $-7,59$ & $-7,15$ & $-5,89$ & $-9,38$ & \begin{tabular}{|l|}
$-8,95$ \\
\end{tabular} & $-12,06$ & $-9,36$ & $-7,01$ & \begin{tabular}{|l|}
$-7,69$ \\
\end{tabular} & $|-3,77|$ & $\mid-3,89$ & $\mid-4,35$ & \begin{tabular}{|l||}
$-3,81$ \\
\end{tabular} & $\mid-3,16$ & $-2,59$ \\
\hline Camarões & $-5,40$ & $-4,49$ & $-5,40$ & & & $-4,33$ & $-5,12$ & $-5,94$ & \begin{tabular}{|l|}
$-6,77$ \\
\end{tabular} & $-5,14$ & $-2,57$ & $\mid-9,71$ & $\mid-9,66$ & $\mid-2,39$ & $-2,79$ & $\mid-2,32$ & $\mid-2,33$ & $-2,29$ \\
\hline China & & & & & & & 0,12 & 0,10 & 0,08 & 0,09 & 0,08 & \begin{tabular}{|l|l|}
0,05 \\
\end{tabular} & 0,04 & 0,03 & 0,02 & $\mid$\begin{tabular}{|l||}
0,01 \\
\end{tabular} & \begin{tabular}{|l|}
$-0,01$ \\
\end{tabular} & 0,00 \\
\hline Costa do Marfim & $\mid-12,10$ & $-8,59 \mid$ & $-4,06$ & $-8,05$ & $-3,81$ & $-3,61$ & $-1,88$ & $-9,88$ & $-1,95$ & $\mid-1,09$ & $|-0,56|$ & $\mid-1,45$ & $|-0,88|$ & $|-2,68|$ & $\mid-10,29$ & $\mid-3,52$ & $\mid-5,88$ & $-10,07$ \\
\hline Egito & $-3,37$ & $-3,22$ & $-2,54$ & $-2,29$ & $-1,77$ & $-1,36$ & $-1,33$ & $-1,50$ & $-1,23$ & $-1,98$ & $-1,16$ & $-0,83$ & $-0,86$ & $-1,06$ & $-0,53$ & $-0,27$ & $-0,18$ & $-0,67$ \\
\hline EI Salvador & $\mid-3,15$ & $-2,95$ & $-2,54$ & $-1,53$ & $-1,50$ & $\mid-1,39$ & $-1,75$ & $-1,67$ & $-1,31$ & $-1,41$ & $-1,23 \mid$ & $\mid-0,90$ & $|-0,45|$ & $\mid-1,11$ & $\mid-1,37$ & $\mid-1,34$ & $\mid-1,23$ & $-0,96$ \\
\hline Equador & & $|-1,03|$ & $-0,56$ & $-0,66$ & $-0,81$ & $-0,86$ & $-0,79$ & $-0,81$ & $-0,57$ & $-0,44$ & $-0,57 \mid$ & $\mid-0,42$ & \begin{tabular}{|l||}
$-0,44$ \\
\end{tabular} & \begin{tabular}{|l||}
$-0,38$ \\
\end{tabular} & \begin{tabular}{|l|l|}
$-0,34$ \\
\end{tabular} & $|-0,21|$ & $|-0,21|$ & $-0,17$ \\
\hline Fiji & & & & & & $-1,70$ & $-1,58$ & $-1,85$ & $\mid-2,21$ & $|-2,40|$ & $|-2,17|$ & $\mid-1,87$ & $|-1,53|$ & $|-1,32|$ & $\mid-2,48$ & $|-2,51|$ & $\mid-2,15$ & $-2,80$ \\
\hline Filipinas & $\mid-1,18$ & $\mid-1,04$ & $-0,78$ & $-0,74$ & $-0,73$ & $-0,60$ & $-0,63$ & $-0,59$ & $-0,70$ & $-0,40 \mid$ & $-0,44 \mid$ & $\mid-0,37$ & $-0,33 \mid$ & $|-0,02|$ & $\mid-0,14$ & $\mid-0,20$ & 0,07 & 0,00 \\
\hline Guatemala & $\mid-1,44$ & $-1,24$ & $-1,51$ & $-1,21$ & $-1,62$ & $-1,38$ & $-1,26$ & $-1,22$ & $-1,14$ & $-0,92 \mid$ & $-0,96 \mid$ & $\mid-1,64$ & $\mid-1,37$ & $\mid-1,40$ & $\mid-1,03$ & $|-0,97|$ & $\mid-0,82$ & $-0,62$ \\
\hline Guiana & & & $-39,32$ & $-14,34$ & $-13,66$ & $-17,54$ & $-17,60$ & $-10,77$ & $-13,90$ & $\mid-21,48$ & $|-19,30|$ & $\mid-12,32$ & $|-7,50|$ & $|-8,72|$ & $\mid-8,63$ & $\mid-7,34$ & $\mid-6,15$ & $-3,97$ \\
\hline Honduras & $\mid-11,03$ & $-9,43$ & $-6,66$ & $-6,34$ & $-15,66$ & $-6,51$ & $-8,99$ & $-5,63$ & $-5,06$ & $-7,91$ & $-7,49$ & $\mid-5,76$ & $|-3,91|$ & & $\mid-3,19$ & $\mid-4,19$ & $-3,69$ & $-3,29$ \\
\hline Índia & $\mid-0,48$ & $-0,48 \mid$ & $-0,39 \mid$ & $-0,38$ & $-0,32$ & $-0,29$ & $-0,35$ & $-0,34$ & $-0,12$ & $-0,11 \mid$ & $|-0,23|$ & $\mid-0,15$ & $|-0,11|$ & $|-0,17|$ & $\mid-0,18$ & $\mid-0,17$ & $|-0,18|$ & $-0,09$ \\
\hline Indonésia & $|-0,66|$ & $-0,48$ & $-0,38$ & $-1,39$ & $\mid-1,64$ & $-1,10$ & $-1,02$ & $-0,76$ & $-0,78$ & $|-0,05|$ & $|-0,93|$ & $\mid-0,38$ & $|-0,22|$ & $|-0,25|$ & $|-0,20|$ & $\mid-0,19$ & $|-0,05|$ & $-0,01$ \\
\hline Moldávia & & & & & & & $-7,91$ & $-8,05$ & $-5,52$ & $-4,04$ & $-5,05$ & $\mid-6,03$ & $-5,53$ & $\mid-4,48$ & $\mid-4,24$ & $\mid-7,49$ & $-6,07$ & $-5,84$ \\
\hline Nicarágua & $\mid-17,22$ & $-23,36$ & $-9,97$ & $-13,54$ & $-14,43$ & $-11,42$ & $-18,32$ & $-10,31$ & $\mid-16,44$ & $\mid-22,13$ & $|-12,37|$ & $\mid-11,35$ & $|-11,62|$ & $|-8,96|$ & $\mid-9,51$ & $\mid-7,79$ & $\mid-7,29$ & $-5,24$ \\
\hline Nigéria & & $|-0,58|$ & $-0,59$ & $-0,70$ & $-0,34$ & $-0,43$ & $-0,44$ & $-0,56$ & $-0,51$ & & & $\mid-8,12$ & $|-1,27|$ & $|-0,67|$ & $|-1,07|$ & $\mid-0,59$ & $|-0,45|$ & $-0,44$ \\
\hline Paquistão & $\mid-1,34$ & $|-1,64|$ & $-1,45$ & $-1,72$ & $-1,19$ & $-0,96$ & $-2,72$ & $-2,90$ & $\mid-1,25$ & $|-1,44|$ & $|-1,44|$ & $\mid-1,56$ & $|-1,46|$ & $|-0,89|$ & $|-1,60|$ & $|-1,64|$ & $\mid-1,57$ & $-0,85$ \\
\hline Paraguai & $\mid-1,71$ & $-0,95$ & \begin{tabular}{|l|}
$-1,18$ \\
\end{tabular} & $-0,93$ & $-1,02$ & $-1,15$ & $-0,91$ & $-0,99$ & \begin{tabular}{|l|}
$-0,94$ \\
\end{tabular} & $-0,33$ & $-0,69$ & $\mid-0,60$ & \begin{tabular}{|l|}
$-0,84$ \\
\end{tabular} & $|-0,77|$ & $\mid-1,00$ & $|-0,65|$ & $|-0,39|$ & $-0,45$ \\
\hline Sri Lanka & & & & & $-1,70$ & $-1,72$ & $-2,21$ & $-2,04$ & $-3,59$ & $-2,48 \mid$ & $|-4,82|$ & $\mid-2,82$ & $|-1,92|$ & $\mid-1,84$ & $\mid-1,69$ & $|-1,04|$ & $\mid$\begin{tabular}{||l}
$\mid-1,04$ \\
\end{tabular} & $-0,84$ \\
\hline Swazilândia & & & & & & $-0,84$ & $-2,01$ & $-1,82$ & $-2,21$ & $-1,03$ & $|-1,69|$ & $\mid-1,17$ & \begin{tabular}{|l||}
$-1,64$ \\
\end{tabular} & & & & & \\
\hline Tailândia & $|-0,50|$ & $-0,46 \mid$ & $-0,43$ & $-0,64$ & $-0,83$ & $-0,56$ & $-0,24$ & $-0,23$ & 0,65 & $-0,03 \mid$ & 0,09 & $\mid 0,10$ & $\mid 0,12$ & |0,22|| & $\mid 0,03$ & 0,00 & $\mid$\begin{tabular}{||l}
$\mid$ \\
0,04
\end{tabular} & 0,04 \\
\hline Ucrânia & & & & & & & & & & & & & & $|-0,35|$ & $\mid-0,58$ & $-0,48$ & $\mid-0,49$ & $-0,44$ \\
\hline Cabo Verde & & & & & & & & & & & & & & $\mid-17,04$ & $\mid-15,44$ & $-26,00$ & $\mid-17,98$ & \\
\hline
\end{tabular}




\begin{tabular}{|c|c|c|c|c|c|c|c|c|c|c|c|c|c|c|c|c|c|c|}
\hline Congo & & & & & & & & & & & & & $-1,99$ & $-7,00$ & $-3,97$ & $\mid-17,40$ & $-3,15$ & $-1,68$ \\
\hline Georgia & & & & & & $-5,47$ & $-9,26$ & $-9,00$ & $-5,47$ & $-6,56 \mid$ & $|-5,46|$ & $\mid-5,90$ & $-5,20$ & $\mid-11,44$ & $|-12,25|$ & $\mid-8,00$ & $-6,59$ & $-7,18$ \\
\hline Lesoto & & & & & & $-5,19$ & $-7,15$ & $-9,40$ & \begin{tabular}{|l|}
$-7,97$ \\
\end{tabular} & $-8,80$ & & & & \begin{tabular}{|l||}
$-9,06$ \\
\end{tabular} & $|-7,75|$ & $\mid-15,10$ & $\mid-13,81$ & $.14,49$ \\
\hline Mauritânia & $\mid-17,93$ & $-21,65$ & & & & $-20,13$ & $-26,18$ & $-32,35$ & $\mid-18,14$ & $\mid-11,75$ & $|-10,19|$ & $\mid-10,03$ & $-13,79$ & $|-16,87|$ & $\mid-14,38$ & $|-13,69|$ & $\mid-12,73$ & $-13,35$ \\
\hline Mongólia & & & $-19,38$ & $-15,05$ & $-15,48$ & $-14,97$ & $-16,18$ & & $-15,20$ & $-12,89$ & $|-10,09|$ & $\mid-8,69$ & $-8,56$ & & & & & \\
\hline Marrocos & $\mid-1,78$ & $-2,00$ & $-1,67$ & $-1,76$ & $-2,24$ & $-1,45$ & $-1,59$ & $-1,10$ & $-1,39$ & $|-1,60|$ & $|-1,49|$ & $\mid-1,99$ & $-1,96$ & $\mid-2,06$ & $\mid-1,43$ & $|-1,33|$ & $|-1,77|$ & $\mid-1,84$ \\
\hline Papua Nova Guin & & & & $-17,75$ & & $-13,76$ & $-11,60$ & $-11,61$ & $\mid-10,27$ & $|-10,20|$ & & & & & & & & \\
\hline Samoa & & & & & & & & & & & & & & & & & & $-22,38$ \\
\hline Ilhas Salomão & & & & & & & & $-18,40$ & $-37,73$ & $-52,97$ & $-72,75 \mid$ & $\mid-68,63$ & $-68,82$ & $\mid-56,32$ & $|-57,63|$ & $|-71,84|$ & $-53,98$ & $-47,50$ \\
\hline PEDmb Médio & $\mid-5,49$ & $-5,18$ & $-5,50$ & $-4,94$ & $-4,63$ & $-4,69$ & $-5,55$ & $-5,56$ & $-5,93$ & $-6,55 \mid$ & $|-6,25|$ & $\mid-6,01$ & $-5,37$ & $|-5,51|$ & $\mid-5,68$ & $|-6,63|$ & $\mid-5,12$ & $-4,97$ \\
\hline \multicolumn{19}{|c|}{$P M D$} \\
\hline Bangladesh & $\mid-3,28$ & $-2,58$ & $-2,04$ & $-2,26$ & & $-2,13$ & $-1,88$ & $-1,59$ & $-2,23$ & $-2,08 \mid$ & $|-1,82|$ & $\mid-1,61$ & $-1,79$ & $|-2,10|$ & $\mid-1,11$ & $\mid-1,13$ & $|-1,07|$ & \\
\hline Benin & & $-12,43$ & $-9,86$ & $-8,40$ & $-7,88$ & $-9,52$ & $-10,42$ & $-7,24$ & $-7,75$ & $|-8,78|$ & $|-7,25|$ & $\mid-7,81$ & $-7,96$ & $|-9,01|$ & $\mid-9,66$ & $\mid-9,98$ & $|-8,67|$ & $-6,32$ \\
\hline Gana & $-10,24$ & $-9,57$ & $-7,30$ & $-9,57$ & $-8,04$ & $-12,37$ & $-12,30$ & $-11,37$ & $-13,17$ & $|-16,34|$ & $|-10,85|$ & $\mid-6,13$ & $-4,73$ & $|-4,60|$ & $|-6,11|$ & $\mid-5,34$ & $|-4,70|$ & $-4,52$ \\
\hline Madagascar & $|-9,97|$ & $-9,24$ & $-24,11$ & $-13,11$ & $-9,74$ & $-8,41$ & $-8,28$ & $-8,64$ & $-10,13$ & $|-29,47|$ & $|-18,41|$ & $\mid-14,38$ & $-12,27$ & $|-9,00|$ & $\mid-5,25$ & $|-5,47|$ & $|-4,57|$ & $-3,91$ \\
\hline Malawi & $\mid-32,16$ & $-21,92$ & $-13,12$ & $-25,42$ & $-25,75$ & $-26,13$ & $-24,32$ & $-14,43$ & $-21,74$ & $|-19,60|$ & $|-21,12|$ & $\mid-23,48$ & $-20,51$ & $|-21,71|$ & $\mid-15,52$ & $\mid-19,18$ & $-14,46$ & $-28,47$ \\
\hline Quênia & $\mid-8,39$ & $-5,03$ & $-3,47$ & $-2,97$ & $-2,44$ & $\mid-4,08$ & $-3,67$ & $-3,02$ & $-3,55$ & $|-4,14|$ & $|-4,05|$ & $\mid-3,68$ & $-4,17$ & $|-3,81|$ & $\mid-4,80$ & $|-4,08|$ & & \\
\hline Senegal & & $-11,49$ & $-9,20$ & $-10,07$ & $-10,59$ & $-9,40$ & $-9,00$ & $-8,47$ & $-6,75$ & $\mid-13,47$ & $|-8,16|$ & $\mid-9,33$ & $-7,77$ & $|-8,01|$ & $|-8,04|$ & $\mid-7,32$ & $\mid-7,39$ & $-7,74$ \\
\hline Tanzânia & $-16,99$ & $-13,50$ & $-12,48$ & $-10,84$ & $-10,33$ & $-10,58$ & $-12,66$ & $-11,86$ & $-15,05$ & $|-14,07|$ & $|-9,04|$ & $\mid-10,13$ & $-13,30$ & $|-8,62|$ & $\mid-10,37$ & $|-9,51|$ & $|-7,26|$ & $-7,33$ \\
\hline Vietnã & & & & & & & & & & & & & $-3,34$ & $|-2,65|$ & $\mid-3,68$ & $|-2,64|$ & $\mid-2,79$ & $-2,75$ \\
\hline Zâmbia & $\mid-56,96$ & $-17,93$ & $-15,04$ & $-10,50$ & $-19,23$ & $-23,07$ & $-14,53$ & $-20,07$ & $\mid-16,28$ & $\mid-19,42$ & $|-15,22|$ & $\mid-12,66$ & $-8,05$ & $|-6,76|$ & $\mid-8,50$ & $\mid-4,85$ & $|-4,58|$ & $-3,88$ \\
\hline Zimbábue & $\mid-7,21$ & $-4,49$ & $-4,13$ & & $-3,76$ & $-2,78$ & $-2,50$ & $-3,27$ & & $\mid-3,39$ & $|-6,80|$ & $\mid-5,42$ & $-9,70$ & $|-15,42|$ & $\mid-9,32$ & $|-8,03|$ & $\mid-7,19$ & $-8,74$ \\
\hline Burkina Faso & $-22,35$ & $-17,63$ & $-16,34$ & $-16,50$ & $-15,32$ & $-8,29$ & $-15,90$ & $-15,91$ & $\mid-15,37$ & $-15,81$ & $-15,33$ & & $-16,61$ & $\mid-15,31$ & $\mid-16,56$ & $\mid-14,82$ & $\mid-12,28$ & \\
\hline Burundi & $-35,12$ & $-15,82$ & $-9,17$ & $-10,89$ & $-11,79$ & $-15,74$ & $-24,29$ & $-26,10$ & $-29,60$ & $\mid-40,78$ & $|-39,15|$ & $\mid-42,51$ & $-41,55$ & $|-40,75|$ & $|-43,63|$ & $|-47,10|$ & $|-38,63|$ & 34,95 \\
\hline
\end{tabular}




\begin{tabular}{|c|c|c|c|c|c|c|c|c|c|c|c|c|c|c|c|c|c|c|}
\hline Camboja & & & & & & & & & & $\mid-10,65$ & $-10,07$ & $-8,90$ & $-9,54$ & $-9,39$ & $-9,27$ & $\mid-8,62$ & $\mid-8,19$ & $-7,81$ \\
\hline R. Centro-Africana & $-16,75$ & $-19,26$ & $-10,77$ & $\mid-14,26$ & $-13,53$ & $-8,87$ & $\mid-9,44$ & $-6,77$ & $\mid-5,46$ & $-10,02$ & $-7,87 \mid$ & $\mid-11,12$ & $-12,80$ & $-17,53$ & $\mid-16,48$ & $-17,45$ & $-15,95$ & $-13,64$ \\
\hline Gâmbia & & $-11,18$ & $-12,28$ & $\mid-12,02$ & $-9,69$ & $-14,05$ & $-14,56$ & $-17,66$ & $-13,85$ & $-11,73$ & $-11,43$ & $-13,56$ & $-15,75$ & $-13,81$ & $-17,97$ & $-15,59$ & $-17,37$ & $-17,49$ \\
\hline Guiné & $-25,15$ & $-18,46$ & $-24,58$ & $-21,96$ & $-14,08$ & $-9,14$ & $-17,44$ & $-13,86$ & $\mid-12,07$ & $-11,84$ & $-8,02$ & $-6,50$ & $-7,93$ & $|-10,25|$ & $-6,74$ & $-6,89$ & $\mid-5,92$ & $-9,69$ \\
\hline Guiné-Bissau & $-26,35$ & & & & & & $\mid-19,63$ & $\mid-17,96$ & $|-37,90|$ & & & & & & & & & \\
\hline Quirguistão & & & & $\mid-18,43$ & $\mid-19,83$ & $-14,71$ & $\mid-13,18$ & $-12,78$ & $\mid-11,23$ & $-13,09$ & $-13,02 \mid$ & $-14,53$ & $-10,71$ & $\mid-12,24$ & $-10,75$ & $-12,84$ & $-15,95$ & $-14,64$ \\
\hline Mali & & $-18,86$ & $-17,27$ & $\mid-13,18$ & $-12,87$ & $\mid-11,72$ & $\mid-12,97$ & $-14,26$ & $\mid-15,05$ & $-14,21$ & $-15,91 \mid$ & $\mid-17,55$ & $-18,13$ & $\mid-15,50$ & & $\mid-16,29$ & $-17,44$ & $-14,10$ \\
\hline Moçambique & $-50,76$ & $-34,43$ & $-35,61$ & & $\mid-25,63$ & $|-29,87|$ & $\mid-28,15$ & $-57,95$ & $\mid-21,85$ & $-21,89$ & $|-20,44|$ & $-22,55$ & $-20,82$ & $|-20,81|$ & $|-20,48|$ & $\mid-18,45$ & $\mid-17,30$ & $-16,58$ \\
\hline Nepal & & & & & & & & & & & & & & & $-9,42$ & $\mid-8,46$ & $-8,30$ & $-7,02$ \\
\hline Níger & & $-13,52$ & $-19,00$ & $\mid-15,21$ & $\mid-9,89$ & $\mid-11,93$ & $\mid-14,42$ & $\mid-15,22$ & $\mid-19,93$ & $\mid-20,56$ & $|-18,40|$ & $-17,64$ & $-15,73$ & $\mid-15,11$ & $\mid-11,93$ & $\mid-17,59$ & $-14,15$ & $-18,12$ \\
\hline Ruanda & & $-53,88$ & $-25,82$ & $-34,61$ & $\mid-33,51$ & & $\mid-25,42$ & $-25,22$ & $\mid-20,13$ & $-24,66$ & $-26,40 \mid$ & $\mid-24,36$ & $-25,14$ & $-28,02$ & $-27,24$ & $-28,14$ & $-30,15$ & $-19,69$ \\
\hline Togo & $-15,53$ & $-11,13$ & $-8,50$ & $-9,43$ & $\mid-5,05$ & $\mid-5,53$ & $\mid-3,86$ & $|-4,17|$ & $\mid-3,31$ & $|-3,87|$ & $|-4,70|$ & & $\mid-5,75$ & $\mid-14,16$ & $\mid-22,30$ & $\mid-16,91$ & $\mid-20,38$ & $-8,86$ \\
\hline Uganda & $-23,19$ & $-17,67$ & $-21,97$ & $\mid-17,08$ & $\mid-14,43$ & $\mid-20,79$ & $\mid-19,56$ & $\mid-15,09$ & $\mid-16,84$ & $|-17,54|$ & $|-15,80|$ & $-18,20$ & $-17,08$ & $\mid-14,19$ & $\mid-14,95$ & $\mid-13,34$ & $-10,73$ & 10,89 \\
\hline PMD Médio & $-22,53$ & $-16,19$ & $-14,38$ & $\mid-13,84$ & $\mid-13,49$ & $\mid-12,34$ & $\mid-13,84$ & $|-14,47|$ & $\mid-14,51$ & $|-15,10|$ & $|-13,45|$ & $-13,91$ & $-12,96$ & $\mid-13,28$ & $\mid-12,92$ & $\mid-12,80$ & $\mid-12,31$ & $-12,14$ \\
\hline
\end{tabular}

Fonte: Elaboração própria. 
Quadro A4-2.2: PREF no período 1995-2012

\begin{tabular}{|c|c|c|c|c|c|c|c|c|c|c|c|c|c|c|c|c|c|c|}
\hline MEMBRO & 1995 & 1996 & 1997 & 1998 & 1999 & 2000 & 2001 & 2002 & 2003 & 2004 & 2005 & 2006 & \begin{tabular}{|l|l}
2007 \\
\end{tabular} & 2008 & 2009 & 2010 & 2011 & 2012 \\
\hline \multicolumn{19}{|c|}{ PAISES DESENVOLVIDOS } \\
\hline PD Médio & $-3,53$ & $-3,73$ & $-3,56$ & $-3,48$ & \begin{tabular}{|l|}
$-3,93$ \\
\end{tabular} & \begin{tabular}{|l|}
$-4,02$ \\
\end{tabular} & $-4,16$ & $-4,93$ & $-5,29$ & $-5,89$ & \begin{tabular}{|l|}
$-6,66$ \\
\end{tabular} & $-7,40$ & \begin{tabular}{|l||}
$-11,59$ \\
\end{tabular} & $\mid-11,86$ & $-11,83$ & \begin{tabular}{|l|}
$-12,65$ \\
\end{tabular} & $-11,97$ & \begin{tabular}{|l|}
$-13,88$ \\
\end{tabular} \\
\hline & & & & & & & & & & & & & & & & & & \\
\hline União Europeia & \begin{tabular}{|c|}
$-0,08$ \\
\end{tabular} & $-0,11$ & $-0,12$ & $-0,12$ & \begin{tabular}{|l|}
$-0,12$ \\
\end{tabular} & \begin{tabular}{|l|}
$-0,10$ \\
\end{tabular} & $-0,11$ & $-0,14$ & $-0,19$ & $\mid-0,15$ & \begin{tabular}{|c|}
$-0,15$ \\
\end{tabular} & \begin{tabular}{|l|}
$-0,15$ \\
\end{tabular} & \begin{tabular}{|l|l|}
$-6,30$ \\
\end{tabular} & $-7,15$ & $-6,52$ & \begin{tabular}{|l|}
$-7,22$ \\
\end{tabular} & \begin{tabular}{|l|l|}
$-7,67$ \\
\end{tabular} & \begin{tabular}{|l|}
$-9,16$ \\
\end{tabular} \\
\hline Estados Unidos & $|-11,15|$ & $-11,63$ & $-12,39$ & $-12,88$ & $\mid-13,61$ & \begin{tabular}{|c|}
$-14,92$ \\
\end{tabular} & $-15,42$ & $-16,69$ & $-17,82$ & $-19,34$ & \begin{tabular}{|c|}
$-21,07$ \\
\end{tabular} & $-22,25$ & $\mid-22,35$ & $\mid-22,39$ & $-21,96$ & \begin{tabular}{|l|}
$-23,74$ \\
\end{tabular} & $-24,30$ & \begin{tabular}{|l|}
$-25,26$ \\
\end{tabular} \\
\hline UE / EUA Média & $-2,65$ & $-2,79$ & $-2,97$ & $-3,05$ & $\mid-3,26$ & $-3,50$ & $-3,38$ & $-3,71$ & $-4,15$ & $-4,66$ & $-5,16$ & $-5,43$ & $\mid-10,18$ & $-10,95$ & $-10,21$ & $-11,31$ & $-11,88$ & $-13,25$ \\
\hline \multicolumn{19}{|c|}{ OUTROS DESENVOLVIDOS } \\
\hline Arábia Saudita & & & & & & & & & & & $-5,10$ & $-5,46$ & \begin{tabular}{|l|}
$-6,48$ \\
\end{tabular} & $-4,70$ & $-4,25$ & 0,00 & 0,00 & $-11,66$ \\
\hline Austrália & 0,00 & $-5,53$ & $-5,81$ & $-5,48$ & $-6,01$ & $-6,18$ & $-5,39$ & $-6,56$ & $-8,54$ & $-11,65$ & $-12,82$ & $-13,69$ & $-16,11$ & $-18,95$ & $-16,00$ & $-22,07$ & $-25,30$ & 0,00 \\
\hline Bahrein & 0,00 & 0,00 & & & & 0,00 & 0,00 & 0,00 & 0,00 & 0,000 & $-5,00$ & $\begin{array}{ll}-3,57 \\
\end{array}$ & $\mid-4,91$ & \begin{tabular}{|c||}
$-10,58$ \\
\end{tabular} & \begin{tabular}{ll|}
$-8,21$ \\
\end{tabular} & 0,00 & $\begin{array}{ll}-0,18 \\
\end{array}$ & $\mid-0,18$ \\
\hline Barbados & 0,00 & $-3,03$ & 0,00 & 0,00 & $-4,37$ & $-4,57$ & $-4,35$ & $-4,80$ & $-4,86$ & $-4,81$ & 0,00 & $-1,72$ & \begin{tabular}{|l|}
$-5,76$ \\
\end{tabular} & 0,00 & 0,00 & 0,00 & 0,00 & 0,00 \\
\hline Canada & $-2,72$ & $-2,71$ & $-2,92$ & $-2,77$ & $-2,87$ & $-3,23$ & $-3,22$ & $-3,55$ & $-4,50$ & $-5,58$ & $-6,83$ & $-8,26$ & \begin{tabular}{|l|l|}
$-9,38$ \\
\end{tabular} & $-9,96$ & $-10,21$ & $-12,67$ & $-13,80$ & $-13,82$ \\
\hline Cingapura & $\mid-14,45$ & 0,00 & 0,00 & 0,00 & 0,00 & 0,00 & $-11,55$ & $-11,92$ & $-13,44$ & 0,00 & $-15,21$ & $-16,34$ & \begin{tabular}{|l||}
$-17,44$ \\
\end{tabular} & $\mid-17,85$ & \begin{tabular}{|l|}
$-16,99$ \\
\end{tabular} & \begin{tabular}{|l|}
$-18,60$ \\
\end{tabular} & 0,00 & $-20,71$ \\
\hline Coréia do Sul & 0,00 & \begin{tabular}{ll|}
$-8,17$ \\
\end{tabular} & 0,00 & 0,00 & $-6,02$ & 0,00 & 0,00 & $-8,00$ & 0,00 & |-9,75 & 0,00 & $-13,08$ & |-14,34| & 0,00 & $-10,59$ & $-12,52$ & 0,00 & 0,00 \\
\hline Croácia & & & & & & 0,00 & 0,00 & $-2,24$ & $-2,97$ & $-4,06$ & $-5,01$ & $-5,65$ & \begin{tabular}{|l|}
$-7,43$ \\
\end{tabular} & $-9,15$ & $-8,11$ & $-8,65$ & $-8,45$ & $-12,17$ \\
\hline \multicolumn{19}{|l|}{ Hong Kong } \\
\hline Islândia & 0,00 & 0,00 & 0,00 & 0,00 & 0,00 & 0,00 & $-2,01$ & 0,00 & $-2,44$ & 0,00 & 0,00 & $-3,93$ & $-4,11$ & $-4,51$ & $-3,32$ & $-4,85$ & $-4,66$ & $-5,21$ \\
\hline Israel & 0,00 & 0,00 & 0,00 & 0,00 & 0,00 & 0,00 & 0,00 & 0,00 & 0,00 & $-5,80$ & $-6,55$ & $-7,00$ & \begin{tabular}{|l||}
$-8,26$ \\
\end{tabular} & $-9,99$ & $-8,57$ & 0,00 & 0,00 & $-10,25$ \\
\hline Japão & $-14,61$ & $-12,88$ & $-11,76$ & $-10,28$ & $-12,28$ & $-13,97$ & $-13,48$ & $\begin{array}{l}-13,09 \\
\end{array}$ & $-14,47$ & $-15,58$ & $-15,50$ & $-14,85$ & $-14,65$ & $-16,47$ & $\begin{array}{l}-19,09 \\
\end{array}$ & $-20,27$ & $-23,18$ & $-24,73$ \\
\hline Kuwait & 0,00 & 0,00 & 0,00 & 0,00 & 0,00 & 0,00 & 0,00 & 0,00 & 0,000 & 0,00 & & $-5,30$ & \begin{tabular}{|l||}
$-0,05$ \\
\end{tabular} & $-4,61$ & & & & \\
\hline Nova Zelândia & 0,00 & $-3,64$ & $-3,80$ & $-3,23$ & $\begin{array}{l}-3,69 \\
\end{array}$ & $\begin{array}{l}-3,55 \\
\end{array}$ & 0,00 & \begin{tabular}{l|l}
$-4,28$ \\
\end{tabular} & \begin{tabular}{ll|}
$-5,69$ \\
\end{tabular} & $\begin{array}{l}-7,00 \\
\end{array}$ & $-8,82$ & $\begin{array}{ll}-8,79 \\
\end{array}$ & -10,88 & $-12,21 \mid$ & $-10,30$ & $-12,09$ & 0,00 & 0,00 \\
\hline Noruega & $-1,84$ & $-1,36$ & 0,00 & $-1,44$ & 0,00 & $-1,40$ & $-1,33$ & \begin{tabular}{|l|}
$-1,96$ \\
\end{tabular} & $-2,15$ & 0,00 & 0,00 & $-3,40$ & \begin{tabular}{|l||}
$-4,15$ \\
\end{tabular} & $-4,97$ & $-4,71$ & \begin{tabular}{|l|}
$-5,53$ \\
\end{tabular} & $-6,56$ & $-7,19$ \\
\hline 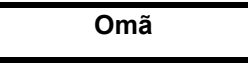 & & & & & & 0,00 & 0,00 & 0,00 & 0,00 & 0,00 & $\begin{array}{l}-4,45 \\
\end{array}$ & $-6,21$ & \begin{tabular}{|l||}
$-8,49$ \\
\end{tabular} & $\begin{array}{l}-0,16 \\
\end{array}$ & $-11,03$ & \begin{tabular}{|l|}
0,00 \\
\end{tabular} & 0,00 & 0,00 \\
\hline Suiçaa & 296,46 & $-247,14$ & $-219,09$ & $-230,03$ & $-211,76$ & $-219,78$ & $-210,99$ & $-247,64$ & $-274,62$ & $-317,12$ & $-341,51$ & $-364,88$ & $-366,94$ & $-391,76$ & $-399,91$ & $-414,81$ & $-507,24$ & 0,00 \\
\hline Taiwan & & & & & & & & $-10,43$ & $-11,02$ & 0,00 & $-11,82$ & $-12,67$ & $-12,65$ & $-13,32$ & $-13,09$ & $-14,52$ & $-15,92$ & $-15,63$ \\
\hline Trinidad e Tobago & 0,00 & $-9,90$ & 0,00 & 0,00 & \begin{tabular}{|l|}
$-8,81$ \\
\end{tabular} & 0,00 & $-11,81$ & $\begin{array}{l}0,00 \\
\end{array}$ & 0,00 & $0,0,00$ & 0,00 & $-15,20$ & -20,39 & $-22,09$ & 0,00 & 0,00 & & \\
\hline Catar & & & & & 0,00 & 0,00 & 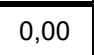 & 0 & 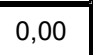 & $0,0,00$ & $-4,35$ & $\begin{array}{l}-5,47 \\
\end{array}$ & \begin{tabular}{l|l}
$-0,38$ \\
\end{tabular} & $\begin{array}{l}-4,84 \\
\end{array}$ & \begin{tabular}{l|l|}
$-5,04$ \\
\end{tabular} & 0,00 & 0,00 & $\mid-2,18$ \\
\hline
\end{tabular}




\begin{tabular}{|c|c|c|c|c|c|c|c|c|c|c|c|c|c|c|c|c|c|c|}
\hline Macau & & & & & & & & & & & & & & & & & & \\
\hline Outros PD Médio & 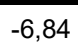 & 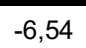 & \begin{tabular}{|c|c|}
$-5,07$ \\
\end{tabular} & \begin{tabular}{c|}
$-4,45$ \\
\end{tabular} & 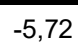 & 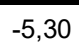 & 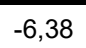 & \begin{tabular}{|l|l|}
$-7,73$ \\
\end{tabular} & $\frac{2-7,62}{2}$ & 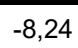 & $-9,55$ & $-111,50$ & $\mid-12,87$ & $-11,64$ & \begin{tabular}{|l|l|}
$-13,62$ \\
\end{tabular} & \begin{tabular}{|c|}
$-13,44$ \\
\end{tabular} & 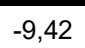 & $-12,42$ \\
\hline \multicolumn{19}{|c|}{ EM DESENVOLVIMENTO } \\
\hline PED Médio & 10,67 & 15,99 & 15,85 & 12,92 & 14,92 & 10,68 & 12,25 & 10,92 & 10,69 & 8,88 & 8,54 & 7,49 & 12,07 & 20,85 & 18,63 & 16,54 & 19,42 & 17,66 \\
\hline \multicolumn{19}{|c|}{ Renda Média-Alta } \\
\hline África do Sul & 5,41 & 6,65 & 5,25 & 5,72 & 6,90 & 6,49 & 5,83 & 6,71 & 6,62 & 6,49 & 5,78 & 5,56 & 11,81 & 9,93 & 12,39 & 9,10 & 5,51 & 5,47 \\
\hline Antigua e Barbuda & & & & & 2,25 & 3,57 & & & & & 0,90 & 0,27 & 23,19 & & 4,64 & 28,82 & 44,30 & 34,52 \\
\hline Argentina & 6,49 & 7,00 & 5,26 & 5,64 & 7,78 & 7,05 & 6,93 & 4,41 & 3,86 & 4,34 & 4,64 & 4,13 & 9,82 & 9,50 & 10,98 & 8,98 & 8,13 & 9,18 \\
\hline Brasil & 18,96 & 21,68 & 17,89 & 18,27 & 17,22 & 16,03 & 12,77 & 13,81 & 12,12 & 11,18 & 11,76 & 12,35 & 22,32 & 19,56 & 22,27 & 20,20 & 17,07 & 17,37 \\
\hline Chile & 6,57 & 7,96 & 6,35 & 6,68 & 7,85 & 6,78 & 6,12 & 7,21 & 5,67 & 5,73 & 4,95 & 5,59 & 7,99 & 6,79 & 7,49 & 7,02 & 6,30 & 6,31 \\
\hline Colômbia & 12,92 & 14,07 & 13,69 & 13,99 & 16,75 & 17,60 & 15,61 & 16,40 & 14,78 & 13,83 & 14,00 & 12,67 & 16,26 & 15,85 & \begin{tabular}{|l|}
16,01 \\
\end{tabular} & 17,68 & 15,72 & 16,14 \\
\hline Costa Rica & 10,48 & 10,20 & 8,16 & 6,39 & 7,19 & 7,82 & 8,35 & \begin{tabular}{|l|}
8,21 \\
\end{tabular} & 7,37 & 6,86 & 5,78 & 6,60 & 10,25 & 10,16 & 14,50 & 24,86 & 23,91 & 25,49 \\
\hline Cuba & & & & & 6,65 & 6,50 & 6,27 & \begin{tabular}{|l|}
8,34 \\
\end{tabular} & 7,43 & 3,87 & 0,96 & 0,94 & & & & & & \\
\hline Dominica & 1,89 & 5,62 & 1,59 & & 3,91 & 2,16 & 2,88 & 2,14 & 4,96 & 3,35 & 2,09 & 3,22 & 8,98 & 13,32 & 18,62 & 5,68 & & 8,53 \\
\hline Granada & & 3,14 & 2,80 & 2,80 & 4,57 & 3,25 & 3,37 & \begin{tabular}{|l|}
3,21 \\
\end{tabular} & 3,48 & 3,25 & 2,88 & 4,50 & \begin{tabular}{|l|}
5,56 \\
\end{tabular} & 9,26 & \begin{tabular}{|l|}
4,86 \\
\end{tabular} & & & \\
\hline Jamaica & 7,77 & 9,04 & 7,75 & & & & & \begin{tabular}{|l|}
8,89 \\
\end{tabular} & 8,10 & 5,04 & 5,50 & 5,46 & \begin{tabular}{|l|}
8,64 \\
\end{tabular} & 7,52 & 9,17 & 7,81 & 9,63 & 6,73 \\
\hline Malásia & 3,41 & 2,41 & 2,26 & 2,04 & 2,18 & 2,11 & 3,28 & \begin{tabular}{|l|l|}
3,44 & \\
\end{tabular} & 3,21 & 2,08 & 2,98 & 2,99 & \begin{tabular}{|l|}
3,17 \\
\end{tabular} & 2,89 & \begin{tabular}{|l|l|}
3,43 \\
\end{tabular} & 4,23 & 2,70 & 3,80 \\
\hline Maurício & 3,55 & 4,58 & 3,35 & 1,69 & 2,75 & 2,03 & 1,07 & \begin{tabular}{|l|}
0,58 \\
\end{tabular} & 2,43 & 2,39 & 1,11 & 0,65 & 4,71 & 4,43 & 4,46 & 10,02 & 2,64 & 1,55 \\
\hline México & 17,96 & 16,15 & 16,73 & 16,30 & 16,50 & 16,17 & 17,90 & \begin{tabular}{|l|}
18,19 \\
\end{tabular} & 17,21 & 16,19 & 15,58 & 15,10 & \begin{tabular}{|l|l|}
15,74 \\
\end{tabular} & 14,88 & \begin{tabular}{|l|}
15,81 \\
\end{tabular} & 14,96 & 13,97 & 13,39 \\
\hline Namíbia & & & & & & 0,94 & 0,37 & \begin{tabular}{|l|}
0,97 \\
\end{tabular} & 1,37 & 1,09 & 0,54 & 0,97 & \begin{tabular}{|l|}
3,95 \\
\end{tabular} & 1,78 & \begin{tabular}{|l|}
1,38 \\
\end{tabular} & 1,97 & 2,37 & 1,70 \\
\hline Panamá & & & 4,05 & 4,37 & 5,45 & 4,33 & 5,34 & 6,12 & 5,89 & 6,32 & 3,38 & 0,66 & 0,99 & 0,83 & 1,57 & 1,44 & 0,49 & 10,01 \\
\hline Peru & 10,31 & 11,19 & \begin{tabular}{|l|l|}
11,04 \\
\end{tabular} & 13,43 & 12,53 & 11,12 & 11,04 & 11,40 & 10,10 & 10,15 & 9,21 & 8,62 & \begin{tabular}{|l|}
11,17 \\
\end{tabular} & 9,34 & \begin{tabular}{|l|}
11,52 \\
\end{tabular} & 10,77 & 8,79 & 8,82 \\
\hline R. Dominicana & 0,00 & 12,43 & 12,29 & & & & 70,40 & 11,30 & 9,61 & 9,63 & 11,78 & 11,68 & 13,45 & 13,62 & \begin{tabular}{|l|}
19,69 \\
\end{tabular} & 18,74 & 15,36 & 13,66 \\
\hline Rússia & & & & & & & & & & & & & & & & & & 10,82 \\
\hline St. Kitts e Nevis & & 11,38 & 8,57 & & 13,95 & 12,61 & 16,72 & 15,88 & 13,73 & 13,34 & 17,15 & 16,58 & 20,62 & 12,96 & 18,49 & 22,56 & 16,75 & \\
\hline St. Lúcia & 1,86 & 2,67 & 4,44 & 3,45 & 4,23 & 6,21 & 8,17 & 3,93 & 2,56 & 2,15 & 3,73 & 3,83 & 20,67 & 3,26 & & & & \\
\hline St. Vincente e Granadinas & 5,64 & 5,39 & 3,55 & 2,44 & 6,32 & 3,30 & 9,15 & 7,77 & 4,18 & 2,70 & 5,03 & 4,71 & 33,33 & 44,83 & 43,90 & 24,67 & 10,82 & 5,75 \\
\hline Suriname & 11,26 & 13,50 & 6,15 & 8,60 & 11,85 & 11,12 & 11,54 & 11,20 & 8,05 & 4,49 & 5,10 & & & & & & & \\
\hline Turquia & 2,78 & 2,43 & 2,02 & 3,09 & 3,94 & 3,93 & 2,82 & 3,57 & 3,47 & 3,46 & 4,01 & 2,85 & 14,40 & 12,44 & 13,43 & 11,08 & 9,04 & 9,75 \\
\hline
\end{tabular}




\begin{tabular}{|c|c|c|c|c|c|c|c|c|c|c|c|c|c|c|c|c|c|c|}
\hline Uruguai & 2,91 & 3,22 & 3,20 & 3,77 & 4,60 & 5,81 & 5,40 & 4,29 & 4,18 & 4,86 & 5,37 & 3,68 & 7,54 & 6,13 & 6,59 & 6,61 & 5,69 & 5,04 \\
\hline Venezuela & 12,15 & 11,12 & 13,14 & 14,56 & 15,66 & 14,00 & 16,60 & 14,40 & 14,91 & 12,50 & 11,20 & 11,23 & 12,51 & 15,28 & 17,16 & 13,63 & 11,02 & 10,30 \\
\hline Albânia & & & & & & 0,57 & 0,54 & 0,51 & 0,78 & 0,46 & 1,07 & 0,62 & \begin{tabular}{|l|}
9,57 \\
\end{tabular} & 8,81 & \begin{tabular}{|l|}
10,33 \\
\end{tabular} & 9,32 & 7,67 & \begin{tabular}{|l|l|}
8,76 \\
\end{tabular} \\
\hline Botswana & 0,00 & 0,00 & 0,00 & 0,00 & 0,00 & 0,40 & $-0,38$ & $-0,30$ & 0,64 & $-0,32$ & $-0,13$ & 1,09 & 3,64 & 2,59 & 2,66 & 3,70 & 7,54 & 6,92 \\
\hline Gabão & & 7,49 & 9,48 & 5,75 & \begin{tabular}{|l|}
8,72 \\
\end{tabular} & 8,88 & 8,70 & 9,14 & 88,91 & 11,77 & 7,22 & 3,53 & \begin{tabular}{|l|}
7,64 \\
\end{tabular} & 6,32 & 6,01 & & & \\
\hline Jordânia & & & & & & 1,21 & 1,11 & 1,62 & 2,58 & 2,86 & 2,85 & 2,83 & 2,97 & 2,21 & 2,91 & 1,78 & 1,64 & 3,28 \\
\hline Maldivas & & & & & & & 15,02 & 15,65 & 10,39 & 5,59 & 1,65 & 1,73 & 4,00 & 4,15 & 6,66 & 4,80 & 6,63 & 4,91 \\
\hline Montenegro & & & & & & & & & & & & & & & & & & 8,23 \\
\hline Tonga & & & & & & & & & & & & & 26,26 & 16,74 & 12,21 & 11,77 & 4,81 & 3,71 \\
\hline Tunísia & 0,23 & 0,35 & 0,30 & 0,34 & 0,36 & 0,42 & 0,39 & 0,39 & 0,45 & 0,45 & 0,52 & 0,76 & \begin{tabular}{|l|}
8,32 \\
\end{tabular} & 6,78 & 8,59 & 7,68 & 7,63 & 7,29 \\
\hline Macedônia & & & & & & & & & 2,13 & 1,96 & 1,68 & 1,89 & \begin{tabular}{|l|}
7,98 \\
\end{tabular} & 8,78 & \begin{tabular}{|l|}
8,02 \\
\end{tabular} & 7,52 & 6,35 & 6,30 \\
\hline PEDma Médio & 8,79 & 10,41 & 9,20 & 9,87 & 11,50 & 10,05 & 12,91 & 9,40 & 12,47 & 7,36 & 7,22 & 6,85 & 16,33 & 13,89 & \begin{tabular}{|l|}
15,47 \\
\end{tabular} & 15,16 & 13,79 & 13,50 \\
\hline \multicolumn{19}{|c|}{ Renda Média-Baixa } \\
\hline Armênia & & & & & & & & & 1,00 & 2,66 & 2,31 & 1,96 & 8,59 & 8,46 & 8,64 & 6,90 & 6,59 & 4,39 \\
\hline Belize & 5,30 & 7,12 & 6,90 & 7,05 & $\mid 10,07$ & 5,85 & 7,07 & 5,10 & 4,89 & 5,72 & 4,78 & 5,28 & 8,29 & 8,64 & 8,72 & 8,69 & 6,93 & 8,93 \\
\hline Bolivia & 4,97 & 5,83 & 4,02 & 3,56 & \begin{tabular}{|l|}
4,16 \\
\end{tabular} & 3,65 & 3,47 & 3,28 & 2,97 & 3,22 & 2,16 & 2,43 & 3,19 & 2,10 & 3,13 & 3,40 & 2,67 & 2,65 \\
\hline Camarões & 1,96 & 1,76 & 1,52 & & & 2,82 & 1,68 & 2,81 & 2,74 & 6,40 & 1,91 & 4,83 & 20,69 & 38,59 & 43,00 & 19,17 & 34,98 & 15,79 \\
\hline China & & & & & & & 7,57 & 7,84 & 6,04 & 5,44 & 5,10 & 5,09 & 7,37 & 7,07 & 9,49 & 7,73 & 6,30 & 7,05 \\
\hline Costa do Marfim & 1,33 & 1,88 & 1,49 & 1,96 & 1,63 & 2,04 & 1,81 & 1,46 & 1,98 & 1,64 & 2,14 & 1,06 & 6,17 & 6,72 & 5,40 & 5,92 & 5,99 & 5,37 \\
\hline Egito & 4,68 & 5,67 & 1,94 & 5,96 & 10,30 & 6,80 & 6,65 & 4,68 & 6,09 & 5,46 & 6,03 & 5,70 & 14,73 & 8,57 & 9,08 & 10,77 & 11,60 & 14,77 \\
\hline El Salvador & 15,25 & 20,38 & 19,78 & 19,56 & 23,21 & 10,23 & 10,14 & 10,01 & 9,53 & 8,84 & 8,66 & 7,29 & 8,06 & 7,51 & 9,07 & 8,42 & 7,89 & 8,10 \\
\hline Equador & & 13,50 & 13,35 & 13,14 & 12,76 & 10,22 & 11,39 & 12,57 & 12,03 & 14,22 & 11,82 & 10,44 & 11,00 & 10,23 & 12,09 & 10,50 & 9,78 & 9,85 \\
\hline Fiji & & & & & & 6,10 & 5,51 & 5,52 & 6,09 & 6,79 & 5,14 & 4,93 & 6,30 & 4,79 & 7,03 & 4,90 & 3,52 & 2,56 \\
\hline Filipinas & 7,40 & 7,69 & 6,04 & 5,97 & 6,03 & 5,66 & 6,69 & 6,44 & 5,79 & 5,13 & 5,75 & 6,07 & 8,01 & 7,98 & 10,93 & 10,10 & 8,09 & 9,66 \\
\hline Guatemala & 20,77 & 24,05 & 23,73 & 21,24 & 23,56 & 22,87 & 17,42 & 22,17 & 19,43 & 18,08 & 10,33 & 17,63 & 9,03 & 9,73 & 10,89 & 8,84 & 8,94 & 10,39 \\
\hline Guiana & & & 2,60 & 2,91 & 3,16 & 2,85 & 3,26 & 3,31 & 3,29 & 2,83 & 2,51 & 4,37 & 6,28 & 6,66 & 7,19 & 7,02 & 7,24 & 5,93 \\
\hline Honduras & 28,55 & 16,06 & 18,39 & 18,41 & 26,48 & 25,86 & 21,85 & 30,80 & 29,45 & 24,27 & 22,66 & 16,04 & 15,03 & & 17,17 & 14,93 & 14,20 & 11,21 \\
\hline Índia & 15,09 & 16,46 & 15,41 & 16,12 & 16,22 & 14,75 & 13,38 & 13,09 & 11,73 & 8,85 & 10,06 & 8,19 & 14,46 & 11,01 & 11,64 & 9,42 & 6,31 & 7,42 \\
\hline Indonésia & 9,29 & 11,60 & 9,04 & 5,13 & 9,81 & 6,89 & 7,22 & 9,47 & 11,93 & 9,33 & 9,01 & 11,46 & 13,53 & 11,44 & 14,56 & 12,35 & 6,63 & 10,15 \\
\hline
\end{tabular}




\begin{tabular}{|c|c|c|c|c|c|c|c|c|c|c|c|c|c|c|c|c|c|c|}
\hline Moldávia & & & & & & & 1,15 & 0,90 & 0,66 & 0,59 & 0,56 & 0,54 & 5,31 & 4,89 & 5,31 & 4,00 & 4,18 & 4,03 \\
\hline Nicarágua & 12,46 & 12,08 & 12,46 & 16,04 & 16,92 & 17,28 & 21,79 & \begin{tabular}{|l|}
20,09 \\
\end{tabular} & 22,21 & 21,24 & 20,57 & 28,28 & 19,87 & 9,63 & \begin{tabular}{|l|}
18,33 \\
\end{tabular} & \begin{tabular}{|l|}
14,56 \\
\end{tabular} & 14,01 & 7,14 \\
\hline Nigéria & & 11,34 & 8,94 & 11,23 & 6,17 & 6,20 & 6,70 & \begin{tabular}{|l|}
6,34 \\
\end{tabular} & 6,90 & & & 8,43 & 14,31 & 12,22 & 11,65 & 14,69 & 11,23 & 10,83 \\
\hline Paquistão & 3,54 & 4,86 & 4,67 & 4,47 & 6,39 & 8,07 & 6,47 & \begin{tabular}{|l|}
7,31 \\
\end{tabular} & 8,35 & 10,12 & 7,96 & 8,26 & 17,59 & 15,91 & \begin{tabular}{|l|l|}
19,04 \\
\end{tabular} & 14,45 & 13,68 & 16,38 \\
\hline Paraguai & 0,91 & 1,47 & 1,39 & 1,00 & 1,08 & 0,92 & 0,80 & \begin{tabular}{|l|}
0,92 \\
\end{tabular} & 0,86 & 0,80 & 1,02 & 0,70 & 2,78 & 2,21 & 2,47 & 2,07 & 2,33 & 2,19 \\
\hline Sri Lanka & & & & & 6,46 & 5,47 & 6,51 & 6,53 & 6,55 & 5,85 & 6,28 & 6,01 & 10,95 & 12,02 & 15,08 & \begin{tabular}{|l|l|}
13,65 \\
\end{tabular} & 10,80 & 11,71 \\
\hline Swazilândia & & & & & & 0,49 & 0,22 & 1,04 & 0,72 & 0,85 & 1,18 & 0,79 & 3,05 & & & & & \\
\hline Tailândia & 5,45 & 5,33 & 4,44 & 4,53 & \begin{tabular}{|l|}
4,77 \\
\end{tabular} & 3,57 & 4,14 & \begin{tabular}{|l|}
4,66 \\
\end{tabular} & 3,94 & 3,30 & 3,32 & 3,34 & 3,93 & 3,29 & 3,96 & 3,83 & 2,69 & 2,91 \\
\hline Ucrânia & & & & & & & & & & & & & 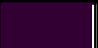 & 607,59 & 366,17 & 319,48 & 541,83 & 475,66 \\
\hline Cabo Verde & & & & & & & & & & & & & & 2,52 & 2,74 & 2,64 & 2,38 & \\
\hline Congo & & & & & & & & & & & & & 5,21 & 6,03 & 4,49 & 5,88 & 2,97 & 4,38 \\
\hline Georgia & & & & & & 1,81 & 2,60 & \begin{tabular}{|l|}
2,48 \\
\end{tabular} & 2,28 & 2,50 & 4,05 & 2,63 & 8,26 & 9,50 & \begin{tabular}{|l|l|}
9,84 \\
\end{tabular} & 7,69 & 5,63 & 4,93 \\
\hline Lesoto & & & & & & 2,65 & 4,32 & 4,61 & 4,47 & 2,38 & & & & 14,85 & 3,66 & 6,28 & 6,21 & 5,54 \\
\hline Mauritânia & 5,62 & 6,18 & & & & 3,32 & 1,84 & 2,30 & 3,99 & 2,86 & 2,09 & 1,75 & 6,65 & 6,08 & 6,30 & 11,65 & 4,22 & 2,60 \\
\hline Mongólia & & & 3,45 & 2,88 & 2,10 & 2,39 & 3,20 & & 2,90 & 2,76 & 2,25 & 1,77 & 1,87 & & & & & \\
\hline Marrocos & 2,98 & 3,94 & 3,42 & 2,41 & 2,69 & 2,61 & 2,52 & \begin{tabular}{|l|}
2,64 \\
\end{tabular} & 2,33 & 1,79 & 1,78 & 1,81 & 11,27 & 8,47 & \begin{tabular}{|l|}
10,72 \\
\end{tabular} & 8,84 & 7,53 & 7,31 \\
\hline Papua Nova Guiné & & & & 3,66 & & 4,52 & 4,78 & 5,83 & 5,09 & 4,42 & & & & & & & & \\
\hline Samoa & & & & & & & & & & & & & & & & & & 0,35 \\
\hline Ilhas Salomão & & & & & & & & \begin{tabular}{|l|}
16,86 \\
\end{tabular} & 7,91 & \begin{tabular}{|l|}
9,27 \\
\end{tabular} & 4,06 & 5,45 & 4,86 & 2,85 & 2,75 & 2,49 & 2,63 & 1,49 \\
\hline PEDmb Médio & 8,05 & 9,08 & 9,35 & 8,92 & 10,93 & 8,66 & 8,86 & 9,74 & 8,35 & 7,40 & 6,68 & 6,72 & 9,89 & 34,28 & 27,43 & 24,51 & 33,53 & 29,61 \\
\hline \multicolumn{19}{|c|}{ PMD } \\
\hline Bangladesh & 34,64 & 38,82 & 38,74 & 32,08 & & 36,46 & 35,45 & 37,68 & 40,21 & 38,56 & 28,75 & 26,30 & 24,08 & 22,08 & 24,00 & 22,78 & 18,15 & \\
\hline Benin & & 8,85 & 5,78 & 3,47 & 7,75 & 8,07 & 11,43 & 7,07 & 6,33 & 8,84 & 13,11 & 19,85 & 22,51 & 17,47 & 13,52 & 7,99 & 15,91 & 2,02 \\
\hline Gana & 10,49 & 7,82 & 9,64 & 17,44 & 15,53 & 7,18 & 7,13 & 7,60 & 7,18 & 6,82 & 5,79 & 8,95 & 10,83 & 13,41 & 7,44 & 8,01 & 4,44 & 3,60 \\
\hline Madagascar & 29,82 & 37,83 & 39,97 & 56,55 & 49,73 & 12,57 & 16,72 & 30,97 & 19,62 & 15,87 & 16,53 & 14,28 & 11,49 & 9,95 & 14,38 & 13,60 & 16,01 & 13,41 \\
\hline Malawi & 8,89 & 13,64 & 15,92 & 9,21 & 12,81 & 14,85 & 12,44 & 15,68 & 11,22 & 11,94 & 13,49 & 9,32 & 10,58 & 9,07 & 10,37 & 9,36 & 8,03 & 6,80 \\
\hline Quênia & 9,66 & 10,92 & 12,52 & 13,29 & 13,60 & 11,35 & 14,78 & \begin{tabular}{|l|}
18,94 \\
\end{tabular} & 10,26 & 10,33 & 9,25 & 10,66 & 10,99 & 10,47 & 12,29 & 7,69 & & \\
\hline Senegal & & 19,16 & 20,07 & 15,39 & \begin{tabular}{|l|}
19,52 \\
\end{tabular} & 8,91 & 10,32 & \begin{tabular}{|l|}
8,88 \\
\end{tabular} & 5,50 & 6,99 & 9,47 & 4,73 & 8,02 & 4,97 & 5,87 & 3,87 & 4,48 & 3,31 \\
\hline Tanzânia & 10,01 & 12,73 & 15,13 & 17,64 & 21,74 & 21,76 & 21,09 & 17,90 & 19,18 & \begin{tabular}{|l|}
17,07 \\
\end{tabular} & 15,24 & 13,07 & 13,74 & 9,17 & \begin{tabular}{|l|l|}
11,74 \\
\end{tabular} & 6,87 & 6,61 & 3,89 \\
\hline
\end{tabular}




\begin{tabular}{|c|c|c|c|c|c|c|c|c|c|c|c|c|c|c|c|c|c|c|}
\hline Vietnã & & & & & & & & & & & & & 6,19 & 5,80 & 6,86 & 5,42 & 4,47 & 4,13 \\
\hline Zâmbia & 9,03 & 8,29 & 17,19 & 7,67 & 7,20 & 5,90 & 6,52 & 13,88 & 4,96 & 5,62 & 10,04 & 11,17 & 10,62 & 10,95 & 12,73 & 7,93 & 6,76 & 2,49 \\
\hline Zimbábue & 8,13 & 14,26 & 12,20 & & 13,56 & 7,78 & 17,49 & 6,17 & & 9,17 & 13,91 & 3,31 & 7,48 & 9,87 & 6,13 & 3,42 & 4,10 & 2,90 \\
\hline Burkina Faso & 12,19 & 9,59 & 9,70 & 12,91 & 11,54 & 12,22 & 15,58 & 24,91 & 10,05 & 6,23 & 9,36 & & 20,40 & 20,11 & 9,98 & 6,29 & 3,79 & \\
\hline Burundi & 30,22 & 42,11 & 43,60 & 34,04 & 39,16 & 49,17 & 32,71 & 39,50 & 19,48 & 10,41 & 16,72 & 4,00 & 12,86 & 8,07 & 15,35 & 8,41 & 9,79 & 5,62 \\
\hline Camboja & & & & & & & & & & 6,84 & 7,12 & 7,16 & 8,54 & 7,58 & 8,01 & 7,25 & 7,72 & 7,36 \\
\hline R. Centro-Africana & 24,98 & 25,83 & 26,28 & 37,74 & 41,01 & 59,95 & 54,14 & 70,18 & 51,41 & 32,50 & 27,68 & 27,23 & 24,48 & 28,89 & 35,58 & 29,32 & 32,37 & 20,25 \\
\hline Gâmbia & & 251,06 & 372,01 & 96,28 & 133,59 & 37,03 & 54,02 & 22,65 & 31,84 & 15,23 & 16,48 & 22,35 & 20,36 & 20,03 & 3,98 & 6,35 & 4,44 & 2,33 \\
\hline Guiné & 17,61 & 20,81 & 19,93 & 24,49 & 27,25 & 21,72 & 19,95 & 25,74 & 18,77 & 22,32 & 12,08 & 12,37 & 14,16 & 8,55 & 11,79 & 11,92 & 9,63 & 8,90 \\
\hline Guiné-Bissau & 14,27 & & & & & & 25,89 & 6,40 & 4,03 & & & & & & & & & \\
\hline Quirguistão & & & & 5,05 & 3,54 & 2,87 & 4,60 & 1,36 & 1,64 & 0,83 & 1,07 & 1,82 & 1,37 & 1,06 & 0,86 & 1,94 & 0,90 & 1,20 \\
\hline Mali & & 7,94 & 8,40 & 7,02 & 5,64 & 5,45 & 3,53 & 2,49 & 1,85 & 1,75 & 2,27 & 3,72 & 2,18 & 1,93 & & 2,59 & 2,29 & 0,39 \\
\hline Moçambique & 14,50 & 14,82 & 21,04 & & 17,56 & 11,15 & 14,59 & 9,60 & 8,94 & 9,98 & 10,80 & 10,92 & 14,80 & 11,77 & 12,13 & 16,23 & 11,23 & 8,61 \\
\hline Nepal & & & & & & & & & & & & & & & 15,50 & 6,04 & 7,25 & 6,30 \\
\hline Níger & & 4,16 & 5,38 & 10,84 & 25,37 & 10,04 & 13,05 & 9,34 & 10,48 & 14,88 & 10,11 & 13,85 & 9,20 & 2,23 & 9,83 & 8,56 & 9,41 & 8,51 \\
\hline Ruanda & & 191,71 & 44,54 & 72,11 & 21,89 & & 8,57 & 18,58 & 55,41 & 86,85 & 11,76 & 19,08 & 15,07 & 9,70 & 16,61 & 12,75 & 10,29 & 4,68 \\
\hline Togo & 6,85 & 4,59 & 5,91 & 3,69 & 5,19 & 4,18 & 6,30 & 5,78 & 2,87 & 4,38 & 7,97 & & 14,36 & 12,62 & 9,80 & 6,41 & 8,27 & 3,13 \\
\hline Uganda & 27,48 & 18,82 & 35,36 & 23,62 & 18,61 & 23,23 & 18,06 & 20,17 & 18,63 & 17,11 & 16,19 & 10,83 & 9,95 & 7,74 & 9,24 & 8,78 & 6,70 & 6,41 \\
\hline PMD Médio & 16,54 & 33,35 & 35,52 & 23,19 & 25,71 & 15,79 & 17,51 & 16,28 & 14,84 & 15,36 & 15,44 & 11,82 & 10,57 & 9,71 & 9,74 & 7,27 & 6,67 & 4,98 \\
\hline
\end{tabular}

Fonte: Elaboração própria. 
Quadro A4-2.3: CAP no período 1995-2012

\begin{tabular}{|c|c|c|c|c|c|c|c|c|c|c|c|c|c|c|c|c|c|c|}
\hline MEMBRO & $1995 \mid$ & 19 & 1997 & 1998 & $\left.1999\right|_{2} ^{2}$ & $2000 \mid 2$ & 2001 & $2002 \mid 2$ & 2003 & 2004 & 2005 & $2006 \mid 2$ & 2007 & $2008 / 2$ & 2009 & 2010 & 2 & 2012 \\
\hline PD Médio & 3,08 & 3,02 & 3,03 & $\mid 3,03$ & 3,05 & 3,00 & 3,00 & $3,01 \mid 3$ & 3,03 & 3,09 & 2,98 & 3,05 & $|3,06|$ & \begin{tabular}{|l|l|}
3,06 & 3 \\
\end{tabular} & 3,09 & 3,09 & 3,07 & 3,07 \\
\hline ião & 3,60 & 3,60 & 3,61 & 3,61 & 3,62 & 3,63 & 3,66 & $3,70 \mid 3$ & 3,72 & 3,71 & $\mid 3,65$ & $3,62 \mid 3$ & $|3,57|$ & \begin{tabular}{|l|l|}
3,59 & 3 \\
\end{tabular} & 3,60 & 3,61 & 3,59 & $\mid$\begin{tabular}{|ll}
$\mid 3,5 \varepsilon$ \\
\end{tabular} \\
\hline Estados Unidos & 4,21 & 4,21 & $4,4,25$ & 4,30 & 4,32 & 4,34 & 4,27 & 4,204 & 4,11 & 4,30 & 4,07 & \begin{tabular}{|l|l|l|}
4,10 & 4 \\
\end{tabular} & 4,15 & \begin{tabular}{|l||l|}
4,10 & 4 \\
\end{tabular} & 4,00 & 4,05 & 4,01 & $\mid 4,01$ \\
\hline$\overline{\text { UE / EU }}$ & 3,90 & 3,90 & 3,93 & 3,95 & 3,97 & 3,98 & 3,97 & $3,95 \mid 3$ & $3,91 \mid$ & 4,01 & $\mid 3,86$ & $|3,86|$ & $\mid 3,86$ & 3,84 & 3,80 & 3,83 & 3,80 & 3,80 \\
\hline & & & & & OUTR & $R O S D E$ & ESEN & VIOLVI & VIDOS & & & & & & & & & \\
\hline$\overline{\text { Arábia S }}$ & & & & & & & & & & & 2,11 & 2,27 & 2,39 & 2,432 & 2,44 & 2,53 & 2,18 & 2,53 \\
\hline Austrá & 4,16 & 4,16 & 4,13 & $\mid 4,10$ & 4,19 & $|4,27|$ & 4,23 & $4,20 \mid 4$ & 4,31 & 4,54 & || $4,27 \mid$ & $|4,26|$ & $\| 4,32$ & $|4,28|$ & $4,20 \mid$ & 4,27 & 4,20 & 4,11 \\
\hline Bahrein & 3,13 & 3,13 & & & & 3,05 & 3,04 & $3,\left.03\right|_{2}$ & 2,96 & 3,09 & || $2,90 \mid$ & $\mid 2,90$ & $\mid 2,92$ & $2,91 \mid 3$ & 3,00 & 2,98 & 3,05 & $\mid 3,04$ \\
\hline Barbados & $|3,94|$ & 3,94 & 3,94 & 3,93 & $3,92 \mid$ & $3,91 \mid 3$ & 3,89 & $3,\left.87\right|^{3}$ & 3,80 & 3,59 & 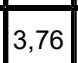 & $|3,98|$ & |3,84| & $4,10 \mid$ & $4,01 \mid$ & 3,91 & $3,96 \mid$ & $\mid 3,95$ \\
\hline Canada & 4,38 & 4,38 & 4,42 & 4,47 & 4,46 & 4,45 & 4,45 & 4,45 & 4,51 & 4,46 & 4,41 & 4,42 & 4,25 & 4,27 & $4,25 \mid 4$ & 4,29 & 4,28 & 4,25 \\
\hline$\overline{\overline{\text { Cinga }}}$ & $|4,60|$ & 4,60 & 4,61 & $\mid 4,62$ & $4,65 \mid$ & $|4,67|$ & 4,51 & 4,35 & 4,46 & 4,53 & $\mid 4,50$ & $\mid 4,68$ & $|4,87|$ & $4,93 \mid$ & $4,78 \mid$ & 4,76 & $4,67 \mid$ & $\mid 4,65$ \\
\hline 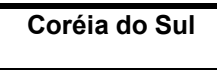 & 3,13 & 3,13 & 2,98 & $|2,83|$ & 3,02 & 3,20 & 3,30 & $3,\left.39\right|^{3}$ & 3,43 & 3,44 & ||3,52|| & $|3,55|$ & $|3,73|$ & 3,55 & $3,61 \mid 3$ & 3,72 & 3,76 & $\mid 3,70$ \\
\hline Croácia & & & & & & $|2,81| 2$ & 2,83 & $2,84 \mid 2$ & 2,88 & 2,97 & |2,98 & $|3,06|$ & $|2,97|$ & $|3,07| 3$ & $3,11 \mid 3$ & 3,13 & 3,06 & 3,20 \\
\hline Hong $\mathrm{r}$ & & & & & & & & & & & & & & & & & & \\
\hline indi & $|4,30|$ & 4,30 & 4,36 & 4,41 & 4,47 & |4,53|| & 4,52 & $4,51 \mid 4$ & $4,62 \mid$ & $4,62 \mid$ & $\mid 4,49$ & $|4,37|$ & $|4,28|$ & $|4,31|$ & $4,15|| 4$ & 4,09 & 4,08 & $\mid 3,99$ \\
\hline rael & 3,47 & 3,47 & 3,55 & 3,63 & 3,64 & 3,65 & 3,64 & \begin{tabular}{l|l|l}
3,62 & 3 \\
\end{tabular} & 3,75 & 3,81 & 3,58 & 3,75 & 3,74 & 3,83 & 3,763 & 3,87 & 3,83 & 3,75 \\
\hline$\overline{\text { pão }}$ & 3,46 & 3,46 & 3,51 & 3,57 & 3,63 & 3,69 & 3,63 & $|3,57|^{3}$ & 3,72 & 3,92 & $\mid$\begin{tabular}{||l||}
$\mid 3,85$ \\
$\mid$
\end{tabular} & $\mid 4,06$ & $|3,95|$ & $|3,96|$ & 3,96 & 4,02 & 3,97 & $\mid 3,90$ \\
\hline Kuwai & 2,63 & 2,63 & 2,51 & 2,39 & 2,39 & 2,38 & 2,48 & $2,\left.58\right|^{2}$ & 2,56 & $2,57 \mid$ & & | $2,74 \mid$ & |2,61|| & $\mid 2,51$ & & & & \\
\hline Nova Zelân & 4,44 & 4,44 & 4,31 & 4,17 & 4,15 & 4,13 & 4,19 & $4,24 \mid 4$ & 4,32 & 4,47 & 4,24 & 4,16 & 4,17 & 4,17 & $4,35 \mid$ & 4,31 & 4,38 & 4,29 \\
\hline Noruega & 52 & 4,52 & 4,51 & 4,49 & 4,45 & 4,41 & 4,41 & 4,40 & 4,42 & 4,60 & 4,35 & |4,44| & 4,53 & 4,34 & 4,32 & 4,36 & 4,34 & $\mid 4,39$ \\
\hline Omã & & & & & & 2,83 & 2,86 & \begin{tabular}{l|l}
2,90 & 2
\end{tabular} & 2,97 & 2,95 & 2,80 & 2,77 & 2,85 & 2,94 & 2,91 & 2,92 & & $\mid 2,76$ \\
\hline
\end{tabular}




\begin{tabular}{|c|c|c|c|c|c|c|c|c|c|c|c|c|c|c|c|c|c|c|}
\hline Suiça & 4,41 & 4,41 & 4,47 & 4,53 & 4,54 & 4,56 & 4,54 & 4,52 & 4,31 & 4,72 & 4,39 & 4,53 & 4,53 & 4,52 & 4,46 & 4,39 & 4,37 & 4,38 \\
\hline Taiwan & & & & & & & & 3,32 & 3,51 & $3,67 \mid$ & 3,51 & 3,65 & $|3,63|$ & |3,64|| & $|3,69|$ & 3,70 & 3,66 & $\mid 3,64$ \\
\hline Trinidad e Tobago & 2,47 & 2,47 & 2,65 & |2,84 & 2,90 & $\mid 2,97 \|$ & |2,91 & 2,85 & 2,98 & $2,87 \mid$ & 2,69 & $2,64 \mid$ & $|2,71|$ & |2,67| & $2,80 \mid$ & $|2,77|$ & & \\
\hline Catar & & & & & 2,94 & $2,94|| z$ & 2,96 & 2,99 & 2,97 & 2,99 & 2,92 & 3,05 & |2,94|| & 3,11 & $|3,50|$ & 3,39 & 3,28 & $\mid 3,28$ \\
\hline Macau & & & & & & & & & & & & & & & & & & \\
\hline Outros PD Médio & 3,19 & 3,14 & 3,14 & $\mid 3,15$ & 3,18 & $3,14||$ & 3,14 & 3,15 & 3,18 & 3,24 & 3,12 & 3,20 & $|3,21|$ & $|3,22|$ & $|3,25|$ & 3,26 & 3,22 & $\mid 3,23$ \\
\hline \multicolumn{19}{|c|}{ EM DESENVOLVIMENTO } \\
\hline PED Médio & 1,87 & 1,81 & 1,81 & 1,83 & 1,82 & 1,80 & 1,79 & 1,77 & 1,79 & 1,76 & 1,74 & 1,75 & 1,77 & 1,76 & 1,75 & 1,75 & 1,76 & 1,74 \\
\hline \multicolumn{19}{|c|}{ Renda Média-Alta } \\
\hline África do Sul & 3,38 & 3,38 & 3,24 & 3,10 & 3,15 & 3,19 & 3,16 & 3,14 & 3,18 & 3,16 & 3,14 & 3,00 & 2,99 & 3,02 & 2,98 & 2,89 & 2,91 & 2,83 \\
\hline Antígua e Barbuda & & & & & 3,13 & $3,11 \mid$ & & & & & 2,91 & 2,97| & 2,96 & & 2,99| & 2,99 & 2,98 & 2,98 \\
\hline Argentina & 2,77 & 2,77 & 2,83 & 2,88 & 2,72 & 2,56 & 2,40 & 2,24 & 2,49 & 2,48 & 2,41 & 2,46 & 2,47 & 2,37 & 2,17 & 2,31 & 2,36 & 2,25 \\
\hline Brasil & 2,35 & 2,35 & $\mid 2,37$ & $\mid 2,39$ & 2,47 & 2,55 & 2,54 & $2,53 \mid$ & 2,68 & $2,57 \mid$ & 2,40 & 2,27| & 2,30 & $\mid 2,41$ & 2,40 & 2,46 & 2,38 & 2,38 \\
\hline Chile & 3,78 & 3,78 & $\mid 3,72$ & $\mid 3,67$ & 3,64 & 3,62 & $\mid 3,63$ & $3,64 \mid$ & 3,74 & $3,70 \mid$ & 3,72 & 3,60 & $|3,76|$ & $|3,67|$ & 3,73 & 3,76 & 3,76 & $\mid 3,75$ \\
\hline Colômbia & 2,31 & 2,31 & $\mid 2,32$ & || $2,33$ & 2,27 & $|2,22|$ & 2,15 & 2,09 & 2,36 & 2,36 & 2,34 & 2,38 & 2,45 & 2,47 & 2,27 & 2,46 & 2,56 & 2,51 \\
\hline Costa Rica & 2,77 & 2,77 & 2,78 & 2,79 & 2,77 & 2,75 & 2,78 & 2,82 & 2,76 & 2,74 & 2,65 & 2,61 & 2,70 & 2,77 & 2,83 & 2,81 & 2,84 & 2,99 \\
\hline Cuba & & & & & 2,17 & $|2,27|$ & $\mid 2,16$ & 2,05 & 2,26 & |2,06|| & 1,96 & 2,04 & & & & & & \\
\hline Dominica & 3,15 & 3,15 & $\mid 2,90$ & & 2,77 & 2,89 & |2,91 & $2,92 \mid$ & 2,72 & $|2,62|$ & 2,93 & |2,98 & $|3,01|$ & $|3,03|$ & $3,11 \mid$ & 3,15 & & $\mid 3,16$ \\
\hline Granada & & 3,15 & $\mid 2,99$ & $\mid 2,83$ & 2,84 & $|2,85|$ & | 2,86 & $2,86 \mid$ & 2,69 & |2,59|| & 2,78 & 2,74 & $|2,72|$ & 2,73 & 2,70 & & & \\
\hline Jamaica & 2,66 & 2,66 & $\mid 2,67$ & & & & & 2,48 & 2,56 & $|2,71|$ & 2,42 & 2,77 & $|2,80|$ & |2,79| & 2,71 & 2,70 & $2,72 \mid$ & 2,48 \\
\hline Malásia & 3,25 & 3,25 & $|3,27|$ & $\mid 3,29$ & 3,42 & $\mid 3,55$ & |3,52 & 3,49 & 3,67 & $3,63 \mid$ & 3,63 & 3,70 & 3,75 & $|3,66|$ & 3,50 & 3,63 & $3,53 \mid$ & 3,51 \\
\hline Maurício & 2,82 & 2,82 & $\mid 2,87$ & $\mid 2,92$ & 2,93 & 2,95 & 2,93 & 2,91 & 3,25 & $3,15 \mid$ & 3,12 & 3,18 & $|3,23|$ & $\mid 3,27$ & 3,26 & 3,35 & 3,36 & $\mid 3,45$ \\
\hline México & 2,57 & 2,57 & $|2,71|$ & $\mid 2,85$ & 2,79 & 2,73 & 2,74 & 2,75 & 2,73 & $2,67 \mid$ & 2,58 & 2,66 & 2,67 & |2,68 & 2,66 & 2,64 & 2,81 & 2,82 \\
\hline Namíbia & & & & & & $|2,67|$ & 2,65 & $2,63 \mid$ & 2,74 & $|2,60|$ & 2,54 & 2,62 & $|2,63|$ & 2,70 & $2,63 \mid$ & 2,61 & 2,59 & $\mid 2,63$ \\
\hline
\end{tabular}




\begin{tabular}{|c|c|c|c|c|c|c|c|c|c|c|c|c|c|c|c|c|c|c|}
\hline Panamá & & & 2,69 & 2,86 & 2,80 & 2,74 & 2,62 & 2,49 & 2,45 & 2,47 & 2,56 & 2,58 & 2,63 & 2,61 & 2,64 & 2,63 & 2,59 & 2,81 \\
\hline Peru & 2,45 & 2,45 & 2,57 & 2,68 & 2,55 & 2,41 & 2,28 & 2,15 & 2,08 & 2,03 & 1,90 & 1,92 & 1,99 & 2,14 & 2,08 & 2,30 & 2,35 & 2,34 \\
\hline R. Dominicana & 2,13 & 2,13 & 2,03 & & & & 2,13 & 2,09 & 1,96 & 1,86 & 1,95 & 1,92 & 1,84 & 1,89 & 1,89 & 1,84 & 1,92 & 1,95 \\
\hline Rússia & & & & & & & & & & & & & & & & & & $\mid$\begin{tabular}{||l|}
$\mid 2,07$ \\
\end{tabular} \\
\hline St. Kitts e Nevis & & 2,50 & 2,28 & & 2,24 & 2,41 & 2,30 & 2,18 & 2,15 & 2,47 & 3,37 & $\mid 3,23$ & 3,16 & 3,18 & 3,27 & 3,22 & 3,27 & \\
\hline St. Lúcia & 2,50 & 2,50 & 2,35 & 2,20 & 2,38 & $\mid 2,56$ & 2,44 & 2,33 & 2,46 & 2,56 & 3,42 & 3,23 & 3,16 & 3,18 & & & & \\
\hline St. Vincente e Granadinas & 2,50 & 2,50 & 2,42 & 2,33 & 2,44 & |2,56 & 2,44 & 2,33 & 2,31 & 2,58 & 3,37 & 3,23 & 3,16 & 3,18 & 3,27 & 3,22 & 3,27 & 3,34 \\
\hline Suriname & $|1,70|$ & 1,70 & 1,85 & 2,00 & 2,16 & $\mid 2,33$ & 2,30 & 2,28 & 2,30 & 2,41 & $\mid 2,41$ & & & & & & & \\
\hline Turquia & |2,49|| & 2,49 & 2,36 & $\mid 2,22$ & 2,37 & $\mid 2,52$ & 2,53 & 2,54 & 2,54 & 2,54 & 2,66 & $\mid 2,66$ & $\mid 2,80$ & 2,76 & 2,79 & 2,81 & 2,86 & 2,90 \\
\hline Uruguai & 3,00 & 3,00 & 2,97 & 2,95 & 2,94 & ||2,93 & 3,01 & 3,08 & 3,00 & 2,85 & 3,01 & $\mid 2,89$ & 3,01 & 3,01 & $\mid 3,10$ & 3,14 & 3,06 & 2,94 \\
\hline Venezuela & $\mid 1,78$ & 1,78 & 1,73 & 1,67 & 1,71 & || $1,74$ & 1,62 & 1,49 & 1,55 & 1,48 & 1,60 & $\mid 1,46$ & $\mid 1,45$ & 1,39 & $\mid 1,53$ & 1,40 & 1,31 & $\mid, 36$ \\
\hline Albânia & & & & & & $\mid$\begin{tabular}{||l|l||}
1,67 &
\end{tabular} & 1,80 & 1,93 & 1,89 & 2,06 & 1,87 & |2,04 & 2,12 & 2,15 & 2,26 & 2,23 & 2,30 & 2,22 \\
\hline Botswana & 2,97 & 2,97 & 2,98 & 3,00 & 3,00 & $\mid 3,01$ & 3,05 & 3,09 & 3,23 & 3,14 & 3,16 & $\mid 3,02$ & 3,09 & 3,06 & 2,98 & 2,96 & 2,98 & 2,95 \\
\hline Gabão & & 2,16 & 2,03 & $\mid 1,91$ & 1,89 & || $1,87$ & 1,99 & 2,11 & 2,02 & 1,70 & $\mid 1,66$ & $\mid 1,65$ & $\mid 1,66$ & 1,67 & 1,75 & 1,72 & $|1,70|$ & $\mid 1,72$ \\
\hline Jordânia & & & & & & 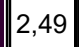 & 2,56 & 2,62 & 2,74 & 2,62 & & $\mid 2,68$ & $\mid 2,72$ & 2,72 & 2,78 & 2,63 & $2,60 \mid$ & 2,46 \\
\hline Maldivas & & & & & & & 2,78 & 2,78 & 2,51 & 2,39 & $\mid 2,66$ & | 2,54 & 2,50 & 2,23 & 2,05 & 2,29 & 2,19 & 2,34 \\
\hline Montenegro & & & & & & & & & & & & & & & & & & $\mid$\begin{tabular}{||l|}
$\mid 2,63$ \\
\end{tabular} \\
\hline Tonga & & & & & & & & & & & & & $\mid$\begin{tabular}{||l|}
2,02 \\
\end{tabular} & 2,02 & 2,15 & 2,18 & 2,14 & 2,31 \\
\hline Tunísia & |2,91| & 2,91 & 2,98 & $\mid 3,05$ & 3,04 & $\mid 3,02$ & 3,07 & 3,13 & 3,05 & 2,98 & 2,92 & $\mid 3,08$ & $\mid 2,97$ & 2,81 & $\mid 2,90$ & 2,74 & 2,53 & 2,45 \\
\hline Macedônia & & & & & & & & & $\mid 2,17$ & 2,37 & 2,22 & $\mid 2,40$ & 2,30 & 2,48 & $\mid 2,41$ & 2,35 & 2,39 & 2,43 \\
\hline PEDma Médio & |2,24 & 2,20 & 2,19 & 2,19 & 2,20 & $\mid 2,19$ & 2,17 & 2,15 & 2,18 & 2,15 & 2,19 & 2,19 & 2,18 & 2,19 & $\mid 2,19$ & 2,19 & 2,19 & 2,16 \\
\hline \multicolumn{19}{|c|}{ Renda Média-Baixa } \\
\hline Armênia & & & & & & & & & || $2,24$ & 2,36 & 2,37 & $\mid 2,29$ & $\mid 2,15$ & 2,34 & $\mid 2,48$ & 2,33 & 2,40 & 2,46 \\
\hline Belize & 2,88 & 2,88 & 2,69 & 2,50 & 2,49 & 2,49 & 2,48 & 2,47 & 2,31 & 2,14 & 2,35 & 2,09 & 2,01 & 1,96 & 2,03 & 2,06 & 2,14 & 2,32 \\
\hline
\end{tabular}




\begin{tabular}{|c|c|c|c|c|c|c|c|c|c|c|c|c|c|c|c|c|c|c|}
\hline Bolivia & 2,31 & 2,31 & 2,37 & 2,44 & 2,30 & 2,17 & 2,19 & 2,21 & 2,22 & 1,95 & 1,82 & 1,86 & 1,95 & 1,89 & 1,91 & 2,00 & 2,04 & 2,13 \\
\hline Camarões & ,50 & 1,50 & 1,63 & & & $\mid 1,83$ & 1,75 & 1,68 & 1,85 & 1,80 & 1,62 & $\mid 1,57$ & $|1,67|$ & 1,71 & 1,68 & $\mid 1,62$ & 1,62 & $\mid 1,60$ \\
\hline China & & & & & & & 2,43 & 2,45 & 2,46 & 2,50 & 2,41 & 2,58 & 2,69 & 2,65 & 2,61 & 2,60 & 2,60 & 2,51 \\
\hline Costa do Marfim & 2,44 & 2,44 & 2,37 & 2,29 & 1,96 & 1,62 & 1,59 & 1,56 & 1,48 & 1,23 & 1,16 & 1,33 & 1,29 & 1,29 & 1,42 & $\mid 1,24$ & 1,37 & 1,39 \\
\hline Egito & $|2,29|$ & 2,29 & 2,31 & |2,33 & 2,34 & 2,34 & 2,22 & 2,10 & 2,20 & 2,27 & $2,11 \|$ & 2,02 & |2,12 | & 2,15 & 2,23 & 2,12 & 1,93 & 1,70 \\
\hline El Salvador & 1,78 & 1,78 & 1,88 & $\mid 1,99$ & 1,98 & 1,96 & 1,98 & 1,99 & 2,16 & 2,23 & 2,18 & 2,31 & 2,30 & 2,34 & 2,48 & 2,50 & 2,39 & 2,36 \\
\hline Equador & & 1,87 & 1,93 & $\mid 1,99$ & 1,84 & 1,70 & 1,67 & 1,64 & 1,67 & 1,65 & 1,58 & 1,53 & $|1,65|$ & 1,65 & 1,72 & || $1,78$ & 1,91 & $\mid 1,99$ \\
\hline $\mathrm{Fiji}$ & & & & & & $\mid 1,96$ & 2,26 & 2,56 & 2,28 & 2,07 & 2,39 & $\mid 2,37$ & 2,05 & 1,74 & 1,59 & $\mid 1,77$ & 1,79 & $\mid 1,60$ \\
\hline Filipinas & $|2,32|$ & 2,32 & 2,43 & ||2,53 & 2,45 & 2,36 & 2,38 & 2,41 & 2,46 & 2,30 & $2,44 \|$ & $\mid 2,44$ & $\mid 2,58$ & 2,53 & 2,47 & 2,48 & 2,58 & $\mid 2,58$ \\
\hline Guatemala & $|2,00|$ & 2,00 & 2,04 & $\mid 2,08$ & 2,03 & $\mid 1,97$ & 1,99 & 2,01 & 2,05 & 1,86 & 1,80 & 1,91 & $|1,95|$ & 1,94 & 1,81 & $\mid 1,80$ & 1,80 & $\mid 1,74$ \\
\hline Guiana & & & 2,28 & 2,45 & 2,38 & 2,31 & 2,27 & 2,23 & 2,32 & 2,31 & 2,02 & 2,29 & 2,46 & 2,33 & 2,33 & 2,38 & 2,40 & 2,36 \\
\hline Honduras & $|1,64|$ & 1,64 & 1,79 & $\mid$\begin{tabular}{||l}
1,94 \\
-1
\end{tabular} & 1,95 & 1,96 & 1,91 & 1,87 & 1,92 & 1,94 & 1,86 & $\mid 1,89$ & $|1,95|$ & & 1,83 & $\mid 1,86$ & 1,95 & $\mid 1,78$ \\
\hline Índia & 2,42 & 2,42 & 2,41 & 2,41 & 2,39 & 2,36 & 2,36 & 2,37 & 2,43 & 2,40 & 2,42 & 2,45 & 2,61 & 2,47 & 2,49 & 2,52 & 2,49 & 2,32 \\
\hline Indonésia & 2,08 & 2,08 & 1,99 & $\mid 1,90$ & 2,07 & 2,23 & 2,15 & 2,07 & 2,05 & 2,12 & 2,06 & 2,16 & $|2,22|$ & 2,26 & 2,22 & $\mid 2,30$ & 2,25 & |2,21 \\
\hline Moldávia & & & & & & & 1,90 & 1,89 & 1,79 & 1,61 & $1,77 \|$ & 1,71 & $|1,69|$ & 1,74 & 1,93 & $\mid 1,86$ & 1,90 & $\mid 1,95$ \\
\hline Nicarágua & $\mid 1,68 \|$ & 1,68 & 1,77 & || $1,85$ & 1,86 & $\mid 1,88$ & 1,80 & 1,72 & 1,78 & 1,82 & 1,70 & 1,65 & $\mid 1,59$ & 1,61 & 1,55 & $\mid 1,54$ & 1,61 & $\mid 1,61$ \\
\hline Nigéria & & 1,52 & 1,45 & $\mid$\begin{tabular}{||l}
1,38 \\
\end{tabular} & 1,46 & 1,54 & 1,49 & 1,44 & 1,54 & & & $\mid 1,54$ & $|1,46|$ & 1,53 & 1,30 & $\mid 1,35$ & 1,42 & $\mid 1,50$ \\
\hline Paquistão & $|1,91|$ & 1,91 & 1,98 & 2,05 & 1,99 & $\mid 1,92$ & 2,01 & 2,11 & 2,11 & 2,05 & 2,08 & 2,13 & 2,04 & 1,80 & 1,72 & $\mid 1,74$ & 1,69 & $\mid 1,71$ \\
\hline Paraguai & $|1,55|$ & 1,55 & 1,48 & $\mid 1,41$ & 1,37 & $\mid 1,33$ & $\mid 1,37$ & 1,41 & 1,59 & 1,60 & $1,71 \|$ & 1,61 & $|1,65|$ & 1,63 & 1,58 & 1,56 & 1,66 & $\mid 1,60$ \\
\hline Sri Lanka & & & & & 2,10 & 2,15 & 2,29 & 2,44 & 2,30 & 2,10 & 2,21 & 2,32 & 2,41 & 2,38 & 2,38 & 2,32 & 2,40 & 2,26 \\
\hline Swazilândia & & & & & & 1,79 & $\mid 1,85$ & 1,92 & 1,68 & 1,45 & $1,41 \|$ & 1,66 & $|1,65|$ & & & & & \\
\hline Tailândia & 2,77 & 2,77 & 2,68 & $\mid 2,59$ & 2,64 & 2,70 & 2,75 & 2,79 & 2,88 & 2,86 & 2,93 & 2,90 & 2,87 & 2,75 & 2,78 & 2,69 & 2,71 & 2,71 \\
\hline Ucrânia & & & & & & & & & & & & & & 1,79 & 1,70 & 1,75 & 1,69 & $\mid 1,92$ \\
\hline Cabo V & & & & & & & & & & & & & & 2,56 & 2,54 & 2,48 & 2,66 & \\
\hline
\end{tabular}




\begin{tabular}{|c|c|c|c|c|c|c|c|c|c|c|c|c|c|c|c|c|c|c|}
\hline Congo & & & & & & & & & & & & & 1,16 & 1,28 & 1,26 & 1,27 & 1,30 & 1,30 \\
\hline Georgia & & & & & & 1,18 & 1,19 & 1,19 & 1,19 & 1,38 & 1,22 & 1,21 & 1,16 & $\|1,28\|$ & $\mid 1,26$ & $\mid 1,27$ & 1,30 & $\mid 1,30$ \\
\hline Lesoto & & & & & & $|2,33|$ & 2,36 & 2,39 & 2,32 & $2,11 \mid$ & & & & |2,11 & 2,21| & 2,18 & 2,20 & 2,11 \\
\hline Mauritânia & 2,36 & 2,36 & & & & $\mid 2,32$ & 2,40 & 2,48 & 2,48 & 2,03 & 2,17 & 1,73 & 1,64 & $\mid 1,55$ & $|1,62|$ & 1,54 & 1,57 & $\mid 1,58$ \\
\hline Mongólia & & & 2,15 & 2,20 & 2,20 & 2,19 & 2,25 & & 2,21 & 2,04 & 2,14 & 2,09 & 1,98 & & & & & \\
\hline Marrocos & 2,47 & 2,47 & 2,50 & 2,53 & 2,50 & 2,47 & 2,41 & 2,36 & 2,40 & 2,42 & 2,24 & 2,36 & 2,34 & 2,33 & 2,37 & 2,41 & 2,35 & 2,43 \\
\hline \multicolumn{19}{|c|}{\begin{tabular}{l||l|l|l|l|}
2,07 & 2,05 & 2,03 & 1,90 & 1,86 \\
\end{tabular}} \\
\hline \multicolumn{19}{|l|}{ Samoa } \\
\hline Ilhas Salomão & & & & & & & & 0,46 & 0,25 & 1,33 & 1,77 & 1,50 & 1,41 & 1,50 & 1,39 & 1,55 & 1,64 & 1,68 \\
\hline PEDmb Médio & 1,79 & 1,75 & 1,73 & 1,74 & 1,72 & $|1,67|$ & 1,66 & 1,65 & 1,65 & 1,62 & 1,61 & 1,61 & 1,62 & 1,60 & 1,59 & 1,59 & 1,60 & 1,58 \\
\hline \multicolumn{19}{|c|}{$\overline{P M D}$} \\
\hline Bangladesh & 1,77 & 1,77 & 1,92 & 2,07 & & 1,94 & 1,87 & 1,80 & 1,79 & 1,72 & 1,64 & 1,73 & 1,82 & 1,79 & 1,71 & 1,75 & 1,74 & \\
\hline Benin & & 2,09 & 2,16 & 2,23 & 2,23 & 2,23 & 2,18 & 2,12 & 2,17 & 2,14 & 1,88 & 1,93 & 1,99 & 2,05 & 1,94 & 1,92 & 1,98 & 1,97 \\
\hline Gana & 2,39 & 2,39 & 2,37 & 2,36 & 2,44 & 2,52 & 2,45 & 2,37 & 2,31 & 2,34 & 2,34 & 2,61 & 2,58 & 2,52 & 2,46 & 2,46 & 2,45 & 2,43 \\
\hline Madagascar & 1,92 & 1,92 & $1,80 \mid$ & 1,67 & 1,77 & $\mid 1,86$ & 1,95 & 2,03 & 2,05 & 2,02 & 2,13 & 1,97 & 2,06 & 1,87 & 1,72 & 1,55 & 1,49 & 1,41 \\
\hline Malawi & 1,99 & 1,99 & 2,09 & 2,19 & 2,16 & |2,12|| & 1,94 & 1,75 & 1,81 & 1,78 & 1,70 & 1,69 & 1,94 & 1,95 & 2,03 & 2,08 & 2,06 & 2,01 \\
\hline Quênia & 2,16 & 2,16 & 2,09 & 2,01 & 1,99 & |1,96|| & 1,90 & 1,83 & 1,89 & $1,97 \mid$ & 1,83 & 1,92 & 2,00 & 1,91 & 1,90 & 1,96 & & \\
\hline Senegal & & 2,52 & 2,45 & 2,38 & 2,38 & 2,38 & 2,45 & 2,52 & 2,24 & 2,32 & 2,25 & 2,18 & 2,04 & 2,36 & 2,00 & 1,94 & 2,03 & 2,03 \\
\hline Tanzânia & 1,77 & 1,77 & 1,93 & 2,08 & 2,08 & 2,08 & 2,09 & 2,102 & 2,13 & 2,08 & 2,11 & 2,16 & 2,12 & 2,02 & 1,91 & 1,92 & 1,87 & 1,81 \\
\hline Vietnã & & & & & & & & & & & & & 2,28 & 2,30 & 2,25 & \begin{tabular}{|l|l|}
2,24 \\
\end{tabular} & 2,27 & 2,21 \\
\hline Zâmbia & 1,44 & 1,44 & 1,54 & 1,64 & 1,64 & 1,64 & 1,67 & 1,69 & 1,68 & 1,68 & 1,56 & 1,69 & 1,79 & 1,77 & 1,71 & 1,67 & 1,86 & 2,00 \\
\hline Zimbábue & 2,27 & 2,27 & 2,20 & & 1,93 & 1,72 & 1,66 & 1,60 & & 1,55 & 1,21 & 1,20 & 1,23 & 1,00 & 0,98 & 1,00 & 1,14 & 1,30 \\
\hline Burkina Faso & 1,48 & 1,48 & 1,61 & 1,75 & 1,81 & 1,88 & 1,83 & 1,78 & 1,88 & 1,97 & 1,90 & & 1,77 & 2,03 & 1,92 & 1,94 & 1,96 & \\
\hline Burundi & 0,77 & 0,77 & 0,81 & 0,84 & 0,95 & 1,06 & 1,06 & 1,05 & 1,03 & 1,19 & 1,24 & 1,42 & 1,26 & 1,41 & 1,47 & 1,40 & 1,45 & 1,19 \\
\hline
\end{tabular}


Camboja

\begin{tabular}{|l|l|l|l|l|l|l|l|l|l|}
1,62 & 1,53 & 1,54 & 1,64 & 1,55 & 1,59 & 1,58 & 1,65 & 1,67 \\
\hline
\end{tabular}

\begin{tabular}{|l|l|l|l|l|l|l|l|l|l|l|l|l|l|l|l|l|l|l|}
\hline R. Centro-Africana & 1,04 & 1,04 & 1,11 & 1,19 & 1,16 & 1,12 & 1,00 & 0,88 & 0,93 & 0,94 & 0,90 & 1,09 & 1,06 & 1,10 & 1,08 & 1,11 & 1,22 & 1,04 \\
\hline
\end{tabular}

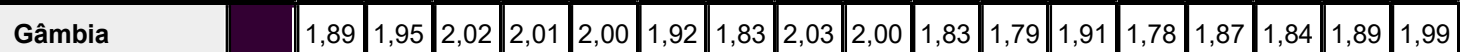

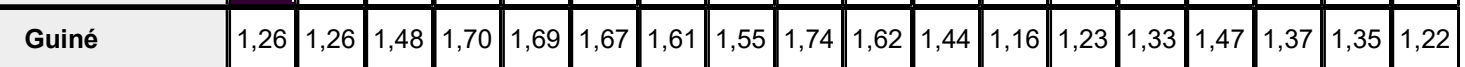

Guiné-Bissau \begin{tabular}{|l||l|l|l|l|l|l|l|l|l|l|l|l|l|l|l|l|l|l|l|}
\hline 1,03 & & & & & & 1,39 & 1,35 & 1,19 \\
\hline
\end{tabular}

Quirguistão

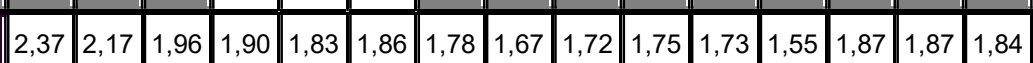

Mali \begin{tabular}{|l|l|l|l|l|l|l|l|l|l|l|l|l|l||l|l|l|}
\hline 1,29 & 1,37 & 1,45 & 1,54 & 1,63 & 1,76 & 1,90 & 1,90 & 1,88 & 1,81 & 1,82 & 1,77 & 1,74 & & 1,66 & 1,71 & 1,51 \\
\hline
\end{tabular}

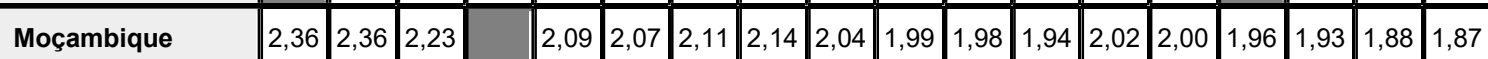

\begin{tabular}{|c|c|c|c|c|c|c|c|c|c|c|c|c|c|c|c|c|c|c|}
\hline Moçamk & 36 & ,36 & 2,23 & & $2,0 s$ & 2,07 & 2,1 & 2,14 & 2,0 & 1,99 & $1^{1,98}$ & 1,94 & 2,0 & 2,00 & 1,96 & 1,9 & 1,8 & (8) \\
\hline Nepal & & & & & & & & & & & & & & & 1,56 & 1,64 & 1,62 & 1,51 \\
\hline Níger & & 1,26 & 1,34 & 1,42 & 1,42 & 1,42 & 1,51 & 1,61 & 1,75 & 1,81 & 1,71 & 1,70 & 1,71 & 1,79 & 1,84 & 1,83 & 1,87 & 1,79 \\
\hline Ruanda & & 1,30 & 1,44 & 1,58 & 1,71 & & 1,71 & 1,57 & 1,76 & 1,94 & 1,61 & 2,21 & 2,30 & 2,36 & 2,33 & 2,45 & 2,57 & 2,44 \\
\hline Togo & 1,70 & 1,70 & 1,61 & 1,52 & 1,39 & 1,26 & 1,19 & 1,13 & 0,95 & 0,90 & 1,00 & & 0,99 & 1,03 & 1,11 & 1,12 & 1,14 & 1,17 \\
\hline Uganda & 1,77 & 1,77 & 1,94 & 2,11 & 2,11 & 2,12 & 2,10 & 2,08 & 2,16 & 2,16 & 1,96 & 2,02 & 2,09 & 1,93 & 1,88 & 1,98 & 1,99 & 1,93 \\
\hline PMD Médio & 1,64 & 1,62 & 1,67 & 1,73 & 1,73 & 1,72 & 1,69 & 1,66 & 1,67 & 1,66 & 1,58 & 1,61 & 1,65 & 1,65 & 1,61 & 1,62 & 1,65 & 1,60 \\
\hline
\end{tabular}

Fonte: Elaboração própria. 
Quadro A4-2.4: APRE no período 1995-2012

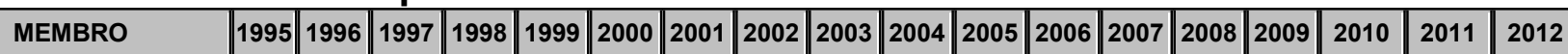
PAISES DESENVOLVIDOS

\begin{tabular}{|l||l|l|l|l|l|l|l|l|l|l|l|l|l|l|l|l||c||c||c|} 
PD Médio & 1,53 & 3,90 & 5,85 & 7,00 & 9,10 & 10,18 & 11,32 & 15,39 & 18,00 & 19,70 & 20,43 & 22,61 & 24,52 & 27,04 & 29,30 & 30,70 & 31,70 & 36,96 \\
\hline
\end{tabular}

\begin{tabular}{|c|c|c|c|c|c|c|c|c|c|c|c|c|c|c|c|c|c|c|}
\hline União Europeia & 4 & 11 & 15 & 18 & 26 & 34 & 41 & 59 & 66 & 70 & 74 & 79 & 88 & 95 & 101 & 111 & 116 & 133 \\
\hline Estados Unidos & 5 & 12 & 22 & 29 & 31 & 37 & 42 & 49 & 58 & 61 & 64 & 71 & 74 & 77 & 84 & 90 & 94 & 105 \\
\hline UE / EUA Média & 4,50 & 11,50 & 18,50 & 23,50 & 28,50 & 35,50 & 41,50 & 54,00 & 62,00 & 65,50 & 69,00 & 75,00 & 81,00 & 86,00 & 92,50 & 100,50 & 105,00 & 119,00 \\
\hline \multicolumn{19}{|c|}{ OUTROS DESENVOLVIDOS } \\
\hline Arábia Saudita & & & & & & & & & & & 0,00 & 0,00 & 0,00 & 1,00 & 4,00 & 6,00 & 9,00 & 21,00 \\
\hline Austrália & 4 & 8 & 13 & 13 & 18 & 22 & 26 & 28 & 32 & 36 & 38 & 44 & 51 & 59 & 61 & 65 & 66 & 78 \\
\hline Bahrein & 0 & 0 & 0 & 0 & 0 & 0 & 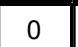 & 0 & 0 & 0 & 0 & 0 & 0 & 1 & 1 & $\overline{c 1}$ & 1 & 1 \\
\hline Barbados & 0 & 0 & 1 & 1 & 1 & 1 & 1 & 3 & 4 & 4 & 4 & 4 & 4 & 4 & 4 & 4 & 4 & 4 \\
\hline Canada & 5 & 14 & 19 & 20 & 29 & 35 & 37 & 49 & 58 & 63 & 63 & 67 & 70 & 73 & 78 & 78 & 78 & 90 \\
\hline Cingapura & 0 & 2 & 4 & 4 & 4 & 4 & 4 & 4 & 4 & 4 & 4 & 4 & 4 & 7 & 7 & 7 & 7 & 12 \\
\hline Coréia do Sul & 0 & 6 & 8 & 13 & 15 & 17 & 18 & 28 & 29 & 33 & 36 & 42 & 44 & 52 & 57 & 61 & 63 & 77 \\
\hline Croácia & & & & & & 0 & 0 & 0 & 0 & 0 & 0 & 0 & 0 & 0 & 0 & 0 & 0 & 0 \\
\hline Hong Kong & 1 & 3 & 3 & 4 & 4 & 5 & 6 & 6 & 7 & 9 & 9 & 10 & 10 & 13 & 13 & 13 & 13 & 13 \\
\hline 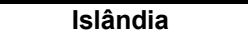 & 4 & 4 & 4 & 4 & 6 & 6 & 6 & 6 & 6 & 6 & 6 & 6 & 6 & 6 & 8 & 8 & 8 & 8 \\
\hline Israel & 0 & 0 & 1 & 2 & 2 & 3 & 4 & 4 & 4 & 4 & 4 & 4 & 4 & 4 & 4 & 4 & 4 & 7 \\
\hline Japão & 3 & 9 & 17 & 22 & 30 & 42 & 445 & 59 & 66 & 71 & 75 & 88 & 97 & 105 & 114 & \begin{tabular}{|l|}
118 \\
\end{tabular} & $\mid 2123$ & 136 \\
\hline Kuwait & $\overline{0}$ & $\overline{0}$ & 0 & 0 & $\overline{0}$ & $\overline{0}$ & $\overline{0}$ & 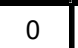 & 0 & 0 & $\overline{0}$ & 0 & 0 & 1 & 1 & $\overline{c 1}$ & $\overline{11}$ & 1 \\
\hline Nova Zelândia & $\overline{0}$ & 2 & 2 & 2 & $\overline{7}$ & $\overline{77}$ & $\overline{77}$ & 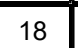 & 23 & 27 & 27 & 27 & 29 & 32 & 33 & 33 & 33 & 36 \\
\hline Noruega & 3 & 7 & 7 & 7 & 7 & 9 & 10 & 18 & 22 & 25 & 25 & 27 & \begin{tabular}{|l|}
28 \\
\end{tabular} & 30 & 36 & 38 & 42 & 53 \\
\hline Omã & & & & & & $\overline{0}$ & $\overline{0}$ & $\overline{0}$ & $\overline{0}$ & $\overline{0}$ & 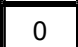 & $\overline{0}$ & $\overline{0}$ & $\overline{0}$ & $\overline{0}$ & $\overline{0}$ & $\overline{0}$ & $\overline{77}$ \\
\hline Suiça & 0 & 0 & 1 & 1 & 2 & 2 & 2 & 8 & 8 & 8 & 8 & 8 & 8 & 8 & 8 & 8 & 8 & 11 \\
\hline Taiwan & & & & & & & & 13 & 24 & 29 & 30 & 36 & 44 & 52 & 61 & 63 & 65 & 74 \\
\hline Trinidad e Tobago & 0 & 0 & 0 & 0 & 0 & 0 & 0 & $\overline{22}$ & 3 & 3 & 3 & 3 & 3 & 3 & 3 & 3 & 3 & 4 \\
\hline Catar & & $\overline{0}$ & $\overline{0}$ & $\overline{0}$ & $\overline{0}$ & $\overline{0}$ & $\overline{0}$ & $\overline{0}$ & $\overline{0}$ & $\overline{0}$ & $\overline{0}$ & $\overline{0}$ & $\overline{0}$ & 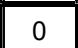 & $\overline{0}$ & 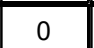 & $\overline{0}$ & $\overline{0}$ \\
\hline
\end{tabular}




\begin{tabular}{|c|c|c|c|c|c|c|c|c|c|c|c|c|c|c|c|c|c|c|}
\hline Macau & 0 & 0 & 0 & 0 & 0 & 0 & 0 & 0 & 0 & 0 & 0 & 0 & 0 & 0 & 0 & 0 & 0 & 0 \\
\hline Outros PD Médio & 1,25 & 3,24 & 4,71 & 5,47 & 7,35 & 8,05 & 8,74 & 12,30 & 14,50 & 16,10 & 15,81 & 17,62 & 19,14 & 21,48 & 23,48 & 24,33 & 25,14 & 30,14 \\
\hline \multicolumn{19}{|c|}{ EM DESENVOLVIMENTO } \\
\hline PED Médio & 0,12 & 0,82 & 1,06 & 1,39 & $\mid 1,65$ & 2,11 & 2,29 & $\mid 4,02$ & 5,00 & 5,19 & 5,53 & 5,87 & 6,26 & 6,62 & 7,35 & 8,04 & 8,29 & 9,69 \\
\hline \multicolumn{19}{|c|}{$\overline{R e n d a}$ Média-Alta } \\
\hline África do Sul & 0 & 0 & 0 & 0 & 0 & 0 & 0 & 0 & 0 & 0 & 0 & 0 & 2 & 2 & 2 & 2 & 2 & 4 \\
\hline Antígua e Barbuda & 0 & 0 & 0 & 0 & 0 & 0 & 0 & 0 & 0 & 0 & 0 & 0 & 0 & 0 & 0 & 0 & 0 & 0 \\
\hline Argentina & 0 & 0 & 2 & 2 & 3 & 5 & 6 & 7 & 12 & 14 & 16 & 19 & 25 & 30 & 36 & 37 & 38 & 45 \\
\hline Brasil & 0 & 1 & 4 & 8 & 11 & 14 & 15 & 26 & 33 & 38 & 39 & 48 & 49 & 56 & 62 & 65 & 67 & 77 \\
\hline Chile & 1 & 1 & 1 & 1 & 2 & 5 & 8 & 12 & 17 & 17 & 18 & 21 & 27 & 27 & 31 & 31 & 33 & 36 \\
\hline Colômbia & 0 & 2 & 3 & 4 & 5 & 6 & 8 & \begin{tabular}{|l||}
11 \\
\end{tabular} & 16 & 16 & 16 & 16 & 19 & 21 & 27 & 34 & 35 & 40 \\
\hline Costa Rica & 0 & 3 & 3 & 4 & 4 & 7 & 8 & 9 & 9 & 9 & 9 & 9 & 9 & 12 & 12 & 15 & 15 & 15 \\
\hline Cuba & 0 & 0 & 1 & 2 & 2 & 3 & 3 & 12 & 13 & 13 & 14 & 14 & 14 & 14 & 14 & 14 & 14 & 17 \\
\hline Dominica & 0 & 1 & 1 & 2 & 3 & 3 & 3 & 3 & 3 & 3 & 3 & 3 & 3 & 3 & 3 & 3 & 3 & 3 \\
\hline Granada & & 1 & 1 & 1 & 1 & 1 & 1 & 1 & 1 & 1 & 1 & 1 & 1 & 1 & 1 & 1 & 1 & 1 \\
\hline Jamaica & 0 & 1 & 2 & 4 & 5 & 5 & 5 & 7 & 8 & 8 & 8 & 8 & 8 & 8 & 8 & 8 & 8 & 8 \\
\hline Malásia & 0 & 1 & 1 & 1 & 1 & 1 & 1 & 1 & 1 & 1 & 1 & 1 & 1 & 1 & 1 & 1 & 1 & 5 \\
\hline Maurício & 0 & 1 & 1 & 2 & 2 & 2 & 2 & 5 & 6 & 6 & 6 & 6 & 6 & 6 & 6 & 6 & 6 & 6 \\
\hline México & 0 & 3 & 9 & 12 & 13 & 18 & 18 & \begin{tabular}{|l||}
30 \\
\end{tabular} & 36 & 39 & 41 & 46 & 50 & 53 & 59 & 63 & 66 & 69 \\
\hline Namíbia & 0 & 0 & 0 & 0 & 0 & 0 & 0 & 0 & 0 & 0 & 0 & 0 & 0 & 0 & 1 & 1 & 1 & 1 \\
\hline Panamá & & & 0 & 0 & 0 & 0 & 0 & 1 & 1 & 1 & 1 & 1 & 1 & 1 & 1 & 5 & 5 & 6 \\
\hline Peru & 1 & 1 & 3 & 3 & 3 & 4 & 4 & 5 & 8 & 8 & 8 & 8 & 8 & 10 & 10 & 10 & 10 & 16 \\
\hline R. Dominicana & 0 & 1 & 1 & 2 & 2 & 3 & 3 & 3 & 3 & 3 & 3 & 3 & 3 & 3 & 3 & 4 & 4 & 6 \\
\hline Rússia & & & & & & & & & & & & & & & & & & 7 \\
\hline St. Kitts e Nevis & & 0 & 0 & 0 & 0 & 0 & 0 & 2 & 3 & 3 & 3 & 3 & 3 & 3 & 3 & 3 & 3 & 3 \\
\hline St. Lúcia & 0 & 1 & 1 & 2 & 3 & 3 & 3 & 3 & 3 & 3 & 3 & 3 & 3 & 3 & 3 & 3 & 3 & 3 \\
\hline St. Vincente e Granadinas & 0 & 1 & 1 & 1 & 1 & 1 & 1 & 1 & 1 & 1 & 1 & 1 & 1 & 1 & 1 & 1 & 1 & 1 \\
\hline Suriname & 1 & 1 & 1 & 1 & 1 & 1 & 1 & 1 & 1 & 1 & 1 & 1 & 1 & 1 & 1 & 1 & 1 & 1 \\
\hline Turquia & 0 & 2 & 2 & 2 & 3 & 4 & 4 & 13 & 16 & 16 & 16 & 16 & 20 & 24 & 30 & 36 & 37 & 52 \\
\hline
\end{tabular}




\begin{tabular}{|c|c|c|c|c|c|c|c|c|c|c|c|c|c|c|c|c|c|c|}
\hline Uruguai & 0 & 1 & 1 & 2 & 2 & 2 & 2 & 2 & 5 & 5 & 5 & 5 & 7 & 7 & 7 & 7 & 7 & 10 \\
\hline Venezuela & 0 & 2 & 2 & 2 & 2 & 3 & 4 & 14 & 14 & 15 & 15 & 15 & 15 & 15 & 15 & 15 & 15 & 15 \\
\hline Albânia & & & & & & 0 & 0 & 0 & 0 & 0 & 0 & 0 & 0 & 0 & 0 & 0 & 0 & 0 \\
\hline Botswana & 0 & 0 & 0 & 0 & 0 & 0 & 0 & 0 & 0 & 0 & 0 & 0 & 0 & 0 & 0 & 0 & 0 & 0 \\
\hline Gabão & 0 & 0 & 0 & 0 & 0 & 0 & 0 & 0 & 0 & 0 & 0 & 0 & 0 & 0 & 0 & 0 & 0 & 0 \\
\hline Jordânia & & & & & & 0 & 0 & 0 & 0 & 0 & 0 & 0 & 0 & 0 & 0 & 0 & 0 & 0 \\
\hline Maldivas & 0 & 0 & 0 & 0 & 0 & 0 & 0 & 0 & 0 & 0 & 0 & 0 & 0 & 0 & 0 & 0 & 0 & 0 \\
\hline Montenegro & & & & & & & & & & & & & & & & & & 0 \\
\hline Tonga & & & & & & & & & & & & & 0 & 0 & 0 & 0 & 0 & 0 \\
\hline Tunísia & 0 & 0 & 0 & 0 & 0 & 0 & 0 & 0 & 0 & 0 & 0 & 0 & 0 & 0 & 0 & 0 & 0 & 0 \\
\hline Macedônia & & & & & & & & & 0 & 0 & 0 & 0 & 0 & 0 & 0 & 0 & 0 & 0 \\
\hline PEDma Médio & 0,12 & 0,89 & 1,41 & 2,00 & 2,38 & |2,94 & 3,23 & 5,45 & 6,56 & 6,91 & 7,13 & 7,75 & 8,36 & 9,15 & 10,21 & 11,09 & 11,39 & 12,77 \\
\hline \multicolumn{19}{|c|}{ Renda Média-Baixa } \\
\hline Armênia & & & & & & & & & 0 & 0 & 0 & 0 & 0 & 0 & 0 & 0 & 0 & 0 \\
\hline Belize & 0 & 1 & 1 & 1 & 1 & 1 & 1 & 3 & 4 & 4 & 4 & 4 & 4 & 4 & 4 & 4 & 4 & 4 \\
\hline Bolivia & 0 & 0 & 0 & 0 & 0 & 0 & 0 & 1 & 1 & 1 & 1 & 1 & 1 & 1 & 1 & 1 & 1 & 1 \\
\hline Camarões & 0 & 1 & 1 & 1 & 1 & 1 & 1 & 1 & 1 & 1 & 1 & 1 & 1 & 1 & 1 & 1 & 1 & 1 \\
\hline China & & & & & & & 1 & 20 & 38 & 48 & 53 & 62 & 65 & 72 & \begin{tabular}{|l|}
78 \\
\end{tabular} & 85 & 89 & 100 \\
\hline Costa do Marfim & 0 & 1 & 1 & 1 & 1 & 1 & 1 & 3 & 4 & 4 & 4 & 4 & 4 & 4 & 4 & 4 & 4 & 4 \\
\hline Egito & 0 & 0 & 0 & 1 & 1 & 1 & 1 & 2 & 2 & 2 & 3 & 4 & 6 & 6 & 6 & 6 & 6 & 7 \\
\hline El Salvador & 0 & 2 & 2 & 2 & 3 & 4 & 4 & 5 & 9 & 9 & 9 & 9 & 9 & 9 & 9 & 13 & 14 & 14 \\
\hline Equador & & 1 & 1 & 2 & 4 & 5 & 6 & 8 & 8 & 8 & 8 & 8 & 10 & 11 & 16 & 17 & 17 & 26 \\
\hline Fiji & & 0 & 0 & 0 & 0 & 0 & 0 & 2 & 3 & 3 & 3 & 3 & 3 & 3 & 3 & 3 & 3 & 3 \\
\hline Filipinas & 0 & 3 & 3 & 3 & 3 & 3 & 3 & 4 & 5 & 5 & 5 & 5 & 5 & 8 & 8 & 8 & 8 & 11 \\
\hline Guatemala & 0 & 1 & 1 & 1 & 2 & 4 & 5 & 6 & 8 & 9 & 10 & 10 & 11 & 14 & 16 & 21 & 21 & 30 \\
\hline Guiana & 0 & 0 & 0 & 0 & 0 & 0 & 0 & 2 & 3 & 3 & 3 & 3 & 3 & 3 & 3 & 3 & 3 & 3 \\
\hline Honduras & 0 & 1 & 1 & 1 & 2 & 6 & 6 & 7 & 10 & 10 & 11 & 11 & 12 & 12 & 12 & 17 & 18 & 21 \\
\hline Índia & 3 & 10 & 14 & 18 & 21 & 28 & 32 & 39 & 43 & 47 & 48 & 50 & 54 & 62 & 68 & 73 & 75 & 91 \\
\hline Indonésia & 1 & 1 & 1 & 2 & 3 & 3 & 4 & 4 & 4 & 4 & 4 & 4 & 4 & 4 & 4 & 4 & 4 & 10 \\
\hline
\end{tabular}




\begin{tabular}{|c|c|c|c|c|c|c|c|c|c|c|c|c|c|c|c|c|c|c|}
\hline Moldávia & & & & & & & 0 & 0 & 0 & 0 & 0 & 0 & 0 & 0 & 0 & 0 & 0 & 1 \\
\hline Nicarágua & 0 & 1 & 1 & 1 & 2 & 4 & 4 & 5 & 6 & 6 & 6 & 6 & 8 & 8 & 8 & 12 & 12 & 15 \\
\hline Nigéria & 0 & 1 & 1 & 1 & 1 & 1 & 1 & 1 & 1 & 1 & 1 & 1 & 1 & 1 & 1 & 1 & 1 & 4 \\
\hline Paquistão & 0 & 3 & 3 & 3 & 3 & 4 & 4 & 7 & 7 & 7 & 8 & 9 & 9 & 9 & 9 & 9 & 9 & 9 \\
\hline Paraguai & 0 & 0 & 0 & 1 & 1 & 3 & 5 & 10 & 14 & 14 & 15 & 15 & 15 & 15 & 15 & 15 & 15 & 15 \\
\hline Sri Lanka & 1 & 2 & 2 & 2 & 2 & 2 & 2 & 3 & 3 & 3 & 3 & 3 & 3 & 3 & 3 & 3 & 3 & 3 \\
\hline Swazilândia & 0 & 0 & 0 & 0 & 0 & 0 & 0 & 2 & 3 & 3 & 3 & 3 & 3 & 3 & 3 & 3 & 3 & 3 \\
\hline Tailândia & 0 & 4 & 6 & 7 & 7 & 8 & 9 & 23 & 29 & 30 & 33 & 39 & 42 & 46 & 49 & 51 & 55 & 63 \\
\hline Ucrânia & & & & & & & & & & & & & & 0 & 0 & 0 & 0 & 2 \\
\hline Cabo Verde & & & & & & & & & & & & & & 0 & 0 & 0 & 0 & 0 \\
\hline Congo & & & 0 & 0 & 0 & 0 & 0 & 0 & 0 & 0 & 0 & 0 & 0 & 0 & 0 & 0 & 0 & 0 \\
\hline Georgia & & & & & & 0 & 0 & 0 & 0 & 0 & 0 & 0 & 0 & 0 & 0 & 0 & 0 & 0 \\
\hline Lesoto & 0 & 0 & 0 & 0 & 0 & 0 & 0 & 0 & 0 & 0 & 0 & 0 & 0 & 0 & 0 & 0 & 0 & 0 \\
\hline Mauritânia & 0 & 0 & 0 & 0 & 0 & 0 & 0 & 0 & 0 & 0 & 0 & 0 & 0 & 0 & 0 & 0 & 0 & 0 \\
\hline Mongólia & & & 0 & 0 & 0 & 0 & 0 & 0 & 0 & 0 & 0 & 0 & 0 & 0 & 0 & 0 & 0 & 0 \\
\hline Marrocos & 0 & 0 & 0 & 0 & 0 & 0 & 0 & 0 & 0 & 0 & 0 & 0 & 0 & 0 & 0 & 0 & 0 & 0 \\
\hline Papua Nova Guiné & & 0 & 0 & 0 & 0 & 0 & 0 & 0 & 0 & 0 & 0 & 0 & 0 & 0 & 0 & 0 & 0 & 0 \\
\hline Samoa & & & & & & & & & & & & & & & & & & 0 \\
\hline Ilhas Salomão & & 0 & 0 & 0 & 0 & 0 & 0 & 0 & 0 & 0 & 0 & 0 & 0 & 0 & 0 & 0 & 0 & 0 \\
\hline PEDmb Médio & 0,23 & 1,27 & 1,39 & 1,71 & 2,07 & 2,72 & 2,90 & 5,10 & 6,44 & 6,94 & 7,38 & 7,97 & 8,53 & 8,79 & 9,44 & 10,41 & 10,76 & 12,60 \\
\hline \multicolumn{19}{|c|}{ PMD } \\
\hline Bangladesh & 0 & 0 & 0 & 0 & 0 & 0 & 0 & 1 & 1 & 1 & 1 & 1 & 1 & 1 & 1 & 1 & 1 & 1 \\
\hline Benin & & 0 & 0 & 0 & 0 & 0 & 0 & 1 & 1 & 1 & 1 & 1 & 1 & 1 & 1 & 1 & 1 & 1 \\
\hline Gana & 0 & 1 & 1 & 1 & 1 & 1 & 1 & 1 & 1 & 1 & 1 & 1 & 1 & 1 & 1 & 1 & 1 & 1 \\
\hline Madagascar & 0 & 1 & 1 & 1 & 1 & 1 & 1 & 3 & 4 & 4 & 4 & 4 & 4 & 4 & 4 & 4 & 4 & 4 \\
\hline Malawi & 0 & 0 & 0 & 0 & 0 & 0 & 0 & 2 & 3 & 3 & 3 & 3 & 3 & 3 & 3 & 3 & 3 & 5 \\
\hline Quênia & 0 & 0 & 0 & 0 & 0 & 0 & 0 & 2 & 3 & 3 & 3 & 3 & 3 & 3 & 3 & 3 & 3 & 3 \\
\hline Senegal & 0 & 2 & 2 & 2 & 2 & 2 & 2 & 2 & 2 & 2 & 2 & 2 & 2 & 2 & 2 & 2 & 2 & 2 \\
\hline Tanzânia & 0 & 0 & 0 & 0 & 0 & 0 & 0 & 2 & 3 & 3 & 3 & 3 & 3 & 3 & 3 & 3 & 3 & 3 \\
\hline
\end{tabular}




\begin{tabular}{|c|c|c|c|c|c|c|c|c|c|c|c|c|c|c|c|c|c|c|}
\hline Vietnã & & & & & & & & & & & & & 2 & 5 & 7 & 9 & 10 & 16 \\
\hline Zâmbia & 0 & 0 & 0 & 0 & 0 & 0 & 0 & 0 & 0 & 0 & 0 & 0 & 0 & 0 & 0 & 0 & 0 & 2 \\
\hline Zimbábue & 0 & 0 & 0 & 1 & 1 & 1 & 1 & 1 & 1 & 1 & 1 & 1 & 1 & 1 & 1 & 1 & 1 & 4 \\
\hline Burkina Faso & 0 & 0 & 0 & 0 & 0 & 0 & 0 & 0 & 0 & 0 & 0 & 0 & 0 & 0 & 0 & 0 & 0 & 0 \\
\hline Burundi & 0 & 0 & 0 & 0 & 0 & 0 & 0 & 0 & 0 & 0 & 0 & 0 & 0 & 0 & 0 & 0 & 0 & 0 \\
\hline Camboja & & & & & & & & & & 0 & 0 & 0 & 0 & 0 & 0 & 0 & 0 & 0 \\
\hline R. Centro-Africana & 0 & 0 & 0 & 0 & 0 & 0 & 0 & 0 & 0 & 0 & 0 & 0 & 0 & 0 & 0 & 0 & 0 & 0 \\
\hline Gâmbia & & 0 & 0 & 0 & 0 & 0 & 0 & 0 & 0 & 0 & 0 & 0 & 0 & 0 & 0 & 0 & 0 & 0 \\
\hline Guiné & 0 & 0 & 0 & 0 & 0 & 0 & 0 & 0 & 0 & 0 & 0 & 0 & 0 & 0 & 0 & 0 & 0 & 0 \\
\hline Guiné-Bissau & 0 & 0 & 0 & 0 & 0 & 0 & 0 & 0 & 0 & 0 & 0 & 0 & 0 & 0 & 0 & 0 & 0 & 0 \\
\hline Quirguistão & & & & 0 & 0 & 0 & 0 & 0 & 0 & 0 & 0 & 0 & 0 & 0 & 0 & 0 & 0 & 0 \\
\hline Mali & 0 & 0 & 0 & 0 & 0 & 0 & 0 & 0 & 0 & 0 & 0 & 0 & 0 & 0 & 0 & 0 & 0 & 0 \\
\hline Moçambique & 0 & 0 & 0 & 0 & 0 & 0 & 0 & 0 & 0 & 0 & 0 & 0 & 0 & 0 & 0 & 0 & 0 & 0 \\
\hline Nepal & & & & & & & & & & 0 & 0 & 0 & 0 & 0 & 0 & 0 & 0 & 0 \\
\hline Níger & & 0 & 0 & 0 & 0 & 0 & 0 & 0 & 0 & 0 & 0 & 0 & 0 & 0 & 0 & 0 & 0 & 0 \\
\hline Ruanda & & 0 & 0 & 0 & 0 & 0 & 0 & 0 & 0 & 0 & 0 & 0 & 0 & 0 & 0 & 0 & 0 & 0 \\
\hline Togo & 0 & 0 & 0 & 0 & 0 & 0 & 0 & 0 & 0 & 0 & 0 & 0 & 0 & 0 & 0 & 0 & 0 & 0 \\
\hline Uganda & 0 & 0 & 0 & 0 & 0 & 0 & 0 & 0 & 0 & 0 & 0 & 0 & 0 & 0 & 0 & 0 & 0 & 0 \\
\hline PMD Médio & 0,00 & 0,18 & 0,18 & 0,22 & 0,22 & 0,22 & 0,22 & 0,65 & 0,83 & 0,76 & 0,76 & 0,76 & 0,81 & 0,92 & 1,00 & 1,08 & 1,12 & 1,62 \\
\hline
\end{tabular}

Fonte: Elaboração própria. 
Quadro A4-2.5: POL no período 1995-2012

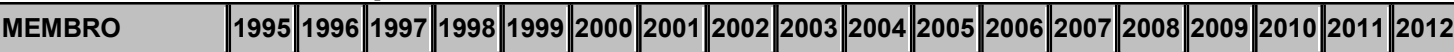

\begin{tabular}{|c|c|c|c|c|c|c|c|c|c|c|c|c|c|c|c|c|c|c|}
\hline MEMBRO & \multirow{2}{*}{\multicolumn{4}{|c|}{\begin{tabular}{||l|l||l||}
1995 & 1996 & 1998 \\
\end{tabular}}} & \multirow{2}{*}{\multicolumn{5}{|c|}{$\frac{|1999| 2000|2001| 2002|2003|}{203}$}} & & & \multicolumn{7}{|c|}{ 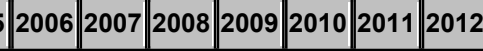 } \\
\hline & & & & & & & & & & & & & & & & & & \\
\hline \multicolumn{19}{|c|}{ UE / EUA } \\
\hline União Europeia & LV & LV & LV & LV & LV & LV & LV & LV & LV & LV & LV & LV & LV & LV & LV & LV & LV & LV \\
\hline Estados Unidos & $\mathrm{LV}$ & LV & LV & LV & LV & LV & LV & LV & LV & LV & LV & LV & LV & LV & LV & LV & LV & LV \\
\hline \multicolumn{19}{|c|}{ OUTROS DESENVOLVIDOS } \\
\hline \multicolumn{19}{|l|}{ Arábia Saudita } \\
\hline Austrália & $\overline{\mathrm{LV}}$ & LV & LV & LV & LV & LV & LV & $\overline{L L V}$ & LV & LV & LV & LV & 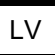 & $\overline{L L V}$ & LV & LV & LVV & $\overline{\mathrm{LLV}}$ \\
\hline Bahrein & $\overline{N L}$ & $\mathrm{NL}$ & $\mathrm{NL}$ & $\mathrm{NL}$ & $\mathrm{NL}$ & $\mathrm{NL}$ & $\mathrm{NL}$ & $\mathrm{PL}$ & $\mathrm{PL}$ & $\mathrm{PL}$ & $\mathrm{PL}$ & $\mathrm{PL}$ & $\overline{P L}$ & $\mathrm{PL}$ & $\mathrm{NL}$ & $\mathrm{NL}$ & $\overline{N L}$ & $\overline{N L}$ \\
\hline Barbados & LV & LV & LV & LV & LV & LV & LV & LV & LV & LV & LV & LV & LV & LV & LV & LV & LV & LV \\
\hline Canada & LV & LV & LV & LV & LV & LV & LV & LV & LV & LV & LV & LV & LV & LV & LV & LV & LV & LV \\
\hline Cingapura & $\mathrm{PL}$ & $\mathrm{PL}$ & $\mathrm{PL}$ & $\mathrm{PL}$ & $\mathrm{PL}$ & $\mathrm{PL}$ & $\mathrm{PL}$ & $\mathrm{PL}$ & $\mathrm{PL}$ & $\mathrm{PL}$ & $\mathrm{PL}$ & $\mathrm{PL}$ & $\mathrm{PL}$ & $\mathrm{PL}$ & $\mathrm{PL}$ & $\mathrm{PL}$ & $\mathrm{PL}$ & $\mathrm{PL}$ \\
\hline Coréia do Sul & LV & LV & LV & LV & LV & LV & LV & LV & LV & LV & LVV & LV & LV & LVV & LV & LV & LV & LV \\
\hline $\begin{array}{l}\text { Croácia } \\
\end{array}$ & & & & & & LV & $\mathrm{LV}$ & $\mathrm{LV}$ & LV & LV & LV & $\mathrm{LV}$ & LVV & $\mathrm{LV}$ & $\mathrm{LV}$ & LV & $\mathrm{LV}$ & LV \\
\hline Hong Kong & $\mathrm{NL}$ & $\mathrm{NL}$ & $\mathrm{NL}$ & $\mathrm{NL}$ & $\mathrm{NL}$ & $\mathrm{NL}$ & $\mathrm{NL}$ & $\mathrm{NL}$ & $\mathrm{NL}$ & $\mathrm{NL}$ & $\mathrm{NL}$ & $\mathrm{NL}$ & $\overline{\mathrm{NL}}$ & $\mathrm{NL}$ & $\mathrm{NL}$ & $\mathrm{NL}$ & $\mathrm{NL}$ & $\mathrm{NL}$ \\
\hline Islândia & |LV & LV & LV & LV & LV & LV & LV & LV & LV & LV & LV & LV & LV & LV & LV & LV & LV & LV \\
\hline Israel & LV & LV & LV & LV & LV & LV & LV & LV & LV & LV & LV & LV & LV & LV & LV & LV & LV & LV \\
\hline Japão & LV & LV & LV & LV & LV & LV & LV & LV & LV & LV & LV & LV & LV & LV & LV & LV & LV & LV \\
\hline Kuwait & $\mathrm{PL}$ & $\mathrm{PL}$ & $\mathrm{PL}$ & $\mathrm{PL}$ & $\mathrm{PL}$ & $\mathrm{PL}$ & $\mathrm{PL}$ & $\mathrm{PL}$ & $\mathrm{PL}$ & $\mathrm{PL}$ & $\mathrm{PL}$ & $\mathrm{PL}$ & $\mathrm{PL}$ & $\mathrm{PL}$ & $\mathrm{PL}$ & $\mathrm{PL}$ & $\mathrm{PL}$ & $\mathrm{PL}$ \\
\hline Nova Zelândia & LV & LV & LV & LV & LV & LV & LV & LV & LV & LV & LV & LV & LLV & LV & LV & LV & LV & LV \\
\hline Noruega & LV & LV & LV & LV & LV & LV & LV & $\mathrm{LV}$ & LV & $\mathrm{LV}$ & LV & $\mathrm{LV}$ & $\mathrm{LV}$ & LV & LV & LV & LV & LV \\
\hline Omã & & & & & & NL & $\mathrm{NL}$ & NL & NL & NL & $\mathrm{NL}$ & NL & NL & NL & NL & NL & NL & NL \\
\hline Suíça & LV & LV & $\mathrm{LV}$ & LV & $\mathrm{LV}$ & LV & $\mathrm{LV}$ & $\mathrm{LV}$ & LV & $\mathrm{LV}$ & $\mathrm{LV}$ & $\mathrm{LV}$ & $\mathrm{LV}$ & $\mathrm{LV}$ & $\mathrm{LV}$ & LV & $\mathrm{LV}$ & LV \\
\hline $\begin{array}{l}\text { Taiwan } \\
\end{array}$ & & & & & & & & $\mathrm{LV}$ & LV & $\mathrm{LV}$ & $\mathrm{LV}$ & LV & $\mathrm{LV}$ & LV & LV & LV & LV & LV \\
\hline Trinidad e Tobago & LV & LV & LV & LV & LV & LV & $\mathrm{PL}$ & $\mathrm{PL}$ & $\mathrm{PL}$ & $\mathrm{PL}$ & LV & LV & LV & LV & LV & LV & LV & LV \\
\hline Catar & & $\mathrm{NL}$ & NL & $\mathrm{NL}$ & $\mathrm{NL}$ & $\mathrm{NL}$ & $\mathrm{NL}$ & NL & $\mathrm{NL}$ & $\mathrm{NL}$ & $\mathrm{NL}$ & $\mathrm{NL}$ & $\mathrm{NL}$ & $\mathrm{NL}$ & NL & $\mathrm{NL}$ & $\mathrm{NL}$ & $\mathrm{NL}$ \\
\hline Macau & NL & $\mathrm{NL}$ & $\mathrm{NL}$ & NL & $\mathrm{NL}$ & $\mathrm{NL}$ & $\mathrm{NL}$ & $\mathrm{NL}$ & $\mathrm{NL}$ & $\mathrm{NL}$ & $\mathrm{NL}$ & $\mathrm{NL}$ & $\mathrm{NL}$ & $\mathrm{NL}$ & $\mathrm{NL}$ & $\mathrm{NL}$ & $\mathrm{NL}$ & $\mathrm{NL}$ \\
\hline \multicolumn{19}{|c|}{ EM DESENVOLVIMENTO } \\
\hline
\end{tabular}




\begin{tabular}{|c|c|c|c|c|c|c|c|c|c|c|c|c|c|c|c|c|c|c|}
\hline \multicolumn{19}{|c|}{ Renda Média-Alta } \\
\hline África do Sul & LV & LV & LV & LV & LV & LV & LV & LV & LV & LV & LV & LV & LV & LV & LV & LV & LV & LV \\
\hline Antigua e Barbuda & PL & PL & PL & |PL & $\mathrm{PL}$ & PL & PL & PL & PL & PL & LV & LV & LV & LV & LV & LV & LV & LV \\
\hline Argentina & LV & LV & LV & LV & LV & LV & PL & PL & LV & LV & LV & LV & LV & LV & LV & LV & LV & LV \\
\hline Brasil & PL & PL & PL & PL & $\mathrm{PL}$ & PL & PL & LV & LV & LV & LV & LV & LV & LV & LV & LV & LV & LV \\
\hline Chile & LV & LV & LV & LV & LV & LV & LV & LV & LV & LV & LV & LV & LV & LV & LV & LV & LV & LV \\
\hline Colômbia & PL & $\mid$ PL & $\mid$ PL & $\mid \mathrm{PL}$ & $\mathrm{PL}$ & PL & PL & PL & PL & PL & PL & PL & PL & $\mathrm{PL}$ & PL & $\mathrm{PL}$ & PL & $\mathrm{PL}$ \\
\hline Costa Rica & LV & LV & LV & LV & LV & LV & LV & LV & LV & LV & LV & LV & LV & LV & LV & LV & LV & LV \\
\hline Cuba & NL & |NL & NL & NL & NL & NL & NL & NL & NL & NL & NL & NL & NL & $\mathrm{NL}$ & NL & $\mathrm{NL}$ & NL & $\mathrm{NL}$ \\
\hline Dominica & LV & LV & LV & LV & LV & LV & LV & LV & LV & LV & LV & LV & LV & LV & LV & LV & LV & LV \\
\hline Granada & & LV & $\mid$ |LV & |LV & LV & LV & LV & LV & LV & LV & LV & LV & LV & LV & LV & LV & LV & LV \\
\hline Jamaica & LV & LV & $\mid$ |LV & |LV & LV & LV & LV & LV & LV & LV & LV & LV & LV & LV & LV & LV & LV & LV \\
\hline Malásia & PL & PL & $\mid$ |PL & PL & PL & PL & PL & PL & PL & PL & PL & PL & PL & $\mathrm{PL}$ & PL & $\mathrm{PL}$ & PL & $\mathrm{PL}$ \\
\hline Maurício & LV & LV & $\mid$ |LV & | LV & LV & LV & LV & LV & LV & LV & LV & LV & LV & LV & LV & LV & LV & LV \\
\hline México & PL & $\mid$\begin{tabular}{||l} 
PL \\
\end{tabular} & $\mid$\begin{tabular}{||l} 
PL \\
\end{tabular} & $\mid$\begin{tabular}{||l} 
PL \\
D
\end{tabular} & PL & LV & LV & LV & LV & LV & LV & LV & LV & LV & LV & LV & PL & $\mathrm{PL}$ \\
\hline Namíbia & LV & |LV & |LV & $\mid$\begin{tabular}{||l}
$\mid l$ \\
LV
\end{tabular} & LV & LVV & LV & LV & LV & LV & LV & LV & LV & LV & LV & LV & LV & LV \\
\hline Panamá & & & $\mid$ LV & $\mid$\begin{tabular}{||l}
$\mid l$ \\
LV
\end{tabular} & LV & LV & LV & LV & LV & LV & LV & LV & LV & LV & LV & LV & LV & LV \\
\hline Peru & PL & $\mid$ PL & $\mid$ PL & PL & PL & PL & LV & LV & LV & LV & LV & LV & LV & LV & LV & LV & LV & LV \\
\hline R. Dominicana & PL & $\mid$ PL & $\mid$ |PL & LV & LV & LV & LV & LV & LV & LV & LV & LV & LV & LV & LV & LV & LV & LV \\
\hline Rússia & & & & & & & & & & & & & & & & & & $\mathrm{NL}$ \\
\hline St. Kitts e Nevis & & 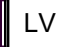 & $\mid$ |LV & | LV & LV & LV & LV & LV & LV & LV & LV & LV & LV & LV & LV & LV & LV & LV \\
\hline St. Lúcia & LV & |LV & $\mid$ LV & LV & LV & LV & LV & LV & LV & LV & LV & LV & LV & LV & LV & LV & LV & LV \\
\hline Vincente e Granadinas & LV & |LV & $\mid$ | LV & | LV & LV & |LV & LV & LV & LV & LV & LV & LV & LV & LV & LV & LV & LV & LV \\
\hline Suriname & PL & PL & $\mid$ PL & PL & PL & LV & LV & LV & LV & LV & LV & LV & LV & LV & LV & LV & LV & LV \\
\hline Turquia & PL & $\mid$\begin{tabular}{||l} 
PL \\
\end{tabular} & $\mid$ |PL & 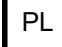 & PL & PL & PL & PL & PL & PL & PL & PL & PL & $\mathrm{PL}$ & PL & $\mathrm{PL}$ & PL & PL \\
\hline Uruguai & LV & |LV & $\mid$ |LV & $\mid$ |LV & LV & LV & LV & LV & LV & LV & LV & LV & LV & LV & LV & LV & LV & 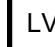 \\
\hline Venezuela & PL & |LV & 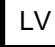 & |LV & PL & PL & PL & PL & $\mathrm{PL}$ & PL & PL & PL & PL & $\mathrm{PL}$ & PL & $\mathrm{PL}$ & $\mathrm{PL}$ & PL \\
\hline Albânia & & & & & & PL & PL & $\mathrm{PL}$ & $\mathrm{PL}$ & PL & PL & PL & PL & $\mathrm{PL}$ & PL & $\mathrm{PL}$ & $\mathrm{PL}$ & $\mathrm{PL}$ \\
\hline Botswana & LV & |LV & LV & LV & LI & LV & LV & LV & LV & LV & LV & LV & LV & LV & LV & LV & LV & LV \\
\hline
\end{tabular}




\begin{tabular}{|c|c|c|c|c|c|c|c|c|c|c|c|c|c|c|c|c|c|c|}
\hline Gabão & \begin{tabular}{|l}
$\mathrm{PL}$ \\
\end{tabular} & $\mathrm{PL}$ & $\mathrm{PL}$ & $\mathrm{PL}$ & $\mathrm{PL}$ & PL & $\mathrm{PL}$ & $\mathrm{PL}$ & $\mathrm{PL}$ & $\mathrm{PL}$ & $\mathrm{PL}$ & $\mathrm{PL}$ & $\mathrm{PL}$ & \begin{tabular}{|l|}
$\mathrm{PL}$ \\
\end{tabular} & \begin{tabular}{|l||}
$N L$ \\
\end{tabular} & $\mathrm{NL}$ & $\mathrm{NL}$ & $\mathrm{PL}$ \\
\hline Jordânia & & & & & & PL & $\begin{array}{l}\mathrm{PL} \\
\end{array}$ & $\overline{P L}$ & PL & $\mathrm{PL}$ & $P$ PL & $P$ PL & $\mathrm{PL}$ & $\mathrm{PL}$ & NL & $\mathrm{NL}$ & $\mathrm{NL}$ & $\mathrm{NL}$ \\
\hline Maldivas & $\mathrm{NL}$ & $\mathrm{NL}$ & $\mathrm{NL}$ & $\mathrm{NL}$ & $\mathrm{NL}$ & NL & $\mathrm{NL}$ & $\mathrm{NL}$ & $\mathrm{NL}$ & $\mathrm{NL}$ & $\mathrm{NL}$ & $\mathrm{NL}$ & $\mathrm{NL}$ & $\mathrm{NL}$ & NL & $\mathrm{PL}$ & $\mathrm{PL}$ & PL \\
\hline Montenegro & & & & & & & & & & & & & & & & & & LV \\
\hline Tonga & & & & & & & & & & & & & $\mathrm{PL}$ & $\mathrm{PL}$ & PL & $\mathrm{PL}$ & $\mathrm{PL}$ & |PL \\
\hline Tunísia & $\mathrm{NL}$ & $\mathrm{NL}$ & $\mathrm{PL}$ & $\mathrm{NL}$ & $\mathrm{NL}$ & NL & $\mathrm{NL}$ & $\overline{N L}$ & $\mathrm{NL}$ & $\mathrm{NL}$ & $\mathrm{NL}$ & $\mathrm{NL}$ & $\mathrm{NL}$ & $\mathrm{NL}$ & NL & $\mathrm{NL}$ & $\mathrm{NL}$ & $\mathrm{PL}$ \\
\hline Macedônia & & & & & & & & & $\mathrm{PL}$ & $\mathrm{PL}$ & $\mathrm{PL}$ & $\mathrm{PL}$ & $\mathrm{PL}$ & $\mathrm{PL}$ & $P L$ & $\mathrm{PL}$ & $\mathrm{PL}$ & PL \\
\hline \multicolumn{19}{|c|}{ Renda Média-Baixa } \\
\hline Armênia & & & & & & & & & $\mathrm{PL}$ & $\mathrm{PL}$ & $\mathrm{PL}$ & $\mathrm{PL}$ & $\mathrm{PL}$ & $\mathrm{PL}$ & \begin{tabular}{|l|}
$P L$ \\
\end{tabular} & $\mathrm{PL}$ & $\mathrm{PL}$ & PL \\
\hline Belize & $\overline{L L V}$ & LV & LV & LV & LV & LV & \begin{tabular}{|l|} 
LVV \\
\end{tabular} & $\overline{L L V}$ & LV & LV & 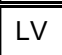 & LVV & LV & LV & LV & LV & $\overline{\mathrm{LLV}}$ & $\overline{L V}$ \\
\hline Bolívia & $\mathrm{PL}$ & LV & LV & LV & LV & LV & LV & LV & $\mathrm{PL}$ & $\mathrm{PL}$ & $\mathrm{PL}$ & $\mathrm{PL}$ & $\mathrm{PL}$ & $\mathrm{PL}$ & \begin{tabular}{|l||}
$P L$ \\
\end{tabular} & $\mathrm{PL}$ & $\mathrm{PL}$ & PL \\
\hline Camarões & $\mathrm{NL}$ & $\mathrm{NL}$ & $\mathrm{NL}$ & $\mathrm{NL}$ & $\mathrm{NL}$ & NL & \begin{tabular}{|l|}
$\mathrm{NL}$ \\
\end{tabular} & $\mathrm{NL}$ & $\mathrm{NL}$ & $\mathrm{NL}$ & $\mathrm{NL}$ & $\mathrm{NL}$ & $\mathrm{NL}$ & $\mathrm{NL}$ & NL & $\mathrm{NL}$ & $\mathrm{NL}$ & $\mathrm{NL}$ \\
\hline China & & & & & & & $\mathrm{NL}$ & $\mathrm{NL}$ & $\mathrm{NL}$ & $\mathrm{NL}$ & $\mathrm{NL}$ & $\mathrm{NL}$ & $\mathrm{NL}$ & $\mathrm{NL}$ & NL & $\mathrm{NL}$ & $\mathrm{NL}$ & $\mid$\begin{tabular}{||ll}
$\mid N L$ \\
\end{tabular} \\
\hline Costa do Marfim & NL & NL & NL & $\mathrm{PL}$ & $\mathrm{PL}$ & PL & $\mathrm{NL}$ & NL & $\mathrm{NL}$ & NL & NL & NL & $\mathrm{NL}$ & $\mathrm{NL}$ & NL & NL & NL & NL \\
\hline Egito & $\mathrm{NL}$ & $\mathrm{NL}$ & $\mathrm{NL}$ & $\mathrm{NL}$ & $\mathrm{NL}$ & NL & $\mathrm{NL}$ & $\mathrm{NL}$ & $\mathrm{NL}$ & $\mathrm{NL}$ & $\mathrm{NL}$ & $\mathrm{NL}$ & $\mathrm{NL}$ & $\mathrm{NL}$ & NL & $\mathrm{NL}$ & $\mathrm{NL}$ & NL \\
\hline El Salvador & PL & $\mathrm{PL}$ & LV & LV & LV & LV & LV & LV & LV & LV & LV & LV & LV & LV & LV & LV & LV & LV \\
\hline Equador & & $\mathrm{PL}$ & $\mathrm{PL}$ & LV & LV & $\mathrm{PL}$ & $\mathrm{PL}$ & $\mathrm{PL}$ & $\mathrm{PL}$ & $\mathrm{PL}$ & $\mathrm{PL}$ & $\mathrm{PL}$ & $\mathrm{PL}$ & $\mathrm{PL}$ & $\mathrm{PL}$ & $\mathrm{PL}$ & $\mathrm{PL}$ & $\mathrm{PL}$ \\
\hline Fiji & & $\mathrm{PL}$ & $\mathrm{PL}$ & $\mathrm{PL}$ & $\mathrm{PL}$ & $\mathrm{PL}$ & $\mathrm{PL}$ & $\mathrm{PL}$ & $\mathrm{PL}$ & $\mathrm{PL}$ & $\mathrm{PL}$ & $\mathrm{PL}$ & $\mathrm{PL}$ & $\mathrm{PL}$ & $\mathrm{PL}$ & $\mathrm{PL}$ & $\mathrm{PL}$ & $\mathrm{PL}$ \\
\hline Filipinas & $\overline{P \mathrm{PL}}$ & LV & $\mid \overline{L V}$ & LV & LV & LV & \begin{tabular}{l|l|} 
LVV \\
\end{tabular} & LV & LV & LV & $\mathrm{PL}$ & $\mathrm{PL}$ & $\mathrm{PL}$ & $\mathrm{PL}$ & PL & $\mathrm{PL}$ & $\mathrm{PL}$ & $\mathrm{PL}$ \\
\hline Guatemala & $\mathrm{PL}$ & $\mathrm{PL}$ & PL & $\mathrm{PL}$ & $\mathrm{PL}$ & $\mathrm{PL}$ & $\mathrm{PL}$ & PL & $\mathrm{PL}$ & $\mathrm{PL}$ & $\mathrm{PL}$ & $\mathrm{PL}$ & $\mathrm{PL}$ & $\mathrm{PL}$ & PL & $\mathrm{PL}$ & $\mathrm{PL}$ & PL \\
\hline 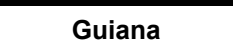 & LVV & LVV & $\mid \overline{L V V}$ & LV & LVV & LV & $\begin{array}{ll}\mathrm{LV} \\
\end{array}$ & 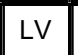 & $\overline{L L V}$ & LV & $\mathrm{PL}$ & LV & LV & LV & LV & LV & LV & $\overline{L V V}$ \\
\hline Honduras & $\mathrm{PL}$ & $\mathrm{PL}$ & LV & LV & $\mathrm{PL}$ & $\mathrm{PL}$ & $\mathrm{PL}$ & $\mathrm{PL}$ & $\mathrm{PL}$ & $\mathrm{PL}$ & $\mathrm{PL}$ & $\mathrm{PL}$ & $\mathrm{PL}$ & $\mathrm{PL}$ & \begin{tabular}{|l|}
$\mathrm{PL}$ \\
\end{tabular} & $\mathrm{PL}$ & $\mathrm{PL}$ & \begin{tabular}{|l}
$\mathrm{PL}$ \\
\end{tabular} \\
\hline Índia & $\mathrm{PL}$ & $\mathrm{PL}$ & $\mathrm{PL}$ & LV & LV & LV & LV & LV & LV & LV & LV & LV & LV & \begin{tabular}{|l|} 
LV \\
\end{tabular} & LV & LV & LV & LV \\
\hline Indonésia & $\mathrm{NL}$ & $\mathrm{NL}$ & NL & $\mathrm{PL}$ & $\mathrm{PL}$ & $\mathrm{PL}$ & $\mathrm{PL}$ & $\mathrm{PL}$ & $\mathrm{PL}$ & $\mathrm{PL}$ & LV & LV & LV & LV & LV & LV & LV & LV \\
\hline Moldávia & & & & & & & $\mathrm{PL}$ & $\mathrm{PL}$ & $\mathrm{PL}$ & $\mathrm{PL}$ & $\mathrm{PL}$ & $\mathrm{PL}$ & $\mathrm{PL}$ & $\mathrm{PL}$ & PL & $\mathrm{PL}$ & $\mathrm{PL}$ & PL \\
\hline Nicarágua & $\mathrm{PL}$ & $\mathrm{PL}$ & PL & $\mathrm{PL}$ & $\mathrm{PL}$ & PL & $\mathrm{PL}$ & $\mathrm{PL}$ & $\mathrm{PL}$ & $\mathrm{PL}$ & $\mathrm{PL}$ & $\mathrm{PL}$ & $\mathrm{PL}$ & $\mathrm{PL}$ & $\mathrm{PL}$ & $\mathrm{PL}$ & $\mathrm{PL}$ & PL \\
\hline Nigéria & $\mathrm{NL}$ & $\mathrm{NL}$ & $\mathrm{NL}$ & $\mathrm{PL}$ & $\mathrm{PL}$ & \begin{tabular}{|l|}
$\mathrm{PL}$ \\
\end{tabular} & $\mathrm{PL}$ & $\mathrm{PL}$ & $\mathrm{PL}$ & $\mathrm{PL}$ & $\mathrm{PL}$ & $\mathrm{PL}$ & $\mathrm{PL}$ & $\mathrm{PL}$ & $\mathrm{PL}$ & $\mathrm{PL}$ & $\mathrm{PL}$ & $\mathrm{PL}$ \\
\hline Paquistão & $\mathrm{PL}$ & $\mathrm{PL}$ & $\mathrm{PL}$ & $\mathrm{PL}$ & $\mathrm{NL}$ & NL & $\mathrm{NL}$ & $\mathrm{NL}$ & $\mathrm{NL}$ & $\mathrm{NL}$ & $\mathrm{NL}$ & $\mathrm{NL}$ & $\mathrm{NL}$ & $\mathrm{PL}$ & \begin{tabular}{|l|l|}
$\mathrm{PL}$ \\
\end{tabular} & $\mathrm{PL}$ & $\mathrm{PL}$ & $\mathrm{PL}$ \\
\hline Paraguai & PL & $\mathrm{PL}$ & PL & $\mathrm{PL}$ & $\mathrm{PL}$ & PL & $\mathrm{PL}$ & PL & $\mathrm{PL}$ & $\mathrm{PL}$ & $\mathrm{PL}$ & $\mathrm{PL}$ & $\mathrm{PL}$ & $\mathrm{PL}$ & PL & $\mathrm{PL}$ & $\mathrm{PL}$ & PL \\
\hline
\end{tabular}




\begin{tabular}{|c|c|c|c|c|c|c|c|c|c|c|c|c|c|c|c|c|c|c|}
\hline Sri Lanka & \begin{tabular}{|l|}
$P L$ \\
\end{tabular} & $\mathrm{PL}$ & \begin{tabular}{|l|}
$\mathrm{PL}$ \\
\end{tabular} & $\mathrm{PL}$ & $\mathrm{PL}$ & PL & \begin{tabular}{|l|}
$\mathrm{PL}$ \\
\end{tabular} & \begin{tabular}{|l|}
$\mathrm{PL}$ \\
\end{tabular} & $\mathrm{PL}$ & $\mathrm{PL}$ & $\mathrm{PL}$ & $\mathrm{PL}$ & $\mathrm{PL}$ & \begin{tabular}{|l|}
$\mathrm{PL}$ \\
\end{tabular} & \begin{tabular}{|l||}
$\mathrm{PL}$ \\
\end{tabular} & $\mathrm{PL}$ & $\mathrm{PL}$ & $\mathrm{PL}$ \\
\hline Swazilândia & $\mathrm{NL}$ & $\mathrm{NL}$ & $\mathrm{NL}$ & $\mathrm{NL}$ & $\mathrm{NL}$ & $\mathrm{NL}$ & $\mathrm{NL}$ & $\mathrm{NL}$ & $\mathrm{NL}$ & $\mathrm{NL}$ & $\mathrm{NL}$ & $\mathrm{NL}$ & $\mathrm{NL}$ & $\mathrm{NL}$ & \begin{tabular}{|l||}
$N L$ \\
\end{tabular} & $\mathrm{NL}$ & $\mathrm{NL}$ & NL \\
\hline Tailândia & $\mathrm{PL}$ & $\mathrm{PL}$ & $\mathrm{PL}$ & LV & LV & LV & LV & LV & LV & LV & $\mathrm{PL}$ & $\mathrm{PL}$ & $\mathrm{PL}$ & $\mathrm{PL}$ & \begin{tabular}{|l||}
$P L$ \\
\end{tabular} & $\mathrm{PL}$ & $\mathrm{PL}$ & PL \\
\hline Ucrânia & & & & & & & & & & & & & & LV & LV & $\mathrm{PL}$ & $\mathrm{PL}$ & PL \\
\hline Cabo Verde & & & & & & & & & & & & & & LV & LV & LV & LV & LV \\
\hline Congo & & & $\mathrm{NL}$ & $\mathrm{NL}$ & $\mathrm{NL}$ & $\mathrm{PL}$ & $\mathrm{PL}$ & $\mathrm{PL}$ & $\mathrm{PL}$ & $\mathrm{PL}$ & $\overline{P L}$ & $\mathrm{NL}$ & $\mathrm{NL}$ & $\mathrm{NL}$ & NL & $\mathrm{NL}$ & $\mathrm{NL}$ & NL \\
\hline Georgia & & & & & & PL & $\mathrm{PL}$ & $\mathrm{PL}$ & $\mathrm{PL}$ & $\mathrm{PL}$ & $\mathrm{PL}$ & $\mathrm{PL}$ & $\mathrm{PL}$ & $\mathrm{PL}$ & $P L$ & $\mathrm{PL}$ & $\mathrm{PL}$ & PL \\
\hline Lesoto & $\overline{P L}$ & $\mathrm{PL}$ & $\mathrm{PL}$ & $\mathrm{PL}$ & $\mathrm{PL}$ & $\mathrm{PL}$ & \begin{tabular}{l|l|}
$\mathrm{PL}$ \\
\end{tabular} & LV & LV & LV & 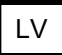 & LV & LV & LV & PL & $\mathrm{PL}$ & $\mathrm{PL}$ & $\mathrm{PL}$ \\
\hline Mauritânia & $\mathrm{NL}$ & $\mathrm{NL}$ & $\mathrm{NL}$ & $\mathrm{NL}$ & $\mathrm{NL}$ & $\mathrm{PL}$ & $\mathrm{PL}$ & $\mathrm{NL}$ & $\mathrm{NL}$ & $\mathrm{PL}$ & $\mathrm{PL}$ & $\mathrm{PL}$ & $\mathrm{NL}$ & $\mathrm{NL}$ & $\mathrm{NL}$ & $\mathrm{NL}$ & $\mathrm{NL}$ & NL \\
\hline Mongólia & & & LVV & LV & LV & LV & LLV & $\overline{\mathrm{LLV}}$ & LV & LVV & 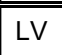 & LVV & LLV & LV & LV & LVV & LV & $\overline{L V V}$ \\
\hline Marrocos & $\mathrm{PL}$ & $\mathrm{PL}$ & $\mathrm{PL}$ & $\mathrm{PL}$ & $\mathrm{PL}$ & $\mathrm{PL}$ & $\mathrm{PL}$ & $P \mathrm{PL}$ & $\mathrm{PL}$ & $\mathrm{PL}$ & $\mathrm{PL}$ & $\mathrm{PL}$ & $\mathrm{PL}$ & $\mathrm{PL}$ & \begin{tabular}{|l||}
$P L$ \\
\end{tabular} & $\mathrm{PL}$ & $\mathrm{PL}$ & PL \\
\hline Papua Nova Guiné & & $\mathrm{PL}$ & $\mathrm{PL}$ & LV & LV & LV & \begin{tabular}{|l|}
$\mathrm{LV}$ \\
\end{tabular} & LV & $\mathrm{PL}$ & $\mathrm{PL}$ & $P \mathrm{PL}$ & $\mathrm{PL}$ & $\mathrm{PL}$ & $\mathrm{PL}$ & PL & $P \mathrm{PL}$ & $\mathrm{PL}$ & PL \\
\hline Samoa & & & & & & & & & & & & & & & & & & $\overline{L V}$ \\
\hline Ilhas Salomão & & LV & LV & LV & LV & $\mathrm{PL}$ & $\mathrm{PL}$ & $\mathrm{PL}$ & $\mathrm{PL}$ & $\mathrm{PL}$ & $\mathrm{PL}$ & $\mathrm{PL}$ & $\mathrm{PL}$ & $\mathrm{PL}$ & PL & $\mathrm{PL}$ & $\mathrm{PL}$ & PL \\
\hline & & & & & & & PMD & & & & & & & & & & & \\
\hline Bangladesh & PL & LV & PL & $\mathrm{PL}$ & $\mathrm{PL}$ & PL & $\mathrm{PL}$ & PL & $\mathrm{PL}$ & PL & PL & PL & $\mathrm{PL}$ & $\mathrm{PL}$ & PL & $\mathrm{PL}$ & PL & |PL \\
\hline Benin & & LV & LV & LV & LV & LV & LV & LV & LV & LV & LV & LV & LV & LV & LV & LV & LV & LV \\
\hline Gana & $\mathrm{PL}$ & $\mathrm{PL}$ & $\mathrm{PL}$ & $\mathrm{PL}$ & $\mathrm{PL}$ & LV & $\begin{array}{ll}\text { LVV } \\
\end{array}$ & LV & LV & LV & LV & LV & LV & LV & LV & LV & LV & $\mid \overline{L V}$ \\
\hline Madagascar & $\mathrm{PL}$ & $\mathrm{PL}$ & $\overline{P L}$ & $\mathrm{PL}$ & $\mathrm{PL}$ & $\mathrm{PL}$ & $\mathrm{PL}$ & $\overline{P L}$ & $\mathrm{PL}$ & $\overline{P L}$ & $\mathrm{PL}$ & $\mathrm{PL}$ & $\mathrm{PL}$ & $\mathrm{PL}$ & PL & $\mathrm{PL}$ & $\overline{P L}$ & $\mathrm{PL}$ \\
\hline Malawi & LV & LV & LV & LV & $\mathrm{PL}$ & $\mathrm{PL}$ & $\mathrm{PL}$ & $\mathrm{PL}$ & $\mathrm{PL}$ & \begin{tabular}{|l|}
$P L$ \\
\end{tabular} & $\mathrm{PL}$ & $\mathrm{PL}$ & $\mathrm{PL}$ & $\mathrm{PL}$ & PL & $\mathrm{PL}$ & $\mathrm{PL}$ & PL \\
\hline Q Quênia & $\overline{\mathrm{NL}}$ & $\mathrm{NL}$ & $\overline{N \mathrm{NL}}$ & $\mathrm{NL}$ & $\mathrm{NL}$ & NL & NL & $\overline{P P L}$ & $\mathrm{PL}$ & $\overline{P \mathrm{PL}}$ & $\mathrm{PL}$ & $\begin{array}{ll}\mathrm{PL} \\
\end{array}$ & $\mathrm{PL}$ & $\mathrm{PL}$ & $\mathrm{PL}$ & $\mathrm{PL}$ & $\overline{P \mathrm{PL}}$ & $\mathrm{PL}$ \\
\hline Senegal & $\mathrm{PL}$ & $\mathrm{PL}$ & PL & $\mathrm{PL}$ & $\mathrm{PL}$ & PL & PL & LV & LV & LV & LV & LV & LV & $\mathrm{PL}$ & PL & $\mathrm{PL}$ & PL & PL \\
\hline Tanzânia & $\mathrm{NL}$ & $\mathrm{PL}$ & PL & $\mathrm{PL}$ & $\mathrm{PL}$ & PL & $\mathrm{PL}$ & PL & $\mathrm{PL}$ & PL & $\mathrm{PL}$ & $\mathrm{PL}$ & $\mathrm{PL}$ & $\mathrm{PL}$ & PL & $\mathrm{PL}$ & PL & PL \\
\hline Vietnã & & & & & & & & & & & & & $\mathrm{NL}$ & $\mathrm{NL}$ & NL & $\mathrm{NL}$ & $\mathrm{NL}$ & $\mathrm{NL}$ \\
\hline Zâmbia & NL & NL & NL & $\mathrm{NL}$ & NL & NL & $\mathrm{NL}$ & NL & NL & NL & NL & NL & NL & $\mathrm{NL}$ & NL & NL & NL & NL \\
\hline Zimbábue & PL & $\mathrm{PL}$ & PL & $\mathrm{PL}$ & PL & PL & $\mathrm{NL}$ & NL & NL & NL & NL & NL & NL & $\mathrm{NL}$ & NL & NL & NL & NL \\
\hline Burkina Faso & PL & $\mathrm{PL}$ & PL & $\mathrm{PL}$ & PL & PL & $\mathrm{PL}$ & PL & $\mathrm{PL}$ & PL & PL & PL & $\mathrm{PL}$ & $\mathrm{PL}$ & PL & $\mathrm{PL}$ & PL & PL \\
\hline Burundi & $\mathrm{NL}$ & $\mathrm{NL}$ & $\mathrm{NL}$ & $\mathrm{NL}$ & $\mathrm{NL}$ & $\mathrm{NL}$ & $\mathrm{NL}$ & $\mathrm{NL}$ & $\mathrm{PL}$ & $\mathrm{PL}$ & $\mathrm{PL}$ & $\mathrm{PL}$ & $\mathrm{PL}$ & $\mathrm{PL}$ & $\mathrm{PL}$ & $\mathrm{PL}$ & $\mathrm{PL}$ & $\mathrm{PL}$ \\
\hline Camboja & & & & & & & & & & $\mathrm{NL}$ & $\mathrm{NL}$ & $\mathrm{NL}$ & $\mathrm{NL}$ & $\mathrm{NL}$ & NL & $\mathrm{NL}$ & $\mathrm{NL}$ & NL \\
\hline
\end{tabular}




\begin{tabular}{|c|c||c||c|c|c|c||c|c|c|c||c||c|c||c|c||c|c|c|}
\hline R. Centro-Africana & $\mathrm{PL}$ & $\mathrm{PL}$ & $\mathrm{PL}$ & $\mathrm{PL}$ & $\mathrm{PL}$ & $\mathrm{PL}$ & $\mathrm{PL}$ & $\mathrm{PL}$ & $\mathrm{NL}$ & $\mathrm{NL}$ & $\mathrm{PL}$ & $\mathrm{PL}$ & $\mathrm{PL}$ & $\mathrm{PL}$ & $\mathrm{PL}$ & $\mathrm{PL}$ & $\mathrm{PL}$ & $\mathrm{PL}$ \\
\hline \hline Gâmbia & & $\mathrm{NL}$ & $\mathrm{NL}$ & $\mathrm{NL}$ & $\mathrm{NL}$ & $\mathrm{NL}$ & $\mathrm{PL}$ & $\mathrm{PL}$ & $\mathrm{PL}$ & $\mathrm{PL}$ & $\mathrm{PL}$ & $\mathrm{PL}$ & $\mathrm{PL}$ & $\mathrm{PL}$ & $\mathrm{PL}$ & $\mathrm{PL}$ & $\mathrm{PL}$ & $\mathrm{PL}$ \\
\hline \hline Guiné & $\mathrm{NL}$ & $\mathrm{NL}$ & $\mathrm{NL}$ & $\mathrm{NL}$ & $\mathrm{NL}$ & $\mathrm{NL}$ & $\mathrm{NL}$ & $\mathrm{NL}$ & $\mathrm{NL}$ & $\mathrm{NL}$ & $\mathrm{NL}$ & $\mathrm{NL}$ & $\mathrm{NL}$ & $\mathrm{NL}$ & $\mathrm{NL}$ & $\mathrm{NL}$ & $\mathrm{PL}$ & $\mathrm{PL}$ \\
\hline \hline Guiné-Bissau & $\mathrm{PL}$ & $\mathrm{PL}$ & $\mathrm{PL}$ & $\mathrm{PL}$ & $\mathrm{PL}$ & $\mathrm{PL}$ & $\mathrm{PL}$ & $\mathrm{PL}$ & $\mathrm{PL}$ & $\mathrm{PL}$ & $\mathrm{PL}$ & $\mathrm{PL}$ & $\mathrm{PL}$ & $\mathrm{PL}$ & $\mathrm{PL}$ & $\mathrm{PL}$ & $\mathrm{PL}$ & $\mathrm{PL}$ \\
\hline \hline Quirguistão & & & & $\mathrm{PL}$ & $\mathrm{PL}$ & $\mathrm{NL}$ & $\mathrm{NL}$ & $\mathrm{NL}$ & $\mathrm{NL}$ & $\mathrm{NL}$ & $\mathrm{PL}$ & $\mathrm{PL}$ & $\mathrm{PL}$ & $\mathrm{PL}$ & $\mathrm{NL}$ & $\mathrm{PL}$ & $\mathrm{PL}$ & $\mathrm{PL}$ \\
\hline \hline Mali & $\mathrm{LV}$ & $\mathrm{LV}$ & $\mathrm{LV}$ & $\mathrm{LV}$ & $\mathrm{LV}$ & $\mathrm{LV}$ & $\mathrm{LV}$ & $\mathrm{LV}$ & $\mathrm{LV}$ & $\mathrm{LV}$ & $\mathrm{LV}$ & $\mathrm{LV}$ & $\mathrm{LV}$ & $\mathrm{LV}$ & $\mathrm{LV}$ & $\mathrm{LV}$ & $\mathrm{LV}$ & $\mathrm{NL}$ \\
\hline Moçambique & $\mathrm{PL}$ & $\mathrm{PL}$ & $\mathrm{PL}$ & $\mathrm{PL}$ & $\mathrm{PL}$ & $\mathrm{PL}$ & $\mathrm{PL}$ & $\mathrm{PL}$ & $\mathrm{PL}$ & $\mathrm{PL}$ & $\mathrm{PL}$ & $\mathrm{PL}$ & $\mathrm{PL}$ & $\mathrm{PL}$ & $\mathrm{PL}$ & $\mathrm{PL}$ & $\mathrm{PL}$ & $\mathrm{PL}$ \\
\hline \hline Nepal & & & & & & & & & & $\mathrm{PL}$ & $\mathrm{PL}$ & $\mathrm{PL}$ & $\mathrm{PL}$ & $\mathrm{PL}$ & $\mathrm{PL}$ & $\mathrm{PL}$ & $\mathrm{PL}$ & $\mathrm{PL}$ \\
\hline \hline Níger & & $\mathrm{NL}$ & $\mathrm{NL}$ & $\mathrm{NL}$ & $\mathrm{PL}$ & $\mathrm{PL}$ & $\mathrm{PL}$ & $\mathrm{PL}$ & $\mathrm{PL}$ & $\mathrm{PL}$ & $\mathrm{PL}$ & $\mathrm{PL}$ & $\mathrm{PL}$ & $\mathrm{PL}$ & $\mathrm{PL}$ & $\mathrm{PL}$ & $\mathrm{PL}$ & $\mathrm{PL}$ \\
\hline \hline Ruanda & & $\mathrm{NL}$ & $\mathrm{NL}$ & $\mathrm{NL}$ & $\mathrm{NL}$ & $\mathrm{NL}$ & $\mathrm{NL}$ & $\mathrm{NL}$ & $\mathrm{NL}$ & $\mathrm{NL}$ & $\mathrm{NL}$ & $\mathrm{NL}$ & $\mathrm{NL}$ & $\mathrm{NL}$ & $\mathrm{NL}$ & $\mathrm{NL}$ & $\mathrm{NL}$ & $\mathrm{NL}$ \\
\hline \hline Togo & $\mathrm{NL}$ & $\mathrm{NL}$ & $\mathrm{NL}$ & $\mathrm{NL}$ & $\mathrm{PL}$ & $\mathrm{PL}$ & $\mathrm{PL}$ & $\mathrm{NL}$ & $\mathrm{NL}$ & $\mathrm{NL}$ & $\mathrm{NL}$ & $\mathrm{NL}$ & $\mathrm{PL}$ & $\mathrm{PL}$ & $\mathrm{PL}$ & $\mathrm{PL}$ & $\mathrm{PL}$ & $\mathrm{PL}$ \\
\hline \hline Uganda & $\mathrm{PL}$ & $\mathrm{PL}$ & $\mathrm{PL}$ & $\mathrm{PL}$ & $\mathrm{PL}$ & $\mathrm{PL}$ & $\mathrm{PL}$ & $\mathrm{PL}$ & $\mathrm{PL}$ & $\mathrm{PL}$ & $\mathrm{PL}$ & $\mathrm{PL}$ & $\mathrm{PL}$ & $\mathrm{PL}$ & $\mathrm{PL}$ & $\mathrm{PL}$ & $\mathrm{PL}$ & $\mathrm{PL}$ \\
\hline
\end{tabular}

Fonte: Elaboração própria. 


\section{Anexo 5 \\ MODELOS: \\ PROGRAMAÇÃO, ESTIMAÇÃO E TESTES}

No presente Anexo apresentaremos a parte final da construção de nossos modelos, alinhada às nossas discussões teóricas e metodológicas precedentes. Para empreender esta tarefa, apresentaremos uma comparação e testes em relação aos modelos "intermediários" (Poisson e Binomial Negativo) investigados na construção de nossos modelos ZINB finais.

$\mathrm{Na}$ primeira seção, serão discutidos aspectos gerais da programação das estimações dos modelos. Na segunda seção introduziremos os conceitos de teste de modelos e de significância de coeficientes que serão necessários na interpretação dos resultados.

\section{A5.1. Programação e estimação dos modelos (Poisson, BN e ZINB)}

$\mathrm{Na}$ presente seção apresentaremos a programação para a estimação dos diferentes modelos "intermediários" investigados até a consecução de nossos modelos finais para ambos os polos (ativo e passivo). Com base na avaliação dos resultados destes modelos, que serão apresentados na próxima seção, procuraremos demonstrar que a proposta de modelagem multinível do tipo ZINB específica desenvolvida neste trabalho é adequada para o tratamento do fenômeno aqui estudado.

Para o suporte computacional ao desenho e às estimações de nossos modelos utilizaremos o software "Statistical Analysis System" (SAS), versão do módulo STAT 13.2, por meio de duas maneiras simultâneas:

i) edição "SAS University Edition"1 rodando localmente; e

ii) edição "SAS OnDemand for Academics"2 rodando a partir de computação na nuvem.

1 Disponível em <http://www.sas.com/en_my/software/university-edition.html>. 
A rotina de operações e programação da estimação foi baseada em:

a) "Modeling Count Data" - Compilação de recomendações de códigos e rotinas de programação para estimações de modelos de contagem/painel no SAS proposta por Hilbe (2014), Universidade de Cambridge;

b) "Fitting Multilevel Hierarchical Mixed Models Using PROC NLMIXED" - Roteiro oficial do SAS Institute, proposto por Kurada (2016), para ajustamento de modelos multiníveis não lineares (NLMIXED), permitindo a especificação das funções de ligação e condições de linearidade; $\mathrm{e}$

c) "Analysis of Zero Inflated Longitudinal Data Using PROC NLMIXED" - Rotina proposta originalmente para aplicação em pesquisas na área de saúde e epidemiologia pelo Departamento de Bioestatística da Faculdade de Medicina da Universidade da Carolina do Sul, por Voronca et. al. (2014).

Os modelos (polo ativo e passivo) testados serão: Poisson, Binomial Negativo (BN) e Binomial Negativo Inflado de Zero (ZINB). Os dois primeiros modelos são modelos de apenas um nível que modelam diretamente a valor esperado da contagem (número de reclamações-padrão [aos quais denominaremos REC] ou acionamentos-padrão [aos quais denominaremos $\mathrm{ACl}$ ] feitos no ano), enquanto o último é um modelo multinível onde no primeiro nível modelaremos o processo de inflação de zeros, separando os zeros estruturais dos condicionais, e no segundo nível efetuaremos a modelagem do processo de contagem em si.

Conforme observado anteriormente, é importante notar que estamos utilizando no presente trabalho um conjunto de variáveis dummy para medir os efeitos dos diferentes subgrupos de renda e de abertura do sistema político em nossa modelagem. Dessa forma, para caracterizar o efeito da variação dos valores de dummies específicas de interesse a modelagem precisará estar centrada em um valor de dummy de referência para cada conjunto de variáveis.

Portanto, no caso das dummies de nível de renda optou-se por centrar a modelagem na média dos países desenvolvidos de modo a permitir uma análise do impacto dos coeficientes dos demais grupos de renda em desenvolvimento. Por sua vez, no caso das dummies para abertura do sistema político, a modelagem centrou-se no valor 
de referência LV (sistemas políticos livres/abertos), sendo nosso interesse medir o impacto da redução de liberdade do sistema político com os efeitos das dummies PL e NL na regressão.

Os preditores lineares dos modelos em quaisquer dos níveis serão os mesmos tanto para o polo ativo quanto passivo, tendo em vista que são faces diferentes do mesmo processo e que parte de nosso objetivo neste trabalho é oferecer uma visão holística e integrada do mesmo. No entanto, deve-se observar que a interpretação da direção e valores dos coeficientes deverá ser distinta em cada um dos polos.

Seguindo nossa abordagem anteriormente discutida de Modelos Lineares Generalizados Mistos, nos modelos de apenas um nível (Poisson e BN) teremos apenas o preditor linear de contagem, o qual definiremos como $L_{c}$ e que será dado por:

$L_{c}=c 0+c A A^{*} A A+c A B^{*} A B+c B A^{*} B A+c B B^{*} B B+c M D^{*} M D+c P L{ }^{*} P L+c N L{ }^{*} N L+$ cPIB ${ }^{*} \mathrm{PIB}+\mathrm{cCOMEX}^{*} \mathrm{COMEX}+\mathrm{cAGRI}^{*} \mathrm{AGRI}+\mathrm{cPREF}^{*} \mathrm{PREF}+\mathrm{cODP}^{*} \mathrm{ODP}+$ $\mathrm{CCAP}^{*} \mathrm{CAP}+\mathrm{CAPRE}{ }^{*} \mathrm{APRE}$

Onde:

- $\mathrm{L}_{c}$ é o preditor linear de contagem de REC (polo ativo) ou ACI (polo passivo);

- c0 é o intercepto da regressão de contagem;

- CAA é o coeficiente do efeito da variável dummy de renda AA na regressão de contagem;

- $\mathrm{CAB}$ é o coeficiente do efeito da variável dummy de renda $A B$ na regressão de contagem;

- cBA é o coeficiente do efeito da variável dummy de renda BA na regressão de contagem;

- cBB é o coeficiente do efeito da variável dummy de renda BB na regressão de contagem;

- cMD é o coeficiente do efeito da variável dummy de renda MD na regressão de contagem;

- cPL é o coeficiente do efeito da variável dummy de abertura do sistema político PL na regressão de contagem;

- cNL é o coeficiente do efeito da variável dummy de abertura do sistema político NL na regressão de contagem; 
- cPIB é o coeficiente do efeito da variável de efeito gravitacional PIB na regressão de contagem;

- cCOMEX é o coeficiente do efeito da variável de efeito gravitacional COMEX na regressão de contagem;

- cAGRI é o coeficiente do efeito da variável de efeito gravitacional AGRI na regressão de contagem;

- cPREF é o coeficiente do efeito da variável de efeito discriminatório PREF na regressão de contagem;

- cODP é o coeficiente do efeito da variável de efeito discriminatório ODP na regressão de contagem;

- cCAP é o coeficiente do efeito da variável de efeito discriminatório CAP na regressão de contagem; e

- CAPRE é o coeficiente do efeito da variável de efeito discriminatório APRE na regressão de contagem.

Após a definição do preditor linear de contagem, o segundo passo será a definição da distribuição da variável resposta (REC ou $\mathrm{ACl}$ ) em cada modelo. Sendo portanto desnecessário discorrer sobre as razões pelas quais o Modelo 1 terá distribuição Poisson e o Modelo 2 terá distribuição BN.

Por fim, o terceiro passo na construção de nossos modelos MLG será a escolha de uma função de ligação responsável por variar a relação entre o preditor linear e o valor da variável resposta de forma a relativizar as condições de linearidade do modelo. Tanto no Modelo 1 quanto Modelo 2 a ligação será logística. Para estimar ambos os modelos foi utilizada um programação no SAS a partir do processo contreg disponível no Anexo 5-1 (v. 02, p. 577 ).

No caso de nosso Modelo 3 (multinível ZINB), em qualquer dos dois níveis o processo de modelagem passará também por três fases conforme discutido acima. Primeiramente, nós definiremos os preditores lineares. Ou seja, nossas funções lineares com as variáveis explicativas em análise. Esta parte do modelo será aditiva e estritamente linear. Após a definição dos preditores lineares tanto para a inflação de zeros quanto para a contagem, o segundo passo é a definição de uma função de ligação, que será responsável por variar a relação entre o preditor linear e o valor da variável resposta de forma a relativizar as condições de linearidade do modelo. 
No caso do primeiro nível, a função de ligação da inflação de zeros será do tipo logística, equivalendo a uma transformação logística do preditor linear de zeros. Sendo assim, considerando $\mathrm{Lz}$ como o preditor linear de zeros, a função de probabilidade de inflação de zeros será dada por $\mathrm{p} 0=1 /\left(1+\exp \left(-L_{z}\right)\right)$. Por sua vez, no segundo nível, a função de ligação será o tipo exponencial e dado um preditor linear de contagem $L_{C^{\prime}} \quad$ a função de probabilidade dada pela função de ligação será $\operatorname{lambda}=\exp \left(L_{C}\right)$.

Sendo por fim o terceiro passo estabelecer que nossa variável resposta possui distribuição binomial negativa com parâmetro de dispersão alfa, sendo a probabilidade de ocorrência de sucesso dada por $p=1 /\left(1+a l f a^{\star} / a m b d a\right)$ em uma quantidade de eventos/ocorrências dada por $m=1 / a$ lfa. Dessa forma, na programação do Modelo 3 , finalizaremos este último passo estabelecendo uma função de verossimilhança para este, que neste caso será especificada na forma logarítmica (LL).

Se o resultado da contagem (REC ou ACl) for zero então:

$\mathrm{LL}=\log \left(\mathrm{p} 0+(1-\mathrm{p} 0)^{\star}\left(\mathrm{p}^{* *} \mathrm{~m}\right)\right)$

Enquanto no caso de o valor de contagem for positivo teremos:

$\mathrm{LL}=\log (1-\mathrm{p} 0)+\log ($ gama$(m+$ "contagem") $-\log ($ gama $($ "contagem"+1) $)-\log ($ gama $(m))+$ $m^{*} \log (p)+" c o n t a g e m " * \log (1-p)$

Onde log(gama) é o logaritmo da função gama, dada pela extensão da função fatorial para o número reais e complexos. No caso a gama aplica-se ao valor da contagem (número inteiro positivo) menos uma unidade, oferecendo através de sua derivada neste ponto a probabilidade marginal de um valor de contagem para o valor imediatamente superior. Conforme vimos no Capítulo 4, esta função tem várias outras aplicações estatísticas.

Uma vez que utilizaremos uma ferramenta de programação não linear para a estimação do Modelo 3, por meio do processo NLMIXED do SAS, é necessário especificarmos nossas condições de linearidade e, portanto, também nossas funções de verossimilhança, definidas acima. Dessa forma, especificaremos também a variável resposta do modelo seguirá distribuição geral dada por esta função. A programação do Modelo 3 está igualmente disponível no Anexo 5-1. 
O preditor linear de contagem $L_{c^{\prime}}$ no nível 2 deste modelo seguirá a mesma especificação de $L_{c}$ dos Modelos 1 e 2 com exceção do parâmetro de intercepto $c 0$. Ou seja, no nível 2 do modelo ZINB não haverá intercepto. Isto se deve ao fato de que o objetivo desta modelagem é exatamente capturar a maior parte dos excessos de zeros (estruturais) existentes no âmbito do nível 1 (inflação de zeros), deixando apenas os zeros efetivos ou condicionais para o nível 2.

No nível 2, ainda, uma vez que o processo de contagem deverá ser uma função das demais variáveis (excluído o efeito dos zeros estruturais) não é razoável teoricamente que exista um intercepto na curva de regressão de contagem que determine um número de contagem independente das demais variáveis (quando o valor destas é nulo). Ademais, conforme abordaremos na discussão dos resultados dos modelos ZINB, a inserção de um intercepto no nível 2 leva a problemas de significância na estimação deste parâmetro.

Já o preditor linear da inflação de zeros seguirá o mesmo padrão de $\mathrm{L}_{c}$. No entanto, enquanto os coeficientes do último indicam o efeito das variáveis explicativas no valor da contagem (REC ou $A C l$ ), os coeficientes das variáveis explicativas de $L_{z}$ indicam a probabilidade de ocorrência de um zero estrutural associada a estas variáveis. Dessa forma, $L_{z}$ será dado por:

$L_{z}=z 0+z A A^{*} A A+z A B^{*} A B+z B A^{*} B A+z B B^{*} B B+z M D^{*} M D+z P L^{*} P L+z N L^{*} N L+$ $z P^{*}{ }^{*} I B+z C O M E X^{*}$ COMEX + zAGRI*AGRI + zPREF*PREF + zODP*ODP + $Z C A{ }^{*} C A P+Z A P R E{ }^{*} A P R E$

\section{Onde:}

- $\mathrm{L}_{z}$ é o preditor linear da curva de densidade de probabilidade de inflação de zeros (zero estrutural $x$ condicional);

- z0 é o intercepto da curva de densidade de probabilidade de inflação de zeros;

- ZAA é o coeficiente do efeito da variável dummy de renda AA na probabilidade de inflação de zeros;

- $\quad \mathrm{ZAB}$ é o coeficiente do efeito da variável dummy de renda $A B$ na probabilidade de inflação de zeros;

- zBA é o coeficiente do efeito da variável dummy de renda BA na probabilidade de inflação de zeros; 
- zBB é o coeficiente do efeito da variável dummy de renda BB na regressão de contagem;

- zMD é o coeficiente do efeito da variável dummy de renda MD na probabilidade de inflação de zeros;

- zPL é o coeficiente do efeito da variável dummy de abertura do sistema político PL na probabilidade de inflação de zeros;

- zNL é o coeficiente do efeito da variável dummy de abertura do sistema político NL na probabilidade de inflação de zeros;

- zPIB é o coeficiente do efeito da variável de efeito gravitacional PIB na probabilidade de inflação de zeros;

- zCOMEX é o coeficiente do efeito da variável de efeito gravitacional COMEX na probabilidade de inflação de zeros;

- zAGRI é o coeficiente do efeito da variável de efeito gravitacional AGRI na probabilidade de inflação de zeros;

- zPREF é o coeficiente do efeito da variável de efeito discriminatório PREF na probabilidade de inflação de zeros;

- zODP é o coeficiente do efeito da variável de efeito discriminatório ODP na probabilidade de inflação de zeros;

- zCAP é o coeficiente do efeito da variável de efeito discriminatório CAP na probabilidade de inflação de zeros; e

- zAPRE é o coeficiente do efeito da variável de efeito discriminatório APRE na probabilidade de inflação de zeros.

$\mathrm{Na}$ programação de todos os modelos forçamos uma maior convergência do algorítimo especificando que o número de iterações na resolução poderia atingir até $500 \mathrm{e}$ estabelecendo o gradiente de convergência em zero. Ou seja, o algoritmo só interrompia o processo de iteração quando havia garantia de que o processo estava de fato estacionário com zero de variação dos gradientes de cada variável entre uma iteração e outra. O método de otimização especificado, por sua vez, foi o quase-newton utilizando-se o processo previamente descrito de quadratura gaussiana. 


\section{A5.2. Testes de modelos e coeficientes}

\section{A5.2.1 Testes dos modelos (Poisson, BN e ZINB)}

A partir da discussão realizada na seção anterior realizamos a estimação dos diferentes modelos em teste. Na presente seção não nos ocuparemos da discussão dos resultados dos coeficientes destes modelos, apenas do ajustamento das estimações e dos testes realizados para a confirmação do modelo ZINB proposto neste trabalho.

Os resultados das estimações dos modelos podem ser conferidos nos Anexos a seguir enumerados:

i) Modelo 1 - Ativo (Poisson) - Anexo 5-2 (v. 02, p. 579)

ii) Modelo 1 - Passivo (Poisson) - Anexo 5-3 (v. 02, p. 581)

iii) Modelo 2 - Ativo (BN) - Anexo 5-4 (v. 02, p. 583)

iv) Modelo 2 - Passivo (BN) - Anexo 5-5 (v. 02, p. 585)

v) Modelo 3 - Ativo (ZINB) - Anexo 5-6 (v. 02, p. 587)

vi) Modelo 3 - Passivo (ZINB) - Anexo 5-7 (v. 02, p. 593)

No Quadro A5.1 abaixo podemos comparar as diferentes medidas do ajustamento dos modelos em análise:

Quadro A5.1: Critérios de comparação de ajustamento dos modelos (ativo e passivo)

\begin{tabular}{|c|c|c|c|}
\hline \multicolumn{3}{|c|}{ Modelo Ativo } \\
\hline Critério & Modelo 1 (Poisson) & Modelo 2 (BN) & Modelo 3 (ZINB) \\
\hline Log-verossimilhança & $-799,6$ & $-734,15$ & $-669,39$ \\
\hline AIC & 1629 & 1500,3 & 1400,78 \\
\hline AICC & $\ldots$ & 1500,6 & 1401,93 \\
\hline BIC ou SBC & $1711(\mathrm{SBC})$ & $1587,8(\mathrm{BIC})$ & $1570,39(\mathrm{BIC})$ \\
\hline Dispersão (alfa) & $\ldots$ & 1,24 & 0,37 \\
\hline \multicolumn{2}{|c|}{ Modelo Passivo } & Modelo 3 (ZINB) \\
\hline Critério & Modelo 1 (Poisson) & $-1038,3$ \\
\hline
\end{tabular}




\begin{tabular}{|c|c|c|c|}
\hline AICC & $\ldots$ & 1254,98 & 1099,4 \\
\hline BIC ou SBC & $1385(\mathrm{SBC})$ & $1342,21(\mathrm{BIC})$ & $1262,5(\mathrm{BIC})$ \\
\hline Dispersão (alfa) & $\ldots$ & 1,58 & 0,20 \\
\hline
\end{tabular}

Fonte: elaboração própria.

Os critérios utilizados na comparação inicial dos modelos são:

i) Log-verossimilhança;

ii) Akaike Information Criterion (AIC);

iii) Akaike Information Criterion Corrected/Penalized (AICC);

iv-a) Bayesian Information Criterion (BIC);

iv-b) Schwarz Bayesian [Information] Criterion (SBC); e

v) Dispersão (alfa).

No caso de todos os critérios de comparação exceto o item "v" quanto menor o valor mais ajustado é o modelo em comparação aos demais. Já no caso do parâmetro de dispersão, ele servirá em nosso caso exclusivamente para avaliar a dispersão na regressão de contagem. Quanto mais distante de zero a dispersão, mais a média e a variância estão afastadas e este é o principal indicativo para a refutação do modelo Poisson quando comparado ao BN.

Tanto no polo ativo quanto no polo passivo os parâmetros de dispersão são bastante altos, sendo de 1,24 e 1,58, respectivamente. Apenas este critério já seria suficiente para descartar o modelo Poisson como uma função de distribuição apropriada para o tratamento do problema aqui estudado. No entanto, o modelo BN além de tratar a dispersão ignorada no Poisson ainda apresenta melhor ajustamento em todos os demais critérios em ambos os níveis.

Uma vez descartado o modelo Poisson, a questão a ser analisada é a pertinência da introdução de uma modelagem multinível na distribuição BN para o controle da inflação de zeros no processo de contagem. Uma comparação preliminar entre os valores de dispersão da contagem para os modelos BN e ZINB em ambos os polos mostra que a modelagem ZINB reduz sensivelmente a dispersão no processo de contagem (polo ativo: $\mathrm{BN}$ alfa = 1,24 e ZINB alfa =0,37; e polo passivo: $B N$ alfa = 1,58 e ZINB alfa =0,20).

Este é um bom indicativo de que grande parte da dispersão observada nos dados adviriam realmente do excesso de zeros estruturais misturados aos zeros condicionais, 
conforme discutido no Capítulo 4. O valor da dispersão residual no nível 2 de contagem do modelo ZINB seria, portanto, a real dispersão da contagem após retirada dos zeros estruturais. O valor de alfa no nível 2 do ZINB de ambos os polos é estatisticamente significativo e maior do que zero, de modo que não se justificaria a proposta de teste do modelo contra uma modelagem de distribuição Poisson com controle de inflação de zeros - estando o Poisson definitivamente descartado.

No entanto, a modelagem multinível utilizada no modelo ZINB é muito mais complexa do que a modelagem do modelo $\mathrm{BN}$ e embora os valores dos demais critérios de comparação entre ambos para os dois polos seja inferior para o ZINB, favorecendo este, é preciso adotar um critério de robustez e parcimônia para a seleção final do modelo. Assim, avaliaremos se a diferença na performance da estimação entre os modelos BN E ZINB é suficientemente grande e estatisticamente significativa para justificar a seleção de um modelo mais complexo em detrimento do mais simples.

Para empreender esta tarefa utilizamos duas metodologias complementares, o teste de Vuong (1989) e o teste de Clarke (2007). Ambos são testes baseados na razão de verossimilhança para seleção entre dois modelos rivais utilizando o critério de informação de Kullback-Leibler. No teste Vuong, a hipótese nula é de que os dois modelos encontram-se igualmente próximos do modelo real, enquanto a hipótese alternativa é de que o modelo de referência está mais próximo.

O teste segue assintoticamente uma distribuição normal padrão sob a hipótese nula. Assume-se que a região crítica é $(-\mathrm{c},+\mathrm{c})$, onde $\mathrm{c}$ é tipicamente ajustado para 1,96. Se o valor do teste é maior do que $+c$, rejeita-se a hipótese nula de que os modelos são equivalentes em favor do modelo de referência. Se o valor for menor do que -c rejeitamos a hipótese nula de que os modelos são equivalentes em favor do modelo rival.

Se o valor estiver dentro do intervalor entre -c e +c então não há diferença estatisticamente significativa entre o poder preditivo dos modelos. No último caso, por extensão do princípio científico da navalha de Ockham recomenda-se a adoção do modelo mais simples. Portanto, o modelo de referência (mais complexo) só será adotado caso o valor do teste for superior $\mathrm{a}+\mathrm{c}$.

Por sua vez, no teste de Clarke, caso os dois modelos sejam estatisticamente equivalentes, as razões de log-verossimilhança das observações devem ser uniformemente distribuídas em torno de zero e cerca de metade destas devem ser maiores do que zero. $O$ teste segue assintoticamente uma distribuição binomial com parâmetros n e 0,5 (para valores de referência ver: CLARKE, Ibid). 
O modelo de referência é considerado mais adequado em relação ao seu rival se o valor do teste é significativamente maior do que seu valor esperado sob a hipótese nula e intuitivamente o contrário no caso do modelo rival. Se o valor do teste não for estatisticamente significativo e diferente de $\mathrm{n} / 2$, então não se pode discriminar um modelo em relação ao outro e como consequência o modelo mais simples deverá ser preferível pelas mesmas razões de simplicidade e parcimônia ditadas pelo princípio de Ockham.

Em ambos os testes utilizaremos como critérios de avaliação para seleção dos modelos tanto o valor não ajustado dos testes, conforme discutido acima, quanto os valores ajustados pelo AIC e SBC/BIC.

No Quadro A5.2 abaixo apresentamos o resultado de ambos os testes comparativos entre o desempenho dos modelos BN e ZINB para ambos os polos (ativo e passivo). O resultado qualitativo dos testes é similar para ambos os polos (ativo e passivo).

\section{Quadro A5.2: Resultado dos testes Vuong e Clarke - ZINB x BN}

\begin{tabular}{|c|c|c|c|c|c|c|c|}
\hline \multicolumn{8}{|c|}{ Modelo Ativo } \\
\hline \multicolumn{4}{|c|}{ Teste Vuong } & \multicolumn{4}{|c|}{ Teste Clarke } \\
\hline Critério & $\mathbf{z}$ & $\operatorname{Pr}>|Z|$ & Modelo & Critério & $M$ & $\operatorname{Pr}>=|M|$ & Modelo \\
\hline $\begin{array}{c}\text { Não } \\
\text { ajustado }\end{array}$ & 5,4194 & $<0,0001$ & ZINB & $\begin{array}{c}\text { Não } \\
\text { ajustado }\end{array}$ & 214,5000 & $<0,0001$ & ZINB \\
\hline $\begin{array}{c}\text { Akaike } \\
\text { Ajustado }\end{array}$ & 4,7495 & $<0,0001$ & ZINB & $\begin{array}{c}\text { Akaike } \\
\text { Ajustado }\end{array}$ & 13,5000 & 0,5351 & ZINB \\
\hline $\begin{array}{l}\text { Schwarz } \\
\text { Ajustado }\end{array}$ & 2,9171 & 0,0035 & ZINB & $\begin{array}{l}\text { Schwarz } \\
\text { Ajustado }\end{array}$ & $-106,500$ & $<0,0001$ & $\mathrm{BN}$ \\
\hline \multicolumn{8}{|c|}{ Modelo Passivo } \\
\hline \multicolumn{4}{|c|}{ Teste Vuong } & \multicolumn{4}{|c|}{ Teste Clarke } \\
\hline Critério & $\mathbf{z}$ & $\operatorname{Pr}>|Z|$ & Modelo & Critério & M & $\operatorname{Pr}>=|M|$ & Modelo \\
\hline $\begin{array}{c}\text { Não } \\
\text { ajustado }\end{array}$ & 1,9744 & 0,0483 & ZINB & $\begin{array}{c}\text { Não } \\
\text { ajustado }\end{array}$ & 89,5000 & $<0,0001$ & ZINB \\
\hline $\begin{array}{c}\text { Akaike } \\
\text { Ajustado }\end{array}$ & 1,5228 & 0,1278 & ZINB & $\begin{array}{c}\text { Akaike } \\
\text { Ajustado }\end{array}$ & $-93,5000$ & $<0,0001$ & ZINB \\
\hline $\begin{array}{l}\text { Schwarz } \\
\text { Ajustado }\end{array}$ & 0,2876 & 0,7737 & ZINB & $\begin{array}{l}\text { Schwarz } \\
\text { Ajustado }\end{array}$ & $-241,500$ & $<0,0001$ & $\mathrm{BN}$ \\
\hline
\end{tabular}

Fonte: elaboração própria.

No caso do teste Vuong, a diferença de desempenho do Modelo 3 ZINB é considerada estatisticamente significativa em relação ao Modelo $2 \mathrm{BN}$ em todos os critérios de análise. Por sua vez, no caso do teste Clarke, o Modelo 2 BN é considerado 
preferível apenas de acordo com o critério "Schwarz Ajustado".

Dessa forma, temos razões suficientes para recomendar a adoção da modelagem proposta neste trabalho para o tratamento da participação dos países em desenvolvimento na OSC. Para ambos os polos, o desempenho do modelo multinível ZINB proposto é estatisticamente significativo em relação à sua contraparte unidimensional BN. Além deste fato, o modelo proposto capta de forma mais completa a dinâmica observada em ambos os polos no OSC e nos permite analisar com maior precisão o comportamento dos diferentes atores no mesmo.

Partindo destes resultados, no item a seguir discutiremos brevemente os critérios de avaliação dos coeficientes estimados nos Modelos ZINB para a seguir discutir na próxima seção com maiores detalhes os resultados da estimação para ambos os polos.

\section{A5.2.2. Teste de significância dos coeficientes}

De acordo com nossa apresentação inicial do propósito da presente pesquisa na Introdução estabelecemos que a hipótese a ser testada por este trabalho é a de que não há efeitos discriminatórios externos relacionados ao nível de renda que inibam a atuação dos países em desenvolvimento nos polos ativo ou passivo do OSC.

Ou seja, quando comparados os modelos finais ajustados, com controle de todos os efeitos, compostos apenas pelas variáveis explicativas e covariáveis qualitativas de níveis de renda relacionadas aos diferentes subgrupos de renda dos países em desenvolvimento, não deverão ser observados coeficientes negativos do efeito destas covariáveis de renda no processo de contagem. Caso existam valores previstos negativos, estes não deverão ser estatisticamente significativos, sendo descartados como preditores do modelo.

Para permitir o teste desta hipótese geral será necessário o teste de hipóteses intermediárias específicas ligadas tanto ao valor quanto à significância estatística de cada um dos coeficientes das variáveis explicativas e covariáveis em questão. Com esta finalidade apresentaremos brevemente o conceito do teste t de Student (BOX,1987).

$\mathrm{O}$ teste $\mathrm{t}$ aplicado ao coeficiente de uma regressão é uma forma de testar sua significância estatística unitária em uma regressão multivariada. A partir do valor obtido pela estatística $t$, pode-se calcular a probabilidade de significância do coeficiente para um intervalo de confiança especificado (como padrão 95\%). 
Em termos formais, considerando a hipótese nula $(\mathrm{H} 0)$ de que o coeficiente da variável em questão não seja um regressor relevante no modelo, enquanto a hipótese alternativa $(\mathrm{H} 1)$ é de que se trata de um regressor relevante, $\mathrm{o}$ valor da estatística $\mathrm{t}$ informará a probabilidade de não rejeição da hipótese nula.

Ou seja, um coeficiente somente poderá ser considerado significativo caso a hipótese alternativa (H1) seja comprovada e para isto é necessário rejeitar H0. Dessa forma, quanto menor for a probabilidade de que o teste não rejeite $\mathrm{H} 0$ mais segurança haverá na significância estatística efetiva do coeficiente. 


\title{
Anexo 5-1
}

MODELOS POISSON, BN E ZINB: PROGRAMAÇÃO SAS

\begin{abstract}
A5-1.1) Programação (SAS) do Modelo Poisson
Proboc countreg data $=\mathrm{gconv}=0$ maxiter $=500$ method $=q n$;

Classe AA AB BA BB MD PL NL;

Modelo $[\mathrm{REC}$ ou $\mathrm{ACl}]=\mathrm{LC} /$ dist=poisson link=logit;

run;

$\mathrm{Lc}=\mathrm{c} 0+\mathrm{CA} A^{*} \mathrm{AA}+\mathrm{CAB}^{*} \mathrm{AB}+\mathrm{CBA}^{*} \mathrm{BA}+\mathrm{CBB}^{*} \mathrm{BB}+\mathrm{cMD}^{*} \mathrm{MD}+\mathrm{cPL} \mathrm{PL}^{*}+\mathrm{CNL}{ }^{*} \mathrm{NL}+$

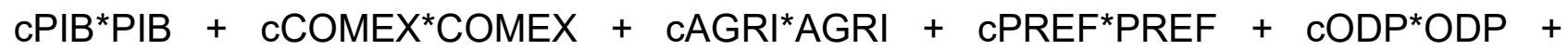
CCAP*CAP + CAPRE*APRE;
\end{abstract}

\section{A5-1.2) Programação (SAS) do Modelo Binomial Negativo}

Proboc countreg data $=\mathrm{gconv}=0$ maxiter $=500$ method $=\mathrm{qn}$;

Classe AA AB BA BB MD PL NL;

Modelo [REC ou ACI] = Lc / dist=negbin $(\mathrm{p}=2)$ link=logit;

run;

$\mathrm{Lc}=\mathrm{c} 0+\mathrm{CAA}{ }^{*} \mathrm{AA}+\mathrm{CAB}^{*} \mathrm{AB}+\mathrm{CBA}^{*} \mathrm{BA}+\mathrm{CBB}^{*} \mathrm{BB}+\mathrm{CMD}^{*} \mathrm{MD}+\mathrm{cPL}{ }^{*} \mathrm{PL}+\mathrm{CNL}{ }^{*} \mathrm{NL}+$ cPIB ${ }^{*} \mathrm{PIB}+\mathrm{cCOMEX}^{*} \mathrm{COMEX}+\mathrm{cAGRI}^{*} \mathrm{AGRI}+\mathrm{cPREF}^{*} \mathrm{PREF}+\mathrm{CODP}^{*} \mathrm{ODP}+$ CCAP* ${ }^{*} A P+$ CAPRE ${ }^{*} A P R E$;

\section{A5-1.3) Programação (SAS) do Modelo ZINB}

Proboc nlmixed data $=$ gconv $=0$ maxiter $=500$ method=gauss;

Parâmetros $c A A=0 \quad c A B=0 \quad c B A=0 \quad c B B=0 \quad c M D=0 \quad c P L=0 \quad c N L=0$ cPIB $=0$ cCOMEX $=0$ $C A G R I=0$ cPREF $=0$ CODP $=0$ cCAP $=0$ cAPRE $=0$

$z 0=0 \quad z A A=0 \quad z A B=0 \quad z B A=0 \quad z B B=0 \quad z M D=0 \quad z P L=0 \quad z N L=0 \quad z P I B=0 \quad z C O M E X=0 \quad z A G R I=0$ $z P R E F=0 \quad z O D P=0 \quad z C A P=0 \quad z A P R E=0$

alpha=1; 
/* Probeditor linear da inflação de zeros */

$L z=z 0+z A A^{*} A A+z A B^{*} A B+z B A^{*} B A+z B B^{*} B B+z M D^{*} M D+z P L^{*} P L+z N L^{*} N L+$

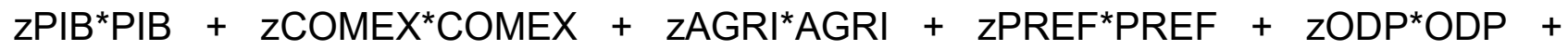
$z C A{ }^{*} C A P+z A P R E * A P R E ;$

$I^{*}$ p0 = Probobabilidade da inflação de zeros */

$1^{*}=$ transdamação logística do Probeditor linear */

$\mathrm{p} 0=1 /(1+\exp (-L z))$

/* Distribuição binomial negativa com dispersão média */

lambda $=\exp \left(L^{\prime}\right)$;

$1 *$ Probeditor linear de contagem */

$\mathrm{LC}^{\prime}=\mathrm{CA} \mathrm{A}^{*} \mathrm{AA}+\mathrm{CAB}^{*} \mathrm{AB}+\mathrm{CBA}^{*} \mathrm{BA}+\mathrm{CBB}^{*} \mathrm{BB}+\mathrm{CMD}^{*} \mathrm{MD}+\mathrm{CPL}{ }^{*} \mathrm{PL}+\mathrm{CNL}{ }^{*} \mathrm{NL}+\mathrm{CPIB}{ }^{*} \mathrm{PIB}$ $+{ }^{C} C O M E X^{*}$ COMEX + CAGRI*AGRI + ${ }^{*} P R E{ }^{*} P R E F+C O D P^{*} O D P+C C A P^{*} C A P+$ CAPRE*APRE;

/* Log-verossimilhança */

$m=1 / a l p h a ;$

$p=1 /\left(1+a l p h a^{*}\right.$ lambda)

if $[\mathrm{REC}$ ou $\mathrm{ACl}]=0$ then

$\|=\log \left(\mathrm{p} 0+(1-\mathrm{p} 0)^{*}\left(\mathrm{p}^{* *} \mathrm{~m}\right)\right)$

else $\|=\log (1-p 0)+\log ($ gamma $(m+[R E C$ ou ACl $]))-\log ($ gamma $([R E C$ ou $A C l]+1))$

- $\log (\operatorname{gamma}(m))+m^{*} \log (p)+[R E C$ ou $A C l]{ }^{*} \log (1-p) ;$

Modelo [REC ou ACl] general(II);

run; 


\section{Anexo 5-2}

\section{MODELO POISSON - POLO ATIVO: RESULTADO DA ESTIMAÇÃO}

\section{Quadro A5-2.1: Variáveis categóricas - Modelo Poisson Ativo}

\begin{tabular}{|c|c|c|}
\hline Classe & Leveis & Valores \\
\hline AA & 2 & 01 \\
\hline$A B$ & 2 & 01 \\
\hline BA & 2 & 01 \\
\hline BB & 2 & 01 \\
\hline MD & 2 & 01 \\
\hline LV & 2 & 01 \\
\hline PL & 2 & 01 \\
\hline NL & 2 & 01 \\
\hline
\end{tabular}

Fonte: adaptado do resultado da estimação SAS.

Quadro A5-2.2: Ajustamento - Modelo Poisson Ativo

\begin{tabular}{|l|r|}
\hline Variável Dependente & REC \\
\hline Número de Observações & 1757 \\
\hline Modelo & ARQUIVO \\
\hline Log-verossimilhança & Poisson \\
\hline Gradientee Máximo Absoluto & $-799,62105$ \\
\hline Número de Iterações & 0,00124 \\
\hline Método de Otimização & 57 \\
\hline AIC & Quase-Newton \\
\hline SBC & 1629 \\
\hline
\end{tabular}

Fonte: adaptado do resultado da estimação SAS. 
Quadro A5-2.3: Estimativa dos Parâmetros - Modelo Poisson Ativo

\begin{tabular}{|c|c|c|c|c|c|}
\hline Parâmetro & DF & Estimativa & $\begin{array}{l}\text { Erro- } \\
\text { padrão }\end{array}$ & Valor $\mathbf{t}$ & $\begin{array}{r}\text { Aprox } \\
\text { Prob }>|\mathbf{t}|\end{array}$ \\
\hline Intercepto & 1 & 1,423739 & 0,859247 & 1,66 & 0,0975 \\
\hline AA 0 & 1 & 0,307441 & 0,293403 & 1,05 & 0,2947 \\
\hline AA 1 & 0 & 0 & & & \\
\hline AB 0 & 1 & $-0,592446$ & 0,212398 & $-2,79$ & 0,0053 \\
\hline AB 1 & 0 & 0 & & & \\
\hline BA 0 & 1 & $-0,145872$ & 0,303315 & $-0,48$ & 0,6306 \\
\hline BA 1 & 0 & 0 & & & \\
\hline BB 0 & 1 & $-0,832712$ & 0,292160 & $-2,85$ & 0,0044 \\
\hline BB 1 & 0 & 0 & & & \\
\hline MD 0 & 1 & $-0,973940$ & 0,335385 & $-2,90$ & 0,0037 \\
\hline MD 1 & 0 & 0 & & & \\
\hline LV 0 & 1 & $-0,854354$ & 0,277574 & $-3,08$ & 0,0021 \\
\hline LV 1 & 0 & 0 & & & \\
\hline PL 0 & 1 & $-0,919791$ & 0,275945 & $-3,33$ & 0,0009 \\
\hline PL 1 & 0 & 0 & & & \\
\hline NL 0 & 0 & 0 & & & \\
\hline NL 1 & 0 & 0 & & & \\
\hline PIB & 1 & 0,205129 & 0,013161 & 15,59 & $<0,0001$ \\
\hline COMEX & 1 & $-0,013072$ & 0,001676 & $-7,80$ & $<0,0001$ \\
\hline AGRI & 1 & $-0,009935$ & 0,005917 & $-1,68$ & 0,0931 \\
\hline PREF & 1 & 0,004298 & 0,000997 & 4,31 & $<0,0001$ \\
\hline ODP & 1 & 0,420493 & 0,064899 & 6,48 & $<0,0001$ \\
\hline CAP & 1 & 0,488483 & 0,122620 & 3,98 & $<0,0001$ \\
\hline APRE & 1 & $-0,009287$ & 0,002057 & $-4,51$ & $<0,0001$ \\
\hline
\end{tabular}

Fonte: adaptado do resultado da estimação SAS. 


\section{Anexo 5-3}

MODELO POISSON - POLO PASSIVO: RESULTADO DA ESTIMAÇÃO

Quadro A5-2.4: Variáveis categóricas - Modelo Poisson Passivo

\begin{tabular}{|c|c|c|}
\hline Classe & Leveis & Valores \\
\hline AA & 2 & 01 \\
\hline$A B$ & 2 & 01 \\
\hline BA & 2 & 01 \\
\hline BB & 2 & 01 \\
\hline MD & 2 & 01 \\
\hline LV & 2 & 01 \\
\hline PL & 2 & 01 \\
\hline NL & 2 & 01 \\
\hline
\end{tabular}

Fonte: adaptado do resultado da estimação SAS.

Quadro A5-2.5: Ajustamento - Modelo Poisson Passivo

\begin{tabular}{|l|r|}
\hline Variável Dependente & ACI \\
\hline Arqmero de Observações & 1757 \\
\hline Modelo & ARQUIVO \\
\hline Log-verossimilhança & Poisson \\
\hline Gradientee Máximo Absoluto & $-677,30436$ \\
\hline Número de Iterações & 0,00225 \\
\hline Método de Otimização & 60 \\
\hline AIC & Quase-Newton \\
\hline SBC & 1385 \\
\hline Font: & 1467 \\
\hline
\end{tabular}

Fonte: adaptado do resultado da estimação SAS. 
Quadro A5-2.6: Estimativa dos Parâmetros - Modelo Poisson Passivo

\begin{tabular}{|c|c|c|c|c|c|}
\hline Parâmetro & DF & Estimativa & $\begin{array}{r}\text { Erro- } \\
\text { padrão }\end{array}$ & Valor $\mathbf{t}$ & $\begin{array}{r}\text { Aprox } \\
\text { Prob }>|t|\end{array}$ \\
\hline Intercepto & 1 & 3,167149 & 0,960550 & 3,30 & 0,0010 \\
\hline AA 0 & 1 & $-0,431571$ & 0,283895 & $-1,52$ & 0,1285 \\
\hline AA 1 & 0 & 0 & & & \\
\hline$A B 0$ & 1 & $-0,909325$ & 0,241768 & $-3,76$ & 0,0002 \\
\hline AB 1 & 0 & 0 & & & \\
\hline BA 0 & 1 & $-0,813390$ & 0,307831 & $-2,64$ & 0,0082 \\
\hline BA 1 & 0 & 0 & & & \\
\hline BB 0 & 1 & $-0,911859$ & 0,324971 & $-2,81$ & 0,0050 \\
\hline BB 1 & 0 & 0 & & & \\
\hline MD 0 & 1 & $-1,015695$ & 0,367903 & $-2,76$ & 0,0058 \\
\hline MD 1 & 0 & 0 & & & \\
\hline LV 0 & 1 & 0,238758 & 0,205498 & 1,16 & 0,2453 \\
\hline LV 1 & 0 & 0 & & & \\
\hline PL 0 & 1 & 0,598534 & 0,217769 & 2,75 & 0,0060 \\
\hline PL 1 & 0 & 0 & & & \\
\hline NL 0 & 0 & 0 & & & \\
\hline NL 1 & 0 & 0 & & & \\
\hline PIB & 1 & 0,266169 & 0,015090 & 17,64 & $<0,0001$ \\
\hline COMEX & 1 & $-0,024693$ & 0,002034 & $-12,14$ & $<0,0001$ \\
\hline AGRI & 1 & $-0,021539$ & 0,007483 & $-2,88$ & 0,0040 \\
\hline PREF & 1 & 0,004134 & 0,001121 & 3,69 & 0,0002 \\
\hline ODP & 1 & 0,727340 & 0,117246 & 6,20 & $<0,0001$ \\
\hline CAP & 1 & 0,196279 & 0,131668 & 1,49 & 0,1360 \\
\hline APRE & 1 & $-0,014221$ & 0,002033 & $-7,00$ & $<0,0001$ \\
\hline
\end{tabular}

Fonte: adaptado do resultado da estimação SAS. 


\section{Anexo 5-4}

MODELO BINOMIAL NEGATIVO - POLO ATIVO: RESULTADO DA ESTIMAÇÃO

Quadro A5-2.7: Variáveis categóricas - Modelo BN Ativo

\begin{tabular}{|c|c|c|}
\hline Classe & Leveis & Valores \\
\hline AA & 2 & 01 \\
\hline$A B$ & 2 & 01 \\
\hline BA & 2 & 01 \\
\hline BB & 2 & 01 \\
\hline MD & 2 & 01 \\
\hline LV & 2 & 01 \\
\hline PL & 2 & 01 \\
\hline NL & 2 & 01 \\
\hline
\end{tabular}

Fonte: adaptado do resultado da estimação SAS.

Quadro A5-2.8: Ajustamento - Modelo BN Ativo

\begin{tabular}{|l|r|}
\hline \multicolumn{2}{|c|}{ Ajustamento do Modelo - Sumário } \\
\hline Variável Dependente & REC \\
\hline Número de Observações & 1757 \\
\hline Arquivo & ARQUIVO \\
\hline Modelo & NegBin( $p=2)$ \\
\hline Log-verossimilhança & $-734,15413$ \\
\hline Gradientee Máximo Absoluto & 0,00125 \\
\hline Número de Iterações & 119 \\
\hline Método de Otimização & Quase-Newton \\
\hline AIC & 1500 \\
\hline SBC & 1588 \\
\hline
\end{tabular}

Fonte: adaptado do resultado da estimação SAS. 
Quadro A5-2.8: Estimativa dos Parâmetros - Modelo BN Ativo

\begin{tabular}{|c|c|c|c|c|c|}
\hline Parâmetro & DF & Estimativa & $\begin{array}{r}\text { Erro- } \\
\text { padrão }\end{array}$ & Valor $\mathbf{t}$ & $\begin{array}{r}\text { Aprox } \\
\text { Prob }>|t|\end{array}$ \\
\hline Intercepto & 1 & 1,658985 & 1,064343 & 1,56 & 0,1191 \\
\hline AA 0 & 1 & 0,167731 & 0,350130 & 0,48 & 0,6319 \\
\hline AA 1 & 0 & 0 & & & \\
\hline AB 0 & 1 & $-0,755184$ & 0,272261 & $-2,77$ & 0,0055 \\
\hline AB 1 & 0 & 0 & & & \\
\hline BA 0 & 1 & $-0,432102$ & 0,361542 & $-1,20$ & 0,2320 \\
\hline BA 1 & 0 & 0 & & & \\
\hline BB 0 & 1 & $-1,082751$ & 0,361135 & $-3,00$ & 0,0027 \\
\hline BB 1 & 0 & 0 & & & \\
\hline MD 0 & 1 & $-1,061200$ & 0,413060 & $-2,57$ & 0,0102 \\
\hline MD 1 & 0 & 0 & & & \\
\hline LV 0 & 1 & $-0,923789$ & 0,313508 & $-2,95$ & 0,0032 \\
\hline LV 1 & 0 & 0 & & & \\
\hline PL 0 & 1 & $-1,121499$ & 0,314719 & $-3,56$ & 0,0004 \\
\hline PL 1 & 0 & 0 & & & \\
\hline NL 0 & 0 & 0 & & & \\
\hline NL 1 & 0 & 0 & & & \\
\hline PIB & 1 & 0,197442 & 0,022504 & 8,77 & $<0,0001$ \\
\hline COMEX & 1 & $-0,011976$ & 0,002217 & $-5,40$ & $<0,0001$ \\
\hline AGRI & 1 & $-0,005369$ & 0,007348 & $-0,73$ & 0,4650 \\
\hline PREF & 1 & 0,004160 & 0,001496 & 2,78 & 0,0054 \\
\hline ODP & 1 & 0,337153 & 0,061750 & 5,46 & $<0,0001$ \\
\hline CAP & 1 & 0,572078 & 0,163215 & 3,51 & 0,0005 \\
\hline APRE & 1 & 0,005993 & 0,003418 & 1,75 & 0,0795 \\
\hline Alfa & 1 & 1,238871 & 0,225166 & 5,50 & $<0,0001$ \\
\hline
\end{tabular}

Fonte: adaptado do resultado da estimação SAS. 


\section{Anexo 5-5}

MODELO BINOMIAL NEGATIVO - POLO PASSIVO: RESULTADO DA ESTIMAÇÃO

Quadro A5-2.9: Variáveis categóricas - Modelo BN Passivo

\begin{tabular}{|c|c|c|}
\hline Classe & Leveis & Valores \\
\hline AA & 2 & 01 \\
\hline$A B$ & 2 & 01 \\
\hline BA & 2 & 01 \\
\hline BB & 2 & 01 \\
\hline MD & 2 & 01 \\
\hline PL & 2 & 01 \\
\hline NL & 2 & 01 \\
\hline
\end{tabular}

Fonte: adaptado do resultado da estimação SAS.

Quadro A5-2.10: Ajustamento - Modelo BN Passivo

\begin{tabular}{|l|r|r|r|}
\hline Critério & DF & Valor & Valor/DP \\
\hline Desvio & 1742 & 514,4116 & 0,2953 \\
\hline Parametrizado Desvio & 1742 & 514,4116 & 0,2953 \\
\hline Pearson Chi-Square & 1742 & 8009,7950 & 4,5980 \\
\hline $\begin{array}{l}\text { Parametrizado } \\
\text { Pearson X2 }\end{array}$ & 1742 & 8009,7950 & 4,5980 \\
\hline Log-verossimilhança & & $-181,0862$ & \\
\hline $\begin{array}{l}\text { Completo Log- } \\
\text { verossimilhança }\end{array}$ & $-611,3355$ & \\
\hline AIC & & 1254,6709 & \\
\hline AICC & & 1254,9836 & \\
\hline BIC & 1342,2127 & \\
\hline
\end{tabular}

Fonte: adaptado do resultado da estimação SAS. 
Quadro A5-2.11: Estimativa dos Parâmetros - Modelo BN Passivo

\begin{tabular}{|c|c|c|c|c|c|c|c|c|}
\hline \multirow{2}{*}{$\begin{array}{l}\text { Parâmetro } \\
\text { Intercepto }\end{array}$} & & \multirow{2}{*}{\begin{tabular}{|r|} 
Estimativa \\
3,1231 \\
\end{tabular}} & \multirow{2}{*}{$\begin{array}{r}\begin{array}{r}\text { Erro- } \\
\text { padrão }\end{array} \\
1,1312\end{array}$} & \multicolumn{2}{|c|}{$\begin{array}{l}\text { Wald } 95 \% \\
\text { Intervalo de } \\
\text { Confiança }\end{array}$} & \multirow{2}{*}{$\begin{array}{r}\text { Wald Chi- } \\
\text { Square } \\
7,62\end{array}$} & \multirow{2}{*}{$\begin{array}{r}\text { Prob > ChiSc } \\
0,0058\end{array}$} \\
\hline & & 1 & & & 0,9060 & 5,3402 & & \\
\hline AA & 0 & 1 & $-0,5108$ & 0,3615 & $-1,2193$ & 0,1977 & 2,00 & 0,1577 \\
\hline AA & 1 & 0 & 0,0000 & 0,0000 & 0,0000 & 0,0000 & & \\
\hline$A B$ & 0 & 1 & $-0,9430$ & 0,3111 & $-1,5528$ & $-0,3332$ & 9,19 & 0,0024 \\
\hline$A B$ & 1 & 0 & 0,0000 & 0,0000 & 0,0000 & 0,0000 & & \\
\hline BA & 0 & 1 & $-0,9049$ & 0,3841 & $-1,6576$ & $-0,1521$ & 5,55 & 0,0185 \\
\hline BA & 1 & 0 & 0,0000 & 0,0000 & 0,0000 & 0,0000 & & \\
\hline BB & 0 & 1 & $-1,1497$ & 0,4166 & $-1,9662$ & $-0,3332$ & 7,62 & 0,0058 \\
\hline BB & 1 & 0 & 0,0000 & 0,0000 & 0,0000 & 0,0000 & & \\
\hline MD & 0 & 1 & $-0,7204$ & 0,4658 & $-1,6332$ & 0,1925 & 2,39 & 0,1220 \\
\hline MD & 1 & 0 & 0,0000 & 0,0000 & 0,0000 & 0,0000 & & \\
\hline PL & 0 & 1 & 0,3500 & 0,2374 & $-0,1153$ & 0,8153 & 2,17 & 0,1404 \\
\hline PL & 1 & 0 & 0,0000 & 0,0000 & 0,0000 & 0,0000 & & \\
\hline NL & 0 & 1 & 0,0983 & 0,2832 & $-0,4568$ & 0,6533 & 0,12 & 0,7286 \\
\hline NL & 1 & 0 & 0,0000 & 0,0000 & 0,0000 & 0,0000 & & \\
\hline PIB & & 1 & 0,2442 & 0,0257 & 0,1939 & 0,2945 & 90,53 & $<0,0001$ \\
\hline COMEX & & 1 & $-0,0305$ & 0,0036 & $-0,0374$ & $-0,0235$ & 73,36 & $<0,0001$ \\
\hline AGRI & & 1 & $-0,0276$ & 0,0102 & $-0,0476$ & $-0,0075$ & 7,27 & 0,0070 \\
\hline PREF & & 1 & 0,0048 & 0,0020 & 0,0008 & 0,0087 & 5,65 & 0,0175 \\
\hline ODP & & 1 & 0,4526 & 0,1132 & 0,2306 & 0,6745 & 15,97 & $<0,0001$ \\
\hline CAP & & 1 & 0,3528 & 0,1840 & $-0,0079$ & 0,7134 & 3,68 & 0,0552 \\
\hline APRE & & 1 & $-0,0025$ & 0,0036 & $-0,0096$ & 0,0047 & 0,46 & 0,4984 \\
\hline Alfa & & 1 & 1,5832 & 0,3079 & 1,0813 & 2,3179 & & \\
\hline
\end{tabular}

Fonte: adaptado do resultado da estimação SAS. 


\section{Anexo 5-6}

MODELO ZINB - POLO ATIVO: RESULTADO DA ESTIMAÇÃO

\begin{tabular}{|c|c|c|c|c|c|}
\hline Iteração & Chamadas & $\begin{array}{r}\text { Log- } \\
\text { verossimilhança } \\
\text { negativa }\end{array}$ & Diferença & $\begin{array}{r}\text { Máximo } \\
\text { Gradiente }\end{array}$ & Derivada \\
\hline 1 & 13 & 1013,8815 & 60,14843 & 218305 & $-9,546 \mathrm{E} 9$ \\
\hline 2 & 19 & 978,7237 & 35,15775 & 89733,5 & -392719 \\
\hline 3 & 21 & 890,6296 & 88,0941 & 164539 & $-8229,04$ \\
\hline 4 & 23 & 811,4972 & 79,13237 & 19876,0 & $-131,602$ \\
\hline 5 & 26 & 774,4098 & 37,0874 & 42293,5 & $-133,386$ \\
\hline 6 & 29 & 765,3458 & 9,064007 & 27998,3 & $-36,5658$ \\
\hline 7 & 31 & 757,6228 & 7,72306 & 48932,7 & $-9,52140$ \\
\hline 8 & 33 & 747,7701 & 9,852649 & 36467,0 & $-11,2120$ \\
\hline 9 & 35 & 741,5158 & 6,254323 & 28907,9 & $-8,17681$ \\
\hline 10 & 37 & 731,0117 & 10,50413 & 14900,2 & $-14,0264$ \\
\hline 11 & 40 & 727,0305 & 3,981201 & 4718,24 & $-8,72139$ \\
\hline 12 & 43 & 724,7149 & 2,315535 & 1536,55 & $-2,98083$ \\
\hline 13 & 46 & 724,0447 & 0,670272 & 4618,01 & $-0,69294$ \\
\hline 14 & 48 & 723,4957 & 0,548947 & 8922,69 & $-0,36991$ \\
\hline 15 & 50 & 722,8157 & 0,679975 & 4748,82 & $-0,68204$ \\
\hline 16 & 53 & 722,3708 & 0,444938 & 913,904 & $-0,33421$ \\
\hline 17 & 56 & 722,0626 & 0,308202 & 5026,23 & $-0,18056$ \\
\hline 18 & 59 & 721,9953 & 0,067344 & 238,923 & $-0,07853$ \\
\hline 19 & 61 & 721,9339 & 0,061399 & 7671,41 & $-0,02844$ \\
\hline 20 & 65 & 721,4713 & 0,462593 & 9013,52 & $-0,09906$ \\
\hline 21 & 71 & 712,6915 & 8,779807 & 12550,9 & $-0,80955$ \\
\hline 22 & 73 & 702,6269 & 10,06453 & 21352,3 & $-59,1064$ \\
\hline 23 & 76 & 701,9444 & 0,682573 & 9672,47 & $-1,46848$ \\
\hline 24 & 79 & 701,7458 & 0,198605 & 655,080 & $-0,31062$ \\
\hline 25 & 81 & 701,6049 & 0,140874 & 1786,34 & $-0,06175$ \\
\hline 26 & 85 & 701,2904 & 0,314449 & 6413,83 & $-0,25242$ \\
\hline 27 & 89 & 699,3856 & 1,904879 & 30240,0 & $-0,36487$ \\
\hline 28 & 91 & 696,4097 & 2,975841 & 7146,08 & $-2,23358$ \\
\hline 29 & 94 & 695,0832 & 1,326527 & 9360,76 & $-2,26572$ \\
\hline 30 & 97 & 694,9884 & 0,094826 & 1538,98 & $-0,21302$ \\
\hline 31 & 100 & 694,9657 & 0,022643 & 1512,31 & $-0,02992$ \\
\hline 32 & 104 & 694,9145 & 0,051165 & 9295,05 & $-0,02214$ \\
\hline
\end{tabular}




\begin{tabular}{|c|c|c|c|c|c|}
\hline Iteração & Chamadas & $\begin{array}{r}\text { Log- } \\
\text { verossimilhança } \\
\text { negativa }\end{array}$ & Diferença & $\begin{array}{r}\text { Máximo } \\
\text { Gradiente }\end{array}$ & Derivada \\
\hline 33 & 106 & 694,9001 & 0,014441 & 13573,1 & $-0,04559$ \\
\hline 34 & 110 & 694,8614 & 0,038716 & 1788,24 & $-0,06244$ \\
\hline 35 & 114 & 694,5884 & 0,272974 & 8904,22 & $-0,01784$ \\
\hline 36 & 118 & 692,4396 & 2,148781 & 11152,5 & $-0,62248$ \\
\hline 37 & 121 & 692,0836 & 0,355995 & 429,969 & $-0,75989$ \\
\hline 38 & 124 & 692,0595 & 0,024127 & 963,892 & $-0,04392$ \\
\hline 39 & 127 & 692,0457 & 0,013854 & 1262,29 & $-0,00655$ \\
\hline 40 & 133 & 691,7711 & 0,274579 & 11941,1 & $-0,02206$ \\
\hline 41 & 137 & 690,3742 & 1,396881 & 17327,7 & $-0,61607$ \\
\hline 42 & 140 & 690,0167 & 0,357505 & 3740,06 & $-0,58598$ \\
\hline 43 & 143 & 689,9995 & 0,017243 & 341,822 & $-0,03706$ \\
\hline 44 & 146 & 689,9969 & 0,002554 & 492,233 & $-0,00370$ \\
\hline 45 & 150 & 689,9760 & 0,020895 & 4531,12 & $-0,00556$ \\
\hline 46 & 156 & 689,5695 & 0,406475 & 22810,3 & $-0,04351$ \\
\hline 47 & 159 & 689,3319 & 0,237626 & 3322,22 & $-0,38828$ \\
\hline 48 & 162 & 689,3203 & 0,011609 & 1073,88 & $-0,02042$ \\
\hline 49 & 165 & 689,3140 & 0,006281 & 380,846 & $-0,00299$ \\
\hline 50 & 169 & 689,2516 & 0,062431 & 1925,09 & $-0,00835$ \\
\hline 51 & 173 & 688,4833 & 0,768329 & 42939,5 & $-0,11660$ \\
\hline 52 & 177 & 684,7488 & 3,734483 & 12179,0 & $-1,51782$ \\
\hline 53 & 180 & 684,1468 & 0,601957 & 4448,48 & $-1,42566$ \\
\hline 54 & 183 & 684,0532 & 0,093596 & 1291,61 & $-0,18734$ \\
\hline 55 & 186 & 684,0446 & 0,008585 & 112,843 & $-0,01671$ \\
\hline 56 & 189 & 684,0427 & 0,001887 & 1065,75 & $-0,00148$ \\
\hline 57 & 193 & 684,0224 & 0,020356 & 6178,68 & $-0,00398$ \\
\hline 58 & 199 & 683,3146 & 0,707757 & 23305,7 & $-0,04164$ \\
\hline 59 & 201 & 682,1409 & 1,173689 & 2528,52 & $-0,97898$ \\
\hline 60 & 204 & 681,8897 & 0,251244 & 1910,78 & $-0,54017$ \\
\hline 61 & 207 & 681,8760 & 0,013733 & 496,131 & $-0,02687$ \\
\hline 62 & 210 & 681,8746 & 0,001371 & 476,064 & $-0,00135$ \\
\hline 63 & 214 & 681,8601 & 0,014469 & 451,739 & $-0,00163$ \\
\hline 64 & 220 & 680,7807 & 1,079392 & 40341,6 & $-0,02714$ \\
\hline 65 & 222 & 679,8322 & 0,94853 & 16515,5 & $-1,41420$ \\
\hline 66 & 227 & 679,5222 & 0,310023 & 8488,81 & $-0,63468$ \\
\hline 67 & 230 & 679,4730 & 0,049196 & 2609,30 & $-0,12337$ \\
\hline 68 & 233 & 679,4691 & 0,003881 & 181,338 & $-0,00650$ \\
\hline 69 & 236 & 679,4675 & 0,00159 & 1117,46 & $-0,00119$ \\
\hline
\end{tabular}




\begin{tabular}{|c|c|c|c|c|c|}
\hline Iteração & Chamadas & $\begin{array}{r}\text { Log- } \\
\text { verossimilhança } \\
\text { negativa }\end{array}$ & Diferença & $\begin{array}{r}\text { Máximo } \\
\text { Gradiente }\end{array}$ & Derivada \\
\hline 70 & 240 & 679,4593 & 0,008243 & 1539,82 & $-0,00205$ \\
\hline 71 & 244 & 679,3741 & 0,085141 & 14490,0 & $-0,01992$ \\
\hline 72 & 248 & 678,3417 & 1,032468 & 6384,33 & $-0,19161$ \\
\hline 73 & 251 & 677,9924 & 0,349252 & 3120,97 & $-0,50514$ \\
\hline 74 & 254 & 677,9657 & 0,026736 & 833,338 & $-0,04443$ \\
\hline 75 & 257 & 677,9627 & 0,002967 & 27,4038 & $-0,00549$ \\
\hline 76 & 260 & 677,9621 & 0,000577 & 197,191 & $-0,00050$ \\
\hline 77 & 264 & 677,9542 & 0,007905 & 1874,52 & $-0,00056$ \\
\hline 78 & 270 & 677,7359 & 0,218366 & 916,729 & $-0,01574$ \\
\hline 79 & 274 & 676,7849 & 0,950978 & 3712,75 & $-0,39404$ \\
\hline 80 & 277 & 676,6317 & 0,153144 & 3432,63 & $-0,33932$ \\
\hline 81 & 280 & 676,6206 & 0,011165 & 668,918 & $-0,03958$ \\
\hline 82 & 283 & 676,6172 & 0,003367 & 268,422 & $-0,00693$ \\
\hline 83 & 286 & 676,6165 & 0,000751 & 1321,59 & $-0,00033$ \\
\hline 84 & 292 & 676,5765 & 0,039957 & 12768,5 & $-0,00141$ \\
\hline 85 & 296 & 675,9056 & 0,670935 & 3390,02 & $-0,08308$ \\
\hline 86 & 299 & 675,4638 & 0,441722 & 2138,55 & $-0,65040$ \\
\hline 87 & 302 & 675,4499 & 0,013912 & 96,5615 & $-0,02370$ \\
\hline 88 & 305 & 675,4492 & 0,000712 & 79,4164 & $-0,00112$ \\
\hline 89 & 307 & 675,4489 & 0,000292 & 293,781 & $-0,00020$ \\
\hline 90 & 311 & 675,4478 & 0,001072 & 20,1234 & $-0,00108$ \\
\hline 91 & 317 & 675,4147 & 0,033168 & 935,415 & $-0,00102$ \\
\hline 92 & 321 & 674,9188 & 0,495851 & 2898,92 & $-0,04743$ \\
\hline 93 & 324 & 674,6698 & 0,24907 & 1319,25 & $-0,38949$ \\
\hline 94 & 327 & 674,6396 & 0,03012 & 491,542 & $-0,05930$ \\
\hline 95 & 330 & 674,6384 & 0,001221 & 178,529 & $-0,00238$ \\
\hline 96 & 333 & 674,6378 & 0,00062 & 356,547 & $-0,00031$ \\
\hline 97 & 339 & 674,6252 & 0,01263 & 1456,08 & $-0,00120$ \\
\hline 98 & 343 & 674,4249 & 0,2003 & 415,515 & $-0,03568$ \\
\hline 99 & 347 & 673,7612 & 0,663699 & 3709,17 & $-0,36588$ \\
\hline 100 & 352 & 673,5619 & 0,199243 & 1485,19 & $-0,26120$ \\
\hline 101 & 355 & 673,5526 & 0,009363 & 396,276 & $-0,04810$ \\
\hline 102 & 357 & 673,5454 & 0,007156 & 127,400 & $-0,01526$ \\
\hline 103 & 360 & 673,5439 & 0,001523 & 5,02664 & $-0,00324$ \\
\hline 104 & 363 & 673,5436 & 0,0003 & 15,4895 & $-0,00012$ \\
\hline 105 & 371 & 673,4561 & 0,087496 & 3784,80 & $-0,00047$ \\
\hline 106 & 375 & 673,0943 & 0,361803 & 1106,45 & $-0,15851$ \\
\hline
\end{tabular}




\begin{tabular}{|c|c|c|c|c|c|}
\hline Iteração & Chamadas & $\begin{array}{r}\text { Log- } \\
\text { verossimilhança } \\
\text { negativa }\end{array}$ & Diferença & $\begin{array}{r}\text { Máximo } \\
\text { Gradiente }\end{array}$ & Derivada \\
\hline 107 & 378 & 673,0086 & 0,085671 & 729,959 & $-0,13539$ \\
\hline 108 & 381 & 673,0031 & 0,005529 & 57,9146 & $-0,01077$ \\
\hline 109 & 384 & 673,0026 & 0,000462 & 66,0702 & $-0,00073$ \\
\hline 110 & 387 & 673,0025 & 0,000087 & 50,7607 & $-0,00010$ \\
\hline 111 & 391 & 673,0016 & 0,000986 & 52,7347 & $-0,00009$ \\
\hline 112 & 397 & 672,9562 & 0,045371 & 6367,09 & $-0,00174$ \\
\hline 113 & 401 & 672,5674 & 0,38883 & 11104,6 & $-0,07626$ \\
\hline 114 & 404 & 672,5336 & 0,033778 & 1121,06 & $-0,06409$ \\
\hline 115 & 407 & 672,5331 & 0,000513 & 159,463 & $-0,00100$ \\
\hline 116 & 410 & 672,5330 & 0,000094 & 92,9803 & $-0,00006$ \\
\hline 117 & 416 & 672,5304 & 0,002607 & 2810,86 & $-0,00013$ \\
\hline 118 & 422 & 672,4048 & 0,125595 & 224,846 & $-0,00524$ \\
\hline 119 & 424 & 672,2855 & 0,119241 & 2014,00 & $-0,12592$ \\
\hline 120 & 427 & 672,2700 & 0,015512 & 49,6017 & $-0,03062$ \\
\hline 121 & 430 & 672,2696 & 0,000456 & 14,0417 & $-0,00091$ \\
\hline 122 & 433 & 672,2695 & 0,000037 & 13,2472 & $-0,00005$ \\
\hline 123 & 437 & 672,2689 & 0,000631 & 116,268 & $-0,00003$ \\
\hline 124 & 441 & 672,2630 & 0,005864 & 586,035 & $-0,00161$ \\
\hline 125 & 447 & 671,8182 & 0,444842 & 6446,83 & $-0,01002$ \\
\hline 126 & 450 & 671,6979 & 0,120297 & 429,043 & $-0,21379$ \\
\hline 127 & 453 & 671,6930 & 0,004894 & 359,847 & $-0,01753$ \\
\hline 128 & 456 & 671,6907 & 0,002316 & 37,1947 & $-0,00468$ \\
\hline 129 & 459 & 671,6905 & 0,000169 & 17,0584 & $-0,00025$ \\
\hline 130 & 462 & 671,6905 & 0,00004 & 1,34776 & $-0,00005$ \\
\hline 131 & 466 & 671,6901 & 0,000398 & 158,280 & $-0,00002$ \\
\hline 132 & 472 & 671,6803 & 0,009769 & 498,508 & $-0,00067$ \\
\hline 133 & 476 & 671,5145 & 0,165765 & 44,0254 & $-0,01639$ \\
\hline 134 & 479 & 671,4492 & 0,065367 & 59,5928 & $-0,13581$ \\
\hline 135 & 482 & 671,4394 & 0,009782 & 79,9443 & $-0,02169$ \\
\hline 136 & 485 & 671,4390 & 0,000342 & 9,25379 & $-0,00100$ \\
\hline 137 & 488 & 671,4389 & 0,000161 & 5,10186 & $-0,00027$ \\
\hline 138 & 491 & 671,4389 & 0,000026 & 3,57990 & $-0,00003$ \\
\hline 139 & 493 & 671,4388 & 0,000045 & 2,00072 & $-0,00001$ \\
\hline 140 & 497 & 671,4385 & 0,000347 & 110,119 & $-0,00011$ \\
\hline 141 & 505 & 671,3353 & 0,103119 & 68,8658 & $-0,00058$ \\
\hline 142 & 507 & 671,2036 & 0,131718 & 1009,60 & $-0,12160$ \\
\hline 143 & 510 & 671,1704 & 0,033205 & 118,542 & $-0,05310$ \\
\hline
\end{tabular}




\begin{tabular}{|r|r|r|r|r|r|}
\hline Iteração & Chamadas & $\begin{array}{r}\text { Log- } \\
\text { verossimança } \\
\text { negativa }\end{array}$ & Diferença & $\begin{array}{r}\text { Máximo } \\
\text { Gradiente }\end{array}$ & Derivada \\
\hline $\mathbf{1 4 4}$ & 513 & 671,1641 & 0,006343 & 363,780 & $-0,01048$ \\
\hline $\mathbf{1 4 5}$ & 515 & 671,1593 & 0,004779 & 316,137 & $-0,01287$ \\
\hline $\mathbf{1 4 6}$ & 518 & 671,1566 & 0,002726 & 18,8504 & $-0,00530$ \\
\hline $\mathbf{1 4 7}$ & 521 & 671,1562 & 0,000398 & 32,3551 & $-0,00050$ \\
\hline $\mathbf{1 4 8}$ & 524 & 671,1561 & 0,000025 & 8,25630 & $-0,00004$ \\
\hline $\mathbf{1 4 9}$ & 526 & 671,1561 & 0,000039 & 12,5164 & $-0,00001$ \\
\hline $\mathbf{1 5 0}$ & 530 & 671,1557 & 0,00045 & 22,5513 & $-0,00008$ \\
\hline $\mathbf{1 5 1}$ & 536 & 671,1230 & 0,032642 & 272,780 & $-0,00082$ \\
\hline $\mathbf{1 5 2}$ & 540 & 670,9799 & 0,143117 & 1053,62 & $-0,10665$ \\
\hline $\mathbf{1 5 3}$ & 544 & 670,6047 & 0,375168 & 883,587 & $-0,37129$ \\
\hline $\mathbf{1 5 4}$ & 546 & 670,2954 & 0,30932 & 335,958 & $-0,67532$ \\
\hline $\mathbf{1 5 5}$ & 549 & 670,1667 & 0,128673 & 147,450 & $-0,27695$ \\
\hline $\mathbf{1 5 6}$ & 552 & 670,1468 & 0,019945 & 175,093 & $-0,04168$ \\
\hline $\mathbf{1 5 7}$ & 555 & 670,1439 & 0,002879 & 83,7334 & $-0,00524$ \\
\hline $\mathbf{1 5 8}$ & 558 & 670,1433 & 0,000619 & 30,5231 & $-0,00135$ \\
\hline $\mathbf{1 5 9}$ & 561 & 670,1432 & 0,000074 & 11,4209 & $-0,00011$ \\
\hline $\mathbf{1 6 0}$ & 564 & 670,1432 & $5,727 \mathrm{E}-6$ & 3,30079 & $-7,29 \mathrm{E}-6$ \\
\hline $\mathbf{1 6 1}$ & 568 & 670,1432 & 0,000018 & 25,2936 & $-4,68 \mathrm{E}-6$ \\
\hline $\mathbf{1 6 2}$ & 572 & 670,1430 & 0,000162 & 39,7030 & $-0,00003$ \\
\hline $\mathbf{1 6 3}$ & 576 & 670,1417 & 0,001356 & 190,786 & $-0,00027$ \\
\hline $\mathbf{1 6 4}$ & 580 & 670,1275 & 0,014183 & 235,990 & $-0,00221$ \\
\hline $\mathbf{1 6 5}$ & 584 & 670,0878 & 0,039709 & 350,615 & $-0,01916$ \\
\hline $\mathbf{1 6 6}$ & 587 & 670,0848 & 0,003001 & 126,576 & $-0,00535$ \\
\hline $\mathbf{1 6 7}$ & 590 & 670,0847 & 0,000054 & 14,7042 & $-0,00011$ \\
\hline $\mathbf{1 6 8}$ & 593 & 670,0847 & $1,24 \mathrm{E}-6$ & 0,90967 & $-2,39 \mathrm{E}-6$ \\
\hline $\mathbf{1 6 9}$ & 596 & 670,0847 & $4,134 \mathrm{E}-8$ & 0,32195 & $-8,22 \mathrm{E}-8$ \\
\hline $\mathbf{1 7 0}$ & 609 & 670,0847 & $1,36 \mathrm{E}-12$ & 0,32195 & $-1,61069$ \\
\hline
\end{tabular}

Fonte: adaptado do resultado da estimação SAS.

\section{Quadro A5-2.13: Ajustamento - Modelo ZINB Ativo}

\begin{tabular}{|l|r|}
\hline -2 Log-verossimilhança & 1340,2 \\
\hline AIC & 1400,2 \\
\hline AICC & 1401,2 \\
\hline BIC & 1564,3 \\
\hline
\end{tabular}

Fonte: adaptado do resultado da estimação SAS. 
Quadro A5-2.14: Estimativa dos Parâmetros - Modelo ZINB Ativo

\begin{tabular}{|c|c|c|c|c|c|c|c|c|}
\hline \multirow{2}{*}{$\begin{array}{l}\text { Parâmetro } \\
\text { z0 }\end{array}$} & \multirow{2}{*}{$\begin{array}{r}\text { Estimativa } \\
9,5160\end{array}$} & \multirow{2}{*}{$\begin{array}{r}\begin{array}{r}\text { Erro- } \\
\text { padrão }\end{array} \\
2,2436\end{array}$} & \multirow{2}{*}{\begin{tabular}{r|} 
DF \\
1757
\end{tabular}} & \multirow{2}{*}{\begin{tabular}{r|} 
Valor t \\
4,24
\end{tabular}} & \multirow{2}{*}{$\begin{array}{r}\text { Prob }>|t| \\
<0,0001\end{array}$} & \multicolumn{2}{|c|}{$\begin{array}{l}95 \% \text { Intervalo de } \\
\text { Confiança }\end{array}$} & \multirow{2}{*}{$\begin{array}{r}\text { Gradiente } \\
9,339 \mathrm{E}-6\end{array}$} \\
\hline & & & & & & 5,1156 & 13,9165 & \\
\hline ZAA & $-1,4959$ & 1,1622 & 1757 & $-1,29$ & 0,1982 & $-3,7752$ & 0,7835 & $-5,05 E-7$ \\
\hline $\mathrm{zAB}$ & $-1,2543$ & 0,8129 & 1757 & $-1,54$ & 0,1230 & $-2,8487$ & 0,3400 & $-0,00003$ \\
\hline zBA & $-2,6792$ & 1,0985 & 1757 & $-2,44$ & 0,0148 & $-4,8338$ & $-0,5247$ & $4,509 \mathrm{E}-7$ \\
\hline zBB & $-3,5097$ & 1,0421 & 1757 & $-3,37$ & 0,0008 & $-5,5535$ & $-1,4659$ & 0,000024 \\
\hline ZMD & $-3,0349$ & 1,1731 & 1757 & $-2,59$ & 0,0098 & $-5,3357$ & $-0,7341$ & $6,945 \mathrm{E}-6$ \\
\hline $\mathrm{zPL}$ & $-1,1542$ & 0,6389 & 1757 & $-1,81$ & 0,0710 & $-2,4072$ & 0,09887 & 0,000018 \\
\hline zNL & 1,1384 & 0,7739 & 1757 & 1,47 & 0,1415 & $-0,3794$ & 2,6563 & $2,347 \mathrm{E}-6$ \\
\hline ZPIB & $-0,00773$ & 0,002018 & 1757 & $-3,83$ & 0,0001 & $-0,01169$ & $-0,00377$ & $-0,00065$ \\
\hline zCOMEX & $-0,00935$ & 0,006121 & 1757 & $-1,53$ & 0,1267 & $-0,02136$ & 0,002652 & $-0,00038$ \\
\hline ZAGRI & $-0,06776$ & 0,02110 & 1757 & $-3,21$ & 0,0013 & $-0,1092$ & $-0,02637$ & 0,000013 \\
\hline ZPREF & $-0,00212$ & 0,002572 & 1757 & $-0,82$ & 0,4096 & $-0,00716$ & 0,002923 & 0,001152 \\
\hline zODP & $-0,2738$ & 0,1113 & 1757 & $-2,46$ & 0,0140 & $-0,4921$ & $-0,05557$ & 0,000062 \\
\hline zCAP & $-1,0642$ & 0,4704 & 1757 & $-2,26$ & 0,0238 & $-1,9868$ & $-0,1415$ & $9,986 \mathrm{E}-6$ \\
\hline ZAPRE & $-0,1761$ & 0,05643 & 1757 & $-3,12$ & 0,0018 & $-0,2868$ & $-0,06541$ & 0,000212 \\
\hline CAA & $-0,3037$ & 0,3499 & 1757 & $-0,87$ & 0,3854 & $-0,9900$ & 0,3825 & $-0,00001$ \\
\hline CAB & 0,5520 & 0,2262 & 1757 & 2,44 & 0,0148 & 0,1083 & 0,9957 & $2,781 \mathrm{E}-6$ \\
\hline cBA & $-0,06910$ & 0,4005 & 1757 & $-0,17$ & 0,8631 & $-0,8547$ & 0,7165 & 0,000026 \\
\hline cBB & 0,09332 & 0,3450 & 1757 & 0,27 & 0,7868 & $-0,5834$ & 0,7700 & $-0,00003$ \\
\hline CMD & 0,3801 & 0,3158 & 1757 & 1,20 & 0,2289 & $-0,2392$ & 0,9995 & 0,000028 \\
\hline cPL & $-0,4129$ & 0,2531 & 1757 & $-1,63$ & 0,1031 & $-0,9094$ & 0,08359 & $-8,6 \mathrm{E}-6$ \\
\hline cNL & $-0,09087$ & 0,3932 & 1757 & $-0,23$ & 0,8173 & $-0,8621$ & 0,6804 & 0,000018 \\
\hline cPIB & 0,000170 & 0,000017 & 1757 & 10,23 & $<0,0001$ & 0,000137 & 0,000202 & $-0,19735$ \\
\hline cCOMEX & $-0,00797$ & 0,002053 & 1757 & $-3,88$ & 0,0001 & $-0,01200$ & $-0,00395$ & 0,000954 \\
\hline cAGRI & $-0,01990$ & 0,009925 & 1757 & $-2,00$ & 0,0451 & $-0,03936$ & $-0,00043$ & 0,000619 \\
\hline cPREF & 0,002658 & 0,001587 & 1757 & 1,67 & 0,0941 & $-0,00045$ & 0,005771 & 0,006361 \\
\hline cODP & 0,02614 & 0,09401 & 1757 & 0,28 & 0,7810 & $-0,1583$ & 0,2105 & $-0,00012$ \\
\hline cCAP & 0,1885 & 0,06063 & 1757 & 3,11 & 0,0019 & 0,06961 & 0,3074 & $-0,00002$ \\
\hline CAPRE & $-0,01272$ & 0,002836 & 1757 & $-4,49$ & $<0,0001$ & $-0,01828$ & $-0,00716$ & 0,000817 \\
\hline alfa & 0,3739 & 0,1115 & 1757 & 3,35 & 0,0008 & 0,1553 & 0,5925 & $-0,00003$ \\
\hline
\end{tabular}

Fonte: adaptado do resultado da estimação SAS. 
Anexo 5-7

MODELO ZINB - POLO PASSIVO: RESULTADO DA ESTIMAÇÃO

Quadro A5-2.15: Histórico de Iterações - Modelo ZINB Passivo

\begin{tabular}{|c|c|c|c|c|c|}
\hline Iteração & Chamadas & $\begin{array}{r}\text { Log- } \\
\text { verossimilhança } \\
\text { negativa }\end{array}$ & Diferença & $\begin{array}{r}\text { Máximo } \\
\text { Gradiente }\end{array}$ & Derivada \\
\hline 1 & 13 & 949,1532 & 65,83932 & 363792 & $-1,64 \mathrm{E} 10$ \\
\hline 2 & 18 & 905,1461 & 44,00714 & 23195,5 & -302620 \\
\hline 3 & 20 & 661,0955 & 244,0506 & 150044 & $-10712,8$ \\
\hline 4 & 22 & 625,1057 & 35,98977 & 55463,4 & $-83,6349$ \\
\hline 5 & 26 & 602,9114 & 22,19427 & 79170,1 & $-22,3399$ \\
\hline 6 & 29 & 598,3105 & 4,600907 & 47340,2 & $-12,8706$ \\
\hline 7 & 31 & 595,9727 & 2,337801 & 48043,1 & $-4,95108$ \\
\hline 8 & 33 & 592,1206 & 3,852173 & 15884,0 & $-6,04727$ \\
\hline 9 & 35 & 587,8352 & 4,285375 & 63152,0 & $-3,73306$ \\
\hline 10 & 37 & 582,3826 & 5,452627 & 24980,8 & $-4,01553$ \\
\hline 11 & 40 & 580,2812 & 2,101313 & 5468,75 & $-2,56716$ \\
\hline 12 & 43 & 579,6098 & 0,671433 & 1113,79 & $-0,82694$ \\
\hline 13 & 45 & 578,9333 & 0,676485 & 1197,73 & $-0,43838$ \\
\hline 14 & 47 & 577,8169 & 1,116404 & 2567,32 & $-0,63561$ \\
\hline 15 & 49 & 576,3754 & 1,441527 & 11918,2 & $-1,15646$ \\
\hline 16 & 51 & 574,7453 & 1,630118 & 4477,65 & $-1,05075$ \\
\hline 17 & 54 & 574,1775 & 0,567743 & 8601,84 & $-0,51275$ \\
\hline 18 & 56 & 573,6165 & 0,561057 & 1065,09 & $-0,52961$ \\
\hline 19 & 59 & 573,3420 & 0,274474 & 880,263 & $-0,32962$ \\
\hline 20 & 62 & 573,1903 & 0,151687 & 3219,80 & $-0,12986$ \\
\hline 21 & 64 & 572,9932 & 0,197061 & 2203,95 & $-0,08573$ \\
\hline 22 & 66 & 572,6858 & 0,307419 & 3944,73 & $-0,26795$ \\
\hline 23 & 69 & 572,5261 & 0,159728 & 2299,88 & $-0,21458$ \\
\hline 24 & 72 & 572,4662 & 0,059919 & 472,268 & $-0,05457$ \\
\hline 25 & 76 & 572,2734 & 0,192824 & 3321,89 & $-0,03830$ \\
\hline 26 & 80 & 570,6422 & 1,63117 & 7314,05 & $-0,29674$ \\
\hline 27 & 83 & 569,9633 & 0,678859 & 5684,24 & $-1,02259$ \\
\hline 28 & 86 & 569,9010 & 0,062326 & 2072,51 & $-0,11139$ \\
\hline 29 & 89 & 569,8821 & 0,018918 & 987,181 & $-0,03458$ \\
\hline 30 & 91 & 569,8543 & 0,0278 & 1365,39 & $-0,01560$ \\
\hline 31 & 95 & 569,7005 & 0,153816 & 11481,8 & $-0,03683$ \\
\hline
\end{tabular}




\begin{tabular}{|c|c|c|c|c|c|}
\hline Iteração & Chamadas & $\begin{array}{r}\text { Log- } \\
\text { verossimilhança } \\
\text { negativa }\end{array}$ & Diferença & $\begin{array}{r}\text { Máximo } \\
\text { Gradiente }\end{array}$ & Derivada \\
\hline 32 & 99 & 567,7439 & 1,956523 & 39804,7 & $-0,23764$ \\
\hline 33 & 103 & 560,7249 & 7,019009 & 84008,0 & $-3,33374$ \\
\hline 34 & 105 & 557,7424 & 2,982533 & 61787,2 & $-15,3213$ \\
\hline 35 & 108 & 555,3326 & 2,409811 & 5278,70 & $-3,28437$ \\
\hline 36 & 111 & 555,2112 & 0,121425 & 11322,2 & $-0,40596$ \\
\hline 37 & 114 & 555,1451 & 0,06602 & 13753,4 & $-0,16079$ \\
\hline 38 & 117 & 555,1284 & 0,016767 & 3346,01 & $-0,04611$ \\
\hline 39 & 121 & 555,0692 & 0,059134 & 8226,82 & $-0,01410$ \\
\hline 40 & 125 & 554,2013 & 0,867996 & 19660,3 & $-0,13834$ \\
\hline 41 & 129 & 552,4372 & 1,764019 & 26230,9 & $-1,68200$ \\
\hline 42 & 132 & 552,1139 & 0,323355 & 268,794 & $-0,79168$ \\
\hline 43 & 135 & 552,1012 & 0,012719 & 140,953 & $-0,04094$ \\
\hline 44 & 138 & 552,0927 & 0,008424 & 363,633 & $-0,01203$ \\
\hline 45 & 140 & 552,0815 & 0,011219 & 646,275 & $-0,00663$ \\
\hline 46 & 144 & 551,8901 & 0,19146 & 9590,22 & $-0,03121$ \\
\hline 47 & 148 & 550,6395 & 1,250606 & 42700,8 & $-0,62614$ \\
\hline 48 & 152 & 544,9137 & 5,72575 & 19983,8 & $-2,30324$ \\
\hline 49 & 155 & 543,9482 & 0,965452 & 1892,03 & $-1,93222$ \\
\hline 50 & 158 & 543,8955 & 0,052767 & 832,493 & $-0,08804$ \\
\hline 51 & 161 & 543,8867 & 0,008777 & 548,815 & $-0,01120$ \\
\hline 52 & 163 & 543,8731 & 0,013623 & 340,688 & $-0,00490$ \\
\hline 53 & 167 & 543,7363 & 0,136831 & 9162,60 & $-0,02755$ \\
\hline 54 & 173 & 539,9929 & 3,743325 & 8277,39 & $-0,26889$ \\
\hline 55 & 176 & 538,7990 & 1,193927 & 629,582 & $-1,89447$ \\
\hline 56 & 179 & 538,6110 & 0,18797 & 209,215 & $-0,27293$ \\
\hline 57 & 181 & 538,3859 & 0,225103 & 1638,66 & $-0,21220$ \\
\hline 58 & 183 & 538,1461 & 0,239834 & 822,749 & $-0,23678$ \\
\hline 59 & 186 & 537,9468 & 0,199322 & 1043,56 & $-0,32933$ \\
\hline 60 & 188 & 537,8049 & 0,141829 & 761,054 & $-0,43342$ \\
\hline 61 & 191 & 537,7444 & 0,060528 & 241,823 & $-0,11803$ \\
\hline 62 & 194 & 537,7384 & 0,005986 & 84,2070 & $-0,00686$ \\
\hline 63 & 197 & 537,7351 & 0,003319 & 125,885 & $-0,00448$ \\
\hline 64 & 199 & 537,7315 & 0,003599 & 277,479 & $-0,00823$ \\
\hline 65 & 203 & 537,6780 & 0,053549 & 451,191 & $-0,01926$ \\
\hline 66 & 207 & 536,8183 & 0,859684 & 1085,67 & $-0,11083$ \\
\hline 67 & 211 & 534,4159 & 2,40236 & 3681,64 & $-1,64949$ \\
\hline 68 & 214 & 533,1820 & 1,233951 & 403,029 & $-2,15929$ \\
\hline
\end{tabular}




\begin{tabular}{|c|c|c|c|c|c|}
\hline Iteração & Chamadas & $\begin{array}{r}\text { Log- } \\
\text { verossimilhança } \\
\text { negativa }\end{array}$ & Diferença & $\begin{array}{r}\text { Máximo } \\
\text { Gradiente }\end{array}$ & Derivada \\
\hline 69 & 217 & 532,9719 & 0,210111 & 325,146 & $-0,62250$ \\
\hline 70 & 220 & 532,8281 & 0,143802 & 162,011 & $-0,25207$ \\
\hline 71 & 223 & 532,7152 & 0,1129 & 48,2528 & $-0,11113$ \\
\hline 72 & 226 & 532,6725 & 0,042661 & 58,4920 & $-0,13529$ \\
\hline 73 & 229 & 532,6467 & 0,02579 & 160,433 & $-0,05665$ \\
\hline 74 & 232 & 532,6450 & 0,001731 & 77,2712 & $-0,00259$ \\
\hline 75 & 234 & 532,6432 & 0,001818 & 273,222 & $-0,00163$ \\
\hline 76 & 238 & 532,6234 & 0,019763 & 2145,87 & $-0,00331$ \\
\hline 77 & 244 & 531,8846 & 0,738835 & 33392,2 & $-0,03473$ \\
\hline 78 & 248 & 529,9036 & 1,980973 & 19327,2 & $-1,19010$ \\
\hline 79 & 251 & 529,6340 & 0,269568 & 1974,99 & $-0,45726$ \\
\hline 80 & 254 & 529,6183 & 0,015665 & 975,226 & $-0,03270$ \\
\hline 81 & 257 & 529,6166 & 0,001768 & 289,193 & $-0,00355$ \\
\hline 82 & 259 & 529,6154 & 0,001161 & 1720,06 & $-0,00103$ \\
\hline 83 & 263 & 529,6108 & 0,004633 & 1560,39 & $-0,00261$ \\
\hline 84 & 271 & 528,3512 & 1,259545 & 31690,1 & $-0,00669$ \\
\hline 85 & 273 & 527,0754 & 1,27583 & 38413,4 & $-1,36716$ \\
\hline 86 & 276 & 526,8850 & 0,190392 & 8418,67 & $-0,36733$ \\
\hline 87 & 279 & 526,8714 & 0,013596 & 3288,69 & $-0,04282$ \\
\hline 88 & 282 & 526,8675 & 0,003943 & 913,496 & $-0,00782$ \\
\hline 89 & 285 & 526,8661 & 0,001357 & 2343,95 & $-0,00098$ \\
\hline 90 & 291 & 526,8330 & 0,033103 & 943,134 & $-0,00221$ \\
\hline 91 & 295 & 526,3609 & 0,47213 & 7591,55 & $-0,06372$ \\
\hline 92 & 297 & 525,8316 & 0,529333 & 3916,85 & $-0,46616$ \\
\hline 93 & 302 & 525,7859 & 0,045687 & 9610,66 & $-0,14862$ \\
\hline 94 & 304 & 525,7127 & 0,073123 & 4326,50 & $-0,19606$ \\
\hline 95 & 307 & 525,7023 & 0,010476 & 709,171 & $-0,01949$ \\
\hline 96 & 310 & 525,7016 & 0,000633 & 217,697 & $-0,00095$ \\
\hline 97 & 313 & 525,7013 & 0,000302 & 121,967 & $-0,00028$ \\
\hline 98 & 317 & 525,7003 & 0,001011 & 1355,54 & $-0,00026$ \\
\hline 99 & 323 & 525,6288 & 0,07149 & 17770,2 & $-0,00168$ \\
\hline 100 & 327 & 524,8414 & 0,787429 & 17121,8 & $-0,13421$ \\
\hline 101 & 330 & 524,6439 & 0,197539 & 1340,19 & $-0,34142$ \\
\hline 102 & 333 & 524,6399 & 0,003968 & 106,131 & $-0,00781$ \\
\hline 103 & 336 & 524,6395 & 0,000369 & 307,800 & $-0,00025$ \\
\hline 104 & 342 & 524,6253 & 0,014225 & 449,380 & $-0,00050$ \\
\hline 105 & 348 & 524,1434 & 0,481935 & 25743,9 & $-0,02765$ \\
\hline
\end{tabular}




\begin{tabular}{|c|c|c|c|c|c|}
\hline Iteração & Chamadas & $\begin{array}{r}\text { Log- } \\
\text { verossimilhança } \\
\text { negativa }\end{array}$ & Diferença & $\begin{array}{r}\text { Máximo } \\
\text { Gradiente }\end{array}$ & Derivada \\
\hline 106 & 350 & 523,3709 & 0,772519 & 990,252 & $-0,54984$ \\
\hline 107 & 353 & 523,2307 & 0,140171 & 2813,65 & $-0,27006$ \\
\hline 108 & 356 & 523,2285 & 0,002147 & 116,847 & $-0,00410$ \\
\hline 109 & 359 & 523,2282 & 0,000337 & 209,228 & $-0,00034$ \\
\hline 110 & 363 & 523,2246 & 0,003642 & 2292,29 & $-0,00034$ \\
\hline 111 & 369 & 523,0576 & 0,166993 & 2523,09 & $-0,00583$ \\
\hline 112 & 373 & 522,5588 & 0,498789 & 6474,87 & $-0,24638$ \\
\hline 113 & 376 & 522,5233 & 0,035456 & 261,805 & $-0,06566$ \\
\hline 114 & 379 & 522,5228 & 0,000561 & 87,6422 & $-0,00107$ \\
\hline 115 & 381 & 522,5224 & 0,000362 & 555,747 & $-0,00009$ \\
\hline 116 & 387 & 522,5148 & 0,007592 & 347,484 & $-0,00066$ \\
\hline 117 & 393 & 522,3593 & 0,155517 & 3230,76 & $-0,01457$ \\
\hline 118 & 397 & 521,5301 & 0,829226 & 1829,73 & $-0,25143$ \\
\hline 119 & 400 & 521,2366 & 0,293419 & 927,572 & $-0,37217$ \\
\hline 120 & 403 & 521,2243 & 0,012306 & 30,5503 & $-0,02667$ \\
\hline 121 & 406 & 521,2213 & 0,00307 & 195,743 & $-0,00614$ \\
\hline 122 & 409 & 521,2208 & 0,000441 & 71,4053 & $-0,00055$ \\
\hline 123 & 412 & 521,2205 & 0,000287 & 94,1562 & $-0,00014$ \\
\hline 124 & 416 & 521,2172 & 0,003367 & 293,353 & $-0,00031$ \\
\hline 125 & 422 & 520,9872 & 0,229983 & 3147,61 & $-0,00536$ \\
\hline 126 & 424 & 520,6471 & 0,340123 & 3135,88 & $-0,26026$ \\
\hline 127 & 427 & 520,6250 & 0,022051 & 89,2807 & $-0,04345$ \\
\hline 128 & 430 & 520,6245 & 0,000543 & 1,19039 & $-0,00092$ \\
\hline 129 & 433 & 520,6243 & 0,000145 & 14,5584 & $-0,00010$ \\
\hline 130 & 437 & 520,6237 & 0,000636 & 70,8534 & $-0,00014$ \\
\hline 131 & 443 & 520,6050 & 0,018725 & 273,573 & $-0,00122$ \\
\hline 132 & 447 & 520,3296 & 0,275355 & 4901,23 & $-0,03310$ \\
\hline 133 & 449 & 519,9364 & 0,393197 & 682,324 & $-0,30247$ \\
\hline 134 & 452 & 519,8588 & 0,077632 & 1056,94 & $-0,13623$ \\
\hline 135 & 455 & 519,8464 & 0,012414 & 306,912 & $-0,02802$ \\
\hline 136 & 458 & 519,8454 & 0,001002 & 38,8374 & $-0,00174$ \\
\hline 137 & 461 & 519,8453 & 0,000035 & 1,73887 & $-0,00005$ \\
\hline 138 & 465 & 519,8451 & 0,000221 & 320,728 & $-0,00002$ \\
\hline 139 & 471 & 519,8360 & 0,009098 & 1259,69 & $-0,00039$ \\
\hline 140 & 475 & 519,7018 & 0,134178 & 6599,65 & $-0,01504$ \\
\hline 141 & 477 & 519,4943 & 0,207501 & 780,112 & $-0,13759$ \\
\hline 142 & 479 & 519,4196 & 0,074754 & 4719,02 & $-0,14681$ \\
\hline
\end{tabular}




\begin{tabular}{|c|c|c|c|c|c|}
\hline Iteração & Chamadas & $\begin{array}{r}\text { Log- } \\
\text { verossimilhança } \\
\text { negativa }\end{array}$ & Diferença & $\begin{array}{r}\text { Máximo } \\
\text { Gradiente }\end{array}$ & Derivada \\
\hline 143 & 481 & 519,3183 & 0,101233 & 1634,97 & $-0,25556$ \\
\hline 144 & 484 & 519,3074 & 0,010954 & 212,959 & $-0,02695$ \\
\hline 145 & 487 & 519,3065 & 0,000885 & 65,6178 & $-0,00134$ \\
\hline 146 & 490 & 519,3064 & 0,000121 & 25,0706 & $-0,00015$ \\
\hline 147 & 493 & 519,3064 & $9,305 E-6$ & 29,0160 & $-8,03 E-6$ \\
\hline 148 & 499 & 519,3060 & 0,000331 & 381,166 & $-7,39 \mathrm{E}-6$ \\
\hline 149 & 505 & 519,2965 & 0,009571 & 1064,50 & $-0,00055$ \\
\hline 150 & 509 & 519,2359 & 0,060567 & 995,512 & $-0,01246$ \\
\hline 151 & 512 & 519,2045 & 0,031423 & 673,049 & $-0,03302$ \\
\hline 152 & 515 & 519,2032 & 0,001273 & 148,982 & $-0,00237$ \\
\hline 153 & 518 & 519,2032 & 0,000022 & 2,88380 & $-0,00004$ \\
\hline 154 & 521 & 519,2032 & $1,903 E-6$ & 15,4039 & $-1,54 \mathrm{E}-6$ \\
\hline 155 & 525 & 519,2032 & 0,000026 & 58,6224 & $-2,08 \mathrm{E}-6$ \\
\hline 156 & 531 & 519,2022 & 0,000968 & 706,358 & $-0,00005$ \\
\hline 157 & 535 & 519,1892 & 0,01303 & 118,084 & $-0,00170$ \\
\hline 158 & 538 & 519,1884 & 0,000712 & 67,8575 & $-0,00128$ \\
\hline 159 & 541 & 519,1884 & $2,315 E-6$ & 3,52733 & $-4,53 \mathrm{E}-6$ \\
\hline 160 & 544 & 519,1884 & $3,865 E-8$ & 7,39538 & $-2,52 \mathrm{E}-8$ \\
\hline 161 & 550 & 519,1884 & $4,566 \mathrm{E}-6$ & 59,9894 & $-4,94 \mathrm{E}-8$ \\
\hline 162 & 556 & 519,1878 & 0,000613 & 428,605 & $-8,82 \mathrm{E}-6$ \\
\hline 163 & 558 & 519,1868 & 0,001048 & 277,085 & $-0,00076$ \\
\hline 164 & 561 & 519,1866 & 0,000196 & 6,11391 & $-0,00039$ \\
\hline 165 & 564 & 519,1866 & $1,784 \mathrm{E}-7$ & 2,06260 & $-2,54 \mathrm{E}-7$ \\
\hline 166 & 570 & 519,1866 & $9,178 \mathrm{E}-6$ & 61,2369 & $-7,67 \mathrm{E}-8$ \\
\hline 167 & 576 & 519,1854 & 0,001165 & 304,725 & $-0,00002$ \\
\hline 168 & 580 & 519,1785 & 0,006925 & 109,190 & $-0,00197$ \\
\hline 169 & 583 & 519,1782 & 0,00025 & 6,39108 & $-0,00043$ \\
\hline 170 & 586 & 519,1782 & $5,792 \mathrm{E}-6$ & 5,83413 & $-0,00001$ \\
\hline 171 & 589 & 519,1782 & $3,096 \mathrm{E}-8$ & 0,10652 & $-5,72 \mathrm{E}-8$ \\
\hline 172 & 603 & 519,1782 & $-159 E-14$ & 0,10652 & $-0,53266$ \\
\hline
\end{tabular}

Fonte: adaptado do resultado da estimação SAS. 
Quadro A5-2.16: Ajustamento - Modelo ZINB Passivo

\begin{tabular}{|l|r|}
\hline -2 Log-verossimilhança & 1038,4 \\
\hline AIC & 1098,4 \\
\hline AICC & 1099,4 \\
\hline BIC & 1262,5 \\
\hline
\end{tabular}

Fonte: adaptado do resultado da estimação SAS.

\section{Quadro A5-2.17: Estimativa dos Parâmetros - Modelo ZINB Passivo}

\begin{tabular}{|c|c|c|c|c|c|c|c|c|}
\hline \multirow{2}{*}{\begin{tabular}{|l} 
Parâmetro \\
zo
\end{tabular}} & \multirow{2}{*}{$\begin{array}{r}\text { Estimativa } \\
4,5604\end{array}$} & \multirow{2}{*}{$\begin{array}{r}\begin{array}{r}\text { Erro- } \\
\text { padrão }\end{array} \\
2,2355\end{array}$} & \multirow{2}{*}{\begin{tabular}{r|} 
DF \\
1757
\end{tabular}} & \multirow{2}{*}{\begin{tabular}{r|} 
Valor t \\
2,04
\end{tabular}} & \multirow{2}{*}{$\begin{array}{r}\text { Prob }>|\mathbf{t}| \\
0,0415\end{array}$} & \multicolumn{2}{|c|}{$\begin{array}{l}95 \% \text { Intervalo de } \\
\text { Confiança }\end{array}$} & \multirow{2}{*}{$\begin{array}{r}\text { Gradiente } \\
-5,04 \mathrm{E}-6\end{array}$} \\
\hline & & & & & & 0,1759 & 8,9449 & \\
\hline zAA & $-3,7853$ & 1,1825 & 1757 & $-3,20$ & 0,0014 & $-6,1046$ & $-1,4660$ & $-3,03 E-6$ \\
\hline$z A B$ & $-2,8612$ & 1,1044 & 1757 & $-2,59$ & 0,0097 & $-5,0272$ & $-0,6952$ & $-3,14 \mathrm{E}-6$ \\
\hline zBA & $-4,2393$ & 1,5470 & 1757 & $-2,74$ & 0,0062 & $-7,2734$ & $-1,2051$ & $1,723 \mathrm{E}-6$ \\
\hline zBB & $-13,7123$ & 6,1331 & 1757 & $-2,24$ & 0,0255 & $-25,7411$ & $-1,6834$ & $1,077 \mathrm{E}-6$ \\
\hline ZMD & $-2,1643$ & 1,8046 & 1757 & $-1,20$ & 0,2306 & $-5,7037$ & 1,3752 & $-8,94 \mathrm{E}-9$ \\
\hline$z P L$ & $-0,3857$ & 0,7415 & 1757 & $-0,52$ & 0,6030 & $-1,8400$ & 1,0686 & $2,004 \mathrm{E}-7$ \\
\hline zNL & 10,0397 & 5,7388 & 1757 & 1,75 & 0,0804 & $-1,2159$ & 21,2952 & $6,427 \mathrm{E}-7$ \\
\hline ZPIB & $-0,01081$ & 0,003088 & 1757 & $-3,50$ & 0,0005 & $-0,01686$ & $-0,00475$ & $-0,00027$ \\
\hline zCOMEX & 0,01622 & 0,008393 & 1757 & 1,93 & 0,0534 & $-0,00024$ & 0,03268 & $-0,00064$ \\
\hline ZAGRI & $-0,00579$ & 0,02506 & 1757 & $-0,23$ & 0,8173 & $-0,05495$ & 0,04337 & $-0,00017$ \\
\hline zPREF & $-0,00060$ & 0,003626 & 1757 & $-0,16$ & 0,8693 & $-0,00771$ & 0,006515 & $-0,00039$ \\
\hline zODP & $-0,5890$ & 0,3099 & 1757 & $-1,90$ & 0,0576 & $-1,1969$ & 0,01890 & $-3,61 \mathrm{E}-6$ \\
\hline zCAP & $-0,03069$ & 0,4349 & 1757 & $-0,07$ & 0,9437 & $-0,8836$ & 0,8222 & $-0,00002$ \\
\hline ZAPRE & 0,008729 & 0,02574 & 1757 & 0,34 & 0,7345 & $-0,04175$ & 0,05921 & $-0,00005$ \\
\hline CAA & $-0,3973$ & 0,3222 & 1757 & $-1,23$ & 0,2177 & $-1,0291$ & 0,2346 & $-0,00001$ \\
\hline CAB & 0,05413 & 0,2677 & 1757 & 0,20 & 0,8398 & $-0,4708$ & 0,5791 & $-4,31 \mathrm{E}-7$ \\
\hline cBA & $-0,4951$ & 0,3763 & 1757 & $-1,32$ & 0,1885 & $-1,2331$ & 0,2430 & $-1,62 \mathrm{E}-6$ \\
\hline cBB & $-2,0306$ & 0,4138 & 1757 & $-4,91$ & $<0,0001$ & $-2,8421$ & $-1,2191$ & $-9,59 \mathrm{E}-6$ \\
\hline cMD & 0,5969 & 0,3307 & 1757 & 1,81 & 0,0712 & $-0,05168$ & 1,2454 & $1,404 \mathrm{E}-6$ \\
\hline CPL & $-0,4455$ & 0,2476 & 1757 & $-1,80$ & 0,0722 & $-0,9312$ & 0,04017 & $-0,00001$ \\
\hline cNL & 2,2401 & 0,3302 & 1757 & 6,78 & $<0,0001$ & 1,5924 & 2,8878 & $-1,13 \mathrm{E}-6$ \\
\hline CPIB & 0,000197 & 0,000018 & 1757 & 10,91 & $<0,0001$ & 0,000162 & 0,000232 & 0,004983 \\
\hline CCOMEX & $-0,00692$ & 0,002868 & 1757 & $-2,41$ & 0,0160 & $-0,01254$ & $-0,00129$ & $-0,00083$ \\
\hline CAGRI & 0,01239 & 0,01117 & 1757 & 1,11 & 0,2677 & $-0,00953$ & 0,03431 & $-0,00061$ \\
\hline cPREF & 0,002019 & 0,002741 & 1757 & 0,74 & 0,4614 & $-0,00336$ & 0,007395 & 0,000331 \\
\hline cODP & 0,1232 & 0,09835 & 1757 & 1,25 & 0,2106 & $-0,06972$ & 0,3161 & 0,000030 \\
\hline
\end{tabular}




\begin{tabular}{|l|r|r|r|r|r|r|r|r|}
\hline & & $\begin{array}{r}\text { Erro- } \\
\text { Parâmetro }\end{array}$ & Estimativa & padrão & DF & Valor t & Prob > |t $\mid$ & \multicolumn{2}{|c|}{$\begin{array}{c}\text { 95\% Intervalo de } \\
\text { Confiança }\end{array}$} & Gradiente \\
\hline cCAP & 0,1556 & 0,06196 & 1757 & 2,51 & 0,0121 & 0,03412 & 0,2771 & $-0,00004$ \\
\hline CAPRE & $-0,02022$ & 0,002645 & 1757 & $-7,64$ & $<0,0001$ & $-0,02541$ & $-0,01503$ & $-0,00087$ \\
\hline alfa & 0,2023 & 0,08727 & 1757 & 2,32 & 0,0206 & 0,03109 & 0,3734 & $-0,00002$ \\
\hline
\end{tabular}

Fonte: adaptado do resultado da estimação SAS. 


\section{Anexo 5-8}

\section{MODELO ZINB - POLO PASSIVO : RESULTADO DA ESTIMAÇÃO} (SEM CHINA E ÍNDIA)

Quadro A5-2.18: Histórico de Iterações - Modelo ZINB Passivo (sem China e Índia)

\begin{tabular}{|c|c|c|c|c|c|}
\hline Iteração & Chamadas & $\begin{array}{r}\text { Log- } \\
\text { verossimilhança } \\
\text { negativa }\end{array}$ & Diferença & $\begin{array}{r}\text { Máximo } \\
\text { Gradiente }\end{array}$ & Derivada \\
\hline 1 & 13 & 890,6570 & 60,57951 & 362538 & $-1,53 \mathrm{E} 10$ \\
\hline 2 & 18 & 851,0567 & 39,60032 & 23364,6 & -270818 \\
\hline 3 & 20 & 593,4084 & 257,6483 & 114866 & $-10817,6$ \\
\hline 4 & 22 & 559,8238 & 33,58457 & 23986,6 & $-52,9769$ \\
\hline 5 & 24 & 541,4543 & 18,36952 & 16739,7 & $-27,4173$ \\
\hline 6 & 27 & 533,7867 & 7,667564 & 56676,8 & $-14,0780$ \\
\hline 7 & 30 & 529,1293 & 4,657415 & 97964,8 & $-2,65392$ \\
\hline 8 & 32 & 522,7226 & 6,406664 & 38093,3 & $-5,77700$ \\
\hline 9 & 35 & 519,0209 & 3,701714 & 36105,8 & $-4,93208$ \\
\hline 10 & 38 & 517,0971 & 1,923842 & 4610,26 & $-1,95124$ \\
\hline 11 & 41 & 516,2091 & 0,887985 & 5873,38 & $-0,75133$ \\
\hline 12 & 43 & 515,7745 & 0,434567 & 352,106 & $-0,56031$ \\
\hline 13 & 45 & 515,1054 & 0,669088 & 1428,27 & $-0,75695$ \\
\hline 14 & 47 & 514,5239 & 0,581537 & 4012,74 & $-0,43742$ \\
\hline 15 & 49 & 513,6723 & 0,851641 & 286,842 & $-0,82295$ \\
\hline 16 & 51 & 512,3174 & 1,35489 & 9550,67 & $-0,97748$ \\
\hline 17 & 53 & 511,0151 & 1,302242 & 14014,1 & $-1,62147$ \\
\hline 18 & 56 & 510,3751 & 0,640013 & 7023,83 & $-0,86373$ \\
\hline 19 & 59 & 510,0287 & 0,346431 & 5571,75 & $-0,22434$ \\
\hline 20 & 61 & 509,6524 & 0,376262 & 3342,30 & $-0,19923$ \\
\hline 21 & 63 & 509,0914 & 0,561059 & 777,576 & $-0,33585$ \\
\hline 22 & 66 & 508,6973 & 0,394081 & 2895,83 & $-0,35262$ \\
\hline 23 & 69 & 508,5283 & 0,169022 & 3626,84 & $-0,17599$ \\
\hline 24 & 72 & 508,4617 & 0,06658 & 977,023 & $-0,04943$ \\
\hline 25 & 74 & 508,3552 & 0,106442 & 1577,56 & $-0,05235$ \\
\hline 26 & 78 & 507,8858 & 0,46946 & 6486,04 & $-0,14609$ \\
\hline 27 & 82 & 505,7791 & 2,106715 & 4436,10 & $-0,70137$ \\
\hline 28 & 87 & 505,4464 & 0,332716 & 4470,65 & $-0,92261$ \\
\hline 29 & 89 & 505,2569 & 0,189498 & 361,346 & $-0,61249$ \\
\hline 30 & 92 & 505,1530 & 0,103809 & 609,355 & $-0,15480$ \\
\hline
\end{tabular}




\begin{tabular}{|c|c|c|c|c|c|}
\hline 31 & 95 & 505,1089 & 0,044193 & 1689,94 & $-0,04651$ \\
\hline 32 & 99 & 504,7857 & 0,323124 & 1878,89 & $-0,09352$ \\
\hline 33 & 106 & 504,5570 & 0,228688 & 1269,14 & $-0,31707$ \\
\hline 34 & 111 & 504,5000 & 0,057008 & 1108,94 & $-0,10126$ \\
\hline 35 & 114 & 504,4736 & 0,02648 & 1130,47 & $-0,40396$ \\
\hline 36 & 118 & 504,4053 & 0,068252 & 1839,25 & $-0,07264$ \\
\hline 37 & 122 & 503,7121 & 0,693207 & 1617,92 & $-0,07238$ \\
\hline 38 & 126 & 490,8365 & 12,87556 & 20989,1 & $-1,32299$ \\
\hline 39 & 129 & 488,5181 & 2,318389 & 12207,2 & $-15,3339$ \\
\hline 40 & 131 & 486,4141 & 2,104059 & 11377,6 & $-5,56898$ \\
\hline 41 & 134 & 485,7474 & 0,666697 & 4730,30 & $-2,16095$ \\
\hline 42 & 139 & 485,6247 & 0,122661 & 26244,8 & $-0,34670$ \\
\hline 43 & 143 & 485,3797 & 0,244975 & 59951,8 & $-0,34942$ \\
\hline 44 & 146 & 485,1674 & 0,212376 & 14057,7 & $-0,57688$ \\
\hline 45 & 151 & 485,0933 & 0,074037 & 11019,5 & $-0,54879$ \\
\hline 46 & 153 & 485,0127 & 0,080642 & 7670,48 & $-0,30202$ \\
\hline 47 & 156 & 485,0041 & 0,008611 & 3375,87 & $-0,01974$ \\
\hline 48 & 159 & 485,0005 & 0,003598 & 2705,42 & $-0,00688$ \\
\hline 49 & 161 & 484,9948 & 0,005662 & 698,588 & $-0,00280$ \\
\hline 50 & 165 & 484,9423 & 0,052475 & 15026,4 & $-0,01392$ \\
\hline 51 & 169 & 484,5617 & 0,380678 & 780,205 & $-0,10688$ \\
\hline 52 & 171 & 484,0155 & 0,54616 & 5232,40 & $-0,56825$ \\
\hline 53 & 174 & 483,9875 & 0,028009 & 321,968 & $-0,06423$ \\
\hline 54 & 177 & 483,9815 & 0,006043 & 281,784 & $-0,0055 \subseteq$ \\
\hline 55 & 181 & 483,8966 & 0,08481 & 193,615 & $-0,00789$ \\
\hline 56 & 185 & 482,6416 & 1,25501 & 13887,4 & $-0,19542$ \\
\hline 57 & 187 & 481,2846 & 1,357083 & 3457,32 & $-1,99342$ \\
\hline 58 & 190 & 480,8060 & 0,478506 & 500,582 & $-0,95638$ \\
\hline 59 & 193 & 480,7413 & 0,06472 & 1602,83 & $-0,10855$ \\
\hline 60 & 198 & 480,7325 & 0,008796 & 2435,23 & $-0,02024$ \\
\hline 61 & 200 & 480,7226 & 0,009898 & 332,133 & $-0,0230 s$ \\
\hline 62 & 203 & 480,7198 & 0,002801 & 511,049 & $-0,00308$ \\
\hline 63 & 205 & 480,7172 & 0,002637 & 19,3913 & $-0,00287$ \\
\hline 64 & 209 & 480,7057 & 0,011529 & 432,628 & $-0,00518$ \\
\hline 65 & 213 & 480,5661 & 0,139605 & 3449,08 & $-0,01760$ \\
\hline 66 & 217 & 479,3891 & 1,176993 & 10210,7 & $-0,20457$ \\
\hline 67 & 220 & 478,6465 & 0,74261 & 2679,33 & $-0,94995$ \\
\hline 68 & 223 & 478,5493 & 0,097124 & 1209,78 & $-0,16372$ \\
\hline 69 & 226 & 478,5390 & 0,010316 & 71,0660 & $-0,01914$ \\
\hline
\end{tabular}




\begin{tabular}{|c|c|c|c|c|c|}
\hline 70 & 229 & 478,5379 & 0,001159 & 22,4263 & $-0,00211$ \\
\hline 71 & 231 & 478,5370 & 0,000865 & 164,601 & $-0,00186$ \\
\hline 72 & 235 & 478,5348 & 0,002165 & 276,929 & $-0,00133$ \\
\hline 73 & 241 & 478,1902 & 0,344656 & 6282,24 & $-0,00306$ \\
\hline 74 & 243 & 477,6448 & 0,54542 & 3152,34 & $-0,45615$ \\
\hline 75 & 246 & 477,4023 & 0,242478 & 1018,40 & $-0,36822$ \\
\hline 76 & 249 & 477,3780 & 0,02423 & 1025,88 & $-0,04516$ \\
\hline 77 & 252 & 477,3766 & 0,00146 & 54,6497 & $-0,00269$ \\
\hline 78 & 255 & 477,3763 & 0,000294 & 172,002 & $-0,00031$ \\
\hline 79 & 259 & 477,3751 & 0,001227 & 489,289 & $-0,00036$ \\
\hline 80 & 265 & 477,2772 & 0,097855 & 16043,5 & $-0,00202$ \\
\hline 81 & 269 & 475,6679 & 1,60932 & 14545,6 & $-0,16994$ \\
\hline 82 & 272 & 475,2031 & 0,464773 & 2013,14 & $-0,84136$ \\
\hline 83 & 275 & 475,1796 & 0,023504 & 235,370 & $-0,05828$ \\
\hline 84 & 278 & 475,1730 & 0,006626 & 12,5876 & $-0,01526$ \\
\hline 85 & 281 & 475,1717 & 0,001338 & 45,9710 & $-0,00153$ \\
\hline 86 & 285 & 475,1677 & 0,003912 & 64,0803 & $-0,00065$ \\
\hline 87 & 291 & 475,0428 & 0,124986 & 751,086 & $-0,00625$ \\
\hline 88 & 295 & 474,0513 & 0,991451 & 7480,98 & $-0,18651$ \\
\hline 89 & 298 & 473,9342 & 0,117062 & 2529,47 & $-0,18294$ \\
\hline 90 & 303 & 473,8968 & 0,037435 & 4009,03 & $-0,06223$ \\
\hline 91 & 306 & 473,8847 & 0,01213 & 582,056 & $-0,02288$ \\
\hline 92 & 309 & 473,8827 & 0,001952 & 163,098 & $-0,00407$ \\
\hline 93 & 312 & 473,8823 & 0,000383 & 118,356 & $-0,00051$ \\
\hline 94 & 316 & 473,8770 & 0,005292 & 1716,02 & $-0,00030$ \\
\hline 95 & 322 & 473,6859 & 0,191105 & 5868,36 & $-0,00983$ \\
\hline 96 & 326 & 473,0553 & 0,630643 & 1718,99 & $-0,26957$ \\
\hline 97 & 329 & 473,0293 & 0,025966 & 192,414 & $-0,04798$ \\
\hline 98 & 332 & 473,0284 & 0,000952 & 84,2541 & $-0,00187$ \\
\hline 99 & 334 & 473,0279 & 0,000454 & 226,351 & $-0,00031$ \\
\hline 100 & 338 & 473,0245 & 0,003435 & 220,572 & $-0,00204$ \\
\hline 101 & 346 & 471,9504 & 1,074099 & 21239,8 & $-0,00482$ \\
\hline 102 & 348 & 470,6657 & 1,284688 & 772,249 & $-1,07456$ \\
\hline 103 & 351 & 470,5282 & 0,137538 & 1871,76 & $-0,21693$ \\
\hline 104 & 354 & 470,5110 & 0,017149 & 647,503 & $-0,03768$ \\
\hline 105 & 357 & 470,5105 & 0,00054 & 432,613 & $-0,00061$ \\
\hline 106 & 361 & 470,5086 & 0,001873 & 260,162 & $-0,00034$ \\
\hline 107 & 367 & 470,4052 & 0,103431 & 25160,2 & $-0,00318$ \\
\hline 108 & 371 & 468,8730 & 1,532208 & 961,481 & $-0,16530$ \\
\hline
\end{tabular}




\begin{tabular}{|c|c|c|c|c|c|}
\hline 109 & 374 & 468,3865 & 0,486471 & 8185,04 & $-0,87273$ \\
\hline 110 & 377 & 468,2106 & 0,175906 & 6434,10 & $-0,52503$ \\
\hline 111 & 379 & 468,0198 & 0,19084 & 2502,70 & $-0,39520$ \\
\hline 112 & 382 & 467,9683 & 0,051432 & 586,148 & $-0,08285$ \\
\hline 113 & 385 & 467,9649 & 0,003386 & 29,2007 & $-0,00671$ \\
\hline 114 & 388 & 467,9637 & 0,001278 & 199,919 & $-0,00182$ \\
\hline 115 & 391 & 467,9631 & 0,000522 & 3,51632 & $-0,00064$ \\
\hline 116 & 393 & 467,9627 & 0,00041 & 309,826 & $-0,00029$ \\
\hline 117 & 397 & 467,9610 & 0,001726 & 550,526 & $-0,00074$ \\
\hline 118 & 403 & 467,8779 & 0,083078 & 5007,93 & $-0,0025 c$ \\
\hline 119 & 407 & 467,0525 & 0,825408 & 25973,1 & $-0,09613$ \\
\hline 120 & 409 & 465,9762 & 1,076329 & 6036,17 & $-0,81468$ \\
\hline 121 & 412 & 465,3580 & 0,618226 & 13253,4 & $-0,82789$ \\
\hline 122 & 415 & 465,2040 & 0,153908 & 2698,55 & $-0,2686 c$ \\
\hline 123 & 418 & 465,1802 & 0,023808 & 540,639 & $-0,05791$ \\
\hline 124 & 421 & 465,1785 & 0,001768 & 14,6411 & $-0,00290$ \\
\hline 125 & 424 & 465,1777 & 0,000767 & 124,522 & $-0,00062$ \\
\hline 126 & 427 & 465,1775 & 0,000237 & 22,6099 & $-0,00027$ \\
\hline 127 & 431 & 465,1763 & 0,001144 & 538,001 & $-0,00015$ \\
\hline 128 & 437 & 465,1408 & 0,035477 & 647,929 & $-0,00204$ \\
\hline 129 & 441 & 464,5560 & 0,584879 & 2638,30 & $-0,05950$ \\
\hline 130 & 444 & 464,2235 & 0,332463 & 987,715 & $-0,45392$ \\
\hline 131 & 447 & 464,1855 & 0,037968 & 439,190 & $-0,06385$ \\
\hline 132 & 450 & 464,1813 & 0,004231 & 178,525 & $-0,01082$ \\
\hline 133 & 453 & 464,1806 & 0,000719 & 37,2977 & $-0,00139$ \\
\hline 134 & 456 & 464,1804 & 0,000161 & 48,9680 & $-0,00014$ \\
\hline 135 & 460 & 464,1785 & 0,001879 & 1084,79 & $-0,00018$ \\
\hline 136 & 464 & 464,1502 & 0,028326 & 207,801 & $-0,00297$ \\
\hline 137 & 468 & 463,9995 & 0,150705 & 3982,05 & $-0,04662$ \\
\hline 138 & 470 & 463,7624 & 0,237069 & 3946,30 & $-0,40004$ \\
\hline 139 & 472 & 463,4812 & 0,281266 & 1324,60 & $-0,39982$ \\
\hline 140 & 475 & 463,4605 & 0,020663 & 157,326 & $-0,05051$ \\
\hline 141 & 478 & 463,4591 & 0,001403 & 30,3009 & $-0,00238$ \\
\hline 142 & 481 & 463,4590 & 0,000161 & 3,56374 & $-0,00018$ \\
\hline 143 & 484 & 463,4589 & 0,000042 & 15,6872 & $-0,00004$ \\
\hline 144 & 488 & 463,4585 & 0,000378 & 87,5409 & $-0,00004$ \\
\hline 145 & 492 & 463,4538 & 0,004686 & 146,584 & $-0,00074$ \\
\hline 146 & 498 & 463,3582 & 0,095623 & 1533,11 & $-0,00729$ \\
\hline 147 & 502 & 463,0701 & 0,288167 & 225,781 & $-0,12506$ \\
\hline
\end{tabular}




\begin{tabular}{|c|c|c|c|c|c|}
\hline 148 & 505 & 462,9081 & 0,161943 & 897,669 & $-0,19224$ \\
\hline 149 & 508 & 462,9005 & 0,007641 & 86,2458 & $-0,01370$ \\
\hline 150 & 511 & 462,9001 & 0,000403 & 6,86410 & $-0,00073$ \\
\hline 151 & 514 & 462,9000 & 0,000038 & 8,76317 & $-0,00005$ \\
\hline 152 & 517 & 462,9000 & 0,000014 & 11,2720 & $-9,26 \mathrm{E}-6$ \\
\hline 153 & 521 & 462,8999 & 0,000136 & 24,8638 & $-0,00001$ \\
\hline 154 & 527 & 462,8947 & 0,005154 & 991,943 & $-0,00023$ \\
\hline 155 & 531 & 462,8054 & 0,089367 & 1178,08 & $-0,00947$ \\
\hline 156 & 533 & 462,7511 & 0,054244 & 979,637 & $-0,10407$ \\
\hline 157 & 536 & 462,7273 & 0,023805 & 57,8785 & $-0,04525$ \\
\hline 158 & 539 & 462,7270 & 0,000272 & 5,74005 & $-0,00043$ \\
\hline 159 & 542 & 462,7270 & 0,00001 & 6,87340 & $-8,63 \mathrm{E}-6$ \\
\hline 160 & 546 & 462,7269 & 0,000161 & 71,7751 & $-0,00001$ \\
\hline 161 & 550 & 462,7251 & 0,001763 & 204,561 & $-0,00035$ \\
\hline 162 & 556 & 462,4724 & 0,252696 & 1342,70 & $-0,00318$ \\
\hline 163 & 559 & 462,3714 & 0,101002 & 462,345 & $-0,13242$ \\
\hline 164 & 562 & 462,3664 & 0,005008 & 8,92350 & $-0,00840$ \\
\hline 165 & 565 & 462,3663 & 0,000057 & 3,24780 & $-0,00011$ \\
\hline 166 & 568 & 462,3663 & $2,501 \mathrm{E}-6$ & 0,86579 & $-4,11 \mathrm{E}-6$ \\
\hline 167 & 572 & 462,3663 & $7,011 \mathrm{E}-6$ & 6,66587 & $-1,54 \mathrm{E}-6$ \\
\hline 168 & 578 & 462,3661 & 0,000271 & 43,6607 & $-0,00001$ \\
\hline 169 & 584 & 462,3567 & 0,009346 & 207,339 & $-0,00044$ \\
\hline 170 & 588 & 462,3111 & 0,045574 & 361,800 & $-0,01370$ \\
\hline 171 & 591 & 462,3067 & 0,004421 & 77,3008 & $-0,00767$ \\
\hline 172 & 594 & 462,3067 & 0,000036 & 0,54934 & $-0,00007$ \\
\hline 173 & 597 & 462,3067 & $3,063 \mathrm{E}-7$ & 1,01833 & $-4,19 \mathrm{E}-7$ \\
\hline 174 & 599 & 462,3067 & $1,005 \mathrm{E}-7$ & 9,09796 & $-6,38 \mathrm{E}-8$ \\
\hline 175 & 603 & 462,3067 & $5,347 \mathrm{E}-7$ & 2,75039 & $-4,44 \mathrm{E}-7$ \\
\hline 176 & 611 & 462,3064 & 0,000259 & 283,693 & $-6,23 \mathrm{E}-7$ \\
\hline 177 & 615 & 462,3050 & 0,001433 & 45,2898 & $-0,00041$ \\
\hline 178 & 618 & 462,3048 & 0,000228 & 33,4242 & $-0,00041$ \\
\hline 179 & 621 & 462,3048 & 4,597E-7 & 0,96783 & $-8,82 \mathrm{E}-7$ \\
\hline 180 & 624 & 462,3048 & $3,449 \mathrm{E}-8$ & 5,10587 & $-1,56 \mathrm{E}-8$ \\
\hline 181 & 630 & 462,3048 & $5,451 \mathrm{E}-6$ & 9,01914 & $-5,11 \mathrm{E}-8$ \\
\hline 182 & 634 & 462,3047 & 0,000085 & 152,799 & $-0,00001$ \\
\hline 183 & 638 & 462,3035 & 0,001173 & 792,664 & $-0,00018$ \\
\hline 184 & 642 & 462,2983 & 0,005235 & 439,269 & $-0,00185$ \\
\hline 185 & 645 & 462,2980 & 0,000248 & 10,0752 & $-0,00047$ \\
\hline 186 & 648 & 462,2980 & $3,855 \mathrm{E}-7$ & 1,23744 & $-6,79 E-7$ \\
\hline
\end{tabular}


Fonte: adaptado do resultado da estimação SAS.

Quadro A5-2.19: Ajustamento - Modelo ZINB Passivo (sem China e Índia)

\begin{tabular}{|l|r|}
\hline -2 Log-verossimilhança & 924,6 \\
\hline AIC & 984,6 \\
\hline AICC & 985,7 \\
\hline BIC & 1148,2 \\
\hline
\end{tabular}

Fonte: adaptado do resultado da estimação SAS.

\section{Quadro A5-2.20: Estimativa dos Parâmetros - Modelo ZINB Passivo}

\begin{tabular}{|l|r|r|r|r|r|r|r|r|}
\hline Parâmetro & Estimativa & $\begin{array}{r}\text { Erro- } \\
\text { padrão }\end{array}$ & DF & Valor t & Prob > |t| & \multicolumn{2}{|c|}{$\begin{array}{r}95 \% \text { Intervalo de } \\
\text { Confiança }\end{array}$} & Gradiente \\
\hline z0 & 5,6705 & 2,4680 & 1727 & 2,30 & 0,0217 & 0,8300 & 10,5110 & $-0,00006$ \\
\hline zAA & $-4,3797$ & 1,3223 & 1727 & $-3,31$ & 0,0009 & $-6,9733$ & $-1,7862$ & $-1,77 \mathrm{E}-7$ \\
\hline zAB & $-3,4120$ & 1,2378 & 1727 & $-2,76$ & 0,0059 & $-5,8397$ & $-0,9843$ & $-0,00003$ \\
\hline zBA & $-5,6129$ & 1,8206 & 1727 & $-3,08$ & 0,0021 & $-9,1837$ & $-2,0421$ & 0,000013 \\
\hline zBB & $-16,1127$ & 6,2984 & 1727 & $-2,56$ & 0,0106 & $-28,4660$ & $-3,7594$ & $-0,00002$ \\
\hline zMD & $-6,2154$ & 2,8503 & 1727 & $-2,18$ & 0,0293 & $-11,8058$ & $-0,6250$ & $-4,74 \mathrm{E}-6$ \\
\hline zPL & $-0,4880$ & 0,8615 & 1727 & $-0,57$ & 0,5711 & $-2,1776$ & 1,2016 & $-0,00003$ \\
\hline zNL & 11,4515 & 5,6853 & 1727 & 2,01 & 0,0441 & 0,3007 & 22,6023 & $-5,32 \mathrm{E}-6$ \\
\hline zPIB & $-0,01290$ & 0,003553 & 1727 & $-3,63$ & 0,0003 & $-0,01987$ & $-0,00593$ & $-0,01116$ \\
\hline zCOMEX & 0,01323 & 0,008778 & 1727 & 1,51 & 0,1319 & $-0,00398$ & 0,03045 & $-0,00461$ \\
\hline zAGRI & $-0,00901$ & 0,02657 & 1727 & $-0,34$ & 0,7347 & $-0,06111$ & 0,04310 & $-0,00212$ \\
\hline zPREF & 0,000479 & 0,004376 & 1727 & 0,11 & 0,9129 & $-0,00810$ & 0,009062 & 0,000686 \\
\hline zODP & $-0,7626$ & 0,3574 & 1727 & $-2,13$ & 0,0330 & $-1,4637$ & $-0,06158$ & 0,000259 \\
\hline zCAP & $-0,04555$ & 0,4712 & 1727 & $-0,10$ & 0,9230 & $-0,9697$ & 0,8786 & $-0,00017$ \\
\hline zAPRE & 0,006546 & 0,02599 & 1727 & 0,25 & 0,8012 & $-0,04442$ & 0,05751 & $-0,00115$ \\
\hline cAA & $-0,4274$ & 0,3235 & 1727 & $-1,32$ & 0,1866 & $-1,0618$ & 0,2070 & $7,678 \mathrm{E}-6$ \\
\hline cAB & 0,01589 & 0,2829 & 1727 & 0,06 & 0,9552 & $-0,5389$ & 0,5707 & 0,000050 \\
\hline cBA & $-0,9235$ & 0,4340 & 1727 & $-2,13$ & 0,0335 & $-1,7747$ & $-0,07218$ & $-0,00001$ \\
\hline cBB & $-2,2323$ & 0,5215 & 1727 & $-4,28$ & $<0,0001$ & $-3,2550$ & $-1,2095$ & $5,179 E-6$ \\
\hline cMD & $-2,0363$ & 1,1234 & 1727 & $-1,81$ & 0,0701 & $-4,2396$ & 0,1670 & $3,224 \mathrm{E}-7$ \\
\hline cPL & $-0,4734$ & 0,2746 & 1727 & $-1,72$ & 0,0849 & $-1,0119$ & 0,06513 & $-0,00005$ \\
\hline cNL & 2,2301 & 0,6842 & 1727 & 3,26 & 0,0011 & 0,8882 & 3,5719 & 0,000025 \\
\hline
\end{tabular}




\begin{tabular}{|l|r|r|r|r|r|r|r|r|}
\hline cPIB & 0,000205 & 0,000018 & 1727 & 11,59 & $<0,0001$ & 0,000170 & 0,000240 & 0,000608 \\
\hline cCOMEX & $-0,00709$ & 0,002892 & 1727 & $-2,45$ & 0,0143 & $-0,01276$ & $-0,00142$ & 0,005720 \\
\hline cAGRI & 0,01648 & 0,01134 & 1727 & 1,45 & 0,1463 & $-0,00576$ & 0,03871 & 0,001252 \\
\hline cPREF & 0,002233 & 0,003071 & 1727 & 0,73 & 0,4672 & $-0,00379$ & 0,008257 & 0,010054 \\
\hline cODP & 0,09044 & 0,1014 & 1727 & 0,89 & 0,3726 & $-0,1084$ & 0,2893 & $-0,00009$ \\
\hline cCAP & 0,1577 & 0,06168 & 1727 & 2,56 & 0,0106 & 0,03677 & 0,2787 & 0,000082 \\
\hline cAPRE & $-0,02263$ & 0,002795 & 1727 & $-8,10$ & $<0,0001$ & $-0,02812$ & $-0,01715$ & 0,005158 \\
\hline alfa & 0,1756 & 0,08186 & 1727 & 2,14 & 0,0321 & 0,01503 & 0,3361 & $-0,00025$ \\
\hline
\end{tabular}

Fonte: adaptado do resultado da estimação SAS. 


\section{Anexo 6-1}

\section{Quadro A6-1: Valores previstos de cREC e p0 - Modelo ZINB Ativo}

\begin{tabular}{|c|c|c|c|c|c|c|c|c|c|c|c|c|c|c|c|c|c|c|c|c|c|}
\hline Obs & ID & AA & $A B$ & BA & BB & MD & LV & PL & NL & REC & PIB & COMEX & AGRI & PREF & ODP & CAP & APRE & PIB2 & $\mathrm{ACl}$ & CREC & po \\
\hline 1 & 1 & 0 & 0 & 0 & 0 & 0 & 1 & 0 & 0 & 2 & 11246416 & 61,55 & 12,81 & $-0,08$ & 0,37 & 3,6 & 4 & 11,2464 & 12 & 6,58433 & 0,00000 \\
\hline 2 & 1 & 0 & 0 & 0 & 0 & 0 & 1 & 0 & 0 & 7 & 11472170 & 63,29 & 12,25 & $-0,11$ & 0,37 & 3,6 & 11 & 11,4722 & 15 & 6,21064 & 0,00000 \\
\hline 3 & 1 & 0 & 0 & 0 & 0 & 0 & 1 & 0 & 0 & 16 & 11792573 & 66,4 & 11,58 & $-0,12$ & 0,33 & 3,61 & 15 & 11,7926 & 8 & 6,12277 & 0,00000 \\
\hline 4 & 1 & 0 & 0 & 0 & 0 & 0 & 1 & 0 & 0 & 17 & 12150920 & 66,75 & 11,24 & $-0,12$ & 0,33 & 3,61 & 18 & 12,1509 & 15 & 6,26755 & 0,00000 \\
\hline 5 & 1 & 0 & 0 & 0 & 0 & 0 & 1 & 0 & 0 & 6 & 12519556 & 67,68 & 10,85 & $-0,12$ & 0,32 & 3,62 & 26 & 12,5196 & 7 & 5,98298 & 0,00000 \\
\hline 6 & 1 & 0 & 0 & 0 & 0 & 0 & 1 & 0 & 0 & 8 & 13006419 & 74,59 & 9,54 & $-0,1$ & 0,32 & 3,63 & 34 & 13,0064 & 4 & 5,65643 & 0,00000 \\
\hline 7 & 1 & 0 & 0 & 0 & 0 & 0 & 1 & 0 & 0 & 1 & 13296756 & 73,56 & 9,74 & $-0,11$ & 0,33 & 3,66 & 41 & 13,2968 & 3 & 5,41667 & 0,00000 \\
\hline 8 & 1 & 0 & 0 & 0 & 0 & 0 & 1 & 0 & 0 & 5 & 13474854 & 71,01 & 10,04 & $-0,14$ & 0,35 & 3,7 & 59 & 13,4749 & 6 & 4,44313 & 0,00000 \\
\hline 9 & 1 & 0 & 0 & 0 & 0 & 0 & 1 & 0 & 0 & 4 & 13652601 & 69,19 & 10,1 & $-0,19$ & 0,36 & 3,72 & 66 & 13,6526 & 8 & 4,22124 & 0,00000 \\
\hline 10 & 1 & 0 & 0 & 0 & 0 & 0 & 1 & 0 & 0 & 5 & 13996937 & 71,52 & 9,57 & $-0,15$ & 0,35 & 3,71 & 70 & 13,9969 & 4 & 4,20255 & 0,00000 \\
\hline 11 & 1 & 0 & 0 & 0 & 0 & 0 & 1 & 0 & 0 & 2 & 14289446 & 74,16 & 9,41 & $-0,15$ & 0,47 & 3,65 & 74 & 14,2894 & 2 & 4,13630 & 0,00000 \\
\hline 12 & 1 & 0 & 0 & 0 & 0 & 0 & 1 & 0 & 0 & 6 & 14766748 & 77,93 & 9 & $-0,15$ & 0,47 & 3,62 & 79 & 14,7667 & 3 & 4,09643 & 0,00000 \\
\hline 13 & 1 & 0 & 0 & 0 & 0 & 0 & 1 & 0 & 0 & 0 & 15221041 & 78,87 & 9,24 & $-6,3$ & 0,43 & 3,57 & 88 & 15,221 & 3 & 3,80558 & 0,00000 \\
\hline 14 & 1 & 0 & 0 & 0 & 0 & 0 & 1 & 0 & 0 & 3 & 15288742 & 80,53 & 9,54 & $-7,15$ & 0,46 & 3,59 & 95 & 15,2887 & 4 & 3,42443 & 0,00000 \\
\hline 15 & 1 & 0 & 0 & 0 & 0 & 0 & 1 & 0 & 0 & 2 & 14618892 & 71,51 & 10,78 & $-6,52$ & 0,48 & 3,6 & 101 & 14,6189 & 4 & 2,97771 & 0,00000 \\
\hline 16 & 1 & 0 & 0 & 0 & 0 & 0 & 1 & 0 & 0 & 1 & 14926815 & 78,14 & 10,28 & $-7,22$ & 0,5 & 3,61 & 111 & 14,9268 & 3 & 2,61603 & 0,00000 \\
\hline 17 & 1 & 0 & 0 & 0 & 0 & 0 & 1 & 0 & 0 & 3 & 15194701 & 83,02 & 10,59 & $-7,67$ & 0,48 & 3,59 & 116 & 15,1947 & 0 & 2,43267 & 0,00000 \\
\hline 18 & 1 & 0 & 0 & 0 & 0 & 0 & 1 & 0 & 0 & 2 & 15129293 & 84,35 & 10,72 & $-9,16$ & 0,45 & 3,58 & 133 & 15,1293 & 3 & 1,88244 & 0,00000 \\
\hline 19 & 2 & 0 & 0 & 0 & 0 & 0 & 1 & 0 & 0 & 6 & 9359504 & 22,38 & 10,49 & $-11,15$ & 0,1 & 4,21 & 5 & 9,3595 & 4 & 6,53774 & 0,00000 \\
\hline 20 & 2 & 0 & 0 & 0 & 0 & 0 & 1 & 0 & 0 & 17 & 9714779 & 22,61 & 10,23 & $-11,63$ & 0,12 & 4,21 & 12 & 9,7148 & 11 & 6,33367 & 0,00000 \\
\hline 21 & 2 & 0 & 0 & 0 & 0 & 0 & 1 & 0 & 0 & 15 & 10150684 & 23,34 & 9,2 & $-12,39$ & 0,09 & 4,25 & 22 & 10,1507 & 10 & 6,02489 & 0,00000 \\
\hline 22 & 2 & 0 & 0 & 0 & 0 & 0 & 1 & 0 & 0 & 9 & 10602380 & 22,76 & 8,52 & $-12,88$ & 0,1 & 4,3 & 29 & 10,6024 & 6 & 6,00939 & 0,00000 \\
\hline 23 & 2 & 0 & 0 & 0 & 0 & 0 & 1 & 0 & 0 & 9 & 11099123 & 23,19 & 7,91 & $-13,61$ & 0,1 & 4,32 & 31 & 11,0991 & 11 & 6,39377 & 0,00000 \\
\hline 24 & 2 & 0 & 0 & 0 & 0 & 0 & 1 & 0 & 0 & 8 & 11553319 & 24,98 & 7,31 & $-14,92$ & 0,1 & 4,34 & 37 & 11,5533 & 19 & 6,32010 & 0,00000 \\
\hline 25 & 2 & 0 & 0 & 0 & 0 & 0 & 1 & 0 & 0 & 1 & 11666077 & 22,8 & 7,69 & $-15,42$ & 0,11 & 4,27 & 42 & 11,6661 & 7 & 6,09971 & 0,00000 \\
\hline 26 & 2 & 0 & 0 & 0 & 0 & 0 & 1 & 0 & 0 & 4 & 11874448 & 22,15 & 7,87 & $-16,69$ & 0,13 & 4,2 & 49 & 11,8744 & 19 & 5,76499 & 0,00000 \\
\hline 27 & 2 & 0 & 0 & 0 & 0 & 0 & 1 & 0 & 0 & 3 & 12207737 & 22,45 & 8,11 & $-17,82$ & 0,15 & 4,11 & 58 & 12,2077 & 6 & 5,37119 & 0,00000 \\
\hline 28 & 2 & 0 & 0 & 0 & 0 & 0 & 1 & 0 & 0 & 4 & 12669891 & 24,29 & 7,69 & $-19,34$ & 0,17 & 4,3 & 61 & 12,6699 & 7 & 5,45656 & 0,00000 \\
\hline 29 & 2 & 0 & 0 & 0 & 0 & 0 & 1 & 0 & 0 & 1 & 13093726 & 25,5 & 7,27 & $-21,07$ & 0,23 & 4,07 & 64 & 13,0937 & 2 & 5,67948 & 0,00000 \\
\hline 30 & 2 & 0 & 0 & 0 & 0 & 0 & 1 & 0 & 0 & 3 & 13442887 & 26,87 & 7,11 & $-22,25$ & 0,18 & 4,1 & 71 & 13,4429 & 6 & 5,39619 & 0,00000 \\
\hline 31 & 2 & 0 & 0 & 0 & 0 & 0 & 1 & 0 & 0 & 4 & 13681978 & 27,96 & 7,56 & $-22,35$ & 0,16 & 4,15 & 74 & 13,682 & 3 & 5,26401 & 0,00000 \\
\hline 32 & 2 & 0 & 0 & 0 & 0 & 0 & 1 & 0 & 0 & 3 & 13642078 & 29,94 & 8,04 & $-22,39$ & 0,18 & 4,1 & 77 & 13,6421 & 6 & 4,90302 & 0,00000 \\
\hline 33 & 2 & 0 & 0 & 0 & 0 & 0 & 1 & 0 & 0 & 2 & 13263438 & 24,77 & 9,08 & $-21,96$ & 0,21 & 4 & 84 & 13,2634 & 3 & 4,31601 & 0,00000 \\
\hline 34 & 2 & 0 & 0 & 0 & 0 & 0 & 1 & 0 & 0 & 4 & 13599258 & 28,18 & 8,8 & $-23,74$ & 0,2 & 4,05 & 90 & 13,5993 & 2 & 4,08315 & 0,00000 \\
\hline 35 & 2 & 0 & 0 & 0 & 0 & 0 & 1 & 0 & 0 & 1 & 13817044 & 30,89 & 9,03 & $-24,3$ & 0,2 & 4,01 & 94 & 13,817 & 3 & 3,90179 & 0,00000 \\
\hline 36 & 2 & 0 & 0 & 0 & 0 & 0 & 1 & 0 & 0 & 5 & 14137749 & 30,7 & 8,84 & $-25,26$ & 0,19 & 4,01 & 105 & 14,1377 & 6 & 3,56136 & 0,00000 \\
\hline 37 & 3 & 0 & 0 & 0 & 0 & 0 & 0 & 0 & 1 & 0 & 328460 & 81,95 & 5,21 & $-5,1$ & 0,01 & 2,11 & 0 & 0,3285 & 0 & 0,00416 & 0,99647 \\
\hline 38 & 3 & 0 & 0 & 0 & 0 & 0 & 0 & 0 & 1 & 0 & 346777 & 89,94 & 5,21 & $-5,46$ & 0,01 & 2,27 & 0 & 0,3468 & 0 & 0,00610 & 0,99443 \\
\hline 39 & 3 & 0 & 0 & 0 & 0 & 0 & 0 & 0 & 1 & 0 & 367557 & 94,86 & 5,66 & $-6,48$ & $-0,03$ & 2,39 & 0 & 0,3676 & 0 & 0,00858 & 0,99168 \\
\hline 40 & 3 & 0 & 0 & 0 & 0 & 0 & 0 & 0 & 1 & 0 & 398532 & 96,1 & 4,11 & $-4,7$ & 0 & 2,43 & 1 & 0,3985 & 0 & 0,01274 & 0,98790 \\
\hline 41 & 3 & 0 & 0 & 0 & 0 & 0 & 0 & 0 & 1 & 0 & 405821 & 84,86 & 5,46 & $-4,25$ & 0 & 2,44 & 4 & 0,4058 & 0 & 0,02280 & 0,97889 \\
\hline 42 & 3 & 0 & 0 & 0 & 0 & 0 & 0 & 0 & 1 & 0 & 425146 & 82,77 & 7,38 & 0 & 0 & 2,53 & 6 & 0,4251 & 0 & 0,04498 & 0,95643 \\
\hline 43 & 3 & 0 & 0 & 0 & 0 & 0 & 0 & 0 & 1 & 0 & 467486 & 85,76 & 6,14 & 0 & 0 & 2,18 & 9 & 0,4675 & 0 & 0,05765 & 0,94361 \\
\hline 44 & 3 & 0 & 0 & 0 & 0 & 0 & 0 & 0 & 1 & 0 & 492658 & 83,74 & 5,72 & $-11,66$ & 0 & 2,53 & 21 & 0,4927 & 0 & 0,40638 & 0,52519 \\
\hline 45 & 4 & 0 & 0 & 0 & 0 & 0 & 1 & 0 & 0 & 0 & 480120 & 37,73 & 17,97 & 0 & 0,34 & 4,16 & 4 & 0,4801 & 2 & 0,83942 & 0,29677 \\
\hline 46 & 4 & 0 & 0 & 0 & 0 & 0 & 1 & 0 & 0 & 1 & 499080 & 38,22 & 19,16 & $-5,53$ & 0,27 & 4,16 & 8 & 0,4991 & 1 & 0,92276 & 0,14661 \\
\hline 47 & 4 & 0 & 0 & 0 & 0 & 0 & 1 & 0 & 0 & 1 & 518781 & 37,95 & 19,48 & $-5,81$ & 0,27 & 4,13 & 13 & 0,5188 & 1 & 0,95012 & 0,05974 \\
\hline 48 & 4 & 0 & 0 & 0 & 0 & 0 & 1 & 0 & 0 & 0 & 541806 & 39,97 & 17,47 & $-5,48$ & 0,27 & 4,1 & 13 & 0,5418 & 2 & 0,98546 & 0,05932 \\
\hline 49 & 4 & 0 & 0 & 0 & 0 & 0 & 1 & 0 & 0 & 2 & 568934 & 39,01 & 17,79 & $-6,01$ & 0,26 & 4,19 & 18 & 0,5689 & 0 & 0,96025 & 0,01837 \\
\hline 50 & 4 & 0 & 0 & 0 & 0 & 0 & 1 & 0 & 0 & 1 & 590945 & 40,9 & 15,66 & $-6,18$ & 0,27 & 4,27 & 22 & 0,5909 & 0 & 0,95060 & 0,00793 \\
\hline 51 & 4 & 0 & 0 & 0 & 0 & 0 & 1 & 0 & 0 & 0 & 602346 & 44,12 & 16,81 & $-5,39$ & 0,25 & 4,23 & 26 & 0,6023 & 0 & 0,86189 & 0,00344 \\
\hline 52 & 4 & 0 & 0 & 0 & 0 & 0 & 1 & 0 & 0 & 1 & 625577 & 41,33 & 16,63 & $-6,56$ & 0,26 & 4,2 & 28 & 0,6256 & 2 & 0,86667 & 0,00223 \\
\hline 53 & 4 & 0 & 0 & 0 & 0 & 0 & 1 & 0 & 0 & 1 & 644787 & 39,97 & 14,66 & $-8,54$ & 0,25 & 4,31 & 32 & 0,6448 & 1 & 0,86410 & 0,00096 \\
\hline 54 & 4 & 0 & 0 & 0 & 0 & 0 & 1 & 0 & 0 & 0 & 671542 & 36,73 & 15,26 & $-11,65$ & 0,25 & 4,54 & 36 & 0,6715 & 0 & 0,81737 & 0,00028 \\
\hline 55 & 4 & 0 & 0 & 0 & 0 & 0 & 1 & 0 & 0 & 0 & 693075 & 38,87 & 12,52 & $-12,82$ & 0,25 & 4,27 & 38 & 0,6931 & 0 & 0,84663 & 0,00030 \\
\hline 56 & 4 & 0 & 0 & 0 & 0 & 0 & 1 & 0 & 0 & 0 & 713749 & 41,02 & 11,84 & $-13,69$ & 0,3 & 4,26 & 44 & 0,7137 & 0 & 0,78279 & 0,00009 \\
\hline 57 & 4 & 0 & 0 & 0 & 0 & 0 & 1 & 0 & 0 & 0 & 740569 & 41,4 & 11,11 & $-16,11$ & 0,32 & 4,32 & 51 & 0,7406 & 1 & 0,71992 & 0,00002 \\
\hline 58 & 4 & 0 & 0 & 0 & 0 & 0 & 1 & 0 & 0 & 0 & 768020 & 42,12 & 9,84 & $-18,95$ & 0,32 & 4,28 & 59 & 0,768 & 0 & 0,66226 & 0,00001 \\
\hline 59 & 4 & 0 & 0 & 0 & 0 & 0 & 1 & 0 & 0 & 0 & 781995 & 44,95 & 11,33 & -16 & 0,29 & 4,2 & 61 & 0,782 & 0 & 0,61576 & 0,00000 \\
\hline 60 & 4 & 0 & 0 & 0 & 0 & 0 & 1 & 0 & 0 & 0 & 797778 & 39,86 & 9,77 & $-22,07$ & 0,32 & 4,27 & 65 & 0,7978 & 0 & 0,62277 & 0,00000 \\
\hline
\end{tabular}


Obs ID AA AB BA BB MD LV PL NL REC PIB COMEX AGRI PREF ODP CAP APRE PIB2 ACI CREC P0

\begin{tabular}{|c|c|c|c|c|c|c|c|c|c|c|c|c|c|c|c|c|c|c|c|c|c|}
\hline 61 & 4 & 0 & 0 & 0 & 0 & 0 & 1 & 0 & 0 & 0 & 816761 & 41,24 & 10,28 & $-25,3$ & 0,34 & 4,2 & 66 & 0,8168 & 0 & 0,60013 & 0,00000 \\
\hline 62 & 4 & 0 & 0 & 0 & 0 & 0 & 1 & 0 & 0 & 0 & 846432 & 42,7 & 10,7 & 0 & 0,36 & 4,11 & 78 & 0,8464 & 3 & 0,53793 & 0,00000 \\
\hline 63 & 5 & 1 & 0 & 0 & 0 & 0 & 0 & 0 & 1 & 0 & 10052 & 152,46 & 7,45 & 0 & 1,72 & 3,13 & 0 & 0,0101 & 0 & 0,01486 & 0,95293 \\
\hline 64 & 5 & 1 & 0 & 0 & 0 & 0 & 0 & 0 & 1 & 0 & 10465 & 164,12 & 12,54 & 0 & 2,18 & 3,13 & 0 & 0,0105 & 0 & 0,02166 & 0,91631 \\
\hline 65 & 5 & 1 & 0 & 0 & 0 & 0 & 0 & 0 & 1 & 0 & 12417 & 135,81 & 4,78 & 0 & 0,68 & 3,05 & 0 & 0,0124 & 0 & 0,00851 & 0,97713 \\
\hline 66 & 5 & 0 & 0 & 0 & 0 & 0 & 0 & 0 & 1 & 0 & 12726 & 127,03 & 5,71 & 0 & 0,82 & 3,04 & 0 & 0,0127 & 0 & 0,00210 & 0,99720 \\
\hline 67 & 5 & 0 & 0 & 0 & 0 & 0 & 0 & 1 & 0 & 0 & 13186 & 130,61 & 5,65 & 0 & 0,68 & 3,03 & 0 & 0,0132 & 0 & 0,01524 & 0,96835 \\
\hline 68 & 5 & 0 & 0 & 0 & 0 & 0 & 0 & 1 & 0 & 0 & 13980 & 128,09 & 4,99 & 0 & 1,25 & 2,96 & 0 & 0,014 & 0 & 0,01593 & 0,96901 \\
\hline 69 & 5 & 0 & 0 & 0 & 0 & 0 & 0 & 1 & 0 & 0 & 14956 & 140,74 & 4,22 & 0 & 0,46 & 3,09 & 0 & 0,015 & 0 & 0,01504 & 0,96665 \\
\hline 70 & 5 & 0 & 0 & 0 & 0 & 0 & 0 & 1 & 0 & 0 & 15969 & 148,31 & 3,43 & -5 & 0 & 2,9 & 0 & 0,016 & 0 & 0,00977 & 0,97685 \\
\hline 71 & 5 & 0 & 0 & 0 & 0 & 0 & 0 & 1 & 0 & 0 & 17002 & 147,1 & 2,84 & $-3,57$ & 0 & 2,9 & 0 & 0,017 & 0 & 0,00961 & 0,97784 \\
\hline 72 & 5 & 0 & 0 & 0 & 0 & 0 & 0 & 1 & 0 & 0 & 18412 & 137,79 & 2,6 & $-4,91$ & 0 & 2,92 & 0 & 0,0184 & 0 & 0,00960 & 0,97958 \\
\hline 73 & 5 & 0 & 0 & 0 & 0 & 0 & 0 & 1 & 0 & 0 & 19561 & 145,88 & 4,1 & $-10,58$ & 0 & 2,91 & 1 & 0,0196 & 0 & 0,01188 & 0,97120 \\
\hline 74 & 5 & 0 & 0 & 0 & 0 & 0 & 0 & 0 & 1 & 0 & 20058 & 117,96 & 5,55 & $-8,21$ & 0 & 3 & 1 & 0,0201 & 0 & 0,00180 & 0,99764 \\
\hline 75 & 5 & 0 & 0 & 0 & 0 & 0 & 0 & 0 & 1 & 0 & 20928 & 120,47 & 4,49 & 0 & 0 & 2,98 & 1 & 0,0209 & 0 & 0,00175 & 0,99776 \\
\hline 76 & 5 & 0 & 0 & 0 & 0 & 0 & 0 & 0 & 1 & 0 & 21367 & 126,81 & 4,45 & $-0,18$ & 0 & 3,05 & 1 & 0,0214 & 0 & 0,00196 & 0,99734 \\
\hline 77 & 5 & 0 & 0 & 0 & 0 & 0 & 0 & 0 & 1 & 0 & 22134 & 122,16 & 6,21 & $-0,18$ & 0 & 3,04 & 1 & 0,0221 & 0 & 0,00209 & 0,99717 \\
\hline 78 & 6 & 1 & 0 & 0 & 0 & 0 & 1 & 0 & 0 & 0 & 3105 & 90,07 & 30,72 & 0 & $-0,05$ & 3,94 & 0 & 0,0031 & 0 & 0,12964 & 0,55365 \\
\hline 79 & 6 & 1 & 0 & 0 & 0 & 0 & 1 & 0 & 0 & 0 & 3230 & 91,57 & 34,46 & $-3,03$ & 0,18 & 3,94 & 0 & 0,0032 & 0 & 0,13965 & 0,46973 \\
\hline 80 & 6 & 1 & 0 & 0 & 0 & 0 & 1 & 0 & 0 & 0 & 3381 & 93,88 & 32,47 & 0 & 0,17 & 3,94 & 1 & 0,0034 & 0 & 0,14686 & 0,45371 \\
\hline 81 & 6 & 1 & 0 & 0 & 0 & 0 & 1 & 0 & 0 & 0 & 3507 & 86,3 & 28,93 & 0 & 0,56 & 3,93 & 1 & 0,0035 & 0 & 0,15359 & 0,51534 \\
\hline 82 & 6 & 1 & 0 & 0 & 0 & 0 & 1 & 0 & 0 & 0 & 3518 & 86,43 & 27,73 & $-4,37$ & $-0,07$ & 3,92 & 1 & 0,0035 & 0 & 0,13081 & 0,58303 \\
\hline 83 & 6 & 0 & 0 & 0 & 0 & 0 & 1 & 0 & 0 & 0 & 3676 & 88,79 & 27,08 & $-4,57$ & 0,01 & 3,91 & 1 & 0,0037 & 0 & 0,04683 & 0,92129 \\
\hline 84 & 6 & 1 & 0 & 0 & 0 & 0 & 1 & 0 & 0 & 0 & 3588 & 84,65 & 30,14 & $-4,35$ & $-0,04$ & 3,89 & 1 & 0,0036 & 0 & 0,13453 & 0,55451 \\
\hline 85 & 6 & 0 & 0 & 0 & 0 & 0 & 1 & 0 & 0 & 0 & 3617 & 81,81 & 31,57 & $-4,8$ & 0,11 & 3,87 & 3 & 0,0036 & 0 & 0,07227 & 0,87019 \\
\hline 86 & 6 & 1 & 0 & 0 & 0 & 0 & 1 & 0 & 0 & 0 & 3695 & 88,31 & 28,23 & $-4,86$ & 0,63 & 3,8 & 4 & 0,0037 & 0 & 0,17099 & \begin{tabular}{|l|l}
0,43708 \\
\end{tabular} \\
\hline 87 & 6 & 1 & 0 & 0 & 0 & 0 & 1 & 0 & 0 & 0 & 3746 & 90,21 & 31,34 & $-4,81$ & 0,85 & 3,59 & 4 & 0,0037 & 0 & 0,15930 & 0,43902 \\
\hline 88 & 6 & 1 & 0 & 0 & 0 & 0 & 1 & 0 & 0 & 0 & 3898 & 95,66 & 27,01 & 0 & $-0,05$ & 3,76 & 4 & 0,0039 & 0 & 0,14633 & 0,49422 \\
\hline 89 & 6 & 0 & 0 & 0 & 0 & 0 & 1 & 0 & 0 & 0 & 4119 & 94,59 & 24,03 & $-1,72$ & $-0,05$ & 3,98 & 4 & 0,0041 & 0 & 0,07014 & 0,88002 \\
\hline 90 & 6 & 0 & 0 & 0 & 0 & 0 & 1 & 0 & 0 & 0 & 4189 & 93,71 & 26,66 & $-5,76$ & 0,4 & 3,84 & 4 & 0,0042 & 0 & 0,07261 & 0,87113 \\
\hline 91 & 6 & 0 & 0 & 0 & 0 & 0 & 1 & 0 & 0 & 0 & 4207 & 98,45 & 29,04 & 0 & 0,16 & 4,1 & 4 & 0,0042 & 0 & 0,10357 & 0,79545 \\
\hline 92 & 6 & 0 & 0 & 0 & 0 & 0 & 1 & 0 & 0 & 0 & 4038 & 85,84 & 30,45 & 0 & 0,27 & 4,01 & 4 & 0,004 & 0 & 0,10032 & 0,81787 \\
\hline 93 & 6 & 0 & 0 & 0 & 0 & 0 & 1 & 0 & 0 & 0 & 4049 & 96,6 & 29,86 & 0 & 0,37 & 3,91 & 4 & 0,004 & 0 & 0,09047 & 0,82421 \\
\hline 94 & 6 & 0 & 0 & 0 & 0 & 0 & 1 & 0 & 0 & 0 & 4078 & 91,46 & 24,93 & 0 & 0 & 3,96 & 4 & 0,0041 & 0 & 0,07213 & 0,87820 \\
\hline 95 & 6 & 0 & 0 & 0 & 0 & 0 & 1 & 0 & 0 & 0 & 4089 & 89,91 & 25,27 & 0 & 0 & 3,95 & 4 & 0,0041 & 0 & 0,07207 & 0,87902 \\
\hline 96 & 7 & 0 & 0 & 0 & 0 & 0 & 1 & 0 & 0 & 5 & 842744 & 69,33 & 12,41 & $-2,72$ & 0,38 & 4,38 & 5 & 0,8427 & 0 & 1,04963 & 0,01765 \\
\hline 97 & 7 & 0 & 0 & 0 & 0 & 0 & 1 & 0 & 0 & 3 & 856899 & 70,48 & 11,99 & $-2,71$ & 0,32 & 4,38 & 14 & 0,8569 & 1 & 0,94404 & 0,00346 \\
\hline 98 & 7 & 0 & 0 & 0 & 0 & 0 & 1 & 0 & 0 & 1 & 893346 & 74,59 & 11,6 & $-2,92$ & 0,34 & 4,42 & 19 & 0,8933 & 5 & 0,86606 & 0,00102 \\
\hline 99 & 7 & 0 & 0 & 0 & 0 & 0 & 1 & 0 & 0 & 4 & 930314 & 78,21 & 10,9 & $-2,77$ & 0,3 & 4,47 & 20 & 0,9303 & 3 & 0,84421 & 0,00062 \\
\hline 100 & 7 & 0 & 0 & 0 & 0 & 0 & 1 & 0 & 0 & 2 & 976804 & 80,4 & 10,32 & $-2,87$ & 0,28 & 4,46 & 29 & 0,9768 & 1 & 0,75048 & 0,00009 \\
\hline 101 & 7 & 0 & 0 & 0 & 0 & 0 & 1 & 0 & 0 & 1 & 1026847 & 83,18 & 10,15 & $-3,23$ & 0,25 & 4,45 & 35 & 1,0268 & 0 & 0,68371 & 0,00002 \\
\hline 102 & 7 & 0 & 0 & 0 & 0 & 0 & 1 & 0 & 0 & 3 & 1044184 & 78,8 & 10,19 & $-3,22$ & 0,22 & 4,45 & 37 & 1,0442 & 1 & 0,69144 & 0,00001 \\
\hline 103 & 7 & 0 & 0 & 0 & 0 & 0 & 1 & 0 & 0 & 4 & 1073441 & 76,28 & 10,36 & $-3,55$ & 0,28 & 4,45 & 49 & 1,0734 & 1 & 0,60337 & 0,00000 \\
\hline 104 & 7 & 0 & 0 & 0 & 0 & 0 & 1 & 0 & 0 & 1 & 1094108 & 70,21 & 10,16 & $-4,5$ & 0,24 & 4,51 & 58 & 1,0941 & 0 & 0,56375 & 0,00000 \\
\hline 105 & 7 & 0 & 0 & 0 & 0 & 0 & 1 & 0 & 0 & 2 & 1128450 & 70,51 & 10,56 & $-5,58$ & 0,27 & 4,46 & 63 & 1,1285 & 1 & 0,52480 & 0,00000 \\
\hline 106 & 7 & 0 & 0 & 0 & 0 & 0 & 1 & 0 & 0 & 0 & 1164144 & 70,02 & 9,69 & $-6,83$ & 0,34 & 4,41 & 63 & 1,1641 & 0 & 0,54245 & 0,00000 \\
\hline 107 & 7 & 0 & 0 & 0 & 0 & 0 & 1 & 0 & 0 & 1 & 1194666 & 68,22 & 9,66 & $-8,26$ & 0,29 & 4,42 & 67 & 1,1947 & 2 & 0,52190 & 0,00000 \\
\hline 108 & 7 & 0 & 0 & 0 & 0 & 0 & 1 & 0 & 0 & 2 & 1218658 & 66,51 & 9,95 & $-9,38$ & 0,29 & 4,25 & 70 & 1,2187 & 0 & 0,51085 & 0,00000 \\
\hline 109 & 7 & 0 & 0 & 0 & 0 & 0 & 1 & 0 & 0 & 2 & 1232983 & 67,21 & 10,16 & $-9,96$ & 0,33 & 4,27 & 73 & 1,233 & 0 & 0,48619 & 0,00000 \\
\hline 110 & 7 & 0 & 0 & 0 & 0 & 0 & 1 & 0 & 0 & 2 & 1199551 & 58,35 & 11,97 & $-10,21$ & 0,3 & 4,25 & 78 & 1,1996 & 0 & 0,46720 & 0,00000 \\
\hline 111 & 7 & 0 & 0 & 0 & 0 & 0 & 1 & 0 & 0 & 0 & 1240027 & 60,02 & 11,44 & $-12,67$ & 0,34 & 4,29 & 78 & 1,24 & 1 & 0,46633 & 0,00000 \\
\hline 112 & 7 & 0 & 0 & 0 & 0 & 0 & 1 & 0 & 0 & 0 & 1276733 & 62,33 & 11,43 & $-13,8$ & 0,32 & 4,28 & 78 & 1,2767 & 1 & 0,45869 & 0,00000 \\
\hline 113 & 7 & 0 & 0 & 0 & 0 & 0 & 1 & 0 & 0 & 0 & 1301282 & 62,26 & 11,25 & $-13,82$ & 0,32 & 4,25 & 90 & 1,3013 & 0 & 0,39489 & 0,00000 \\
\hline 114 & 8 & 0 & 0 & 0 & 0 & 0 & 0 & 1 & 0 & 1 & 76309 & 345,74 & 12,12 & $-14,45$ & $-0,02$ & 4,6 & 0 & 0,0763 & 0 & 0,05038 & 0,12188 \\
\hline 115 & 8 & 0 & 0 & 0 & 0 & 0 & 0 & 1 & 0 & 0 & 82057 & 335,93 & 10 & 0 & $-0,02$ & 4,6 & 2 & 0,0821 & 0 & 0,05922 & 0,10520 \\
\hline 116 & 8 & 0 & 0 & 0 & 0 & 0 & 0 & 1 & 0 & 0 & 88860 & 325,39 & 9,89 & 0 & 0 & 4,61 & 4 & 0,0889 & 0 & 0,06507 & 0,08048 \\
\hline 117 & 8 & 0 & 0 & 0 & 0 & 0 & 0 & 1 & 0 & 0 & 86883 & 313,88 & 12,13 & 0 & 0 & 4,62 & 4 & 0,0869 & 0 & 0,06822 & 0,07817 \\
\hline 118 & 8 & 0 & 0 & 0 & 0 & 0 & 0 & 1 & 0 & 0 & 92178 & 337,54 & 12,8 & 0 & 0 & 4,65 & 4 & 0,0922 & 0 & 0,05629 & 0,05415 \\
\hline 119 & 8 & 0 & 0 & 0 & 0 & 0 & 0 & 1 & 0 & 0 & 100380 & 366,07 & 9,95 & 0 & 0 & 4,67 & 4 & 0,1004 & 0 & 0,04768 & 0,04462 \\
\hline & & & & & & & & & & & 9942 & 352,75 & 12,22 & 55 & & 4,51 & 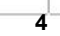 & 0,0994 & &, 04903 & 0,0568 \\
\hline
\end{tabular}


Obs ID AA AB BA BB MD LV PL NL REC PIB COMEX AGRI PREF ODP CAP APRE PIB2 ACI CREC P0

\begin{tabular}{|c|c|c|c|c|c|c|c|c|c|c|c|c|c|c|c|c|c|c|c|c|c|}
\hline 121 & 8 & 0 & 0 & 0 & 0 & 0 & 0 & 1 & 0 & 0 & 103612 & 354,28 & 11,84 & $-11,92$ & $-0,01$ & 4,35 & 4 & 0,1036 & 0 & 0,04858 & 0,06960 \\
\hline 122 & 8 & 0 & 0 & 0 & 0 & 0 & 0 & 1 & 0 & 0 & 108207 & 382,79 & 2,78 & $-13,44$ & $-0,01$ & 4,46 & 4 & 0,1082 & 0 & 0,04619 & \begin{tabular}{|l|l|}
0,07897 \\
\end{tabular} \\
\hline 123 & 8 & 0 & 0 & 0 & 0 & 0 & 0 & 1 & 0 & 0 & 118540 & 406,29 & 7,78 & 0 & $-0,01$ & 4,53 & 4 & 0,1185 & 0 & 0,03631 & 0,03620 \\
\hline 124 & 8 & 0 & 0 & 0 & 0 & 0 & 0 & 1 & 0 & 0 & 127418 & 422,33 & 5,94 & $-15,21$ & 0 & 4,5 & 4 & 0,1274 & 0 & 0,03201 & 0,03493 \\
\hline 125 & 8 & 0 & 0 & 0 & 0 & 0 & 0 & 1 & 0 & 0 & 138707 & 430,36 & 5,26 & $-16,34$ & 0 & 4,68 & 4 & 0,1387 & 0 & 0,03037 & 0,02401 \\
\hline 126 & 8 & 0 & 0 & 0 & 0 & 0 & 0 & 1 & 0 & 0 & 151345 & 398,66 & 5,47 & $-17,44$ & 0 & 4,87 & 4 & 0,1513 & 0 & 0,03917 & 0,02323 \\
\hline 127 & 8 & 0 & 0 & 0 & 0 & 0 & 0 & 1 & 0 & 0 & 154051 & 439,66 & 5,97 & $-17,85$ & 0 & 4,93 & 7 & 0,1541 & 0 & 0,02654 & 0,00769 \\
\hline 128 & 8 & 0 & 0 & 0 & 0 & 0 & 0 & 1 & 0 & 0 & 153121 & 360,23 & 6,5 & $-16,99$ & 0 & 4,78 & 7 & 0,1531 & 0 & 0,05135 & 0,02204 \\
\hline 129 & 8 & 0 & 0 & 0 & 0 & 0 & 0 & 1 & 0 & 0 & 176458 & 372,1 & 6,23 & $-18,6$ & 0 & 4,76 & 7 & 0,1765 & 0 & 0,04698 & 0,01719 \\
\hline 130 & 8 & 0 & 0 & 0 & 0 & 0 & 0 & 1 & 0 & 0 & 187411 & 376,15 & 5,69 & 0 & 0 & 4,67 & 7 & 0,1874 & 0 & 0,04845 & 0,01722 \\
\hline 131 & 8 & 0 & 0 & 0 & 0 & 0 & 0 & 1 & 0 & 0 & 193810 & 368,23 & 5,47 & $-20,71$ & 0 & 4,65 & 12 & 0,1938 & 0 & 0,04684 & 0,00828 \\
\hline 132 & 9 & 0 & 0 & 0 & 0 & 0 & 1 & 0 & 0 & 0 & 553331 & 54,32 & 7,4 & 0 & 0,02 & 3,13 & 0 & 0,5533 & 3 & 0,28120 & 0,81027 \\
\hline 133 & 9 & 0 & 0 & 0 & 0 & 0 & 1 & 0 & 0 & 0 & 593093 & 54,71 & 7,36 & $-8,17$ & 0,03 & 3,13 & 6 & 0,5931 & 2 & 0,63223 & 0,53059 \\
\hline 134 & 9 & 0 & 0 & 0 & 0 & 0 & 1 & 0 & 0 & 2 & 627295 & 60,23 & 6,79 & 0 & 0,04 & 2,98 & 8 & 0,6273 & 3 & 0,75512 & 0,42476 \\
\hline 135 & 9 & 0 & 0 & 0 & 0 & 0 & 1 & 0 & 0 & 0 & 591452 & 72,91 & 6,23 & 0 & 0,05 & 2,83 & 13 & 0,5915 & 0 & 0,77124 & 0,31158 \\
\hline 136 & 9 & 0 & 0 & 0 & 0 & 0 & 1 & 0 & 0 & 1 & 654918 & 65,43 & 5,92 & $-6,02$ & 0,07 & 3,02 & 15 & 0,6549 & 3 & 0,98749 & 0,14440 \\
\hline 137 & 9 & 0 & 0 & 0 & 0 & 0 & 1 & 0 & 0 & 3 & 712756 & 67,95 & 5,19 & 0 & 0,04 & 3,2 & 17 & 0,7128 & 0 & 1,06847 & 0,05704 \\
\hline 138 & 9 & 0 & 0 & 0 & 0 & 0 & 1 & 0 & 0 & 0 & 745010 & 63,91 & 5,68 & 0 & 0,06 & 3,3 & 18 & 0,745 & 0 & 1,10611 & 0,03352 \\
\hline 139 & 9 & 0 & 0 & 0 & 0 & 0 & 1 & 0 & 0 & 1 & 800383 & 60,15 & 5,6 & -8 & 0,05 & 3,39 & 28 & 0,8004 & 1 & 1,01544 & 0,00375 \\
\hline 140 & 9 & 0 & 0 & 0 & 0 & 0 & 1 & 0 & 0 & 3 & 823860 & 63,39 & 5,1 & 0 & 0,06 & 3,43 & 29 & 0,8239 & 0 & 1,00908 & 0,00244 \\
\hline 141 & 9 & 0 & 0 & 0 & 0 & 0 & 1 & 0 & 0 & 2 & 864228 & 72,76 & 4,45 & $-9,75$ & 0,06 & 3,44 & 33 & 0,8642 & 1 & 0,88218 & 0,00086 \\
\hline 142 & 9 & 0 & 0 & 0 & 0 & 0 & 1 & 0 & 0 & 0 & 898137 & 71,18 & 4,05 & 0 & 0,1 & 3,52 & 36 & 0,8981 & 0 & 0,89096 & 0,00036 \\
\hline 143 & 9 & 0 & 0 & 0 & 0 & 0 & 1 & 0 & 0 & 1 & 944626 & 73,55 & 3,8 & $-13,08$ & 0,05 & 3,55 & 42 & 0,9446 & 0 & 0,78814 & 0,00009 \\
\hline 144 & 9 & 0 & 0 & 0 & 0 & 0 & 1 & 0 & 0 & 0 & 996235 & 77,24 & 3,9 & $-14,34$ & 0,07 & 3,73 & 44 & 0,9962 & 0 & 0,73890 & 0,00003 \\
\hline 145 & 9 & 0 & 0 & 0 & 0 & 0 & 1 & 0 & 0 & 0 & 1024420 & 99,93 & 3,92 & 0 & 0,09 & 3,55 & 52 & 1,0244 & 0 & 0,57578 & 0,00001 \\
\hline 146 & 9 & 0 & 0 & 0 & 0 & 0 & 1 & 0 & 0 & 1 & 1031668 & 90,41 & 4,13 & $-10,59$ & 0,1 & 3,61 & 57 & 1,0317 & 1 & 0,56523 & 0,00000 \\
\hline 147 & 9 & 0 & 0 & 0 & 0 & 0 & 1 & 0 & 0 & 0 & 1098694 & 95,65 & 4,06 & $-12,52$ & 0,12 & 3,72 & 61 & 1,0987 & 0 & 0,51368 & 0,00000 \\
\hline 148 & 9 & 0 & 0 & 0 & 0 & 0 & 1 & 0 & 0 & 1 & 1139144 & 110 & 4,42 & 0 & 0,12 & 3,76 & 63 & 1,1391 & 0 & 0,45460 & 0,00000 \\
\hline 149 & 9 & 0 & 0 & 0 & 0 & 0 & 1 & 0 & 0 & 0 & 1165258 & 109,89 & 4,28 & 0 & 0,14 & 3,7 & 77 & 1,1653 & 0 & 0,38192 & 0,00000 \\
\hline 150 & 10 & 1 & 0 & 0 & 0 & 0 & 1 & 0 & 0 & 0 & 36454 & 76,06 & 11,56 & 0 & 0,31 & 2,81 & 0 & 0,0365 & 0 & 0,02533 & 0,95459 \\
\hline 151 & 10 & 1 & 0 & 0 & 0 & 0 & 1 & 0 & 0 & 0 & 37706 & 80,84 & 12,02 & 0 & 0,54 & 2,83 & 0 & 0,0377 & 0 & 0,02892 & 0,94590 \\
\hline 152 & 10 & 1 & 0 & 0 & 0 & 0 & 1 & 0 & 0 & 0 & 39685 & 83,22 & 12,72 & $-2,24$ & 0,54 & 2,84 & 0 & 0,0397 & 0 & 0,03047 & 0,94051 \\
\hline 153 & 10 & 1 & 0 & 0 & 0 & 0 & 1 & 0 & 0 & 0 & 41890 & 85,22 & 12,87 & $-2,97$ & 0,36 & 2,88 & 0 & 0,0419 & 1 & 0,03120 & 0,93713 \\
\hline 154 & 10 & 1 & 0 & 0 & 0 & 0 & 1 & 0 & 0 & 0 & 43601 & 84,92 & 11,11 & $-4,06$ & 0,29 & 2,97 & 0 & 0,0436 & 0 & 0,03211 & \begin{tabular}{|l|l|}
0,93741 \\
\end{tabular} \\
\hline 155 & 10 & 1 & 0 & 0 & 0 & 0 & 1 & 0 & 0 & 0 & 45416 & 84,73 & 11,58 & $-5,01$ & 0,28 & 2,98 & 0 & 0,0454 & 0 & 0,03337 & 0,93413 \\
\hline 156 & 10 & 1 & 0 & 0 & 0 & 0 & 1 & 0 & 0 & 0 & 47589 & 86,07 & 11,82 & $-5,65$ & 0,41 & 3,06 & 0 & 0,0476 & 0 & 0,03942 & 0,92083 \\
\hline 157 & 10 & 1 & 0 & 0 & 0 & 0 & 1 & 0 & 0 & 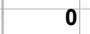 & 50040 & 85,27 & 11,32 & $-7,43$ & 0,28 & 2,97 & 0 & 0,05 & 0 & 0,03332 & 0,93403 \\
\hline 158 & 10 & 0 & 0 & 0 & 0 & 0 & 1 & 0 & 0 & 0 & 51068 & 84,99 & 10,94 & $-9,15$ & 0,35 & 3,07 & 0 & 0,0511 & 0 & 0,00937 & 0,99027 \\
\hline 159 & 10 & 0 & 0 & 0 & 0 & 0 & 1 & 0 & 0 & 0 & 47297 & 72,76 & 13,66 & $-8,11$ & 0,28 & 3,11 & 0 & 0,0473 & 0 & 0,01044 & 0,98955 \\
\hline 160 & 10 & 0 & 0 & 0 & 0 & 0 & 1 & 0 & 0 & 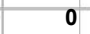 & 46492 & 75,9 & 13,19 & $-8,65$ & 0,23 & 3,13 & 0 & 0,0465 & 0 & 0,01034 & 0,98945 \\
\hline 161 & 10 & 0 & 0 & 0 & 0 & 0 & 1 & 0 & 0 & 0 & 46362 & 81,27 & 13,71 & $-8,45$ & 0 & 3,06 & 0 & 0,0464 & 0 & 0,00908 & 0,99012 \\
\hline 162 & 10 & 0 & 0 & 0 & 0 & 0 & 1 & 0 & 0 & 0 & 45347 & 82,68 & 14,84 & $-12,17$ & 0 & 3,2 & 0 & 0,0453 & 0 & 0,01138 & 0,98691 \\
\hline 163 & 11 & 0 & 0 & 0 & 0 & 0 & 1 & 0 & 0 & 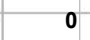 & 10678 & 65,96 & 46,36 & 0 & 0 & 4,3 & 4 & 0,0107 & 0 & 0,19848 & 0,54662 \\
\hline 164 & 11 & 0 & 0 & 0 & 0 & 0 & 1 & 0 & 0 & 0 & 11188 & 70,38 & 44,74 & 0 & 0 & 4,3 & 4 & 0,0112 & 0 & 0,19178 & 0,56206 \\
\hline 165 & 11 & 0 & 0 & 0 & 0 & 0 & 1 & 0 & 0 & 0 & 11738 & 70,36 & 43,47 & 0 & 0 & 4,36 & 4 & 0,0117 & 0 & 0,19707 & 0,56177 \\
\hline 166 & 11 & 0 & 0 & 0 & 0 & 0 & 1 & 0 & 0 & 0 & 12504 & 72,19 & 41,92 & 0 & 0 & 4,41 & 4 & 0,0125 & 0 & 0,19943 & 0,56439 \\
\hline 167 & 11 & 0 & 0 & 0 & 0 & 0 & 1 & 0 & 0 & 0 & 13024 & 69,85 & 38,93 & 0 & 0,09 & 4,47 & 6 & 0,013 & 0 & 0,23991 & 0,50826 \\
\hline 168 & 11 & 0 & 0 & 0 & 0 & 0 & 1 & 0 & 0 & 0 & 13639 & 71,95 & 35,73 & 0 & 0,1 & 4,53 & 6 & 0,0136 & 0 & 0,23921 & 0,53549 \\
\hline 169 & 11 & 0 & 0 & 0 & 0 & 0 & 1 & 0 & 0 & 0 & 14152 & 75,72 & 37,81 & $-2,01$ & 0,13 & 4,52 & 6 & 0,0142 & 0 & 0,24160 & 0,48988 \\
\hline 170 & 11 & 0 & 0 & 0 & 0 & 0 & 1 & 0 & 0 & 0 & 14217 & 70,55 & 39,77 & 0 & 0,15 & 4,51 & 6 & 0,0142 & 0 & 0,25188 & 0,47060 \\
\hline 171 & 11 & 0 & 0 & 0 & 0 & 0 & 1 & 0 & 0 & 0 & 14606 & 68,99 & 37,5 & $-2,44$ & 0,17 & 4,62 & 6 & 0,0146 & 0 & 0,26427 & 0,47426 \\
\hline 172 & 11 & 0 & 0 & 0 & 0 & 0 & 1 & 0 & 0 & 0 & 15807 & 70,75 & 35,31 & 0 & 0,18 & 4,62 & 6 & 0,0158 & 0 & 0,26023 & 0,50401 \\
\hline 173 & 11 & 0 & 0 & 0 & 0 & 0 & 1 & 0 & 0 & 0 & 16749 & 72,87 & 30,14 & 0 & 0,18 & 4,49 & 6 & 0,0167 & 0 & 0,21519 & 0,63272 \\
\hline 174 & 11 & 0 & 0 & 0 & 0 & 0 & 1 & 0 & 0 & 0 & 17454 & 79,44 & 25,91 & $-3,93$ & 0,27 & 4,37 & 6 & 0,0175 & 0 & 0,17360 & 0,71649 \\
\hline 175 & 11 & 0 & 0 & 0 & 0 & 0 & 1 & 0 & 0 & 0 & 19111 & 75,9 & 24,22 & $-4,11$ & 0,27 & 4,28 & 6 & 0,0191 & 0 & 0,15191 & \begin{tabular}{|l|l|}
0,76974 \\
\end{tabular} \\
\hline 176 & 11 & 0 & 0 & 0 & 0 & 0 & 1 & 0 & 0 & 0 & 19393 & 85,2 & 24,04 & $-4,51$ & 0,47 & 4,31 & 6 & 0,0194 & 0 & 0,16331 & 0,73476 \\
\hline 177 & 11 & 0 & 0 & 0 & 0 & 0 & 1 & 0 & 0 & 0 & 18485 & 90,6 & 29,82 & $-3,32$ & 0,35 & 4,15 & 8 & 0,0185 & 0 & 0,19378 & 0,61519 \\
\hline 178 & 11 & 0 & 0 & 0 & 0 & 0 & 1 & 0 & 0 & 0 & 17822 & 97,27 & 28,63 & $-4,85$ & 0,29 & 4,09 & 8 & 0,0178 & 0 & 0,17368 & 0,64390 \\
\hline 179 & 11 & 0 & 0 & 0 & 0 & 0 & 1 & 0 & 0 & 0 & 18176 & 105,24 & 28,61 & $-4,66$ & 0,21 & 4,08 & 8 & 0,0182 & 0 & 0,16773 & 0,63130 \\
\hline 00 & 11 & & & & & & & & & & 3 & 07,91 &, 26 & & 24 & 3,9 & & 018 & & 15675 & 0,6436 \\
\hline
\end{tabular}


Obs ID AA AB BA BB MD LV PL NL REC PIB COMEX AGRI PREF ODP CAP APRE PIB2 ACI CREC P0

\begin{tabular}{|c|c|c|c|c|c|c|c|c|c|c|c|c|c|c|c|c|c|c|c|c|c|}
\hline 181 & 12 & 0 & 0 & 0 & 0 & 0 & 1 & 0 & 0 & 0 & 98662 & 62,96 & 7,69 & 0 & $-0,28$ & 3,47 & 0 & 0,0987 & 0 & 0,01643 & 0,98664 \\
\hline 182 & 12 & 0 & 0 & 0 & 0 & 0 & 1 & 0 & 0 & 0 & 104737 & 61,36 & 7,62 & 0 & $-1,82$ & 3,47 & 0 & 0,1047 & 0 & 0,01072 & 0,99084 \\
\hline 183 & 12 & 0 & 0 & 0 & 0 & 0 & 1 & 0 & 0 & 0 & 109012 & 60,53 & 7,29 & 0 & $-0,96$ & 3,55 & 1 & 0,109 & 0 & 0,01849 & 0,98474 \\
\hline 184 & 12 & 0 & 0 & 0 & 0 & 0 & 1 & 0 & 0 & 0 & 113647 & 59,8 & 6,98 & 0 & $-0,85$ & 3,63 & 2 & 0,1136 & 0 & 0,02546 & 0,97900 \\
\hline 185 & 12 & 0 & 0 & 0 & 0 & 0 & 1 & 0 & 0 & 0 & 117895 & 67,76 & 6,13 & 0 & $-0,7$ & 3,64 & 2 & 0,1179 & 0 & 0,02730 & 0,97653 \\
\hline 186 & 12 & 0 & 0 & 0 & 0 & 0 & 1 & 0 & 0 & 0 & 128437 & 71,19 & 4,72 & 0 & $-0,6$ & 3,65 & 3 & 0,1284 & 0 & 0,03405 & 0,97060 \\
\hline 187 & 12 & 0 & 0 & 0 & 0 & 0 & 1 & 0 & 0 & 0 & 128747 & 64,93 & 5,07 & 0 & $-0,13$ & 3,64 & 4 & 0,1287 & 0 & 0,04530 & 0,96289 \\
\hline 188 & 12 & 0 & 0 & 0 & 0 & 0 & 1 & 0 & 0 & 0 & 128659 & 68,62 & 5,05 & 0 & $-0,55$ & 3,62 & 4 & 0,1287 & 0 & 0,03922 & 0,96630 \\
\hline 189 & 12 & 0 & 0 & 0 & 0 & 0 & 1 & 0 & 0 & 0 & 130174 & 70,09 & 5,21 & 0 & $-0,31$ & 3,75 & 4 & 0,1302 & 0 & 0,05126 & 0,95537 \\
\hline 190 & 12 & 0 & 0 & 0 & 0 & 0 & 1 & 0 & 0 & 0 & 136831 & 78,16 & 3,55 & $-5,8$ & $-0,32$ & 3,81 & 4 & 0,1368 & 0 & 0,05342 & 0,95125 \\
\hline 191 & 12 & 0 & 0 & 0 & 0 & 0 & 1 & 0 & 0 & 0 & 142838 & 81,48 & 4,79 & $-6,55$ & 0 & 3,58 & 4 & 0,1428 & 0 & 0,04773 & 0,95506 \\
\hline 192 & 12 & 0 & 0 & 0 & 0 & 0 & 1 & 0 & 0 & 0 & 151125 & 81,11 & 4,86 & -7 & 0 & 3,75 & 4 & 0,1511 & 0 & 0,06357 & 0,93966 \\
\hline 193 & 12 & 0 & 0 & 0 & 0 & 0 & 1 & 0 & 0 & 0 & 160396 & 81,49 & 5,19 & $-8,26$ & 0 & 3,74 & 4 & 0,1604 & 0 & 0,06767 & 0,93500 \\
\hline 194 & 12 & 0 & 0 & 0 & 0 & 0 & 1 & 0 & 0 & 0 & 165303 & 77,29 & 5,54 & $-9,99$ & 0 & 3,83 & 4 & 0,1653 & 0 & 0,07877 & 0,92576 \\
\hline 195 & 12 & 0 & 0 & 0 & 0 & 0 & 1 & 0 & 0 & 0 & 167401 & 63,79 & 6,33 & $-8,57$ & 0 & 3,76 & 4 & 0,1674 & 0 & 0,07414 & 0,93704 \\
\hline 196 & 12 & 0 & 0 & 0 & 0 & 0 & 1 & 0 & 0 & 0 & 176636 & 67,81 & 6,11 & 0 & 0 & 3,87 & 4 & 0,1766 & 0 & 0,09476 & 0,91850 \\
\hline 197 & 12 & 0 & 0 & 0 & 0 & 0 & 1 & 0 & 0 & 0 & 185521 & 71,47 & 5,91 & 0 & 0 & 3,83 & 4 & 0,1855 & 0 & 0,09556 & 0,91592 \\
\hline 198 & 12 & 0 & 0 & 0 & 0 & 0 & 1 & 0 & 0 & 0 & 190864 & 72,45 & 5,87 & $-10,25$ & 0 & 3,75 & 7 & 0,1909 & 0 & 0,13156 & 0,87620 \\
\hline 199 & 13 & 0 & 0 & 0 & 0 & 0 & 1 & 0 & 0 & 1 & 4132182 & 16,75 & 10,56 & $-14,61$ & 0,27 & 3,46 & 3 & 4,1322 & 4 & 3,12431 & 0,00000 \\
\hline 200 & 13 & 0 & 0 & 0 & 0 & 0 & 1 & 0 & 0 & 3 & 4240034 & 18,94 & 10,49 & $-12,88$ & 0,2 & 3,46 & 9 & 4,24 & 4 & 2,88911 & 0,00000 \\
\hline 201 & 13 & 0 & 0 & 0 & 0 & 0 & 1 & 0 & 0 & 1 & 4307689 & 20,39 & 9,68 & $-11,76$ & 0,21 & 3,51 & 17 & 4,3077 & 3 & 2,64343 & 0,00000 \\
\hline 202 & 13 & 0 & 0 & 0 & 0 & 0 & 1 & 0 & 0 & 1 & 4221400 & 19,69 & 9,4 & $-10,28$ & 0,27 & 3,57 & 22 & 4,2214 & 1 & 2,47564 & 0,00000 \\
\hline 203 & 13 & 0 & 0 & 0 & 0 & 0 & 1 & 0 & 0 & 2 & 4212985 & 18,76 & 9,09 & $-12,28$ & 0,27 & 3,63 & 30 & 4,213 & 0 & 2,23695 & 0,00000 \\
\hline 204 & 13 & 0 & 0 & 0 & 0 & 0 & 1 & 0 & 0 & 1 & 4308093 & 20,31 & 7,86 & $-13,97$ & 0,28 & 3,69 & 42 & 4,3081 & 0 & 1,95186 & 0,00000 \\
\hline 205 & 13 & 0 & 0 & 0 & 0 & 0 & 1 & 0 & 0 & 0 & 4323406 & 20,26 & 8,32 & $-13,48$ & 0,23 & 3,63 & 45 & 4,3234 & 0 & 1,86525 & 0,00000 \\
\hline 206 & 13 & 0 & 0 & 0 & 0 & 0 & 1 & 0 & 0 & 2 & 4335925 & 21,16 & 7,99 & $-13,09$ & 0,23 & 3,57 & 59 & 4,3359 & 1 & 1,55725 & 0,00000 \\
\hline 207 & 13 & 0 & 0 & 0 & 0 & 0 & 1 & 0 & 0 & 0 & 4408990 & 22,09 & 7,39 & $-14,47$ & 0,2 & 3,72 & 66 & 4,409 & 0 & 1,42509 & 0,00000 \\
\hline 208 & 13 & 0 & 0 & 0 & 0 & 0 & 1 & 0 & 0 & 1 & 4513074 & 24,46 & 6,94 & $-15,58$ & 0,19 & 3,92 & 71 & 4,5131 & 1 & 1,32341 & 0,00000 \\
\hline 209 & 13 & 0 & 0 & 0 & 0 & 0 & 1 & 0 & 0 & 0 & 4571867 & 27,22 & 6,41 & $-15,5$ & 0,28 & 3,85 & 75 & 4,5719 & 0 & 1,26278 & 0,00000 \\
\hline 210 & 13 & 0 & 0 & 0 & 0 & 0 & 1 & 0 & 0 & 0 & 4649265 & 31,09 & 5,78 & $-14,85$ & 0,25 & 4,06 & 88 & 4,6493 & 1 & 1,04336 & 0,00000 \\
\hline 211 & 13 & 0 & 0 & 0 & 0 & 0 & 1 & 0 & 0 & 0 & 4751185 & 33,8 & 5,62 & $-14,65$ & 0,17 & 3,95 & 97 & 4,7512 & 0 & 0,92582 & 0,00000 \\
\hline 212 & 13 & 0 & 0 & 0 & 0 & 0 & 1 & 0 & 0 & 1 & 4701695 & 35,23 & 5,59 & $-16,47$ & 0,19 & 3,96 & 105 & 4,7017 & 0 & 0,81249 & 0,00000 \\
\hline 213 & 13 & 0 & 0 & 0 & 0 & 0 & 1 & 0 & 0 & 0 & 4441834 & 25,02 & 6,56 & $-19,09$ & 0,18 & 3,96 & 114 & 4,4418 & 0 & 0,73135 & 0,00000 \\
\hline 214 & 13 & 0 & 0 & 0 & 0 & 0 & 1 & 0 & 0 & 1 & 4648469 & 29,15 & 5,87 & $-20,27$ & 0,2 & 4,02 & 118 & 4,6485 & 0 & 0,69973 & 0,00000 \\
\hline 215 & 13 & 0 & 0 & 0 & 0 & 0 & 1 & 0 & 0 & 0 & 4627424 & 31,16 & 6,26 & $-23,18$ & 0,18 & 3,97 & 123 & 4,6274 & 0 & 0,63213 & 0,00000 \\
\hline 216 & 13 & 0 & 0 & 0 & 0 & 0 & 1 & 0 & 0 & 3 & 4708575 & 31,34 & 6,1 & $-24,73$ & 0,17 & 3,9 & 136 & 4,7086 & 0 & 0,53953 & 0,00000 \\
\hline 217 & 14 & 0 & 0 & 0 & 0 & 0 & 0 & 1 & 0 & 0 & 49547 & 94,32 & 7,58 & 0 & $-0,01$ & 2,63 & 0 & 0,0495 & 0 & 0,00942 & 0,98497 \\
\hline 218 & 14 & 0 & 0 & 0 & 0 & 0 & 0 & 1 & 0 & 0 & 49847 & 91,47 & 7,47 & 0 & $-0,07$ & 2,63 & 0 & 0,0498 & 0 & 0,00916 & 0,98573 \\
\hline 219 & 14 & 0 & 0 & 0 & 0 & 0 & 0 & 1 & 0 & 0 & 51080 & 92,45 & 7,26 & 0 & 0 & 2,51 & 0 & 0,0511 & 0 & 0,00794 & 0,98772 \\
\hline 220 & 14 & 0 & 0 & 0 & 0 & 0 & 0 & 1 & 0 & 0 & 52950 & 94,95 & 8,96 & 0 & $-0,02$ & 2,39 & 0 & 0,053 & 0 & 0,00738 & 0,98794 \\
\hline 221 & 14 & 0 & 0 & 0 & 0 & 0 & 0 & 1 & 0 & 0 & 52003 & 85,37 & 8,58 & 0 & $-0,02$ & 2,39 & 0 & 0,052 & 0 & 0,00703 & 0,98950 \\
\hline 222 & 14 & 0 & 0 & 0 & 0 & 0 & 0 & 1 & 0 & 0 & 54444 & 86,62 & 5,11 & 0 & $-0,01$ & 2,38 & 0 & 0,0544 & 0 & 0,00603 & 0,99162 \\
\hline 223 & 14 & 0 & 0 & 0 & 0 & 0 & 0 & 1 & 0 & 0 & 54841 & 86,84 & 5,47 & 0 & $-0,01$ & 2,48 & 0 & 0,0548 & 0 & 0,00708 & 0,99000 \\
\hline 224 & 14 & 0 & 0 & 0 & 0 & 0 & 0 & 1 & 0 & 0 & 56486 & 81,23 & 5,71 & 0 & $-0,02$ & 2,58 & 0 & 0,0565 & 0 & 0,00820 & 0,98884 \\
\hline 225 & 14 & 0 & 0 & 0 & 0 & 0 & 0 & 1 & 0 & 0 & 66270 & 86,56 & 5,01 & 0 & $-0,01$ & 2,56 & 0 & 0,0663 & 0 & 0,00844 & | 0,98821 \\
\hline 226 & 14 & 0 & 0 & 0 & 0 & 0 & 0 & 1 & 0 & 0 & 73402 & 89,3 & 4,2 & 0 & $-0,01$ & 2,57 & 0 & 0,0734 & 0 & 0,00875 & 0,98773 \\
\hline 227 & 14 & 0 & 0 & 0 & 0 & 0 & 0 & 1 & 0 & 0 & 86874 & 89,71 & 4,24 & $-5,3$ & 0 & 2,74 & 0 & 0,0869 & 0 & 0,01202 & 0,98272 \\
\hline 228 & 14 & 0 & 0 & 0 & 0 & 0 & 0 & 1 & 0 & 0 & 92079 & 91,73 & 4,35 & $-0,05$ & 0 & 2,61 & 0 & 0,0921 & 0 & 0,01081 & $\mid$\begin{tabular}{l|l} 
& 0,98448
\end{tabular} \\
\hline 229 & 14 & 0 & 0 & 0 & 0 & 0 & 0 & 1 & 0 & 0 & 94363 & 92,68 & 4,43 & $-4,61$ & 0 & 2,51 & 1 & 0,0944 & 0 & 0,01105 & 0,98369 \\
\hline 230 & 15 & 0 & 0 & 0 & 0 & 0 & 1 & 0 & 0 & 0 & 81915 & 56,91 & 36,78 & 0 & 0,23 & 4,44 & 0 & 0,0819 & 0 & 0,18666 & 0,70485 \\
\hline 231 & 15 & 0 & 0 & 0 & 0 & 0 & 1 & 0 & 0 & 1 & 84881 & 55,12 & 36,94 & $-3,64$ & 0,21 & 4,44 & 2 & 0,0849 & 0 & 0,22994 & 0,62738 \\
\hline 232 & 15 & 0 & 0 & 0 & 0 & 0 & 1 & 0 & 0 & 3 & 86559 & 55,25 & 36,32 & $-3,8$ & 0,26 & 4,31 & 2 & 0,0866 & 0 & 0,20548 & 0,67454 \\
\hline 233 & 15 & 0 & 0 & 0 & 0 & 0 & 1 & 0 & 0 & 0 & 87081 & 57,9 & 35,52 & $-3,23$ & 0,27 & 4,17 & 2 & 0,0871 & 0 & 0,17665 & 0,72189 \\
\hline 234 & 15 & 0 & 0 & 0 & 0 & 0 & 1 & 0 & 0 & 1 & 91884 & 61,4 & 34,01 & $-3,69$ & 0,27 & 4,15 & 7 & 0,0919 & 0 & 0,27742 & 0,53601 \\
\hline 235 & 15 & 0 & 0 & 0 & 0 & 0 & 1 & 0 & 0 & 0 & 94423 & 68,52 & 35,53 & $-3,55$ & 0,25 & 4,13 & 7 & 0,0944 & 0 & 0,27549 & 0,49326 \\
\hline 236 & 15 & 0 & 0 & 0 & 0 & 0 & 1 & 0 & 0 & 0 & 97661 & 67,23 & 37,1 & 0 & 0,25 & 4,19 & 7 & 0,0977 & 0 & 0,29894 & 0,43908 \\
\hline 237 & 15 & 0 & 0 & 0 & 0 & 0 & 1 & 0 & 0 & 1 & 102432 & 62,58 & 37,09 & $-4,28$ & 0,22 & 4,24 & 18 & 0,1024 & 0 & 0,42527 & 0,09944 \\
\hline 238 & 15 & 0 & 0 & 0 & 0 & 0 & 1 & 0 & 0 & 0 & 107176 & 57,84 & 36,24 & $-5,69$ & 0,23 & 4,32 & 23 & 0,1072 & 0 & 0,44617 & 0,04246 \\
\hline 239 & 15 & 0 & 0 & 0 & 0 & 0 & 1 & 0 & 0 & v & 111266 & 58,71 & 35,63 & -7 & 0,23 & 4,47 & 27 & 0,1113 & 0 & 0,43214 & 0,01750 \\
\hline 240 & & 0 & & & & & & & & & 1506 & , & 4,99 & 3,8 & & 4,24 & 1 &,, 11 & & ,443 & 0,024 \\
\hline
\end{tabular}




\begin{tabular}{|c|c|c|c|c|c|c|c|c|c|c|c|c|c|c|c|c|c|c|c|c|c|}
\hline bs & ID & AA & $A B$ & BA & BB & MD & LV & PL & NL & REC & PIB & OMEX & AGRI & PREF & ODP & CAP & APRE & PIB2 & $\mathrm{ACl}$ & CREC & po \\
\hline 241 & 15 & 0 & 0 & 0 & 0 & 0 & 1 & 0 & 0 & 0 & 118241 & 59,66 & 35,67 & $-8,79$ & 0,27 & 4,16 & 27 & 0,1182 & 0 & 0,43169 & 0,02547 \\
\hline 242 & 15 & 0 & 0 & 0 & 0 & 0 & 1 & 0 & 0 & 1 & 121740 & 58,6 & 35,89 & $-10,88$ & 0,27 & 4,17 & 29 & 0,1217 & 0 & 0,42326 & 0,01740 \\
\hline 243 & 15 & 0 & 0 & 0 & 0 & 0 & 1 & 0 & 0 & 0 & 119774 & 64,99 & 35,65 & $-12,21$ & 0,3 & 4,17 & 32 & 0,1198 & 0 & 0,38932 & 0,00994 \\
\hline 244 & 15 & 0 & 0 & 0 & 0 & 0 & 1 & 0 & 0 & 0 & 119473 & 55,56 & 39,63 & $-10,3$ & 0,28 & 4,35 & 33 & 0,1195 & 0 & 0,37856 & 0,00540 \\
\hline 245 & 15 & 0 & 0 & 0 & 0 & 0 & 1 & 0 & 0 & 0 & 121195 & 58,75 & 39,87 & $-12,09$ & 0,26 & 4,31 & 33 & 0,1212 & 0 & 0,36537 & 0,00542 \\
\hline 246 & 15 & 0 & 0 & 0 & 0 & 0 & 1 & 0 & 0 & 0 & 123884 & 60,01 & 39,86 & 0 & 0,28 & 4,38 & 33 & 0,1239 & 0 & 0,37177 & 0,00458 \\
\hline 247 & 15 & 0 & 0 & 0 & 0 & 0 & 1 & 0 & 0 & 0 & 126581 & 57,69 & 39,74 & 0 & 0,28 & 4,29 & 36 & 0,1266 & 0 & 0,36790 & 0,00314 \\
\hline 248 & 16 & 0 & 0 & 0 & 0 & 0 & 1 & 0 & 0 & 0 & 231758 & 68,33 & 9,67 & $-1,84$ & 0,86 & 4,52 & 3 & 0,2318 & 0 & 0,34711 & 0,67972 \\
\hline 249 & 16 & 0 & 0 & 0 & 0 & 0 & 1 & 0 & 0 & 0 & 243411 & 71,12 & 8,98 & $-1,36$ & 0,83 & 4,52 & 7 & 0,2434 & 0 & 0,51255 & 0,49820 \\
\hline 250 & 16 & 0 & 0 & 0 & 0 & 0 & 1 & 0 & 0 & 0 & 256274 & 73,06 & 8,77 & 0 & 0,84 & 4,51 & 7 & 0,2563 & 0 & 0,53370 & 0,47479 \\
\hline 251 & 16 & 0 & 0 & 0 & 0 & 0 & 1 & 0 & 0 & 0 & 263000 & 72,02 & 9,92 & $-1,44$ & 0,89 & 4,49 & 7 & 0,263 & 0 & 0,54958 & 0,44978 \\
\hline 252 & 16 & 0 & 0 & 0 & 0 & 0 & 1 & 0 & 0 & 0 & 268295 & 70,01 & 9,61 & 0 & 0,88 & 4,45 & 7 & 0,2683 & 0 & 0,55062 & 0,46536 \\
\hline 253 & 16 & 0 & 0 & 0 & 0 & 0 & 1 & 0 & 0 & 0 & 276894 & 74,62 & 7,65 & $-1,4$ & 0,76 & 4,41 & 9 & 0,2769 & 0 & 0,59418 & 0,40846 \\
\hline 254 & 16 & 0 & 0 & 0 & 0 & 0 & 1 & 0 & 0 & 0 & 282669 & 73,27 & 7,75 & $-1,33$ & 0,8 & 4,41 & 10 & 0,2827 & 0 & 0,64556 & 0,35642 \\
\hline 255 & 16 & 0 & 0 & 0 & 0 & 0 & 1 & 0 & 0 & 1 & 286732 & 67,65 & 8,17 & $-1,96$ & 0,89 & 4,4 & 18 & 0,2867 & 0 & 0,82691 & 0,12001 \\
\hline 256 & 16 & 0 & 0 & 0 & 0 & 0 & 1 & 0 & 0 & 0 & 289370 & 66,58 & 7,8 & $-2,15$ & 0,92 & 4,42 & 22 & 0,2894 & 0 & 0,85024 & 0,06243 \\
\hline 257 & 16 & 0 & 0 & 0 & 0 & 0 & 1 & 0 & 0 & 0 & 300826 & 69,05 & 7,34 & 0 & 0,87 & 4,6 & 25 & 0,3008 & 0 & 0,83428 & 0,02743 \\
\hline 258 & 16 & 0 & 0 & 0 & 0 & 0 & 1 & 0 & 0 & 1 & 308722 & 70,85 & 6,83 & 0 & 0,94 & 4,35 & 25 & 0,3087 & 0 & 0,83879 & 0,03688 \\
\hline 259 & 16 & 0 & 0 & 0 & 0 & 0 & 1 & 0 & 0 & 1 & 316116 & 72,39 & 6,44 & $-3,4$ & 0,89 & 4,44 & 27 & 0,3161 & 0 & 0,81367 & 0,02259 \\
\hline 260 & 16 & 0 & 0 & 0 & 0 & 0 & 1 & 0 & 0 & 0 & 325378 & 73,19 & 6,66 & $-4,15$ & 0,95 & 4,53 & 28 & 0,3254 & 0 & 0,79713 & 0,01505 \\
\hline 261 & 16 & 0 & 0 & 0 & 0 & 0 & 1 & 0 & 0 & 0 & 326628 & 74,94 & 6,21 & $-4,97$ & 0,89 & 4,34 & 30 & 0,3266 & 0 & 0,77832 & 0,01433 \\
\hline 262 & 16 & 0 & 0 & 0 & 0 & 0 & 1 & 0 & 0 & 1 & 321329 & 67,13 & 8,19 & $-4,71$ & 1,06 & 4,32 & 36 & 0,3213 & 0 & 0,74611 & 0,00492 \\
\hline 263 & 16 & 0 & 0 & 0 & 0 & 0 & 1 & 0 & 0 & 0 & 323263 & 68,41 & 8,38 & $-5,53$ & 1,05 & 4,36 & 38 & 0,3233 & 0 & 0,71351 & 0,00316 \\
\hline 264 & 16 & 0 & 0 & 0 & 0 & 0 & 1 & 0 & 0 & 0 & 326394 & 69,83 & 7,97 & $-6,56$ & 0,96 & 4,34 & 42 & 0,3264 & 0 & 0,67255 & 0,00165 \\
\hline 265 & 16 & 0 & 0 & 0 & 0 & 0 & 1 & 0 & 0 & 0 & 335366 & 68,31 & 8,05 & $-7,19$ & 0,93 & 4,39 & 53 & 0,3354 & 0 &, 58550 & 0,00021 \\
\hline 266 & 17 & 1 & 0 & 0 & 0 & 0 & 0 & 0 & 1 & 0 & 29769 & 79,59 & 9,95 & 0 & 0,42 & 2,83 & 0 & 0,0298 & 0 & 0,00737 & 0,98622 \\
\hline 267 & 17 & 1 & 0 & 0 & 0 & 0 & 0 & 0 & 1 & 0 & 31103 & 81,04 & 12,22 & 0 & 0,04 & 2,86 & 0 & 0,0311 & 0 & 0,00771 & 0,98432 \\
\hline 268 & 17 & 1 & 0 & 0 & 0 & 0 & 0 & 0 & 1 & 0 & 30761 & 77,02 & 11,84 & 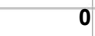 & 0,41 & 2,9 & 0 & 0,0308 & 0 & ,00885 & 0,98300 \\
\hline 269 & 17 & 1 & 0 & 0 & 0 & 0 & 0 & 0 & 1 & 0 & 29940 & 82,55 & 2,78 & 0 & 0,31 & 2,97 & 0 & 0,0299 & 0 & 0,00624 & 0,98976 \\
\hline 270 & 17 & 1 & 0 & 0 & 0 & 0 & 0 & 0 & 1 & 0 & 30327 & 90,25 & 7,78 & 0 & 0,42 & 2,95 & 0 & 0,0303 & 0 & 0,00810 & 0,98413 \\
\hline 271 & 17 & 1 & 0 & 0 & 0 & 0 & 0 & 0 & 1 & 0 & 31082 & 89,34 & 5,94 & $-4,45$ & 0,06 & 2,8 & 0 & 0,0311 & 0 &, 00532 & 0,98992 \\
\hline 272 & 17 & 1 & 0 & 0 & 0 & 0 & 0 & 0 & 1 & 0 & 32752 & 87,84 & 5,26 & $-6,21$ & 0,16 & 2,77 & 0 & 0,0328 & 0 & 0,00509 & 0,99063 \\
\hline 273 & 17 & 0 & 0 & 0 & 0 & 0 & 0 & 0 & 1 & 0 & 34210 & 96,47 & 5,47 & $-8,49$ & 0,52 & 2,85 & 0 & 0,0342 & 0 & 0,00152 & 0,99842 \\
\hline 274 & 17 & 0 & 0 & 0 & 0 & 0 & 0 & 0 & 1 & 0 & 37015 & 95,66 & 5,97 & $-0,16$ & 0,13 & 2,94 & 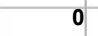 & 0,037 & 0 &, 00167 & 0,99826 \\
\hline 275 & 17 & 0 & 0 & 0 & 0 & 0 & 0 & 0 & 1 & 0 & 39278 & 85,28 & 6,5 & $-11,03$ & 0,32 & 2,91 & 0 & 0,0393 & 0 & 0,00163 & 0,99839 \\
\hline 276 & 17 & 0 & 0 & 0 & 0 & 0 & 0 & 0 & 1 & 0 & 41164 & 89,82 & 6,23 & 0 & $-0,04$ & 2,92 & 0 & 0,0412 & 0 & 0,00158 & 0,99840 \\
\hline 277 & 17 & 0 & 0 & 0 & 0 & 0 & 0 & 0 & 1 & 0 & 40715 & 115,94 & 5,69 & 0 & 0 & 2,77 & 0 & 0,0407 & 0 & 0,00135 & 0,99834 \\
\hline 278 & 17 & 0 & 0 & 0 & 0 & 0 & 0 & 0 & 1 & 0 & 43598 & 116,87 & 5,47 & 0 & 0 & 2,76 & 7 & 0,0436 & 0 & 0,00415 & 0,99439 \\
\hline 279 & 18 & 0 & 0 & 0 & 0 & 0 & 1 & 0 & 0 & 0 & 2023 & 77,3 & 5,95 & $-296,46$ & 0,33 & 4,41 & 0 & 0,002 & 0 & 0,00833 & 0,98409 \\
\hline 280 & 18 & 0 & 0 & 0 & 0 & 0 & 1 & 0 & 0 & 0 & 2101 & 79,82 & 5,79 & $-247,14$ & 0,32 & 4,41 & 0 & 0,0021 & 0 & 0,01046 & 0,98198 \\
\hline 281 & 18 & 0 & 0 & 0 & 0 & 0 & 1 & 0 & 0 & 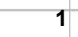 & 2166 & 89,35 & 5,49 & $-219,09$ & 0,32 & 4,47 & 1 & 0,0022 & 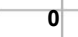 & 0,01530 & 0,97305 \\
\hline 282 & 18 & 0 & 0 & 0 & 0 & 0 & 1 & 0 & 0 & 2 & 2222 & 88,89 & 5,38 & $-230,03$ & 0,31 & 4,53 & 1 & 0,0022 & 0 & 0,01564 & 0,97178 \\
\hline 283 & 18 & 0 & 0 & 0 & 0 & 0 & 1 & 0 & 0 & 0 & 2288 & 90,1 & 5,27 & $-211,76$ & 0,34 & 4,54 & 2 & 0,0023 & 0 & 0,02032 & 0,96422 \\
\hline 284 & 18 & 0 & 0 & 0 & 0 & 0 & 1 & 0 & 0 & 0 & 2328 & 98,25 & 4,93 & $-219,78$ & 0,32 & 4,56 & 2 & 0,0023 & 0 & 0,02004 & 0,96166 \\
\hline 285 & 18 & 0 & 0 & 0 & 0 & 0 & 1 & 0 & 0 & 0 & 2355 & 96,17 & 4,77 & $-210,99$ & 0,33 & 4,54 & 2 & 0,0024 & 0 & 0,02015 & 0,96312 \\
\hline 286 & 18 & 0 & 0 & 0 & 0 & 0 & 1 & 0 & 0 & 1 & 2397 & 91,24 & 4,78 & $-247,64$ & 0,32 & 4,52 & 8 & 0,0024 & 0 & 0,04057 & 0,91563 \\
\hline 287 & 18 & 8 & 0 & 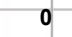 & 0 & 0 & 1 & 0 & 0 & 0 & 2451 & 89,76 & 4,93 & $-274,62$ & 0,36 & 4,31 & 8 & 0,0025 & 0 & 0,02771 & 0,93981 \\
\hline 288 & 18 & 0 & 0 & 0 & 0 & 0 & 1 & 0 & 0 & 0 & 2522 & 94,14 & 4,72 & $-317,12$ & 0,39 & 4,72 & 8 & 0,0025 & 0 & 03907 & 1049 \\
\hline 289 & 18 & 0 & 0 & 0 & 0 & 0 & 1 & 0 & 0 & 0 & 2584 & 100,62 & 4,64 & $-341,51$ & 0,42 & 4,39 & 8 & 0,0026 & 0 & 0,02322 & 0,93508 \\
\hline 290 & 18 & 0 & 0 & 0 & 0 & 0 & 1 & 0 & 0 & 0 & 2669 & 104,94 & 4,58 & $-364,88$ & 0,38 & 4,53 & 8 & 0,0027 & 0 & 0,02491 & 0,92285 \\
\hline 291 & 18 & 0 & 0 & 0 & 0 & 0 & 1 & 0 & 0 & 0 & 2763 & 111,89 & 4,78 & $-366,94$ & 0,37 & 4,53 & 8 & 0,0028 & 0 & ,02512 & 0,91661 \\
\hline 292 & 18 & 0 & 0 & 0 & 0 & 0 & 1 & 0 & 0 & 0 & 2829 & 115,37 & 5,1 & $-391,76$ & 0,42 & 4,52 & 8 & 0,0028 & 0 & 0,02290 & 0,91637 \\
\hline 293 & 18 & 0 & 0 & 0 & 0 & 0 & 1 & 0 & 0 & 0 & 2864 & 107,32 & 5,64 & $-399,91$ & 0,44 & 4,46 & 8 & 0,0029 & 0 & 0,02073 & 0,92725 \\
\hline 294 & 18 & 0 & 0 & 0 & 0 & 0 & 1 & 0 & 0 & 0 & 2912 & 117,77 & 5,32 & $-414,81$ & 0,39 & 4,39 & 8 & 0,0029 & 0 &, 01751 & 0,93099 \\
\hline 295 & 18 & 0 & 0 & 0 & 0 & 0 & 1 & 0 & 0 & 0 & 2951 & 123,08 & 5,23 & $-507,24$ & 0,46 & 4,37 & 8 & 0,003 & 0 & 0,01146 & 0,94107 \\
\hline 296 & 18 & 0 & 0 & 0 & 0 & 0 & 1 & 0 & 0 & 0 & 3040 & 124,18 & 5,12 & 0 & 0,47 & 4,38 & 11 & 0,003 & 0 & 0,16515 & 0,74436 \\
\hline 297 & 19 & 0 & 0 & 0 & 0 & 0 & 1 & 0 & 0 & 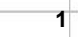 & 307781 & 80,75 & 4,38 & $-10,43$ & 0 & 3,32 & 13 & 0,3078 & 0 & 0,33146 & 0,66455 \\
\hline 298 & 19 & 0 & 0 & 0 & 0 & 0 & 1 & 0 & 0 & 0 & 314794 & 86,75 & 4,34 & $-11,02$ & 0 & 3,51 & 24 & 0,3148 & 0 & 0,67086 & 0,16392 \\
\hline 299 & 19 & 0 & 0 & 0 & 0 & 0 & 1 & 0 & 0 & 1 & 344635 & 99,98 & 3,93 & 0 & 0,15 & 3,67 & 29 & 0,3446 & 0 & 0,66823 & 0,04147 \\
\hline 100 & 19 & 0 & $v$ & 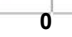 & 0 & 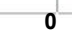 & & 0 & 0 & 0 & 364849 & 101,68 & 3,76 & $-11,82$ & 0,14 & 3,51 & 30 & 0,3648 & 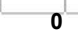 & 0,64318 & 0,03886 \\
\hline
\end{tabular}




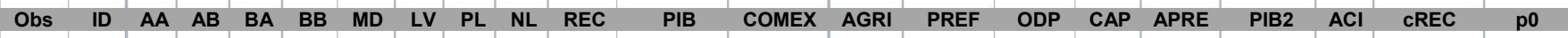

\begin{tabular}{|c|c|c|c|c|c|c|c|c|c|c|c|c|c|c|c|c|c|c|c|c|c|}
\hline 301 & 19 & 0 & 0 & 0 & 0 & 0 & 1 & 0 & 0 & 0 & 372225 & 113,38 & 3,29 & $-12,67$ & 0,14 & 3,65 & 36 & 0,3722 & 0 & 0,55476 & 0,00986 \\
\hline 302 & 19 & 0 & 0 & 0 & 0 & 0 & 1 & 0 & 0 & 0 & 386846 & 121,77 & 3,23 & $-12,65$ & 0,13 & 3,63 & 44 & 0,3868 & 0 & 0,46996 & 0,00208 \\
\hline 303 & 19 & 0 & 0 & 0 & 0 & 0 & 1 & 0 & 0 & 1 & 382192 & 127,07 & 3,49 & $-13,32$ & 0,11 & 3,64 & 52 & 0,3822 & 0 & 0,40037 & 0,00049 \\
\hline 304 & 19 & 0 & 0 & 0 & 0 & 0 & 1 & 0 & 0 & 0 & 363175 & 102,84 & 3,8 & $-13,09$ & 0,13 & 3,69 & 61 & 0,3632 & 0 & 0,43141 & 0,00014 \\
\hline 305 & 19 & 0 & 0 & 0 & 0 & 0 & 1 & 0 & 0 & 0 & 407637 & 125,23 & 3,51 & $-14,52$ & 0,1 & 3,7 & 63 & 0,4076 & 0 & 0,35019 & 0,00006 \\
\hline 306 & 19 & 0 & 0 & 0 & 0 & 0 & 1 & 0 & 0 & 0 & 428955 & 129,83 & 3,69 & $-15,92$ & 0,09 & 3,66 & 65 & 0,429 & 0 & 0,32712 & 0,00003 \\
\hline 307 & 19 & 0 & 0 & 0 & 0 & 0 & 1 & 0 & 0 & 0 & 430449 & 126,45 & 3,76 & $-15,63$ & 0,06 & 3,64 & 74 & 0,4304 & 0 & 0,29830 & 0,00001 \\
\hline 308 & 20 & 1 & 0 & 0 & 0 & 0 & 1 & 0 & 0 & 0 & 7481 & 92,12 & 11,92 & 0 & 0,51 & 2,47 & 0 & 0,0075 & 0 & 0,01442 & 0,97080 \\
\hline 309 & 20 & 1 & 0 & 0 & 0 & 0 & 1 & 0 & 0 & 0 & 8008 & 86,89 & 11,06 & $-9,9$ & 0,31 & 2,47 & 0 & 0,008 & 0 & 0,01237 & \begin{tabular}{|l|l|}
0,97574 \\
\end{tabular} \\
\hline 310 & 20 & 1 & 0 & 0 & 0 & 0 & 1 & 0 & 0 & 0 & 8624 & 108,5 & 10,63 & 0 & 0,62 & 2,65 & 0 & 0,0086 & 0 & 0,01873 & 0,95744 \\
\hline 311 & 20 & 1 & 0 & 0 & 0 & 0 & 1 & 0 & 0 & 0 & 9324 & 102,33 & 11,79 & 0 & 0,24 & 2,84 & 0 & 0,0093 & 0 & 0,02259 & 0,94860 \\
\hline 312 & 20 & 1 & 0 & 0 & 0 & 0 & 1 & 0 & 0 & 0 & 10072 & 94,68 & 10,31 & $-8,81$ & 0,41 & 2,9 & 0 & 0,0101 & 1 & 0,02291 & \begin{tabular}{|l|}
0,95197 \\
\end{tabular} \\
\hline 313 & 20 & 1 & 0 & 0 & 0 & 0 & 1 & 0 & 0 & 0 & 10833 & 104,91 & 7,29 & 0 & $-0,02$ & 2,97 & 0 & 0,0108 & 1 & 0,02075 & 0,95577 \\
\hline 314 & 20 & 1 & 0 & 0 & 0 & 0 & 0 & 1 & 0 & 0 & 11285 & 100,45 & 7,15 & $-11,81$ & $-0,02$ & 2,91 & 0 & 0,0113 & 0 & 0,03785 & 0,87399 \\
\hline 315 & 20 & 1 & 0 & 0 & 0 & 0 & 0 & 1 & 0 & 0 & 12181 & 95,6 & 8,01 & 0 & $-0,1$ & 2,85 & 2 & 0,0122 & 0 & 0,04933 & 0,83963 \\
\hline 316 & 20 & 1 & 0 & 0 & 0 & 0 & 0 & 1 & 0 & 0 & 13940 & 90 & 6,71 & 0 & $-0,03$ & 2,98 & 3 & 0,0139 & 0 & 0,06394 & 0,80435 \\
\hline 317 & 20 & 1 & 0 & 0 & 0 & 0 & 0 & 1 & 0 & 0 & 15048 & 94,27 & 5,95 & 0 & $-0,01$ & 2,87 & 3 & 0,015 & 0 & 0,05573 & 0,82753 \\
\hline 318 & 20 & 1 & 0 & 0 & 0 & 0 & 1 & 0 & 0 & 0 & 15982 & 105,33 & 5,56 & 0 & $-0,01$ & 2,69 & 3 & 0,016 & 0 & 0,02178 & 0,95421 \\
\hline 319 & 20 & 0 & 0 & 0 & 0 & 0 & 1 & 0 & 0 & 0 & 18093 & 119,28 & 4,24 & $-15,2$ & 0,08 & 2,64 & 3 & 0,0181 & 0 & 0,00460 & 0,99427 \\
\hline 320 & 20 & 0 & 0 & 0 & 0 & 0 & 1 & 0 & 0 & 0 & 18953 & 102,59 & 4,79 & $-20,39$ & 0,1 & 2,71 & 3 & 0,019 & 0 & 0,00493 & 0,99451 \\
\hline 321 & 20 & 0 & 0 & 0 & 0 & 0 & 1 & 0 & 0 & 0 & 19596 & 105,8 & 4,26 & $-22,09$ & 0,03 & 2,67 & 3 & 0,0196 & 0 & 0,00447 & 0,99493 \\
\hline 322 & 20 & 0 & 0 & 0 & 0 & 0 & 1 & 0 & 0 & 0 & 18736 & 90,48 & 6,39 & 0 & 0,04 & 2,8 & 3 & 0,0187 & 0 & 0,00632 & 0,99369 \\
\hline 323 & 20 & 0 & 0 & 0 & 0 & 0 & 1 & 0 & 0 & 0 & 18718 & 90,33 & 5,92 & 0 & 0,02 & 2,77 & 3 & 0,0187 & 0 & 0,00589 & 0,99420 \\
\hline 324 & 22 & 0 & 0 & 0 & 0 & 0 & 0 & 0 & 1 & 0 & 20271 & 85,73 & 4,83 & 0 & $-0,05$ & 2,94 & 0 & 0,0203 & 0 & 0,00128 & 0,99879 \\
\hline 325 & 22 & 0 & 0 & 0 & 0 & 0 & 0 & 0 & 1 & 0 & 30084 & 89,61 & 2,23 & 0 & $-0,01$ & 2,94 & 0 & 0,0301 & 0 & 0,00125 & 0,99885 \\
\hline 326 & 22 & 0 & 0 & 0 & 0 & 0 & 0 & 0 & 1 & 0 & 31257 & 94,97 & 2,31 & 0 & $-0,02$ & 2,96 & 0 & 0,0313 & 0 & 0,00132 & 0,99873 \\
\hline 327 & 22 & 0 & 0 & 0 & 0 & 0 & 0 & 0 & 1 & 0 & 33502 & 88,47 & 2,34 & 0 & $-0,02$ & 2,99 & 0 & 0,0335 & 0 & 0,00137 & $\mid 0,99874$ \\
\hline 328 & 22 & 0 & 0 & 0 & 0 & 0 & 0 & 0 & 1 & 0 & 34748 & 90,16 & 2,8 & 0 & $-0,02$ & 2,97 & 0 & 0,0347 & 0 & 0,00138 & $\mid 0,99871$ \\
\hline 329 & 22 & 0 & 0 & 0 & 0 & 0 & 0 & 0 & 1 & 0 & 41427 & 90,37 & 2,03 & 0 & $-0,01$ & 2,99 & 0 & 0,0414 & 0 & 0,00145 & 0,99867 \\
\hline 330 & 22 & 0 & 0 & 0 & 0 & 0 & 0 & 0 & 1 & 0 & 44530 & 94,75 & 2,32 & $-4,35$ & 0 & 2,92 & 0 & 0,0445 & 0 & 0,00135 & 0,99869 \\
\hline 331 & 22 & 0 & 0 & 0 & 0 & 0 & 0 & 0 & 1 & 0 & 56184 & 98,57 & 2,21 & $-5,47$ & 0 & 3,05 & 0 & 0,0562 & 0 & 0,00178 & 0,99822 \\
\hline 332 & 22 & 0 & 0 & 0 & 0 & 0 & 0 & 0 & 1 & 0 & 66289 & 96,11 & 2,15 & $-0,38$ & 0 & 2,94 & 0 & 0,0663 & 0 & 0,00167 & 0,99839 \\
\hline 333 & 22 & 0 & 0 & 0 & 0 & 0 & 0 & 0 & 1 & 0 & 77998 & 89,43 & 2,49 & $-4,84$ & 0 & 3,11 & 0 & 0,078 & 0 & 0,00226 & 0,99788 \\
\hline 334 & 22 & 0 & 0 & 0 & 0 & 0 & 0 & 0 & 1 & 0 & 87324 & 80,14 & 2,71 & $-5,04$ & 0 & 3,5 & 0 & 0,0873 & 0 & 0,00414 & 0,99633 \\
\hline 335 & 22 & 0 & 0 & 0 & 0 & 0 & 0 & 0 & 1 & 0 & 104433 & 86,07 & 2,54 & 0 & 0 & 3,39 & 0 & 0,1044 & 0 & 0,00417 & 0,99621 \\
\hline 336 & 22 & 0 & 0 & 0 & 0 & 0 & 0 & 0 & 1 & 0 & 118401 & 97,54 & 2,47 & 0 & 0 & 3,28 & 0 & 0,1184 & 0 & 0,00408 & 0,99596 \\
\hline 337 & 22 & 0 & 0 & 0 & 0 & 0 & 0 & 0 & 1 & 0 & 124179 & 103,83 & 2,63 & $-2,18$ & 0 & 3,28 & 0 & 0,1242 & 0 & 0,00431 & 0,99545 \\
\hline 338 & 24 & 0 & 1 & 0 & 0 & 0 & 1 & 0 & 0 & 0 & 186132 & 43,61 & 10,49 & 5,41 & $-0,25$ & 3,38 & 0 & 0,1861 & 0 & 0,20216 & 0,88573 \\
\hline 339 & 24 & 0 & 1 & 0 & 0 & 0 & 1 & 0 & 0 & 0 & 194136 & 46,67 & 11,69 & 6,65 & $-0,25$ & 3,38 & 0 & 0,1941 & 0 & 0,22552 & 0,86603 \\
\hline 340 & 24 & 0 & 1 & 0 & 0 & 0 & 1 & 0 & 0 & 0 & 199184 & 46,85 & 11,08 & 5,25 & $-0,33$ & 3,24 & 0 & 0,1992 & 0 & 0,18652 & 0,89081 \\
\hline 341 & 24 & 0 & 1 & 0 & 0 & 0 & 1 & 0 & 0 & 0 & 200179 & 48,9 & 11,41 & 5,72 & $-0,38$ & 3,1 & 0 & 0,2002 & 0 & 0,15815 & 0,90575 \\
\hline 342 & 24 & 0 & 1 & 0 & 0 & 0 & 1 & 0 & 0 & 0 & 204984 & 46,86 & 10,32 & 6,9 & $-0,41$ & 3,15 & 0 & 0,205 & 1 & 0,16557 & 0,90542 \\
\hline 343 & 24 & 0 & 1 & 0 & 0 & 0 & 1 & 0 & 0 & 0 & 213593 & 51,44 & 9,16 & 6,49 & $-0,37$ & 3,19 & 0 & 0,2136 & 0 & 0,17908 & 0,89646 \\
\hline 344 & 24 & 0 & 0 & 1 & 0 & 0 & 1 & 0 & 0 & 0 & 219360 & 54,8 & 8,88 & 5,83 & $-0,36$ & 3,16 & 0 & 0,2194 & 0 & 0,30956 & 0,62233 \\
\hline 345 & 24 & 0 & 0 & 1 & 0 & 0 & 1 & 0 & 0 & 0 & 227477 & 59,76 & 10,26 & 6,71 & $-0,45$ & 3,14 & 0 & 0,2275 & 0 & 0,31715 & 0,58348 \\
\hline 346 & 24 & 0 & 0 & 1 & 0 & 0 & 1 & 0 & 0 & 0 & 234186 & 51,4 & 9,65 & 6,62 & $-0,38$ & 3,18 & 0 & 0,2342 & 1 & 0,34413 & 0,58571 \\
\hline 347 & 24 & 0 & 1 & 0 & 0 & 0 & 1 & 0 & 0 & 0 & 244852 & 51,08 & 8,6 & 6,49 & $-0,28$ & 3,16 & 0 & 0,2449 & 0 & 0,21374 & 0,87969 \\
\hline 348 & 24 & 0 & 1 & 0 & 0 & 0 & 1 & 0 & 0 & 0 & 257773 & 53,15 & 8,01 & 5,78 & $-0,27$ & 3,14 & 0 & 0,2578 & 0 & 0,22265 & 0,87443 \\
\hline 349 & 24 & 0 & 1 & 0 & 0 & 0 & 1 & 0 & 0 & 0 & 272169 & 60,28 & 7,06 & 5,56 & $-0,27$ & 3 & 0 & 0,2722 & 0 & 0,20041 & 0,88369 \\
\hline 350 & 24 & 0 & 1 & 0 & 0 & 0 & 1 & 0 & 0 & 0 & 286759 & 63,68 & 7,18 & 11,81 & $-0,28$ & 2,99 & 2 & 0,2868 & 0 & 0,29527 & 0,82154 \\
\hline 351 & 24 & 0 & 1 & 0 & 0 & 0 & 1 & 0 & 0 & 0 & 295910 & 72,87 & 7,58 & 9,93 & $-0,4$ & 3,02 & 2 & 0,2959 & 1 & 0,31621 & 0,78930 \\
\hline 352 & 24 & 0 & 1 & 0 & 0 & 0 & 1 & 0 & 0 & 0 & 291358 & 55,42 & 9,75 & 12,39 & $-0,37$ & 2,98 & 2 & 0,2914 & 0 & 0,32028 & 0,80819 \\
\hline 353 & 24 & 0 & 1 & 0 & 0 & 0 & 1 & 0 & 0 & 0 & 300215 & 55,99 & 9,7 & 9,1 & $-0,28$ & 2,89 & 2 & 0,3002 & 0 & 0,30774 & 0,81544 \\
\hline 354 & 24 & 0 & 1 & 0 & 0 & 0 & 1 & 0 & 0 & 0 & 309859 & 60,02 & 9,53 & 5,51 & $-0,34$ & 2,91 & 2 & 0,3099 & 0 & 0,32275 & 0,79829 \\
\hline 355 & 24 & 0 & 1 & 0 & 0 & 0 & 1 & 0 & 0 & 0 & 316737 & 60,74 & 9,72 & 5,47 & $-0,28$ & 2,83 & 4 & 0,3167 & 1 & 0,40107 & 0,74193 \\
\hline 356 & 25 & 1 & 0 & 0 & 0 & 0 & 0 & 1 & 0 & 0 & 806 & 153,74 & 20,75 & 2,25 & $-1,71$ & 3,13 & 0 & 0,0008 & 0 & 0,04833 & 0,63355 \\
\hline 357 & 25 & 1 & 0 & 0 & 0 & 0 & 0 & 1 & 0 & 0 & 846 & 123,15 & 26,23 & 3,57 & $-1,32$ & 3,11 & 0 & 0,0008 & 0 & 0,06094 & 0,60359 \\
\hline 358 & 25 & 0 & 0 & 0 & 0 & 0 & 1 & 0 & 0 & 0 & 997 & 123,12 & 19,07 & 0,9 & $-0,82$ & 2,91 & 0 & 0,001 & 0 & 0,00608 & 0,98918 \\
\hline 359 & 25 & 0 & 0 & 0 & 0 & 0 & 1 & 0 & 0 & 0 & 1131 & 120,39 & 21,78 & 0,27 & $-0,3$ & 2,97 & 0 & 0,0011 & 0 & 0,00870 & 0,98416 \\
\hline 360 & & & & & & & & & & & & 17, & 9,23 & & 0,6 & 2,96 & & 0,0012 & & 0,01226 & 0,9752 \\
\hline
\end{tabular}


Obs ID AA AB $\quad$ BA $\quad$ BB $\quad$ MD LV PL NL REC PIB COMEX AGRI PREF ODP CAP APRE PIB2 ACI CREC P0

\begin{tabular}{|c|c|c|c|c|c|c|c|c|c|c|c|c|c|c|c|c|c|c|c|c|c|}
\hline 361 & 25 & 0 & 0 & 0 & 0 & 0 & 1 & 0 & 0 & 0 & 1090 & 105,11 & 32,94 & 4,64 & $-0,49$ & 2,99 & 0 & 0,0011 & 0 & 0,01394 & 0,97113 \\
\hline 362 & 25 & 0 & 0 & 0 & 0 & 0 & 1 & 0 & 0 & 0 & 1012 & 105,92 & 35,85 & 28,82 & $-1,73$ & 2,99 & 0 & 0,001 & 0 & 0,01234 & 0,97264 \\
\hline 363 & 25 & 1 & 0 & 0 & 0 & 0 & 1 & 0 & 0 & 0 & 994 & 104,35 & 41,53 & 44,3 & $-1,41$ & 2,98 & 0 & 0,001 & 0 & 0,06112 & 0,72467 \\
\hline 364 & 25 & 0 & 0 & 0 & 0 & 0 & 1 & 0 & 0 & 0 & 1034 & 103,69 & 46,93 & 34,52 & $-0,2$ & 2,98 & 0 & 0,001 & 0 & 0,03171 & 0,91744 \\
\hline 365 & 26 & 1 & 0 & 0 & 0 & 0 & 1 & 0 & 0 & 0 & 176167 & 19,77 & 30,32 & 6,49 & $-0,06$ & 2,77 & 0 & 0,1762 & 0 & 0,11453 & 0,80776 \\
\hline 366 & 26 & 1 & 0 & 0 & 0 & 0 & 1 & 0 & 0 & 1 & 185903 & 21,51 & 30,55 & 7 & $-0,05$ & 2,77 & 0 & 0,1859 & 1 & 0,12311 & 0,78982 \\
\hline 367 & 26 & 1 & 0 & 0 & 0 & 0 & 1 & 0 & 0 & 1 & 200982 & 23,34 & 27,04 & 5,26 & $-0,04$ & 2,83 & 2 & 0,201 & 1 & 0,16256 & 0,73202 \\
\hline 368 & 26 & 1 & 0 & 0 & 0 & 0 & 1 & 0 & 0 & 0 & 208720 & 23,35 & 27,1 & 5,64 & $-0,03$ & 2,88 & 2 & 0,2087 & 4 & 0,17925 & 0,70400 \\
\hline 369 & 26 & 1 & 0 & 0 & 0 & 0 & 1 & 0 & 0 & 0 & 201654 & 21,38 & 27,13 & 7,78 & $-0,03$ & 2,72 & 3 & 0,2017 & 3 & 0,16629 & 0,72974 \\
\hline 370 & 26 & 1 & 0 & 0 & 0 & 0 & 1 & 0 & 0 & 1 & 200063 & 22,62 & 25,44 & 7,05 & $-0,02$ & 2,56 & 5 & 0,2001 & 3 & 0,16759 & 0,73028 \\
\hline 371 & 26 & 1 & 0 & 0 & 0 & 0 & 0 & 1 & 0 & 1 & 191242 & 21,85 & 27,78 & 6,93 & $-0,06$ & 2,4 & 6 & 0,1912 & 3 & 0,21566 & 0,41785 \\
\hline 372 & 26 & 0 & 1 & 0 & 0 & 0 & 0 & 1 & 0 & 4 & 170407 & 41,75 & 34,5 & 4,41 & $-0,09$ & 2,24 & 7 & 0,1704 & 0 & 0,37971 & 0,39682 \\
\hline 373 & 26 & 0 & 1 & 0 & 0 & 0 & 1 & 0 & 0 & 1 & 185466 & 40,64 & 34,78 & 3,86 & $-0,09$ & 2,49 & 12 & 0,1855 & 0 & 0,56889 & 0,38464 \\
\hline 374 & 26 & 0 & 1 & 0 & 0 & 0 & 1 & 0 & 0 & 0 & 202213 & 36,97 & 30,97 & 4,34 & $-0,05$ & 2,48 & 14 & 0,2022 & 0 & 0,66626 & 0,34776 \\
\hline 375 & 26 & 0 & 1 & 0 & 0 & 0 & 1 & 0 & 0 & 0 & 220814 & 36,8 & 29,13 & 4,64 & $-0,05$ & 2,41 & 16 & 0,2208 & 1 & 0,74111 & 0,29277 \\
\hline 376 & 26 & 0 & 1 & 0 & 0 & 0 & 1 & 0 & 0 & 5 & 239368 & 35,89 & 28,06 & 4,13 & $-0,04$ & 2,46 & 19 & 0,2394 & 0 & 0,85499 & 0,17759 \\
\hline 377 & 26 & 1 & 0 & 0 & 0 & 0 & 1 & 0 & 0 & 0 & 258436 & 35,86 & 30,95 & 9,82 & $-0,03$ & 2,47 & 25 & 0,2584 & 0 & 0,36851 & 0,03425 \\
\hline 378 & 26 & 1 & 0 & 0 & 0 & 0 & 1 & 0 & 0 & 0 & 266382 & 36,27 & 31,98 & 9,5 & $-0,03$ & 2,37 & 30 & 0,2664 & 0 & 0,34424 & 0,01474 \\
\hline 379 & 26 & 1 & 0 & 0 & 0 & 0 & 1 & 0 & 0 & 1 & 266516 & 30,18 & 31,61 & 10,98 & $-0,03$ & 2,17 & 36 & 0,2665 & 0 & 0,34515 & 0,00764 \\
\hline 380 & 26 & 1 & 0 & 0 & 0 & 0 & 1 & 0 & 0 & 0 & 291705 & 32,21 & 29,93 & 8,98 & $-0,03$ & 2,31 & 37 & 0,2917 & 1 & 0,34608 & 0,00481 \\
\hline 381 & 26 & 1 & 0 & 0 & 0 & 0 & 1 & 0 & 0 & 0 & 316169 & 33,57 & 30,59 & 8,13 & $-0,02$ & 2,36 & 38 & 0,3162 & 0 & 0,33284 & 0,00294 \\
\hline 382 & 26 & 0 & 0 & 0 & 0 & 0 & 1 & 0 & 0 & 3 & 318704 & 29,2 & 30,72 & 9,18 & $-0,03$ & 2,25 & 45 & 0,3187 & 5 & 0,59756 & 0,00855 \\
\hline 383 & 27 & 0 & 1 & 0 & 0 & 0 & 0 & 1 & 0 & 1 & 695120 & 16,63 & 22,53 & 18,96 & $-0,04$ & 2,35 & 0 & 0,6951 & 1 & 1,14439 & 0,10125 \\
\hline 384 & 27 & 0 & 1 & 0 & 0 & 0 & 0 & 1 & 0 & 0 & 710465 & 15,64 & 22,46 & 21,68 & $-0,03$ & 2,35 & 1 & 0,7105 & 4 & 1,18106 & 0,07830 \\
\hline 385 & 27 & 0 & 1 & 0 & 0 & 0 & 0 & 1 & 0 & 4 & 734586 & 16,58 & 21,41 & 17,89 & $-0,03$ & 2,37 & 4 & 0,7346 & 2 & 1,19114 & 0,04208 \\
\hline 386 & 27 & 0 & 1 & 0 & 0 & 0 & 0 & 1 & 0 & 1 & 737071 & 16,44 & 21,08 & 18,27 & $-0,03$ & 2,39 & 8 & 0,7371 & 1 & 1,16472 & 0,02089 \\
\hline 387 & 27 & 0 & 1 & 0 & 0 & 0 & 0 & 1 & 0 & 0 & 740528 & 20,98 & 20,64 & 17,22 & $-0,02$ & 2,47 & 11 & 0,7405 & 1 & 1,09231 & 0,01064 \\
\hline 388 & 27 & 0 & 1 & 0 & 0 & 0 & 0 & 1 & 0 & 7 & 770983 & 22,64 & 17,36 & 16,03 & $-0,04$ & 2,55 & 14 & 0,771 & 2 & 1,11905 & 0,00561 \\
\hline 389 & 27 & 0 & 1 & 0 & 0 & 0 & 0 & 1 & 0 & 4 & 783765 & 26,94 & 18,38 & 12,77 & $-0,04$ & 2,54 & 15 & 0,7838 & 1 & 1,03566 & 0,00389 \\
\hline 390 & 27 & 0 & 1 & 0 & 0 & 0 & 1 & 0 & 0 & 5 & 807694 & 27,62 & 20,38 & 13,81 & $-0,04$ & 2,53 & 26 & 0,8077 & 0 & 1,35841 & 0,00154 \\
\hline 391 & 27 & 0 & 0 & 1 & 0 & 0 & 1 & 0 & 0 & 0 & 816904 & 28,14 & 21,91 & 12,12 & $-0,04$ & 2,68 & 33 & 0,8169 & 0 & 0,56937 & 0,00006 \\
\hline 392 & 27 & 0 & 1 & 0 & 0 & 0 & 1 & 0 & 0 & 0 & 863965 & 29,68 & 20,74 & 11,18 & $-0,02$ & 2,57 & 38 & 0,864 & 0 & 1,13069 & 0,00011 \\
\hline 393 & 27 & 0 & 1 & 0 & 0 & 0 & 1 & 0 & 0 & 0 & 891630 & 27,09 & 19,24 & 11,76 & $-0,03$ & 2,4 & 39 & 0,8916 & 1 & 1,19938 & 0,00011 \\
\hline 394 & 27 & 0 & 1 & 0 & 0 & 0 & 1 & 0 & 0 & 0 & 926943 & 26,04 & 18,56 & 12,35 & $-0,01$ & 2,27 & 48 & 0,9269 & 1 & 1,10742 & 0,00002 \\
\hline 395 & 27 & 0 & 1 & 0 & 0 & 0 & 1 & 0 & 0 & 1 & 983230 & 25,29 & 18,73 & 22,32 & $-0,02$ & 2,3 & 49 & 0,9832 & 0 & 1,13052 & 0,00001 \\
\hline 396 & 27 & 1 & 0 & 0 & 0 & 0 & 1 & 0 & 0 & 1 & 1033313 & 27,26 & 18,26 & 19,56 & $-0,03$ & 2,41 & 56 & 1,0333 & 0 & 0,42583 & 0,00000 \\
\hline 397 & 27 & 1 & 0 & 0 & 0 & 0 & 1 & 0 & 0 & 0 & 1032010 & 22,11 & 21,91 & 22,27 & $-0,02$ & 2,4 & 62 & 1,032 & 0 & 0,37989 & 0,00000 \\
\hline 398 & 27 & 1 & 0 & 0 & 0 & 0 & 1 & 0 & 0 & 1 & 1109707 & 22,52 & 19,82 & 20,2 & $-0,02$ & 2,46 & 65 & 1,1097 & 0 & 0,38351 & 0,00000 \\
\hline 399 & 27 & 1 & 0 & 0 & 0 & 0 & 1 & 0 & 0 & 0 & 1153100 & 23,72 & 19,56 & 17,07 & $-0,03$ & 2,38 & 67 & 1,1531 & 0 & 0,37317 & 0,00000 \\
\hline 400 & 27 & 1 & 0 & 0 & 0 & 0 & 1 & 0 & 0 & 1 & 1175187 & 24,81 & 20,09 & 17,37 & $-0,05$ & 2,38 & 77 & 1,1752 & 0 & 0,32064 & 0,00000 \\
\hline 401 & 28 & 0 & 1 & 0 & 0 & 0 & 1 & 0 & 0 & 1 & 82598 & 56,41 & 23,06 & 6,57 & $-0,23$ & 3,78 & 1 & 0,0826 & 0 & 0,29945 & 0,73397 \\
\hline 402 & 28 & 0 & 1 & 0 & 0 & 0 & 1 & 0 & 0 & 0 & 88721 & 56,24 & 22,31 & 7,96 & $-0,27$ & 3,78 & 1 & 0,0887 & 0 & 0,30220 & 0,73729 \\
\hline 403 & 28 & 0 & 1 & 0 & 0 & 0 & 1 & 0 & 0 & 1 & 94582 & 56,29 & 20,59 & 6,35 & $-0,16$ & 3,72 & 1 & 0,0946 & 3 & 0,28444 & 0,76358 \\
\hline 404 & 28 & 0 & 1 & 0 & 0 & 0 & 1 & 0 & 0 & 0 & 97637 & 55,87 & 22,11 & 6,68 & $-0,14$ & 3,67 & 1 & 0,0976 & 0 & 0,28942 & 0,75287 \\
\hline 405 & 28 & 0 & 1 & 0 & 0 & 0 & 1 & 0 & 0 & 0 & 96894 & 56,92 & 24,24 & 7,85 & $-0,1$ & 3,64 & 2 & 0,0969 & 0 & 0,33702 & 0,69263 \\
\hline 406 & 28 & 0 & 1 & 0 & 0 & 0 & 1 & 0 & 0 & 1 & 101251 & 57,87 & 21,91 & 6,78 & $-0,06$ & 3,62 & 5 & 0,1013 & 2 & 0,43466 & 0,60643 \\
\hline 407 & 28 & 0 & 1 & 0 & 0 & 0 & 1 & 0 & 0 & 3 & 104641 & 61,41 & 22,7 & 6,12 & $-0,11$ & 3,63 & 8 & 0,1046 & 4 & 0,55643 & 0,44738 \\
\hline 408 & 28 & 0 & 1 & 0 & 0 & 0 & 1 & 0 & 0 & 2 & 106908 & 61,94 & 23,55 & 7,21 & 0,01 & 3,64 & 12 & 0,1069 & 1 & 0,69378 & 0,26085 \\
\hline 409 & 28 & 0 & 1 & 0 & 0 & 0 & 1 & 0 & 0 & 1 & 111138 & 65,12 & 23,23 & 5,67 & $-0,12$ & 3,74 & 17 & 0,1111 & 0 & 0,75335 & 0,11234 \\
\hline 410 & 28 & 0 & 1 & 0 & 0 & 0 & 1 & 0 & 0 & 0 & 117852 & 68,26 & 19,81 & 5,73 & $-0,06$ & 3,7 & 17 & 0,1179 & 0 & 0,77994 & 0,13394 \\
\hline 411 & 28 & 0 & 1 & 0 & 0 & 0 & 1 & 0 & 0 & 1 & 124404 & 69,97 & 16,99 & 4,95 & $-0,15$ & 3,72 & 18 & 0,1244 & 0 & 0,81026 & 0,12876 \\
\hline 412 & 28 & 1 & 0 & 0 & 0 & 0 & 1 & 0 & 0 & 0 & 129884 & 71,94 & 14,87 & 5,59 & $-0,07$ & 3,6 & 21 & 0,1299 & 2 & 0,36342 & 0,07066 \\
\hline 413 & 28 & 1 & 0 & 0 & 0 & 0 & 1 & 0 & 0 & 0 & 136587 & 75,79 & 15,14 & 7,99 & $-0,07$ & 3,76 & 27 & 0,1366 & 0 & 0,33998 & 0,01842 \\
\hline 414 & 28 & 1 & 0 & 0 & 0 & 0 & 1 & 0 & 0 & 0 & 141084 & 81,04 & 16,48 & 6,79 & $-0,06$ & 3,67 & 27 & 0,1411 & 0 & 0,31646 & 0,01746 \\
\hline 415 & 28 & 1 & 0 & 0 & 0 & 0 & 1 & 0 & 0 & 0 & 139622 & 66,77 & 17,81 & 7,49 & $-0,05$ & 3,73 & 31 & 0,1396 & 1 & 0,33084 & 0,00861 \\
\hline 416 & 28 & 1 & 0 & 0 & 0 & 0 & 1 & 0 & 0 & 0 & 147655 & 69,73 & 15,46 & 7,02 & $-0,1$ & 3,76 & 31 & 0,1477 & 0 & 0,33944 & 0,00899 \\
\hline 417 & 28 & 1 & 0 & 0 & 0 & 0 & 1 & 0 & 0 & 0 & 156278 & 72,95 & 15,82 & 6,3 & $-0,07$ & 3,76 & 33 & 0,1563 & 0 & 0,32025 & 0,00558 \\
\hline 418 & 28 & 0 & 0 & 0 & 0 & 0 & 1 & 0 & 0 & 0 & 164806 & 68,81 & 15,98 & 6,31 & $-0,05$ & 3,75 & 36 & 0,1648 & 0 & 0,59211 & 0,02624 \\
\hline 419 & 29 & 0 & 0 & 1 & 0 & 0 & 0 & 1 & 0 & 0 & 115545 & 35,5 & 22,13 & 12,92 & $-0,19$ & 2,31 & 0 & 0,1155 & 0 & 0,18704 & 0,60429 \\
\hline 420 & 29 & 0 & 0 & & 0 & 0 & 0 & & 0 & 0 & 117921 & 36,04 & 22,28 & 14,07 & $-0,2$ & 2,31 & 2 & 0,1179 & 0 & 0,22434 & 0,50993 \\
\hline
\end{tabular}




\begin{tabular}{|c|c|c|c|c|c|c|c|c|c|c|c|c|c|c|c|c|c|c|c|c|c|}
\hline bs & ID & $A A$ & $A B$ & BA & BB & MD & LV & PL & NL & REC & PIB & COMEX & AGRI & PREF & ODP & CAP & APRE & PIB2 & $\mathrm{ACl}$ & CREC & po \\
\hline 421 & 29 & 0 & 0 & 1 & 0 & 0 & 0 & 1 & 0 & 1 & 121966 & 35,6 & 23,26 & 13,69 & $-0,19$ & 2,32 & 3 & 0,122 & 0 & 0,24864 & 0,43867 \\
\hline 422 & 29 & 0 & 0 & 1 & 0 & 0 & 0 & 1 & 0 & 0 & 122661 & 35,91 & 23,49 & 13,99 & $-0,17$ & 2,33 & 4 & 0,1227 & 0 & ,26679 & 0,38539 \\
\hline 423 & 29 & 0 & 0 & 1 & 0 & 0 & 0 & 1 & 0 & 0 & 117504 & 36,15 & 22,24 & 16,75 & $-0,36$ & 2,27 & 5 & 0,1175 & 1 & ,26222 & ,40496 \\
\hline 424 & 29 & 0 & 0 & 1 & 0 & 0 & 0 & 1 & 0 & 1 & 122698 & 32,67 & 19,13 & 17,6 & $-0,19$ & 2,22 & 6 & 0,1227 & 0 & 0,28174 & 0,42267 \\
\hline 425 & 29 & 0 & 0 & 1 & 0 & 0 & 0 & 1 & 0 & 2 & 124756 & 33,9 & 18,27 & 15,61 & $-0,4$ & 2,15 & 8 & 0,1248 & 0 & 0,29208 & 0,38538 \\
\hline 426 & 29 & 0 & 0 & 1 & 0 & 0 & 0 & 1 & 0 & 0 & 127880 & 32,98 & 19,07 & 16,4 & $-0,46$ & 2,09 & 11 & 0,1279 & 0 & 0,32751 & 0,27721 \\
\hline 427 & 29 & 0 & 0 & 1 & 0 & 0 & 0 & 1 & 0 & 0 & 132891 & 36,52 & 18,46 & 14,78 & $-0,88$ & 2,36 & 16 & 0,1329 & 0 & 0,36012 & 0,10470 \\
\hline 428 & 29 & 0 & 0 & 1 & 0 & 0 & 0 & 1 & 0 & 0 & 139978 & 35,86 & 17,02 & 13,83 & $-0,46$ & 2,36 & 16 & 0,14 & 0 & 0,38286 & 0,09999 \\
\hline 429 & 29 & 0 & 0 & 1 & 0 & 0 & 0 & 1 & 0 & 0 & 146566 & 35,63 & 16,12 & 14 & $-0,44$ & 2,34 & 16 & 0,1466 & 0 & 0,39150 & 0,10375 \\
\hline 430 & 29 & 0 & 0 & 1 & 0 & 0 & 0 & 1 & 0 & 0 & 156383 & 38,17 & 15,32 & 12,67 & $-0,64$ & 2,38 & 16 & 0,1564 & 1 & 0,38738 & 0,09943 \\
\hline 431 & 29 & 0 & 1 & 0 & 0 & 0 & 0 & 1 & 0 & 1 & 167174 & 36,33 & 14,87 & 16,26 & $-0,36$ & 2,45 & 19 & 0,1672 & 1 & 0,70170 & 0,21445 \\
\hline 432 & 29 & 0 & 1 & 0 & 0 & 0 & 0 & 1 & 0 & 0 & 173103 & 38,05 & 14,64 & 15,85 & $-0,41$ & 2,47 & 21 & 0,1731 & 0 & 0,72723 & 0,15325 \\
\hline 433 & 29 & 0 & 1 & 0 & 0 & 0 & 0 & 1 & 0 & 0 & 175962 & 34,28 & 15,06 & 16,01 & $-0,47$ & 2,27 & 27 & 0,176 & 0 & 0,75396 & 0,07887 \\
\hline 434 & 29 & 0 & 1 & 0 & 0 & 0 & 0 & 1 & 0 & 0 & 182951 & 33,7 & 13,11 & 17,68 & $-0,24$ & 2,46 & 34 & 0,183 & 0 & 0,77221 & 0,01927 \\
\hline 435 & 29 & 0 & 1 & 0 & 0 & 0 & 0 & 1 & 0 & 0 & 195007 & 38,67 & 11,92 & 15,72 & $-0,32$ & 2,56 & 35 & 0,195 & 0 & 0,74636 & 0,01359 \\
\hline 436 & 29 & 0 & 1 & 0 & 0 & 0 & 0 & 1 & 0 & 0 & 202893 & 38,3 & 11,43 & 16,14 & $-0,22$ & 2,51 & 40 & 0,2029 & 0 & 0,72073 & 0,00587 \\
\hline 437 & 30 & 0 & 1 & 0 & 0 & 0 & 1 & 0 & 0 & 1 & 12846 & 77,92 & 38,91 & 10,48 & $-0,26$ & 2,77 & 0 & 0,0128 & 0 & 0,09624 & 0,86105 \\
\hline 438 & 30 & 0 & 1 & 0 & 0 & 0 & 1 & 0 & 0 & 0 & 12960 & 82,1 & 42,01 & 10,2 & 0,11 & 2,77 & 3 & 0,013 & 0 & 0,17084 & 0,71824 \\
\hline 439 & 30 & 0 & 1 & 0 & 0 & 0 & 1 & 0 & 0 & 0 & 13683 & 85,34 & 31,93 & 8,16 & 0,06 & 2,78 & 3 & 0,0137 & 0 &, 12299 & 0,83400 \\
\hline 440 & 30 & 0 & 1 & 0 & 0 & 0 & 1 & 0 & 0 & 0 & 14832 & 97,53 & 26,78 & 6,39 & $-0,13$ & 2,79 & 4 & 0,0148 & 0 & 0,11317 & 0,84578 \\
\hline 441 & 30 & 0 & 1 & 0 & 0 & 0 & 1 & 0 & 0 & 1 & 16052 & 97,67 & 20,26 & 7,19 & 0,07 & 2,77 & 4 & 0,0161 & 0 & 0,09182 & 0,89370 \\
\hline 442 & 30 & 0 & 1 & 0 & 0 & 0 & 1 & 0 & 0 & 1 & 16341 & 94,39 & 21,03 & 7,82 & $-0,07$ & 2,75 & 7 & 0,0163 & 0 & ,13458 & 0,83891 \\
\hline 443 & 30 & 0 & 1 & 0 & 0 & 0 & 1 & 0 & 0 & 0 & 16517 & 86,01 & 21,63 & 8,35 & 0 & 2,78 & 8 & 0,0165 & 0 & 0,16488 & 0,81163 \\
\hline 444 & 30 & 0 & 1 & 0 & 0 & 0 & 1 & 0 & 0 & 0 & 16996 & 90,02 & 21 & 8,21 & 0 & 2,82 & 9 & 0,017 & 0 & 0,19193 & 0,77284 \\
\hline 445 & 30 & 0 & 1 & 0 & 0 & 0 & 1 & 0 & 0 & 0 & 18085 & 95,2 & 20,69 & 7,37 & $-0,17$ & 2,76 & 9 & 0,0181 & 0 & ,17132 & 0,78842 \\
\hline 446 & 30 & 0 & 1 & 0 & 0 & 0 & 1 & 0 & 0 & 0 & 18855 & 95,74 & 22,22 & 6,86 & $-0,07$ & 2,74 & 9 & 0,0189 & 0 & 0,18093 & 0,76834 \\
\hline 447 & 30 & 0 & 1 & 0 & 0 & 0 & 1 & 0 & 0 & 1 & 19965 & 102,47 & 19,39 & 5,78 & $-0,13$ & 2,65 & 9 & 0,02 & 0 & 0,14761 & 0,81269 \\
\hline 448 & 30 & 0 & 1 & 0 & 0 & 0 & 1 & 0 & 0 & 0 & 21718 & 104,41 & 19,34 & 6,6 & $-0,14$ & 2,61 & 9 & 0,0217 & 0 & ,14258 & 0,81703 \\
\hline 449 & 30 & 0 & 1 & 0 & 0 & 0 & 1 & 0 & 0 & 0 & 23441 & 102,23 & 20,14 & 10,25 & $-0,23$ & 2,7 & 9 & 0,0234 & 0 & 0,16246 & 0,79156 \\
\hline 450 & 30 & 0 & 1 & 0 & 0 & 0 & 1 & 0 & 0 & 0 & 24081 & 100,63 & 20,85 & 10,16 & $-0,22$ & 2,77 & 12 & 0,0241 & 0 & 0,25216 & 0,66099 \\
\hline 451 & 30 & 0 & 1 & 0 & 0 & 0 & 1 & 0 & 0 & 0 & 23837 & 83,98 & 17,35 & 14,5 & $-0,38$ & 2,83 & 12 & 0,0238 & 0 &, 24173 & 0,74023 \\
\hline 452 & 30 & 0 & 1 & 0 & 0 & 0 & 1 & 0 & 0 & 1 & 25018 & 79,1 & 23,26 & 24,86 & $-0,26$ & 2,81 & 15 & 0,025 & 0 &, 39333 & 0,53063 \\
\hline 453 & 30 & 1 & 0 & 0 & 0 & 0 & 1 & 0 & 0 & 0 & 26148 & 79,4 & 22,92 & 23,91 & $-0,09$ & 2,84 & 15 & 0,0261 & 0 & 0,20596 & 0,41741 \\
\hline 454 & 30 & 1 & 0 & 0 & 0 & 0 & 1 & 0 & 0 & 0 & 27499 & 78,94 & 23,35 & 25,49 & $-0,06$ & 2,99 & 15 & 0,0275 & 0 &, 22619 & 0,35420 \\
\hline 455 & 31 & 0 & 0 & 1 & 0 & 0 & 0 & 0 & 1 & 0 & 31513 & 31,87 & 38,18 & 6,65 & $-0,21$ & 2,17 & 2 & 0,0315 & 0 & 0,04420 & 0,90798 \\
\hline 456 & 31 & 0 & 0 & 1 & 0 & 0 & 0 & 0 & 1 & 0 & 33378 & 31,08 & 32,08 & 6,5 & $-0,15$ & 2,27 & 3 & 0,0334 & 0 & 0,04643 & 0,91536 \\
\hline 457 & 31 & 0 & 0 & 1 & 0 & 0 & 0 & 0 & 1 & 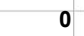 & 34440 & 29,36 & 37,41 & 6,27 & $-0,17$ & 2,16 & 3 & 0,0344 & 0 & 0,05013 & 0,89850 \\
\hline 458 & 31 & 0 & 0 & 1 & 0 & 0 & 0 & 0 & 1 & 0 & 34932 & 24,73 & 36,21 & 8,34 & $-0,19$ & 2,05 & 12 & 0,0349 & 0 & 0,13646 & 0,71181 \\
\hline 459 & 31 & 0 & 1 & 0 & 0 & 0 & 0 & 0 & 1 & 0 & 36256 & 26,59 & 31,28 & 7,43 & $-0,21$ & 2,26 & 13 & 0,0363 & 0 & 0,08822 & 0,91606 \\
\hline 460 & 31 & 0 & 1 & 0 & 0 & 0 & 0 & 0 & 1 & 0 & 38349 & 31,31 & 26,44 & 3,87 & $-0,28$ & 2,06 & 13 & 0,0383 & 0 & 0,05431 & 0,95196 \\
\hline 461 & 31 & 0 & 1 & 0 & 0 & 0 & 0 & 0 & 1 & 0 & 42644 & 39,36 & 22,2 & 0,96 & $-0,21$ & 1,96 & 14 & 0,0426 & 0 & 0,04842 & 0,95799 \\
\hline 462 & 31 & 0 & 1 & 0 & 0 & 0 & 0 & 0 & 1 & 0 & 47790 & 37,19 & 11,5 & 0,94 & $-0,18$ & 2,04 & 14 & 0,0478 & 0 & 0,03464 & 0,97697 \\
\hline 463 & 32 & 0 & 0 & 1 & 0 & 0 & 1 & 0 & 0 & 0 & 306 & 114,22 & 38,55 & 1,89 & $-11,87$ & 3,15 & 0 & 0,0003 & 0 & 0,01193 & 0,91755 \\
\hline 464 & 32 & 0 & 0 & 1 & 0 & 0 & 1 & 0 & 0 & & 314 & 112,71 & 38,49 & 5,62 & $-19,81$ & 3,15 & 1 & 0,0003 & 0 & 0,00135 & 0,98702 \\
\hline 465 & 32 & 0 & 1 & 0 & 0 & 0 & 1 & 0 & 0 & 0 & 318 & 126,13 & 38,15 & 1,59 & $-6,36$ & 2,9 & 1 & 0,0003 & 0 &, 02185 & 0,93666 \\
\hline 466 & 32 & 0 & 1 & 0 & 0 & 0 & 1 & 0 & 0 & 0 & 336 & 126,02 & 34,04 & 3,91 & $-4,06$ & 2,77 & 3 & 0,0003 & 0 & 0,04053 & 0,90200 \\
\hline 467 & 32 & 0 & 1 & 0 & v & 0 & 1 & 0 & 0 & & 338 & 97,54 & 30,39 & 2,16 & $-5,12$ & 2,89 & 3 & 0,0003 & 0 & 0,02828 & 0,94788 | \\
\hline 468 & 32 & 0 & 1 & 0 & 0 & 0 & 1 & 0 & 0 & 0 & 339 & 83,64 & 30,37 & 2,88 & $-6,19$ & 2,91 & 3 & 0,0003 & 0 & ,02066 & 0,96463 \\
\hline 469 & 32 & 0 & 1 & 0 & 0 & 0 & 1 & 0 & 0 & 0 & 333 & 82,74 & 33,07 & 2,14 & $-9,56$ & 2,92 & 3 & 0,0003 & 0 & 0,00863 & 0,98193 \\
\hline 470 & 32 & 0 & 1 & 0 & 0 & 0 & 1 & 0 & 0 & 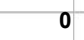 & 359 & 78,76 & 29,79 & 4,96 & $-3,46$ & 2,72 & 3 & 0,0004 & 0 & 0,03479 & 0,95061 \\
\hline 47 & 32 & 0 & 1 & 0 & 0 & 0 & 1 & 0 & 0 & 0 & 371 & 81,27 & 29,97 & 3,35 & $-8,62$ & 2,62 & 3 & 0,0004 & 0 & ,00656 & 0,98813 \\
\hline 472 & 32 & 0 & 1 & 0 & 0 & 0 & 1 & 0 & 0 & 0 & 370 & 87,9 & 26,78 & 2,09 & $-6,18$ & 2,93 & 3 & 0,0004 & 0 & 0,01821 & 0,97020 \\
\hline 473 & 32 & 0 & 1 & 0 & 0 & 0 & 1 & 0 & 0 & 0 & 381 & 87,95 & 28,05 & 3,22 & $-5,2$ & 2,98 & 3 & 0,0004 & 0 & 0,02771 & 0,95517 \\
\hline 474 & 32 & 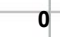 & 1 & 0 & 0 & 0 & 1 & 0 & 0 & 0 & 405 & 91,12 & 27,67 & 8,98 & $-4,83$ & 3,01 & 3 & 0,0004 & 0 & 03267 & 0,94768 \\
\hline 475 & 32 & 0 & 1 & 0 & 0 & 0 & 1 & 0 & 0 & 0 & 434 & 96,93 & 29,63 & 13,32 & $-5,05$ & 3,03 & 3 & 0,0004 & 0 & ,03537 & $\mid 0,93771$ \\
\hline 476 & 32 & 0 & 1 & 0 & 0 & 0 & 1 & 0 & 0 & 0 & 429 & 84,25 & 33,37 & 18,62 & $-7,56$ & 3,11 & 3 & 0,0004 & 0 & 0,02231 & 0,95753 \\
\hline 477 & 32 & 0 & 1 & 0 & 0 & 0 & 1 & 0 & 0 & 0 & 432 & 88,82 & 25,93 & 5,68 & $-6,7$ & 3,15 & 3 & 0,0004 & 0 & ,02065 & 0,96574 \\
\hline 478 & 32 & 0 & 1 & 0 & 0 & 0 & 1 & 0 & 0 & 0 & 426 & 84,56 & 21,78 & 8,53 & $-5,41$ & 3,16 & 3 & 0,0004 & 0 & 0,02551 & 0,96515 \\
\hline 47 & 33 & 0 & 0 & 1 & 0 & 0 & 1 & 0 & 0 & 0 & 446 & 110,23 & 52,54 & 3,14 & $-4,24$ & 3,15 & 1 & 0,0004 & 0 & 0,09948 & 0,32704 \\
\hline 80 & 33 & & 0 & & 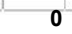 & 0 & t & 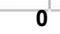 & 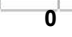 & 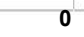 & 466 & 113,68 & 46,41 & 2,8 & $-3,08$ & 2,99 & 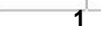 & 0,0005 & 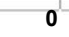 & 0,10482 & 0,40276 \\
\hline
\end{tabular}


Obs ID AA AB BA BB MD LV PL NL REC PIB COMEX AGRI PREF ODP CAP APRE PIB2 ACI CREC PO

\begin{tabular}{|c|c|c|c|c|c|c|c|c|c|c|c|c|c|c|c|c|c|c|c|c|c|}
\hline 481 & 33 & 0 & 0 & 1 & 0 & 0 & 1 & 0 & 0 & 0 & 497 & 120,47 & 35,2 & 2,8 & $-1,96$ & 2,83 & 1 & 0,0005 & 0 & 0,09874 & 0,56665 \\
\hline 482 & 33 & 0 & 1 & 0 & 0 & 0 & 1 & 0 & 0 & 0 & 547 & 127,58 & 50,77 & 4,57 & $-2,91$ & 2,84 & 1 & 0,0005 & 0 & 0,08254 & 0,72209 \\
\hline 483 & 33 & 0 & 1 & 0 & 0 & 0 & 1 & 0 & 0 & 0 & 557 & 104,97 & 27 & 3,25 & $-3,39$ & 2,85 & 1 & 0,0006 & 0 & 0,02882 & 0,95295 \\
\hline 484 & 33 & 0 & 1 & 0 & 0 & 0 & 1 & 0 & 0 & 0 & 546 & 91,72 & 33,15 & 3,37 & $-2,29$ & 2,86 & 1 & 0,0005 & 0 & 0,05105 & 0,91795 \\
\hline 485 & 33 & 0 & 1 & 0 & 0 & 0 & 1 & 0 & 0 & 0 & 564 & 82,31 & 44 & 3,21 & $-2,05$ & 2,86 & 1 & 0,0006 & 0 & 0,08267 & 0,84349 \\
\hline 486 & 33 & 0 & 1 & 0 & 0 & 0 & 1 & 0 & 0 & 0 & 618 & 83,08 & 42,8 & 3,48 & $-1,99$ & 2,69 & 1 & 0,0006 & 0 & 0,06552 & 0,88017 \\
\hline 487 & 33 & 0 & 1 & 0 & 0 & 0 & 1 & 0 & 0 & 0 & 614 & 86,27 & 47,35 & 3,25 & $-2,93$ & 2,59 & 1 & 0,0006 & 0 & 0,05367 & 0,88382 \\
\hline 488 & 33 & 0 & 1 & 0 & 0 & 0 & 1 & 0 & 0 & 0 & 695 & 78,38 & 38,36 & 2,88 & $-7,87$ & 2,78 & 1 & 0,0007 & 0 & 0,01096 & 0,97755 \\
\hline 489 & 33 & 0 & 1 & 0 & 0 & 0 & 1 & 0 & 0 & 0 & 667 & 80,84 & 36,82 & 4,5 & $-3,99$ & 2,74 & 1 & 0,0007 & 0 & 0,03091 & 0,94747 \\
\hline 490 & 33 & 0 & 1 & 0 & 0 & 0 & 1 & 0 & 0 & 0 & 708 & 85,16 & 27,77 & 5,56 & $-3,21$ & 2,72 & 1 & 0,0007 & 0 & 0,02561 & 0,96477 \\
\hline 491 & 33 & 0 & 1 & 0 & 0 & 0 & 1 & 0 & 0 & 0 & 715 & 79,85 & 34,31 & 9,26 & $-4,23$ & 2,73 & 1 & 0,0007 & 0 & 0,02594 & 0,95885 \\
\hline 492 & 33 & 0 & 1 & 0 & 0 & 0 & 1 & 0 & 0 & 0 & 668 & 71,08 & 37 & 4,86 & $-6,75$ & 2,7 & 1 & 0,0007 & 0 & 0,01280 & 0,97747 \\
\hline 493 & 34 & 0 & 0 & 1 & 0 & 0 & 1 & 0 & 0 & 0 & 10404 & 111,3 & 18,98 & 7,77 & $-1,95$ & 2,66 & 0 & 0,0104 & 0 & 0,05039 & 0,86514 \\
\hline 494 & 34 & 0 & 0 & 1 & 0 & 0 & 1 & 0 & 0 & 0 & 10392 & 99,07 & 19,78 & 9,04 & $-0,91$ & 2,66 & 1 & 0,0104 & 0 & 0,07765 & 0,81558 \\
\hline 495 & 34 & 0 & 0 & 1 & 0 & 0 & 1 & 0 & 0 & 0 & 10274 & 90,99 & 20,77 & 7,75 & $-0,97$ & 2,67 & 2 & 0,0103 & 0 & 0,08996 & 0,79183 \\
\hline 496 & 34 & 0 & 1 & 0 & 0 & 0 & 1 & 0 & 0 & 0 & 10572 & 81,85 & 19,24 & 8,89 & $-0,26$ & 2,48 & 7 & 0,0106 & 0 & 0,08122 & 0,91696 \\
\hline 497 & 34 & 0 & 1 & 0 & 0 & 0 & 1 & 0 & 0 & 0 & 10960 & 88,15 & 19,23 & 8,1 & $-0,07$ & 2,56 & 8 & 0,011 & 0 & 0,11022 & 0,87973 \\
\hline 498 & 34 & 0 & 1 & 0 & 0 & 0 & 1 & 0 & 0 & 0 & 11105 & 89,32 & 19,23 & 5,04 & $-0,86$ & 2,71 & 8 & 0,0111 & 0 & 0,10560 & 0,87769 \\
\hline 499 & 34 & 0 & 1 & 0 & 0 & 0 & 1 & 0 & 0 & 0 & 11204 & 90,49 & 16,63 & 5,5 & $-0,38$ & 2,42 & 8 & 0,0112 & 0 & 0,07567 & 0,91982 \\
\hline 500 & 34 & 0 & 1 & 0 & 0 & 0 & 1 & 0 & 0 & 0 & 11529 & 100,75 & 16,27 & 5,46 & $-0,33$ & 2,77 & 8 & 0,0115 & 0 & 0,11907 & 0,86099 \\
\hline 501 & 34 & 0 & 1 & 0 & 0 & 0 & 1 & 0 & 0 & 0 & 11694 & 101,24 & 14,45 & 8,64 & $-0,23$ & 2,8 & 8 & 0,0117 & 0 & 0,12026 & 0,86629 \\
\hline 502 & 34 & 0 & 1 & 0 & 0 & 0 & 1 & 0 & 0 & 0 & 11610 & 113,58 & 13,66 & 7,52 & $-0,65$ & 2,79 & 8 & 0,0116 & 0 & 0,10370 & 0,87173 \\
\hline 503 & 34 & 0 & 1 & 0 & 0 & 0 & 1 & 0 & 0 & 0 & 11096 & 86,89 & 22,28 & 9,17 & $-1,31$ & 2,71 & 8 & 0,0111 & 0 & 0,10680 & 0,86870 \\
\hline 504 & 34 & 0 & 1 & 0 & 0 & 0 & 1 & 0 & 0 & 0 & 10931 & 80,93 & 21,09 & 7,81 & $-1,11$ & 2,7 & 8 & 0,0109 & 0 & 0,10486 & 0,88151 \\
\hline 505 & 34 & 0 & 1 & 0 & 0 & 0 & 1 & 0 & 0 & 0 & 11119 & 83,92 & 19,27 & 9,63 & $-0,28$ & 2,72 & 8 & 0,0111 & 0 & 0,12711 & 0,86416 \\
\hline 506 & 34 & 0 & 1 & 0 & 0 & 0 & 1 & 0 & 0 & 0 & 11052 & 82,16 & 19,19 & 6,73 & $-0,18$ & 2,48 & 8 & 0,0111 & 0 & 0,09530 & 0,90093 \\
\hline 507 & 35 & 0 & 1 & 0 & 0 & 0 & 0 & 1 & 0 & 0 & 90111 & 192,11 & 10,82 & 3,41 & $-0,13$ & 3,25 & 0 & 0,0901 & 1 & 0,15874 & 0,48813 \\
\hline 508 & 35 & 0 & 1 & 0 & 0 & 0 & 0 & 1 & 0 & 1 & 99124 & 181,77 & 10,38 & 2,41 & 0,47 & 3,25 & 1 & 0,0991 & 0 & 0,19864 & 0,42591 \\
\hline 509 & 35 & 0 & 1 & 0 & 0 & 0 & 0 & 1 & 0 & 0 & 106383 & 185,66 & 9,93 & 2,26 & 0,25 & 3,27 & 1 & 0,1064 & 0 & 0,19532 & 0,41697 \\
\hline 510 & 35 & 0 & 1 & 0 & 0 & 0 & 0 & 1 & 0 & 0 & 98554 & 209,49 & 10,43 & 2,04 & $-0,3$ & 3,29 & 1 & 0,0986 & 0 & 0,16145 & 0,38678 \\
\hline 511 & 35 & 0 & 1 & 0 & 0 & 0 & 0 & 1 & 0 & 0 & 104603 & 217,57 & 9,15 & 2,18 & $-0,2$ & 3,42 & 1 & 0,1046 & 0 & 0,17009 & 0,32714 \\
\hline 512 & 35 & 0 & 1 & 0 & 0 & 0 & 0 & 1 & 0 & 0 & 113869 & 220,41 & 7,05 & 2,11 & $-0,05$ & 3,55 & 1 & 0,1139 & 0 & 0,18443 & 0,28857 \\
\hline 513 & 35 & 0 & 1 & 0 & 0 & 0 & 0 & 1 & 0 & 0 & 114459 & 203,36 & 7,49 & 3,28 & $-0,04$ & 3,52 & 1 & 0,1145 & 0 & 0,19995 & 0,32945 \\
\hline 514 & 35 & 0 & 1 & 0 & 0 & 0 & 0 & 1 & 0 & 0 & 120629 & 199,36 & 8,21 & 3,44 & $-0,09$ & 3,49 & 1 & 0,1206 & 0 & 0,20333 & 0,33042 \\
\hline 515 & 35 & 0 & 1 & 0 & 0 & 0 & 0 & 1 & 0 & 0 & 127612 & 194,19 & 8,88 & 3,21 & $-0,1$ & 3,67 & 1 & 0,1276 & 0 & 0,22666 & 0,26707 \\
\hline 516 & 35 & 0 & 1 & 0 & 0 & 0 & 0 & 1 & 0 & 0 & 136268 & 210,37 & 8,77 & 2,08 & $-0,26$ & 3,63 & 1 & 0,1363 & 0 & 0,20360 & 0,24188 \\
\hline 517 & 35 & 0 & 1 & 0 & 0 & 0 & 0 & 1 & 0 & 0 & 143534 & 203,85 & 8,09 & 2,98 & $-0,02$ & 3,63 & 1 & 0,1435 & 0 & 0,22157 & 0,24222 \\
\hline 518 & 35 & 0 & 1 & 0 & 0 & 0 & 0 & 1 & 0 & 0 & 151550 & 202,58 & 8,3 & 2,99 & $-0,15$ & 3,7 & 1 & 0,1516 & 0 & 0,22778 & 0,21921 \\
\hline 519 & 35 & 0 & 1 & 0 & 0 & 0 & 0 & 1 & 0 & 0 & 161096 & 192,47 & 9,78 & 3,17 & $-0,11$ & 3,75 & 1 & 0,1611 & 0 & 0,24748 & 0,19489 \\
\hline 520 & 35 & 0 & 1 & 0 & 0 & 0 & 0 & 1 & 0 & 0 & 168880 & 176,67 & 11,71 & 2,89 & $-0,07$ & 3,66 & 1 & 0,1689 & 0 & 0,26707 & 0,21134 \\
\hline 521 & 35 & 0 & 1 & 0 & 0 & 0 & 0 & 1 & 0 & 0 & 166324 & 162,56 & 11,91 & 3,43 & $-0,07$ & 3,5 & 1 & 0,1663 & 0 & 0,27470 & 0,28450 \\
\hline 522 & 35 & 1 & 0 & 0 & 0 & 0 & 0 & 1 & 0 & 0 & 178675 & 157,94 & 12,44 & 4,23 & 0 & 3,63 & 1 & 0,1787 & 0 & 0,13703 & 0,16880 \\
\hline 523 & 35 & 1 & 0 & 0 & 0 & 0 & 0 & 1 & 0 & 0 & 188133 & 154,94 & 14,58 & 2,7 & $-0,01$ & 3,53 & 1 & 0,1881 & 0 & 0,13494 & 0,16378 \\
\hline 524 & 35 & 1 & 0 & 0 & 0 & 0 & 0 & 1 & 0 & 0 & 198431 & 147,84 & 13,14 & 3,8 & $-0,01$ & 3,51 & 5 & 0,1984 & 0 & 0,15211 & 0,09997 \\
\hline 525 & 36 & 0 & 1 & 0 & 0 & 0 & 1 & 0 & 0 & 0 & 4083 & 119,74 & 24,48 & 3,55 & $-0,57$ & 2,82 & 0 & 0,0041 & 0 & 0,05096 & 0,92240 \\
\hline 526 & 36 & 0 & 1 & 0 & 0 & 0 & 1 & 0 & 0 & 0 & 4311 & 127,86 & 25,46 & 4,58 & $-0,44$ & 2,82 & 1 & 0,0043 & 0 & 0,06480 & 0,89124 \\
\hline 527 & 36 & 0 & 1 & 0 & 0 & 0 & 1 & 0 & 0 & 0 & 4556 & 127,81 & 22,68 & 3,35 & -1 & 2,87 & 1 & 0,0046 & 0 & 0,05251 & 0,91497 \\
\hline 528 & 36 & 0 & 1 & 0 & 0 & 0 & 1 & 0 & 0 & 0 & 4832 & 132,2 & 22,61 & 1,69 & $-0,97$ & 2,92 & 2 & 0,0048 & 0 & 0,06499 & 0,88883 \\
\hline 529 & 36 & 0 & 1 & 0 & 0 & 0 & 1 & 0 & 0 & 0 & 4959 & 131,35 & 20,03 & 2,75 & $-0,97$ & 2,93 & 2 & 0,005 & 0 & 0,05960 & 0,90491 \\
\hline 530 & 36 & 0 & 1 & 0 & 0 & 0 & 1 & 0 & 0 & 0 & 5406 & 123,33 & 17,47 & 2,03 & $-0,44$ & 2,95 & 2 & 0,0054 & 0 & 0,06303 & 0,91325 \\
\hline 531 & 36 & 0 & 1 & 0 & 0 & 0 & 1 & 0 & 0 & 0 & 5545 & 130,99 & 21,73 & 1,07 & $-0,46$ & 2,93 & 2 & 0,0055 & 0 & 0,07315 & 0,88105 \\
\hline 532 & 36 & 0 & 1 & 0 & 0 & 0 & 1 & 0 & 0 & 0 & 5662 & 120,6 & 23,89 & 0,58 & $-0,49$ & 2,91 & 5 & 0,0057 & 0 & 0,11392 & 0,81412 \\
\hline 533 & 36 & 0 & 1 & 0 & 0 & 0 & 1 & 0 & 0 & 0 & 5869 & 112,07 & 22,38 & 2,43 & 0,25 & 3,25 & 6 & 0,0059 & 0 & 0,21149 & 0,69124 \\
\hline 534 & 36 & 0 & 1 & 0 & 0 & 0 & 1 & 0 & 0 & 0 & 6207 & 110,41 & 23,05 & 2,39 & $-0,52$ & 3,15 & 6 & 0,0062 & 0 & 0,16335 & 0,75458 \\
\hline 535 & 36 & 0 & 1 & 0 & 0 & 0 & 1 & 0 & 0 & 0 & 6284 & 125,71 & 24,48 & 1,11 & $-0,55$ & 3,12 & 6 & 0,0063 & 0 & 0,16219 & 0,71223 \\
\hline 536 & 36 & 0 & 1 & 0 & 0 & 0 & 1 & 0 & 0 & 0 & 6532 & 131,38 & 22,51 & 0,65 & $-0,28$ & 3,18 & 6 & 0,0065 & 0 & 0,17264 & 0,69514 \\
\hline 537 & 36 & 0 & 1 & 0 & 0 & 0 & 1 & 0 & 0 & 0 & 6917 & 125,04 & 24,46 & 4,71 & $-0,86$ & 3,23 & 6 & 0,0069 & 0 & 0,17128 & 0,69477 \\
\hline 538 & 36 & 0 & 1 & 0 & 0 & 0 & 1 & 0 & 0 & 0 & 7298 & 119,03 & 25,19 & 4,43 & $-1,13$ & 3,27 & 6 & 0,0073 & 0 & 0,17172 & 0,69995 \\
\hline 539 & 36 & 0 & 1 & 0 & 0 & 0 & 1 & 0 & 0 & 0 & 7520 & 107,28 & 28,4 & 4,46 & $-1,76$ & 3,26 & 6 & 0,0075 & 0 & 0,16204 & 0,71655 \\
\hline 540 & 36 & 0 & & 0 & 0 & 0 & 1 & 0 & 0 & 0 & 7829 & 116,26 & 29,79 & 10,02 & $-1,27$ & 3,35 & 6 & 0,0078 & 0 & 0,20510 & 0,61153 \\
\hline
\end{tabular}




\begin{tabular}{|c|c|c|c|c|c|c|c|c|c|c|c|c|c|c|c|c|c|c|c|c|c|}
\hline bs & ID & AA & $A B$ & BA & BB & MD & LV & PL & NL & REC & PIB & COMEX & AGRI & PREF & ODP & CAP & APRE & PIB2 & $\mathrm{ACl}$ & CREC & po \\
\hline 541 & 36 & 1 & 0 & 0 & 0 & 0 & 1 & 0 & 0 & 0 & 8133 & 119,78 & 28,49 & 2,64 & $-1,66$ & 3,36 & 6 & 0,0081 & 0 & 0,09455 & 0,55656 \\
\hline 542 & 36 & 1 & 0 & 0 & 0 & 0 & 1 & 0 & 0 & 0 & 8393 & 121,27 & 29,34 & 1,55 & $-1,55$ & 3,45 & 6 & 0,0084 & 0 & 0,10341 & 0,49744 \\
\hline 543 & 37 & 0 & 1 & 0 & 0 & 0 & 0 & 1 & 0 & 2 & 623097 & 46,11 & 8,88 & 17,96 & $-0,12$ & 2,57 & 0 & 0,6231 & 0 & ,03985 & 0,21375 \\
\hline 544 & 37 & 0 & 1 & 0 & 0 & 0 & 0 & 1 & 0 & 3 & 659703 & 50,72 & 8,52 & 16,15 & $-0,07$ & 2,57 & 3 & 0,6597 & 1 & I,10556 & 0,10591 \\
\hline 545 & 37 & 0 & 1 & 0 & 0 & 0 & 0 & 1 & 0 & 0 & 705637 & 49,32 & 7,55 & 16,73 & $-0,02$ & 2,71 & 9 & 0,7056 & 1 & 1,15530 & 0,02515 \\
\hline 546 & 37 & 0 & 1 & 0 & 0 & 0 & 0 & 1 & 0 & 0 & 738815 & 51,78 & 7,32 & 16,3 & 0 & 2,85 & 12 & 0,7388 & 1 & 1,10726 & 0,00948 \\
\hline 547 & 37 & 0 & 1 & 0 & 0 & 0 & 0 & 1 & 0 & 3 & 758520 & 51,27 & 6,37 & 16,5 & $-0,01$ & 2,79 & 13 & 0,7585 & 0 & 1,13108 & 0,00811 \\
\hline 548 & 37 & 0 & 1 & 0 & 0 & 0 & 1 & 0 & 0 & 1 & 798694 & 53,13 & 5,77 & 16,17 & 0,01 & 2,73 & 18 & 0,7987 & 3 & 1,68835 & 0,01029 \\
\hline 549 & 37 & 0 & 1 & 0 & 0 & 0 & 1 & 0 & 0 & 1 & 793858 & 48,53 & 6,42 & 17,9 & $-0,02$ & 2,74 & 18 & 0,7939 & 1 & 1,73158 & 0,01059 \\
\hline 550 & 37 & 0 & 1 & 0 & 0 & 0 & 1 & 0 & 0 & 0 & 794906 & 48,37 & 6,53 & 18,19 & $-0,02$ & 2,75 & 30 & 0,7949 & 0 & 1,48773 & 0,00128 \\
\hline 551 & 37 & 0 & 1 & 0 & 0 & 0 & 1 & 0 & 0 & 3 & 806215 & 51,24 & 7,08 & 17,21 & $-0,02$ & 2,73 & 36 & 0,8062 & 3 & 1,32485 & 0,00040 \\
\hline 552 & 37 & 0 & 1 & 0 & 0 & 0 & 1 & 0 & 0 & 0 & 840847 & 54,23 & 6,9 & 16,19 & $-0,01$ & 2,67 & 39 & 0,8408 & 2 & 1,25505 & 0,00019 \\
\hline 553 & 37 & 0 & 1 & 0 & 0 & 0 & 1 & 0 & 0 & 2 & 866346 & 54,58 & 6,66 & 15,58 & $-0,02$ & 2,58 & 41 & 0,8663 & 1 & 1,23434 & 0,00013 \\
\hline 554 & 37 & 1 & 0 & 0 & 0 & 0 & 1 & 0 & 0 & 1 & 909183 & 56,46 & 6,53 & 15,1 & $-0,03$ & 2,66 & 46 & 0,9092 & 1 & 0,47708 & 0,00002 \\
\hline 555 & 37 & 1 & 0 & 0 & 0 & 0 & 1 & 0 & 0 & 1 & 938503 & 57,08 & 6,78 & 15,74 & $-0,01$ & 2,67 & 50 & 0,9385 & 0 & 0,45024 & 0,00001 \\
\hline 556 & 37 & 1 & 0 & 0 & 0 & 0 & 1 & 0 & 0 & 3 & 951454 & 58,07 & 7,2 & 14,88 & $-0,01$ & 2,68 & 53 & 0,9515 & 0 & 0,42450 & 0,00000 \\
\hline 557 & 37 & 1 & 0 & 0 & 0 & 0 & 1 & 0 & 0 & 1 & 906320 & 56,13 & 7,98 & 15,81 & $-0,02$ & 2,66 & 59 & 0,9063 & 0 & 0,38944 & 0,00000 \\
\hline 558 & 37 & 1 & 0 & 0 & 0 & 0 & 1 & 0 & 0 & 0 & 953440 & 61,02 & 7,11 & 14,96 & $-0,05$ & 2,64 & 63 & 0,9534 & 0 & 0,36339 & 0,00000 \\
\hline 559 & 37 & 1 & 0 & 0 & 0 & 0 & 0 & 1 & 0 & 0 & 990811 & 63,88 & 7,49 & 13,97 & $-0,08$ & 2,81 & 66 & 0,9908 & 0 & 0,21135 & 0,00000 \\
\hline 560 & 37 & 1 & 0 & 0 & 0 & 0 & 0 & 1 & 0 & 2 & 1030829 & 66,53 & 6,78 & 13,39 & $-0,04$ & 2,82 & 69 & 1,0308 & 0 & 0,20311 & 0,00000 \\
\hline 561 & 38 & 0 & 0 & 1 & 0 & 0 & 1 & 0 & 0 & 0 & 5708 & 85,43 & 23,54 & 0,94 & $-3,86$ & 2,67 & 0 & 0,0057 & 0 & 0,03275 & 0,91358 \\
\hline 562 & 38 & 0 & 0 & 1 & 0 & 0 & 1 & 0 & 0 & 0 & 5775 & 88,85 & 24,61 & 0,37 & $-3,16$ & 2,65 & 0 & 0,0058 & 0 &, 04069 & 0,88996 \\
\hline 563 & 38 & 0 & 0 & 1 & 0 & 0 & 1 & 0 & 0 & 0 & 6052 & 94,08 & 25,88 & 0,97 & $-4,19$ & 2,63 & 0 & 0,0061 & 0 & 0,03175 & 0,90363 \\
\hline 564 & 38 & 0 & 0 & 1 & 0 & 0 & 1 & 0 & 0 & 0 & 6308 & 95,86 & 30,98 & 1,37 & $-2,83$ & 2,74 & 0 & 0,0063 & 0 & 0,06323 & 0,79174 \\
\hline 565 & 38 & 0 & 0 & 1 & 0 & 0 & 1 & 0 & $\sigma$ & 0 & 7082 & 81,89 & 24,67 & 1,09 & $-2,59$ & 2,6 & 0 & 0,0071 & 0 &, 04498 & 0,88850 \\
\hline 566 & 38 & 0 & 0 & 1 & 0 & 0 & 1 & 0 & 0 & 0 & 7261 & 80,76 & 25,28 & 0,54 & $-1,75$ & 2,54 & 0 & 0,0073 & 0 & 0,05370 & 0,87123 \\
\hline 567 & 38 & 0 & 1 & 0 & 0 & 0 & 1 & 0 & 0 & 0 & 7775 & 87,03 & 21,92 & 0,97 & $-1,91$ & 2,62 & 0 & 0,0078 & 0 & 0,02232 & 0,97449 \\
\hline 568 & 38 & 0 & 1 & 0 & 0 & 0 & 1 & 0 & 0 & 0 & 8289 & 106,3 & 19,95 & 3,95 & $-2,53$ & 2,63 & 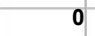 & 0,0083 & 0 & ,01827 & 0,97604 \\
\hline 569 & 38 & 0 & 1 & 0 & 0 & 0 & 1 & 0 & 0 & 0 & 8509 & 121,21 & 18,37 & 1,78 & $-2,52$ & 2,7 & 0 & 0,0085 & 0 & 0,01924 & 0,97214 \\
\hline 570 & 38 & 0 & 1 & 0 & 0 & 0 & 1 & 0 & 0 & 0 & 8534 & 125,48 & 19,12 & 1,38 & $-3,74$ & 2,63 & 1 & 0,0085 & 0 & 0,01482 & 0,97590 \\
\hline 571 & 38 & 0 & 1 & 0 & 0 & 0 & 1 & 0 & 0 & 0 & 9050 & 108,41 & 20,12 & 1,97 & $-2,36$ & 2,61 & 1 & 0,0091 & 0 & 0,02207 & 0,97012 \\
\hline 572 & 38 & 0 & 1 & 0 & 0 & 0 & 1 & 0 & 0 & 0 & 9510 & 103 & 19,47 & 2,37 & $-2,35$ & 2,59 & 1 & 0,0095 & 0 & 0,02076 & 0,97364 \\
\hline 573 & 38 & 0 & 1 & 0 & 0 & 0 & 1 & 0 & 0 & 0 & 9992 & 103,57 & 19,87 & 1,7 & $-2,04$ & 2,63 & 1 & 0,01 & 0 & 0,02453 & 0,96870 \\
\hline 574 & 39 & 0 & 1 & 0 & 0 & 0 & 1 & 0 & 0 & 1 & 10931 & 175,81 & 44,73 & 4,05 & $-0,48$ & 2,69 & 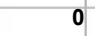 & 0,0109 & 0 &, 09528 & 0,62964 \\
\hline 575 & 39 & 0 & 1 & 0 & 0 & 0 & 1 & 0 & 0 & 0 & 11733 & 160,28 & 44,21 & 4,37 & $-0,21$ & 2,86 & 0 & 0,0117 & 0 & 0,11868 & 0,60175 \\
\hline 576 & 39 & 0 & 1 & 0 & 0 & 0 & 1 & 0 & 0 & 1 & 12193 & 134,28 & 42,05 & 5,45 & $-0,12$ & 2,8 & 0 & 0,0122 & 0 & 0,11320 & 0,71345 \\
\hline 577 & 39 & 0 & 1 & 0 & 0 & 0 & 1 & 0 & 0 & 0 & 12524 & 142,39 & 44,29 & 4,33 & $-0,14$ & 2,74 & 0 & 0,0125 & 0 & 0,11172 & 0,68065 \\
\hline 578 & 39 & 0 & 1 & 0 & 8 & 0 & 1 & 0 & 0 & 0 & 12596 & 138,64 & 47,01 & 5,34 & $-0,23$ & 2,62 & 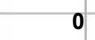 & 0,0126 & 0 & 0,10556 & 0,69027 \\
\hline 579 & 39 & 0 & 1 & 0 & 0 & 0 & 1 & 0 & 0 & 0 & 12876 & 129,74 & 48,46 & 6,12 & $-0,17$ & 2,49 & 1 & 0,0129 & 0 & 0,11055 & 0,68849 \\
\hline 580 & 39 & 0 & 1 & 0 & 0 & 0 & 1 & 0 & 0 & 0 & 13418 & 122,14 & 52,05 & 5,89 & $-0,22$ & 2,45 & 1 & 0,0134 & 0 & 0,11620 & 0,66610 \\
\hline 581 & 39 & 0 & 1 & 0 & 0 & 0 & 1 & 0 & 0 & 0 & 14427 & 131,52 & 50,76 & 6,32 & $-0,17$ & 2,47 & 1 & 0,0144 & 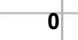 & 0,11551 & 0,65194 \\
\hline 582 & 39 & 0 & 1 & 0 & 0 & 0 & 1 & 0 & 0 & 0 & 15465 & 144,55 & 51,21 & 3,38 & $-0,19$ & 2,56 & 1 & 0,0155 & 1 & 0,12181 & 0,58011 \\
\hline 583 & 39 & 0 & 1 & 0 & 0 & 0 & 1 & 0 & 0 & 1 & 16783 & 146,19 & 48,64 & 0,66 & $-0,17$ & 2,58 & 1 & 0,0168 & 0 & 0,11751 & 0,61057 \\
\hline 584 & 39 & 0 & 1 & 0 & 0 & 0 & 1 & 0 & 0 & 2 & 18816 & 145,38 & 48,2 & 0,99 & 0,6 & 2,63 & 1 & 0,0188 & 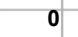 & 0,14263 & 0,54956 \\
\hline 585 & 39 & 0 & 1 & 0 & 0 & 0 & 1 & 0 & 0 & 0 & 20538 & 149 & 49,28 & 0,83 & $-0,11$ & 2,61 & 1 & 0,0205 & 0 & 0,12478 & 0,57088 \\
\hline 586 & 39 & 0 & 1 & 0 & 0 & 0 & 1 & 0 & 0 & 0 & 21354 & 138,73 & 50,4 & 1,57 & $-0,24$ & 2,64 & 1 & 0,0214 & 0 & 0,13077 & 0,57475 \\
\hline 587 & 39 & 0 & 1 & 0 & 8 & 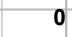 & 1 & 0 & 0 & 0 & 22603 & 39,69 & 41,99 & 1,44 & $-0,42$ & 2,63 & 5 & 0,0226 & 0 & 0,15356 & 0,56056 \\
\hline 588 & 39 & 1 & 0 & 0 & 0 & 0 & 1 & 0 & 0 & 0 & 25038 & 158,35 & 6,71 & 0,49 & $-0,35$ & 2,59 & 5 & 0,025 & 0 & ,02880 & 906 \\
\hline 589 & 39 & 1 & 0 & 0 & 0 & 0 & 1 & 0 & 0 & 1 & 27603 & 154,75 & 42,78 & 10,01 & $-0,14$ & 2,81 & 6 & 0,0276 & 0 & 0,09143 & 0,28285 \\
\hline 590 & 40 & 0 & 0 & 1 & 0 & 0 & 0 & 1 & 0 & 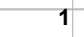 & 53491 & 31,64 & 23,07 & 10,31 & $-0,75$ & 2,45 & 1 & 0,0535 & 0 & 0,15569 & 0,65344 \\
\hline 59 & 40 & 0 & 0 & 1 & 0 & 0 & 0 & 1 & 0 & 0 & 54988 & 32,25 & 24,83 & 11,19 & $-0,63$ & 2,45 & 1 & 0,055 & 0 & 16747 & 270 \\
\hline 592 & 40 & 0 & 0 & 1 & 0 & 0 & 0 & 1 & 0 & 0 & 58550 & 34,01 & 25,17 & 11,04 & $-0,71$ & 2,57 & 3 & 0,0586 & 1 & 0,21539 & 0,47092 \\
\hline 593 & 40 & 0 & 0 & 1 & 0 & 0 & 0 & 1 & 0 & 0 & 58321 & 33,23 & 22,5 & 13,43 & $-0,93$ & 2,68 & 3 & 0,0583 & 0 & 0,21865 & 0,49381 \\
\hline 594 & 40 & 0 & 0 & 1 & 0 & 0 & 0 & 1 & 0 & 0 & 59192 & 33,4 & 24,42 & 12,53 & $-0,92$ & 2,55 & 3 & 0,0592 & 8 & ,20530 & 0,50504 \\
\hline 595 & 40 & 0 & 0 & 1 & 0 & 0 & 0 & 1 & 0 & 0 & 60787 & 35,58 & 22,85 & 11,12 & $-0,8$ & 2,41 & 4 & 0,0608 & 0 & 0,20015 & 52450 \\
\hline 596 & 40 & 0 & 0 & 1 & 0 & 0 & 1 & 0 & 0 & 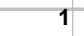 & 61163 & 34,8 & 23,73 & 11,04 & $-0,89$ & 2,28 & 4 & 0,0612 & 1 & 0,11450 & 0,82671 \\
\hline 597 & 40 & 0 & 0 & 1 & 0 & 0 & 1 & 0 & 0 & 0 & 64498 & 34,83 & 23,38 & 11,4 & $-0,92$ & 2,15 & 5 & 0,0645 & 2 & ,11257 & 0,82998 \\
\hline 598 & 40 & 0 & 0 & 1 & 0 & 0 & 1 & 0 & 0 & 0 & 67185 & 36,67 & 21,79 & 10,1 & $-0,91$ & 2,08 & 8 & 0,0672 & 0 & 0,14642 & 0,77509 \\
\hline 599 & 40 & 0 & 0 & 1 & 0 & 0 & 1 & 0 & 0 & 0 & 70516 & 41,03 & 20,82 & 10,15 & $-0,74$ & 2,03 & 8 & 0,0705 & 0 & 0,14311 & 0,77936 \\
\hline 00 & 40 & & 0 & I & 0 & & & & & . & 74948 & 46,87 & 18,49 & 9,21 & $-0,64$ & 1,9 & 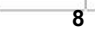 & 0,0749 & 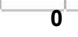 & 0,12043 & 0,81707 \\
\hline
\end{tabular}




\begin{tabular}{|c|c|c|c|c|c|c|c|c|c|c|c|c|c|c|c|c|c|c|c|c|c|}
\hline bs & ID & AA & $A B$ & BA & BB & MD & LV & PL & NL & REC & PIB & COMEX & AGRI & PREF & ODP & CAP & APRE & PIB2 & $\mathrm{ACl}$ & CREC & po \\
\hline 601 & 40 & 0 & 0 & 1 & 0 & 0 & 1 & 0 & 0 & 0 & 80591 & 50,83 & 16,18 & 8,62 & $-0,58$ & 1,92 & 8 & 0,0806 & 0 & 0,11961 & 0,82212 \\
\hline 602 & 40 & 0 & 0 & 1 & 0 & 0 & 1 & 0 & 0 & 0 & 87456 & 53,88 & 15,15 & 11,17 & $-0,33$ & 1,99 & 8 & 0,0875 & 0 & 0,14070 & 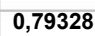 \\
\hline 603 & 40 & 0 & 0 & 1 & 0 & 0 & 1 & 0 & 0 & 0 & 95452 & 56,47 & 15,96 & 9,34 & $-0,41$ & 2,14 & 10 & 0,0955 & 0 & 0,21416 & 0,65818 \\
\hline 604 & 40 & 0 & 0 & 1 & 0 & 0 & 1 & 0 & 0 & 0 & 96453 & 46,42 & 18,81 & 11,52 & $-0,39$ & 2,08 & 10 & 0,0965 & 0 & 0,22347 & 0,65342 \\
\hline 605 & 40 & 0 & 1 & 0 & 0 & 0 & 1 & 0 & 0 & 1 & 104604 & 50,01 & 16,83 & 10,77 & 0,22 & 2,3 & 10 & 0,1046 & 0 & 0,18873 & 0,86239 \\
\hline 606 & 40 & 0 & 1 & 0 & 0 & 0 & 1 & 0 & 0 & 0 & 111354 & 55,24 & 17,22 & 8,79 & $-0,38$ & 2,35 & 10 & 0,1114 & 0 & 0,18043 & 0,85665 \\
\hline 607 & 40 & 0 & 1 & 0 & 0 & 0 & 1 & 0 & 0 & 0 & 117980 & 52,27 & 16,35 & 8,82 & $-0,21$ & 2,34 & 16 & 0,118 & 0 & 0,39205 & 0,68047 \\
\hline 608 & 41 & 0 & 0 & 1 & 0 & 0 & 0 & 1 & 0 & 0 & 20482 & 75,09 & 18,62 & 0 & $-0,77$ & 2,13 & 0 & 0,0205 & 0 & 0,06879 & 0,80023 \\
\hline 609 & 41 & 0 & 0 & 1 & 0 & 0 & 0 & 1 & 0 & 0 & 21942 & 73,35 & 14,52 & 12,43 & $-0,57$ & 2,13 & 1 & 0,0219 & 0 & 0,07607 & 0,80731 \\
\hline 610 & 41 & 0 & 0 & 1 & 0 & 0 & 0 & 1 & 0 & 0 & 23699 & 76,42 & 14,66 & 12,29 & $-0,38$ & 2,03 & 1 & 0,0237 & 0 & 0,07252 & 0,81341 \\
\hline 611 & 41 & 0 & 0 & 1 & 0 & 0 & 1 & 0 & 0 & 0 & 29111 & 74,72 & 26,9 & 70,4 & $-0,45$ & 2,13 & 3 & 0,0291 & 0 & 0,11410 & 0,78210 \\
\hline 612 & 41 & 0 & 0 & 1 & 0 & 0 & 1 & 0 & 0 & 0 & 30796 & 72,81 & 16,95 & 11,3 & $-0,57$ & 2,09 & 3 & 0,0308 & 0 & 0,05682 & 0,90190 \\
\hline 613 & 41 & 0 & 0 & 1 & 0 & 0 & 1 & 0 & 0 & 0 & 30718 & 86,49 & 17,29 & 9,61 & $-0,35$ & 1,96 & 3 & 0,0307 & 2 & 0,05259 & 0,89847 \\
\hline 614 & 41 & 0 & 0 & 1 & 0 & 0 & 1 & 0 & 0 & 0 & 31121 & 83,88 & 15,71 & 9,63 & $-0,42$ & 1,86 & 3 & 0,0311 & 0 & 0,04245 & 0,92298 \\
\hline 615 & 41 & 0 & 0 & 1 & 0 & 0 & 1 & 0 & 0 & 0 & 34004 & 65,53 & 14,68 & 11,78 & $-0,25$ & 1,95 & 3 & 0,034 & 1 & 0,04788 & 0,92803 \\
\hline 616 & 41 & 0 & 0 & 1 & 0 & 0 & 1 & 0 & 0 & 0 & 37633 & 67,97 & 16,22 & 11,68 & $-0,16$ & 1,92 & 3 & 0,0376 & 0 & 0,05191 & 0,91789 \\
\hline 617 & 41 & 0 & 1 & 0 & 0 & 0 & 1 & 0 & 0 & 0 & 40822 & 61,94 & 15,9 & 13,45 & $-0,29$ & 1,84 & 3 & 0,0408 & 0 & 0,01921 & 0,98619 \\
\hline 618 & 41 & 0 & 1 & 0 & 0 & 0 & 1 & 0 & 0 & 0 & 42105 & 61,44 & 17,71 & 13,62 & $-0,34$ & 1,89 & 3 & 0,0421 & 0 & 0,02228 & 0,98329 \\
\hline 619 & 41 & 0 & 1 & 0 & 0 & 0 & 1 & 0 & 0 & 0 & 42499 & 50,6 & 19,28 & 19,69 & $-0,26$ & 1,89 & 3 & 0,0425 & 0 & 0,02469 & 0,98280 \\
\hline 620 & 41 & 0 & 1 & 0 & 0 & 0 & 1 & 0 & 0 & 0 & 46028 & 54,83 & 20,21 & 18,74 & $-0,34$ & 1,84 & 4 & 0,046 & 4 & 0,02839 & 0,97872 \\
\hline 621 & 41 & 0 & 1 & 0 & 0 & 0 & 1 & 0 & 0 & 0 & 47326 & 57,5 & 19,54 & 15,36 & $-0,4$ & 1,92 & 4 & 0,0473 & 0 & 0,03018 & 0,97687 \\
\hline 622 & 41 & 0 & 1 & 0 & 0 & 0 & 1 & 0 & 0 & 1 & 48570 & 57,5 & 18,97 & 13,66 & $-0,45$ & 1,95 & 6 & 0,0486 & 0 & 0,04134 & 0,96764 \\
\hline 623 & 42 & 0 & 0 & 0 & 0 & 0 & 0 & 0 & 1 & 0 & 980326 & 51,82 & 8,54 & 10,82 & 0 & 2,07 & 7 & 0,9803 & 0 & 0,85955 & 0,42285 \\
\hline 624 & 43 & 1 & 0 & 0 & 0 & 0 & 1 & 0 & 0 & 0 & 396 & 100,68 & 41,79 & 11,38 & $-2,25$ & 2,5 & 0 & 0,0004 & 0 & 0,02496 & 0,88011 \\
\hline 625 & 43 & 1 & 0 & 0 & 0 & 0 & 1 & 0 & 0 & 0 & 423 & 94,26 & 39,89 & 8,57 & $-2,14$ & 2,28 & 0 & 0,0004 & 0 & 0,01763 & 0,92411 \\
\hline 626 & 43 & 1 & 0 & 0 & 0 & 0 & 1 & 0 & 0 & 0 & 434 & 90,16 & 24,32 & 13,95 & $-1,29$ & 2,24 & 0 & 0,0004 & 0 & 0,01095 & 0,96997 \\
\hline 627 & 43 & 1 & 0 & 0 & 0 & 0 & 1 & 0 & 0 & 0 & 456 & 95,01 & 23,55 & 12,61 & -1 & 2,41 & 0 & 0,0005 & 0 & 0,01458 & 0,95903 \\
\hline 628 & 43 & 1 & 0 & 0 & 0 & 0 & 1 & 0 & 0 & 0 & 479 & 85,8 & 22,19 & 16,72 & $-2,38$ & 2,3 & 0 & 0,0005 & 0 & 0,00781 & 0,97948 \\
\hline 629 & 43 & 1 & 0 & 0 & 0 & 0 & 1 & 0 & 0 & 0 & 488 & 85,27 & 22,71 & 15,88 & $-6,35$ & 2,18 & 2 & 0,0005 & 0 & 0,00280 & 0,99103 \\
\hline 630 & 43 & 1 & 0 & 0 & 0 & 0 & 1 & 0 & 0 & 0 & 475 & 90,93 & 20,64 & 13,73 & $-0,04$ & 2,15 & 3 & 0,0005 & 0 & 0,01891 & 0,95293 \\
\hline 631 & 43 & 1 & 0 & 0 & 0 & 0 & 1 & 0 & 0 & 0 & 497 & 86,92 & 25,62 & 13,34 & $-0,01$ & 2,47 & 3 & 0,0005 & 0 & 0,03553 & 0,90223 \\
\hline 632 & 43 & 0 & 0 & 0 & 0 & 0 & 1 & 0 & 0 & 0 & 543 & 93,3 & 12,98 & 17,15 & $-0,49$ & 3,37 & 3 & 0,0005 & 0 & 0,01543 & 0,98130 \\
\hline 633 & 43 & 0 & 0 & 0 & 0 & 0 & 1 & 0 & 0 & 0 & 575 & 87,47 & 14,87 & 16,58 & $-0,85$ & 3,23 & 3 & 0,0006 & 0 & 0,01226 & 0,98509 \\
\hline 634 & 43 & 0 & 0 & 0 & 0 & 0 & 1 & 0 & 0 & 0 & 591 & 84,68 & 16,11 & 20,62 & $-0,53$ & 3,16 & 3 & 0,0006 & 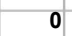 & 0,01314 & 0,98437 \\
\hline 635 & 43 & 0 & 0 & 0 & 0 & 0 & 1 & 0 & 0 & 0 & 616 & 91,53 & 15,98 & 12,96 & $-6,68$ & 3,18 & 3 & 0,0006 & 0 & 0,00205 & 0,99659 \\
\hline 636 & 43 & 0 & 0 & 0 & 0 & 0 & 1 & 0 & 0 & 0 & 581 & 76,73 & 18,8 & 18,49 & $-0,76$ & 3,27 & 3 & 0,0006 & 0 & 0,01572 & 0,98099 \\
\hline 637 & 43 & 0 & 0 & 0 & 0 & 0 & 1 & 0 & 0 & 0 & 563 & 83,69 & 17,92 & 22,56 & $-1,72$ & 3,22 & 3 & 0,0006 & 0 & 0,01093 & 0,98587 \\
\hline 638 & 43 & 0 & 0 & 0 & 0 & 0 & 1 & 0 & 0 & 0 & 572 & 85,4 & 20,08 & 16,75 & $-2,3$ & 3,27 & 3 & 0,0006 & 0 & 0,01063 & 0,98471 \\
\hline 639 & 44 & 0 & 1 & 0 & 0 & 0 & 1 & 0 & 0 & 0 & 722 & 136,86 & 48,42 & 1,86 & $-9,25$ & 2,5 & 0 & 0,0007 & 0 & 0,00762 & 0,96646 \\
\hline 640 & 44 & 0 & 1 & 0 & 0 & 0 & 1 & 0 & 0 & 0 & 762 & 130,85 & 50,08 & 2,67 & $-7,27$ & 2,5 & 1 & 0,0008 & $v$ & 0,01691 & 0,93167 \\
\hline 641 & 44 & 0 & 1 & 0 & 0 & 0 & 1 & 0 & 0 & 0 & 765 & 127,89 & 47,88 & 4,44 & $-4,48$ & 2,35 & 1 & 0,0008 & 0 &, 02815 & 0,90765 \\
\hline 642 & 44 & 0 & 1 & 0 & 0 & 0 & 1 & 0 & 0 & 0 & 813 & 122,96 & 51,04 & 3,45 & $-0,99$ & 2,2 & 2 & 0,0008 & 0 & 0,07591 & 0,77673 \\
\hline 643 & 44 & 0 & 1 & 0 & 0 & 0 & 1 & 0 & 0 & 0 & 832 & 119,44 & 51,33 & 4,23 & $-3,94$ & 2,38 & 3 & 0,0008 & 0 & 0,05048 & 0,83190 \\
\hline 644 & 44 & 0 & 1 & 0 & 0 & 0 & 1 & 0 & 0 & 0 & 869 & 105,37 & 50,61 & 6,21 & $-1,48$ & 2,56 & 3 & 0,0009 & 0 & 0,11059 & 0,70916 \\
\hline 645 & 44 & 0 & 1 & 0 & 0 & 0 & 1 & 0 & 0 & 0 & 841 & 98,4 & 51,67 & 8,17 & $-2,38$ & 2,44 & 3 & 0,0008 & 0 & 0,08198 & 0,78609 \\
\hline 646 & 44 & 0 & 1 & 0 & 0 & 0 & 1 & 0 & 0 & 0 & 841 & 96,53 & 47,48 & 3,93 & $-4,69$ & 2,33 & 3 & 0,0008 & 0 & 0,03232 & 0,91662 \\
\hline 647 & 44 & 0 & 1 & 0 & 0 & 0 & 1 & 0 & 0 & 0 & 882 & 109,84 & 45,67 & 2,56 & $-2,03$ & 2,46 & 3 & 0,0009 & 0 & 0,07344 & 0,81641 \\
\hline 648 & 44 & 0 & 1 & 0 & 0 & 0 & 1 & 0 & 0 & 0 & 954 & 108,28 & 48,41 & 2,15 & 2,59 & 2,56 & 3 & 0,001 & 0 & 0,23497 & 0,48892 \\
\hline 649 & 44 & 0 & 1 & 0 & 0 & 0 & 1 & 0 & 0 & 0 & 947 & 118,28 & 47,21 & 3,73 & $-1,2$ & 3,42 & 3 & 0,0009 & 0 & 0,20620 & 0,41621 \\
\hline 650 & 44 & 0 & 1 & 0 & 0 & 0 & 1 & 0 & 0 & 0 & 1025 & 106,72 & 39,03 & 3,83 & $-1,81$ & 3,23 & 3 & 0,001 & 0 & 0,14327 & 0,69182 \\
\hline 651 & 44 & 0 & 1 & 0 & 0 & 0 & 1 & 0 & 0 & 0 & 1031 & 102,66 & 38,64 & 20,67 & $-1,76$ & 3,16 & 3 & 0,001 & 0 & 0,14385 & 0,71756 \\
\hline 652 & 44 & 0 & 1 & 0 & 0 & 0 & 1 & 0 & 0 & 0 & 1060 & 113,55 & 37,39 & 3,26 & $-1,7$ & 3,18 & 3 & 0,0011 & 0 & 0,13307 & 0,70984 \\
\hline 653 & 45 & 0 & 0 & 1 & 0 & 0 & 1 & 0 & 0 & 0 & 389 & 98,36 & 51,79 & 5,64 & $-15,64$ & 2,5 & 0 & 0,0004 & 0 &, 00295 & 0,97280 \\
\hline 654 & 45 & 0 & 0 & 1 & 0 & 0 & 1 & 0 & 0 & 0 & 394 & 101,22 & 52,57 & 5,39 & $-8,16$ & 2,5 & 1 & 0,0004 & 0 & 0,02894 & 0,79455 \\
\hline 655 & 45 & 0 & 0 & 1 & 0 & 0 & 1 & 0 & 0 & 0 & 408 & 108,49 & 51,33 & 3,55 & $-1,76$ & 2,42 & 1 & 0,0004 & 0 & 0,09834 & 0,45061 \\
\hline 656 & 45 & 0 & 0 & 1 & 0 & 0 & 1 & 0 & 0 & 0 & 424 & 108,78 & 51,98 & 2,44 & $-5,7$ & 2,33 & 1 & 0,0004 & 0 &, 04245 & 0,71525 \\
\hline 657 & 45 & 0 & 1 & 0 & 0 & 0 & 1 & 0 & 0 & 0 & 436 & 106,77 & 52,65 & 6,32 & $-4,4$ & 2,44 & 1 & 0,0004 & 0 & 0,03813 & 0,88347 \\
\hline 658 & 45 & 0 & 1 & 0 & 0 & 0 & 1 & 0 & 0 & 0 & 443 & 95,87 & 56,45 & 3,3 & $-1,64$ & 2,56 & 1 & 0,0004 & 0 & 0,09919 & 0,72766 \\
\hline 659 & 45 & 0 & 1 & 0 & 0 & 0 & 1 & 0 & 0 & 0 & 451 & 89,62 & 54,87 & 9,15 & $-1,96$ & 2,44 & & 0,0005 & 0 & 0,07881 & 0,80378 \\
\hline 660 & & & & 0 & 0 & 0 & & 0 & 0 & & 479 & 85,11 & 56,36 & 7,77 & 1,03 & 2,33 & & 0,0005 & & 0,09190 & 0,78149 \\
\hline
\end{tabular}




\begin{tabular}{|c|c|c|c|c|c|c|c|c|c|c|c|c|c|c|c|c|c|c|c|c|c|}
\hline bs & ID & AA & $A B$ & BA & BB & MD & LV & PL & NL & REC & PIB & COMEX & AGRI & PREF & ODP & CAP & APRE & PIB2 & $\mathrm{ACl}$ & CREC & po \\
\hline 661 & 45 & 0 & 1 & 0 & 0 & 0 & 1 & 0 & 0 & 0 & 516 & 85,98 & 41,64 & 4,18 & $-1,41$ & 2,31 & 1 & 0,0005 & 0 & 0,04575 & 0,92044 \\
\hline 662 & 45 & 0 & 1 & 0 & 0 & 0 & 1 & 0 & 0 & 0 & 537 & 87,5 & 50,66 & 2,7 & $-2,16$ & 2,58 & 1 & 0,0005 & 0 & 0,07371 & 0,83129 \\
\hline 663 & 45 & 0 & 1 & 0 & 0 & 0 & 1 & 0 & 0 & 0 & 551 & 89,29 & 49,95 & 5,03 & $-1,48$ & 3,37 & 1 & 0,0006 & 0 & 0,18605 & 0,57026 \\
\hline 664 & 45 & 0 & 1 & 0 & 0 & 0 & 1 & 0 & 0 & 0 & 593 & 88,06 & 47,93 & 4,71 & $-0,81$ & 3,23 & 1 & 0,0006 & 0 & 0,18280 & 0,61543 \\
\hline 665 & 45 & 0 & 1 & 0 & 0 & 0 & 1 & 0 & 0 & 0 & 583 & 94,3 & 45,65 & 33,33 & $-10,46$ & 3,16 & 1 & 0,0006 & 0 & 0,01418 & 0,95825 \\
\hline 666 & 45 & 0 & 1 & 0 & 0 & 0 & 1 & 0 & 0 & 0 & 623 & 92,17 & 44,55 & 44,83 & $-3,99$ & 3,18 & 1 & 0,0006 & 0 & 0,08894 & 0,81479 \\
\hline 667 & 45 & 0 & 1 & 0 & 0 & 0 & 1 & 0 & 0 & 0 & 610 & 85,99 & 44,79 & 43,9 & $-4,65$ & 3,27 & 1 & 0,0006 & 0 & 0,08323 & 0,82867 \\
\hline 668 & 45 & 0 & 1 & 0 & 0 & 0 & 1 & 0 & 0 & 0 & 589 & 84,02 & 42,7 & 24,67 & $-2,52$ & 3,22 & 1 & 0,0006 & 0 & 0,11592 & 0,78662 \\
\hline 669 & 45 & 0 & 1 & 0 & 0 & 0 & 1 & 0 & 0 & 0 & 587 & 82,74 & 44,08 & 10,82 & $-2,69$ & 3,27 & 1 & 0,0006 & 0 & 0,11565 & 0,77270 \\
\hline 670 & 45 & 0 & 1 & 0 & 0 & 0 & 1 & 0 & 0 & 0 & 595 & 85,44 & 44,7 & 5,75 & $-1,24$ & 3,34 & 1 & 0,0006 & 0 & 0,17265 & 0,66330 \\
\hline 671 & 46 & 0 & 0 & 0 & 1 & 0 & 0 & 1 & 0 & 0 & 1261 & 50,06 & 16,35 & 11,26 & $-11,1$ & 1,7 & 1 & 0,0013 & 0 & 0,00450 & 0,98789 \\
\hline 672 & 46 & 0 & 0 & 0 & 1 & 0 & 0 & 1 & 0 & 0 & 1277 & 54,11 & 18,56 & 13,5 & $-12,64$ & 1,7 & 1 & 0,0013 & 0 & 0,00320 & 0,99004 \\
\hline 673 & 46 & 0 & 0 & 0 & 1 & 0 & 0 & 1 & 0 & 0 & 1350 & 59,99 & 15,51 & 6,15 & $-8,27$ & 1,85 & 1 & 0,0014 & 0 & 0,01243 & 0,96769 \\
\hline 674 & 46 & 0 & 0 & 0 & 1 & 0 & 0 & 1 & 0 & 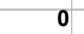 & 1371 & 83,6 & 13,82 & 8,6 & $-6,29$ & 2 & 1 & 0,0014 & 0 & 0,02661 & \begin{tabular}{|l}
0,92507 \\
\end{tabular} \\
\hline 675 & 46 & 0 & 0 & 0 & 1 & 0 & 0 & 1 & 0 & 0 & 1359 & 60,87 & 15,59 & 11,85 & $-4,26$ & 2,16 & 1 & 0,0014 & 0 & 0,06043 & 0,86579 \\
\hline 676 & 46 & 0 & 0 & 0 & 1 & 0 & 1 & 0 & 0 & 0 & 1358 & 52,93 & 9,76 & 11,12 & $-3,85$ & 2,33 & 1 & 0,0014 & 0 & 0,03079 & 0,96505 \\
\hline 677 & 46 & 0 & 0 & 0 & 1 & 0 & 1 & 0 & 0 & 0 & 1420 & 78 & 10,94 & 11,54 & $-3,39$ & 2,3 & 1 & 0,0014 & 0 & 0,03765 & 0,94681 \\
\hline 678 & 46 & 0 & 0 & 0 & 1 & 0 & 1 & 0 & 0 & 0 & 1481 & 58,38 & 11,39 & 11,2 & $-1,12$ & 2,28 & 1 & 0,0015 & 0 & 0,06932 & 0,92399 \\
\hline 679 & 46 & 0 & 0 & 1 & 0 & 0 & 1 & 0 & 0 & 0 & 1570 & 65,3 & 10,05 & 8,05 & $-0,89$ & 2,3 & 1 & 0,0016 & 0 & 0,02969 & 0,95860 \\
\hline 680 & 46 & 0 & 0 & 1 & 0 & 0 & 1 & 0 & 0 & 0 & 1715 & 74,22 & 7,89 & 4,49 & $-1,68$ & 2,41 & 1 & 0,0017 & 0 & 0,02484 & 0,96270 \\
\hline 681 & 46 & 0 & 0 & 1 & 0 & 0 & 1 & 0 & 0 & 0 & 1794 & 75,58 & 6,24 & 5,1 & $-2,52$ & 2,41 & 1 & 0,0018 & 0 & 0,01808 & 0,97265 \\
\hline 682 & 47 & 0 & 0 & 1 & 0 & 0 & 0 & 1 & 0 & 0 & 317018 & 44,24 & 16,37 & 2,78 & $-0,19$ & 2,49 & 0 & 0,317 & 0 & 0,36669 & 0,26787 \\
\hline 683 & 47 & 0 & 0 & 1 & 0 & 0 & 0 & 1 & 0 & 0 & 340413 & 49,37 & 15,68 & 2,43 & $-0,14$ & 2,49 & 2 & 0,3404 & 4 & 0,39326 & 0,17524 \\
\hline 684 & 47 & 0 & 1 & 0 & 0 & 0 & 0 & 1 & 0 & 0 & 366208 & 54,97 & 14,92 & 2,02 & 0 & 2,36 & 2 & 0,3662 & 0 & , 47484 & 0,51177 \\
\hline 685 & 47 & 0 & 1 & 0 & 0 & 0 & 0 & 1 & 0 & 0 & 374661 & 41,52 & 14,19 & 3,09 & $-0,01$ & 2,22 & 2 & 0,3747 & 0 & 0,45310 & 0,59627 \\
\hline 686 & 47 & 0 & 1 & 0 & 0 & 0 & 0 & 1 & 0 & 0 & 362052 & 38,73 & 12,54 & 3,94 & 0 & 2,37 & 3 & 0,3621 & 0 & 0,51676 & 0,55797 \\
\hline 687 & 47 & 0 & 1 & 0 & 0 & 0 & 0 & 1 & 0 & 1 & 386579 & 43,19 & 10,56 & 3,93 & $-0,12$ & 2,52 & 4 & 0,3866 & 1 & 0,63939 & 0,44496 \\
\hline 688 & 47 & 0 & 1 & 0 & 0 & 0 & 0 & 1 & 0 & 0 & 364554 & 50,76 & 10,85 & 2,82 & $-0,07$ & 2,53 & 4 & 0,3646 & 1 & 0,58357 & 0,45342 \\
\hline 689 & 47 & 0 & 1 & 0 & 0 & 0 & 0 & 1 & 0 & 0 & 387025 & 48,8 & 9,49 & 3,57 & $-0,12$ & 2,54 & 13 & 0,387 & 1 & 0,85638 & 0,14069 \\
\hline 690 & 47 & 0 & 1 & 0 & 0 & 0 & 0 & 1 & 0 & 1 & 407402 & 47,03 & 9,3 & 3,47 & $-0,06$ & 2,54 & 16 & 0,4074 & 0 & ,90509 & 0,07816 \\
\hline 691 & 47 & 0 & 1 & 0 & 0 & 0 & 0 & 1 & 0 & 0 & 445547 & 49,74 & 8,09 & 3,46 & $-0,07$ & 2,54 & 16 & 0,4455 & 0 & 0,92973 & 0,06340 \\
\hline 692 & 47 & 0 & 1 & 0 & 0 & 0 & 0 & 1 & 0 & 0 & 482980 & 47,21 & 8,15 & 4,01 & $-0,08$ & 2,66 & 16 & 0,483 & 1 & 0,97033 & 0,04217 \\
\hline 693 & 47 & 0 & 1 & 0 & 0 & 0 & 0 & 1 & 0 & 0 & 516274 & 50,25 & 7,35 & 2,85 & $-0,11$ & 2,66 & 16 & 0,5163 & 0 & 0,97256 & 0,03432 \\
\hline 694 & 47 & 1 & 0 & 0 & 0 & 0 & 0 & 1 & 0 & 0 & 540377 & 49,81 & 7,23 & 14,4 & $-0,12$ & 2,8 & 20 & 0,5404 & 0 & 0,40830 & 0,00806 \\
\hline 695 & 47 & 1 & 0 & 0 & 0 & 0 & 0 & 1 & 0 & 0 & 543937 & 52,25 & 7,53 & 12,44 & $-0,15$ & 2,76 & 24 & 0,5439 & 0 & 0,37677 & 0,00401 \\
\hline 696 & 47 & 1 & 0 & 0 & 0 & 0 & 0 & 1 & 0 & 0 & 517687 & 47,74 & 8,96 & 13,43 & $-0,22$ & 2,79 & 30 & 0,5177 & 0 & 0,34806 & 0,00158 \\
\hline 697 & 47 & 1 & 0 & 0 & 0 & 0 & 0 & 1 & 0 & 0 & 565092 & 47,97 & 8,74 & 11,08 & $-0,14$ & 2,81 & 36 & 0,5651 & 0 & 0,32404 & 0,00038 \\
\hline 698 & 47 & 1 & 0 & 0 & 0 & 0 & 0 & 1 & 0 & 0 & 614666 & 56,62 & 9 & 9,04 & $-0,43$ & 2,86 & 37 & 0,6147 & 0 &, 29174 & 0,00020 \\
\hline 699 & 47 & 1 & 0 & 0 & 0 & 0 & 0 & 1 & 0 & 0 & 627742 & 57,75 & 8,93 & 9,75 & $-0,4$ & 2,9 & 52 & 0,6277 & 1 & 0,23760 & \begin{tabular}{|l}
, 00001 \\
\end{tabular} \\
\hline 700 & 48 & 0 & 1 & 0 & 0 & 0 & 1 & 0 & 0 & 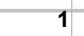 & 14936 & 38,1 & 36,75 & 2,91 & $-0,35$ & 3 & 0 & 0,0149 & 0 & 0,10707 & 0,89152 \\
\hline 701 & 48 & 1 & 0 & 0 & 0 & 0 & 1 & 0 & 0 & 0 & 15769 & 39,53 & 37,94 & 3,22 & $-0,17$ & 3 & 1 & 0,0158 & 0 &, 07842 & 0,80130 \\
\hline 702 & 48 & 1 & 0 & 0 & 0 & 0 & 1 & 0 & 0 & 0 & 17117 & 37,71 & 35,68 & 3,2 & $-0,14$ & 2,97 & 1 & 0,0171 & 0 & 0,07111 & 0,83226 \\
\hline 703 & 48 & 1 & 0 & 0 & 0 & 0 & 1 & 0 & 0 & 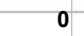 & 17891 & 35,64 & 34,85 & 3,77 & $-0,1$ & 2,95 & 2 & 0,0179 & 0 & 0,07820 & 0,82063 \\
\hline 704 & 48 & 1 & 0 & 0 & 0 & 0 & 1 & 0 & 0 & 0 & 17544 & 33,39 & 34,85 & 4,6 & $-0,09$ & 2,94 & 2 & 0,0175 & 0 & , 07749 & 0,82616 \\
\hline 705 & 48 & 1 & 0 & 0 & 0 & 0 & 1 & 0 & 0 & 0 & 17205 & 36,71 & 33,18 & 5,81 & $-0,08$ & 2,93 & 2 & 0,0172 & 0 & 0,07275 & 0,83918 \\
\hline 706 & 48 & 1 & 0 & 0 & 0 & 0 & 1 & 0 & 0 & 0 & 16544 & 36,31 & 33,55 & 5,4 & $-0,07$ & 3,01 & 2 & 0,0165 & 0 & 0,08056 & 0,82002 \\
\hline 707 & 48 & 0 & 1 & 0 & 0 & 0 & 1 & 0 & 0 & 0 & 15265 & 40,03 & 41,01 & 4,29 & $-0,1$ & 3,08 & 2 & 0,0153 & 1 & 0,19328 & 0,77628 \\
\hline 708 & 48 & 0 & 1 & 0 & 0 & 0 & 1 & 0 & 0 & 0 & 15387 & 51,76 & 41,98 & 4,18 & $-0,2$ & 3 & 5 & 0,0154 & 0 & 0,24944 & 0,66031 \\
\hline 709 & 48 & 0 & 1 & 0 & 0 & 0 & 1 & 0 & 0 & 0 & 16157 & 61,48 & 39,04 & 4,86 & $-0,22$ & 2,85 & 5 & 0,0162 & 0 & 0,19896 & 0,72783 \\
\hline 710 & 48 & 0 & 1 & 0 & 0 & 0 & 1 & 0 & 0 & 0 & 17363 & 58,88 & 37,81 & 5,37 & $-0,09$ & 3,01 & 5 & 0,0174 & 0 & 23450 & 0,69447 \\
\hline 711 & 48 & 0 & 1 & 0 & 0 & 0 & 1 & 0 & 0 & 0 & 18074 & 61,97 & 36,84 & 3,68 & $-0,11$ & 2,89 & 5 & 0,0181 & 0 & 0,20075 & 0,73801 \\
\hline 712 & 48 & 0 & 1 & 0 & 0 & 0 & 1 & 0 & 0 & 0 & 19257 & 59,21 & 36,81 & 7,54 & $-0,16$ & 3,01 & 7 & 0,0193 & 0 & 0,28185 & 0,63151 \\
\hline 713 & 48 & 0 & 1 & 0 & 0 & 0 & 1 & 0 & 0 & 0 & 20639 & 65,21 & 36,47 & 6,13 & $-0,11$ & 3,01 & 7 & 0,0206 & 0 & ,28026 & 0,61701 \\
\hline 714 & 48 & 1 & 0 & 0 & 0 & 0 & 1 & 0 & 0 & 0 & 21515 & 53,41 & 42,87 & 6,59 & $-0,16$ & 3,1 & 7 & 0,0215 & 0 & 0,17032 & 0,41186 \\
\hline 715 & 48 & 1 & 0 & 0 & 0 & 0 & 1 & 0 & 0 & 0 & 23193 & 51,69 & 41,86 & 6,61 & $-0,12$ & 3,14 & 7 & 0,0232 & 0 & 0,17626 & 0,41404 \\
\hline 716 & 48 & 1 & 0 & 0 & 0 & 0 & 1 & 0 & 0 & 0 & 24391 & 53,28 & 41,8 & 5,69 & $-0,05$ & 3,06 & 7 & 0,0244 & 0 & 16935 & 0,43326 \\
\hline 717 & 48 & 0 & 0 & 0 & 0 & 0 & 1 & 0 & 0 & 0 & 25201 & 54,94 & 40,63 & 5,04 & $-0,04$ & 2,94 & 10 & 0,0252 & 0 & 0,09701 & 0,82541 \\
\hline 718 & 49 & 0 & 0 & 1 & 0 & 0 & 0 & 1 & 0 & 1 & 123574 & 48,92 & 10,01 & 12,15 & $-0,06$ & 1,78 & 0 & 0,1236 & 1 & 0,08081 & 0,86062 \\
\hline 719 & 49 & 0 & 0 & 1 & 0 & 0 & 1 & 0 & 0 & 0 & 123330 & 57,84 & 8,59 & 11,12 & $-0,06$ & 1,78 & 2 & 0,1233 & 0 & 0,04975 & 0,94186 \\
\hline 720 & 49 & 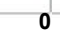 & 1 & 0 & 0 & 0 & & 0 & 0 & 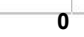 & 131187 & 51,25 & 7,31 & 13,14 & $-0,01$ & 1,73 & 2 & 0,1312 & 0 & 0,01965 & 0,98992 \\
\hline
\end{tabular}




\begin{tabular}{|c|c|c|c|c|c|c|c|c|c|c|c|c|c|c|c|c|c|c|c|c|c|}
\hline obs & ID & AA & $A B$ & BA & BB & MD & LV & PL & NL & REC & PIB & COMEX & AGRI & PREF & ODP & CAP & APRE & PIB2 & $\mathrm{ACl}$ & CREC & po \\
\hline 721 & 49 & 0 & 1 & 0 & 0 & 0 & 1 & 0 & 0 & 0 & 131573 & 43,6 & 9,1 & 14,56 & $-0,05$ & 1,67 & 2 & 0,1316 & 0 & 0,01925 & 0,99040 \\
\hline 722 & 49 & 0 & 1 & 0 & 0 & 0 & 0 & 1 & 0 & 0 & 123717 & 42,07 & 8,07 & 15,66 & $-0,05$ & 1,71 & 2 & 0,1237 & 0 & 0,04164 & 0,96825 \\
\hline 723 & 49 & 0 & 1 & 0 & 0 & 0 & 0 & 1 & 0 & 0 & 128279 & 47,86 & 6,16 & 14 & $-0,07$ & 1,74 & 3 & 0,1283 & 0 & 0,04800 & 0,96251 \\
\hline 724 & 49 & 0 & 1 & 0 & 0 & 0 & 0 & 1 & 0 & 0 & 132633 & 42,14 & 6,95 & 16,6 & $-0,04$ & 1,62 & 4 & 0,1326 & 0 & 0,05138 & 0,96114 \\
\hline 725 & 49 & 0 & 1 & 0 & 0 & 0 & 0 & 1 & 0 & 0 & 120887 & 48,58 & 6,4 & 14,4 & $-0,06$ & 1,49 & 14 & 0,1209 & 1 & 0,16858 & 0,84793 \\
\hline 726 & 49 & 0 & 1 & 0 & 0 & 0 & 0 & 1 & 0 & 0 & 111512 & 50,58 & 7,19 & 14,91 & $-0,1$ & 1,55 & 14 & 0,1115 & 0 & 0,17411 & \begin{tabular}{|l|l|}
0,8638 \\
\end{tabular} \\
\hline 727 & 49 & 0 & 1 & 0 & 0 & 0 & 0 & 1 & 0 & 0 & 131904 & 55,37 & 6,34 & 12,5 & $-0,04$ & 1,48 & 15 & 0,1319 & 0 & 0,20343 & 0,80295 \\
\hline 728 & 49 & 0 & 1 & 0 & 0 & 0 & 0 & 1 & 0 & 0 & 145513 & 60,13 & 4,1 & 11,2 & $-0,04$ & 1,6 & 15 & 0,1455 & 0 & 0,23315 & 0,77506 \\
\hline 729 & 49 & 0 & 1 & 0 & 0 & 0 & 0 & 1 & 0 & 0 & 159879 & 58,67 & 3,32 & 11,23 & $-0,03$ & 1,46 & 15 & 0,1599 & 0 & 0,21305 & 0,80282 \\
\hline 730 & 49 & 0 & 1 & 0 & 0 & 0 & 0 & 1 & 0 & 0 & 173874 & 56,2 & 3,62 & 12,51 & $-0,03$ & 1,45 & 15 & 0,1739 & 0 & 0,23285 & 0,78876 \\
\hline 731 & 49 & 1 & 0 & 0 & 0 & 0 & 0 & 1 & 0 & 0 & 183051 & 51,83 & 7,22 & 15,28 & $-0,02$ & 1,39 & 15 & 0,1831 & 0 & 0,14399 & 0,67659 \\
\hline 732 & 49 & 1 & 0 & 0 & 0 & 0 & 0 & 1 & 0 & 0 & 177189 & 38,52 & 9,17 & 17,16 & $-0,02$ & 1,53 & 15 & 0,1772 & 0 & 0,17012 & 0,64137 \\
\hline 733 & 49 & 1 & 0 & 0 & 0 & 0 & 0 & 1 & 0 & 0 & 174551 & 46,14 & 6,49 & 13,63 & $-0,01$ & 1,4 & 15 & 0,1746 & 0 & 0,13636 & 0,71153 \\
\hline 734 & 49 & 1 & 0 & 0 & 0 & 0 & 0 & 1 & 0 & 0 & 181841 & 49,64 & 6,84 & 11,02 & $-0,02$ & 1,31 & 15 & 0,1818 & 0 & 0,12905 & 0,71628 \\
\hline 735 & 49 & 1 & 0 & 0 & 0 & 0 & 0 & 1 & 0 & 0 & 192071 & 50,4 & 8,06 & 10,3 & $-0,01$ & 1,36 & 15 & 0,1921 & 0 & 0,14732 & 0,66373 \\
\hline 736 & 50 & 0 & 0 & 0 & 1 & 0 & 0 & 1 & 0 & 0 & 6134 & 55,92 & 8,38 & 0,57 & $-8,45$ & 1,67 & 0 & 0,0061 & 0 & 0,00564 & 0,98805 \\
\hline 737 & 50 & 0 & 0 & 0 & 1 & 0 & 0 & 1 & 0 & 0 & 6622 & 57,43 & 8,58 & 0,54 & $-6,77$ & 1,8 & 0 & 0,0066 & 0 & 0,01137 & 0,97699 \\
\hline 738 & 50 & 0 & 0 & 0 & 1 & 0 & 0 & 1 & 0 & 0 & 6902 & 63,93 & 9,26 & 0,51 & $-6,91$ & 1,93 & 0 & 0,0069 & 0 & 0,01367 & 0,96989 \\
\hline 739 & 50 & 0 & 0 & 0 & 1 & 0 & 0 & 1 & 0 & 0 & 7300 & 65,44 & 7,76 & 0,78 & $-6,61$ & 1,89 & 0 & 0,0073 & 0 & 0,01332 & 0,97177 \\
\hline 740 & 50 & 0 & 0 & 1 & 0 & 0 & 0 & 1 & 0 & 0 & 7717 & 66,36 & 8,4 & 0,46 & $-4,8$ & 2,06 & 0 & 0,0077 & 0 & 0,01206 & 0,96969 \\
\hline 741 & 50 & 0 & 0 & 1 & 0 & 0 & 0 & 1 & 0 & 0 & 8159 & 70,3 & 7,55 & 1,07 & $-4,7$ & 1,87 & 0 & 0,0082 & 0 & 0,00936 & 0,97656 \\
\hline 742 & 50 & 0 & 0 & 1 & 0 & 0 & 0 & 1 & 0 & 0 & 8602 & 73,46 & 7,44 & 0,62 & $-4,37$ & 2,04 & 0 & 0,0086 & 0 & 0,01307 & 0,96658 \\
\hline 743 & 50 & 0 & 0 & 1 & 0 & 0 & 0 & 1 & 0 & 0 & 9109 & 82,87 & 7,71 & 9,57 & $-3,59$ & 2,12 & 0 & 0,0091 & 0 & 0,01976 & 0,94760 \\
\hline 744 & 50 & 0 & 1 & 0 & 0 & 0 & 0 & 1 & 0 & 0 & 9795 & 86,03 & 7,76 & 8,81 & $-3,69$ & 2,15 & 0 & 0,0098 & 0 & 0,00846 & 0,98876 \\
\hline 745 & 50 & 0 & 1 & 0 & 0 & 0 & 0 & 1 & 0 & 0 & 10123 & 83,36 & 10,18 & 10,33 & $-3,59$ & 2,26 & 0 & 0,0101 & 0 & 0,01141 & 0,98434 \\
\hline 746 & 50 & 0 & 1 & 0 & 0 & 0 & 0 & 1 & 0 & 0 & 10499 & 85,46 & 9,57 & 9,32 & $-3,61$ & 2,23 & 0 & 0,0105 & 0 & 0,01061 & 0,98537 \\
\hline 747 & 50 & 0 & 1 & 0 & 0 & 0 & 0 & 1 & 0 & 0 & 10766 & 90,76 & 7,02 & 7,67 & $-3,46$ & 2,3 & 0 & 0,0108 & 0 &, 01093 & 0,98511 \\
\hline 748 & 50 & 0 & 1 & 0 & 0 & 0 & 0 & 1 & 0 & 0 & 10919 & 85,34 & 6,53 & 8,76 & $-3,31$ & 2,22 & 0 & 0,0109 & 0 & 0,00993 & 0,98740 \\
\hline 749 & 51 & 0 & 1 & 0 & 0 & 0 & 1 & 0 & 0 & 0 & 6454 & 94,6 & 14,79 & 0 & $-1,98$ & 2,97 & 0 & 0,0065 & 0 & 0,02555 & 0,97296 \\
\hline 750 & 51 & 0 & 0 & 1 & 0 & 0 & 1 & 0 & 0 & 0 & 6831 & 90,96 & 14,79 & 0 & $-1,46$ & 2,97 & 0 & 0,0068 & 0 &, 06588 & 0,86332 \\
\hline 751 & 51 & 0 & 0 & 1 & 0 & 0 & 1 & 0 & 0 & 0 & 7379 & 108,6 & 14,99 & 0 & $-2,5$ & 2,98 & 0 & 0,0074 & 0 & 0,05192 & 0,86847 \\
\hline 752 & 51 & 0 & 0 & 1 & 0 & 0 & 1 & 0 & 0 & 0 & 7432 & 101,84 & 11,99 & 0 & $-2,01$ & 3 & 0 & 0,0074 & 0 & 0,05369 & 0,88264 \\
\hline 753 & 51 & 0 & 0 & 1 & 0 & 0 & 1 & 0 & 0 & 0 & 8151 & 98,93 & 15,35 & 0 & $-1,07$ & 3 & 0 & 0,0082 & 0 & 0,07847 & 0,82611 \\
\hline 754 & 51 & 0 & 1 & 0 & 0 & 0 & 1 & 0 & 0 & 0 & 8313 & 91,92 & 14,2 & 0,4 & $-0,58$ & 3,01 & 0 & 0,0083 & 0 & 0,04015 & 0,96136 \\
\hline 755 & 51 & 0 & 1 & 0 & 0 & 0 & 1 & 0 & 0 & 0 & 8333 & 87,53 & 13,79 & $-0,38$ & $-0,57$ & 3,05 & 0 & 0,0083 & 0 & 0,04119 & 0,96203 \\
\hline 756 & 51 & 0 & 0 & 1 & 0 & 0 & 1 & 0 & 0 & 0 & 8839 & 91,84 & 11,9 & $-0,3$ & $-0,61$ & 3,09 & 0 & 0,0088 & 0 & 0,08663 & 0,83556 \\
\hline 757 & 51 & 0 & 1 & 0 & 0 & 0 & 1 & 0 & 0 & 0 & 9248 & 85,83 & 40,84 & 0,64 & $-0,4$ & 3,23 & 0 & 0,0092 & 0 & 0,15596 & 0,73322 \\
\hline 758 & 51 & 0 & 1 & 0 & 0 & 0 & 1 & 0 & 0 & 0 & 9498 & 91 & 14,83 & $-0,32$ & $-0,66$ & 3,14 & 0 & 0,0095 & 0 & 0,04821 & 0,95269 \\
\hline 759 & 51 & 0 & 1 & 0 & 0 & 0 & 1 & 0 & 0 & 0 & 9931 & 88,51 & 11,66 & $-0,13$ & $-0,59$ & 3,16 & 0 & 0,0099 & 0 & 0,04382 & 0,96100 \\
\hline 760 & 51 & 0 & 1 & 0 & 0 & 0 & 1 & 0 & 0 & 0 & 10762 & 86,33 & 10,59 & 1,09 & $-0,74$ & 3,02 & 0 & 0,0108 & 0 & 0,03326 & 0,97180 \\
\hline 761 & 51 & 0 & 1 & 0 & 0 & 0 & 1 & 0 & 0 & 0 & 11653 & 95,1 & 12,15 & 3,64 & $-0,99$ & 3,09 & 0 & 0,0117 & 0 & 0,03787 & 0,96382 \\
\hline 762 & 51 & 0 & 1 & 0 & 0 & 0 & 1 & 0 & 0 & 0 & 12380 & 96,72 & 10,17 & 2,59 & $-5,92$ & 3,06 & 0 & 0,0124 & 0 & 0,00759 & 0,99134 \\
\hline 763 & 51 & 0 & 1 & 0 & 0 & 0 & 1 & 0 & 0 & 0 & 11433 & 86,69 & 12,49 & 2,66 & $-2,59$ & 2,98 & 0 & 0,0114 & 0 & 0,02002 & 0,98086 \\
\hline 764 & 51 & 0 & 1 & 0 & 0 & 0 & 1 & 0 & 0 & 0 & 12412 & 88,14 & 12,16 & 3,7 & $-1,28$ & 2,96 & 0 & 0,0124 & 0 & 0,02883 & 0,97391 \\
\hline 765 & 51 & 0 & 1 & 0 & 0 & 0 & 1 & 0 & 0 & 0 & 13163 & 95,62 & 12,31 & 7,54 & $-0,91$ & 2,98 & 0 & 0,0132 & 0 & 0,03468 & 0,96724 \\
\hline 766 & 51 & 0 & 1 & 0 & 0 & 0 & 1 & 0 & 0 & 0 & 13799 & 100,77 & 12,61 & 6,92 & $-0,53$ & 2,95 & 0 & 0,0138 & 0 & 0,03825 & 0,96261 \\
\hline 767 & 52 & 0 & 1 & 0 & 0 & 0 & 0 & 1 & 0 & 0 & 8878 & 95,67 & 25,78 & 7,49 & $-1,91$ & 2,16 & 0 & 0,0089 & 0 & ,03325 & 0,93195 \\
\hline 768 & 52 & 0 & 1 & 0 & 0 & 0 & 0 & 1 & 0 & 0 & 9387 & 98,54 & 27,18 & 9,48 & $-0,63$ & 2,03 & 0 & 0,0094 & 0 & 0,04367 & 0,91150 \\
\hline 769 & 52 & 0 & 1 & 0 & 0 & 0 & 0 & 1 & 0 & 0 & 9714 & 95,97 & 22,18 & 5,75 & $-0,69$ & 1,91 & 0 & 0,0097 & 0 & 0,02904 & 0,94852 \\
\hline 770 & 52 & 0 & 1 & 0 & 0 & 0 & 0 & 1 & 0 & 0 & 8846 & 97,73 & 21,18 & 8,72 & $-0,84$ & 1,89 & 0 & 0,0088 & 0 & ,02617 & 0,95409 \\
\hline 771 & 52 & 0 & 1 & 0 & 0 & 0 & 0 & 1 & 0 & 0 & 8679 & 101,7 & 21,05 & 8,88 & $-0,24$ & 1,87 & 0 & 0,0087 & 0 & 0,03042 & 0,94642 \\
\hline 772 & 52 & 0 & 1 & 0 & 0 & 0 & 0 & 1 & 0 & 0 & 8865 & 83,64 & 18,03 & 8,7 & $-0,14$ & 1,99 & 0 & 0,0089 & 0 & 0,03105 & 0,95618 \\
\hline 773 & 52 & 0 & 1 & 0 & 0 & 0 & 0 & 1 & 0 & 0 & 8843 & 84,76 & 17,14 & 9,14 & $-1,31$ & 2,11 & 0 & 0,0088 & 0 & 0,02495 & 0,96320 \\
\hline 774 & 52 & 0 & 1 & 0 & 0 & 0 & 0 & 1 & 0 & 0 & 9041 & 80,3 & 17,59 & 88,91 & 0,17 & 2,02 & 0 & 0,009 & 0 & 0,05000 & 0,94491 \\
\hline 775 & 52 & 0 & 1 & 0 & 0 & 0 & 0 & 1 & 0 & 0 & 9104 & 81,77 & 17,5 & 11,77 & $-0,53$ & 1,7 & 0 & 0,0091 & 0 & 0,01842 & 0,97492 \\
\hline 776 & 52 & 0 & 1 & 0 & 0 & 0 & 0 & 1 & 0 & 0 & 9459 & 84,75 & 15,1 & 7,22 & $-0,76$ & 1,66 & 0 & 0,0095 & 0 & 0,01440 & 0,98062 \\
\hline 777 & 52 & 0 & 1 & 0 & 0 & 0 & 0 & 1 & 0 & 0 & 9115 & 89,77 & 14,76 & 3,53 & $-0,37$ & 1,65 & 0 & 0,0091 & 0 & 0,01558 & 0,97847 \\
\hline 778 & 52 & 0 & 1 & 0 & 0 & 0 & 0 & 1 & 0 & 0 & 9706 & 85,13 & 16,09 & 7,64 & $-0,55$ & 1,66 & 0 & 0,0097 & 0 & 0,01613 & 0,97795 \\
\hline 779 & 52 & 0 & 1 & 0 & 0 & 0 & 0 & 1 & 0 & 0 & 9412 & 88,17 & 16,78 & 6,32 & $-0,64$ & 1,67 & 0 & 0,0094 & 0 & 0,01641 & 0,97642 \\
\hline 780 & 52 & & 0 & 0 & 0 & 0 & 0 & & & 0 & 9300 & 81,69 & 17,81 & 6,01 & $-0,84$ & 1,75 & 0 & 0,0093 & 3 & 0,00143 & 0,99680 \\
\hline
\end{tabular}


Obs ID AA AB $\quad$ BA $\quad$ BB $\quad$ MD LV PL NL REC PIB COMEX AGRI PREF ODP CAP APRE PIB2 ACI CREC P0

\begin{tabular}{|c|c|c|c|c|c|c|c|c|c|c|c|c|c|c|c|c|c|c|c|c|c|}
\hline 781 & 53 & 0 & 0 & 0 & 1 & 0 & 0 & 1 & 0 & 0 & 9241 & 110,49 & 41,14 & 1,21 & $-8,45$ & 2,49 & 0 & 0,0092 & 0 & 0,05752 & 0,56360 \\
\hline 782 & 53 & 0 & 0 & 0 & 1 & 0 & 0 & 1 & 0 & 0 & 9729 & 109,44 & 41,48 & 1,11 & $-6,86$ & 2,56 & 0 & 0,0097 & 0 & 0,08008 & 0,43040 \\
\hline 783 & 53 & 0 & 0 & 1 & 0 & 0 & 0 & 1 & 0 & 0 & 10292 & 114,19 & 43,88 & 1,62 & $-7,79$ & 2,62 & 0 & 0,0103 & 0 & 0,04073 & 0,58811 \\
\hline 784 & 53 & 0 & 0 & 1 & 0 & 0 & 0 & 1 & 0 & 0 & 10721 & 115,86 & 46,42 & 2,58 & $-15,54$ & 2,74 & 0 & 0,0107 & 0 & 0,00777 & 0,88188 \\
\hline 785 & 53 & 0 & 0 & 1 & 0 & 0 & 0 & 1 & 0 & 0 & 11639 & 134,82 & 46,71 & 2,86 & $-6,32$ & 2,62 & 0 & 0,0116 & 0 & 0,05106 & 0,38422 \\
\hline 786 & 53 & 0 & 0 & 1 & 0 & 0 & 0 & 1 & 0 & 0 & 12589 & 146,91 & 47,49 & 2,85 & $-6,64$ & 2,65 & 0 & 0,0126 & 0 & 0,04718 & 0,34789 \\
\hline 787 & 53 & 0 & 0 & 1 & 0 & 0 & 0 & 1 & 0 & 0 & 13608 & 141,75 & 53,09 & 2,83 & $-4,86$ & 2,68 & 0 & 0,0136 & 0 & 0,05827 & 0,18424 \\
\hline 788 & 53 & 0 & 0 & 1 & 0 & 0 & 0 & 1 & 0 & 0 & 14720 & 145,99 & 61,09 & 2,97 & $-4,75$ & 2,72 & 0 & 0,0147 & 0 & 0,05159 & 0,09980 \\
\hline 789 & 53 & 0 & 0 & 1 & 0 & 0 & 0 & 1 & 0 & 0 & 15785 & 144,02 & 57,69 & 2,21 & $-4,91$ & 2,72 & 0 & 0,0158 & 0 & 0,05443 & 0,13006 \\
\hline 790 & 53 & 0 & 0 & 1 & 0 & 0 & 0 & 0 & 1 & 0 & 16649 & 114,96 & 63,58 & 2,91 & $-4,74$ & 2,78 & 0 & 0,0166 & 0 & 0,04427 & 0,58120 \\
\hline 791 & 53 & 0 & 0 & 1 & 0 & 0 & 0 & 0 & 1 & 0 & 17038 & 117,26 & 63,45 & 1,78 & $-5,92$ & 2,63 & 0 & 0,017 & 0 & 0,02998 & 0,69861 \\
\hline 792 & 53 & 0 & 0 & 1 & 0 & 0 & 0 & 0 & 1 & 0 & 17474 & 121,51 & 60,91 & 1,64 & $-5,71$ & 2,6 & 0 & 0,0175 & 0 & 0,02849 & 0,72305 \\
\hline 793 & 53 & 0 & 1 & 0 & 0 & 0 & 0 & 0 & 1 & 0 & 17938 & 120,51 & 63,53 & 3,28 & $-6,58$ & 2,46 & 0 & 0,0179 & 0 & 0,01073 & 0,94546 \\
\hline 794 & 54 & 0 & 1 & 0 & 0 & 0 & 0 & 0 & 1 & 0 & 889 & 104,08 & 30,08 & 15,02 & $-4,16$ & 2,78 & 0 & 0,0009 & 0 & 0,00665 & 0,98796 \\
\hline 795 & 54 & 0 & 1 & 0 & 0 & 0 & 0 & 0 & 1 & 0 & 940 & 104,43 & 28,15 & 15,65 & $-4,34$ & 2,78 & 0 & 0,0009 & 0 & 0,00577 & 0,98992 \\
\hline 796 & 54 & 0 & 1 & 0 & 0 & 0 & 0 & 0 & 1 & 0 & 1074 & 107,19 & 35,65 & 10,39 & $-2,83$ & 2,51 & 0 & 0,0011 & 0 & 0,00874 & 0,98259 \\
\hline 797 & 54 & 0 & 1 & 0 & 0 & 0 & 0 & 0 & 1 & 0 & 1225 & 117,35 & 25,85 & 5,59 & $-2,81$ & 2,39 & 0 & 0,0012 & 0 & 0,00471 & 0,99182 \\
\hline 798 & 54 & 0 & 1 & 0 & 0 & 0 & 0 & 0 & 1 & 0 & 1120 & 120,83 & 22,88 & 1,65 & $-7,9$ & 2,66 & 0 & 0,0011 & 0 & 0,00126 & 0,99732 \\
\hline 799 & 54 & 0 & 1 & 0 & 0 & 0 & 0 & 0 & 1 & 0 & 1351 & 123,66 & 15,3 & 1,73 & $-3,35$ & 2,54 & 0 & 0,0014 & 0 & 0,00300 & 0,99554 \\
\hline 800 & 54 & 0 & 1 & 0 & 0 & 0 & 0 & 0 & 1 & 0 & 1497 & 197,53 & 14,72 & 4 & $-2,72$ & 2,5 & 0 & 0,0015 & 0 & 0,00405 & 0,98921 \\
\hline 801 & 54 & 0 & 1 & 0 & 0 & 0 & 0 & 0 & 1 & 0 & 1684 & 191,44 & 15,99 & 4,15 & $-3,31$ & 2,23 & 0 & 0,0017 & 0 & 0,00244 & 0,99359 \\
\hline 802 & 54 & 0 & 1 & 0 & 0 & 0 & 0 & 0 & 1 & 0 & 1591 & 147,89 & 23,49 & 6,66 & $-2,08$ & 2,05 & 0 & 0,0016 & 0 & 0,00356 & 0,99282 \\
\hline 803 & 54 & 0 & 1 & 0 & 0 & 0 & 0 & 1 & 0 & 0 & 1686 & 159,39 & 24,37 & 4,8 & $-6,5$ & 2,29 & 0 & 0,0017 & 0 & 0,01039 & 0,95631 \\
\hline 804 & 54 & 0 & 1 & 0 & 0 & 0 & 0 & 1 & 0 & 0 & 1833 & 204,76 & 23,18 & 6,63 & $-2,36$ & 2,19 & 0 & 0,0018 & 0 & 0,03032 & 0,84856 \\
\hline 805 & 54 & 0 & 1 & 0 & 0 & 0 & 0 & 1 & 0 & 0 & 1878 & 184,5 & 24,36 & 4,91 & $-2,96$ & 2,34 & 0 & 0,0019 & 0 & 0,03147 & 0,85870 \\
\hline 806 & 55 & 1 & 0 & 0 & 0 & 0 & 1 & 0 & 0 & 0 & 2814 & 111,77 & 43,53 & 8,23 & $-1,98$ & 2,63 & 0 & 0,0028 & 0 & 0,03375 & 0,81381 \\
\hline 807 & 56 & 0 & 0 & 1 & 0 & 0 & 0 & 1 & 0 & 0 & 244 & 64,79 & 11,03 & 26,26 & $-15,84$ & 2,02 & 0 & 0,0002 & 0 & 0,00049 & 0,99807 \\
\hline 808 & 56 & 0 & 0 & 1 & 0 & 0 & 0 & 1 & 0 & 0 & 250 & 66,5 & 10,77 & 16,74 & $-12,44$ & 2,02 & 0 & 0,0003 & 0 & 0,00130 & 0,99540 \\
\hline 809 & 56 & 0 & 0 & 1 & 0 & 0 & 0 & 1 & 0 & 0 & 253 & 68,98 & 10,17 & 12,21 & $-18,49$ & 2,15 & 0 & 0,0003 & 0 & 0,00024 & 0,99889 \\
\hline 810 & 56 & 0 & 0 & 1 & 0 & 0 & 0 & 1 & 0 & 0 & 264 & 61,03 & 9,93 & 11,77 & $-27,47$ & 2,18 & 0 & 0,0003 & 0 & 0,00002 & 0,99990 \\
\hline 811 & 56 & 0 & 0 & 1 & 0 & 0 & 0 & 1 & 0 & 0 & 269 & 66,04 & 12,02 & 4,81 & $-32,96$ & 2,14 & 0 & 0,0003 & 0 & 0,00000 & 0,99997 \\
\hline 812 & 56 & 0 & 1 & 0 & 0 & 0 & 0 & 1 & 0 & 0 & 270 & 75,61 & 10,47 & 3,71 & $-27,71$ & 2,31 & 0 & 0,0003 & 0 & 0,00001 & 0,99997 \\
\hline 813 & 57 & 0 & 0 & 0 & 1 & 0 & 0 & 0 & 1 & 0 & 20279 & 93,71 & 21,97 & 0,23 & $-0,52$ & 2,91 & 0 & 0,0203 & 0 & 0,08998 & 0,81635 \\
\hline 814 & 57 & 0 & 0 & 1 & 0 & 0 & 0 & 0 & 1 & 0 & 21728 & 85,72 & 21,74 & 0,35 & $-0,82$ & 2,91 & 0 & 0,0217 & 0 & 0,03584 & 0,91480 \\
\hline 815 & 57 & 0 & 0 & 1 & 0 & 0 & 0 & 1 & 0 & 0 & 22910 & 80,5 & 23,99 & 0,3 & $-1,28$ & 2,98 & 0 & 0,0229 & 0 & 0,14779 & 0,45402 \\
\hline 816 & 57 & 0 & 0 & 1 & 0 & 0 & 0 & 0 & 1 & 0 & 24006 & 79,98 & 18,57 & 0,34 & $-0,92$ & 3,05 & 0 & 0,024 & 0 & 0,03678 & 0,92176 \\
\hline 817 & 57 & 0 & 0 & 1 & 0 & 0 & 0 & 0 & 1 & 0 & 25460 & 77,91 & 18,97 & 0,36 & $-1,52$ & 3,04 & 0 & 0,0255 & 0 & 0,03132 & 0,93225 \\
\hline 818 & 57 & 0 & 0 & 1 & 0 & 0 & 0 & 0 & 1 & 0 & 26659 & 82,46 & 15,07 & 0,42 & $-1,29$ & 3,02 & 0 & 0,0267 & 0 & 0,02802 & 0,94314 \\
\hline 819 & 57 & 0 & 0 & 1 & 0 & 0 & 0 & 0 & 1 & 0 & 27671 & 89,55 & 16,44 & 0,39 & $-2,19$ & 3,07 & 0 & 0,0277 & 0 & 0,02499 & 0,94204 \\
\hline 820 & 57 & 0 & 0 & 1 & 0 & 0 & 0 & 0 & 1 & 0 & 28037 & 85,34 & 17,4 & 0,39 & $-1,23$ & 3,13 & 0 & 0,028 & 0 & 0,03690 & 0,91868 \\
\hline 821 & 57 & 0 & 0 & 1 & 0 & 0 & 0 & 0 & 1 & 0 & 29355 & 82,39 & 16,61 & 0,45 & $-1,32$ & 3,05 & 0 & 0,0294 & 0 & 0,03150 & 0,93362 \\
\hline 822 & 57 & 0 & 0 & 1 & 0 & 0 & 0 & 0 & 1 & 0 & 31186 & 86,95 & 15,67 & 0,45 & $-1,34$ & 2,98 & 0 & 0,0312 & 0 & 0,02801 & 0,94016 \\
\hline 823 & 57 & 0 & 0 & 1 & 0 & 0 & 0 & 0 & 1 & 0 & 32273 & 90,25 & 15,3 & 0,52 & $-1,31$ & 2,92 & 0 & 0,0323 & 0 & 0,02606 & 0,94353 \\
\hline 824 & 57 & 0 & 0 & 1 & 0 & 0 & 0 & 0 & 1 & 0 & 33965 & 93,94 & 14,51 & 0,76 & $-1,47$ & 3,08 & 0 & 0,034 & 0 & 0,03029 & 0,93248 \\
\hline 825 & 57 & 0 & 0 & 1 & 0 & 0 & 0 & 0 & 1 & 0 & 36244 & 104,08 & 13,33 & 8,32 & $-0,92$ & 2,97 & 0 & 0,0362 & 0 & 0,03128 & 0,92959 \\
\hline 826 & 57 & 0 & 1 & 0 & 0 & 0 & 0 & 0 & 1 & 0 & 37780 & 115,4 & 13,66 & 6,78 & $-0,97$ & 2,81 & 0 & 0,0378 & 0 & 0,01098 & 0,98677 \\
\hline 827 & 57 & 0 & 1 & 0 & 0 & 0 & 0 & 0 & 1 & 0 & 38930 & 94,37 & 16,06 & 8,59 & $-1,28$ & 2,9 & 0 & 0,0389 & 0 & 0,01226 & 0,98676 \\
\hline 828 & 57 & 0 & 1 & 0 & 0 & 0 & 0 & 0 & 1 & 0 & 40297 & 105,76 & 14,83 & 7,68 & $-1,39$ & 2,74 & 0 & 0,0403 & 0 & 0,00927 & 0,98931 \\
\hline 829 & 57 & 0 & 1 & 0 & 0 & 0 & 0 & 0 & 1 & 0 & 39524 & 105,74 & 13,57 & 7,63 & $-2,27$ & 2,53 & 0 & 0,0395 & 0 & 0,00496 & 0,99431 \\
\hline 830 & 57 & 0 & 1 & 0 & 0 & 0 & 0 & 1 & 0 & 0 & 41142 & 107,8 & 14,52 & 7,29 & $-2,59$ & 2,45 & 0 & 0,0411 & 0 & 0,03164 & 0,94252 \\
\hline 831 & 58 & 0 & 0 & 0 & 1 & 0 & 0 & 1 & 0 & 0 & 5709 & 71,07 & 26,61 & 2,13 & $-6,28$ & 2,17 & 0 & 0,0057 & 0 & 0,04674 & 0,83866 \\
\hline 832 & 58 & 0 & 0 & 1 & 0 & 0 & 0 & 1 & 0 & 0 & 5976 & 80,87 & 26,17 & 1,96 & $-5,52$ & 2,37 & 0 & 0,006 & 0 & 0,03188 & 0,85639 \\
\hline 833 & 58 & 0 & 0 & 1 & 0 & 0 & 0 & 1 & 0 & 0 & 6259 & 85,84 & 37,68 & 1,68 & $-4,41$ & 2,22 & 0 & 0,0063 & 0 & 0,05183 & 0,69835 \\
\hline 834 & 58 & 0 & 0 & 1 & 0 & 0 & 0 & 1 & 0 & 0 & 6580 & 92,55 & 43,8 & 1,89 & $-3,7$ & 2,4 & 0 & 0,0066 & 0 & 0,07617 & 0,46935 \\
\hline 835 & 58 & 0 & 0 & 1 & 0 & 0 & 0 & 1 & 0 & 0 & 7006 & 106,09 & 32,76 & 7,98 & $-3,11$ & 2,3 & 0 & 0,007 & 0 & 0,06598 & 0,61939 \\
\hline 836 & 58 & 0 & 1 & 0 & 0 & 0 & 0 & 1 & 0 & 0 & 7389 & 111,57 & 40,12 & 8,78 & $-2,8$ & 2,48 & 0 & 0,0074 & 0 & 0,06727 & 0,76755 \\
\hline 837 & 58 & 0 & 1 & 0 & 0 & 0 & 0 & 1 & 0 & 0 & 7363 & 87,18 & 44,9 & 8,02 & $-2,69$ & 2,41 & 0 & 0,0074 & 0 & 0,07422 & 0,76856 \\
\hline 838 & 58 & 0 & 1 & 0 & 0 & 0 & 0 & 1 & 0 & 0 & 7610 & 97,88 & 46,54 & 7,52 & $-2,59$ & 2,35 & 0 & 0,0076 & 0 & 0,07480 & 0,73624 \\
\hline 839 & 58 & 0 & 1 & 0 & 0 & 0 & 0 & 1 & 0 & 0 & 7788 & 113,19 & 46,08 & 6,35 & $-2,46$ & 2,39 & 0 & 0,0078 & 0 & 0,07814 & 0,68959 \\
\hline 840 & 58 & 0 & 1 & 0 & 0 & 0 & 0 & 1 & 0 & 0 & 7753 & 112,22 & 48,95 & 6,3 & $-1,99$ & 2,43 & 0 & 0,0078 & 0 & 0,09560 & 0,60421 \\
\hline
\end{tabular}




\begin{tabular}{|c|c|c|c|c|c|c|c|c|c|c|c|c|c|c|c|c|c|c|c|c|c|}
\hline bs & ID & AA & $A B$ & BA & BB & MD & LV & PL & NL & REC & PIB & COMEX & AGRI & PREF & ODP & CAP & APRE & PIB2 & $\mathrm{ACl}$ & CREC & po \\
\hline 841 & 59 & 0 & 0 & 0 & 1 & 0 & 0 & 1 & 0 & 0 & 3896 & 82,19 & 17,55 & 1 & $-8,75$ & 2,24 & 0 & 0,0039 & 0 & 0,01781 & \begin{tabular}{|l}
0,93883 \\
\end{tabular} \\
\hline 842 & 59 & 0 & 0 & 0 & 1 & 0 & 0 & 1 & 0 & 0 & 4304 & 75,04 & 19,46 & 2,66 & $-6,88$ & 2,36 & 0 & 0,0043 & 0 &, 03807 & \begin{tabular}{|l|l|}
0,88088 \\
\end{tabular} \\
\hline 843 & 59 & 0 & 0 & 0 & 1 & 0 & 0 & 1 & 0 & 0 & 4900 & 72,04 & 17,46 & 2,31 & $-3,34$ & 2,37 & 0 & 0,0049 & 0 & 0,09031 & \begin{tabular}{|l|l|}
0,77358 \\
\end{tabular} \\
\hline 844 & 59 & 0 & 0 & 0 & 1 & 0 & 0 & 1 & 0 & 0 & 5547 & 62,61 & 16,01 & 1,96 & $-3,22$ & 2,29 & 0 & 0,0055 & 0 & 0,08108 & 0,82027 \\
\hline 845 & 59 & 0 & 0 & 1 & 0 & 0 & 0 & 1 & 0 & 0 & 6310 & 58,34 & 16,29 & 8,59 & $-3,61$ & 2,15 & 0 & 0,0063 & 0 & 0,02762 & 0,92697 \\
\hline 846 & 59 & 0 & 0 & 1 & 0 & 0 & 0 & 1 & 0 & 0 & 6745 & 55,7 & 20,29 & 8,46 & $-2,45$ & 2,34 & 0 & 0,0067 & 0 & 0,05653 & $\mid 0,84557$ \\
\hline 847 & 59 & 0 & 0 & 1 & 0 & 0 & 0 & 1 & 0 & 0 & 5791 & 58,48 & 20,51 & 8,64 & $-5,84$ & 2,48 & 0 & 0,0058 & 0 & 0,02673 & 0,91252 \\
\hline 848 & 59 & 0 & 0 & 1 & 0 & 0 & 0 & 1 & 0 & 0 & 5918 & 66,15 & 18,54 & 6,9 & $-3,52$ & 2,33 & 0 & 0,0059 & 1 & 0,03912 & 0,88226 \\
\hline 849 & 59 & 0 & 0 & 1 & 0 & 0 & 0 & 1 & 0 & 0 & 6196 & 71,11 & 20,35 & 6,59 & $-3,78$ & 2,4 & 0 & 0,0062 & 0 & 0,04283 & 0,85749 \\
\hline 850 & 59 & 0 & 0 & 1 & 0 & 0 & 0 & 1 & 0 & 0 & 6643 & 75,97 & 22,36 & 4,39 & $-2,46$ & 2,46 & 0 & 0,0066 & 0 & 0,06855 & 0,76234 \\
\hline 851 & 60 & 0 & 0 & 1 & 0 & 0 & 1 & 0 & 0 & 0 & 642 & 97,07 & 53,25 & 5,3 & $-3,05$ & 2,88 & 0 & 0,0006 & 0 & 0,10491 & \begin{tabular}{|l|l}
0,40737 \\
\end{tabular} \\
\hline 852 & 60 & 0 & 0 & 1 & 0 & 0 & 1 & 0 & 0 & 0 & 651 & 100,27 & 50,42 & 7,12 & $-3,34$ & 2,88 & 1 & 0,0007 & 0 & 0,10405 & 0,42252 \\
\hline 853 & 60 & 0 & 0 & 1 & 0 & 0 & 1 & 0 & 0 & 0 & 674 & 108,49 & 52,68 & 6,9 & $-2,23$ & 2,69 & 1 & 0,0007 & 0 & 0,10807 & 0,35976 \\
\hline 854 & 60 & 0 & 0 & 1 & 0 & 0 & 1 & 0 & 0 & 0 & 699 & 109,51 & 51,37 & 7,05 & $-2,3$ & 2,5 & 1 & 0,0007 & 0 & 0,09557 & 0,45064 \\
\hline 855 & 60 & 0 & 0 & 1 & 0 & 0 & 1 & 0 & 0 & 0 & 761 & 122,41 & 18,43 & 10,07 & $-6,67$ & 2,49 & 1 & 0,0008 & 0 & 0,01153 & 0,95909 \\
\hline 856 & 60 & 0 & 1 & 0 & 0 & 0 & 1 & 0 & 0 & 0 & 860 & 126,64 & 45,57 & 5,85 & $-1,88$ & 2,49 & 1 & 0,0009 & 0 & 0,06218 & 0,82802 \\
\hline 857 & 60 & 0 & 1 & 0 & 0 & 0 & 1 & 0 & 0 & 0 & 903 & 119,97 & 23,38 & 7,07 & $-2,75$ & 2,48 & 1 & 0,0009 & 0 & 0,01889 & 0,96961 \\
\hline 858 & 60 & 0 & 1 & 0 & 0 & 0 & 1 & 0 & 0 & 0 & 949 & 118,69 & 16,58 & 5,1 & $-2,59$ & 2,47 & 3 & 0,0009 & 0 & 0,01934 & 0,97310 \\
\hline 859 & 60 & 0 & 1 & 0 & 0 & 0 & 1 & 0 & 0 & 0 & 1038 & 119,12 & 47,38 & 4,89 & $-1,31$ & 2,31 & 4 & 0,001 & 0 & 0,09030 & 0,75366 \\
\hline 860 & 60 & 0 & 1 & 0 & 0 & 0 & 1 & 0 & 0 & 0 & 1086 & 109,08 & 47,79 & 5,72 & $-0,81$ & 2,14 & 4 & 0,0011 & 0 & 0,08648 & \begin{tabular}{|l|l|l} 
\\
\end{tabular} \\
\hline 861 & 60 & 0 & 1 & 0 & 0 & 0 & 1 & 0 & 0 & 0 & 1114 & 117,36 & 50,03 & 4,78 & $-1,22$ & 2,35 & 4 & 0,0011 & 0 &, 10364 & 0,70404 \\
\hline 862 & 60 & 0 & 1 & 0 & 0 & 0 & 1 & 0 & 0 & 0 & 1165 & 122,79 & 43,34 & 5,28 & $-0,79$ & 2,09 & 4 & 0,0012 & 0 & 0,07095 & 0,82468 \\
\hline 863 & 60 & 0 & 1 & 0 & 0 & 0 & 1 & 0 & 0 & 0 & 1178 & 122,31 & 39,96 & 8,29 & $-1,92$ & 2,01 & 4 & 0,0012 & 0 & 0,04227 & 0,90033 \\
\hline 864 & 60 & 0 & 1 & 0 & 0 & 0 & 1 & 0 & 0 & 0 & 1216 & 132,02 & 34,43 & 8,64 & $-1,98$ & 1,96 & 4 & 0,0012 & 0 &, 03149 & 0,92922 \\
\hline 865 & 60 & 0 & 1 & 0 & 0 & 0 & 1 & 0 & 0 & 0 & 1225 & 107,85 & 41,94 & 8,72 & $-2,21$ & 2,03 & 4 & 0,0012 & 0 & 0,04251 & 0,90603 \\
\hline 866 & 60 & 0 & 1 & 0 & 0 & 0 & 1 & 0 & 0 & 0 & 1266 & 115,68 & 40 & 8,69 & $-1,95$ & 2,06 & 4 & 0,0013 & 0 & 0,04441 & \begin{tabular}{|l|l|}
0,90064 \\
\end{tabular} \\
\hline 867 & 60 & 0 & 1 & 0 & 0 & 0 & 1 & 0 & 0 & 0 & 1292 & 123,2 & 33,91 & 6,93 & $-1,59$ & 2,14 & 4 & 0,0013 & 0 &, 04250 & 0,91264 \\
\hline 868 & 60 & 0 & 1 & 0 & 0 & 0 & 1 & 0 & 0 & 0 & 1342 & 125,37 & 42,53 & 8,93 & $-1,73$ & 2,32 & 4 & 0,0013 & 0 & 0,07170 & 0,81426 \\
\hline 869 & 61 & 0 & 0 & 0 & 1 & 0 & 0 & 1 & 0 & 0 & 6925 & 49,74 & 20,31 & 4,97 & $-10,96$ & 2,31 & 0 & 0,0069 & 0 & 0,01128 & 0,96578 \\
\hline 870 & 61 & 0 & 0 & 0 & 1 & 0 & 1 & 0 & 0 & 0 & 7227 & 49,86 & 23,94 & 5,83 & $-11,44$ & 2,31 & 0 & 0,0072 & 0 &, 00513 & $\mid 0,98911$ \\
\hline 871 & 61 & 0 & 0 & 0 & 1 & 0 & 1 & 0 & 0 & 0 & 7585 & 50,47 & 23,31 & 4,02 & $-9,03$ & 2,37 & 0 & 0,0076 & 0 & 0,01113 & $\mid 0,97871$ \\
\hline 872 & 61 & 0 & 0 & 0 & 1 & 0 & 1 & 0 & 0 & 0 & 7967 & 52,28 & 19,12 & 3,56 & $-7,59$ & 2,44 & 0 & 0,008 & 0 & 0,01562 & 0,97400 \\
\hline 873 & 61 & 0 & 0 & 0 & 1 & 0 & 1 & 0 & 0 & 0 & 8001 & 44,17 & 18,16 & 4,16 & $-7,15$ & 2,3 & 0 & 0,008 & 0 &, 01384 & 0,97956 \\
\hline 874 & 61 & 0 & 0 & 0 & 1 & 0 & 1 & 0 & 0 & 0 & 8201 & 45,6 & 22,46 & 3,65 & $-5,89$ & 2,17 & 0 & 0,0082 & 0 & 0,02059 & \begin{tabular}{|l|l}
0,96794 \\
\end{tabular} \\
\hline 875 & 61 & 0 & 0 & 0 & 1 & 0 & 1 & 0 & 0 & 0 & 8339 & 45,23 & 24,24 & 3,47 & $-9,38$ & 2,19 & 0 & 0,0083 & 0 & 0,00808 & 0,98481 \\
\hline 876 & 61 & 0 & 0 & 0 & 1 & 0 & 1 & 0 & 0 & 0 & 8547 & 49,35 & 22,93 & 3,28 & $-8,95$ & 2,21 & 1 & 0,0085 & 0 & 0,01053 & 0,98019 \\
\hline 877 & 61 & 0 & 0 & 0 & 1 & 0 & 0 & 1 & 0 & 0 & 8778 & 51,97 & 23,79 & 2,97 & $-12,06$ & 2,22 & 1 & 0,0088 & 0 &, 00995 & 0,96458 \\
\hline 878 & 61 & 0 & 0 & 0 & 1 & 0 & 0 & 1 & 0 & 0 & 9145 & 57,46 & 21,98 & 3,22 & $-9,36$ & 1,95 & 1 & 0,0091 & 0 & 0,01432 & 0,95507 \\
\hline 879 & 61 & 0 & 0 & 0 & 1 & 0 & 0 & 1 & 0 & 0 & 9549 & 67,64 & 17,44 & 2,16 & $-7,01$ & 1,82 & 1 & 0,0095 & 0 & 0,01993 & 0,94479 \\
\hline 880 & 61 & 0 & 0 & 0 & 1 & 0 & 0 & 1 & 0 & 0 & 10007 & 74,54 & 13,82 & 2,43 & $-7,69$ & 1,86 & 1 & 0,01 & 0 & 0,01496 & 0,95836 \\
\hline 881 & 61 & 0 & 0 & 0 & 1 & 0 & 0 & 1 & 0 & 0 & 10464 & 76,06 & 14,49 & 3,19 & $-3,77$ & 1,95 & 1 & 0,0105 & 0 & 0,05325 & 0,87051 \\
\hline 882 & 61 & 0 & 0 & 0 & 1 & 0 & 0 & 1 & 0 & 0 & 11107 & 82,87 & 13 & 2,1 & $-3,89$ & 1,89 & 1 & 0,0111 & 0 & 0,04550 & 0,88630 \\
\hline 883 & 61 & 0 & 0 & 0 & 1 & 0 & 0 & 1 & 0 & 0 & 11480 & 68,63 & 15,61 & 3,13 & $-4,35$ & 1,91 & 1 & 0,0115 & 0 & 0,04506 & 0,89203 \\
\hline 884 & 61 & 0 & 0 & 0 & 1 & 0 & 0 & 1 & 0 & 0 & 11954 & 75,51 & 12,73 & 3,4 & $-3,81$ & 2 & 1 & 0,012 & 0 & 0,05285 & 0,87677 \\
\hline 885 & 61 & 0 & 0 & 0 & 1 & 0 & 0 & 1 & 0 & 0 & 12576 & 82,48 & 11,34 & 2,67 & $-3,16$ & 2,04 & 1 & 0,0126 & 0 & 0,06320 & 0,85218 \\
\hline 886 & 61 & 0 & 0 & 1 & 0 & 0 & 0 & 1 & 0 & & 13220 & 84,95 & 11,85 & 2,65 & $-2,59$ & 2,13 & 1 & 0,0132 & 0 & 0,03678 & 0,89200 \\
\hline 887 & 62 & 0 & 0 & 0 & 0 & 1 & 0 & 0 & 1 & 0 & 11006 & 41,37 & 39,67 & 1,96 & $-5,4$ & 1,5 & 0 &, 011 & 0 &, 00579 & 0,98944 \\
\hline 888 & 62 & 0 & 0 & 0 & 0 & 1 & 0 & 0 & 1 & 0 & 11546 & 41,77 & 34,82 & 1,76 & $-4,49$ & 1,5 & 1 & 0,0115 & 0 & 0,00714 & 0,98862 \\
\hline 889 & 62 & 0 & 0 & 0 & 0 & 1 & 0 & 0 & 1 & 0 & 12160 & 39,79 & 36,62 & 1,52 & $-5,4$ & 1,63 & 1 & 0,0122 & 0 & 0,00707 & 0,98789 \\
\hline 890 & 62 & 0 & 0 & 0 & 0 & 1 & 0 & 0 & 1 & 0 & 13827 & 42,91 & 22,06 & 2,82 & $-4,33$ & 1,83 & 1 &, 0138 & 0 & ,00668 & 0,99194 \\
\hline 891 & 62 & 0 & 0 & 0 & 0 & 1 & 0 & 0 & 1 & 0 & 14451 & 45,13 & 27,02 & 1,68 & $-5,12$ & 1,75 & 1 & 0,0145 & 0 & 0,00598 & 0,99149 \\
\hline 892 & 62 & 0 & 0 & 0 & 0 & 1 & 0 & 0 & 1 & 0 & 15031 & 40,65 & 24,81 & 2,81 & $-5,94$ & 1,68 & 1 & 0,015 & 0 & 0,00380 & 0,99491 \\
\hline 893 & 62 & 0 & 0 & 0 & 0 & 1 & 0 & 0 & 1 & 0 & 15637 & 40,15 & 24,35 & 2,74 & $-6,77$ & 1,85 & I & 0,0156 & 0 &, 00368 & 0,99493 \\
\hline 894 & 62 & 0 & 0 & 0 & 0 & 1 & 0 & 0 & 1 & 0 & 16215 & 39,23 & 25,32 & 6,4 & $-5,14$ & 1,8 & 1 & 0,0162 & 0 & 0,00600 & 0,99225 \\
\hline 895 & 62 & 0 & 0 & 0 & 1 & 0 & 0 & 0 & 1 & 0 & 16588 & 41,93 & 24,82 & 1,91 & $-2,57$ & 1,62 & 1 & 0,0166 & 0 & 0,01090 & 0,98433 \\
\hline 896 & 62 & 0 & 0 & 0 & 1 & 0 & 0 & 0 & 1 & 0 & 17123 & 43,96 & 24,16 & 4,83 & $-9,71$ & 1,57 & 1 & 0,0171 & 0 &, 00116 & 0,99777 \\
\hline 897 & 62 & 0 & 0 & 0 & 1 & 0 & 0 & 0 & 1 & 0 & 17680 & 48,54 & 20,99 & 20,69 & $-9,66$ & 1,67 & 1 & 0,0177 & 0 & 0,00127 & 0,99771 \\
\hline 898 & 62 & 0 & 0 & 0 & 1 & 0 & 0 & 0 & 1 & 0 & 18190 & 52,34 & 42,95 & 38,59 & $-2,39$ & 1,71 & 1 & 0,0182 & 0 & 0,03594 & 0,92143 \\
\hline 899 & 62 & 0 & 0 & 0 & 1 & 0 & 0 & 0 & 1 & 0 & 18541 & 37,07 & 48,66 & 43 & $-2,79$ & 1,68 & 1 & 0,0185 & 0 & 0,03909 & 0,91386 \\
\hline 900 & 62 & 0 & 0 & 0 & 1 & 0 & 0 & 0 & 1 & 0 & 19147 & 40,36 & 27,85 & 19,17 & $-2,32$ & 1,62 & 1 & 0,0191 & 0 & 0,01489 & 0,97852 \\
\hline
\end{tabular}




\begin{tabular}{|c|c|c|c|c|c|c|c|c|c|c|c|c|c|c|c|c|c|c|c|c|c|}
\hline os & ID & $A A$ & AB & BA & BB & MD & LV & PL & NL & REC & PIB & COMEX & AGRI & PREF & ODP & CAP & APRE & PIB2 & $\mathrm{ACl}$ & CREC & po \\
\hline 901 & 62 & 0 & 0 & 0 & 1 & 0 & 0 & 0 & 1 & 0 & 19940 & 44,86 & 45,31 & 34,98 & $-2,33$ & 1,62 & 1 & 0,0199 & 0 & 0,03533 & 0,92334 \\
\hline 902 & 62 & 0 & 0 & 0 & 1 & 0 & 0 & 0 & 1 & 0 & 20855 & 45,4 & 25,8 & 15,79 & $-2,29$ & 1,6 & 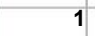 & 0,0209 & 0 & 0,01342 & 0,98063 \\
\hline 903 & 63 & 0 & 0 & 0 & 1 & 0 & 0 & 0 & 1 & 0 & 1542080 & 38,25 & 14,75 & 7,57 & 0,12 & 2,43 & 1 & 1,5421 & 0 & 1,26479 & 0,00023 \\
\hline 904 & 63 & 0 & 0 & 0 & 1 & 0 & 0 & 0 & 1 & 1 & 1682269 & 42,46 & 13,52 & 7,84 & 0,1 & 2,45 & 20 & 1,6823 & 0 & 0,99588 & 0,00000 \\
\hline 905 & 63 & 0 & 0 & 0 & 1 & 0 & 0 & 0 & 1 & 0 & 1850832 & 51,61 & 12,87 & 6,04 & 0,08 & 2,46 & 38 & 1,8508 & 0 & 0,75160 & 0,00000 \\
\hline 906 & 63 & 0 & 0 & 0 & 1 & 0 & 0 & 0 & 1 & 0 & 2037315 & 59,45 & 12,11 & 5,44 & 0,09 & 2,5 & 48 & 2,0373 & 1 & 0,64341 & 0,00000 \\
\hline 907 & 63 & 0 & 0 & 0 & 1 & 0 & 0 & 0 & 1 & 0 & 2268599 & 62,9 & 11,19 & 5,1 & 0,08 & 2,41 & 53 & 2,2686 & 0 & 0,62251 & 0,00000 \\
\hline 908 & 63 & 0 & 0 & 0 & 1 & 0 & 0 & 0 & 1 & 0 & 2556444 & 64,77 & 10,51 & 5,09 & 0,05 & 2,58 & 62 & 2,5564 & 3 & 0,57221 & 0,00000 \\
\hline 909 & 63 & 0 & 0 & 1 & 0 & 0 & 0 & 0 & 1 & 1 & 2919330 & 62,28 & 10,65 & 7,37 & 0,04 & 2,69 & 65 & 2,9193 & 4 & 0,47901 & 0,00000 \\
\hline 910 & 63 & 0 & 0 & 1 & 0 & 0 & 0 & 0 & 1 & 1 & 3200268 & 56,8 & 11,25 & 7,07 & 0,03 & 2,65 & 72 & 3,2003 & 5 & 0,47241 & 0,00000 \\
\hline 911 & 63 & 0 & 0 & 1 & 0 & 0 & 0 & 0 & 1 & 3 & 3495767 & 43,59 & 11,67 & 9,49 & 0,02 & 2,61 & 78 & 3,4958 & 4 & 0,51101 & 0,00000 \\
\hline 912 & 63 & 0 & 1 & 0 & 0 & 0 & 0 & 0 & 1 & 1 & 3867426 & 49,33 & 11,59 & 7,73 & 0,01 & 2,6 & 85 & 3,8674 & 4 & 0,97117 & 0,00000 \\
\hline 913 & 63 & 0 & 1 & 0 & 0 & 0 & 0 & 0 & 1 & 1 & 4234233 & 48,83 & 12,23 & 6,3 & $-0,01$ & 2,6 & 89 & 4,2342 & 2 & 0,96282 & 0,00000 \\
\hline 914 & 63 & 0 & 1 & 0 & 0 & 0 & 0 & 0 & 1 & 3 & 4562398 & 45,71 & 12,47 & 7,05 & 0 & 2,51 & 100 & 4,5624 & 7 & 0,90225 & 0,00000 \\
\hline 915 & 64 & 0 & 0 & 0 & 0 & 1 & 0 & 0 & 1 & 0 & 14639 & 76,2 & 55,43 & 1,33 & $-12,1$ & 2,44 & 0 & 0,0146 & 0 &, 00654 & 0,96740 \\
\hline 916 & 64 & 0 & 0 & 0 & 0 & 1 & 0 & 0 & 1 & 0 & 15771 & 73,52 & 51,6 & 1,88 & $-8,59$ & 2,44 & 1 & 0,0158 & 0 & 0,01805 & 0,92995 \\
\hline 917 & 64 & 0 & 0 & 0 & 0 & 1 & 0 & 0 & 1 & 0 & 16361 & 78,21 & 47,47 & 1,49 & $-4,06$ & 2,37 & 1 & 0,0164 & 0 & 0,04963 & 0,85038 \\
\hline 918 & 64 & 0 & 0 & 0 & 0 & 1 & 0 & 1 & 0 & 0 & 17168 & 76,37 & 48,84 & 1,96 & $-8,05$ & 2,29 & 1 & 0,0172 & 0 &, 07593 & 0,58731 \\
\hline 919 & 64 & 0 & 0 & 0 & 0 & 1 & 0 & 1 & 0 & 0 & 17446 & 76,54 & 45,17 & 1,63 & $-3,81$ & 1,96 & 1 & 0,0174 & 0 & 0,12317 & 0,49548 \\
\hline 920 & 64 & 0 & 0 & 0 & 0 & 1 & 0 & 1 & 0 & 0 & 17085 & 74,64 & 43,37 & 2,04 & $-3,61$ & 1,62 & 1 & 0,0171 & 0 & 0,09573 & 0,64062 \\
\hline 921 & 64 & 0 & 0 & 0 & 0 & 1 & 0 & 0 & 1 & 0 & 17105 & 73,55 & 45,68 & 1,81 & $-1,88$ & 1,59 & 1 & 0,0171 & 0 & 0,03188 & 0,92284 \\
\hline 922 & 64 & 0 & 0 & 0 & 0 & 1 & 0 & 0 & 1 & 0 & 16820 & 79,86 & 49,53 & 1,46 & $-9,88$ & 1,56 & 3 & 0,0168 & 0 & 0,00475 & 0,98084 \\
\hline 923 & 64 & 0 & 0 & 0 & 0 & 1 & 0 & 0 & 1 & 0 & 16591 & 75,27 & 45,9 & 1,98 & $-1,95$ & 1,48 & 4 & 0,0166 & 0 & 0,04238 & 0,89150 \\
\hline 924 & 64 & 0 & 0 & 0 & 0 & 1 & 0 & 0 & 1 & 0 & 16796 & 84,61 & 37,83 & 1,64 & $-1,09$ & 1,23 & 4 & 0,0168 & 0 &, 02840 & 0,93799 \\
\hline 925 & 64 & 0 & 0 & 0 & 1 & 0 & 0 & 0 & 1 & 0 & 17085 & 93,92 & 31,83 & 2,14 & $-0,56$ & 1,16 & 4 & 0,0171 & 0 & 0,02604 & 0,93617 \\
\hline 926 & 64 & 0 & 0 & 0 & 1 & 0 & 0 & 0 & 1 & 0 & 17344 & 95,07 & 31,8 & 1,06 & $-1,45$ & 1,33 & 4 & 0,0173 & 0 & 0,02512 & 0,93465 \\
\hline 927 & 64 & 0 & 0 & 0 & 1 & 0 & 0 & 0 & 1 & 0 & 17650 & 89,44 & 34,09 & 6,17 & $-0,88$ & 1,29 & 4 & 0,0177 & 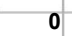 &, 03146 & 0,92087 \\
\hline 928 & 64 & 0 & 0 & 0 & 1 & 0 & 0 & 0 & 1 & 0 & 18099 & 87,27 & 35,94 & 6,72 & $-2,68$ & 1,29 & 4 & 0,0181 & 0 &, 02033 & 0,94348 \\
\hline 929 & 64 & 0 & 0 & 0 & 1 & 0 & 0 & 0 & 1 & 0 & 18687 & 90,78 & 40,69 & 5,4 & $-10,29$ & 1,42 & 4 & 0,0187 & 0 & 0,00316 & 0,98585 \\
\hline 930 & 64 & 0 & 0 & 0 & 1 & 0 & 0 & 0 & 1 & 0 & 19064 & 93,96 & 41,15 & 5,92 & $-3,52$ & 1,24 & 4 & 0,0191 & 0 &, 01902 & 0,93455 \\
\hline 931 & 64 & 0 & 0 & 0 & 1 & 0 & 0 & 0 & 1 & 0 & 18228 & 91,15 & 48,49 & 5,99 & $-5,88$ & 1,37 & 4 & 0,0182 & 0 & 0,01551 & 0,93110 \\
\hline 932 & 64 & 0 & 0 & 0 & 1 & 0 & 0 & 0 & 1 & 0 & 20180 & 92,81 & 40,29 & 5,37 & $-10,07$ & 1,39 & 4 & 0,0202 & 0 &, 00323 & \begin{tabular}{|l|l}
0,98559 \\
\end{tabular} \\
\hline 933 & 65 & 0 & 0 & 0 & 1 & 0 & 0 & 0 & 1 & 0 & 58533 & 50,25 & 26,68 & 4,68 & $-3,37$ & 2,29 & 0 & 0,0585 & 0 &, 02812 & 0,95259 \\
\hline 934 & 65 & 0 & 0 & 0 & 1 & 0 & 0 & 0 & 1 & 0 & 61453 & 46,95 & 26,36 & 5,67 & $-3,22$ & 2,29 & 0 & 0,0615 & 0 &, 02955 & 0,95237 \\
\hline 935 & 65 & 0 & 0 & 0 & 1 & 0 & 0 & 0 & 1 & 0 & 64828 & 43,74 & 23,33 & 1,94 & $-2,54$ & 2,31 & 0 & 0,0648 & 0 &, 03238 & 0,95358 \\
\hline 936 & 65 & 0 & 0 & 0 & 1 & 0 & 0 & 0 & 1 & 0 & 67445 & 41,93 & 23,01 & 5,96 & $-2,29$ & 2,33 & 1 & 0,0674 & 0 &, 04247 & 0,94089 \\
\hline 937 & 65 & 0 & 0 & 0 & 1 & 0 & 0 & 0 & 1 & 0 & 71562 & 38,36 & 23,13 & 10,3 & $-1,77$ & 2,34 & 1 & 0,0716 & 0 &, 05247 & 0,93125 \\
\hline 938 & 65 & 0 & 0 & 0 & 1 & 0 & 0 & 0 & 1 & 0 & 75404 & 39,02 & 22,89 & 6,8 & $-1,36$ & 2,34 & 1 & 0,0754 & 2 &, 05911 & 0,92328 \\
\hline 939 & 65 & 0 & 0 & 0 & 1 & 0 & 0 & 0 & 1 & 0 & 78070 & 39,81 & 23,72 & 6,65 & $-1,33$ & 2,22 & 1 & 0,0781 & 0 &, 05389 & 0,92880 \\
\hline 940 & 65 & 0 & 0 & 0 & 1 & 0 & 0 & 0 & 1 & 0 & 79920 & 40,99 & 25,27 & 4,68 & $-1,5$ & 2,1 & 2 & 0,0799 & 0 & 0,05471 & \begin{tabular}{|l|l|}
0,9288 \\
\end{tabular} \\
\hline 941 & 65 & 0 & 0 & 0 & 1 & 0 & 0 & 0 & 1 & 0 & 82472 & 46,18 & 22,9 & 6,09 & $-1,23$ & 2,2 & 2 & 0,0825 & 1 &, 06289 & 0,91318 \\
\hline 942 & 65 & 0 & 0 & 0 & 1 & 0 & 0 & 0 & 1 & 0 & 85847 & 57,82 & 22,39 & 5,46 & $-1,98$ & 2,27 & 2 & 0,0858 & 0 & 0,05665 & 0,91147 \\
\hline 943 & 65 & 0 & 0 & 0 & 1 & 0 & 0 & 0 & 1 & & 89686 & 62,95 & 17,84 & 6,03 & $-1,16$ & 2,11 & 3 & 0,0897 & 1 &, 05787 & 0,91779 \\
\hline 944 & 65 & 0 & 0 & 0 & 1 & 0 & 0 & 0 & 1 & 0 & 95823 & 61,52 & 15,68 & 5,7 & $-0,83$ & 2,02 & 4 & 0,0958 & 0 & 06225 & 0,91744 \\
\hline 945 & 65 & 0 & 0 & 0 & 1 & 0 & 0 & 0 & 1 & 0 & 102615 & 65,08 & 17,29 & 14,73 & $-0,86$ & 2,12 & 6 & 0,1026 & 0 & 0,10813 & 0,84491 \\
\hline 946 & 65 & 0 & 0 & 0 & 1 & 0 & 0 & 0 & 1 & 0 & 109954 & 71,68 & 16,74 & 8,57 & $-1,06$ & 2,15 & 6 & 0,11 & 0 &, 10688 & 0,83599 \\
\hline 947 & 65 & 0 & 0 & 0 & 1 & 0 & 0 & 0 & 1 & 0 & 115106 & 56,55 & 20,11 & 9,08 & $-0,53$ & 2,23 & 6 & 0,1151 & 0 & 15433 & 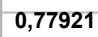 \\
\hline 948 & 65 & 0 & 0 & 0 & 1 & 0 & 0 & 0 & 1 & 0 & 121021 & 47,94 & 21,35 & 10,77 & $-0,27$ & 2,12 & 6 & 0,121 & 0 & 0,15836 & 0,78809 \\
\hline 949 & 65 & 0 & 0 & 1 & 0 & 0 & 0 & 0 & 1 & 0 & 123220 & 45,26 & 22,63 & 11,6 & $-0,18$ & 1,93 & 6 & 0,1232 & 0 &, 06092 & 0,90005 \\
\hline 950 & 65 & 0 & 0 & 1 & 0 & 0 & 0 & 0 & 1 & 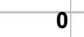 & 125923 & 41,16 & 21,86 & 14,77 & $-0,67$ & 1,7 & 7 & 0,1259 & 0 & 4545 & 0,92836 \\
\hline 951 & 66 & 0 & 0 & 0 & 1 & 0 & 0 & 1 & 0 & 0 & 13093 & 59,4 & 31,83 & 15,25 & $-3,15$ & 1,78 & 0 & 0,0131 & 0 &, 08729 & \begin{tabular}{|l|l|l}
0,7489 \\
\end{tabular} \\
\hline 952 & 66 & 0 & 0 & 0 & 1 & 0 & 0 & 1 & 0 & 0 & 13316 & 55,01 & 32,8 & 20,38 & $-2,95$ & 1,78 & 2 & 0,0133 & 0 & 0,11950 & 0,65393 \\
\hline 953 & 66 & 0 & 0 & 0 & 1 & 0 & 1 & 0 & 0 & 0 & 13881 & 63,45 & 34,52 & 19,78 & $-2,54$ & 1,88 & 2 & 0,0139 & 0 & 09247 & 0,81310 \\
\hline 954 & 66 & 0 & 0 & 0 & 1 & 0 & 1 & 0 & 0 & 0 & 14402 & 61,87 & 30,76 & 19,56 & $-1,53$ & 1,99 & 2 & 0,0144 & 0 & 0,11917 & \begin{tabular}{l|l}
0,79009 \\
\end{tabular} \\
\hline 955 & 66 & 0 & 0 & 0 & 1 & 0 & 1 & 0 & 0 & 0 & 14898 & 62,22 & 29,6 & 23,21 & $-1,5$ & 1,98 & 3 & 0,0149 & 0 & 0,13181 & 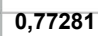 \\
\hline 956 & 66 & 0 & 0 & 0 & 1 & 0 & 1 & 0 & 0 & 0 & 15219 & 69,83 & 16,07 & 10,23 & $-1,39$ & 1,96 & 4 & 0,0152 & 0 & 08895 & 0,87598 \\
\hline 957 & 66 & 0 & 0 & 0 & 1 & 0 & 1 & 0 & 0 & 0 & 15479 & 67,47 & 14,8 & 10,14 & $-1,75$ & 1,98 & 4 & 0,0155 & 0 & ,07843 & 0,89421 \\
\hline 958 & 66 & 0 & 0 & 0 & 1 & 0 & 1 & 0 & 0 & 0 & 15841 & 67,44 & 14,59 & 10,01 & $-1,67$ & 1,99 & 5 & 0,0158 & 0 & 0,09283 & 0,87409 \\
\hline 959 & 66 & 0 & 0 & 0 & 1 & 0 & 1 & 0 & 0 & 0 & 16206 & 70,04 & 14,6 & 9,53 & $-1,31$ & 2,16 & 9 & 0,0162 & 0 & ,20351 & 0,70356 \\
\hline 960 & 66 & & 0 & 7 & 0 & 0 & 1 & 0 & 0 & 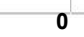 & 16506 & 71,26 & 14,92 & 8,84 & $-1,41$ & 2,23 & 9 & 0,0165 & 0 & 0,10162 & 0,81154 \\
\hline
\end{tabular}




\begin{tabular}{|c|c|c|c|c|c|c|c|c|c|c|c|c|c|c|c|c|c|c|c|c|c|}
\hline bs & ID & $A A$ & $A B$ & BA & BB & MD & LV & PL & NL & REC & PIB & COMEX & AGRI & PREF & ODP & CAP & APRE & PIB2 & $\mathrm{ACl}$ & CREC & po \\
\hline 961 & 66 & 0 & 0 & 1 & 0 & 0 & 1 & 0 & 0 & 0 & 17094 & 69,8 & 16,01 & 8,66 & $-1,23$ & 2,18 & 9 & 0,0171 & 0 & 0,10460 & 0,80545 \\
\hline 962 & 66 & 0 & 0 & 1 & 0 & 0 & 1 & 0 & 0 & 0 & 17763 & 71,85 & 16,09 & 7,29 & $-0,9$ & 2,31 & 9 & 0,0178 & 0 & ,13086 & 0,75270 \\
\hline 963 & 66 & 0 & 0 & 1 & 0 & 0 & 1 & 0 & 0 & 0 & 18445 & 74,18 & 17,17 & 8,06 & $-0,45$ & 2,3 & 9 & 0,0184 & 0 & 0,14933 & 0,71112 \\
\hline 964 & 66 & 0 & 0 & 1 & 0 & 0 & 1 & 0 & 0 & 0 & 18680 & 76,58 & 17,86 & 7,51 & $-1,11$ & 2,34 & 9 & 0,0187 & 0 &, 13574 & 0,71887 \\
\hline 965 & 66 & 0 & 0 & 1 & 0 & 0 & 1 & 0 & 0 & 0 & 18094 & 61,87 & 19,62 & 9,07 & $-1,37$ & 2,48 & 9 & 0,0181 & 0 & 0,15590 & 0,69857 \\
\hline 966 & 66 & 0 & 0 & 1 & 0 & 0 & 1 & 0 & 0 & 1 & 18341 & 68,77 & 17,97 & 8,42 & $-1,34$ & 2,5 & 13 & 0,0183 & 0 & 0,22243 & ,53643 \\
\hline 967 & 66 & 0 & 0 & 1 & 0 & 0 & 1 & 0 & 0 & 0 & 18748 & 74,64 & 19,59 & 7,89 & $-1,23$ & 2,39 & 14 & 0,0187 & 0 & 0,22748 & 0,48049 \\
\hline 968 & 66 & 0 & 0 & 1 & 0 & 0 & 1 & 0 & 0 & 0 & 19101 & 69,7 & 20,26 & 8,1 & $-0,96$ & 2,36 & 14 & 0,0191 & 0 & 0,23946 & 0,47468 \\
\hline 969 & 67 & 0 & 0 & 0 & 1 & 0 & 0 & 1 & 0 & 1 & 31569 & 44,22 & 33,9 & 13,5 & $-1,03$ & 1,87 & 1 & 0,0316 & 0 & 0,18951 & 0,52390 \\
\hline 970 & 67 & 0 & 0 & 0 & 1 & 0 & 0 & 1 & 0 & 0 & 32936 & 45,02 & 35,72 & 13,35 & $-0,56$ & 1,93 & 1 & 0,0329 & 0 & 0,21777 & \begin{tabular}{|l|l|}
0,43457 \\
\end{tabular} \\
\hline 971 & 67 & 0 & 0 & 0 & 1 & 0 & 1 & 0 & 0 & 0 & 34012 & 43,4 & 36,44 & 13,14 & $-0,66$ & 1,99 & 2 & 0,034 & 0 & 0,18913 & 0,68276 \\
\hline 972 & 67 & 0 & 0 & 0 & 1 & 0 & 1 & 0 & 0 & 0 & 32400 & 49,2 & 37,68 & 12,76 & $-0,81$ & 1,84 & 4 & 0,0324 & 1 & 0,19817 & 0,63113 \\
\hline 973 & 67 & 0 & 0 & 0 & 1 & 0 & 0 & 1 & 0 & 0 & 32753 & 59,46 & 27,51 & 10,22 & $-0,86$ & 1,7 & 5 & 0,0328 & 1 & 0,20521 & 0,47154 \\
\hline 974 & 67 & 0 & 0 & 0 & 1 & 0 & 0 & 1 & 0 & 1 & 34069 & 50,75 & 27,43 & 11,39 & $-0,79$ & 1,67 & 6 & 0,0341 & 0 & 0,22633 & 0,45682 \\
\hline 975 & 67 & 0 & 0 & 0 & 1 & 0 & 0 & 1 & 0 & 0 & 35464 & 49,38 & 27,15 & 12,57 & $-0,81$ & 1,64 & 8 & 0,0355 & 0 & 0,25340 & 0,38910 \\
\hline 976 & 67 & 0 & 0 & 1 & 0 & 0 & 0 & 1 & 0 & 0 & 36430 & 47,24 & 27,8 & 12,03 & $-0,57$ & 1,67 & 8 & 0,0364 & 1 & 0,15883 & 0,53070 \\
\hline 977 & 67 & 0 & 0 & 1 & 0 & 0 & 0 & 1 & 0 & 0 & 39421 & 50,67 & 23,13 & 14,22 & $-0,44$ & 1,65 & 8 & 0,0394 & 0 & 0,15035 & 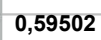 \\
\hline 978 & 67 & 0 & 0 & 1 & 0 & 0 & 0 & 1 & 0 & 1 & 41507 & 56,1 & 20,82 & 11,82 & $-0,57$ & 1,58 & 8 & 0,0415 & 0 & 0,13033 & 0,64918 \\
\hline 979 & 67 & 0 & 0 & 1 & 0 & 0 & 0 & 1 & 0 & 0 & 43335 & 59,71 & 19,79 & 10,44 & $-0,42$ & 1,53 & 8 & 0,0433 & 0 &, 12549 & 0,66203 \\
\hline 980 & 67 & 0 & 0 & 1 & 0 & 0 & 0 & 1 & 0 & 0 & 44284 & 62,59 & 20,42 & 11 & $-0,44$ & 1,65 & 10 & 0,0443 & 0 & 0,16694 & 0,51679 \\
\hline 981 & 67 & 0 & 1 & 0 & 0 & 0 & 0 & 1 & 0 & 0 & 47099 & 68,06 & 19,48 & 10,23 & $-0,38$ & 1,65 & 11 & 0,0471 & 0 & 0,12501 & 0,81838 \\
\hline 982 & 67 & 0 & 1 & 0 & 0 & 0 & 0 & 1 & 0 & 0 & 47366 & 52,1 & 25,01 & 12,09 & $-0,34$ & 1,72 & 16 & 0,0474 & 0 &, 27698 & 0,57362 \\
\hline 983 & 67 & 0 & 1 & 0 & 0 & 0 & 0 & 1 & 0 & 0 & 49036 & 60,3 & 20,87 & 10,5 & $-0,21$ & 1,78 & 17 & 0,049 & 0 & 0,29676 & 0,54866 \\
\hline 984 & 67 & 0 & 1 & 0 & 0 & 0 & 0 & 1 & 0 & 0 & 52894 & 64,49 & 21,31 & 9,78 & $-0,21$ & 1,91 & 17 & 0,0529 & 0 & 0,32692 & 0,47493 \\
\hline 985 & 67 & 0 & 1 & 0 & 0 & 0 & 0 & 1 & 0 & 0 & 55878 & 61,75 & 20,31 & 9,85 & $-0,17$ & 1,99 & 26 & 0,0559 & 0 & ,48959 & 0,15184 \\
\hline 986 & 68 & 0 & 0 & 1 & 0 & 0 & 0 & 1 & 0 & 0 & 2667 & 135,42 & 26,61 & 6,1 & $-1,7$ & 1,96 & 0 & 0,0027 & 0 & 0,05336 & 0,68223 \\
\hline 987 & 68 & 0 & 0 & 1 & 0 & 0 & 0 & 1 & 0 & 0 & 2720 & 129,4 & 34,66 & 5,51 & $-1,58$ & 2,26 & 0 & 0,0027 & 0 & 0,07985 & 0,44734 \\
\hline 988 & 68 & 0 & 0 & 1 & 0 & 0 & 0 & 1 & 0 & 0 & 2807 & 125,41 & 37,42 & 5,52 & $-1,85$ & 2,56 & 2 & 0,0028 & 0 & ,09903 & 0,25309 \\
\hline 989 & 68 & 0 & 0 & 1 & 0 & 0 & 0 & 1 & 0 & 0 & 2836 & 128,11 & 35,34 & 6,09 & $-2,21$ & 2,28 & 3 & 0,0028 & 0 & 0,08792 & 0,34634 \\
\hline 990 & 68 & 0 & 0 & 1 & 0 & 0 & 0 & 1 & 0 & 0 & 2986 & 124,23 & 33,56 & 6,79 & $-2,4$ & 2,07 & 3 & 0,003 & 0 & 0,07692 & 0,47226 \\
\hline 991 & 68 & 0 & 1 & 0 & 0 & 0 & 0 & 1 & 0 & 0 & 3007 & 118,25 & 38,77 & 5,14 & $-2,17$ & 2,39 & 3 & 0,003 & 0 & ,09194 & 0,66830 \\
\hline 992 & 68 & 0 & 1 & 0 & 0 & 0 & 0 & 1 & 0 & 0 & 3062 & 117,82 & 38,57 & 4,93 & $-1,87$ & 2,37 & 3 & 0,0031 & 0 &, 09590 & 0,66145 \\
\hline 993 & 68 & 0 & 1 & 0 & 0 & 0 & 0 & 1 & 0 & 0 & 3036 & 110,63 & 39,43 & 6,3 & $-1,53$ & 2,05 & 3 & 0,003 & 0 & 0,07841 & 0,74377 \\
\hline 994 & 68 & 0 & 1 & 0 & 0 & 0 & 0 & 1 & 0 & 0 & 3068 & 130,72 & 41,22 & 4,79 & $-1,32$ & 1,74 & 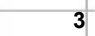 & 0,0031 & 0 &, 06235 & 0,75363 \\
\hline 995 & 68 & 0 & 0 & 1 & 0 & 0 & 0 & 1 & 0 & 0 & 3025 & 109,25 & 44,85 & 7,03 & $-2,48$ & 1,59 & 3 & 0,003 & 0 &, 06594 & 0,49406 \\
\hline 996 & 68 & 0 & 0 & 1 & 0 & 0 & 0 & 1 & 0 & 0 & 3115 & 121,73 & 42,02 & 4,9 & $-2,51$ & 1,77 & 3 & 0,0031 & 0 & 0,06809 & 0,44706 \\
\hline 997 & 68 & 0 & 0 & 1 & 0 & 0 & 0 & 1 & 0 & 0 & 3020 & 124,19 & 43,76 & 3,52 & $-2,15$ & 1,79 & 3 & 0,003 & 0 & 0,07239 & 0,38145 \\
\hline 998 & 68 & 0 & 0 & 1 & 0 & 0 & 0 & 1 & 0 & 0 & 3069 & 125,11 & 45,57 & 2,56 & $-2,8$ & 1,6 & 3 & 0,0031 & 0 &, 05927 & 0,45719 \\
\hline 999 & 69 & 0 & 0 & 0 & 1 & 0 & 0 & 1 & 0 & 1 & 69129 & 80,54 & 12,29 & 7,4 & $-1,18$ & 2,32 & 0 & 0,0691 & 0 & 0,17577 & 0,62682 \\
\hline 1000 & 69 & 0 & 0 & 0 & 1 & 0 & 1 & 0 & 0 & 1 & 73170 & 89,8 & 10,72 & 7,69 & $-1,04$ & 2,32 & 3 & 0,0732 & 0 & 0,15522 & 0,77609 \\
\hline 1001 & 69 & 0 & 0 & 0 & 1 & 0 & 1 & 0 & 0 & & 76964 & 108,25 & 9,27 & 6,04 & $-0,78$ & 2,43 & 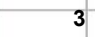 & 0,077 & 2 & 0,17893 & 0,70844 \\
\hline 1002 & 69 & 0 & 0 & 0 & 1 & 0 & 1 & 0 & 0 & 0 & 76520 & 98,66 & 8,95 & 5,97 & $-0,74$ & 2,53 & 3 & 0,0765 & 0 & ,19815 & 0,70340 \\
\hline 1003 & 69 & 0 & 0 & 0 & 1 & 0 & 1 & 0 & 0 & 0 & 78879 & 94,91 & 7,59 & 6,03 & $-0,73$ & 2,45 & 3 & 0,0789 & 0 & 0,17903 & 0,74995 \\
\hline 1004 & 69 & 0 & 0 & 0 & 1 & 0 & 1 & 0 & 0 & & 82358 & 104,73 & 6,89 & 5,66 & $-0,6$ & 2,36 & 3 & 0,0824 & 2 & 0,16740 & 0,75250 \\
\hline 1005 & 69 & 0 & 0 & 0 & 1 & 0 & 1 & 0 & 0 & 0 & 84742 & 98,91 & 7,56 & 6,69 & $-0,63$ & 2,38 & 3 & 0,0847 & 0 &, 17642 & 0,74797 \\
\hline 1006 & 69 & 0 & 0 & 0 & 1 & 0 & 1 & 0 & 0 & 2 & 87831 & 102,44 & 6,97 & 6,44 & $-0,59$ & 2,41 & 4 & 0,0878 & 0 & 0,20502 & 0,69829 \\
\hline 1007 & 69 & 0 & 0 & 0 & I & 0 & 1 & 0 & 0 & & 92197 & 101,85 & 7,03 & 5,79 & $-0,7$ & 2,46 & 5 & 0,0922 & 0 & 0,23780 & 0,64363 \\
\hline 1008 & 69 & 0 & 0 & 0 & 1 & 0 & 1 & 0 & 0 & 0 & 98372 & 102,64 & 7,09 & 5,13 & $-0,4$ & 2,3 & 5 & 0,0984 & 0 & ,22596 & 0,66580 \\
\hline 1009 & 69 & 0 & 0 & 0 & 1 & 0 & 0 & 1 & 0 & 0 & 103072 & 97,88 & 7,25 & 5,75 & $-0,44$ & 2,44 & 5 & 0,1031 & 0 & 0,30358 & 0,30843 \\
\hline 1010 & 69 & 0 & 0 & 0 & 1 & 0 & 0 & 1 & 0 & 8 & 108476 & 94,94 & 6,79 & 6,07 & $-0,37$ & 2,44 & 5 & 0,1085 & 0 & 0,31553 & 0,30969 \\
\hline 1011 & 69 & 0 & 0 & 0 & 1 & 0 & 0 & 1 & 0 & 0 & 115653 & 86,62 & 7,26 & 8,01 & $-0,33$ & 2,58 & 5 & 0,1157 & 0 & 5622 & 0,26568 \\
\hline 1012 & 69 & 0 & 0 & 0 & 1 & 0 & 0 & 1 & 0 & 1 & 120456 & 76,28 & 9,9 & 7,98 & $-0,02$ & 2,53 & 8 & 0,1205 & 0 & 0,40866 & 0,16013 \\
\hline 1013 & 69 & 0 & 0 & 0 & 1 & 0 & 0 & 1 & 0 & 0 & 121839 & 65,59 & 10,31 & 10,93 & $-0,14$ & 2,47 & 8 & 0,1218 & 1 & 0,43126 & 0,18770 \\
\hline 1014 & 69 & 0 & 0 & 1 & 0 & 0 & 0 & 1 & 0 & 0 & 131138 & 71,42 & 9,95 & 10,1 & $-0,2$ & 2,48 & 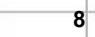 & 0,1311 & 1 & 28815 & 0,29708 \\
\hline 1015 & 69 & 0 & 0 & 1 & 0 & 0 & 0 & 1 & 0 & 0 & 35937 & 67,7 & 11,22 & 8,09 & 0,07 & 2,58 & 8 & 0,1359 & 0 & 0,31314 & 0,23885 \\
\hline 1016 & 69 & 0 & 0 & 1 & 0 & 0 & 0 & 1 & 0 & 0 & 145023 & 64,9 & 10,51 & 9,66 & 0 & 2,58 & 11 & 0,145 & 0 & 0,34630 & 0,16055 \\
\hline 1017 & 70 & 0 & 0 & 0 & 1 & 0 & 0 & 1 & 0 & 1 & 19312 & 44,69 & 37,48 & 20,77 & $-1,44$ & 2 & 0 & 0,0193 & 0 & ,18286 & 0,50066 \\
\hline 1018 & 70 & 0 & 0 & 0 & 1 & 0 & 0 & 1 & 0 & 1 & 19883 & 40,39 & 37,67 & 24,05 & $-1,24$ & 2 & 1 & 0,0199 & 1 & 0,20884 & 0,44961 \\
\hline 1019 & 70 & 0 & 0 & 0 & 1 & 0 & 0 & 1 & 0 & 0 & 20751 & 41,55 & 36,69 & 23,73 & $-1,51$ & 2,04 & 1 & 0,0208 & 0 & 0,20262 & 0,46526 \\
\hline 1020 & 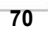 & & $v$ & 0 & T & 0 & 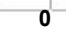 & & 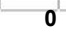 & 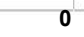 & 21787 & 44,42 & 34,32 & 21,24 & $-1,21$ & 2,08 & 1 & 0,0218 & 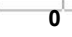 & 0,21018 & 0,46465 \\
\hline
\end{tabular}




\begin{tabular}{|c|c|c|c|c|c|c|c|c|c|c|c|c|c|c|c|c|c|c|c|c|c|}
\hline bs & ID & AA & $A B$ & BA & BB & MD & LV & PL & NL & REC & PIB & OMEX & AGRI & PREF & ODP & CAP & APRE & PIB2 & $\mathrm{ACl}$ & CREC & po \\
\hline 1021 & 70 & 0 & 0 & 0 & 1 & 0 & 0 & 1 & 0 & 1 & 22626 & 46,36 & 33,59 & 23,56 & $-1,62$ & 2,03 & 2 & 0,0226 & 1 & 0,20326 & 0,47100 \\
\hline 1022 & 70 & 0 & 0 & 0 & 1 & 0 & 0 & 1 & 0 & 0 & 23442 & 49,15 & 32,81 & 22,87 & $-1,38$ & 1,97 & 4 & 0,0234 & 0 & 0,22726 & ,39649 \\
\hline 1023 & 70 & 0 & 0 & 0 & 1 & 0 & 0 & 1 & 0 & 1 & 23989 & 69,54 & 31,6 & 17,42 & $-1,26$ & 1,99 & 5 & 0,024 & 0 & ,21877 & , 31277 \\
\hline 1024 & 70 & 0 & 0 & 0 & 1 & 0 & 0 & 1 & 0 & 0 & 24916 & 66,03 & 32,4 & 22,17 & $-1,22$ & 2,01 & 6 & 0,0249 & 0 & 0,23744 & 0,26171 \\
\hline 1025 & 70 & 0 & 0 & 0 & 1 & 0 & 0 & 1 & 0 & 1 & 25547 & 65,96 & 28,39 & 19,43 & $-1,14$ & 2,05 & 8 & 0,0255 & 0 & 0,26166 & 0,23536 \\
\hline 1026 & 70 & 0 & 0 & 4 & 1 & 0 & 0 & 1 & 0 & 0 & 26352 & 69,08 & 27,56 & 18,08 & $-0,92$ & 1,86 & 9 & 0,0264 & 0 & 0,25657 & ,24764 \\
\hline 1027 & 70 & 0 & 0 & 0 & 1 & 0 & 0 & 1 & 0 & 1 & 27211 & 66,05 & 21,57 & 10,33 & $-0,96$ & 1,8 & 10 & 0,0272 & 0 & 0,26228 & 0,32820 \\
\hline 1028 & 70 & 0 & 0 & 0 & 1 & 0 & 0 & 1 & 0 & 0 & 28675 & 66,82 & 27,53 & 17,63 & $-1,64$ & 1,91 & 10 & 0,0287 & 0 & 0,25250 & 0,23884 \\
\hline 1029 & 70 & 0 & 0 & 0 & 1 & 0 & 0 & 1 & 0 & 0 & 30483 & 67,9 & 23,28 & 9,03 & $-1,37$ & 1,95 & 11 & 0,0305 & 0 & 0,26999 & 0,23743 \\
\hline 1030 & 70 & 0 & 0 & 1 & 0 & 0 & 0 & 1 & 0 & 0 & 31483 & 64,13 & 24,59 & 9,73 & $-1,4$ & 1,94 & 14 & 0,0315 & 0 & 0,20239 & 0,26515 \\
\hline 1031 & 70 & 0 & 0 & 1 & 0 & 0 & 0 & 1 & 0 & 1 & 31649 & 57,11 & 28,66 & 10,89 & $-1,03$ & 1,81 & 16 & 0,0316 & 0 & 0,21680 & 0,18392 \\
\hline 1032 & 70 & 0 & 0 & 1 & 0 & 0 & 0 & 1 & 0 & 1 & 32557 & 62,11 & 27,78 & 8,84 & $-0,97$ & 1,8 & 21 & 0,0326 & 0 & 0,22173 & 0,08632 \\
\hline 1033 & 70 & 0 & 0 & 1 & 0 & 0 & 0 & 1 & 0 & 0 & 33912 & 63,98 & 27,62 & 8,94 & $-0,82$ & 1,8 & 21 & 0,0339 & 0 & 0,22163 & 0,08180 \\
\hline 1034 & 70 & 0 & 0 & 1 & 0 & 0 & 0 & 1 & 0 & 0 & 34919 & 60,98 & 28,52 & 10,39 & $-0,62$ & 1,74 & 30 & 0,0349 & 0 & 0,21446 & 0,01807 \\
\hline 1035 & 71 & 0 & 0 & 0 & 0 & 1 & 1 & 0 & 0 & 0 & 798 & 209,14 & 37,9 & 2,6 & $-39,32$ & 2,28 & 0 & 0,0008 & 0 & 0,00000 & 0,99992 \\
\hline 1036 & 71 & 0 & 0 & 0 & 1 & 0 & 1 & 0 & 0 & 0 & 784 & 203,84 & 39,63 & 2,91 & $-14,34$ & 2,45 & 0 & 0,0008 & 0 & 0,00697 & 0,90889 \\
\hline 1037 & 71 & 0 & 0 & 0 & 1 & 0 & 1 & 0 & 0 & 0 & 807 & 201,06 & 34,3 & 3,16 & $-13,66$ & 2,38 & 0 & 0,0008 & 0 & 0,00615 & 0,93297 \\
\hline 1038 & 71 & 0 & 0 & 0 & 1 & 0 & 1 & 0 & 0 & 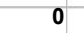 & 796 & 206,77 & 37,11 & 2,85 & $-17,54$ & 2,31 & 0 & 0,0008 & 0 & 0,00206 & 0,97046 \\
\hline 1039 & 71 & 0 & 0 & 0 & 1 & 0 & 1 & 0 & 0 & 0 & 814 & 206,41 & 36,66 & 3,26 & $-17,6$ & 2,27 & 0 & 0,0008 & 0 & 00188 & 0,97344 \\
\hline 1040 & 71 & 0 & 0 & 0 & 1 & 0 & 1 & 0 & 0 & 0 & 823 & 198,23 & 40,73 & 3,31 & $-10,77$ & 2,23 & 2 & 0,0008 & 0 & 0,01896 & 0,78909 \\
\hline 1041 & 71 & 0 & 0 & 0 & 1 & 0 & 1 & 0 & 0 & 0 & 815 & 189,6 & 40,92 & 3,29 & $-13,9$ & 2,32 & 3 & 0,0008 & 0 & 0,01061 & 0,87176 \\
\hline 1042 & 71 & 0 & 0 & 0 & 1 & 0 & 1 & 0 & 0 & 0 & 841 & 201,45 & 37,72 & 2,83 & $-21,48$ & 2,31 & 3 & 0,0008 & 0 & ,00103 & 0,98233 \\
\hline 1043 & 71 & 0 & 0 & 0 & 1 & 0 & 0 & 1 & 0 & 0 & 825 & 203,83 & 39,21 & 2,51 & $-19,3$ & 2,02 & 3 & 0,0008 & 0 & 0,00313 & 0,91928 \\
\hline 1044 & 71 & 0 & 0 & 0 & 1 & 0 & 1 & 0 & 0 & 0 & 867 & 128,04 & 35,43 & 4,37 & $-12,32$ & 2,29 & 3 & 0,0009 & 0 & 0,01165 & 0,93177 \\
\hline 1045 & 71 & 0 & 0 & 0 & 1 & 0 & 1 & 0 & 0 & 0 & 928 & 129,15 & 33,72 & 6,28 & $-7,5$ & 2,46 & 3 & 0,0009 & 0 & ,04958 & 0,76937 \\
\hline 1046 & 71 & 0 & 0 & 0 & 1 & 0 & 1 & 0 & 0 & 0 & 946 & 138,59 & 34,52 & 6,66 & $-8,72$ & 2,33 & 3 & 0,0009 & 0 & 0,03254 & 0,82539 \\
\hline 1047 & 71 & 0 & 0 & 1 & 0 & 0 & 1 & 0 & 0 & 0 & 978 & 124,97 & 38,33 & 7,19 & $-8,63$ & 2,33 & 3 & 0,001 & 0 & 0,01670 & 0,89252 \\
\hline 1048 & 71 & 0 & 0 & 1 & 0 & 0 & 1 & 0 & 0 & 0 & 1021 & 131,3 & 36,85 & 7,02 & $-7,34$ & 2,38 & 3 & 0,001 & 0 & ,02396 & 0,85073 \\
\hline 1049 & 71 & 0 & 0 & 1 & 0 & 0 & 1 & 0 & 0 & 0 & 1076 & 140,77 & 34,83 & 7,24 & $-6,15$ & 2,4 & 3 & 0,0011 & 0 & 0,03136 & 0,80786 \\
\hline 1050 & 71 & 0 & 0 & 1 & 0 & 0 & 1 & 0 & 0 & 0 & 1128 & 145,26 & 33,78 & 5,93 & $-3,97$ & 2,36 & 3 & 0,0011 & 0 & 0,04920 & 0,72122 \\
\hline 1051 & 72 & 0 & 0 & 0 & 0 & 1 & 0 & 1 & 0 & 1 & 6635 & 91,78 & 50,21 & 28,55 & $-11,03$ & 1,64 & 0 & 0,0066 & 0 & ,01819 & 0,88213 \\
\hline 1052 & 72 & 0 & 0 & 0 & 0 & 1 & 0 & 1 & 0 & 1 & 6874 & 98,82 & 43,6 & 16,06 & $-9,43$ & 1,64 & 1 & 0,0069 & 0 & 0,02389 & 0,86252 \\
\hline 1053 & 72 & 0 & 0 & 0 & 0 & 1 & 1 & 0 & 0 & 0 & 7217 & 98 & 42,51 & 18,39 & $-6,66$ & 1,79 & 1 & 0,0072 & 0 & 0,02977 & 0,90682 \\
\hline 1054 & 72 & 0 & 0 & 0 & 0 & 1 & 1 & 0 & 0 & 0 & 7426 & 100,5 & 44,24 & 18,41 & $-6,34$ & 1,94 & 1 & 0,0074 & 0 &, 04211 & 0,86049 \\
\hline 1055 & 72 & 0 & 0 & 0 & 1 & 0 & 0 & 1 & 0 & 1 & 7286 & 97 & 38,6 & 26,48 & $-15,66$ & 1,95 & 2 & 0,0073 & 0 & 0,00657 & 0,94670 \\
\hline 1056 & 72 & 0 & 0 & 0 & 1 & 0 & 0 & 1 & 0 & 1 & 7705 & 120,39 & 47,93 & 25,86 & $-6,51$ & 1,96 & 6 & 0,0077 & 0 & 0,08640 & 0,23846 \\
\hline 1057 & 72 & 0 & 0 & 0 & 1 & 0 & 0 & 1 & 0 & 0 & 7915 & 115,94 & 45,23 & 21,85 & $-8,99$ & 1,91 & 6 & 0,0079 & 0 & 0,06134 & 0,45312 \\
\hline 1058 & 72 & 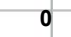 & 0 & 0 & 1 & 0 & 0 & 1 & 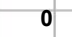 & 0 & 8212 & 118 & 40,58 & 30,8 & $-5,63$ & 1,87 & 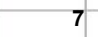 & 0,0082 & 0 & 0,10192 & 0,28887 \\
\hline 1059 & 72 & 0 & 0 & 0 & 1 & 0 & 0 & 1 & 0 & 2 & 8585 & 122,25 & 39,13 & 29,45 & $-5,06$ & 1,92 & 10 & 0,0086 & 0 & 11622 & 0,16920 \\
\hline 1060 & 72 & 0 & 0 & 0 & 1 & 0 & 0 & 1 & 0 & 0 & 9120 & 135,46 & 38,53 & 24,27 & $-7,91$ & 1,94 & 10 & 0,0091 & 0 & 0,08027 & 0,27527 \\
\hline 1061 & 72 & 0 & 0 & 0 & 1 & 0 & 0 & 1 & 0 & & 9672 & 136,49 & 38,83 & 22,66 & $-7,49$ & 1,86 & 11 & 0,0097 & 0 & 0,08362 & 0,23702 \\
\hline 1062 & 72 & 0 & 0 & 0 & 1 & 0 & 0 & 1 & 0 & 0 & 10307 & 133,13 & 34,42 & 16,04 & $-5,76$ & 1,89 & 11 & 0,0103 & 0 & 0,10401 & 0,21318 \\
\hline 1063 & 72 & 0 & 0 & 0 & 1 & 0 & 0 & 1 & 0 & 0 & 10945 & 135,07 & 31,44 & 15,03 & $-3,91$ & 1,95 & 12 & 0,0109 & 0 & 0,12813 & 0,13403 \\
\hline 1064 & 72 & 0 & 0 & 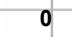 & 1 & 0 & 0 & 1 & 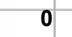 & & 11131 & 96,91 & 36,23 & 17,17 & $-3,19$ & 1,83 & 12 & 0,0111 & 0 & 0,16404 & 0,14144 \\
\hline 1065 & 72 & 0 & 0 & 0 & 1 & 0 & 0 & 1 & 0 & 1 & 11546 & 109,44 & 34,67 & 14,93 & $-4,19$ & 1,86 & 17 & 0,0115 & 0 & 0,14632 & 0,07703 \\
\hline 1066 & 72 & 0 & 0 & 0 & 1 & 0 & 0 & 1 & 0 & 0 & 11989 & 122,22 & 39,5 & 14,2 & $-3,69$ & 1,95 & 18 & 0,012 & 0 & 0,12307 & 0,03205 \\
\hline 1067 & 72 & 8 & 0 & 0 & 1 & 0 & 0 & 1 & 8 & 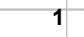 & 12484 & 121,19 & 34,57 & 11,21 & $-3,29$ & 1,78 & 21 & 0,0125 & 0 & , 13654 & 0,03160 \\
\hline 1068 & 73 & 0 & 0 & 0 & 0 & 1 & 0 & 1 & 0 & 1 & 448721 & 22,47 & 13,85 & 15,09 & $-0,48$ & 2,42 & 3 & 0,4487 & 0 & 38889 & 836 \\
\hline 1069 & 73 & 0 & 0 & 0 & 0 & 1 & 0 & 1 & 0 & 4 & 482598 & 21,55 & 14,14 & 16,46 & $-0,48$ & 2,42 & 10 & 0,4826 & 1 & 0,87770 & 0,02142 \\
\hline 1070 & 73 & 0 & 0 & 0 & 0 & 1 & 0 & 1 & 0 & 0 & 502142 & 22,23 & 14,2 & 15,41 & $-0,39$ & 2,41 & 14 & 0,5021 & 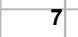 & 0,84063 & 0,00916 \\
\hline 1071 & 73 & 0 & 0 & 0 & 0 & 1 & 1 & 0 & 0 & 3 & 533197 & 23,29 & 15,3 & 16,12 & $-0,38$ & 2,41 & 18 & 0,5332 & 4 & 22608 & 0 \\
\hline 1072 & 73 & 0 & 0 & 0 & 0 & 1 & 1 & 0 & 0 & 1 & 580362 & 24,39 & 13,09 & 16,22 & $-0,32$ & 2,39 & 21 & 0,5804 & 1 & 1,25097 & 0,00595 \\
\hline 1073 & 73 & 0 & 0 & 0 & 0 & 1 & 1 & 0 & 0 & 2 & 602653 & 26,44 & 11 & 14,75 & $-0,29$ & 2,36 & 28 & 0,6027 & 0 & 1,18421 & 0,00176 \\
\hline 1074 & 73 & 0 & 0 & 0 & 0 & 1 & 1 & 0 & 0 & 2 & 631725 & 25,55 & 12,05 & 13,38 & $-0,35$ & 2,36 & 32 & 0,6317 & 0 & 10361 & 00067 \\
\hline 1075 & 73 & 0 & 0 & 0 & 0 & 1 & 1 & 0 & 0 & 2 & 655756 & 29 & 11,43 & 13,09 & $-0,34$ & 2,37 & 39 & 0,6558 & 1 & 0,99383 & 00016 \\
\hline 1076 & 73 & 0 & 0 & 0 & 0 & 1 & 1 & 0 & 0 & 0 & 707301 & 30,07 & 10,64 & 11,73 & $-0,12$ & 2,43 & 43 & 0,7073 & 0 & 0,96162 & 0,00005 \\
\hline 1077 & 73 & 0 & 0 & 0 & 0 & 1 & 1 & 0 & 0 & 1 & 763340 & 36,86 & 9,48 & 8,85 & $-0,11$ & 2,4 & 47 & 0,7633 & 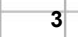 & 779 & 002 \\
\hline 1078 & 73 & 0 & 0 & 0 & 0 & 1 & 1 & 0 & 0 & 0 & 834215 & 41,31 & 7,88 & 10,06 & $-0,23$ & 2,42 & 48 & 0,8342 & 0 & 0,88289 & 00001 \\
\hline 1079 & 73 & 0 & 0 & 0 & 0 & 1 & 1 & 0 & 0 & 1 & 911496 & 45,3 & 7,37 & 8,19 & $-0,15$ & 2,45 & 50 & 0,9115 & 1 & 0,84909 & 00000 \\
\hline 000 & 10 & 0 & 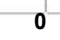 & 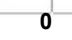 & & & & & & 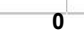 & 000835 & 44,88 & 7,97 & 14,46 & $-0,11$ & 2,61 & 54 & 1,0008 & & 0,66385 & 0,0000 \\
\hline
\end{tabular}




\begin{tabular}{|c|c|c|c|c|c|c|c|c|c|c|c|c|c|c|c|c|c|c|c|c|c|}
\hline Obs & ID & AA & $\mathrm{AB}$ & BA & BB & MD & LV & PL & NL & REC & PIB & COMEX & AGRI & PREF & ODP & CAP & APRE & PIB2 & $\mathrm{ACl}$ & CREC & po \\
\hline 1081 & 73 & 0 & 0 & 0 & 1 & 0 & 1 & 0 & 0 & 1 & 1039777 & 52,27 & 7,5 & 11,01 & $-0,17$ & 2,47 & 62 & 1,0398 & 1 & 0,56828 & 0,00000 \\
\hline 1082 & 73 & 0 & 0 & 0 & 1 & 0 & 1 & 0 & 0 & 0 & 1127948 & 45,48 & 7,3 & 11,64 & $-0,18$ & 2,49 & 68 & 1,1279 & 0 & 0,56642 & 0,00000 \\
\hline 1083 & 73 & 0 & 0 & 0 & 1 & 0 & 1 & 0 & 0 & 1 & 1243675 & 48,31 & 7,79 & 9,42 & $-0,17$ & 2,52 & 73 & 1,2437 & 0 & 0,51758 & 0,00000 \\
\hline 1084 & 73 & 0 & 0 & 0 & 1 & 0 & 1 & 0 & 0 & 0 & 1326235 & 55,02 & 7,84 & 6,31 & $-0,18$ & 2,49 & 75 & 1,3262 & 0 & 0,47879 & 0,00000 \\
\hline 1085 & 73 & 0 & 0 & 0 & 1 & 0 & 1 & 0 & 0 & 2 & 1393626 & 55,55 & 8,79 & 7,42 & $-0,09$ & 2,32 & 91 & 1,3936 & 1 & 0,38689 & 0,00000 \\
\hline 1086 & 74 & 0 & 0 & 0 & 1 & 0 & 0 & 0 & 1 & 0 & 219165 & 53,96 & 16,49 & 9,29 & $-0,66$ & 2,08 & 1 & 0,2192 & 0 & 0,11060 & 0,86967 \\
\hline 1087 & 74 & 0 & 0 & 0 & 1 & 0 & 0 & 0 & 1 & 0 & 235915 & 52,26 & 16,63 & 11,6 & $-0,48$ & 2,08 & 1 & 0,2359 & 4 & 0,13133 & 0,84941 \\
\hline 1088 & 74 & 0 & 0 & 0 & 1 & 0 & 0 & 0 & 1 & 0 & 247003 & 55,99 & 14,8 & 9,04 & $-0,38$ & 1,99 & 1 & 0,247 & 0 & 0,12064 & 0,86385 \\
\hline 1089 & 74 & 0 & 0 & 0 & 0 & 1 & 0 & 1 & 0 & 1 & 214579 & 96,19 & 16,5 & 5,13 & $-1,39$ & 1,9 & 2 & 0,2146 & 0 & 0,27590 & 0,40221 \\
\hline 1090 & 74 & 0 & 0 & 0 & 0 & 1 & 0 & 1 & 0 & 0 & 216277 & 62,94 & 18,74 & 9,81 & $-1,64$ & 2,07 & 3 & 0,2163 & 0 & 0,36312 & 0,36148 \\
\hline 1091 & 74 & 0 & 0 & 0 & 0 & 1 & 0 & 1 & 0 & 1 & 226918 & 71,44 & 14,53 & 6,89 & $-1,1$ & 2,23 & 3 & 0,2269 & 0 & 0,40768 & 0,30739 \\
\hline 1092 & 74 & 0 & 0 & 0 & 0 & 1 & 0 & 1 & 0 & 0 & 235186 & 69,79 & 14,69 & 7,22 & $-1,02$ & 2,15 & 4 & 0,2352 & 0 & 0,42704 & 0,27963 \\
\hline 1093 & 74 & 0 & 0 & 0 & 0 & 1 & 0 & 1 & 0 & 0 & 245768 & 59,08 & 16,33 & 9,47 & $-0,76$ & 2,07 & 4 & 0,2458 & 0 & 0,46487 & 0,27301 \\
\hline 1094 & 74 & 0 & 0 & 0 & 1 & 0 & 0 & 1 & 0 & 0 & 257516 & 53,62 & 16,54 & 11,93 & $-0,78$ & 2,05 & 4 & 0,2575 & 0 & 0,43096 & 0,21307 \\
\hline 1095 & 74 & 0 & 0 & 0 & 1 & 0 & 0 & 1 & 0 & 1 & 270472 & 59,76 & 15,88 & 9,33 & $-0,05$ & 2,12 & 4 & 0,2705 & 0 & 0,45749 & 0,15282 \\
\hline 1096 & 74 & 0 & 0 & 0 & 1 & 0 & 1 & 0 & 0 & 0 & 285869 & 63,99 & 14,3 & 9,01 & $-0,93$ & 2,06 & 4 & 0,2859 & 0 & 0,44308 & 0,46622 \\
\hline 1097 & 74 & 0 & 0 & 0 & 1 & 0 & 1 & 0 & 0 & 0 & 301594 & 56,66 & 15,46 & 11,46 & $-0,38$ & 2,16 & 4 & 0,3016 & 0 & 0,55984 & 0,36584 \\
\hline 1098 & 74 & 0 & 0 & 0 & 1 & 0 & 1 & 0 & 0 & 0 & 320730 & 54,83 & 17,77 & 13,53 & $-0,22$ & 2,22 & 4 & 0,3207 & 0 & 0,62336 & 0,27469 \\
\hline 1099 & 74 & 0 & 0 & 0 & 1 & 0 & 1 & 0 & 0 & 1 & 340018 & 58,56 & 17,33 & 11,44 & $-0,25$ & 2,26 & 4 & 0,34 & 0 & 0,63850 & 0,23673 \\
\hline 1100 & 74 & 0 & 0 & 0 & 1 & 0 & 1 & 0 & 0 & 0 & 355757 & 45,51 & 17,08 & 14,56 & $-0,2$ & 2,22 & 4 & 0,3558 & 0 & 0,71370 & 0,25204 \\
\hline 1101 & 74 & 0 & 0 & 1 & 0 & 0 & 1 & 0 & 0 &. & 377899 & 46,7 & 17,44 & 12,35 & $-0,19$ & 2,3 & 4 & 0,3779 & 0 & 0,50190 & 0,33248 \\
\hline 1102 & 74 & 0 & 0 & 1 & 0 & 0 & 1 & 0 & 0 & 0 & 401214 & 50,18 & 18,51 & 6,63 & $-0,05$ & 2,25 & 4 & 0,4012 & 0 & 0,51054 & 0,28181 \\
\hline 1103 & 74 & 0 & 0 & 1 & 0 & 0 & 1 & 0 & 0 & 1 & 425408 & 49,58 & 17,31 & 10,15 & $-0,01$ & 2,21 & 10 & 0,4254 & 0 & 0,60963 & 0,11598 \\
\hline 1104 & 75 & 0 & 0 & 0 & 0 & 1 & 0 & 1 & 0 & 0 & 2252 & 123,39 & 36,37 & 1,15 & $-7,91$ & 1,9 & 0 & 0,0023 & 0 & 0,03021 & 0,82362 \\
\hline 1105 & 75 & 0 & 0 & 0 & 0 & 1 & 0 & 1 & 0 & 0 & 2428 & 130,67 & 36,35 & 0,9 & $-8,05$ & 1,89 & 0 & 0,0024 & 0 & 0,02889 & 0,81953 \\
\hline 1106 & 75 & 0 & 0 & 0 & 0 & 1 & 0 & 1 & 0 & 0 & 2588 & 140,73 & 35,34 & 0,66 & $-5,52$ & 1,79 & 0 & 0,0026 & 0 & 0,04680 & 0,72215 \\
\hline 1107 & 75 & 0 & 0 & 0 & 0 & 1 & 0 & 1 & 0 & 0 & 2780 & 132,71 & 32,56 & 0,59 & $-4,04$ & 1,61 & 0 & 0,0028 & 0 &, 05111 & 0,75317 \\
\hline 1108 & 75 & 0 & 0 & 0 & 1 & 0 & 0 & 1 & 0 & 0 & 2988 & 142,82 & 35,76 & 0,56 & $-5,05$ & 1,77 & 0 & 0,003 & 0 & 0,05176 & 0,62033 \\
\hline 1109 & 75 & 0 & 0 & 0 & 1 & 0 & 0 & 1 & 0 & 0 & 3132 & 137,15 & 29,79 & 0,54 & $-6,03$ & 1,71 & 0 & 0,0031 & 0 & 0,03331 & 0,78960 \\
\hline 1110 & 75 & 0 & 0 & 0 & 1 & 0 & 0 & 1 & 0 & 0 & 3228 & 144,59 & 28,55 & 5,31 & $-5,53$ & 1,69 & 0 & 0,0032 & 0 &, 03623 & 0,77114 \\
\hline 1111 & 75 & 0 & 0 & 0 & 1 & 0 & 0 & 1 & 0 & 0 & 3478 & 134,42 & 27,75 & 4,89 & $-4,48$ & 1,74 & 0 & 0,0035 & 0 & 0,04805 & 0,73770 \\
\hline 1112 & 75 & 0 & 0 & 0 & 1 & 0 & 0 & 1 & 0 & 0 & 3270 & 110,36 & 36,06 & 5,31 & $-4,24$ & 1,93 & 0 & 0,0033 & 0 & 0,07572 & 0,59115 \\
\hline 1113 & 75 & 0 & 0 & 0 & 1 & 0 & 0 & 1 & 0 & 0 & 3502 & 117,77 & 35,1 & 4 & $-7,49$ & 1,86 & 0 & 0,0035 & 0 &, 03288 & 0,78786 \\
\hline 1114 & 75 & 0 & 0 & 0 & 1 & 0 & 0 & 1 & 0 & 1 & 3727 & 130,8 & 33,75 & 4,18 & $-6,07$ & 1,9 & 0 & 0,0037 & 1 & 0,04608 & 0,69648 \\
\hline 1115 & 75 & 0 & 0 & 0 & 1 & 0 & 0 & 1 & 0 & 0 & 3701 & 127,42 & 30,13 & 4,03 & $-5,84$ & 1,95 & 1 & 0,0037 & 0 & 0,05173 & 0,69369 \\
\hline 1116 & 76 & 0 & 0 & 0 & 0 & 1 & 0 & 1 & 0 & 0 & 4236 & 44,04 & 40,33 & 12,46 & $-17,22$ & 1,68 & 0 & 0,0042 & 0 &, 00165 & 0,99234 \\
\hline 1117 & 76 & 0 & 0 & 0 & 1 & 0 & 0 & 1 & 0 & 0 & 4505 & 48,48 & 35,23 & 12,08 & $-23,36$ & 1,68 & 1 & 0,0045 & 0 & 0,00026 & 0,99816 \\
\hline 1118 & 76 & 0 & 0 & 0 & 1 & 0 & 0 & 1 & 0 & 0 & 4683 & 58,01 & 34,59 & 12,46 & $-9,97$ & 1,77 & 1 & 0,0047 & 0 & 0,01659 & 0,93021 \\
\hline 1119 & 76 & 0 & 0 & 0 & 1 & 0 & 0 & 1 & 0 & 0 & 4857 & 57,01 & 42,89 & 16,04 & $-13,54$ & 1,85 & 1 & 0,0049 & 0 & 0,00957 & 0,94381 \\
\hline 1120 & 76 & 0 & 0 & 0 & 1 & 0 & 0 & 1 & 0 & 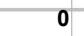 & 5199 & 62,54 & 40,3 & 16,92 & $-14,43$ & 1,86 & 2 & 0,0052 & 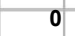 & 0,00791 & 0,95185 \\
\hline 1121 & 76 & 0 & 0 & 0 & 1 & 0 & 0 & 1 & 0 & 0 & 5412 & 61,3 & 40,62 & 17,28 & $-11,42$ & 1,88 & 4 & 0,0054 & 2 & 0,02578 & 0,85867 \\
\hline 1122 & 76 & 0 & 0 & 0 & 1 & 0 & 0 & 1 & 0 & 0 & 5572 & 57,98 & 39,31 & 21,79 & $-18,32$ & 1,8 & 4 & 0,0056 & 0 & 0,00305 & 0,97918 \\
\hline 1123 & 76 & 0 & 0 & 0 & 1 & 0 & 0 & 1 & 0 & 0 & 5614 & 58,09 & 35,58 & 20,09 & $-10,31$ & 1,72 & 5 & 0,0056 & 0 & 0,02740 & 0,87640 \\
\hline 1124 & 76 & 0 & 0 & 0 & 1 & 0 & 0 & 1 & 0 & 1 & 5756 & 62,18 & 38,54 & 22,21 & $-16,44$ & 1,78 & 6 & 0,0058 & 0 &, 00692 & 0,95449 \\
\hline 1125 & 76 & 0 & 0 & 0 & 1 & 0 & 0 & 1 & 0 & 0 & 6062 & 67,2 & 38,98 & 21,24 & $-22,13$ & 1,82 & 6 & 0,0061 & 0 & 0,00138 & 0,98777 \\
\hline 1126 & 76 & 0 & 0 & 0 & 1 & 0 & 0 & 1 & 0 & 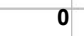 & 6321 & 71,65 & 38,68 & 20,57 & $-12,37$ & 1,7 & 6 & 0,0063 & 0 & 0,02024 & 0,87842 \\
\hline 1127 & 76 & 0 & 0 & 0 & 1 & 0 & 0 & 1 & 0 & 0 & 6584 & 76,76 & 38,76 & 28,28 & $-11,35$ & 1,65 & 6 & 0,0066 & 0 & 0,02621 & 0,84567 \\
\hline 1128 & 76 & 0 & 0 & 0 & 1 & 0 & 0 & 1 & 0 & 0 & 6932 & 82,55 & 41,01 & 19,87 & $-11,62$ & 1,59 & 8 & 0,0069 & 0 & 0,03099 & 0,78645 \\
\hline 1129 & 76 & 0 & 0 & 0 & 1 & 0 & 0 & 1 & 0 & 0 & 7130 & 87,76 & 27,15 & 9,63 & $-8,96$ & 1,61 & 8 & 0,0071 & 0 & 0,03740 & 0,82135 \\
\hline 1130 & 76 & 0 & 0 & 0 & 1 & 0 & 0 & 1 & 0 & 0 & 6933 & 77,92 & 45,92 & 18,33 & $-9,51$ & 1,55 & 8 & 0,0069 & 0 &, 05500 & 0,62580 \\
\hline 1131 & 76 & 0 & 0 & 0 & 1 & 0 & 0 & 1 & 0 & 0 & 7154 & 96,38 & 45,92 & 14,56 & $-7,79$ & 1,54 & 12 & 0,0072 & 0 & 0,08815 & 0,30602 \\
\hline 1132 & 76 & 0 & 0 & 0 & 1 & 0 & 0 & 1 & 0 & 0 & 7600 & 107,34 & 47,09 & 14,01 & $-7,29$ & 1,61 & 12 & 0,0076 & 0 & 0,08910 & 0,22118 \\
\hline 1133 & 76 & 0 & 0 & 0 & 1 & 0 & 0 & 1 & 0 & 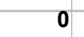 & 7990 & 110,72 & 31,69 & 7,14 & $-5,24$ & 1,61 & 15 & 0,008 & 0 & 0,12768 & 0,22258 \\
\hline 1134 & 77 & 0 & 0 & 0 & 0 & 1 & 0 & 0 & 1 & 0 & 60724 & 57,69 & 10,07 & 11,34 & $-0,58$ & 1,52 & 1 & 0,0607 & 0 & 0,01180 & 0,99008 \\
\hline 1135 & 77 & 0 & 0 & 0 & 0 & 1 & 0 & 0 & 1 & 0 & 62425 & 76,86 & 8,96 & 8,94 & $-0,59$ & 1,45 & 1 & 0,0624 & 0 & 0,01063 & 0,98973 \\
\hline 1136 & 77 & 0 & 0 & 0 & 0 & 1 & 0 & 1 & 0 & 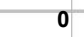 & 64121 & 66,17 & 11,53 & 11,23 & $-0,7$ & 1,38 & 1 & 0,0641 & 0 &, 07424 & 0,89585 \\
\hline 1137 & 77 & 0 & 0 & 0 & 0 & 1 & 0 & 1 & 0 & 0 & 64425 & 55,85 & 11,47 & 6,17 & $-0,34$ & 1,46 & 1 & 0,0644 & 0 & 0,08734 & 0,88775 \\
\hline 1138 & 77 & 0 & 0 & 0 & 0 & 1 & 0 & 1 & 0 & 0 & 67851 & 71,38 & 5,84 & 6,2 & $-0,43$ & 1,54 & 1 & 0,0679 & 0 & 0,07861 & 0,89812 \\
\hline 1139 & 77 & 0 & 0 & 0 & 0 & 1 & 0 & 1 & 0 & 0 & 70844 & 81,81 & 10,82 & 6,7 & $-0,44$ & 1,49 & 1 & 0,0708 & 0 & 0,09261 & 0,85324 \\
\hline 1140 & 77 & & 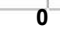 & 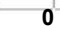 & 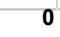 & & 0 & 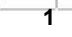 & 0 & & 73525 & 63,38 & 9,43 & 6,34 & $-0,56$ & 1,44 & & 0,0735 & 0 & 0,07946 & 0,89553 \\
\hline
\end{tabular}


Obs ID AA AB $\quad$ BA $\quad$ BB $\quad$ MD LV PL NL REC PIB COMEX AGRI PREF ODP CAP APRE PIB2 ACI CREC P0

\begin{tabular}{|c|c|c|c|c|c|c|c|c|c|c|c|c|c|c|c|c|c|c|c|c|c|}
\hline 1141 & 77 & 0 & 0 & 0 & 0 & 1 & 0 & 1 & 0 & 0 & 81138 & 75,22 & 7,6 & 6,9 & $-0,51$ & 1,54 & 1 & 0,0811 & 0 & 0,09088 & 0,87324 \\
\hline 1142 & 77 & 0 & 0 & 0 & 0 & 1 & 0 & 1 & 0 & 0 & 121465 & 64,61 & 6,47 & 8,43 & $-8,12$ & 1,54 & 1 & 0,1215 & 0 & 0,01263 & 0,97856 \\
\hline 1143 & 77 & 0 & 0 & 0 & 1 & 0 & 0 & 1 & 0 & 0 & 129759 & 64,46 & 11,23 & 14,31 & $-1,27$ & 1,46 & 1 & 0,1298 & 0 & 0,11489 & 0,80435 \\
\hline 1144 & 77 & 0 & 0 & 0 & 1 & 0 & 0 & 1 & 0 & 0 & 137895 & 64,97 & 5,6 & 12,22 & $-0,67$ & 1,53 & 1 & 0,1379 & 0 & 0,12459 & 0,81647 \\
\hline 1145 & 77 & 0 & 0 & 0 & 1 & 0 & 0 & 1 & 0 & o & 147458 & 61,8 & 9,24 & 11,65 & $-1,07$ & 1,3 & 1 & 0,1475 & 0 & 0,10360 & 0,83766 \\
\hline 1146 & 77 & 0 & 0 & 0 & 1 & 0 & 0 & 1 & 0 & 0 & 159018 & 42,65 & 7,44 & 14,69 & $-0,59$ & 1,35 & 1 & 0,159 & 0 & 0,12548 & 0,84408 \\
\hline 1147 & 77 & 0 & 0 & 0 & 1 & 0 & 0 & 1 & 0 & 0 & 166790 & 52,79 & 18,84 & 11,23 & $-0,45$ & 1,42 & 1 & 0,1668 & 0 & 0,20233 & 0,64034 \\
\hline 1148 & 77 & 0 & 0 & 0 & 1 & 0 & 0 & 1 & 0 & 0 & 173927 & 44,38 & 15,77 & 10,83 & $-0,44$ & 1,5 & 4 & 0,1739 & 0 & 0,28083 & 0,54800 \\
\hline 1149 & 78 & 0 & 0 & 0 & 0 & 1 & 0 & 1 & 0 & 0 & 73113 & 36,13 & 19,74 & 3,54 & $-1,34$ & 1,91 & 0 & 0,0731 & 0 & 0,13939 & 0,80487 \\
\hline 1150 & 78 & 0 & 0 & 0 & 0 & 1 & 0 & 1 & 0 & 1 & 76657 & 38,33 & 17,23 & 4,86 & $-1,64$ & 1,91 & 3 & 0,0767 & 1 & 0,17728 & 0,74957 \\
\hline 1151 & 78 & 0 & 0 & 0 & 0 & 1 & 0 & 1 & 0 & 0 & 77434 & 36,85 & 18,73 & 4,67 & $-1,45$ & 1,98 & 3 & 0,0774 & 1 & 0,20821 & 0,70032 \\
\hline 1152 & 78 & 0 & 0 & 0 & 0 & 1 & 0 & 1 & 0 & 0 & 79409 & 34,01 & 20,65 & 4,47 & $-1,72$ & 2,05 & 3 & 0,0794 & 0 & 0,22266 & 0,66766 \\
\hline 1153 & 78 & 0 & 0 & 0 & 0 & 1 & 0 & 0 & 1 & 0 & 82316 & 32,32 & 19 & 6,39 & $-1,19$ & 1,99 & 3 & 0,0823 & 0 & 0,04208 & 0,96164 \\
\hline 1154 & 78 & 0 & 0 & 0 & 0 & 1 & 0 & 0 & 1 & 1 & 85822 & 28,13 & 15,51 & 8,07 & $-0,96$ & 1,92 & 4 & 0,0858 & 0 & 0,04187 & 0,96623 \\
\hline 1155 & 78 & 0 & 0 & 0 & 0 & 1 & 0 & 0 & 1 & 0 & 87524 & 30,37 & 14,8 & 6,47 & $-2,72$ & 2,01 & 4 & 0,0875 & 0 & 0,02743 & 0,97589 \\
\hline 1156 & 78 & 0 & 0 & 0 & 0 & 1 & 0 & 0 & 1 & 0 & 90346 & 30,54 & 14,53 & 7,31 & $-2,9$ & 2,11 & 7 & 0,0903 & 0 & 0,04809 & 0,95573 \\
\hline 1157 & 78 & 0 & 0 & 0 & 0 & 1 & 0 & 0 & 1 & 0 & 94724 & 32,84 & 14,43 & 8,35 & $-1,25$ & 2,11 & 7 & 0,0947 & 0 & 0,08053 & 0,92993 \\
\hline 1158 & 78 & 0 & 0 & 0 & 0 & 1 & 0 & 0 & 1 & 0 & 101704 & 30,3 & 14,16 & 10,12 & $-1,44$ & 2,05 & 7 & 0,1017 & 0 & 0,07347 & \begin{tabular}{|l|l}
0,93788 \\
\end{tabular} \\
\hline 1159 & 78 & 0 & 0 & 0 & 0 & 1 & 0 & 0 & 1 & 1 & 109502 & 35,25 & 14,29 & 7,96 & $-1,44$ & 2,08 & 8 & 0,1095 & 0 & 0,09405 & 0,91520 \\
\hline 1160 & 78 & 0 & 0 & 0 & 0 & 1 & 0 & 0 & 1 & 0 & 116267 & 35,68 & 13,7 & 8,26 & $-1,56$ & 2,13 & 9 & 0,1163 & 0 & 0,11481 & 0,89551 \\
\hline 1161 & 78 & 0 & 0 & 0 & 0 & 1 & 0 & 0 & 1 & 0 & 121886 & 32,99 & 13,74 & 17,59 & $-1,46$ & 2,04 & 9 & 0,1219 & 0 & 0,11397 & 0,90185 \\
\hline 1162 & 78 & 0 & 0 & 0 & 1 & 0 & 0 & 1 & 0 & 0 & 123959 & 35,59 & 17,7 & 15,91 & $-0,89$ & 1,8 & 9 & 0,124 & 0 & 0,38511 & 0,33590 \\
\hline 1163 & 78 & 0 & 0 & 0 & 1 & 0 & 0 & 1 & 0 & 0 & 127469 & 32,07 & 16,69 & 19,04 & $-1,6$ & 1,72 & 9 & 0,1275 & 0 & 0,34547 & 0,42544 \\
\hline 1164 & 78 & 0 & 0 & 0 & 1 & 0 & 0 & 1 & 0 & 0 & 129518 & 32,87 & 18,25 & 14,45 & $-1,64$ & 1,74 & 9 & 0,1295 & 0 & 0,34590 & 0,39092 \\
\hline 1165 & 78 & 0 & 0 & 0 & 1 & 0 & 0 & 1 & 0 & 0 & 133077 & 32,94 & 18,98 & 13,68 & $-1,57$ & 1,69 & 9 & 0,1331 & 0 & 0,34443 & 0,38550 \\
\hline 1166 & 78 & 0 & 0 & 0 & 1 & 0 & 0 & 1 & 0 & 0 & 137744 & 32,81 & 16,69 & 16,38 & $-0,85$ & 1,71 & 9 & 0,1377 & 0 & 0,39104 & 0,36337 \\
\hline 1167 & 79 & 0 & 0 & 0 & 1 & 0 & 0 & 1 & 0 & 0 & 7784 & 118,06 & 50,92 & 0,91 & $-1,71$ & 1,55 & 0 & 0,0078 & 0 & 0,09826 & 0,28837 \\
\hline 1168 & 79 & 0 & 0 & 0 & 1 & 0 & 0 & 1 & 0 & 0 & 7906 & 103,04 & 52,24 & 1,47 & $-0,95$ & 1,55 & 0 & 0,0079 & 0 & 0,11604 & 0,26262 \\
\hline 1169 & 79 & 0 & 0 & 0 & 1 & 0 & 0 & 1 & 0 & 0 & 8242 & 95,93 & 52,48 & 1,39 & $-1,18$ & 1,48 & 0 & 0,0082 & 0 & 0,11438 & 0,30792 \\
\hline 1170 & 79 & 0 & 0 & 0 & 1 & 0 & 0 & 1 & 0 & 0 & 8247 & 104,69 & 56,37 & 1 & $-0,93$ & 1,41 & 1 & 0,0082 & 0 & 0,11057 & 0,21082 \\
\hline 1171 & 79 & 0 & 0 & 0 & 1 & 0 & 0 & 1 & 0 & 0 & 8135 & 82,1 & 54,27 & 1,08 & $-1,02$ & 1,37 & 1 & 0,0081 & 0 & 0,12433 & 0,30199 \\
\hline 1172 & 79 & 0 & 0 & 0 & 1 & 0 & 0 & 1 & 0 & 0 & 7946 & 85,09 & 51,97 & 0,92 & $-1,15$ & 1,33 & 3 & 0,0079 & 0 & 0,12861 & 0,27648 \\
\hline 1173 & 79 & 0 & 0 & 0 & 1 & 0 & 0 & 1 & 0 & 0 & 7880 & 80,74 & 53,25 & 0,8 & $-0,91$ & 1,37 & 5 & 0,0079 & 0 & 0,14294 & 0,18614 \\
\hline 1174 & 79 & 0 & 0 & 0 & 1 & 0 & 0 & 1 & 0 & 0 & 7878 & 90,14 & 55,64 & 0,92 & $-0,99$ & 1,41 & 10 & 0,0079 & 0 & 0,13332 & 0,06538 \\
\hline 1175 & 79 & 0 & 0 & 0 & 1 & 0 & 0 & 1 & 0 & 0 & 8219 & 94,86 & 55,07 & 0,86 & $-0,94$ & 1,59 & 14 & 0,0082 & 0 & 0,12725 & 0,02536 \\
\hline 1176 & 79 & 0 & 0 & 0 & 1 & 0 & 0 & 1 & 0 & 0 & 8552 & 95,59 & 53,94 & 0,8 & $-0,33$ & 1,6 & 14 & 0,0086 & 0 & 0,13351 & 0,02288 \\
\hline 1177 & 79 & 0 & 0 & 0 & 1 & 0 & 0 & 1 & 0 & 0 & 8735 & 104,2 & 51,64 & 1,02 & $-0,69$ & 1,71 & 15 & 0,0087 & 0 & 0,12697 & $\mid 0,01929$ \\
\hline 1178 & 79 & 0 & 0 & 0 & 1 & 0 & 0 & 1 & 0 & 0 & 9155 & 107,77 & 48,55 & 0,7 & $-0,6$ & 1,61 & 15 & 0,0092 & 0 & 0,13267 & 0,02587 \\
\hline 1179 & 79 & 0 & 0 & 0 & 1 & 0 & 0 & 1 & 0 & 0 & 9651 & 103,52 & 50,57 & 2,78 & $-0,84$ & 1,65 & 15 & 0,0097 & 0 & 0,13058 & 0,02345 \\
\hline 1180 & 79 & 0 & 0 & 0 & 1 & 0 & 0 & 1 & 0 & 0 & 10265 & 103,55 & 50,34 & 2,21 & $-0,77$ & 1,63 & 15 & 0,0103 & 0 & 0,13155 & 0,02400 \\
\hline 1181 & 79 & 0 & 0 & 0 & 1 & 0 & 0 & 1 & 0 & 0 & 9858 & 96,3 & 51,58 & 2,47 & -1 & 1,58 & 15 & 0,0099 & 0 & 0,13462 & 0,02719 \\
\hline 1182 & 79 & 0 & 0 & 1 & 0 & 0 & 0 & 1 & 0 & 0 & 11148 & 106,58 & 35,66 & 2,07 & $-0,65$ & 1,56 & 15 & 0,0111 & 0 & 0,13157 & 0,12774 \\
\hline 1183 & 79 & 0 & 0 & 1 & 0 & 0 & 0 & 1 & 0 & 0 & 11632 & 102,82 & 35,61 & 2,33 & $-0,39$ & 1,66 & 15 & 0,0116 & 0 & 0,13968 & 0,10958 \\
\hline 1184 & 79 & 0 & 0 & 1 & 0 & 0 & 0 & 1 & 0 & 0 & 11488 & 98,63 & 34,09 & 2,19 & $-0,45$ & 1,6 & 15 & 0,0115 & 0 & 0,14536 & 0,13754 \\
\hline 1185 & 80 & 0 & 0 & 0 & 1 & 0 & 0 & 1 & 0 & 0 & 18954 & 78,75 & 19,49 & 6,46 & $-1,7$ & 2,1 & 2 & 0,019 & 0 & 0,14455 & 0,62523 \\
\hline 1186 & 80 & 0 & 0 & 0 & 1 & 0 & 0 & 1 & 0 & 0 & 20091 & 88,64 & 17,75 & 5,47 & $-1,72$ & 2,15 & 2 & 0,0201 & 0 & 0,14275 & 0,61112 \\
\hline 1187 & 80 & 0 & 0 & 0 & 1 & 0 & 0 & 1 & 0 & 0 & 19780 & 80,9 & 18,96 & 6,51 & $-2,21$ & 2,29 & 2 & 0,0198 & 0 & 0,15122 & 0,59266 \\
\hline 1188 & 80 & 0 & 0 & 0 & 1 & 0 & 0 & 1 & 0 & 0 & 20565 & 76,34 & 18,71 & 6,53 & $-2,04$ & 2,44 & 3 & 0,0206 & 0 & 0,19148 & 0,49954 \\
\hline 1189 & 80 & 0 & 0 & 0 & 1 & 0 & 0 & 1 & 0 & 0 & 21786 & 75,34 & 18,6 & 6,55 & $-3,59$ & 2,3 & 3 & 0,0218 & 0 & 0,12772 & 0,65024 \\
\hline 1190 & 80 & 0 & 0 & 0 & 1 & 0 & 0 & 1 & 0 & 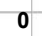 & 22972 & 79,48 & 17,62 & 5,85 & $-2,48$ & 2,1 & 3 & 0,023 & 0 & 0,13199 & 0,65439 \\
\hline 1191 & 80 & 0 & 0 & 0 & 1 & 0 & 0 & 1 & 0 & 0 & 24406 & 73,6 & 18,34 & 6,28 & $-4,82$ & 2,21 & 3 & 0,0244 & 0 & 0,08922 & 0,74911 \\
\hline 1192 & 80 & 0 & 0 & 0 & 1 & 0 & 0 & 1 & 0 & 0 & 26278 & 71,26 & 18,54 & 6,01 & $-2,82$ & 2,32 & 3 & 0,0263 & 0 & 0,15618 & 0,60008 \\
\hline 1193 & 80 & 0 & 0 & 0 & 1 & 0 & 0 & 1 & 0 & 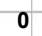 & 28064 & 68,61 & 18,8 & 10,95 & $-1,92$ & 2,41 & 3 & 0,0281 & 0 & 0,20530 & 0,50596 \\
\hline 1194 & 80 & 0 & 0 & 0 & 1 & 0 & 0 & 1 & 0 & 0 & 29734 & 63,37 & 20,26 & 12,02 & $-1,84$ & 2,38 & 3 & 0,0297 & 0 & 0,21306 & 0,49667 \\
\hline 1195 & 80 & 0 & 0 & 0 & 1 & 0 & 0 & 1 & 0 & 0 & 30786 & 49,15 & 22,42 & 15,08 & $-1,69$ & 2,38 & 3 & 0,0308 & 0 & 0,23772 & 0,48401 \\
\hline 1196 & 80 & 0 & 0 & 0 & 1 & 0 & 0 & 1 & 0 & 0 & 33254 & 46,36 & 22,72 & 13,65 & $-1,04$ & 2,32 & 3 & 0,0333 & 0 & 0,25922 & 0,46196 \\
\hline 1197 & 80 & 0 & 0 & 1 & 0 & 0 & 0 & 1 & 0 & 0 & 36049 & 52,96 & 21,26 & 10,8 & $-1,04$ & 2,4 & 3 & 0,036 & 0 & 0,14597 & 0,61216 \\
\hline 1198 & 80 & 0 & 0 & 1 & 0 & 0 & 0 & 1 & 0 & 0 & 39345 & 52,96 & 20,07 & 11,71 & $-0,84$ & 2,26 & 3 & 0,0393 & 0 & 0,13380 & \begin{tabular}{|l|l}
0,66084 \\
\end{tabular} \\
\hline 1199 & 81 & 0 & 0 & 0 & 1 & 0 & 0 & 0 & 1 & 0 & 2328 & 162,34 & 31,66 & 0,49 & $-0,84$ & 1,79 & 0 & 0,0023 & 0 & 0,02966 & 0,87019 \\
\hline 1200 & 81 & 0 & & & & & & & & & 355 & 83,92 & $s, 5$ &, 22 &, 0 & 1,85 & & 0,0024 & & , ,02589 & 0,8485 \\
\hline
\end{tabular}




\begin{tabular}{|c|c|c|c|c|c|c|c|c|c|c|c|c|c|c|c|c|c|c|c|c|c|}
\hline bs & ID & AA & $A B$ & BA & BB & MD & LV & PL & NL & REC & PIB & COMEX & AGRI & PREF & ODP & CAP & APRE & PIB2 & $\mathrm{ACl}$ & CREC & po \\
\hline 1201 & 81 & 0 & 0 & 0 & 1 & 0 & 0 & 0 & 1 & 0 & 2397 & 196,74 & 21,06 & 1,04 & $-1,82$ & 1,92 & 2 & 0,0024 & 0 & 0,02436 & 0,87983 \\
\hline 1202 & 81 & 0 & 0 & 0 & 1 & 0 & 0 & 0 & 1 & 0 & 2451 & 202,85 & 20,76 & 0,72 & $-2,21$ & 1,68 & 3 & 0,0025 & 0 & 0,01860 & 0,90240 \\
\hline 1203 & 81 & 0 & 0 & 0 & 1 & 0 & 0 & 0 & 1 & 0 & 2522 & 172,4 & 18,92 & 0,85 & $-1,03$ & 1,45 & 3 & 0,0025 & 0 & 0,01700 & 0,93814 \\
\hline 1204 & 81 & 0 & 0 & 0 & 1 & 0 & 0 & 0 & 1 & 0 & 2584 & 178,26 & 22,43 & 1,18 & $-1,69$ & 1,41 & 3 & 0,0026 & 0 & 0,01572 & 0,93309 \\
\hline 1205 & 81 & 0 & 0 & 1 & 0 & 0 & 0 & 0 & 1 & 0 & 2669 & 155,63 & 25,46 & 0,79 & $-1,17$ & 1,66 & 3 & 0,0027 & 0 & 0,01150 & 0,94667 \\
\hline 1206 & 81 & 0 & 0 & 1 & 0 & 0 & 0 & 0 & 1 & 0 & 2763 & 152,63 & 24,86 & 3,05 & $-1,64$ & 1,65 & 3 & 0,0028 & 0 & 0,00968 & 0,95624 \\
\hline 1207 & 82 & 0 & 0 & 1 & 0 & 0 & 0 & 1 & 0 & 1 & 140119 & 89,76 & 15,67 & 5,45 & $-0,5$ & 2,77 & 0 & 0,1401 & 0 & 0,20253 & 0,38293 \\
\hline 1208 & 82 & 0 & 0 & 1 & 0 & 0 & 0 & 1 & 0 & 3 & 148039 & 84,27 & 15,83 & 5,33 & $-0,46$ & 2,77 & 4 & 0,148 & 0 & 0,25001 & 0,23236 \\
\hline 1209 & 82 & 0 & 0 & 1 & 0 & 0 & 0 & 1 & 0 & 0 & 143963 & 95,05 & 15,37 & 4,44 & $-0,43$ & 2,68 & 6 & 0,144 & 0 & 0,23882 & 0,18620 \\
\hline 1210 & 82 & 0 & 0 & 0 & 1 & 0 & 1 & 0 & 0 & 0 & 132973 & 100,24 & 16,23 & 4,53 & $-0,64$ & 2,59 & 7 & 0,133 & 1 & 0,37732 & 0,28877 \\
\hline 1211 & 82 & 0 & 0 & 0 & 1 & 0 & 1 & 0 & 0 & 1 & 139053 & 100,71 & 14,75 & 4,77 & $-0,83$ & 2,64 & 7 & 0,1391 & 0 & 0,38199 & 0,29509 \\
\hline 1212 & 82 & 0 & 0 & 0 & 1 & 0 & 1 & 0 & 0 & 2 & 145249 & 121,3 & 12,89 & 3,57 & $-0,56$ & 2,7 & 8 & 0,1452 & 0 & 0,37389 & 0,20709 \\
\hline 1213 & 82 & 0 & 0 & 0 & 1 & 0 & 1 & 0 & 0 & 1 & 150252 & 120,27 & 13,5 & 4,14 & $-0,24$ & 2,75 & 9 & 0,1503 & 0 & 0,39914 & 0,14860 \\
\hline 1214 & 82 & 0 & 0 & 0 & 1 & 0 & 1 & 0 & 0 & 0 & 159491 & 114,97 & 13,36 & 4,66 & $-0,23$ & 2,79 & 23 & 0,1595 & 0 & 0,40278 & 0,01404 \\
\hline 1215 & 82 & 0 & 0 & 0 & 1 & 0 & 1 & 0 & 0 & 2 & 170957 & 116,69 & 13,56 & 3,94 & 0,65 & 2,88 & 29 & 0,171 & 0 & 0,38086 & 0,00308 \\
\hline 1216 & 82 & 0 & 0 & 0 & 1 & 0 & 1 & 0 & 0 & 1 & 181709 & 127,41 & 12,51 & 3,3 & $-0,03$ & 2,86 & 30 & 0,1817 & 0 & 0,34206 & 0,00282 \\
\hline 1217 & 82 & 0 & 0 & 1 & 0 & 0 & 0 & 1 & 0 & 0 & 189318 & 137,85 & 11,07 & 3,32 & 0,09 & 2,93 & 33 & 0,1893 & 0 & 0,15903 & 0,00075 \\
\hline 1218 & 82 & 0 & 0 & 1 & 0 & 0 & 0 & 1 & 0 & 1 & 198724 & 134,09 & 11,33 & 3,34 & 0,1 & 2,9 & 39 & 0,1987 & 0 & 0,15128 & 0,00026 \\
\hline 1219 & 82 & 0 & 0 & 1 & 0 & 0 & 0 & 1 & 0 & 0 & 209525 & 129,87 & 11,52 & 3,93 & 0,12 & 2,87 & 42 & 0,2095 & 0 & 0,15087 & 0,00015 \\
\hline 1220 & 82 & 0 & 1 & 0 & 0 & 0 & 0 & 1 & 0 & 1 & 213140 & 140,44 & 12,64 & 3,29 & 0,22 & 2,75 & 46 & 0,2131 & 2 & 0,26584 & 0,00037 \\
\hline 1221 & 82 & 0 & 1 & 0 & 0 & 0 & 0 & 1 & 0 & 0 & 211567 & 118,88 & 13,58 & 3,96 & 0,03 & 2,78 & 49 & 0,2116 & 0 & 0,29770 & 0,00026 \\
\hline 1222 & 82 & 0 & 1 & 0 & 0 & 0 & 0 & 1 & 0 & 0 & 227448 & 126,76 & 12,95 & 3,83 & 0 & 2,69 & 51 & 0,2274 & 0 & 0,27678 & 0,00018 \\
\hline 1223 & 82 & 0 & 1 & 0 & 0 & 0 & 0 & 1 & 0 & 0 & 229345 & 138,86 & 14,29 & 2,69 & 0,04 & 2,71 & 55 & 0,2293 & 0 & 0,22899 & 0,00007 \\
\hline 1224 & 82 & 0 & 1 & 0 & 0 & 0 & 0 & 1 & 0 & 0 & 246139 & 137,95 & 12,94 & 2,91 & 0,04 & 2,71 & 63 & 0,2461 & 0 & 0,21475 & 0,00002 \\
\hline 1225 & 83 & 0 & 0 & 1 & 0 & 0 & 1 & 0 & 0 & 0 & 102026 & 101,83 & 12,24 & 607,59 & $-0,35$ & 1,79 & 0 & 0,102 & 0 &, 52828 & 0,77694 \\
\hline 1226 & 83 & 0 & 0 & 1 & 0 & 0 & 1 & 0 & 0 & 0 & 86926 & 94,42 & 18,16 & 366,17 & $-0,58$ & 1,7 & 0 & 0,0869 & 0 & 0,17611 & 0,85376 \\
\hline 1227 & 83 & 0 & 0 & 1 & 0 & 0 & 0 & 1 & 0 & 1 & 90577 & 104,31 & 15,18 & 319,48 & $-0,48$ & 1,75 & 0 & 0,0906 & 0 & 0,24621 & ,63162 \\
\hline 1228 & 83 & 0 & 0 & 1 & 0 & 0 & 0 & 1 & 0 & 1 & 95287 & 106,24 & 13,71 & 541,83 & $-0,49$ & 1,69 & 0 & 0,0953 & 1 & ,53988 & 0,54262 \\
\hline 1229 & 83 & 0 & 0 & 1 & 0 & 0 & 0 & 1 & 0 & 1 & 95478 & 104,09 & 17,46 & 475,66 & $-0,44$ & 1,92 & 2 & 0,0955 & 0 & 0,58636 & 0,34936 \\
\hline 1230 & 84 & 0 & 0 & 1 & 0 & 0 & 1 & 0 & 0 & 0 & 1289 & 90,4 & 40,12 & 2,52 & $-17,04$ & 2,56 & 0 & 0,0013 & 0 & 0,00119 & 0,99163 \\
\hline 1231 & 84 & 0 & 0 & 1 & 0 & 0 & 1 & 0 & 0 & 0 & 1273 & 79,9 & 44,9 & 2,74 & $-15,44$ & 2,54 & 0 & 0,0013 & 0 &, 00229 & 0,98463 \\
\hline 1232 & 84 & 0 & 0 & 1 & 0 & 0 & 1 & 0 & 0 & 0 & 1291 & 86,92 & 46,54 & 2,64 & -26 & 2,48 & 0 & 0,0013 & 0 & 0,00009 & 0,99892 \\
\hline 1233 & 84 & 0 & 0 & 1 & 0 & 0 & 1 & 0 & 0 & 0 & 1343 & 91,76 & 46,08 & 2,38 & $-17,98$ & 2,66 & 0 & 0,0013 & 0 & 0,00136 & 0,98830 \\
\hline 1234 & 85 & 0 & 0 & 0 & 1 & 0 & 0 & 0 & 1 & 0 & 6364 & 132,05 & 4,62 & 5,21 & $-1,99$ & 1,16 & 8 & 0,0064 & 0 & 0,00264 & 0,99525 \\
\hline 1235 & 85 & 0 & 0 & 0 & 1 & 0 & 0 & 0 & 1 & 0 & 6719 & 122,15 & 5,44 & 6,03 & -7 & 1,28 & 0 & 0,0067 & 0 & 0,00070 & 0,99854 \\
\hline 1236 & 85 & 0 & 0 & 0 & 1 & 0 & 0 & 0 & 1 & 0 & 7221 & 120,62 & 5,32 & 4,49 & $-3,97$ & 1,26 & 0 & 0,0072 & 0 & 0,00168 & 0,99695 \\
\hline 1237 & 85 & 0 & 0 & 0 & 1 & 0 & 0 & 0 & 1 & 0 & 7853 & 139,82 & 4,46 & 5,88 & $-17,4$ & 1,27 & 0 & 0,0079 & 0 & 0,00003 & 0,99989 \\
\hline 1238 & 85 & 0 & 0 & 0 & 1 & 0 & 0 & 0 & 1 & 0 & 8121 & 145,12 & 3,27 & 2,97 & $-3,15$ & 1,3 & 0 & 0,0081 & 0 & 0,00220 & 0,99544 \\
\hline 1239 & 85 & 0 & 0 & 0 & 1 & 0 & 0 & 0 & 1 & 0 & 8430 & 144,1 & 3,47 & 4,38 & $-1,68$ & 1,3 & 0 & 0,0084 & 0 & 0,00349 & 0,99326 \\
\hline 1240 & 86 & 0 & 0 & 0 & 0 & 1 & 0 & 1 & 0 & 0 & 4501 & 62,66 & 26,58 & 1,81 & $-5,47$ & 1,18 & 0 & 0,0045 & 0 & 0,01479 & 0,96464 \\
\hline 1241 & 86 & 0 & 0 & 0 & 0 & 1 & 0 & 1 & 0 & 0 & 4717 & 63,33 & 24,16 & 2,6 & $-9,26$ & 1,19 & 0 & 0,0047 & 0 & 0,00434 & 0,98843 \\
\hline 1242 & 86 & 0 & 0 & 0 & 1 & 0 & 0 & 1 & 0 & 0 & 4976 & 71,63 & 26,88 & 2,48 & -9 & 1,19 & 0 & 0,005 & 0 & 0,00604 & 0,97764 \\
\hline 1243 & 86 & 0 & 0 & 0 & 1 & 0 & 0 & 1 & 0 & 0 & 5526 & 78,26 & 27,15 & 2,28 & $-5,47$ & 1,19 & 0 & 0,0055 & 0 & 0,01762 & 0,94022 \\
\hline 1244 & 86 & 0 & 0 & 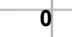 & 1 & 0 & 0 & 1 & 0 & & 5849 & 79,74 & 26,5 & 2,5 & $-6,56$ & 1,38 & 0 & 0,0058 & 0 & 0,01615 & 0,94214 \\
\hline 1245 & 86 & 0 & 0 & 0 & 1 & 0 & 0 & 1 & 0 & 0 & 6411 & 85,32 & 26,01 & 4,05 & $-5,46$ & 1,22 & 0 & 0,0064 & 0 & 0,01799 & 0,93708 \\
\hline 1246 & 86 & 0 & 0 & 0 & 1 & 0 & 0 & 1 & 0 & 0 & 7012 & 89,88 & 21,17 & 2,63 & $-5,9$ & 1,21 & 0 & 0,007 & 0 & 0,01270 & 0,95785 \\
\hline 1247 & 86 & 8 & 0 & 0 & 1 & 0 & 0 & 1 & 0 & 0 & 7878 & 89,16 & 20,33 & 8,26 & $-5,2$ & 1,16 & 0 & 0,0079 & 0 & 0,01450 & 0,95526 \\
\hline 1248 & 86 & 0 & 0 & 1 & 0 & 0 & 0 & 1 & 0 & 0 & 8060 & 87,02 & 17,09 & 9,5 & $-11,44$ & 1,28 & 0 & 0,0081 & 0 & 0,00091 & 0,99586 \\
\hline 1249 & 86 & 0 & 0 & 1 & 0 & 0 & 0 & 1 & 0 & 0 & 7756 & 78,67 & 24,38 & 9,84 & $-12,25$ & 1,26 & 0 & 0,0078 & 0 & 0,00096 & 0,99503 \\
\hline 1250 & 86 & 0 & 0 & 1 & 0 & 0 & 0 & 1 & 0 & 0 & 8241 & 87,72 & 20,53 & 7,69 & -8 & 1,27 & 0 & 0,0082 & 0 & 0,00298 & 0,98719 \\
\hline 1251 & 86 & 0 & 0 & 1 & 0 & 0 & 0 & 1 & 0 & 0 & 8834 & 91,02 & 16,93 & 5,63 & $-6,59$ & 1,3 & 0 & 0,0088 & 0 & ,00402 & 0,98448 \\
\hline 1252 & 86 & 0 & 0 & 1 & 0 & 0 & 0 & 1 & 0 & 0 & 9381 & 95,95 & 21,82 & 4,93 & $-7,18$ & 1,3 & 0 & 0,0094 & 0 & 0,00428 & 0,98016 \\
\hline 1253 & 87 & 0 & 0 & 0 & 0 & 1 & 0 & 1 & 0 & 0 & 1187 & 169,57 & 15,97 & 2,65 & $-5,19$ & 2,33 & 0 & 0,0012 & 0 & 0,04959 & 0,75777 \\
\hline 1254 & 87 & 0 & 0 & 0 & 0 & 1 & 0 & 1 & 0 & 0 & 1238 & 190,4 & 25,54 & 4,32 & $-7,15$ & 2,36 & 0 & 0,0012 & 0 &, 04205 & 0,66739 \\
\hline 1255 & 87 & 0 & 0 & 0 & 0 & 1 & 1 & 0 & 0 & 0 & 1244 & 209,89 & 20,69 & 4,61 & $-9,4$ & 2,39 & 0 & 0,0012 & 0 & 0,01110 & 0,93573 \\
\hline 1256 & 87 & 0 & 0 & 0 & 0 & 1 & 1 & 0 & 0 & 8 & 1302 & 199,44 & 16,73 & 4,47 & $-7,97$ & 2,32 & 0 & 0,0013 & 0 & 0,01264 & 0,94280 \\
\hline 1257 & 87 & 0 & 0 & 0 & 0 & 1 & 1 & 0 & 0 & 0 & 1332 & 186,15 & 13,09 & 2,38 & $-8,8$ & 2,11 & 0 & 0,0013 & 0 & 0,00608 & 0,97676 \\
\hline 1258 & 87 & 0 & 0 & 0 & 1 & 0 & 1 & 0 & 0 & 0 & 1581 & 176,55 & 22,24 & 14,85 & $-9,06$ & 2,11 & 0 & 0,0016 & 0 & 0,00978 & 0,94871 \\
\hline 1259 & 87 & 0 & 0 & 0 & 1 & 0 & 0 & 1 & 0 & 0 & 1634 & 158,46 & 24,71 & 3,66 & $-7,75$ & 2,21 & 0 & 0,0016 & 0 & 0,03204 & 76321 \\
\hline 260 & 81 & 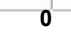 & 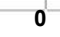 & 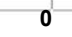 & & 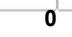 & 0 & & . & 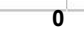 & 1763 & 155,76 & 22,49 & 6,28 & $-15,1$ & 2,18 & 0 & 0,0018 & 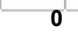 & 0,00374 & 0,96524 \\
\hline
\end{tabular}




\begin{tabular}{|c|c|c|c|c|c|c|c|c|c|c|c|c|c|c|c|c|c|c|c|c|c|}
\hline bs & ID & AA & $A B$ & BA & BB & MD & LV & PL & NL & REC & PIB & COMEX & AGRI & PREF & ODP & CAP & APRE & PIB2 & $\mathrm{ACl}$ & CREC & po \\
\hline 1261 & 87 & 0 & 0 & 0 & 1 & 0 & 0 & 1 & 0 & 0 & 1834 & 151,86 & 23,93 & 6,21 & $-13,81$ & 2,2 & 0 & 0,0018 & 0 & 0,00593 & 0,94769 \\
\hline 1262 & 87 & 0 & 0 & 0 & 1 & 0 & 0 & 1 & 0 & 0 & 1925 & 147,09 & 22,48 & 5,54 & $-14,49$ & 2,11 & 0 & 0,0019 & 0 & 0,00398 & 0,96656 \\
\hline 1263 & 88 & 0 & 0 & 0 & 0 & 1 & 0 & 0 & . & 0 & 1556 & 98,57 & 44,79 & 5,62 & $-17,93$ & 2,36 & 0 & 0,0016 & 0 & 0,00060 & 0,99644 \\
\hline 1264 & 88 & 0 & 0 & 0 & 0 & 1 & 0 & 0 & 1 & 0 & 1647 & 94,71 & 44,18 & 6,18 & $-21,65$ & 2,36 & 0 & 0,0016 & 0 & 0,00019 & 0,99876 \\
\hline 1265 & 88 & 0 & 0 & 0 & 0 & 1 & 0 & 1 & 0 & 0 & 1742 & 75,26 & 19,89 & 3,32 & $-20,13$ & 2,32 & 0 & 0,0017 & 0 & 0,00064 & 0,99709 \\
\hline 1266 & 88 & 0 & 0 & 0 & 0 & 1 & 0 & 1 & 0 & 0 & 1777 & 76,03 & 21,17 & 1,84 & $-26,18$ & 2,4 & 0 & 0,0018 & 0 & 0,00012 & 0,99926 \\
\hline 1267 & 88 & 0 & 0 & 0 & 0 & 1 & 0 & 0 & 1 & 0 & 1789 & 70,61 & 22,66 & 2,3 & $-32,35$ & 2,48 & 0 & 0,0018 & 0 & 0,00000 & 0,99999 \\
\hline 1268 & 88 & 0 & 0 & 0 & 0 & 1 & 0 & 0 & 1 & 0 & 1896 & 68,26 & 26,82 & 3,99 & $-18,14$ & 2,48 & 0 & 0,0019 & 0 & 0,00026 & 0,99920 \\
\hline 1269 & 88 & 0 & 0 & 0 & 0 & 1 & 0 & 1 & 0 & 0 & 2005 & 92,26 & 18,04 & 2,86 & $-11,75$ & 2,03 & 0 & 0,002 & 0 & 0,00520 & 0,98209 \\
\hline 1270 & 88 & 0 & 0 & 0 & 0 & 1 & 0 & 1 & 0 & 0 & 2184 & 113,2 & 14,34 & 2,09 & $-10,19$ & 2,17 & 0 & 0,0022 & 0 & 0,00886 & 0,96836 \\
\hline 1271 & 88 & 0 & 0 & 0 & 0 & 1 & 0 & 1 & 0 & 0 & 2597 & 98,44 & 22,8 & 1,75 & $-10,03$ & 1,73 & 0 & 0,0026 & 0 & 0,00726 & 0,97298 \\
\hline 1272 & 88 & 0 & 0 & 0 & 0 & 1 & 0 & 0 & 1 & 0 & 2670 & 103,01 & 20,99 & 6,65 & $-13,79$ & 1,64 & 0 & 0,0027 & 0 & 0,00025 & 0,99928 \\
\hline 1273 & 88 & 0 & 0 & 0 & 1 & 0 & 0 & 0 & 1 & 0 & 2699 & 112,99 & 22,86 & 6,08 & $-16,87$ & 1,55 & 0 & 0,0027 & 0 & 0,00011 & 0,99951 \\
\hline 1274 & 88 & 0 & 0 & 0 & 1 & 0 & 0 & 0 & 1 & 0 & 2671 & 97,7 & 27,33 & 6,3 & $-14,38$ & 1,62 & 0 & 0,0027 & 0 & 0,00031 & 0,99879 \\
\hline 1275 & 88 & 0 & 0 & 0 & 1 & 0 & 0 & 0 & 1 & 0 & 2798 & 111,92 & 33,14 & 11,65 & $-13,69$ & 1,54 & 0 & 0,0028 & 0 & 0,00047 & 0,99768 \\
\hline 1276 & 88 & 0 & 0 & 0 & 1 & 0 & 0 & 0 & 1 & 0 & 2921 & 121,52 & 16,96 & 4,22 & $-12,73$ & 1,57 & 0 & 0,0029 & 0 & 0,00030 & 0,99892 \\
\hline 1277 & 88 & 0 & 0 & 0 & 1 & 0 & 0 & 0 & 1 & 0 & 3095 & 144,39 & 19,07 & 2,6 & $-13,35$ & 1,58 & 0 & 0,0031 & 0 & 0,00030 & 0,99861 \\
\hline 1278 & 89 & 0 & 0 & 0 & 0 & 1 & 1 & 0 & 0 & 0 & 1711 & 99,99 & 23,23 & 3,45 & $-19,38$ & 2,15 & 0 & 0,0017 & 0 & 0,00034 & 0,99875 \\
\hline 1279 & 89 & 0 & 0 & 0 & 0 & 1 & 1 & 0 & 0 & 0 & 1768 & 107,35 & 25,85 & 2,88 & $-15,05$ & 2,2 & 0 & 0,0018 & 0 & 0,00158 & 0,99455 \\
\hline 1280 & 89 & 0 & 0 & 0 & 0 & 1 & 1 & 0 & 0 & 0 & 1822 & 112,24 & 23,42 & 2,1 & $-15,48$ & 2,2 & 0 & 0,0018 & 0 & 0,00125 & 0,99568 \\
\hline 1281 & 89 & 0 & 0 & 0 & 0 & 1 & 1 & 0 & 0 & 0 & 1843 & 121,89 & 23,77 & 2,39 & $-14,97$ & 2,19 & 0 & 0,0018 & 0 & 0,00150 & 0,99445 \\
\hline 1282 & 89 & 0 & 0 & 0 & 0 & 1 & 1 & 0 & 0 & 0 & 1898 & 115,82 & 21,26 & 3,2 & $-16,18$ & 2,25 & 0 & 0,0019 & 0 &, 00099 & 0,99654 \\
\hline 1283 & 89 & 0 & 0 & 0 & 0 & 1 & 1 & 0 & 0 & 0 & 2127 & 120,3 & 15,35 & 2,9 & $-15,2$ & 2,21 & 0 & 0,0021 & 0 & 0,00096 & 0,99708 \\
\hline 1284 & 89 & 0 & 0 & 0 & 0 & 1 & 1 & 0 & 0 & 0 & 2353 & 131,33 & 14,7 & 2,76 & $-12,89$ & 2,04 & 0 & 0,0024 & 0 & 0,00153 & 0,99549 \\
\hline 1285 & 89 & 0 & 0 & 0 & 1 & 0 & 1 & 0 & 0 & 0 & 2523 & 122,38 & 14,3 & 2,25 & $-10,09$ & 2,14 & 0 & 0,0025 & 0 & 0,00438 & 0,98700 \\
\hline 1286 & 89 & 0 & 0 & 0 & 1 & 0 & 1 & 0 & 0 & 0 & 2739 & 112,93 & 13,89 & 1,77 & $-8,69$ & 2,09 & 0 & 0,0027 & 0 & 0,00597 & 0,98477 \\
\hline 1287 & 89 & 0 & 0 & 0 & 1 & 0 & 1 & 0 & 0 & 0 & 3020 & 117,88 & 12,98 & 1,87 & $-8,56$ & 1,98 & 0 & 0,003 & 0 & 0,00519 & 0,98666 \\
\hline 1288 & 90 & 0 & 0 & 0 & 1 & 0 & 0 & 1 & 0 & 0 & 38078 & 53,82 & 29,67 & 2,98 & $-1,78$ & 2,47 & 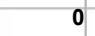 & 0,0381 & 0 & 0,20993 & 0,43969 \\
\hline 1289 & 90 & 0 & 0 & 0 & 1 & 0 & 0 & 1 & 0 & 0 & 43203 & 48,66 & 29,25 & 3,94 & -2 & 2,47 & 0 & 0,0432 & 0 & 0,20998 & 0,46559 \\
\hline 1290 & 90 & 0 & 0 & 0 & 1 & 0 & 0 & 1 & 0 & 0 & 42334 & 53,27 & 27,22 & 3,42 & $-1,67$ & 2,5 & 0 & 0,0423 & 0 & 0,21697 & 0,45827 \\
\hline 1291 & 90 & 0 & 0 & 0 & 1 & 0 & 0 & 1 & 0 & 0 & 45712 & 52,52 & 20,1 & 2,41 & $-1,76$ & 2,53 & 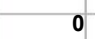 & 0,0457 & 0 & 0,20066 & 0,57535 \\
\hline 1292 & 90 & 0 & 0 & 0 & 1 & 0 & 0 & 1 & 0 & 0 & 45954 & 55,96 & 19,37 & 2,69 & $-2,24$ & 2,5 & 0 & 0,046 & 0 & 0,17475 & 0,61883 \\
\hline 1293 & 90 & 0 & 0 & 0 & 1 & 0 & 0 & 1 & 0 & 0 & 46686 & 61,33 & 19,83 & 2,61 & $-1,45$ & 2,47 & 0 & 0,0467 & 0 & 0,19938 & 0,55578 \\
\hline 1294 & 90 & 0 & 0 & 0 & 1 & 0 & 0 & 1 & 0 & 0 & 50212 & 61,35 & 19,9 & 2,52 & $-1,59$ & 2,41 & 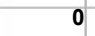 & 0,0502 & 0 & 0,18832 & 0,57876 \\
\hline 1295 & 90 & 0 & 0 & 0 & 1 & 0 & 0 & 1 & 0 & 0 & 51877 & 62,41 & 20,07 & 2,64 & $-1,1$ & 2,36 & 0 & 0,0519 & 0 & 0,20067 & 0,55617 \\
\hline 1296 & 90 & 0 & 0 & 0 & 1 & 0 & 0 & 1 & 0 & 0 & 55154 & 60,16 & 18,46 & 2,33 & $-1,39$ & 2,4 & 0 & 0,0552 & 0 & 0,19393 & 0,58869 \\
\hline 1297 & 90 & 0 & 0 & 0 & 1 & 0 & 0 & 1 & 0 & 0 & 57802 & 63,69 & 16,99 & 1,79 & $-1,6$ & 2,42 & 0 & 0,0578 & 0 & 0,18441 & 0,60627 \\
\hline 1298 & 90 & 0 & 0 & 0 & 1 & 0 & 0 & 1 & 0 & 0 & 59524 & 70,23 & 17,81 & 1,78 & $-1,49$ & 2,24 & 0 & 0,0595 & 0 & 0,16418 & 0,62792 \\
\hline 1299 & 90 & 0 & 0 & 0 & 1 & 0 & 0 & 1 & 0 & 0 & 64143 & 73,88 & 16,29 & 1,81 & $-1,99$ & 2,36 & 0 & 0,0641 & 0 & 0,16161 & 0,62527 \\
\hline 1300 & 90 & 0 & 0 & 0 & 1 & 0 & 0 & 1 & 0 & 0 & 65878 & 78,49 & 17,4 & 11,27 & $-1,96$ & 2,34 & 0 & 0,0659 & 0 & 0,16957 & 0,59110 \\
\hline 1301 & 90 & 0 & 0 & 1 & 0 & 0 & 0 & 1 & 0 & 0 & 69781 & 85,67 & 15,75 & 8,47 & $-2,06$ & 2,33 & 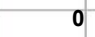 & 0,0698 & 0 & 0,07894 & 0,75650 \\
\hline 1302 & 90 & 0 & 0 & 1 & 0 & 0 & 0 & 1 & 0 & 0 & 72742 & 67,92 & 17,92 & 10,72 & $-1,43$ & 2,37 & 0 & 0,0727 & 0 & 0,10492 & 0,71608 \\
\hline 1303 & 90 & 0 & 0 & 1 & 0 & 0 & 0 & 1 & 0 & 0 & 75517 & 75,25 & 16,66 & 8,84 & $-1,33$ & 2,41 & 0 & 0,0755 & 0 & 0,10817 & 0,69679 \\
\hline 1304 & 90 & 0 & 0 & 1 & 0 & 0 & 0 & 1 & 0 & 8 & 79479 & 83,43 & 16,28 & 7,53 & $-1,77$ & 2,35 & 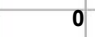 & 0,0795 & 0 & 0,09229 & 0,72014 \\
\hline 1305 & 90 & 0 & 0 & 1 & 0 & 0 & 0 & 1 & 0 & 0 & 81871 & 85,12 & 15,99 & 7,31 & $-1,84$ & 2,43 & 0 & 0,0819 & 0 & 0,09856 & 0,69653 \\
\hline 1306 & 91 & 0 & 0 & 0 & 1 & 0 & 1 & 0 & 0 & 0 & 4403 & 102,86 & 28,13 & 3,66 & $-17,75$ & 1,97 & 0 & 0,0044 & 0 & 0,00063 & 0,99700 \\
\hline 1307 & 91 & 0 & 0 & 0 & 0 & 1 & 1 & 0 & 0 & 0 & 4372 & 115,42 & 18,14 & 4,52 & $-13,76$ & 2,07 & 0 & 0,0044 & 0 & 0,00142 & 0,99591 \\
\hline 1308 & 91 & 0 & 0 & 0 & 0 & 1 & 1 & 0 & 0 & 0 & 4367 & 117,58 & 17,96 & 4,78 & $-11,6$ & 2,05 & 0 & 0,0044 & 0 & 00265 & 0,99294 \\
\hline 1309 & 91 & 0 & 0 & 0 & 0 & 1 & 1 & 0 & 0 & 0 & 4360 & 118,92 & 24,28 & 5,83 & $-11,61$ & 2,03 & 0 & 0,0044 & 0 & 0,00349 & 0,98913 \\
\hline 1310 & 91 & 0 & 0 & 0 & 0 & 1 & 0 & 1 & 0 & 0 & 4454 & 123,45 & 20,53 & 5,09 & $-10,27$ & 1,9 & 0 & 0,0045 & 0 & 0,00837 & 0,96305 \\
\hline 1311 & 91 & 0 & 0 & 0 & 0 & 1 & 0 & 1 & 0 & 0 & 4576 & 131,08 & 25,67 & 4,42 & $-10,2$ & 1,86 & 0 & 0,0046 & 0 & 0,01031 & 0,94540 \\
\hline 1312 & 92 & 0 & 0 & 1 & 0 & 0 & 1 & 0 & 0 & 0 & 518 & 79,39 & 29,09 & 0,35 & $-22,38$ & 2,59 & 0 & 0,0005 & 0 & 0,00014 & 0,99913 \\
\hline 1313 & 93 & 0 & 0 & 0 & 1 & 0 & 0 & 1 & 0 & 8 & 351 & 50,55 & 34,16 & 16,86 & $-18,4$ & 0,46 & 0 & 0,0004 & 0 & 0,00017 & 0,99912 \\
\hline 1314 & 93 & 0 & 0 & 0 & 1 & 0 & 0 & 1 & 0 & 0 & 374 & 58,08 & 27,47 & 7,91 & $-37,73$ & 0,25 & 0 & 0,0004 & 0 & 00000 & 1,00000 \\
\hline 1315 & 93 & 0 & 0 & 0 & 1 & 0 & 0 & 1 & 0 & 0 & 393 & 73,3 & 25,23 & 9,27 & $-52,97$ & 1,33 & 0 & 0,0004 & 0 & 0,00000 & 1,00000 \\
\hline 1316 & 93 & 0 & 0 & 0 & 1 & 0 & 0 & 1 & 0 & 0 & 414 & 88,68 & 17,47 & 4,06 & $-72,75$ & 1,77 & 0 & 0,0004 & 0 & 0,00000 & 1,00000 \\
\hline 1317 & 93 & 0 & 0 & 0 & 1 & 0 & 0 & 1 & 0 & 0 & 443 & 93,37 & 13 & 5,45 & $-68,63$ & 1,5 & 0 & 0,0004 & 0 & 0,00000 & 1,00000 \\
\hline 1318 & 93 & 0 & 0 & 0 & 1 & 0 & 0 & 1 & 0 & 0 & 475 & 105,67 & 11,28 & 4,86 & $-68,82$ & 1,41 & 0 & 0,0005 & 0 & 0,00000 & 1,00000 \\
\hline 1319 & 93 & 0 & 0 & 0 & 1 & 0 & 0 & 1 & 0 & 0 & 509 & 111,5 & 12,15 & 2,85 & $-56,32$ & 1,5 & 0 & 0,0005 & 0 & 0,00000 & 1,00000 \\
\hline 1320 & 93 & 0 & 0 & 8 & 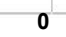 & & 0 & & 0 & 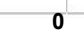 & 485 & 96,9 & 13,96 & 2,75 & $-57,63$ & 1,39 & 0 & 0,0005 & 0 & 0,00000 & 1,00000 \\
\hline
\end{tabular}




\begin{tabular}{|c|c|c|c|c|c|c|c|c|c|c|c|c|c|c|c|c|c|c|c|c|c|}
\hline bs & ID & AA & $\mathrm{AB}$ & BA & BB & MD & LV & PL & NL & REC & PIB & COMEX & AGRI & PREF & ODP & CAP & APRE & PIB2 & $\mathrm{ACl}$ & CREC & po \\
\hline 1321 & 93 & 0 & 0 & 0 & 0 & 1 & 0 & 1 & 0 & 0 & 518 & 132,35 & 14,06 & 2,49 & $-71,84$ & 1,55 & 0 & 0,0005 & 0 & 0,00000 & 1,00000 \\
\hline 1322 & 93 & 0 & 0 & 0 & 1 & 0 & 0 & 1 & 0 & 0 & 585 & 134,43 & 17,05 & 2,63 & $-53,98$ & 1,64 & 0 & 0,0006 & 0 & 0,00000 & 1,00000 \\
\hline 1323 & 93 & 0 & 0 & 0 & 1 & 0 & 0 & 1 & 0 & 0 & 612 & 125,45 & 9,6 & 1,49 & $-47,5$ & 1,68 & 0 & 0,0006 & 0 & 0,00000 & 1,00000 \\
\hline 1324 & 95 & 0 & 0 & 0 & 0 & 1 & 0 & 1 & 0 & 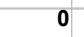 & 42812 & 28,21 & 17,76 & 34,64 & $-3,28$ & 1,77 & 0 & 0,0428 & 0 & 0,05972 & 0,92516 \\
\hline 1325 & 95 & 0 & 0 & 0 & 0 & 1 & 1 & 0 & 0 & 0 & 44749 & 26,08 & 17,93 & 38,82 & $-2,58$ & 1,77 & 0 & 0,0447 & 0 & 0,03468 & 0,97406 \\
\hline 1326 & 95 & 0 & 0 & 0 & 0 & 1 & 0 & 1 & 0 & 0 & 46758 & 26,33 & 17,71 & 38,74 & $-2,04$ & 1,92 & 0 & 0,0468 & 0 & 0,10641 & 0,87594 \\
\hline 1327 & 95 & 0 & 0 & 0 & 0 & 1 & 0 & 1 & 0 & 0 & 49178 & 27,88 & 15,72 & 32,08 & $-2,26$ & 2,07 & 0 & 0,0492 & 0 & 0,11017 & 0,87146 \\
\hline 1328 & 95 & 0 & 0 & 0 & 0 & 1 & 0 & 1 & 0 & 0 & 54200 & 29,32 & 16,86 & 36,46 & $-2,13$ & 1,94 & 0 & 0,0542 & 0 & 0,10745 & 0,87283 \\
\hline 1329 & 95 & 0 & 0 & 0 & 0 & 1 & 0 & 1 & 0 & 0 & 56952 & 32,1 & 16,84 & 35,45 & $-1,88$ & 1,87 & 0 & 0,057 & 0 & 0,10734 & 0,87161 \\
\hline 1330 & 95 & 0 & 0 & 0 & 0 & 1 & 0 & 1 & 0 & 0 & 59135 & 28,97 & 14,93 & 37,68 & $-1,59$ & 1,8 & 1 & 0,0591 & 0 & 0,11613 & 0,87179 \\
\hline 1331 & 95 & 0 & 0 & 0 & 0 & 1 & 0 & 1 & 0 & 0 & 61937 & 27,66 & 18,42 & 40,21 & $-2,23$ & 1,79 & 1 & 0,0619 & 0 & 0,11347 & 0,86287 \\
\hline 1332 & 95 & 0 & 0 & 0 & 0 & 1 & 0 & 1 & 0 & 1 & 65183 & 26,86 & 17,17 & 38,56 & $-2,08$ & 1,72 & 1 & 0,0652 & 0 & 0,10483 & 0,87862 \\
\hline 1333 & 95 & 0 & 0 & 0 & 0 & 1 & 0 & 1 & 0 & 0 & 69443 & 34,4 & 15,68 & 28,75 & $-1,82$ & 1,64 & 1 & 0,0694 & 0 & 0,09559 & 0,88514 \\
\hline 1334 & 95 & 0 & 0 & 0 & 0 & 1 & 0 & 1 & 0 & 0 & 74076 & 38,11 & 16,78 & 26,3 & $-1,61$ & 1,73 & 1 & 0,0741 & 0 & 0,12056 & 0,84636 \\
\hline 1335 & 95 & 0 & 0 & 0 & 0 & 1 & 0 & 1 & 0 & 0 & 79305 & 39,94 & 21,5 & 24,08 & $-1,79$ & 1,82 & 1 & 0,0793 & 0 & 0,15352 & 0,77421 \\
\hline 1336 & 95 & 0 & 0 & 0 & 0 & 1 & 0 & 1 & 0 & 0 & 84074 & 42,62 & 17,67 & 22,08 & $-2,1$ & 1,79 & 1 & 0,0841 & 0 & 0,12334 & 0,82763 \\
\hline 1337 & 95 & 0 & 0 & 0 & 0 & 1 & 0 & 1 & 0 & 0 & 88316 & 40,09 & 16,74 & 24 & $-1,11$ & 1,71 & 1 & 0,0883 & 0 & 0,14540 & 0,81530 \\
\hline 1338 & 95 & 0 & 0 & 0 & 0 & 1 & 0 & 1 & 0 & 0 & 93236 & 37,8 & 17,24 & 22,78 & $-1,13$ & 1,75 & 1 & 0,0932 & 0 & 0,15767 & 0,80020 \\
\hline 1339 & 95 & 0 & 0 & 0 & 0 & 1 & 0 & 1 & 0 & 0 & 99264 & 47,42 & 17,9 & 18,15 & $-1,07$ & 1,74 & 1 & 0,0993 & 0 & 0,16476 & 0,76820 \\
\hline 1340 & 96 & 0 & 0 & 0 & 0 & 1 & 1 & 0 & 0 & 0 & 3236 & 56,52 & 61,9 & 8,85 & $-12,43$ & 2,09 & 0 & 0,0032 & 0 & 0,01441 & 0,93445 \\
\hline 1341 & 96 & 0 & 0 & 0 & 0 & 1 & 1 & 0 & 0 & 0 & 3421 & 58,71 & 60,51 & 5,78 & $-9,86$ & 2,16 & 0 & 0,0034 & 0 & 0,03035 & 0,87654 \\
\hline 1342 & 96 & 0 & 0 & 0 & 0 & 1 & 1 & 0 & 0 & 0 & 3557 & 59,59 & 59,58 & 3,47 & $-8,4$ & 2,23 & 0 & 0,0036 & 0 & 0,04661 & 0,82264 \\
\hline 1343 & 96 & 0 & 0 & 0 & 0 & 1 & 1 & 0 & 0 & 0 & 3747 & 64,67 & 53,03 & 7,75 & $-7,88$ & 2,23 & 0 & 0,0037 & 0 & 0,04311 & 0,85774 \\
\hline 1344 & 96 & 0 & 0 & 0 & 0 & 1 & 1 & 0 & 0 & 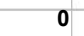 & 3966 & 55,99 & 51,88 & 8,07 & $-9,52$ & 2,23 & 0 & 0,004 & 0 & 0,02597 & 0,91698 \\
\hline 1345 & 96 & 0 & 0 & 0 & 0 & 1 & 1 & 0 & 0 & 0 & 4178 & 57,28 & 45,81 & 11,43 & $-10,42$ & 2,18 & 0 & 0,0042 & 0 & 0,01468 & 0,95769 \\
\hline 1346 & 96 & 0 & 0 & 0 & 0 & 1 & 1 & 0 & 0 & 0 & 4372 & 51,48 & 53,81 & 7,07 & $-7,24$ & 2,12 & 1 & 0,0044 & 0 & 0,05229 & 0,84583 \\
\hline 1347 & 96 & 0 & 0 & 0 & 0 & 1 & 1 & 0 & 0 & 0 & 4523 & 48,72 & 53,35 & 6,33 & $-7,75$ & 2,17 & 1 & 0,0045 & 0 &, 04738 & 0,86141 \\
\hline 1348 & 96 & 0 & 0 & 0 & 0 & 1 & 1 & 0 & 0 & 0 & 4723 & 46,37 & 53,6 & 8,84 & $-8,78$ & 2,14 & 1 & 0,0047 & 0 & 0,03514 & 0,89495 \\
\hline 1349 & 96 & 0 & 0 & 0 & 0 & 1 & 1 & 0 & 0 & 0 & 4804 & 45,82 & 57,33 & 13,11 & $-7,25$ & 1,88 & 1 & 0,0048 & 0 & 0,04572 & 0,86441 \\
\hline 1350 & 96 & 0 & 0 & 0 & 0 & 1 & 1 & 0 & 0 & 0 & 4993 & 46,85 & 54,86 & 19,85 & $-7,81$ & 1,93 & 1 & 0,005 & 0 &, 03916 & 0,88829 \\
\hline 1351 & 96 & 0 & 0 & 0 & 0 & 1 & 1 & 0 & 0 & 0 & 5292 & 57,8 & 54,7 & 22,51 & $-7,96$ & 1,99 & 1 & 0,0053 & 0 & 0,04133 & 0,87065 \\
\hline 1352 & 96 & 0 & 0 & 0 & 0 & 1 & 1 & 0 & 0 & 0 & 5551 & 56,5 & 51,34 & 17,47 & $-9,01$ & 2,05 & 1 & 0,0056 & 0 & 0,02847 & 0,91347 \\
\hline 1353 & 96 & 0 & 0 & 0 & 0 & 1 & 1 & 0 & 0 & 0 & 5680 & 52,7 & 52,43 & 13,52 & $-9,66$ & 1,94 & 1 & 0,0057 & 0 & 0,02096 & 0,93472 \\
\hline 1354 & 96 & 0 & 0 & 0 & 0 & 1 & 1 & 0 & 0 & 0 & 5800 & 60,99 & 61,97 & 7,99 & $-9,98$ & 1,92 & 1 & 0,0058 & 0 & 0,02740 & 0,88255 \\
\hline 1355 & 96 & 0 & 0 & 0 & 0 & 1 & 1 & 0 & 0 & 0 & 5972 & 55,58 & 52,4 & 15,91 & $-8,67$ & 1,98 & 1 & 0,006 & 0 & 0,02976 & 0,90934 \\
\hline 1356 & 96 & 0 & 0 & 0 & 0 & 1 & 1 & 0 & 0 & 0 & 6249 & 60,37 & 60,46 & 2,02 & $-6,32$ & 1,97 & 1 & 0,0062 & 0 & 0,06926 & 0,75170 \\
\hline 1357 & 98 & 0 & 0 & 0 & 0 & 1 & 0 & 1 & 0 & 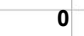 & 6794 & 57,42 & 36,37 & 10,49 & $-10,24$ & 2,39 & 0 & 0,0068 & 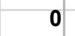 & 0,02929 & 0,89185 \\
\hline 1358 & 98 & 0 & 0 & 0 & 0 & 1 & 0 & 1 & 0 & 0 & 7107 & 72,2 & 37,54 & 7,82 & $-9,57$ & 2,39 & 1 & 0,0071 & 0 & 0,04218 & 0,82002 \\
\hline 1359 & 98 & 0 & 0 & 0 & 0 & 1 & 0 & 1 & 0 & 0 & 7405 & 85,4 & 30,12 & 9,64 & $-7,3$ & 2,37 & 1 & 0,0074 & 0 & 0,05795 & 0,78999 \\
\hline 1360 & 98 & 0 & 0 & 0 & 0 & 1 & 0 & 1 & 0 & 0 & 7753 & 80,6 & 38,61 & 17,44 & $-9,57$ & 2,36 & 1 & 0,0078 & 0 & 0,04443 & 0,79645 \\
\hline 1361 & 98 & 0 & 0 & 0 & 0 & 1 & 0 & 1 & 0 & 0 & 8094 & 81,71 & 34,79 & 15,53 & $-8,04$ & 2,44 & 1 & 0,0081 & 0 & 0,06213 & 0,75153 \\
\hline 1362 & 98 & 0 & 0 & 0 & 0 & 1 & 1 & 0 & 0 & 0 & 8393 & 116,05 & 33,45 & 7,18 & $-12,37$ & 2,52 & 1 & 0,0084 & 0 & 0,01004 & 0,95949 \\
\hline 1363 & 98 & 0 & 0 & 0 & 0 & 1 & 1 & 0 & 0 & 0 & 8729 & 110,05 & 34,84 & 7,13 & $-12,3$ & 2,45 & 1 & 0,0087 & 0 & 0,00982 & 0,96138 \\
\hline 1364 & 98 & 0 & 0 & 0 & 0 & 1 & 1 & 0 & 0 & 0 & 9122 & 97,49 & 42,39 & 7,6 & $-11,37$ & 2,37 & 1 & 0,0091 & 0 & 0,01583 & 0,93620 \\
\hline 1365 & 98 & 0 & 0 & 0 & 0 & 1 & 1 & 0 & 0 & 0 & 9596 & 97,29 & 44,42 & 7,18 & $-13,17$ & 2,31 & 1 & 0,0096 & 0 & 0,00947 & 0,95696 \\
\hline 1366 & 98 & 0 & 0 & 0 & 0 & 1 & 1 & 0 & 0 & 0 & 10134 & 99,67 & 37,62 & 6,82 & $-16,34$ & 2,34 & 1 & 0,0101 & 0 & 0,00282 & 0,98718 \\
\hline 1367 & 98 & 0 & 0 & 0 & 0 & 1 & 1 & 0 & 0 & 0 & 10732 & 98,17 & 31,32 & 5,79 & $-10,85$ & 2,34 & 1 & 0,0107 & 0 & 0,01089 & 0,96660 \\
\hline 1368 & 98 & 0 & 0 & 0 & 0 & 1 & 1 & 0 & 0 & 0 & 11418 & 65,92 & 33,92 & 8,95 & $-6,13$ & 2,61 & 1 & 0,0114 & 0 & 0,06425 & 0,86878 \\
\hline 1369 & 98 & 0 & 0 & 0 & 0 & 1 & 1 & 0 & 0 & 0 & 11915 & 65,35 & 36,85 & 10,83 & $-4,73$ & 2,58 & 1 & 0,0119 & 0 & 0,10050 & 0,79523 \\
\hline 1370 & 98 & 0 & 0 & 0 & 1 & 0 & 1 & 0 & 0 & 0 & 13005 & 69,51 & 36,19 & 13,41 & $-4,6$ & 2,52 & 1 & 0,013 & 0 & 0,10070 & 0,74704 \\
\hline 1371 & 98 & 0 & 0 & 0 & 1 & 0 & 1 & 0 & 0 & 0 & 13635 & 71,59 & 37,74 & 7,44 & $-6,11$ & 2,46 & 1 & 0,0136 & 0 & 0,06683 & 0,80894 \\
\hline 1372 & 98 & 0 & 0 & 0 & 1 & 0 & 1 & 0 & 0 & 0 & 14712 & 75,38 & 36,44 & 8,01 & $-5,34$ & 2,46 & 1 & 0,0147 & 0 & 0,07849 & 0,78279 \\
\hline 1373 & 98 & 0 & 0 & 0 & 1 & 0 & 1 & 0 & 0 & 0 & 16779 & 86,3 & 23,27 & 4,44 & $-4,7$ & 2,45 & 1 & 0,0168 & 0 & 0,05757 & 0,87396 \\
\hline 1374 & 98 & 0 & 0 & 0 & 1 & 0 & 1 & 0 & 0 & 0 & 18338 & 93,17 & 22,88 & 3,6 & $-4,52$ & 2,43 & 1 & 0,0183 & 0 & 0,05892 & 0,86540 \\
\hline 1375 & 99 & 0 & 0 & 0 & 0 & 1 & 0 & 1 & 0 & 0 & 3731 & 55,85 & 42,75 & 29,82 & $-9,97$ & 1,92 & 0 & 0,0037 & 0 & 0,02410 & 0,90643 \\
\hline 1376 & 99 & 0 & 0 & 0 & 0 & 1 & 0 & 1 & 0 & 0 & 3811 & 46,5 & 35,37 & 37,83 & $-9,24$ & 1,92 & 1 & 0,0038 & 0 & 0,02577 & 0,92509 \\
\hline 1377 & 99 & 0 & 0 & 0 & 0 & 1 & 0 & 1 & 0 & 0 & 3952 & 51,83 & 35,11 & 39,97 & $-24,11$ & 1,8 & 1 & 0,004 & 0 & 0,00025 & 0,99857 \\
\hline 1378 & 99 & 0 & 0 & 0 & 0 & 1 & 0 & 1 & 0 & 0 & 4107 & 50,8 & 29,54 & 56,55 & $-13,11$ & 1,67 & 1 & 0,0041 & 0 & 0,00497 & 0,98548 \\
\hline 1379 & 99 & 0 & 0 & 0 & 0 & 1 & 0 & 1 & 0 & 0 & 4298 & 56,68 & 26,25 & 49,73 & $-9,74$ & 1,77 & 1 & 0,0043 & 0 & 0,01320 & 0,96674 \\
\hline 1380 & 99 & 0 & 0 & 0 & 0 & & 0 & 1 & 0 & 0 & 4503 & 68,68 & 25,92 & 12,57 & $-8,41$ & 1,86 & 1 & 0,0045 & 0 & 0,01876 & 0,94595 \\
\hline
\end{tabular}




\begin{tabular}{|c|c|c|c|c|c|c|c|c|c|c|c|c|c|c|c|c|c|c|c|c|c|}
\hline bs & ID & $A A$ & $A B$ & BA & BB & MD & LV & PL & NL & REC & PIB & COMEX & AGRI & PREF & ODP & CAP & APRE & PIB2 & $\mathrm{ACl}$ & CREC & po \\
\hline 1381 & 99 & 0 & 0 & 0 & 0 & 1 & 0 & 1 & 0 & 0 & 4774 & 61,37 & 32,47 & 16,72 & $-8,28$ & 1,95 & 1 & 0,0048 & 0 & 0,02919 & 0,90887 \\
\hline 1382 & 99 & 0 & 0 & 0 & 0 & 1 & 0 & 1 & 0 & 0 & 4169 & 38,58 & 36,53 & 30,97 & $-8,64$ & 2,03 & 3 & 0,0042 & 0 &, 04694 & 0,86572 \\
\hline 1383 & 99 & 0 & 0 & 0 & 0 & 1 & 0 & 1 & 0 & 0 & 4577 & 55,16 & 34,7 & 19,62 & $-10,13$ & 2,05 & 4 & 0,0046 & 0 & 0,03337 & ,88292 \\
\hline 1384 & 99 & 0 & 0 & 0 & 0 & 1 & 0 & 1 & 0 & 0 & 4818 & 80,12 & 25,55 & 15,87 & $-29,47$ & 2,02 & 4 & 0,0048 & 0 & 0,00007 & 0,99946 \\
\hline 1385 & 99 & 0 & 0 & 0 & 0 & 1 & 0 & 1 & 0 & 0 & 5039 & 73,77 & 24,57 & 16,53 & $-18,41$ & 2,13 & 4 & 0,005 & 0 & 0,00214 & 0,98999 \\
\hline 1386 & 99 & 0 & 0 & 0 & 0 & 1 & 0 & 1 & 0 & 0 & 5292 & 75,5 & 24,77 & 14,28 & $-14,38$ & 1,97 & 4 & 0,0053 & 0 & 0,00580 & 0,97682 \\
\hline 1387 & 99 & 0 & 0 & 0 & 0 & 1 & 0 & 1 & 0 & 0 & 5623 & 82,39 & 22,73 & 11,49 & $-12,27$ & 2,06 & 4 & 0,0056 & 0 & 0,01123 & 0,95803 \\
\hline 1388 & 99 & 0 & 0 & 0 & 0 & 1 & 0 & 1 & 0 & 0 & 6023 & 83,45 & 15,25 & 9,95 & -9 & 1,87 & 4 & 0,006 & 0 & 0,01623 & 0,95558 \\
\hline 1389 & 99 & 0 & 0 & 0 & 0 & 1 & 0 & 1 & 0 & 0 & 5782 & 74 & 18,17 & 14,38 & $-5,25$ & 1,72 & 4 & 0,0058 & 0 & 0,04443 & 0,89958 \\
\hline 1390 & 99 & 0 & 0 & 0 & 0 & 1 & 0 & 1 & 0 & 0 & 5797 & 68,02 & 20,2 & 13,6 & $-5,47$ & 1,55 & 4 & 0,0058 & 0 & 0,03610 & 0,91858 \\
\hline 1391 & 99 & 0 & 0 & 0 & 0 & 1 & 0 & 1 & 0 & 0 & 5881 & 69,08 & 25,19 & 16,01 & $-4,57$ & 1,49 & 4 & 0,0059 & 0 & 0,05325 & 0,87014 \\
\hline 1392 & 99 & 0 & 0 & 0 & 0 & 1 & 0 & 1 & 0 & 0 & 6059 & 72,98 & 24,66 & 13,41 & $-3,91$ & 1,41 & 4 & 0,0061 & 0 & 0,05625 & 0,86356 \\
\hline 1393 & 100 & 0 & 0 & 0 & 0 & 1 & 1 & 0 & 0 & 0 & 2069 & 78,46 & 44,68 & 8,89 & $-32,16$ & 1,99 & 0 & 0,0021 & 0 & 0,00002 & 0,99987 \\
\hline 1394 & 100 & 0 & 0 & 0 & 0 & 1 & 1 & 0 & 0 & 0 & 2220 & 54,7 & 46,08 & 13,64 & $-21,92$ & 1,99 & 0 & 0,0022 & 0 & 0,00035 & 0,99840 \\
\hline 1395 & 100 & 0 & 0 & 0 & 0 & 1 & 1 & 0 & 0 & 0 & 2304 & 54,94 & 43,73 & 15,92 & $-13,12$ & 2,09 & 0 & 0,0023 & 0 & 0,00529 & 0,98429 \\
\hline 1396 & 100 & 0 & 0 & 0 & 0 & 1 & 1 & 0 & 0 & 0 & 2394 & 70,88 & 50,51 & 9,21 & $-25,42$ & 2,19 & 0 & 0,0024 & 0 & 0,00020 & 0,99861 \\
\hline 1397 & 100 & 0 & 0 & 0 & 0 & 1 & 0 & 1 & 0 & 0 & 2467 & 71,32 & 43,92 & 12,81 & $-25,75$ & 2,16 & 0 & 0,0025 & 0 & 0,00030 & 0,99714 \\
\hline 1398 & 100 & 0 & 0 & 0 & 0 & 1 & 0 & 1 & 0 & 0 & 2506 & 60,94 & 45,31 & 14,85 & $-26,13$ & 2,12 & 0 & 0,0025 & 0 & 0,00027 & $\mid 0,99759$ \\
\hline 1399 & 100 & 0 & 0 & 0 & 0 & 1 & 0 & 1 & 0 & 0 & 2381 & 67,12 & 45,05 & 12,44 & $-24,32$ & 1,94 & 0 & 0,0024 & 0 &, 00036 & 0,99689 \\
\hline 1400 & 100 & 0 & 0 & 0 & 0 & 1 & 0 & 1 & 0 & 0 & 2422 & 54,96 & 48,53 & 15,68 & $-14,43$ & 1,75 & 2 & 0,0024 & 0 & 0,00858 & 0,95177 \\
\hline 1401 & 100 & 0 & 0 & 0 & 0 & 1 & 0 & 1 & 0 & 0 & 2555 & 67,29 & 46,28 & 11,22 & $-21,74$ & 1,81 & 3 & 0,0026 & 0 & 0,00112 & 0,99072 \\
\hline 1402 & 100 & 0 & 0 & 0 & 0 & 1 & 0 & 1 & 0 & 0 & 2679 & 68,15 & 42,43 & 11,94 & $-19,6$ & 1,78 & 3 & 0,0027 & 0 &, 00172 & 0,98805 \\
\hline 1403 & 100 & 0 & 0 & 0 & 0 & 1 & 0 & 1 & 0 & 0 & 2755 & 76,23 & 39,46 & 13,49 & $-21,12$ & 1,7 & 3 & 0,0028 & 0 & 0,00087 & 0,99362 \\
\hline 1404 & 100 & 0 & 0 & 0 & 0 & 1 & 0 & 1 & 0 & 0 & 2812 & 69,73 & 38,88 & 9,32 & $-23,48$ & 1,69 & 3 & 0,0028 & 0 & 0,00039 & 0,99700 \\
\hline 1405 & 100 & 0 & 0 & 0 & 0 & 1 & 0 & 1 & 0 & 0 & 3079 & 68,59 & 43,72 & 10,58 & $-20,51$ & 1,94 & 3 & 0,0031 & 0 &, 00173 & 0,98691 \\
\hline 1406 & 100 & 0 & 0 & 0 & 0 & 1 & 0 & 1 & 0 & 0 & 3335 & 77,1 & 41,04 & 9,07 & $-21,71$ & 1,95 & 3 & 0,0033 & 0 & 0,00109 & 0,99117 \\
\hline 1407 & 100 & 0 & 0 & 0 & 0 & 1 & 0 & 1 & 0 & 0 & 3637 & 63,61 & 43,72 & 10,37 & $-15,52$ & 2,03 & 3 & 0,0036 & 0 & 0,00856 & 0,94945 \\
\hline 1408 & 100 & 0 & 0 & 0 & 0 & 1 & 0 & 1 & 0 & 0 & 3874 & 74,32 & 40,44 & 9,36 & $-19,18$ & 2,08 & 3 & 0,0039 & 0 &, 00272 & 0,98083 \\
\hline 1409 & 100 & 0 & 0 & 0 & 0 & 1 & 0 & 1 & 0 & 0 & 4043 & 69,39 & 42,69 & 8,03 & $-14,46$ & 2,06 & 3 & 0,004 & 0 & 0,01161 & \begin{tabular}{|l|l|}
0,93228 \\
\end{tabular} \\
\hline 1410 & 100 & 0 & 0 & 0 & 0 & 1 & 0 & 1 & 0 & 0 & 4119 & 89,22 & 39,35 & 6,8 & $-28,47$ & 2,01 & 5 & 0,0041 & 0 & 0,00020 & 0,99763 \\
\hline 1411 & 101 & 0 & 0 & 0 & 0 & 1 & 0 & 0 & 1 & 0 & 14089 & 71,75 & 35,36 & 9,66 & $-8,39$ & 2,16 & 0 & 0,0141 & 0 & ,00549 & 0,98644 \\
\hline 1412 & 101 & 0 & 0 & 0 & 0 & 1 & 0 & 0 & 1 & 0 & 14673 & 57,31 & 35,87 & 10,92 & $-5,03$ & 2,16 & 0 & 0,0147 & 0 & 0,01502 & 0,97130 \\
\hline 1413 & 101 & 0 & 0 & 0 & 0 & 1 & 0 & 0 & 1 & 0 & 14743 & 54,06 & 37,05 & 12,52 & $-3,47$ & 2,09 & 0 & 0,0147 & 0 & 0,02288 & 0,95943 \\
\hline 1414 & 101 & 0 & 0 & 0 & 0 & 1 & 0 & 0 & 1 & 0 & 15228 & 48,9 & 36,87 & 13,29 & $-2,97$ & 2,01 & 0 & 0,0152 & 0 &, 02351 & 0,96134 \\
\hline 1415 & 101 & 0 & 0 & 0 & 0 & 1 & 0 & 0 & 1 & 0 & 15579 & 48,19 & 36,84 & 13,6 & $-2,44$ & 1,99 & 0 & 0,0156 & 0 & 0,02679 & 0,95731 \\
\hline 1416 & 101 & 0 & 0 & 0 & 0 & 1 & 0 & 0 & 1 & 0 & 15673 & 53,31 & 37,26 & 11,35 & $-4,08$ & 1,96 & 0 & 0,0157 & 0 & 0,01616 & 0,97076 \\
\hline 1417 & 101 & 0 & 0 & 0 & 0 & 1 & 0 & 0 & 1 & 0 & 16265 & 55,95 & 39,03 & 14,78 & $-3,67$ & 1,9 & 0 & 0,0163 & 0 & 0,01872 & 0,96496 \\
\hline 1418 & 101 & 0 & 0 & 0 & 0 & 1 & 0 & 1 & 0 & & 16354 & 55,17 & 27,27 & 18,94 & $-3,02$ & 1,83 & 2 & 0,0164 & 0 & 0,10488 & 0,78029 \\
\hline 1419 & 101 & 0 & 0 & 0 & 0 & 1 & 0 & 1 & 0 & 0 & 16834 & 54,13 & 31,74 & 10,26 & $-3,55$ & 1,89 & 3 & 0,0168 & 0 & 0,12186 & 0,70153 \\
\hline 1420 & 101 & 0 & 0 & 0 & 0 & 1 & 0 & 1 & 0 & 0 & 17693 & 59,48 & 37,31 & 10,33 & $-4,14$ & 1,97 & 3 & 0,0177 & 0 & 0,13106 & 0,60592 \\
\hline 1421 & 101 & 0 & 0 & 0 & 0 & 1 & 0 & 1 & 0 & & 18738 & 64,48 & 27,37 & 9,25 & $-4,05$ & 1,83 & 3 & 0,0187 & 0 & 0,08982 & 0,77868 \\
\hline 1422 & 101 & 0 & 0 & 0 & 0 & 1 & 0 & 1 & 0 & 0 & 19951 & 55,24 & 29,23 & 10,66 & $-3,68$ & 1,92 & 3 & 0,02 & 0 &, 11586 & 0,72832 \\
\hline 1423 & 101 & 0 & 0 & 0 & 0 & 1 & 0 & 1 & 0 & 0 & 21317 & 53,89 & 30,19 & 10,99 & $-4,17$ & 2 & 3 & 0,0213 & 0 & 0,11615 & 0,71783 \\
\hline 1424 & 101 & 0 & 0 & 0 & 0 & 1 & 0 & 1 & 0 & & 21367 & 57,58 & 30,73 & 10,47 & $-3,81$ & 1,91 & 3 & 0,0214 & 0 & 0,11669 & 0,70938 \\
\hline 1425 & 101 & 0 & 0 & 0 & 0 & 1 & 0 & 1 & 0 & 0 & 22074 & 50,86 & 32,66 & 12,29 & $-4,8$ & 1,9 & 3 & 0,0221 & 0 &, 09820 & \begin{tabular}{|l|l}
0,74927 \\
\end{tabular} \\
\hline 1426 & 101 & 0 & 0 & 0 & 0 & 1 & 0 & 1 & 0 & 0 & 23928 & 54,23 & 30,84 & 7,69 & $-4,08$ & 1,96 & 3 & 0,0239 & 0 & 0,11609 & 0,71237 \\
\hline 1427 & 102 & 0 & 0 & 0 & 0 & 1 & 0 & 1 & 0 & & 5785 & 59,75 & 21,95 & 19,16 & $-11,49$ & 2,52 & 2 & 0,0058 & 0 & 0,01841 & 0,94710 \\
\hline 1428 & 102 & 0 & 0 & 0 & 0 & 1 & 0 & 1 & 0 & 0 & 5966 & 60,87 & 22,11 & 20,07 & $-9,2$ & 2,45 & 2 &, 006 & 0 &, 03290 & $\mid 0,91367$ \\
\hline 1429 & 102 & 0 & 0 & 0 & 0 & 1 & 0 & 1 & 0 & 0 & 6318 & 61,96 & 27,07 & 15,39 & $-10,07$ & 2,38 & 2 & 0,0063 & 0 & 0,02841 & 0,91166 \\
\hline 1430 & 102 & 0 & 0 & 0 & 0 & 1 & 0 & 1 & 0 & 5 & 6719 & 63,11 & 24,35 & 19,52 & $-10,59$ & 2,38 & 2 & 0,0067 & 0 & 0,02236 & 0,93331 \\
\hline 1431 & 102 & 0 & 0 & 0 & 0 & 1 & 0 & 1 & 0 & 0 & 6934 & 65,14 & 37,72 & 8,91 & $-9,4$ & 2,38 & 2 & 0,0069 & 0 & ,04982 & 0,79840 \\
\hline 1432 & 102 & 0 & 0 & 0 & 0 & 1 & 0 & 1 & 0 & 0 & 7251 & 66,49 & 37,25 & 10,32 & -9 & 2,45 & 2 & 0,0073 & 0 & 0,05898 & 0,76512 \\
\hline 1433 & 102 & 0 & 0 & 0 & 0 & 1 & 1 & 0 & 0 & 0 & 7299 & 67,51 & 24,87 & 8,88 & $-8,47$ & 2,52 & 2 & 0,0073 & 0 & 0,02268 & 0,95763 \\
\hline 1434 & 102 & 0 & 0 & 0 & 0 & 1 & 1 & 0 & 0 & 0 & 7786 & 65,36 & 35,12 & 5,5 & $-6,75$ & 2,24 & 2 & 0,0078 & 0 & 3955 & 0,91500 \\
\hline 1435 & 102 & 0 & 0 & 0 & 0 & 1 & 1 & 0 & 0 & 0 & 8244 & 66,91 & 33,29 & 6,99 & $-13,47$ & 2,32 & 2 & 0,0082 & 0 & 0,00570 & 0,98416 \\
\hline 1436 & 102 & 0 & 0 & 0 & 0 & 1 & 1 & 0 & 0 & 0 & 8707 & 69,44 & 30,2 & 9,47 & $-8,16$ & 2,25 & 2 & 0,0087 & 0 & 0,02229 & 0,95349 \\
\hline 1437 & 102 & 0 & 0 & 0 & 0 & 1 & 1 & 0 & 0 & 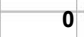 & 8921 & 68,72 & 33,95 & 4,73 & $-9,33$ & 2,18 & 4 & 0,0089 & 0 & ,01664 & 0,96011 \\
\hline 1438 & 102 & 0 & 0 & 0 & 0 & 1 & 1 & 0 & 0 & 0 & 9362 & 73,29 & 31,21 & 8,02 & $-7,77$ & 2,04 & 2 & 0,0094 & 0 & 0,01984 & 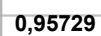 \\
\hline 1439 & 102 & 0 & 0 & 0 & 1 & 0 & 0 & 1 & 0 & 0 & 9707 & 78,56 & 25,55 & 4,97 & $-8,01$ & 2,36 & 2 & 0,0097 & 0 & 0,04848 & 0,80705 \\
\hline 440 & 102 & 0 & 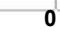 & 0 & 1 & & 0 & 1 & 0 & 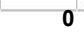 & 9942 & 65,49 & 27,54 & 5,87 & $-8,04$ & & 2 & 0,0099 & 0 & 0,03363 & 0,87720 \\
\hline
\end{tabular}


Obs ID AA AB BA BB MD LV PL NL REC PIB COMEX AGRI PREF ODP CAP APRE PIB2 ACI CREC P0

\begin{tabular}{|c|c|c|c|c|c|c|c|c|c|c|c|c|c|c|c|c|c|c|c|c|c|}
\hline 1441 & 102 & 0 & 0 & 0 & 1 & 0 & 0 & 1 & 0 & 0 & 10357 & 65,11 & 26,25 & 3,87 & $-7,32$ & 1,94 & 2 & 0,0104 & 0 & 0,03594 & 0,87674 \\
\hline 1442 & 102 & 0 & 0 & 0 & 1 & 0 & 0 & 1 & 0 & 0 & 10540 & 66,85 & 28,65 & 4,48 & $-7,39$ & 2,03 & 2 & 0,0105 & 0 & 0,04324 & 0,83975 \\
\hline 1443 & 102 & 0 & 0 & 0 & 1 & 0 & 0 & 1 & 0 & 0 & 11000 & 66,62 & 28,41 & 3,31 & $-7,74$ & 2,03 & 2 & 0,011 & 0 & 0,03898 & 0,85406 \\
\hline 1444 & 103 & 0 & 0 & 0 & 0 & 1 & 0 & 0 & $T$ & 0 & 9681 & 65,58 & 37,46 & 10,01 & $-16,99$ & 1,77 & 0 & 0,0097 & 0 & 0,00025 & 0,99915 \\
\hline 1445 & 103 & 0 & 0 & 0 & 0 & 1 & 0 & 1 & 0 & 0 & 10121 & 51,88 & 43,46 & 12,73 & $-13,5$ & 1,77 & 0 & 0,0101 & 0 & 0,00703 & 0,96777 \\
\hline 1446 & 103 & 0 & 0 & 0 & 0 & 1 & 0 & 1 & 0 & 0 & 10478 & 41,91 & 45,83 & 15,13 & $-12,48$ & 1,93 & 0 & 0,0105 & 0 & 0,01300 & 0,94444 \\
\hline 1447 & 103 & 0 & 0 & 0 & 0 & 1 & 0 & 1 & 0 & 0 & 10867 & 37,42 & 40,1 & 17,64 & $-10,84$ & 2,08 & 0 & 0,0109 & 0 & 0,01997 & 0,93283 \\
\hline 1448 & 103 & 0 & 0 & 0 & 0 & 1 & 0 & 1 & 0 & 0 & 11393 & 35,38 & 41,38 & 21,74 & $-10,33$ & 2,08 & 0 & 0,0114 & 0 & 0,02485 & 0,91802 \\
\hline 1449 & 103 & 0 & 0 & 0 & 0 & 1 & 0 & 1 & 0 & 0 & 11955 & 33,49 & 42,03 & 21,76 & $-10,58$ & 2,08 & 0 & 0,012 & 0 & 0,02382 & 0,92068 \\
\hline 1450 & 103 & 0 & 0 & 0 & 0 & 1 & 0 & 1 & 0 & 0 & 12672 & 38,29 & 42,69 & 21,09 & $-12,66$ & 2,09 & 0 & 0,0127 & 0 & 0,01379 & 0,94681 \\
\hline 1451 & 103 & 0 & 0 & 0 & 0 & 1 & 0 & 1 & 0 & 0 & 13579 & 37,42 & 42,66 & 17,9 & $-11,86$ & 2,1 & 2 & 0,0136 & 0 & 0,02341 & 0,91033 \\
\hline 1452 & 103 & 0 & 0 & 0 & 0 & 1 & 0 & 1 & 0 & 0 & 14515 & 41,37 & 41,69 & 19,18 & $-15,05$ & 2,13 & 3 & 0,0145 & 0 & 0,01106 & 0,95036 \\
\hline 1453 & 103 & 0 & 0 & 0 & 0 & 1 & 0 & 1 & 0 & 0 & 15651 & 45,72 & 39,3 & 17,07 & $-14,07$ & 2,08 & 3 & 0,0157 & 0 & 0,01249 & 0,94714 \\
\hline 1454 & 103 & 0 & 0 & 0 & 0 & 1 & 0 & 1 & 0 & 0 & 16930 & 39,08 & 37,94 & 15,24 & $-9,04$ & 2,11 & 3 & 0,0169 & 0 & 0,04962 & 0,84382 \\
\hline 1455 & 103 & 0 & 0 & 0 & 0 & 1 & 0 & 1 & 0 & 0 & 17719 & 42,11 & 33,59 & 13,07 & $-10,13$ & 2,16 & 3 & 0,0177 & 0 & 0,03314 & 0,89792 \\
\hline 1456 & 103 & 0 & 0 & 0 & 0 & 1 & 0 & 1 & 0 & 0 & 19219 & 50,6 & 29,59 & 13,74 & $-13,3$ & 2,12 & 3 & 0,0192 & 0 & 0,01094 & 0,96241 \\
\hline 1457 & 103 & 0 & 0 & 0 & 0 & 1 & 0 & 1 & 0 & 0 & 20289 & 49,44 & 22,95 & 9,17 & $-8,62$ & 2,02 & 3 & 0,0203 & 0 & 0,02754 & 0,93388 \\
\hline 1458 & 103 & 0 & 0 & 0 & 0 & 1 & 0 & 1 & 0 & 0 & 21381 & 43,65 & 23,92 & 11,74 & $-10,37$ & 1,91 & 3 & 0,0214 & 0 & 0,01502 & 0,96266 \\
\hline 1459 & 103 & 0 & 0 & 0 & 0 & 1 & 0 & 1 & 0 & 0 & 22740 & 47,88 & 21,97 & 6,87 & $-9,51$ & 1,92 & 3 & 0,0227 & 0 & 0,01789 & 0,95699 \\
\hline 1460 & 103 & 0 & 0 & 0 & 0 & 1 & 0 & 1 & 0 & 0 & 24538 & 56,8 & 20,59 & 6,61 & $-7,26$ & 1,87 & 3 & 0,0245 & 0 & 0,03119 & 0,92901 \\
\hline 1461 & 103 & 0 & 0 & 0 & 0 & 1 & 0 & 1 & 0 & 0 & 25799 & 54,4 & 24,24 & 3,89 & $-7,33$ & 1,81 & 3 & 0,0258 & 0 & 0,03277 & 0,91995 \\
\hline 1462 & 104 & 0 & 0 & 0 & 0 & 1 & 0 & 0 & 1 & 0 & 66051 & 154,61 & 15,67 & 6,19 & $-3,34$ & 2,28 & 2 & 0,0661 & 0 & 0,02776 & 0,92689 \\
\hline 1463 & 104 & 0 & 0 & 0 & 1 & 0 & 0 & 0 & 1 & 0 & 69790 & 154,32 & 15,98 & 5,8 & $-2,65$ & 2,3 & 5 & 0,0698 & 0 & 0,05798 & 0,80935 \\
\hline 1464 & 104 & 0 & 0 & 0 & 1 & 0 & 0 & 0 & 1 & 0 & 73557 & 136,31 & 16,66 & 6,86 & $-3,68$ & 2,25 & 7 & 0,0736 & 0 & 0,05678 & 0,82644 \\
\hline 1465 & 104 & 0 & 0 & 0 & 1 & 0 & 0 & 0 & 1 & 1 & 78282 & 152,22 & 17,17 & 5,42 & $-2,64$ & 2,24 & 9 & 0,0783 & 0 & 0,09455 & 0,67020 \\
\hline 1466 & 104 & 0 & 0 & 0 & 1 & 0 & 0 & 0 & 1 & 0 & 83167 & 162,91 & 17,29 & 4,47 & $-2,79$ & 2,27 & 10 & 0,0832 & 0 & 0,10429 & 0,59116 \\
\hline 1467 & 104 & 0 & 0 & 0 & 1 & 0 & 0 & 0 & 1 & 1 & 87531 & 156,55 & 15,78 & 4,13 & $-2,75$ & 2,21 & 16 & 0,0875 & 0 & 0,15831 & 0,38825 \\
\hline 1468 & 105 & 0 & 0 & 0 & 0 & 1 & 0 & 0 & 1 & 0 & 5164 & 69,23 & 7,92 & 9,03 & $-56,96$ & 1,44 & 0 & 0,0052 & 0 & 0,00000 & 1,00000 \\
\hline 1469 & 105 & 0 & 0 & 0 & 0 & 1 & 0 & 0 & 1 & 0 & 5485 & 63,82 & 10,92 & 8,29 & $-17,93$ & 1,44 & 0 & 0,0055 & 0 & 0,00003 & 0,99994 \\
\hline 1470 & 105 & 0 & 0 & 0 & 0 & 1 & 0 & 0 & 1 & 0 & 5694 & 58,27 & 9,77 & 17,19 & $-15,04$ & 1,54 & 0 & 0,0057 & 0 & 0,00008 & 0,99987 \\
\hline 1471 & 105 & 0 & 0 & 0 & 0 & 1 & 0 & 0 & 1 & 0 & 5672 & 56,25 & 14,47 & 7,67 & $-10,5$ & 1,64 & 0 & 0,0057 & 0 & 0,00046 & 0,99934 \\
\hline 1472 & 105 & 0 & 0 & 0 & 0 & 1 & 0 & 0 & 1 & 0 & 5936 & 59,77 & 15,26 & 7,2 & $-19,23$ & 1,64 & 0 & 0,0059 & 0 & 0,00003 & 0,99993 \\
\hline 1473 & 105 & 0 & 0 & 0 & 0 & 1 & 0 & 0 & 1 & 0 & 6167 & 60,39 & 12,04 & 5,9 & $-23,07$ & 1,64 & 0 & 0,0062 & 0 & 0,00001 & 0,99998 \\
\hline 1474 & 105 & 0 & 0 & 0 & 0 & 1 & 0 & 0 & 1 & 0 & 6495 & 64,67 & 12,3 & 6,52 & $-14,53$ & 1,67 & 0 & 0,0065 & 0 & 0,00013 & 0,99977 \\
\hline 1475 & 105 & 0 & 0 & 0 & 0 & 1 & 0 & 0 & 1 & 0 & 6788 & 64,92 & 14,8 & 13,88 & $-20,07$ & 1,69 & 0 & 0,0068 & 0 & 0,00003 & 0,99993 \\
\hline 1476 & 105 & 0 & 0 & 0 & 0 & 1 & 0 & 0 & 1 & 0 & 7259 & 62,31 & 14,69 & 4,96 & $-16,28$ & 1,68 & 0 & 0,0073 & 0 & 0,00009 & 0,99983 \\
\hline 1477 & 105 & 0 & 0 & 0 & 0 & 1 & 0 & 0 & 1 & 0 & 7770 & 70,81 & 16,04 & 5,62 & $-19,42$ & 1,68 & 0 & 0,0078 & 0 & 0,00004 & 0,99991 \\
\hline 1478 & 105 & 0 & 0 & 0 & 0 & 1 & 0 & 0 & 1 & 0 & 8332 & 62,2 & 13,05 & 10,04 & $-15,22$ & 1,56 & 0 & 0,0083 & 0 & 0,00010 & 0,99983 \\
\hline 1479 & 105 & 0 & 0 & 0 & 0 & 1 & 0 & 0 & 1 & 0 & 8990 & 57,86 & 8,59 & 11,17 & $-12,66$ & 1,69 & 0 & 0,009 & 0 & 0,00020 & 0,99972 \\
\hline 1480 & 105 & 0 & 0 & 0 & 0 & 1 & 0 & 0 & 1 & 0 & 9741 & 65,77 & 7,2 & 10,62 & $-8,05$ & 1,79 & 0 & 0,0097 & 0 & 0,00091 & 0,99893 \\
\hline 1481 & 105 & 0 & 0 & 0 & 1 & 0 & 0 & 0 & 1 & 0 & 10499 & 59,45 & 6,35 & 10,95 & $-6,76$ & 1,77 & 0 & 0,0105 & 0 & 0,00140 & 0,99824 \\
\hline 1482 & 105 & 0 & 0 & 0 & 1 & 0 & 0 & 0 & 1 & 0 & 11467 & 56,12 & 8,08 & 12,73 & $-8,5$ & 1,71 & 0 & 0,0115 & 0 & 0,00083 & 0,99887 \\
\hline 1483 & 105 & 0 & 0 & 0 & 1 & 0 & 0 & 0 & 1 & 0 & 12647 & 67,9 & 6,15 & 7,93 & $-4,85$ & 1,67 & 0 & 0,0126 & 0 & 0,00220 & 0,99726 \\
\hline 1484 & 105 & 0 & 0 & 0 & 1 & 0 & 0 & 0 & 1 & 0 & 13449 & 69,89 & 7,34 & 6,76 & $-4,58$ & 1,86 & 0 & 0,0134 & 0 & 0,00332 & 0,99566 \\
\hline 1485 & 105 & 0 & 0 & 0 & 1 & 0 & 0 & 0 & 1 & 0 & 14354 & 79,27 & 9,85 & 2,49 & $-3,88$ & 2 & 2 & 0,0144 & 0 & 0,00782 & 0,98809 \\
\hline 1486 & 106 & 0 & 0 & 0 & 0 & 1 & 0 & 1 & 0 & 0 & 7536 & 79,16 & 28,24 & 8,13 & $-7,21$ & 2,27 & 0 & 0,0075 & 0 & 0,04293 & 0,86150 \\
\hline 1487 & 106 & 0 & 0 & 0 & 0 & 1 & 0 & 1 & 0 & 0 & 8317 & 72,07 & 35,68 & 14,26 & $-4,49$ & 2,27 & 0 & 0,0083 & 0 & 0,10865 & 0,65556 \\
\hline 1488 & 106 & 0 & 0 & 0 & 0 & 1 & 0 & 1 & 0 & 0 & 8540 & 82,21 & 30,83 & 12,2 & $-4,13$ & 2,2 & 0 & 0,0085 & 0 & 0,09588 & 0,70835 \\
\hline 1489 & 106 & 0 & 0 & 0 & 0 & 1 & 0 & 1 & 0 & 0 & 8714 & 70,92 & 36,85 & 13,56 & $-3,76$ & 1,93 & 1 & 0,0087 & 0 & 0,10628 & 0,66906 \\
\hline 1490 & 106 & 0 & 0 & 0 & 0 & 1 & 0 & 1 & 0 & 0 & 8447 & 74,07 & 34,62 & 7,78 & $-2,78$ & 1,72 & 1 & 0,0084 & 0 & 0,09949 & 0,70963 \\
\hline 1491 & 106 & 0 & 0 & 0 & 0 & 1 & 0 & 0 & 1 & 0 & 8569 & 67,9 & 36,87 & 17,49 & $-2,5$ & 1,66 & 1 & 0,0086 & 0 & 0,01987 & 0,96296 \\
\hline 1492 & 106 & 0 & 0 & 0 & 0 & 1 & 0 & 0 & 1 & 0 & 7807 & 66,81 & 25 & 6,17 & $-3,27$ & 1,6 & 1 & 0,0078 & 0 & 0,00790 & 0,98829 \\
\hline 1493 & 106 & 0 & 0 & 0 & 0 & 1 & 0 & 0 & 1 & 0 & 6104 & 76,04 & 32,38 & 9,17 & $-3,39$ & 1,55 & 1 & 0,0061 & 0 & 0,01027 & 0,98054 \\
\hline 1494 & 106 & 0 & 0 & 0 & 0 & 1 & 0 & 0 & 1 & 0 & 5755 & 76,04 & 23,6 & 13,91 & $-6,8$ & 1,21 & 1 & 0,0058 & 0 & 0,00153 & 0,99734 \\
\hline 1495 & 106 & 0 & 0 & 0 & 0 & 1 & 0 & 0 & 1 & 0 & 5556 & 82,82 & 23,47 & 3,31 & $-5,42$ & 1,2 & 1 & 0,0056 & 0 & 0,00221 & 0,99609 \\
\hline 1496 & 106 & 0 & 0 & 0 & 0 & 1 & 0 & 0 & 1 & 0 & 5353 & 84,17 & 19,61 & 7,48 & $-9,7$ & 1,23 & 1 & 0,0054 & 0 & 0,00053 & 0,99896 \\
\hline 1497 & 106 & 0 & 0 & 0 & 0 & 1 & 0 & 0 & 1 & 0 & 4407 & 109,52 & 25,15 & 9,87 & $-15,42$ & 1 & 1 & 0,0044 & 0 & 0,00009 & 0,99968 \\
\hline 1498 & 106 & 0 & 0 & 0 & 0 & 1 & 0 & 0 & 1 & 0 & 4671 & 68,48 & 29,12 & 6,13 & $-9,32$ & 0,98 & 1 & 0,0047 & 0 & 0,00063 & 0,99870 \\
\hline 1499 & 106 & 0 & 0 & 0 & 0 & 1 & 0 & 0 & 1 & 0 & 5202 & 100,37 & 21,69 & 3,42 & $-8,03$ & 1 & 1 & 0,0052 & 0 & 0,00072 & 0,99843 \\
\hline 1500 & & & & & & & & & & & & 22,31 & & & & & & 0,005 & &, 001 & 1966 \\
\hline
\end{tabular}


Obs ID AA AB BA $\quad$ BB $\quad$ MD LV PL NL REC PIB COMEX AGRI PREF ODP CAP APRE PIB2 ACI CREC P0

\begin{tabular}{|c|c|c|c|c|c|c|c|c|c|c|c|c|c|c|c|c|c|c|c|c|c|}
\hline 1501 & 106 & 0 & 0 & 0 & 0 & 1 & 0 & 0 & 1 & 0 & 6437 & 96,11 & 26,54 & 2,9 & $-8,74$ & 1,3 & 4 & 0,0064 & 0 & 0,00180 & 0,99537 \\
\hline 1502 & 107 & 0 & 0 & 0 & 0 & 1 & 0 & 1 & 0 & 0 & 2897 & 40,75 & 46,96 & 12,19 & $-22,35$ & 1,48 & 0 & 0,0029 & 0 & 0,00035 & 0,99772 \\
\hline 1503 & 107 & 0 & 0 & 0 & 0 & 1 & 0 & 1 & 0 & 0 & 3216 & 38,18 & 43,19 & 9,59 & $-17,63$ & 1,48 & 0 & 0,0032 & 0 & 0,00121 & 0,99418 \\
\hline 1504 & 107 & 0 & 0 & 0 & 0 & 1 & 0 & 1 & 0 & 0 & 3419 & 37,42 & 35,32 & 9,7 & $-16,34$ & 1,61 & 0 & 0,0034 & 0 & 0,00149 & 0,99439 \\
\hline 1505 & 107 & 0 & 0 & 0 & 0 & 1 & 0 & 1 & 0 & 0 & 3669 & 40,94 & 40,85 & 12,91 & $-16,5$ & 1,75 & 0 & 0,0037 & 0 & 0,00229 & 0,98977 \\
\hline 1506 & 107 & 0 & 0 & 0 & 0 & 1 & 0 & 1 & 0 & 0 & 3940 & 33,69 & 38,77 & 11,54 & $-15,32$ & 1,81 & 0 & 0,0039 & 0 & 0,00316 & 0,98793 \\
\hline 1507 & 107 & 0 & 0 & 0 & 0 & 1 & 0 & 1 & 0 & 0 & 4012 & 34,51 & 33,09 & 12,22 & $-8,29$ & 1,88 & 0 & 0,004 & 0 & 0,02184 & 0,94527 \\
\hline 1508 & 107 & 0 & 0 & 0 & 0 & 1 & 0 & 1 & 0 & 0 & 4277 & 32,37 & 40,76 & 15,58 & $-15,9$ & 1,83 & 0 & 0,0043 & 0 & 0,00305 & 0,98773 \\
\hline 1509 & 107 & 0 & 0 & 0 & 0 & 1 & 0 & 1 & 0 & 0 & 4464 & 30,87 & 39,74 & 24,91 & $-15,91$ & 1,78 & 0 & 0,0045 & 0 & 0,00282 & 0,98934 \\
\hline 1510 & 107 & 0 & 0 & 0 & 0 & 1 & 0 & 1 & 0 & 0 & 4812 & 30,73 & 39,78 & 10,05 & $-15,37$ & 1,88 & 0 & 0,0048 & 0 & 0,00357 & 0,98625 \\
\hline 1511 & 107 & 0 & 0 & 0 & 0 & 1 & 0 & 1 & 0 & 0 & 5027 & 37,13 & 40,19 & 6,23 & $-15,81$ & 1,97 & 0 & 0,005 & 0 & 0,00360 & 0,98469 \\
\hline 1512 & 107 & 0 & 0 & 0 & 0 & 1 & 0 & 1 & 0 & 0 & 5463 & 35,54 & 38,95 & 9,36 & $-15,33$ & 1,9 & 0 & 0,0055 & 0 & 0,00362 & 0,98573 \\
\hline 1513 & 107 & 0 & 0 & 0 & 0 & 1 & 0 & 1 & 0 & 0 & 6133 & 35,42 & 40,98 & 20,4 & $-16,61$ & 1,77 & 0 & 0,0061 & 0 & 0,00239 & 0,98994 \\
\hline 1514 & 107 & 0 & 0 & 0 & 0 & 1 & 0 & 1 & 0 & 0 & 6580 & 36,31 & 39,15 & 20,11 & $-15,31$ & 2,03 & 0 & 0,0066 & 0 & 0,00468 & 0,98173 \\
\hline 1515 & 107 & 0 & 0 & 0 & 0 & 1 & 0 & 1 & 0 & 0 & 6775 & 40,42 & 38,98 & 9,98 & $-16,56$ & 1,92 & 0 & 0,0068 & 0 & 0,00263 & 0,98859 \\
\hline 1516 & 107 & 0 & 0 & 0 & 0 & 1 & 0 & 1 & 0 & 0 & 7347 & 48,87 & 43,67 & 6,29 & $-14,82$ & 1,94 & 0 & 0,0073 & 0 & 0,00571 & 0,97216 \\
\hline 1517 & 107 & 0 & 0 & 0 & 0 & 1 & 0 & 1 & 0 & 0 & 7826 & 58,15 & 45,78 & 3,79 & $-12,28$ & 1,96 & 0 & 0,0078 & 0 & 0,01372 & 0,93127 \\
\hline 1518 & 108 & 0 & 0 & 0 & 0 & 1 & 0 & 0 & 1 & 0 & 1078 & 40,2 & 46,2 & 30,22 & $-35,12$ & 0,77 & 0 & 0,0011 & 0 & 0,00000 & 1,00000 \\
\hline 1519 & 108 & 0 & 0 & 0 & 0 & 1 & 0 & 0 & 1 & 0 & 992 & 21,57 & 39,08 & 42,11 & $-15,82$ & 0,77 & 0 & 0,001 & 0 & 0,00009 & 0,99981 \\
\hline 1520 & 108 & 0 & 0 & 0 & 0 & 1 & 0 & 0 & 1 & 0 & 976 & 24,28 & 56,2 & 43,6 & $-9,17$ & 0,81 & 0 & 0,001 & 0 & 0,00166 & 0,99607 \\
\hline 1521 & 108 & 0 & 0 & 0 & 0 & 1 & 0 & 0 & 1 & 0 & 1022 & 27,44 & 47,45 & 34,04 & $-10,89$ & 0,84 & 0 & 0,001 & 0 & 0,00065 & 0,99857 \\
\hline 1522 & 108 & 0 & 0 & 0 & 0 & 1 & 0 & 0 & 1 & 0 & 1012 & 23,54 & 44,65 & 39,16 & $-11,79$ & 0,95 & 0 & 0,001 & 0 & 0,00051 & 0,99895 \\
\hline 1523 & 108 & 0 & 0 & 0 & 0 & 1 & 0 & 0 & 1 & 0 & 1003 & 22,55 & 49,05 & 49,17 & $-15,74$ & 1,06 & 0 & 0,001 & 0 & 0,00023 & 0,99939 \\
\hline 1524 & 108 & 0 & 0 & 0 & 0 & 1 & 0 & 0 & 1 & 0 & 1024 & 20,96 & 40,35 & 32,71 & $-24,29$ & 1,06 & 0 & 0,001 & 0 & 0,00001 & 0,99997 \\
\hline 1525 & 108 & 0 & 0 & 0 & 0 & 1 & 0 & 0 & 1 & 0 & 1069 & 21,67 & 37,51 & 39,5 & $-26,1$ & 1,05 & 0 & 0,0011 & 0 & 0,00001 & \begin{tabular}{|l|l}
0,99998 \\
\end{tabular} \\
\hline 1526 & 108 & 0 & 0 & 0 & 0 & 1 & 0 & 1 & 0 & 0 & 1056 & 27,38 & 41,08 & 19,48 & $-29,6$ & 1,03 & 0 & 0,0011 & 0 & 0,00002 & 0,99990 \\
\hline 1527 & 108 & 0 & 0 & 0 & 0 & 1 & 0 & 1 & 0 & 0 & 1107 & 31,58 & 31,21 & 10,41 & $-40,78$ & 1,19 & 0 & 0,0011 & 0 & 0,00000 & 1,00000 \\
\hline 1528 & 108 & 0 & 0 & 0 & 0 & 1 & 0 & 1 & 0 & 0 & 1117 & 41,65 & 24,22 & 16,72 & $-39,15$ & 1,24 & 0 & 0,0011 & 0 & 0,00000 & 1,00000 \\
\hline 1529 & 108 & 0 & 0 & 0 & 0 & 1 & 0 & 1 & 0 & 0 & 1177 & 54,15 & 34,34 & 4 & $-42,51$ & 1,42 & 0 & 0,0012 & 0 & 0,00000 & 1,00000 \\
\hline 1530 & 108 & 0 & 0 & 0 & 0 & 1 & 0 & 1 & 0 & 0 & 1234 & 41,48 & 21,62 & 12,86 & $-41,55$ & 1,26 & 0 & 0,0012 & 0 & 0,00000 & 1,00000 \\
\hline 1531 & 108 & 0 & 0 & 0 & 0 & 1 & 0 & 1 & 0 & 0 & 1296 & 47,42 & 26,51 & 8,07 & $-40,75$ & 1,41 & 0 & 0,0013 & 0 & 0,00000 & 1,00000 \\
\hline 1532 & 108 & 0 & 0 & 0 & 0 & 1 & 0 & 1 & 0 & 0 & 1341 & 49,93 & 23,52 & 15,35 & $-43,63$ & 1,47 & 0 & 0,0013 & 0 & 0,00000 & 1,00000 \\
\hline 1533 & 108 & 0 & 0 & 0 & 0 & 1 & 0 & 1 & 0 & 0 & 1392 & 48,1 & 26,36 & 8,41 & $-47,1$ & 1,4 & 0 & 0,0014 & 0 & 0,00000 & 1,00000 \\
\hline 1534 & 108 & 0 & 0 & 0 & 0 & 1 & 0 & 1 & 0 & 0 & 1450 & 47,02 & 35,18 & 9,79 & $-38,63$ & 1,45 & 0 & 0,0015 & 0 & 0,00000 & 0,99999 \\
\hline 1535 & 108 & 0 & 0 & 0 & 0 & 1 & 0 & 1 & 0 & 0 & 1508 & 46,42 & 38,87 & 5,62 & $-34,95$ & 1,19 & 0 & 0,0015 & 0 & 0,00000 & 0,99997 \\
\hline 1536 & 109 & 0 & 0 & 0 & 0 & 1 & 0 & 0 & 1 & 0 & 5557 & 134,51 & 6,8 & 6,84 & $-10,65$ & 1,62 & 0 & 0,0056 & 0 & 0,00036 & 0,99916 \\
\hline 1537 & 109 & 0 & 0 & 0 & 0 & 1 & 0 & 0 & 1 & 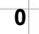 & 6293 & 136,83 & 6,31 & 7,12 & $-10,07$ & 1,53 & 0 & 0,0063 & 0 & 0,00038 & 0,99914 \\
\hline 1538 & 109 & 0 & 0 & 0 & 0 & 1 & 0 & 0 & 1 & 0 & 6971 & 144,61 & 5,7 & 7,16 & $-8,9$ & 1,54 & 0 & 0,007 & 0 & 0,00054 & 0,99876 \\
\hline 1539 & 109 & 0 & 0 & 0 & 0 & 1 & 0 & 0 & 1 & 0 & 7683 & 138,27 & 5,27 & 8,54 & $-9,54$ & 1,64 & 0 & 0,0077 & 0 & 0,00050 & 0,99889 \\
\hline 1540 & 109 & 0 & 0 & 0 & 0 & 1 & 0 & 0 & 1 & 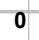 & 8197 & 133,32 & 5,26 & 7,58 & $-9,39$ & 1,55 & 0 & 0,0082 & 0 & 0,00046 & 0,99904 \\
\hline 1541 & 109 & 0 & 0 & 0 & 0 & 1 & 0 & 0 & 1 & 0 & 8204 & 105,14 & 6,3 & 8,01 & $-9,27$ & 1,59 & 0 & 0,0082 & 0 & 0,00049 & 0,99917 \\
\hline 1542 & 109 & 0 & 0 & 0 & 0 & 1 & 0 & 0 & 1 & 0 & 8693 & 113,6 & 6,52 & 7,25 & $-8,62$ & 1,58 & 0 & 0,0087 & 0 & 0,00061 & 0,99892 \\
\hline 1543 & 109 & 0 & 0 & 0 & 0 & 1 & 0 & 0 & 1 & 0 & 9308 & 113,58 & 7,18 & 7,72 & $-8,19$ & 1,65 & 0 & 0,0093 & 0 & 0,00080 & 0,99859 \\
\hline 1544 & 109 & 0 & 0 & 0 & 0 & 1 & 0 & 0 & 1 & 0 & 9984 & 120,74 & 6,92 & 7,36 & $-7,81$ & 1,67 & 0 & 0,01 & 0 & 0,00093 & 0,99829 \\
\hline 1545 & 110 & 0 & 0 & 0 & 0 & 1 & 0 & 1 & 0 & 0 & 1153 & 50,48 & 24,88 & 24,98 & $-16,75$ & 1,04 & 0 & 0,0012 & 0 & 0,00039 & 0,99877 \\
\hline 1546 & 110 & 0 & 0 & 0 & 0 & 1 & 0 & 1 & 0 & 0 & 1107 & 47,08 & 25,7 & 25,83 & $-19,26$ & 1,04 & 0 & 0,0011 & 0 & 0,00019 & 0,99935 \\
\hline 1547 & 110 & 0 & 0 & 0 & 0 & 1 & 0 & 1 & 0 & 0 & 1166 & 55,82 & 25,67 & 26,28 & $-10,77$ & 1,11 & 0 & 0,0012 & 0 & 0,00282 & 0,99267 \\
\hline 1548 & 110 & 0 & 0 & 0 & 0 & 1 & 0 & 1 & 0 & 0 & 1220 & 51,05 & 31,92 & 37,74 & $-14,26$ & 1,19 & 0 & 0,0012 & 0 & 0,00153 & 0,99499 \\
\hline 1549 & 110 & 0 & 0 & 0 & 0 & 1 & 0 & 1 & 0 & 0 & 1264 & 43,21 & 30,98 & 41,01 & $-13,53$ & 1,16 & 0 & 0,0013 & 0 & 0,00175 & 0,99497 \\
\hline 1550 & 110 & 0 & 0 & 0 & 0 & 1 & 0 & 1 & 0 & 0 & 1233 & 45,66 & 29,22 & 59,95 & $-8,87$ & 1,12 & 0 & 0,0012 & 0 & 0,00686 & 0,98492 \\
\hline 1551 & 110 & 0 & 0 & 0 & 0 & 1 & 0 & 1 & 0 & 0 & 1288 & 39,73 & 30,88 & 54,14 & $-9,44$ & 1 & 0 & 0,0013 & 0 & 0,00507 & 0,98862 \\
\hline 1552 & 110 & 0 & 0 & 0 & 0 & 1 & 0 & 1 & 0 & 0 & 1334 & 36,11 & 27,38 & 70,18 & $-6,77$ & 0,88 & 0 & 0,0013 & 0 & 0,00872 & 0,98511 \\
\hline 1553 & 110 & 0 & 0 & 0 & 0 & 1 & 0 & 0 & 1 & 0 & 1262 & 36,23 & 27,83 & 51,41 & $-5,46$ & 0,93 & 0 & 0,0013 & 0 & 0,00169 & 0,99807 \\
\hline 1554 & 110 & 0 & 0 & 0 & 0 & 1 & 0 & 0 & 1 & 0 & 1338 & 33,24 & 47,92 & 32,5 & $-10,02$ & 0,94 & 0 & 0,0013 & 0 & 0,00101 & 0,99772 \\
\hline 1555 & 110 & 0 & 0 & 0 & 0 & 1 & 0 & 1 & 0 & 0 & 1350 & 34,73 & 44,37 & 27,68 & $-7,87$ & 0,9 & 0 & 0,0014 & 0 & 0,01154 & 0,96628 \\
\hline 1556 & 110 & 0 & 0 & 0 & 0 & 1 & 0 & 1 & 0 & 0 & 1399 & 36,4 & 35,93 & 27,23 & $-11,12$ & 1,09 & 0 & 0,0014 & 0 & 0,00384 & 0,98915 \\
\hline 1557 & 110 & 0 & 0 & 0 & 0 & 1 & 0 & 1 & 0 & 0 & 1464 & 37,57 & 34,15 & 24,48 & $-12,8$ & 1,06 & 0 & 0,0015 & 0 & 0,00201 & 0,99404 \\
\hline 1558 & 110 & 0 & 0 & 0 & 0 & 1 & 0 & 1 & 0 & 0 & 1494 & 34,44 & 38,67 & 28,89 & $-17,53$ & 1,1 & 0 & 0,0015 & 0 & 0,00064 & 0,99753 \\
\hline 1559 & 110 & 0 & 0 & 0 & 0 & 1 & 0 & 1 & 0 & 0 & 1520 & 33,92 & 39,33 & 35,58 & $-16,48$ & 1,08 & U & 0,0015 & 0 & 0,00090 & 0,99666 \\
\hline 1560 & & & & & & & & & & & & & & & 7,45 & & & & & 0,00 & 982 \\
\hline
\end{tabular}


Obs ID AA AB $\quad$ BA $\quad$ BB $\quad$ MD LV PL NL REC PIB COMEX AGRI PREF ODP CAP APRE PIB2 ACI CREC P0

\begin{tabular}{|c|c|c|c|c|c|c|c|c|c|c|c|c|c|c|c|c|c|c|c|c|c|}
\hline 1561 & 110 & 0 & 0 & 0 & 0 & 1 & 0 & 1 & 0 & 0 & 1618 & 37,88 & 33,11 & 32,37 & $-15,95$ & 1,22 & 0 & 0,0016 & 0 & 0,00096 & 0,99686 \\
\hline 1562 & 110 & 0 & 0 & 0 & 0 & 1 & 0 & 1 & 0 & 0 & 1684 & 36,41 & 32,09 & 20,25 & $-13,64$ & 1,04 & 0 & 0,0017 & 0 & 0,00135 & 0,99606 \\
\hline 1563 & 111 & 0 & 0 & 0 & 0 & 1 & 0 & 0 & 1 & 0 & 441 & 50,95 & 50,62 & 251,06 & $-11,18$ & 1,89 & 0 & 0,0004 & 0 & 0,00887 & 0,98390 \\
\hline 1564 & 111 & 0 & 0 & 0 & 0 & 1 & 0 & 0 & 1 & 0 & 463 & 48,32 & 51,9 & 372,01 & $-12,28$ & 1,95 & 0 & 0,0005 & 0 & 0,01291 & 0,98157 \\
\hline 1565 & 111 & 0 & 0 & 0 & 0 & 1 & 0 & 0 & 1 & 0 & 479 & 53,87 & 63,66 & 96,28 & $-12,02$ & 2,02 & 0 & 0,0005 & 0 & 0,00734 & 0,97168 \\
\hline 1566 & 111 & 0 & 0 & 0 & 0 & 1 & 0 & 0 & 1 & 0 & 510 & 52,41 & 57,28 & 133,59 & $-9,69$ & 2,01 & 0 & 0,0005 & 0 & 0,01284 & 0,96521 \\
\hline 1567 & 111 & 0 & 0 & 0 & 0 & 1 & 0 & 0 & 1 & 0 & 538 & 56,36 & 57,51 & 37,03 & $-14,05$ & 2 & 0 & 0,0005 & 0 & 0,00222 & 0,99046 \\
\hline 1568 & 111 & 0 & 0 & 0 & 0 & 1 & 0 & 1 & 0 & 0 & 569 & 46,93 & 64,72 & 54,02 & $-14,56$ & 1,92 & 0 & 0,0006 & 0 & 0,01759 & 0,87874 \\
\hline 1569 & 111 & 0 & 0 & 0 & 0 & 1 & 0 & 1 & 0 & 0 & 551 & 59,64 & 63,24 & 22,65 & $-17,66$ & 1,83 & 0 & 0,0006 & 0 & 0,00540 & 0,95084 \\
\hline 1570 & 111 & 0 & 0 & 0 & 0 & 1 & 0 & 1 & 0 & 0 & 589 & 68,86 & 64,63 & 31,84 & $-13,85$ & 2,03 & 0 & 0,0006 & 0 & 0,02227 & 0,80957 \\
\hline 1571 & 111 & 0 & 0 & 0 & 0 & 1 & 0 & 1 & 0 & 0 & 630 & 69,09 & 58,66 & 15,23 & $-11,73$ & 2 & 0 & 0,0006 & 0 & 0,02807 & 0,80129 \\
\hline 1572 & 111 & 0 & 0 & 0 & 0 & 1 & 0 & 1 & 0 & 0 & 624 & 70,31 & 56,64 & 16,48 & $-11,43$ & 1,83 & 0 & 0,0006 & 0 & 0,02338 & 0,84450 \\
\hline 1573 & 111 & 0 & 0 & 0 & 0 & 1 & 0 & 1 & 0 & 0 & 631 & 61,95 & 47,62 & 22,35 & $-13,56$ & 1,79 & 0 & 0,0006 & 0 & 0,00853 & 0,95391 \\
\hline 1574 & 111 & 0 & 0 & 0 & 0 & 1 & 0 & 1 & 0 & 0 & 654 & 56,8 & 48,13 & 20,36 & $-15,75$ & 1,91 & 0 & 0,0007 & 0 & 0,00528 & 0,96934 \\
\hline 1575 & 111 & 0 & 0 & 0 & 0 & 1 & 0 & 1 & 0 & 0 & 692 & 56,05 & 43,75 & 20,03 & $-13,81$ & 1,78 & 0 & 0,0007 & 0 & 0,00642 & 0,96939 \\
\hline 1576 & 111 & 0 & 0 & 0 & 0 & 1 & 0 & 1 & 0 & 0 & 736 & 64,61 & 51,16 & 3,98 & $-17,97$ & 1,87 & 0 & 0,0007 & 0 & 0,00279 & 0,97876 \\
\hline 1577 & 111 & 0 & 0 & 0 & 0 & 1 & 0 & 1 & 0 & 0 & 784 & 66,46 & 55,62 & 6,35 & $-15,59$ & 1,84 & 0 & 0,0008 & 0 & 0,00674 & 0,94814 \\
\hline 1578 & 111 & 0 & 0 & 0 & 0 & 1 & 0 & 1 & 0 & 0 & 750 & 67,08 & 53,48 & 4,44 & $-17,37$ & 1,89 & 0 & 0,0008 & 0 & 0,00385 & 0,96922 \\
\hline 1579 & 111 & 0 & 0 & 0 & 0 & 1 & 0 & 1 & 0 & 0 & 794 & 74,92 & 45,08 & 2,33 & $-17,49$ & 1,99 & 0 & 0,0008 & 0 & 0,00292 & 0,97916 \\
\hline 1580 & 112 & 0 & 0 & 0 & 0 & 1 & 0 & 0 & 1 & 0 & 2083 & 45,64 & 21,26 & 17,61 & $-25,15$ & 1,26 & 0 & 0,0021 & 0 & 0,00000 & 0,99999 \\
\hline 1581 & 112 & 0 & 0 & 0 & 0 & 1 & 0 & 0 & 1 & 0 & 2176 & 43,54 & 15,19 & 20,81 & $-18,46$ & 1,26 & 0 & 0,0022 & 0 & 0,00002 & 0,99996 \\
\hline 1582 & 112 & 0 & 0 & 0 & 0 & 1 & 0 & 0 & 1 & 0 & 2289 & 42,42 & 17,21 & 19,93 & $-24,58$ & 1,48 & 0 & 0,0023 & 0 & 0,00001 & 0,99999 \\
\hline 1583 & 112 & 0 & 0 & 0 & 0 & 1 & 0 & 0 & 1 & 0 & 2372 & 48,21 & 17,09 & 24,49 & $-21,96$ & 1,7 & 0 & 0,0024 & 0 & 0,00002 & 0,99996 \\
\hline 1584 & 112 & 0 & 0 & 0 & 0 & 1 & 0 & 0 & 1 & 0 & 2463 & 47,67 & 19,49 & 27,25 & $-14,08$ & 1,69 & 0 & 0,0025 & 0 & 0,00022 & 0,99963 \\
\hline 1585 & 112 & 0 & 0 & 0 & 0 & 1 & 0 & 0 & 1 & 0 & 2525 & 53,48 & 16,51 & 21,72 & $-9,14$ & 1,67 & 0 & 0,0025 & 0 & 0,00083 & 0,99889 \\
\hline 1586 & 112 & 0 & 0 & 0 & 0 & 1 & 0 & 0 & 1 & 0 & 2617 & 58,6 & 13,91 & 19,95 & $-17,44$ & 1,61 & 0 & 0,0026 & 0 & 0,00005 & 0,99990 \\
\hline 1587 & 112 & 0 & 0 & 0 & 0 & 1 & 0 & 0 & 1 & 0 & 2752 & 55,45 & 14,06 & 25,74 & $-13,86$ & 1,55 & 0 & 0,0028 & 0 & 0,00015 & 0,99977 \\
\hline 1588 & 112 & 0 & 0 & 0 & 0 & 1 & 0 & 0 & 1 & 0 & 2786 & 51,14 & 12,8 & 18,77 & $-12,07$ & 1,74 & 0 & 0,0028 & 0 & 0,00031 & 0,99958 \\
\hline 1589 & 112 & 0 & 0 & 0 & 0 & 1 & 0 & 0 & 1 & 0 & 2852 & 50,44 & 12,49 & 22,32 & $-11,84$ & 1,62 & 0 & 0,0029 & 0 & 0,00028 & 0,99963 \\
\hline 1590 & 112 & 0 & 0 & 0 & 0 & 1 & 0 & 0 & 1 & 0 & 2937 & 69,9 & 14,51 & 12,08 & $-8,02$ & 1,44 & 0 & 0,0029 & 0 & 0,00077 & 0,99892 \\
\hline 1591 & 112 & 0 & 0 & 0 & 0 & 1 & 0 & 0 & 1 & 0 & 3010 & 83,21 & 20,43 & 12,37 & $-6,5$ & 1,16 & 0 & 0,003 & 0 & 0,00114 & 0,99811 \\
\hline 1592 & 112 & 0 & 0 & 0 & 0 & 1 & 0 & 0 & 1 & 0 & 3063 & 65,18 & 12,13 & 14,16 & $-7,93$ & 1,23 & 0 & 0,0031 & 0 & 0,00053 & 0,99934 \\
\hline 1593 & 112 & 0 & 0 & 0 & 0 & 1 & 0 & 0 & 1 & 0 & 3215 & 75,01 & 10,72 & 8,55 & $-10,25$ & 1,33 & 0 & 0,0032 & 0 & 0,00028 & 0,99959 \\
\hline 1594 & 112 & 0 & 0 & 0 & 0 & 1 & 0 & 0 & 1 & 0 & 3206 & 57,33 & 14,44 & 11,79 & $-6,74$ & 1,47 & 0 & 0,0032 & 0 & 0,00115 & 0,99863 \\
\hline 1595 & 112 & 0 & 0 & 0 & 0 & 1 & 0 & 0 & 1 & 0 & 3268 & 64,88 & 14,7 & 11,92 & $-6,89$ & 1,37 & 0 & 0,0033 & 0 & 0,00098 & 0,99873 \\
\hline 1596 & 112 & 0 & 0 & 0 & 0 & 1 & 0 & 1 & 0 & 0 & 3395 & 78,38 & 15,2 & 9,63 & $-5,92$ & 1,35 & 0 & 0,0034 & 0 & 0,01034 & 0,97813 \\
\hline 1597 & 112 & 0 & 0 & 0 & 0 & 1 & 0 & 1 & 0 & 0 & 3529 & 91,69 & 15,8 & 8,9 & $-9,69$ & 1,22 & 0 & 0,0035 & 0 & 0,00293 & 0,99177 \\
\hline 1598 & 113 & 0 & 0 & 0 & 0 & 1 & 0 & 1 & 0 & 0 & 591 & 46,81 & 57,98 & 14,27 & $-26,35$ & 1,03 & 0 & 0,0006 & 0 & 0,00009 & 0,99904 \\
\hline 1599 & 113 & 0 & 0 & 0 & 0 & 1 & 0 & 1 & 0 & 0 & 550 & 48,02 & 67,86 & 25,89 & $-19,63$ & 1,39 & 0 & 0,0006 & 0 & 0,00202 & 0,98049 \\
\hline 1600 & 113 & 0 & 0 & 0 & 0 & 1 & 0 & 1 & 0 & 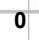 & 545 & 41,18 & 65,79 & 6,4 & $-17,96$ & 1,35 & 0 & 0,0005 & 0 & 0,00257 & 0,97823 \\
\hline 1601 & 113 & 0 & 0 & 0 & 0 & 1 & 0 & 1 & 0 & 0 & 548 & 43,27 & 74,8 & 4,03 & $-37,9$ & 1,19 & 0 & 0,0005 & 0 & 0,00001 & 0,99982 \\
\hline 1602 & 114 & 0 & 0 & 0 & 0 & 1 & 0 & 1 & 0 & 0 & 1870 & 94,51 & 26,85 & 5,05 & $-18,43$ & 2,37 & 0 & 0,0019 & 0 & 0,00170 & 0,99009 \\
\hline 1603 & 114 & 0 & 0 & 0 & 0 & 1 & 0 & 1 & 0 & 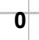 & 1938 & 99,2 & 17,56 & 3,54 & $-19,83$ & 2,17 & 0 & 0,0019 & 0 & 0,00054 & 0,99720 \\
\hline 1604 & 114 & 0 & 0 & 0 & 0 & 1 & 0 & 0 & 1 & 0 & 2043 & 89,43 & 23,2 & 2,87 & $-14,71$ & 1,96 & 0 & 0,002 & 0 & 0,00032 & 0,99910 \\
\hline 1605 & 114 & 0 & 0 & 0 & 0 & 1 & 0 & 0 & 1 & 0 & 2152 & 73,75 & 23,28 & 4,6 & $-13,18$ & 1,9 & 0 & 0,0022 & 0 & 0,00045 & 0,99895 \\
\hline 1606 & 114 & 0 & 0 & 0 & 0 & 1 & 0 & 0 & 1 & 0 & 2152 & 82,92 & 27,45 & 1,36 & $-12,78$ & 1,83 & 0 & 0,0022 & 0 & 0,00057 & 0,99845 \\
\hline 1607 & 114 & 0 & 0 & 0 & 0 & 1 & 0 & 0 & 1 & 0 & 2303 & 83,93 & 23,02 & 1,64 & $-11,23$ & 1,86 & 0 & 0,0023 & 0 & 0,00077 & 0,99821 \\
\hline 1608 & 114 & 0 & 0 & 0 & 0 & 1 & 0 & 0 & 1 & 0 & 2465 & 93,82 & 22,16 & 0,83 & $-13,09$ & 1,78 & 0 & 0,0025 & 0 & 0,00038 & 0,99897 \\
\hline 1609 & 114 & 0 & 0 & 0 & 0 & 1 & 0 & 1 & 0 & 0 & 2460 & 95,08 & 18,15 & 1,07 & $-13,02$ & 1,67 & 0 & 0,0025 & 0 & 0,00216 & 0,99205 \\
\hline 1610 & 114 & 0 & 0 & 0 & 0 & 1 & 0 & 1 & 0 & 0 & 2537 & 120,75 & 20,13 & 1,82 & $-14,53$ & 1,72 & 0 & 0,0025 & 0 & 0,00172 & 0,99119 \\
\hline 1611 & 114 & 0 & 0 & 0 & 0 & 1 & 0 & 1 & 0 & 0 & 2753 & 137,06 & 21,39 & 1,37 & $-10,71$ & 1,75 & 0 & 0,0028 & 0 & 0,00623 & 0,96786 \\
\hline 1612 & 114 & 0 & 0 & 0 & 0 & 1 & 0 & 1 & 0 & 0 & 2985 & 146,11 & 15,89 & 1,06 & $-12,24$ & 1,73 & 0 & 0,003 & 0 & 0,00304 & 0,98411 \\
\hline 1613 & 114 & 0 & 0 & 0 & 0 & 1 & 0 & 0 & 1 & 0 & 3071 & 133,38 & 22,31 & 0,86 & $-10,75$ & 1,55 & 0 & 0,0031 & 0 & 0,00063 & 0,99787 \\
\hline 1614 & 114 & 0 & 0 & 0 & 0 & 1 & 0 & 1 & 0 & 0 & 3056 & 133,23 & 24,79 & 1,94 & $-12,84$ & 1,87 & 0 & 0,0031 & 0 & 0,00453 & 0,97303 \\
\hline 1615 & 114 & 0 & 0 & 0 & 0 & 1 & 0 & 1 & 0 & 0 & 3238 & 136,18 & 22,96 & 0,9 & $-15,95$ & 1,87 & 0 & 0,0032 & 0 & 0,00164 & 0,98902 \\
\hline 1616 & 114 & 0 & 0 & 0 & 1 & 0 & 0 & 1 & 0 & 0 & 3235 & 139,68 & 20,36 & 1,2 & $-14,64$ & 1,84 & 0 & 0,0032 & 0 & 0,00232 & 0,98257 \\
\hline 1617 & 115 & 0 & 0 & 0 & 0 & 1 & 1 & 0 & 0 & 0 & 3492 & 52,49 & 46,34 & 7,94 & $-18,86$ & 1,29 & 0 & 0,0035 & 0 & 0,00033 & 0,99873 \\
\hline 1618 & 115 & 0 & 0 & 0 & 0 & 1 & 1 & 0 & 0 & 0 & 3661 & 57,04 & 49,74 & 8,4 & $-17,27$ & 1,37 & 0 & 0,0037 & 0 & 0,00072 & 0,99710 \\
\hline 1619 & 115 & 0 & 0 & 0 & 0 & 1 & 1 & 0 & 0 & 0 & 3938 & 50,18 & 49,03 & 7,02 & $-13,18$ & 1,45 & U & 0,0039 & 0 & 0,00262 & 0,99164 \\
\hline 1620 & & & & & & & & & & & & 0,08 & & & -12, & & &, 004 & & ,00283 & 915 \\
\hline
\end{tabular}


Obs ID AA AB BA BB MD LV PL NL REC PIB COMEX AGRI PREF ODP CAP APRE PIB2 ACI CREC P0

\begin{tabular}{|c|c|c|c|c|c|c|c|c|c|c|c|c|c|c|c|c|c|c|c|c|c|}
\hline 1621 & 115 & 0 & 0 & 0 & 0 & 1 & 1 & 0 & 0 & 0 & 4026 & 55,52 & 46,67 & 5,45 & $-11,72$ & 1,63 & 0 & 0,004 & 0 & 0,00472 & 0,98580 \\
\hline 1622 & 115 & 0 & 0 & 0 & 0 & 1 & 1 & 0 & 0 & 0 & 4503 & 60,37 & 35,64 & 3,53 & $-12,97$ & 1,76 & 0 & 0,0045 & 0 & 0,00232 & 0,99399 \\
\hline 1623 & 115 & 0 & 0 & 0 & 0 & 1 & 1 & 0 & 0 & 0 & 4698 & 60,32 & 45,31 & 2,49 & $-14,26$ & 1,9 & 0 & 0,0047 & 0 & 0,00300 & 0,98961 \\
\hline 1624 & 115 & 0 & 0 & 0 & 0 & 1 & 1 & 0 & 0 & 0 & 5055 & 62,13 & 49,04 & 1,85 & $-15,05$ & 1,9 & 0 & 0,0051 & 0 & 0,00283 & 0,98876 \\
\hline 1625 & 115 & 0 & 0 & 0 & 0 & 1 & 1 & 0 & 0 & 0 & 5169 & 57,05 & 44,04 & 1,75 & $-14,21$ & 1,88 & 0 & 0,0052 & 0 & 0,00277 & 0,99096 \\
\hline 1626 & 115 & 0 & 0 & 0 & 0 & 1 & 1 & 0 & 0 & 0 & 5486 & 57,94 & 44,62 & 2,27 & $-15,91$ & 1,81 & 0 & 0,0055 & 0 & 0,00155 & 0,99447 \\
\hline 1627 & 115 & 0 & 0 & 0 & 0 & 1 & 1 & 0 & 0 & 0 & 5774 & 62,81 & 47,64 & 3,72 & $-17,55$ & 1,82 & 0 & 0,0058 & 0 & 0,00113 & 0,99519 \\
\hline 1628 & 115 & 0 & 0 & 0 & 0 & 1 & 1 & 0 & 0 & 0 & 6023 & 61,83 & 44,65 & 2,18 & $-18,13$ & 1,77 & 0 & 0,006 & 0 & 0,00076 & 0,99693 \\
\hline 1629 & 115 & 0 & 0 & 0 & 0 & 1 & 1 & 0 & 0 & 0 & 6322 & 47,36 & 38,64 & 1,93 & $-15,5$ & 1,74 & 0 & 0,0063 & 0 & 0,00117 & \begin{tabular}{|l}
0,99674 \\
\end{tabular} \\
\hline 1630 & 115 & 0 & 0 & 0 & 0 & 1 & 1 & 0 & 0 & 0 & 6989 & 46,17 & 41,29 & 2,59 & $-16,29$ & 1,66 & 0 & 0,007 & 0 & 0,00094 & 0,99717 \\
\hline 1631 & 115 & 0 & 0 & 0 & 0 & 1 & 1 & 0 & 0 & 0 & 7179 & 51,72 & 36,38 & 2,29 & $-17,44$ & 1,71 & 0 & 0,0072 & 0 & 0,00057 & 0,99831 \\
\hline 1632 & 115 & 0 & 0 & 0 & 0 & 1 & 0 & 0 & 1 & 0 & 7181 & 55,04 & 40,97 & 0,39 & $-14,1$ & 1,51 & 0 & 0,0072 & 0 & 0,00044 & 0,99864 \\
\hline 1633 & 116 & 0 & 0 & 0 & 0 & 1 & 0 & 1 & 0 & 0 & 2926 & 70,13 & 36,39 & 14,5 & $-50,76$ & 2,36 & 0 & 0,0029 & 0 & 0,00000 & 1,00000 \\
\hline 1634 & 116 & 0 & 0 & 0 & 0 & 1 & 0 & 1 & 0 & 0 & 3712 & 53,72 & 37,82 & 14,82 & $-34,43$ & 2,36 & 0 & 0,0037 & 0 & 0,00002 & 0,99979 \\
\hline 1635 & 116 & 0 & 0 & 0 & 0 & 1 & 0 & 1 & 0 & 0 & 4114 & 46,08 & 42,57 & 21,04 & $-35,61$ & 2,23 & 0 & 0,0041 & 0 & 0,00002 & 0,99983 \\
\hline 1636 & 116 & 0 & 0 & 0 & 0 & 1 & 0 & 1 & 0 & 0 & 4962 & 49,69 & 29,83 & 17,56 & $-25,63$ & 2,09 & 0 & 0,005 & 0 & 0,00014 & 0,99921 \\
\hline 1637 & 116 & 0 & 0 & 0 & 0 & 1 & 0 & 1 & 0 & 0 & 5045 & 52,4 & 25,5 & 11,15 & $-29,87$ & 2,07 & 0 & 0,005 & 0 & 0,00003 & $|0,99981|$ \\
\hline 1638 & 116 & 0 & 0 & 0 & 0 & 1 & 0 & 1 & 0 & 0 & 5687 & 55,42 & 19,25 & 14,59 & $-28,15$ & 2,11 & 0 & 0,0057 & 0 & 0,00004 & 0,99979 \\
\hline 1639 & 116 & 0 & 0 & 0 & 0 & 1 & 0 & 1 & 0 & 0 & 6187 & 80,42 & 18,54 & 9,6 & $-57,95$ & 2,14 & 0 & 0,0062 & 0 & 0,00000 & 1,00000 \\
\hline 1640 & 116 & 0 & 0 & 0 & 0 & 1 & 0 & 1 & 0 & 0 & 6590 & 76,51 & 17,31 & 8,94 & $-21,85$ & 2,04 & 0 & 0,0066 & 0 & 0,00024 & 0,99891 \\
\hline 1641 & 116 & 0 & 0 & 0 & 0 & 1 & 0 & 1 & 0 & 0 & 7104 & 77,21 & 17,68 & 9,98 & $-21,89$ & 1,99 & 0 & 0,0071 & 0 & 0,00023 & 0,99895 \\
\hline 1642 & 116 & 0 & 0 & 0 & 0 & 1 & 0 & 1 & 0 & 0 & 7724 & 76,37 & 17,19 & 10,8 & $-20,44$ & 1,98 & 0 & 0,0077 & 0 & 0,00035 & 0,99855 \\
\hline 1643 & 116 & 0 & 0 & 0 & 0 & 1 & 0 & 1 & 0 & 0 & 8485 & 71,2 & 16,42 & 10,92 & $-22,55$ & 1,94 & 0 & 0,0085 & 0 & 0,00017 & 0,99929 \\
\hline 1644 & 116 & 0 & 0 & 0 & 0 & 1 & 0 & 1 & 0 & 0 & 9115 & 70,75 & 16,59 & 14,8 & $-20,82$ & 2,02 & 0 & 0,0091 & 0 & 0,00032 & 0,99872 \\
\hline 1645 & 116 & 0 & 0 & 0 & 0 & 1 & 0 & 1 & 0 & - & 9742 & 64,1 & 16,47 & 11,77 & $-20,81$ & 2 & 0 & 0,0097 & 0 & 0,00031 & 0,99886 \\
\hline 1646 & 116 & 0 & 0 & 0 & 0 & 1 & 0 & 1 & 0 & 0 & 10360 & 68,73 & 20,62 & 12,13 & $-20,48$ & 1,96 & 0 & 0,0104 & 0 & 0,00040 & 0,99833 \\
\hline 1647 & 116 & 0 & 0 & 0 & 0 & 1 & 0 & 1 & 0 & 0 & 11053 & 76,16 & 15,65 & 16,23 & $-18,45$ & 1,93 & 0 & 0,0111 & 0 & 0,00058 & 0,99789 \\
\hline 1648 & 116 & 0 & 0 & 0 & 0 & 1 & 0 & 1 & 0 & 0 & 11840 & 82,36 & 17,38 & 11,23 & $-17,3$ & 1,88 & 0 & 0,0118 & 0 & 0,00083 & 0,99681 \\
\hline 1649 & 116 & 0 & 0 & 0 & 0 & 1 & 0 & 1 & 0 & 0 & 12692 & 104,23 & 15,91 & 8,61 & $-16,58$ & 1,87 & 0 & 0,0127 & 0 & 0,00100 & 0,99565 \\
\hline 1650 & 117 & 0 & 0 & 0 & 0 & 1 & 0 & 1 & 0 & 0 & 9639 & 47,08 & 20,26 & 15,5 & $-9,42$ & 1,56 & 0 & 0,0096 & 0 & 0,00611 & 0,98711 \\
\hline 1651 & 117 & 0 & 0 & 0 & 0 & 1 & 0 & 1 & 0 & 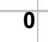 & 10103 & 45,98 & 17,73 & 6,04 & $-8,46$ & 1,64 & 0 & 0,0101 & 0 & 0,00776 & 0,98492 \\
\hline 1652 & 117 & 0 & 0 & 0 & 0 & 1 & 0 & 1 & 0 & 0 & 10449 & 41,83 & 18,17 & 7,25 & $-8,3$ & 1,62 & 0 & 0,0104 & 0 & 0,00807 & $\mid 0,98487$ \\
\hline 1653 & 117 & 0 & 0 & 0 & 0 & 1 & 0 & 1 & 0 & 0 & 10949 & 43,66 & 20,84 & 6,3 & $-7,02$ & 1,51 & 0 & 0,0109 & 0 & 0,01156 & 0,97790 \\
\hline 1654 & 118 & 0 & 0 & 0 & 0 & 1 & 0 & 0 & 1 & 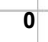 & 2519 & 44,4 & 39,95 & 4,16 & $-13,52$ & 1,26 & 0 & 0,0025 & 0 & 0,00034 & 0,99911 \\
\hline 1655 & 118 & 0 & 0 & 0 & 0 & 1 & 0 & 0 & 1 & 0 & 2589 & 41,47 & 35,67 & 5,38 & -19 & 1,34 & 0 & 0,0026 & 0 & 0,00006 & 0,99983 \\
\hline 1656 & 118 & 0 & 0 & 0 & 0 & 1 & 0 & 0 & 1 & 0 & 2859 & 44,1 & 37,03 & 10,84 & $-15,21$ & 1,42 & 0 & 0,0029 & 0 & 0,00023 & 0,99941 \\
\hline 1657 & 118 & 0 & 0 & 0 & 0 & 1 & 0 & 1 & 0 & 0 & 2842 & 39,13 & 37,4 & 25,37 & $-9,89$ & 1,42 & 0 & 0,0028 & 0 & 0,00946 & 0,97248 \\
\hline 1658 & 118 & 0 & 0 & 0 & 0 & 1 & 0 & 1 & 0 & 0 & 2802 & 43,49 & 44,16 & 10,04 & $-11,93$ & 1,42 & 0 & 0,0028 & 0 & 0,00660 & 0,97357 \\
\hline 1659 & 118 & 0 & 0 & 0 & 0 & 1 & 0 & 1 & 0 & 0 & 3001 & 41,53 & 48,65 & 13,05 & $-14,42$ & 1,51 & 0 & 0,003 & 0 & 0,00441 & 0,97859 \\
\hline 1660 & 118 & 0 & 0 & 0 & 0 & 1 & 0 & 1 & 0 & 0 & 3091 & 42,39 & 40,96 & 9,34 & $-15,22$ & 1,61 & 0 & 0,0031 & 0 & 0,00274 & 0,98823 \\
\hline 1661 & 118 & 0 & 0 & 0 & 0 & 1 & 0 & 1 & 0 & 0 & 3255 & 39,98 & 37,98 & 10,48 & $-19,93$ & 1,75 & 0 & 0,0033 & 0 & 0,00070 & 0,99665 \\
\hline 1662 & 118 & 0 & 0 & 0 & 0 & 1 & 0 & 1 & 0 & 0 & 3259 & 45,27 & 39,62 & 14,88 & $-20,56$ & 1,81 & 0 & 0,0033 & 0 & 0,00070 & 0,99627 \\
\hline 1663 & 118 & 0 & 0 & 0 & 0 & 1 & 0 & 1 & 0 & 0 & 3405 & 47,4 & 38,58 & 10,11 & $-18,4$ & 1,71 & 0 & 0,0034 & 0 & 0,00110 & 0,99467 \\
\hline 1664 & 118 & 0 & 0 & 0 & 0 & 1 & 0 & 1 & 0 & 0 & 3603 & 45,92 & 35,41 & 13,85 & $-17,64$ & 1,7 & 0 & 0,0036 & 0 & 0,00119 & 0,99491 \\
\hline 1665 & 118 & 0 & 0 & 0 & 0 & 1 & 0 & 1 & 0 & 0 & 3716 & 47,35 & 30,04 & 9,2 & $-15,73$ & 1,71 & 0 & 0,0037 & 0 & 0,00164 & 0,99415 \\
\hline 1666 & 118 & 0 & 0 & 0 & 0 & 1 & 0 & 1 & 0 & 0 & 4072 & 53,42 & 35,07 & 2,23 & $-15,11$ & 1,79 & 0 & 0,0041 & 0 & 0,00277 & 0,98838 \\
\hline 1667 & 118 & 0 & 0 & 0 & 0 & 1 & 0 & 1 & 0 & 0 & 4043 & 67,18 & 23 & 9,83 & $-11,93$ & 1,84 & 0 & 0,004 & 0 & 0,00471 & 0,98557 \\
\hline 1668 & 118 & 0 & 0 & 0 & 0 & 1 & 0 & 1 & 0 & 0 & 4382 & 71,29 & 19,3 & 8,56 & $-17,59$ & 1,83 & 0 & 0,0044 & 0 & 0,00071 & 0,99738 \\
\hline 1669 & 118 & 0 & 0 & 0 & 0 & 1 & 0 & 1 & 0 & 0 & 4483 & 68,69 & 17,26 & 9,41 & $-14,15$ & 1,87 & 0 & 0,0045 & 0 & 0,00193 & 0,99424 \\
\hline 1670 & 118 & 0 & 0 & 0 & 0 & 1 & 0 & 1 & 0 & 0 & 5013 & 61,22 & 26,91 & 8,51 & $-18,12$ & 1,79 & 0 & 0,005 & 0 & 0,00080 & 0,99668 \\
\hline 1671 & 119 & 0 & 0 & 0 & 0 & 1 & 0 & 0 & 1 & 0 & 1249 & 32,23 & 31,17 & 191,71 & $-53,88$ & 1,3 & 0 & 0,0012 & 0 & 0,00000 & 1,00000 \\
\hline 1672 & 119 & 0 & 0 & 0 & 0 & 1 & 0 & 0 & 1 & 0 & 1422 & 33,47 & 30,29 & 44,54 & $-25,82$ & 1,44 & 0 & 0,0014 & 0 & 0,00001 & 0,99998 \\
\hline 1673 & 119 & 0 & 0 & 0 & 0 & 1 & 0 & 0 & 1 & 0 & 1548 & 28,79 & 36,63 & 72,11 & $-34,61$ & 1,58 & 0 & 0,0015 & 0 & 0,00000 & 1,00000 \\
\hline 1674 & 119 & 0 & 0 & 0 & 0 & 1 & 0 & 0 & 1 & 0 & 1666 & 30,75 & 36,87 & 21,89 & $-33,51$ & 1,71 & 0 & 0,0017 & 0 & 0,00000 & 0,99999 \\
\hline 1675 & 119 & 0 & 0 & 0 & 0 & 1 & 0 & 0 & 1 & 0 & 1961 & 32,75 & 32,26 & 8,57 & $-25,42$ & 1,71 & 0 & 0,002 & 0 & 0,00001 & 0,99996 \\
\hline 1676 & 119 & 0 & 0 & 0 & 0 & 1 & 0 & 0 & 1 & 0 & 2225 & 30,75 & 16,54 & 18,58 & $-25,22$ & 1,57 & 0 & 0,0022 & 0 & 0,00000 & 0,99999 \\
\hline 1677 & 119 & 0 & 0 & 0 & 0 & 1 & 0 & 0 & 1 & 0 & 2258 & 32 & 30,97 & 55,41 & $-20,13$ & 1,76 & 0 & 0,0023 & 0 & 0,00007 & 0,99983 \\
\hline 1678 & 119 & 0 & 0 & 0 & 0 & 1 & 0 & 0 & 1 & 0 & 2415 & 35,88 & 32,24 & 86,85 & $-24,66$ & 1,94 & 0 & 0,0024 & 0 & 0,00003 & 0,99992 \\
\hline 1679 & 115 & 0 & 0 & 0 & 0 & 1 & 0 & 0 & 1 & 0 & 2581 & 36,67 & 30,41 & 11,76 & $-26,4$ & 1,61 & 0 & 0,0026 & 0 & 0,00001 & 0,99998 \\
\hline 1680 & & 0 & 0 & & & & & & & & 2820 & 7,59 & $0,8 /$ & 9,08 & $-24,36$ & 2,21 & & 0,002 & &, 000 & \\
\hline
\end{tabular}


Obs ID AA AB BA BB MD LV PL NL REC PIB COMEX AGRI PREF ODP CAP APRE PIB2 ACI CREC P0

\begin{tabular}{|c|c|c|c|c|c|c|c|c|c|c|c|c|c|c|c|c|c|c|c|c|c|}
\hline 1681 & 119 & 0 & 0 & 0 & 0 & 1 & 0 & 0 & 1 & 0 & 3035 & 40,34 & 28,83 & 15,07 & $-25,14$ & 2,3 & 0 & 0,003 & 0 & 0,00003 & $\mid 0,99991$ \\
\hline 1682 & 119 & 0 & 0 & 0 & 0 & 1 & 0 & 0 & 1 & 0 & 3373 & 40,56 & 29,32 & 9,7 & $-28,02$ & 2,36 & 0 & 0,0034 & 0 & 0,00001 & 0,99995 \\
\hline 1683 & 119 & 0 & 0 & 0 & 0 & 1 & 0 & 0 & 1 & 0 & 3585 & 38,71 & 22,59 & 16,61 & $-27,24$ & 2,33 & 0 & 0,0036 & 0 & 0,00001 & 0,99997 \\
\hline 1684 & 119 & 0 & 0 & 0 & 0 & 1 & 0 & 0 & 1 & 0 & 3847 & 40,05 & 25,74 & 12,75 & $-28,14$ & 2,45 & 0 & 0,0038 & 0 & 0,00001 & 0,99996 \\
\hline 1685 & 119 & 0 & 0 & 0 & 0 & 1 & 0 & 0 & 1 & 0 & 4149 & 44,05 & 26,56 & 10,29 & $-30,15$ & 2,57 & 0 & 0,0041 & 0 & 0,00001 & 0,99997 \\
\hline 1686 & 119 & 0 & 0 & 0 & 0 & 1 & 0 & 0 & 1 & 0 & 4514 & 46,09 & 28,53 & 4,68 & $-19,69$ & 2,44 & 0 & 0,0045 & 0 & 0,00016 & 0,99955 \\
\hline 1687 & 120 & 0 & 0 & 0 & 0 & 1 & 0 & 0 & 1 & 0 & 1618 & 69,85 & 37,37 & 6,85 & $-15,53$ & 1,7 & 0 & 0,0016 & 0 & 0,00032 & 0,99890 \\
\hline 1688 & 120 & 0 & 0 & 0 & 0 & 1 & 0 & 0 & 1 & 0 & 1761 & 77,42 & 34,65 & 4,59 & $-11,13$ & 1,7 & 0 & 0,0018 & 0 & 0,00110 & 0,99690 \\
\hline 1689 & 120 & 0 & 0 & 0 & 0 & 1 & 0 & 0 & 1 & 0 & 2014 & 73,78 & 32,94 & 5,91 & $-8,5$ & 1,61 & 0 & 0,002 & 0 & 0,00198 & 0,99537 \\
\hline 1690 & 120 & 0 & 0 & 0 & 0 & 1 & 0 & 0 & 1 & 0 & 1968 & 72,99 & 25,49 & 3,69 & $-9,43$ & 1,52 & 0 & 0,002 & 0 & 0,00091 & 0,99815 \\
\hline 1691 & 120 & 0 & 0 & 0 & 0 & 1 & 0 & 1 & 0 & 0 & 2017 & 67,89 & 31,67 & 5,19 & $-5,05$ & 1,39 & 0 & 0,002 & 0 & 0,02784 & 0,92268 \\
\hline 1692 & 120 & 0 & 0 & 0 & 0 & 1 & 0 & 1 & 0 & 0 & 2001 & 81,99 & 28,27 & 4,18 & $-5,53$ & 1,26 & 0 & 0,002 & 0 & 0,01803 & 0,94704 \\
\hline 1693 & 120 & 0 & 0 & 0 & 0 & 1 & 0 & 1 & 0 & 0 & 1969 & 82,29 & 25,86 & 6,3 & $-3,86$ & 1,19 & 0 & 0,002 & 0 & 0,02426 & 0,93768 \\
\hline 1694 & 120 & 0 & 0 & 0 & 0 & 1 & 0 & 0 & 1 & 0 & 1950 & 85,59 & 29,07 & 5,78 & $-4,17$ & 1,13 & 0 & 0,002 & 0 & 0,00322 & 0,99383 \\
\hline 1695 & 120 & 0 & 0 & 0 & 0 & 1 & 0 & 0 & 1 & 0 & 2047 & 102,48 & 22,99 & 2,87 & $-3,31$ & 0,95 & 0 & 0,002 & 0 & 0,00251 & 0,99538 \\
\hline 1696 & 120 & 0 & 0 & 0 & 0 & 1 & 0 & 0 & 1 & 0 & 2090 & 96,43 & 26,39 & 4,38 & $-3,87$ & 0,9 & 0 & 0,0021 & 0 & 0,00230 & 0,99556 \\
\hline 1697 & 120 & 0 & 0 & 0 & 0 & 1 & 0 & 0 & 1 & 0 & 2115 & 98,7 & 22 & 7,97 & $-4,7$ & 1 & 0 & 0,0021 & 0 & 0,00171 & 0,99687 \\
\hline 1698 & 120 & 0 & 0 & 0 & 0 & 1 & 0 & 1 & 0 & 0 & 2251 & 92,41 & 19,77 & 14,36 & $-5,75$ & 0,99 & 0 & 0,0023 & 0 & 0,00857 & 0,97813 \\
\hline 1699 & 120 & 0 & 0 & 0 & 0 & 1 & 0 & 1 & 0 & 0 & 2301 & 87,43 & 19,69 & 12,62 & $-14,16$ & 1,03 & 0 & 0,0023 & 0 & 0,00069 & 0,99756 \\
\hline 1700 & 120 & 0 & 0 & 0 & 0 & 1 & 0 & 1 & 0 & 0 & 2382 & 89,09 & 15,72 & 9,8 & $-22,3$ & 1,11 & 0 & 0,0024 & 0 & 0,00005 & 0,99975 \\
\hline 1701 & 120 & 0 & 0 & 0 & 0 & 1 & 0 & 1 & 0 & 0 & 2477 & 97,47 & 17,82 & 6,41 & $-16,91$ & 1,12 & 0 & 0,0025 & 0 & 0,00031 & 0,99869 \\
\hline 1702 & 120 & 0 & 0 & 0 & 0 & 1 & 0 & 1 & 0 & 0 & 2598 & 95,76 & 19,51 & 8,27 & $-20,38$ & 1,14 & 0 & 0,0026 & 0 & 0,00012 & 0,99940 \\
\hline 1703 & 120 & 0 & 0 & 0 & 0 & 1 & 0 & 1 & 0 & 0 & 2752 & 106,6 & 19,68 & 3,13 & $-8,86$ & 1,17 & 0 & 0,0028 & 0 & 0,00424 & 0,98558 \\
\hline 1704 & 121 & 0 & 0 & 0 & 0 & 1 & 0 & 1 & 0 & 0 & 4863 & 32,62 & 37,36 & 27,48 & $-23,19$ & 1,77 & 0 & 0,0049 & 0 & 0,00028 & 0,99864 \\
\hline 1705 & 121 & 0 & 0 & 0 & 0 & 1 & 0 & 1 & 0 & 0 & 5304 & 35,39 & 36,07 & 18,82 & $-17,67$ & 1,77 & 0 & 0,0053 & 0 & 0,00136 & 0,99465 \\
\hline 1706 & 121 & 0 & 0 & 0 & 0 & 1 & 0 & 1 & 0 & 0 & 5575 & 34,16 & 42,75 & 35,36 & $-21,97$ & 1,94 & 0 & 0,0056 & 0 & 0,00069 & 0,99633 \\
\hline 1707 & 121 & 0 & 0 & 0 & 0 & 1 & 0 & 1 & 0 & 0 & 5848 & 30,04 & 39,58 & 23,62 & $-17,08$ & 2,11 & 0 & 0,0058 & 0 & 0,00311 & 0,98748 \\
\hline 1708 & 121 & 0 & 0 & 0 & 0 & 1 & 0 & 1 & 0 & 0 & 6319 & 36,02 & 41,11 & 18,61 & $-14,43$ & 2,11 & 0 & 0,0063 & 0 & 0,00736 & 0,97083 \\
\hline 1709 & 121 & 0 & 0 & 0 & 0 & 1 & 0 & 1 & 0 & 0 & 6518 & 32,75 & 34,22 & 23,23 & $-20,79$ & 2,12 & 0 & 0,0065 & 0 & 0,00080 & 0,99658 \\
\hline 1710 & 121 & 0 & 0 & 0 & 0 & 1 & 0 & 1 & 0 & 0 & 6856 & 35,33 & 36,29 & 18,06 & $-19,56$ & 2,1 & 0 & 0,0069 & 0 & 0,00124 & 0,99459 \\
\hline 1711 & 121 & 0 & 0 & 0 & 0 & 1 & 0 & 1 & 0 & 0 & 7454 & 36,28 & 38,19 & 20,17 & $-15,09$ & 2,08 & 0 & 0,0075 & 0 & 0,00515 & 0,98044 \\
\hline 1712 & 121 & 0 & 0 & 0 & 0 & 1 & 0 & 1 & 0 & 0 & 7937 & 36,59 & 39,13 & 18,63 & $-16,84$ & 2,16 & 0 & 0,0079 & 0 & 0,00354 & 0,98503 \\
\hline 1713 & 121 & 0 & 0 & 0 & 0 & 1 & 0 & 1 & 0 & 0 & 8477 & 35,46 & 42,57 & 17,11 & $-17,54$ & 2,16 & 0 & 0,0085 & 0 & 0,00335 & 0,98429 \\
\hline 1714 & 121 & 0 & 0 & 0 & 0 & 1 & 0 & 1 & 0 & 0 & 9014 & 38,99 & 41,66 & 16,19 & $-15,8$ & 1,96 & 0 & 0,009 & 0 & 0,00414 & 0,98198 \\
\hline 1715 & 121 & 0 & 0 & 0 & 0 & 1 & 0 & 1 & 0 & 0 & 9986 & 43,63 & 34,09 & 10,83 & $-18,2$ & 2,02 & 0 & 0,01 & 0 & 0,00152 & 0,99351 \\
\hline 1716 & 121 & 0 & 0 & 0 & 0 & 1 & 0 & 1 & 0 & 0 & 10826 & 46,78 & 33,64 & 9,95 & $-17,08$ & 2,09 & 0 & 0,0108 & 0 & 0,00232 & 0,99032 \\
\hline 1717 & 121 & 0 & 0 & 0 & 0 & 1 & 0 & 1 & 0 & 0 & 11769 & 56,26 & 37,99 & 7,74 & $-14,19$ & 1,93 & 0 & 0,0118 & 0 & 0,00555 & 0,97558 \\
\hline 1718 & 121 & 0 & 0 & 0 & 0 & 1 & 0 & 1 & 0 & 0 & 12622 & 49,7 & 36,48 & 9,24 & $-14,95$ & 1,88 & 0 & 0,0126 & 0 & 0,00384 & 0,98419 \\
\hline 1719 & 121 & 0 & 0 & 0 & 0 & 1 & 0 & 1 & 0 & 0 & 13275 & 45,73 & 35,39 & 8,78 & $-13,34$ & 1,98 & 0 & 0,0133 & 0 & 0,00674 & 0,97537 \\
\hline 1720 & 121 & 0 & 0 & 0 & 0 & 1 & 0 & 1 & 0 & 0 & 14559 & 52,71 & 30,63 & 6,7 & $-10,73$ & 1,99 & 0 & 0,0146 & 0 & 0,01213 & 0,96214 \\
\hline 1721 & 121 & 0 & 0 & 0 & 0 & 1 & 0 & 1 & 0 & 0 & 15201 & 53,1 & 26,55 & 6,41 & $-10,89$ & 1,93 & 0 & 0,0152 & 0 & 0,00889 & 0,97460 \\
\hline 1722 & 122 & 0 & 0 & 0 & 0 & 0 & 0 & 0 & 1 & 0 & 129723 & 290,35 & 10,08 & 0 & 0,01 & 3,72 & 1 & 0,1297 & 0 & 0,02006 & 0,87274 \\
\hline 1723 & 122 & 0 & 0 & 0 & 0 & 0 & 0 & 0 & 1 & 1 & 135247 & 274,21 & 10,19 & 0 & 0,01 & 3,72 & 3 & 0,1352 & 0 & 0,02701 & 0,84634 \\
\hline 1724 & 122 & 0 & 0 & 0 & 0 & 0 & 0 & 0 & 1 & 0 & 142144 & 262,02 & 10,11 & 0 & 0 & 3,69 & 3 & 0,1421 & 0 & 0,02679 & 0,86318 \\
\hline 1725 & 122 & 0 & 0 & 0 & 0 & 0 & 0 & 0 & 1 & 0 & 133782 & 248 & 8,91 & 0 & 0 & 3,67 & 4 & 0,1338 & 0 & 0,02671 & 0,88070 \\
\hline 1726 & 122 & 0 & 0 & 0 & 0 & 0 & 0 & 0 & 1 & 0 & 137136 & 248,88 & 8,17 & 0 & 0 & 3,73 & 4 & 0,1371 & 0 & 0,02859 & 0,87318 \\
\hline 1727 & 122 & 0 & 0 & 0 & 0 & 0 & 0 & 0 & 1 & 0 & 147645 & 279,12 & 7,44 & 0 & 0 & 3,8 & 5 & 0,1476 & 0 & 0,03764 & 0,78435 \\
\hline 1728 & 122 & 0 & 0 & 0 & 0 & 0 & 0 & 0 & 1 & 0 & 148473 & 269,55 & 7,52 & 0 & 0 & 3,86 & 6 & 0,1485 & 0 & 0,04565 & 0,75440 \\
\hline 1729 & 122 & 0 & 0 & 0 & 0 & 0 & 0 & 0 & 1 & 0 & 150933 & 286,57 & 7,7 & 0 & 0 & 3,92 & 6 & 0,1509 & 0 & 0,04897 & 0,69322 \\
\hline 1730 & 122 & 0 & 0 & 0 & 0 & 0 & 0 & 0 & 1 & 0 & 155546 & 327,17 & 7,51 & 0 & 0 & 4,16 & 7 & 0,1555 & 0 & 0,06026 & 0,45481 \\
\hline 1731 & 122 & 0 & 0 & 0 & 0 & 0 & 0 & 0 & 1 & 0 & 169078 & 364,59 & 7,32 & 0 & 0 & 4,29 & 9 & 0,1691 & 0 & 0,06042 & 0,22743 \\
\hline 1732 & 122 & 0 & 0 & 0 & 0 & 0 & 0 & 0 & 1 & 0 & 181570 & 377,09 & 6,76 & 0 & 0 & 4,13 & 9 & 0,1816 & 0 & 0,05510 & 0,23505 \\
\hline 1733 & 122 & 0 & 0 & 0 & 0 & 0 & 0 & 0 & 1 & 0 & 194339 & 392,44 & 6,88 & 0 & 0 & 4,4 & 10 & 0,1943 & 0 & 0,05421 & 0,11677 \\
\hline 1734 & 122 & 0 & 0 & 0 & 0 & 0 & 0 & 0 & 1 & 0 & 206903 & 396,77 & 8,33 & 0 & 0 & 4,37 & 10 & 0,2069 & 0 & 0,05179 & 0,09760 \\
\hline 1735 & 122 & 0 & 0 & 0 & 0 & 0 & 0 & 0 & 1 & 0 & 211305 & 407,38 & 10,28 & 0 & 0 & 4,35 & 13 & 0,2113 & 0 & 0,04595 & 0,04709 \\
\hline 1736 & 122 & 0 & 0 & 0 & 0 & 0 & 0 & 0 & 1 & 0 & 206109 & 374,58 & 13,8 & 0 & 0 & 4,24 & 13 & 0,2061 & 0 & 0,05530 & 0,06329 \\
\hline 1737 & 122 & 0 & 0 & 0 & 0 & 0 & 0 & 0 & 1 & 0 & 220058 & 432,95 & 14,25 & 0 & 0 & 4,2 & 13 & 0,2201 & 0 & 0,03457 & 0,03173 \\
\hline 1738 & 122 & 0 & 0 & 0 & 0 & 0 & 0 & 0 & 1 & 0 & 230653 & 447,06 & 16,9 & 0 & 0 & 4,17 & 13 & 0,2307 & 0 & 0,02921 & 0,02193 \\
\hline 1739 & 122 & 0 & 0 & 0 & 0 & 0 & 0 & 0 & 1 & 0 & 234575 & 449,99 & 18,7 & 0 & 0 & 4,32 & 13 & 0,2346 & 0 & 0,02730 & 0,01467 \\
\hline & & & & & & & & & & & & 37,91 & & & & 8.00 & &, 00 & &, 002 & 944 \\
\hline
\end{tabular}


$\begin{array}{lllllllllllllllllllll}\text { Obs ID } & \text { AA } & \text { AB } & \text { BA } & B B & M D & \text { LV } & \text { PL NL REC } & \text { PIB } & \text { COMEX AGRI PREF ODP CAP APRE PIB2 ACI CREC P0 }\end{array}$

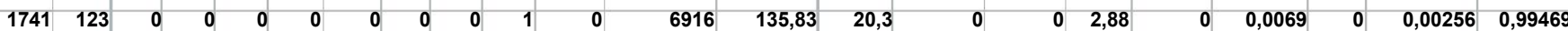

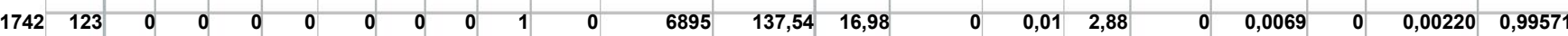

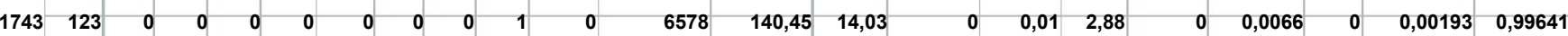
$\begin{array}{llllllllllllllllllllll}1744 & 123 & 0 & 0 & 0 & 0 & 0 & 0 & 0 & 1 & 0 & 6420 & 148,73 & 12,97 & 0 & 0,01 & 3 & 0 & 0,0064 & 0 & 0,00221 & 0,99566\end{array}$ $\begin{array}{lllllllllllllllllllllllll}1745 & 123 & 0 & 0 & 0 & 0 & 0 & 0 & 0 & 1 & 0 & 6786 & 165,05 & 13,69 & 0 & 0 & 3,11 & 0 & 0,0068 & 0 & 0,00278 & 0,99358\end{array}$ $\begin{array}{lllllllllllllllllllllllllll}1746 & 123 & 0 & 0 & 0 & 0 & 0 & 0 & 0 & 1 & 0 & 6983 & 168,31 & 15,53 & 0 & 0 & 3,22 & 0 & 0,007 & 0 & 0,00357 & 0,99110\end{array}$ $\begin{array}{lllllllllllllllllllllllll}1747 & 123 & 0 & 0 & 0 & 0 & 0 & 0 & 0 & 1 & 0 & 7604 & 174,45 & 15,59 & 0 & 0 & 3,33 & 0 & 0,0076 & 0 & 0,00425 & 0,98874\end{array}$ $\begin{array}{llllllllllllllllllllll}1748 & 123 & 0 & 0 & 0 & 0 & 0 & 0 & 0 & 1 & 0 & 8561 & 176,2 & 15,36 & 0 & 0 & 3,8 & 0 & 0,0086 & 0 & 0,00816 & 0,97759\end{array}$ $\begin{array}{rrrrrrrrrrrrrrrrrrrrrrrr}1749 & 123 & 0 & 0 & 0 & 0 & 0 & 0 & 0 & 1 & 0 & 10863 & 173,72 & 13,84 & 0 & 0 & 3,59 & 0 & 0,0109 & 0 & 0,00575 & 0,98525\end{array}$

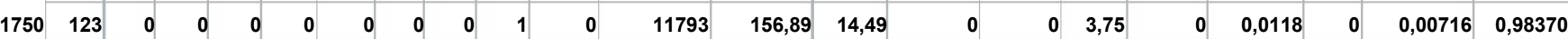
\begin{tabular}{|l|l|l|l|l|l|l|l|l|l|l|l|l|r|r|r|r|r|r|r|r|r|r|r|}
1751 & 123 & 0 & 0 & 0 & 0 & 0 & 0 & 0 & 1 & 0 & 13493 & 151,31 & 13,43 & 0 & 0 & 3,49 & 0 & 0,0135 & 0 & 0,00474 & 0,99011 \\
\hline
\end{tabular}

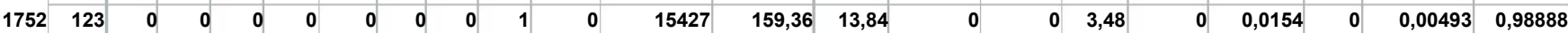

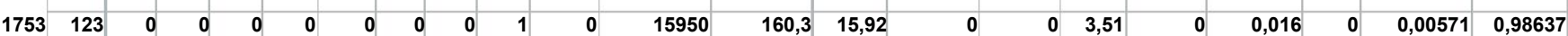

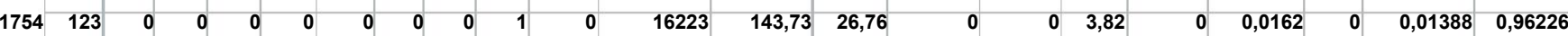
$\begin{array}{lllllllllllllllllllllll}1755 & 123 & 0 & 0 & 0 & 0 & 0 & 0 & 0 & 1 & 0 & 20684 & 155,78 & 17,64 & 0 & 0 & 3,82 & 0 & 0,0207 & 0 & 0,00972 & 0,97634\end{array}$ $\begin{array}{llllllllllllllllllllll}1756 & 123 & 0 & 0 & 0 & 0 & 0 & 0 & 0 & 1 & 0 & 25088 & 165,28 & 16,52 & 0 & 0 & 3,81 & 0 & 0,0251 & 0 & 0,00962 & 0,97531\end{array}$ $\begin{array}{lllllllllllllllllllllllll}1757 & 123 & 0 & 0 & 0 & 0 & 0 & 0 & 0 & 1 & 0 & 27387 & 159,76 & 17,63 & 0 & 0 & 3,57 & 0 & 0,0274 & 0 & 0,00731 & 0,98189\end{array}$

Fonte: adaptado de resultado SAS. 
Quadro A6-2: Valores previstos de cACI e p0 - Modelo ZINB Passivo

\begin{tabular}{|c|c|c|c|c|c|c|c|c|c|c|c|c|c|c|c|c|c|c|c|}
\hline 1 & 1 & 0 & 0 & 0 & 0 & 0 & 1 & 0 & 0 & 2 & 11246416 & 61,55 & 12,81 & $-0,08$ & 0,37 & 3,6 & 4 & 11,2464 & 12 \\
\hline 2 & 1 & 0 & 0 & 0 & 0 & 0 & 1 & 0 & 0 & 7 & 11472170 & 63,29 & 12,25 & $-0,11$ & 0,37 & 3,6 & 11 & 11,4722 & 15 \\
\hline 3 & 1 & 0 & 0 & 0 & 0 & 0 & 1 & 0 & 0 & 16 & 11792573 & 66,4 & 11,58 & $-0,12$ & 0,33 & 3,61 & 15 & 11,7926 & 8 \\
\hline 4 & 1 & 0 & 0 & 0 & 0 & 0 & 1 & 0 & 0 & 17 & 12150920 & 66,75 & 11,24 & $-0,12$ & 0,33 & 3,61 & 18 & 12,1509 & 15 \\
\hline 5 & 1 & 0 & 0 & 0 & 0 & 0 & 1 & 0 & 0 & 6 & 12519556 & 67,68 & 10,85 & $-0,12$ & 0,32 & 3,62 & 26 & 12,5196 & 7 \\
\hline 6 & 1 & 0 & 0 & 0 & 0 & 0 & 1 & 0 & 0 & 8 & 13006419 & 74,59 & 9,54 & $-0,1$ & 0,32 & 3,63 & 34 & 13,0064 & 4 \\
\hline 7 & 1 & 0 & 0 & 0 & 0 & 0 & 1 & 0 & 0 & 1 & 13296756 & 73,56 & 9,74 & $-0,11$ & 0,33 & 3,66 & 41 & 13,2968 & 3 \\
\hline 8 & 1 & 0 & 0 & 0 & 0 & 0 & 1 & 0 & 0 & 5 & 13474854 & 71,01 & 10,04 & $-0,14$ & 0,35 & 3,7 & 59 & 13,4749 & 6 \\
\hline 9 & 1 & 0 & 0 & 0 & 0 & 0 & 1 & 0 & 0 & 4 & 13652601 & 69,19 & 10,1 & $-0,19$ & 0,36 & 3,72 & 66 & 13,6526 & 8 \\
\hline 10 & 1 & 0 & 0 & 0 & 0 & 0 & 1 & 0 & 0 & 5 & 13996937 & 71,52 & 9,57 & $-0,15$ & 0,35 & 3,71 & 70 & 13,9969 & 4 \\
\hline 11 & 1 & 0 & 0 & 0 & 0 & 0 & 1 & 0 & 0 & 2 & 14289446 & 74,16 & 9,41 & $-0,15$ & 0,47 & 3,65 & 74 & 14,2894 & 2 \\
\hline 12 & 1 & 0 & 0 & 0 & 0 & 0 & 1 & 0 & 0 & 6 & 14766748 & 77,93 & 9 & $-0,15$ & 0,47 & 3,62 & 79 & 14,7667 & 3 \\
\hline 13 & 1 & 0 & 0 & 0 & 0 & 0 & 1 & 0 & 0 & 0 & 15221041 & 78,87 & 9,24 & $-6,3$ & 0,43 & 3,57 & 88 & 15,221 & 3 \\
\hline 14 & 1 & 0 & 0 & 0 & 0 & 0 & 1 & 0 & 0 & 3 & 15288742 & 80,53 & 9,54 & $-7,15$ & 0,46 & 3,59 & 95 & 15,2887 & 4 \\
\hline 15 & 1 & 0 & 0 & 0 & 0 & 0 & 1 & 0 & 0 & 2 & 14618892 & 71,51 & 10,78 & $-6,52$ & 0,48 & 3,6 & 101 & 14,6189 & 4 \\
\hline 16 & 1 & 0 & 0 & 0 & 0 & 0 & 1 & 0 & 0 & 1 & 14926815 & 78,14 & 10,28 & $-7,22$ & 0,5 & 3,61 & 111 & 14,9268 & 3 \\
\hline 17 & 1 & 0 & 0 & 0 & 0 & 0 & 1 & 0 & 0 & 3 & 15194701 & 83,02 & 10,59 & $-7,67$ & 0,48 & 3,59 & 116 & 15,1947 & 0 \\
\hline 18 & 1 & 0 & 0 & 0 & 0 & 0 & 1 & 0 & 0 & 2 & 15129293 & 84,35 & 10,72 & $-9,16$ & 0,45 & 3,58 & 133 & 15,1293 & 3 \\
\hline 19 & 2 & 0 & 0 & 0 & 0 & 0 & 1 & 0 & 0 & 6 & 9359504 & 22,38 & 10,49 & $-11,15$ & 0,1 & 4,21 & 5 & 9,3595 & 4 \\
\hline 20 & 2 & 0 & 0 & 0 & 0 & 0 & 1 & 0 & 0 & 17 & 9714779 & 22,61 & 10,23 & $-11,63$ & 0,12 & 4,21 & 12 & 9,7148 & 11 \\
\hline 21 & 2 & 0 & 0 & 0 & 0 & 0 & 1 & 0 & 0 & 15 & 10150684 & 23,34 & 9,2 & $-12,39$ & 0,09 & 4,25 & 22 & 10,1507 & 10 \\
\hline 22 & 2 & 0 & 0 & 0 & 0 & 0 & 1 & 0 & 0 & 9 & 10602380 & 22,76 & 8,52 & $-12,88$ & 0,1 & 4,3 & 29 & 10,6024 & 6 \\
\hline 23 & 2 & 0 & 0 & 0 & 0 & 0 & 1 & 0 & 0 & 9 & 11099123 & 23,19 & 7,91 & $-13,61$ & 0,1 & 4,32 & 31 & 11,0991 & 11 \\
\hline 24 & 2 & 0 & 0 & 0 & 0 & 0 & 1 & 0 & 0 & 8 & 11553319 & 24,98 & 7,31 & $-14,92$ & 0,1 & 4,34 & 37 & 11,5533 & 19 \\
\hline 25 & 2 & 0 & 0 & 0 & 0 & 0 & 1 & 0 & 0 & 1 & 11666077 & 22,8 & 7,69 & $-15,42$ & 0,11 & 4,27 & 42 & 11,6661 & 7 \\
\hline 26 & 2 & 0 & 0 & 0 & 0 & 0 & 1 & 0 & 0 & 4 & 11874448 & 22,15 & 7,87 & $-16,69$ & 0,13 & 4,2 & 49 & 11,8744 & 19 \\
\hline 27 & 2 & 0 & 0 & 0 & 0 & 0 & 1 & 0 & 0 & 3 & 12207737 & 22,45 & 8,11 & $-17,82$ & 0,15 & 4,11 & 58 & 12,2077 & 6 \\
\hline 28 & 2 & 0 & 0 & 0 & 0 & 0 & 1 & 0 & 0 & 4 & 12669891 & 24,29 & 7,69 & $-19,34$ & 0,17 & 4,3 & 61 & 12,6699 & 7 \\
\hline 29 & 2 & 0 & 0 & 0 & 0 & 0 & 1 & 0 & 0 & 1 & 13093726 & 25,5 & 7,27 & $-21,07$ & 0,23 & 4,07 & 64 & 13,0937 & 2 \\
\hline 30 & 2 & 0 & 0 & 0 & 0 & 0 & 1 & 0 & 0 & 3 & 13442887 & 26,87 & 7,11 & $-22,25$ & 0,18 & 4,1 & 71 & 13,4429 & 6 \\
\hline 31 & 2 & 0 & 0 & 0 & 0 & 0 & 1 & 0 & 0 & 4 & 13681978 & 27,96 & 7,56 & $-22,35$ & 0,16 & 4,15 & 74 & 13,682 & 3 \\
\hline 32 & 2 & 0 & 0 & 0 & 0 & 0 & 1 & 0 & 0 & 3 & 13642078 & 29,94 & 8,04 & $-22,39$ & 0,18 & 4,1 & 77 & 13,6421 & 6 \\
\hline 33 & 2 & 0 & 0 & 0 & 0 & 0 & 1 & 0 & 0 & 2 & 13263438 & 24,77 & 9,08 & $-21,96$ & 0,21 & 4 & 84 & 13,2634 & 3 \\
\hline 34 & 2 & 0 & 0 & 0 & 0 & 0 & 1 & 0 & 0 & 4 & 13599258 & 28,18 & 8,8 & $-23,74$ & 0,2 & 4,05 & 90 & 13,5993 & 2 \\
\hline 35 & 2 & 0 & 0 & 0 & 0 & 0 & 1 & 0 & 0 & 1 & 13817044 & 30,89 & 9,03 & $-24,3$ & 0,2 & 4,01 & 94 & 13,817 & 3 \\
\hline 36 & 2 & 0 & 0 & 0 & 0 & 0 & 1 & 0 & 0 & 5 & 14137749 & 30,7 & 8,84 & $-25,26$ & 0,19 & 4,01 & 105 & 14,1377 & 6 \\
\hline 37 & 3 & 0 & 0 & 0 & 0 & 0 & 0 & 0 & 1 & 0 & 328460 & 81,95 & 5,21 & $-5,1$ & 0,01 & 2,11 & 0 & 0,3285 & 0 \\
\hline 38 & 3 & 0 & 0 & 0 & 0 & 0 & 0 & 0 & 1 & 0 & 346777 & 89,94 & 5,21 & $-5,46$ & 0,01 & 2,27 & 0 & 0,3468 & 0 \\
\hline 39 & 3 & 0 & 0 & 0 & 0 & 0 & 0 & 0 & 1 & 0 & 367557 & 94,86 & 5,66 & $-6,48$ & $-0,03$ & 2,39 & 0 & 0,3676 & 0 \\
\hline 40 & 3 & 0 & 0 & 0 & 0 & 0 & 0 & 0 & 1 & 0 & 398532 & 96,1 & 4,11 & $-4,7$ & 0 & 2,43 & 1 & 0,3985 & 0 \\
\hline 41 & 3 & 0 & 0 & 0 & 0 & 0 & 0 & 0 & 1 & 0 & 405821 & 84,86 & 5,46 & $-4,25$ & 0 & 2,44 & 4 & 0,4058 & 0 \\
\hline 42 & 3 & 0 & 0 & 0 & 0 & 0 & 0 & 0 & 1 & 0 & 425146 & 82,77 & 7,38 & 0 & 0 & 2,53 & 6 & 0,4251 & 0 \\
\hline 43 & 3 & 0 & 0 & 0 & 0 & 0 & 0 & 0 & 1 & 0 & 467486 & 85,76 & 6,14 & 0 & 0 & 2,18 & 9 & 0,4675 & 0 \\
\hline 44 & 3 & 0 & 0 & 0 & 0 & 0 & 0 & 0 & 1 & 0 & 492658 & 83,74 & 5,72 & $-11,66$ & 0 & 2,53 & 21 & 0,4927 & 0 \\
\hline 45 & 4 & 0 & 0 & 0 & 0 & 0 & 1 & 0 & 0 & 0 & 480120 & 37,73 & 17,97 & 0 & 0,34 & 4,16 & 4 & 0,4801 & 2 \\
\hline 46 & 4 & 0 & 0 & 0 & 0 & 0 & 1 & 0 & 0 & 1 & 499080 & 38,22 & 19,16 & $-5,53$ & 0,27 & 4,16 & 8 & 0,4991 & 1 \\
\hline 47 & 4 & 0 & 0 & 0 & 0 & 0 & 1 & 0 & 0 & 1 & 518781 & 37,95 & 19,48 & $-5,81$ & 0,27 & 4,13 & 13 & 0,5188 & 1 \\
\hline 48 & 4 & 0 & 0 & 0 & 0 & 0 & 1 & 0 & 0 & 0 & 541806 & 39,97 & 17,47 & $-5,48$ & 0,27 & 4,1 & 13 & 0,5418 & 2 \\
\hline 49 & 4 & 0 & 0 & 0 & 0 & 0 & 1 & 0 & 0 & 2 & 568934 & 39,01 & 17,79 & $-6,01$ & 0,26 & 4,19 & 18 & 0,5689 & 0 \\
\hline 50 & 4 & 0 & 0 & 0 & 0 & 0 & 1 & 0 & 0 & 1 & 590945 & 40,9 & 15,66 & $-6,18$ & 0,27 & 4,27 & 22 & 0,5909 & 0 \\
\hline 51 & 4 & 0 & 0 & 0 & 0 & 0 & 1 & 0 & 0 & 0 & 602346 & 44,12 & 16,81 & $-5,39$ & 0,25 & 4,23 & 26 & 0,6023 & 0 \\
\hline 52 & 4 & 0 & 0 & 0 & 0 & 0 & 1 & 0 & 0 & 1 & 625577 & 41,33 & 16,63 & $-6,56$ & 0,26 & 4,2 & 28 & 0,6256 & 2 \\
\hline 53 & 4 & 0 & 0 & 0 & 0 & 0 & 1 & 0 & 0 & 1 & 644787 & 39,97 & 14,66 & $-8,54$ & 0,25 & 4,31 & 32 & 0,6448 & 1 \\
\hline 54 & 4 & 0 & 0 & 0 & 0 & 0 & 1 & 0 & 0 & 0 & 671542 & 36,73 & 15,26 & $-11,65$ & 0,25 & 4,54 & 36 & 0,6715 & 0 \\
\hline 55 & 4 & 0 & 0 & 0 & 0 & 0 & 1 & 0 & 0 & 0 & 693075 & 38,87 & 12,52 & $-12,82$ & 0,25 & 4,27 & 38 & 0,6931 & 0 \\
\hline 56 & 4 & 0 & 0 & 0 & 0 & 0 & 1 & 0 & 0 & 0 & 713749 & 41,02 & 11,84 & $-13,69$ & 0,3 & 4,26 & 44 & 0,7137 & 0 \\
\hline 57 & 4 & 0 & 0 & 0 & 0 & 0 & 1 & 0 & 0 & 0 & 740569 & 41,4 & 11,11 & $-16,11$ & 0,32 & 4,32 & 51 & 0,7406 & 1 \\
\hline 58 & 4 & 0 & 0 & 0 & 0 & 0 & 1 & 0 & 0 & 0 & 768020 & 42,12 & 9,84 & $-18,95$ & 0,32 & 4,28 & 59 & 0,768 & 0 \\
\hline 59 & 4 & 0 & 0 & 0 & 0 & 0 & 1 & 0 & 0 & 0 & 781995 & 44,95 & 11,33 & -16 & 0,29 & 4,2 & 61 & 0,782 & 0 \\
\hline 60 & 4 & 0 & 0 & 0 & 0 & 0 & 1 & 0 & 0 & 0 & 797778 & 39,86 & 9,77 & $-22,07$ & 0,32 & 4,27 & 65 & 0,7978 & 0 \\
\hline 61 & 4 & 0 & 0 & 0 & 0 & 0 & 1 & 0 & 0 & 0 & 816761 & 41,24 & 10,28 & $-25,3$ & 0,34 & 4,2 & 66 & 0,8168 & 0 \\
\hline 62 & 4 & 0 & 0 & 0 & 0 & 0 & 1 & 0 & 0 & 0 & 846432 & 42,7 & 10,7 & 0 & 0,36 & 4,11 & 78 & 0,8464 & 3 \\
\hline 63 & 5 & 1 & 0 & 0 & 0 & 0 & 0 & 0 & 1 & 0 & 10052 & 152,46 & 7,45 & 0 & 1,72 & 3,13 & 0 & 0,0101 & 0 \\
\hline 64 & 5 & 1 & 0 & 0 & 0 & 0 & 0 & 0 & 1 & 0 & 10465 & 164,12 & 12,54 & 0 & 2,18 & 3,13 & 0 & 0,0105 & 0 \\
\hline 65 & 5 & 1 & 0 & 0 & 0 & 0 & 0 & 0 & 1 & 0 & 12417 & 135,81 & 4,78 & 0 & 0,68 & 3,05 & 0 & 0,0124 & 0 \\
\hline 66 & 5 & 0 & 0 & 0 & 0 & 0 & 0 & 0 & 1 & 0 & 12726 & 127,03 & 5,71 & 0 & 0,82 & 3,04 & 0 & 0,0127 & 0 \\
\hline 67 & 5 & 0 & 0 & 0 & 0 & 0 & 0 & 1 & 0 & 0 & 13186 & 130,61 & 5,65 & 0 & 0,68 & 3,03 & 0 & 0,0132 & 0 \\
\hline 68 & 5 & 0 & 0 & 0 & 0 & 0 & 0 & 1 & 0 & 0 & 13980 & 128,09 & 4,99 & 0 & 1,25 & 2,96 & 0 & 0,014 & 0 \\
\hline 69 & 5 & 0 & 0 & 0 & 0 & 0 & 0 & 1 & 0 & 0 & 14956 & 140,74 & 4,22 & 0 & 0,46 & 3,09 & 0 & 0,015 & 0 \\
\hline 70 & 5 & 0 & 0 & 0 & 0 & 0 & 0 & 1 & 0 & 0 & 15969 & 148,31 & 3,43 & -5 & 0 & 2,9 & 0 & 0,016 & 0 \\
\hline 71 & 5 & 0 & 0 & 0 & 0 & 0 & 0 & 1 & 0 & 0 & 17002 & 147,1 & 2,84 & $-3,57$ & 0 & 2,9 & 0 & 0,017 & 0 \\
\hline 72 & 5 & 0 & 0 & 0 & 0 & 0 & 0 & 1 & 0 & 0 & 18412 & 137,79 & 2,6 & $-4,91$ & 0 & 2,92 & 0 & 0,0184 & 0 \\
\hline 73 & 5 & 0 & 0 & 0 & 0 & 0 & 0 & 1 & 0 & 0 & 19561 & 145,88 & 4,1 & $-10,58$ & 0 & 2,91 & 1 & 0,0196 & 0 \\
\hline 74 & 5 & 0 & 0 & 0 & 0 & 0 & 0 & 0 & 1 & 0 & 20058 & 117,96 & 5,55 & $-8,21$ & 0 & 3 & 1 & 0,0201 & 0 \\
\hline 75 & 5 & 0 & 0 & 0 & 0 & 0 & 0 & 0 & 1 & 0 & 20928 & 120,47 & 4,49 & 0 & 0 & 2,98 & 1 & 0,0209 & 0 \\
\hline 76 & 5 & 0 & 0 & 0 & 0 & 0 & 0 & 0 & 1 & 0 & 21367 & 126,81 & 4,45 & $-0,18$ & 0 & 3,05 & 1 & 0,0214 & 0 \\
\hline 77 & 5 & 0 & 0 & 0 & 0 & 0 & 0 & 0 & 1 & 0 & 22134 & 122,16 & 6,21 & $-0,18$ & 0 & 3,04 & 1 & 0,0221 & 0 \\
\hline 78 & 6 & 1 & 0 & 0 & 0 & 0 & 1 & 0 & 0 & 0 & 3105 & 90,07 & 30,72 & 0 & $-0,05$ & 3,94 & 0 & 0,0031 & 0 \\
\hline 79 & 6 & 1 & 0 & 0 & 0 & 0 & 1 & 0 & 0 & 0 & 3230 & 91,57 & 34,46 & $-3,03$ & 0,18 & 3,94 & 0 & 0,0032 & 0 \\
\hline
\end{tabular}

$\begin{array}{lllllllll}2 & 02316 & 1757 & 5,80719 & 0,00000 & 0,05 & 7,78081 & 15,7169\end{array}$ $\begin{array}{llllllll}1,69586 & 1757 & 6,17084 & 0,00000 & 0,05 & 7,13876 & 13,7910\end{array}$ $\begin{array}{llllllll}1,59300 & 1757 & 6,24839 & 0,00000 & 0,05 & 6,82929 & 13,0780\end{array}$ $\begin{array}{lllllllll}1,58267 & 1757 & 6,31070 & 0,00000 & 0,05 & 6,88364 & 13,0919\end{array}$ $\begin{array}{lllllll}1,35487 & 1757 & 6,67638 & 0,00000 & 0,05 & 6,38830 & 11,7030\end{array}$ $\begin{array}{llllllll}1,22021 & 1757 & 6,53010 & 0,00000 & 0,05 & 5,57486 & 10,3613\end{array}$ $\begin{array}{lllllll}1,08251 & 1757 & 6,88511 & 0,00000 & 0,05 & 5,33005 & 9,5763\end{array}$ $\begin{array}{llllllll}0,72959 & 1757 & 7,59814 & 0,00000 & 0,05 & 4,11260 & 6,9745\end{array}$ $\begin{array}{llllllll}0,66413 & 1757 & 7,64547 & 0,00000 & 0,05 & 3,77500 & 6,3801\end{array}$ $\begin{array}{llllllll}\mathbf{0 , 6 7 1 2 1} & 1757 & 7,27910 & 0,00000 & 0,05 & 3,56935 & 6,2023\end{array}$ $\begin{array}{llllllll}0,69363 & 1757 & 6,76805 & 0,00000 & 0,05 & 3,33408 & 6,0549\end{array}$ $\begin{array}{llllllll}0,71830 & 1757 & 6,25873 & 0,00000 & 0,05 & 3,08683 & 5,9045\end{array}$ $\begin{array}{llllllll}0,68615 & 1757 & 5,79585 & 0,00000 & 0,05 & 2,63107 & 5,3226\end{array}$ $\begin{array}{llllllll}0,63373 & 1757 & 5,51716 & 0,00000 & 0,05 & 2,25344 & 4,7393\end{array}$ $\begin{array}{llllllll}0,52470 & 1757 & 5,61900 & 0,00000 & 0,05 & 1,91920 & 3,9774\end{array}$ $\begin{array}{llllllll}0,48538 & 1757 & 5,02952 & 0,00000 & 0,05 & 1,48924 & 3,3932\end{array}$ $\begin{array}{llllllll}0,47937 & 1757 & 4,68339 & 0,00000 & 0,05 & 1,30488 & 3,1853\end{array}$ $\begin{array}{llllllll}0,37833 & 1757 & 4,09221 & 0,00004 & 0,05 & 0,80619 & 2,2902\end{array}$ $\begin{array}{llllllll}1,67370 & 1757 & 6,38292 & 0,00000 & 0,05 & 7,40044 & 13,9657\end{array}$ $\begin{array}{llllllll}1,45474 & 1757 & 6,81680 & 0,00000 & 0,05 & 7,06346 & 12,7699\end{array}$ $\begin{array}{llllllll}1,19830 & 1757 & 7,25680 & 0,00000 & 0,05 & 6,34557 & 11,0460\end{array}$ $\begin{array}{llllllll}1,14060 & 1757 & 7,27579 & 0,00000 & 0,05 & 6,06170 & 10,5359\end{array}$ $\begin{array}{llllllll}1,22209 & 1757 & 7,13389 & 0,00000 & 0,05 & 6,32133 & 11,1151\end{array}$ $\begin{array}{llllllll}1,15015 & 1757 & 7,21117 & 0,00000 & 0,05 & 6,03811 & 10,5497\end{array}$ $\begin{array}{llllllll}1,01716 & 1757 & 7,58112 & 0,00000 & 0,05 & 5,71625 & 9,7062\end{array}$ $\begin{array}{lllllll}0,87395 & 1757 & 7,92350 & 0,00000 & 0,05 & 5,21067 & 8,6389\end{array}$ $\begin{array}{llllllll}0,74806 & 1757 & 8,10820 & 0,00000 & 0,05 & 4,59823 & 7,5326\end{array}$ $\begin{array}{llllllll}0,86759 & 1757 & 7,35619 & 0,00000 & 0,05 & 4,68054 & 8,0838\end{array}$ $\begin{array}{llllllll}0,77929 & 1757 & 7,92051 & 0,00000 & 0,05 & 4,64392 & 7,7008\end{array}$ $\begin{array}{llllllll}0,74874 & 1757 & 7,56456 & 0,00000 & 0,05 & 4,19540 & 7,1325\end{array}$ $\begin{array}{llllllll}0,76621 & 1757 & 7,34099 & 0,00000 & 0,05 & 4,12198 & 7,1276\end{array}$ $\begin{array}{llllllll}0,69540 & 1757 & 7,44511 & 0,00000 & 0,05 & 3,81341 & 6,5412\end{array}$ $\begin{array}{llllllll}0,62593 & 1757 & 6,88736 & 0,00000 & 0,05 & 3,08336 & 5,5387\end{array}$ $\begin{array}{llllllll}0,60545 & 1757 & 6,59987 & 0,00000 & 0,05 & 2,80843 & 5,1834\end{array}$ $\begin{array}{llllllll}0,58368 & 1757 & 6,43503 & 0,00000 & 0,05 & 2,61122 & 4,9008\end{array}$ $\begin{array}{llllllll}0,55988 & 1757 & 5,70010 & 0,00000 & 0,05 & 2,09329 & 4,2895\end{array}$ $\begin{array}{llllllll}0,00021 & 1757 & 0,17379 & 0,86205 & 0,05 & -0,00038 & 0,0005\end{array}$ $\begin{array}{llllllll}0,00022 & 1757 & 0,17412 & 0,86179 & 0,05 & -0,00040 & 0,0005\end{array}$ $\begin{array}{llllllll}0,00025 & 1757 & 0,17418 & 0,86175 & 0,05 & -0,00045 & 0,0005\end{array}$ $\begin{array}{llllllll}0,00033 & 1757 & 0,17449 & 0,86150 & 0,05 & -0,00059 & 0,0007\end{array}$ $\begin{array}{llllllll}0,00044 & 1757 & 0,17446 & 0,86153 & 0,05 & -0,00079 & 0,0009\end{array}$ $\begin{array}{llllllll}\mathbf{0}, 00057 & 1757 & 0,17454 & 0,86146 & 0,05 & -0,00103 & 0,0012\end{array}$ $\begin{array}{lllllll}0,00072 & 1757 & 0,17444 & 0,86154 & 0,05 & -0,00128 & 0,0015\end{array}$ $\begin{array}{llllllll}0,00072 & 1757 & 0,17399 & 0,86189 & 0,05 & -0,00129 & 0,0015\end{array}$ $\begin{array}{llllllll}0,37212 & 1757 & 3,14808 & 0,00167 & 0,05 & 0,44162 & 1,9013\end{array}$ $\begin{array}{llllllll}0,34045 & 1757 & 3,31776 & 0,00093 & 0,05 & 0,46181 & 1,7973\end{array}$ $\begin{array}{llllllll}0,30727 & 1757 & 3,54782 & 0,00040 & 0,05 & 0,48749 & 1,6928\end{array}$ $\begin{array}{lllllll}0,28486 & 1757 & 3,91467 & 0,00009 & 0,05 & 0,55643 & 1,6738\end{array}$ $\begin{array}{llllllll}0,26738 & 1757 & 4,16863 & 0,00003 & 0,05 & 0,59020 & 1,6390\end{array}$ $\begin{array}{llllllll}0,23735 & 1757 & 4,40853 & 0,00001 & 0,05 & 0,58085 & 1,5119\end{array}$ $\begin{array}{llllllll}0,22501 & 1757 & 4,26210 & 0,00002 & 0,05 & 0,51770 & 1,4003\end{array}$ $\begin{array}{llllllll}0,20986 & 1757 & 4,68828 & 0,00000 & 0,05 & 0,57227 & 1,3955\end{array}$ $\begin{array}{lllllll}0,19224 & 1757 & 4,86564 & 0,00000 & 0,05 & 0,55834 & 1,3124\end{array}$ $\begin{array}{llllllll}0,20728 & 1757 & 4,66061 & 0,00000 & 0,05 & 0,55952 & 1,3726\end{array}$ $\begin{array}{lllllll}0,15626 & 1757 & 5,44166 & 0,00000 & 0,05 & 0,54382 & 1,1568\end{array}$ $\begin{array}{llllllll}0,13808 & 1757 & 5,43811 & 0,00000 & 0,05 & 0,48009 & 1,0217\end{array}$ $\begin{array}{llllllll}0,12601 & 1757 & 5,27414 & 0,00000 & 0,05 & 0,41746 & 0,9118\end{array}$ $\begin{array}{llllllll}0,10728 & 1757 & 5,17591 & 0,00000 & 0,05 & 0,34487 & 0,7657\end{array}$ $\begin{array}{llllllll}0,10183 & 1757 & 5,20692 & 0,00000 & 0,05 & 0,33051 & 0,7300\end{array}$ $\begin{array}{llllllll}0,10047 & 1757 & 5,02377 & 0,00000 & 0,05 & 0,30770 & 0,7018\end{array}$ $\begin{array}{llllllll}0,09681 & 1757 & 5,05729 & 0,00000 & 0,05 & 0,29974 & 0,6795\end{array}$ $\begin{array}{llllllll}0,08695 & 1757 & 4,62534 & 0,00000 & 0,05 & 0,23165 & 0,5727\end{array}$ $\begin{array}{llllllll}0,00016 & 1757 & 0,18417 & 0,85390 & 0,05 & -0,00028 & 0,0003\end{array}$ $\begin{array}{llllllll}\mathbf{0}, 00018 & 1757 & 0,18676 & 0,85187 & 0,05 & -0,00032 & 0,0004\end{array}$ $\begin{array}{llllllll}0,00011 & 1757 & 0,17842 & 0,85841 & 0,05 & -0,00019 & 0,0002\end{array}$ $\begin{array}{llllllll}0,00001 & 1757 & 0,17365 & 0,86216 & 0,05 & -0,00001 & 0,0000\end{array}$ $\begin{array}{llllllll}0,00258 & 1757 & 0,68104 & 0,49594 & 0,05 & -0,00330 & 0,0068\end{array}$ $\begin{array}{llllllll}0,00411 & 1757 & 0,66730 & 0,50467 & 0,05 & -0,00532 & 0,0108\end{array}$ $\begin{array}{llllllll}\mathbf{0 , 0 0 1 7 6} & 1757 & 0,67831 & \mathbf{0 , 4 9 7 6 6} & \mathbf{0 , 0 5} & -0,00226 & \mathbf{0 , 0 0 4 6}\end{array}$ $\begin{array}{llllllll}0,00103 & 1757 & 0,66758 & 0,50449 & 0,05 & -0,00133 & 0,0027\end{array}$ $\begin{array}{llllllll}\mathbf{0}, 00106 & 1757 & 0,66718 & 0,50475 & 0,05 & -0,00137 & 0,0028\end{array}$ $\begin{array}{llllllll}0,00132 & 1757 & 0,67224 & 0,50152 & 0,05 & -0,00170 & 0,0035\end{array}$ $\begin{array}{llllllll}0,00108 & 1757 & 0,67888 & 0,49730 & 0,05 & -0,00138 & 0,0028\end{array}$ $\begin{array}{llllllll}0,00000 & 1757 & 0,16959 & 0,86535 & 0,05 & -0,00001 & 0,0000\end{array}$ $\begin{array}{lllllll}0,00000 & 1757 & 0,16951 & 0,86541 & 0,05 & -0,00001 & 0,0000\end{array}$ $\begin{array}{llllllll}0,00000 & 1757 & 0,16960 & 0,86535 & 0,05 & -0,00001 & 0,0000\end{array}$ $\begin{array}{llllllll}0,00000 & 1757 & 0,16968 & 0,86528 & 0,05 & -0,00001 & 0,0000\end{array}$ $\begin{array}{llllllll}0,07136 & 1757 & 1,75129 & 0,08007 & 0,05 & -0,01499 & 0,2649\end{array}$ $\begin{array}{llllllll}0,08747 & 1757 & 1,70083 & 0,08915 & 0,05 & -0,02278 & 0,3203\end{array}$ $\begin{array}{lllllll}0,07724 & 1757 & 1,72904 & 0,08398 & 0,05 & -0,01794 & 0,2850\end{array}$ 


\begin{tabular}{|c|c|c|c|c|c|c|c|c|c|c|c|c|c|c|c|}
\hline & ID & AA & & & & & & & & & PIB & COMEX & AGRI & PREF & ODP \\
\hline 82 & 6 & 1 & 0 & 0 & 0 & 0 & 1 & 0 & 0 & 0 & 3518 & 86,43 & $\begin{array}{l}32,73 \\
\end{array}$ & $-4,37$ & $-0,07$ \\
\hline 83 & 6 & & 0 & 0 & 0 & 0 & 1 & 0 & 0 & 0 & 3676 & 88,79 & 27,08 & $-4,57$ & 0,01 \\
\hline 84 & 6 & & & 0 & 0 & 0 & & 0 & 0 & & 3588 & 65 & 50,14 & $-4,35$ & $-0,04$ \\
\hline 85 & 6 & & & 0 & 0 & 0 & 1 & 0 & 0 & & 3617 & 81,81 & 31,57 & 4,8 & 11 \\
\hline 86 & 6 & & 0 & 0 & 0 & 0 & 1 & 0 & 0 & & 3695 & 88,31 & 28,23 & $-4,86$ & 0,63 \\
\hline 87 & 6 & & & & 0 & 0 & & 0 & & & 3746 & 21 & 31,34 & 81 & 85 \\
\hline 88 & 6 & & & 0 & 0 & 0 & 1 & 0 & 0 & & 98 & ;66 & 27,01 & & $-0,05$ \\
\hline 89 & 6 & & 0 & 0 & 0 & 0 & 1 & 0 & 0 & & 4119 & 94,59 & 24,03 & $-1,72$ & $-0,05$ \\
\hline 90 & 6 & & 0 & 0 & 0 & 0 & 1 & 0 & 0 & & 4189 & 3,71 & 26,66 &, 76 & 0,4 \\
\hline 91 & 6 & & 0 & 0 & 0 & 0 & 1 & 0 & 0 & & 4207 & 45 & 529,04 & 0 & 0,16 \\
\hline 92 & 6 & & & 0 & 0 & 0 & 1 & 0 & 0 & & 4038 & 85,84 & 30,45 & & 0,27 \\
\hline 93 & 6 & & 0 & 0 & 0 & 0 & 1 & 0 & 0 & 0 & 4049 & 96,6 & 29,86 & 0 & 37 \\
\hline 94 & 6 & & 0 & 0 & 0 & 0 & 1 & 0 & 0 & & 4078 & 91,46 & 24,93 & 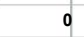 & 0 \\
\hline 95 & 6 & & 0 & 0 & 0 & 0 & 1 & 0 & 0 & 0 & 4089 & 89,91 & 25,27 & 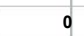 & 0 \\
\hline 96 & 7 & & & 0 & 0 & 0 & 1 & 0 & 0 & & 842744 & 69,33 & $3 \quad 12,41$ & $-2,72$ & 0,38 \\
\hline 97 & 7 & 0 & 0 & 0 & 0 & 0 & 1 & 0 & 0 & 3 & 856899 & 70,48 & $3 \quad 11,99$ & $-2,71$ & 0,32 \\
\hline 98 & 7 & 0 & 0 & 0 & 0 & 0 & 1 & 0 & 0 & 1 & 3346 & 74,59 & 1,6 & $-2,92$ & 0,34 \\
\hline 99 & 7 & & c & 0 & 0 & 0 & 1 & 0 & 0 & 4 & 30314 & 78,21 & 10,9 & $-2,77$ & 0,3 \\
\hline 100 & 7 & c & 0 & 0 & 0 & 0 & 1 & 0 & 0 & 2 & 6804 & 80,4 & 10,32 & $-2,87$ & 0,28 \\
\hline 101 & 7 & 0 & 0 & 0 & 0 & 0 & 1 & 0 & 0 & 1 & 26847 & 3,18 & 15 & $-3,23$ & 0,25 \\
\hline 102 & 7 & 0 & 0 & 0 & 0 & 0 & 1 & 0 & 0 & $3^{3}$ & 444184 & 78,8 & 19 & $-3,22$ & 0,22 \\
\hline 103 & 7 & 0 & 0 & 0 & 0 & 0 & 1 & 0 & 0 & 4 & 1073441 & 76,28 & $\begin{array}{l}310,36 \\
\end{array}$ & $-3,55$ & $\mathbf{0 , 2 8}$ \\
\hline 104 & 7 & 0 & 0 & 0 & 0 & 0 & 1 & 0 & 0 & 1 & 94108 & 70,21 & 10,16 & $-4,5$ & 0,24 \\
\hline 105 & 7 & 0 & 0 & 0 & 0 & 0 & 1 & 0 & 0 & 2 & 28450 & .51 & 1 & $-5,5$ & 27 \\
\hline 106 & 7 & 0 & 0 & 0 & 0 & 0 & 1 & 0 & 0 & 0 & 164144 & 70,02 & 9,69 & $-6,83$ & 0,34 \\
\hline 107 & 7 & 0 & 0 & 0 & 0 & 0 & 1 & 0 & 0 & 1 & 194666 & 68,22 & 9,66 & $-8,2$ & 0,29 \\
\hline 108 & 7 & 0 & 0 & 0 & 0 & 0 & 1 & 0 & 0 & 2 & 18658 & 0,51 & 35 & $-9,38$ & 0,29 \\
\hline 109 & 7 & 0 & 0 & 0 & 0 & 0 & 1 & 0 & 0 & & 32983 & 67,21 & 16 & $-9,96$ & 0,33 \\
\hline 110 & 7 & 0 & 0 & to & 0 & 0 & 1 & 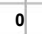 & 0 & 2 & 199551 & 58,35 & $\begin{array}{ll}511,97 \\
\end{array}$ & $-10,21$ & 0,3 \\
\hline 111 & 7 & 0 & 0 & 0 & 0 & 0 & 1 & 0 & 0 & 0 & 40027 & 60,02 & 2 11,44 & $-12,67$ & 0,34 \\
\hline 112 & 7 & 0 & 0 & 0 & 0 & 0 & 1 & 0 & 0 & 0 & 6733 & 33 & 3 & -13 & 0,32 \\
\hline 113 & 7 & 0 & 0 & 0 & 0 & 0 & 1 & 0 & 0 & 0 & 1301282 & 62,26 & 11,25 & $-13,82$ & 0,32 \\
\hline 114 & 8 & & 0 & 0 & 0 & 0 & 0 & 1 & 0 & & 76309 & 15,74 & 12,12 & $-14,45$ & $-0,02$ \\
\hline 115 & 8 & & 0 & 0 & 0 & 0 & 0 & 1 & 0 & ( & 82057 & 93 & 3 & 0 & 02 \\
\hline 116 & 8 & & 0 & 0 & 0 & 0 & 0 & 1 & 0 & & 88860 & ; 39 & 9,89 & 0 & 0 \\
\hline 117 & 8 & & 0 & 0 & 0 & 0 & 0 & 1 & 0 & & 86883 & 3,88 & $\begin{array}{l}32,13 \\
\end{array}$ & 0 & 0 \\
\hline 118 & 8 & & 0 & 0 & 0 & 0 & 0 & 1 & 0 & & 92178 &, 54 & 8 & & 0 \\
\hline 119 & 8 & & 0 & 0 & 0 & 0 & 0 & 1 & 0 & 0 & 100380 & & & & 0 \\
\hline 120 & 8 & & 0 & 0 & 0 & 0 & 0 & 1 & 0 & 0 & 99424 & 2,75 & $5 \quad 12,22$ & $-11,55$ & 0 \\
\hline 121 & 8 & & 0 & 0 & 0 & 0 & 0 & 1 & 0 & 0 & 103612 & 4,28 & $\begin{array}{ll}31,84 \\
\end{array}$ & $-11,92$ & $-0,01$ \\
\hline 122 & 8 & & 0 & 0 & 0 & 0 & 0 & 1 & 0 & 0 & 108207 & 79 & 78 & 3,44 & $-0,01$ \\
\hline 123 & 8 & & 0 & 0 & 0 & 0 & c & 1 & 0 & & 118540 & 29 & 78 & 0 & 01 \\
\hline 124 & 8 & & 0 & 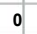 & 0 & 0 & 0 & 1 & 0 & & 127418 & 22,33 & $3 \quad 5,94$ & $-15,21$ & 0 \\
\hline 125 & 8 & & 0 & 0 & 0 & 0 & 0 & 1 & 0 & & 138707 & 0,36 & 5,26 & $-16,34$ & 0 \\
\hline 126 & 8 & & 0 & 0 & 0 & 0 & , & 1 & 0 & & 45 & 8,66 & o & $-17,44$ & 0 \\
\hline 127 & 8 & & 0 & 0 & 0 & 0 & 0 & 1 & 0 & & 154051 & 9,66 & 97 & $-17,85$ & 0 \\
\hline 128 & 8 & & 0 & 0 & 0 & 0 & 0 & 1 & 0 & 0 & 153121 & 60,23 & 6,5 & $-16,99$ & 0 \\
\hline 129 & 8 & & 0 & 0 & 0 & 0 & 0 & 1 & 0 & 0 & 176458 & 2,1 & 23 & 18,6 & 0 \\
\hline 130 & 8 & & 0 & 0 & 0 & 0 & c & 1 & 0 & & 1 & 5 & 5 & & 0 \\
\hline 131 & 8 & & 0 & 0 & 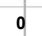 & 0 & 0 & 1 & 0 & 0 & 193810 & 368,23 & 47 & $-20,71$ & 0 \\
\hline 132 & 9 & & 0 & 0 & 0 & 0 & 1 & 0 & 0 & 0 & 553331 & 54,32 & 4 & 0 & 0,02 \\
\hline 133 & 9 & & 0 & 0 & o & 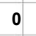 & 1 & 0 & 0 & & 5 & 1 & 1 & 17 & 0,03 \\
\hline 134 & 9 & & c & 0 & 0 & 0 & 1 & 0 & 0 & & 627295 & 3 & & & 4 \\
\hline 135 & 9 & 0 & 0 & 0 & 0 & 0 & 1 & 0 & 0 & 0 & 591452 & 91 & 1 & 0 & 0,05 \\
\hline 136 & 9 & 0 & 0 & 0 & 0 & 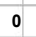 & 1 & 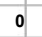 & 0 & 1 & 654918 & 43 & 3 &, 02 & 7 \\
\hline 137 & 9 & & 0 & 0 & 0 & 0 & 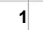 & 0 & 0 & & 71 & ,95 & 5 & & 0,04 \\
\hline 138 & 9 & & & 0 & 0 & 0 & 1 & 0 & 0 & 0 & 7450 & 63,91 & 5,68 & & \\
\hline 139 & 9 & 0 & 0 & 0 & 0 & 0 & 1 & 0 & 0 & 1 & 800383 & 15 & 5,6 & -8 & 0,05 \\
\hline 140 & 9 & & 0 & 0 & 0 & 0 & 1 & 0 & 0 & & 823860 & & 5, & & 0,06 \\
\hline 41 & 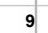 & & & 0 & 0 & 0 & 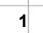 & 0 & 0 & & 86 & & 4, &, 75 & 0,06 \\
\hline 142 & 9 & & 0 & 0 & 0 & 0 & 1 & 0 & 0 & 0 & 898137 & 71,18 & 05 & 0 & 0.1 \\
\hline 143 & 9 & 0 & 0 & 0 & 0 & 0 & 1 & 0 & 0 & 1 & 944626 & 73,55 & 3,8 & 08 & 0,05 \\
\hline 144 & 9 & & 0 & 0 & 0 & 0 & 1 & 0 & 0 & 0 & 996235 & 77,24 & 3,9 & 34 & 0,07 \\
\hline 145 & 9 & & & 0 & 0 & & & 0 & 0 & & 24420 & & 3 & & 9 \\
\hline 146 & 9 & & 0 & 0 & 0 & 0 & 1 & 0 & 0 & 1 & 31668 & 90,41 & 1 & 59 & 0,1 \\
\hline 147 & 9 & 0 & 0 & 0 & 0 & 0 & 1 & 0 & 0 & 0 & 198694 & 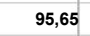 & 5 & .52 & 0,12 \\
\hline 148 & 9 & & & 0 & c & 0 & 1 & 0 & 0 & & 39144 & 10 & & 0 & 0,12 \\
\hline 148 & 9 & & & 0 & c & & & 0 & 0 & & 652 & & & & \\
\hline 150 & 10 & 1 & 0 & 0 & 0 & 0 & 1 & 0 & 0 & & 36454 & & 6 & & \\
\hline 151 & 10 & & 0 & 0 & 0 & 0 & 1 & 0 & 0 & & 37706 & & 12,02 & & 0,54 \\
\hline 152 & 1 & & & 0 & c & 0 & & 0 & & & & & & & \\
\hline & 10 & & & 0 & 0 & 0 & & 0 & 0 & & & & & & \\
\hline 154 & 10 & 1 & 0 & o & 0 & 0 & 1 & 0 & 0 & & 43601 & & 2 & & \\
\hline 155 & 10 & 1 & 0 & 0 & 0 & 0 & 1 & 0 & 0 & & 4541 & & 3 & -5 , & 8 \\
\hline 156 & 10 & & & 0 & c & & & 0 & & & & & & & \\
\hline & 10 & & 0 & 0 & 0 & 0 & & 0 & 0 & & & & & & \\
\hline 158 & 10 & 0 & 0 & 0 & 0 & 0 & 1 & 0 & 0 & & 51068 & & & & \\
\hline 159 & 10 & & & 0 & c & 0 & & 0 & & & & & & & 0.28 \\
\hline 166 & 10 & & & 0 & c & 0 & & 0 & & & & & & & 0,23 \\
\hline 101 & 10 & & & 0 & 0 & 0 & 1 & 0 & 0 & & & & & & \\
\hline 162 & 10 & 0 & 0 & 0 & 0 & 0 & 1 & 0 & & & 5347 & 1 & 14,84 & 2,17 & 0 \\
\hline 163 & 11 & & & 0 & & 0 & & & & & 0678 & & 36 & & \\
\hline
\end{tabular}




\begin{tabular}{|c|c|c|c|c|c|c|c|c|c|c|c|c|c|c|c|}
\hline & 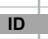 & AA & & $B A E$ & BB & & & N & VL & & & & RI & XEF & \\
\hline 164 & 11 & 0 & 0 & 0 & 0 & 0 & 1 & 0 & 0 & 0 & 11188 & 70,38 & 44,74 & 0 & 0 \\
\hline 165 & 11 & 0 & 0 & 0 & 0 & 0 & 1 & 0 & 0 & 0 & 11738 & 70,36 & 43,47 & 0 & 0 \\
\hline 166 & 11 & 0 & & & & & & & 0 & & 504 & 19 & 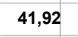 & & \\
\hline 167 & 11 & 0 & & 0 & 0 & 0 & 1 & 0 & 0 & & 024 & 85 & 38,93 & & 9 \\
\hline 168 & 11 & 0 & 0 & 0 & 0 & 0 & 1 & 0 & 0 & 0 & 13639 & 71,95 & 35,73 & 0 & 0,1 \\
\hline 169 & 11 & 0 & & 0 & 0 & 0 & 1 & 0 & 0 & & 14152 & 75,72 & 37,81 & $-2,01$ & 0,13 \\
\hline 170 & 11 & 0 & & 0 & 0 & 0 & 1 & 0 & 0 & 0 & 14217 & 70,55 & 39,77 & 0 & 0,15 \\
\hline 171 & 11 & 0 & 0 & 0 & 0 & 0 & 1 & 0 & 0 & & 14606 & 68,99 &, 5 & 2,44 & 0,17 \\
\hline 172 & 11 & 0 & 0 & 0 & 0 & 0 & 1 & 0 & 0 & 0 & 15807 & 70,75 & 35,31 & 0 & 18 \\
\hline 173 & 11 & 0 & & 0 & 0 & 0 & 1 & 0 & 0 & 0 & 16749 & 72,87 & 14 & 0 & 0,18 \\
\hline 174 & 11 & 0 & 0 & 0 & 0 & 0 & 1 & 0 & 0 & 0 & 17454 & 79,44 & 25,91 & $-3,93$ & 0,27 \\
\hline 175 & 11 & 0 & 0 & 0 & 0 & 0 & 1 & 0 & 0 & 0 & 19111 & 75,9 & 24,22 & $-4,11$ & 0,27 \\
\hline 176 & 11 & 0 & 0 & 0 & 0 & 0 & 1 & 0 & 0 & & 19393 & 85,2 & , 04 & $-4,51$ & 47 \\
\hline 177 & 11 & 0 & 0 & 0 & 0 & 0 & 1 & 0 & 0 & 0 & 18485 & 90,6 & 29,82 & $-3,32$ & 0,35 \\
\hline 178 & 11 & 0 & 0 & 0 & 0 & 0 & 1 & 0 & 0 & 0 & 17822 & 97,27 & 28,63 & $-4,85$ & 0,29 \\
\hline 179 & 11 & 0 & & 0 & 0 & 0 & 1 & 0 & 0 & & 18176 & 105,24 & 28,61 & $-4,66$ & 0,21 \\
\hline 180 & 11 & 0 & 0 & 0 & 0 & 0 & 1 & 0 & 0 & 0 & 18391 & 107,91 & 29,26 &, 21 &, 22 \\
\hline 181 & 12 & 0 & 0 & 0 & 0 & 0 & 1 & 0 & 0 & 0 & 98662 & 62,96 & 69 & 0 & $-0,28$ \\
\hline 182 & 12 & 0 & & 0 & 0 & 0 & 1 & 0 & 0 & 0 & 104737 & 61,36 & 7,62 & 0 & $-1,82$ \\
\hline 183 & 12 & 0 & & 0 & 0 & 0 & 1 & 0 & 0 & 0 & 9012 & 60,53 & 29 & 0 & $-0,96$ \\
\hline 184 & 12 & 0 & 0 & 0 & 0 & 0 & 1 & 0 & 0 & 0 & 113647 & 59,8 & 6,98 & 0 & $-0,85$ \\
\hline 185 & 12 & 0 & 0 & 0 & 0 & 0 & 1 & 0 & 0 & 0 & 117895 & 67,76 & 6,13 & 0 & $-0,7$ \\
\hline 186 & 12 & 0 & 0 & 0 & 0 & 0 & 1 & 0 & 0 & 0 & 128437 & 71,19 & 4,7 & 0 & $-0,6$ \\
\hline 187 & 12 & 0 & & 0 & 0 & 0 & 1 & 0 & 0 & 0 & 128747 & ,93 & 5,07 & 0 & $-0,13$ \\
\hline 188 & 12 & 0 & 0 & 0 & 0 & 0 & 1 & 0 & 0 & 0 & 28659 & 62 & 5,05 & 0 & 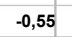 \\
\hline 189 & 12 & 0 & 0 & 0 & 0 & 0 & 1 & 0 & 0 & 0 & 130174 & 70,09 & 5,21 & 0 & $-0,31$ \\
\hline 190 & 12 & 0 & & 0 & c & 0 & I & 0 & 0 & 0 & 8831 & 78,16 & 3,5 & $-5,8$ & 32 \\
\hline 191 & 12 & 0 & 0 & 0 & 0 & 0 & 1 & 0 & 0 & 0 & 838 & 18 & 4,7 & -6, & \\
\hline 192 & 12 & 0 & 0 & 0 & 0 & 0 & 1 & 0 & 0 & 0 & 151125 & 81,11 & 4,86 & -7 & 0 \\
\hline 193 & 12 & 0 & 0 & 0 & 0 & 0 & 1 & 0 & 0 & 0 & 160396 & 81,49 & 5,19 & $-8,26$ & 0 \\
\hline 194 & 12 & 0 & & 0 & 0 & 0 & 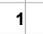 & 0 & 0 & 0 & 303 & 29 & 5, & -9 & 0 \\
\hline 195 & 12 & 0 & 0 & 0 & 0 & 0 & 1 & 0 & 0 & 0 & 167401 & 79 & 6,33 & 57 & 0 \\
\hline 196 & 12 & 0 & 0 & 0 & 0 & 0 & 1 & 0 & 0 & 0 & 176636 & 67,81 & 6, & 0 & 0 \\
\hline 197 & 12 & 0 & & 0 & c & 0 & 1 & 0 & 0 & 0 & 521 & 17 & 5,91 & 0 & 0 \\
\hline 198 & 12 & 0 & & 0 & 0 & 0 & 1 & 0 & 0 & 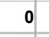 & 0864 & 15 & 17 &, 25 & 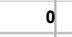 \\
\hline 199 & 13 & 0 & 0 & 0 & 0 & 0 & 1 & 0 & 0 & 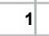 & 32182 & 16,75 & 10,56 & $-14,61$ & 0,27 \\
\hline 200 & 13 & 0 & 0 & 0 & 0 & 0 & 1 & 0 & 0 & 3 & 10034 & 18,94 & 10,49 & $-12,88$ & 0,2 \\
\hline 201 & 13 & 0 & & 0 & 0 & 0 & 1 & 0 & 0 & 1 & 7689 & 20,39 & 9,68 & ,76 & 21 \\
\hline 202 & 13 & 0 & & 0 & 0 & 0 & 1 & 0 & 0 & 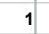 & 21400 & 9,69 & 9,4 & $-10,28$ & 77 \\
\hline 203 & 13 & 0 & & 0 & 0 & 0 & 1 & 0 & 0 & 2 & 2985 & , 76 & 9,09 &, 28 & 0,27 \\
\hline 20 & 13 & 0 & & 0 & c & 0 & 1 & 0 & 0 & 1 & 8093 & ,31 & 7,86 & ;97 & 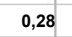 \\
\hline 205 & 13 & 0 & & 0 & 0 & 0 & 1 & 0 & 0 & 0 & 2340 & & 8, & & \\
\hline 206 & 13 & 0 & 0 & 0 & 0 & 0 & 1 & 0 & 0 & 2 & 5925 & 16 & 7,99 & 3,09 & 0,23 \\
\hline 207 & 13 & 0 & 0 & 0 & 0 & 0 & 1 & 0 & 0 & 0 & 108990 & 22,09 & 39 & -14,47 & 2 \\
\hline 208 & 13 & 0 & & 0 & 0 & 0 & 1 & 0 & 0 & 1 & 13074 & 24,46 & 34 & ,58 & 9 \\
\hline 209 & 13 & 0 & & 0 & 0 & 0 & 1 & 0 & 0 & 0 & 1867 & 22 & 1 & $-15,5$ & 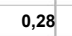 \\
\hline 210 & 13 & 0 & 0 & 0 & 0 & 0 & 1 & 0 & 0 & 0 & 49265 & 31,09 & 78 & -14,85 & 0,25 \\
\hline 211 & 13 & 0 & 0 & 0 & c & 0 & 1 & 0 & 0 & 0 & 51185 & 33,8 & 62 & $-14,65$ & 0,17 \\
\hline 212 & 13 & 0 & & 0 & 0 & 0 & 1 & 0 & 0 & 1 & 169 & 23 & 59 & , 47 & 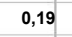 \\
\hline 213 & 13 & 0 & & 0 & c & 0 & 1 & 0 & 0 & 0 & 11834 & & & 99 & \\
\hline 214 & 13 & 0 & 0 & 0 & 0 & 0 & 1 & 0 & 0 & 1 & 48469 & 15 & 5,87 & 0,27 & 0,2 \\
\hline 215 & 13 & 0 & & 0 & 0 & 0 & 1 & 0 & 0 & 0 & 27424 & 16 & 6,26 & 3,18 & 8 \\
\hline 216 & 13 & 0 & & 0 & 0 & 0 & 1 & 0 & 0 & 3 & 85 & 31,34 & 6,1 & 4,73 & 17 \\
\hline 217 & 14 & 0 & & 0 & 0 & 0 & 0 & 1 & 0 & 0 & 49547 & 32 & 7,58 & & 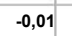 \\
\hline 218 & 14 & 0 & & 0 & 0 & 0 & 0 & 1 & 0 & 0 & 49847 & 47 & 7,47 & & 37 \\
\hline 21 & 14 & 0 & & 0 & c & 0 & 0 & 1 & 0 & c & 51080 & & & & 0 \\
\hline 220 & 14 & 0 & & 0 & c & 0 & 0 & . & 0 & & & & & & 12 \\
\hline 221 & 14 & 0 & 0 & 0 & 0 & 0 & 0 & 1 & 0 & 0 & 003 & 85,37 & 8,58 & & 0,02 \\
\hline 222 & 14 & 0 & & 0 & 0 & 0 & 0 & 1 & 0 & 0 & 144 & 32 & 11 & & $.0,01$ \\
\hline 223 & 14 & 0 & & 0 & c & 0 & 0 & 1 & 0 & 0 & 54841 & 86,84 & 5,4 & & $-0,01$ \\
\hline 224 & 14 & 0 & & 0 & c & 0 & 0 & & 0 & & 56486 & & & & \\
\hline 225 & 14 & 0 & 0 & 0 & c & 0 & 0 & 1 & 0 & & 270 & .56 & 5,01 & & $-0,01$ \\
\hline 226 & 14 & 0 & & 0 & c & 0 & 0 & 1 & 0 & & 73402 & 3 & 4,2 & & ,01 \\
\hline 227 & 14 & 0 & & 0 & ( & 0 & 0 & 1 & 0 & & & & & & 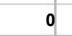 \\
\hline 228 & 14 & 0 & & 0 & & 0 & 0 & & 0 & & 92 & & & & \\
\hline 229 & 14 & 0 & 0 & 0 & 0 & 0 & 0 & 1 & 0 & 0 & 94363 & 92,68 & 4,43 & $-4,61$ & 0 \\
\hline 230 & 15 & 0 & & 0 & c & 0 & 1 & ( & 0 & & 81915 & 1 & 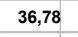 & & \\
\hline 23 & 15 & 0 & & 0 & ( & 0 & & & 0 & & & & & & \\
\hline 232 & & 0 & & ( & ( & 0 & 1 & & 0 & & & 5 & & & \\
\hline 233 & 15 & 0 & 0 & 0 & c & 0 & 1 & ( & 0 & 0 & 87081 & 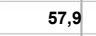 & 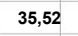 & -3 & 27 \\
\hline 234 & 15 & 0 & & 0 & & 0 & 1 & ( & 0 & & & 4 & & & \\
\hline 23 & & & & ( & & 0 & & & 0 & & & & & -3, & \\
\hline 236 & 15 & 0 & 0 & 0 & & 0 & 1 & ( & 0 & & & & & & \\
\hline 237 & 15 & 0 & 0 & 0 & 0 & 0 & 1 & 0 & 0 & 1 & 2432 & 58 & 09 & $-4,28$ & 0,22 \\
\hline 238 & 15 & 0 & & 0 & & 0 & 1 & & 0 & & & & & $-5,69$ & \\
\hline 23 & & 0 & & 0 & & 0 & & & 0 & & & & & & \\
\hline 240 & 15 & 0 & 0 & 0 & c & 0 & 1 & 0 & 0 & & & & & & \\
\hline 241 & 15 & 0 & 0 & 0 & c & 0 & 1 & 0 & 0 & 0 & & 59,66 & 67 & $-8,79$ & 0,27 \\
\hline $24 \mathrm{i}$ & 15 & 0 & & 0 & & 0 & 1 & & 0 & & & & & & 0, \\
\hline 243 & & 0 & & 0 & & 0 & 1 & & 0 & & & & & & \\
\hline 244 & 15 & 0 & & 0 & 0 & 0 & 1 & 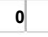 & 0 & & & & & & \\
\hline 245 & 15 & 0 & 0 & 0 & 0 & 0 & 1 & 0 & 0 & & 1195 & 75 & 87 & ,09 & 0,26 \\
\hline
\end{tabular}




\begin{tabular}{|c|c|c|c|c|c|c|c|c|c|c|c|c|c|c|c|}
\hline & ID & 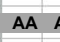 & & 3A & BB & MD & LV F & PL N & IL Rt & EC & DIE & 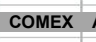 & A & REF & ODP \\
\hline 246 & 15 & 0 & 0 & 0 & 0 & 0 & 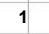 & 0 & 0 & 0 & 23884 & 60,01 & 39,86 & 0 & 0,28 \\
\hline 247 & 15 & 0 & 0 & 0 & 0 & 0 & 1 & 0 & 0 & 0 & 26581 & 57,69 & 39,74 & 0 & 0,28 \\
\hline 248 & & & & 0 & 0 & 0 & & 0 & 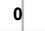 & 0 & 1758 & 3,33 & $\begin{array}{ll}3 & 9,67\end{array}$ & $-1,84$ & 0,86 \\
\hline 249 & & & & 0 & 0 & 0 & 1 & 0 & 0 & 0 & 3411 & 71,12 & $\begin{array}{l}28,98 \\
\end{array}$ & & 0,83 \\
\hline 250 & 16 & 0 & 0 & 0 & 0 & 0 & 1 & 0 & 0 & 0 & 66274 & 73,06 & $\begin{array}{l}6,77 \\
6\end{array}$ & & 84 \\
\hline 251 & 10 & & 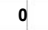 & & 0 & 0 & 1 & 0 & 0 & 0 & 3000 & 72,02 & 2. 9,92 & $-1,44$ & 0,89 \\
\hline 252 & & & 0 & 0 & 0 & 0 & 1 & 0 & 0 & 0 & 8295 & 0,01 & $9, \mathbf{6 1}$ & 0 & 0,88 \\
\hline 253 & 16 & 0 & c & 0 & 0 & 0 & 1 & 0 & 0 & 0 & 66894 & 74,62 & 27,65 & $-1,4$ & 76 \\
\hline 254 & 16 & 0 & 0 & 0 & 0 & 0 & 1 & 0 & 0 & 0 & 32669 & 73,27 & 7,75 & $-1,33$ & 0,8 \\
\hline 255 & & 0 & 0 & 0 & 0 & 0 & 1 & 0 & 0 & 1 & 6732 & 67,65 & $8,8,17$ & $-1,96$ & 0,89 \\
\hline 256 & 16 & 0 & 0 & 0 & 0 & 0 & 1 & 0 & 0 & 0 & 289370 & 66,58 & 7,8 & $-2,15$ & 0,92 \\
\hline 257 & 16 & 0 & 0 & 0 & 0 & 0 & 1 & 0 & 0 & 0 & 0826 & 69,05 & $5 \quad 7,34$ & & 0,87 \\
\hline 258 & 16 & 0 & 0 & 0 & 0 & 0 & 1 & 0 & 0 & 1 & 88722 & 70,85 & $5 \quad 6,83$ & 0 & 0,94 \\
\hline 259 & & 0 & 0 & 0 & 0 & 0 & 1 & 0 & 0 & 1 & 6116 & 72,39 & 6,44 & $-3,4$ & 0,89 \\
\hline 260 & 16 & 0 & 0 & 0 & 0 & 0 & 1 & 0 & 0 & 0 & 25378 & 73,19 & $\begin{array}{l}3,66 \\
\end{array}$ & $-4,15$ & 0,95 \\
\hline 261 & 16 & 0 & 0 & 0 & 0 & 0 & 1 & 0 & 0 & 0 & 26628 & 74,94 & 6,21 & $-4,97$ & 0,89 \\
\hline 262 & 16 & 0 & 0 & 0 & 0 & 0 & 1 & 0 & 0 & 1 & 21329 & 67,13 & $\begin{array}{ll}3 & 8,19\end{array}$ & $-4,7$ & 1,06 \\
\hline 263 & 10 & 0 & 0 & 0 & 0 & 0 & 1 & 0 & 0 & 0 & 3263 & 68,41 & $\begin{array}{l}8,38 \\
\end{array}$ & $-5,53$ & 1,05 \\
\hline 264 & & 0 & 0 & 0 & 0 & 0 & 1 & 0 & 0 & 0 & 26394 & 69,83 & $\begin{array}{ll}3 & 7,97\end{array}$ & $-6,56$ & 0,96 \\
\hline 265 & & c & 0 & 0 & 0 & 0 & 1 & 0 & 0 & & 5366 & 68,31 & 8,05 & $-7,19$ & 0,93 \\
\hline 266 & & 1 & 0 & 0 & 0 & 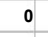 & 0 & 0 & 1 & & 769 & ,59 & 9,95 & 0 & 0,42 \\
\hline 267 & 17 & 1 & 0 & 0 & 0 & 0 & 0 & 0 & 1 & & 31103 & 81,04 & $4 \quad 12,22$ & 0 & 0,04 \\
\hline 268 & 17 & 1 & 0 & 0 & 0 & 0 & 0 & 0 & 1 & 0 & 30761 & 77,02 & 2) 11,84 & 0 & 0,41 \\
\hline 269 & & 1 & 0 & 0 & 0 & 0 & 0 & 0 & 1 & & 29940 & 82,55 & 5 & 0 & 31 \\
\hline 270 & 17 & 1 & 0 & 0 & 0 & 0 & 0 & 0 & 1 & 0 & 30327 & 90,25 & $5,7,78$ & 0 & 0,42 \\
\hline 271 & 17 & 1 & 0 & 0 & 0 & 0 & 0 & 0 & 1 & & 31082 & 89,34 & 5,94 & $-4,45$ & 0,06 \\
\hline 272 & 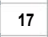 & 1 & 0 & 0 & 0 & 0 & 0 & 0 & 1 & & 32752 & 87,84 & $\begin{array}{l}4,26 \\
4\end{array}$ & $-6,21$ & 0,16 \\
\hline 273 & & 0 & 0 & 0 & 0 & 0 & 0 & 0 & 1 & & 10 & & 7 & $-8,49$ & 0,52 \\
\hline 274 & 17 & 0 & 0 & 0 & 0 & 0 & 0 & 0 & 1 & 0 & 37015 & 95,66 & 97 & -0, & 0,13 \\
\hline 275 & $\pi$ & 0 & 0 & 0 & 0 & 0 & 0 & 0 & 1 & 0 & 39278 & 85,28 & 6,5 & $-11,03$ & 32 \\
\hline 276 & 17 & . & 0 & 0 & 0 & 0 & 0 & 0 & 1 & ( & 41164 & 89,82 & ,23 & 0 & $-0,04$ \\
\hline 277 & 17 & 0 & 0 & 0 & 0 & 0 & 0 & 0 & 1 & & 40715 & 5,94 & 5,69 & & 0 \\
\hline 278 & 17 & 0 & 0 & 0 & 0 & O & 0 & 0 & 1 & 0 & 43598 & 116,87 & 5,47 & 0 & 0 \\
\hline 279 & 18 & 0 & c & 0 & 0 & 0 & 1 & 0 & 0 & & 2023 & 77,3 & $\begin{array}{l}3,95 \\
\end{array}$ & 6,46 & 0,33 \\
\hline 280 & 18 & 0 & 0 & 0 & 0 & 0 & 1 & 0 & 0 & & 21 & 79,82 & 9 & & 0,32 \\
\hline 281 & 18 & 0 & 0 & t & 0 & 0 & 1 & 0 & 0 & 1 & 2166 & 89,35 & $5 \quad 5,49$ & 9,09 & 0,32 \\
\hline 282 & 18 & 0 & 0 & 0 & 0 & 0 & 1 & 0 & 0 & 2 & 2222 & 88,89 & $\begin{array}{ll}9 \\
\end{array}$ & 30,03 &, 31 \\
\hline 283 & 18 & 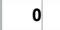 & 0 & 0 & 0 & 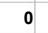 & $\mathrm{T}$ & 0 & 0 & 0 & 2288 & 90,1 & 1),27 & 1,76 & 0,34 \\
\hline 284 & 18 & 0 & 0 & 0 & 0 & 0 & 1 & 0 & 0 & 0 & 28 & 3,25 & $5 \quad 4,93$ & - & 0,32 \\
\hline 285 & 18 & 0 & 0 & 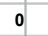 & 0 & S & 1 & 0 & 0 & 0 & 355 & 96,17 & 4,77 & 10,99 & 0,33 \\
\hline 286 & 18 & 0 & 0 & 0 & 0 & 0 & 1 & 0 & 0 & 1 & 2397 & 91,24 & 4,78 & 7,64 & 0,32 \\
\hline 28 & & 0 & 0 & 0 & 0 & 0 & 1 & 0 & 0 & 0 & 51 & & 3 & $\therefore$ & 0,36 \\
\hline 288 & 18 & 0 & 0 & 0 & 0 & 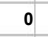 & 1 & 0 & 0 & 0 & 22 & 14 & $\begin{array}{l}4,72 \\
4\end{array}$ & 2 & 0,39 \\
\hline 289 & 18 & 0 & 0 & 0 & 0 & 0 & 1 & 0 & 0 & 0 & 2584 & 00,62 & 2) 4,64 & 51 & 0,42 \\
\hline 290 & 18 & 0 & 0 & 0 & 0 & 0 & 1 & 0 & 0 & 0 & 2669 & 1,94 & 58 &, 88 & 38 \\
\hline 291 & 18 & 0 & 0 & 0 & 0 & 0 & 1 & 0 & 0 & & 63 & 89 & 78 & 4 & 0,37 \\
\hline 292 & 18 & 0 & 0 & 0 & 0 & 0 & 1 & 0 & 0 & 0 & 2829 & 15,37 & 5,1 & 1,76 & 0,42 \\
\hline 293 & 18 & 0 & 0 & 0 & 0 & 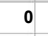 & 1 & 0 & 0 & 0 & 2864 & 7,32 & 25,64 & 9,91 & 0,44 \\
\hline 29 & & & 0 & 0 & o & S & 1 & 0 & 0 & 0 & 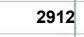 & 77 & 2 & & 9 \\
\hline 295 & 18 & 0 & 0 & 0 & 0 & 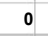 & 1 & 0 & 0 & & & 08 & 3 & & 6 \\
\hline 296 & 18 & 0 & 0 & 0 & 0 & 0 & 1 & 0 & 0 & 0 & 40 & 24,18 & 12 & 0 & ,47 \\
\hline 297 & 19 & 0 & 0 & 0 & 0 & 0 & 1 & 0 & 0 & 1 & 781 & 80,75 & ,38 &, 43 & 0 \\
\hline 298 & 19 & 0 & 0 & 0 & 0 & 0 & 1 & 0 & 0 & 0 & 94 & 75 & 5 & 02 & 0 \\
\hline 299 & 19 & 0 & , & 0 & 0 & 0 & 1 & 0 & 0 & & 635 & 1,98 & 3 & & ,15 \\
\hline 300 & 19 & 0 & 0 & 0 & 0 & 0 & 1 & 0 & 0 & & 4849 & 1,68 & $\begin{array}{ll}3 & 3,76\end{array}$ & 82 & 14 \\
\hline 301 & 19 & & 0 & 0 & 0 & 0 & 1 & 0 & 0 & & 25 & & 3,2 & & 0,14 \\
\hline 302 & 19 & 0 & c & 0 & c & 0 & 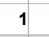 & 0 & 0 & & 46 & & & & 0 , \\
\hline 303 & 19 & 0 & 0 & 0 & 0 & 0 & 1 & 0 & 0 & 1 & 192 & 07 & 49 & $\begin{array}{c}-13,32 \\
\end{array}$ & 0,11 \\
\hline 304 & 19 & 0 & 0 & 0 & 0 & 0 & 1 & 0 & 0 & 0 & 175 & 84 & 4 & $-13,09$ & 0,13 \\
\hline 305 & 19 & 0 & 0 & 0 & 0 & 0 & 1 & 0 & 0 & 0 & 37 & 23 & 3 & $-14,52$ & 0,1 \\
\hline 306 & & 0 & & & & 0 & & 0 & 0 & & 955 & 83 & 3 & & 99 \\
\hline 307 & 19 & 0 & 0 & 0 & 0 & 0 & 1 & 0 & 0 & & 8449 & 6,45 & 76 & 63 & 06 \\
\hline 308 & & & 0 & 0 & 0 & 0 & 1 & 0 & 0 & 0 & 7481 & 2 & 2 & & 0,51 \\
\hline 309 & 2 & & c & 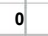 & 0 & 0 & 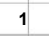 & 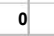 & 0 & & & & & & 0,31 \\
\hline 310 & 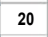 & 1 & c & 0 & c & 0 & & 0 & & & & & 5 & & \\
\hline 311 & 20 & 1 & 0 & 0 & 0 & 0 & 1 & 0 & 0 & 0 & 9324 & 33 & 3 & & 0,24 \\
\hline 312 & 20 & & 0 & 0 & 0 & 0 & 1 & 0 & 0 & & 10072 & 94,68 & 3 & 1 & 0,41 \\
\hline 313 & & & & & & 0 & & 0 & & & & & 1 & & 2 \\
\hline 314 & & 1 & & 0 & c & 0 & & 1 & & & 11285 & 45 & 5 & 81 &, 02 \\
\hline 31 & 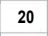 & 1 & 0 & 0 & 0 & 0 & 0 & ${ }^{\circ}$ & 0 & 0 & 12181 & 95,6 & 8,01 & 0 & $-0,1$ \\
\hline 316 & 20 & & c & 0 & $c_{-1}$ & 0 & & 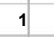 & 0 & & 13940 & 90 & 6,7 & & $-0,03$ \\
\hline 317 & & & & & & & & 1 & & & & & & & \\
\hline $31 \mathrm{C}$ & 2 & 1 & 0 & 0 & 0 & 0 & & 0 & & & & & & & \\
\hline 319 & 20 & 0 & 0 & 0 & 0 & 0 & 1 & 0 & 0 & 0 & 093 & 19,28 & 4,24 & 2 & 0,08 \\
\hline 320 & 2 & & c & 0 & 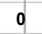 & 0 & 1 & 0 & & & 953 & 59 & 9 & 39 & 0,1 \\
\hline 321 & & & & 0 & & 0 & & 0 & & & & & & & \\
\hline 322 & 2 & & 0 & 0 & 0 & 0 & 1 & 0 & & & & & & & \\
\hline 323 & 20 & 0 & 0 & 0 & 0 & 0 & 1 & 0 & 0 & & 187 & & 5,92 & & 02 \\
\hline 324 & & & & 0 & & 0 & & 0 & & & & & & & \\
\hline 32 & 22 & & 0 & 0 & c & 0 & & 0 & & & & & & & \\
\hline 326 & 22 & 0 & 0 & 0 & 0 & 0 & c & 0 & & & & & & & \\
\hline 327 & 22 & 0 & 0 & 0 & 0 & 0 & 0 & 0 & & & 502 & , 47 & 2,34 & & ,02 \\
\hline
\end{tabular}




\begin{tabular}{|c|c|c|c|c|c|c|c|c|c|c|c|c|c|c|c|}
\hline & ID & AA & & & & MD & LV & & & & PIB & co & AGRI & PREF & ODP \\
\hline 328 & 22 & 0 & 0 & 0 & 0 & 0 & 0 & 0 & 1 & 0 & 34748 & 90,16 & 2,8 & 0 & $-0,02$ \\
\hline 329 & 22 & 0 & & 0 & 0 & 0 & 0 & 0 & 1 & 0 & 41427 & 90,37 & 2,03 & 0 & $-0,01$ \\
\hline 330 & & & & 0 & 0 & 0 & & 0 & 1 & 0 & 44530 & 4,75 & 2,32 & $-4,35$ & 0 \\
\hline 331 & & 0 & & 0 & 0 & 0 & & 0 & 1 & 0 & 6184 & 98,57 & 2,21 & $-5,47$ & 0 \\
\hline 332 & 22 & 0 & & & 0 & 0 & 0 & 0 & 1 & 0 & 66289 & 96,11 & 15 & $-0,38$ & 0 \\
\hline .333 & & & & & 0 & 0 & & 0 & 1 & & 198 & 43 & 19 & $-4,84$ & 0 \\
\hline 334 & & & & 0 & o & 0 & & 0 & 1 & 0 & 324 & 14 & 11 & 34 & 0 \\
\hline 335 & 22 & 0 & & 0 & 0 & 0 & 0 & 0 & 1 & 0 & 104433 & 86,07 &, 54 & & 0 \\
\hline 336 & & 0 & & & 0 & 0 & 0 & 0 & 1 & 0 & 18401 & 7,54 & 47 & 0 & 0 \\
\hline 337 & 22 & 0 & & 0 & 0 & 0 & 0 & 0 & 1 & 0 & 4179 & 3,83 & 63 & $-2,18$ & 0 \\
\hline 338 & 24 & & & 0 & 0 & 0 & 1 & 0 & 0 & 0 & 186132 & 43,61 & 10,49 & 41 & $-0,25$ \\
\hline 339 & & 0 & & 0 & 0 & 0 & 1 & 0 & 0 & 0 & 94136 & 46,67 & 69 & 65 & $-0,25$ \\
\hline 340 & & & & 0 & 0 & 0 & 1 & 0 & 0 & 0 & 99184 & 46,85 & 08 & 25 & $-0,33$ \\
\hline 341 & 24 & 0 & & 0 & 0 & 0 & 1 & 0 & 0 & 0 & 200179 & 48,9 & 11,41 & 22 & $-0,38$ \\
\hline 342 & & 0 & & 0 & 0 & 0 & 1 & 0 & 0 & 0 & 04984 & 46,86 & 10,32 & 9 & $-0,41$ \\
\hline 343 & & 0 & & 0 & 0 & 0 & 1 & 0 & 0 & 0 & 13593 & 51,44 & 9,16 & 6,49 & $-0,37$ \\
\hline 344 & & 0 & & 1 & 0 & 0 & 1 & 0 & 0 & 0 & 9360 & 1,8 & 8,88 & 33 & $-0,36$ \\
\hline 345 & & 0 & & 1 & 0 & 0 & 1 & 0 & 0 & 0 & 227477 & 59,76 & 10,26 & 1 & $-0,45$ \\
\hline 346 & & 0 & & 1 & 0 & 0 & 1 & 0 & 0 & 0 & 234186 & 51,4 & 9,65 & 22 & $-0,38$ \\
\hline 347 & & 0 & & 0 & 0 & 0 & 1 & 0 & 0 & 0 & 244852 & ,08 & 8,6 & 9 & 28 \\
\hline 348 & & 0 & & 0 & 0 & 0 & 1 & 0 & 0 & 0 & 7773 & 3,15 & 8,01 & 8 & $-0,27$ \\
\hline 349 & & 0 & & & 0 & 0 & 1 & 0 & 0 & 0 & 72169 & 60,28 & 7,06 & 56 & $-0,27$ \\
\hline 350 & & 0 & & 0 & 0 & 0 & 1 & 0 & 0 & 0 & 6759 & 63,68 & 7,18 & 81 & $-0,28$ \\
\hline 351 & & 0 & & 0 & 0 & 0 & 1 & 0 & 0 & 0 & 5910 & 72,87 & 7,58 & 93 & ,4 \\
\hline 352 & 24 & 0 & & 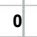 & 0 & 0 & 1 & 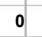 & 0 & 0 & 291358 & 55,42 & 9,75 & 12,39 & $-0,37$ \\
\hline 353 & & 0 & & 0 & 0 & 0 & 1 & 0 & 0 & 0 & 300215 & 55,99 & 9, & 1 & $-0,28$ \\
\hline 354 & & c & & 0 & 0 & 0 & 1 & 0 & 0 & 0 & 309859 &, 02 & 9,5 & 51 & 34 \\
\hline 355 & & 0 & & 0 & 0 & 0 & 1 & 0 & 0 & 0 & 316737 &, 74 & 9,72 & 47 & $-0,28$ \\
\hline 356 & & 1 & & 0 & 0 & 0 & 0 & 1 & 0 & 0 & 806 & 53,74 & 20,75 & 5 & $-1,71$ \\
\hline 357 & & 1 & & 0 & 0 & 0 & 0 & 1 & 0 & 0 & 846 & 15 & 26,23 & 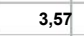 & $-1,32$ \\
\hline 358 & & 0 & & 0 & 0 & 0 & 1 & 0 & 0 & 0 & 997 & 12 & & & 82 \\
\hline 359 & 25 & 0 & & 年 & 0 & 0 & 1 & 0 & 0 & 0 & 1131 & 0,39 & 21,78 & 0,27 & $-0,3$ \\
\hline 360 & & 0 & & 0 & 0 & 0 & 1 & 0 & 0 & 0 & 1238 & 117,41 & 29,23 & 19 & $-0,6$ \\
\hline 361 & & c & & 0 & 0 & 0 & 1 & 0 & 0 & 0 & 1090 & 5,11 & 32,94 & 34 & $-0,49$ \\
\hline 362 & 25 & 0 & & 0 & 0 & 0 & 1 & 0 & 0 & 0 & 012 & 105,92 & 35,85 & 82 & $-1,73$ \\
\hline 363 & & 1 & & 0 & 0 & 0 & 1 & 0 & 0 & 0 & 994 & 104,35 & 41,53 &, 3 & $-1,41$ \\
\hline 364 & & 0 & & 0 & 0 & 0 & 1 & 0 & 0 & 0 & 1034 & 103,69 & 46,93 & 52 & $-0,2$ \\
\hline 365 & & 1 & & 0 & 0 & 0 & 1 & 0 & 0 & 0 & 7 & & & & 06 \\
\hline 366 & 26 & 1 & & 0 & 0 & 0 & 1 & 0 & 0 & 1 & 185903 &, 51 & 30,55 & 7 & $-0,05$ \\
\hline 367 & 26 & 1 & & 0 & 0 & 0 & 1 & 0 & 0 & 1 & 200982 & 23,34 & 27,04 & 26 & $-0,04$ \\
\hline 368 & & 1 & c & 0 & 0 & 0 & 1 & 0 & 0 & 0 & 208720 & 35 & 27,1 & 4 & ,03 \\
\hline 369 & 26 & 1 & & 0 & 0 & 0 & & 0 & 0 & 0 & 201654 & 38 & 27,1 & & $-0,03$ \\
\hline 370 & & 1 & & 0 & 0 & 0 & 1 & 0 & 0 & 1 & 200063 & 22,62 & 25,44 & 7,05 & $-0,02$ \\
\hline 371 & & 1 & & 0 & 0 & 0 & 0 & 1 & 0 & 1 & 191242 & 85 & 27,78 & 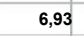 & $-0,06$ \\
\hline 372 & & 0 & & 0 & 0 & 0 & 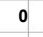 & 1 & 0 & 4 & 17 & & & & 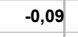 \\
\hline 373 & 26 & 0 & & 0 & 0 & 0 & 1 & 0 & 0 & 1 & 185466 & 64 & 34,7 & 36 & $-0,09$ \\
\hline 374 & 26 & 0 & 1 & 0 & 0 & 0 & 1 & 0 & 0 & 0 & 202213 & 36,97 & 30,97 & 4,34 & $-0,05$ \\
\hline 375 & & 0 & 1 & 0 & O & 0 & 1 & 年 & 0 & 0 & 0814 & 8 & 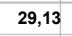 & 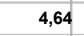 & 5 \\
\hline 376 & & 0 & & 0 & o & 0 & 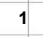 & 0 & 0 & 5 & 23 & 9 & & & 4 \\
\hline 377 & 26 & 1 & & 0 & 0 & 0 & 1 & 0 & 0 & 0 & 258436 &, 86 & 30,95 & 32 & $-0,03$ \\
\hline 378 & & 1 & & 0 & 0 & 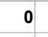 & 1 & 0 & 0 & 0 & 6382 & 27 & 98 & 9,5 & 33 \\
\hline 379 & & 1 & & 0 & o & 0 & 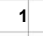 & 0 & 0 & 1 & 266516 & 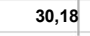 & & 3 & $-0,03$ \\
\hline 380 & 26 & 1 & & 0 & 0 & 0 & & 0 & 0 & 0 & $2 s$ & & & & $-0, c$ \\
\hline 381 & 26 & 1 & 0 & 0 & 0 & 0 & 1 & 0 & 0 & 0 & 316169 & .57 & 30,59 & 13 & $-0,02$ \\
\hline 382 & 26 & 0 & 0 & 0 & . & 0 & 1 & 年 & 0 & 3 & 8704 & 2 & 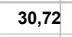 & 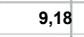 & 03 \\
\hline 383 & 2 & 0 & & 0 & 0 & 0 & & 1 & 0 & 1 & 695120 & 3 & 2 & 6 & $-0,04$ \\
\hline 384 & & 0 & & 0 & 0 & 0 & & 1 & 0 & 0 & 710465 & 4 & 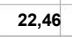 & 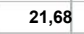 & $-0,03$ \\
\hline 385 & & 0 & & 0 & 0 & 0 & & 1 & 0 & 4 & 734586 & 8 & 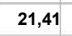 & 17,89 & $-0,03$ \\
\hline 386 & & 0 & & 0 & 0 & 0 & & 1 & 0 & 1 & 7071 & & & & -0, \\
\hline 387 & 2 & 0 & & 0 & 0 & 0 & & 1 & 0 & 0 & 740528 & & & & $-0,02$ \\
\hline 388 & 27. & 0 & & 0 & 0 & 0 & 0 & 1 & 0 & 7 & 770983 & 4 & 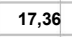 & 16,03 & $-0,04$ \\
\hline 389 & 27 & 0 & 1 & 0 & 0 & 0 & 0 & 1 & 0 & 4 & 783765 & 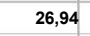 & 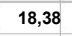 & 2,77 & $-0,04$ \\
\hline 390 & 27 & & & 0 & 0 & 0 & & 0 & 0 & 5 & 694 & 2 & 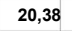 & 3,81 & $-0,04$ \\
\hline 391 & & & & 1 & & 0 & & 0 & 0 & & 8 & & & & \\
\hline 392 & 27 & 0 & & 0 & 0 & 0 & & 0 & 0 & 0 & 3965 & & 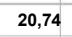 & ,18 & $-0,02$ \\
\hline 393 & 27 & 0 & 1 & 0 & 0 & 0 & 1 & 0 & 0 & 0 & 891630 & & & & \\
\hline 394 & & & & 0 & c & 0 & & 0 & 0 & 0 & 9 & & & & $-0,01$ \\
\hline 395 & & & & 0 & & 0 & & 0 & 0 & & & & & & \\
\hline 39 & 27 & 1 & & 0 & 0 & 0 & 1 & 0 & 0 & 1 & 33. & & & & 03 \\
\hline 397 & 27 & 1 & & 0 & 0 & 0 & 1 & 0 & 0 & 0 & 2010 & 1 & 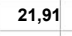 & 22,27 & $-0,02$ \\
\hline 398 & & & & & & 0 & & & & & & & & & \\
\hline 399 & & & & 0 & c & 0 & & 0 & & & & & & & \\
\hline 400 & 27 & 1 & c & 0 & 0 & 0 & 1 & 0 & 0 & 1 & 11751 & & & ;,37 & 05 \\
\hline 401 & 28 & 0 & & 0 & c & 0 & 1 & 0 & 0 & 1 & 82 & & & & $-0,2$ \\
\hline 40 & & & & 0 & & & & & & & & & & & \\
\hline 40 & 28 & & & 0 & 0 & 0 & & 0 & 0 & & & & & & \\
\hline 404 & 28 & 0 & 1 & 0 & 0 & 0 & 1 & 0 & 0 & 0 & 9 & & & & -0, \\
\hline 405 & 28 & & & 0 & & 0 & & 0 & & 0 & & & & & 1 \\
\hline 406 & 28 & & & 0 & & 0 & & 0 & & & & & & & -0, \\
\hline 407 & 28 & 0 & & 0 & 0 & 0 & I & 0 & 0 & & & & & & \\
\hline 408 & 28 & 0 & & 0 & 0 & 0 & 1 & 0 & & 2 & 6908 & & 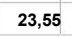 & 7,2 & 0,0 \\
\hline & 28 & & & & & 1 & & & & & & & & 67 & 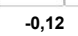 \\
\hline
\end{tabular}




\begin{tabular}{|c|c|c|c|c|c|c|c|c|c|c|c|c|c|c|c|}
\hline & & AA & & & & & & & & & PIB & COMEX & AGRI & PREF & ODP \\
\hline 410 & 28 & 0 & 1 & 0 & 0 & 0 & 1 & 0 & 0 & 0 & 117852 & 68,26 & 19,81 & 5,73 & $-0,06$ \\
\hline 411 & 28 & & & 0 & 0 & 0 & 1 & 0 & 0 & 1 & 24404 & 69,97 & 16,99 & 4,95 & $-0,15$ \\
\hline 412 & & & & 0 & 0 & 0 & & 0 & 0 & & 8884 & 71,94 & 14,87 & 59 & $-0,07$ \\
\hline 413 & & & & 0 & 0 & 0 & 1 & 0 & 0 & & 36587 & 75,79 & 15,14 & 7,99 & $-0,07$ \\
\hline 414 & & 1 & & & 0 & 0 & 1 & 0 & 0 & & 41084 & 81,04 & 16,48 & 6,79 & $-0,06$ \\
\hline 415 & & & & 0 & 0 & 0 & & 0 & 0 & & 39622 & 66,77 & 1 & 7,499 & $-0,05$ \\
\hline 416 & 28 & 1 & 0 & 0 & 0 & 0 & 1 & 0 & 0 & & 147655 & 69,73 & 15,46 & 7,02 & $-0,1$ \\
\hline 417 & 28 & 1 & 0 & 0 & 0 & 0 & 1 & 0 & 0 & 0 & 56278 & 72,95 & 15,82 & 6,3 & $-0,07$ \\
\hline 418 & 20 & 0 & & 0 & 0 & 0 & & 0 & 0 & & 64806 & 68,81 & 15,98 & 6,31 & $-0,05$ \\
\hline 419 & 29 & 0 & 0 & 1 & 0 & 0 & 0 & 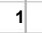 & 0 & 0 & 115545 &, 5 & 22,13 & ,92 & $-0,19$ \\
\hline 420 & 29 & 0 & 0 & 1 & 0 & 0 & 0 & 1 & 0 & & 117921 & 36,04 & 22,28 & 14,07 & $-0,2$ \\
\hline 421 & 29 & 0 & 0 & 1 & 0 & 0 & 0 & 1 & 0 & 1 & 21966 & 35,6 & 23,26 & 13,69 & $-0,19$ \\
\hline 422 & & 0 & & 1 & 0 & 0 & & T & 0 & 0 & 2661 & ;,91 & 23,49 & 13,99 & $-0,17$ \\
\hline 423 & 29 & 0 & 0 & 1 & 0 & 0 & & 1 & 0 & & 117504 & 36,15 & 22,24 & 16,75 & $-0,36$ \\
\hline 424 & 29 & 0 & 0 & 1 & 0 & 0 & 0 & 1 & 0 & & 2698 & 32,67 & 19,13 & 17,6 & $-0,19$ \\
\hline 425 & & 0 & 0 & 1 & 0 & 0 & 0 & 1 & 0 & 2 & 24756 & 33,9 & 18,27 & 15,61 & $-0,4$ \\
\hline 426 & 29 & 0 & 0 & 1 & 0 & 0 & & 1 & 0 & 0 & 7880 & 32,98 & 19,07 & 16,4 & $-0,46$ \\
\hline 427 & 29 & 0 & 0 & 1 & 0 & 0 & & 1 & 0 & & 132891 & 36,52 & 18,46 & 14,78 & $-0,88$ \\
\hline 428 & & 0 & c & 1 & 0 & 0 & & 1 & 0 & & 9978 & 35,86 & 17,02 & 13,83 & $-0,46$ \\
\hline 429 & & 0 & 0 & 1 & 0 & 0 & & 1 & 0 & & 5566 & 63 & 16,12 & 14 & 44 \\
\hline 430 & 29 & 0 & 0 & 1 & 0 & 0 & & 1 & 0 & 0 & 6383 & 38,17 & 1 & 12,67 & $-0,64$ \\
\hline 431 & 29 & 0 & 1 & 0 & 0 & 0 & 0 & 1 & 0 & & 67174 & 36,33 & 14,87 & 16,26 & $-0,36$ \\
\hline 432 & & 0 & 1 & 0 & 0 & 0 & 0 & 1 & 0 & 0 & 103 & 38,05 & 14,64 & 85 & $-0,41$ \\
\hline 433 & 29 & 0 & 1 & 0 & 0 & 0 & & 1 & 0 & 0 & 962 & 28 & 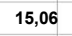 & 16,01 & $-0,47$ \\
\hline 434 & 29 & 0 & 1 & 0 & 0 & 0 & 0 & 1 & 0 & 0 & 182951 & 33,7 & 13,11 & 17,68 & $-0,24$ \\
\hline 435 & & 0 & 1 & 0 & 0 & 0 & 0 & 1 & 0 & & 195007 & 38,67 & 11,92 & 15,72 & $-0,32$ \\
\hline 436 & & 0 & 1 & 0 & 0 & 0 & 0 & 1 & 0 & & 2893 &, 3 & 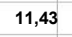 & 14 & 22 \\
\hline 437 & 30 & 0 & 1 & 0 & 0 & 0 & 1 & 0 & 0 & 1 & 2846 & 77,92 & 38,91 & ,48 & $-0,26$ \\
\hline 438 & 30 & 0 & 1 & 0 & 0 & 0 & 1 & 0 & 0 & 0 & 2960 & 82,1 & 42,01 & 10,2 & 0,11 \\
\hline 439 & & 0 & 1 & 0 & 0 & 0 & 1 & 0 & 0 & 0 & 13683 & 85,34 & 31,93 & 8,16 & 0,06 \\
\hline 440 & 30 & 0 & 1 & 0 & 0 & 0 & 1 & 0 & 0 & 0 & 14832 & 97,53 & 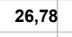 & 6,39 & $-0,13$ \\
\hline 441 & 30 & 0 & 1 & 0 & 0 & 0 & 1 & 0 & 0 & 1 & 16052 & 97,67 & 20,26 & 19 & 0,07 \\
\hline 442 & 30 & 0 & & 0 & 0 & 0 & 1 & 0 & 0 & 1 & 16341 & 94,39 & 21,03 & 7,82 & $-0,07$ \\
\hline 443 & & 0 & 1 & 0 & 0 & 0 & 1 & 0 & 0 & & & & & & 0 \\
\hline 444 & 30 & 0 & 1 & 0 & 0 & 0 & 1 & 0 & 0 & & 996 &, 02 & 21 & 21 & 0 \\
\hline 445 & 30 & 0 & 1 & 0 & 0 & 0 & 1 & 0 & 0 & 0 & 18085 & 95,2 & 20,69 & 37 & $-0,17$ \\
\hline 446 & & 0 & 1 & 0 & 0 & 0 & 1 & 0 & 0 & 0 & 18855 & 95,74 & 22 & 6,86 & $-0,07$ \\
\hline 447 & & 0 & 1 & 0 & 0 & 0 & & 0 & 0 & 1 & 19965 & 2,47 & & & $-0,13$ \\
\hline 448 & 30 & 0 & 1 & . & 0 & 0 & 1 & 0 & 0 & 0 & 21718 & 104,41 & 19,34 & 6,6 & $-0,14$ \\
\hline 449 & & 0 & 1 & 0 & 0 & 0 & T & 0 & 0 & & 23441 & 2,23 & 20,14 & 10,25 & $-0,23$ \\
\hline 450 & & & 1 & 0 & 0 & 0 & & 0 & 0 & & 81 & 63 & 35 & 16 & $-0,22$ \\
\hline 451 & 30 & 0 & 1 & 0 & 0 & 0 & & 0 & 0 & & 23837 & 3,98 & 1 & .5 & $-0,38$ \\
\hline 452 & 30 & 0 & 1 & 0 & 0 & 0 & 1 & 0 & 0 & 1 & 25018 & 79,1 & 26 & 1,86 & $-0,26$ \\
\hline 453 & 30 & 1 & 0 & 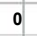 & 0 & 0 & 1 & 0 & 0 & & 148 & 79,4 & 92 & 91 & $-0,09$ \\
\hline 454 & 3 & 1 & 0 & 0 & 0 & 0 & & 0 & 0 & & 27 & 78,94 & & 49 & $-0,06$ \\
\hline 455 & 31 & 0 & 0 & 1 & 0 & 0 & & 0 & 1 & 0 & 31513 & 31,87 & 38,18 & 6,65 & $-0,21$ \\
\hline 456 & 31 & 0 & 0 & 1 & 0 & 0 & & 0 & 1 & & 33378 & 31,08 & 32,08 & 6,5 & $-0,15$ \\
\hline 457 & & & 0 & 1 & 0 & 0 & & 0 & 1 & & 440 & 9,36 & 3 & 7 & $-0,17$ \\
\hline 458 & 31 & 0 & 0 & 1 & 0 & 0 & & 0 & 1 & & 932 & 73 & & 4 & $-0,19$ \\
\hline 459 & 31 & 0 & 1 & 0 & 0 & 0 & & 0 & 1 & & 36256 & 26,59 & 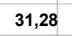 & 7,43 & $-0,21$ \\
\hline 460 & 31 & 0 & 1 & 0 & 0 & 0 & & 0 & 1 & & 3349 & 31 & 2 & 3,87 & $-0,28$ \\
\hline 461 & 3 & & 1 & 0 & 0 & 0 & . & 0 & 1 & & 42644 & 6 & 22 & 36 & $-0,21$ \\
\hline 462 & 31 & 0 & & 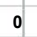 & 0 & 0 & & 0 & 1 & & 47790 & , 19 & 11,5 & 34 & $-0,18$ \\
\hline 463 & 32 & 0 & 0 & 1 & 0 & 0 & 1 & 0 & 0 & 0 & 306 & 4,22 & 38,55 & 89 & $-11,87$ \\
\hline 464 & & & 0 & 1 & 0 & 0 & & 0 & 0 & & 4 & ,71 & 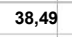 & 32 & $-19,81$ \\
\hline 465 & 32 & 0 & 1 & 0 & 0 & 0 & & 0 & 0 & & 3 & 13 & & & 6 \\
\hline 466 & 32 & 0 & 1 & 0 & 0 & 0 & & 0 & 0 & 0 & 336 & 26,02 & 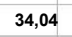 & 3,91 & $-4,06$ \\
\hline 467 & 32 & 0 & 1 & 0 & 0 & 0 & 1 & 0 & 0 & & 338 & 97,54 & 30,39 & 2,16 & 12 \\
\hline 468 & & & 1 & 0 & 0 & 0 & & 0 & 0 & 0 & 339 & 54 & 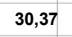 & 2,88 & $-6,19$ \\
\hline 469 & & 0 & & 0 & 0 & 0 & & 0 & 0 & & & 74 & & & 56 \\
\hline 470 & 32 & 0 & 1 & 0 & 0 & 0 & 1 & 0 & 0 & & 359 & 76 & 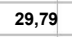 & 4,96 & ,46 \\
\hline 471 & 32 & & 1 & 0 & 0 & 0 & & 0 & 0 & & 371 &, 27 & 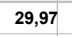 & 3,35 & 52 \\
\hline 477: & 32 & & 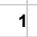 & S & 0 & 0 & & 0 & 0 & & & 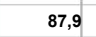 & & 2,09 & 8 \\
\hline 473 & & 0 & & 0 & 0 & 0 & & 0 & 0 & & & 5 & & & \\
\hline 474 & 32 & 0 & 1 & 0 & 0 & 0 & 1 & 0 & 0 & & & 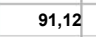 & 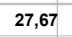 & & $-4,83$ \\
\hline 475 & & & 1 & 0 & 0 & 0 & & 0 & 0 & 0 & 434 & 3 & 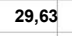 & 3,32 & $-5,05$ \\
\hline 476 & & & & 0 & 0 & 0 & & 0 & 0 & & & 5 & & 18,62 & $-7,56$ \\
\hline 477 & & & & 0 & c & 0 & & 0 & 0 & & & & & & \\
\hline 478 & 32 & 0 & 1 & 0 & 0 & 0 & 1 & 0 & 0 & & & 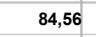 & & 53 & 41 \\
\hline 479 & 33 & & c & 1 & 0 & 0 & & 0 & 0 & & & 23 & 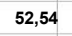 & 3,14 & $-4,24$ \\
\hline $48 \mathrm{C}$ & & & & & c & 0 & & & & & & & & & \\
\hline 48 & 33 & & c & 1 & c & 0 & & 0 & 0 & & & & & & \\
\hline 482 & 33 & 0 & 1 & 0 & 0 & 0 & 1 & 0 & 0 & & & 8 & 50,77 & & -2 \\
\hline 48 & 33 & & & 0 & 0 & 0 & & 0 & 0 & & & 104,97 & & & $-3,39$ \\
\hline 484 & & & & 0 & c & 0 & & 0 & & & & & 33 & & -2 \\
\hline 485 & 33 & & 1 & 0 & c & 0 & & 0 & 0 & & & & & & \\
\hline 486 & 33 & 0 & 1 & 0 & 0 & 0 & & 0 & 0 & & & 83,08 & & & $-1,99$ \\
\hline 487 & 33 & & & 0 & c & 0 & & 0 & & & & & & & -2, \\
\hline 488 & 33 & & & 0 & c & 0 & & 0 & & & & & & & \\
\hline 489 & 33 & 0 & 1 & 0 & 0 & 0 & & 0 & & & & & & & \\
\hline 490 & 33 & 0 & 1 & 0 & 0 & 0 & 1 & 0 & & 0 & 70 & 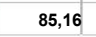 & 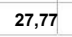 & 5,56 & $-3,21$ \\
\hline & 33 & & & & & 0 & & & & & 175 & & & 26 & \\
\hline
\end{tabular}




\begin{tabular}{|c|c|c|c|c|c|c|c|c|c|c|c|c|c|c|c|}
\hline s & ID & AA & & $3 A$ & BB I & MD L & & DL N & & $E C$ & PIB & NEX & AGRI & PREF & DDP \\
\hline 492 & 33 & 0 & 1 & 0 & 0 & 0 & 1 & 0 & 0 & 0 & 668 & 71,08 & 37 & 4,86 & $-6,75$ \\
\hline 493 & 34 & 0 & 0 & 1 & 0 & 0 & 1 & 0 & 0 & 0 & 10404 & 111,3 & 18,98 &, 77 & $-1,95$ \\
\hline 494 & & & & 1 & 0 & 0 & & 0 & 0 & 0 & 392 & 99,07 & 19,78 & 04 & $-0,91$ \\
\hline 495 & & & 0 & 1 & 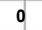 & 0 & 1 & 0 & 0 & 0 & 274 & 90,99 & 20,77 & 75 & $-0,97$ \\
\hline 496 & & 0 & 1 & 0 & 0 & 0 & 1 & 0 & 0 & 0 & 10572 & 81,85 & ,24 & 8,89 & $-0,26$ \\
\hline 497 & & 0 & 1 & 0 & 0 & 0 & 1 & 0 & 0 & 0 & 10960 & 88,15 & 19,23 & 8,1 & $-0,07$ \\
\hline 498 & & 0 & 1 & 0 & 0 & 0 & 1 & 0 & 0 & 0 & 11105 & 89,32 & 19,23 & 5,04 & $-0,86$ \\
\hline 499 & & 0 & 1 & 0 & 0 & 0 & 1 & 0 & 0 & 0 & 11204 & 90,49 & 16,63 & 5,5 & $-0,38$ \\
\hline 500 & & 0 & 1 & 0 & 0 & 0 & 1 & 0 & 0 & 0 & 11529 & 100,75 & 16,27 & 5,46 & $-0,33$ \\
\hline 501 & & & 1 & 0 & 0 & 0 & 1 & 0 & 0 & 0 & 11694 & 101,24 & 14,45 & 64 & $-0,23$ \\
\hline 502 & 4 & 0 & 1 & 0 & 0 & 0 & 1 & 0 & 0 & 0 & 11610 & 113,58 & 13,66 & 7,52 & $-0,65$ \\
\hline 503 & & 0 & 1 & 0 & 0 & 0 & 1 & 0 & 0 & 0 & 11096 & 86,89 & 22,28 & 17 & $-1,31$ \\
\hline 504 & & 0 & 1 & 0 & 0 & 0 & 1 & 0 & 0 & 0 & 10931 & 80,93 & 21,09 & 31 & $-1,11$ \\
\hline 505 & & 0 & 1 & 0 & 0 & 0 & 1 & 0 & 0 & 0 & 119 & 83,92 & 19,27 & 33 & $-0,28$ \\
\hline 506 & & 0 & 1 & 0 & 0 & 0 & 1 & 0 & 0 & 0 & 11052 & 82,16 & 19,19 & 6,73 & $-0,18$ \\
\hline 507 & & 0 & 1 & 0 & 0 & 0 & 0 & 1 & 0 & 0 & 90111 & 192,11 & 82 & 41 & $-0,13$ \\
\hline 508 & & 0 & 1 & 0 & 0 & 0 & 0 & 1 & 0 & 1 & 99124 & 81,77 & 10,38 & 2,41 & 0,47 \\
\hline 509 & & 0 & 1 & 0 & 0 & 0 & 0 & 1 & 0 & 0 & 6383 & 185,66 & 9,93 & 26 & 0,25 \\
\hline 510 & & 0 & 1 & 0 & 0 & 0 & 0 & 1 & 0 & 0 & 98554 & 209,49 & 10,43 & 2,04 & $-0,3$ \\
\hline 511 & & 0 & 1 & 0 & 0 & 0 & 0 & 1 & 0 & 0 & 4603 & 7,57 & 9,15 & 18 & $-0,2$ \\
\hline 512 & & 0 & 1 & 0 & 0 & 0 & 0 & 1 & 0 & 0 & 3869 & 1,41 & 7,0 & 11 & $-0,05$ \\
\hline 513 & & 0 & 1 & 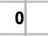 & 0 & 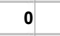 & 0 & 1 & 0 & 0 & 4459 & 3,36 & 7,49 & 8 & $-0,04$ \\
\hline 514 & & 0 & 1 & 0 & 0 & 0 & 0 & 1 & 0 & 0 & 120629 & 199,36 & 8,2 & 14 & $-0,09$ \\
\hline 515 & & 0 & 1 & 0 & 0 & 0 & 0 & 1 & 0 & 0 & 7612 & ,19 & 8,88 & 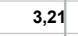 & $-0,1$ \\
\hline 516 & 35 & 0 & 1 & 0 & 0 & 0 & 0 & 1 & 0 & 0 & 5268 & 0,37 & 8,77 & 88 & $-0,26$ \\
\hline 517 & & 0 & 1 & 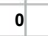 & 0 & 0 & 0 & 1 & 0 & 0 & 143534 & 3,85 & 8,09 & 2,98 & $-0,02$ \\
\hline 518 & & 0 & 1 & 0 & 0 & 0 & 0 & 1 & 0 & 0 & 151550 & 2,58 & 8,3 & 9 & $-0,15$ \\
\hline 519 & & 0 & 1 & 0 & 0 & 0 & & 1 & 0 & 0 & 1096 & 0,47 & 9,78 & 7 &, 11 \\
\hline 520 & & 0 & 1 & 0 & 0 & 0 & 0 & 1 & 0 & 0 & 8880 & 6,67 & 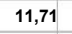 & 9 & $-0,07$ \\
\hline 521 & & 0 & 1 & 0 & 0 & 0 & 0 & 1 & 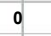 & 0 & 166324 & 162,56 & 11 & 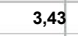 & $-0,07$ \\
\hline 522 & & 1 & 0 & 0 & 0 & 0 & 0 & 1 & 0 & 0 & 178675 & 7,94 & 12,44 & 3 & 0 \\
\hline 523 & 35 & 1 & 0 & 0 & 0 & 0 & 0 & 1 & 0 & 0 & 188133 & 4,94 & 1 & 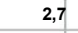 & $-0,01$ \\
\hline 524 & & 1 & 0 & 0 & 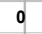 & 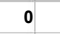 & 0 & 1 & 0 & 0 & 198431 & 147,84 & 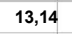 &, 8 & $-0,01$ \\
\hline 525 & & 0 & 1 & 0 & 0 & 0 & 1 & 0 & 0 & 0 & 4083 & 9,74 & 2 & 3,55 & $-0,57$ \\
\hline 526 & & 0 & 1 & 0 & 0 & 0 & 1 & 0 & 0 & 0 & 4311 & & & & $-0,44$ \\
\hline 527 & 36 & 0 & 1 & 0 & 0 & 0 & 1 & 0 & 0 & 0 & 4556 & 7,81 & 22,68 & 3,35 & -1 \\
\hline 528 & 30 & 0 & 1 & 0 & 0 & 0 & 1 & 0 & 0 & 0 & 4832 & 132,2 & 22,61 & 99 & $-0,97$ \\
\hline 529 & & 0 & 1 & 0 & 0 & 0 & 1 & 0 & 0 & 0 & 4959 & 1,35 & 20,03 & 5 & $-0,97$ \\
\hline 530 & & 0 & 1 & 0 & 0 & 0 & 1 & 0 & 0 & 0 & 5406 & 33 & 17 & & $-0,44$ \\
\hline 531 & & 0 & 1 & 0 & 0 & 0 & 1 & 0 & 0 & 0 & 5545 & 130,99 & 21,73 & 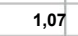 & $-0,46$ \\
\hline 532 & & 0 & 1 & 0 & 0 & 0 & 1 & 0 & 0 & 0 & 5662 & 120,6 & 23,89 & 88 & $-0,49$ \\
\hline 533 & & 0 & 1 & 0 & 0 & 0 & 1 & 0 & 0 & 0 & 5869 & 07 & & & 0,25 \\
\hline 534 & & 0 & 1 & 0 & 0 & 0 & 1 & 0 & 0 & 0 & 6207 & 0,41 & 23 & & $-0,52$ \\
\hline 535 & & 0 & 1 & . & 0 & 0 & 1 & 0 & 0 & 0 & 6284 & 5,71 & 24,4 & 1,11 & $-0,55$ \\
\hline 536 & & 0 & 1 & 0 & 0 & 0 & 1 & 0 & 0 & 0 & 6532 & 38 & 22 & 5 & 28 \\
\hline 537 & 36 & 0 & 1 & 0 & 0 & 0 & 1 & 0 & 0 & 0 & 7 & 04 & 24 & & $-0,86$ \\
\hline 538 & & 0 & 1 & 0 & 0 & 0 & 1 & 0 & 0 & 0 & 7298 & 119,03 & 25,19 & 4,43 & $-1,13$ \\
\hline 539 & & 0 & 1 & 0 & 0 & 0 & 1 & 0 & 0 & 0 & 7520 & 107,28 & 28,4 & 4,46 & $-1,76$ \\
\hline 540 & & 0 & 1 & 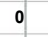 & 0 & 0 & 1 & 0 & 0 & 0 & 9 & 6,26 & 29,79 & 02 & 27 \\
\hline 541 & 36 & 1 & 0 & 0 & 0 & 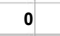 & & 0 & 0 & 0 & & 78 & 28 & & 6 \\
\hline 542 & & 1 & 0 & 0 & 0 & 0 & 1 & 0 & 0 & 0 & 8393 & 121,27 & 29,34 & 55 & $-1,55$ \\
\hline 543 & & 0 & 1 & 0 & 0 & 0 & 0 & 1 & 0 & 2 & 097 & 46,11 & 8,88 & 36 & ,12 \\
\hline 544 & & 0 & 1 & 0 & 0 & 0 & & 1 & 0 & 3 & 9703 & 50,72 & 8,52 & & $-0, C$ \\
\hline 545 & & 0 & 1 & 0 & 0 & 0 & & 1 & 0 & 0 & 705637 & 32 & 7,55 & 73 & $-0,02$ \\
\hline 546 & & 0 & 1 & 0 & 0 & 0 & 0 & 1 & 0 & 0 & 738815 & 51,78 & 7,32 & 16,3 & 0 \\
\hline 547 & & 0 & 1 & 0 & 0 & 0 & & 1 & 0 & 3 & 758520 & 51,27 & & & $-0,01$ \\
\hline 548 & & 0 & 1 & 0 & 0 & 0 & & 0 & 0 & 1 & & & & & 0, \\
\hline 549 & 37 & 0 & 1 & 0 & 0 & 0 & 1 & 0 & 0 & 1 & 3858 & 8,53 & 6,42 & ,9 & 02 \\
\hline 550 & & 0 & 1 & 0 & 0 & 0 & 1 & 0 & 0 & 0 & 794906 & 37 & 6,5 & 9 & 02 \\
\hline 551 & & 0 & 1 & 0 & 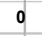 & 0 & 1 & 0 & 0 & 3 & 806215 & 24 & 7,08 & 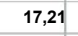 & $-0,02$ \\
\hline 552 & & 0 & 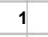 & 0 & 0 & 0 & & 0 & 0 & 0 & 0847 & & & & $-0,01$ \\
\hline 553 & & 0 & 1 & 0 & 0 & 0 & 1 & 0 & 0 & 2 & 866346 & 54,58 & 6,66 & 88 & 02 \\
\hline 554 & & & 0 & 0 & 0 & 0 & 1 & 0 & 0 & 1 & 909183 & & & 15,1 & $-0,03$ \\
\hline 555 & & & 0 & 年 & 0 & 0 & & 0 & 0 & 1 & & 08 & & & $-0,01$ \\
\hline 556 & & 1 & c & 0 & 0 & 0 & & 0 & 0 & 3 & 1454 & 58,07 & & & $-0,01$ \\
\hline 557 & 37 & 1 & 0 & 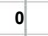 & 0 & 0 & 1 & 0 & 0 & 1 & 906320 & 56,13 & 7,98 & 15,81 & $-0,02$ \\
\hline 55 & & & 0 & 0 & 0 & 0 & 1 & 0 & 0 & 0 & 953440 & 61,02 & & 14,96 & $-0,05$ \\
\hline 559 & & & & 0 & 0 & 0 & & 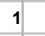 & 0 & & & & & & -0,08 \\
\hline 560 & & & 0 & 0 & 0 & 0 & & 1 & 0 & & 30829 & 53 & & & \\
\hline 561 & 38 & 0 & 0 & 1 & 0 & 0 & 1 & 0 & 0 & 0 & 5708 & 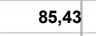 & 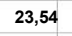 & & $-3,86$ \\
\hline 56 & 38 & & & 1 & 0 & 0 & & 0 & 0 & 0 & & 5 & & & $-3,16$ \\
\hline 563 & & & & 1 & c & 0 & & 0 & 0 & & & & & & \\
\hline 56 & 38 & 0 & 0 & 1 & 0 & 0 & 1 & 0 & 0 & & & & & & \\
\hline 565 & 38 & 0 & 0 & 1 & 0 & 0 & 1 & 0 & 0 & 0 & 7082 & 9 & 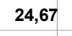 & & $-2,59$ \\
\hline 56 & 38 & & c & 1 & G & 0 & & 0 & 0 & & & & & & $-1,75$ \\
\hline 567 & & & & 0 & c & 0 & & 0 & 0 & & & & & & \\
\hline 568 & 38 & & 1 & 0 & 0 & 0 & 1 & 0 & 0 & & & & & & \\
\hline 569 & 38 & 0 & 1 & 0 & 0 & 0 & 1 & 0 & 0 & 0 & & 21 & 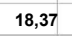 & & $-2,52$ \\
\hline 570 & 38 & & 1 & 0 & c & 0 & & 0 & 0 & & & & & & $-3,74$ \\
\hline $5 / 1$ & 38 & & 1 & 0 & 0 & 0 & & 0 & 0 & & & & & & \\
\hline 572 & 38 & 0 & 1 & 0 & 0 & 0 & & 0 & 0 & & & & & & $-2,3$ \\
\hline & 38 & 0 & 1 & 0 & 0 & 0 & & 0 & & & 992 & 57 & 87 & & 04 \\
\hline
\end{tabular}




\begin{tabular}{|c|c|c|c|c|c|c|c|c|c|c|c|c|c|c|c|}
\hline obs & ID & 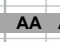 & & $B A B$ & BB & UD L & & PL N & & REC & PIB & COMEX & $y=$ & EF & ODP \\
\hline 574 & 39 & 0 & 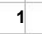 & 0 & 0 & 0 & 1 & 0 & 0 & 1 & 10931 & 175,81 & 44,73 & 4,05 & $-0,48$ \\
\hline 575 & 39 & 0 & 1 & 0 & 0 & 0 & 1 & 0 & 0 & 0 & 11733 & 60,28 & 44,21 & 4,37 & $-0,21$ \\
\hline 576 & & 0 & & 0 & 0 & 0 & 1 & c & 0 & 1 & 12193 & 34,28 & 42,05 & 5,45 & $-0,12$ \\
\hline 677 & 19 & 0 & 1 & 0 & 0 & 0 & 1 & 0 & 0 & 0 & 12524 & 142,39 & 44,29 & 33 & $-0,14$ \\
\hline 578 & & 0 & 1 & 0 & 0 & 0 & 1 & 0 & 0 & 0 & 12596 & 38,64 & 47,01 & 5,34 & $-0,23$ \\
\hline 579 & & 0 & 1 & 0 & 0 & 0 & 1 & 0 & 0 & 0 & 12876 & 29,74 & 48,46 & 6,12 & $-0,17$ \\
\hline 580 & 39 & 0 & 1 & 0 & 0 & 0 & 1 & 0 & 0 & 0 & 13418 & 22,14 & 52,05 & 89 & $-0,22$ \\
\hline 581 & & 0 & 1 & 0 & 0 & 0 & 1 & 0 & 0 & 0 & 14427 & 1,52 & 50,76 & 6,32 & $-0,17$ \\
\hline 582 & & 0 & 1 & 0 & 0 & 0 & 1 & 0 & 0 & 0 & 15465 & 44,55 & 51,21 & 3,38 & $-0,19$ \\
\hline 583 & & 0 & 1 & 0 & 0 & 0 & 1 & 0 & 0 & 1 & 16783 & 46,19 & 48,64 & 0,66 & $-0,17$ \\
\hline 584 & 39 & 0 & 1 & 0 & 0 & 0 & 1 & 0 & 0 & 2 & 18816 & 145,38 & 48,2 & 0,99 & 0,6 \\
\hline 585 & 9 & 0 & 1 & 0 & 0 & 0 & 1 & 0 & 0 & 0 & 20538 & 149 & 49,28 & 0,83 & $-0,11$ \\
\hline 586 & & 0 & 1 & 0 & 0 & 0 & 1 & 0 & 0 & . & 21354 & 138,73 & 50,4 & 1,57 & $-0,24$ \\
\hline 587 & 39 & 0 & 1 & 0 & 0 & 0 & 1 & 0 & 0 & 0 & 22603 & 9,69 & 41,99 & 1,44 & $-0,42$ \\
\hline 588 & 39 & 1 & 0 & 0 & 0 & 0 & 1 & 0 & 0 & 0 & 25038 & 158,35 & 6,71 & 0,49 & $-0,35$ \\
\hline 589 & & 1 & 0 & 0 & 0 & 0 & 1 & 0 & 0 & 1 & 27603 & 154,75 & 42,78 & 10,01 & $-0,14$ \\
\hline 590 & & 0 & 0 & 1 & 0 & 0 & 0 & 1 & 0 & 1 & 53491 & 31,64 & 23,07 & 10,31 & $-0,75$ \\
\hline 591 & & 0 & 0 & 1 & 0 & 0 & 0 & 1 & 0 & 0 & 54988 & 32,25 & 24,83 & 11,19 & $-0,63$ \\
\hline 592 & 40 & 0 & 0 & 1 & 0 & 0 & 0 & 1 & 0 & 0 & 58550 & 34,01 & 25,17 & 11,04 & $-0,71$ \\
\hline 593 & & 0 & & 1 & 0 & 0 & 0 & 1 & 0 & . & 58321 & 33,23 & 22,5 & 13,43 & $-0,93$ \\
\hline 594 & & 0 & 0 & 1 & 0 & 0 & 0 & 1 & 0 & 0 & 59192 & 3,4 & 24,42 & 12,53 & $-0,92$ \\
\hline 595 & & 0 & 0 & 1 & 0 & 0 & 0 & 1 & 0 & 0 & 60787 & 35,58 & 22,85 & 11,12 & $-0,8$ \\
\hline 596 & 40 & 0 & 0 & 1 & 0 & 0 & 1 & 0 & 0 & 1 & 61163 & 34,8 & 23,73 & 11,04 & $-0,89$ \\
\hline 597 & & 0 & 0 & 1 & 0 & 0 & 1 & 0 & 0 & 0 & 64498 & 83 & 38 & 11,4 & $-0,92$ \\
\hline 598 & & 0 & 0 & 1 & 0 & 0 & 1 & 0 & 0 & 0 & 67185 & 67 & 79 & 10,1 & $-0,91$ \\
\hline 599 & 40 & 0 & 0 & 1 & 0 & 0 & 1 & 0 & 0 & 0 & 70516 & 41,03 & 20,82 & 10,15 & $-0,74$ \\
\hline 600 & & 0 & 0 & 1 & 0 & 0 & 1 & 0 & 0 & 0 & 74948 & 46,87 & 18,49 & 9,21 & $-0,64$ \\
\hline 601 & & 0 & 0 & 1 & 0 & 0 & 1 & 0 & 0 & 0 & 591 & 83 & 18 & 62 & $-0,58$ \\
\hline 602 & & 0 & 0 & 1 & 0 & 0 & 1 & 0 & 0 & 0 & 87456 & 53,88 & 15,15 & ,17 & $-0,33$ \\
\hline 603 & 40 & 0 & 0 & 1 & 0 & 0 & 1 & 0 & 0 & 0 & 95452 & 56,47 & 15,96 & 34 & $-0,41$ \\
\hline 604 & & 0 & 0 & 1 & 0 & 0 & 1 & 0 & 0 & 0 & 96453 & 6,42 & 18,81 & 11,52 & $-0,39$ \\
\hline 605 & & 0 & 1 & 0 & 0 & 0 & 1 & 0 & 0 & 1 & 104604 & 50,01 & 16,83 & 0,77 & 0,22 \\
\hline 606 & & 0 & 1 & 0 & 0 & 0 & 1 & 0 & 0 & 0 & 111354 & 55,24 & 17,22 & 8,79 & $-0,38$ \\
\hline 607 & & 0 & 1 & 0 & 0 & 0 & 1 & 0 & 0 & 0 & 17980 & ,27 & 16,35 & 8,82 & $-0,21$ \\
\hline 608 & & 0 & & 1 & 0 & 0 & 0 & 1 & 0 & 0 & 482 & 09 & 1 & 0 & $-0,77$ \\
\hline 609 & & 0 & 0 & 1 & 0 & 0 & 0 & 1 & 0 & 0 & 21942 & 73,35 & 14,52 & 12,43 & $-0,57$ \\
\hline 610 & 41 & 0 & 0 & 1 & 0 & 0 & $\theta$ & 1 & 0 & 0 & 23699 & 76,42 & 14,66 & 12,29 & $-0,38$ \\
\hline 611 & 41 & & 0 & 1 & 0 & 0 & 1 & 0 & 0 & 0 & 29111 & 4,72 & 26,9 & 70,4 & $-0,45$ \\
\hline 612 & & & & 1 & 0 & 0 & 1 & 0 & 0 & 0 & 30796 & 81 & 16,95 & 11,3 & $-0,57$ \\
\hline 613 & & 0 & 0 & 1 & 0 & 0 & 1 & 0 & 0 & 0 & 30718 & 6,49 & 17,29 & 9,61 & $-0,35$ \\
\hline 614 & & & 0 & 1 & 0 & 0 & 1 & 0 & 0 & 0 & 31121 & 88 & 15,71 & 9,63 & $-0,42$ \\
\hline 615 & & & & 1 & 0 & 0 & 1 & 0 & 0 & 0 & 34004 & & & 11,78 & $-0,2$ \\
\hline 616 & & 0 & 0 & 1 & 0 & 0 & 1 & 0 & 0 & 0 & 37633 & 97 & 16,22 & 68 & $-0,16$ \\
\hline 617 & & 0 & 1 & 0 & 0 & 0 & 1 & 0 & 0 & 0 & 40822 & 61,94 & 15, & , 45 & $-0,29$ \\
\hline 618 & & & 1 & 0 & 0 & 0 & 1 & 0 & 0 & 0 & 42105 & 61,44 & 17,71 & 62 & $-0,34$ \\
\hline 619 & & & 1 & 0 & 0 & 0 & 1 & 0 & 0 & 0 & 42499 & 50,6 & 1 & 19,69 & $-0,26$ \\
\hline 620 & 41 & 0 & 1 & 0 & 0 & 0 & 1 & 0 & 0 & 0 & 46028 & 54,83 & ,21 & 18,74 & $-0,34$ \\
\hline 621 & & & 1 & 0 & 0 & 0 & 5 & 0 & 0 & 0 & 47326 & 57,5 & 19,54 & 15,36 & $-0,4$ \\
\hline 622 & & & 1 & 0 & 0 & 0 & 1 & 0 & 0 & 1 & 570 &, 5 & 18,97 & 13,66 & $-0,45$ \\
\hline 623 & & & 0 & 0 & 0 & 0 & 0 & 0 & 1 & 0 & 0326 & 32 & ? & 10,82 & 0 \\
\hline 624 & & 1 & 0 & 0 & 0 & 0 & 1 & 0 & 0 & 0 & 396 & 0,68 & 34 & 1,38 & $-2,25$ \\
\hline 625 & & & 0 & 0 & 0 & 0 & 1 & 0 & 0 & 0 & 423 & 26 & 89 & 57 & $-2,14$ \\
\hline 626 & & & & 0 & 0 & 0 & 1 & 0 & 0 & 0 & 434 & 16 & is & 95 & 29 \\
\hline 627 & & & 0 & 0 & 0 & 0 & 1 & 0 & 0 & 0 & 456 & 01 & 55 & 12,61 & -1 \\
\hline 628 & & 1 & 0 & 0 & 0 & 0 & 1 & 0 & 0 & 0 & 479 & 5,8 & 19 & 16,72 & $-2,38$ \\
\hline 629 & & & & 0 & 0 & 0 & 1 & 0 & 0 & & 488 & 7 & 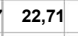 & 15,88 & $-6,35$ \\
\hline 630 & & & 0 & 0 & 0 & 0 & 1 & c & 0 & & 47 & & & & $-0,04$ \\
\hline 631 & & 1 & 0 & 0 & 0 & 0 & 1 & 0 & 0 & 0 & 497 & 92 & ? & 13,34 &, 01 \\
\hline 632 & & & 0 & 0 & 0 & 0 & 1 & 0 & 0 & 0 & 543 &, 3 & 98 & 15 & $-0,49$ \\
\hline 633 & & & 0 & 0 & 0 & 0 & 1 & 0 & 0 & 0 & 575 & 17 & 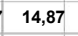 & 16,58 & $-0,85$ \\
\hline 634 & & & & c & 0 & 0 & 1 & o & 0 & & 59 & 8 & & 62 & $-0,53$ \\
\hline 635 & & & 0 & 0 & 0 & 0 & 1 & 0 & 0 & 0 & 616 &, 53 & 98 & 12,96 & $-6,68$ \\
\hline 636 & & & 0 & 0 & 0 & 0 & 1 & 0 & 0 & & 58 & 73 & 3 & 18,49 &, 76 \\
\hline 637 & & & & 0 & c & 0 & 1 & c & 0 & & & 69 & 1 & 22,56 & $-1,72$ \\
\hline 638 & & & 0 & c & 0 & 0 & 1 & c & 0 & & & 4 & & 16,75 & $-2,3$ \\
\hline 639 & & & 1 & 0 & 0 & 0 & 1 & 0 & 0 & 0 & 722 & , 86 & is & 1,86 & $-9,25$ \\
\hline 640 & & & 1 & 0 & 0 & 0 & 1 & 0 & 0 & & 762 & 85 & 5 & 2,67 & $\begin{array}{l}-7,27 \\
\end{array}$ \\
\hline 64 & & & & 0 & c & 0 & 1 & ( & 0 & & & & & 4,44 & 48 \\
\hline 642 & & & 1 & o & 0 & 0 & 1 & 0 & 0 & & & 6 & & & $-0,99$ \\
\hline 643 & & & 1 & 0 & 0 & 0 & 1 & 0 & 0 & & 832 & 44 & 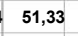 & 4,23 & 94 \\
\hline 644 & & & 1 & 0 & c & 0 & 1 & o & 0 & & 86 & 37 & 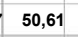 & 6,21 & $-1,48$ \\
\hline 64 & & & & 0 & c & 0 & 1 & , & 0 & & & & & & -2, \\
\hline 646 & & & 1 & 0 & c & 0 & 1 & c & 0 & & & & & & 99 \\
\hline 647 & 44 & & 1 & 0 & 0 & 0 & 1 & 0 & 0 & 0 & 882 & ,84 & 45,67 & 56 & $-2,03$ \\
\hline 64 & & & 1 & 0 & c & 0 & 1 & 0 & 0 & & 95 & 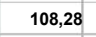 & 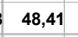 & 2,15 & 2,59 \\
\hline 64 & & & & c & c & 0 & 1 & & 0 & & & & & & \\
\hline 650 & 44 & & 1 & 0 & c & 0 & 1 & 0 & 0 & & & & & & 81 \\
\hline 651 & 44 & 0 & 1 & 0 & 0 & 0 & 1 & 0 & 0 & 0 & 10 & 2,66 & 38,64 & 20,67 & $-1,76$ \\
\hline 652 & & & & 0 & c & 0 & 1 & 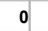 & 0 & & 106 & 55 & & 3,2 & $-1,7$ \\
\hline 653 & 4 & & & 1 & 0 & 0 & 1 & 0 & 0 & & & & & & 0,0 \\
\hline 654 & 45 & 0 & 0 & 1 & 0 & 0 & 1 & 0 & 0 & & 39 & 2 & & & 6 \\
\hline 655 & 45 & & 0 & 1 & 0 & 0 & 1 & 0 & 0 & & 408 & 8,49 & 33 & ,55 & ,76 \\
\hline
\end{tabular}




\begin{tabular}{|c|c|c|c|c|c|c|c|c|c|c|c|c|c|c|c|}
\hline & 1 & Af & & & & MD & LV $F$ & & & & PIB & 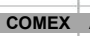 & AGRI & PREF & ODP \\
\hline 656 & 45 & 0 & 0 & 1 & 0 & 0 & 1 & 0 & 0 & 0 & 424 & 108,78 & 51,98 & 2,44 & $-5,7$ \\
\hline 657 & 45 & 0 & & 0 & 0 & 0 & 1 & 0 & 0 & 0 & 436 & 106,77 & 52,65 & 6,32 & $-4,4$ \\
\hline 658 & & & & 0 & 0 & 0 & & 0 & 0 & & 443 & 95,87 & 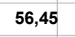 & 3,3 & 64 \\
\hline 659 & & 0 & & 0 & 0 & 0 & 1 & 0 & 0 & & 451 & 89,62 & 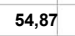 & 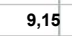 & $-1,96$ \\
\hline 660 & 45 & 0 & & 0 & 0 & 0 & 1 & 0 & 0 & & 479 & 85,11 & 56,36 & 77 & $-1,03$ \\
\hline ;61 & & & & 0 & 0 & 0 & & 0 & 0 & & 516 & , & 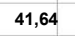 & 18 & $-1,41$ \\
\hline 662 & 45 & 0 & & 0 & 0 & 0 & 1 & 0 & 0 & & 37 & 87,5 & 50,66 & 7 & $-2,16$ \\
\hline 663 & 45 & 0 & & 0 & 0 & 0 & 1 & 0 & 0 & & 551 & 89,29 & 49,95 & 3 & $-1,48$ \\
\hline 664 & 15 & 0 & & 0 & 0 & 0 & 1 & 0 & 0 & & 593 & 88,06 & 47,93 & 4,71 & $-0,81$ \\
\hline 665 & 45 & 0 & & 0 & 0 & 0 & 1 & 0 & 0 & 0 & 83 & 94,3 & 45,65 &, 33 & $-10,46$ \\
\hline 666 & 45 & 0 & & 0 & 0 & 0 & 1 & 0 & 0 & & 623 & 92,17 & 44,55 &, 83 & $-3,99$ \\
\hline 667 & 45 & 0 & & 0 & 0 & 0 & 1 & 0 & 0 & 0 & 610 & 85,99 & 44,79 & 3,9 & $-4,65$ \\
\hline 668 & 45 & 0 & & 0 & 0 & 0 & 1 & 0 & 0 & & 589 & 84,02 & 42,7 &, 67 & $-2,52$ \\
\hline 669 & 45 & 0 & & 0 & 0 & 0 & 1 & 0 & 0 & 0 & 587 & 82,74 & 44,08 & 82 & $-2,69$ \\
\hline 670 & & c & & 0 & 0 & 0 & 1 & 0 & 0 & & 595 & 85,44 & 44,7 & 5 & $-1,24$ \\
\hline 671 & 46 & 0 & & 0 & 1 & 0 & 0 & 1 & 0 & & 1261 & 50,06 & 16,35 & 11,26 & $-11,1$ \\
\hline 672 & & 0 & & 0 & 1 & 0 & 0 & 1 & 0 & 0 & 1277 & 4,11 & 56 &, 5 & $-12,64$ \\
\hline 673 & 46 & 0 & & 0 & 1 & O & 0 & 1 & 0 & 0 & 13 &, 99 & 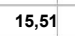 & 5 & $-8,27$ \\
\hline 674 & & 0 & & 0 & 1 & 0 & 0 & 1 & 0 & & 1371 & 83,6 & 13,82 & 6 & $-6,29$ \\
\hline 675 & & 0 & & 0 & 1 & 0 & 0 & 1 & 0 & & 359 & 0,87 & 15,59 & 85 & $-4,26$ \\
\hline 676 & & 0 & & 0 & 1 & 0 & 1 & 0 & 0 & 0 & 1358 & 52,93 & ,76 & 12 & $-3,85$ \\
\hline 677 & 46 & 0 & & 0 & 1 & 0 & 1 & 0 & 0 & & 1420 & 78 & 10,94 & 1,54 & $-3,39$ \\
\hline 678 & & 0 & & 0 & 1 & 0 & 1 & 0 & 0 & & 1481 & 58,38 & 11,39 & 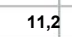 & $-1,12$ \\
\hline 679 & & 0 & & 1 & 0 & 0 & 1 & 0 & 0 & 0 & 1570 & $;, 3$ & 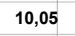 & & $-0,89$ \\
\hline 680 & 46 & 0 & & 1 & 1 & 0 & 1 & 0 & 0 & 0 & 1715 & 74,22 & 7,89 & 19 & $-1,68$ \\
\hline 681 & 46 & 0 & & 1 & 0 & 0 & 1 & 0 & 0 & 0 & 1794 & 75,58 & 6,24 & 5,1 & $-2,52$ \\
\hline 682 & & 0 & c & 1 & 0 & 0 & 0 & 1 & 0 & 0 & 7018 & 44,24 & 37 & 8 & $-0,19$ \\
\hline 683 & 47 & 0 & & 1 & 0 & 0 & 0 & 1 & 0 & 0 & 2413 & 49,37 & 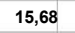 & 3 & $-0,14$ \\
\hline 684 & & 0 & & 0 & 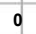 & 0 & 0 & 1 & 0 & 0 & 6208 & 54,97 & 92 & 2,02 & 0 \\
\hline 685 & & 0 & & 0 & 0 & 0 & 0 & 1 & 0 & 0 & 4661 & 41,52 & 19 & 9 & $-0,01$ \\
\hline 686 & & 0 & & 0 & 0 & 0 & 0 & 1 & 0 & 0 & 2052 & 3 & & & 0 \\
\hline 687 & 47 & 0 & & 0 & 0 & 0 & 0 & 1 & 0 & 1 & 6579 & 43,19 & 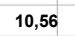 & 3 & $-0,12$ \\
\hline 688 & 47 & 0 & & 0 & 0 & 0 & 0 & 1 & 0 & 0 & 64554 & 50,76 & 10,85 & 12 & $-0,07$ \\
\hline 689 & & c & & 0 & 0 & 0 & 0 & 1 & 0 & 0 & 025 & 48,8 & 9,49 & & $-0,12$ \\
\hline 690 & 47 & 0 & & 0 & 0 & 0 & 0 & 1 & 0 & 1 & 402 & 47,03 & 9,3 & & $-0,06$ \\
\hline 691 & 47 & 0 & & 0 & 0 & 0 & 0 & 1 & 0 & 0 & 5547 & 49,74 & 8,09 & 16 & $-0,07$ \\
\hline 692 & $4 \pi$ & 0 & & 0 & 0 & 0 & 0 & 1 & 0 & 0 & 2980 & 47,21 & 8,15 & 1 & $-0,08$ \\
\hline 693 & & 0 & & 0 & 0 & 0 & 0 & 1 & 0 & 0 & & & & & $-0,11$ \\
\hline 694 & $\Delta 7$ & 1 & & 0 & 0 & 0 & 0 & 1 & 0 & 0 & 377 & 81 & 7,2 & 4 & $-0,12$ \\
\hline 695 & 47 & 1 & & 0 & 0 & 0 & 0 & 1 & 0 & 0 & 3937 & 52,25 & 7,53 & 44 & $-0,15$ \\
\hline 696 & & 1 & c & 0 & 0 & 0 & 0 & 1 & 0 & 0 & 687 & ,74 & 8,96 & 43 & $-0,22$ \\
\hline 697 & 47 & 1 & & 0 & 0 & 0 & c & 1 & 0 & & 092 & 97 & & 88 & $-0,14$ \\
\hline 698 & 47 . & 1 & & 0 & 0 & 0 & 0 & 1 & 0 & 0 & 4666 & 56,62 & 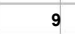 & 4 & $-0,43$ \\
\hline 699 & $4 \pi$ & 1 & c & 0 & 0 & 0 & 0 & 1 & 0 & 0 & 7742 & 57,75 & 8, & 3 & $-0,4$ \\
\hline 700 & & 0 & & 0 & 0 & 0 & 1 & 0 & 0 & & & 1 & & & -0 \\
\hline 701 & 48 & 1 & & 0 & 0 & 0 & 1 & 0 & 0 & 0 & 15769 & 39,53 & 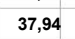 & & $-0,17$ \\
\hline 702 & 48 & 1 & 0 & 0 & 0 & 0 & 1 & 0 & 0 & 0 & 17117 & 37,71 & 68 & 3,2 & $-0,14$ \\
\hline 703 & 48 & 1 & 0 & 0 & o & 0 & 1 & 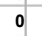 & 0 & 0 & 391 & 64 & 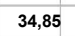 & 3,77 & $-0,1$ \\
\hline 704 & & 1 & & 0 & 0 & 0 & 1 & 0 & 0 & 0 & 17544 & 9 & & & $-0,09$ \\
\hline 705 & 48. & 1 & & 0 & 0 & 0 & 1 & 0 & 0 & 0 & 1720 & 36,71 & 18 & 31 & $-0,08$ \\
\hline 706 & 48 & 1 & 0 & 0 & 0 & 0 & 1 & 0 & 0 & & 654 & 31 & 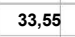 & 5,4 & $-0,07$ \\
\hline 707 & & 0 & 1 & 0 & o & 0 & 1 & 0 & 0 & & 15 & 3 & & & -0 \\
\hline 708 & 48 & 0 & & 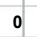 & 0 & 0 & 1 & 0 & 0 & & & & & & -0 \\
\hline 709 & 48 & 0 & 1 & 0 & 0 & 0 & 1 & 0 & 0 & 0 & 16157 & 18 & 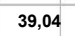 & 4,86 & $-0,22$ \\
\hline 710 & 48 & 0 & 1 & 0 & 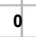 & 0 & 1 & 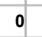 & 0 & 0 & 63 & 88 & 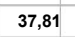 & 37 & $-0,09$ \\
\hline 711 & & 0 & & 0 & 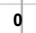 & 0 & 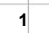 & 0 & 0 & & 18 & 7 & 3 & & $-0,11$ \\
\hline 712 & (2) & 0 & & 0 & 0 & 0 & 1 & 0 & 0 & & 19257 & 21 & & & $-0,16$ \\
\hline 713 & 48 & 0 & 1 & 0 & 0 & 0 & 1 & 0 & 0 & & 20639 & 21 & 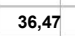 & & $-0,11$ \\
\hline 714 & & 1 & 0 & 0 & 0 & 0 & 1 & 0 & 0 & 0 & & 1 & & & 6 \\
\hline 715 & & 1 & & 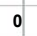 & 0 & 0 & . & 0 & 0 & & & & & & -0, \\
\hline 716 & 18 & 1 & & 0 & 0 & 0 & 1 & 0 & 0 & 0 & 24391 & 53,28 & & & $-0,05$ \\
\hline 717 & 48 & 0 & 0 & 0 & 0 & 0 & 1 & 0 & 0 & 0 & 25201 & 4 & 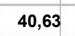 & & 04 \\
\hline 718 & & 0 & & 1 & 0 & 0 & 0 & 1 & 0 & 1 & 3574 & 2 & 1 & ,15 & -0 \\
\hline 719 & & 0 & & 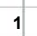 & 0 & 0 & & 0 & 0 & & & & & & $-0,06$ \\
\hline 720 & 49 & 0 & & 0 & 0 & 0 & 1 & 0 & 0 & & 1117 & 51,25 & 7,31 & & $-0,01$ \\
\hline 721 & 49 & 0 & 1 & 0 & 0 & 0 & 1 & 0 & 0 & 0 & 1573 & & & & $-0,05$ \\
\hline 722 & 4. & 0 & & 0 & c & 0 & & 1 & 0 & & & & & 6 & -0, \\
\hline 723 & & & & 0 & & 0 & & 1 & 0 & & & & & & -0, \\
\hline 724 & 49 & 0 & 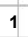 & 0 & 0 & 0 & & 1 & 0 & & & 2.14 & & & $-0,04$ \\
\hline 725 & 49 & 0 & 1 & 0 & 0 & 0 & 0 & 1 & 0 & 0 & & 58 & 6 & & $-0,06$ \\
\hline 726 & & & & 0 & & 0 & & 1 & & & & & & & 1 \\
\hline 727 & 49 & & & 0 & c & 0 & & 1 & 0 & & & & & & $-0,04$ \\
\hline 728 & 49 & 0 & 1 & 0 & 0 & 0 & 0 & 1 & 0 & & & & & & $-0,04$ \\
\hline 729 & 49 & 0 & & 0 & c & 0 & c & 1 & 0 & & & & & & $-0,03$ \\
\hline 730 & & & & 0 & & 0 & & & & & & & & & $-0,03$ \\
\hline 73 & 49 & & & 0 & 0 & 0 & & 1 & 0 & & & & & & \\
\hline 732 & 49 & 1 & c & 0 & 0 & 0 & 0 & 1 & 0 & & & & & & $-0,02$ \\
\hline 733 & 49 & 1 & & 0 & c & 0 & & 1 & & & & & & & $-0, C$ \\
\hline 734 & 49 & 1 & & 0 & c & 0 & & 1 & & & & & & & $-0, C$ \\
\hline 735 & 49 & 1 & & 0 & 0 & 0 & 0 & 1 & 0 & & & & & & \\
\hline 736 & 50 & 0 & & 0 & 1 & 0 & 0 & 1 & & 0 & 61 & 2 & 8,3 & & $-8,45$ \\
\hline & 50 & & & & & 0 & & & & & 622 & & 8,58 & 54 & 77 \\
\hline
\end{tabular}




\begin{tabular}{|c|c|c|c|c|c|c|c|c|c|c|c|c|c|c|c|}
\hline bs & ID & AA & AB & BA & BB & MD & LV & PL I & & EC & PIE & COMEX & AGRI & PREF & ODP \\
\hline 738 & 50 & 0 & 0 & 0 & 1 & 0 & 0 & 1 & 0 & 0 & 6902 & 63,93 & $\begin{array}{ll}3 & 9,26\end{array}$ & 0,51 & $-6,91$ \\
\hline 739 & 50 & 0 & 0 & 0 & 1 & 0 & 0 & 1 & 0 & 0 & 7300 & 65,44 & 7,76 & 0,78 & $-6,61$ \\
\hline 740 & 50 & 0 & 0 & 1 & 0 & 0 & 0 & 1 & 0 & 0 & 7717 & 66,36 & 8,4 & 0,46 & $-4,8$ \\
\hline 741 & 50 & 0 & 0 & 1 & 0 & 0 & 0 & 1 & 0 & 0 & 8159 & 70,3 & $\begin{array}{l}3 \quad 7,55 \\
3\end{array}$ & 1,07 & $-4,7$ \\
\hline 742 & 50 & 0 & 0 & 1 & 0 & 0 & 0 & 1 & 0 & 0 & 8602 & 73,46 & i 7,44 & 0,62 & $-4,37$ \\
\hline 743 & 50 & 0 & 0 & 1 & 0 & 0 & 0 & 1 & 0 & 0 & 9109 & 82,87 & 7,71 & 9,57 & $-3,59$ \\
\hline 744 & 50 & 0 & 1 & 0 & 0 & 0 & 0 & 1 & 0 & 0 & 9795 & 86,03 & $\begin{array}{l}3 \\
3,76\end{array}$ & 8,81 & $-3,69$ \\
\hline 745 & 50 & 0 & 1 & 0 & 0 & 0 & 0 & 1 & 0 & 0 & 10123 & 83,36 & 10,18 & 10,33 & $-3,59$ \\
\hline 746 & 50 & 0 & 1 & 0 & 0 & 0 & 0 & 1 & 0 & 0 & 10499 & 85,46 & b 9,57 & 9,32 & $-3,61$ \\
\hline 747 & 50 & 0 & 1 & 0 & 0 & 0 & 0 & 1 & 0 & 0 & 10766 & 90,76 & 7,02 & 7,67 & $-3,46$ \\
\hline 748 & 50 & 0 & 1 & 0 & 0 & 0 & 0 & 1 & 0 & 0 & 10919 & 85,34 & $4 \quad 6,53$ & 8,76 & $-3,31$ \\
\hline 749 & 51 & 0 & 1 & 0 & 0 & 0 & 1 & 0 & 0 & 0 & 6454 & 94,6 & is, 19 & 0 & $-1,98$ \\
\hline 750 & 51 & 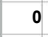 & 0 & 1 & 0 & 0 & 1 & 0 & 0 & 0 & 6831 & 90,96 & $\begin{array}{l}\text { b } 14,79 \\
\end{array}$ & 0 & $-1,46$ \\
\hline 751 & 51 & 0 & 0 & 1 & 0 & 0 & 1 & 0 & 0 & 0 & 7379 & 108,6 & is 14,99 & 0 & $-2,5$ \\
\hline 752 & 51 & 0 & 0 & 1 & 0 & 0 & 1 & 0 & 0 & 0 & 7432 & 101,84 & $4 \quad 11,99$ & 0 & $-2,01$ \\
\hline 753 & 51 & 0 & 0 & 1 & 0 & 0 & 1 & 0 & 0 & 0 & 8151 & 98,93 & $\begin{array}{ll}3 & 15,35\end{array}$ & 0 & $-1,07$ \\
\hline 754 & 51 & 0 & 1 & 0 & 0 & 0 & 1 & 0 & 0 & 0 & 8313 & 91,92 & $2 \quad 14,2$ & 0,4 & $-0,58$ \\
\hline 755 & 51 & 0 & 1 & 0 & 0 & 0 & 1 & 0 & 0 & 0 & 8333 & 87,53 & $\begin{array}{ll}3 & 13,79\end{array}$ & $-0,38$ & $-0,57$ \\
\hline 756 & 51 & 0 & 0 & 1 & 0 & 0 & 1 & 0 & 0 & 0 & 8839 & 91,84 & $4 \quad 11,9$ & $-0,3$ & $-0,61$ \\
\hline 757 & 51 & 0 & 1 & 0 & 0 & 0 & 1 & 0 & 0 & 0 & 9248 & 85,83 & $\begin{array}{l}3 \\
\text { 3 } 40,84\end{array}$ & 0,64 & $-0,4$ \\
\hline 758 & 51 & 0 & 1 & 0 & 0 & 0 & 1 & 0 & 0 & 0 & 9498 & 91 & 14,83 & $-0,32$ & $-0,66$ \\
\hline 759 & 51 & 0 & 1 & 0 & 0 & 0 & 1 & 0 & 0 & 0 & 9931 & 88,51 & 11,66 & $-0,13$ & $-0,59$ \\
\hline 760 & 51 & 0 & 1 & 0 & 0 & 0 & 1 & 0 & 0 & 0 & 10762 & 86,33 & $\begin{array}{ll}310,59\end{array}$ & 1,09 & $-0,74$ \\
\hline 761 & 51 & 0 & 1 & 0 & 0 & 0 & 1 & 0 & 0 & 0 & 11653 & 95,1 & $1 \quad 12,15$ & 3,64 & $-0,99$ \\
\hline 762 & 51 & 0 & 1 & 0 & 0 & 0 & 1 & 0 & 0 & 0 & 12380 & 96,72 & L 10,17 & 2,59 & $-5,92$ \\
\hline 763 & 51 & 0 & 1 & 0 & 0 & 0 & 1 & 0 & 0 & 0 & 11433 & 86,69 & 12,49 & 2,66 & $-2,59$ \\
\hline 764 & 51 & 0 & 1 & 0 & 0 & 0 & 1 & 0 & 0 & 0 & 12412 & 88,14 & 4 12,16 & 3,7 & $-1,28$ \\
\hline 765 & 51 & 0 & 1 & 0 & 0 & 0 & 1 & 0 & 0 & 0 & 13163 & 95,62 & $\begin{array}{ll}2 & 12,31\end{array}$ & 7,54 & $-0,91$ \\
\hline 766 & 51 & 0 & 1 & 0 & 0 & 0 & 1 & 0 & 0 & 0 & 13799 & 100,77 & 712,61 & 6,92 & $-0,53$ \\
\hline 767 & 52 & 0 & 1 & 0 & 0 & 0 & 0 & 1 & 0 & 0 & 8878 & 95,67 & 25,78 & 7,49 & $-1,91$ \\
\hline 768 & 52 & 0 & 1 & 0 & 0 & 0 & 0 & 1 & 0 & 0 & 9387 & 98,54 & + 27,18 & 9,48 & $-0,63$ \\
\hline 769 & 52 & 0 & 1 & 0 & 0 & 0 & 0 & 1 & 0 & 0 & 9714 & 95,97 & 22,18 & 5,75 & $-0,69$ \\
\hline 770 & 52 & 0 & 1 & 0 & 0 & 0 & 0 & 1 & 0 & 0 & 8846 & 97,73 & 321,18 & 8,72 & $-0,84$ \\
\hline 771 & 52 & 0 & 1 & 0 & 0 & 0 & 0 & 1 & 0 & 0 & 8679 & 101,7 & 7. 21,05 & 8,88 & $-0,24$ \\
\hline 772 & 52 & 0 & 1 & 0 & 0 & 0 & 0 & 1 & 0 & 0 & 8865 & 83,64 & $4 \quad 18,03$ & 8,7 & $-0,14$ \\
\hline 773 & 52 & 0 & 1 & 0 & 0 & 0 & 0 & 1 & 0 & 0 & 8843 & 84,76 & 6) 17,14 & 9,14 & $-1,31$ \\
\hline 774 & 52 & 0 & 1 & 0 & 0 & 0 & 0 & 1 & 0 & 0 & 9041 & 80,3 & $\begin{array}{ll}317,59 \\
\end{array}$ & 88,91 & 0,17 \\
\hline 775 & 52 & 0 & 1 & 0 & 0 & 0 & 0 & 1 & 0 & 0 & 9104 & 81,77 & 17,5 & 11,77 & $-0,53$ \\
\hline 776 & 52 & 0 & 1 & 0 & 0 & 0 & 0 & 1 & 0 & 0 & 9459 & 84,75 & $5 \quad 15,1$ & 7,22 & $-0,76$ \\
\hline 777 & 52 & 0 & 1 & 0 & 0 & 0 & 0 & 1 & 0 & 0 & 9115 & 89,77 & 14,76 & 3,53 & $-0,37$ \\
\hline 778 & 52 & 0 & 1 & 0 & 0 & 0 & 0 & 1 & 0 & 0 & 9706 & 85,13 & $\begin{array}{ll}3 & 16,09\end{array}$ & 7,64 & $-0,55$ \\
\hline 779 & 52 & 0 & 1 & 0 & 0 & 0 & 0 & 1 & 0 & 0 & 9412 & 88,17 & 16,78 & 6,32 & $-0,64$ \\
\hline 780 & 52 & 1 & 0 & 0 & 0 & 0 & 0 & 0 & 1 & 0 & 9300 & 81,69 & (17,81 & 6,01 & $-0,84$ \\
\hline 781 & 53 & 0 & 0 & 0 & 1 & 0 & 0 & 1 & 0 & 0 & 9241 & 110,49 & 41,14 & 1,21 & $-8,45$ \\
\hline 782 & 53 & 0 & 0 & 0 & 1 & 0 & 0 & 1 & 0 & 0 & 9729 & 109,44 & 4. 41,48 & 1,11 & $-6,86$ \\
\hline 783 & 53 & 0 & 0 & 1 & 0 & 0 & 0 & 1 & 0 & 0 & 10292 & 114,19 & $\begin{array}{ll}3 & 43,88\end{array}$ & 1,62 & $-7,79$ \\
\hline 784 & 53 & 0 & 0 & 1 & 0 & 0 & 0 & 1 & 0 & 0 & 10721 & 115,86 & 46,42 & 2,58 & $-15,54$ \\
\hline 785 & 53 & 0 & 0 & 1 & 0 & 0 & 0 & 1 & 0 & 0 & 11639 & 134,82 & 2. 46,71 & 2,86 & $-6,32$ \\
\hline 786 & 53 & 0 & 0 & 1 & 0 & 0 & 0 & 1 & 0 & 0 & 12589 & 146,91 & 47,49 & 2,85 & $-6,64$ \\
\hline 787 & 53 & 0 & 0 & 1 & 0 & 0 & 0 & 1 & 0 & 0 & 13608 & 141,75 & $\begin{array}{l}53,09 \\
5\end{array}$ & 2,83 & $-4,86$ \\
\hline 788 & 53 & 0 & 0 & 1 & 0 & 0 & 0 & 1 & 0 & 0 & 14720 & 145,99 & $\begin{array}{l}31,09 \\
\end{array}$ & 2,97 & $-4,75$ \\
\hline 789 & 53 & 0 & 0 & 1 & 0 & 0 & 0 & 1 & 0 & 0 & 15785 & 144,02 & 2 57,69 & 2 & $-4,91$ \\
\hline 790 & 53 & 0 & 0 & 1 & 0 & 0 & 0 & 0 & 1 & 0 & 16649 & 114,96 & $\begin{array}{l}03,58 \\
6\end{array}$ & 2,91 & $-4,74$ \\
\hline 791 & 53 & 0 & 0 & 1 & 0 & 0 & 0 & 0 & 1 & 0 & 17038 & 117,26 & $\begin{array}{l}63,45 \\
6\end{array}$ & 1,78 & $-5,92$ \\
\hline 792 & 53 & 0 & 0 & 1 & 0 & 0 & 0 & 0 & 1 & 0 & 17474 & 121,51 & 1) 60,91 & 1,64 & $-5,71$ \\
\hline 793 & 53 & 0 & 1 & 0 & 0 & 0 & 0 & 0 & 1 & 0 & 17938 & 120,51 & 63,53 & 3,28 & $-6,58$ \\
\hline 794 & 54 & 0 & 1 & 0 & 0 & 0 & 0 & 0 & 1 & 0 & 889 & 104,08 & 30,08 & 15,02 & $-4,16$ \\
\hline 795 & 54 & 0 & 1 & 0 & 0 & 0 & 0 & 0 & 1 & 0 & 940 & 104,43 & 328,15 & 15,65 & $-4,34$ \\
\hline 796 & 54 & 0 & 1 & 0 & 0 & 0 & 0 & 0 & 1 & 0 & 1074 & 107,19 & 35,65 & 10,39 & $-2,83$ \\
\hline 797 & 54 & 0 & 1 & 0 & 0 & 0 & 0 & 0 & 1 & 0 & 1225 & 117,35 & $5 \quad 25,85$ & 5,59 & $-2,81$ \\
\hline 798 & 54 & 0 & 1 & 0 & 0 & 0 & 0 & 0 & 1 & 0 & 1120 & 120,83 & $\begin{array}{ll}3 \quad 22,88\end{array}$ & 1,65 & $-7,9$ \\
\hline 799 & 54 & 0 & 1 & 0 & 0 & 0 & 0 & 0 & 1 & 0 & 1351 & 23,66 & $\begin{array}{ll}6 & 15,3\end{array}$ & 1,73 & $-3,35$ \\
\hline 800 & 54 & 0 & 1 & 0 & 0 & 0 & 0 & 0 & 1 & 0 & 1497 & 197,53 & $\begin{array}{ll}3 & 14,72\end{array}$ & 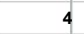 & $-2,72$ \\
\hline 801 & 54 & 0 & 1 & 0 & 0 & 0 & 0 & 0 & 1 & 0 & 1684 & 191,44 & $4 \quad 15,99$ & 4,15 & $-3,31$ \\
\hline 802 & 54 & 0 & 1 & 0 & 0 & 0 & 0 & 0 & 1 & 0 & 1591 & 7,89 & 23,49 & 6,66 & $-2,08$ \\
\hline 803 & 54 & 0 & 1 & 0 & 0 & 0 & 0 & 1 & 0 & 0 & 1686 & 159,39 & 24,37 & 4,8 & $-6,5$ \\
\hline 804 & 54 & 0 & 1 & 0 & 0 & 0 & 0 & 1 & 0 & 0 & 1833 & 204,76 & क 23,18 & 63 & $-2,36$ \\
\hline 805 & 54 & 0 & 1 & 0 & 0 & 0 & 0 & 1 & 0 & 0 & 878 & 4,5 & $5 \quad 24,36$ & 4,91 & $-2,96$ \\
\hline 806 & 55 & 1 & 0 & 0 & 0 & 0 & 1 & 0 & 0 & 0 & 2814 & 111,77 & 43,53 & 3,23 & $-1,98$ \\
\hline 807 & 56 & 0 & 0 & 1 & 0 & 0 & 0 & 1 & 0 & 0 & 244 & 64,79 & $\begin{array}{ll}311,03 \\
3\end{array}$ & 26,26 & $-15,84$ \\
\hline 808 & 56 & 0 & 0 & 1 & 0 & 0 & c & 1 & 0 & 0 & 250 &, 5 & $\begin{array}{ll}5 & 10,77\end{array}$ & 16,74 & $-12,44$ \\
\hline 809 & 56 & 0 & 0 & 1 & 0 & 0 & 0 & 1 & 0 & 0 & 253 & 98 & , 17 & 21 & \begin{tabular}{|l|l|}
$-18,49$ \\
\end{tabular} \\
\hline 810 & 56 & 0 & 0 & 1 & 0 & 0 & 0 & 1 & 0 & 0 & 264 & 61,03 & 9,93 & 11,77 & $-27,47$ \\
\hline 811 & 56 & 0 & 0 & 1 & 0 & 0 & 0 & 1 & 0 & 0 & 269 & 66,04 & $\begin{array}{l}412,02 \\
\end{array}$ & 4,81 & $\mid-32,96$ \\
\hline 812 & 56 & 0 & 1 & 0 & 0 & 0 & & 1 & 0 & 0 & 270 & 75,61 & 10,47 & 3,71 & $|-27,71|$ \\
\hline 813 & 57 & 0 & 0 & 0 & 1 & 0 & 0 & 0 & 1 & 0 & 20279 & ,71 & 1 & 0,23 & $-0,52$ \\
\hline 814 & 57 & 0 & 0 & 1 & 0 & 0 & 0 & 0 & 1 & 0 & 21728 & 85,72 & 21,74 & 0,35 & $-0,82$ \\
\hline 815 & 57 & 0 & 0 & 1 & 0 & 0 & 0 & 1 & 0 & 0 & 22910 & 80,5 & $5 \quad 23,99$ & 0,3 & $-1,28$ \\
\hline 816 & 57 & 0 & 0 & 1 & 0 & 0 & 0 & 0 & 1 & 0 & 24006 & 8 & 3 & 0,34 & 2 \\
\hline 817 & 57 & 0 & 0 & 1 & 0 & 0 & 0 & 0 & 1 & 0 & 2 &, 91 & & & $-1,52$ \\
\hline 818 & 57 & 0 & 0 & 1 & 0 & 0 & 0 & 0 & 1 & 0 & 26659 & 82,46 & $\begin{array}{ll}15,07\end{array}$ & 0,42 & $-1,29$ \\
\hline 819 & 57 & 0 & 0 & 1 & 0 & 0 & 0 & 0 & & 0 & 27671 & 89,55 & $\begin{array}{ll}5 & 16,44\end{array}$ & 0,39 & $-2,19$ \\
\hline
\end{tabular}




\begin{tabular}{|c|c|c|c|c|c|c|c|c|c|c|c|c|c|c|c|}
\hline Obs & ID & 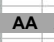 & & $3 A \quad B$ & BB I & MD & LV $\mathrm{F}$ & PL N & IL $\mathrm{RE}$ & EC & PIB & IEX & AGRI & PREF & ODP \\
\hline 820 & 57 & 0 & 0 & 1 & 0 & 0 & r & 0 & 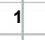 & 0 & 28037 & 85,34 & 17,4 & 0,39 & $-1,23$ \\
\hline 821 & 57 & 0 & 0 & 1 & 0 & 0 & 0 & 0 & 1 & 0 & 29355 & 82,39 & 16,61 & 145 & $-1,32$ \\
\hline 822 & bl & & 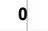 & 1 & 0 & 0 & & 0 & 1 & 0 & 1186 & 86,95 & 15,67 & 0,45 & $-1,34$ \\
\hline 823 & & & 0 & 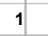 & 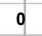 & 0 & & ${ }_{0}$ & 1 & 0 & 273 & 0,25 & 15,3 & & $-1,31$ \\
\hline 824 & 57 & 0 & 0 & 1 & 0 & 0 & 0 & 0 & 1 & 0 & 3965 & 93,94 & 14,51 & 0,76 & $-1,47$ \\
\hline 825 & & 0 & 0 & 1 & 0 & 0 & 0 & 0 & 1 & 0 & 36244 & 104,08 & 13,33 & 3,32 & $-0,92$ \\
\hline 826 & 57 & 0 & 1 & 0 & 0 & 0 & 0 & 0 & 1 & 0 & 37780 & 115,4 & 13,66 & 6,78 & $-0,97$ \\
\hline 827 & 57 & 0 & 1 & 0 & 0 & 0 & 0 & 0 & 1 & 0 & 38930 & 94,37 & 16,06 & 59 & $-1,28$ \\
\hline 828 & 57 & 0 & 1 & 0 & 0 & 0 & 0 & 0 & 1 & 0 & 40297 & 105,76 & 14,83 & 68 & $-1,39$ \\
\hline 829 & & 0 & 1 & 0 & 0 & 0 & 0 & 0 & 1 & 0 & 39524 & 05,74 & 13,57 & 63 & $-2,27$ \\
\hline 830 & 57 & 0 & 1 & 0 & 0 & 0 & 0 & 1 & 0 & 0 & 41142 & 107,8 & 14,52 & 7,29 & $-2,59$ \\
\hline 831 & 58 & 0 & 0 & 0 & 1 & 0 & 0 & 1 & 0 & 0 & 5709 & 71,07 & 26,61 & 13 & $-6,28$ \\
\hline 832 & 58 & 0 & 0 & 1 & 0 & 0 & 0 & 1 & 0 & 0 & 5976 & 80,87 & 26,17 & 36 & $-5,52$ \\
\hline 83: & 0 & 0 & 0 & 1 & 0 & 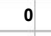 & 0 & 1 & 0 & 0 & 6259 & 85,84 & 37,68 & 68 & $-4,41$ \\
\hline 834 & 50 & 0 & 0 & 1 & 0 & 0 & 0 & 1 & 0 & 0 & 6580 & 92,55 & 43,8 & 89 & $-3,7$ \\
\hline 835 & 58 & 0 & 0 & 1 & 0 & 0 & 0 & 1 & 0 & 0 & 7006 & 106,09 & 32,76 & 7,98 & $-3,11$ \\
\hline 836 & 58 & 0 & 1 & 0 & 0 & 0 & 0 & 1 & 0 & 0 & 7389 & 111,57 & 40,12 & ,78 & $-2,8$ \\
\hline 837 & 58 & 0 & 1 & 0 & 0 & 0 & 0 & 1 & 0 & 0 & 7363 & 87,18 & 44,9 & 02 & $-2,69$ \\
\hline 838 & 58 & 0 & 1 & 0 & 0 & 0 & 0 & 1 & 0 & 0 & 7610 & 97,88 & 46,54 & ,, 52 & $-2,59$ \\
\hline 839 & 8 & 0 & 1 & 0 & 0 & 0 & 0 & 1 & 0 & 0 & 7788 & 113,19 & 46,08 & 6,35 & $-2,46$ \\
\hline 840 & & 0 & 1 & 0 & 0 & 0 & 0 & 1 & 0 & 0 & 753 & 2,22 & 48,95 & 6,3 & $-1,99$ \\
\hline 841 & 59 & 0 & 0 & 0 & 1 & 0 & 0 & 1 & 0 & 0 & 3896 & 82,19 & 17,55 & 1 & $-8,75$ \\
\hline 842 & 59 & 0 & 0 & 0 & 1 & 0 & 0 & 1 & 0 & 0 & 4304 & 75,04 & 19,46 & 2,66 & $-6,88$ \\
\hline 843 & & 0 & 0 & 0 & 1 & 0 & 0 & 1 & 0 & 0 & 4900 & 72,04 & 17 & 1 & $-3,34$ \\
\hline 844 & 59 & 0 & 0 & 0 & 1 & 0 & 0 & 1 & 0 & 0 & 5547 & 62,61 & 16,01 & 6 & $-3,22$ \\
\hline 845 & 59 & 0 & 0 & 1 & 0 & 0 & 0 & 1 & 0 & 0 & 6310 & 58,34 & 16,29 & 8,59 & $-3,61$ \\
\hline 846 & 59 & 0 & 0 & 1 & 0 & 0 & 0 & 1 & 0 & 0 & 6745 & 55,7 & 20,29 & t6 & $-2,45$ \\
\hline 847 & & 0 & 0 & 1 & 0 & 0 & 0 & 1 & 0 & 0 & 11 & 48 & 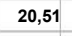 & 4 & $-5,84$ \\
\hline 848 & 59 & 0 & 0 & 1 & 0 & 8 & 0 & 1 & 0 & 0 & 5918 & 66,15 & 18,54 & 9 & $-3,52$ \\
\hline 849 & 59 & 0 & 0 & 1 & 0 & 0 & 0 & 1 & 0 & 0 & 6196 & 71,11 & 20,35 & 6,59 & $-3,78$ \\
\hline 850 & 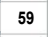 & 0 & 0 & 1 & 0 & 0 & 0 & 1 & 0 & 0 & 6643 & 75,97 & 22,36 & 4,39 & $-2,46$ \\
\hline 851 & 60 & 0 & 0 & 1 & 0 & 0 & 1 & 0 & 0 & 0 & 642 & 7,07 & 53,25 & 5,3 & $-3,05$ \\
\hline 852 & 60 & 0 & 0 & 1 & 0 & 0 & 1 & 0 & 0 & 0 & 651 & 100,27 & 50,42 & 7,12 & $-3,34$ \\
\hline 853 & 60 & 0 & 0 & 1 & 0 & 0 & 1 & 0 & 0 & 0 & 674 & 8,49 & 52,68 & 6,9 & $-2,23$ \\
\hline 85. & & 0 & 0 & 1 & 0 & 0 & 1 & 0 & 0 & 0 & 9 & 51 & & 05 & $-2,3$ \\
\hline 855 & 60 & 0 & 0 & 1 & 0 & 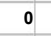 & 1 & 0 & 0 & 0 & 761 & 122,41 & 18,43 & 0,07 & $-6,67$ \\
\hline 856 & 60 & 0 & 1 & 年 & 0 & 0 & 1 & 0 & 0 & 0 & 860 & 126,64 & 45,57 & 5,85 & $-1,88$ \\
\hline 857 & 60 & 0 & I & 0 & 0 & 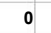 & 1 & 0 & 0 & 0 & 903 & 19,97 & 23,38 & 7,07 & $-2,75$ \\
\hline 858 & 60 & 0 & 1 & 0 & 0 & 0 & 1 & 0 & 0 & 0 & 19 & 118,69 & 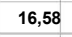 & 5,1 & $-2,59$ \\
\hline 859 & 60 & 0 & 1 & 0 & 0 & 0 & 1 & 0 & 0 & 0 & 338 & 119,12 & 47,38 & 4,89 & $-1,31$ \\
\hline 860 & 60 & 0 & 1 & 0 & 0 & 0 & 1 & 0 & 0 & 0 & 1086 & 109,08 & 47,79 & .72 & $-0,81$ \\
\hline 861 & ${ }^{6}$ & 0 & 1 & 0 & 0 & 0 & 1 & 0 & 0 & 0 & & 117,36 & 5 & & $-1,22$ \\
\hline 862 & 60 & 0 & 1 & 0 & 0 & 0 & 1 & 0 & 0 & 0 & 5 & 122,79 & 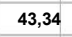 & 5 & $-0,79$ \\
\hline 863 & 60 & 0 & 1 & t & 0 & 0 & 1 & 0 & 0 & 0 & 1178 & 122,31 & 39 & 8,29 & $-1,92$ \\
\hline 864 & 60 & 0 & 1 & 0 & 0 & 0 & 1 & 年 & 0 & 0 & 16 & 2,02 & 34,43 & 4 & $-1,98$ \\
\hline 865 & 60 & 0 & 1 & 0 & 0 & 0 & 1 & 0 & 0 & 0 & 5 & 107,85 & 41,94 & 2 & $-2,21$ \\
\hline 866 & 60 & 0 & 1 & 0 & 0 & 0 & 1 & 0 & 0 & 0 & 266 & 115,68 & 40 & 69 & $-1,95$ \\
\hline 867 & 60 & 0 & 1 & 0 & 0 & 0 & 1 & 0 & 0 & 0 & 292 & 123,2 & 33,91 & 93 & $-1,59$ \\
\hline 868 & 60 & 0 & 1 & 0 & 0 & 0 & 1 & 0 & 0 & 0 & & 5,37 & 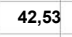 & 8,93 & $-1,73$ \\
\hline 869 & 61 & 0 & 0 & 0 & 1 & 0 & 0 & 1 & 0 & 0 & & 74 & & & $-10,96$ \\
\hline 870 & 61 & 0 & 0 & 0 & 1 & 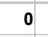 & 1 & 0 & 0 & 0 & 7227 & 86 & 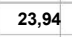 & 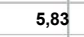 & $-11,44$ \\
\hline 871 & 61 & 0 & 0 & 0 & 1 & 0 & 1 & 0 & 0 & 0 & 7585 & 47 & 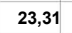 & 4,02 & $-9,03$ \\
\hline 874 & 61 & 0 & 0 & 0 & 1 & 0 & 1 & 0 & 0 & 0 & 7967 & 8 & 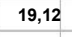 & 56 & $-7,59$ \\
\hline 873 & 61 & 0 & 0 & 0 & 1 & 0 & 1 & 0 & 0 & 0 & 8001 & 17 & 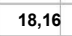 & 4,16 & $-7,15$ \\
\hline 874 & 61 & 0 & 0 & 0 & 1 & 0 & 1 & . & 0 & 0 & 8201 & ;,6 & 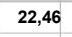 & 3,65 & $-5,89$ \\
\hline 875 & 61 & c & 0 & . & 1 & 0 & 1 & 0 & 0 & 0 & 8339 & 23 & & & $-9,38$ \\
\hline 876 & 6 & 0 & 0 & 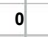 & 1 & 0 & 1 & 0 & 0 & & & & & & $-8,95$ \\
\hline 877 & 61 & 0 & 0 & 0 & 1 & 0 & 0 & 1 & 0 & 0 & 8778 & 7 & 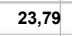 & 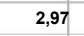 & $-12,06$ \\
\hline 878 & 61 & 0 & 0 & 0 & 1 & 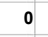 & 0 & 1 & 0 & 0 & 9145 & 46 & 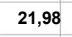 & 3,22 & $-9,36$ \\
\hline 879 & 61 & 0 & 0 & 0 & 1 & 0 & 0 & 1 & 0 & 0 & 9549 & 4 & 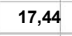 & 2,16 & $-7,01$ \\
\hline 880 & 6 & 0 & ( & 0 & 1 & 0 & & 1 & 0 & & 10007 & 54 & & & 69 \\
\hline 881 & 61 & 0 & 0 & 0 & 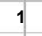 & 0 & 0 & 1 & 0 & 0 & 10464 & 6 & 1,49 & 3,19 & $-3,77$ \\
\hline 882 & 61 & 0 & 0 & 0 & 1 & 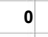 & 0 & 1 & 0 & 0 & 107 & 1,87 & 1 & 2,1 & 89 \\
\hline 88: & 6 & c & 0 & 0 & 1 & 0 & & 1 & 0 & & & 3 & & & $-4,35$ \\
\hline 884 & 6 & 0 & c & 0 & 1 & 0 & & 1 & 0 & & & & & & $-3,81$ \\
\hline 885 & 61 & 0 & 0 & $\sigma_{1}$ & 1 & 0 & 0 & T & 0 & 0 & 12576 & 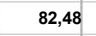 & 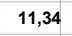 & 2, & ,16 \\
\hline 88 & 61 & 0 & 0 & 1 & 0 & 0 & 0 & 1 & 0 & 0 & 13220 & 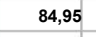 & & & $-2,59$ \\
\hline 887 & 6 & & . & 0 & 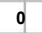 & 1 & & 0 & 1 & & & & & & \\
\hline 888 & 62 & 0 & c & 0 & 0 & 1 & & 0 & & & & & & & $-4,49$ \\
\hline 889 & 62 & 0 & 0 & 0 & 0 & 1 & 0 & 0 & 1 & 0 & 12160 & 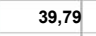 & 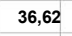 & 52 & $-5,4$ \\
\hline 890 & 62 & 0 & c & 0 & 0 & 1 & 0 & 0 & 1 & 0 & 13827 & 31 & 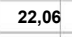 & &, 33 \\
\hline 891 & 6 & & & 0 & & $2+$ & & 0 & & & & & & & -5 \\
\hline 89 & 62 & 0 & 0 & 0 & 0 & 1 & 0 & 0 & 1 & & & & & & \\
\hline 893 & 62 & 0 & 0 & 0 & 0 & 1 & 0 & 0 & 1 & 0 & 15637 & , 15 & 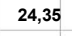 & 2, & $-6,77$ \\
\hline 894 & 62 & & 0 & 0 & 0 & 1 & 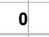 & 0 & 1 & & & & & & $-5,14$ \\
\hline 895 & 62 & & & 0 & 1 & 0 & & 0 & & & & & & & \\
\hline 896 & 62 & & 0 & 0 & 1 & 0 & 0 & 0 & 1 & & & & & &, 71 \\
\hline 897 & 62 & 0 & 0 & 0 & 1 & 0 & 0 & 0 & 1 & 0 & 17680 & 4 & $=$ & 69 & $-9,66$ \\
\hline 89 & 62 & & c & 0 & 1 & 0 & & 0 & & & & & & 38,59 & $-2,39$ \\
\hline 895 & 62 & & 0 & 0 & 1 & 0 & & 0 & & & & & & & \\
\hline 90 & 62 & 0 & 0 & 0 & 1 & 0 & 0 & 0 & & & & & & & -2 \\
\hline & 62 & 0 & 0 & 0 & 1 & 0 & 0 & 0 & & & 1940 & 86 & 31 & 98 &, 33 \\
\hline
\end{tabular}




\begin{tabular}{|c|c|c|c|c|c|c|c|c|c|c|c|c|c|c|c|}
\hline & 1 & A & & & & MD & LV F & & & & PIB & con & AGRI & EF & ODP \\
\hline 902 & 62 & 0 & 0 & 0 & 1 & 0 & 0 & 0 & 1 & 0 & 20855 & 45,4 & 25,8 & 15,79 & $-2,29$ \\
\hline 903 & 63 & 0 & & 0 & 1 & 0 & 0 & 0 & 1 & 0 & 1542080 & 38,25 & 14,75 & 7,57 & 0,12 \\
\hline 904 & & & & 0 & 1 & 0 & & 0 & 1 & & 269 & 1,46 & 13,52 & 年 & , 1 \\
\hline 905 & & 0 & & 0 & 1 & 0 & 0 & 0 & 1 & & 50832 & 1,61 & 87 & 6,04 & 0,08 \\
\hline 906 & 63 & 0 & & & 1 & 0 & 0 & 0 & 1 & 0 & 37315 & 59,45 & 12,11 & 5,44 & 0,09 \\
\hline 的7 & & & & & 1 & 0 & & 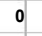 & 1 & & 68599 & 62,9 & 19 & 5,1 & 08 \\
\hline 908 & 63 & 0 & & 0 & 1 & 0 & & 0 & 1 & & 2556444 & 64,77 & 10,51 & 5,09 & 0,05 \\
\hline 909 & 63 & 0 & & 1 & 0 & 0 & 0 & 0 & 1 & & 19330 & 2,28 & 10,65 & 37 & 0,04 \\
\hline 910 & & 0 & & & o & 0 & 0 & 0 & 1 & 1 & 00268 & 56,8 & 11,25 & 07 & ,03 \\
\hline 911 & 6 & 0 & & 1 & 0 & 0 & 0 & 0 & 1 & 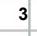 & 55767 & 43,59 & 11,67 & 19 & 0,02 \\
\hline 912 & 63 & c & & 0 & 0 & 0 & 0 & 0 & 1 & & 3867426 & 49,33 & 11,59 & 73 & 0,01 \\
\hline 913 & 63 & 0 & & 0 & 0 & 0 & 0 & 0 & 1 & & 234233 & 48,83 & 12,23 & 3 & $-0,01$ \\
\hline 914 & & & & 0 & 0 & 0 & 0 & 0 & 1 & 3 & 4562398 & 45,71 & 12,47 & 7,05 & 0 \\
\hline 915 & 64 & 0 & & 0 & 0 & 1 & 0 & 0 & 1 & 0 & 14639 & 76,2 & 55,43 & 1,33 & $-12,1$ \\
\hline 916 & & 0 & & 0 & 0 & 1 & 0 & 0 & 1 & & 15771 & 73,52 & 51,6 & 88 & $-8,59$ \\
\hline 917 & & 0 & & 0 & 0 & 1 & 0 & 0 & 1 & & 16361 & 8,21 & 47,47 & 49 & $-4,06$ \\
\hline 918 & & 0 & & 0 & 0 & 1 & 0 & 1 & 0 & 0 & 17168 & 6,37 & 48,84 & 96 & $-8,05$ \\
\hline 919 & & 0 & & 0 & 0 & 1 & 0 & 1 & 0 & 0 & 17446 & 76,54 & 45,17 & 63 & $-3,81$ \\
\hline 920 & & 0 & & 0 & 0 & 1 & 0 & 1 & 0 & & 17085 & 74,64 & 43,37 & 2,04 & $-3,61$ \\
\hline 921 & & 0 & & 0 & 0 & 1 & 0 & 0 & 1 & & 17105 &, 55 & 45,68 & 31 & 88 \\
\hline 922 & 64 & 0 & & 0 & 0 & 1 & 0 & 0 & 1 & 0 & 16820 & 79,86 & 49,53 & 46 & $-9,88$ \\
\hline 923 & 64 & 0 & & 0 & 0 & 1 & 0 & 0 & 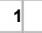 & & 16591 & 75,27 & 45,9 & ,98 & $-1,95$ \\
\hline 924 & & 0 & & 0 & 0 & 1 & 0 & 0 & 1 & & 16796 & 84,61 & 37,83 & 34 & \begin{tabular}{|c|} 
\\
\end{tabular} \\
\hline 925 & & 0 & & 0 & 1 & 0 & 0 & 0 & 1 & & 085 & 92 & 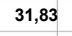 & 4 & \begin{tabular}{|c|}
$-0,56$ \\
\end{tabular} \\
\hline 926 & 64 & 0 & & 0 & 1 & 0 & 0 & 0 & 1 & & 17344 & 95,07 & 31,8 & 1,06 & $-1,45$ \\
\hline 927 & & 0 & & 0 & 1 & 0 & 0 & 0 & 1 & & 17650 & 89,44 & 34,09 & 6,17 & $-0,88$ \\
\hline 928 & & 0 & c & 0 & 1 & 0 & 0 & 0 & 1 & & 099 & ,27 & 35,94 & 2 & $-2,68$ \\
\hline 929 & & 0 & & 0 & 1 & 0 & 0 & 0 & 1 & & 3687 & 1,78 & 40,69 & 5,4 & $\begin{array}{l}-10,29 \\
\end{array}$ \\
\hline 930 & & 0 & & 0 & 1 & 0 & 0 & 0 & 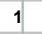 & & 19064 & 93,96 & 41,15 & 5,92 & $-3,52$ \\
\hline 931 & 6 & 0 & & 0 & 1 & 0 & 0 & 0 & 1 & & 18228 & 91,15 & 48,49 & 99 & $-5,88$ \\
\hline 932 & & 0 & & 0 & 1 & 0 & 0 & 0 & 1 & & 180 & 81 & 4 & 7 & $-10,07$ \\
\hline 933 & 65 & 0 & & 0 & 1 & 0 & 0 & 0 & 1 & & 58533 & 50,25 & 26,68 & 88 & $-3,37$ \\
\hline 934 & & 0 & & 0 & 1 & 0 & 0 & 0 & 1 & & 61453 & 46,95 & 26,36 & 77 & $-3,22$ \\
\hline 935 & & c & c & 0 & 1 & 0 & 0 & 0 & 1 & & 64828 & 3,74 & 23,33 & 4 & .54 \\
\hline 936 & 65 & 0 & & 0 & 1 & 0 & 0 & 0 & 1 & 0 & 67445 & 41,93 & 23,01 & 36 & $-2,29$ \\
\hline 937 & 65 & 0 & & 0 & 1 & 0 & 0 & 0 & 1 & & 71562 & 38,36 & 23,13 &, 3 & $-1,77$ \\
\hline 938 & 65 & 0 & & 0 & 1 & 0 & 0 & 0 & 1 & & 75404 & 39,02 & 22,89 & 6,8 & $-1,36$ \\
\hline 939 & & 0 & & 0 & 1 & 0 & 0 & 0 & 1 & & & 81 & 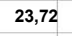 & &, 33 \\
\hline 940 & 65 & 0 & & 0 & 1 & 0 & 0 & 0 & 1 & & 9920 & ,99 & 25,27 & 68 & $-1,5$ \\
\hline 941 & 65 & 0 & & 0 & 1 & 0 & 0 & 0 & 1 & & 82472 & 46,18 & 22,9 & 6,09 & $-1,23$ \\
\hline 942 & & 0 & c & 0 & 1 & 0 & 0 & 0 & 1 & & 85847 & 82 & 22,39 & 6 & $-1,98$ \\
\hline 943 & 65 & 0 & & 0 & 1 & 0 & . & 0 & 1 & & 686 & 95 & 17,84 & & 16 \\
\hline 944 & & 0 & & 0 & 1 & 0 & 0 & 0 & 1 & & 95823 & 61,52 & 15,68 & 5,7 & $-0,83$ \\
\hline 945 & & 0 & & 0 & 1 & 0 & 0 & 0 & 1 & & 2615 & 5,08 & 17,29 & 73 & $-0,86$ \\
\hline 946 & & 0 & c & 0 & 1 & 0 & 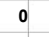 & 0 & 1 & & 54 & 8 & & & 6 \\
\hline 947 & 65 & 0 & & 0 & 1 & 0 & 0 & 0 & 1 & & 5106 & 56,55 & 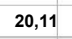 & 8 & $-0,53$ \\
\hline 948 & 65 & 0 & & 0 & 1 & 0 & 0 & 0 & 1 & 0 & 121021 & 47,94 & 21,35 &, 77 & $-0,27$ \\
\hline 949 & & 0 & 0 & 1 & 0 & 0 & 0 & 0 & 1 & & 3220 & 26 & 63 & 6 & , 18 \\
\hline 950 & s & 0 & & 1 & 0 & 0 & 0 & 0 & 1 & & 23 & 6 & 2 & 7 & 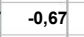 \\
\hline 951 & 66 & 0 & & 0 & 1 & 0 & 0 & 1 & 0 & 0 & 093 & 59,4 & 31,83 & 25 & $-3,15$ \\
\hline 952 & 66 & 0 & & 0 & 1 & 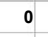 & 0 & 1 & 0 & & 3316 & ,01 & 32,8 & 8 & 95 \\
\hline 953 & & & & 0 & 1 & 0 & 1 & 0 & 0 & & 81 & 5 & & & 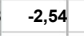 \\
\hline 954 & 6 & 0 & & 0 & 1 & 0 & 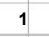 & 0 & 0 & & 402 & 37 & & & 53 \\
\hline 955 & 66 & 0 & c & 0 & 1 & 0 & 1 & 0 & 0 & 0 & 489 & .22 & 29,6 & 23,21 & $-1,5$ \\
\hline 956 & & 0 & 0 & 0 & 1 & 0 & 1 & 0 & 0 & & 219 & 83 & 16,07 & 23 & , 39 \\
\hline 95 & c & 0 & & 0 & 1 & 0 & 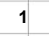 & 0 & 0 & & 15479 & 7 & & 4 & 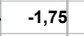 \\
\hline 958 & 66 & 0 & & 0 & 1 & 0 & 1 & 0 & 0 & & 15 & 14 & 1 & 11 & 67 \\
\hline 959 & 60 & 0 & 0 & 0 & 1 & 0 & 1 & 0 & 0 & & 16206 & 0,04 & 14,6 & 53 & $-1,31$ \\
\hline 960 & & 0 & & 1 & 0 & 0 & 1 & 0 & 0 & & 16506 & 26 & & & 41 \\
\hline 961 & 6 & 0 & & 1 & 0 & 0 & . & 0 & 0 & & & 8 & & & 23 \\
\hline 962 & & 0 & & 1 & 0 & 0 & 1 & 0 & 0 & 0 & 17763 & 85 & 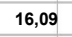 & 29 & $-0,9$ \\
\hline 963 & 66 & 0 & 0 & 1 & 0 & 0 & 1 & 0 & 0 & 0 & 18445 & 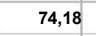 & 17,17 & 8,06 & 45 \\
\hline 964 & & 0 & & 1 & 0 & 0 & 1 & 年 & 0 & 0 & 18680 & 8 & 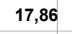 & 51 & $-1,11$ \\
\hline 965 & & & & 1 & 0 & 0 & & 0 & 0 & & & & & & \\
\hline 966 & 66 & 0 & & . & 0 & 0 & 1 & 0 & 0 & 1 & 18341 & 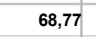 & 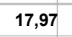 & & 44 \\
\hline 967 & & 0 & 0 & 1 & 0 & 0 & 1 & 0 & 0 & 0 & 18748 & 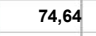 & & 3 & 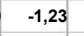 \\
\hline 968 & & & & 1 & c & 0 & & 0 & 0 & & & 7 & & & $-0,96$ \\
\hline 969 & & & & & & 0 & & 1 & 0 & & & & & & \\
\hline 970 & 67 & 0 & c & 0 & 1 & 0 & 0 & 1 & 0 & & & ? & 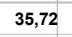 & & $-0,56$ \\
\hline 971 & 67 & 0 & & 0 & 1 & 0 & 1 & 0 & 0 & 0 & 34012 & 4 & & , 14 & $-0,66$ \\
\hline 972 & & & & & 1 & 0 & & 0 & 0 & & & & & & \\
\hline 973 & 6 & & & 0 & 1 & 0 & & 1 & 0 & & & & & & \\
\hline 974 & 67 & 0 & c & at & 1 & 0 & 0 & 1 & 0 & & & & & & 79 \\
\hline 975 & 67 & 0 & & 0 & 1 & 0 & c & 1 & 0 & & & & & & $-0,81$ \\
\hline 976 & & & & & & 0 & & & & & & & & & \\
\hline 977 & 67 & & & 1 & 0 & 0 & & 1 & 0 & & & & & & \\
\hline 978 & 67 & 0 & 0 & 1 & 0 & 0 & 0 & 1 & 0 & & 41507 & & & & \\
\hline 979 & 67 & & & 1 & $c_{-1}$ & 0 & & 1 & 0 & & & & & 14 & $-0,42$ \\
\hline 980 & 67 & & & & c & 0 & & 1 & & & & & & & \\
\hline 981 & 67 & 0 & & 0 & 0 & 0 & 0 & 1 & 0 & & & & & & \\
\hline 982 & 67 & 0 & 1 & 0 & 0 & 0 & 0 & 1 & 0 & 0 & 36 & 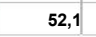 & . & 09 & $-0,34$ \\
\hline & 67 & & & & & 0 & & & & & & & 87 & 0,5 & 21 \\
\hline
\end{tabular}

Fonte: adaptado do resultado da estimação SAS. 


\section{Referências Bibliográficas}

BANCO MUNDIAL (BM). (2013a), World Bank GNI per capita Operational - Guidelines \& Analytical Classifications. Disponivel em: <http://siteresources.worldbank.org/DATASTATISTICS/Resources/OGHIST.xIs>. Acesso em novembro de 2013.

(2013b), A Short History - GNI per capita. Disponível em: <http://data.worldbank.org/about/country-classifications/a-short-history>. Acesso em novembro de 2013.

BARRON, D. N. (1992), The Analysis of Count Data: Overdispersion and Autocorrelation. American Sociological Association, v. 22 , p. 179-220.

BOX, J. F. (1987), Guinness, Gosset, Fisher, and Small Samples. Statistical Science, v. 2, n. 1, p. 45-52.

BRESLOW, N. E; CLAYTON, D. G. (1993), Aproximate inference in generalized linear mixed models. Journal of the American Statistical Association, v. 88, n. 421, p. 925.

CAMERON, A. C.; TRIVEDI, P. K. (2013). Regression Analysis of Count Data. $2^{\text {nd }}$ Edition. Cambridge University Press, New York.

CLARKE, K. A. (2007), A Simple Distribution-Free Test for Nonnested Hypotheses. Political Analysis, v. 15, n. 3, p. 347-363.

COLLET, D. (1991), Modelling Binary Data. $2^{\text {nd }}$ Editon. Chapman \& Hall, London.

DOBSON, A. J.; BARNETT, A. G. (2008), An introduction to generalized linear models. $3^{\text {rd }}$ Editon. Taylon and Francis, Boca Raton.

Grupo de Cairs. (2012), Website oficial. Disponível em: <http://www.cairnsgroup.org/index.html>. Acesso em janeiro de 2013.

GUPTA, P. L.; GUPTA, R. C.; TRIPATHI, R. C. (1996), Analysis of zero adjusted count data. Computational Statisticas \& Data Analysis, n. 23, p. 207-218.

HILBE, J. M. (2011), Negative Binomial Regression. Cambridge University Press (ebook), Cambridge.

. (2014), Modeling Count Data. Cambridge University Press (ebook), Cambridge.

HOFFMAN, L. (2015), Longitudinal Analysis: Modeling Withing-person Fluctuation and Change. Taylor and Francis (ebook), New York.

HOX, J. J.; MOERBEEK, M.; SCHOOT, R. V. (2010), Multilevel Analysis: Technics and Applications. Taylor and Francis (ebook), New York. 
KURADA, R. R. (2016), Fitting Multilevel Hierarchical Mixed Models Using PROC NLMIXED. Paper SAS4720-2016. SAS Institute - NC.

LEE, Y.; NELDER, J. A.; (2005), Likelihood for random-effect models. SORT 29, n. 2, July-December, p. 141-164.

LINDSEY, J. (1995). Modelling Frequency and Count Data. Oxford University Press, New York.

LONG, J. S. (1997), Regression Models for Categorical and Limited Dependent Variables. Sage Publications, New York.

MANCO, O. C. U. (2013), Modelos de Regressão Beta com Efeitos Aleatórios Normais e Não-normais para Dados Longitudinais. Tese 123 (Doutorado em Ciências). Instituto de Matemática e Estatística - Universidade de São Paulo.

McCULLOCH, C. E.; SEARLE, S. R.; NEUHAUS, J. M. (2008), Generalized, Linear, and Mixed Models. $2^{\text {nd }}$ Editon. Wiley, New York.

McGILCHRIST, C. A. (1994), Estimation in generalized mixed models. Journal of the Royal Statistical Socity B, v. 56, n. 1, p 61-69.

MOGHIMBEIGI, A.; ESHRAGHIAN, M. R.; MOHAMMAD, K.; MCARDLE, B. (2008), Multilevel zero-inflated negative binomial regression modeling for overdispersed count data with extra zeros. Journal of Applied Statistics, v. 35 n. 10, p. 1193-1202.

NELDER, J. A.; WEDDERBURN, R. W. M. (1972), Generalized Linear Models. Journal of the Royal Statistical Society, n. 135, p. 370-384.

ORGANIZAÇÃO MUNDIAL DO COMÉRCIO (OMC). (2013), Who are the developing $\begin{array}{llll}\text { countries in } \text { WTO? Disponível em: } & \text { the }\end{array}$ <http://www.wto.org/english/tratop_e/devel_e/d1who_e.htm>. Acesso em julho de 2013.

ROBSON, K; PEVALIN, D. (2016), Multilevel Modeling in Plain Language. SAGE (ebook), Washington DC.

SCHALL, R. (1991), Estimation in generalized linear models with random effects. Biometrika, v. 78, n. 4, p. 719-727.

TUCÍDIDES. (2001), História da Guerra do Peloponeso. $4^{\text {a }}$ Edição, Coleção IPRI - Editora UnB, Brasília.

VORONCA, D. C.; EDEDE, L.; GEBREGZIABHER, M. (2014), Analysis of Zero Inflated Longitudinal Data Using PROC NLMIXED. University of South Carolina, Department of Biostatistics - Charleston SC. 
VOUNG, Q. H. (1989). Likelihood Ratio Tests for Model Selection and non-nested Hypotheses. Econometrica, v. 57, n, 2, p. 307-333.

WINKELMANN, R. (2003), Econometric Analysis of Count Data. Springer, New York. 


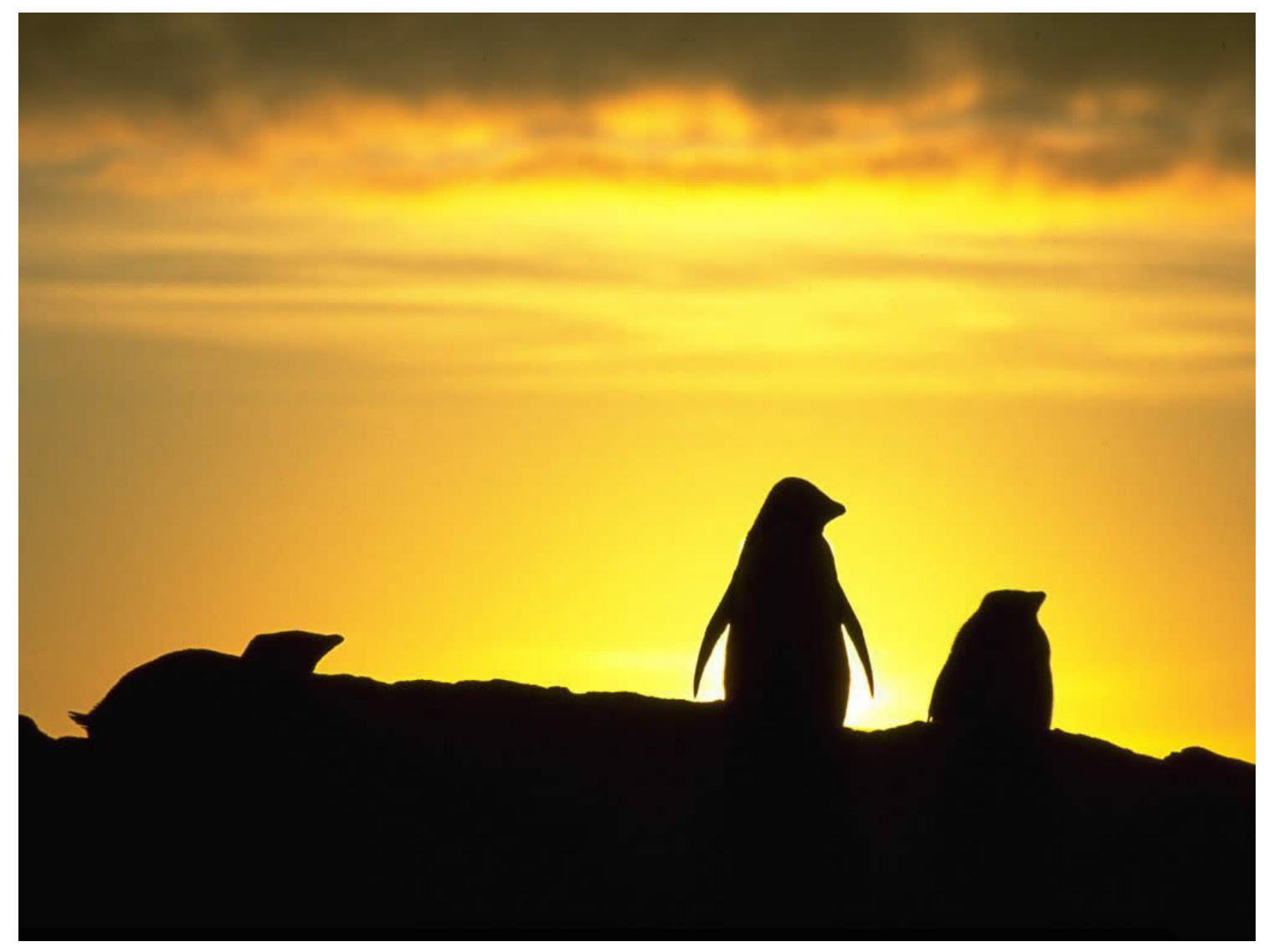

